
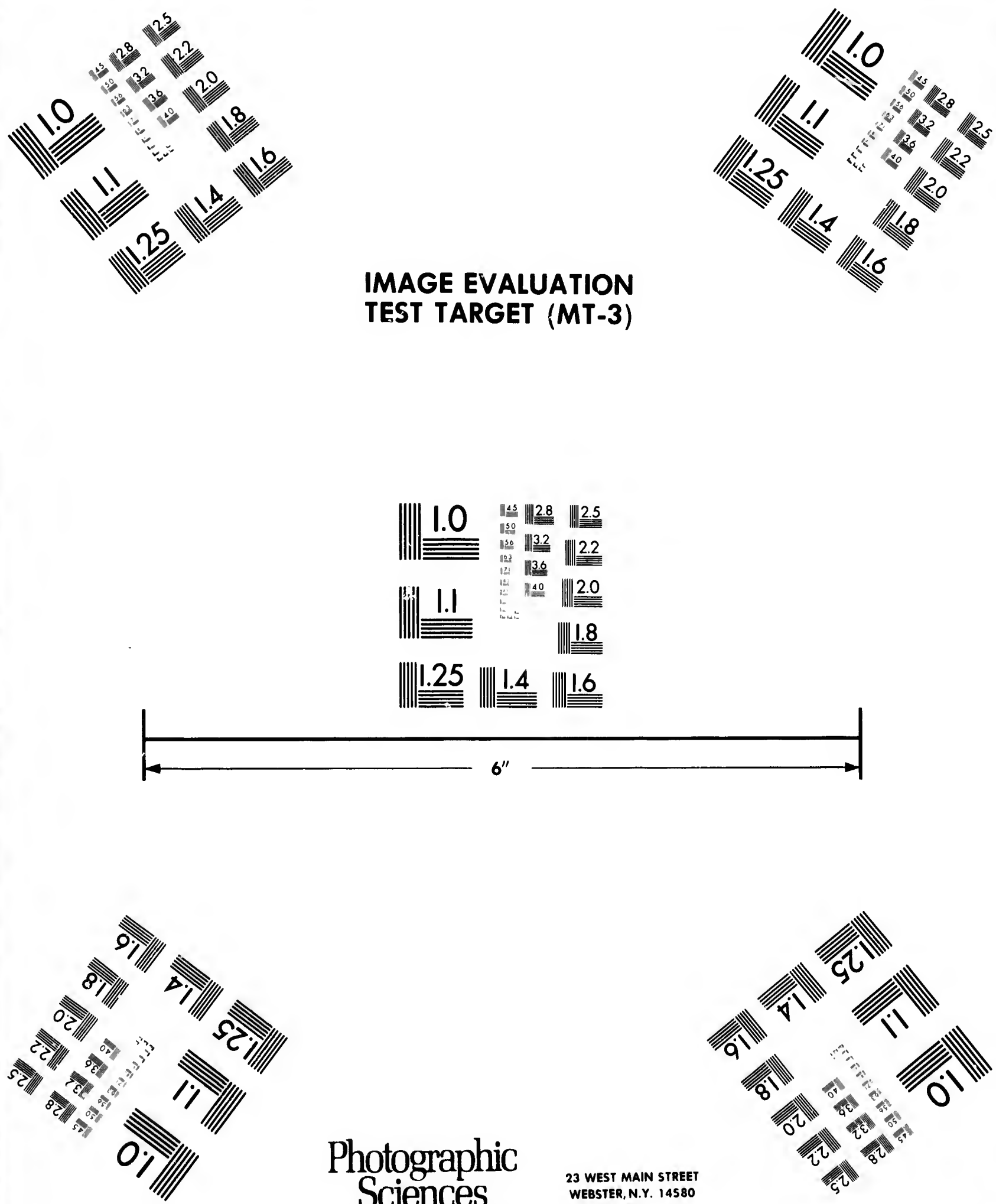

Photographic Sciences Corporation
23 WEST MAIN STREET WEBSTER, N.Y. 14580 (716) 872-4503

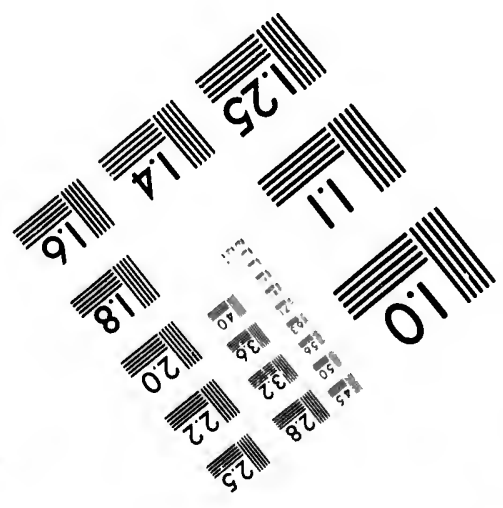




\section{CIHM/ICMH Microfiche Series.}

\section{CIHM/ICMH Collection de microfiches.}


The Institute has attempted to obtain the best original copy available for filming. Features of this copy which may be bibliographically unique, which may alter any of the images in the reproduction, or which may significantly change the usual method of filming, are checked below.

Coloured covers/

Couverture de couleur

Covers damaged/

Couverture endommagée

Covers restored and/or laminated/

Couverture restaurée et/ou pelliculée

Cover title missing/

Le titre de couverture manque

Coloured maps/

Cartes géographiques en couleur

Coloured ink (i.e. other than blue or black)/

Encre de couleur (i.e. autre que bleue ou noire)

Coloured plates and/or illustrations/

Planches et/ou illustrations en coulour

Bound with other material/

Relié avec d'autres documents

Tight binding may cause shadows or distortion along interior margin/

La reliure serrée peut causer de l'ombre ou de la distortion le long de la marge intérieure

Blank leaves added during restoration may appear within the text. Whenever possible, these have been omitted from filming/

II se peut que certaines pages blanches ajoutées lors d'une restauration apparaissent dans le texte, mais, lorsque cela était possible, ces pages n'ont pas été filmées.

Additional comments:/

Commentaires supplémentaires:
L'Institut a microfilmé le meilleur exemplaire qu'il lui a été possible de se procurer. Les détails de cet exemplaire qui sont peut-être uniques du point de vue bibliographique, qui peuvent modifier une image reproduite, ou qui peuvent exiger une modification dans la méthode normale de filmage sont indiqués ci-dessous.

Coloured pages/

Pages de couleur

Pages damaged/

Pages endommagées

Pages restored and/or laminated/

Pages restaurées et/ou pelliculées

Pages discoloured, stained or foxed/

Pages décolorées, tachetées ou piquées

Pages detached/

Pages détachées

\section{Showthrough/}

Transparence

Quality of print varies/

Qualité inégale de l'impression

Includes supplementary material/

Comprend du matériel supplémentaire

Only edition available/

Seule édition disponible

Pages wholly or partially ohscuren by errata slips, tissues, etc., have been refilmed to ensure the best possible image/ Les pages totalement ou partiellement obscurcies par un feuiliet d'errata, une pelure, etc., ont été filmées à nouveau de façon à obtenir la meilleure image possible.

This item is filmed at the recluction ratio checked below/ Ce document est filmé au taux de réduction indiqué ci-dessous.

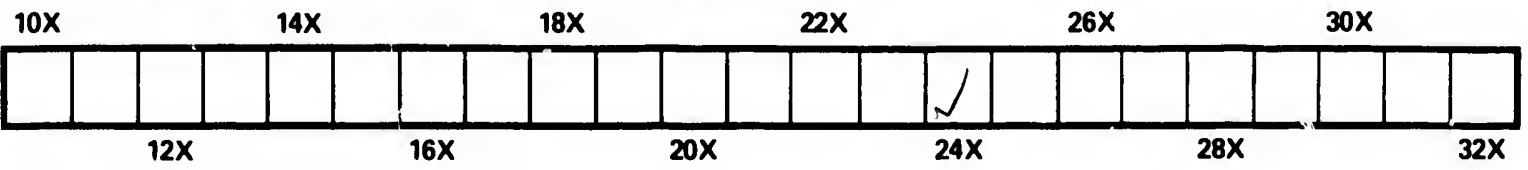


The copy filmed here has been reproduced thanks to the generosity of:

\section{National Library of Canada}

The images appearing here are the best quality possible considering the condition and legibility of the original copy and in keeping with the filming contract specifications.

Original copies in printed paper covers are filmed beginning with the front cover and ending on the last page with a printed or illustrated impression, or the back cover when appropriate. All other original copies are filmed beginning on the first page with a printed or illustrated impression, and ending on the last page with a printed or illustrated impression.

The last recorded frame on each microfiche shall contain the symbol $\rightarrow$ Imeaning "CONTINUED"), or the symbol $\nabla$ (meaning "END"), whichever applies.

Maps, plates, charts, etc., may be filmed at different reduction ratios. Those too large to be entirely included in one exposure are filmed beginning in the upper left hand corner, left to right and top to bottom, as many frames as required. The following diagrams illustrate the method:
L'exemplaire filmé fut reproduit grâce à la générosité de:

Bibliothèque nationale du Canada

Les images suivantes ont été reproduites avec le plus grand soin, compte tenu de la condition et de lis netteté de l'exemplaire filmé, et en conformité avec les conditions du contrat de filmage.

Les exemplaires originaux dont la couverture en papier est imprimée sont filmés en commençant par le premier plat et en terminant soit par la derniere page qui comporte une empreinte d'impression ou d'illustration, soit par le second plat, selon le cas. Tous les autres exemplaires originaux son tilmés en commençant par la première page qui comporte une empreinte d'impression ou d'illustration et en terminant par la derniere page qui comporte une telle empreinte.

Un des symboles suivants apparaîtra sur la dernière image de chaque microfiche, selon le cas: le symbole $\rightarrow$ signifie "A SUIVRE", le symbole $\nabla$ signifie "FIN".

Les cartes, planches, tableaux, etc., peuvent être filmés à des taux de réduction différents.

Lorsque le document est trop grand pour être reproduit en un seul cliché, il est filmé à partir de l'angle supérieur gauche, de gauche a droite. et de haut en bas, en prenant le nombre d'images nécessaire. Les diagrammes suivants illustrent la méthode.
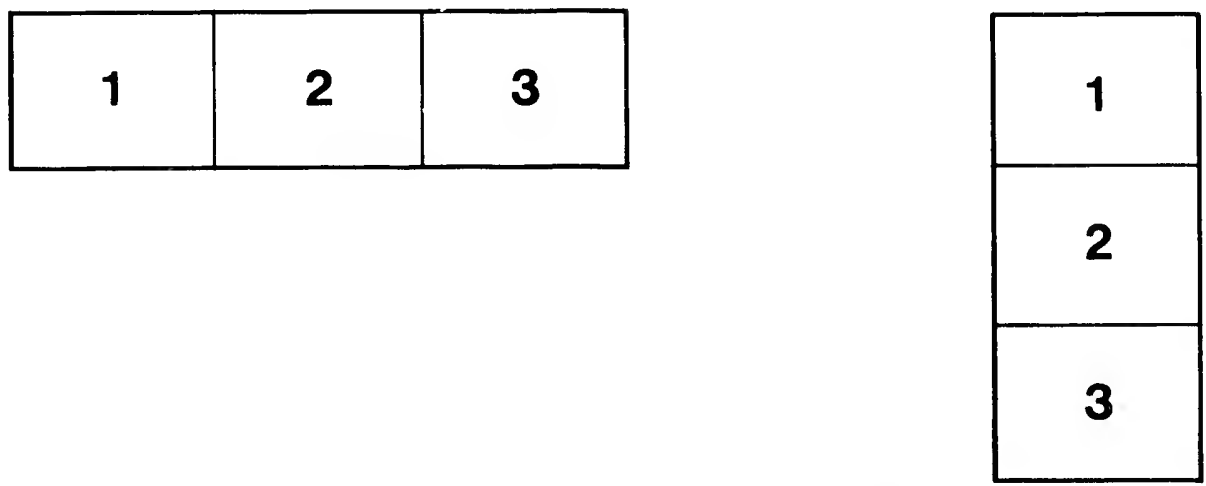

\begin{tabular}{|l|l|l|}
\hline 1 & 2 & 3 \\
\hline 4 & 5 & 6 \\
\hline
\end{tabular}



(1)

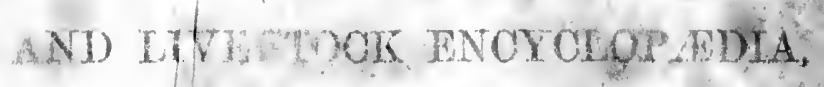

tyis

aitis

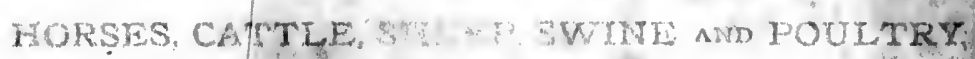

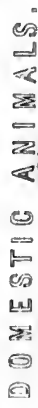

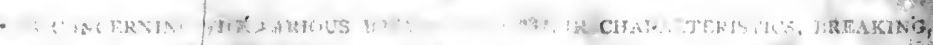

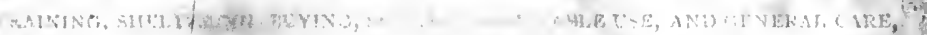

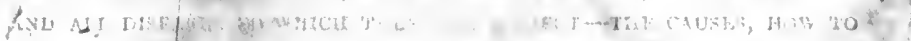

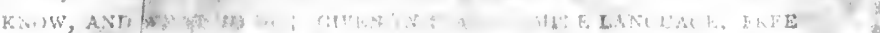

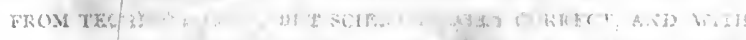

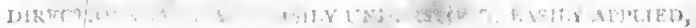
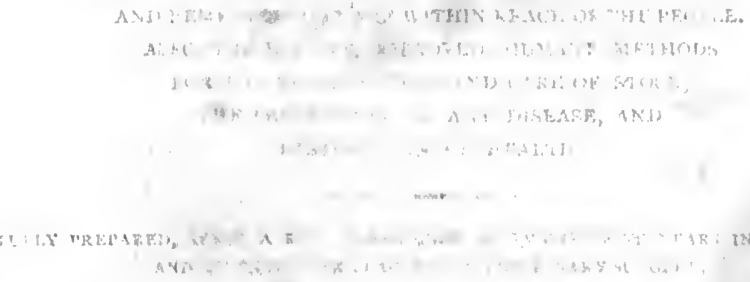

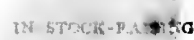

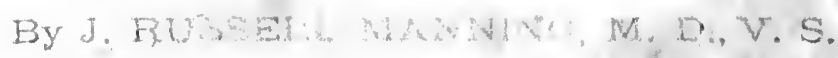

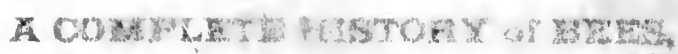

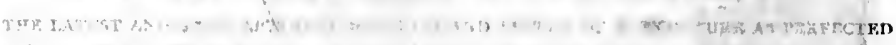

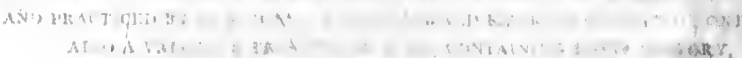

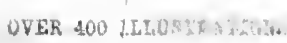

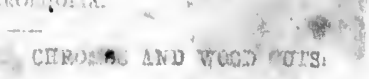




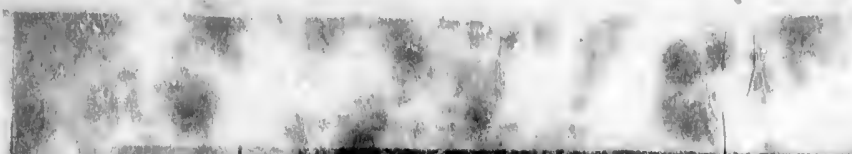

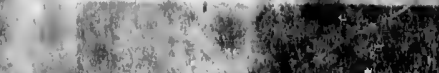

(3) (1)

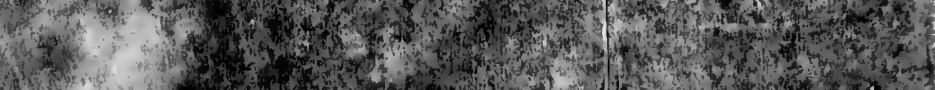
6.

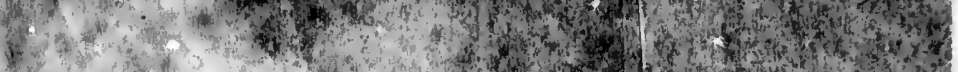

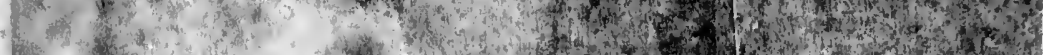

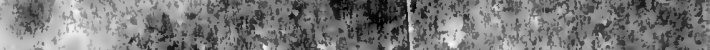

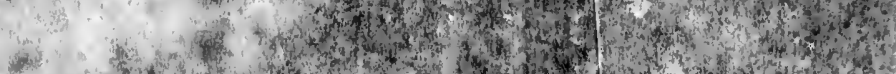

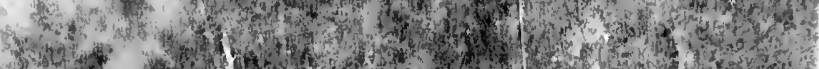
(n)

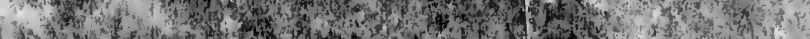

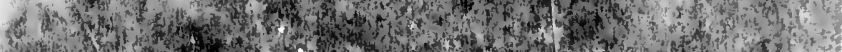

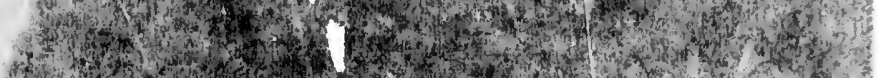

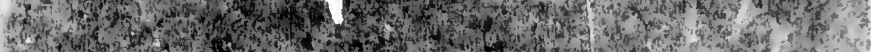

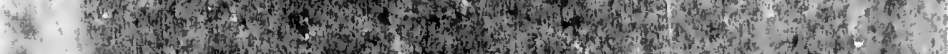

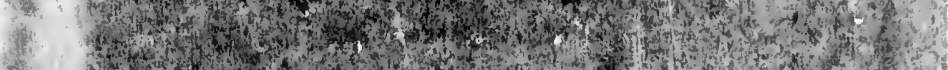
a.

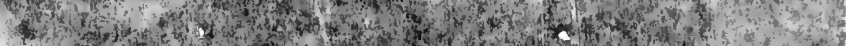
$\left\{\begin{array}{l}0 \\ 10\end{array}\right.$ 1.

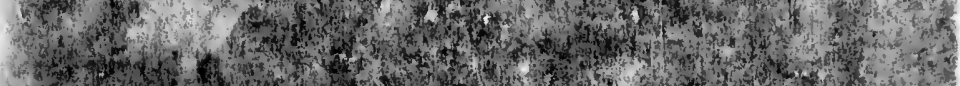

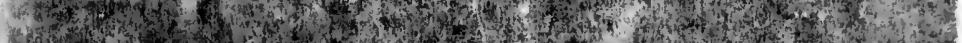
H. int

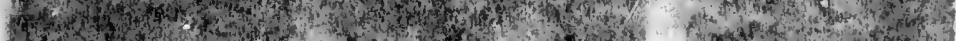
13. Thow

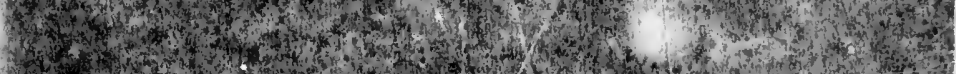

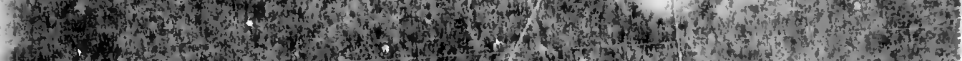

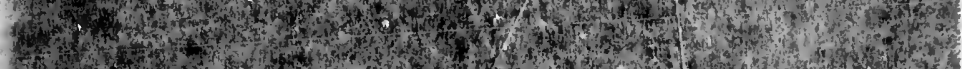

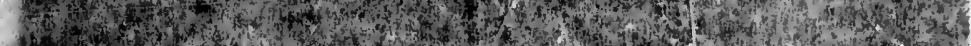

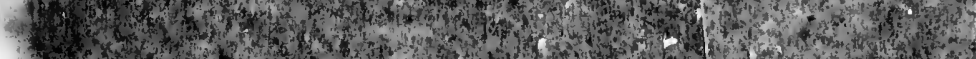

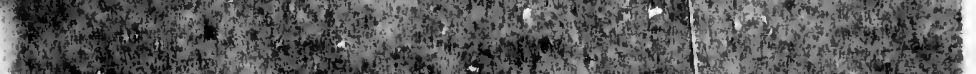

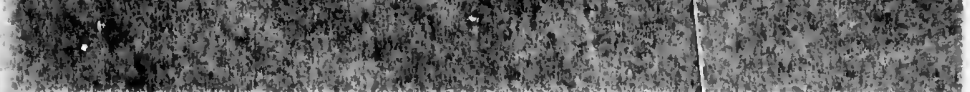




\title{
THE ILLUSTRATED
}
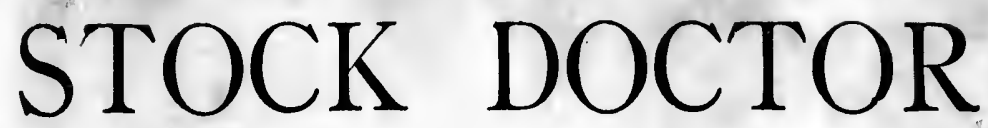

\section{AND LIVE-STOCK ENCYCLOP ÆDIA,}

\author{
INCLUDING
}

\section{HORSES, CATTLE, SHEEP, SWINE AND POULTRY,} WITH ALL THE

FACTS CONCERNING THE VARIOUS BREEDS AND THEIR CHARACTERISTICS, BREAKING, TRAINING, SHELTERING, BUYING, SELLING, PROFITABLE USE, AND GENERAL CARE, AND ALL DISEASES TO WHICH THEY ARE SUBJECT-THE CAUSES, HOW TO kNOW, AND What TO DO; GIVEN IN PLAiN, SIMPLE LANGUAGE, FREE FROM TECHNICALITIES, BUT SCIENTIFICALLY CORRECT, AND WITH DIRECTIONS THAT ARE EASILY UNDERSTOOD, EASILY APPLIED, AND REMEDIES THAT ARE WITHIN REACH OF THE PEOPLE. ALSO, THE RECENT, APPROVED, HUMANE METHODS FOR THE PERSERVATION AND CARE OF STOCK, THE PREVENTION OF ANY DISEASE, AND RESTORATION OF HEAI TH.

CAREFULLY PREPARED, AFTER A RIDE EXPERIENCE OF TWENTY-PIYE YEARS IN STOCK-RAISING AND AN EXTENSIVE PRACTICE IN VETERINARY SURGERY,

By J. RUSSELL MANNING, M. D., V. S.

TO WHICH HAS BEEN ADDED

\section{A COMPLETE HISTORY OP BEES,}

GIVING THE LATEST AND MOST APPROVED METHODS AND SYSTEM OF BEE CULTURE AS PERFECTPD AND PRACTICED BY D. A. JONES, THE RENOWNED BEE-KING OF BEETON, ONTARIO.

ALSO A VALUADLE TREATISE ON DOGS, CONTAINING THEIR IIISTORY, BREEDS, TRAINING, DISEASES, AND ESPECIALLY, GIVING

$\triangle$ SURE PREVENTIVE OF IIYDROPIOBIA.

OVFR 400 IILOSTRATIONS, INOLUDING STEELS, OHBOMOS AND WOOD OUTS.

WORLD PUBLISHING CO.,

Guelph, Ontario.

1881. 



\section{PUBLISHER'S PREFACE.}

It is with especial pleasure and pride that the publishers present to the public this volume. They believe that in design, extent, variety of matter and illustration, especial adaptnbility to the wants of the farmer and stock owner, and in its explicit and practical teachings, it has not been equalied in the history of American ngricultural publications. No author has to the same extent carried into effect in this department of literature the inodern and popular idea of "abject teaching." And in no department of literature is such teaching so useful and practical in character. With our author it has not been enough to describe ; but he illustratesteaching through the eye as well as by word, and with a definiteness in both respects that will enable any one, by proper study, however unfamiliar with the subjects of which it treats, to become well versed in all the-essentials of a practical knowledge of the use, care, diseases and treatment of domestic animals. Though the book is large, the system of the arrangement is so perfect that any fact in its contents can be readily found, and this constitutes it a most convenient work for ready reference as well as for general study. The illustrations, covering the subjects of breeds, characteristics, points, character, and the various stages of diseases, etc., are exhaustive, while the elaborate charts, so minutely illustrating the ages of the horse and cow, are decided features and most useful as well as novel.

The author's careful education in the profession of Veterinary Medicine, his large practice, and his experience in the general care and management of live stock, have eminently qualified him for the task he has undertaken, and we place the result of his labor before the public, believing that he has done his work well-that he has produced a book that will be of most practical and pecuniary value to every stock-owner. Believing this, the book is launched upon the sea of agricultural literature with the confident belief that it is demanded and that it will accomplish its mission of usefulness. 


\section{A UTHOR'S PREFACE.}

The author's object in writing the following book was to impart such practical information to the American farmer and stock-owner, as will lead to a much needed and beneticial reform in the breeding, care and general treatment of domestic animals; to offer such information in pruetical shape as will enable him to realize a greater henefit from live stock in health, and familiarize him with the causes that produce diseases, that he may avoid them; and also to give such facts that ho may know the nature of a disorder when it exists, as well as the proper romedies to apply.

In the suggestions offered wo have kept steadily in view the necessity of simplicity in describing disease, and of prescribing those remedies that the ordinary farmer can without difficulty procure and easily administer. In a practice of twenty-five ycars in country districts, among the agricultuJal classes, wo believe wo have learned to know their wants in this respect, and this volume is an earnest effort to meet them. It has always been a matter of surprise that such a work for farmers and small stock-ownerssimple in style and diction, yet scientifically exact, covering the entire subject of domestic animals-has never been prepared; yet we believe we speak within the facts in saying that our agricultural literature has to the present time been without a volume fulfilling these requisites.

The effort has been to produce a systematic work, accessible to the farmer, giving the known facts and principles of the art of handling, improving, breeding, care and management of domestic animals in health, the causes which produce disease, and how to avoid them; how to know disease, and what to do. In short, to produce such a work us will servo as a valuable hand-book, both for study and for constant reference for the farmer, and which will enable him to turn the industry of stockbreeding, raising, buying and selling to greater profit. 
In what we have said concerning the characteristics, excellences and defects of the various breeds of live stock (and in this we have tried to be full, explicit und exact), we have not been biased by partinlity for any, and have studiously avoided expressing my preforenec, when the facts, obtuined by long familiarity with the subjects, and much reading and observation, did not eleurly sustain the position taken.

The book is not in any sense in the interest of any breed or breeds, and even less is it in the interest of uny class of breeders or importers. In these things the interests of truth and the reader have been the influences that controlled. There is no advertisement in its pages.

If in the directions given throughout the work we have subjected ourselves to the charge of making a hobby of careful and tender treatment of animals, we reply that a long experience, and the observations of a life-time, have vely strongly impressed us that not only humanity but economy is loest served by kindness, and if the influence of this book shall lead to a more general study of the comfort of domestic animals, we will feel that we have served the financial interest of the breeder in an equal proportion to the welfare of the animals.

One of the facts that has always forcibly impressed us is, that among horse owners, and even those long familinr with horses, there are so fow good judges of a horse. The different developments of the horse for the different purposes for which horses are used, seem to be little understood, yet it is susceptible of very accurate knowledge, and in the approprinte places in these pages, we have, by careful analysis of the points of the horse, and very copious illustrations, given facts that will enable any one to readily determine a liorse's appropriate uses and his value. In this is included the very extensive chart for telling the age, and also the easy directions for ascertaining vices and unsoundness.

With the other donestic animals like information is given and with equal plainness. With these facts beforo him, so explicitly stuted and so exhaustively illustrated, any one can soon learn to buy to advantage. We have endeavored to guard the unsuspecting against the arts of the jockey, and to point out so plainly the difference between an elegant and common horse, a good and bad one, a sound and unsound one, an old and a young one, a vicious, dangerous horse, and a kind, tractable one, that any person may easily learn to protect himself against imposition. The same plan has been sustained with the other subjects.

Hard names and technical terms have been avoided as much as possible, but when terms of anatomical and medieal science have been necessarily employed they are explained and applied with a degree of plainness and preeision that brings them within the ready comprehension of overy reader. 
To aid the non-professional owner in deciding the nature of disease, ongravings are given which show the positions in the different stages of various disenses, and which eannot fail to be of great value in determining the character of the disorder.

This prefuce ought not to be concluded without acknowledging the able assistance rendered in the preparation of this book by Hon. Jonathun Periam, of Chicago, whose great experience with stock, and as an agricultural writer, extending through a quarter of a century, has been of such advantage in its preparation. To his extensive infornation, praetical suggestions, and ready pen, overy department of tho work is indehted, and acknowledgments are hereby made.

To Prof. Ed. Porter Thompson of Bentonville, Arkansas, a graceful and prolitic writer, and a scholar of classical attainments, obligation is also expressed.

J. R. M

Nork.-The present edition of the Illustrated Stock Doctor is presented to the publio wlth various additions, which will doubtless be received as improvements. Prominent among them are the chapter on Bees, and varlous full-page illustrations. 


\title{
TABLE OF CONTENTS.
}

\author{
PART I. \\ THE HURSE, HIS HISTORY, BREEDS, CHARACTERISTICS AND \\ MANAGEMENT.
}

CHAPTER I.

IIS IISTORY AS A COMPANION AND GERVANT OF MAK.

Pagn.

Connected with Man from a Very Early Age.-Hls Importance as a Helper in the Work of the World.-His Snperiority Over the Other Animals.-The Horse and Hile Rlder beoome in Some Measure ony Creature.-Hls Natlvity: Doubt Concernlog 1t.-His Exiatence upon Earth Probably Contemporaneous with that of Man.-The Most Anelent Authors Allude to Him.He Passes ln to Difrerent Parts of the Globe.-Wild Herds in the Esstern Continent.-Origln of the Wlid Herde in Americs.- Found as a Domestio among Nearly all People,-Grester Llability to Disenee In a Domestlo than In a Wild State. - Subject to Deterloration under Ignorant Management.-The Wladom of the $\Lambda$ rubs as Breeders and Keepere.-Direrence of Opinlon amoag Men as to Bystems of Breeding; Attention Called to its Treatment in thls Work. -Knowledge and skill necessary to Ills Proper Care.......................................

\section{CIIAPTER II.}

\section{ILLUSTRATED DESCRIPTION.}

Necessity for a Comprehensive Idea of the Constructlon of the Forse, and the Relatione of His Parts.-Sclentlfo Terms Used, but Explainod,-Subsequent Portlons of the Work More Readily Understood by Reference to this Chapter. -Knowledge of Structure Indispensable to Surgery.Skeleton; Scetional Vlew of Thorax, Abdomen, and Pelvls; Vertleal section of Head, Section of Foot, Front and Back Vlew of Foot; and External Parts............................. 38

\section{CHAPTER III.}

\section{HOW TO TELL $\triangle$ HORSE'S AGE.}

A Knowledge of Changes in the Teeth the Only Means.-This Chapter to be Studled In Connection with the Chart whloh Follows.-Bayers Likely, without this Knowledge, to be Deceived.-Inelsors Chleny to be Relled on.-Condition of a Foal's Mouth.-The Changes that Follow.-How Foal Teeth are wo be Distinguiahed from Horse Teeth.-Wearing a way of the Grinder or Enamaler Portion.-Number of Testh in a Full Grown Animsl.-Diference between Horses and Yares ae to Number.-Inclsors, Hooks, and "Wolf' B Teeth." How to Determine $A$ ige till Foul ls Two Yeare Old.-How from Two to Old $\Delta$ g8.-The Horse of Medium Slze to be Takeu as a Stand- 


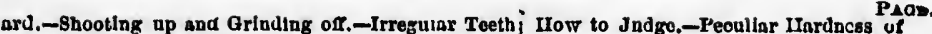
Bones and slowness of Change in Certain Urcede.-Tie Mules Aga Iard to Fird Out with Exactness.-Deceptions; How to Detect.-Crib Bitera: Ilow to Examine.-Terms defaed.

CHAPTER IV.

\section{DIFFERENT BREEDS AND THEIR CHAIACTERISTICS.}

I. 'She Inferior Varietlos: Many found in Both Henispheres. Some Guod, but Little Inown ot Them.-II. Some considered as to Work rather than Breed, the Farm IIorses tho Funter, tho Hackney ; Horses for Heavy Draft.-III. The Arabian.-IV. The English Thoroughbred.V. The Barb.-VI. The Persian.-VII. The Turk.-VIII. The Turkoman,-IX. The Egyptian.-X. The Dongoln.-XI. The Wild Horse of America.-XII. The Norman Percheron.-XIII. The Ciydesdale IIorse.-XIV. The Thoroughbred in Americn.-XV. The Morgan.-XVI. The Narragansett Pacer.-XVII. The Vermont Draft Horse.-XVIII. The Canadian. -XIX. The Connestoga.-XX. Ponies.

\section{CHAPTER V.}

\section{BREEDING AND RAISING。}

I. Importance of the Subject.-II. The Best Stock the Cheapeat.-III. Feroditary Tendencles and Immaturity to be Guarded Against.-IV. Princlples of Transmission.-V. The two Methode, "in-and-In" and "oross" Breeding Consldered.-VI. Treatmont of the Mare after being Served, During Pregnanoy, ete.-VII. How to Know whether a Mare is in Foal.-VIII. How to Know Time of Foaling,-IX. Abortion, or Slinking the Foal,-X. How to Raise Colts.-XI. Mules... 94

\section{CHAPTER VI.}

HOW TO BREAK AND TRAN A HORSE.

I. American va. English Foale.-II. At Wesning Time.-III. The Firat Lesson.-IV. Training. - V. Training to Work.-VI. Training to Back.-VII. Training to Saddle and Harness.-VIII. To Handle a Horse. - IX. How to Handie n Viclous Colt. $-X$. Saddling and Harnessing. $-X I$. How to Subdue a Vicious Horse.-XII. How to Traln to the Saddle.-XIII. Treining to Trot in Harness.-XIV. How to Train to trot in Light Harness. $-X V$. How to Train for tha Plow. $-X V I$. Training to the Wagon.-XVII. How to Train a Racer, $-X V I U I$. Training a Stallion............ 111

\section{CHAPTER VII.}

\section{HOW TO SHELTER.}

1. Comfortable Sheiter Eoonomlcal.-II. Consideration in Constructing Stables.-III. Mangers and Racks -IV. How to Insnre a Good Temperature.-V. Cleaning the Stables.-VI. The Loft.VII. The Harness Room.-VIII. The Out-shed.-IX. The Surroundings.-X. Water.

\section{CHAPTER VIII.}

\section{HOW TO FEED, WATER AND GROOM.}

1. Laying the Fonndation. - II. What to Feed.-III. When to Feed.-IV. Watering. $-\nabla$. Finds and Quantitles of Food to be Given.-VI. How to Prepare the Food.-VII. How to Make Mashes. Gruele and Hey-tea.-VIII. The Valne of Hay and Straw.-IX. Feeding Grain.-X. Stable Care and Grooming.-XI. The Time to Clean. -XII. Care of the Feet.-XIII. Blanketing, when Neoessary.-XIV. Proper Tools for the stable. 


\section{CHAPTER IX. \\ BENEFITS OF KIND AND CAREFUL TREATMENT.}

I. Abusing a Faithful Servant.--II. What are Barbarities.-III. A Picture from Llfe.-IV. The Other Sido.-V. A Good Farmer's Surroundings.-VI. Farmer Unthrif's Farm.-VII. His Home.-VIII. The Careful Man's Theory.-IX. Using the Means We Have.-X. An Infallible Rule.

CHAPTER $\mathbf{X}$.

How To BUY.

I. How to Get Correct Information.-II. The Buyer Must Know What He Wants.-III. Proportions of the Horse.-IV. The Cleveland Bay for Profit.-V. The Light IIaruess Horse.-VI. SaddIe Horses of all Gaits.-VII. The HIigh-Bred IIunting Horse.-VIII. Racing Horses.IX. What the Racer Should be,-X. To Avoid Vices and Defects; How to Detect.-XI. Other Faults and Imperfections.

CHAPTER XI.

HOW TO BUY, CONTINUED.

I. Buying Cheap Horses.-II. Color, in relation to Value.-III. Áction.-IV. Fast walking Horses.-V. What a Horse shouId be.-VI. What Constitutes Unsouudness,-VII. Definltion of Unsoundness.-VIII. IlIustration of Form and Symmetry.-IX. The Body and Limbs.-X. The Body as Standing Facing You.-XI. Front View of Fore-quarters.-Showing Different Bad Conformations.-XII. The IIind-quarters.-XIII. The View from Behind.-XIV. What Not to Buy.-XV. Buying for BIood...

\section{CHAPTER XII. \\ RACING, OR TURF HORSES.}

I. Early Aistory of the English Blood Horse.-II. How Ile was Improved.-III. The American 'Blood Horse.-IV. Celebrated American Horses.-V. History of Their Performances.-VI. Training to Trotting.

\section{PART II.}

\section{DISEASES OF THE HORSE. THEIR CAUSES; HOW TO KNOW THEM, AND HOW TO CURE THEM. \\ CHAPTER I.}

I. Introduction.-II. External Manlfestation of Disease.

\section{CHAPTER II.}

DISEASES OF THE SKIY AND SUB-CU RANEOUS TISSUES.

I. Scratches.-II. Grease.-III. Thrush.-IV. Swelled Ankles.-V. Swolled Legs.-VI Surfelt. VII. Mange.-VIII. Ring-worm.-IX. Hide-boun1. $-X$. Saddle Galls, or sltfusts.-XI. Yungous Collar Tumor.-XII. Warte.-XIII. Vermln.--XIV. Larva in the Skln.-XV. Tetter... XVI. Rat-talle.-XVII. Mrollenders end Sallenders,--XVIII. Poll-evll,-XIX. Fistule.

CHAPTER III.

DISEASES OF THE GLANDS AND NASAL MEMBRANES.

I. Glanders.-II. Farcy-III. Dlstemper.-IV. Nasal Gleet.-V. Naeal Polypus.. 
CHAFTER IV.

\author{
DROPSICAL AFEECTIONS.
}

I. Dropsy of the Heart.-II. Drepsy of the Brain.-III. Dropey of the Chent.-IV. Dropey of the Skin of the Chest.-W. Dropey of the Serotum. -VI. Dropsy of the Abdomen.................. 313

\title{
CHAPTER V.
}

DISEASES OF THE THROAT, CHFST, AND LUNGS.

I Chest Founder.-II. Bronchltis.-III. Pneumonia, or Inflammation of the Lnngs.-IV. Consumption.-V. Plourlsy.-VI. Colds.-VII. Eularged Glands.-VIII. 8welled Throat. - IX. Chronio Cough.-X. Malignaut Epldemjo.-XI. Diflculty of Breathing.-XII. Broken Wind, Bellows, Heaves.-XIII. Influenza.-XIV. Spasmodlo Aotion of the Glottle and Epiglottis.XV. Croup. $-X V I$. Blecding from the Nose. $-X V I I$. Strangies.

\section{CHAPTER VI.}

DISEASES OF THE STOMACH AXD BOWELS.

I. Sour Stomach.-II. Collo,-III. The Bot.-IV. Infiammntion and Rupture of the Colon. -V. Infismmation and Bleeding of the Rectum.-VI. Spontaneous Sallvation.-VII. Inflammation of the Stomach.-VIII. Soreness and Itching of the Anus.-IX. Chronic Gastritis.-X. Spasm of the Dlaphragin.-XI. Rupture of the Stomach -XIt. Gorged Stomach.-XIII. Inflammation of the Peritoneum.-XIV. Strangulation of the Iatestines, $-X V$. Functlonal Diseases of the Liver. -XVI. Parasites whlch Afreot the Intestines - XVII. Dinrchos......................... 34

\section{CHAPTER VIT.}

UISEASES OF THE LIVER, URINARY ORGANS, \&C.

I. Jaundice.-II. Entargement of the Spleeu.-III. Infammation of the Kidneys.-IV. Profuse Staling, or Dlabetes.-V. Bloody Urine, or Hamaturia.-VI. Thick and Albuminons Urine.V1I. "Vhite or LIme Urine.-VIII. Gravel, or Stone In the Bladder.-IX. Suppression the the Urine.-X. Inflummation of the Bladder-XI. Foul Sheath.-XII. Rupture of the Bladder.XIII. Spasm of the Urethra.-XIV. Infammation of the Organe of Generation.

\section{CHAPTER VIII.}

DISEASES OF THE TEETH AND MOUTH.

I. Teething, or Dentition.-II. Shedding Teeth -III Blind Teeth.-IV. Decay of the Teeth.-V. Scurvy. - VI. Stump-sucking, or Crlb-biting. - VII. Lampas.- VIII. Infammstion in and $\Lambda$ round the Teeth.-IX. Slavering.-X. Infammation of the Tongue.-XI. Sharp and Projecting Teeth.-XII. Scald Mouth.--XIII. Aptha.-XIV. Inflammation of the Parotld Gland.-XV. Fiatula of the Parotid Duct

\section{CHAPTER IX.}

DISEASES OF THE HEART, BLOOD, zo.

I. Thumpa.-II. Scrofala.-IIr. Fever, or General Intammation.-IV. Enlargement of the IIeart. -V. Fatty Degeneration of the Feart.-VI. Ealargement of the Arteries.-VI1. Inflammation of the Jugular Vein.-VIII. Infammation of the Abeorbents.-IX. Scarlatina.

\section{CHAPTER $\mathbf{X}$.}

DISEASES OF THE BRAIN AND NERVOUS SYSTRY.

I. Hydrophobia, or Rabies.-If. Mad Staggers, or Phrenitis,-III. Blind Staggers, Megrims, or Vertigo.-IV. Apoplexy, or Sleepy Staggers.-V. Abscess within the Brain. 
DISEASES OF THE MUSCLES AND TENDONS.

I. Blood Spavin.-II. Bog Spevin.-III. Curb.-IV. Thorough-pln.-V. Tetanus, or Lockjaw..-VI. Cramps.--VII. Rhenmatism.--VIII, String-hait.

\section{CHAPTER XII.}

DISE.ISES OF TIIE EYE.

I. Naturally Weak Eyes.-II. Sore Eye-lids.-III. Moon eyes.-IV. Cataract.-V. Hooks or Inflammation of the Haw.-VI. Dimuess of Vision.-VII. Worms in the Eye.-VIII. Purvlent Ophthalmia.-IX. Fungoid Tumors in the Substance of the Eye.-X. Impediment in the Lachrymal Duct.-XI. Gutta Serena..

\section{CHAP'TER XIII.}

\section{DISEASE3 OF TILE BONES.}

-V. Inimation of Spasm of amation of the Liver.

eeth.-V. in and Projectnd. $-\mathrm{Xv}$.

egrims,

I. Big Head and Blg Jaw,-II. Sweeny of the Shoulder,-III. 'Sweeny of the Hlp.-IV. Bone Spavin.-V. Enlarged Hock.-VI. --Rlug-bone.-VII. Stlfle.-VIII. Splint.-IX. Sore shlps, Inflammation of the Metacarpal Bones.4X. Rotten Bodes.-XI. Inflammation of the Knee Bone. XII. Caries of the lower jaw.

\section{CHAPTER XIV.}

DISEASE 3 OF THE FEET.

I. Ulceration of the Foot (navicular disease).-II. Cracked Hoof.-III. Hoof Rot.-IV. Corns.-V. Contraotion of the Hoof (narrow heel).-Vir. Injurles of the Frog.-VII. Fonnder.-VIrr. Nall Pricklóg,-IX. Canker. $-X$. Saod Crack. -XI. False Quarter -XII. Quittor. -XIII. Toe Crack -XIV. Pumice Foot.-XV. Seedy Toe.-XVI. Ossifed Cartilages.-XVII. Side Bones. XVIII. Inoised Wounds of the Sols......

\section{CHAPTER XV.}

\section{WOUNDS AND INJURIES AND THEIR RESULTS.}

I. Strains and Sprains, -II. Orerreach. -III. Brushlng, or Speedy Cut.-IV. Broken Rnees._V. Capped Elbow.-VI. Frost-bite.-VII. Burns and Scalde.-VIIr. Rupture.-IX. Choking.-X. Wounds Penetrating the Abdominal Cavity.-XI. Contused Wounds.-XII. Lacerated Wounds.-XIII. Punctured Wounds.-XIV. Broken Hock.-XV. Dislocations,-XVI. Various Fractures.-XVII. Various Distortions,-XVIII. Diseases of the Ear.

\section{CHAPTER XVI.}

\section{PoIsons.}

I. Internal Poison.-II. Poisoning from Stings,-III. Poisoned Skin.

\section{CHAPTER XVII.}

\section{VETERINARY SURGERY.}

I. Catzating.-II. Bleeding.-IIr. Tracheotomy.-IV. Perlosteotomy,-V. Nenrotomy.-VI. DIvision of the Tendone, to , do., to. 


\section{CHAPTER XVIII.}

\section{MIISCELLAXEOUS AITIOR DISEASES.}

1. Melanosig, or Biact Pigment Tumors. -II. Eplthelial Cancer.-III. Dropey of the Lungs.,IV Stugs and Bites, -V. W.ling off of the Fiair.-VI, Aeute Irritation of the Skin.-VIr. Hardening of the Skia.-VIII. Exotosis of the Lower Jaw.-IX. 8welling, by Pressure of the Bridie.X. Sore Nose._XI. Roaring, or High Blowing.-XII. Wind Gelis.-XIII. Rupture of the Fum string.-XIV. Broken Wind.-XV. Internal Hemorrhage.-XVI. Partial 1'aralysis.

CHAPTER XIX.

Medieines: What to Keep; Ilow to Obtain; How to Prepare; and How to Give Them. 500

\section{CHAPTER XX.}

Implements: What to Keep; How to Use

\section{PART III.}

\section{CATTLE.}

\section{THEIR HISTORY, ORIGIN, BREEDS AND CHARACTERISTICS, MANAGEMENT AND CARE.}

\section{CHAPTER $Y$}

\section{NATURAL HISTORY OF CATTLE.}

Their Origin.-Early Domestication.-The Different Kinds and Their Peeuliarities.-Improved Breeds.-Devons,-Herefords.-Sussex.-Short IIorns.-Alderneys.-Ayrshires.-Holsteins. -Kerry Cows.-Polled Cattle.-Galloways.-The Cherokee or Texas Cattle, Etc., Etc... ..... 519

\section{CHAPTER II.}

BREEDING AND FEEDING.

Grasses,-Best Breeds.-IIow to Breed.--General Utility.-Breeding in Line.-Form and Quality.-Practical Suggestions,_Breeding Grndes.-Start the IIerd.-Ten Years' Produce.Selection.-Comnon-Sense.-Gestation of Cows.-Feeding Standards.-Ration for Mileh Cows.-Raising Young Cattle.-Castration

\section{CHAPTER III.}

TRAINING AND WORKING.

Training v8. Breaking.-Training the Calf.-Haltering.-Training to Mrllk.-Feeding at Milking Time.-Viclousnees in Cews. - Hooking Cows. - Training Oxen. -Train Stonk Young. - Summlug up.-Managlng a Kleking Cow...

\section{CHAPTER IV.}

\section{HOW TO SHELTER.}

Necessity of Shelter.-Artinclal Protection.-A Framed Stable.-A Cheap Stable.-Abont Barns.A Common Bense Barn.-A Bquare Cross Baru.-Basements for Cattle.-Arranging the Basement.-Adapting Means to the End. - What to Plant. 


\section{HOW TO PASTURE, FEED AND WATER.}

Alsout Paaturage.-Clovers that do Well -Undesirable Clovers.-AJfals.-The True Grasses. 't'imothy, or Cst's Tail Grass.-BIne Grass.-Red Top.-Orchurd Grase,-Fowl Meadow Grase. -rime for Pssturing. - Watering. - Feeding Stoci Cattle.-How to Feed.-Feeding Mlich Cowa.. 675

\section{CHAPTER VI.}

\section{BENEFITS OF KIND AND CARETUL TREATMENT.}

Feeding for Profl.,-As between well and ill Kept stock.-Heavy Welghts.-Profit In Early Maturity.-Make Beef Xoung.-Baby Beef.-Feeding। Cost In Engiand.-Summer Feoding.-Animal Waste.-Animal Heat.-Advantages of Summer and Winter Feeding.

\section{CHAPTER VIr.}

HOW TO BUY AND HOW TO SELL.

The Valne of Good Care.-Estimating Welght.-Estimating by Mresenrement.-Bnying to Feed.How to Buy Breeders. - Where Good Beef Lles.-Buying Feeding Stock.-Analyzing the Cercass. -Proper shape of Well-Bred Fattening stock.-How to Buy.-Buying Mrlich Cows.-Buying Dairy Milkers.-Milk Mirrors.-The True Vslue of Mtlk Mirrors.-Valne of Escntcheon Marks.Milkers in all breeds.-Heredity.-Digestion.-Respiration._Milk Veins.-Veins of the Udder.-Judging Age by the Teeth.

\section{CHAPTER VIII.} TILE DAIRY.

Jushing into New Industries.-The Importance of Dairsing.-Estimated Production of Butter and Cheese.-Conditione Necessary to Dalrying.-How to Bulid.-Sub-earth Ventllation.-Care of Milk.-Modern Home Dairies.-Animal Odor.-Temperature.-Various Methods of Raising Cream.-Making Dairy Butter.-Salting Butter.-Washing or Working Butter.-Packing Buticr.-Prcparing Packages.-Kind of Salt to Use.-Cheese Making.-Cheddar Cheese.Cheshire Cheese.-How to Sell Butter.-Utilizing Waste Products.

\section{PART IV.}

\section{Diseases of Cattle.}

\section{THEIR CAUSES; HOW TO KNOW THEM; WHAT TO DO.}

t Mrilking Summlug

-

Barne.he Base-

\section{CHAPTER I.}

\section{DISEASES IN GENERAL_RECOGIUZING AND DISTINGUISIING THEM.}

Furmers Should Understand 8ymptoms.-Oe Disesses in General.-Use Common Sense.-GraduaIion of Doses.-Frequency of Administering.-Formg of Doses.-How to Give Medicine.Injectlons.-Vapors, Spraying and Fumigstion,-Anæsthetics.-To Deprive of Sensation.Blistering.-Wing.-Setons.-Rowels.-Sewing up Wounds.-Fomentations.-Operation of Bloeding. - Recogniaing and Distingniahing Illseases.-The Puise.-The Breathing. -The Animal Hest.-The Skin and Hair,-The Posture.-Indications of Pain.-Speolal signs in Cattle. 
CHAPTER II.

PAe.

\section{GESTATION, DISEASES AND ACCIDENTS THEREOF.}

Plural and Multiple Gestation.-Treatment During Gestation.-Birth.-Prolonged Labor.-Large Presentation.-Unnatnral Positions of the Calf.-Flooding.-Presentation of After-birth.-Inversion of the Womb.-Languid Labor.-Irritability and Straining.--Temporary Paralysis.-Abortion.-Isolation.-Milk Fever.-Mammitis.

\section{CHAPTER III.}

\section{INFECTIUUS, CONTAGIOUS AND EPIDEMIC DISEASES.}

Pneamonla.-History.-Its Mallguant Coutagiousness.-Defnition.-How the Infection enters the System.-How Long is a Diseased Animal Infections. - How to Kuow it. -What to do.-Texas Fever.-How to Know it._Bloody Murrain.-Its Mallgnant Character.-Preventives.-What to do,-Foot and Mouth Diseases.-Malignant Catarrh.-Lice,-Fouls.

\section{CHAPTER IV.}

MEDICINES AND INSTRUMEXTS: WHAT TO KEEP.

1. Dlssection.-II. Aotion of Medioines.-IIr. Mediclnes to be Kept, ana Doses.-IV. Simple and Valuable Recipes.-V. Forms of Clysters.-VI. Infusiona.-VII. Antl-Spasmodics.--VIII. MuL oliages,-IX. Washes.-X. Poultices,-XI. Fumigatlone.-XUI. Tincture for Wounds.......... 773

\section{PART V.

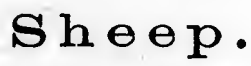

THEIR HISTORY, BREEDS, CHARACTERISTICS, BREFDING AND MANAGEMENT.

CHAPTER I.

ORIGIN, PRINCIPAL BREEDS AND CHARACTERISTICS.

Cosmopolitan Naturo of Bheep.-Long-Wooled 8heep.-I. Lelcester.-II. Borler Leicester.-III. Cotswold.-Good Qualities of Cotswolds.-Cotswolde in the West.-IV. Lincoln 8heep -V. New Oxfordshire sheep.-VI. Middle-Wooled sheep.-VII. Chevlot sheep.-VIII. White-Faced Highland 8heep.-IX. Dorset Sheep.-X. Southdowns.-XI. Inmpshire Downs.-XII. Shropshire Downs.-XuI. Oxford Downs,-Fine-Wooled Bheep.-XIV. American Merinos.-The Fleece,-The Head,-The Body.-The Most Proftable Sheep-Divlsions of Wool

\section{Chapter II.}

\section{BREEDING AND MANAGEMENT OF GHEEP.}

Watchtniness Necessary.-How to Breed. -Time for Breeding.-Coupling. -Keeping the Record.The Management of Rams, - Training Rams.-Pasturing sheep.-Shade in Pastures.-Water.Dosing Sheep.-Fall Pasturage and Feeding.-Sheep Barns. - Special Winter Food.-Management of Lambs.-Dooking Lambs.-Castration.- Weaning.-The Nursery. 


\title{
PART VI. \\ Diseases of Sheep. \\ HOW TO KNOW AND HOW TO CURE.
}

\author{
CHAPTER I.
}

ANATOMY AND DISEASES OF SHEEP.

The Fead.-The Trunk.-The Fore-Leg.-The Hind-Leg.-Importance of the Iread to Breeders.Diseases of the Head and Brain, -The Teeth. - Swelled IIesd.-Vegetable Polsoning.-Intammation of the Eye. - Sheep Distemper.-How to Know it. - What to do.-Grubs in the Head.-How to Bave the Sheep.-Apoplexy.-Prevention.-Inflammation of the Brain.-Tetanns, or LockJaw.-Pelsy.-Rables.-Hydatids on the Brain,-Parasites of the Body and Skin.-The Scab.How to Know it.-Disesses of the Generative and Urinary.Organs.-Diseases of the Limbs and Hoof, - Foot Rot.-How to Cure it. -Fouls, snd Travel-Sore Feet.-Gravel,-The Bifex Canal. Maggoty Sheep.-Lung Vorms.-Intestinal Worms.-Rotten Llyer.-Collo

\section{PART VII.}

\section{S wine.}

\section{HISTORY, BREEDS, CHARACTERISTICS AND MANAGEMENT.}

Drigin of the Hog.-Teeth of the Hog.-Importance of Swine to Man.-I. Improved Breeds of Swine.-English Breeds.-II. The Berkshires.-Establishing the Improved Berkshire.-Standard Charasteriatice of Berkshtres.-III. Neapolltan Hogs.-IV. Essex Breed.-V. Yorkshire Hog.-VI. Snffolks.-VII. Lancashire Ilogs.-VIIr. Lancashire Middle-Breed.-IX. Large Lancashire. - Lmerican Breeds.-X: Polend Chins.-XI. Chester Whites.-XII. Jersey Reds. -Chesnires._XIII. Charaoteristics.-Recapitulation of Breeds.

\section{CHAPTER II.}

\section{BREEDING AND MANAGEATENT.}

Importance of Swine.-A Back-Woods Hog.-Fixing and Holding the Chsreoteriatice - Selection Always Important.-Breeding $\Delta$ ge of Ewine.-Care of Breeding Sows.-Weaning.-Mnnagement

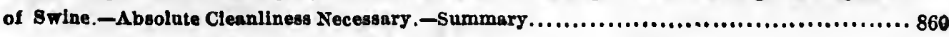

\section{CHAPTER III.}

\section{FEEDING AND SHELTER.} Bonth.-Mast.-Feeding in Confnement.-Hog Barns.-A Cross Barn.-A simple Pen.-sum-

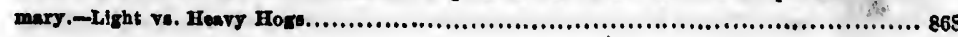


PART VIII.

PAQE.

\author{
Diseases of Swine. \\ HOW TO KNOW AND HOW TO CURE THEM. \\ CHAPTER I. \\ DISE ASES OF SWINE.
}

Vxyianulton of Cat.-Dimoulty of Adminiatering Medicine.-Good Nuraing the Essential.-Malle nant and Contagtous Diseases.-Mslignant Eplzont to Cstarrh.-How to Know It.-What to do.-. Inteatinal "Heg Cholerw," - How to Know It. - Csanes. - Treatment. - Prevention. Contaglous Pnenmo-enteritls. - Its Origin. - The Erysipeletous Form. - The Form with Mulignsnt Throat. - What to Do. - Malignsnt Anthrsx, splealo Fever. - True Charbon. -Infammatory Diseaces.-Quiney, or Strangles.-Rising of the Lights.-Pneumonis.-Catarrh in the Head.-Diseases of the Bkin. - Meables -How to Know It.-The Lard Worm.-What to do. -Trtchlna Spiralis.-How to Cure-Lice.-Disrrhea.-Summary.

\title{
PART IX. \\ Poultry.
}

HISTORY; BREEDS, THEIR CHARACTERISTICS; BREEDING AND GENERAL MANAGEMENT.

\section{CHAPTER I.}

History and Wild Trpes.

CHAPTER II.

VARIETIES OF B.IRN-TARD FOWLS.

t. Dorzing Fowl3.,Il. Shver Greg Dorkings,-III. Blnek Dorkings.-IV. Fawn.Colored DorkInga.-V. Bolton Greys.-VI, Dominique Fowls.-VIl. 1'jymouth Rookn.-VIIf. The Ostrich Foivls.-IX. Hambnrg Fowls.-X. Black IIamburgs.-XI. Legborns.-XII White Leghorns. -XIII. Spanlsh Fowls.-XIV, French Fowls.-XV, The Houdsns.-XV1. La Fleche Fowls.XXIr. The Creve Cours.-XVIIr. Laige Aslatlo Breels.-XIX. The Chittagonga.-XX. Jür Cochins.-XXI. Partrldge Cochins -XXII. White Cochlns.-XXIII. Brabma Fowis.-XXIV. Light Bruhmns.-XXV. Frizzled Fowla.-XXVI. Silkies.-XXVII. Breda or Guelder Fowls.XXVIII. Game Fowls.-1. Brown-breasted Reds.-2. Earl Derby Gnme.-3. Dack-winged Gsme.-4. White Georgian Game.-6. Gsme Bantams, -6. Other Bantams -7. Seabright Bantams. -8. Japanese Bantsms................................................. 908

\section{CHAPTER III RREDEIxG.}

The Plumage.-Ideal Shape.-Breeding to Type,-Disparlty of Sexes.-Mating.-Breeding Grades. 934

\section{CHAPTER IV.}

\section{MAXAGEMENT OF FOWLS.}

Going Into Business.-Villego Yarus.-The Ponltry IInike.-Proper Food for Fowle.-Best Breeds For Market - Igg Produoers.-HuW to Futten.-How to klll and dress Fowle.-Packing sor "urket. 
TUE IIOSE OF TIE 'URKEY.

Verietles of the Domestio Turkey.-I. The Common Turkey,-II. Eagltsh Turkey.-III.-The IIoudures Tarkey.-IV. Bronzed-Black Turkey.-V. Gulnea Fowi -VI. The Peacock.

\section{CHAPTER VI.}

DUCKs.

1. Ronen Dacks.-II. Ajleabury Duck8.-III, Csll Ducks.-IV. Cayuga Blaek Dacka.-V. Fancy Dooke -VI. Black East India Ducks . - Summary

\section{CHAPTER VII. \\ GEESE.}

I. Embden or Bremen Geese.-II. Toulouse Geese.-III. IIong Kong Geese.-IV. Whtte Chivese Geese.-V. Afrlean Geese.-VI. Canada Wild Geese.-Wanagement of teese.

Glossary of Terms Used Dy Fanciers and Breeders

\section{PART XI.}

\section{BEES: THEIR HISTORY, CHARACTERISTICS, AND MANAGEMENT}

\section{CHAPTER I.}

Classlfiention of Bees and Hiatory.-Qneens, Drones, und Workers.-Stages of Bee-Life.-The Qucen.-Products of Bees.-Management.-Old and New Styles.-Honey Extractor.-Wax Extractor.-New Races of Bees.-Prospects of Bee-Culturc.-Starting an A piary.-Hives.Transferring Bees,-The Bee-Snioker,-Location of the Apiary.-Bee-Veils.-Example of Suecessful Bee-Keeping.-The Way to do it.-Settlng out Hives.-Artificial Swarming.Introducing Queens,_Extracting Comb-Honey,-Treatment of Comb-Honey.-Wintering.. 979

lored DorkThe Ostrich e Leghorns. he rowis.. XX. 33nr vls.-XXIV. er Fowls.ack-winged bright Ban-

\section{PART XII.}

\section{THE DOG: HISTORY, BREEDS AND CHARACTERISTICS.}

\section{CHAPTER I.}

Origin of the dog.-Usefulness of the dog to man.-The English Setter.-The Irish Setter.-The Gordon Setter.-The Native Setter.-The Dropper.-The Pointer.-The Spaniel.-The Newfoundland dog.-The Mastiff.-The Bull dog.-The Blood hound.-The Fox hound.-The Beagle.-The Sheep dog.-The Greyhound.-The Dalnatian or Coach dog.-The Seoteh Terrier.-The Eaglish Terrier.-The Skye Terrier.-Tlıe Poodle.

\section{CHAPTER II.}

Choice of Sire and Dam in Breeding.-Age to Breed.-Time of Year to Breed.-Management of Bitch in Season.-Duration of Heat.-Manngement of Bitch in Whelp.-Whelping.Care of Whelps.-Weaning.-Feeding.-Training of Pointers and Setters.-Training of Spaniels. -Training of Hounds,-Training of Vermin Dogs.-To Prevent and to Break from Gun Shyness.-Hunting a Bitch while In Whelp. 
xviii TABLE OF CONTENTS.

\section{CHAPTER III.}

\section{DISEAgES OF DOGS AND THEIR TREATMENT.}

Treatment of Asthma.-Bronchitts.-Common Cold.-Influenza.-Pleurisy.-Pneumonia.Consumption.-Rheumatio Fever.-Distemper.-Inflammation of the Stomach,-Inflam. mation of the Iiver.-Inflammation of the Bowels.-Mange.-Canker of the Ear.-Flees and Lice.-Chorea or Jerks.-Fits.-Worms.-Rickets or Large Joints.-Tumor and Cancer.Puerperal Fits.-Protracted Labar.-Sprains,-To Harden Tender Feet.-Rabies or IIydrophobia.. 


\section{ILLUSTRATIONS.}

imonia.-Inflain. -Flees and Cancer.zables or . .1025

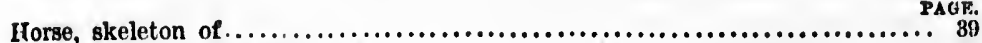

" longitudinal section of....................................... 42

IIorse's heal, vertical section of....................................... 43

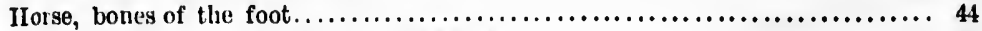

" " " sectional view of ................................ 44

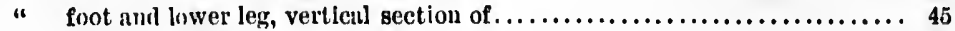

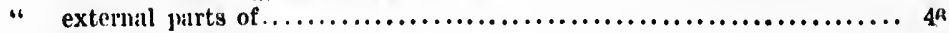

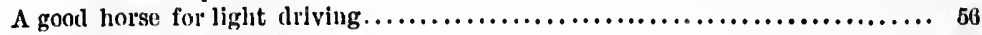

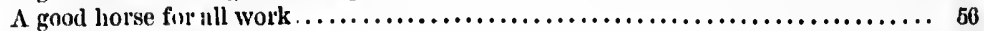

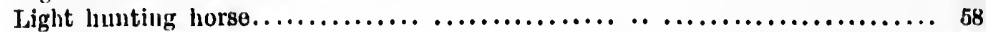

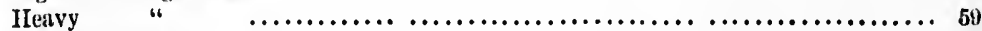

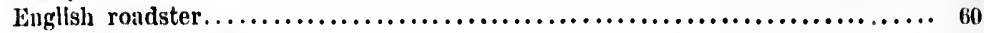

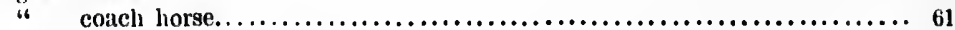

Gen. Grant's Arabian Stallions...................................... $6 \tilde{5}$

English race horse, Eclipse.......................................... 69

Norman Percheron stallion............................................. 75

" " mave

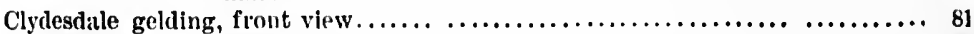

" " rear view............................................ 82

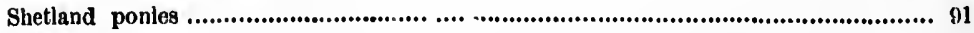

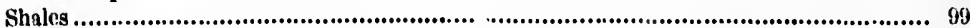

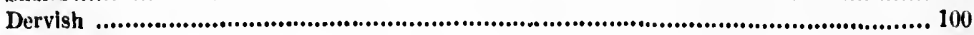

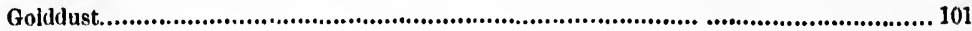

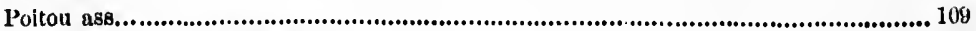

Horse's head with bearing-reln............................................................................. 124

" withont " .......................................................................... 124

Tenm of the cruel and Improvldent master.................................................................... 146

" " kind and careful master.................................................................. 147

Barn of the provilent master......................................................................... 149

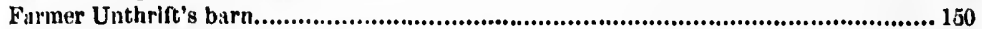

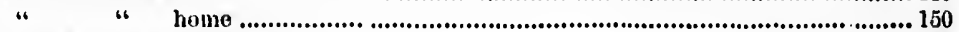

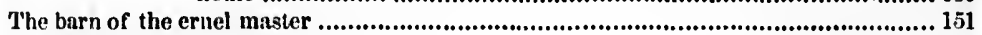

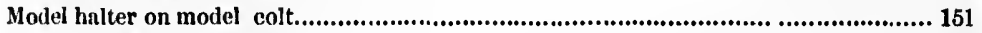

Team of the kind master .......................................................................................... 158

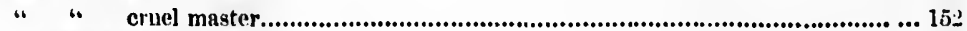

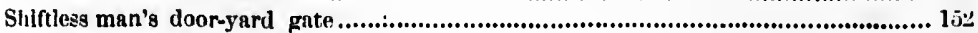

" " field gate.......................................................................................... 16:

Iligh-bred roadster......................................................................................................... 156

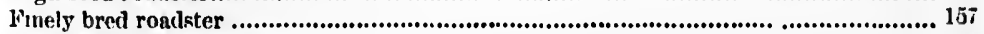

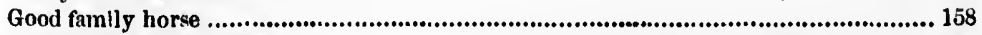

Proportions of the horse......................................................................................... 159

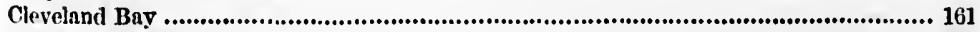

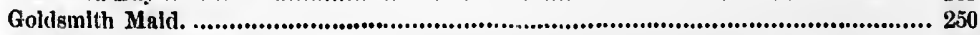

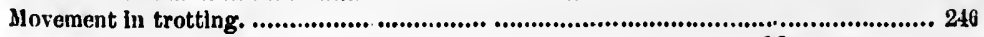


PAaE.

Fine trotter in light harness .......................................................................... 164

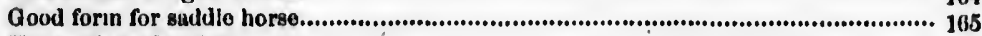

Horse of good actlon................................................................................... 166

Model form for speed ill running ..................................................................... 108

Progresslon of bllnd horse ...................................................................... 171

Movement in walking ............................................................................. 170

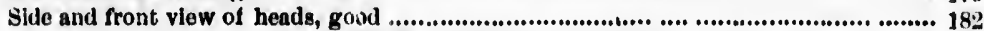

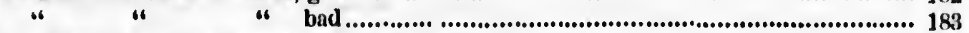

Slde viow of for quarters, slowing good slsoulder............................................ 184

"1 " " bad conformation........................................ 186

Frout vlew, showing breast and limbs, good................................................... 18i

" of fore-quarters, showing bad conformitlons...................................... 191

Good hind-quarters.................................................................................. 192

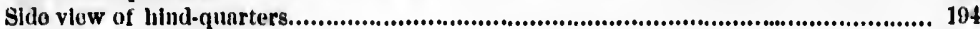

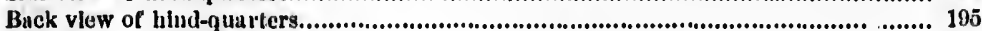

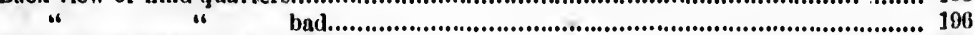

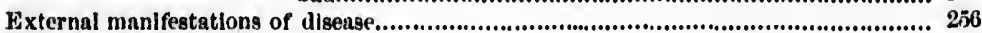

First stage of confirmed grease exudatioul........................................................ 203

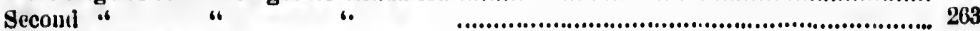

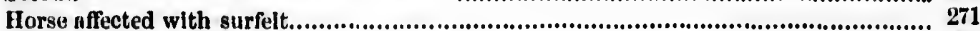

One of the csuses of hlde-bound In horses........................................................ 277

Poll-tvll durlng flrst stage.................................................................... 288

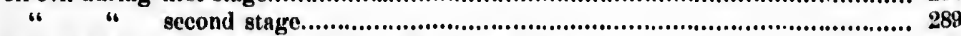

Slight enlargement, which muy end in tistulous withers..................................... 292

Fistulous withers, worst stage.................................................................... 292

A fit subject for founder or bronchitls......................................................... 321

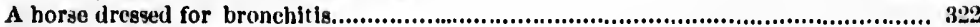

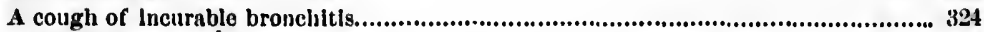

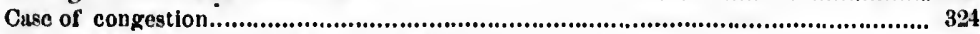

Position assumed by horse with an attaok of pneamonla...................................... 32 ;

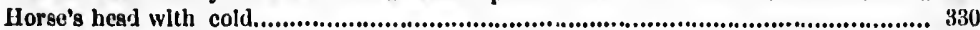

" of 4 lympluatio giand swolien...................................................... 331

Nose-bag for stemuing horse with cold ................................. 881

6. " the throat blistered............................................................... 333

Seton in the thront of a horse.......................................................................... 333

A horse quidding................................................................................... 334

'I'he act of conghing ............................................................................. 334

Bit betring upon jaw............................................................................ 338

Confirmed influenza...................................................................................... 339

Opening thic abscess of strangles...................................................................... 343

Tine first stage of spasmodlo collc.................................................................. 346

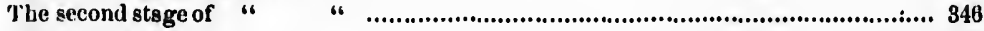

The third stage of "

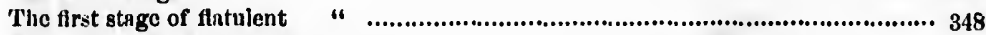

Ilorse dying of flatulent collo..................................................................... 348

Acstrus hemorrhoidalis............................................................................ 350

" eggs, lnrvis and fly................................................................... 350

Nose strsined upward......................................................................... 352

Application of an ammoniacal bilster............................................................ 353

Horse suffering irom acute gastritis.............................................................. 354

Unuatural attitude indlcative of abdominal Injury......................................... 358

Positinn assumed by horse suffering from abdontnal injury ............................... 358

Test for liemorrhage of the liver.................................................................... 360

Coit picking hair from its leg, giving proot of worms........................................ 361

Symptoms attending disease of trinary organs.................................................. 367

Test for Inflamination of the kidneys............................n............................. 866 
PAGE.

IIorgo suffering from bloody $n$ rine............................................................... 370

Postion assumed by horse having albumlnous urlne........................................... 371

Horse suffering with tooth-aehe................................................................ 380

Burning for lampas............................................................................... 381

Eftects of eruel use of bit........................................................................... 383

A ptha.................................................................................................. 384

Countenance of a horge wlth rables.............................................................. 400

Destruetlve Impulse of hydrophobla............................................................. 401

Horbe durlng the mad stage of staggers...................................................... $40 t$

Expresslon characteristic of megrlins........................................................ 409

A liorse dying with abscess within the braln ................................................... 414

$\Lambda$ horse mad Irom inflammation of the bralu............................................... 414

'Teat for tetanus......................................................................................... 419

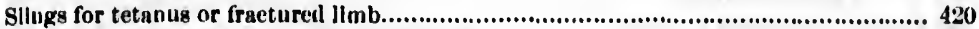

Mode of feeding horse with elironle tetainus.................................................. 421

Showing how far a horse wlth tetanus ls eapuble of motlon.................................. 421

Horse having string-hilt........................................................................ 424

Modu of bllnding a horse and upplying lotion to the eye.. .................................... 430

Extirpation of the eye.............................................................................. 432

Obstruction of the lachrynat glund............................................................. 433

Eye effected by gutta serena....................................................................... 434

Foot, Incapable of belng rulsed Irom grouml by reason of spavin............................ 439

Natural position of foot when rulsed from the ground during an ensy trot.................. 439

Closing erack in hoof................................................................................... 453

Acute fever In the feet................................................................................ 457

The low choke......................................................................................... 470

Manner of using seton needle................................................................... 408

A horse suffering Irom drastlc puleon........................................................... 482

Tumor caused by eurh chall........................................................................... 492

How to hear the sound made in a korse' 8 winclpipe............................................ 496

Internal hemorrhage..................................................................................... 497

Horse euftering fronı partial parulysls of the hlual ligg........................................ 498

Teeth of ox nt age of Ave years..................................................................... 520

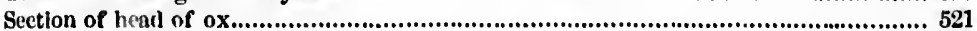

Devon bull " Wilmot " "............................................................................ 521

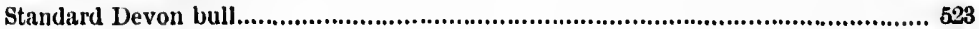

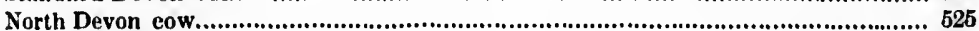

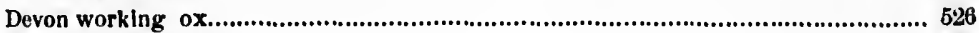

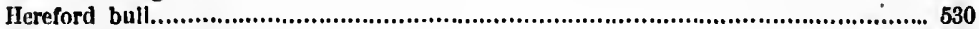

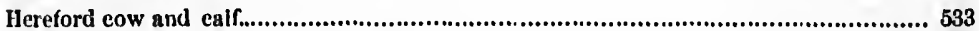

Susgex cow............................................................................................... 536

Durham bull and cow, old style................................................................... 538

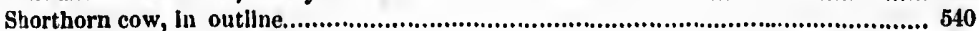

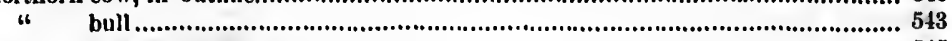

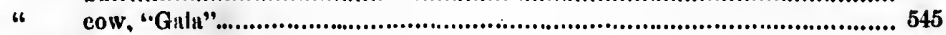

Yearllng Shorthorn bill........................................................................ 547

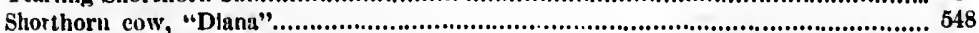

" bull, "Hiawgtha"”...................................................................... 551

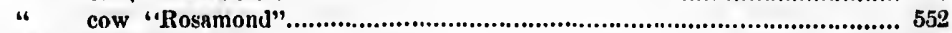

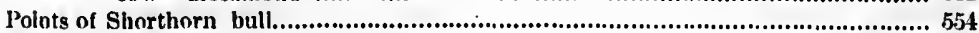

Jersey bull, "Comet"'................................................................................ 564

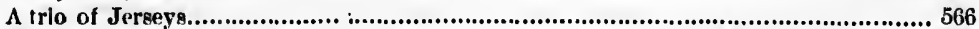

Model tow, perfeetion, polints Illısirated............................................................. 569

Jtrsey hull $"$ "

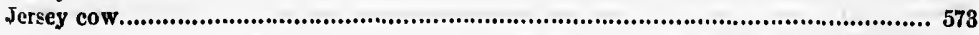


PAGE.

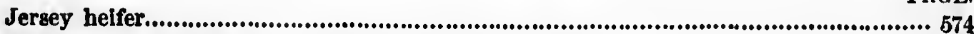

Modern Ayrshlre cow............................................................................ 577

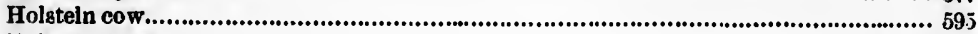

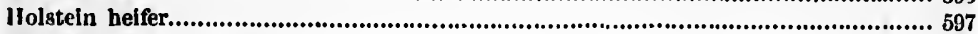

Holstein bull....................................................................................... 603

"6 of the Chenery milking gtock........................................................... 607

Prilied Angus cow..................................................................................611

Polled Angus bull.$\ldots \ldots \ldots \ldots \ldots \ldots \ldots \ldots \ldots \ldots \ldots \ldots \ldots \ldots \ldots \ldots \ldots \ldots \ldots \ldots \ldots \ldots \ldots \ldots$

A 'lexas steer...................................................................................... 616

Modifi: 'Texans, or Cherokee cuttle............................................................... 618

Working by main force........................................................................... 645

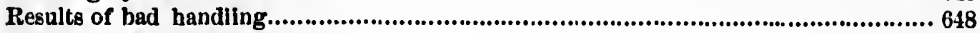

"1 of good handling............................................................................... 649

To prevent a cow from kicking............................................................... 651

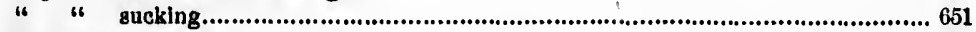

Harness to prevent sucklng...................................................................6...62 652

To prevent hooking..................................................................................6 652

A primitive tackle, but good trainer............................................................6 673

Old style farm yard................................................................................. 658

Farmer Thriftless' mode of protection.........................................................6 658

4 Thrifty's mode of protection..........................................................659 659

Prlmitive protection................................................................................. 658

Main floor of dairy barn...................................................................... 662

Plan of stables in basement........................................................................ 664

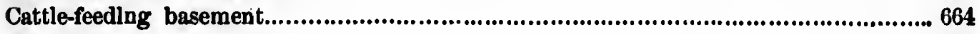

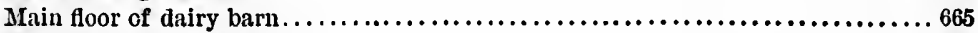

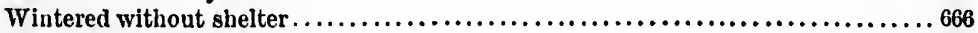

Wintered with gond shelter. ...................................666

Farmer Thrifty's cattle.......................................668

Farmer Slack's shelter.......................................669

A pastoral scene.................................................................................6 673

Earl Spencer's prize ox............................................................................ 698

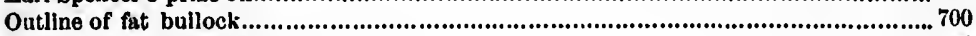

Mlik mirror of Jerseys.......................................................................... 704

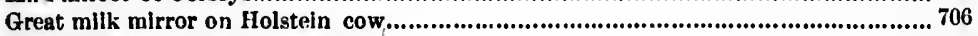

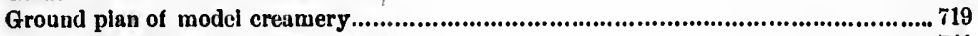

Application of steam to the nostrils........................................................... 741

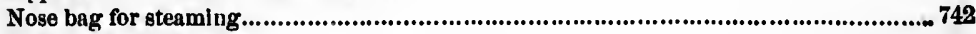

A pastoral scene.............................................681

To prevent inversion of the vagina $\ldots \ldots \ldots \ldots \ldots \ldots \ldots \ldots \ldots \ldots \ldots \ldots \ldots \ldots \ldots \ldots \ldots$

Malignant catarrh, second or gloughing gtage.............................................. 769

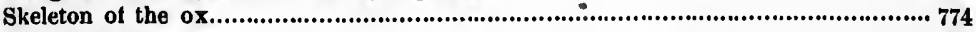

Points of sheep..................................................................................... 792

Leicester ewe and lamb......................................................................... 793

Lelcester ram........................................................................................ 794

Sheared Cotswold ram........................................................................... 797

Group of Cotswold ewes........................................................................... 796

Sheared Cotswoid ewe............................................................................... 798

Yearling Cotgwold..................................................................................... 799

Cotswold ewes.......................................................................................... 799

New Oxfordshire ewe.................................................................................. 800

Black-faced Highland sheep.................................................................... 801

Hlghland sheep..................................................................................... 802

Dorset ram............................................................................................. 803

Southdown ram........................................................................................ 803 
Hampshire Down.

PAGR

Oxford Downshire Ram

Group of American Merinos.

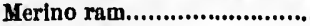

Division of wool.

Convenient feeding trough for sheep.

809

Allowed to shift for itself.

810

(1)......................................................................... 817

Wintered with good shelter and feed.

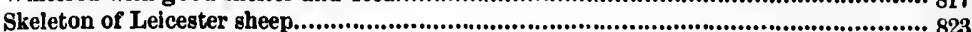

Skull of a polled sheep............................................................................. 825

Head of sheep, vertical section.................................................................... 825

A bad case of scab................................................................................. 832

Old China boar....................................................................................... 844

China sow................................................................................................ 845

Berkshire boar...................................................................................... 847

Essex boar................................................................................................. 849

Short-faced Lancashire hogg...................................................................... 852

Poland-China boar.................................................................................... 854

Chester white hogs

Improved Cheshire.................................................................................., 858

Backwoods hog.................................................................................... , 861

Berkshire sow, breeder......................................................................... . 865

Hazel splitter, sow.............................................................................. 866

Brecder in good flesh, gow.......................................................................... 878

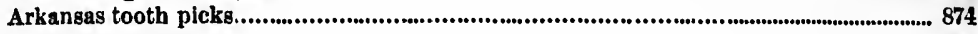

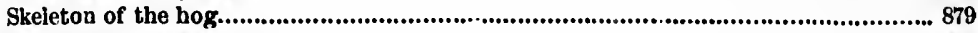

Creve Cœur cock and hen................................................................................. 895

Mexican wild Turkey................................................................................. 896

Embden or Bremen geese............................................................................. 897

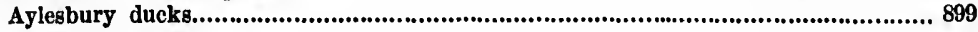

Galius Sonneratil.................................................................................. 900

Head of single-wattled Brakma fowl....................................................... 901

"6 Breda or Gueldre......................................................................... 901

White Dorking cock............................................................................. 904

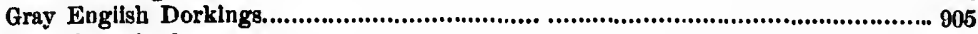

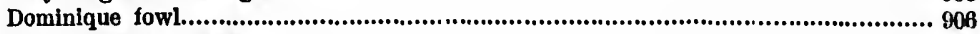

Plymouth Rock fowls......................................................................... 907

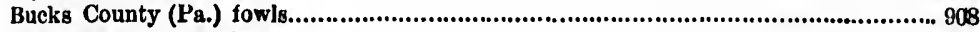

Black Hamburg fowls............................................................................. 809

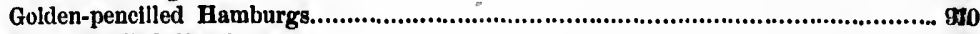

Sliver penclied Hamburgs.................................................................... 911

White Leghorns................................................................................ 912

Standard White Leghorns...................................................................... 913

Black Spanish fowis................................................................................. 914

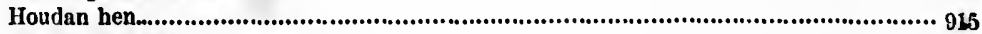

La Fleche fowls ..................................................................................... Gr6

Creve Cour fowls...................................................................................... 917

Buff Cochin cock................................................................................... 918

" " ben.................................................................................. 919

Psrtridge Cochins.................................................................................... 920

White Cochin fowis......................................................................................... 922

Dark and Light Brahmas.............................................................................. 923

Pair of Silky fowls.................................................................................... 925

Breda cock and hen................................................................................... 926 
PAG

Brown Breasted Red Game............................................................................ 927

Earl Derby Game........................................................................................ 928

Duck Winged Game fowls......................................................................... 929

White Georglan Games............................................................................. 830

Seabrlght Bantams................................................................................. 981

Barren Full-feathered hen................................ ............................................ 932

Japanese Bantam cock................................................................................... 939

"4 " pullet ............................................................................ 933

Polnts of poultry...... ......................................................................... 83.

Points of head of cock............................................................................. 935

Analysis of wing plumage......................................................................... 936

Polnts of the fowl.............................................................................. 837

llustration showlng points........................................................................ 938

Breeding to type......................................................................................... 940

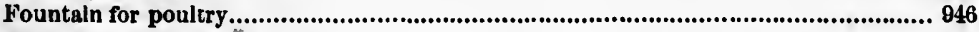

Wild turkey............................................................................................ 948

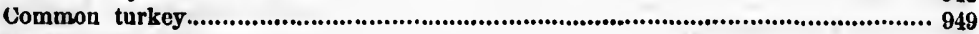

Ocelated turkey...................................................................................... 950

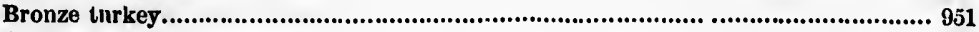

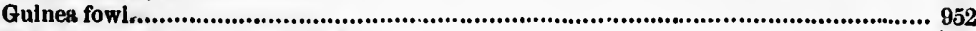

Peacock................................................................................................. 953

Ronen duck............................................................................................. 955

Aylesbury and Rouen ducks compared....................................................... 956

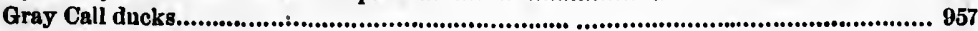

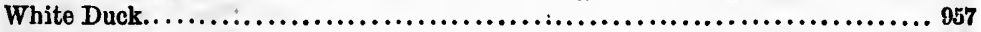

Cayuga Black dnck8...........................................................................958, 960

Rlack East India ducks............................................................................. 959

Aylesbury duck8.................................................................................... 961

Embden geese.............................................................................................. 963

Toulouse geese...................................................................................... 964

Hong Kong geese..................................................................................... 955

White China geese................................................................................... 966

African goose.......................................................................................... 967

Anatoing of the hen.............................................................................. 974

Bone of $\mathrm{leg}$ and foot of fowl................................................................... 974

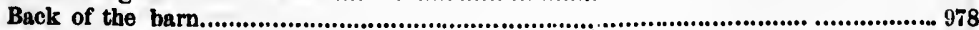

Straw Hive. ................................................. 979

Drone, Queen, and Worker. ..................................980

Comb Foundation. ............................................980

Egg and Brood $\ldots \ldots \ldots \ldots \ldots \ldots \ldots \ldots \ldots \ldots \ldots \ldots \ldots \ldots \ldots \ldots \ldots \ldots \ldots \ldots \ldots \ldots \ldots \ldots ., 981$

Honey Extractor $\ldots \ldots \ldots \ldots \ldots \ldots \ldots \ldots \ldots \ldots \ldots \ldots \ldots \ldots \ldots \ldots \ldots \ldots \ldots \ldots \ldots \ldots \ldots, \ldots \ldots$

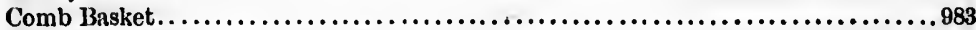

Wax Extractor.............................................. 984

Specimens of Queen Bees....................................... 984

Double-IValled Hive.......................................... 986

Pictu:e of D. A. Jones, the Bee-King, of Beeton, Ont.................986

Bee Smoker...............................................988

Bee Vail... .............................................. 988

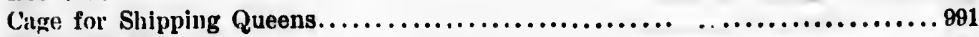

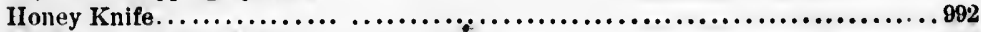

Wolf searching for food $\ldots \ldots \ldots \ldots \ldots \ldots \ldots \ldots \ldots \ldots \ldots \ldots \ldots \ldots \ldots \ldots \ldots \ldots \ldots \ldots$

English Setter.................................................1000

Pointer and Wounded Grouse......................................1006

Hunting Spaniel..............................................100e 
Newfoundland Dog rescuing a man..................................

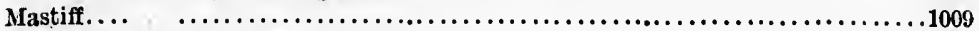

Mount St. Bernard Dogs...........................................1010

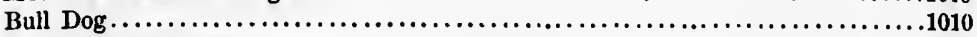

British Bloodhound..............................................1012

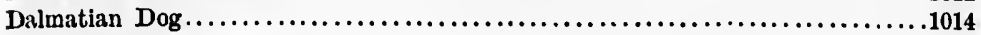

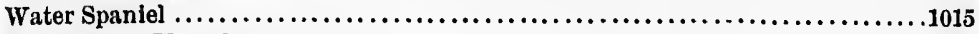

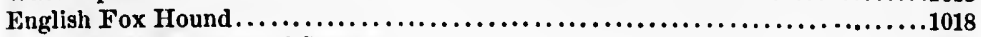

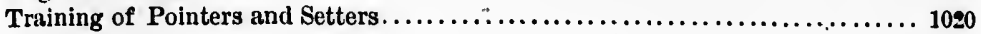

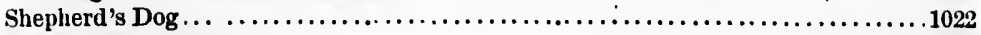

English Bloodhound.............................................1023

Gordon Setter..............................................1024

British Greyhounds.............................................1027

Scotch Terrier...............................................1029

English Terrier..................................................1031

Skye Terrler....................................................1034

Chart for telling age of Horses (49 Illustrations) $. \ldots \ldots \ldots \ldots \ldots \ldots \ldots \ldots \ldots \ldots, 40$

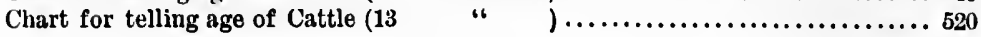




\section{PART I. \\ THE HORSE; \\ :HIS:-}

HISTORY, BREEDS, CHARACTERISTICS AND MANAGEMENT. 


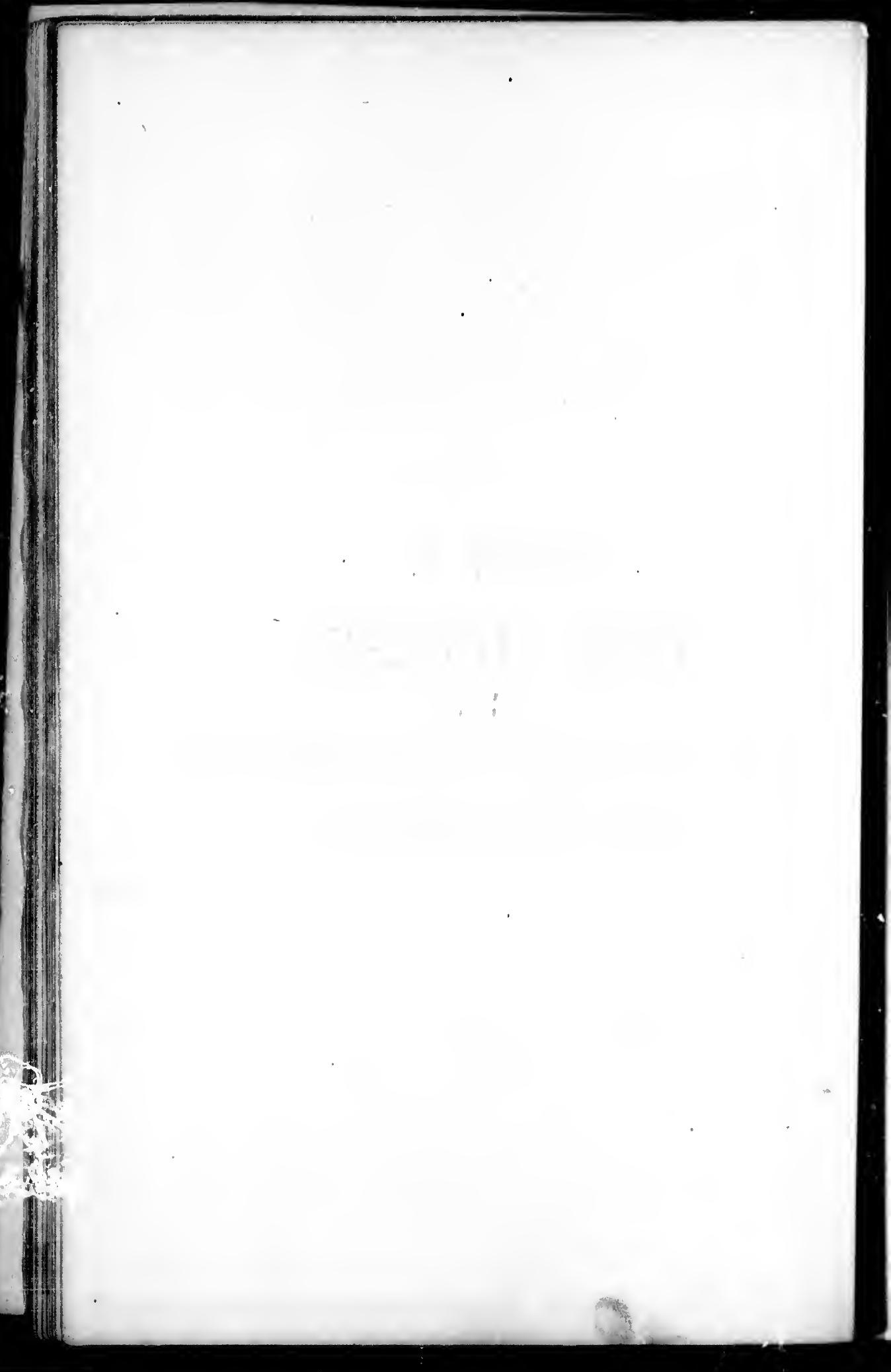




\section{THE HORSE.}

CHAPTER I.

\section{HIS HISTORY AS A COMPANION AND SERVANT OF MAN.}

CONNECTED WITH MAN FROM A VERY KARLY AOE.- HIS INPORTANCE AS A HELPER IN THE WORK OF THE WURLD. - WIS SUPERIURITY OVER THE OTHER ANIMALS. - THE HORSE AND IIS RIDER BECOME IN BOME MEASURE ONG CheatURE.-WIS NaTIVITY: DUUBT

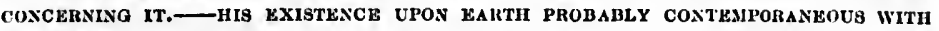

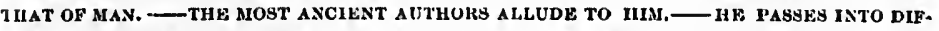
FERENT PARTS OF THE GLOBE. — WILD HERDS IN THE EASTERN CONTINENT. — OKIOIN OP THE WII.D HERDS IN AMEHICA.— YOUND AS A DOMESTIO AMONG NEAKLY ALL PEOPLE. - GREATER LIABLLTT TO DISEASE IN A DONESTIC THAN IN A WILD STATE. SUBJECT TO DETERIORATION UNDER IGNURANT MANAGEMENT. THE WISDOM OF THE ARABS AS BREEDERS AND KEEPERS. - DIFEERENCE OF OPINION AMONG MEN AS TO SYSTEMY OF BREEDING: ATtENTION CALLED TO ITS TREATMENT IN THIS WORK,- KNOWLYUGE AND SKILL NECGSSARY TO IHS PROPER CAIG.

"And God made the beast of the earth after his kind, and eattle aftel their kind, and everything that ereepeth upon the earth after his kind: and God saw that it was good. And God said, Let us make man in our image, after our likeness; and let them have dominion over the fish of the sea, and over the fowl of the air, and over the eattle, and over all the earth."

Although the precise period at which the horse was subjected to the use of man is unknown, it is not unrensonable to conjecture that it was at a time long anterior to his mention in history; and it is probable that since the day when man was made mister of all other created things, no animal has been more constantly his companion and friend; and that "no other has contributed so much assistance in subduing wild nature and making everything subservient to his will and promotive of his happiness. Other animals, particularly sheep and cattle, have shared with the horse this usefulness to mankind, it is true; and in our present civilized state, when mechanieal ingenuity is making such rupid strides in dispensing with 
animal labor, it may be, as is sometimes claimed, that the wool-bearing and milk-giving animals-especially cousidering that these sume animals furnish also a lirge proportion of our flesh food-are to be held as taking the precedence; but as to adaptability, becoming, as it were, a creature of all work; as to comeliness and quickness of motion; as to a certain sympathy with his master that makes him at times so to partake of his spirit and motions as to seem one with him; as to a readiness of submission to drudgery as well as to proud employments, he is without a rival in the world.

It is affirmed by many that the horse is a native of Asia, but of this we really know nothing. Others affirm with equal, or almost equal, plausibility, that he is a native of central Africa. Where all is conjecture, it is needless in a practicul work of this eharacter to speculate. Wherever his primal home may havo been, it is at least within the bounds of probability that his existence in Asia, in his present state of development, is contemporary with that of man upon earth. Some among the very earliest records of the human raee contain allusions to him as a well known animal, in the service of man. The description in the Book of Job, a production ndmitted to be of the very highest antiquity, is a case in point. He is mentioned here, in glowing terms, as a martial adjunet to his master-and not as a nowly-discoversd or recently-subdued creature, but as one with which the world was familiar. Seulptured images of horses as beautiful of form almost as the noble Arabian of to-day have been found among the ruins of the cities of the desert. Ho is mentioned by Moses in connection with the Egyptians; and records older than the writings of Moses point to his having been known and used by that singular people from the dawn of their wonderful civilization.

We find him thus in both Asia and Africa; and during all the historic period he has been present with man as though native to the soil of many districts of both Contiuents. Whether borne thither by natural result of migratory wandering, in a wild state, or whether by the ever-spreading human family, there is little to guide us in determining. In the more thinly populated districts of Asia, notably in Southern Siberia, great wild herds have been long known to exist.

'Though, as we have previously intimated, there must have been a noble breed of horses in Arabia in the days of their most ancient eities, the introduction of the present breed into that country is thought to have been of a comparatively modern date. It seems clear that long subsequent to the beginning of the Christian era there were few horses in Arabia, and those few of no striking excellence, and that the now celebrated Arabians have either sprung from good horses introduced into the 
l-boaring

0 animals as taking reature of tain symhis spirit mission to val in the of this we al, plausiijecture, it Wherever 3 of probaopment, is very earlirell known of Job, a se in point. to his masure, but as $f$ horses as been found l by Moses writings of ilar people

the historic bil of many al result of r-spreading the more , great wild ave been a ient cities, ght to have ong subsehorses in now eeleed into the country within the last thousand years, or are the result of judicious breeding and kirdly care bestowed upon $\mathrm{a}$ native stock.

He was brought as a domestic animul to the New World, by tho early adventurers; - and no trace of him, (if we except a kind of cloven-footed species), having been fonnd upon the Continent, wo can account for the herds of wild horses, known to have long existed in different parts of North and South America, upon no other supposition than that they are the descendants of certain Andalusian mares and steeds brought over by tho Spaniurds, and abmudoned by them when they could no longer render them service, or left free to escape to the forests on the death of their masters in battle. There is a story current-of doubtful authenticity, however-that als theso immense herds, in both North and South Americil, are sprung from one stallion and two mares that eseaped from the expedition of De Soto through Florida, Georgia, and elsewhere. Be this as it may, thero are now many great herds-a single one, especially in South America, sometimes numbering many thousands.

As a domestic animal, tho horso is found among almost every people on the globe; and his uses vary with the degree of civilization enjoyed by his owners. It may bo remirked also that this degree of usefulness is intimately associated with the degree of his deterioration and with the discases to which he is subject. In a wild state, he is almost free from disorders of every kind, - so much so that unless killed by accident or by deprivation of neessary food and drink, as is sometimes the case, he lives to a great age-dying in the course of nature, it is believed, at from thirty to sixty years. Among the Arabs, where his condition approaches more nearly to a natural state than among any other people, except the Indians, and where his laborious service to his master is limited almost exclusively to earrying a single rider, he displays his greatest perfections as a domestic animal, and enjoys the greatest immunity from disease. Among the lending nations of Europe and their colonies, where he is for the most part made literally "a beast of burden" in the different capaçities of animal for the saddlo and for every species of draught, and where man practices almost unrestrained not only his active cruelties but many unwitting enormities, he is said by good authority to be constantly deteriorating and becoming more and more subject to diseases and to prematuro deatl.

Among the Arabs, too, the best breeds are preserved in their purity, whereas, among more civilized nations all efforts of man to improve the stock, or even to preserve any desired quality, result at last in rendering the subjects of his experiments more linble to fall into various disorders, and, except in rare instances, in ultimate failure. 
It may not be irrelevant to state in this connection that the great exeel. lence of the Arabian of the present day, whatever nay have been his origin, is due in part to the extruordinmy affection felt for him by his master, which manifests itself in tho extreme caro that is lavished upon him, and to which he is ulmost us sensitive as a luman creature; in part to his froedom from that severe labor by which the loorses of other nations aro promaturely broken, stiffened, und deprived of spirit; and partly, no doubt, by the steps which ure taken, not so much to improve, but to preserve, a choice breed. While other nations, notably the Einglish, French und American, ure engaged in ceaseless endeavors to improve, and, according to some authorities, constantly muking lnmentable fuilures-defenting thoir own ends by the systems of breeding, training, and use, which thoy adopt-the wild sons of the desert maintuin for their horses from lige to age the superiority which they were first found to possess.

Men differ in opinion as to the cause of all this, and the mooted questions of crossing and in-and-in breeding find their respective champions, and the discussion is from time to time renewed; but the fact remains that the horses of Arnbin excel ull others; whilo another important fuct seems to be most generully overlooked, that the Arabs neither cross nor netually breed in-mnd-ij, but, having by some means obtained a noble race they guard equally against admitting admixture of blood and against too close consanguinity.

The subject of breeding, howercr, will bo found to have been more fully discussed under its proper head; and in conclusion it will perhaps bc, sufticient to urgo upon the attention of the intelligent owner and breeder some few facts which huve been touched upon in the courso of this brief sketch, namely: That among horses in a wild state disease is rmely kiown, though admixturo of blood most probnbly does tnko place, and, for aught we know to the contrary, as close in-and-in hreeding as the most pronounced advocate of that system could wish. Thus, wo find exemption from destructive disorders, but ordinurily no strongly marked characteristics of race constantly prevailing, and but rarely among them what may be termed really fine animals.

Again, that among the horses of the Arabs and tho American Indinus, diseaso is almost as rure as among the wild herds. And again, among those nations where the horse is in the highest degreo useful, becoming more the slave than the companion of man, he is the subject of a multitude of infirmities scarcely equalled in number by those to which nan is himself heir. It has been said that in hecoming the companion and the servant of man, he has partuken, in some measure, of both man's spirit and his physical frailties. In battle, he adds to the terrors of the conflict 
cat excel. been his im by his hed upon ; in purt other nairit ; and improve, the Eingors to imamentable , training, in for their f found to

oted queshampions, ct remains ortant fact 1 cross nor noble race igainst too been more ill perhaps owner and course of te discase does take in-and-in ould wish. inarily no , and but

Indians, in, among becoming f a multi(ch man is d the serspirit and e conflict hy his fierceness as well as by his strencth and swiftness; in the stables of careless opulenoe, ho becomes the pan serod victim of abundance, and falls a prey to diseases that come by irr ugular exercise and surfeiting; with hard and driving task-mastors, in the marts of trade, and subject to the exactions of business, he is soon stiffened, spavined, and generally broken as to both conformation and locomotion; while among the poorer class of tillers of the soil and other toilers, he seems to become spiritless and dull, and subject to diseases that come rather from want of care than from either over-work or actual deprivation of food and drink.

In his best estate, he is the noblest of the lower animals ; in his worst, he is still a property of man, and a helper in his work. A knowledge of his ailments, and the possession of that skill necessary to his reliof, is therefore essential to every one who owns even the commonest of the species. 
AND THE RE-BUBSEqUENT HIS CHAPTKR. ON ; ARCTLONSAD; BEOTION

sive knowlthe proper in one eonscen in Fig. . 2 ; of the foot, Figs.

ntifie terms necessary, all meaning

persede the throughout of the illused on that b the treatss which ho ly familiar, upter.

er simple, ic animals, ucture, and

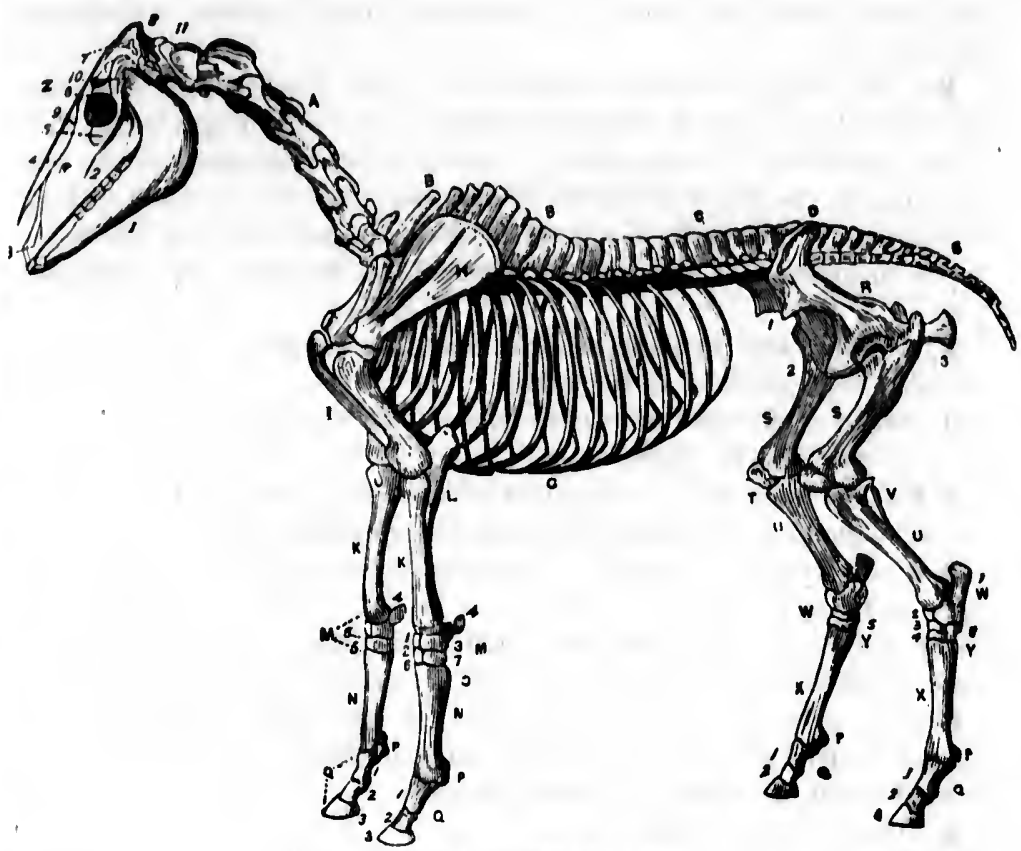

Fig. 1. Skeletor.

Explanations.-A-Cervical vertebræ, or seven bones or joints of the neck.

B, B-Dorsul vertehræ, or the eighteen larger joints of the back-bone. C-Lumbar vertebre:-the six joints of the back-bone lying between the upper ends of the false ribs, and the upper edge of the haunch bones.

D-Sacrun, or bone which forms the back part of the pelvis.

E-Coceygeal bones, or tril bones.

F, F-Rilos.

G-Costal cartilages, or the cartilages by which the ends of the ribs are joined.

H-The scapula, or shoulder blade.

I-The humerus, or large round bone between the point of the shoulder and the elhow, ol upper part of the fore-leg.

$K, K$-The rndinses, the outer bones of the fore-legs, extending from humerus to knee. 
L-The ulna, the larger of the two bones of the upper part of foreleg, lying bohind the radius and extending from the knee to the lower part of chest.

M-The carpus, or knee, composed of : 1 , the scaphoid, or bone having a boat-like form; 2 , the semi-lunar, or bone resembling a half-moon ; 3 , the cuneiform, or wedge-shaped hone; 4 , the trapezium, or bone resembling the mathematical figure of that name; 5 , the trapezoid, or bone resembling a trapezoid; 6, the os magnum, or great bone of the knee; 7, the unciform, or hook-shuped bone; 8 , the pisiform, or pea-shaped bone.

N, N-The large metacarpal or cannon, the big bone of the fore-leg reaching from the knee to the ankle.

0-Small metacarpal or "splint bones," the two smaller bones of the lower part of the fore-.legs.

P, P-The scssamoil bones-two small bones found in the substance of the tendons at the joining of the fore-leg to the ankle.

a, $\mathrm{Q}$-Phalanges, embracing: 1 , the upper pastern bone; 2 , the os corona, or lower pastern bonc; 3 , the os pedis, or first bone in the leg, inside the hoof-the coffin-bone; and naviculare, a small ship-shaped bone, at the back of the lower pastern, not marked in the figure.

R-The pelvis, or basin, composed of : 1 , the ilium, or flank bone; 2 , the pubis, or fore-part of one of the bones of the pelvis; 3 . the ischium, or hinder and lower part of the hip-bone.

S-The femur, or thigh bone.

T-The patella, or small bone covering the stifle joint-the joint of the hind leg near the flank.

$\mathrm{U}$-The tibia, or large, long bone between the hock and the stifle joint.

$V$-The fibula, the small, long bone behind and attached to the tibia.

W--The hock, or that joint of the hind leg between the stifle-joint and the fetlock, embracing the following small bones: 1, the os calcis, or back point of the hock; 2, the astragalus, or upper bone of the hock that supports the tilhia; 3 , the cuneiform magnum, or largest wedgeshaped bone; 4 , the cuneiform medium, or middle-sized wedge-shaped bone; 5 , the cuneiform parvum, or smallest wedge-shaped bone; 6 , that small bone of the hock having a somewhat cubical form.

$X$-Large metatarsal, the front bone of the hind leg, between the hock and the pastern joint, below which are $1,2,3$, the phalanges of the hind $\operatorname{leg}$.

Y. The small motatarsal, or small bone of the hind leg in rear of large metatarsal.

Z-The head, ombracing: 1, the inforior maxilla, or lower jaw; 2 , the superior maxilla, or upper jaw ; 3 , anterior maxilla, or outer part of 
fore-

lower

hav-

mooll;

ne re-

or bone

knee ;

shąed

ore-leg

of the

bstance

e os $\mathrm{co}-$

the leg, rshaped

one; 2 , ischiurn,

joint of

fle joint. tibia.

oint and alcis, or the hock wedgee-shapod ; 6, that

the hock the hind

rof large

jaw ; 2, $r$ part of the jaw ; 4, the nasal bone, or bone in front of the nostrils; 5 , the malar, or prominent check-bone; 6 , the frontal or forehead bone; 7 , parietal, the sides and upper part of the skull bones-(wall bones); 8, oceipital, the bone of the hinder part of the head; 9, the lachryme!, or bone inclosing the lachrymal gland and duct; 10 , the squamous, or sealy portion of the temporil bones; 11 , the petrous, or hard part of the temporal bones inclosing the organs of hearing.

To summarize, the spine is divided into eervical, dorsal, and lumbar vertebre, or joints, in all, thirty-one; the tail contains about seventeen joints ; the dorsal vertebre, with eighteen ribs attached on each side, and the breast-bone (which is not shown in the figure), form the thorax, or cavity inelosing the heart, lungs, \&e.,-thirty-seven bones; the fore part is made up of forty bones, taking both sides together; the pelvis, or basin, of three bones; the remainder of the hinder part, of thirty-eight bones; the cranium of ten; the face and lower jaw of eighteen; of teeth there are forty (in the male); the small bones of the internal ar, taking both, are eight; and the hyoid, or tongue bone, consists of five parts.

It is not the province of this work to enter into minute anatomical desicriptions; and for all really practical purposes the foregoing will he found ample.

It must however be borne in mind that a thorough study of the anatomy and frame work of the animal is absolutely necessary to a perfect understanding of how to breed, rear, care for, break and train an animal. At the same time, neither the horse breeder, trainer, or driver, needs to understand thom so critically as must the veterinarian. The one repuires simply a general knowledge of the several parts, the other must understand intimately and critically each and every purt, not only in itself but with reference to its bearing and influence on, and relation to other parts of the body. Thus what we give in illustration, while not going into minutia such as would be necessary to make the veterinary expert, will be fully sufficient for the instruction and every day use of the practical man, whether he be breeder, trainer, or simply the gentleman who drives for pleasure. 


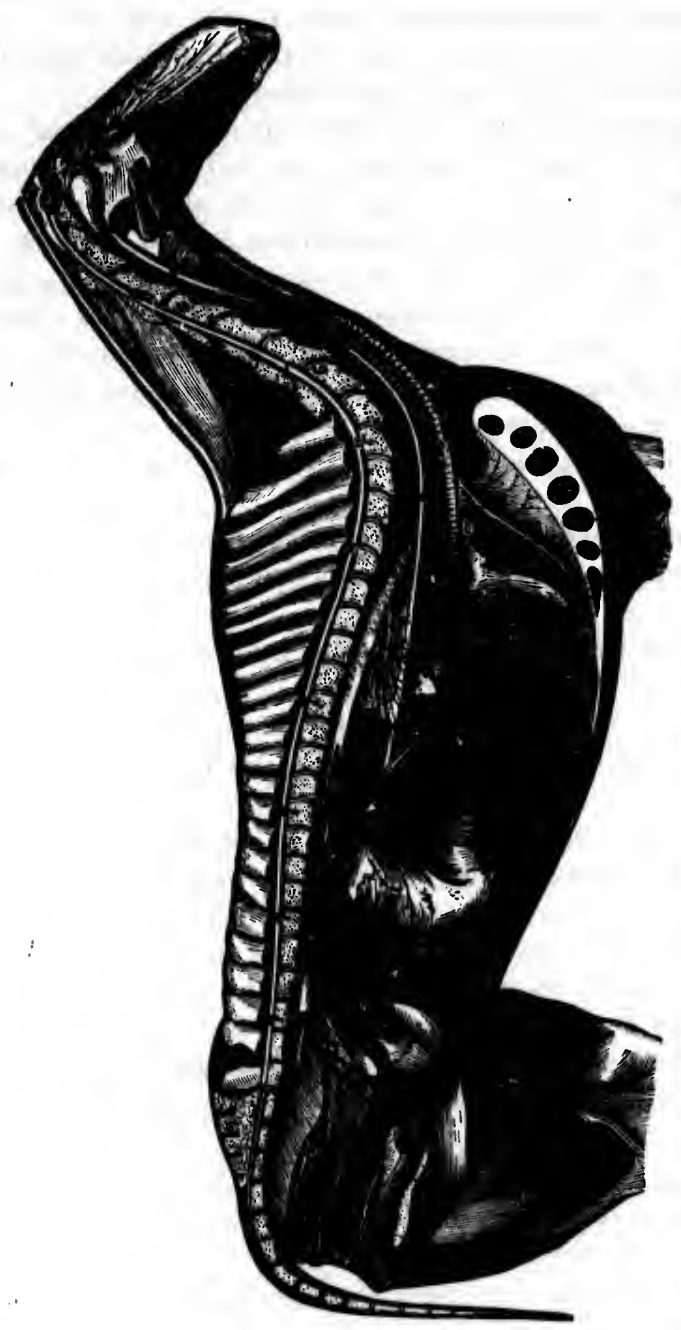

章 
Explanations.-1-The occiput, or that part of the skull which forms the hind part of the head. 2-The cerebellum, or hinder and smaller division of the brain. 3-The cerebrum, or front and larger division of the brain. 4-The nasal membrane, or cartilage between the nostrils. 5-The tongue. $\quad 6,6$ - Joints of the neck bone, 7, 7, 7, 7-The spinal cord, or marrow. 8 -The pharynx, or cavity bounded by the membraneous and muscular walls beneath the base of the skull, into which the nose and mouth both open, and which is continuous below the resophagus. $9,9,9$-The resophagus, or passage through which food and drink go into the stomach. 10-The oritice of the stomach passing through the diaphragm. 11-The pylorus, or the orifice of the stomach through which the food passes into the intestines. 12, 12-The hinder surfuce of the diaphringm, or membiane which separates the stomach and bowels from the heart and lungs. 13, 13-The trachen, or windpipe. 14-The lungs. 15-The heart. a-The stomach. b-The spleen, or milt. c-The left kidney. d-The broad ligament of the uterus or womb, with the left portion, and the ovary or that part which contains the seed displayed. e-The rectum, or terminal portion of the large intestines. f-The anus. $g, h$, $\mathrm{i}, \mathrm{j}, \mathrm{k}, \mathrm{l}$-Internal nuseles of the thigh.

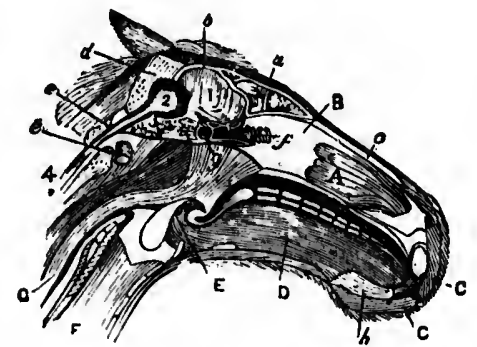

Fit. 3, Vertical Section of Horse's Head.

This cut illustrates still more fully the structure of the head and its contents. a--The frontal bone, showing sinus or ehannel beneath. bThe parietal or wall bone, covering the brain. c---The nose bone. d--'The oceipital or back head bone. e, e---The Atlas, or first bone of the neek, showing the spinal marrow in its center. f--The ethmoid or sieve-like bone, through which the olfuctory or nerve of smelling passes. g--The sphenoid or wedge-like bone, which, with the ethmoid, supports the hase; of the brain. h--Part of the lower maxillary or jaw bones, with the lower incisor teeth. 1-The cerebrum, or large brain. 2.--The cerebellum, or small bruin. 3--The medulha oblongata, or upper portion of 
the spinal marrow. 4-The spinal marrow. A-The turbinated bones, ol thin, bony plates, in the form of a scroll or horn, found in the nostrils, and serving to give wider distribution to the lining membrane of the nose. $\mathrm{B}$-The septum nasi, or cartilaginous division between the two nostrils. C, C-The lips. D. The tongue. E-The epiglottis, or valve of the larynx. F-The trachea, or windpipe. G-The esophagus or gullet.

It will be observed that the great object in the formation of the cranium, that of furnishing a firm cover and a sure protector of the brain against all ordinary accidents, is secured by the employment of nine bones, arranged in this manner: The two frontal bones (a), make up the anterior or forward part; the parietals (b), comprise the upper and central parts, and cover the outer lobes of the cerebrum; the occipital bone (d), a single bone of great solidity, is at the back of the head; a little lower, and back of the occipitnl bone, is the aperture through which the spinal cord, together with some nerves and an artery, make their exit from the brain. Here the bone is smooth and rounded for the purpose of jointing with the atlas, the first bone of the neck. The sphenoid bone (g); forms the inferior and central part of the cranium. The ethmoid (f), through which the olfactory nerve passes, together with the sphenoid, as noted above, assists in upholding the base of the brain. In proximity to the facial bones are found sinuses bearing names derived from their nearness to particular bones.

The temporal bones forming the sides of the cranium are composed of two parts, the squamous, or sealy, and the petrous, or stone-like. The petrous portion of the tempornl bone contains the organs of hearing, having upon its inside surface the openings for the passage of the auditory nerve; and upon its outside, large passages for the conveyance of sound.
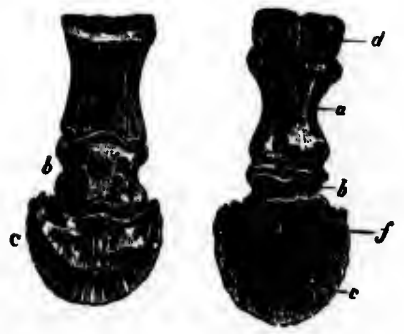

FIG. 4. Front and BaCK VIEW OF THE BONES OF TH! FOOT.

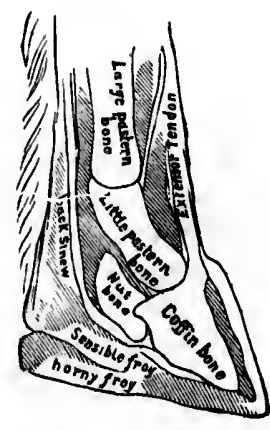

Fig. 5. Shctional VIEW OF THK BONES OF THE FOOT. 
ted bones, in the nosrane of the re two nosor valve of 8 or gullet. f the cranthe brain ent of nine iake up the $r$ and eensipital bone ad; a little ugh which e their exit the purpose ienoid bone he ethmoid e sphenoid, n proximity from their

omposed of -like. The of heuring, he auditory of sound.

Figs. 4 and 5 , taken in connection, will serve to give the reader still more definite knowledge than that aonveyed by the skeleton of the relative situation of the different parts of the horse's foot, and the terms applied to each. The bones exhibited in the front and back view, Fig. 4, are : c, $c$ -The coffin bone, or first bone of the leg. $d$-The sessamoid bone. b, b -The small pastern. a, a-The large pastern.

The parts exhibited by Fig. 6 are : a-The large metacarpal or cannon lone. $b-T h e$ os suffraginis, or large pastern bone. c-One of the sessamoid bones. d-The os coronæ, or small pastern bone. e-The navic-

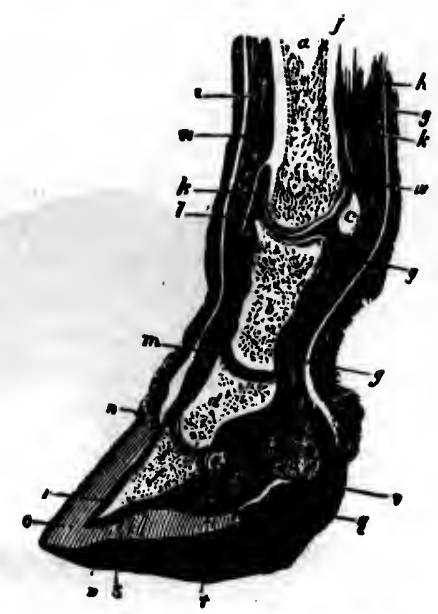

Fig. 6. VERTical SkCtion of the root AND LOWER LEG. ular bone. f-The os pedis, or coffin bone. $g, g$, $g$-The flexor perforans, or penetrating tendon. $\mathrm{h}, \mathrm{h}$-The flexor perforatus, or penetrated tendon. i-The extensor tendon. j-The suspensory lig:ment. $k, k-$ The cupsular ligament, or membraneous elastic bag surrounding the joint. l-The fetlock joint. m-The pastern joint. n-The coffin joint. oThe horny erust. p, p-The horny sole. q-The frog. r.-The sensible laminæ. $t$-The sensible frog. $u$-The cushion. v-The navieular joint.

It will be observed that the parts exhibited by Fig. 5 are plainly named on the engraving. Every thoughtful reader will observe further that these parts of the horse are most wonderfully put together. The delicate and welladapted mechanism is not surpassed by that of any mechanical combination ever produced. The entire structure is one that seeures the utmost elasticity and freedom of movement, with the immense strength needed in the usuai work of the horse. An understanding of this must go far toward compelling care and attention in all that pertains to the foot of the auimal. Shoeing, and especially service on rough, stony places, should be subjects of constant regard.

The next cut furnishes a beautiful and comprehensive view of the trims applied to the various parts of the animal, and it can but prove of great use to those who would not only "talk horse" themselves, but understand the talk of others-especinlly of veterinary writers when trenting of disorders, their location, and the proper means for their relief. 


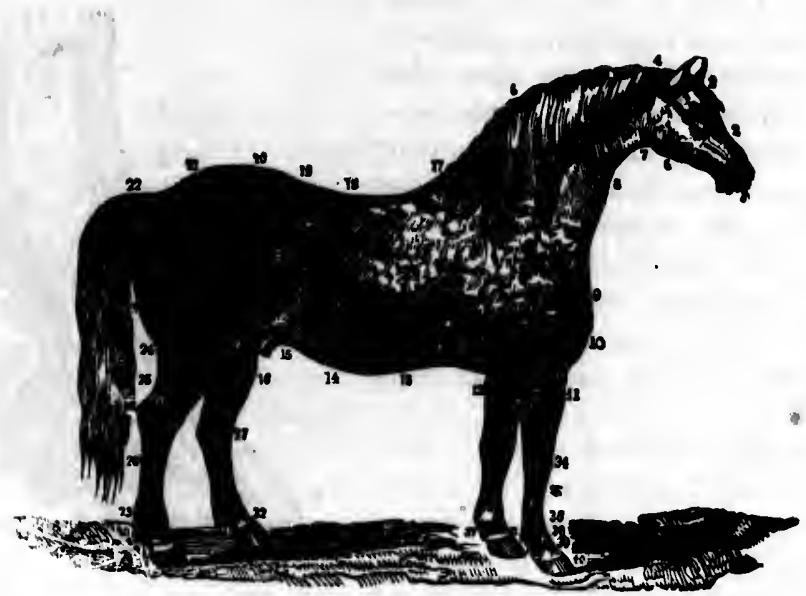

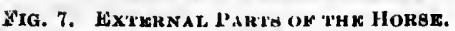

Explar. "in. - "he muzzle. 2-The face. 3-The forehead. 4The poll. 5- lie c ". "-The jowl. 7-The gullet. 8-The windpipe. 9-Point of the shoulder. 10-The breast. 11.-The arm. 12 -The elbow. 13-The girth. 14-The flank. 15-The sheath. 16The stifle. 17-The withers. 18-The back. 19-The loins. 20'The hip. 21-The croup. 22-The dock. 23-The quarter. 24-The thigh or gaskin. 25-The hamstring. 26-The point of hock. 27-The hock, (hough) 28-The canmon hone of hind leg. 29-The fetlock. 30 -The large pastern. 31-The small pastern. 32-The coronet. 33The hoof. 34-The knee. 35-The cannon ot' tore leg. 36-The fetlock. 37-The heel. 38-The large pastern. 39-The small pastern. 40-The hoof. 


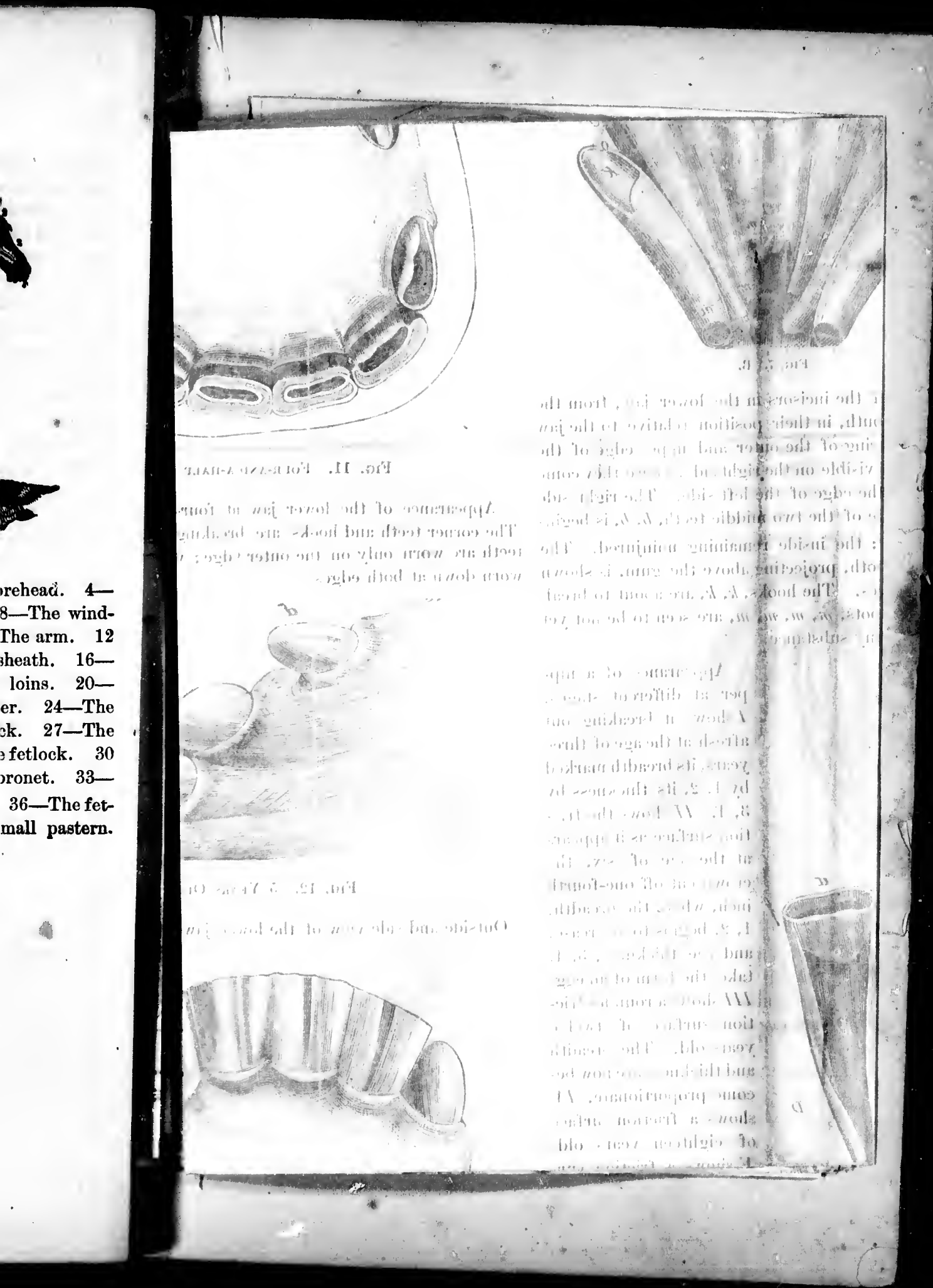




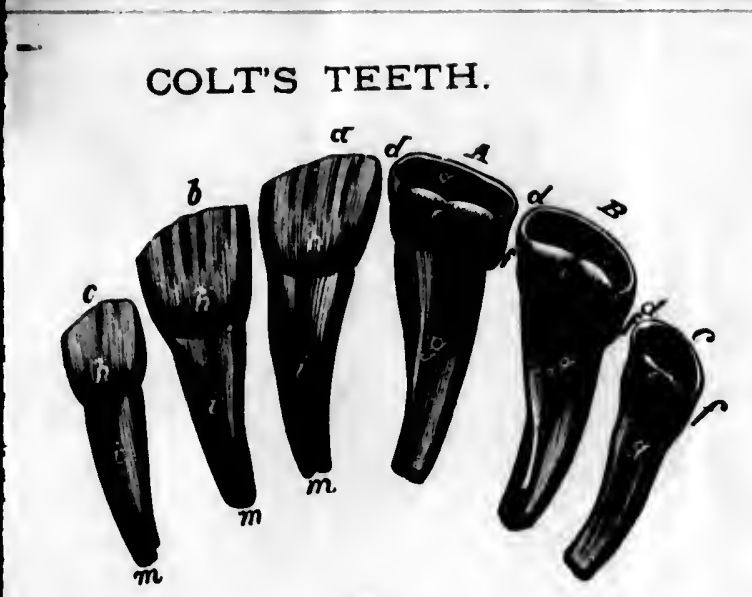

Fig. 1.

The right side of the milk incisors of the lower jaw is here shown, of nutural size and fully developed. $A, B$, $C$ show the concave side of these teeth towards the hollow of the mouth. The mirk of ehange, or nge, is inclosed within the outer elge d $A \mathrm{f}$; $\mathrm{l} B \mathrm{f}$; I $C \mathrm{f}$; and the inner and rather lower one, $d$ e $f$. The different kinds are $a$, the nippers; $b$, the middle teeth ; $c$, the corner teeth; and the different parts shown ane $g$, the hollow inside surfine of the hody of the teeth; $h$, the contracted boly of the teeth; $i$, the nirrow neek; $m$, the root. The surface is represented as arched on the outer side.

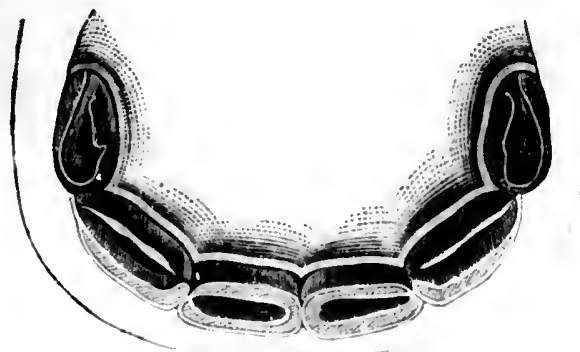

Fid, 2. II, Yitat.

Lower jaw of a colt a half year ollt. Both the onter

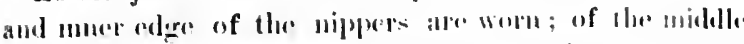
sueth, ouly the onter edge; the romere tereth an not worn it all.

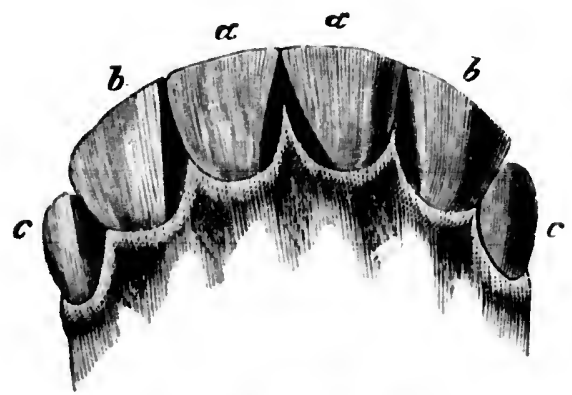

Fig. 3. Half Year.

This represents the outer side of the jaw of a lualf enc ald rolt. The different toeth are us follows: a, a,

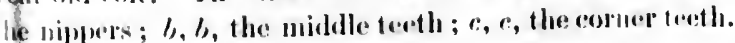

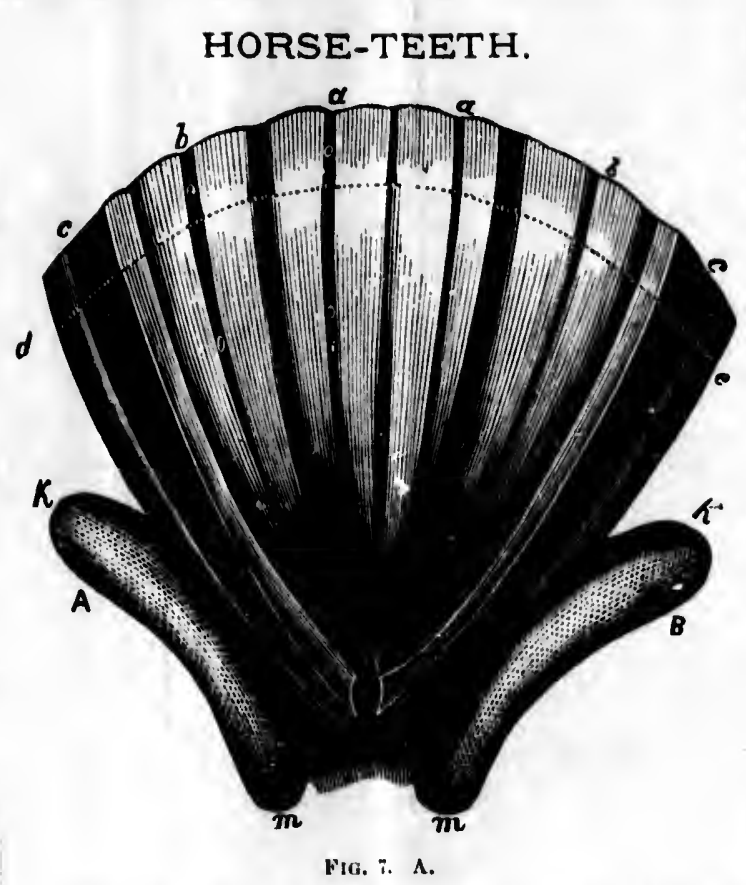

Appearance of the horse incisors in place, with their outer surfacer arehed townd the bouy blucle of the socket, us follows: $a, a$, the two nippors: $b, b$, the two middle tecth; $c, c$, the corner teeth : $k, k$, the hooks. The cnvity in the ouler partition of the mark is indicated hy $e$, $d$; the furmors which distinguish the horse teeth by $o, o$; and tho roots of the hooks by $m, m$.

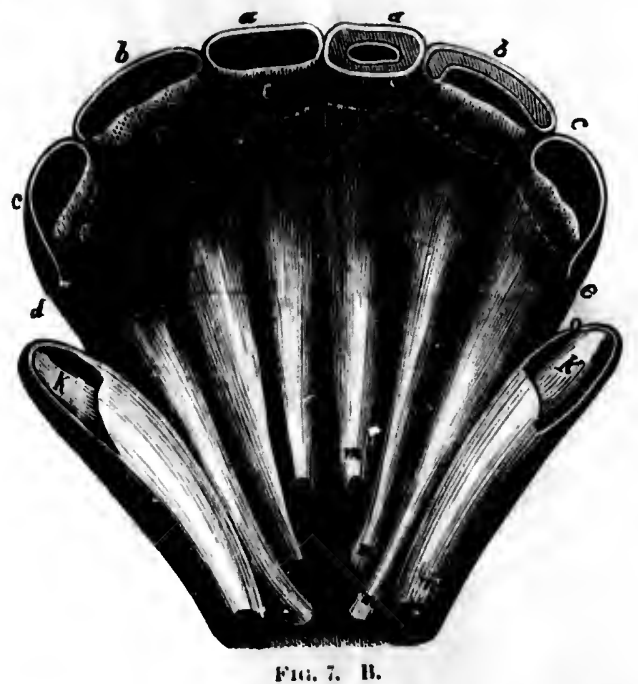

Aprearme of the incisors in the lower jaw, from the inside of the mouth, in their position relative to the jaw home. The wearing of the outer and upper enge of the nippers, $a$, $"$, is visille on the right side, where they coms in contast with the ealge of the loft side. The right side of the outer edge of the two middle teeth, $b, b$, is heginning to be worl ; the inside remaining uninjured. 'ithe crown of ench tootli, projecting nbove the gum, is whown hy the dotted lines. The hooks, $k, k$, are about to brenk thiourls. Tho poots, $m, m, m, m$, are seen to be not yot filled ont with bony substance.

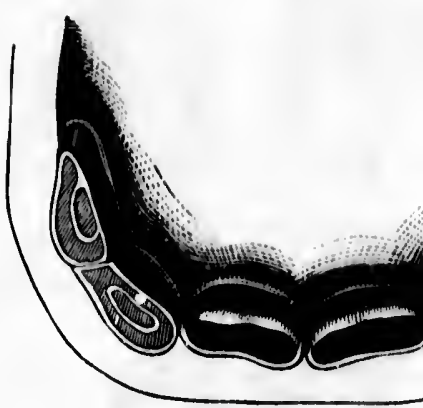

Fig. 9. TwO-AND-A-HALY

Appearance of the lower juw at two-a which two nippers are breaking through while the foul teeth appear as a smooth f

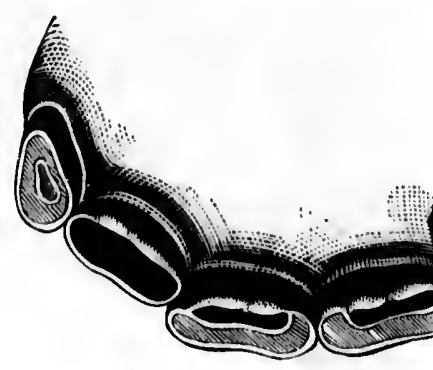

Fig. 10. Three-and-A-Hat.

Appearance of the lower juw at thre when the middle torth are just breaki edge of the nipper's alrendy worn down blunted.

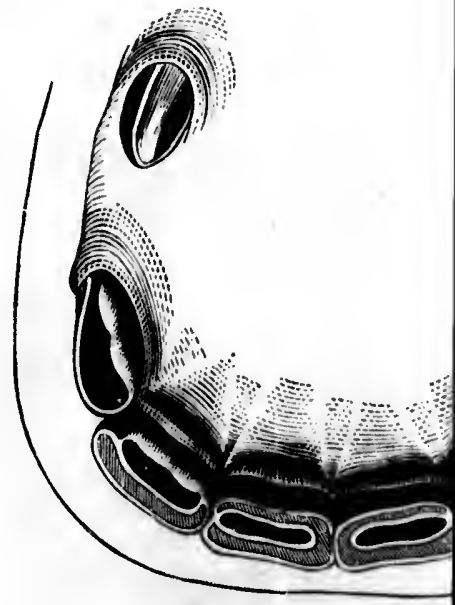

Fig. 11. Four-AND-A-HA

Appearance of the lower juw at fo The corner teeth and hooks are break weeth are worn only on the outer edge worn down int both edges.

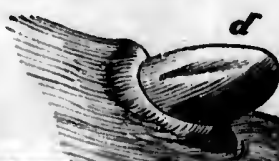




\section{Months to 20 Tears.}

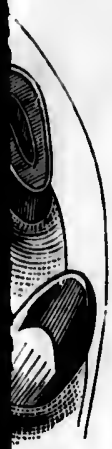

the mark of

nark of the

ppers have ddle teeth nerestso in

FIO. 20. 15 YEARs OLD.

Appearance of the upper juw at fitteen. The nippers are rounded.

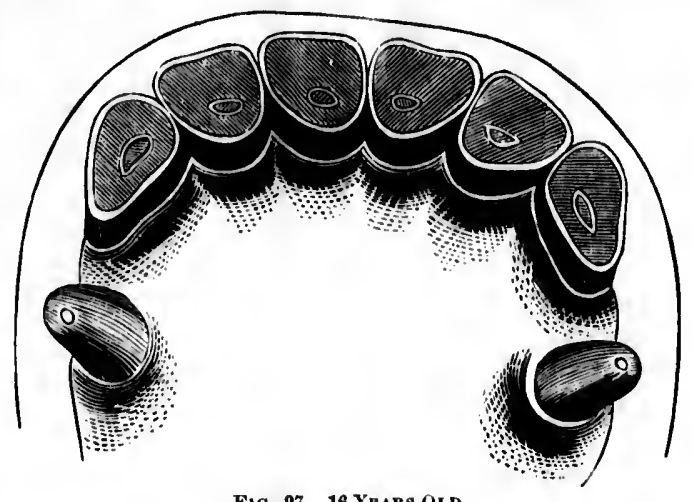

Fig, 27, 16 YeARs OLd.

Appearance of the upper jaw at sixteeu. The middle teeth are rounded.

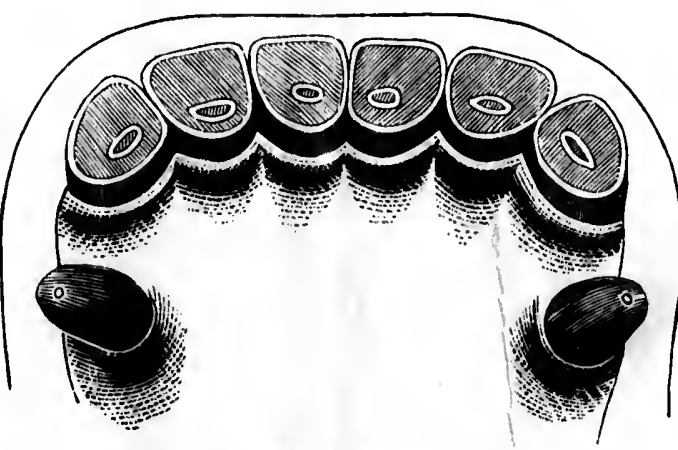

FiG. 28. 17 YIIARS OLD.

Appearance of the upper jaw at this age. The corner teeth are rounded.

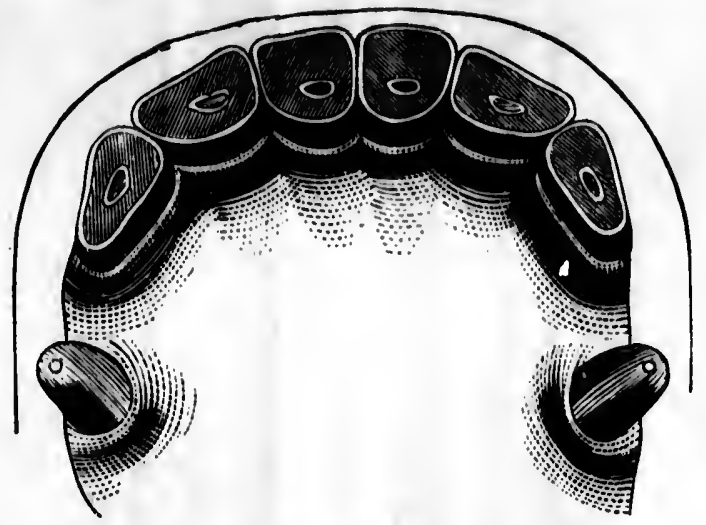

Appearance of the upper jaw at this age. have become somewhat tringular.

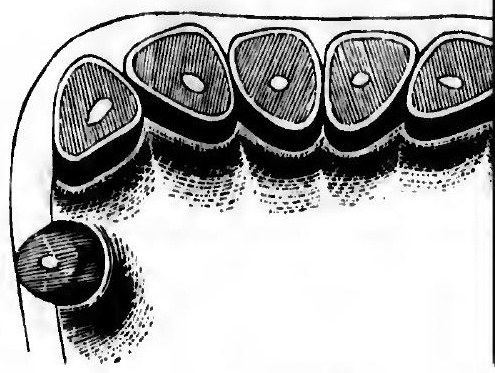

Fio. 34, 23 Ykans OLd.

Appearance of the upper jaw at twenty-tl teeth have become triangular.

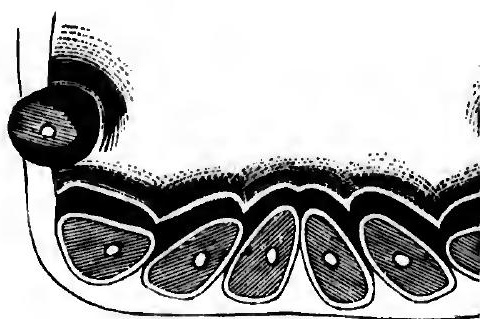

Fra. 35. 24 Years Old.

Appearance of the lower jaw at this age. become twice as thick as broad.

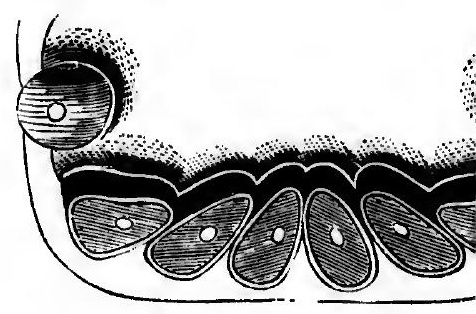

Fig. 36. 25 Years Old.

Appearance of the lower jaw at twenty-f teeth have become twice as thick as broad.

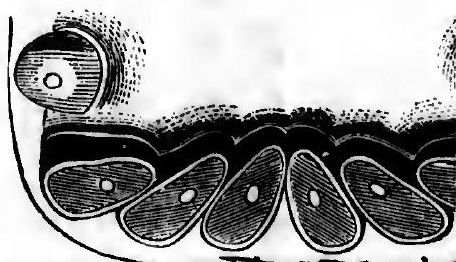


Fig. 3. Hale Yeah.

This represents the outer side of the juw of a half rear old colt. The different woth are as follows: "t, "s. the nippers; $b, b$, the milldle ferth : $c, c$, the eormer tewth.

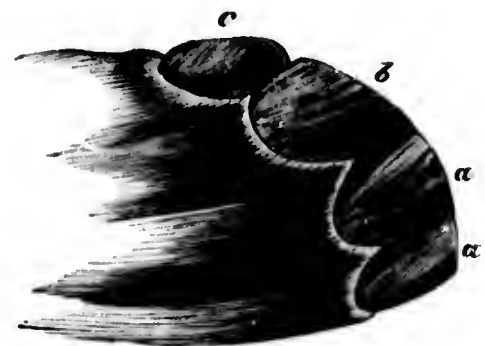

HiL:. 4. IIAI.F Yíali.

This is a side view of the jow of a half pear wal colt

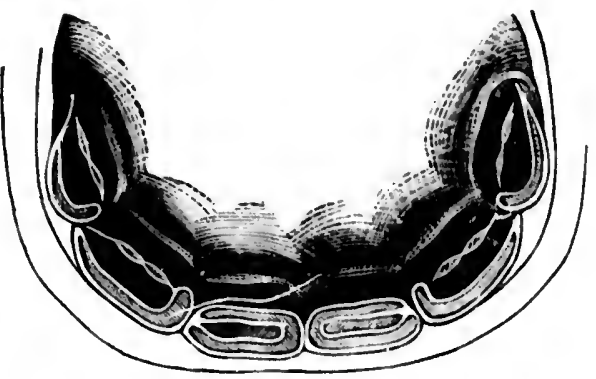

Fili. 5. ONE Yrals Oh.

This is the appearance of the lower jaw at one vear old. The edges of all the incisors are partly worn ly friction, white the comer teeth remain uninjures.

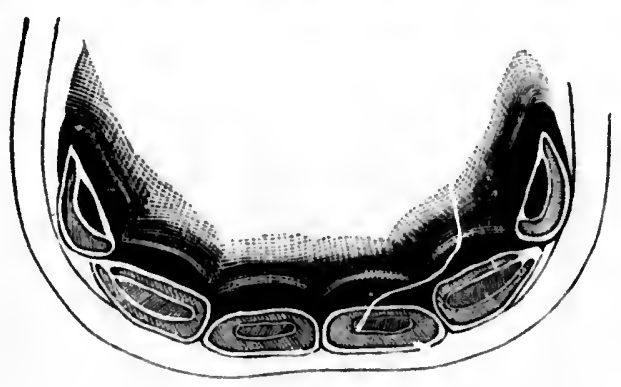

Fig. 6. Two Years Old.

Appearance of the lower jaw at two years olld. The edges of the nippers and of the middle tecth, and their mark, are worn down, so that the inner edge of the corner is brought into requisition.

The teeth begin to change at two-and-a-lualf yenrs, and the permanent or horse teeth appear.

Copyrighted according to Act of Congress.

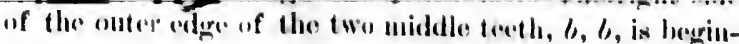
ning to be worn; the insicle remuining uninjurevl. The crown of ench tooth, projecting ulove the gum, is shown by the dotted lines. The hooks, $k, k$, ure nbout to bienk through. The roots, $m, m, m, m$, ure seen to be not yet filled ont with houy' substunce.

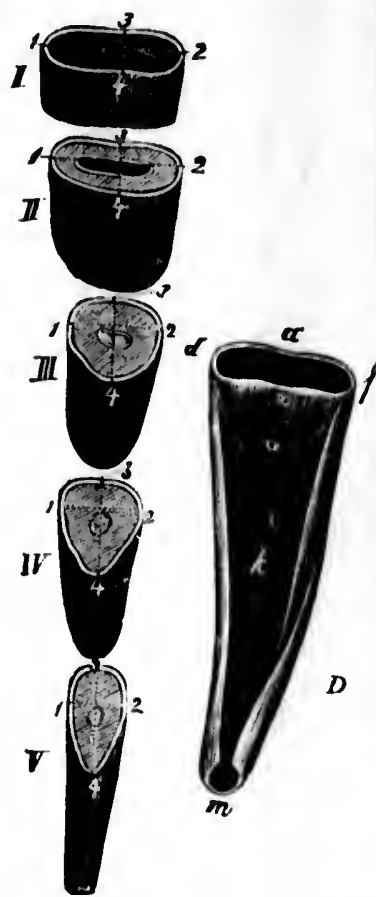

Fia. 8. A, D
Appenrance of $n$ nipper nt different stuges, $I$ shows it breaking out afresh it the uge of three yeurs, its brendth marked loy 1,2 , its thickuess by 3, 4. II shows the friction surfuce ns it nppenrs it the nge of six, the crown cut off one-fourth inch, where the brendth, 1,2 , begins to decrense, and the thickness, 3,4 , takess the form of an egrg. III shows a romder friction surface of twelve yen's olll. 'The brendth nud thickness nre now become proportionate. IV shows a friction surface of eighteen yenrs old. $\checkmark$ slows a frietion surface of 24 yeurs, in which the brendth, 1, 2, mensures only half as much as the thickness, 3, 4. I) shows an incisor of " full grown loorse, split lengthwise, of which $d, a, f$ is the onter raised odge; $a, o$, the fumnel shaped eavity of the tooth; $k$, the hollow body; $m$, the still unfilled root of the tooth.

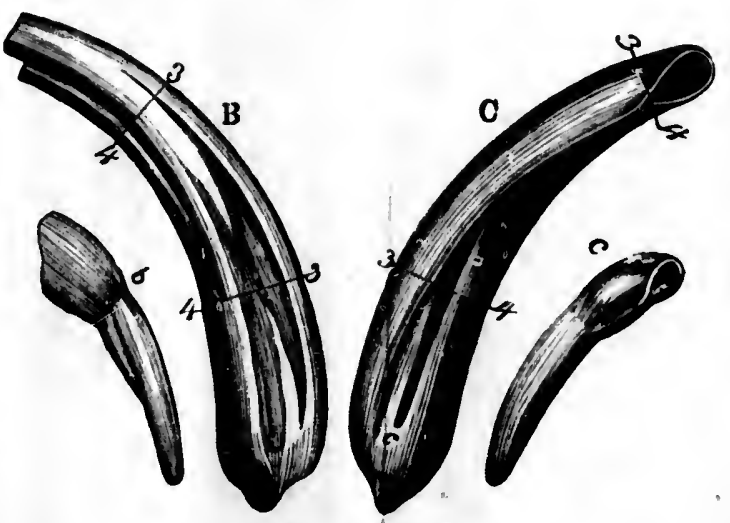

Fia. 8. B, C.

Appearance of horse incisors, (viewed from the side,) in which the roots, $e, e$, are twice us thick as the upper end. Also, of two foul treth, $b, c$, ruised out of the socket and viewed from the side.
Appenrince of the lower juw at f,
he eorner teeth ind hooks are brenk teeth ure worn only on the outer odge worn down at hoth edges.

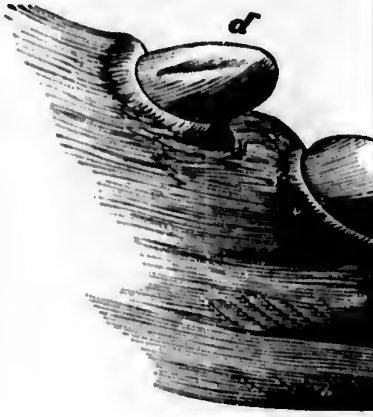

Fia, 12. 5 YeaRs

Outside and side view of the lower

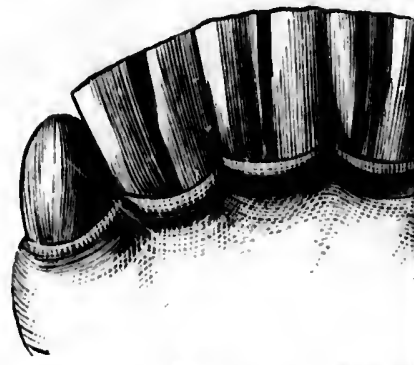

Fio. $13 \quad 3$ Yrars

Outside front viow of the lower jaw

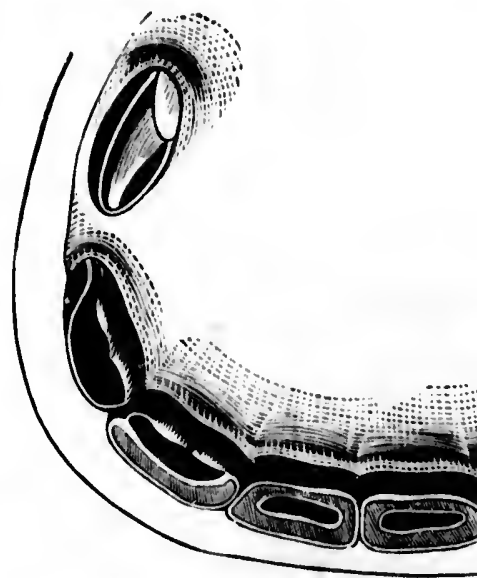

F10. 14. 5 YeARS

Appenrinee of surfices of toeth in old. Both edges of the nippers ure mark is ulmost gone; the middle teet outer edge; the corner ones havo attai the others and have also come into w full grown, but not worn at all.

- See Chapter III for explumation of terms, and further facts conoerning the Ages of Horses. 


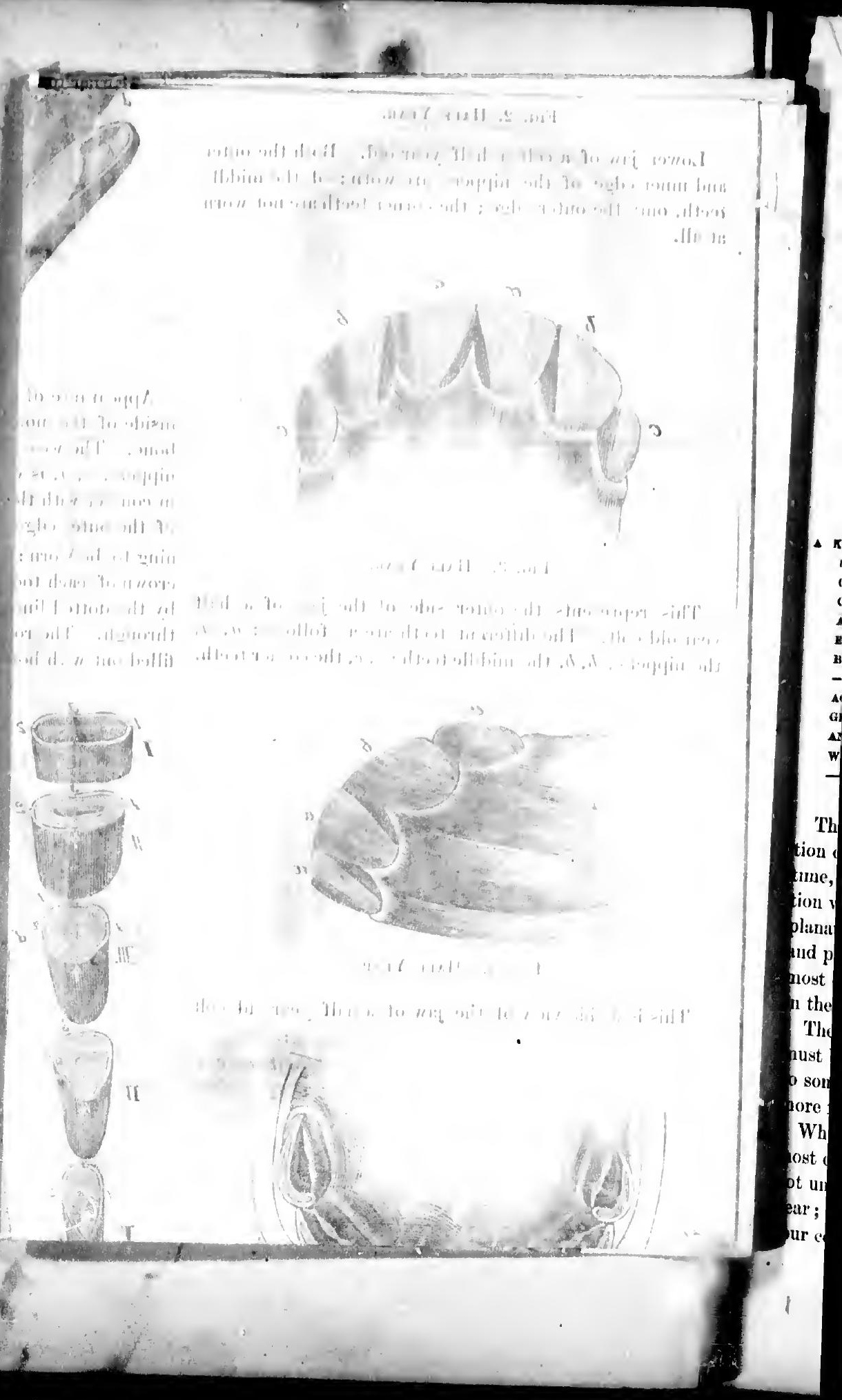


CHAPTER III.

HOW TO TELI $\triangle$ HORSF'S $\triangle \mathrm{GM}$.

A KNOWLEDG OE CRANGES IA THE TEETH THE ONLY MKAN8,- THIS CHAPTER TO BE GTUDIED IN CONNEOTION WITH THE CHAKT WHCH YOLLOWS. — BUYERS LIKKLY, WITHoUT THIS IKNOWLADG, TO BE DECEIVED, - INCISOR CHHYY TO BE RELIKD ON, CONDITION OY A HOAL'B MOUTH. - THE CHANGES THAT FOLLOW. - HOW FOAL TKETH ARE TO BE DISTINGUIBHED FROM HORSE TEETH. - WRARING AWAY OF THE GRINDER OR HNAMELLED PORTION. - NUMBER OF THETH IN A FULL-OROWN ANIMAL.-DIFHERHNCB BETWEAN HORSES AND MARES AB TO NUMBER,— INCISORS, HOOKS, AND "WOLF'S TRRTH." - HOW TO DETERMINE AGE TILL FOAL IS TWO YHARS OLD.— HOW FROM TWO TO OLD $\triangle Q K$. - THE HORSE OF MEDIUM BIZE TO RK TAKEN $\triangle B$ A GTANDARD. - BHOOTING UP AND GRINDING OFF.—IRREGULAR TEKTH; HOW TO JUDGE. — PEOULIAR HARDNESS OH BONES AND SLOWNKSS OF CHANGE IN CERTAIN BRLEDS. - THE MULE; $\triangle$ GR HARD TO FIND OUT WITH EXACTNESB.—DECEPTIONB; HOW TO DETECT. C CRIB BITERA; HOW TO EXAMINE. CTERMS DEYINED.

The uge of a horse is to be accurately determined only by an examination of the teeth, with a knowledge of the changes which, from time to lume, take place in them. The following directions, studied in connecfion with the drawings exhibited on the nceompaiying chart, and the exolinations written under them, will enable any one of ordinary acuteness and powers of observation, to judge for himself, and thus to avoid that nost common of all the jockey's impositions, a liability to be deceived In the age of horses held for sale.

The incisors furnish the chief indications; and to them the attention pust be mostly directed; but the back and hook teeth should be observed b some extent, as their condition may occusionully serve to correct and pore frequently to corroborate the indicutions of the incisors.

When first fonled, the colt has no incisors. Twelve back teeth have in ost enses forced their points by this time through the gums; but it is pt until from two to three months nfterward that the four nippers apzar ; in six weeks the nippers are seen; and in about eight months the ur corner teeth. There ure now, at eight or nine months old, twenty- 
four teoth, (upper und lower), called foal-teeth. These are all changed by the fifth or sixth year, and those that follow are ealled horse-teeth.

The back teeth appear as follows: the three front double pair are seen at birth, and are afterward changed; the fourth double pair appear from the eighth to the ninth month; (this fourth double pair are the first that remain stationary, and they are found in every year-old colt); the tiftl double pair, or fifth four, appear in the second or third yenr; the sixth, usually in the fourth or early in the fifth year. These thres double pairs of back teeth (last named), remain unchanged, as do ulso the four hook teetis.

The hook teeth are uneertain as to time of appearance, coming sonsotimes at the end of the third year, sometimes in the middle or at the end of the fourth, sometimes in the middle or ut the end of the tifth, sometimes at the beginning of the sixth.

Observe particularly that the incisors of the foal differ from those of the horse: (1) By their regular, conical formation; (2) by u narrow contraction called the neck, visible almost in the center of the body of each tooth, while nothing of the kind is seen in horse-teeth ; (3) by therr smaller size, even when full grown. The milk teeth, (or those teeth which are cast or shed), tuken from the jaws of dead fonls and compared with horse-teeth similarly obtained; are found to be only aloout half as long as the latter. The breadth is not to be depended on, since the milk teeth of large foals appear almost as broad as those of small horses. When the nippers become horse-teeth, they form a great contrast to the middle and corner teeth. The size of these last will at once show them to be milk tecth. (4) By the fact that the outer surface of the foul-teeth is smooth and striped with brown, whlle on horse-teeth the same surface is divided by a dirty yellow indentation inclining toward the center, which is sometimes double upon the upper teeth.

One should study the form of the incisors by curefully exanuning those taken from dead horses of difforent ages. Each incisor will be found to consist of a hard, enamelled part, culled the grinder, which has protruded above the gum ; of a bony substance, which has heen for the most part hidden in the gum; and of a root, which las ocenpied the cavity of the jaw-bone.

These tceth, (of the foal as well us of the horse), are slowly hut continually worn away by biting and chewing, so that the length is eonstantly decreasing, - sometimes evenly and regularly, - so that in old uge the tooth that was once two and a half or three inches long is found to be not exceeding half an inch in length. The brendth generully decreases in about ihe sume proportion; but with this difference in foil and horseteeth, that the thickness and breadth of foal-teeth me constantly decreas:- 
11 changed -teeth.

ir are seen pear from e first that ; the tifth the sixth, ouble pairs four look

ning someat the end ifth, some-

$m$ those of $y$ a narrow he body of 3) by their those teeth d compared out half as ce the milk nall horses. trust to the show them lo foul-teeth ime surface the center,

examuning isor will be , which has een for the ceupied the

vly but cons constantly old uge the ud to be not. decreanes in and horsetly decreas- ing from the grinder or hard enamelled part to the end of the root, while horse-teeth decrease from the root upward. The grinder, or luard, grating portion of the tooth, which has not yet been used, has somewhat the form of an egg; it is three times as broad as thick, and hollowed out in the shape of a funnel, which hollow has two sharp edges inclosing it. This socket or hollow is called the mark. In the center of this mark, a sort of kernol may be seen-a tube commencing at the end of the rootthat contains the nerves of the tooth ; but this inner hole must always be distinguished from the mark, which is the outer depression, lying next to the sharp edges. The inner cavity is a funnel-shaped socket, of hard, enumel shell, around which, and inside the outward shell, is a thick fluid, which remains during the life of the tooth, becoming, by degrees, gray matter. This fluid averages about four lines in depth in the lower incisors and about eight in the upper ones.

The outer edge of each incisor always rises a line or two above the mner edge ; therefore, when the upper and lower are first grated together, bly the outer edges touch for some time; and the inner edges do not ouch until the outer ones are worn down to an equal height with them. Iorse-teeth generally do this in about one year. At the age of two and half, the teeth begin to change, and those which then appear are called gorse-teeth. (See chart, Fig. 7, A).

A full grown stallion or gelding has 40 , and a mare 36 teeth-the male aving four hook teeth which are lacking in the female, except that somemes she has imperfect teeth in the corresponding part of the mouth. Those teetl. found in some young horses, next to the first double teeth, and called "wolf's teeth," are not included in this number, us they are not pal teeth,-frequently not breaking through the gums at all, and usually, any case, disappearing in eight or nine years. Twenty-four of the wrue teeth, in both horses and mares, are situated in the upper part of the "mouth, (that is, in both jaws, above the lips). They are divided into six double pairs, counting upwards from below, so that those situated next to the incisors in all the four rows are first; those next to them, second; and so on to the last pair, which are callod back teeth.

Twelve others are in the lower part of the moutl', surrounded by the lips, six in the upper and six in the lower jaw, stunding, each lot, in the form of an arch, and occupying the entrance to the hollow of the mouth. These twelve are called incisors. The four innermost, two in each jawthose forming the koy of each arch-are called nippers; the other two in each arch are called eorner teeth; and those betweon the nippers and the corner tecth are called middle teeth. Each of these teeth in the lower jaw rubs against the corresponding one in the upper jaw. The teeth of the upper jaw are broader und thicker than those of the lower. The four 
hooks are sented ulone, over each corner tooth, but nearer to the cornet teeth of the upper than those of the lower, so that they, (the hooks), never come in contact with each other.

The horse has always attained the age of four and a half or five years before he has a fuli number of perfect teeth. Bofore this time, the younger the animal the fewer the teeth, and even these are not all perma. nent.

The more a permanent incisor loses in length, by friction, the more it also loses in width, so that the nearer the friction surface approaches to the root, the narrower and thicker it must appenr.

Every new hook tooth is cylindrical and somewhat hooked, with a coneshaped projecting grinder, and this is surrounded by a spoon-shaped edge, turned toward the hollow of the mouth, so that the cone cunnot be seen from the outside; and the whole grinder, or hard, enumelled part, has the appearance of the back part of the bowl of a spoon-the edge, like a sereen, surrounding the short cone, but so that two deep furrows remain between. Except this grinder, the rest of the body is uniformly round, und the surface almost even. As previously said, however, these by themselves afford no reliable indiention us to inge.

Figures 2, 3, 4, 5, 6 show how the age of a colt nny be determined till he is two years old. The following further explanntions, taken ill connection with the chart from Fig. 7 to Fig. 46, inclusive, will tearh how the age, from two to thirty, cun be aseertained.

Large horses have, of course, larger teeth than small ones ; but takiug a horse of medium size as a standurd, one cun muke allowances for either larger or smaller, and easily arrive at just conclusions.

The incisors being our main reliance, our remarks must be understood to refer chiefly to them. The length of the tooth of n horse of medium size is three inches, or thirty-six lines. After the changed tooth has arrived at its proper length, it shoots up a line regularly every year, and if the teeth stand right, the grinder is worn off a line every year. It is also, as has been suid, worn off in both width and breadth, so that the grinder becomes, from year to yenr, shorter and smaller, us shown by the ehart.

If, however, the teeth stand too far forward, (irregulnr teeth, see chart, Fig. 41), they do not wear down in the sume proportion as ther shoot upward, und they beeome very long. The age in this ense can he ascertained with ense and exactness by observing direetions given under Fig. 41, und noticing with care the following points: At the nge of fire years, the comer teeth of the lower jnw have grown up five lines above the gum; euch middle tooth, soven lines; and each nipper, nine. At eight yeurs, and older, ench comer tooth of the sume horse projects only 
$r$ to the cornet $y$, (the hooks),

If or five years this time, the e not all perma.

on, the more it approaches to ed, with a cone. on-shaped edge, cunnot be seen relled purt, has the edge, like a furrows remnin iformly round, ever, these br

- he determined ations, taken in ssive, will tearh

nes; but taking ances for either

be understood rse of medium nged tooth has very yenr, and ry year. It is th, so that the s shown by the

ulur teeth, see ortion us thes dis ense ean be ns given under the uge of tive ive lines above per, nine. At a projects only our, the middle teeth, six, and the nippers, eight lines above the gums. This is absolutely necessary to be taken into account, because it is the mly means by which one can decide with certainty as to the age of a horse hose teeth have become longer than they would have been if set right nd wearing regularly.

The foregoing remarks and directions are lased upon the assumption hnt there is no peculiarity about the individunl animal or the breed to hich he belongs that would materially interfere with the prineiples laid own. It remains, however, to notice that to those breeds of horses hich develop very slowly, of which the Spmish horse may be eited as h example, the rules nre a little more difficult of sppliention. The ones of these, and perhaps of some few other kinds, seem to be harder, hd the teeth change somewhat later and appear to wenr down more owly; so that it sometimes happens that such horses, after their fifth ar, appear a year or two younger than they really are; but the same imals ure upt to be more than ordinarily strong, hurdy, and long-lived, a to be tuken at a diminished age really detracts nothing from their prth.

The age of a mule is somewhat difficult to determine with exactnews, fing to the enuse just atated.

Deceptions may be practiced with very thrifty young horses, when it is sirubie to make them uriear of suituble age for work or for breeding, knocking out the incisors a yenr sooner than they would naturally ange themselves. If a purchnser suspects deception, he cun determine omatter by closely examining the remuining teeth. If the nippers ve changed, and the imner edges of the corner teeth have not yet come - o eontact, the fonl is but one yenr old - and so on.

The opposite cheat - that of trying to make n horse appear younger in he really is by burning artiticial marks in upon the teeth - (an bes ected by closely examining the enamel nnd the effect of the mark on it. When, a horse has reached un advmneed age, suy twelve to 3nonty, the enmelled surface has become so minute that burning in as large a mork as is found in horses considerably younger would disturb tho whole enumel and so lenve a means of detecting the framd.

- In the ense of erib-biters, that wenr out their tecth prematurely, and o appear renlly older than they are, eximinution must he directed to the orner teeth, which are seldom injured; or, if the corner teeth prove to o injured, deduct from the appurent uge ns unny lines as are wiuting to pake the teeth of the natural length. To feed constantly, from weaning me, upon hard, unshelled corn, sometimes produces the sume effeet as rib-biting, and the same directions must be followed in forming an timate. 
We close the chapter with a short vocabulary, by reference to which the rcader may more readily apprehend the meaning of the terms employed in the ensuing chart.

INCISOR.-A cutter; a fore-tooth which cuts or bites. In the horse, those twelve teeth, six in the upper jaw, six in the lower, which are surrounded by the lips, are called incisors.

GrINDER.-As used in the present chapter, it denotes the hard, grating, upper portion of the front teeth.

LinE.-One-twelfth of an inch.

Mark.-As used with reference to horse teeth, it denotes that depression in the grinder lying inside the sharp edges and adjacent to them.

Nippens.-Those two teeth in each jaw that occupy the middle of the semi-circular row.

Corner Tereth.-The two outer of the six front teeth in each jaw.

Midde Tremr.-The teeth between the nippers and the corner teeth.

Hooks.-Four teeth, two in eaeh jaw, situated over corner teeth, or beyond the incisors, reckoning from the front of the lips, and having a cylindrieal and somewhat hooked shape.

MrL TeETH.-The front teeth of a foal which appear at about three months of age and are cast within two or three years. 
ence to which of the terms

In the horse, er, which are

hard, grating,

s that depres$t$ to them. middle of the each jaw. corner teeth. rner teeth, or and having a

t about three

\section{CHAPTER IV.}

\section{DIFEERENT BREEDS AND THEIR CHARACTERISTICS.}

I. THE INFERIOR VARIETIES: MANY FOUND IN BOTH hEMISPRERES. SOMF GOOD, BUT LITTLE KNOWN OF THEM._II. SOME CONSIDERED AS TO WORK RATHER THAN BREED; THE FARM HORSE; THE HUNTER; THU HACKNEY; HORSES YOR HEAVY DRAFT.—-III. THE ARABIAN.—IV. THE BARB.—V. THE ENOLISH THOROUOHBRED.—VI. THB PERSIAN.—-VII. THE TURK.—VII. THE TURKOMAN.—IX. THE EGYPTIAN.—X. THE DONGOLA.—XI. THE NORMAN PERCHERON. - XII. THE THONOUGHBRED IN AMERICA.—XII. THE MORGAN.—XIV. THE NARRAGANSETT PACER.—XV. THE CANA* DIAN. - XVI. THE CONNRSTOOA.-XVII. PONIRS.

\section{The Inferior and Little Known.}

Among the great variety of horses there nre many that are either of inferior importance or so little known that it is deemed unnecessary to notice them in detail. India, China, Japan, Sinm, several of the European States, and North and South Ameriea, have horses that are in some instances widely different from each other, us well us from the approved breeds; but they are not known to possess any remarkable excellence, or uny distinetive points that are constantly reproduced in their offspring,so that a mere easual reference to them, with very general statements as to qualities and eharacteristies, is considered to be suffieient.

In Indin alone there are various stoeks, known to have been so long in the various regions of that great eountry as to seem native to the soil ; hut with the exception of the Turko, recoguized to be $n$ eross between the Turkoman or South Tartary breed and the Persinn, they are regarded in cold blooded and inferior. The Turko is said to carry himself in a grand and stately way, and to be both benutiful and tractuble.

The Tartar and Calmuck horses, with the exception of the Turkoman, whieh is deseribed elsewhere in this chapter, are for the most part small und ill-made. They are hardy, however, being able to perform great journeys, with burdens disproportioned to their size, and to live on the piorest fure. 
The horses of China are small, and have no points of exeellence as to either shape or spirit.

The horses of Turkestan huve been described by some as huving heavy heads and ewe-necks, with long legs and a scanty body; while others speak of high erests and long, bony bodies, and assert these hores crossed with those of Persia, produce magnificent animals-elegant, netive, strong, and larger than the best Arabians. In Bokharn is a breed of small and shaggy but stout horses, called Kussaks, which has attracted some attention. Their manes and tails are long us compured with their general make up.

Belgium, Holland, and the German states have breeds of horses noted only, or chiefly at least, for being large, strong, and well-formed, and admirably adapted to purposes of heavy draft.

In the forests of Sweden, Finland, and Norway is found a race of horses in a half wild state, from which the inhahitints, without taking upon themselves the trouble of breeding and rearing, supply themselves when the creatures are wanted for use. They are small, but well-formed, atetive, and spirited.

The Hungarian horse, though evidently of the same origin as those of Germany, is somewhat lighter than they, and possesses more spirit and action. He shows some signs of oriental blood, to which he probably owes his superiority to his neighbors.

The horses of Iceland run nt large and piek up their own scanty fare, wherever they ean find it, until they are needed by the inhabitants, when they are caught and subjected to use. The origin of these unimals is in doubt. Some assert that their progenitors were carried into that island from the forests of Sweden; others, that they were of the stock of ponies found in the Scottish isles. They are small, but active, and generally well disposed.

The horses of Italy were formerly much better than now. Few of them may at present be regarded as possessing any striking excellence. There are said to be some, unnong the people of Naples, that are large, of fine appearance, and excellent as carringe horses.

The French people have many breeds, adapted to the saddle, the light carriage, cavalry, and light artillery, besides those that are required for the plow and the cart. The most famous among them is the Norman, or Norman Percheron, which is described elsewhere in this chupter.

The fact is well established that the horses of Spain, previous to the Moorish conquest, were possessed of many noble qualities; but they were much improved by a mixture of Barb blood, consequent upon the invasion and the introduction of horses from the Barbary States. They 
ence as to

ving heavy aile others ese horeses - eleg:ant, is a breed is attriacted with their

rses noted rmed, and

I a race of lout taking themselves ell-formed,

as those of spirit and he probably

scanty fare, tants, when imals is in tluat island he stock of e, and gen-

w. Few of excellence. are large,

e, the light equired for he Norman, apter.

ious to the ; but they t upon the tes. They still show both their original and derived excellences; and a pure-blood Spanish Barb is a fine and beautiful creature.

In the plains of South Ameriea, Mexico, Texas, and the Western Territories of the United States are found great herds of wild horses, of which there are different varieties, though they must have had a common origin, as we have stated in Chapter I. Chance mixture with horses imported into the country subsequently to those brought from Spain, together with the influences of different climates and food to which they have long been subject, may perhaps account for this. The most marked types of these wild Americans are the Mustang and the Indian poties, which are noticed on succeeding pages. As a general thing they retain the striking characteristies of their old Spanish or Andalusian progenitors ; in size, shape, and spirit they show whence they are derived. Their lieads are pretty and their limbs clean. They are capable of great endurance; and though not especially rapid in action, it is related of them that they are sometimes ridden at the rate of ten or twelve miles an hour for a stretch of eighty miles, without anything more than a temporary halt and such little food as could be hastily eaten. Seldom is any gait known among them except a walk and a lope; but an occasional pacer is discovered. Many of them do well for the saddle; but care is required in handling them. In the hands of the cruel or inconsiderate, their wild nature returns to them, and they become intractable and even dangerous.

\section{Eome Considered as to Work, rather than Breed.}

In treating of the different stocks and specifying distinguishing points, it is perhaps not amiss to consider some characteristics that should mark animals chosen or set aside for special purposes. And yet in this consideration it must not be forgotten, that very few liorses, comparatively, are kept for but one class of duties. Few horses are for the saddle exclusively, as compared with those who render service in harness at times, as well as under saddle. And so with other grades of horses. A. varied work is usually required, and especially so among farmers, and the well-to-do residents of cities and villages.

The good farm horse cannot, of course, be confined to any particular hreed. If ta combines within himself certain desirsble qualitics, it is not pertinent to inquire particularly what blood he earries. Some points that should distinguish him may be thus enumerated: He should be (lose-built and strong, but not gross and clumsy, sinee he is to serve as a sort of horse of all work-doing duty, by turne, under the saddle, and before the plow, the farm-wagon and the carriage. 


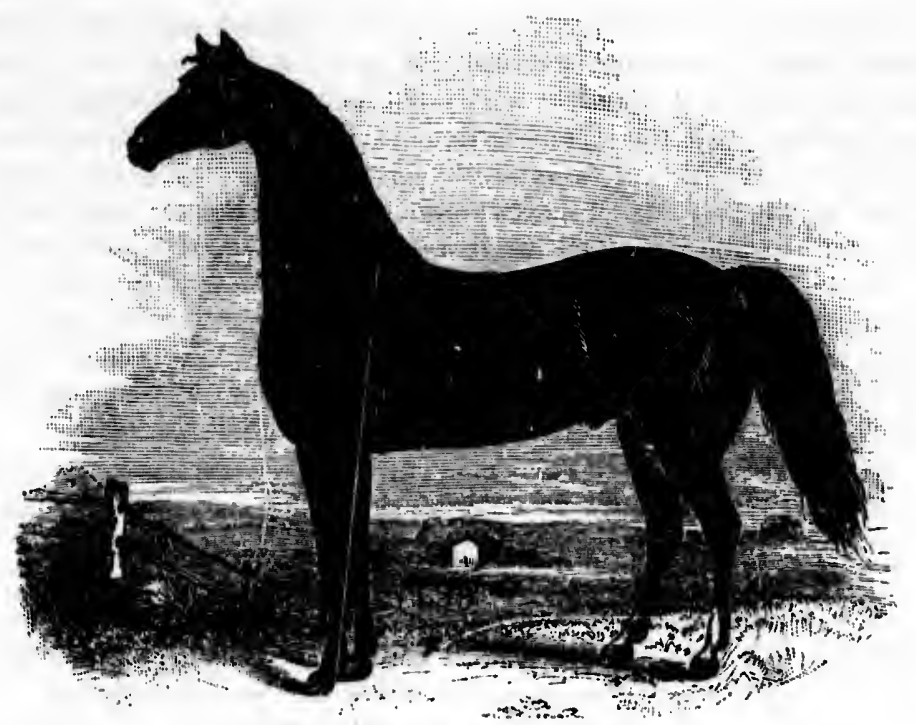

A Good Horse for light Driving.

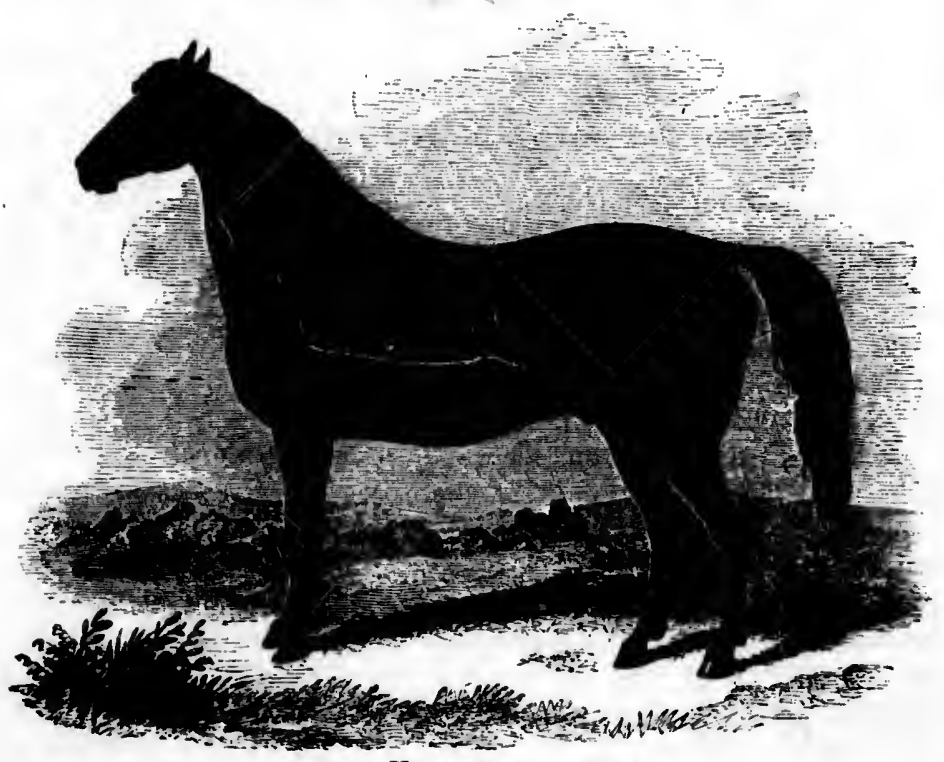

A GoOn Horse for a d.t. Work. 
Fifteen to sixteen lunds mark the proper stature; and his limbs should be sinewy without alssolute henviness, while lis feet should be of medium size. He should lo rensombly springy under the snddle, and active, without dash, in light harness. To these he should add a certain thriftiness, that will enublo him to uppenr well even under good, close work, if well treated; and in temper he should be mild. His brenking in and training should have been such as to render him readily adaptablo to any work that he muy be ealled upon to perform about the country home.

The hunter, or horse for the chase, speuking with reference to a pastime which is still common in England, but to which little or no importance is attached in this country, is usuully the better estecmed for having some blood, but more for the absolute fents of speed and leaping which he may be able to perform, and for his ability to stand a hurd day's run.

The best hunters are said to be a combination of the thorough-bred with some courser animal-producing more strength, substance, and hardihood, with less length of body. $\mathrm{He}$ is at the present time whit may be called three-quarters bred; and he is lighter and more flect than formerly.

The engraving upon the page next following, entitled "A light hunting horse," conveys an excellent idea of what this horse is now most commonly found to be.

That is to say, a horse of good style and form, capable of long continued exertion under tho weight of an ordinary sized man, and aiso capable of showing as high a rate of speed as possible, combined with an aptitude to leap successfully such obstucles as may ordinarily interpose. In all this class of horses, whether they be light or heavy weight animals, blood-that is, the possessor of a fair amount of thorough blood as transmitted by thor ough-bred sires-is absolutely necessary. It gives style, form, hard and fine bones, muscular tissue, lung power, and all this means endurunce to perform feats under which the cold blooded horse would soon succumb. Such n horse as the engraving shows will not only make a capitul saddle horse, but also a most valuable horse for general utility, if properly broken, good for the light carriage and buggy and good also at a load if properly trained and handled; but let it ulways be remembered that in as much as you put a saddle horse, and especially a hunting horse, to labor, you detract from his value in the field. This is to be regretted possibly, especially by those of somewhat limited purse, but such is the fact nevertheless. The best work in many lines cannot be had at one and the same time from one and the same auimal. Excellence in some points necessitates unfitness elsewhere. 
During the last century, however, and the first of this, it was deemed essential that he should be a heavier horse - an animul capablo of making

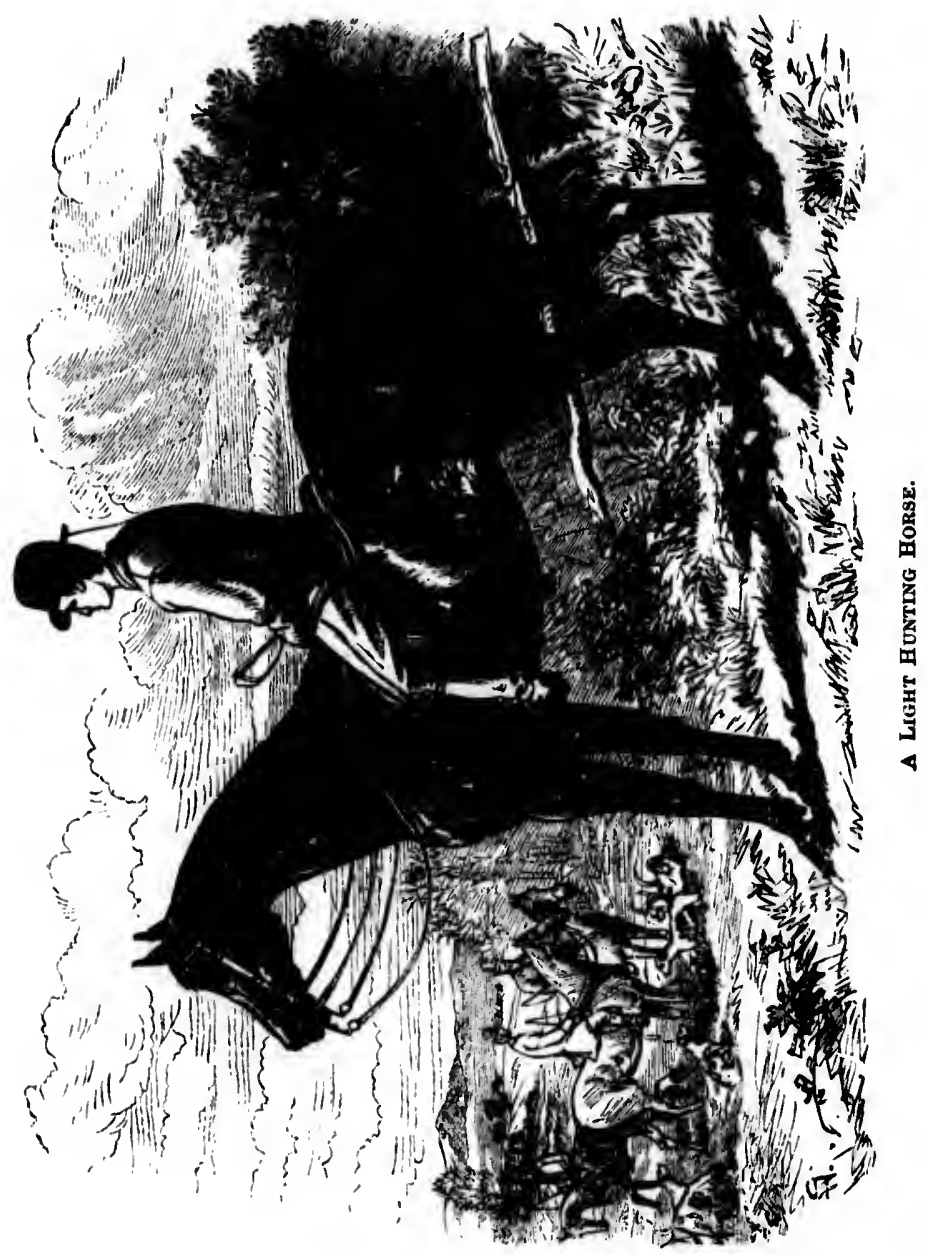

prodigious leaps while carrying a heavy weight. This type is well reprewented by the subjoined eut of "A heavier hunting horse." 
The Hacknny, ths the horse of a!l saddle and light harness purposes, the common rondster, or general knoek-about, is termed in England, may bo considered in pretty much the sane light as the good farm-lorse pro-

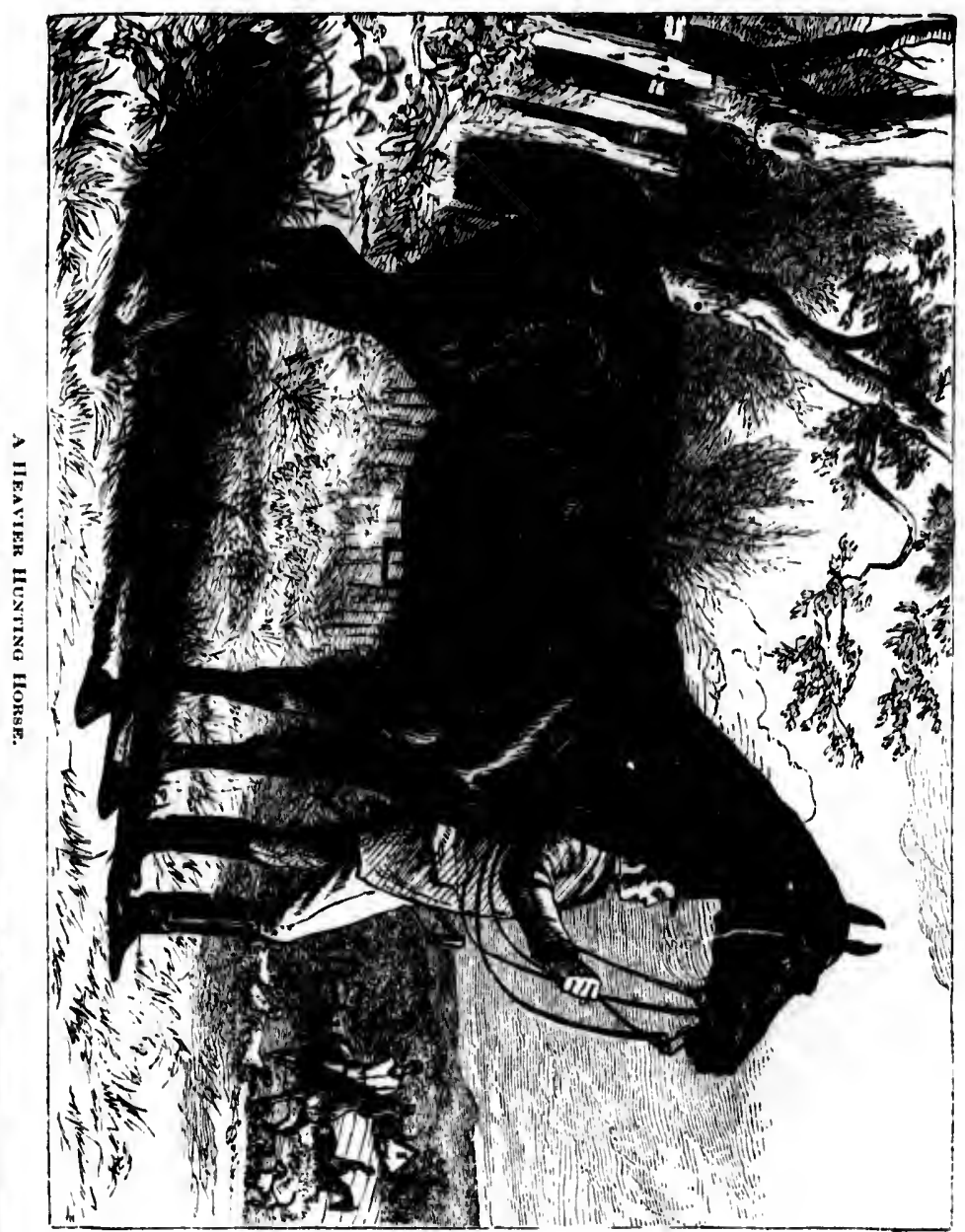

viously noticed. Among the English people it seems to be essentiul thit in animal must at least be supposed to possess some blood before he can be considered a good hackney. When known, or believed, to have a 
streak of the thorough-bred in him, and to possess the following churac. teristics, nothing more is desiruble:

He must be ubout fifteen hands high; loth his fore mind hind parts . must be strong and well muscled; he should bo short in the back und well coupled; his chest should be wide und deep, ullowing full play for

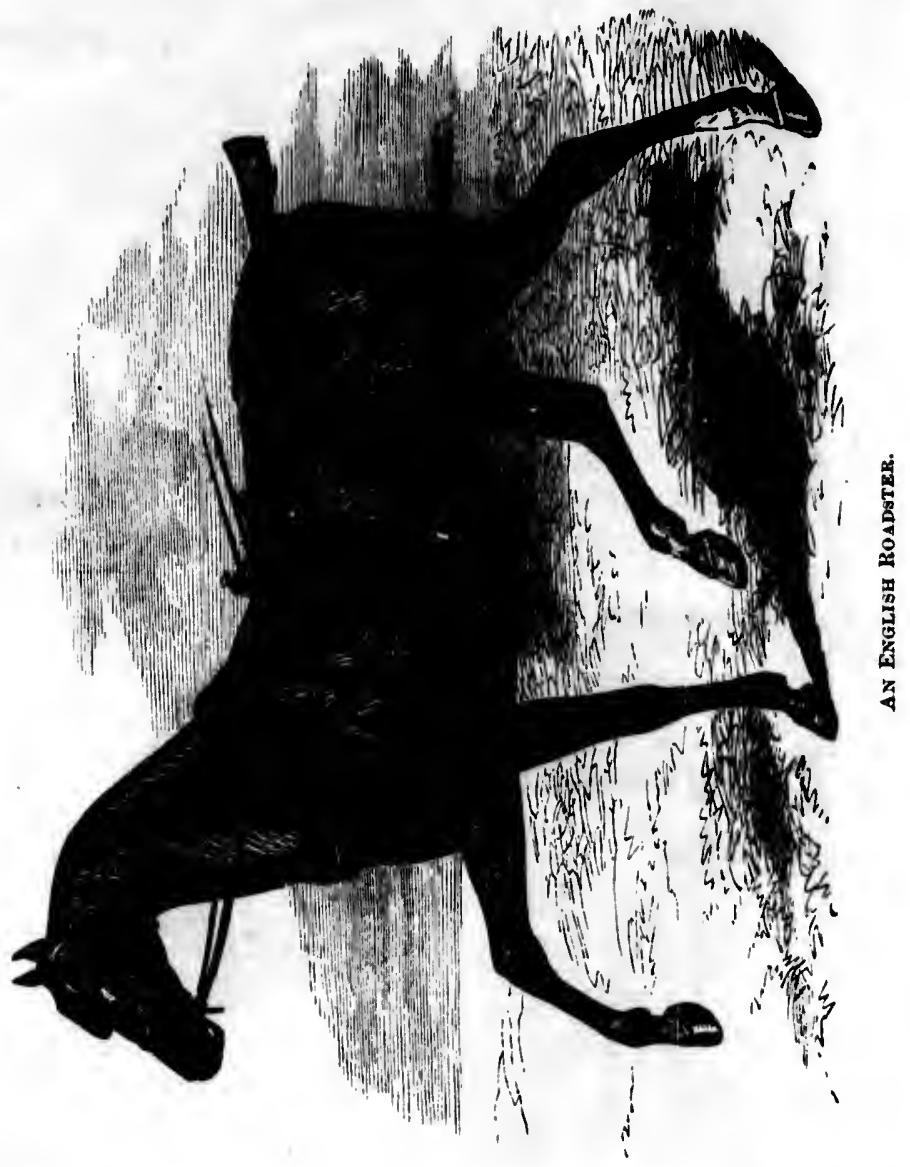

the lungs; his head should be light and his neck carried well up; his limbs should be clcan and bony, and with somewhat oblique pasterns; he should be quick and springy ; and in temper he should bc kind and easily controlled. 
Of Hravy Draft Honsks there ure severnl breeds in both Ligland and the United Stutes ; or ruther, severul kinds thut have some of the blood and some of the charucteristics of the old henvy draft unimuls. When it hecane the fashion in Englund to seek udmixture with the henvy mures und stallions of Belgium or Flanders, the English druft stock was really much improved, though severul English breeds soon lost thereby, for the most part, their identity.

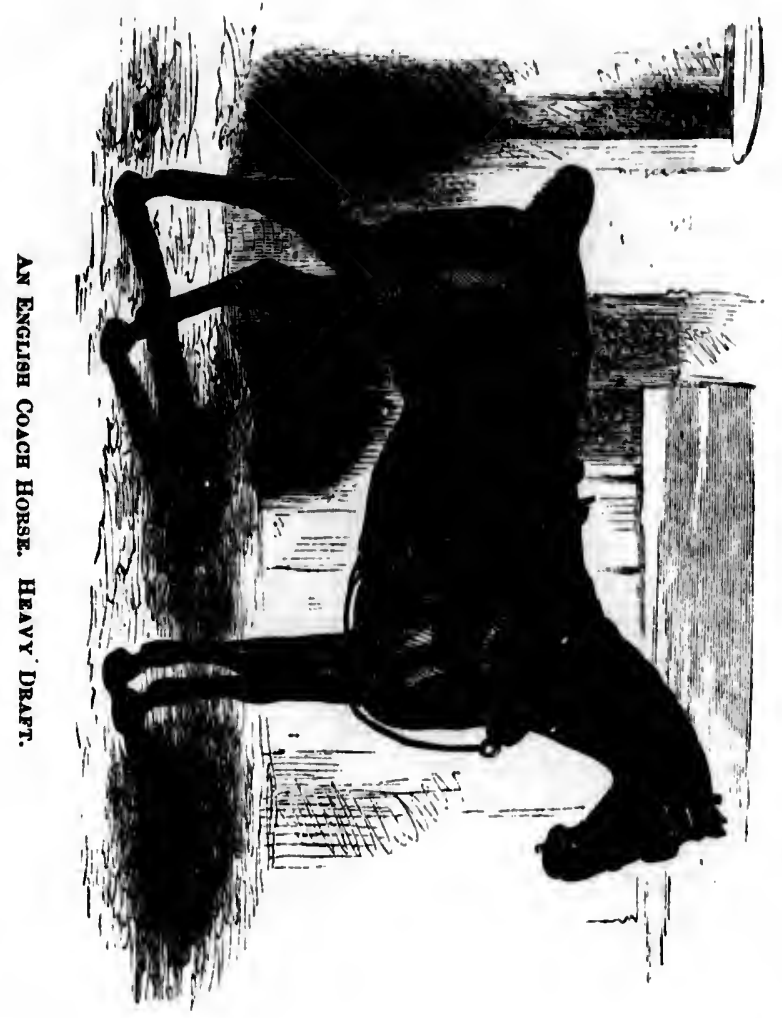

The Cleveland Bay, a powerful horse, though not of extraordinary

up ; his terns; he nd easily size, was found chiefly in the four Counties of Yorkshire, Durham, Lincolnshire, and Northumberland. He was capable of carrying a great weight, and of maintnining under it a rapid rate of speed. A lighter horse, and one better adapted to the carriage, was produced by crossing the 
Clevelund mare with a good-sized thorough-bred stallion. The best hunters and hackneys, hnving an arched erest and proud action, wero produced by crossing the Cleveland mare with a horse lighter than the true thorough-breds, yet possessing renl spirit and quick movement. Tho Clevelund, as a distinct breed, is iearly extinct.

The Suffolk Puich is considered is be an excellent heavy draft horse. He is believed to be the offspring of the Suffolk cart-mare und the Norman stallion. When furthor crossed with the Yorkshire half-bred, (tho product of the Cleveland Bay and the thorough-brea), he is active, spirited, and indomitable at a pull.

The Suffolk, now hardly known as a distinet breed, was a horse of good size, being ordinarily from fifteen to sixteen hands high, and vary stout in proportion. His distisguishing color was sorrel; he had a large head; his shoulders were thick on top and low; his chest wis round and deep; ho had round legs and short pnsterns; his back was long; his croup, high ; his flanks full; his quarters heavy and strong; and he was every waty a spirited und determined animul, active und enduring.

The Clydesdale horse, found principally on the Clyde in Scotland, was the product of certain Seottish mares with Flanders stallions. IIe is a larger horse than the Suffolk, but less clumsy in uppenrunee, as his heal is better and his burrel lighter. He l:us a long ne:k and deep legs ; und is strong, hardy, patient, and $\boldsymbol{n}$ fuithful pulier. Some of the horses in the United states said to be of this stock preserve most of these cluma:teristies, but their bodies are rounder and their neeks are not particularly noted for length. An extended description will be given further on.

Between Lincolnshire and Staffordshire, in the midland counties of Englund, is fortund whut is called the Heavy Bluck Horse, a large, wellbuilt minual, of splendid appearunce, and much in demand in London and elsewhere as a wagon-horse; but no horses of this partlcular kind are known to have been brought to America for breeding purposes.

Of American heavy druft stock, the Vermont cart-horse is deserving of special mention. He is sxid by one who is eonsidered good authority to exist in Vermont und adjacent States as a distinct breed, and to be the very model of what a good curt-horse should be-puick and full of power. yet ensily manngrd. As a generul thing, he has a well-set head, a lóny crest, thin withers, mnne and tail medium, and olenn fetlocks. Ho has sufficient action to insure a good rate of speed, and makes, "non the whole, a fine show.

His origin seems doubtful. There is a pony appearance about him, though often more than sixteen hands high-his peculiar shortness of buck, roundness of body, and general compactness contributing to make 

nd snd is eroup is every nd, was IIe is a his houl g' ; Imd orses in charneicularly nties of te, wolllon and ind are ving of ority to be the power, a los.cy IIt h: ha ont tho

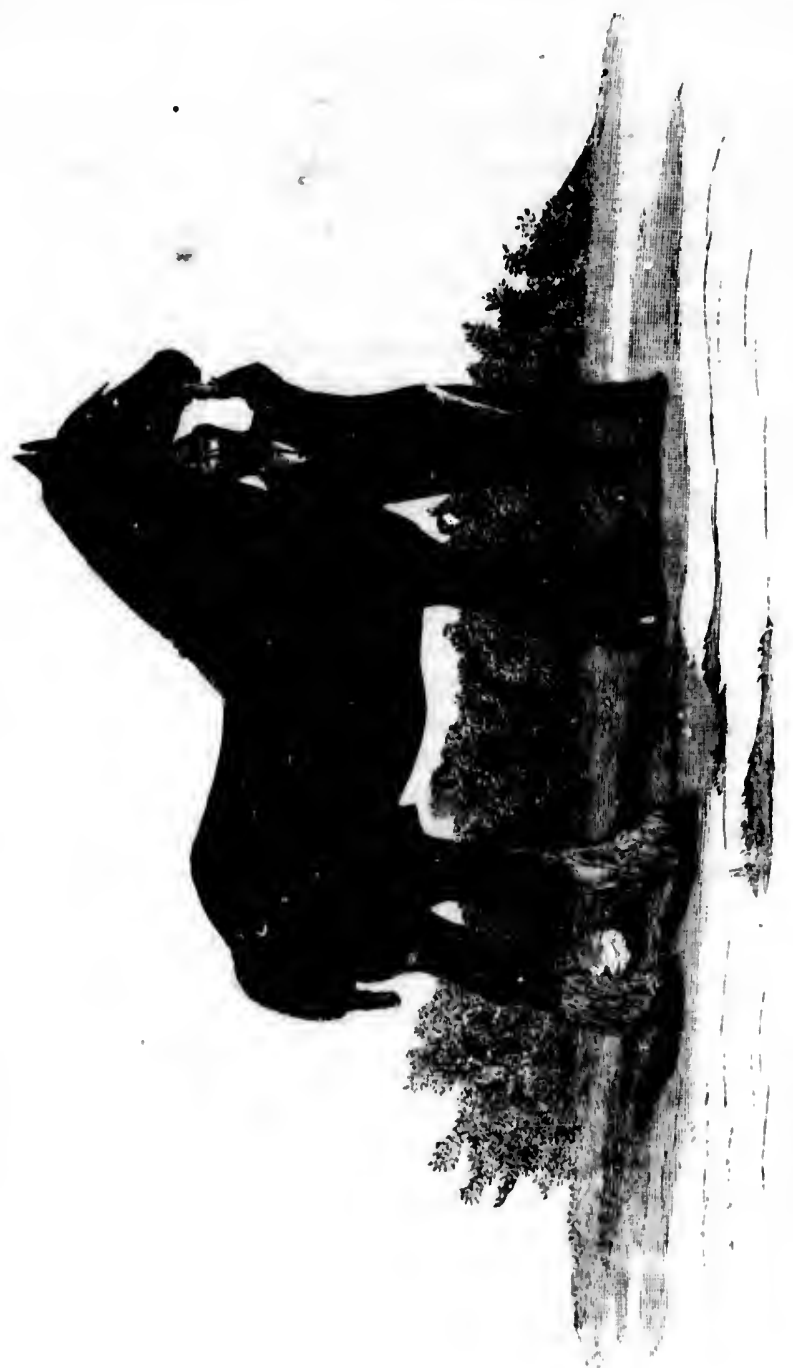

lt him, less of b make 
him scem much less in bulk than he is found to bo by actual measure: ment.

\section{The Arabian.}

We eome now to notice some of the most distinct, strongly marked, mnd valuable breeds, among which the Arabian, or that species of the Arabian best known to us, is justly celebruted.

Whether the present pure blood Arab is nutive to Arabia or imported; whether of recont origin or of a lineage as ancient ns the seulptured ruins of Nineveh and Babylon, it is needless to inquire; but the people of thit country claim thint they bave nuthentic pedigrees reaching bnek for more

- than two thousand yeurs; while on the other hand, it is asserted by some who have tried to discover tho :en! erigin of this fumous stock that prior to the thirteenth century the horses of Arabin were a poor raee and lightly esteemed. Be that as it muy, the horse of the present day, so renowned throughout the world, undoubtedly begm to attraet notiae some tive or six lundred yeurs ago, since which time he has grown into his, great repute; and now the best horses of most eivilized lands are thought to derive their highest chinus to noble descent from the Aralie Kochlani, und those of his congeners that have shured his excellen m.

In a subsequent elupter the subject of breeding will be apprc!." trented; but we may udvert here to a singular fuct in connection sons of the desert and the horse that shures their name and their affertions. So thoroughly are the principles of breeding understood among them, or such is their extraordinary eure, (and perhap)s climatic influence inuy luve something to do with it), that their loorses long since reached a cuegree of perfection unrivalled in my country, and this perfeetion is t teudily maintained.

Travelers differ ns to the number and names of the distinet breed of horses which ure found in Arabia ; but a counparntively' reeent Mohumunedan writer, who seems to huve hud more than ordinary opportunities for kuowing the facts in the case, hus stated that there are six distinct hreesh, whicls lie numes and chumeterizes thus:

(1) The Dgelfe, found chiefly in Arabia Felix, seldom seen at Damascus, but conmon in the neighborhood of Anaze. Horsen of this breed are of lofty stature, have marrow ehests, but are deep in the girth, and their ears are long. They are remarkahle for spirit and fleetness, but are exceedingly tructable, and their nbility to endure hunger and thirst is a renurkuble fenture. A two-yenrold colt, he says, will cost in his own country two thousand Turkish pinsters.

(2) The Secnloni, a breed from the enstern part of the desert, somewhat inferior to the Igelfe, though resembling him in most points. 
monsure:

marked, ies of the

imported ; ured ruins le of that $k$ for more al by some s that prior and lightily it duy, so notice some "ne into his lands are the Arabis: :Hen'.... ppre.". ion their affectood munong ie influences nes reached erfection is

$t$ breeds of Mohumonetunities for inct loreeds,

1 at Damasisthis breed girth, and ess, but are d thirst !s a in his own ssert, someoints.
(3) The Mofki, he informs us, is a hundsome horse; but he is not so ficet is either the Dgelfe or the Seenloni. In figure, he beurs a resemhlince to the Spanish or Andalusian stock.

(4) A fourth breed is ealled the Sabi, which is similar to the Mefki, but seems to possess no speeially nseful or striking qualities.

(5) The Fridi. This breed is very eommon ; but they are often vicious :nd untrunt worthy, and lack some of the exeellent qualities possessed by the best of the others.

(6) The Nejdi, found ehiefly in the region of Bussorah. These are sirid to be at lenst the equuls of the Dgelfo and the Secaloni. Some judges assert that there is no horse to be compared with them, and they stiud very high in the murket.

'This writer considers the Dgelfe and the Nejdi to be the most valuable. They ure known to be the favorites of the horse-funciers of India, many fine animuls of these stocks lutving been carried thither by the sportsmen of that country.

Other writers make mention of but three distinet breeds, to which they attribute numes different from those above given; and it is difficult to reconcile the statements of the two, and to determine whether they have really ngreed in my way in pointing out the sume animsl, though by diverse numes, us possessing the striking exeellenees which have mude a crrtain breed funous and well known to us. Writers of the latter elass speik of in inferior race, little esteemed, at home or abroad, which they (all the Attechi. These are sometimes found in a wild state. Then come the Kindis hi, a sort of lumlf-breed stock, possessing some points of resemblance to the true blood, und being sometimes imposed upon dealors for the genuine. Finally, they deseribe a superb rnee, the pure desendants of some extroordinury ancestors, and these they call the Kochlani or Kitilhum. The hest of them are found numong the Shammar nnd Aneyza tribes. The Anube themselves pretend to trace the Kochlmi bick to the dilys and the stables of Solomon. While this comnot be eredited, it is knewn that some of them have written pedigrees for at lenst fonr hundred years, knpt with the most extreme enre, and always on the side of the mare. These animals are sometimes sold to foreigners; but they bear almost fuluulous prices, and it is believed to be a very rare thing for a true Kochlani to fall into the hunds of a stringere.

The striking points of the pure Arub may be thus stated: In size, loe is eonviderably smuller th:" the modern thorough-lored, senrely ever exceeding in height fourteen and a half hands. His head is extriondinary for its besuty, - the forehend being hrond and square, the muzale short and fine, so that some of them seem us though they could reslly "stick their voses into a tumbler." The face, upon which the veins appear 


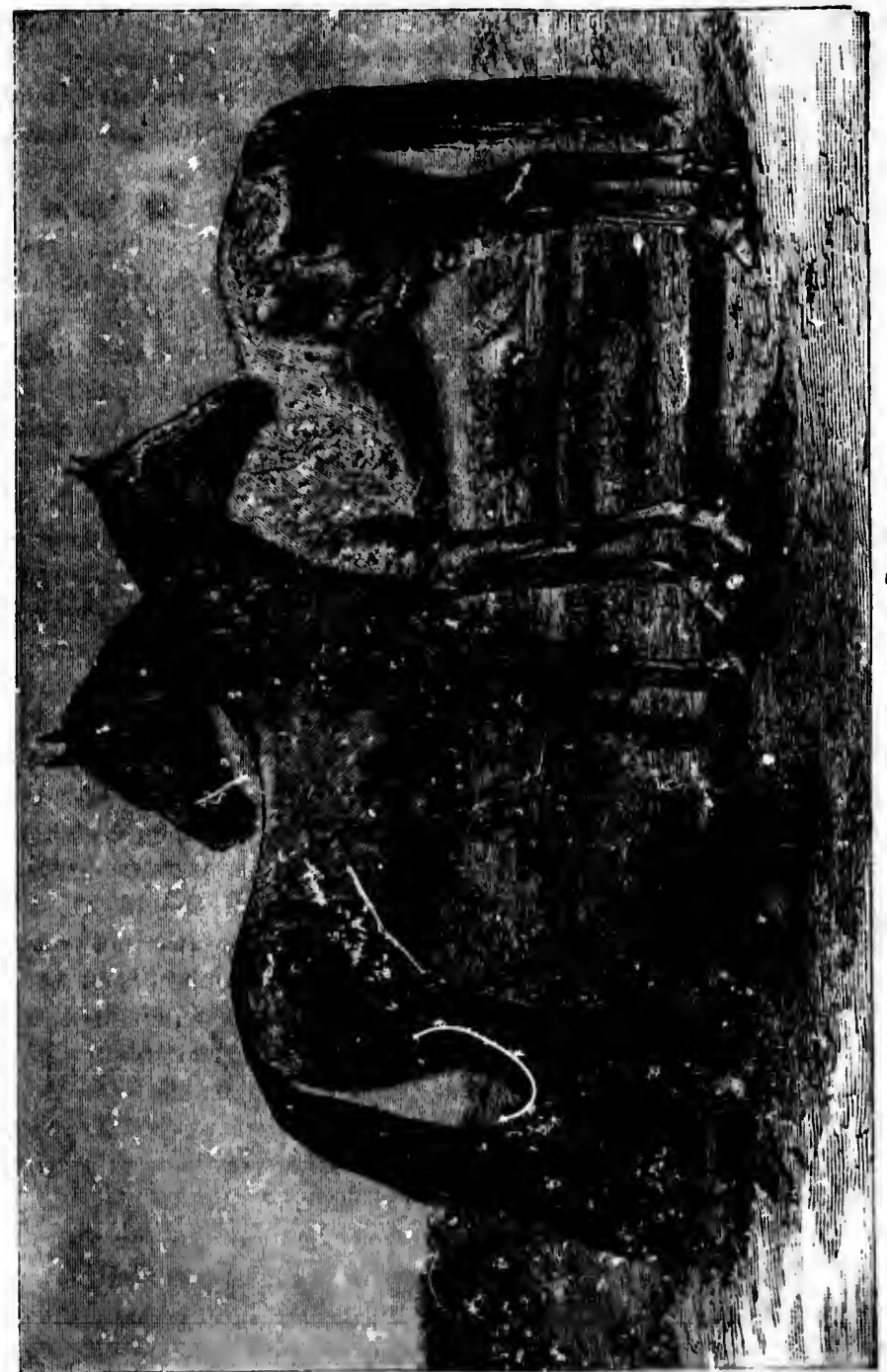


hentifully coursed, is bony; the nostrils ure wide; the well-set ears are small, while the eyes are large, prominent and brilliant. The neck, rising bentifully from the shoulders, and well arehed, is very tine; the withers are high and moderately thin; the shoulder: inelining backward, is perfect in form and position - muscular as well as finely shuped. Tho body is light and narrow before; but behind the mms the chest is expanded and affords sufficient capacity for we lungs; the hips, though somewhut nurrow, are well united to the back, and the quarter's are strong, muscular, and well set. The legs mo smull, flat, sinewy; the pasterns are oblique in their position; the croup is high, while the tuil is wet on with consideruble arch. The muscles of the arm, like those of the ham, are full and strong. The bones of the leg are large in proportion to the size, there being no superfluous fitty mutter, but full, free, strong, and clean tendons and suspensory ligaments. The hocks are large, but freo from both curbs und spavins; while the fect are smmll and somd. 'The elbow joint is prominent but fine, and generally pluys elear of the body.

Especially does the Arab differ from other breeds in the superior fineness of his muzzle; the somewhit hollowed but grneeful fice; the fully developed juws that yet give no impression of heuviness; the beautifully pricked und expuisite shupe of the enr; the conspicuous nentness of the leg below the knee; and the benutiful muke of the hind quarters. The flectest among them are ulso noted for a struight-dropped hind leg,

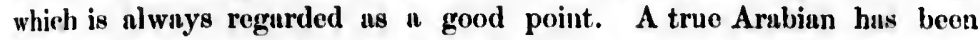
deseribed as "looking the gentleman all over, with a benring as stately ws that of an autocrnt."

In spirit he is as noble as in his physical formution. Though kind and docile when with his native master, he is sensitive and full of spirit, und when excited is so indomitable that he would run or pull to the death ruther than yield. With a cruel master he is upt to become in a measure mgovernable; lut his intelligence is sueh that proper treatment will soon win his confidence and remove $n$ vicious thalit.

His sagacity is as remarkuble us his susceptibility to kind trentmont. Instances ure not wanting in which his master, overeome hy the heat of the desert, and lost in a lethargie sleep, has been watched over by his faithful animal, and gunrded from the approach of mun and heast.

The colors mostly prevalent among them are bny, gray, and chestnut. Ocensionally a bluck is found.

Ho is not so swift as the best English, French, and Ancrienn coursers; nor is it here that his grest excellenee must be sought. That arisos from a combinution of qualities, to some of which the vest of other breeds are wholly strangers. 
He is peculiarly adnpted to that waste and lonren comntry, and to the uses for which he is prized by the wundering tribes. The food and drink upon which he em live me perform grent journeys would be wholly inadeyunte to the keeping of one of ours which we are plessed to call thrifty.

As has been said, this remarkuble stock has long maintained its essential purity ; nor does it show, in recent times, any tendency to dewenerite. Those good Arabians that me offered for sale to British residents and other horse deulers in the matkets of Bengal nnd Bombay commund prices ranging from seven hundred and fifty to one thousind dollars ; and it is said by travelers that their best mares me seldom if arel sold.

\section{The English Thorough-bred.}

We have nlready referved to different vinrieties of English horse's, some of which have had more or less inlluenee upon those of our own country; hut the most exeellent and famous of all is the thorough-lored, or lan'ihorse, descended chiefly from imported Armbians, Barlss, and 'l'urki. The animal known to-dny as the real English thorough-lored is perb:eps of almost purely enstem origin. His exeellences are drived, it is thought, from an admixture of various pure breeds, native to those regions (1) which the noblest of the ruce are indigenous, so far as eitler listory or tradition determines. Arabin, Syria, Persia, 'Turkestan, Nubia, Abyssinia, and the 13arbary States, all have breeds closely comected with each other, and yet possessing different chinacteristics; but the English morehorse is a superior animal to any of them; and his blook cannot now be improved by crossing with any known stock.

There seems to be in him a larger mixture of the Barl) than of any other breed; but the enrliest and most celebrited importntions into Fuylanel were Arabians. Much attention has long been paid there to the improvement of ricing stock. The minds of linglishmen were most probably tumed to this by the necession of the Norman Conqueror's ; an any rate, seos nfter the Normuns were established in the island, the tirs Arabian of which any reeord has been preserved was imported. Thi:

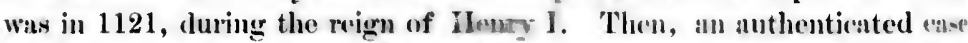
of importation from Arabia took pince in the reign of James I. This holse was condemned, not having mes the popular expectution; but the true value of enstern bleod beam now to be appreenated. and the White Turk was soon brought over; then a horse known as the Ilelmesley 'Turk; soon afterward, Fairfax's Morocen Barb. The interest in the improve ment of racing stock then so actively munifested has never suffored more than a temporary abatement, and in no other rountry than in England has such suceess been attined. During the troublous times conserpunt upon the overthrow of Charles. I. mel the aceession of the Puritans to 
to the d drink ly inadthrifty. 4 essenmeriste. nits and d prices. and it is

(is, sollle "(6)tutity' or liser1 'lurk(r):: os of t loought, ergions to isitory or in. Alyyswith each rish rueret now lie In of any into Gingre to the ere most lerol's ; at 1. the tir: cd. 'Thi: anted "ans" I. This: ; but the the White lev Turk: iniprose cered more Englum onsequent Guritans to power, there seems to have been a decline; hut a love of raeing, und v corresponding desire to produce the hest horses for this purpose, wins

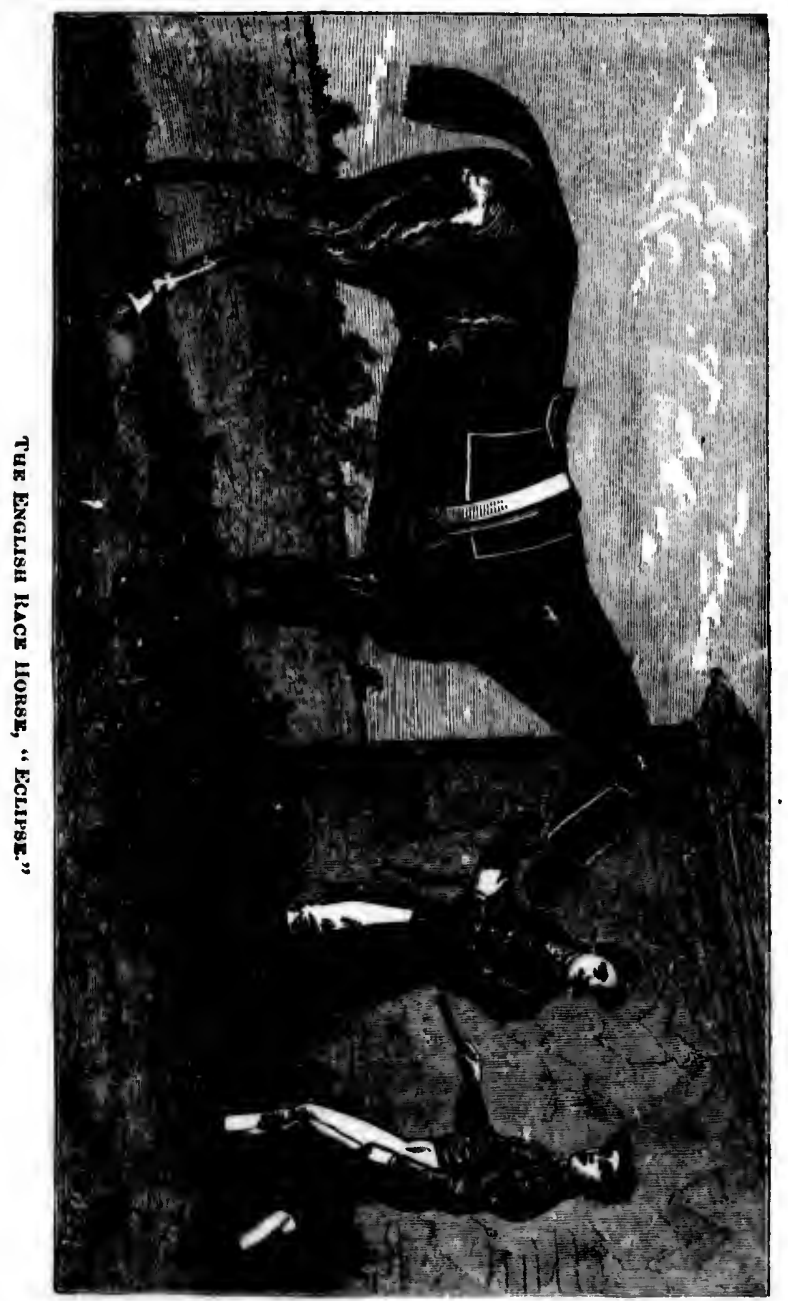

revivel unon the restomation of Clinles II, to the rhoune. 'This prince himself sent to the east to purchase hrood mares and stallions, but he 5 
affectod chiefly Barbs and Turks. Many of his wealthior suljects engaged in like enterprise on their own private necount.

But the most marked improvenent of English stock followed the introduction into thet country of the Durley Arul,iun, a fine and vigorous stallion imported during the litter part of Queen Ame's :eign by one Mr. Darley. Several horses of grent repute descended from hin, of which the most noted were Almanzer, Flying Childors, nud Bartlett's Childers; and from the Childers, besides numerous others, of more or less celebrity, Childers, Bluze, Sumson, Sunp, and Eelipse deserve special mention. Of the last numed, it is recorded thut though he wus thickwinded or what is termed a "rourer," he never lost a raee und never puid a forfeit ; und that throe hundred and thirty-four of his descendunts proved to be winuing horses.

During the reign of Louis XIV., of Frunce, and when the Arubian stoek, the descendants of the Durley, were ulrendy in high repute, $a$ horse called the Godolphin Arabian, but which was renlly a benutiful Barb, of exeellent spirit and action, was rescued by one Mr. Coke from the ignoble employment of drawing a enrt in the streets of Paris, (where his striking characteristics seem to huvo been wholly overlooked), und carried to Englund. Ho is suid to have been about fifteen hunds high, of a brown color, and to have been distinguished by the height of his erest and for round and drooping quarters. From him is deseended much of the finest raeing blood in England.

We have spoken of the thorough-lired as a pure-blooded horse; and though this ought doubtless to be understood with some limitations, as evei in the best of the stock there is probubly some tinge of old Finglish and Spanish blood; yet, such has been the grent cure lestowed upon him that he is regarded as " the enstern horse brought to the very highest state of perfection." It is certuin that, as previously remurked, he is in some respects superior to the best of the original breeds. This has been brought about by long continued cureful attention to breeding, to freding, to all those points, in fact, necessury to the elimimution of vicious struins and the presorvation and improvemont of those quulities that tend to the one great end in view-flectness, with a eorresponding power of endurance. The elimate of Engrland is suid to be peculinrly favorable to the horse; and this influence his perhaps contrilouted something to the muking of the English racer a pre-eminently fine and much admired animul. The following may be regurded as his distinguishing points:

His chest is his one and only mark of superior strength; this is wide and deep. His body is round, his flunks and belly light. His enrs am fue; his eyes prominent; his nostrils ure wide; his lips are small und thin, while he is remarkably wide between the juws. Ho has a long and 
ects engaged

collowed the and vigorous' eign by one om him, of ad Burtlett's of more or sserve special te wis thickce and never descendints

I the Armbian opute, $n$ horse tiful Barl, of rom the ignois, (where his 1), and carried bli, of a brown crest und for h of the tinest

looded horse; no limitntions, fo of old Enge bestowed upon to very highest arked, he is in This has been eding, to feedtion of vicious lities that tend ding power of y favorablo to nething to the much admired ing points : 2 ; this is wide His ears are ure small und bus a long and fine neck, to which a thin mane lies elose. His withers aro uneommonly thin tnd high ; his back is low at the withers, then straight to the haunches. .Measured from the haunches to the tur'n of the rump, ho is long ; from the turn of the rump to the tip of the hock he is long and thin. He has great power of springing, to force himself forward, by renson of his legs standing rnther under tho body than ereet. His buttocks rurely touch each other'; his legs below the kneo und hock nro smull, and the cords stund out conspicuously. His tuil is slight und thin-huired, sometimes slightly waved; the hair of his legs is very tine; he hus no fetlock tufts, and his hoof is smull nnd cupped. Hie color is generally bay, brown, or chestnut; his height varies from fifteen to seventeen hands. His cout is thimer und the huir more silky than in common breeds.

The soundness of feet and legs, and the powers of endurance, which characterizo the Arab, lave been transmitted to the thorough-bred; and while the latter is not himself well suited to henvy harness work, or indeed to any of the general purposes of the furmer, animnls mo often obtained hy judicious cromses with him which aro admirably adapted to various isses. Ile is valued solely for the turf, and for light single draft, exeept, as we have before remarked, for the improvement of the general stock of horses by admixture; nnd for this latter purpose we aro largoly dependent upon him in Ameriea as well as in Grent Britnin.

\section{The Barb.}

The horse of the Burbary States las long been known for his excellent qualities; and he is especially remurkable for fine and grneoful action. His powers of trunsmission are great, so thut his marked truits aro found in his descendunts at remote periods und after commixture of various and inferior breeds.

He has impressed himself particularly upon the Spanish horso and tho English racing stock. It is thought that the horses of Spain owe all their exeellences to Barb blood, which was brouglit into that country by the Moors, at the time of the conquest.

The Barb is found chiofly in Moroceo, Fen, and Tripoli, and with the exeeption of an excellent species found in the kingdom of Bournon, he is the only Africun horse deserving of special mention. The horse of Bournon is represented by some as being superior to both the Arabian and the Barh.

In addition to what has been said in those sections in which we have treated of the Arubian and the thorougl-bred, the following deseription of the Barl, will be sufficient to convey to the mind of the render what $a$ true horse of this breed really is : 
In height, he is from fourteen to fifteeu hunds; his chest is round; hit shoulders are broad, lout light, and somewhat obliquely sloping; his withers ure thin und ruther high; his loins are struight and short; his flanks and ribs ure round and well developed; his haunches me strong; his eroup is somewhint too long for nice correspondence witl the rest of the body; his quurters are musculur and full; his legs me clem, anl the tendons ure eleurly murked; his pasterns, like his eroup, are somewhat too long and slanting, but not 30 much so as to umount to real dofect; and his feet me sound and of good shape. But his hend is especinlly heautiful. It is smnll and lenn, while the enrs are of medium size and admirubly placed. The mane is rather meager; but the nerk rises bolally from the withers, and gives an impression of ense and grace in carringe.

In spurit and flectness he is not regarded as the equal of the Arah, much less of the real thorough-bred; but in a certain nutive vigor and in form he is superior.

\section{The Persian.}

No traveler to whose writings we huve access in this country has sufficiently described the horses of Persia to enuble us to poin' out with exactness the difference between the inferior und tho better breeds that are known to exist in that country. The term the Persian horse is ordinarily applied to the most excollent of ..ll, which has been celebrated for hundreds of years longer than the Arnbian. At the present day, he has a large proportion of Arab blood in his veins. As a general thing, he is somewhat taller than the Arabians; and in beauty and speed he is their equal ; but his powers of endurance are not so grent.

VII. The Turkish.

This horse is believed to bo descended from the best stoek of Arabs,crossed, however, with some breed that has given him grenter proportions than his ancestors; at any rate, the Turkish horse of to-day is full sixteon hands high, often more; and he is more muscular than the Arial, though still of elegnnt uppenrunec, clean limbed und uctive. It is usserted by some that he is descended from Arabs and Persians; and it is known that he possesses many of the best qualities of these stocks. Though strong and of sufficient spirit, he is docile, and well adapted to domestiv uses.

An arched neck, with a high erest, is a striking characteristic of the ireed.

\section{The Turkoman.}

As we have said elsewhere, none of the Tartar breeds exeept the Turko- 
sound; his loping; his d short; his are strong; ; the rest of o clemin, :min! p, are somerount to real $t$ his hend is o of medium lout the nerk ise und grice of the Aritil, vigor und in

country has yin' out with $r$ loreeds that rsian horse is een celebrated esent day, he general thing, ind speed he is

$k$ of Arabs,er proportions: to-daly is full han the Arah, It is asserted d it is known cks. Though d to domesti eristic of the cyt the Turkn- min or South Tinrtury horse ure worthy to be ruted muong the better class of animals. He is famous for purity of blood, for good speed, and for - wonderful powers of endurnee. It is reluted that one of them lins loen known to truvel nine hundred miles, benring $\boldsymbol{n}$ rider, in eleven successive days. He is not renlly n groceful unimal, however, us his heud is rather larger, and his leggs aro long in proportion to his height, which is from fifteen to sixteen hands.

Other domestiented horses umong the Tarturs me evidently of the same breed as the wild horses which are found in various parts of the country and in inmense numbers, us the charucteristies of the wild nee exhibited in a marked manuer in the domesticuted. Indeed, it is known that these wild herds are often drnwn upon for recruits when necessity drives the inharhitants to add to their stoek of servicenble nuimals.

All these inferior creatures are small and narrow; they have long necks, appmrently wenk legs, lurge hends, und light burrels. The prevniling color is a reddlish sorrel, with n hlack stripe along the lnck. Their manes and tails ne black, except at the roots, where the huir's preserve this reddish enst. Their generial alpenumee is rough and inelegnnt; but they are of the most hardy nature; and, contriny to appenrmee, they are rupid truvelers. They live and even perform long and arduous journeys upon the sparsest und poorest food.

\section{The Egyptian.}

It is represented by some who lawe devoted nore thm ordinury euro to the study of the origin of breeds, and to the horse in his relations to various peoples and comtries, that the horse of the ancient Egyptians was identienl with $\mathrm{mn}$ inferior rnce that nfterward existed among the dssyrims. Sonne sculptures, found among the ruins of Nineveh, correfully executed and woll preserved, port ruy a horse wholly different from that nobler aninnal enred in other bus-reliefs found in the sume ruins. He is sticl to have been the Egyptian horse; and as thus conveyed to us, he was a large and heary animal, having a course and ill-proportioned heat, hut a high crest.

The moderu bygptim is nlso of unplensing uspeet. From wheresoever derived, he is rough and ugly. Frequently his legs, knees and nowk lecome positive defects: but a good head is ocensionally found. Ho would seareely be deserving of mention were it not that he is spirited and impetuons: and this, together with his weight, lenders him raluable. for leesy covalry, in which enpacity he has won some celebrity. His powers of endurance are not great.

\section{The Dongola.}

This horse is also entitled to considerition ehiefly upon the ground of 


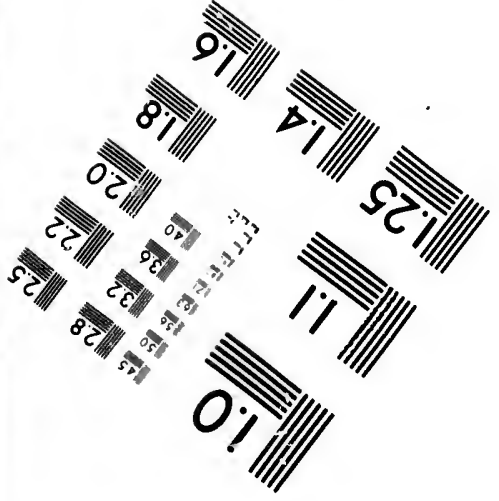

Photographic Sciences Corporation

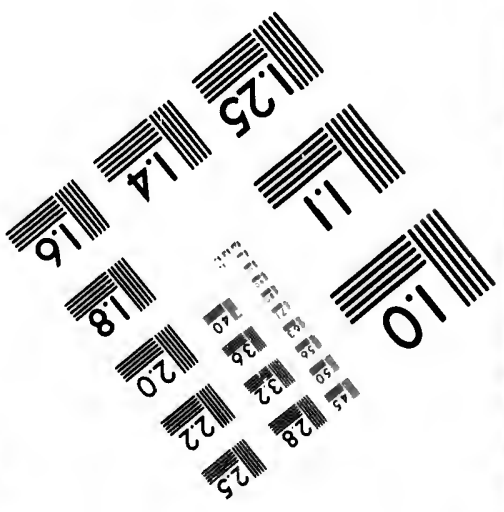



his being greatly prized as a war horse. Unlike the Egyptian, however, he has not only speed but powers of endurance; and some have described him as both beautiful and tractable. Yet, even those who have had opportunities for personal observation do not agrea in their descriptions and their estimates. One speaks of him as being deficient in substance and wanting in stoutnesss; while another thinks him to possess the highest type of symmetry, size, and strength. From another we get this more particular description: 'In height, he is full sixteen hands; his body is short; his neck is long and slim; he has a fine crest; and his withers are high and sharp; but his breast is narrow, his quarters and flanks are flat, and he has a rather ugly back.

He is found in the kingdom of Dongola and in adjacent regions.

\section{Wild Horse of America.}

That the horse existed in America at some far distant epoch is undensable since the fossil remains found prove this conclusively, and progressing naturally from age to age into more and more perfectly developed types. Yet at the discovery of America at the several points by the early navigators, no mention is made of native horses, as would surely have been done if such had been known to the Indians.

America is undoubtedly indebted for her wild or feral horses which have roamed the great valleys of the Pacific slope, the inmense plains of the West and South-west, and the grassy portions of Mexico, to the early Spanish adventurers on the Pacific slope, as were the wild horses of the great plains and of Texas to the horses abandoned by De Soto when he turned his fice eastward towards the Mississippi, after having abandoned his starch for the fountain of youth and the new Eldorado. So Mexieo and the Isthmus were stocked with horses in like manner, for it is futile to suppose that the increase of horses escaping from the Spanish corquerors of South America would have made their way northward through interminable and tangled forests, and mountain fastnesses, hut that rather they would have betaken them to the panpas, which in reality they did. Thus in a comparatively short time they covered most areas of country with immense droves, in reality as wild and as free as though they had always existed there.

That the facts are as we have stated, is patent from the fact that the produce resembles in many close characteristics the Spanish and Andalusian horses of the early Spanish adventurers, as did those found wild in New Foundland resemble the French horse of that period; as does the Canadian pony of the present day, although diminished in size from insufficient food and the inclemencies of the climate through the long generations which have passed since their introduction into Acadia ia 1604, and into Canada four years later.

Among attention d

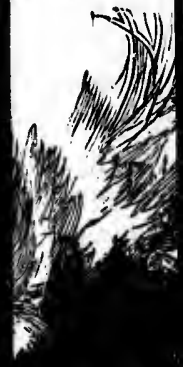

s.

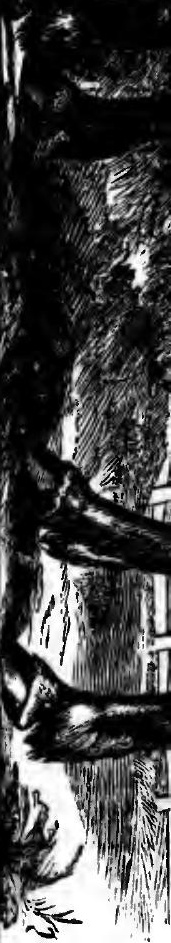

wise known 


\section{The Norman Percheron.}

Among the striking and useful breeds, no horse bas attracted more attention during the last half-century than the Normar Percheron, other-

iptions stance iss the we get hands; tnd his ars and

inden!ogressreloped by the surely which ains of e early of the hen he hdoned Mexico futile rquerprough rather y did. buntry $y$ had at the ndaluvild in es the insuflong dia in
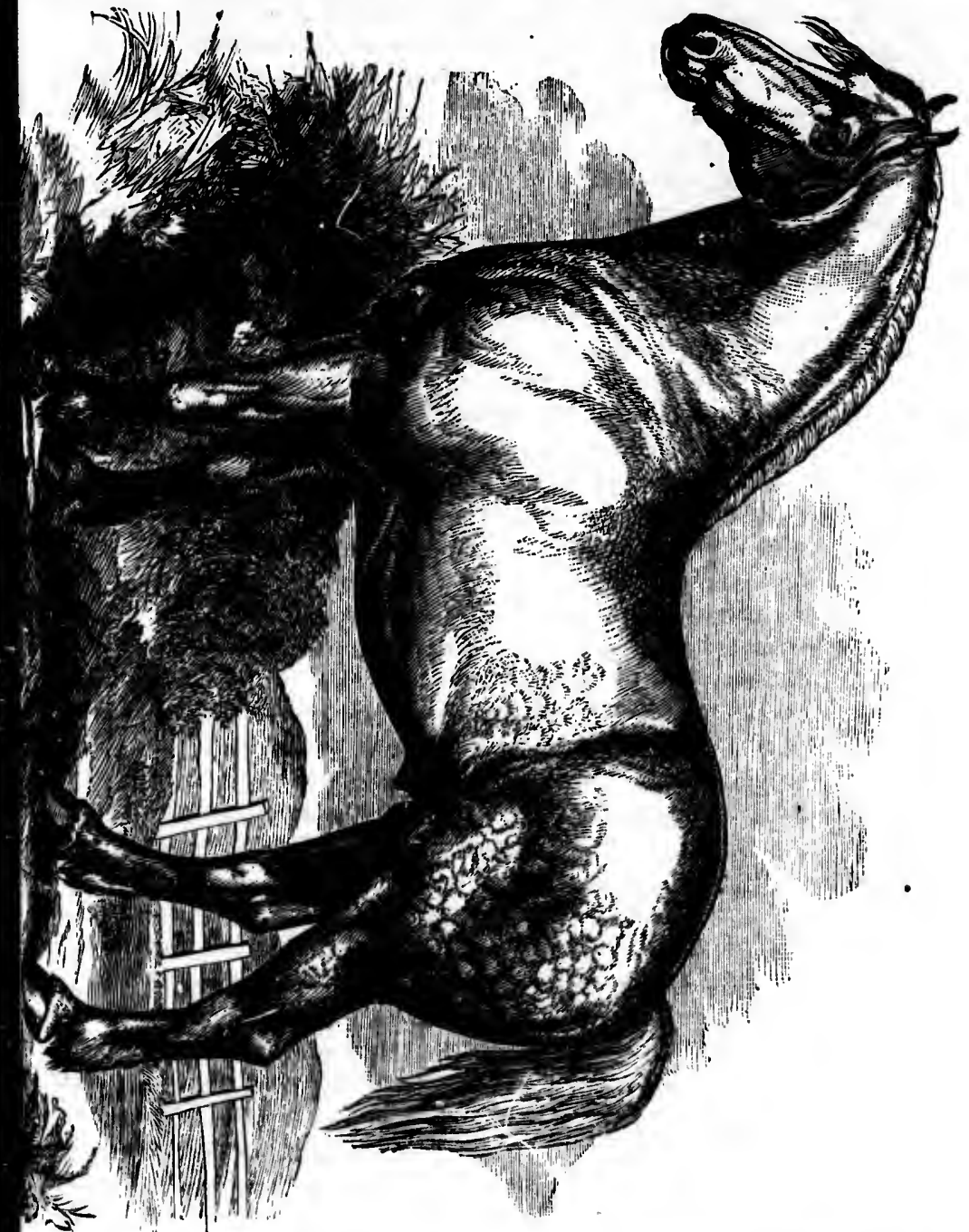

wise known simply as the Percheron,--il stock peculiar to La Perehe, a 
district in France. Volumes have been written respeeting this horse, and various theories as to his origin and cievelopment have been advanced, by interested partizans at times, and again by pure lovers of horses who pursued truth for truth's sake alone.

One writer insists that he is deseended from what some call the primitive or natural horse, the pure blood Arabian, crossed with a stock of heavy draft horses existing in that section, but without historic mention, prior to the Crusades. He thinks that after the defeat of the Saracen hief, Abderame, by Charles Martel, in Vouille, in which battle a host of Saracens perished, the eavalry of the enemy, Oriental horses of marked haracter, true Arabs, fell into the hands of the French,- thence many of these horses were brought by their victorious masters to the districts of Normandy and La Perehe. Here commixture of blood with a heavier horse of excellent quality followed, and the cross resulted in rroducing the now celebrated Pereheron.

The native race referred to is thought by some to have been the old war horse of the Normans-heavy, bony and slow-good for cuvalry use during the days of chivalrv, when the carrying of a knight and his armor required an animal of great strength and powers of endurance."

Others think that it was a stock of horses then peculiar to Brittany and used for draft rather than for war.

One author asserts that the Pereheron is descended from a remote cross letween the Andalusians (after their commixture with the Morocco Barbs) and the Normans; and this somewhat fanciful reason is given for the active ageney of man in bringing it about: that the Norman, though powerful, was too slow for a fully caparisoned knight-the Andalusian or Spanish Barb was too light-and a cross was effected for the purpose of securing a horse that combined speed with power.

But it is not within the scope of the present work to enter into minute particulars of this kind, nor to indulge in the discussion of mooted points that have a merely eurious interest.

Whatever may have been the origin of the Percheron, it is evidently a pure race, one capable of producing and reproducing itself unchanged through a long suceession of years, and without deterioration of qualities when like sires are bred to like dams. Even when the Percheron stallion is put to the service of inferior mares, he impresses himself in a remarkable manner upon his offspring, transmitting to them his own striking characteristics. Percheron mares bred to inferior stallions affect in like manner, and in almost equal intensity, their progeny-though the rule is that the stallion exerts the greater influence in determining the eharacter of the foal. 
se, and $y$ interd truth primiock of ention, Jaracen host of marked nany of ricts of heavier oducing the old alry use $s$ armor cany and te cross p Barbs) for the gh powusian or purpose

ininute d points dently a changed qualities stallion remarkstriking $t$ in like e rule is Laracter
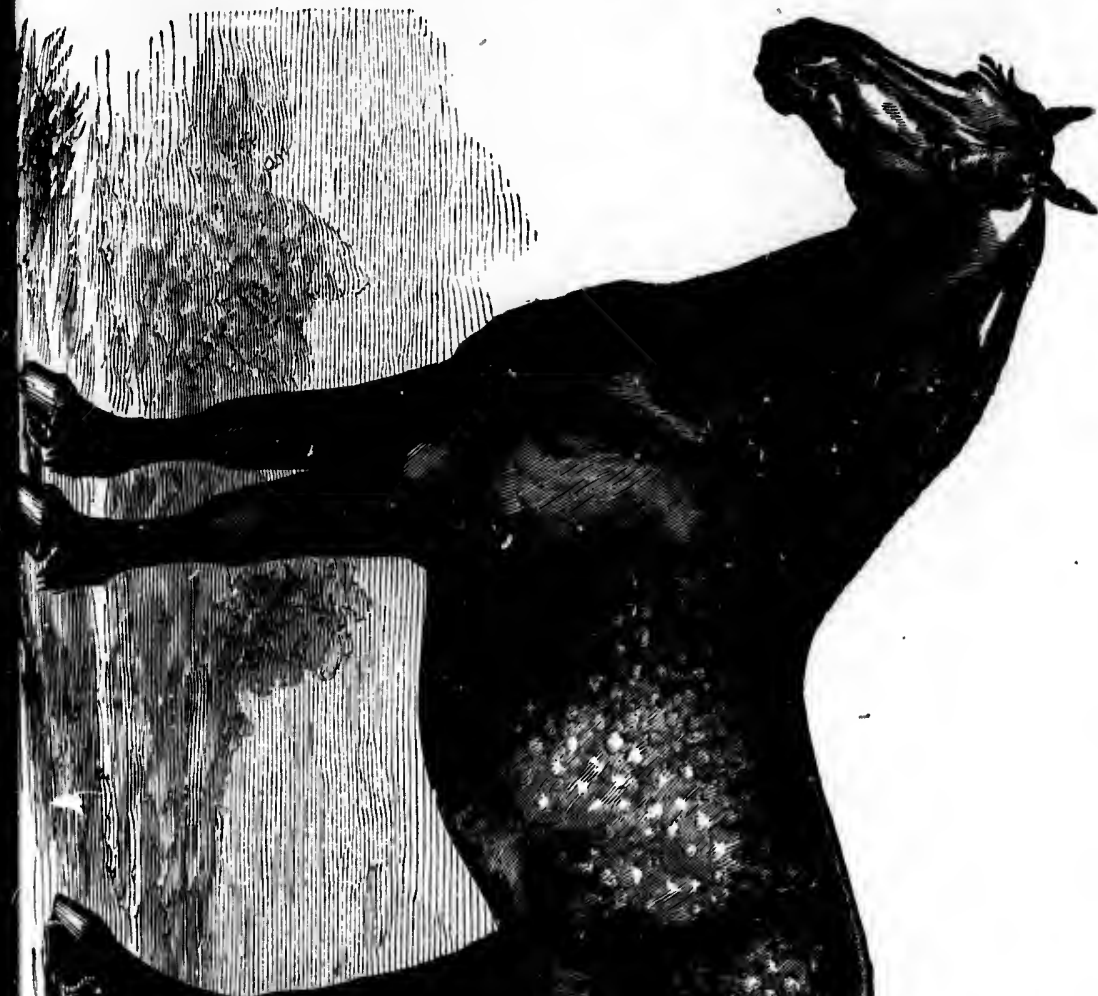
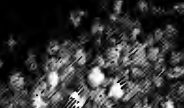

(2) 1903
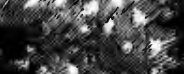

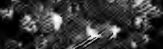
2.8.

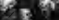

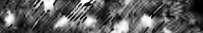

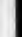

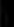


been described as being capable of carrying great burdens at a reasonable rate of speed ; to have been large, compact, muscular, and possessing the greatest endurance.

The points of the Percheron may be stated as follows:

The head is short; the brow is broad, and has that lollow of profile between the eyes and nostrils sometimes known as the dish-face-(in this greatly resembling the Arab); but the head in gencral is not heavier than seems in keeping with the general massiveness of the frame; the neck is long, well-arched and heavy, but, like the head, not disproportioned to the general bulk. The back is short; they are well ribbed up and round barrelled; their legs are particularly short from the knees and hocks downward; they are heavily haired, but have not such shaggy fetlocks and feet as this would seem to indicate; their sinews are ironlike ; and their feet are hard, sound, apparently insensible to disease. In height, they are from fourteen and a half to fifteen and a half hands, the latter being rather more than the average. Gray is the characteristic, alinost the only, color.

For hard work on ordinary fare the Perche on is unequalled; and his energy and endurance are wonderful. He will keep his condition where another horse would die of hard labor and neglect. Though full of spirit, unflinching under even pumful effort, he is yet docile.

In mere speed he is by no means the equal of the thorough-bred; but for quickness of movement at heavy draft he has no rival. Hitched to a light car :age or wagon he is capable of maintaining a good rate of speed ior a long time together, or of making comparatively short journeys with a rapidity that is astonishing. One, carrying a light vehicle and the driver, is known to have made 55 3-5 miles over a hilly and difficult road, in four hours and twenty-four minutes; and another, harnessed in like manner, is said to have traveled 58 miles and back in two consecutive days, without being touched with the whip, occupying four hours and less than two minutes going, and four hours, one and a half minutes returning.

The Percheron of to-day makes an excellent cross with either the Arab or the English thorough-bred. For the improvement of our draft. stock in the United States, no other horse is to be compared to him. Bred to good mares, this half-breed would partake more of the qualities of the sire than of the dam, and the progeny would be almost the equals of the pure French horses. Another step, bringing a pure imported stallion to the service of these half-breeds, would give us a race of horses for all work that, would so far excel the ordinary race of scrubs as to seem almost like a different species of animal.

At Okklawn, Du Page Co., Ill., is onc of the largest stud farms of the world, and it is devoted exclusively to the Percheron stock. 


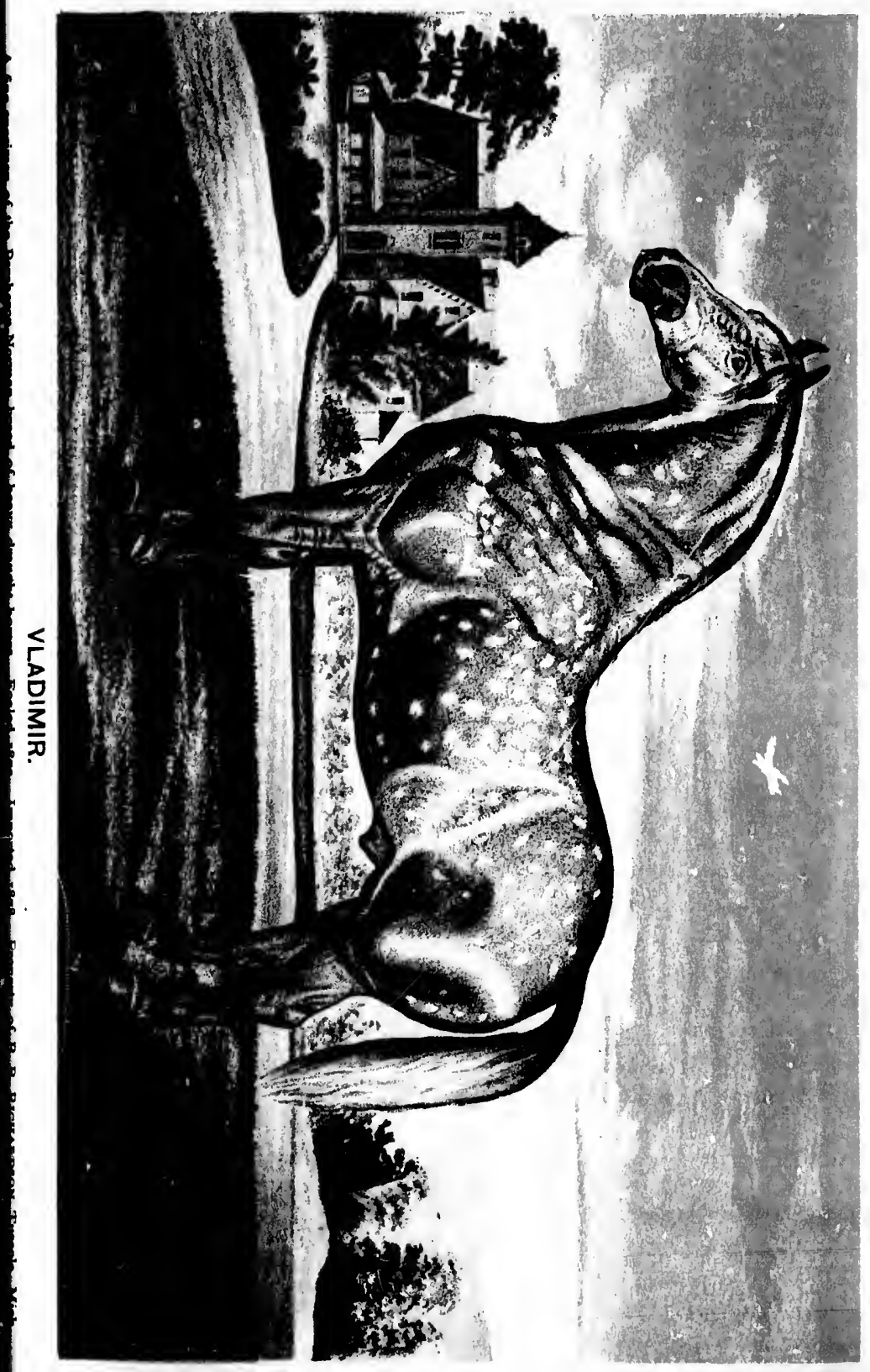





\section{The Clydesdale Horse.}

The west of Scotland has been long famous for its draught horses. Away in the upper ward of Lanarkshire, the progenitors of that noble race of horses so called Clydesdale, from the Vale in which they were originally reared, were first bronght to the front and made famous throughout the whole of Scotlauc; so much so that the common work horse of that country is now, to all intents and purposes, a Clyde; and many of the Shire Horses of England are deep in their blood also.

Where the originals came from, and how they were bred, are questions that have often been discussed in the public press. Tradition, without any foundation in facts, points to the importation of Flemish Stallions into the above ward nearly two centuries ago, by one of the Dukes of Hamilton, who sought improvement in his stock.

Whether such is the case or not, certain it is that by some means or other, the farmers in that country possessed a grand lot of brood mares, from which the Clydesdales of the present day owe their activity and hardiness. Our own opinion is, that they grew up into the state of perfection in which they were found about the beginning of the last century, through the judicious mating of the home stock, and that up to that time, little or no fresh blood was introduced.

The upper ward of Lanarkshire is a wild and somewhat bare country, with a thin soil, which, however, is admirably adapted for grazing purposes; the farms are small, and the husbandmen who made their livelihood from the profits of the soil, were a shrewd and saving race, witls a love for their stock born in them. Proud of their cattle and horses, and considerably skilled in their care, they developed for the district in which they lived, a class specially suited to their wants.

In kine they modelled, as it were, the Ayrshire Cow, and in horses, more especially in this particular district, they produced and kept continually in-proving the Clyde. 'Just as on the banks of the Tees, long years ago, there existed a grand race of cattle, so on the hills that rise gently away from the waters of the Clyde, a class of horses belonged to it, which were associated with no other shire or county in Great Britain, till a more enlightened day with the aid of the printing press spread their fame abroad, and created for them an immense demand.

Thus we find the horses about the year 1720, when Mr. John Paterson, of Lochlyoch, introduced a Flemish Stallion.

Whether through the introduction of this horse or otherwise, the Lochlyoch mares became very famous, and from them, directly or indirectly, most of the noted stock of the present day trace their origin.

From the Lampits mare, a descendant of the above stock, came Glancer (335), the horse that may be called the father of the present race of Clydesdales. 
In a table compiled for the "Clydesdale Horse Society" it is astonishing to see the influence that this horse has wielded. Without any system, most of the breeders were ignorant that such a horse ever existed, till the herculean labors of Mr. Dykes, secretary to the above society, ferreted out all these facts.

It is most interesting to study the relationships of the various crack horses of the present day.

Wherever you begin, the pedigree by some means runs into Glancer (335).

Gradually, but surely, fiom those wild uplands, Clydesdales have spread, as it were, over the whole workl.

They found, early in this century, a congenial lome amid the richer soils of Galloway, and while thriving there, they obtained even a greater notoriety on tlie bare hillsides of Kintyre.

Branching out thus, they spread over all Scotland, reaching some favored spots in England, and within later years they have found their way to Ameriea aud Australia, where they are as much prized as upon their native heath.

In the Antipodes, they have no rival, but in the United States they come into competition with the "Percherons."

The inherent value of the Clydesdale lies in his reproducing powers. Bred for generations among themselves, ofttimes brecl in and in, they are most impressive, and put upon the common maves of this continent, the produce is a splendid farmer's horse, while those animals which have two or three crosses of this blood, are becoming exceedingly valuable for draying in towns, and, owing to their special fitness for heavy work, at the present moment the demand far exceeds the supply.

The indications are, that the Clydesdales and Percherons will gradually become the work horses of America.

Farmers who in olden times (and, we are sorry to say, even in these days), merely scratch their land, have no use for either of those breeds, but as agriculture advances, as science surely overcomes brute force, when the days of deep plonghing and thorough eultivation become a necessity, then will the husbandman know the value of heavy, well-luilt horses.

To attain this end, horses of the above breeds nust be used. Each will serve their end, but for wear and tear it is likely the Clydes will eventually take the lead.

It is true, the Clydesdales of the present day are unt so hardy as they were. The system of feeding for show, carried to great excess by the Scotch breeders, has given rise to diseases among pure-bred animals, which they do not happily reproduce, and which has tended to nuake some of the best horses that ever were bred, but indifferent stock-getters.

Then little attention was paid to systematic breeding. The old way and style which, no doubt, was conducted with great sncess as far as it went, did not tend to produce so many good horses as we may expect under the skilful mating of both well-bred and good-looking animals. 


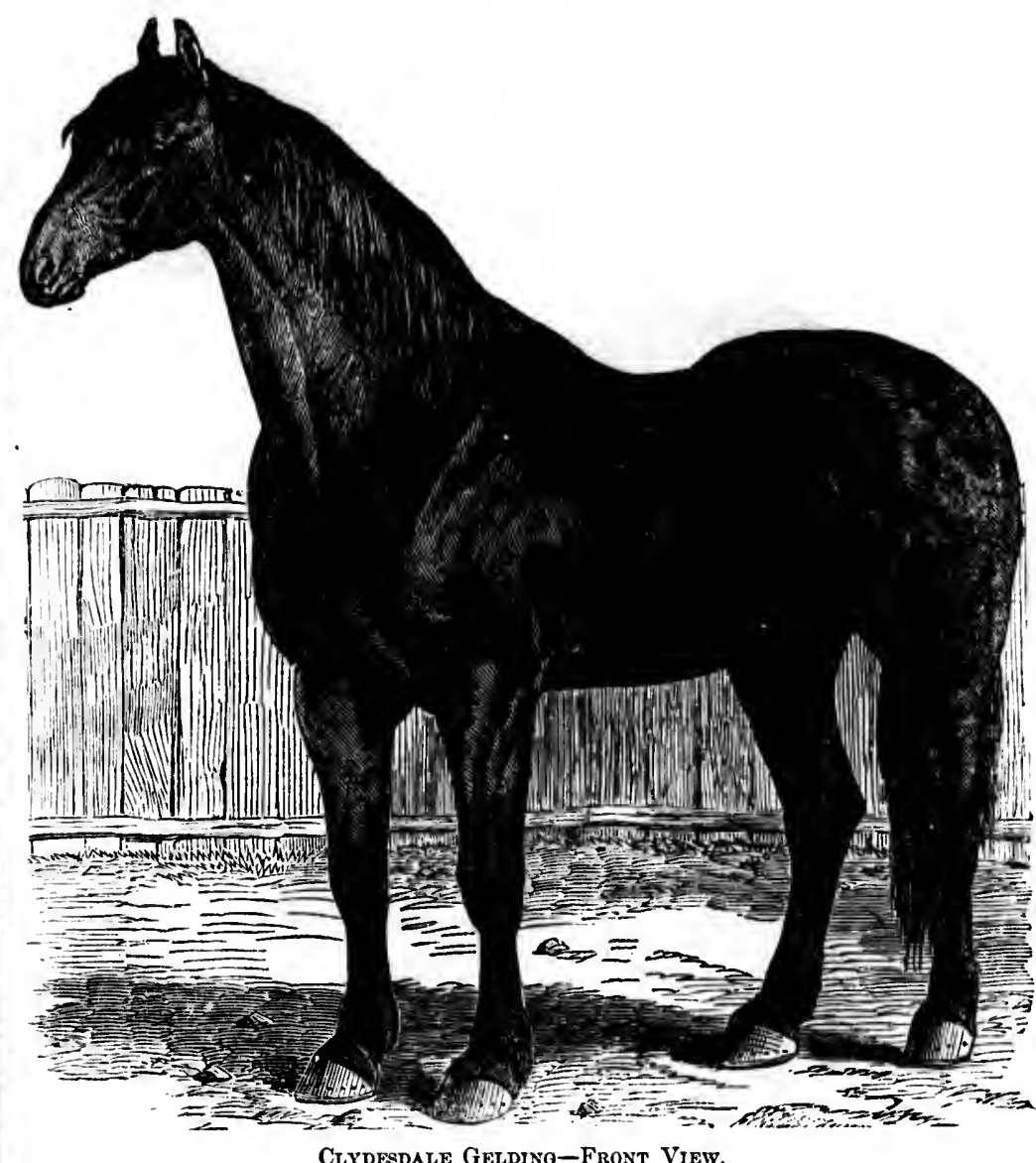

Aside from the general form here given, many special points of the Clydesdale horse are shown by the front view.

Note especially the jaw, muzzle and nostrils. The eye full and vigorous, yet mild. Note the breadth of forehead between the eyes; the evident activity of the ears; the strong neck and lightly supported head; the free shoulder, promoting easy stepping. Note, too, the shortness of leg below the knee, and comparative length above, the big and bony knees, the good hoofs, sloping pasterns, full chest, etc. Observe also the round formation of the body; in short, the whole horse is finely shown by this view. 


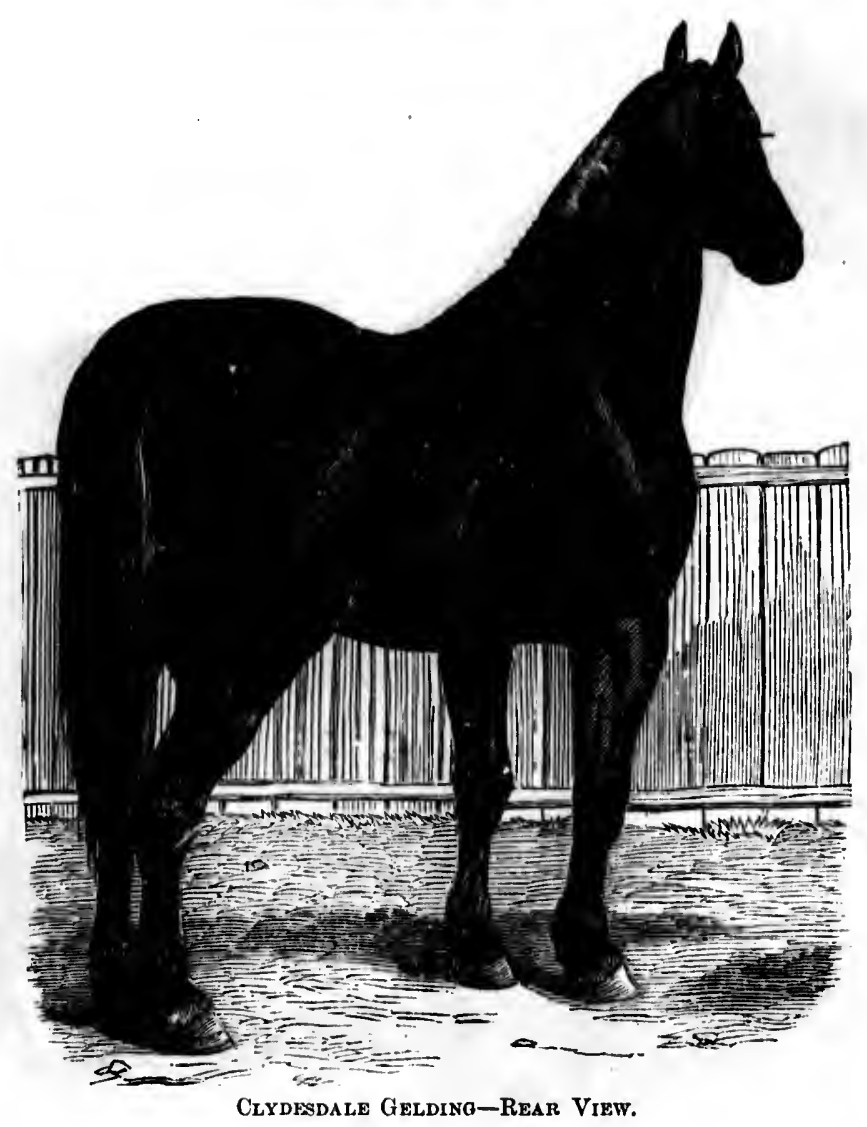

This rear view is added to the front view already given, that the horse may be seen on all sides, and with respect to all his points. Some of those mentioned in the foregoing description are repeated in this, but they are seen from a different standpoint, and some of them are shown to better advantage.

The fullness of the eye is clearly seen in this cut. 'The long, active ear is also prominent. The strong, full neck, with its good development of muscle on the top, is finely shown here. The relative length of lower and upper parts of the front leg, nnd the good muscular development of the forearm are also very clear. The feet as sloping pasterns are also characteristic of this class of horses. The broal, low-set quarters and muscular thighs, with the broad, well-proportioned hocks are here shown.
Just a it was v virious | pedigrees

They 1 results fr they hav and here with a ze 'This A given a $\mathrm{g}$ grand resi and holdi work thar Lanarksh It is to grand colo the Clydes

The ma hardiness. being tran practice an wild state, ment unti enchurance A fat co Treated th well-rleveld perchance, deserts, car now writin

Treated had receive found engr:

Just as th stupernatura as slaves of looked on combine stre a horse succ

The write 
Just as we have seen grade bulls vie in excellency with the thoroughbred, so it was with the Clydesdale horse. Five years ago, through the efforts of vurious purties, all lovers of the Clyde, a society was established for registering peligrees, and their operations huve met with signal success.

They have laid the foundation of a system by which breeders cau attain grand results from a careful and judieious selection of good blood. And so in America they have a Stud Book, drawn up on the same basis as the Scoteh publication, and here breeling is being carried on, more especially by Western breeders, with a zest second only to that of the farmers in Scotland.

This American and Colonial demand for good horses with pedigrees, has given a great impetus to breeding at home, and it is likely we shall see some grand results from the efforts that are being made. Blessed with perseverance, and holding their own judgment at a premium, no men are better suited for this work than the small dairy furmers from the regions of Ayrshire, Galloway and Lanarkshire.

It is to them and some larger farmers and proprietors we need to look for the graul colossal horses which have made, and are destined to make, the name of the Clydesdale more famous than ever.

The main feature of the Clydesdale is its size, combined with activity and hardiness. Bred upon a bare, and not very prolific soil, they thrive well upon being transplanted to a more generons and richer location. It is the universal practice among the west of Scotland breeders to keep their young stock in a semiwild state, giving them only as mueh food as is necessary for health and development until they are between two and three years old. Great capacity for endurance is thus secured.

A fat colt is never seen, searee even among those reserved for the stud. Treated thus when they are young, they grow up hardy, with elean bones and well-rleveloped museles, and almost entirely free from hereditary disease. Aul, perchance, no horse of the present day, excepting those existing on the Arabiau leserts, can compare for genuine and valuable intelligence with those we are now writing about.

Treated for generations by their masters as companions, that is, after they had received their primary edueation, a sense almost human in some eases is found engraved in their nature.

Just as the Scottish Collie and the noble Newfoundland have developed almost supernatural instincts, so the Clydesdale liorses, being the companions as well as slaves of a elass of men who took pride in their sagacity, lave come to be looked on as possessing a rarely and widely defined instinct. Thus they combine strength, soundness ind sense, the three attributes necessary to make a horse successful in the wagon or plough.

\section{THE POINTS OF THE CLYDESDALE.}

The writer had much to do with the formation of the Clydesdale Stud Book, 
and for a full description and history of the breed of horses we refer our readers to this volume.

In the meantime we cannot do better than abridge as shortly as possible the beau ideal of the liorse as given there:

The head, a broad jaw, ending, as a rule, in a not very fine or well-developed muzzle, but with largc, open nostrils.

The eye full and vigorous, yet mild.

The forehead broad and full, especially between the eyes.

The ears long and active.

The neck should be strong and massive, supporting the head gaily, and showing on its top a good levelopment of muscle.

The shoulder should be oblique, like a thoroughbred, so that the horse can step out boldly.

The legs should be short from the fetlock to the knee, and comparatively long from the knee upwards.

The forearm should be well developed, showing lots of muscle.

The bones must be hard and flinty, flat-shaped, with no fleshiness; both muscle and bone seeming entirely separate. Lots of hair is essential. Of little use itself, it shows forth quality and strength of bone, and is typical of the pure-bred horse.

The knees should be big and bony.

The feet of the Clydesdale are nearly invariably good; great, big, widely developed hoofs of the best quality, and connected with the leg with sloping pasterns, which help every horse to go up and down hill. Nothing, in our idea, is so essential to a draught horse as good pasterns.

The chest should be broad and full.

The back and barrel slıould be straight and round, with the ribs going well back towards the quarters. In this particular we find the weak part of the Clydesdale. He is not altogether so symmetrical as he slould be, as a rule, in this respent.

Broad, low-set quarters, with muscular thighs descending into broad and proportionately-developed hocks, sum up the good points of the hind end of the Clydesdale. Avoid fleshy hocks; let them be clean cut and devoid of fat or puffing.

The hind leg should be short, broad, flat, clean and slightly inclined forward, while the pastern should also incline forwards ere it joins the hoof.

The height of the Clydesdale averages about sixteen hands two inches; over that height they become clumsy, except when very well developed.

The best color undoubtedly is brown, with white marks, and, so far as possible, this color is being adopted among breeders.

Good action is sure to be possessed by a horse modeled on the above type.

Both walking and trotting, there will be a style and majesty that attracts the eye and is useful when at work. 


\section{The Thorough-bred in Amerioa.}

The Flemish and Danish horses, large, strong, heavy draft breeds, have had more or less influence upon the horses of the United States, partieulirly in Pennsylvania, Ohio, and the northwestern States; but no other blood is so widely disseminated among our various stocks as that of the English thorough-bred. We have been dependent ehiefly upon this animal for the improvement of the horses among us; and from a time long prior to the Revolution, it has been the eustom of our most ambitious breeders to import from England both stallions and mares, but more especially the former, for this purpose.

Leonard Calvert, Lord Baltimore, sometime between 1740 and 1750, presented to a Mr. Ogle an English thorough-bred stallion, by which the colonial horse of that portion of the country was much improved; and this same gentleman, Ogle, imported Queen Mab, shortly after he came in pessession of "Spark," the Baltimore horse. Selina, a mare sired by the Godolphin Arabian, was brought over by one Col. Trasker; Miss Colville, or Wilkes' Old Hautboy Mare, was imported by Col. Colville; Jemnie Cameron, Crab, and others, by different persons, at various times.

It was not until within about fifty years ago that any reliable stud book or turf register began to bo kept in the United States; so that it is often difticult to establish a claim to good pedigree extending beyond that time; but many valuable importations are known to have taken place previous to 1829 ; and the register since kept shows that there is a very large admixture of English blood in many parts of the country.

The work stoek of the southern States before the war, as now, was, of course, drawn mostly from States farther north and east, and was of indifferent eharacter; but much attention was paid in that part of the country to raising stoek; and ull horses raised there have more or less of the thorough-bred in them. Many really fine animals were found there, -the race-horse preserved in his purity,-Dut the true thorough-bred has rarely been found at any time in the northern States. In New Eugland, the good driving horse, the horse of all work, medium sized and stoutlybuilt, is mostly found; in New York, they have unimals representing almost every variety of breed known in the United States, and among them the descendants of many famous riteers.

In Penusylvania, Ohio, and the Northwest generally, they have a great variety of heavy draft horses - some of them of grear size-not much attention having been paid, as yet, to saddle, light carriage, mid race horses. In the West however, considerable improvement has been made by the introduetion of fine stallions from Kentucky and Tenuessee, of both the thorough-bred and the Morgan strain. In Kentucky and Tennessee, the breeds are various, but there is a very large admixture of the 
thorough-bred: Their snddle, light carriage, trotting and racing stock are justly renowned. Scarcely any country in the world is better adapted to the production of fine horses than the blue-grass region of Kentucky; and it constitutes a sort of Arabia of the West, to whose breeders and trainers the buyers of the United States, sometimes even foreign gentlemen, come to purchase mares, stallions, and trained coursers.

The Ameriean thorough-bred retains many of the striking characteristics of the Arabian and his hest old world representative, the English racer; and in speed he compares well with the best horses of England. He is more stoutly built, however, and capable of more endurance than the English horse.

\section{The Morgan Horse.}

A story is current to the effect that during the war of the Revolution, one of the British officers, Gen. DeLancy, rode a very beautiful stallion, of great value - said to have been a true thorough-bred. This horse was stolen by one Smith, an American, and retuined within the American lines. He was the sire of a colt from a Wild Air mare; and the colt, being foaled or having become by purchase the property of one Justin Morgan, of Randolph, Vermont, received the name of his master, and his descendants have ever. since been known as the Morgan horse.

The stolen stallion, called "The True Briton" or "Beautiful Bay," has been described as not only beautiful, but as having possessed great action, and being capable of leaping fences, hedges, and ditches, bearing a rider, from which it has been argued that he was not a thorough-bred, since that stock eannot jump; but he was in any event a remarkable horse, and his valuable quulities have been transmitted to his descendants. Of so pure blood and marked character was he that his powers of reproducing himself equalled those of the most unimistakable Arabian; and the Morgan blood is perceptible after various crosses, and that too, with many inferior breeds.

So marked are the characteristics of these horses, and so different are they, in some particulars, from other races, that they seem fully entitled to be considered a distinct breed. They are in great repute, also, in many portions of the country; and sone efforts have been made with much suceess, to bring the stock back to its former and better condition, by breeding from the best and most strongly marked stallions and mares.

They are stout and hardy, while at the same time of good formcapable of performing the greatest amount of labor, and that, too, with quickness of movement. They are always in demand, and command the highest market prices.

The following are the distinguishing points of a true Morgan : 
ig stock adapted ntucky; ders and gentle-

haracterEnglish England. nce than

volution, stallion, corse was Ameriean the colt, ne Justin เster, and e.

ul Bay," sed great $s$, bearing ugh-bred, markable cendants. of repropian ; and too, with

cerent are y entitled , also, in hade with ondition, id mares. formtoo, with mand the
In leight he is from fourteen to sixteen hands; in weight sufficiently heavy for this height, with no appearance whatever of coarse bulkiness. $\mathrm{He}$ is compaetly built, and of great strength; his action is fine, his endurance unsurpassed, and in spirit he is indomitable - never failing at a pull, if rightly handled-yet patient and trustworthy. As roadsters and horses of all work they are excellent-having no equals, perhaps, in this country. He walks fast, and many horses of this breed have been extraordinary trotters. In harness he is quiet, but nimble, and of eager movement. Bay, chestnut, and blaek are the prevailing colors. The mine and tail are rather heavy and coarse, and in general wavy.

The head is not extremely small, but there is no superfluous musele or fatty matter about it; the face is straight, the forehead broad, the ears are small, fine, and set far apart, the nostrils aro wide, the lips are elose and firm, the muzzle is small, the eyes are not large, but very dark, prominent, set wide apart, and full of animation. The back is short; the shoulder-blades and hip-bones aro large and oblique, the loins broad and muscular ; the body is long, round, deep, and elosely ribbed up ; the chestbone is prominent, the chest wide and deep, the legs seem rather short for the height, but they are close-jointed, and though thin, they are very wide, hard, elean, and yet with powerful muscles ; the feet are small and round ; the hair is short and flossy at almost all seasons; the fetlocks are moderately long, and there is some long hair up the backs of the legs.

In some parts of the country the Morgans are the premium horses, and their peeuliar adaptability to all the ordinary purposes of the farmer is such that they enjoy a high degree of favor.

As a breed, they are unusually long-lived, and this constitutes one of their great points of excellence.

\section{The Narragangett Pacer.}

This breed, now almost unknown as a distinct one, was remarkable chiefly as being natural pacers, and of such peeuliar action as to render them peculiarly easy under the saddle. Though small, they were hardy and full of power, and their docility was such as to render them very pleasant to handle. The stock are said to have been imported into New England, from Andalusia, by one Gov. Robinson, and to have been bred chietly in Rhode Island, where they were long held in great repute. Good saddle horses were in much demand in $\mathrm{Cuba}$, and prior to the time when the Narragansett Pacer began to attract attention, the Cubans had been dependent for their horses upon the mother country. But the voyago was long, the risk considerable, and the cost great, und when it was once ascertained that a superior saddle animal, (according tc the taste of 
the times ), could be had in Rhodo Island, much nearer home, a trade was at once opened, which continued, with much protit to the Rhode Jslana breeders, till the roadways of the West Indios beeame so mueh improved as to render the introduction of light earriages a natural eonsequence. A somewhat different. L.orse was then required, and the trade in Americall stock began to decline. As the Cuban murket became less and less profitable, the interest of the stock-owuers experienced a corresponding decrease, till at last the effort to preserve the pacer as a distinct breed ceased altogether.

At the present day, though the influence of the Narragansett Pacer upon New England horses is in many instances pereeptible, he is 110 longer known in his former purity.

\section{The Vermont Draft Horse.}

Vermont has given the United States one of the two celebrated families of draft horses, than which few of the breeds have combined greater excellence. Animals with lofty crests, thin withers, short baeked, round barrelled, close ribbed, clean and sinewy limbed, that would at first be taken for ponies. Standing next to them they would be found to be sixteen hands high and over, and on the scales they would tilt the lever at from 1150 to 1250 pounds.

Of the origin of the Vermont draft horse but little is known, but it is more than probable that the old Suffolk cart horse, imported into Massachusetts in 1821 , the Cleveland bay, brought there in 1825, and the thorough-bred horses introduced in 1828, bred upon the best common mares of the country, have produced a class of horses, the lighter ones of which were driven to the stage coaches of thirty to fifty years ago, as they have seldom been driven in any other hill country.

And this elass was grand for heavy work. The heavier specimens of which furnished the best heavy team horses in the country, not excepting the Conestoga, a horse fully a hand higher, and admirable in every respect for heary draft; as we used to see them, in the great six and seven horse teams coming from the mountains of Pennsylvania through to New York. It is to be regretted that the furot over the Morgans since that time lias caused the Vermont draft lorse to become quite rare, so that now it is ratler difficult to find a good specimen of the breed as it once existed.

The disappearance of these fine old horses, however, is of a piece with the disappearanee of many other relics of the good c'd times. We think foudly of what once prevailed, and it seems as though nothing ever could be so good again, but those who never knew our favorites seen quite content, and get on full as well as though our pet things never had existence. Thus the essential things of one age sink from sight in another. 


\section{The Canadian.}

This horse, when pure, is entitled to be considered distinct. He can lay no claim, of course, to being regarded as the natural horse, no more than the Norman, Percheron or the English thorough-bred; but his characteristics are so marked as to render him worthy of being classed scparately and noticed with some minuteness.

He is supposed to be descended from the Norman-French horse, brought over by the pioneers of Canada; but how crossed, (though he is evidently the result of a cross), it is impossible to say. In some particulars, he so much resembles the old horse of Normandy as to seem the unmistakable descendant of that stock; whereas in others he is so unlike him as to indicate that the cross must have been with a very strongly marked animil, of great powers of transmission.

The distinguishing characteristics may be stated as follows: The average height is about fourteen hands ; the body is solid, compactly put together, but somewhat inclined to flatness of side; the hend is rather large for a horse of the height stated, but it is well formed and lean, so that it does not appear out of proportion and cumbersome; the forehead is broad; the ears are wide apart, and earried well up ; the eye is small and clear, and has a bold expression; the chest is broad and full; the shoulder is strong, but inclining to be straight and rather low and heavy at the withers ; the loins are fine ; the croup round and fleshy; the thighs museular; the legs comparatively heavy and joints pretty large, but the hones are flat, and no race of horses has sounder and inore powerful limbs; aid none can equal the Canadian as to feet-these being tough, hard, iroul-like, and free from disease, even under the most unfavorable circumstances. This seems to be one of his most valuablo eharacteristics of body. Bad handling, awkward shoeing, hard travel-nothing in the bounds of reason seems to affect his feet. Diseases of this part are almost absolutely unknown.

The mane and tail are peculiar, being very.heavy, and in almost all eases, wavy. The baek sinews are shaggy-coated, nearly to the knce, and the fetlocks are long.

The prevailing color is black; but browns and chestnuts ure frequently found; sometimes sorrels and duns, having manes and tails lighter than the body. Occasionally there may be found a dark i.on-gray, with black legs.

Cunadians are long-lived, easily-kept, and capable of the greatest. endurance. They are heavy enough for the purposes of the farmer; and as roaristers, while they are not to be regarded as rapid travelers, they maintain a reasonable rnte of speed, say six miles an hour, for long jour- 
neys and continuously, and this whilo earrying a heary weight. It is nothing uncommon for them to do fifty miles a day for many days in succession; and some have been known to do seventy, eighty, even ninety miles, at a single stretch of one day.

The breed is widely spread, but chiefly in a mixed stnte, (inferior to the true Cunadian in almost every instumce), in the Northern and Eastern States. Few horses are entitled to more consideration at the hands of those who would obtain the best medium-sized and ensily-kept unimals for the farm, and for medium heavy and moderately rapid draft.

\section{The Connestoga.}

A somewhat peculiar horse of all-work, said to have originated as a distinet stock in the valley of Connestogin. They are believed to be descended from Flemish and Danish cart-horses brought over by the early Germau settlers of this part of the country, with a probable admixture of the ordinary draft horse in common use in the Gernm States at that day. There is, however, no record of the origin of the breed, and all speculation may be at fault. They resemble for the most part the Flemish horse, especially in color, all the prevailing Flemish colors exeept black being found among them in like proportion.

The Connestoga is a tall horse, often seventeen hands high ; but his limbs are light for his height, and he is not inelined to be full of flesh, having a muscular rather than a fatty heaviness, so that he is very powerful in proportion to his weight. He is used chiefly for wagons, camal boats, and heavy carriages, for which purposes he is both strong and quick enough.

He is less distinct than formerly, and no pains are taken to preserve the rapad as such.

\section{Ponies.}

The small, or pony breeds, are numerous; but the only ones deserving special mention are the Shetlands, the Indian, and the Mexican Mustang. The former is the most distinct and best type of the ponies of the Old World, while the Indian and the Mustang are the ehief, if not the only native kinds, known among us.

There are ponies somewhat similar to the Shetlands in the northem parts of Sweden and of Iceland, in Wales, and on the southwestern coast of England. All these little animals scem to have originated in latitudes to which the horse is not native, and to be dwarfed deszendants of large and powerful progenitors.

Noticing first the Shetlands, those of most perfect form, though of small size, ni In height, the

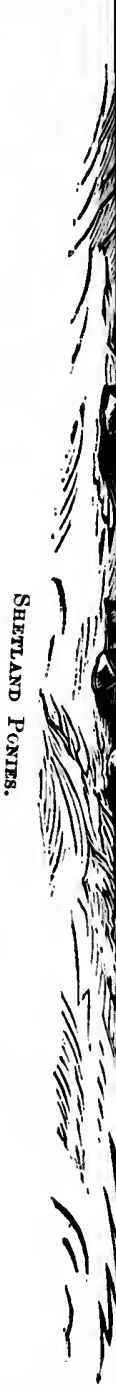

are found that do Shetland ean be 
THE HORSE, DIFFERENT BREEDS, ETC.

small size, are found in the extreme northern isles of Yell and Unst. In height, they do not average more than nine or ten hands; and many

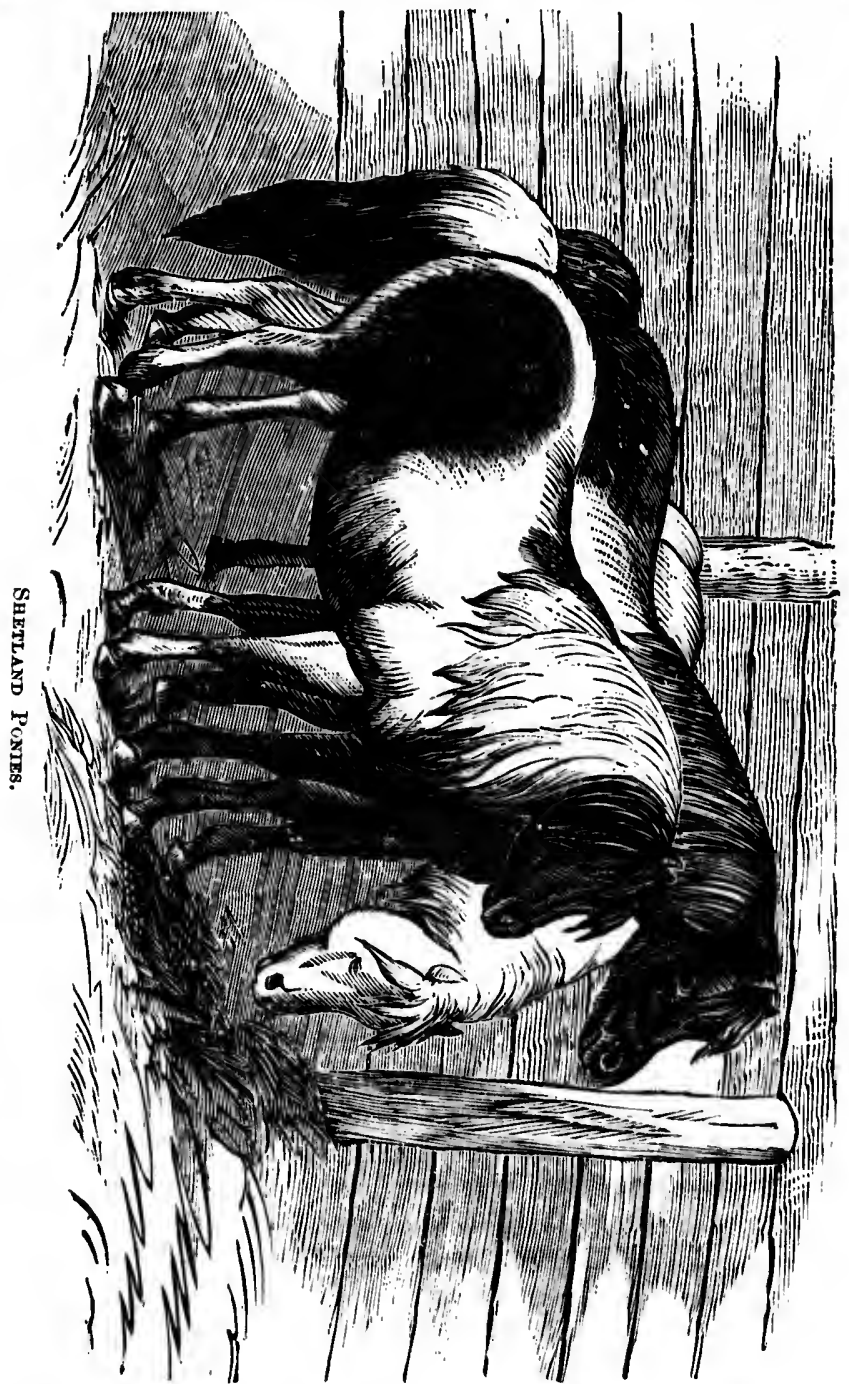

are found that do no exceed seven and a half. It is held that no true Shetland can be so tall as eleven hauds. In form they are round and 
closely ribbed up; the head is well shaped - lenn and bony, wide in the brow, sometimes slightly basin-faced, like the Arab; the ears are very small, well placed, are carried erect; the eyes are large and bright, with a fine look of intelligence; the neck is short and thick, and covered with a great mass of coarse mane; the shoulder is sloping, thick, and having little elevation at the withers; the loins are broad but fincly formed; the quarters are well made, but not large in proportion to other parts; the back is gently curving, with never any tendency towards what is called sway-back; the legs and feet are of excellent shape, and of the most powerful texture, so that the Shetlander is a stranger to all those discases of the feet and legs to which many horses are suljject, and a lame Shetland is almost unknown; the tail, like the mane, is of great volume.

When roaming wild they live on the poorest fare, and are exposed to all the inclemencies of the seasons. When they camnot pick up their scanty subsistence upon the uplands, by reason of the snows of winter, they betake themselves to the sea shore and live upon kelp and sea weed. When taken by the peasants of those localities which they most inhabit, and reduced to subjection, they still require but little food and little care.

Their endurance is very great; "and though they are of course incapable of great speed, they will carry weights largely disproportioned to their size, and keep up a uniform pace of from four to five miles an hour throughout the day, accomplishing forty, even fifty miles between morning and evening with apparent ease.

They are gentle, affectionate, easily truined, and as children's horses, and for all other purposes for which a pony can be at all serviceable, they are the best of all found in either hemisphere.

The prevailing colors are black, brown, and a dark sorrel.

The Mexican Mustang, one of the most widely known and distinct of American ponies, is found chiefly on the prairies of Texas and Mexico. His origin is doubtful; though it is affirmed that notwithstanding his díminutive size, and some striking points of degeneracy, there is clear indication of Spanish origin. It is difficult, however, to account for the difference between him and other wild horses, that discover in size as well as in general formation that they are the descendants of animals left or lost upon the American continent by the early Spanish discoverers and conquerors.

These ponies are undersized ; of very slight limbs ; often ugly and disproportionately made ; with long neck, long back, and long, slender and weak posteriors. Their hoofs are often badly formed, tending to flatuess and irregularity. Their heads, however, though long, are lean, well shaped, and wellset; and their nostrils are wide. Therr manes and 
$e$ in the are very ght, with red with $d$ having ned; the arts ; the is called the most o diseases d a lanne t volume. cposed to up their ff winter, sea weed. it inhabit, and little

incapable $d$ to their an hour between

's horses, able, they

distinct of Mexico. nding his 0 is clear it for the n size as animals iscoverers $y$ and disender and o flatness ean, well anes and tails are fine. They have some activity and spirit, and are sometimes vicious, but not difficult to subdue. In a wild state, they are ensily outwinded by well-trained horses of the lurger breeds; but doniestication seems to have the effect of Improving their powers of endurance, as they do good service for the Comanche Indians as a cavalry horse-carrying those warriors, and enabling them successfully to evade the pursuit of well-trained United States cavalry.

Almost every color is found among the:n.

The Indian Pony, another American, is thouglit to be a degenerated Norman-having sprung from horses of that stoek brought to Canada by the first French emigrants, and nllowed by some means to eseape into the forests, as was the case with certan Andalusians farther south. Wandering, from generation to generation, in those cold regions, and under circuinstances altogether unfavorable to the produetion of generous growth, they have become dwarfed and in other particulars modified as to form. They seem in their present state to be a perfectly distinct animal; and they possess many points of excellence. They are found in the upper Mississippi eountry, on the borders of Canada, and west of the great lakes, and are used ehiefly by the different tribes of northern Indians. Great herds of them are found 12 a wild state on the nortlwestern prairies.

They are a larger animal than the Mustung, and in most respects fur superior to him. Though he is to be considered a true pony, he is often thirteen, sometimes even fourteen, hands high. The body is very strongly built, being round-ribbed, short-barreled, and with powerful limbs. The neck is thick and short; the legs ure corered with thick hair, and seem somewhat heavy and clumsy, but they are as firm, nuscular, iron-like and sound, as those of the Shetlands. The mane is very henvy, often falling on both sides of the neck, whilo the forelocks cover the eyes, and give a sort of shaggy appearance about the upper portion of the head; the tail is also heavy and generally inelined to be wavy. They have a high crest, and quite a proud carriage of the head. They are docile, intelligent, sure-footed, capable of enduring all the rigors of a northern Winter, and able to perform long-continued journeys, at a moderate pace, while carrying or drawing disproportionate burdens."

Their courage is so high that they do not readily succumb to any hardship, however trying its nature, and though coupled with poorness and scantiness of fare. 
I. MPORTANCE OF THE SUBJCT. - II, THE BEST STOCK THE CHEAPEST. — II. HE. REDITARY TENDENCIES AND IMMATURTTY TO BE GUARDED AGAINST. - IV. PRINOFPLES OF TRANSMISSION,_ $\mathrm{V}$, THE TWO MKTLODg, "IN-AND-IN" AND " CROAS" BREED. ING CONBIDERED. - VI. TREATMENT OF THK MARY $\triangle$ FTER BEING BERVED, DURING PREGNANCY, ETC.—VII. HOW TO KNOW WHETHER A MARE IS IN FOAL.—VII. HOW TO KNOW TIME OF FOALING. - IX. ABORTION, OR SLINKING THE FOAL. - $X$. HOW TO RAISE COLTS, - XI. MULES.

\section{Importance of the Subject.}

No subject connected with the rearing and use of stock can be of more importance to the furmer and stock-grower, the intelligent, practical business man, than that of breeding. 'Thut it is every way more profitable to any one who rears and trains a single colt to have that colt of the very best ruther than of any indifferent quality is almost too palpable to need a moment's consideration. 'That it is possible for every man of observation and good judgment to improve his stock is equally obvious. There is no line of work which horses are culled upon to perform that has not its peculiar requirements, that can be better met by some specific kind of animal than by one chosen at haphazard. It is a matter, then, of the plainest common sense that every one who means to rear a horse for his own use should consider beforchand to what purposes he will most probably devote it. If it is designed for market, he needs no less to consult his interests by determining what markets are accessable to him, and what description of animal will be apt to find most ready sale therein, at most remunerative prices.

For the farmer who wants to breed and rear horses of all work, it would be manifestly foolish to seek a high-priced pure-blooded race, for his 94 111arc like it stesdier pluck a the min be of $\mathrm{gc}$ sion, mi obtuinin penny-w advautas 'alkin, deapest equal, tl hound to garded 1 ends ratt

III. H

A caur relating $t$ itself. I the huma a moment crdinary horses dis in this wa 
mares, unless the mures themselves were of such type as to render it necessary to breed to high and elegunt stallions in order to obtain those medium-sized, but compuct, and moderately quiek-paced animuls that are so well adnpted to ull the wants of the farmer.

On the other hand, one wunting a light and fleet animal would set his inconsideruteness in a striking manner who should so disregard nll the dicintes of sound sense as to hope to succeed by any chance selection of sither mares or stallions.

\section{The Best Stock the Cheapest.}

It may be linid down ns the first rule-a foundation principlo-that the rery best and purest stock that is really adapted to the end in view should lie sought after.

It costs even less to feed a horse of good blood and linetge than it does to maintain n scrub ; it costs no more to shelter him ; it costs less to groom him and keep him in eondition than it does to keep the serub from looking like a seare-crow; his movement is almost invariably smoother and stendier for the sume rutes of speed ; his temper is generally better; his pluck and energy not less so ; and if it is found necessary to put him upon the market, he brings a better price. 'The service of a stallion known to be of good, generous blood, and possessing adequate powers of transmission, must of course cost more; there must be a dam adapted to the obtaining of a foal of the best type possible from such a sire; but the pemy-wise, pound-foolish policy of refusing to avail one's self of these advantages, when in the bounds of possibility, is too apparent.

Taking it for granted, then, that the best, in this ease, is always the (heapest-that the finer and purer the horse can be, other things being "fual, the more useful, more ensily maintained, and nore marketable he is hound to be, it remains to consider some points that must always be regarded by the intelligent breeder, who seeks wisely to adapt means to ends rather than to trust to clance.

\section{Hereditary Tendencies and Immaturity to be Guarded Against.}

A caution most needful to be insisted upon at the outset is that relating to the transmission of tendeneies to disease and of netual disense itself. It scems that no man in his right senses, knowing the results to the human family when this consideration is disregarded, would think for a moment of utterly ignoring the possibilities of evil consequences; but crdinary observation leads to the diselosure of the fact that among horses diseases and impaired constitutional powers are often transmitted in this way. Mares at an advanced age, too stiff, too weak, too slow to 
be of any further active use, are turned to account for breeding purposes - ind the result is, " weak fonl, heking thrift mnd lacking spirit. Mares hucked ubout until they are ring-boned, spuvined, and splinted, or perhups dropsical or with a glanderous tendency,-no longer useful on the farm or on the road, are relieved from tho work which they ean no longer do with my chunee of profit, and sent to the stullion. Result : a fonl with a rickety or knotty ossoous system, or with a tendeney to some form of dropsy, or rendy, in the presence of any exciting enuse, to develop a case of glunders. And so of other disorders, more especinlly of rouring, thick-wind, blindness, contracted fect, grense, und affections of the brain and nervous system. Some mares linve a peculiur predisyosition to surfeit, somo to swelled legs, some to vertigo, some to a sort of unuccountuble viciousness. No wise breeder com ufford to disregurd these things. If he wishes to renr a lorwe for service, he wants a sound fonl; for he knows he ean get from such a one more work for less cost than from one unsound in bone, muscle, secretions or integument. If he designs to breed for market he is aware that neither a puny nor a diseased creature ean be palmed off there either to his profit or his eredit.

To insure healthy, active, thrifty progeny, then, the dam must be sound and vigorous; and this is no less true of the sire. We dwell less upon the latter because it is of far less frequent occurrence for a broken down and diseused stullion to be kept for the service of mures than for mares of this deseription to be put to breeding becuuse they are known to be fit for nothing else, but are erroneously deemed useful for this. The condition of the stullion, however, niust not be overlooked. Every breeder must have a care to choose a vigorous stallion, and one free from blemishes, mal-formution and hereditary tuints.

Nor should mares be put to breeding too young. They should be full grown and vigorous, and when their powers begin to fail they should no longer be subjected to this service. It is the practice of some to begin to breed at two yeurs of age. This is injurious to the nare, and otherwise unprofitable to the owner. The growth of the mare is hindered; her form is modified both by the weight of the stallion and by carrying the fonl. And the foal itself is upt to lack fullness and power. Yet, it takes from the young mother that sustenance which she needs for her own development, so that she is dwarfed, while it grows up a more or less puny creature - of insufficient value to compensate for the injury done to the dam. No mure should be so used till she is at least three years old - four would be the better and more profitable age. It is said that mares which are.allowed to mature, and are well treated afterwards, will not lose enough of their natural vigor to disqualify them for bringing forth good foals till after they are twenty years old; but it is idle to 
expect good, strong, well-formed, thrifty, and spirited offspring from a mure that is oither too young or too old ; or that is subjected, even in unturity, to hard work, poor and insufficient food, and eruel handling.

\section{Prinoiples of Transmission.}

Lot us next notice this principle, thut when the dam and the sire both Inssess a due amount of vigor, the foal will combine in itself the mosi warked charanteristics of both; while any quality that is peculiar to either of them is apt to be prominent in the offspring. 'This upplies to both disposition und physical conformation.

It will be seen from this statement that no matter what the general line of policy to be pursued by the breeder, that of in-and-in, or that of arosing, he must select his stallions and mares with tho view to having one supplement the other. If the mure is deficient in any point, the horse should be full or predominant there, and vice versa; and if any peculinr truit is desired, that should be very strongly developed in either sire or daun, while merely nominal in the other.

Another special point to be considered is this: that for tho production of in full-formed, symmetrical, vigorous, and thrifty foal, the mare should be proportionately larger than the horse. An overgrown stallion, of grent power, serving a mare of diminutive size, or of size somewhat less in proportion than his own, will beget her a strong embryo that will require more room and more nourishment than the mure enn afford; and tho result :must be weakness, and, probably, deformity -almost inevitably diminutive wize. Men's minds were particulnrly culled to this fuct in Great Britain when, during a course of yeurs, the furmers of Yorkshire thought that by breeding their mares to the very largest stallions they could find, and without regard to the size of the mare, they could meet the demand in London for great overgrown horses, which it was then the fashion to drive in coaches and other heavy carriages. The result was a race of almost worthless creatures.

In other points than mere size, more depends upon the selection of the mare than that of the horse. The grent majority are mares bred after their own stock unless the stallion is so powerful as to neutralize or overcome this physiologienl peculiarity; so that it is necessary for her to be of good lineage if the best results are winted. If she has come from diseased, vicious, or in any way evil ancestry, though sho may bo free from perceptible taint, the bad points of her stock will very probably appear in her offspring. This principie makes it necessary to have a regard for her eolor and for the color that is known to have been prevalent in her line, since any dirty, vari-tinted, and otherwise disagrecable color's may appear in a foal of hers if her progewitors have had such a hue.1 


\section{The two Mechods, "In-and-in" and "Crosg" Breeding Considered.}

As for the two leading methods of breeding, circumstances generally determine which the farmer or other breeder on a moderute scule is to adopt. He is now almost always under the absolute necessity of crossing; and the main point with him is, how to cross, in order to secure the best results. The main directions are already laid down, with sufficient minuteness to enable anyone of ordinary intelligence to judge as to the best means. One point must not be overlooked, that really to improve the stock of horses as to blood-to obtain a strain that has the power of transmitting itself, and of so continuing in a steady line of improvement, recourse inust be had to pure blooded horses. The English racer or thoroughbred is almost our sole reliance in this respect; although an Arab may oecusionally be found. The true Norman Percheron is endowed with this characteristic of pure-blooded horses-he has great powers of impressing himself upon his offspring, and perpetuating the strain; but he is too heavy for the ordinary run of mares in this country; and if heavy draft stock rather than the lighter horse of all work is wanted, the Percheron mare should also be used-or some other of equal length and weight. Good mares of the common mixed breeds in the United States, bred to the light Arab, Barb, or thorough-bred stallions, will almost invariably produce foals partaking of their own size and strength, and of the finer forms, activity, and wind of the stallion. It i difficult to lay down any specific rule for crossing. The whole matter must be left to the good scnse of the breeder, afier the general statement of principles previously set forth. If the breeder has in view a mere racer, and is unable to obtain both thorough-bred mare and stallion, let him seck the racing stallion, at least, and one that will, as previously directed, supplement his mare-supply the points in which she is wauting for that specifie purpose. If he wishes a trotter, the same care must be observed. As trotting horses are of late days in great demand in the United States, we insert here a cut of one of the most celebrated of the Old World trotters, the "Marshland Shales," a horse foaled in 1802, and which was known to old age as the very best in the British Jsles. A careful study of his conformation will be of advantage to those who seek to learn the peculiar points of a horse of known excellence. He was a half-bred; and the impression long prevailed among the sporting men of England, (if it is even yet extinct), that no pure thorough-bred nor Arabian could excel as a trotter.

Now, let the reader compare him with "Dervish," and note the points of difference. "Dervish" was a little bay Arab, exceedingly fine, and remarkable for a darting or straight trot-throwing out his fore-leg and straightening sound, hardy upon any wel

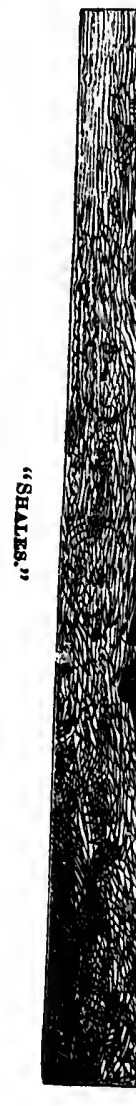

apt to produce $t$ compact, and wit Notice particu horse, foaled nea prior to the civi 
straightening the knee before the foot touched the ground. He was sound, hardy, and a powerful foal-getter; and a cross with such a horse, upon any well-formed, large and reasombly long-bodied mare, would be

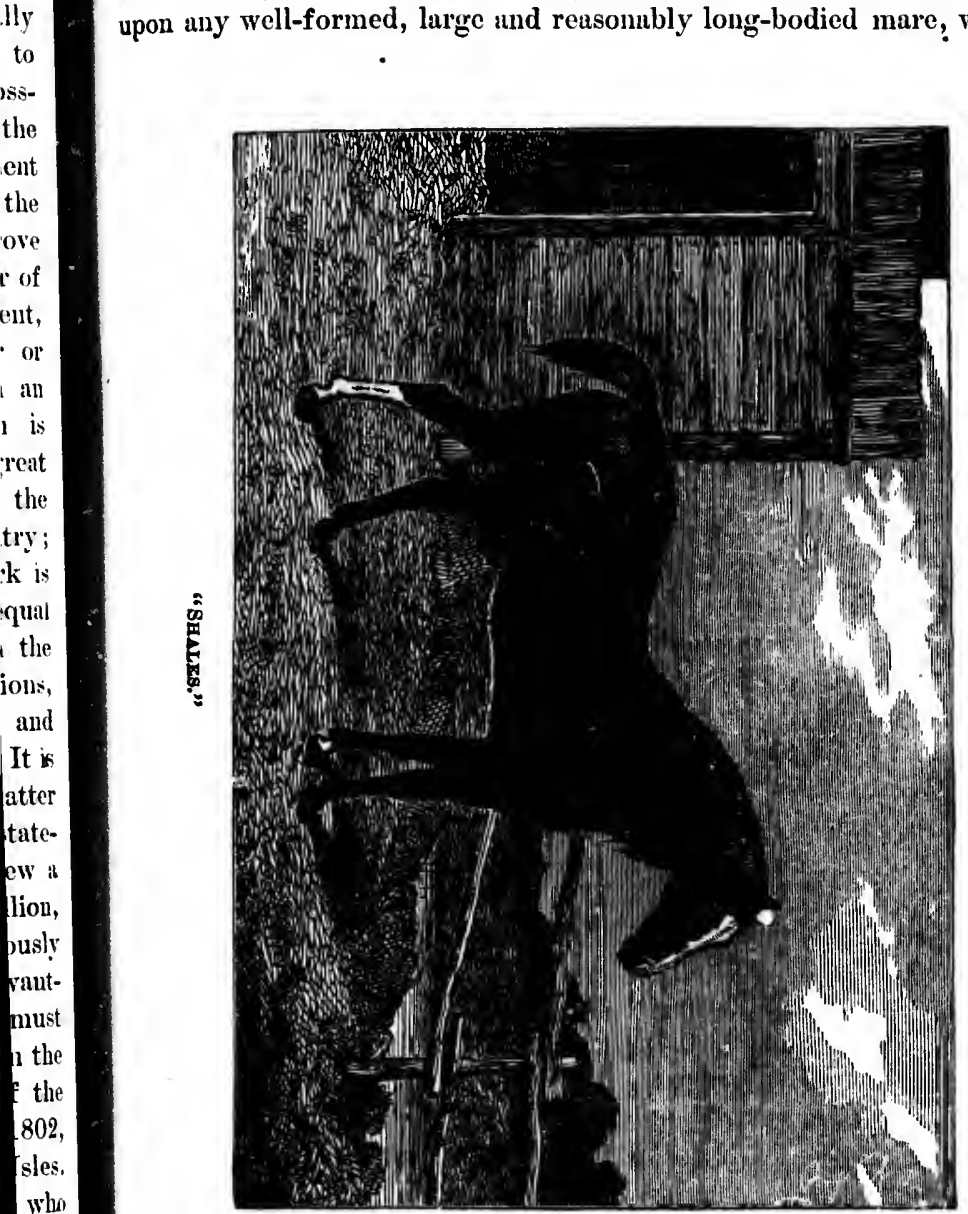

$\mathrm{He}$

rting

bred

oints

and

and

apt to produce the beau ideal of a trotter-moderately large, long, yet compact, and with light and clean yet powerful limbs.

Notice particularly the cut representing "Gold Dust," a Kentucky horse, foaled near Lexington, the property of L. L. Dorsey, a few years prior to the civil war. He was mixed blooded, having been sired by 
Vermont Morgan, a great trotter, while his dam had in her both Arabian and thorough-bred blood.

It is worthy of consideration on the part of the breeder that the colts of "Gold Dust" showed stronger marks of their Arabian and English

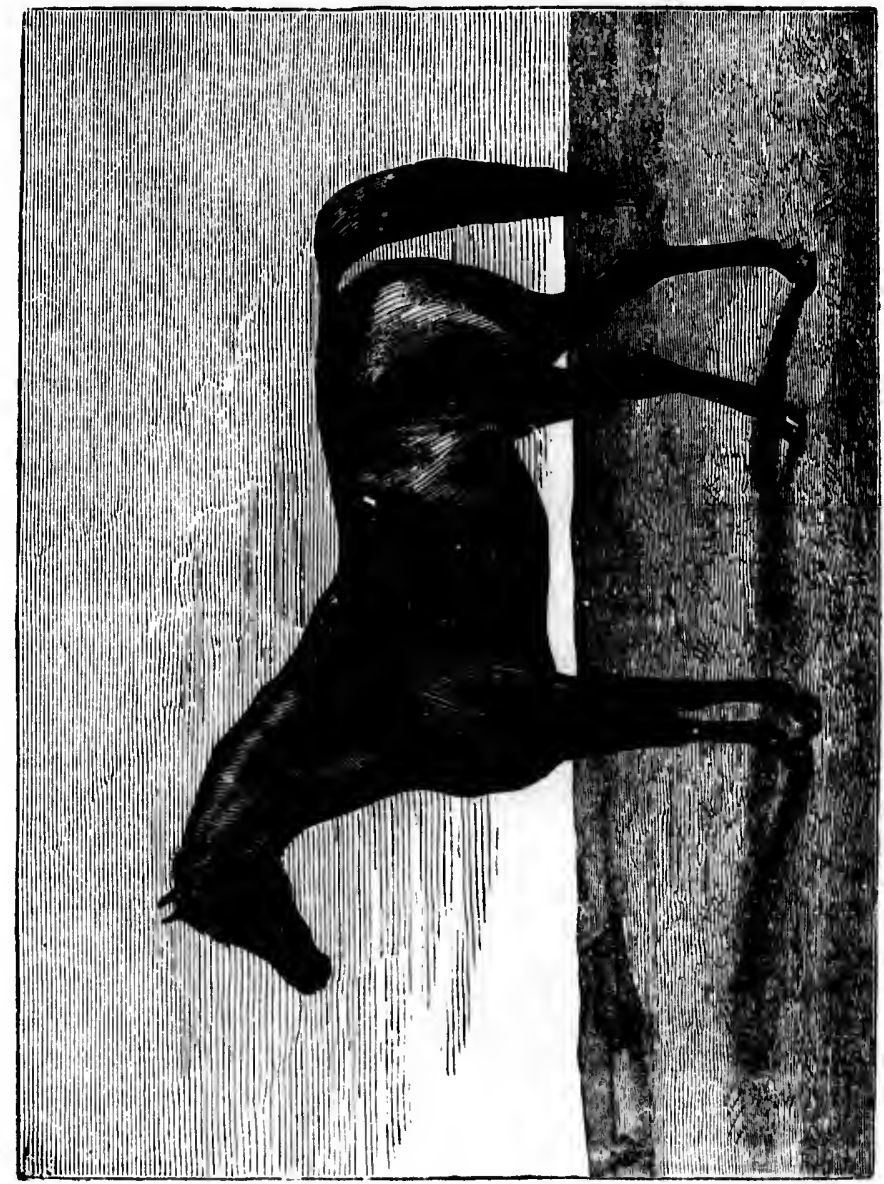

aneestry, which came by his dam's side, and remoteiy, thin of the Morgan, his sire, so superior is the pure blooded horse as a transmitter of his own qualities, und an improver of breed. "Gold Dust" is worthr

of study. a fast walk such as he finds it in 
of study. He was not only beautiful, but a horse of the finest actiona fast walker and fumous as a trotter. When native American stallions such as he ean be found, the owner of good mares need not repine if he finds it impossible to come at the much-to-be-desired pure blooded

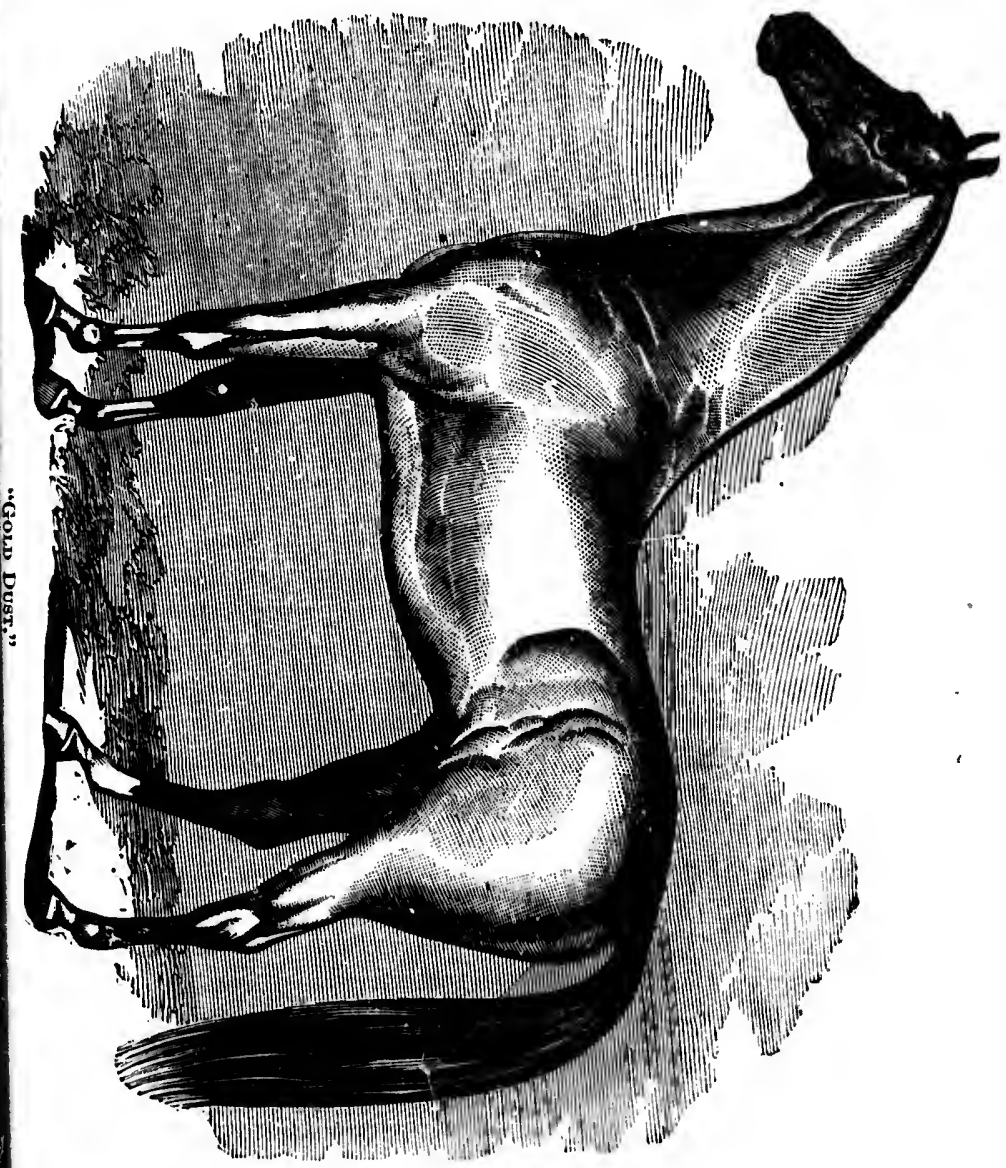

foreigner. He may rest assured of getting improved colts, and of such character as will, if judieiously handled, perpetuate, to some extent at least, their own good quilities.

If it is heavy draft stoek that is to be sought, the Norman Percheron 
stallion, as we have previously intimated, ought to be had, provided the breeder has mares of such size as to render it judicious to put them to so large a horse; otherwise, the Norman Percheron mare may be most advantageously bred to some native stallion, say a Morgan, a good Canadian, or some other compactly built and quick-paeed horse.

But it is unuecessary to extend these suggestions. If the breeder will consider with care what he really wants, and observe the points upon which we have touched, he will be at no loss to judge intelligently what course to pursue when cross-breeding is his only resource. He may often, of course, find it difficult to obtain just the stallion which his judgment tells him he should have for his class of mares; but this is a pointed argument in favor of that care which our farmers should long ago have exercised in this matter. Intelligent attention to the inprovenient of our stock throughout the Union will soon make it possible for them to select their stallions, rather than to be forced to take up with every hack that comes along with a flowrish of red sureingles and a wonderful pedigree, manyfactured to order.

As to in-and-in breeding, but little need be said. All the long-winded, voluminous, and learned discussions of the subject have resulted in adding but little more to our stock of knowledge than this: that too close in -and-in breeding is likely to bring about weakness, malformation, and general deterioration; but that to fix and preserve and intensify a certain strain, the Jew, (to speak in a figure), must not intermarry with tho heathens round about him. In other words, to have true Morgans, both sire and dam must be of that stock, though of different families: to keep up the real Norman Percheron horse, we must have Norman Percherons, both male and female, to breed from; and so on.

The objection to close in-and-in breeding seems to be here: that nearness of kin is apt to be associated with likeness of qualities, both physical and mental, (if we may so speak of tho horse); and thus the great requirement that one parent must supplement the other is not complied with. If there is a weak point in both, the weakness is perpetuated and made worse, whereas $a$ weak point in one should be counteracted by $s$ correspondingly strong point in the other. If it could be known with absolute certainty that two nnimals, close of kin, had strongly marked opposite traits of character, constitution and conformation, they might be bred to each other, and with the best of results. Such is sometimes the ease; but it is not likely to be, and the rule should be as we have said-let the strain be the same, but the kinship as fur removed as possible. This is believed by the most eandid observers to be the secret of Arab success. The individual breeder knows not alone his own animals, but those of his tribe, and of other tribes as well. Moreover, the Arabs is left to after cop away fro period, b the castir After will be $\mathbf{r}$ about the guard he in any wo

It some made, pro here give seek the a

The ma the noxt $t$ is to be br 
svided the them to so $y$ be most n, a good a. reeder will oints upon ently what He may which his at this is a hould long o inprovepossible for ke up with ggles and a

ong-winded, resulted in is : that too alformation, I intensify a rmarry with e Morgans, ht families: wve Norman h.

here: that alities, both us the great ot complied etuated and practed by s known with igly marked they might sometimes as we have removed as the secret of wn animals. r, the Arals are close observers and astute judges of horse flesh, and an intelligent son of the Desert could by no reasonable means be induced to breed his mare to a stallion in which his eye had marked some weakness or evil tendency which he knew the mare likewise to possess, however slight the iudications might be in either.

Then, to rectpitulate briefly: if the breeder has it in his power to keep up a certiin stock, let him guard against the slightest admixture of heathen blood; and to be as sure as possible of no evil results, let him look to securing sires and dams as widely removed from kinship as possible; but ho ein never afford to disregard the point previously so much insisted upon, as a prineiple to be observed in erossing, that if either parent has a fault, the other must be correspondingly strong there.

\section{Treatment of the Mare After Being Served, During Pregnency, etc.}

It is proper $r$ st to notice some little matters of detail in eonnection with the man' gement of brood milres.

Forty-four weeks is regarded as the time which a mare goes with foal; but this must be taken as mean time, since one occasionally brings forth a perfect colt four or five weeks sooner, and others will go equally as long beyond this period. When once the time of a mare is known, the breeder can generally regulate her going to the horse so as to have the eolt appear at whatever season he consideres most desirable, but without this knowledge he cannot.

After having been served by a horse, the mare should be allowed to stand idle awhile, as conception will be far more apt to take place if she is left to herself. If put to brisk motion, or to any strain immediately after copulation, she is apt to fail of conception. She should also be kept away from string-proud or badly eastrated geldings, not only at this period, but during her entire pregnaney, as they are apt to worry her to the casting of the coneeption, or, at a later period, to slinking the foal.

After she has been allowed a reasonable season of quiet, moderate work will be rather beneficial than injurious; and this may be kept up until about the time of foaling. Special care should always be exereised to guard her against being kicked, heavily thrown, or inordinately strained in any way.

It sometimes occurs that at the time of foaling, a false presentation is made, producing difficulty of delivery ; but no reliable instructions can bo here given as to what course to pursue in these cases; and it is best to seek the aid of some skillful veterinary surgeon.

The mare which has had a colt will be found in season sometime within the next thirty days, and she ought to go to the horse at this time if she is to be bred at all. The ninth day after foaling will generally be found 
to be the right time. Whenever indications of hent ure discovered, the matter should not be delayed, as the senscn may pass off and not return. After putting, the days of trial are the ninth, then, if she refuses, the seventh after this, and upon a second refusal, the fifth after this, which is sufficient to prove her.

\section{How to Know Whether a Mare is in Foal.}

It is often important for both breeders and triders to know whether a mare is really in foal ; and one writer has published the following directions for determining this point, which he says may be iuplieitly relied on:

"After the first service of the horse, and before the next trial, on examining the vagina, or beuring, if conception lus not taken place it will be of a fresh, bright, or florid and moist appenrance, with a clear drop appearing at the lower part, and which, if touched, will incline to extend; but if conception is present, a different appearance of the surface of the vagina will be presented. It will be found dry, and of a dirty brown or rust color; and a dark, brown looking drop will reylace the former elear drop. When these latter appearances are preser', pregnancy may be regarded as certain."

\section{How to Know Time of Foaling.}

Two days, (in some mares only one), before foaling, a sort of sticky substance will be found protruding from each teat, somewhat resembling drops of milk. Care should now be taken to provide a suitable place for her, as this is a certain indication of near delivery. She should be removed from other animals, and a careful person should see to her often enough to guard against aceidents.

Before the signs referred to, as shown by the teats, however, there is on each side of the spinal column, from the tail to the haunch, a furrow. like fold; and the bag will generally be found considerably inereased in size. These signs show that delivery is not very remote, but cannot be relied ou to denote the day.

\section{Abortion, or Slinking the Foal.}

When about half the time of pregnancy is passed, more than ordinury pains should be taken with the mme, as it is at this time, if nt all, that she is apt to slink. She ought now to have better feeding, and even gentler handling than she lad previously ; though at all times the owner but consults his own interests when he curefully guards her against ill usage. She has more need of food, and is less able, at this time, to endure hunger, as the rapid growth of the fotus makes a constant and

If the six mont all unnes and devo be taken so) copiou after for mation a) a day for food than will tend 1 idder will 
ered, the ot return. fuses, the his, which

whether a ving direcrelied on: rial, on exlace it will cleur drop to extend; face of the y brown or ormer clear may be re-

rt of sticky resembling ble place for should be to her ofteu

er, there is h, a furrowincreased in t camnot be

an ordinary at all, that $y$, and even 5 the owner against ill his time, to onstant and severe draft upon her system. Want of care may cause abortion; and if a mure once casts her foal, she is upt to do so at a corresponding period of pregnancy afterwards,-more especially if like provocation occurs.

Various other cuuses of ubortion, some of which may be briefly adverted to, for the purpose of pointing out certain preventive mensures and suggcating others. Blows, strains, and any violent excitement may have this effect; and it is said that to allow a mure to see and smell food to which she has been accustomed, and of which she is fond, without suffering her to eat of it, will cause slinking. Feeding hogs or other stock upon corn, in sight of a mire that is not also thus fed, is, for this reason dangerous. Sympathy is a known cause: a pregnant mare, seeing another cast her foal, is apt to be affected in like manner. Nervous spasms, or a sort of animal hysteria, resulting from sympathy of the womb with a discased stomach 'or other organ, occasionally results in causing the foal to be cast. Some afirm that a smell of blood, or of freshly slaughtered meat, will do it.

If a mare slinks because of a hurt, a strain, or some acute attack of disease, she is not apt to fall into the habit of abortion, provided proper care is taken to guard against exeiting causes at a corresponding period of her next pregnancy.

When once this tendency is established, however, it is difficult to counteract it, as the slinking is more than likely to take place ut times when the mare is not under observation. If symptoms of casting chance to be discovered in time, it may be prevented by promptly burning pigeon feathers, (or those of other birds, if these cannot be obtained), on a hot pan, or a pan of coals, and holding them so that she will be obliged to inhale the smoke.

\section{How to Raise Colte.}

If the colt is healthy and thriving, he should be weaned at from five to six months old. If allowed to run with the dam after this period, he is an unnecessary burden to her, since he has already learned to pick up and devote to his own use other sustenance, and he may most judiciously be taken awaty. If at this time the dam is still inclined to furnisin milk so copiously as to render the udder painful to her, she should be looked after for a few days, to see that the over fullness does not result in inflammation and swelling. If necessary, draw away the milk by hand once a day for three days. It is a good plan to keep her at this time on dryer food than usual, and at more than ordinarily steady work. This course will tend to prevent the secretion of the usual quantity of milk, and the ndder will soon be dry. 
No matter how well born a colt may be he can never amount to anything if raised a starveling. If the dam is what she should be, he will have been furnished with abundant sustenance from the time of conception to thut of delivery, which is one of the sccrets of full-formed, finely-proportioned, vigorous foals. From foal-time to weaning he will have been kept vigorcus and growing by the quantity and charucter of the milk furnished him, together with such little food as he has early learned to partake of at the manger and in the pasture of the dum. And now, upon being weaned, it is of the utmost importance that he have liberal food and sufficient protection from the inclemencies of the weather. This must be carefully attended to during the whole period of growth if be is expected to make any adequate return to the owner. Bruised oats and bran have been recommended as the very best food to be given for a considerable time aftor weaning. In any event let his food be supplied with regularity ; and it must be nutritious, yet of such kind and so disposed as to be easily partaken.

He should not be stabled too much, nor in any onner way too closely confined - being allowed all that range and exposure to out-door wouther common to older stock in the more clement sensons ; but ho should never be left out in cool rains nor in the storms and biting cold of Winter. If a place is provided in which he may always shelter himself when the condition of the weather inclines him to scek cover, it will save trouble and yet insure a natural growth and that hardihood which comes of sufficient contact with cold and heat. For this purpose a straw rick is sometimes recommended-so constructed as to furnish shelter on the leeward side. This will give at the same time both bedding and a light species of food.

Provision must of course be made for his obtaining readily, and at such times as the wants of nature may dictate, plenty of pure waterthe purer the better.

Thus much as to food, drink, and shelter. Another point of importance must not be omitted in his raising, that is, fumiliarizing him with his master or with whomsoever has charge of him. He should be handled sufficiently and in such a way as thoroughly to overcome all shyness, and to lead him to feel that man is his friend. This confidence once established, his training - when the proper time comes for that - will he easily and successfully accomplished; his subsequent relations with his master will be always pleasant, and his value thereby much enhanced.

And this, indeed, touches a fundamental principle in the care of all dumb beasts. Lead them to recognize that man is their friend; that they can depend on him to advance their comforts, and to secure their welfare. 


\section{x. Mules.}

The breeding and rearing of mules, so common in many portions of the United States, requires more than a passing consideration. To obtain the best results in crossing with the ass demands as much intelligent care as in the case of the horse : and the mule-breeder will find it much to his advuntuge thoroughly to inform himself as to how these results are to be obtuined.

Many mistaken impressions prevail as to the relative usefulness of the mulc, as compared with the cost of breeding and maintenance.

It is thought by the inexperienced that he is almost equally adapted to every kind of draft work to which the horse may be put; that his power as a pack-aninal is much grealur than that of the horse; that his endurance is grenter; that he can subsist on less food; and that he demands every way less care. All these things nre set down to his advantage; but in most instances the impressions are wholly erroneous. As a general thing, he is not well adapted to road or to city purposes at all. Especially are hard roads and pavements destructive to him if he is large of body and disproportionntely small of leg. He is not so stout as a horse of proportionate size; he is utterly incipable of carrying so great burdens as some have represented, even if loaded and attended by experienced packers,-particularly if the journey is to be continuous and the roads are at all heavy; his powcrs of endurance are not greater than those of the hardier kinds of horses; he will consume as much food as a horse of proportionate size, if required to do like work and to maintain a like condition; and as to care, he can do without it-so can a horse-but both fail thereby of that eminent thriftiness, sprightliness and longevity which is to be expected of animals to which it is extended.

On the other hand, and to his.discredit, it is commonly thought that he is naturally vicious, and wholly incenpable of appreciating kindly treatment-that the only way to controi him is by violence. Hence, those who handle hin generally feel as though they are justifiable in whipping, beating, kicking and whatsoever other crueltios they may choose to inflict. This is a grievous, foolish and wicked mistake. The mule has one means of defense, and his heels are dangerous to those who wantonly provoke or startle him and place themselves in his way. His long ears are sensitive, and by roughly handling them his combativeness is easily aroused, and distrust is awakened to that degree that renders him almost ummanageable. Yet, the mule may be so raised and trained as to make him gentle, obedient, even affectionate and ready to follow his master like a dog-so trusty that only the one always necessary precaution need be observed in dealing with him-to keep out of the way of his heels, which 
he throws out as instinetively when startled, irritated or approached by a stranger, as a cut thrusts out her claws. It has been remurked that "when a mule gets perfeetly gentle, he is unfit for service ;" and that, taken in connection with the prevailing method of training him, is doubtless true; but there is a better way, and, if followed, it would result is we have stated above.

Now, while the mule is not adapted to everything, and endowed with powers that are adequate to endure starvation and brutal treatment while in the performance of hard and faithful service, he is admirably calculated to meet many of the wants of individuals and corporations; and his breeding, rearing and training aro matters for intelligent consideration. For supplying the urmy he caunot be replaced; for towing cunal boats he answers admirably ; for hauling cars inside of coal mines, he is indispensable; for the generul knock-about work of a farm he is good in all temperate climates; and in a cotton and sugur country, where it is warm and sandy, he is most especially valuable. 'Though he cannot endure everything and still meet every requirement of a heartless task-master, he is yet gifted with a hardihood that is admirable, and recuperative powers that are astonishing. Seemingly half dead, utterly broken down and worthless, he will, with a little rest and care, soon be again ready for service.

In breeding for mules no less attention should be paid to the selection of suitable mares and a suitable jack than in the case of horses. It is folly to use old, worn-out, diseased, ill-formed, ill-conditioned mares, and yet bope to obtain a good foal. As a general thing a great, overgiown, long-legged mule is next to worthless. He is expensive to keep and unreliable as a worker-lacking wind, strength and nimbleness. The medium-sized, clean, compact mule is by all odds the best, unless a team can be found to combine more than the ordinary height with round bodies, not disposed to fleshiness, and larger, stronger legs than usual, with feet above the common size - which is seldom the case. The Spanish or Mexican mule - the offspring of stout, close-built, active Mustang or Mexican mares is superior in endurance to nny known in the United States. He requires less food, takes it quicker, and is always in better fix for travel. If it is more profitable to raise good animals than poor ones, (and no man of ordinary intelligence can doubt this proposition), select mares for mule bearing that are sound, compactly built, and yet without any contractedness of body - active, strong, every way serviceable. Then, the choice of a suitable jack is important-doubly so from the fact that the great majority of mares breed after the jack in the matter of legs and feet, and, if it is a good and powerful jack, the foal will generally bear his marks, which is a matter of some imnortance, 
since mules so murked are always regarded by expernenced stock men as being most hardy and valuable. The jack should be large - the larger the letter, other things being equal, since it is impossible to find one so

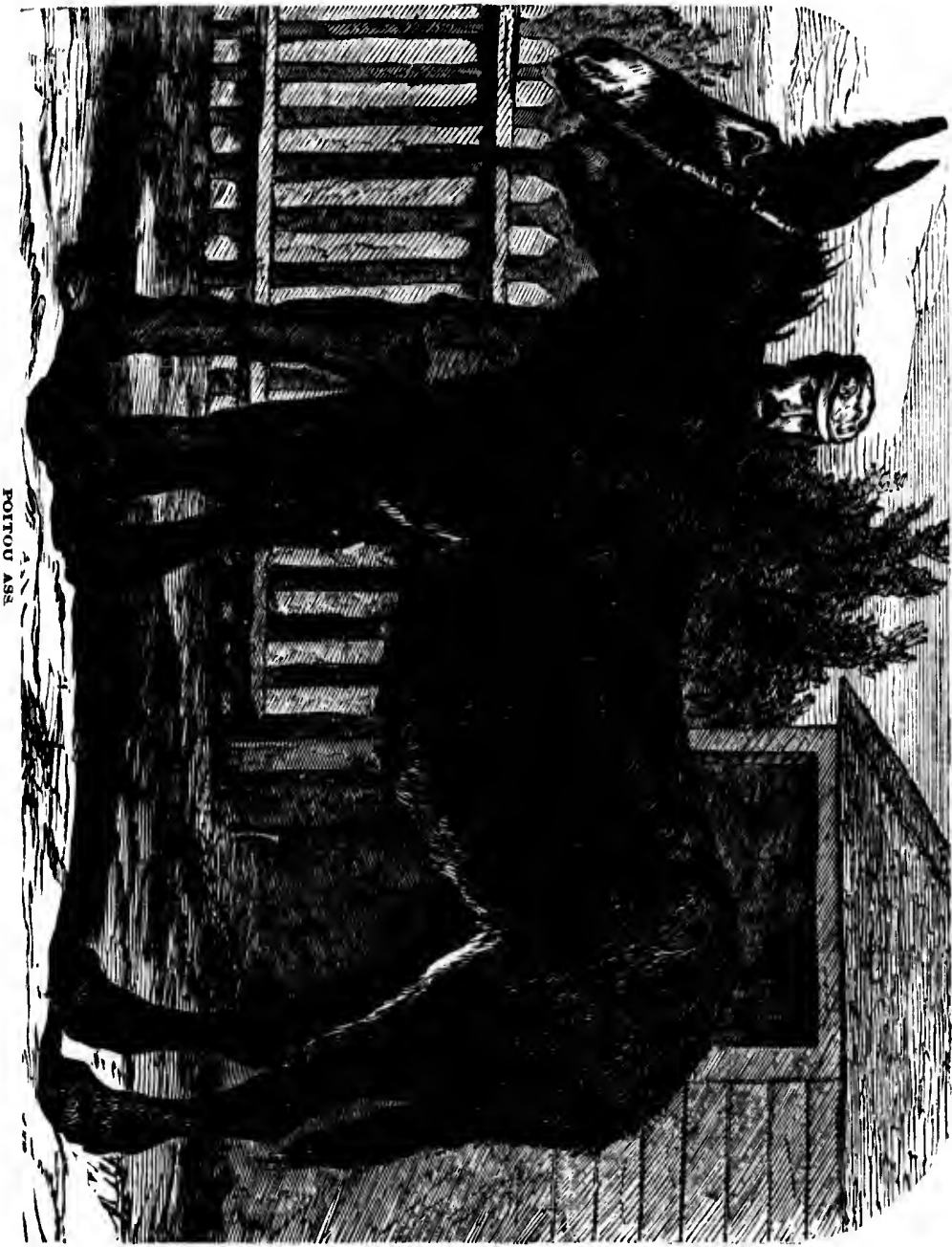

much surpassing in size the mares we have described as to render him objectionable on account of disproportion, as may easily be the case with 
a horse. Most especially must the breeder have an oye to his legs and feet ; for here, if at all, the mule is apt to be a failure - having a horse's body, ready to take on flesh beyond his requirements, mounted on legs that are tco slight of bone and too small of muscle, with feet below the standard size for highest usefulness.

The cut on preceding page is a portrait of a large and powerful Poitou ass, an animal much valued in that district of France for breeding heavy draft mules from cart mares. The one here represented hus heen described as being fourteen and one-fourth hands high; greatest girth, seventy-seven inches; girth behind the shoulders, sixty-six inches; length of ear, fifteen inches; ears, tip to tip across, thirty-two inches; with loofs much larger than those of the common ass. Compare him with the small, light ass, now in too coinmon use among us. The differ. ence seems to be almost one of kind; and with these representations in his mind, no observant stock-grower can be persuaded to put up with a poor pretense of a jack for the service of his mares.

As for the treatment of mares that are to be thus bred, no farther directions need be laid down, since it must be substantinlly the same as that prescribed for the breeding of horse fouls. The like instructions relutive to weaning, feeding, and sheltering the colt must also be carried out ; and too much importance cannot be attached to beginuing early the work of familiarizing him with man. He should be taught to regurd his keepers without fenr, to allow himself to be haltered, and readily to submit to direction and guidance. If this is done, he will be easily trained, when the proper time shall have arrived ; and if properly handled and judicionsly taught then, he will be not only a useful, but a trusty und agreeable animal. 

entations in up with a

no further he same as instructions be carried ig early the , regard his $d$ readily to ill be easily orly handled ut a trusty

HOW TO BREAK AND TRAIN A HORSE.

\begin{abstract}
. AMERICAN VS. ENGLISH FOALS. - II. AT WRANING TIME. - IIX. THE FIRAT LESBON.— IV. TRAINING.—V. TRAINING TO WORK.—VI. TRAINING TO BAOK. — VII. TRAININa TO BADDLE AND HARNEGS. — VIII. TO HANDLE A HORBE. — IX. HOW TO HANDLE A vicious COLT. - X. SADDLINO AND FARXESGING. - XI. HOW TO BUHDUR A VICIOUS HORBE. - XII. HOW TO TRAIN TO THE SADDLE. - XIII. TRAINING TO TROT IN HARNRg8. - XIV. HOW TO TRAIN TO TROT IN LIGHT HARNGBS. - XV. HOW TO TRAIN FOR THE PLOW. - XVI. TRAINING TO THE WACON. - XVI. HOW TO TRAIN A RACER. XVII. TRAINING A BTALLION
\end{abstract}

\title{
I. American vs. Fnglish Foals.
}

It is a common remark among Fnglishmen visiting America that our horses are more easily controlled and managed in the breaking in and training than English horses, and hence they have been led into the error of supposing that they were deficient in courage and spirit. Nothing could be farther from the fact. The true reason is, the growing foals in the United States are more the companions of the children of the farmer than in England. They are not as a rule, beaten and abused, and thus do not find their real powers of resistance as they do in England under the handling of hirelings of little intelligence, and almost no education. In the United States the fondling of the colts and fillies commences almost with birth. They are special pets of the boys of the family. On the farm, and even on the road, the mares are often regularly worked with the colts running at the feet, a very bad plan for the celts, and 
especially so for the mares, but which, nevertheless, early accustoms the young animals to strange sights, while it renders them tame and confiding.

\section{At Weaning Time.}

The true education of the colt or filly should begin early ; at weaning time. They should then be haltered and taught to lead, to stand quietly in the stall when tied. After this is thoroughly understood the colts may then have their liberty, for there is nothing more healthful, or hettor calculated to develop those powers necessary to the exhibition of speed. endurance, or great muscclar exertion, than constant, every-day exercise, which all young animals maturally take in their play, and this often of the most violent character.

\section{The Rirst Lesson.}

The first lesson the young foal should be taught is to come readily at call. This is easily accomplished by providing one's self with delicacies, such as sugar and salt, of which horses are especially fond. If there are a number of them they will all iake the lessons together, and easier, for the most intelligent will assist the others. At the same ime they must be taught to be quiet by a light tap of the whip to unruly ones.

In haltering, the colt or filly should be approached from the near side, tive halter in both hands. Let the colt smell it until it no longer fears it, when, holding it properly in the left hand the right hand may be passed over the colt's neck and taking the strap of the halter it may be drawn on and buckled almost before the colt knows it. In case the colt should be wild, shy, or vicious, it must be confined in some place wbere the halter may be put on, but no haste must be manifested, until at the moment when it is to be buckled. Then do it quietly and quickly. If very strong, two ends of rope, each ten feet long, should be attached to the ring of the halter, and a free passage out of the stable allowed, one man holding each rope. In the case of a colt three or more years old, and strong, these ends should be twenty feet long, and the halter should have a cavesson so the muzzle will be pinched during violent struggles. The men holding the ropes - there may be one or more, according to the struggles of the animal - are not to seek to throw the colt or horse, but simply to restrain him in his struggles to escape. The yard should be soft so that if the colt falls it will not be injured. But if the animal does fall, when down it should be firmly held so for five minutes, or until resistance entirely eeases. As a rule, before the expiration of fifteen minutes, the colt will take a lick of salt from the hand and thereafter follow quietly. As soon as the colt gives up he should be led to the stable, 
tied, given a little water and fed, and then be left to himself, being certain he can neither break the halter or injure himself. As before stated, the foal once haltered, taught to stand quietly, and to lead kindly it may then be given its liberty until of the proper age for training. The animal three years old and over once in hand should be thoroughly broken and made waywise without delay.

\section{Training.}

The regular training of a colt or filly should begin at the age of two years past. There are many urgent reasons for this ; first, the animal has neither the full strength, nor ihe disposition to resist, that it will have at a more mature age ; second, it is more tractable, and will acquire its lessons more easily; third, it will not have contracted habits of self-will difficult to be broken off ; and fourth, lessons in flexions of the body may be taught that will naturally increase its usefulness in whatever direction it may be wanted.

In the whole munner of breaking and training the trainer must not only understand himself, but the young horse as well and also as of special importance, the particular use for which the animal is intended. If the colt is of cold blood, that is of no particular breeding, it will not pay to spend much time on its education. It is simply to be taught to lead quietly, to stand still to be harnessed and unharnessed, to be accustomed to the ordinary sights and objects he will encounter, to work quietly at the plow, or other furm implements, and to the wagon on the road, and to stand quietly when tied on the public streets. If to be trained as a road horse, or as a saddle horse, or both, or as a hunting horse, a trotting horse, or a racer, all these will require special, and sometimes, long contiuned lessous according as the animal is intelligent and tractable or otherwise. It should always be remembered, however, that there is nothing gained by cruelty and abuse. A contrary animal may be punished, but it should always be done calmly and with judgment.

\section{Training to Work.}

The first lesson for any use is implicit and perfect obedience to the will of the master. This thoroughly accomplished the rest of the task is comparatively easy, it is only a question of time. It is supposed the animal is entirely free from acquired vice, that it has been halter broken, and taught to stand quietly at the end of the halter, to follow quietly, to lead hy the side of the raster, and te stand quietly in the stable.

The next step is to procure a bitting bridle, a strong bridle with a heavy smooth snaffle bit with $g$ tongue piece and keys depending from the center 
of the bit, it must also have a check rein that may be lengthened or shortened, and two side strups one on each side. The harness is simply a very wide strong surcingle, with padded back piece, having at the top a strap and bucklo to form a loop for the check rein and also a buckle on each side of the sureingle in which to buckle to side straps. To the rear of the pad of the circingle is attached a back strap and round crupper strap, the latter to buckle and unbuckle.

Take the harness, and approaling the colt in the stall, let him smell it until satisfied, then put it on without undue haste or fuss. If the colt is nervous or skittish, talk to him and take time. The harness on, put on the bridle, giving plenty of length to the cheek rein and side straps, so the colt will not be unduly hampered, and let it out in a smooth, tight yard, following it about with the whip under the arm. Sometimes a strong colt will struggle and sweat violently, but if he has been properly handled heretofore, he will take the subjection pretty mueh is a matter of course. Let him exereise an hour a day for a few days, tightening the check rein and side straps gradually, until his head is brought into proper position, but not a constrained position. When he censes to fret at the harness, pass the snap of a leading rope through the near ring of the bit and snap it into the off one. This rope should be about fifteen feet long. Taking the end in the hand, exereise the colt in a circle, allowing him to walk if he will. When somewhat tired let him stop and standing in front of him, say come, tapping him lightly on the fore-legs with the whip. If he pulls, hold him firmly, but without undue violence while he resists, tapping him on the fore-legs at intervals, using the word come. He will soon find the way to eseape the whip to be to get near to you. Then fondle him and give him a trifle of sugar or salt and let him follow to the stable. So proceed from day to day, cxereising him in a eirele both to the right and left, (lunging it is called), gradually increasing his pace to a fair trot, until he will work as you wimt him, turning at the word to the right or left circle, or to stand and come to his master at the word of command.

\section{Learning to Back.}

This is one of the most difficult things to teach a colt properly, and one most commonly slurred over. No horse is properly trained for the most simple use, until he will back as readily and as perfeetly as he will go forward. It should be taught him while in the bitting harness, so that at the command to back he will do so to the extent of one or more steps. This is done first by standing in front of the colt and taking a rein in each hand; or take hold of the rings of the bits themselves. At

the wor enough gravity should.1 in walki fifteen the tim horses. the anin the lessi and well sugar, 01

We ha this age, two year else, and limbs tha in mind a a saddle 1 essential t another supple. that he wi

Put $a b$ fits and th be eisily s curb-rein bit, and th the branc same time the horse flexes his the same the head 1 until it is the bits.

The jaw the horse in it, so the $t$ 
hened or is simply the top a uuckle on the rear crupper

aim smell f the colt is on, put de straps, oth, tight a strong $y$ handled of course. check rein - position, e harness, $t$ and suap Taking to walk if a front of ip. If he esists, tap-

$\mathrm{He}$ will ou. Then low to the le both to his pace to rord to the c word of

perly, and ed for the as he will harness, so he or more d taking a elves. At the word back, use pressure enough to curb the neck somewhat, but not enough to force the body in such a position as to cause the center of gravity of the animal to be strongly displaced. In backing, a hind leg should be lifted first, then a fore leg, and so on in rotation, the reverse us in walking. When the animal will back promptly and in line for ten or fifteen steps consecutively, the further lessons may be safely left until the time when the rider is in the saddle or in the vehicle behind the horses. Sometimes the motion may be made by standing at the side of the animal. However it is accomplished, if strong resistance is made the lesson must begin again and again until it is entirely comprehended and well executed. When so, a slice of sweet apple, carrot, a little sugar, or something the animal likes may be given it.

\section{Training to Baddle.and Harness.}

We have stated that the colt should be broken at two years old. At this age, however, it should never be put to hard labor. 'The work at two years old should be more in the nature of exercise than anything else, and this exercise should be to insure proper flexions of the body and limbs than for the amount of work the animal will accomplish, bearing in mind always, as before stated, what the animal is designed for. If as a saddle horse solely, or in connection with light driving, it is absolutely essential that the flexions should be thorough. The word flexion is but another name for rendering the head, neck, body and limbs perfectly supple. The animal must first have been rendered so quiet and obedient that he will not strongly resist the will and action of the trainer.

Put a bridle with a curb-bit on the colt, being careful to know that it fits and that there is space between the chain and jaw, so the finger can be easily slipped between. Standing in front of the horse, seize the right curb-rein with the right hand, about six inches from the branch of the bit, and the left rein with the left hand at about half the distance from the branch. Draw the right hand towards the body, pushing at the same time with the left, so as to turn the bit in the horse's mouth. If the horse backs, continue the operation until he vields. When the horse flexes his jaw and lowers his head, let the left hand slip along the rein to the same distance as the right, then drawing the two reins equally bring the head near the breast, and hold it there oblique and perpendicular, until it is sustained of itself. The horse will give notice by champing the bits.

The jaw is flexed to the left by a contrary move as given above. So the horse may be fmade to hold his head up, and perpendicular, to lower it, so the trainer can make the horse flex his neck to the right and left. 
Standing at his shoulder, the trainer may make him move the hind-legs to one side or the other, the fore-legs remaining stationary, or to move the fore purts in a circle the hind-legs remaining intact, and this by means that will naturally suggest themselves.

But in all this there must be no ill temper displayed by the trainer no matter how bad the horse my act. Even if it be necessary to punish him the operator must be perfectly oool, never speaking in a loud voice or doing anything to cause undue resistance in the animal. The object is to teach the animal subjection to the will of wman, and this can never be done by intemperate violence. Our practice has always been to break at two years old so the animal may become way-wise, tlexible to the bit, to draw light loads, and under the saddle to walk, trot, or gallop, at command. Then at the age of three to four years, we let it again have its liberty. The reason of this is, at this age the colt is shedding some principal teeth, and therefore not fit for work. If the lessons have been carefully given they will never be forgotten. If however he be properly fed, in the stable, he may continue to do light work through his third and fourth year. In no case, however, should ho be put to heavy draft until he is five years past. As a carriage horse, the animal should not have hard work until he is the same age. Then he will get better and better until eight years old, and often do good service at the age of fifteen to eighteen and sometimes when past twenty years of age. There are more horses ruined between the ages of four and five years than at any other age.

\section{vIII. To Handle a Horse.}

As we have stated, the foul should be handled as early as possible, and by different persous, to early accustom it to different sights and sound, but always gently. It should be carefully brushed so as not to irritate it; its feet should be liftor and lightly tapped with a hammer; a head stall should be put on the foal having a ring but no strap, but so the strap may be attached at any time to lead and exercise it. Thus, the trainer beside it, the colt may be taught to walk, to trot, or stand still, allowing it to do pretty much as it likes, within bounds. Never beat it under any circumstances at this age. Reward it with a trifle of sugar, or a little bread, or a slice of currot, and fondle it when it has done well. Remember the $f_{L}$ '"ure horse is to be the servant of man for ten or fiften years of his life, and that it will pay to take pains with the education of so noble an animal, if well bred. In this day and genention it is moner thrown away to breed or handle any other, whatever tho breed may be.

When the foal is six months old strap a pad to itg back and attach stirrup 
ind-legs

to move

y means

rainer no

o punish

suid voice

he object

can never

1 to break

to the bit,

b, at com.

n have its sone prinhave been - properly $s$ third and draft until d not have and better of fifteen to re are more t any other

ossible, and and sounds, to irritate er ; $a$ head but so the Thus, the stand still, ever best it o of sugar, is done well. en or fifteen education of it is mone? $d$ may be. ttach stirrup leathers so they may flap about. In the Spring following its birth put a colt's bit in his mouth, with keys attached. Rein lim comfortably to the surcingle, to which a crupper must bo attached. In this, however, everything nust be easy to the animal. Don't try to get his head up. He mily be flexed from time to time, that is taught to open his jaw to the left and right; to turn his head to the right and left shoulder; to raise and lower his head; to turn with his hind or his fore-fect in a circle, those not used being the pivot; to come to his trainer at the word; to back, to guide right or left by the rein; in fact at the age of two years he may be made pretty well waywise, so that when actually ridden, or hitched beside a steady horse, there will be little fear or resistaice to combit. To get him used to the rattling of a wagon, tie him by a leading strap to the trace buckle of the back band to the off and also to the neir horse in the team. This will instruct him and get him used to the word, and to walking and trotting. quietly. All this may seem like taking a great deul of trouble, but remember that much of it may be done while doing the ordinary labor of the farm.

\section{How to Handle a Vicious Colt.}

Suppose you come into possession of a wild colt at three or four years old, or one that has never been handled. Put him in a close place like a narrow stall, where he cannot turn round or by any means escape. Put on a cavesson halter (a cavesson is a nose-band) and it may end under the jaw in a running noose, so as to press with force when drawn tight. Have lunging straps attached to the halter ring and securely fastened. Allow the young horse free access out of the stable, being careful not to throw him down before he gets out. Let the yard be rather small, but quite tight, and with none near except his trainer and assistant, who holds the ropes. Thus with a strong man to each rope acting in concert the wildest colt may be handled without danger. Let him struggle and rear and plunge, the ropes being well spread to each side. If he rear, ease on the ropes so as not to throw him, checking him as he comes down again.

Only one person should speak, the trainer, using only the necessary words and those spoken in a firm but rather low tone of voice.

Have a good aud reliable whip, a long, straight, flexible one, but not for use except in cases of an emergency; as in case the horse should get his liberty by slipping the halter and turn to fight. Then it must be used determinedly, but without exhibition of temper. If he rushes on you, a sharp, strong cut across the muzzle, avoiding the eyes, to be followed by others, as necessary. This will subdue him. If he kicks, a determined sharp cut $g$ tho hind legs next tho body, will tame him. 
A self-possessed man, understanding the use of the whip, is in but little danger from a young horse. But there is no need that the animal eseape. The straps and lending ropes must be secure.

When the colt gives up, let the assistant hold the rope, while the trainer, with the whip under his arm, the butt forwurd, gently and gradually shortens his rope, advaneing to the horse. Take plenty of time, spenking firmly but soothingly to the horse, watching for uny indications of $i$. If the ears are held naturally or thrown forword, all is right. wher uigohief is intended they will be thrown back. When the horse nllows you to approach hin and will smell the whip or your hand, give him a trifle of salt or sugar, rub his nose gently, and induce him to follow you. Then lead him into the stable and tie him in the stall securely. Frnm this time on he should have a daily lesson until broken.

... ... nust be remembered; in first tying up in the stable, the haiter ... " 40 strong thit the animal canuot by any possible means breal: $\therefore, a_{n}$ \& p rectly fitting and secure that he cannot slip or rub it off. Thus you i nover again have to break him of pulling at the halter.

\section{:"rrdling and Harnessing.}

The training of the horse rairly commenced, it should proceed day by day. Get him used to the harness and saddle by putting them on every day. Do not throw them on. Buckle every straj as carefully as thougl the animal was to be taken to work. The saddle being allowed to be put on without restiveness, and kindly taken, gradually draw the girth tighter from day to day until sufficiently tight so it will not turn. Begin by bearing some weight upon it, first with the hand and then by pulling on the stirrup. If the colt cringes at first and leans over to the side pulled uyon, it will soon get over it, and will at length allow the full weight of the man sitting upright upon the saddle in the stall.

Then accustom the colt to being touched in different parts of the body with the legs, to be squeezed somewhat with the thighs and knees, mounting and dismounting repeatedly. This being pernitted, lead him out of the stable, and while an assistant holds him loy the bridle above the bits -not by the reins- the truiner mounts, the assistant lets go, and in nine cases out of ten the horse will move off at the word of command. If he does not, use no haste; give him time. If he rears and plunges, the rider must have full command and confidenee in himself, or else quietly dismount and use the previons course until the animal understands what is wanted. If the rider is mister of the saddle, and the horse plunges of throws himself about, get him into motion in a field of not less than ten acres, and if rather soft, so much the hetter; circie him about the field 
until he wishes to stop, and then force him forward until he is thoroughly tired and subdued. Ride hin to the stable, gentle him, wash his mouth, let him take two or three swallows of water, add a taste of some food that he likes, and the real work of breaking is done. Thereafter it is simply a question of training.

When the horse is to be put to the wagon, know that the harness is strong, and that it fits perfectly and ensily. If the colt has been tied beside another horse on the road, until he is not afruid of the wagon, so much the better. Hitch him beside an old, thoroughly broken horse, tying the doubletree back so the steady horse may pull all the load if necessary. Get quickly into the wagon while an assistant is attracting the attention of the colt by talking to him and stroking his nose; pick up the reins and bid them go. Keep the broken horse in a walk or slow trot, us the case may be, and the colt will generally take kindly to the rork in less than five minutes. Drive for about half an hour, at a walking pace if possible, letting the colt have his own way if not too awkward and ugly, turning from right to left in rather long curves. When the colt shows signs of fatigue, and certainly before he is tired, but not until he has ceased resistance, drive to the stable and unharness carefully and quietly as before described.

\section{How to Subdue a Vicious Horse.}

If he be a colt that has never been handled, the directions we have given for bitting and training will succeed. If he has been made tricky by a previous owner, who was timid, go into the stable when he is tied, watch him closely, but keep cool and show no signs of fear. Take him by the head, and speak to him in a firm voice, put on a strong bridle and curb, and order him to back. If he docs not comply, give him a sharp cut on the fore-legs with the whip, and hold him firmiy with the left hand, standing facing partly towards his rear, but with the head turned so you can see every movement of his eyes and ears. If the stall is not roomy and high do not at'empt it. The struggle is better in a small close yard. If he rear cut him sharply again over the fore-legs while up, and if ho kick cut him on the hind-legs near the body, but never more than one stroke at a time. When he ceases to resist, gentle him, and so proceed until the animal is entirely submissive to your will. If a horse has acquired vicious habits from having beaten a timid, or worse, brutal master, the case is more serious. Have nothing to do with him unless fully assured of your powers to subdue him.

To succeed he must be made to lie down; to do this confine him in a stall so close that he cagpot turt round in iţ, and with the near side so 
arranged that you cau upproach him sufficiently near to operate in any direction. If the horse will submit to fondling so much the better. Under no circumstances uso a whip. The work must be doue by showing he horse that his struggles are always against himself.

Have the side of the stall so arranged that it may be taken down and allow free egress to a yard thirty feet square, with a high board fence, or, better still, a large square barn floor covered a foot deep with straw tramped solid. Procure the following articles : a simple single-rein brjdle, strong, and having a garg bit with large rings and long guards, the reius to be only sufficiently long so they will lie on the withers; have also a strong, padded surcingle, made with a two inch ring at the belly; also, one strap an inch and a quarter wide, and three feet or more in length, with a strong loop to form a slip noose, and a strong buckle on the end; and another strap five feet long with the end turned into a loop and firmly sewed; also two strong knee pads, to protect the knees in falling.

Put on the bridle, buckle on the kueo pads, loop the short strap around the near fetlock of the fore-foot, raise the foot and buckle the end tightly around the arm of the fore-leg next the body, thus you have one foot firmly held up. Put the loop of the second or long strap about the fetlook of the off fore-leg, and pass the end of the strap through the ring of the surcingle under the horse. Do not be in a hurry, and in no case lose your temper. If it takes two hours, well and good, you have the horse then perfectly under command however vicious he nay be.

See that there is entirely free egress out of the stable and let bim go. Approach him slowly, but without hesitation, steadying him by the voice. If he show fight do not hesitate, he is on three legs and nearly powerless, except to bite, or to strike you in the act of rearing. Seize him by the near bridle rein about twelve inches from the bit, and placing yourself inmediately at his near quarter, or just behind his shoulder, gather the long strap in the right hand and when the horse rears draw up the other leg.

If the horse struggles let him doso. It will not be necessary to exert much strength, simply tact and coolness in steering him. When he comes down it must necessarily be on his knees. If he continue to struggle let him exhaust himself. It will rarely take over five minutes, and never ten by tho watch. Having him on his knees always seek to draw the head from you by pulling on the rein that comes over the neck. Once you have the head turned keep pulling on him until he gives up completely and lies down. Use no violence on the rein. It is only to be used to steer or guide the horse. It is the strap that does the work. However many attempts he may make to regain his liberty it will only end in the more complete dispcomfiture of the horse. Once down unless

he lie: dued, caress touchy may

Sho to frigl handle and col firmly, with $h$ gives word, bidding over hi him soc thing h

This on very tiolls p solt

No pe thoroug on a hor and witl movemes to steady him. If the horse

WALKI horse. I be given. ately well -only ju exhibited should be should en and with the lower 
in any better. howing

wwn and I fence, h struw rein briards, the ave also $y$; also, l length, the end; ad firmly $\mathrm{p}$ around d tightly one foot $t$ the fet10 ring of case lose the horse

him go. the voice. oowerless, m by the yourself ather the the other

$y$ to exert When he ontinue to minutes, is seck to the neck. gives up only to be the work. will only wn unless he lies still hold his head still by sitting on it. When completely subdued, stroke his head, rub him on various parts of the hody, soothe and caress him, and especially handle him wherever he is disposed to bo touchy, being careful alwnys to be on your guard, thit if he resist he may be immediately checked.

Show him a buffalo robe, an umbrella, or anything ho would be likely to frighten nt, and always let him smell it until satisfied. Sit on his side, bandle his fect, tap them, and at last remove the straps from his feet, and continue to fondle him. If he attempt to rise hold down his head firmly, and bend up one fore-leg. If he get the advantage do not struggle with him but let him rise to his feet again. Lay him down until he gives completely up. He will soon come to lie down quietly at the word, simply by tying up one foot, and at last will do so at your bidding without tying. When down and quiet pass your hand repeatedly over his body, breathe in his nostrils, gently open his month, give him sootling words, and when on his feet give him a taste of something he likes.

This is substantially Rarey's plan, and it may be practiced successfully on very vicious horses, as we have done. As a rule, however, the directions previously given will be found to be fully effectual in breaking solt

\section{How to Train to the Saddle.}

No person should attempt to break a horse to the saddle unless he be a thorough horseman himself. It is not sufficient that he be able to stick on a horse's back with or without a saddle. He must be able to do so, and without aid from the bridle, when the horse is undergoing any of the movements likely to occur when on his fect. The bridle is used simply to steady a borse under certain circumstances, and as a signal to guide him. If the trainer be not able to ride thus, and with ense to himself and the horse, he has no business as a trainer.

WaLising.-A fast walk is the most valuable of all the gaits of the horse. To walk rapidly is the first and most persistent of the lessons to be given. To teach a horse to walk fast the head must be kept moderately well up, and yet but little real weight should be borne on the bridle -only just enough to assist the swaying motion and nodding head always exhibited in fast walking. During the acquirement of this gait, no other should be alıowed, and when the horse shows signs of fatigue, the lesson should end. In this, the seat of the rider is important, it should be easy and with sufficient grip of the limbs to stendy the rider, and with play of the lower part of the legs to keep the horse well up to his work, and assist 
in increasing the gait. Thus by care and practice almost any horse can be gotten up to four miles an hour and a really nctive cne to five.

li breaking to wulk fust to the wagon, there should be just sufficient bearing on the reins to steady the lorse. The eheck-rein should be quite loose, for no horse can walk fast and easily with his head gagged back in an unnatural position. The horse, however, should be first trained to walk fast uinder the saddle, and by the means we have indicated. Then, when harnessed, he will not forget the lessons given, and muy even be improved in his walk, if not already brought up to his maximum speed.

A naturally slow walking horse may be made to wulk much faster; a fast walking hor'se may be greatly improved in his gnit, but a lnzy, slow dolt will never pay for nuy education beyond that of honestly puling such a load as he miny be able to comfortably move. For the saddle he is a nuisance, and no attempts whatever, should be mude to bring him out as a riding horse. If a good one, however, bring out his walking powers. Like the trotter, he will improve until he is eight or ten years old.

How ro 'Train to 'Trot.-Every farmer's boy thinks he knows how to drive a trotting horse to a wago:. Very few really do. Still fower understimd how to trot a horse under the saddle. If properly performed it is the least exhausting to the horse within the limit of his natural speed, and need not be umpleasant to the rider. That it is mmong the best and most pleasant exercise the horsenun can take is without doubt.

Certain drivers have denied that the trot and the pace were natural to the horse. Every person who has been nmong the wild horses of the plains knows the contrary. It is a fact, however, that the trot is but a modification of the walk. There are two styles of motion for the rider; one the rising motion, by which the rider eases himself in the stirrupsnot ungriceful when properly performed-the other where the rider keeps a close seat, supporting himself by the knees and stirrups. The elbows should be kept rather elose to the side, and with only just enough bearing on the curb and snaffle to keep the horse's head correct and the animal under perfect command. In fact, under no circuinstances is the rein and bit for any other use but to guide and steady the horse. The rider maintains his equilibrium, keeps his seat, and renders hinself entirely at home in the saddle, through the science of equitation and the proper pressure of the limbs against the saddle. Until this is thoroughly accomplished, no person has any business trying to train a horse to saddle gaits. The rider must train himself first.

In the trot, when the rider rises in the stirrups, the snaffle-rein only should be used, a rein in each hand, and once grasped and properly arranged, the arms must be held rather closa to the body, but without

olingri down,

The icient horso contro fitet, $h$

The for ple be. $\mathrm{Ir}$ his pow sible, a race rid tho roa

In tre sired, b' hoofs $n$ by the dle, und or eante is under company

In tro the sadd be avoid bit. Th how to d mouthed u sensitiv and make such as $t$ lady. In was supe the reins.

In traij squartely beyond it at least ei Do not 
rso can

ufticient

be quite

bnck in

ained to

Then, even be

n speed. uster ; a izy, slow puling addle be ring him walking it or ten

ws how to ewer unformed it ral speed, best and

naturul to ses of the bt is but : the rider; stirrupsthe rider ups. The ast enough ct and the nces is the prse. The imself en$n$ and the thoroughly rse to sad-

-rein only coperly arut without clinging thareto. The feet should rest in the stirrup so the heel is well down, the leg from the knce down fully struight, and moving but little.

The rise nud fall of the body must bo as slight as possible, only sufficient to escapo thumping, and to ease the horso. Tho hend of the hor'se should be kept pretty well up, the limbs of the horso well under control. The rider will appear to support the horse with the bit. In fact, he does not. He simply holds the horso to his pace.

There is this differonce between road riding and ruce riding: in riding for pleasure, the animal is never severely pushed, whatever the gait may be. In riding a trotting or running rueo, the animal must put forth all his powers, the only object being that he extend himself ns nueh as possible, and without reference especially to the style of going. As a rule, race riders are disqualified for riding or trotting a horso grucefully on the road.

In trotting, always train tho horso to slackon his pace and stop if desired, by slacking the roin, and at the word. In square trotting, the hoofs move in exact time, $1,2,3,4$. Some horses acquire a pace denoted by the time 1,2. With this motion it is difficult to rise easily in the saddle, and it should not be allowed. To ease tho horse's wind lot him walk or eanter slowly; or better, give him a jog trot. The jog trot, however, is nuder no circumstanees to be allowed when traveling on the rond in company. After a hard ride at any gait, it enses the tired horse immensely.

\section{Training to Trot in Harness.}

In trotting in harness the horse is more firmly held than when under the saddle, und for obvious reasons. Yet here a dead strong pull is to be avoided. The horse is simply to be supported and steadied by the bit. The driver must learn by his own study, and by observing others, how to do this. The bit must be adipted to the horse. A boring, hard mouthed brute could not be driven with comfort in a bit that would suit a sensitive mouth. Very many trotting drivers spoil their hor'ses' mouths and make them pullers. The pull of a trotting horse should never be such as to tiro the well trained muscles of the driver, even though it be a lady. Indeed, one of the best drivers we ever knew was a lady, and she was superior by the delicacy and yet firmness with which sho handled the reins.

In training to trot in harness, the object should be to keep the horse squarely to his work, and at the top of his speed, without forcing him beyond it. In fact, no horse comes to his best trotting speed until he is at least eight years old.

Do not forco him beyond his power, and above all do not rein him so 
hard us to make him a boler. One of the best pair of rond trotters we ever broke, were trained with curb bits, und when under smootl motion were appurently driven with a loose rein; such, however, was only ॥pparent; they hind been given such delicnte nouths by enreful driving that the least indiention kept them in proper form. Below we give two illustrutions: one showing a horso unduly checked and gagged buck, the other with tho hend in an easy-going position. The use of tine bea … rein is simply to keep the horse from getting his hend too low, nc draw it back in an umatural position. Under the saddle this is precisely the use of the eurb.

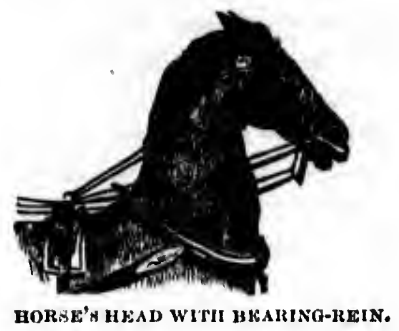

The Pacina Gart.-This is a gait natural to many horses, and ex ingly diffienlt to teach a horse that it is not naturnl to. On the . hand it is not difficult to make a trotter of a pacer. In pacing, a horse lifts both feet on a side simultaneously, and on perfectly smooth ground it may be made an exceedingly fast gait. It is easy to the rider but ungraceful in the extreme, from the fact that, as in sculling a boat, the body is swayed from side to side. If the liorse has the pace naturully he should be trained to increase the pace by precisely the sume general rules for increasing the trotting pace; by kecping him well in hand and inducing him by every possible means to increase his stride.

The rack, amble, and single foot, as it is sometimes ealled, are all but modifications of the pacing stride and the gnllop, just as the jog-trot and the walk are modifications of the trot.

The amble is a slow, smooth gallop, or rather canter, and must be taught to the horse under the curb.

The rack is a modification of the pace, the fect instead of being lifted up simultaneously side by side, represented by tho figures 1-2, may be represented by the figures $1-2,3-4$, that is, the feet are not lifted regularly as in the walk.

Single foot is a truined rack. It requires patience and time to teach, except in a horse having a natural adaptation thereto. Once the aninal catches him to

It is plish th fuil. ' subject is attem patience sufficicu underst:

Cirani shonld the fir'st pulling Jegr whic slightly naturally be is leat right, wh upon whi

Galisol horse. I top of hi the utmo the groun til when horse - he horse into and restra

The ha rider, :tud gait as wil that gait w without ses of the hor speed, or

Trotting to a light $v$ Used in th 
snaffle, or other trotting bit according to the delicacy of the hand of the driver, or mouth of the horse. We prefer, after they are way wise and used to the curb, to drive them thus, until they have aequired the proper earriage, and this entirely without the bearing rein. The object aecomplished in this is, the horse becomes entirely subservient to the driver but at the same time learns to rely on himself so far as sure-footedness is coneerned. When he will go in proper form he may be driven with a trotting bit, until he has learned to extend himself fully, when he may again be placed in the curb, and if delicetely handled will give satisfaction any where on the road. Thus trained under the curb, when.used with a trotting bit, they may be made to exhibit all the style they are capable of at un ordinary gait, and $n$, ay be shaken up instantly for a brush and extend themselves to the utmost.

In trotting at any speed the horse must be trained to take hold of the bit, so he may be steadied by the rein. He must never be allowed to suppose that this loold of the bit is for the purpose of pulling on. It is to be used simply to steady himself, and as a means of quick comprehension of the driver's wishes.

\section{How to Train for the Plow.}

In training a team for plowing, they must be made to walk at such a pace as will lay the best furrow, to walk evenly and straight ahead, without pulling apart or erowding each other, to obey the slightest check of the driver in laying out lands, and at the end of the furrow to come immediately and quickly about. To this end the reins should be carefully adjusted, the whiffle trees should be as light as will suffice to do the work, and the team must never be over driven. I they must be kept so completely under control, as never to spring forward when the plow strikes an obstruction.

In turning quartering about at the end, on square lands, in plowing right landed furrows, the near horse should back slightly, that the off horse may not step on his feet, and the traces should be kept slads enough so the plowman may easily enter the point of the plow in the next furrow.

In back furrowing, the section of the eircle deseribed must be that which will bring the plow, with the aid of the plowmnn, most easily to the next furrow, the off horse in this case, keeping slightly behind.

In plowing there is nothing gained by hurrying a team, and then stopping to rest. Plowing is lard work beeause it is a constant strain on particular sets of muscles. The team, however, may be very much eased 
and of the $y$ wise and the proper iect accomdriver but otedness is iven with a hen he may satisfartion used with a capiable of ush and ex-

hold of the allowed to ig on. It is comprehen-

alk at such a ahead, with. test check of to come imbe carefully ce to do the grubby land o spring for-

, in plowing that the off e kept slack plow in the

nust be that host easily to behind. $\mathrm{m}$, and then tant strain on y much eased by the tact of the plowman in holding his team up in plowing through hard or tough places, by knowing that the harness fits perfectly, and by always having his plow clean and in a condition to scour.

In laying out land the team should be rather wider apart than when plowing furrow after furrow, or so the plowman may ses the line stakes between the horses. In laying out lands always have the reins of such length that they may be carried over the left band plow handle.. Thus by taking the right hand roin a little beyond the center the hand may easily grasp the handle. A puli directly bock will carry the horses gee and carrying the hand forward will tighten the near rein and carry the horses haw, while a steady bearing will keep the team in a direct line ahead.

The only position for the reins if carried otherwise than on the handle is to carry them just above the hips, and of such a length that when the team is going at ease they will be loose, and yet may be easily tightened by the plowman walking a little farther in the rear than usuat. With a hard-mouthed team "feeling their oats" this will do. By the means we have indicated, if the lines are nicely adjusted, the team may be made to pull on the plow, and once used to this way of driving we have never known of its being abandoned, except for a time as a change. The practice of earrying a rein in each hand adopted by some good plownen is not to be commended, except with a kind team. In this case to cairy them over the left handle is easier, whether the team be wild or gentle. In any case the reins should never be carried over the neck. It is awkward, and the team is never under control. Carried quer one shoul. der and under one arm is an improvement upon this awkward plan.

\section{Training to the Wagon.}

But little need be said on this score if attention has been paid to what has been said previously. Upon good roads and with an ordinary load the team should be kept up to their maximum gait in walking. When the road is good in some places and bad in others, as country roads usually are, the load must be such as the team can move by hard pulling in the worst places. After a heavy pull al ways give the team a breathing spell, and in the middle of $a$ pull if the team can start the load once stopped. This any honest team will do unless the bottom is miry, that is, uuless from standing the team and wheels sink deeper and deeper. In this case, the only way is to keep going until firm ground is reached. The average driver is sure to hurry his team in the mud. They should we taught to pull steadily and slowly, and when started again, after rest- 
ing, $t$, take hold of the load steadily and with a growing impulse until it moves.

\section{How to Train a Racer.}

The training of racing stock, whether for running or trotting, is a fine art, and one which it would take a volume to properly describe in print. There are certain essentials, however, which are easily understood, and which every one who breeds stock for speed should know. The colt having been taught to gallop easily and naturally, should be put upon yood sound oats and the cleanest hay. He should be carefully blanketed and groomed and his legs hand rubbed until fine. The exercise should be daily, upon a good course, and ridden under the direction of a horseman who is thoroughly up in his business. When this cannot be, the work must be done under the instruction of the master.

In race riding, the jockey throws about all his weight in the stirrup, steadying himself with the knees and thighs. The seat of the body is carried well back, the loin slightly arched, so the weight will not be brought too far forward, as the breech would be if the rider should stand straight in the stirrups. A jockey of ordinary weight will be found to earry his leg, from the knee, slightly thrown back; thus by stiffening his knee he can change his center of gravity without ceasing to stand in the stirrups.

Very light jockeys ride with longer stirrups, throwing their weight principally on their thighs, and with their breech raised entirely from the saddle, thus giving them a strong hold on the horse. Standing in the stirrup, however, cannot be long endured, and is only used for fast racing or galloping over bad ground, rough or deep, or in the case of a hill that must be passed quickly over.

Training to racing speed on the farm may be summed up as follows: a smooth track, regular feeding four times a day with the soundest of oats and hay, with a bran mash often enough to keep the bowels in regl. lar condition ; the most careful grooming, with plenty of hand rubbing of the legs ; sweating exercise every day, and thorough cleaning afterwards; a trial gallop to extend the limbs, with an occasional spurt to note the is crease of speed, and occasionally a fair trial at the distance which the horse is trained, to test his speed, powers of endurance, improvement, and capabilities.

\section{Training a stallion.}

The training of a stallion should commence from the time that it is in tended to keep him as such, and certainly from the uge of one yesr, 
impulse untll

tting, is a fine cribe in print. derstood, and w. The colt be put upon ully blanketed xercise should on of a horsecannot be, the

n the stirrups, of the body is ht will not be er should stand ill be found to y stiffening his to stand in the

ng their weight tirely from the Standing in the for fast racing se of a hill that

up as foliows: the soundest of bowels in regr. and rubbing of ing afterwards; to note the in ance which the , improvement,

me that it is in of one year, when colts are usually gelded. He should be exercised in a close yard, first at the end of the halter, and at length without bridle or halter rein, and made to advance, to back, to circle, to describe a figure eight, to rear and come down at the word of cominand, to kneel, to sit on his haunches, to lie down, and especially to come instantly to his keeper at the word of command.

All this takes time, but is labor well spent, for henceforth his usefulness us a sire, and escapes from accidents by being kicked, may depend upou his thorough training. Any observing person will have noted that in fully half the cases a stallion will be found dragging his keeper about like a puppet. All this may be avoided by proper care and training, so the horse will retain his full exhuberance of spirit, and yet be entirely under control.

His care and keeping should be of the best possible, and his daily exercise enough to keep his muscles firm, certainly not less than eight miles a day during the season of service. However well trained the stallion, when it comes to actual service, there is always a time when he may refuse to obey. Then he must be made to do so at whatever cost, and to accomplish the object, the whip must be used to any extent sufficient to conquer him. Cut sharp and strong, but with temperate judgment. Do not rain a succession of blows. This will only make him fight. A few well-directed blows will generally suffice, if they are sharp and cutting. Do not be afraid of drawing blood. If it can be done at the first stroke, so much the better. Give him time to think before you strike the second time. Give him the order you wish him to execute. If there is the lenst hesitation, strike again, and so on until he is conquered. If he has been properly trained previously, he will handle nearly as easy as a gelding. If not, he may become a brute, dangerous for any man to handle. Above all, a stallion once trained, never intrust him to an incompetent keeper, and nerer allow a valuable one to be ridden during the season of hard service. If he travels from one station to another, or is otherwise exercised, it should be with a leading rein, the rider being on another borse. 
CHAPTER VII.

HOW TO SHELTER.

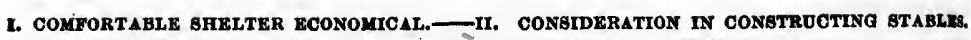
III. MANGERS AND RACKS. - IV. HOV TO INSUBE A GOOD TEMPERATURH.-V. CLELN. ING THI STABLES. — VI. THE LOET. — VIr. THE HARNKSS BOOM. — VH. THE OUT GHED. - IX. WATER.

\section{Comfortable Shelter Economiosl.}

Although the horse is found wherever civilized man has made his home, and has been subjected by barbarian tribes wherever subsistence may be found Summer and Winter, yet in a wild state he is only found where the Winter and the Summer climate is mild enough to furnish herbage the year round. While it is true that the horse will stand weather as inclem. ent as cattle, yet the owner who subjects either horses or cattle to the storms of Winter, not only makes no money from them, but deserves to lose them entirely. Thus the humane man always consults his best interests when he keeps his horse stock not only well fed but comfortably housed.

\section{Considerations in Constructing stables.}

The first consideration in the construction of a stable is the number of horses to be kept. After this comes in economy of space in connection with convenience, ventilation in connection with the health of the horses, and las warmth the char it is a $f_{i}$ In th harness for oat spouts necessa pipe $\mathrm{pl}$ more th each ot of the Whe or the two co from $t$ never th or arti throug The horses width and th If the to eac feet. or par If the seven

The and, iron: Howe splint feet $t$ The 1 the b and 
and lastly the cost. In the construction of stables the question of warmth, convenience and ventilation are the prime integers, and whatever the character of the structure it must combine these three essentials, else it is a failure.

In the construction of stables the horse and carriage floor, including harness and tool room, and the loft, in which should be situated the bins for oats, shelled corn, corn in the eur, meal and bran, with suituble spouts and slides for delivering the feed on the lower floor, are all that is necessary. Every stable, however, should be supplied with a ventilnting pipe placed about midway over one of the centre stalls. If there are more than four horses kept there should be two, and one in addition for each other four, but all connecting with the principal air shaft at the peak of the roof.

Where the horses are near the ground, and especially if the first story, or the walls of the whole building be of brick, there should be at least two courses above the ground laid in water-lime, to prevent the dampness from the ground ascending up the walls by capillary attraction. However the foundation be laid there nust be perfect druinage, either nutural or artifical. under the stnble. Muny valuable borses have been lost khrough inartention to this simple matter.

The size of the stuble must of course correspond to the number of horses to be kept, and the number of vehicles to be sheltered. The width of the stalls should not be less than five feet ench - six is betterand there should be at least one loose box in every stuble, however small. If there are a number of breeding mares there should be one loose box to each four horses. These boxes should not be less than ten by twelve feet. Fourteen feet in depth for the stall is little enough. The travis or partition between stalls should not be less than six feet six inches long. If the stable is fourteen feet deep seven feet is better. It should be seven feet high at the head and five feet at the rear part.

\section{Mangers and Racks.}

The mangers and racks should be of the most substantinl character, and, if expense is no object, of enmmeled iron, as to the mangers, and of irou as to the racks. If made of wood, onk or elm is a good material. However made there should be no rough edges to annoy the horses, nor splinters to wound. The top of the cap should not be less than three feet three inclies from the floor, nor more than three feet six inches. The manger to be about thirteen inches wide nt the top, nime inches at the botton and eleven inches deep. The caps may be four inches deep and three inches wide, securely placed. The sides and bottom of the

number of connection

the horses,
H. CL. CLes

tde his home, nd where the herbage the cattle to the deserves to comfortably 
manger muy be of inch oak, or other hard wood. If made of pine they should be of inch and a hulf thickness.

\section{How to Insure a Good Temperature.}

If the stable be of brick or stone, it may or may not be lined with wood with an air space between. If of wood, there should always be a lining, and the sheathing upon which the weather bourding is nailed should be covered with tarred paper. Ventilation must be attended to ; this is best secured by orifices at proper distunces next the ceiling, that may be opened or closed at pleasure, and provided with lattice work to throw the air up when opened. This with the doors and windows in Summer will give plenty of ventilation and in Winter the ventilators alono will suffice. It is one of the most essential points in building a stable in our American climate, with torrid Sunımers and Arctic Winters, that no expense be spared to make the buildings comfortable. We aro decidedly in favor of a vestibule, large enough to hold a harnessed team, or if preferred, if the carriage room be large enough and separated by a eloso pnrtition from the stable, as it should be, this may be made to do. Froin this the entrance to the stable may be a sliding door, through which to lead the horses; the object being to prevent the rush of cold air into tho stable chilling every horse in it.

Whore more than five horses are kept in a stable we advise a close partition between each four stalls and their accompanying loose box. The reason is, that in each compartment an equal temperature is retained. It is not so much the degree of cold that affects horses, us sudden changes of temperature. Thus each may have its separate ventilation and air shaft, and conduce very much to the comfort of the animals kept therein.

\section{v. Cleaning the Stable.}

Cleanliness in the stable is of the utmost importance. There should be sufficient bedding under the horses at all times to insure cleanliness; all damp portions together with the droppings should be removed twice a day. We have never found a better nur more economical way than to use a wheel barrow, with sides sufficiently wide and flaring to hold the load a man may handle, in which the manure and damp bedding could be thrown and wheeled on planks immediately to the pile. Where it is thruwn oul of windows it often heats so as to be offensive in Summer, and in Winter these windows, besides often allowing the wind and storm to beat in, are objectionable in many ways. 
We have already advised that the granary be in the loft, the shoots, however, should not enter the stable ; first, because they create more or less dust, and second, they are liable to contract more or less effluvia from the stable. They should communicate with a room by itself, sufficiently large for sifting oats and mixing feed. The granary must also be made rat proof, which is best done by covering the bottom and two feet of the sides, and the top with sheet iron. The floor of the whole loft should also be covered with a tight floor of planks, plowed and grooved, so that by no possibility dust or trash can drop through; the loft should also be high enough to hold straw for bedding, and hay enough for at least two months' feed. In fact, if it be a farm barn, it were better to hold enough, if possible, for the Winter. This might detract somewhat from the architectural appearance of the building, unless the storage and stable room be large below. In any event we should not build any stable, however small, less than eight feet high, with a loft above of the same height, and in the case of a large building we should extend the loft to ten, twelve or fourteen feet as the size of the ground foor might allow.

\section{The Harness Room.}

a close parbox. The retained. It Iden changes tion and air kept therein.

re should be anliness ; all oved twice a way than to to hold the ing could be

Where it is in Summer, d and storm

The harness room should be as complete as possible with suitable pegs for harness and seats or frames for saddles. It should also be provided with a saddler's horse for sewing : 'raps, awls, needles, wax, thread, etc. ; also a table for oiling harness, and if it have a boiler set in a stove for heating water, it will often be called in requisition in Winter, not only for its hot water facilities, but for drying harness and saddles as well

\section{The Out shed.}

If the stable is provided with an out-shed for cleaning horses when the weather is not inclement, it will be found to save much dust and dirt inside. If this shed be a vestibule to the stable, with sliding windows, so much the better. It may even be used, in case of need, for temporary stables or for baiting a double team when it is not considered necessary to unharness. In fact there are many uses to which it may be aside from the protection it would give the stable, in opening the doors in cold and inclement weather.

\section{The Surroundings.}

Every stable should have a smooth, close yard, with a tight high fence 
surrounding it, and if one side can be covered with a shed roof, fourteen feet wide, so much the better. This yard should be about 30 or 40 feet wide, and if it contains a place in the center of strong posts for a man to take shelter in from a vicious brute, it is not amiss. We once saw a lifo saved in this way, from an ugly bull, which broke from his fastenings and would have killed his keeper but for this safeguard. There should also be a grass lot near for cutting forage in Summer for soiling, and for turning in a sick horse occasionally.

\section{x. Water.}

The water supply is important. If taken from a well and pump it is absolutely essential that there be no contamination from the drainage of the stables and yards. If a tank can be so arranged that it will not freeze, build one by all means, and connect by pipes, pumping the water by means of a windmill. Or the tank may be situated where it will supply the house, and a pipe laid to the stable underground, ending in a penstock. In this case, the windmill and tank may be entirely isolated from the barn or house, and the water carried for any distance, provided the head is higher than the outflow. 
of, fourteen 30 or 40 feet for a inan to cee saw a life is fastenings There should iling, and for

nd pump it is te drainage of aat it will not jing the water ore it will supd, ending in a tirely isolated ance, provided
Chapter VIII.

EOW TO FEFD, WATER AND GROOY.

2. LATING THE YOUNDATION, -II. WHAT TO FEED, - IIY, WHEN TO FEED. - TV, WATERING. - V. KINDS AXD QUANTITIES OF FOOD TO BE GIVAN, — VI. HOW TO PREPARE THE YOOD. - VII. HOW TO MAKE MASEES, GRUELS AND RAT-TIL. — VIU. THB VALUE OP HAY AND BTRAW.- IX. FERDIXG GRAN, —X. OTABLI CARE AND OROOY. NNG. - XI. THE TIME TO CLEAN. - XII. CARE OF THE FERT. - XIII. BLANTETENG WHEN NECESSARY. - PROPER TOOLS FOR THE BTABLE.

\section{Laying the Foundation.}

The feeding of horses must be either simple or complex according to the circumstances under which they are placed and the nature of the work required of them. It would, for instance, be as foolish with the farm or ordinary work horse to pamper with fire-warmed stables, highly stimulating food, and exquisite grooming, together with all the paraphernalia of blankets, hoods, bandages for the legs, and necessities of the trotting or racing stable, as it would be to allow this latter cor to receive only the same care and attention usually bestowed upon the veam kept solely for the plow and other drudgery of the farm. At the same time the extremes to which horses are subject, either on the farm or in racing otables, might well be modified in very many cases to the health and well 
being either of the farm horse or the pampered and high-bred racer. That is to say, racers are often "drawn down" too fine, and the ordinury work horse too often suffers from neglect. Thus in tho first class we seo a number of diseases seldom shown in the stables of horses with suf. ficient care, while the stables of horses carefully kept seldom suffer with the class of diseases found when horses are allowed to go dirty from day to day, and often froin week to week.

To commence at the beginning, the breeder who would succed with any class of horses, should see that the mare, while carrying the foal, has sufficient food and shelter, and that the foal itself is sufficiently nour. ished during the period of growth. Nothing is gained by insufficient shelter and food, whatever the use for which the animal is intended, and this brings us to the question of the food itself.

\section{What to Feed.}

In the West the feed of all horses of whatever class is oats, Indian corn, bran and hay. Whatever the work to be done, bran should alwars be kept, since a horse being off his feed, or slightly ailing from any cause not indicative of violent disease, bran mashes with good uursing will bring him out all right in nine cases out of ten. So, in the Winter when horses are confined to hard food, a bran-mash once a week should be given, and this generally on Sunday morning. On the farm there is nothing better than an occasional feed of roots-carrots, Swedish turnips, or mangel wurtzel-being valuable in the order named. If a peck of these could be given daily as an evening or noonday meal, the good effects of this feeding would be quickly shown. For the mares befor foaling time, for the farm or draft horse, for the carriage horses of the citizen, and even for the fast driven roadster, or racer, when not being driven to exhaustive work, these will be found valuable.

The foal itself should be learned to eat roots as quickly as possible, and if the mare takes kindly to them it will not be a difficult matter fo: the foal to learn to eat them. As to the other food of the young colt of filly, oats alone with grass or hay, according to the season, should bx allowed. In the Winter, half oats and half corn may be given with ber efit, unless the young things are intended for racing or trotting, and an kept in warm, stables; then Indian corn would not be desirable, as being too hea $y$ under the circumstances.

For the ordinary farm team, or other horses of slow work, Indian con may be the main dependence in Winter, in commection with good har: especially so if a few roots can be allowed as a portion of the dait? provender. For fast working horses, sound outs and hay will be the 
bred racer. he ordinury class we see es with sufo suffer with ty from day succeed with ing the foal, ciently nour. $y$ insufficient ntended, and

outs, Indian should always ing from any good nursing in the Winter a week should farm there : vedish turnips, If a peck of heal, the good mares befort horses of the hen not being

ly as possible, cult matter for young colt o son, should be given with ber otting, and ar rable, as being

rk, Indian con with good har: on of the dait? ay will be the principal dependence, but in the Winter we have always given one-third of the weight of the daily grain ration in Indian corn, and we have always thought, with decided benefit.

\section{When to Feed.}

The importance of strict regularity in feeding is underestımated by nine-tenths of the ordinary feeders, and by fully one-half of the stablemen having the care of well bred horses. The horse, for whatever purpose he is used, if actively omployed, should not get less than three foeds a day, besides the hay ho ents during the night. All fast working horses should have four feeds a day. Tho hours of feeding are of prime inportunce. These should be, as closely as possible, at six in the morning, at noon, and at six at night, except at thoso pressing seasons of extra labor, when the morning feed may bo an hour earlier and the evening, feed an hour later. In this ease, however, nose-bags should be carried to the field, or they should be turned to the wagen at $10 \mathrm{~A}$. M. and at 4 P. M. to take one-third their usual ullowance, as given morning and evening, which meals, as a rule, should be rither more than the noonday feed. When corn is the main dependence as feed these lunches should be of oats, und if bruised so much the better.

Fust working horses should receive their food four times a day, at six in the morning, at ten, at two, and at nine at night. Carriage horses should be fed the same number of times, the first feed being at six, and the last after their real work for the day is done, say at nine at night, since simply going to some place of amusement at eleven o'clock or later can hardly be called work. The mid-morning and afternoon meals will depend upon the hours at which they are generally used, nine A. M. and $1 \mathrm{P}$. M. being the usual times for feeding.

\section{Watering.}

Watering and the water used is of fully as much importance as the feeding. A horse is particular as to the water he drinks, but yet may be accustomed to any water without detriment if it be fit for human use. The water of large lakes, rivers and running brooks is best and in the order named. That of ponds without outlet or inlet the worst; in faet pond water should never be used; well water is altogether better and may be given without fear, when used constantly, but as with man, the horse scustomed to lake or river water, which is always partially soft, should be given well water, when necessity requires, with care and only in small guantities, the shange being gradually made. Water should always be 
offered before feeding, and never given in large drafts immediatoly after feeding; two to four quarts may be given with benefit immedintely after dry feed, to properly moisten the stomach, and it may be freely given in two or three hours after feeding. When driving, water should be offered, especially in hot weather, at every stop, but only a few quarts should be taken at a time, for a heated horse, like a hented man, will take more than is good for him. Upon" stopping, wash the horse's mouth with a sponge soaked in water, and let him swallow each time two or three light sips, just onongh to moisten the throat, and upon starting give him four to six quarts each as the occnsion seems to demand. Under no circum. stances allow a heated horse to drink heartily. Farm teams and slow draft horses, at ordinary lulor, may be allowed what they will naturally drink, but when heated the same rule must be observed as with hard driven horses. With these simple rules kept in view any intelligent owner or driver may keep his team fresh and without danger.

\section{v. Kinds and Quantities of Food to be Given.}

We have already spoken of the proper food to be given under ordinary circumstances; they are sound, whole grain, and bright, clean hay. Cer. tain classes of horses, as omnibus horses, stage horses, car horses, and the draft horses of lurge mercantile firms in cities, are generally fed ground feed and cut hay. When the hours of feeding and rest may be estimated with accuracy, this is on the whole as conducive to the health of the animal as may be, when the economy of such feeding is considered, especially when we remember that in large citics a regular veterinary sur. geon is employed, who visits the stubles regularly to look after the well. being of the horses, and also where the superintendents and foremen are supposed to be experts.

On the farm, and in the stables of road-driving horsemen, and where carringe horses are kept, cut feed may very properly and economically form from one-third to one-hulf of the daily food given. When only one feed is given it should be in the morning; when two are given, ther should be the morning and evening feeds.

As to the quantity to be given, no definite rule can be laid i? horse must have a quantity fully sufficient to keep work. Hard working horses may, if regularly fed, Which

hay they will eat clean, and in this case there is no bet judge, wan the animal itself, except in the case of ravenous gluttons, sometimes found among horses as in the hinman family. Elaborate rules have been laid down hy theorists, including a per cent. of grain according to the weigtt of the animal. In practice they will not work, since the labor, conditios

The $\operatorname{good} \mathrm{br}$ boiling ing it 
diately after dintely after ely given in $d$ be offered, ts should he I take more louth with a or three light ive him fous c no eircum. ms and slow will naturally as with hard elligent owne:

inder ordinary an hay. Cer. ar horses, and generally fed id rest may be to the health is considered, veterinary sur. after the well. dd foremen ate

en, and where d economically When only one re given, ther judge wan the metimes foudd have lieen lail ig to the weigte labor, condition of the unmal, temperature of the season, and of stables must be considered. In the largo ommibus stables whore all the work is to be got out of horses that they en endure, from ton to fourteen pounds of eut hay per duy are given, with from eighteen to twenty pounds of corn meal. Vix into provender, und on it thoy will go from eighteen to twenty miles each day. With this about three pounds of salt may be allowed each month. Some stable mell do not fced more than oue pound, arguing that a large quantity produces profuse staling; others feed up to four. In times of extra severe labor the cornmeal is inereased by about three pounds. It would be botter if the three pounds of meal where omitted und one extra feed of six quarts of whole oats be substituted, and given daily. The average livery horse may be kept in good eondition on twelve pounds of hay and eight pounds of cornmeal daily, to be given at two feeds with the addition of six quarts of oats at noon, eight pounds of hay to be fed cut, with the meal, and sour pounds from the manger. This same feed would do for ordinary farm horses at usual work, or if the grain is fed whole, five quarts of shelled eorn, or its equivalent in ears, and six quarts of oats, with what hay will be eaten should koep tho ani. mal in working condition.

\section{vI. How to Prepare the Food.}

In p:eparing chopped feed, half the hay to be used, or elean, bright, long straw cut into about three-quarters to one inch lengths, should be put into the mixing trough half an hour before it is to be mixed, and thoroughly moistened. On this throw the meal, mill-feed, or whatever article is to be used, and moisten it. Then cover with suffieient hay to make the mess for the desired number of horses, weighing both hay and menl. Let it stand until feeding time, when the whole should be worked over and over until thoroughly mixed. If salt is given with the mess, put in the required quantity for each horse, from one-quarter to half an ounce per horse each feed. Many stablemen mix the mess half a day in advanee, but this we do not like. Horses, like men, like their food "esh. An iron box is best for mixing, and it should be thoroughly rleuned after each meal.

\section{How to Make Mashes, Gruel and Hay-tea.}

The ordinary sweet mash, as usually made, is to take four quarts of good bran, moisten it gradually with hot water, and then mix with what boiling wor will bring it up to the proper consisteney for eating, covering it wi a cloth and feeding either warm if the animal will eat it so, 
or else cold. What salt will lie on a quarter dollar may or may not be mixed with it.

A better mash, especially for dry fed horses, is to boil two quarts of oats and a pint of linseed, for each horse, for about three hours, and then mix with it sufficient bran to bring it to a proper consistency. Cover with a cloth and feed cold. Such a mash given once $n$ week, if the horses are on average feed, will kecp their bowels in condition. If off their feed, add a little salt and a half pint of molasses.

Gruen is one of the best possible things for a beaten out horse. Stir gradually in a gallon of w.ter, a pint or a quart of out-meal, or half flour and half corn-meal, according as the horse likes it thick or thin, and fill up the pail with cold water. If the horse hesitates about drinking it, give him first a mouthful of water. If he be very tired a quart of sound ale will do him good, but under no circumstances, when exhausted, should he be given a feed either of grain or hay. If the horse will take nothing else, turn down a bottle of sound ale, rub him until dry and refreshed, and then feed.

HAY TEA is also a good stimulant. To make it-fill a bucket threequarters full of bright, clean hay, pour over it enough boiling water to fill the pail, and cover tight, to keep in the steam. Press the hay down occusionally, let it stand fifteen minutes, turn off, and add water enough to make a bucket three-quarters full. Give to the horse when the liqui. is 'cool enough to drink.

\section{The Value of Hay and straw.}

In the feeding of horses the principal use of hay is to distend the stomach. For this reason lean horses, and those just off the pasture on coarse feed, require more than those which are regularly stabled and groomed. The change to grain must not be too sudden, else indigestion is apt to set in. Once a horse is used to full rations of gruin, if oats are used, or corn meal and bran, he may get along daily with from six to eight pounds of hay a day. The hay, however, must be of the very best, bright, clean and free from dust. There is no economy in feeding bad hay. It is the cause of heaves, broken wind and other diseases produced by indigestion. Good clean straw is altogether better than poor hay. Straw is altogether the best material for bedding, and should always be used when it can be had. In the West it is plenty, and yet not one farmor in ten uses it for bedding in sufficient quautity or reuews it often encugh. 
may not be

two quarts of ours, and then

Cover with the horses are off their feed,

t horse. Stir , or half flour $r$ thin, and fill ut drinking it, quart of sound nausted, should ill take nothing and refreshed,

a bucket threeoiling water to the hay down $d$ water enough when the liqui

to distend the the pasture on rly stabled and else indigestion gruin, if oats are ith from six to be of the very nouny in feeding other diseases ther better than ling, and should plenty, and yet iantity or reners

\section{Ix. Fooding Grain.}

The most economical way. of feeding grain on the farm is in its whole state. Oats and corn should be shuken in a sieve with a mesh so small that it will not go through, all dust and light matter blown away, and all stones, bits of iron or wire, carefully picked out. It will pay the farmer to do this as well as any other stable man. In feeding corn allow one-half the measure of shelled corn that would be deemed sufficient of oats, since corn weighs about double that of oats. If corn in the ear is te $\mathrm{I}$, one-third more by neasure heaped should be allowed than when shelled zrain is used. In other words the stable must use seventy pounds of ear corn when fifty-six of shelled corn would be given, or 112 pounds of oats.

Some horses eat their grain better for being moistened. If sn, moisten it, but as a rule we like to feed whole grain dry, since the horse is obliged to grind it better to get it in condition for swallowing. Horses with bad teeth always bolt their food whole. All such horses, and also aged ones, should be fed cut hay and ground feed.

\section{Stable Care and Training.}

The importance of steadiness and eare in the management of the stable and in the cleaning of borses cannot be over-estimated. A brutal stableman, or one which a norse fears, should be inmediately discharged. There is indeed now and then a horse that requires to be kept in terror. These of course are exceptions. The competent stable-man should use neither fear nor brutality. Not half the so-called strappers (cleaners) ire tit to be about a horse.

Many stable-men imagine the curry comb is an instrument for cleaning the legs and body of the horse. It is an instrument for cleaning the brush and for loosening the scurf on the fleshy - not bony-parts of the body. In using the curry comb, do so lightly, carrying it in circles rather than in straight lines. Use a wisp of hay for rubbing the dust from the legs, and a corn cob for the fetlocks, finishing with the brush. In brushing, do so thoroughly, with firm, long strokes, where possible, being careful in working about the head and bony parts. Clean the brush often by passing it over the teeth of the curry comb. When the scurf and dust are thoronghly clenned out, go over the horse with a damp wisp of hay, and finish with dry eloths, being particular to get any particles of dirt out of the fetlocks, the ears, about the head, next the tail, below the thighs, under the jaws, and between the fore-legs. A horse 
thus cleaned, whether he belongs to the farm or the city stable will not occasion shane on the part of the owner.

It is a question imong horsemen, whether when a team comes in wet and muddy at night, it is proper to wash them. We have never found advantage in so doing. Clothe them warmly, bandage the legs loosely, and when dry, clean them, at least so far as removing the dirt, and getting up a glow at the surface is concerned. Thus handled, horses will seldom be found liable to surfeit, scratches, grease, and other diseases induced by checking the uatural perspiration.

\section{The Time to Clean.}

Clean when the horse is dirty. Always once a day when the horse is kept in the stable. Horses that run in the fields in Summer, or in the shed yard in Winter require 110 cleaning. Nature provides a natural scurf that defends them from the changes of the weather. Before work horses are littered down for the night they should be igain thoroughly clenned if necessary. As, for instance, if the animal has been on the road or in the field ; it is important and will lighten the morning cleaning, apart from real necessity of the casc.

Whenever the horse comes into the stable from the plow or wagon, for the day, he should be thoroughly cleaned when dry enough, and if sweating or otherwise wet should be thoroughly scraped at once. The scraper is a thin, flexible piece of wood; a seetion of barrel hoop makes a good one. In any event a horse once in the stable, elean him thoroughly, unless he be taken out again after being "baited." If he remain in the stable long enough for the operation, clean bim especially as to the limbs, and if there is time, as to the body. It may seem like a good deal of work, but it will pay.

\section{Care of the Feet.}

The feet are half the horse, in fact a horse with bad feet, is as near s worthless animal as possible. Attention to the feet is therefore of the first importunce. In this eonnection shoeing is to be attended to. Know that the blacksmith understands his business. There are as many ignorant boteh-workmen in cities as in the country. The horse's foot should be a study, and every horseman should understand the anatomy of the foot; this will be given in its proper place. How to care for the feet is in place here. When the horse is brought in from work, each foot should be lifted, cleaned, and examined with the picker to see that no gravel or other hard substance has found lodgment between the shoe and hoof, or 
able will not

comes in wet never found legs loosely, $t$, and getting es will seldom eases induced

$n$ the horse is mer, or in the ides a natural Before work in thoroughly is been on the rning cleaning,

or wagon, for , and if sweat-

The scraper makes a good thoroughly, unhin in the stable the limbs, and deal of work,

eet, is as near a herefore of the ded to. Know a as many ignose's foot should anatomy of the e for the feet is ach foot should ant no gravel or oe and hoof, or about the frog. Examine the frog to see that no substance is wedged therein, and that no nail or other sharp object has pierced the sole. If the hoofs are inolined to be hard and dry, fill them with a mixture of cow-dung and clay, or with onkum saturated with tar and petroleum. Watch them for contraction of the hoof, caused by allowing the shoe to remain on too long, or from bad shoeing. If the frog gets torn and raggel, cut the ragged edges but leave the frog intact. If the hoof be found pierced with a nail, and you are not perfectly sure you have pulled out every bit, cut it out at whatever labor it may be to you, or pain to the animal. Then dress the wound with a pledget of tow suturated with tar. If the hoofs are inclined to be hard and brittle, oil them occasionally, or let the horse stand, say for an hour or two, or for a half day on Sunday, in a box of soft clay and cow-manure, coming prettywell up the hoofs. Thus by the exercise of care and judgment you may keep the feet, what they ought to be, the better part of the horse.

\section{Blanketing-When Necossary.}

A blanket is always necessary when the horse is standing in the stable in Winter. A light sheet is about as necessury in Summer, during fly time. A blanket should always be thrown over the horse in cold wenther, or even in the cool weather of Spring and Autumn, when stunding after being driven. A horse should always be blanketed when standing in a draft, or in the rain, using a cloth or rubber blanket as the case may be.

In blanketing a horse, see that the blanket is sufficiently large to cover the aninal from the neck to the tail, see also that the breast flaps are sufficient to protect this sensitive part, and that the blanket is large enough to cover the sides and flank fully. If not, do not buy it at any price. Buy a blanket for each horse, and having them use them when necessary, buckling them on so they will stay. Very many stable-men have a number of blankets for each horse ; this is well enough if they can afford it, but one blanket to euch horse, with enough in reserve so a dry blanket may be had as occasion requires, and with a good surcingle to each blanket, is all that is really necessary.

\section{Proper Tools for the 8table.}

The tools necessary for cleaning a horse properly may be very few or many. As a rule any horse may be properly cleanct with a scraper, a curry comb, a brush, a sponge, a comb, a wisp of straw, and a rubbing cloth. Horse pails both for washing the horse and for watering are indispensable ts any stable but never use one for the other. These should 
be of oak, half an inch thick, and with strong iron bails, and to hold fourteen quarts. The set of cleaning tools should be provided for evory two horses. Every stable should have two manure forks, one of steel and one of wood, splint broom, a scoop shovel, and a wheel-barrow. With these any stable may be kept clean, and if the oye of the master is kept on the help, the horses will not suffer for want of care. And these essentials to a stable, and the treatment suggested, are urged on the score of economy. They pay. We also urge them from humane considerations, and those of neatuess and system. In all respects kindness and attention to a horse are both satisfactory and remunerative. 
and to hold ed for every of steel and row. With aster is kept these essenthe score of nsiderntions, and attention

\section{CHAPTER IX.}

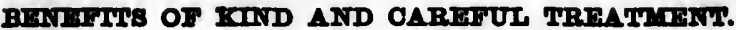

1. ABUSING A TATTHFUL BERVANT.-II. WHAT ARE BAREARTTIE.- - IIT. A PIOTURE FROY LWE. - IV, THI OTHER BIDE.—V. A GOOD FARUER'B BURROONDINGS.—VI. FAKMER

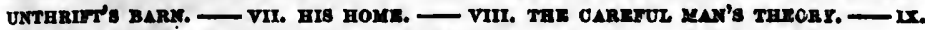

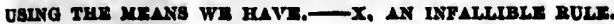

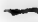

\section{Abuing \& Faithful Bervent.}

The horse 18 the most useful servant of man, as he is one of the most noble of animals. He is fortunate if he falls into the hands of a kind and considerate master. Fully one-half of the horses used in civilized countries are driven by persons brutal in their temper and instincts, who, coming into possession cf a horse suffering from disability, inflicted by some former owner, or perhaps reduced in value by age, are sold for a song, and thereafter the poor tortured brutes wear out a most miserable existence, until at length they drop in their tracks, literally driven to death. This pioture is not overdrawn. Go into any of our cities, and on to many of the farms of the land, and see animals in every stage of incurable disorders. On farms horses disabled for city use in the posses sion of some renter, whose only aim seems to be to see how soon and on how little food he can wear out the miserable animal. Contrast these with the horses that are carefully fed and cured for, and by actual count the result will be surprising even to a veterinarian.

As a rule, the horses of the better class of farmers fare the best. They are not pampered, it is true, neither are they overdriven or overworked. If they remain on the farm, they are capable of full work until they are 
twenty years old. How many arrive at this age? Not one in fifty. The most of them dio under seven years of age.

\section{What Are Barbarities.}

Their name is legion. It is barbarous to overload or overdrive anunals; to give them insufticient food and water; to allow them to stmi

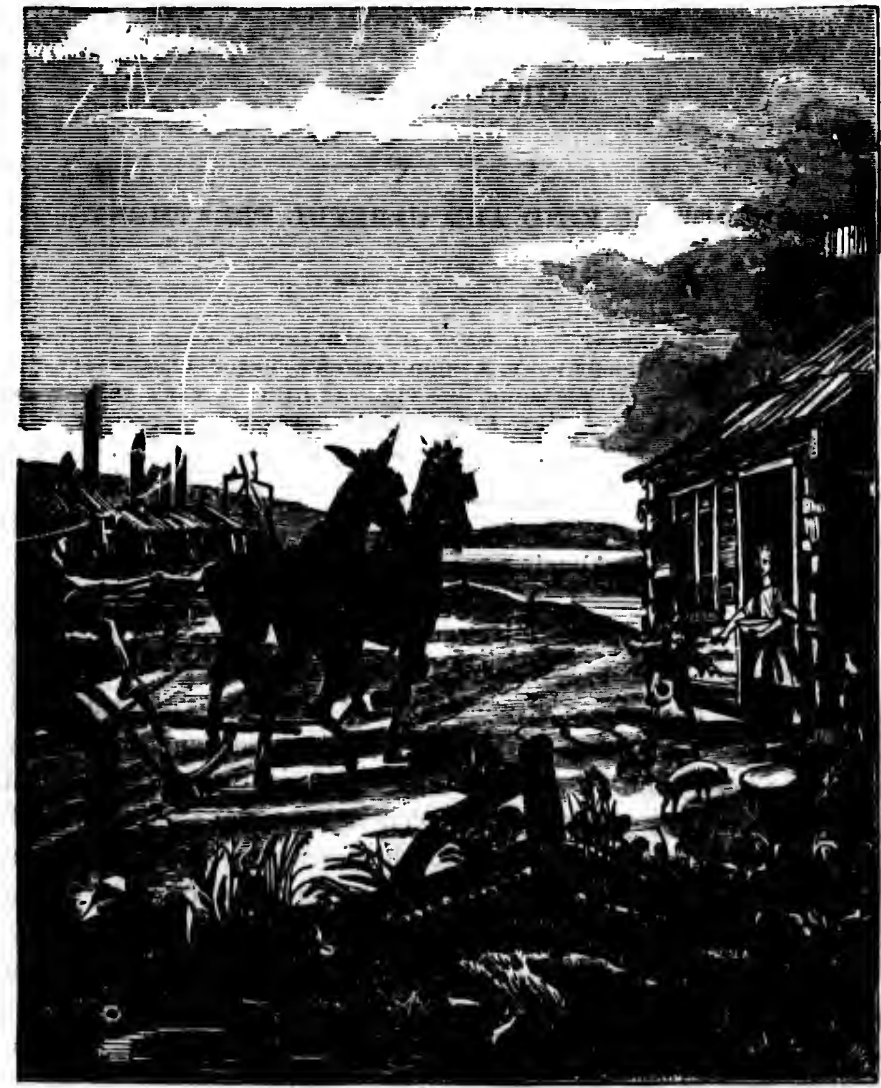

THX TKAM OY THK CRUEL AND IMPROVIDENT MASTEK, AND TRK USUAL BUKHOUNUING

day after day unclemued and in filth, denying them even the poor boou of cleaning themselves; to work them during the progress of spavin or ringe bone, navicular disease, with corns, gravel, or other painful ailments of

the for bles, it and $\mathrm{mi}$ dles, or 
drive an. to stiund

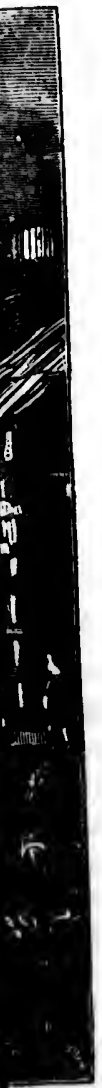

OUNUINGS

por boon of vin or ring: ailments of the foot; to let them stand shivering in tho cold, or in apologies for stables, in inelement weather without blankets; to drive them in the mud and mire and neglect to clean them; to ride them under torturing saddles, or to drive them in galling collars and harness; to use badly fitting

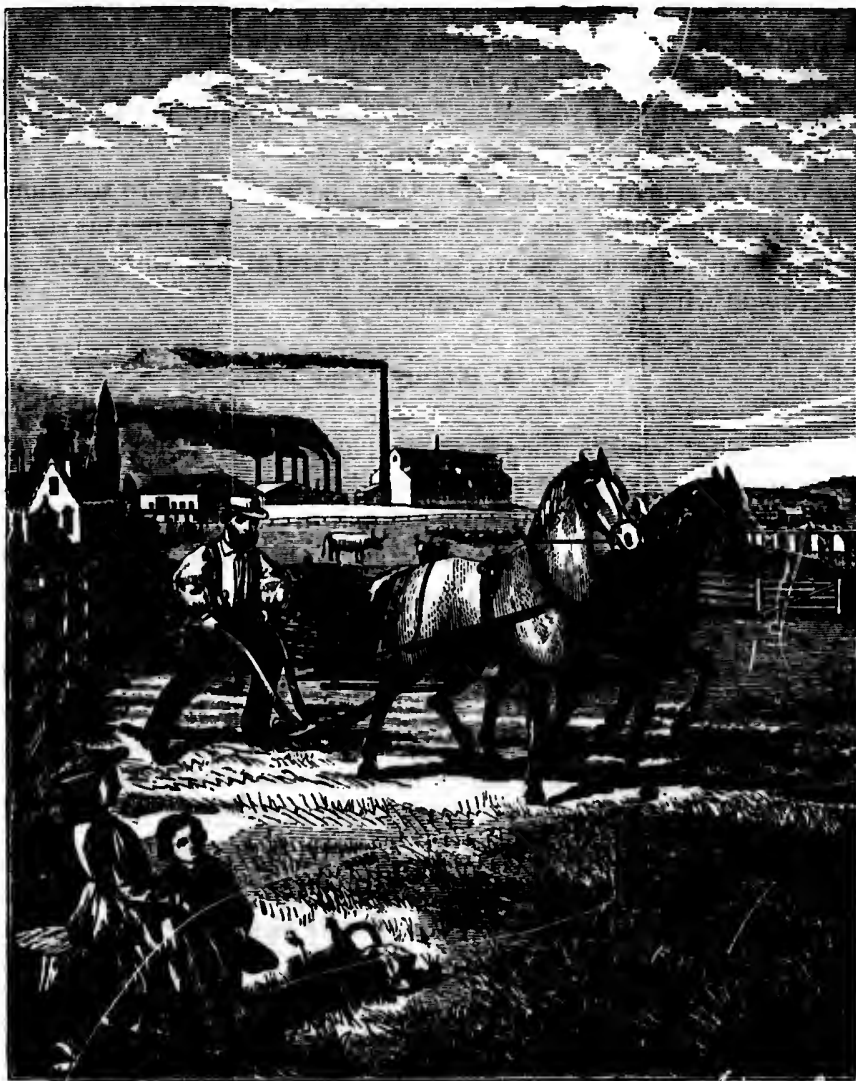

THE THAM ON THE KIND AND CARTEUL MASTER, AND THE NATURAL SURROUNDINOS.

or torturing bits, and then jerk their tender mouths because their agony will not allow them to curry their hends directly in line or go straight ahead; to ride or drive through deep mud at a pace which quickly exhausts the animal, and then beat with a loaded whip, because they flag, or spur then until their sides ure a gore of blood; to keep the poor 
creatures in terror, from fear of the whip, and then beat with renewed vigor because the innocent brute does not comprehend what the master really does not know hinself; to give the faithful servant over to the tender mercies of some man who calls himself a blacksmith, who either pricks him with a nail, pares down the hoof and the frog to the quick, and then because the poor animal cringes, holds back or perhaps stum. bles, beats him for it. Such are a fow of the more common of the cruelties inflicted, and which may be seen day by day by any who will notice. A man cannot pass álong the streets in any large city, on any day, without sceing some of these things.

The observing man need not travel fur in the country to see some such picture as we present of the farmer who believes in letting his stock shift for thembelves when not at work, and is careful not to over-feed when they struggle with the plow or wagon.

\section{A Pioture fróm Iife.}

But, say some readers, the picture on page 146 is a fancy sketch. Not at all. It is drawn from life. The superannuated, rat-tailed horse, with one ear gone, blind, spavined, ill kept and ill fed; the mule, still more rat-tuiled than the horse, intact only as to his ears, the broken-down fence, the edge of the marshy pond, serving as a wallowing place for hogs, and as a watering place for the family and stock; the dilapidated stable; the log cabin - all are true to life.' There is but one redeeming feature in the whole scene: the wife begging that a little land may be left in front of the house unplowed. Will it be granted? Not so. The ragged edged plow will cut as close to the corner of the cabin as possible, and then bear off in a circle in the near distance beyond. Land is too valuable to spare any next the house, but the weeds and dilapidated fence tell a tale of plenty of land beyond. If the traveler chose he might learn the cause of all this. A history made in the corner grocery of the village, over the broken bridge.

Cuntrast this with the companion picture we give on page 147, and which tells a very different tale.

\section{The Other side.}

It is of the farmer who is well-to-do by his own lact and energy. Hib team is trained to almost human intelligence. Strong, able horses, whose dams were kindly worked and curefully fed. When foals they were early taught to take their outs. In Winter they were carefully housed, their training commencing within a few days of their birth; broken in at two 
ith renewed $t$ the master over to the , who either o the quick, orhaps stum. nmon of the tny who will city, on any

zee some such his stock shift er-feed when

sketch. Not at ed horse, with ule, still more broken-down wing place for the dilapidated one redeeming land may be ted? Not so. the cabiu as peyond. Land and dilapidated veler chose be corner grocery

page 147, and

d energy. Hiv horses, whose they were early housed, their oken in at two years old, worked gently, and at three past given full liberty again until four. They nre now six years old, truined to go without lines, a gray and a bay; woll bred; weighing 1250 each; capalole of going a mile in four minutes to the fnrm wagon. How much think you they are worth? Let us whisper it; $\$ 800$ has been refused. A foolish farmer is he not, to keep so much money in a farm team? Perhaps not. He asks $\$ 1200$, and he will get it. Ho has fulfilled the conditions we have given as to breeding, feeding, watoring, care, shelter, breaking and training. They bave lacked for nothing he could give them, and in turn refuse nothing they may be able to do for him.

\section{v. A Good Farmer's Surroundings.}

The surroundings of a man in any condition in life, whether he be rich or poor, are an index to his character. The animus of all men is to make money, but some possess in connection, a love of the beautiful. Without method in labor no man can be successful. The farmer who has method, and an eye for the beautiful, and only confortably well off, perhaps, will show his barn yards and surroundings something like the following illustration:

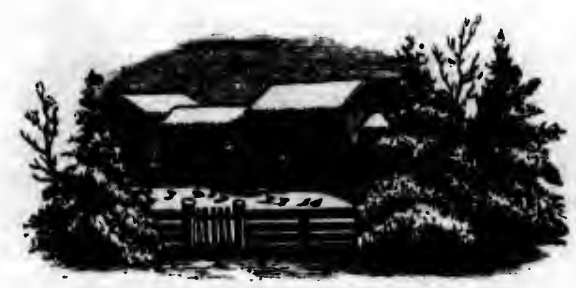

THE BARN OP THE PROVIDENT MABTER.

His narns are tight and ample, and filled to the ridge-pole with fodder lis yards are protected with shelter-belts and wind-breaks, his pasture. and meadows ample and luxuriant, and his crops well tilled and heary. Inside his barns will be found a place for everything and everything in its place.

\section{v. Farmer Unthrift's Barn.}

On the other hand we give a view of the harn of the improvident master. His well, simply a hole in the ground where the drainage of the yard may enter, the roof of the bovel rent and torn, the delapidated doors propped 10 
up with rails, the weather-boards fullen or falling off, and the whole thing shaky, like the master's mind. Fine stock, fut, and well groomed, have come out of hovels of barus; they

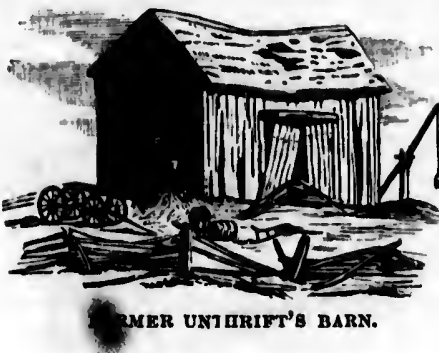
were made warm and comfortable. it is not the most expensive structure that nlways contain the best stock. but in the end the better barn will be bailt. We have never seen good stock issue from such a barn as we have shown, and it only ueeds to show the house the farmer lives in, with its brush henp, its line of ragged clothes, the rugged, dirty children, and generally dilapidated appearance, to complete the pictorial story of general unthrift

VII. Farmer Unthrif's Fome.

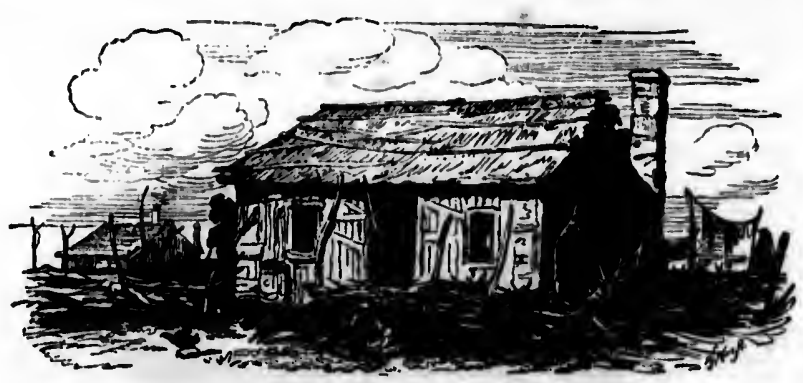

FARMER UNTHRIYT'B HOME.

Such a man will raise his colts from spavined and broken down mares they will shift, for themselves upon scanty pasture in Summer, und in th brush in Winter. Ho believes in hardening his stock, and he does it; hardens them into "runts," not worth a month's keeping. They an literally broken to work, broken in body und temper with cruel blows they are halter-broken too, the halter is $\mathrm{n}$ rope knotted about the neck like the poor old horse shown on next page, tied outside the barn for the benefit of the fresh air it muy get; a starved out skeleton horse, contem plating the skeleton of a barn. Even in such a barn there are capahilitie that may be utilized for comfort. It may be reshingled, and new cly boarded, and the doors hung on their hinges. It may even be patche wp so as not to leak, and be banked up to keep out the cold. But will? 
o whole thing roomed, have barns; they ifortable. It ive structures o best stack, barn will be $r$ seen good a barn as we needs to shor lives in, with no of ragged dirty children, ctorial story of

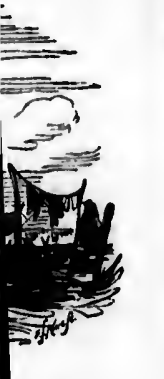

en down mares, imer, and in the and he does it; ping. They art th cruel blows: about the neck the barn for tox $n$ horse, contem e are capabilitio , and new clap even be patche cold. But will be? Hardly! The picture of the old house, the wreck of a horse, the old rope around the neck, the rotten barn, all tell of more money spent at the dram-shop than for the maintenance and comfort of the family or the well-being of the stock.

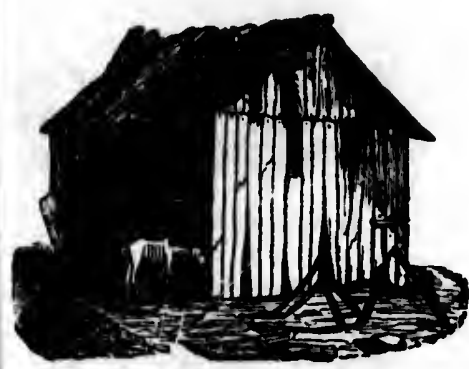

THE BARN OF THE CRUET, MABTER.

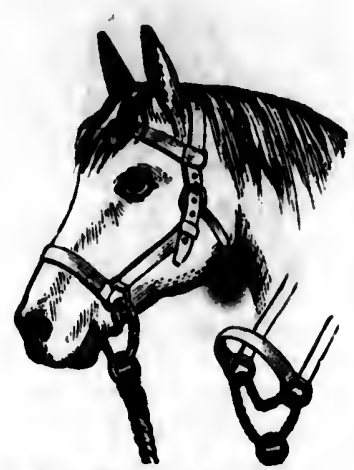

$\triangle$ MODEC EARTER ON A MODEL COLT.

\section{The Careful Man's Theory.}

As an accompaniment to this we give an illustration of a well-kept colt in a model halter for unbroken horses. By slipping both ends of the chin strap through the ring of the tying rope, it is a halter for a well broken horse. The man who possesses such stock and fixtures may not he rich; probably is not, but he is a careful, thinking, reading, methodical man, who believes in doing everything well. He uses no cruel bridles, gives his colts no excuse for getting cast in their halters. His harness seldorn galls the team, and when it does, it is remedied at the first indication. However dirty his team goes into the stable, it always comes out clean and blooming; not only this, such a master never finally leaves his team for the night, after a hard day's labor, until it is dry, well grooned, well littered down, and in every way comfortable for the night. In the morning his team are always ready for the field or road; and mowever eager or spirited they may be, will travel along together, either head of or behind the master, und looking like the picture that we bere ive on following page-a lordly team, that only could belong to a kind nd considerate master.

They are not too many. The cruel, or shiftless, or drunken masters re plenty enough. The farm stock of many get barely enough to ent, nd that in an irregular and improvident kind of way. They never pull ery heavy loads, the master has not many to haul, and he believ $s$ in 
skim plowing. When he comes home, he "runs them into the barn," such as it is ; or they take the yard for it, and in the morning very closely resemble the picture on the left.

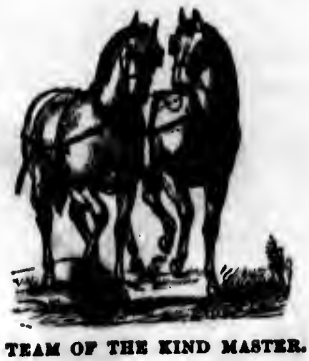

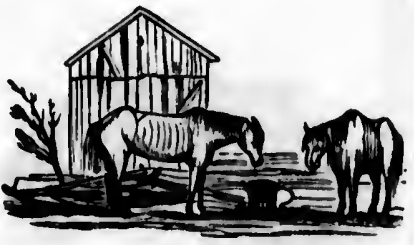

TEAM OF THE ORUEL MASTR.

A "humped up," hungry, thirsty pair of servants to a cruel, because improvident master.

Such a man may not be cruel in the sense of beating. He may be really a kind-hearted man, a good neighbor, "' thoroughly honest, as the world goes," he may even be a good Christian man, or think so at least. He is cruel nevertheless. More cruel perhaps than the brute who belabors his beasts and then repents. Cruel in his improvidence, in his neglect of his farm and his stock.

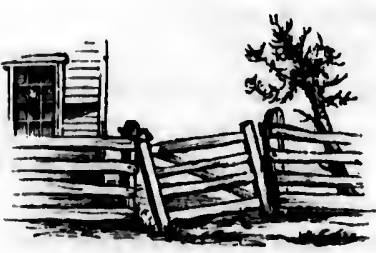

GIS DOOR-IARD GATE.

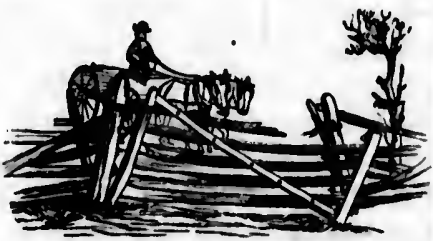

His YTLLDGAT

Is it any wonder that in the rnorning the team should be found in the yard, waiting for their breakfust. The wonder is that there should be anything, either in the house or out for either man or beast to brenkfast on

If to neglect we add a cruel or brutal disposition, the animals of the farm are to be pitied, and the household likewise pitied, and prayed for

This chapter is pictorial, and not particularly given to practical information on the cure of horses. It is a chapter of contrasts, and giver deliberately, as indicating far more eloquently than mere words can, the difference between, careful and kind treatment of stock, and cruel of 
to the barn," ng very closely

\section{Q}

UET MASTLR.

cruel, because

5. He may be honest, as the or think so at in the brute who ovidence, in his

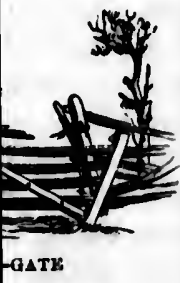

be found in the there should be to brenkfast on. b animals of the and prayed for. practical infor. rasts, and given o words can, the ck, and cruel a ueglectful trentment. It is, In fact, the story of thrift and unthrift. We expect fow whom it might benefit will see it. The unthrifty man whom wo have depicted, seldom sees books, and we might almost say, never buys one. Those however who do, may perform good missionary work among the class we have represented, by showing them how quickly thrift will follow good intentions, religiously kept, backed up by honest industry, guided by careful judgment, and accompanied by a will to perform. It will repair houses and barns, build gates and fences, cultivate smiling fields, rear and train good stock, lift the mortgage off the farm, educate the growing family, and bring comfort and happiness to a once cheerless and suffering family.

\section{Ix. Uaing the Meano We Have.}

In the foregoing, it is not to be understood that expensive appearances are necessary for training a horse, neither is it to be understood that costly buildings are necessary. We have stated more than once that any farm unimal may be kept in the most comfortable manner, in a structure made of poles and hay, and we will add, kept in as good health as in expensive stables. The reason is that the master who uses care in making a simple structure warm and coinfortable has humanity to start with, and generally gives his own personal care and supervision, while in costly stables the animals are usually left to the care of men hired for the pur. pose. The owner, often, from the pressure of other business pursuits, being unable to do more than to drive a favorite animal or team. In perhaps a majority of cases he knows little or nothing of how a horse should be cared for, and of course nothing as to the fitness of those whom he pays for doing the work.

The object of this work is to present in 4 condensed form the best practices, founded upon common sense, and the experience of superior stockmen in the care of unimals. A study of these pages will enable uny person to acquire a good idea of the simplest and best means for arriving at a correct knowledge of how animals should be bred, raised, fed, trained, and cared for. Ho may thus understind how to do the work himself, or, in case he be a man of business, or wealth and leisure, he may quickly know whether the help he relies on are doing their duty, not only in feeding and cleaning, in exercising and the general care of the animnls under them, but also know at a glance, whether the nnimals are treated with the kindness and consideration that dumb brutes, but faithful servants, deserve from man. The closest and most constant attention to these points will abundantly pay every furmer, and every wise farmer will be certain to bestow such care. 


\section{An Infallible Iaule.}

We have known a brutal stable-man to flog a horse in the most terrible manner, simply to get rid of his own ugliness, as he expressed it, while at ordinary times he petted and made mich of the animal. Such an ani. mal will be frantic at the sight of a whip beld in a threatening manner. Animals that are in the habit of being struck with the pitchfork, or being ki'ked and cuffed, will watch earefully the stable-man, and show by their nervousness in the stable what they are expecting, while of the master they will show no sign of fear. Stable-men are often euming creatures; they will have soothing words to quiet the animal in che presence of the muster. Wo have always held that the horse should be spoken to firmly but quic, and always have an inherent suspicion that a team exhibiting signs of fea: at times, where we always hear the keeper speaking to them in soothing tones, are subused in secret.

No sane man would practice such treatment to his own stock, and no man who is obliged to leave valuable animals in the care of servants should fail to know that they are doing their duty. It is not enough that thes stable-men fced the regular rations, that they clean and exercise prop. eliy. It ahould be made important that in all their intereourse with the animals under their care, they be not unduly punished, nor in any other respect abused. 
nost terrible sed it, while Such an ani. ing manner. rk, or being how by their $f$ the master ig creatures; esence of the ken to firmly am exhibiting aking to them stock, and no o of servants it enough that exercise propourso with the $r$ in auy other
CHAPTER $\mathbf{X}$.

H.W TO BUY.

1. HOW TO GET CORBECT IFPORMATION. - II. THE BUYER XTET KNOW WHAT HB WANTS. - III. PROPORTIONS OF THE HORSz.--IV. THE CLEVELAND BAY POR PRORT,--V. THE LIOUT HARNESS HORSE.-VI. BADDLE HORSES OF ALL G:ITS. - VII. TUE IIOIIBRED HUNTINO HORSE. - VIII. RACINO HORSRS, -IX. WHAT THE RACER BIIOLLD BE. -X. TO AVOID VICES AND DEFECTS-HOW TO DETICT. - XI. OTHER FAULTS AND IMPKRFECTIONS.

\section{How to Get Correct Information.}

Every horse owner sooner or later becomes a judge of what he is buying. If he depends entirely upon the lessons lenrned through chents that are practiced ujon him by sharp jockeys, life is too short for him ever to heeome an adept in distinguishing vice, unsoundness, "dosed up" and used up horses as among the various tricks and swindles practiced upon the ignorint and unwary. Generally after being cheated, or a! slutely swindled a few times, the breeder goes to the only correct source of information, concisely written and eneefully illustrated books. $\mathrm{He}$ is thus ennbled not only to stndy, but subsequently to carry in his mind what he has read and seen; he eomes to compare critically the living animal with the illustrations and descriptions, nud thus becomes an expert himself, and in a hundredth part of the time by which he could acquire correet information in any other way. This is precisely the means used by any professional man in the acquisition of true knowledge in the pursuit of his profession, whether it be in a learued profession or in the education to practical art. Thereafter practice makes perfect.

\section{The Buyer Muat Know What he Wante.}

Suppose he is looking for stock from which to breed trotting horses. He must then consider the typo of horso he wishes to breed; whether for 
speed alone, or for style and speed. That is, first class road horses, os large, strong, able horses, combining in as great a degree as may be large size, strength, endurance and such style as may be conformable with this class of horses.

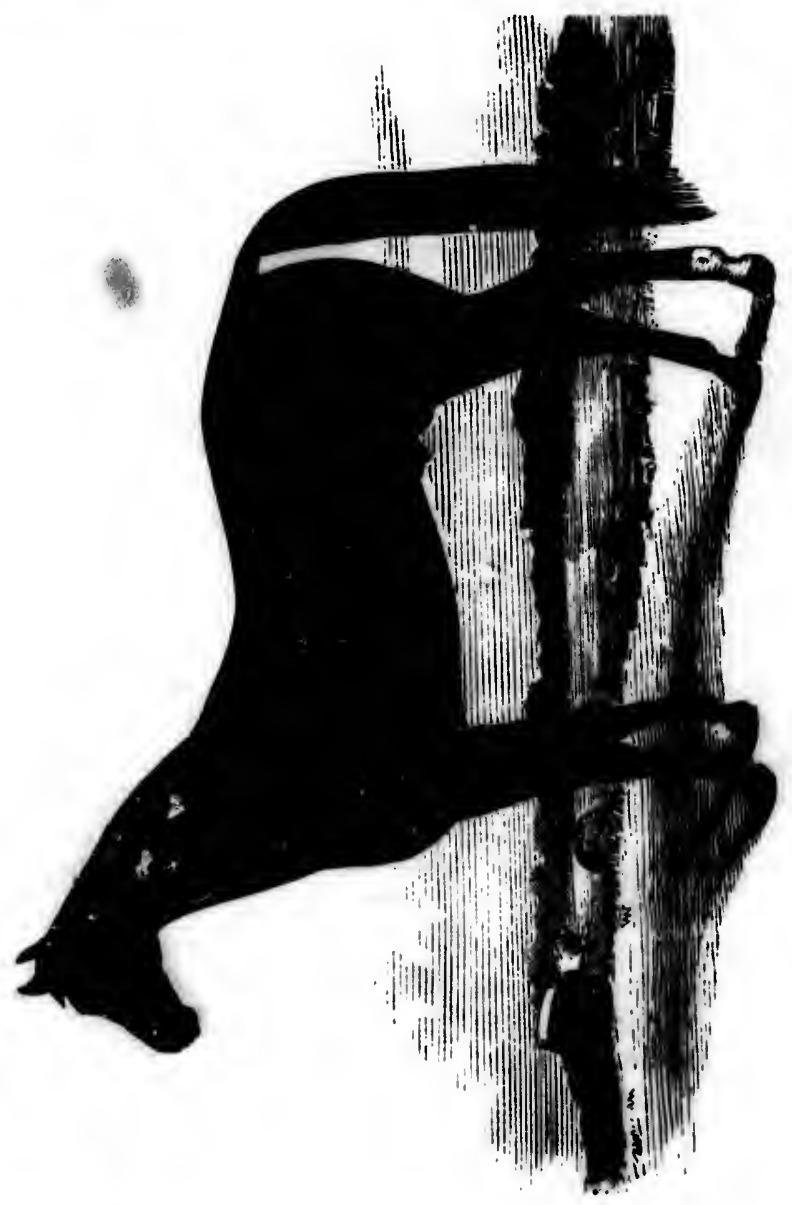

As showing what may be done in colts got by breeding up out of roomy mares of fair style, bred to high cluss trotting stallions, we give three cuts of stallions, certainly good enough for aires, and as models of what such horses should be. The first showing eminent breeding, with 
10rses, of be large with this

up out of $\mathrm{hs,}$ we give 3 models of eding, with style enough : rather straight on his fetlocks, according to the idea of muny good horsenen, but with length enough, from our standpoint, to give flexibility. A horse compact and smooth, with excellent flat and

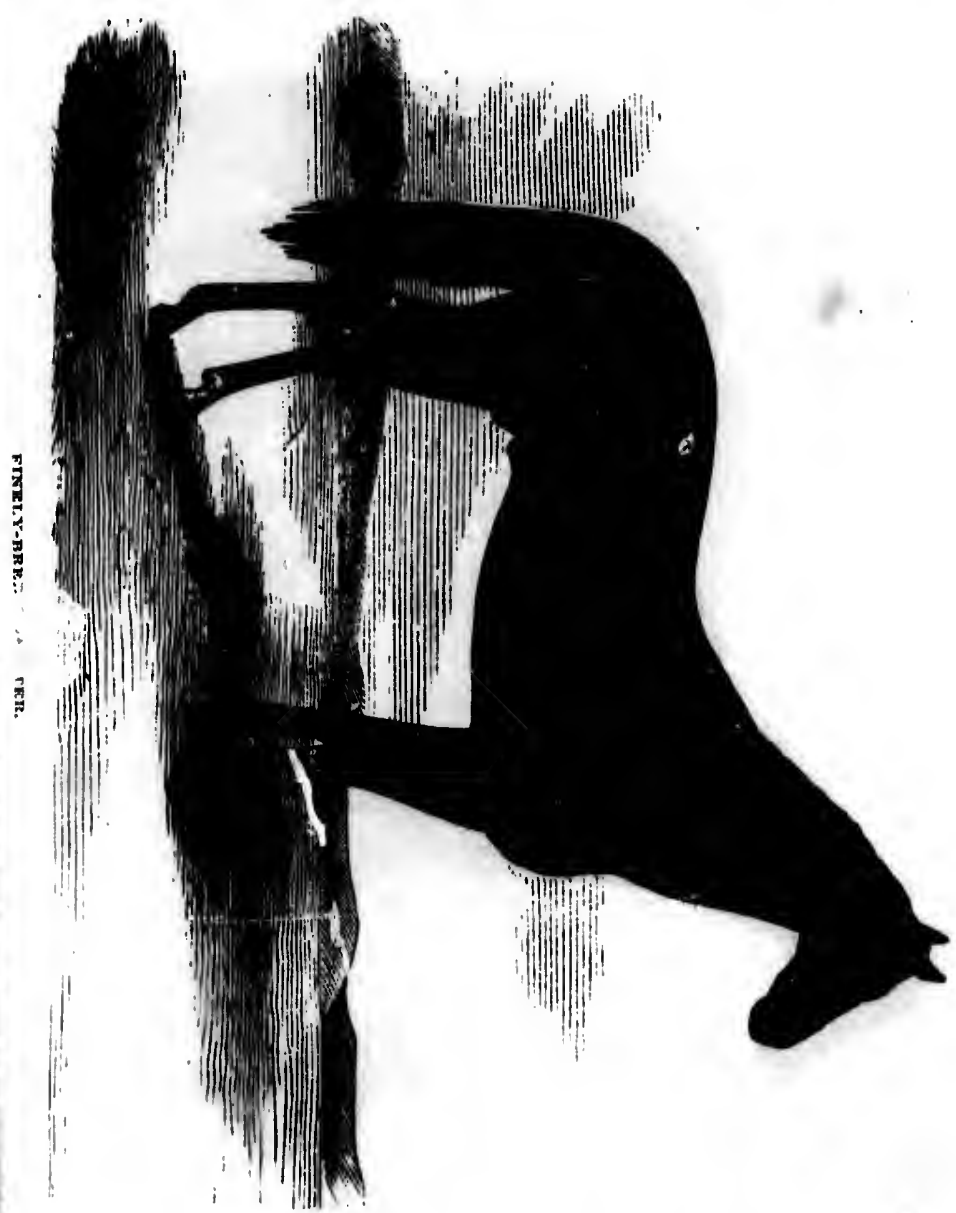

sinewy limbs, good feet, ample chest, good lungs, fine eye, broad forehead, and strong jaws. The liead not the ideal of modern "blood horsemen," but nevertheless showing docility and intelligence in a high degree. Showing also high breeding in every part. 
The cut on page 157 is of a horse of great style and endurance, fine all over. A horse that will go with his heud well up; limbs exceedingly fine, mane rather light, but with plenty of tail, as a horse should have; ovidently showing Morgan blood, dushed with Bell Foundor and other thorough blood.

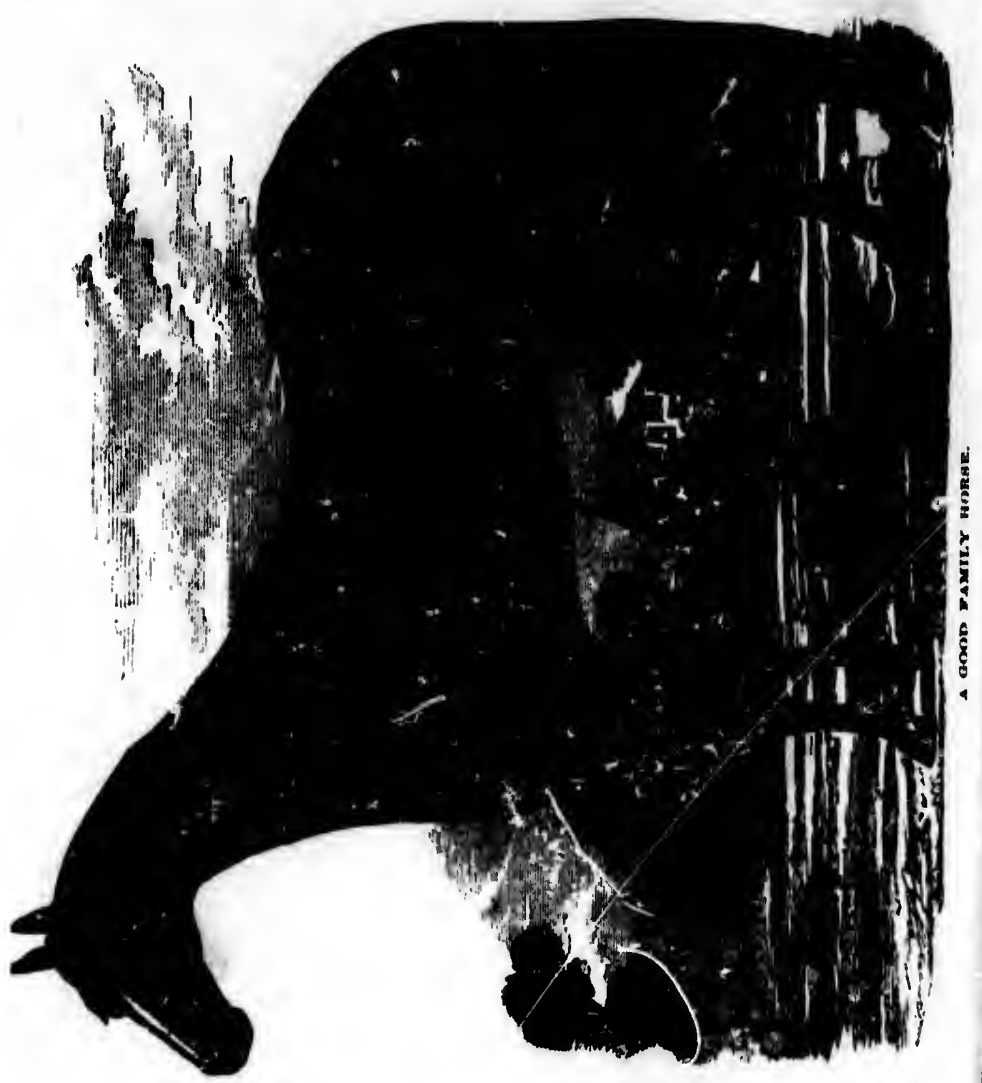

Between the two, for real and intrinsie merit, tho first shou!d be taken. There is plenty of style about him, and strength. There is also a body of fine character on limbs of great power. Such will be found neceptable and sought after always by gentlemen winting a single horse, or a pair for driving on the road, or for driving in the eity park-ways ir the 
ce, fine all cceedingly uld have; and other

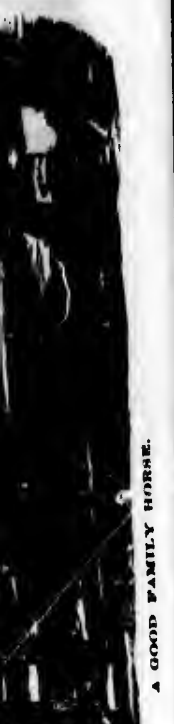

-ld he takell. also a body and accept. horse, ur a -ways in thit afternoou. Either of the two will make capital and stylish saddle horses, if well trained, such as no gentleman of ordinary weight or any lady need be ashamed of when taking the afternoon trot or canter on the fashionable boulevards or park-drives of our largo cities, or on the streets or roadings of cities having no parks. The first the best horse, the second tho most stylish.

The third cut we give is that of a horse of large size and strong build, adapted for drawing as a single horse for the coupe, or one of a team to the family carriage; as one of a pair for a coach or barouche; 'one that will give satisfaction almost anywhere, if not driven over eight miles an hour, and capable as well of hauling loads on good roads, at a fast walking pace.

A horse of this stamp, sixteen to sixteen and a half hands high, not particularly heavy set, rather long-limbed, with rangy neck and good heau, with plenty of spirit, and weighing about 1200 pounds, may be called a general utility horse. Such will cominand ready sale at any time, if well broken and trained, say at from $\$ 210$ to $\$ 300$ each, and if particularly nice and well matched, of $\$ n$ at $\$ 801$ ) or $\$ 900$ the pair, as carriage horses when five or six years old.

III. Proportions of the Horee.

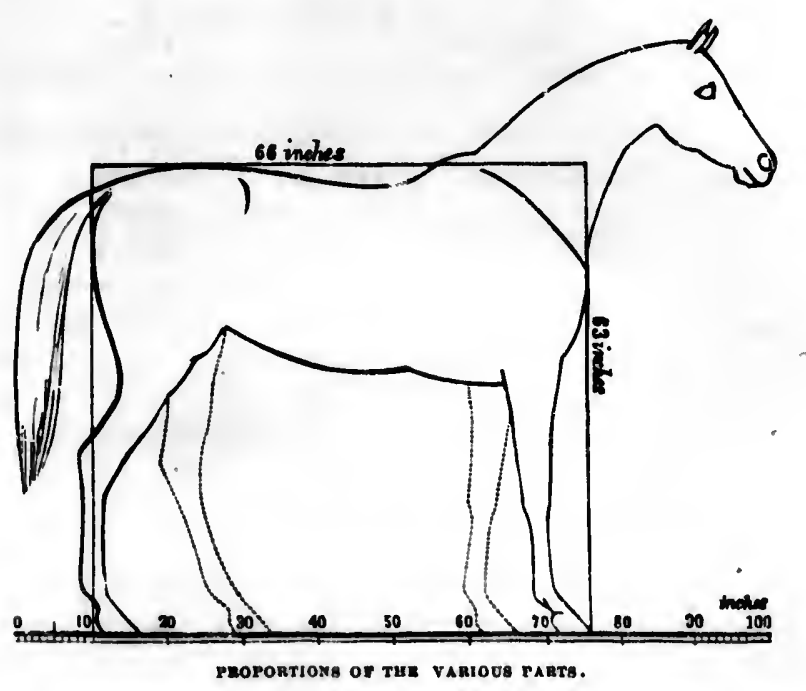

To arrive at a clear understanding of the proportions of the horse, we give ail outline that will be a good study, not only for the beginner, but 
will be valuable for reference for any horseman, however expert he may be. This illustrntion combines the average mensurements of six horses, accepted for perfect symmetry, and taken, says Mr. J. H. Walsh (Stonehenge)-one of the most gruphic and lueid of English writers on the horse-two of them fiom celebrnted stallions, two from thorough-bred hunters, and two froin chargers of grent value. 'This, therefore, will not apply to draft horses, but it will be found that the nearer the general utility horse comes to these measurements, the better he will be.

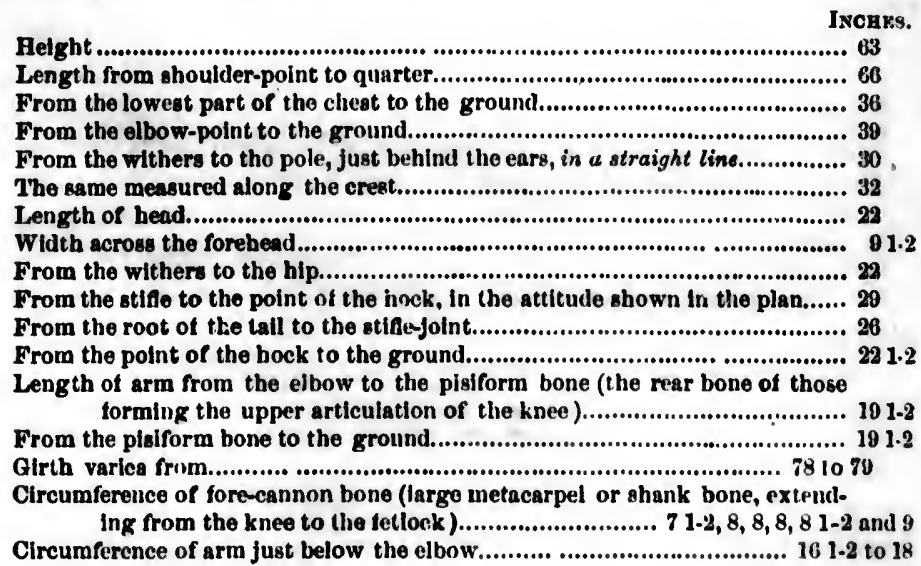

The foregoing is not to he taken as a fixed rule in comparing ordinary horses, nor even those well-bred. Felipse, for instance, may be given as It most wonderful horse, differing in many muterial respects from these measurements. He was three inclses taller at the withers, und yet higher in the croup than at the withers. His head was of the same length as the avernge given, but it is sa:-! to have heen twelve inches neross at the forehead. He wis a big horse in every respect ; tall, lengthy, cupacious in body, higher belind than before, his neck and back long, the loin ronched, his limbs would by some be called long. hat they were strong with large joints, but fine; his quarters stroight, square and extended; thighs long and muscular; shoulders only moderately oblique, and of fair depth; his knees and hocks lorond und well formed; head snall, and as will be ohserved from its great hreadth of forehead, Arab-like. On the whole it would probahly be difficult to improve the proportions of Eclipse, simply as a weight-carrying rucer. For the hunting field, the fine saddle horse, or any of the uses to which practical men put their borses, aside from flat racing, select as muny of the superior points of 
Eclipse as you can find, but leave out tho low withers and high croup. The horse that will come to the standard that we have given in the diagram, is as a rule the horse to buy.

on the 1-bred ill not eneral

HEks.

63

60

36

39

30

32

92

26

rdinary yiven as in these t higher ngth as $s$ at the upucious the loin - strong tended; and of all, and ke. $O$ tions of ield, the ut their oints of

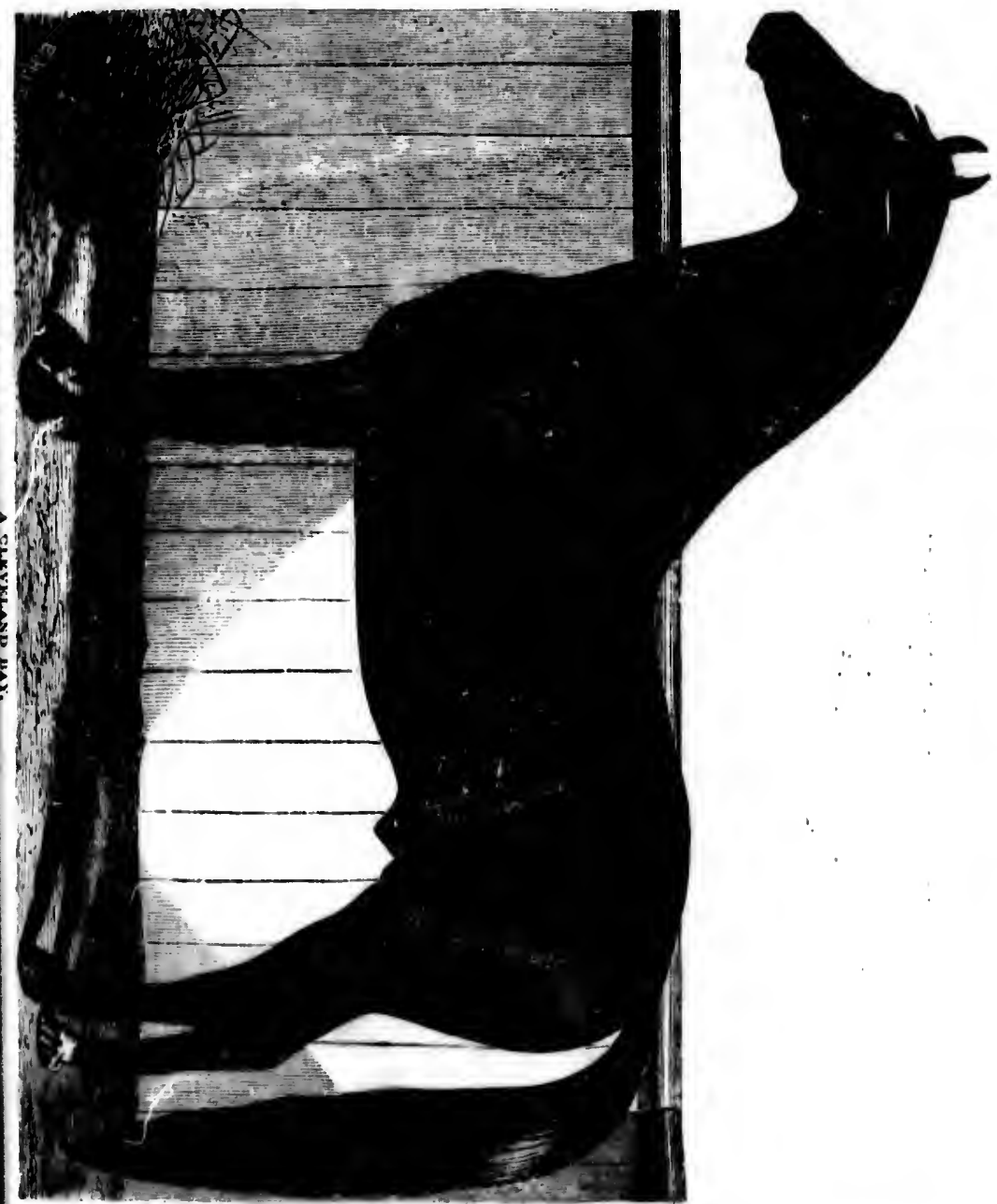

IV. The Cleveland Bay for Proflt.

Of late yeurs this admirable and stylish horso as improved from the 
old farm horse of fifty yenrs ngo, has attractea nttention in the United States, and especially in the West, where many fuir specimens havo been imported. As showing the characteristios when standing extended and at rest, wo give a portrait of a pure buy, in color, with a star in the forehead, and one white hind fetlock. These dashes of white not detracting from the style of any horse, und showing breeding. It is a horse showing blood and breeding, with lnfty crest, magnificent withers, round barrelled, and clean limbed, a coat like satin, and a head of excellent proportions. Colts from such a horse out of large, roomy mares of good style, will always sell for high prices. Whon you find such a stallion do not be afraid to buy, ho will pay, and his foals will pay for their feed and training.

The old fashioned horse of this ruce, the Cleveland bny, is extinet and gone. The prosent form is the result of crosses with staunch thoroughbreds, giving better form throughout, greater speed and eminent style. We consider thom as among the very best from which to breed stylish animals from proper mares. Horses that may do the ordinary farm work until six years past, and then be sold at good priees for stylish omnibus, express, light druft, and carriage horses in our cities. Furmers who bave large, well built mures, wishing to breed colts that shall have sizo enough for any farm or road work ; that will breed to uniform color, so that they muy be ensily matehed ; that will have styleenot that of the blood horse, or light driving, or trotting horse-will do well to investigate the characteristics of the Cleveland buys. Cumadn has nequired a high reputation for stylish, well unatehed coach horses. It is founded in a great measure upon crosses produced by breeding the modern Cleveland bays upon large, handsome mares of more or less breeding.

Such horses if properly eared for will do eight or nine miles an hour. in harness, and under the saddle may be pushed up to twelve miles an hour; the netive in all their gaits, traetuhle, ensily managed, intelligent, fast walkers, always ready for their feed, and as eager at labor, as they are kind and intelligent every where. The late Henry William Herhert, (Frank Forester), in thorough horseman, an accurate judgo of borse flesh, and a finished writer, : his voluminous work, "The Horse of Amerien," thus describes the original Cleveland bny, and also the improved horse of his time: "The Cleveland bay, in its nutural and unmixed form, is a tall, powerfully built, bony animal, averaging, I should say, fifteen hands three inches in height, rurcly falling short of fifteen and a half or exceeding sixteen ond a half hands.

The crest and wither's are almust invariably good, the head bony, lean, and well set on. Ewe-necks are, probably, rarer in this family than in any other, unless it be the dray-horse, in which it is never seen. 
10 United inve been ed and at the foredetracting rse ehowound barllent pro$s$ of good stallion do $r$ feed and

xtinet and thoroughnent style. oed stylish farm work h omnibus, who have size enough so that they lood horse, to the eharreputation eat measure upon lnrge,

es an hour, ve niles an intelligent, oor, as they m Herhert, horse flesh, Amerien," ed horse of $\mathrm{m}$, is a tall, tteen hands half or exhony, lean, ily than in n.
The faults of shape to which the Cleveland Bay is most liable are narrowncss of body, and flutness of the cumnon and shank bones. Their color is universally bay, ruther on the yellow bay than on the blood bay ('olor, with bluck mane, tnil, nnd legs.

They are sound, hardy, active, powerful horses, with excellent eapabilities for druft, and good ondurunce, so long ns they are not pushed beyond their speed, which may be estimated at from six to eight miles an hour, on a trot, or from ten to twelve - the latter quite the maximum - on a gallop, under almost any weight."

The large and more showy of these animuls, of the tallest and heaviest type, were the favorite conch horses of their dny ; the more springy and lightly built, of equal height, were the hunters, in the days when the fox was hinuted by his drag, unkennelled, and run hulf a dozen hours or more, before he was either earthed or worn out and worried to death. Then the shorter, lower, and more closely ribhed up were the road hackneys, a style of horse unlapppily now almost extinet, and having unequally substituted in its place a wretehed, weedy, half-bred or throequarters-bred beast, fit neither to go the pace with a weight on its baek, nor to lust the time.

From these Cleveland Bays, however, though in their puro state nearly extinct, a very superior animal has deseended, which, after several steps and grudations, has settled dewn into a family common throughout all Yorkshire and more or less all the mid-land counties, as the farm horse, and riding or driving horse of the furmers, lanving about two crosses, more ar less, of blood on the originul Cleveland stock.

The first gradation; when pace beeame a desiderntum with hounds, was the stinting of the best Cleveland Bay mares to good thorough-bred horses, with a view to the progeny turning out hunters, troop horses, or, in the last resort, stago-coach horses, or, as they were termed, machines. The most promising of these well bred colts were kept as stallions; und mares of the same type, with their dums, stinted to them produced the inproved carriage horse of fifty years ago.

The next step was putting the half-bred fillies, by thorough-breds out of Cleveland Bay mares, a second time to thorough-bred stullions; theirprogeny to become the hunters, while themselves and their brothers were lowered into the curringe horses; and the half-bred stallions which had heen the getters of enrringe horses were degrnded into the sires of the new, improved eart horse.

\section{v. The Light Harness Horse.}

In many enses, where tio ronds aro superior, and the animnl is used in a velicle of the liglatest consizuction, to carry only one person, size is 
not always necessury. Very muny horses of fourteon und a half hands, are exquisitely hundsome und cmpuble of very fust work. One of the best we ever know was a St. Lawrence mure fourteen hunds high, that

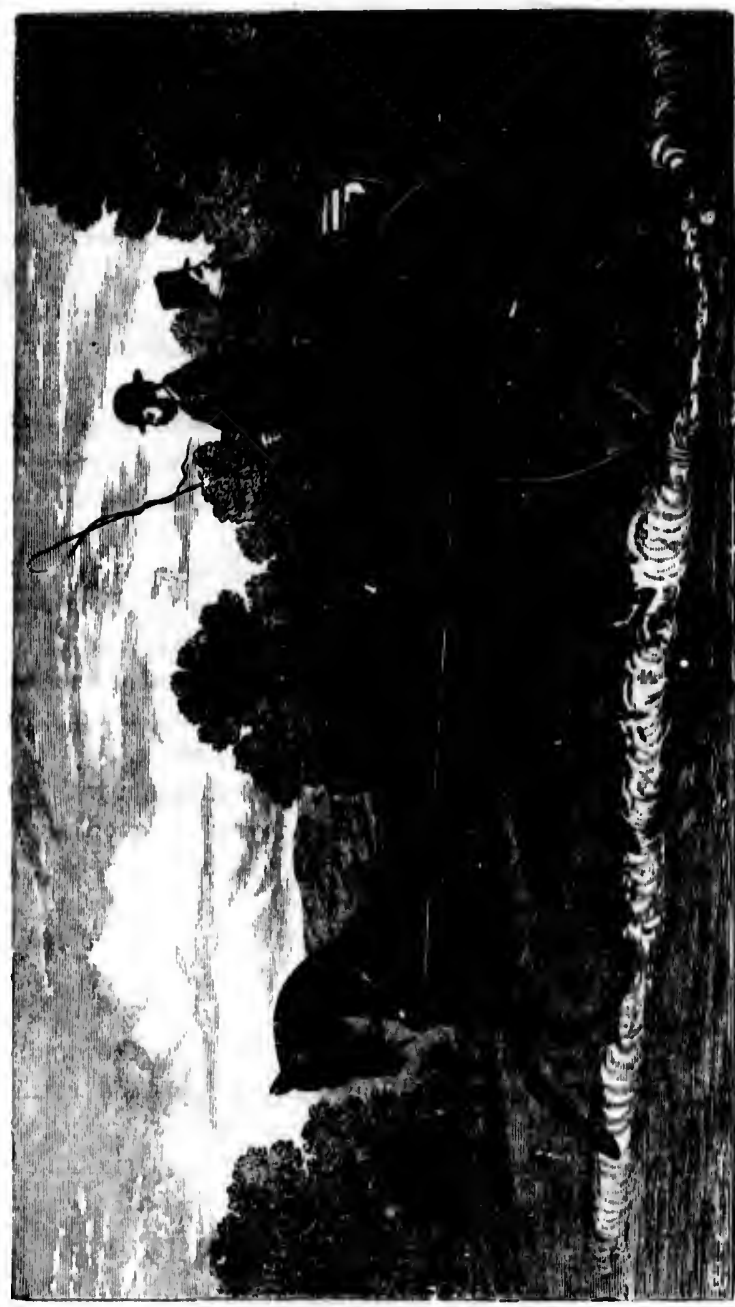

wheel young lauds tred s

very few large horses could get by on a smooth road-the "Baby," as she was called-when driven on a track, always goiug as a pacer.

It hus kindly to 
haunds, of the gh, that er.
The illustrution on opposite puge is of un English light huruess, twowheeled turn-out, a vehicle now orensionally putronized by fast living young gentlemen. For style of going, the horse is as perfeet as he is handsome in his make-up, but not showing the high knee action considered stylish with all two-wheeled turn-outs.

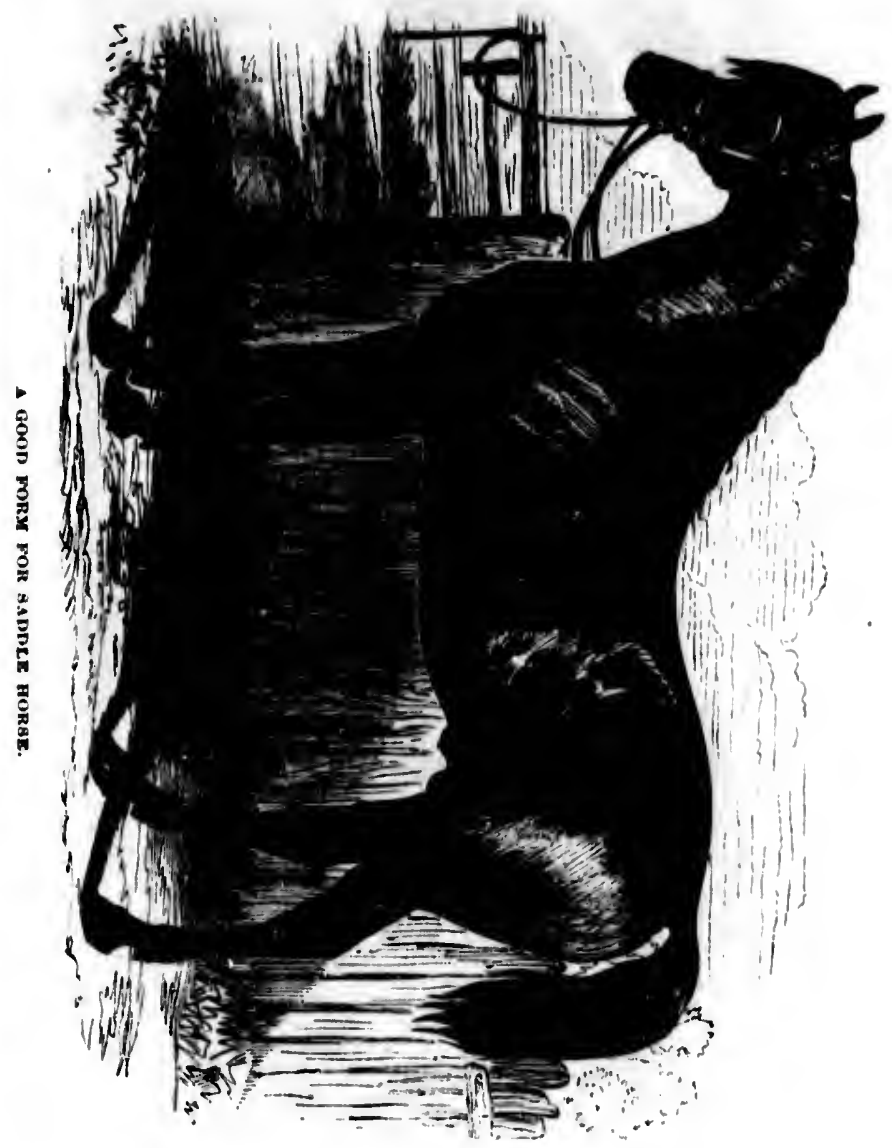

VI. Baddle Horses of all Gaits.

It has always seemed a pity that farners soms have not taken more kindly to the saddle than American youths do. It is well enough for 11 


\section{IMAGE EVALUATION \\ TEST TARGET (MT-3)}
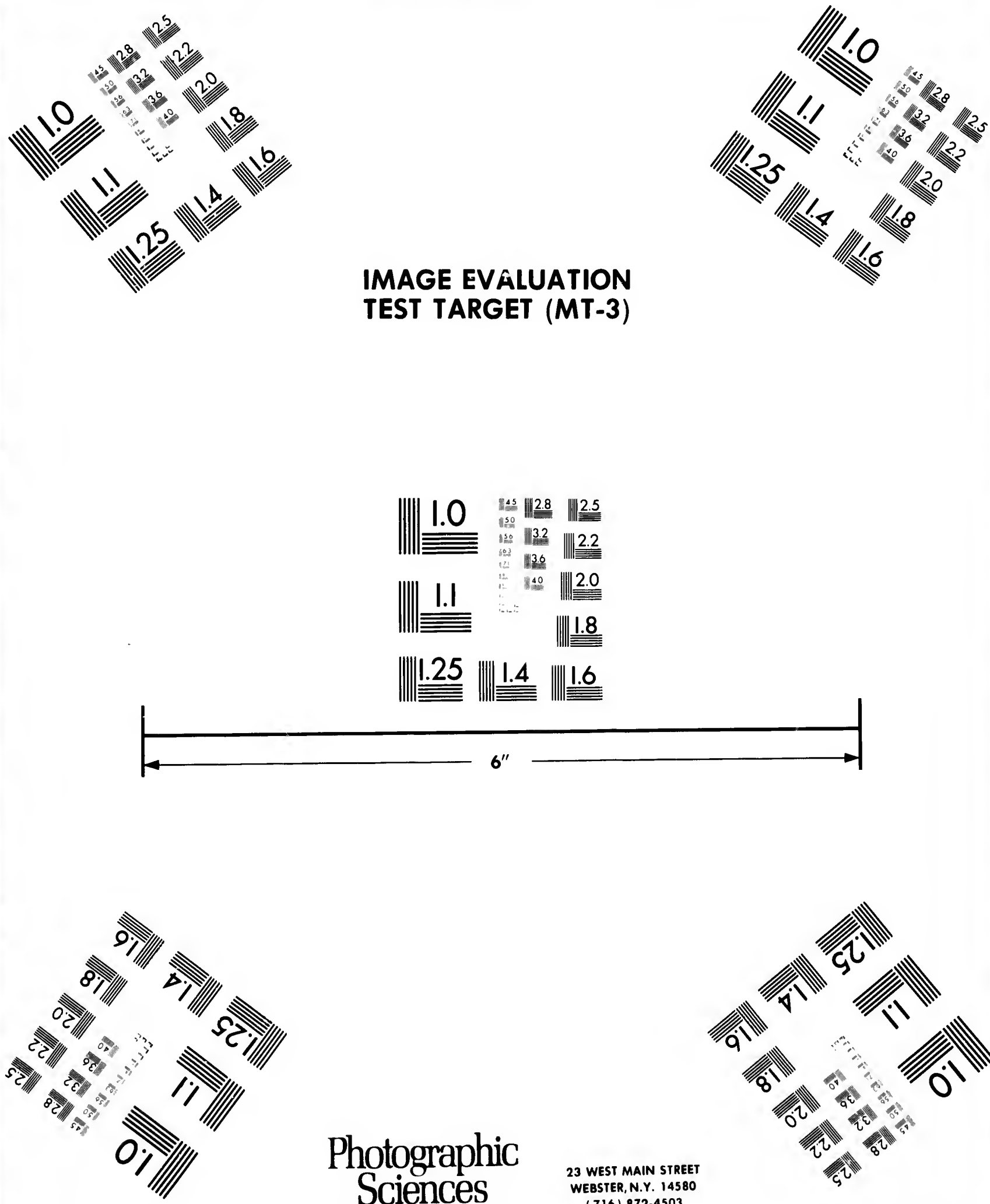

Photographic Sciences Corporation
23 WEST MAIN STREET WEBSTER, N.Y. 14580

(716) 872-4503

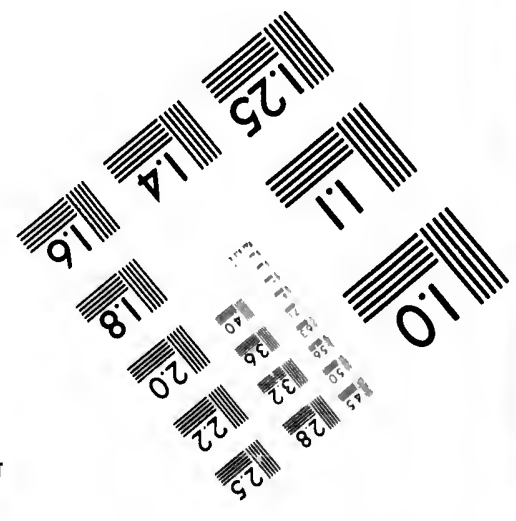


men of mature age to favor the buggy or light wagon, but every young man and woman raised in the country should be taught to sit a horse per. feetly, and to manage him at all gaits. In the South this is the case, but

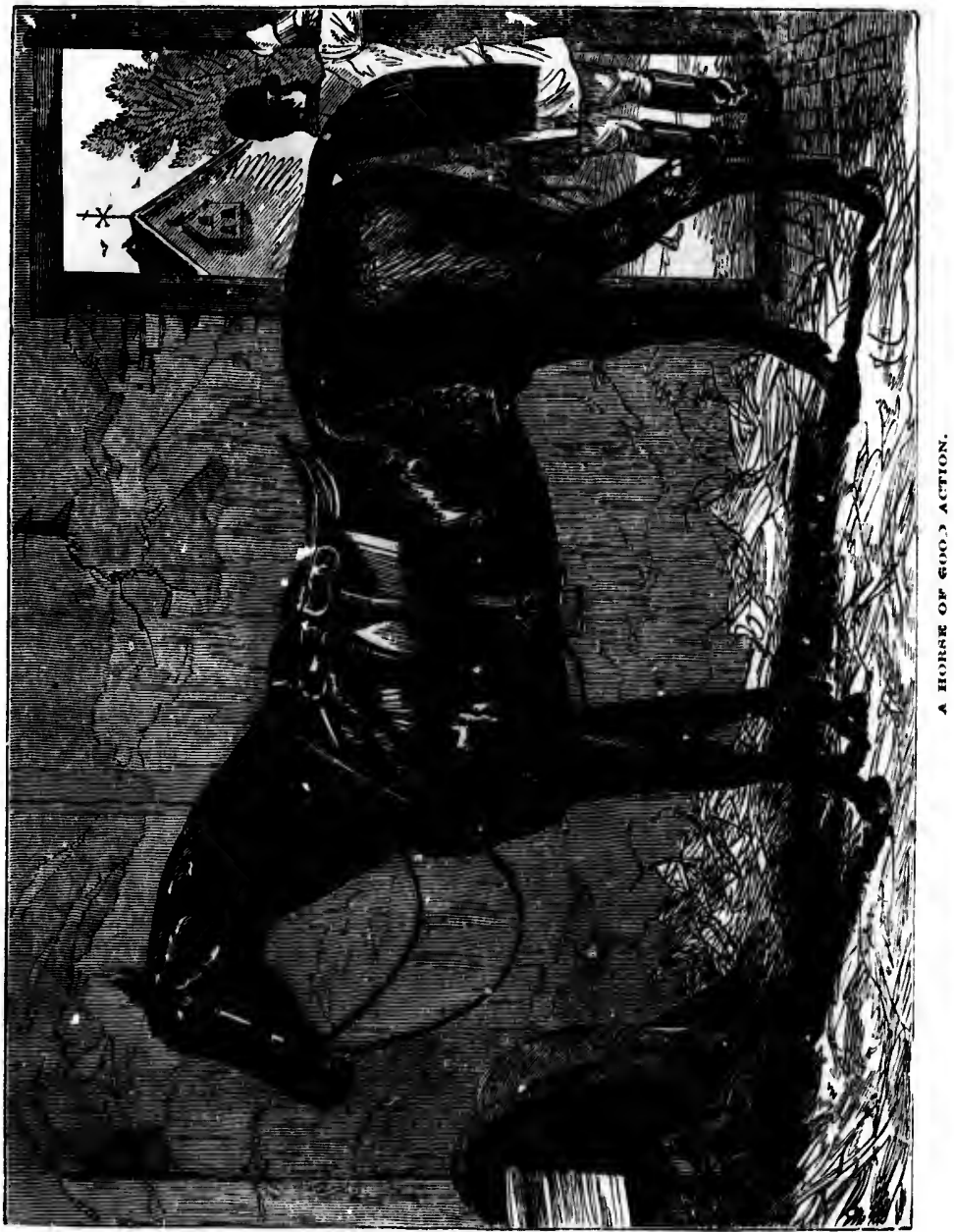

in the North the perfect saddle-seated rider is rarely found. Lately, thoroughly trained saddle horses are much sought after in our cities, and ocrtainly there is no place where they may be so perfectiy trined as in the West. Eve trained saddle ho will put them in good leaper, of illustration, page should be.

When a long distances at high one-half to three. the South, wher England. The il page 166 , will be great weight; his lungs ; great leng ble; a high caste

There is one $\mathrm{m}$ thorough-bred ra that is valuable bone, sinew and on the race cours there always will by all breeders $o$ tions rules of the lived up to. If animus of the tu improving the $b$ weight, and with ligh speed. Th end of a quarter Englishman wou

The model rae hands high, full backed, round is 
the West. Every respectable farmer should have at least one well trained saddle horse to sell when called for. Twelve months truining, will put them in form. For good wear-ard-tear, compact, able as a good leaper, of fine form, and undoubted bottom for any distance, the illustration, page 165 , will give an idea of what such a saddle horse should be.

\section{vII. The High-bred Flunting Horse.}

When a long stride, great leaping powers, and ability to go long distances at high speed is required, the horse should be not less than one-half to threc-quarters bred. A greater proportion even is favored in the South, where the passion for hunting is only second to that in England. The illustration of a horse of extra good action as given on page 166 , will be seen to combine size, indicating capucity for carrying great weight; high breeding, as shown in the crest and head; wonderful lungs ; great length of hip and limbs, and being near perfection as possible; a high caste horse that will not fail his rider in time of need.

\section{Racing Horses.}

There is one more class of saddle horses wortny of special notice : the thorough-bred racing horse, the foundation upon which has been built all that is valuable in every horse where speed, bottom, elegance, and great bone, sinew and muscle in every respect are required. It is the fact that on the race course there have been schemes and tricks practiced, probably there always will be those scandalous in the extreme, but frowned upon by all breeders of respectability. Among the more respectable associations rules of the most stringent character have been drawn, and fairly lived up to. If dishonest jockeying can be still further eliminated the true animus of the turf may have a bright future before it in still farther improving the breed of staunch thorough-breds, capable of currying weight, and with bottom to get the rider two, three and four miles at ligh speed. These are what are really wanted, and not those that at the end of a quarter or a half mile are entircly blown and jaded, or as an Englishman would express it, quite "pumped out."

\section{What the Racer Should Be:}

The model racing horse should be from fifteen and a half to sixteen hands high, full and muscular in his build, with clean, sound limbs, short backed, round in the barrel, with long hips, deep and oblique shoulders, 
a rangy and not too muscular neck; a head fine, bony and with rather large muzzle and prominent nostrils, broad in the forehead, with a full, bright, but mild eye, denoting a high nervous temperament, uniting

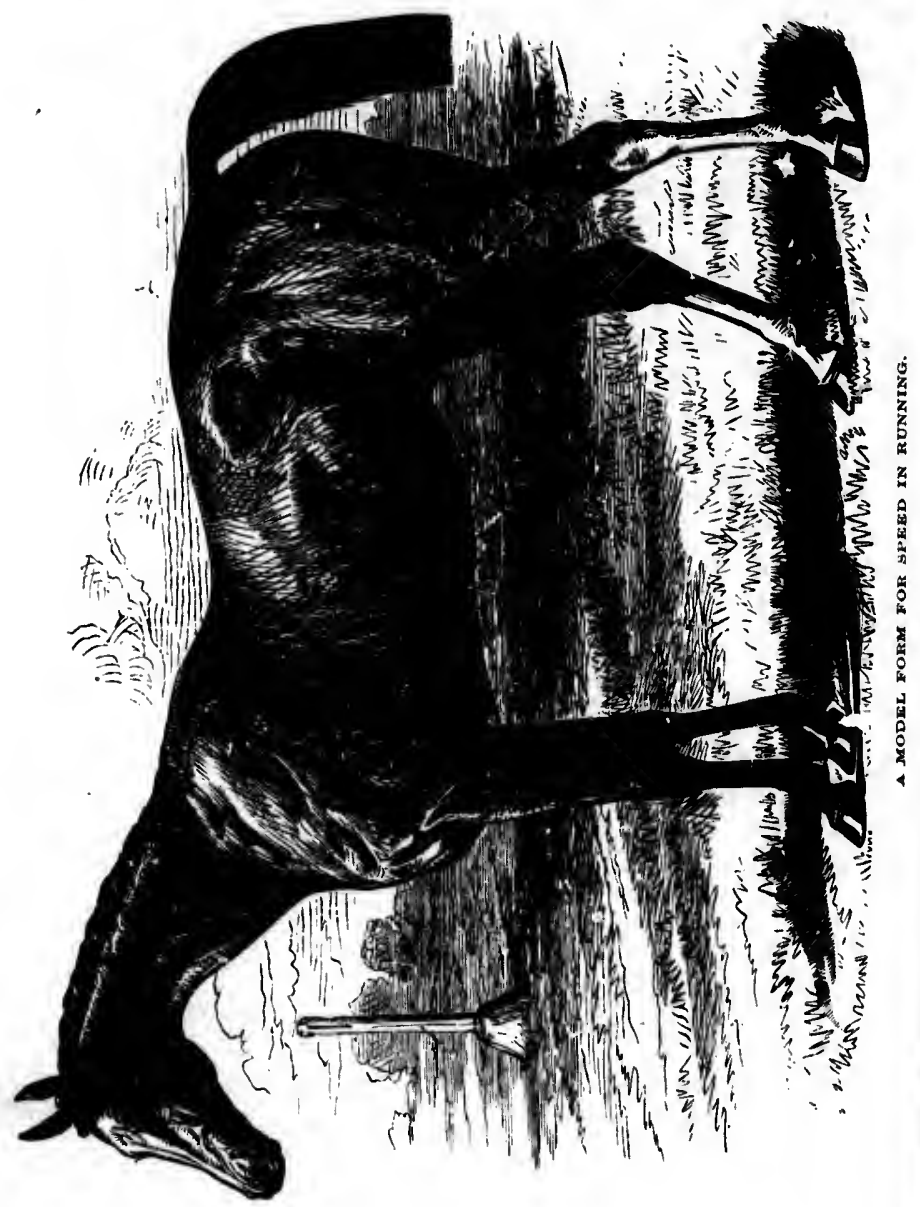

great courage with docility. The accompanying illustration will give a correct idea of a horse of great speed, high courage and lasting powers of endurance.
Thev are legi speed or work, cipal disabilities

1.- BONE SP. look at the hor hocks; for ring Feel the bones a appe:tr, reject th riding or driving 2.-STUMBLiN show the marks callosities. Th pace, with an on leg than on the animal a man cs the latter, since 3.-KICKING.if approached in sometimes from their ears more c tention. Exami marks of their hc propensity when 4.-Pulling A close yard, with about half an hov 5.-CRIB-BITIN the central inciso able lim to get stump, or at a being in his sight 6.-BALKING when they do, th denly when unde. ficult to detect, months all right, exhibited by bad respectable owner if a person stran 


\section{To Avoid Vices and Defects-How to Detect.}

I'hev are legiou, and he who at present buys any horse, whether for speed or work, must be on his guard against them. Among the principal disabilities to be guarded against are :

1.- BoNe spavin, CURi, RING-BONE AND spLINTs. - To detect these look at the horse from before and behind, for spavin and curb at the hocks; for ring-bone, at the fetloeks; and for splints, below the knee. Feel the bones at all these parts for tenderness or enlargement. If they uppeil', reject the horse instantly. He will be worthless as a sire, or for riding or driving.

2.-Stumbling.-Examine the knees to find if they are scarred, or show the marks of previous injuries, or that have been operated upon for callosities. Then walk him over somewhat rough ground, and at a slow pace, with an entirely loose rein, to see if he trips or goes weaker on one leg than on the other. If he is a stumbler, he is the most dangerous animal a man can own, unless it be a kicker; in fact, more so than the latter, since kicking may be guarded against, when knowing the vice.

3.-KICKING. - If this is suspected, the animul will lay back his ears if approached in an apparently careless manner, though horses do this sometimes from mere playfulness. If they are vicious, they will lay their ears more completely back, and the eyes will also denote their intention. Examine the stall where it is known they have stood for marks of their hoofs, and above all, give the aninal a chance to show his propensity when the groom is not near.

4.-Pulling at the halter or bridle when tied.--Tic him up in a close yard, with a halter he can easily break, leaving him quite alone for about half an hour, to exhibit his propensity if he will.

5.-CRIB-BITINa.-If the horse is a confirmed crib-biter, his teeththe central incisors-will show wear where he has grasped objects to enable him to get leverage to perform the operation. Tie him out to a stump, or at a post about three feet high, and watch him, no person being in his sight.

6.-BALKING AND BACKING.-Horses seldom balk under the saddle; when they do, they are dangerous in the extreme, often stopping suddenly when under motion, or backing into dangerous places. It is üifticult to detect, for they will sometimes go days, weeks and even months all right, and then suddenly show the vice. As a rule, it is exhibited by bad tempered, badly trained horses. A warrant from a respectable owner is the best guaruntec. It may sometimes be detected, if a person strange to the horse mounts and attempts to start him sud- 
denly. In harness it may often be detected by the manner in which the aninal starts and travels.

7.-The Rogue.-The rogue is the horse of vices; loe may take the bit in his mouth and run away, he will rear, back, kick, strike, bite, and do twenty other unpleasant tricks, not always from pure vice, but often from exhuberance of spirits, or from being crossed in some way. They generally perform well enough after they have found ont that their rider is their master. They are difficult to detect in their vices, except by the thorough horseman, who is well versed in every expression and act of the horse.

8.-Bishoped Teeth.- So named from the scoundrel who invented filing an old horse's teeth to make him look young, oven to burning and blackening the cups formed. A careful study of the chart of the horse's teeth, given in this book, will enable any person to detect this, since it is impossible to cover the shrinizing of the gums, by which the teeth show narrow, and are peculiar in slape.

9.-WEak Eyes.-Whatever the occasion, have nothing to do with a horse with bad eyes. Bring the animal from a rather dark stable just inside the door where the full ligh may strike the eyes. Examinc the lids and pupils curefully, to see if there is any considerable shrinking; the eye should be able to bear the full light. Horses are sometimes nearsighted, and also far sighted. Nearly all shying horses become so either from defect in vision or from cowardice.

10.-Moon Eyes.-This is a specific ophthalmy, from which one or both eyes periodically change color, and during the paroxysm it may become entirely blind. During the interval the eyes look natural. It is better, if the buyer suspects this, to take a warranty against it.

11.-Bundness.-This is sometimes difficult to detect by the ordinary observer by looking at the eyes. In rare cases the eyes may seen natural. A blind horse, however, may be detected by his mode of progression. As an example we give an illustration showing the mode of progression of a totally blind horse.

\section{Othor Faults and Imperfoctions.}

The disabilities noticed in the previous sections are those of positive unsoundness, or else of determined vice. Some others that should not he overlooked, are easily discovered by careful examination and test. These are :

1. Grass Ere.-This, if not complicated with specific disease, does not interfere with sight in any respect. It is a serious defect, simply $s 0$ far as looks are concerned. Usually only one eye has this peculiar white glussy appear: affect the pric

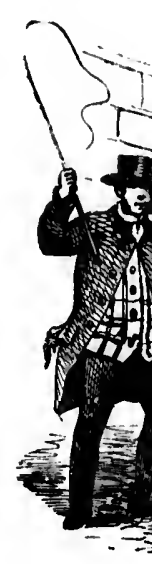

2. WIITE $S$ eye of a young near the outer c increasing to the ration is variable a short time. I history is known cataract or not. this is entirely a

3. Roaring.larynx or trache sound when the States, being chi chronic cough. horse of fast wo discovered by urs

4. Oblique ? the muscles of $\mathrm{th}$ a surgical operati horse, and especis 
glassy appearance, the pupil perfeet, and the iris quite natural. It should affect the price of the animal, only as detracting from elegance.

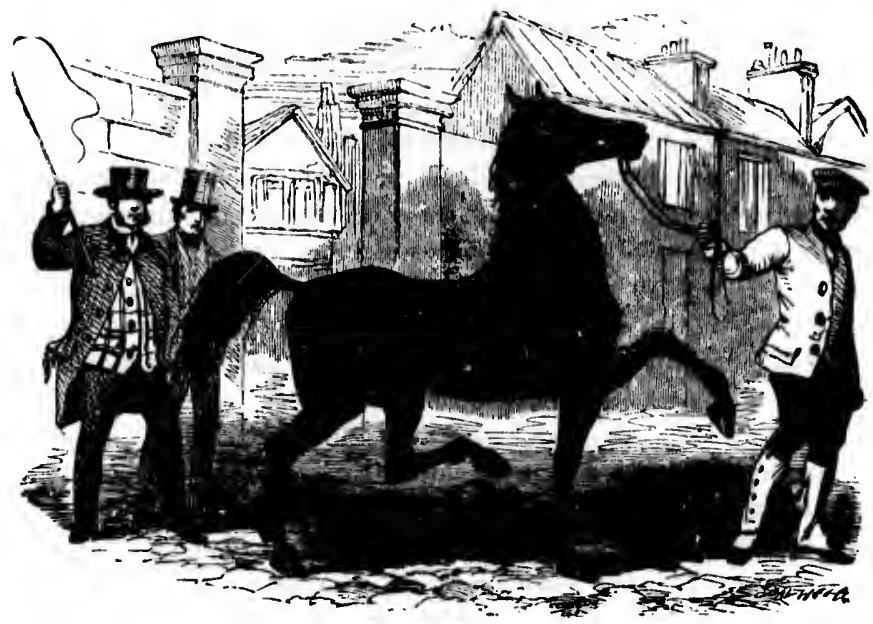

THK MODE IN WHICI A HORSE PIOGRKSSKS WUEN BLINP.

2. Wirte SPOt.-Sometimes a small white spot will appear on the eye of a young horse, generally after three years of age, and usually near the outer corner. It has a peculiar cloudy app arance, sometimes increasing to the size of a hemp seed, and occasionally larger. The duration is variable, sometimes lasting for years, and again disappearing in a short time. It really impairs the vision but little, if any. Unless its history is known a veterinary surgecn should decide whether it is ineipient cataract or not. Some veterinarians have termed it spurious cataraet, but this is entirely a misnomer. The name white spot describes it perfectly.

3. RonRING.-This is the result of obstruction in some part of the larynx or trachea, impeding the breath, and eausing a peeuliar roaring sound when the animal is in motion. It is rarely found in the United States, being chiefly confined to draft horses. It is often the result of chronic cough. In Eugland it is quite common, and when present in a horse of fast work, will render him worthless for the road. It may be discovered by urging the horse to a fist gait.

4. Oblique TaIL, on Wry TAIL.-This is eaused by contraction of the muscles of the tail on one side. It may sometimes be improved by a surgical operation, and shoild be considered a serious defect in any horse, and especially so in a driving horse. 
5. Turning the Toe of tire Hoof out or in Unduly, Sand Crackg, Quartei Cracks, Disi Hoofs, Over-keaching, Interfering, etc., are all to be looked for before finally buying a horse. They are all disabilities that should not-be present where the purchaser pays full price for the animal. They are, however, all so apparent that the purchaser is to blame if he fails to sec them.

6. WoLF TeEтн.-These rudimentary teeth, which are found in some horses but not in mares, and which have been supposed by ignorant persons to produce blinduess, and other diseases, are entirely harmless, except for the abrasion they sometimes occusion to the tongue and cheeks. If they do so they are easily taken out by any sensible blacksmith. In fact it is quite well to extract them, not that they will produce serious disease, but simply because they are not of any value, are useless to the animal, and may occasion slight inconvenience.

7. Shying.-This is one of the most dangerous habits a horse can have, whether it be occasioned by cowardice - seldom the case ; injudicious punishment-more comıon ; or from defective eyesight, or from all these combined. If you are so unfortunate as to have a shying horse endeavor to break him of the vice by allowing him to examine objects of which he is afraid, by speaking soothingly to him, but never by whipping or spurring him. When he shows a disposition to shy turn his head to rather thim from the object. Stop him ; let him approach the object and touch it with his nose, for soon he will approach it himself. If simply caused by nervousness, he may thus be cured. If caused by being short sighted there is no means of relief. Before you buy a horse be certain that he has not this infirmity, as dangerous a one as it is disagreeable. Such an animal is only fit to be driven by the side of another horse who wil. keep him to his work, and upon which he at length will come to depend, or of being driven as a wheeler in a team of four horses. 


\section{HOW TO BUY, CONTINUED.}

I. BUYiNg CheAP hORSES.-II. COLOR, iN RELATION tO VALUE. - II. ACTION. - IV. FABT-WALKINO HORSES. - $v$. WHAT A HORSE SHOULD BE, — VI. WHAT CONSTITUTBS UNSOUNDNESS. - VII. ILLUSTRATION OF FORM AND SYMMRTRX.—-VII. THE BODY AND LIMBS. - IX, THE BODX AS STANDING FACINO YOU.-X. FRONT VIEW OF YORE-QUARTERS, SHOWING DIPFERENT BAD CONFORMATIONS. - XI. TIK HIND-QUARTERS.—XIY. THE VIKW FROM BEHIND. - XIIl. WHAT NOT TO BUY, - XIV, BUYING FOR BLOOD.

\section{Buying Cheap Horses.}

In the preceding chapter on this important subject we have endeavored to show some of the principal points to be considered in buying a horse, especially those relating to the use for which they are intended. There is one rule that will always. apply in buying any horse. Never buy him because he is offered at a price evidently far below his worth, that is, except it be from a friend that you can trust, who does not want the horse himself, and wishes to do you a favor. These cases will be found very rare. In every other case rest assured the horse has some dangerous vice, or is permanently unsound. In this country never buy a horse at any price which has any appearance of broken knees by falling. Hunting horses are too rare here for one to have gotten the hurt in the field, and, accidentally, by being put at a barrier beyond his power.

Reject a horse with any weakness in his eyesight, unless you have use for a blind horse, then buy him at a blind horse's price. A one-eyed horse may do useful, but not elegant work. Never buy a lame horse at any price, until you are assured that the disability is not permanent.

Foot lameness, except it may be from a slight corn, and consequently 
curable, should bo un insupernble bar to purchise. You can never pateh up a bad foot. Therefore be sure you always try the intended purchase on a hard road. Mnny game horses, dead lame on hard roads, will get along without much flinching on soft roads, or the turf. If you are certain as to the eause of the lameness and know you can cure it, the purchase, as a speculation, may do ; but never rely on the assurance of the horse dealer. It is his business to sell.

Never buy a narrow chested horse for hard service. It shows weak lungs and those liable to inflammation. If for saddle, avoid a very broad chested horse, though us trotters they are sometimes fast. The best und most perfeet ehest is a medium between the narrow and broad chest.

A ked up washy looking horse should be avoided. They may indeed do for light work or short drives, but are totully unfit for renl work.

In buying avoid nll defects in the wind; he sure the disability has not been temporarily covered up, by speeial means known to horse dealers. A whistler or roarer may show no indicntion of his infirmity at a slow pace, or up to a certain speed. Beyond that it is apparent. Broken wind is an incurable infirmity and probably as distressing to the horse as the asthma is to man. A horse may make more or less noise and yet not have broken wind. Any indication of this, however, is to be looked on with suspicion.

In buying a horse his points of excellence and infirmity are better shown if only in fair working condition than when very fat. A horse very fat is pretty nearly a useless creature until his condition has been brought down to that of bone, sinew and muscle, with just sufficient fat to lubricate, so to speak, the working parts. Yet a horse for slow draft may be serviceable and earry far more flesh and fat than one used for fast work. Many superior horses have been ruined by hard driving when fat, or soft.

\section{Color in Rolation to Value.}

It is a saying as trite as it is old that any color is good in a good horse. Yet a horse, however good otherwise, should be invariably rejeeted if his color is bad. For instance, it would essentially mark both an ignorant and vulgar person who would select a piebald, spotted, or otherwise extraordinary color for a carriage horse. It would savor of the circus or show ring.

As saddle horses for gentlemen, self-colors are the best, and those distinet. A star in the forehead and two white feet behind give character. A snip in the face, if large, is objectionable. Four white stockings more so. Bay, brown and dark chestnut are the preferable colors. If the horse is exe Gray horses docile. For that rime con gant if of go and form, is

For single or euriously in distinct er strong contrit be harmonion brown : a cres and tuil would cream-eolored the most man except both w where the fine mismatch in riage as possi

There are re high-stepping, parade and sh high-stepping slow und safe,

A horse with his hind legs round action in sure-footed, bu Horses that st neither of thes saddle horse or

We have bef only indispensa could have for four and a half 2-3-4 time, noc gets such a hor 
horse is exceptionably stylish, blnek and dupple gray are gool colors. Gray horses are often hal tempered, mul black horses are not as a rule, docile. For ladies' use "dark crem eolor with white mue and tail, or that rure combinution, a durk chestnut with darker tail und mane are elegant if of good form. So a struwberry roun, if unexeeptionuble in style and form, is elegint.

For single or donble light driving, all distinet eolors are good. Uneven or curiously marked horses are allowable in a fancy team- is a mismutch in distinct colors-as it is ealled. The eolors should be distinct and in strong contrast, or else hurmonious. I chestnut and $n$ dark buy would be harmonious, and yet distinct colors. So wonld be a clestnut and a brown : a crean with white mane and tail, and a chestnut with dark mane aul tail would show a marked contrast, and yet be elegant; so wonld he creim-colored horses so marked. A pure whito and a jet black would be the most marked contrast possible, and not for a moment admissible, except both were faultless in form and style of going. Here in fuct is where the fine, art lies in teams of two distinct eolors: Whatever the mismatch in color, the team should be as near alike in form and carriage as possible.

\section{Action.}

There are really but two styles of action : low, smooth, safe action, and higrh-stepping, showy action. The latter of little account except for parule and showing off on the rosid in cunnection with fine style. A high-stepping dolt is as unsafe as he is unguinly. The action that is slow and safe, and fast and safe, if combined in an unimal is invaluable.

A horse with really good action moves all his limbs evenly, and brings his hind legs well under him at every movement. Some horses with round action in front-paddlers they are called-are often staunch and sure-footed, but this is in spite of this action, not in consequence of it. IIorses that struddle behind are often exceedingly fast trotters. Yct neither of these movements are what would be sought, either in a fine saddle horse or in a good harness horse.

\section{Fast-walking Horses.}

We have before stated that a perfect and fast walking gait was not only indispensable to every horse, but the most valuable gait a horse could have for cvery day use. Yet we seldom see a hor'se that will walk four and a half or five miles an hour, even when urged and in regular 12-3-4 time, nodding his head harmoniously in eadence. If a purchaser gets such a horse, or one that will do four miles under the saddle with- 
out stumbling, shufling, dropping the step or brenking, be sure you have a good one at speed, if ho has speed, for many great walkers are an broad chested that they eannot trot fast, und in galloping they will roll.

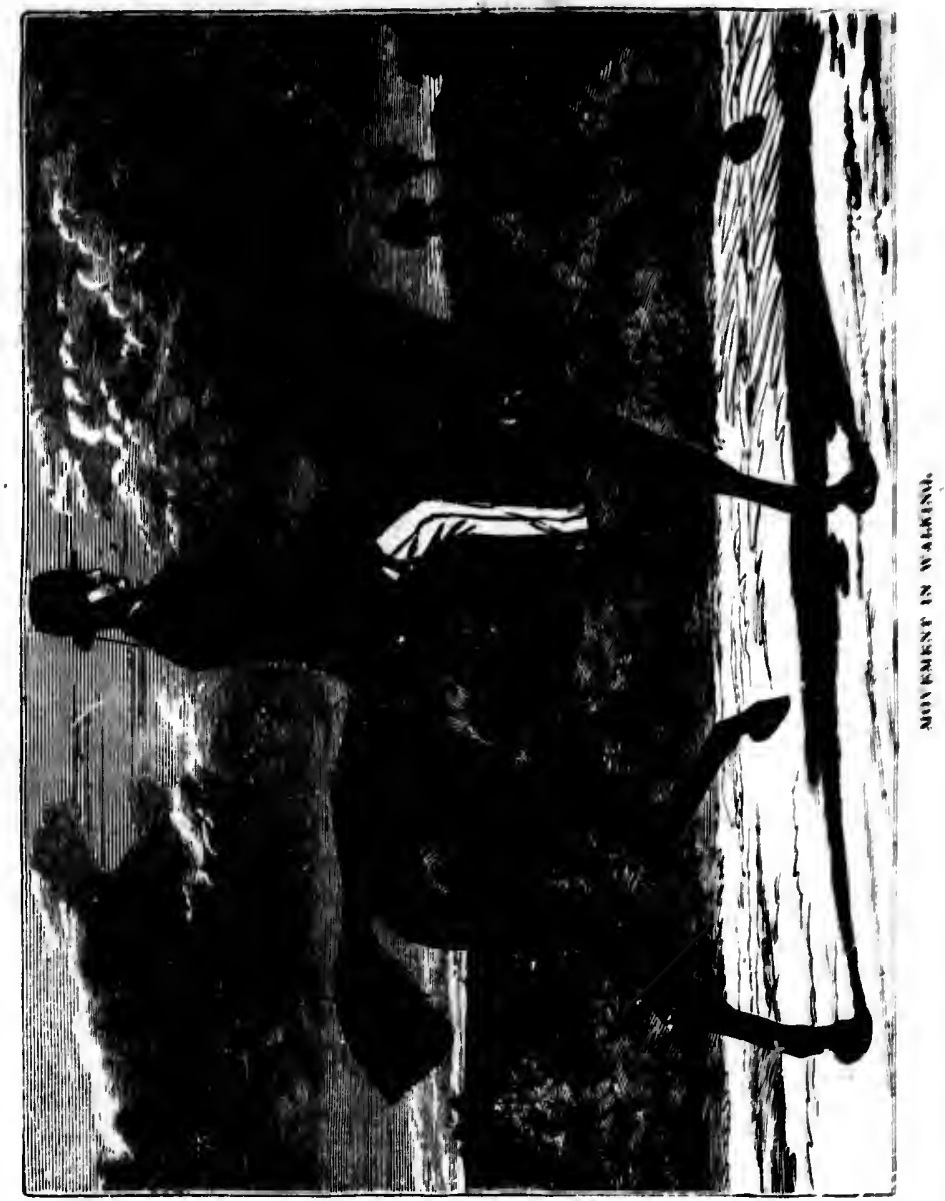

Yet occasionally a horse will be found good at all gaits. When so, it is the result of exceptionably good form and careful training. He who can so tras a horse, may get a long price for his trouble and skill.
We have b horse, and has should bo sul authorities, we structure of $t]$ conformution.

"The points. indeed the who motors all th Therefore, to ohliquely set, atrove. The u broad, flat ind not round, witl and oblique, be werikness; tho generally large large, powerful from behind. et down, so as should be lárge heir posterior short and flat, : should be short which ought to and for a horse great speed and deep from the $t$ which is called these parts give neck and setting the animal, but bence, with an animal cannot b one to manage. above from the so set on that w bow, and brings the ehest. Hor: conversc of thi 


\section{What a Horse Rhould Be.}

We have been very minute in stating the points of porfection in a horse, and have been particular in urging that the lungs, limbs and feet should be super-excellent. In nddition, and as from one of tho best authorities, we quote from the late H. W. Herbert, upon the physienl structure of the horse, before illustruting physieal perfection nnd perfect conformation. Mr. Herbert silys :

"The points of the physienl structure of a horse on which the most, inded the whole of his utility depends, are his legs. Without his loeomotors all the rest, however benutiful it may be, is nothing worth. Therefore, to these we look first. The fore-shoulder should be long, obliquely set, with a consideruble slope, high in the withers and thin above. The upper arm should bo very long and museular, the knee broad, that and bony, the shank, or cmmon bone, as short as ma be, flut, not round, with elem. firm sinews; the pastern joints moderately long and oblique, but not too much so, as the excess produces springiness and wakness; the hoofs firm, erect or deep, ns opposed to tlut, and the feet generally large and round. In the hind-legs the quirters should be large, powerful, broad when looked at in profile, and square and solid from behind. The hums should be sickle-shaped, not strnight, and well et down, so as to bring the hocks well toward the ground. The hocks should be large and bony, stright, not nugular and convexly curved in heir posterior outlines; the shanks, corresponding to the camnon bones, short and flat, and the hind feet similar in form to the front. The back should be short above, from the point of the withers and shoulder-blade, which ought to run well back to the eroup. The barrel should bo round, and for a horse in which strength nnd quickness are looked to more thim great speed and stride, closely ribbed up. A lorse can scarcely be too deep from the tip of his shoulder to the intersection of his fore-legwhich is called the heart-plnee-or too wide in the chest, as room in these parts gives free play to the most important vitals. The form of the neck and setting on of the head are essential not only to the benuty of the animal, but to the facility and pleasure of riding or driving him; bence, with an ill-shaped, short, stubborn neek, or ill set on head, the animal cannot by any possibility be a pleasant-mouthed horse, or an easy one to manage. The neck should be moderately long, convexly arehed above from the shoulders to the erest, thin where it joins the head, and so set on that when yielding to the bit it forms a semi-circle, like a bended bow, and brings the ehin downward and inward until it nearly touches the ehest. Horses so made are always manageable to the hand. The converse of this neck. which is concave above and stuck out at the 
windpipe like a cock's wattle, is the worst possible form ; and horses so made almost invariably throw up their heads at a pull, and the most exceptionahle of brutes, regular star-gazers. The head should be rather sinall, bony, not beefy, in the jowl ; brond between the eyes, and rather concave, or what is called basin-faced, than Roman-nosed, between the eyes and nostrils. The ears should be fine, small and pointed; the eyes large, clear and prominent, and the nostrils wide and wall opened. A horse so framed cannot fail, if free from physical defects, constitutional disease and vice, to be a good one for any purpose - degree of strength, lightness and speed being weighed in accordance with the purpose for which he is desired."

\section{What Constitutes Unsoundness.}

1.-Spavin, whether it be bog spavin, blood spavin or bone spavin, when sufficiently developed to be known.

2.-Ossification of any of the structures adjacent to any of the joints and also without doubt ossification of the lateral cartilages.

3.-Corns are considered as constituting unsoundness, but they must be discovered within a short time, say a few days of the purchase.

4.-Curbs constitute unsoundness, but they must be shown to exist at the time of the sale.

5.-Founder or Laminitis, is unsoundness whether it produces lameness or not, for if it has existed the laminæ will have been injured and the horse will be lanne when worked.

6.--Pumiced Foot is unsoundness as evidence of laninitis.

7.-Quittor may render the horse permanently unsound.

8.-Ring-bones and side-bones constitute unsoundness.

9.-A Verved Lorse is unsound as showing the existence of disease for which the operation was performed, and also from the division of tile nerves.

10.-String-Halt is unsoundness.

11. - Thrush is so.when severe.

12.-Breaking down, even though the horse has recovered so as not to go laune.

13.-Thickening of the Back Sinews, or suspensory ligament, if known to exist, is unsoundness.

14.-Broken Wind, Thick Wind, Whistling and Roaring are all considered as constituting unsounduess, as forming impediments in breathing, injuring the animal for drawing or other active service.

15.-Farcy and Glanders.

16.-Grease and Mange.
17.-Cough unsound.

18.-Megrie before the sale

19.-Ophtha of a veterinary of the disease.

20.-Catara 21.-Broken

There are als 1.-Biting,

2.-Bolting,

3.-Crib-biti

4.-Kicking,

5.-Balking.

6.--Rearing.

7.-Shying,

8.-Weaving body from side $t$

VII

unsoundness $\mathrm{x}$ ation of structur Vice may be de the natural usefu either must be $\mathrm{m}$ would not constit

1-Slight bog 3-capped hocks, sult of diseasc, la ough pin, and $8-$ in a mild way.

the case of thrus? be lame at the tim or 11 , winägalls.

They are found When a horse is so. Do not allow cover the whole gr

Received. ...(insd 
17.-Cough, if it lasts. A horse with a chronic cough is clearly unsound.

18. - Megriems, if it ean be shown that the horse has had an attack before the sale.

19.-Ophthalmia, if it occurs soon after the purchase. The evidence of a veterinary surgeon may be necessary to show the previous presence of the disease.

20.-Critaract, however slight, constitutes a horse unsound.

21.-Broken kness, when the joint is injured.

There are also vices for which a horse may be returned. These are:

1.-Biting, when clearly vicious.

2.-Bolting, or running away.

3.-Crib-biting.

4.-Kicking, when shown to be vicious.

5. - Balking.

6.--Rearing.

7.-Shying, when habitual.

8.-Weaving in the stable; that is, the horse throwing his head and body from side to side with a peculiar motion.

\section{Definition of Unsoundness and Vice.}

Insoundness may be considered to be the existence of disease or alteration of structure sufficient to impair the natural usefulness of the horse. Vice may be defined as the prevalence of a habit which interferes with the natural usefulness of the horse. In unsoundness or vice, however, either must be marked, as for instance the following diseases or accidents would not constitute unsoundness :

1-Slight bog spavin; 2-broken knee, when the joint is not injured; 3-capped hocks, or elbows; 4-contractions of the foot, unless the result of disease, laming the horse ; 5-curby hocks; 6-splints; 7-thorough pin, and 8-thrush, are not unsoundness in their incipient stage, or in a mild way. But the buyer should refuse all such except, perhaps, in the case of thrush. 9-Cutting is not unsoundness, except the horsc he lame at the time of sale, neither $10 \longrightarrow$ soreness of the joints from labor, or 11, winàgalls.

They are found often upon colts, but if the animal be lame reject him. When a horse is bought on warrantee, it must be written and concisely so. Do not allow verbiage to cause litigation. The following form wil cover the whole ground:

Received.........(insert place and date) of $\boldsymbol{M r}$. (Insert name). .Dollars, 
for......(describe horse or mare, and pedigree of same, if any).........varranted..........years old..........(state age).........sound, free from vice, and quiet to ride or drive.

When filled out this might read us follows:

Received, St. Louis, Mo., March 1st, 1880, of Mr. Juhn Doe, five hundred dollars for a bay mare by Lancer, dam Lady, warranted five years old and under six years, sound, free from vice, and quiet to ride or drive. Ricinard Rov.

This, with such careful examination as we have advised, ought to insure any buyer against danger in case the seller is solvent.

\section{Ilustrations of Form and Symmetry.}

The head of the horse is the scat of intelligence, and to the conformation of the head we must look not only for intelligence but docility and courage, or the opposite character, as we must look to the teeth for indications of his age, to the nostrils as indicating his eapacity for breathing, to the muzzle and jaw for indications of capacity and feeding, and to the eye and ear as showing fire, courage, and good temper. No man's head and face are more expressive than are these clements of a horse.

Speed and bottom, which means the bone and muscle of good breeding whatever the family of the horse may be, is the sine qua non desired in a horse. His mission is labor, work of some kind, whether it be currying a man on his back, or trotting to a wagon, or hauling a load through the mud. The head of the horse is, therefore, one of the first things to be looked at. The extract we have given a few pages back, from one of the most eminent writers of this country on the horse, will convey an idea of what a riding or driving horse should be. The nearer the horse, for general utility, comes to the illustrations we have given, the better be will be.

The horse for heavy draft, while coarser, nore stocky and heavier in his frame, should conform to the general characteristics except that he should be more upright as to his shoulders, and not so flexible as to his limbs; then the better will he be. In fact one of the best draft horses we ever owned was $\mathrm{u}$ three parts bred Monmouth Eelipse, seventeen hands high, weighing $1250 \mathrm{lbs}$., pretty well up on legs, and those of exceeding flexibility. But when he got down to work he appeared to go close to the ground. This getting down to work-this getting elose to the ground with the body, so every bone and sinew may exert the greatest possible leverage, is one of the fine arts of training. It really brings the oblique shoulder of the blood horse stranght in the collar a possibility few horses hav $\bullet$ the knack of attaining naturally.
Explanation. and front view what should co side and front the reider mily view, page 16 and yet bright shape and setti tine its finenes 'ulusculal' neck hetween the ey head, and yet widening and $s$ bones at the sic head between $t$ flexibility and si will be found $y$ healthy surface,

Let us now The side riew at nose and lower $j$ the nose. It is accompanied wi the head broad, The muzzle is $t$ The ear's, althou the hend is set or

The figure to $t$ will be noticed th are placed very page 182 ; too cl of the eye shows not held in that on page 182. Th

The figure of shows a head not shows doltishness show not ouly a $\mathrm{c}$ The lower side rating a horse th: willed, obstinate giving a Roinan 12 
Explanation.- The illustrations we give on page 182 show a side and frout view of heids of blooded horses, that may be taken as a type of what should constitute ns near perfection as may be. Those on page 183, side and front views of heads are bad. By comparing them with the text the reader may form a gqod idea of characteristics. Olsserve in the side view, page 162, a fine head, tapering to muzzle, the chin, the prominent and yet bright, elear and soft eye, with a rather prominent brow; the shape and setting on of the ears; the strength of jaw, and at the same time its fineness ; how the head is set on to the neck, and the fine, elean, aluicular neek as well. In the front view observe especially the width hetween the eyes, the eyes being in fact apparently at the side of the head, and yet looking straight forward: Observe the eheek bones, widening and strengthening the lower part of the head; the temporal hones at the side of the eyd; and the oeeipital bone at the top of the head between the ears. Especially observe the nostrils and lips as to flexibility und size. Turn baek the folds at the end of the nostril, and it will be found you ean look clear into the passage, showing a moist and healthy surface, or the reverse.

Let us now examine the side and front views of head on page 183 . The side view at the top shows a head somewhat heavy in character, the nose and lower jaw thiek to exeess. Observe the peculiar formation of the nose. It is not the dish face of the first illustration, giving temper, accompanied with intelligent obedience. The eyebrows are prominent, the head broad, but the expression indicates not only fire but malice. The muzzle is that of a cruel horse, the intelligence that of self-will. The ears, although of good shape and breeding, are thrown back, ana the head is set on at too great an angle with the neek.

The figure to the left shows the front view of a badly formed head. It will be noticed that it is of nearly the same widtl throughout. The eyes are placed very different from those of the front view of good head on page 182 ; too close together, and too much in front. The expression of the eye shows a stubborn disposition; the ears are good enough, but not held in that position of intelligent action as shown in the lower figuro in page 182. They are pointed too close together.

The figure of the front part of a head to the right, on page 183. shows a head not badly formed, but the general expression of the face shows doltishness, and the drooping ears, and the expression of the eyes show not only a cruel but a stupid disposition.

The lower side riew of head and neek on stune page shows a herd indi rating a horse that will not only be wild sometimes, but sulky; a selp willed, obstinite lırute, deficient in intelligence. The profile is eurved, giving a Roman nose; the eyebrows are raised, giving the eye a wild 12 


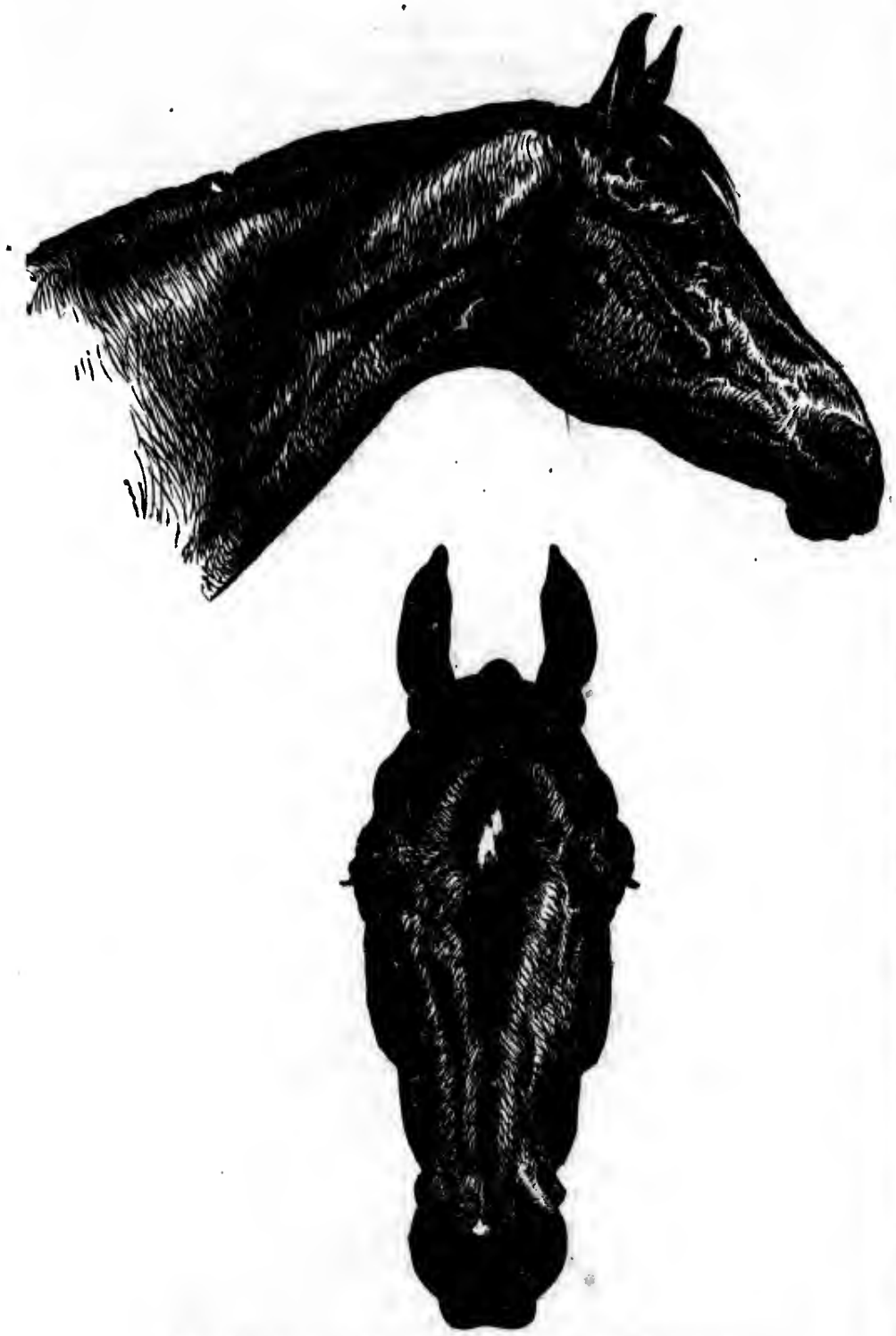

GISE AND FRONT VIEW OF HEADS-GOOD. (See Explanation).

BIDE AN 


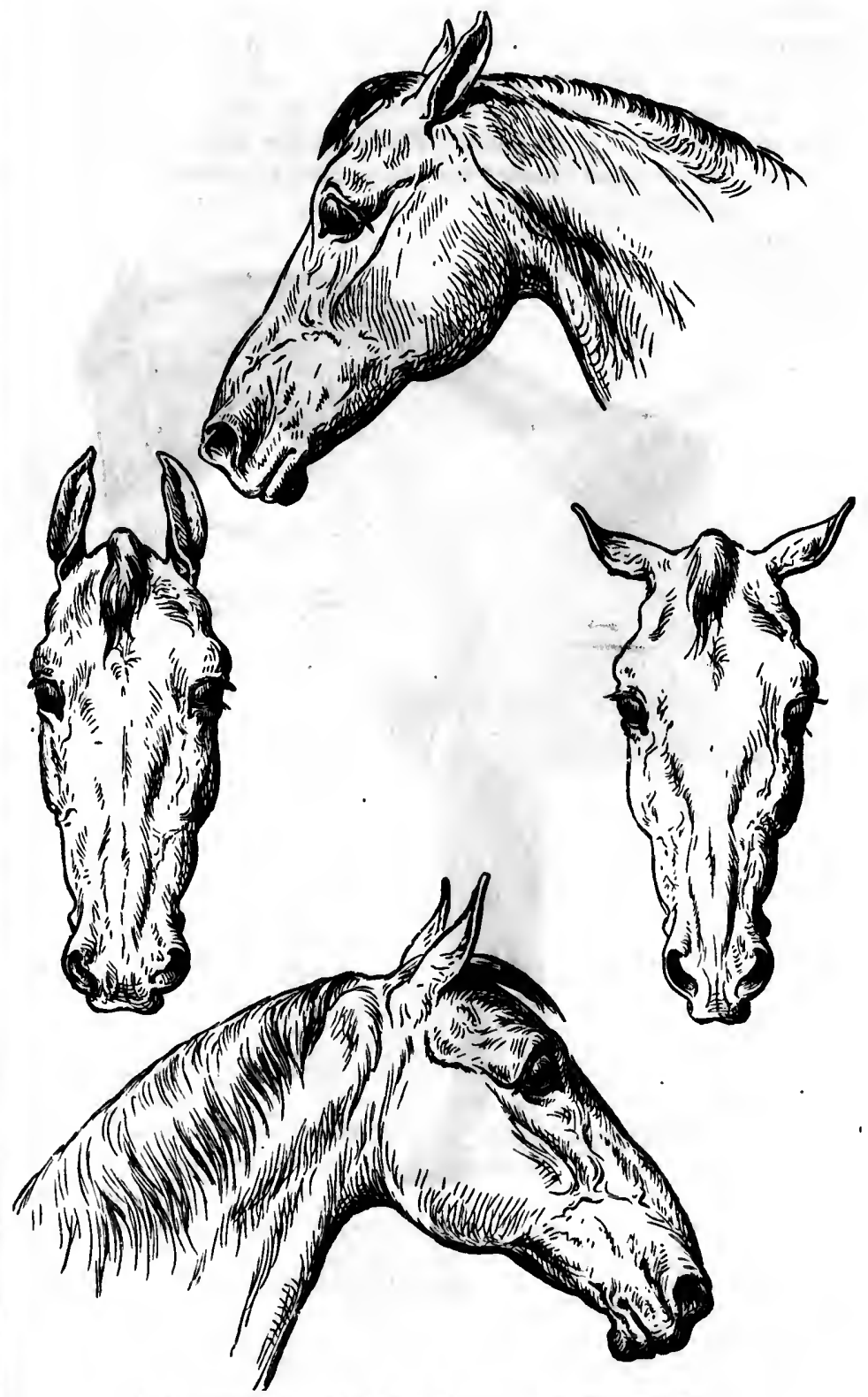

SIDE AND FRONT VIFW OF HHADS-BAD. (See Explanation). 
expression, and with the firm jaw, a stubborn character. Following the subject still further, we may find all the gradations of ehuracter, including the exhibition of nervous timidity, fear, idiocy, and even insanity ; for that there are horses subject to aberration, from mere hallucination to actual insanity, there is no doult. The latter the most dungerous trait in a horse, since neither earesses nor punishment can cure.

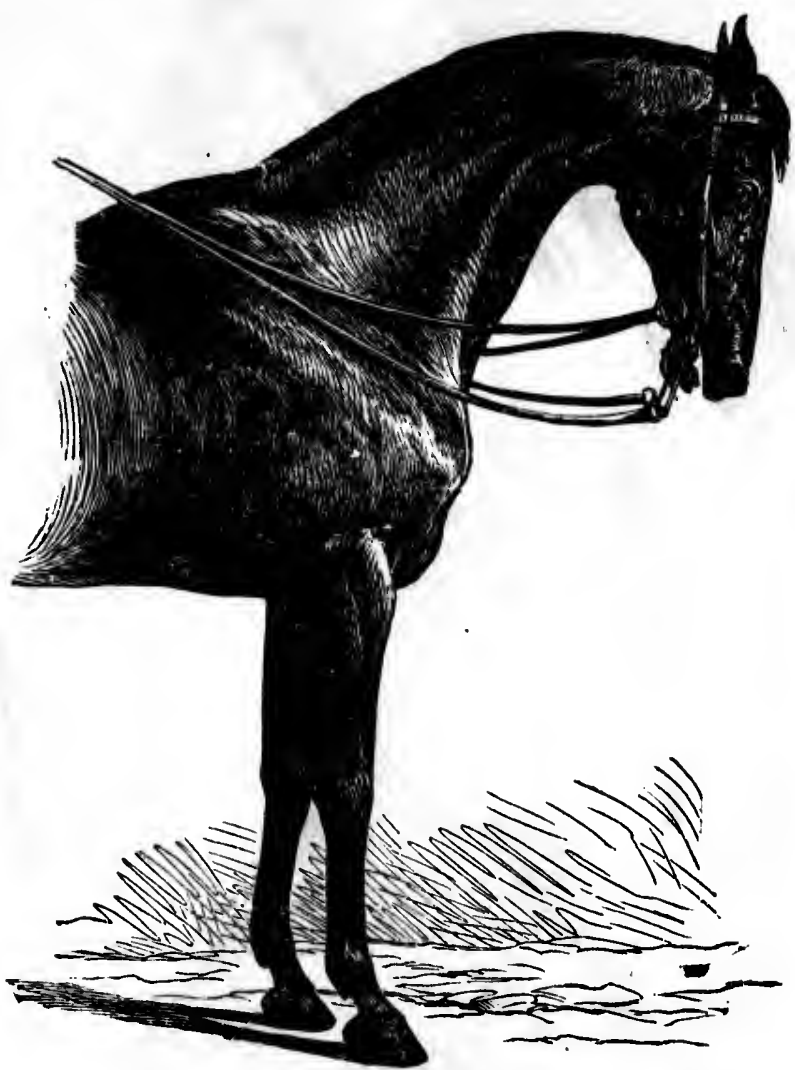

GDE VIEW OF FORE-QUARTERS, SHOWING A GOOD SHOULDER. (Seb Explanation.) IX. The Body and Limbs.

Explanation.-Following up the subject on pages 184, 186, and 187, we present side views, showing good and bad fore-quarters. The first illus staunch , without s shoulder ing to gi down to and yet locks of : of $\operatorname{good} d$ as shown. long cont trations $n$ written de not only a bave so ob of the bes

So the $\mathrm{t}$ might be should hat road, this practice $m$ of niere st one; yet t the highest the breedin.

\section{Explanat} to the left under. $\mathbf{T h}$ the shanks, knec and pa

The uppe ding one, a above being

The left well placed, straight.

standing on

The lowe or all combi not only we limbs in buy 
first illustration shows as near perfection as may be in the shoulcier for staunch qualities, good action and a fast walk. The neck muscular, but without superfluous flesh, but with plenty of substance where it joins the shoulder ; the shoulder oblique and deep; the shoulder-blade high, helping to give stability to the withers; the breast prominent, but tupering down to where the legs come out of the body ; the arm long, museular, and yet tapering; the joints large, but yet firm and compact; the fetlocks of fair length and yet flexible; and the hoofs of good size, round, of good deptl, tough and sound. An animal possessing the conformation as shown, will indicate a hosse good for any purpose where speed and long continued powers of enduranee are required. While the illustratious we give are perfect of their kind, and more valuable than any written description alone can be, yet the living animal must be studied, not only at rest, but in motion. The harness horse, however, need not have so oblique a sloulder as we have shown. In fact, few horses, even of the best class, do.

So the trotting gait, combining speed with high aetion and grand style might be considered vile in a saddle horse. In fact, the saddle horse should hive a springy yet smooth motion, and except for show on the rond, this will be found to be best for fast and easy work in harness. In practice much of this is often sacrificed, in pleasure horses, for the sake of mere style. The breeding of such horses is a fine art, often a costly one; yet those which fail in the style and action necessary to command the highest price as road and saddle horses, will be found to amply repay the breeding for the general purposes of the farm and for the road.

Explanation.-On page 186 are illustrations showing, the upper one, to the left, a str:tight shoulder, a heavy chest, and legs placed too far under. The ar'm seems longer than it is because it lacks muscularity; the shanks, while not positively weak, do not show due strength near the knee and pasterns, and are not as strong as they should be.

The upper figure, to the right, shows a shoulder as bad as the preceding one, and also weak legs and pasterns, the length from hoof to joint above being too great.

The left hand figure at bottom of same page, shows a shoulder fairly well placed, but with the legs set too much under, and the pasterns too straight. Such a conformation will give the horse the appearance of standing on the toes.

The lower figure to the right, shows what old age, hard work, abuse, or all combined, may bring any animal to, that originally may have been not only well lred, bnt of fair quality throughout. Watch for such limbs in buying, and avoid them. 

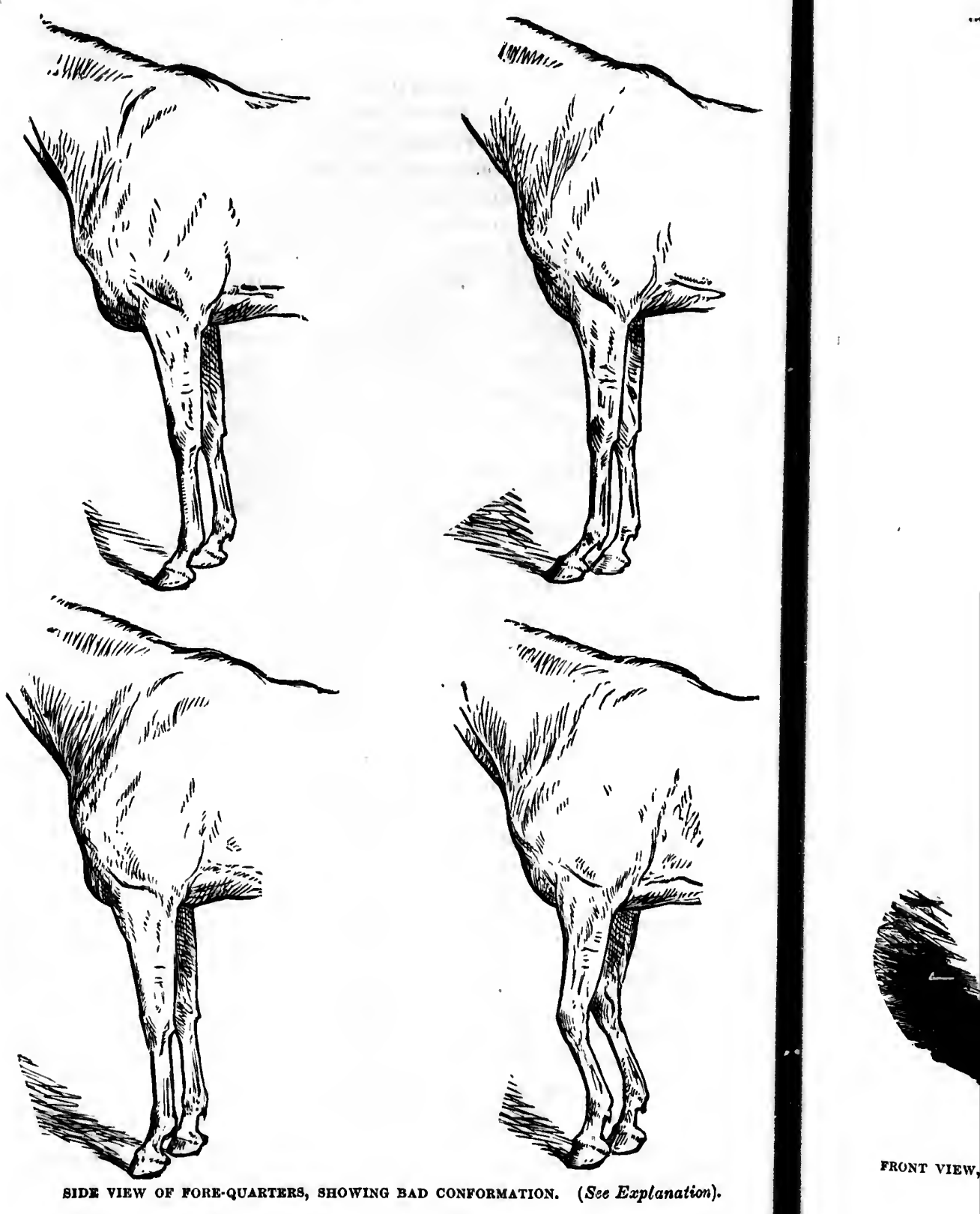
THE HORgE, HOW 'TO BUY.

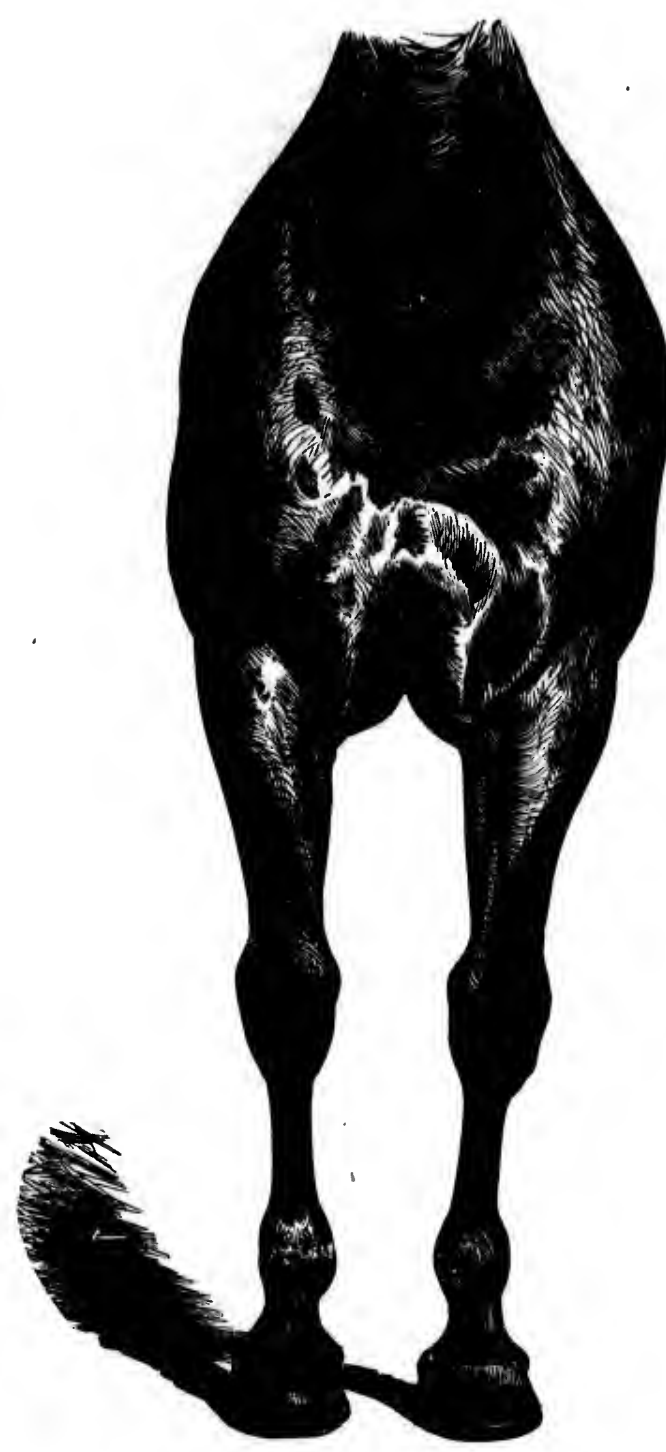

FRONT VIEW, SHOWING BREAST AND LIMBS-GOJD. (See Explanation). 


\section{The Body as Standing Faoing You.}

The body of the horse viowed in front should present an oval shape, squared off from the arm or elbow joint in front to the point of the shoulder as on pago 187. 'The perfeet contour of breast, and especiully the magniticent muscularity of the arm is near perfection. The neck rising grandly from the ehest shows the perfect proportion of the purts euch to the other; the knee und fetlock joints we strong and compact, grudunlly rounded to mect the shank or leg and bones of the pastern joint. The hoofs are staunch, tough, streng, with nothing about them to denote a flat foot, yet rather open behind, showing a perfect hoof.

Let us now examine the blood horse of the present day as quoted from Herbert, and nlso thit of the ancient Greeks as written upon by Xenophon. It will show that in those days the breeding of horses was a tine urt, as was also equestrinnism as exhibited in the exquisite seulptures that have come down to us. Yet the quotation we make will show that the horse of the Greeks, useful and admirable as he wus, was what the English would call a cab or Gallowny, with a dash of thorough blood, and what we would call pony built with a dash of thorough blood-something in fact like a ehunky Morgan horse. The quotation nevertheless will make a good study for the young horseman, and is as follows:

"We will write how one may he the lenst deceived in the purchase of horses. It is evident then that of the unbroken colt one must judge by the construetion, since, if he have never been backed he will afford no very elear evidences of his spirit. Of his hody then, we sny it is necessary first to examine the feet, for as in a house it matters not how fine may be the superstructure if there be not sufficient foundations, so in a war horse there is no utility, no, not if he have all other points perfect but be badly footed. But in examining the feet, it is befitting first to look to the horny portion of the hoofs, for those horses which have the horn thiek are far superior in their feet to those which have it thin. Nor will it be well if one fail next to observe whether the hoofs be upright, both before and behind, or low and flat to the ground; for high loofs keep the frog at a distance from the enrth, while the flat tread with equal pressure on the soft and hard parts of the foot, as is the case with bandylegged men. And Simon justly observes thit well footed horses can be known by their tramp, for the hollow hoof rings like a cymbal when it strikes the solid enrth. But having begun from below, let us ascend to the other parts of the body. It is ncedful, then, that the parts above the hoofs and below the fetlocks (pusterns) be not too erect, like those of the goat; for legs of this kind being stiff and inflexible, are apt to jar the rider, and are more liable to inflammation. The bones must not, howeve to be, al The bo the eolt and fle gallopec and wil skin be it often lame.

you may all horse Aud flex are mucl unbendis and inus with a 1 strength, which do "Agrai from the the chest have a sn the rider, horse thu be very ll in but by to observ or the otl likely to that a hor will see to for respirs when one being ridd the erest, the head produee a

'A dou than if it the horse and the sh 
however, be too low and springy, for in that ease the fetlocks are liable to be,abraded and wounded if the horse be galloped over elods or stones. The bones of the shank (eannon bones) should be thick, for these are the columns which support the body; but they should not have the veins and flesh thick likewise. For if they huve when the horse shall be galloped over diftieult ground they will neessarily be filled with blood, and will beeome vurieose, so that the shanks will be thickened, and the skin be distended und relnxed from the bone; and, when this is the case it often follows thit the buek sinew gives way mud renders the horse lame. But if the horse when in action bends his knees flexibly at a walk you may judge thut he will luve his legs flexible when in full gareer; for all horses as they increase in years inerense in the flexibility of the knee. And flexible goers are esteemed highly, and with justice, for such horses are much less liable to blunder or stumble than those which have rigid, unbending joints. But if the arms, below the shoulder-bludes, be thick and muscular they nppear stronger und handsomer, as is the case also with a man. The breast also should he broad, as well for beaty as strength, and beeause it enuses a hundsomer action of the fore-legs, which do not then interfere but are earried well apart.

"Agrain, the neek onght not to be set on like thut of a boar, horizontally from the ehest; lut, like that of a game coek, shonld be upright toward the chest, and slack toward the flexure; and the head being long should have a small and nurrow jaw bone, so that the neck shall be in front of the rider, and that the eye shall look down at what is before the feet. A horse thus made will be the least likely to run violently away, even if he be very high spirited, for horses do not attempt to run away by bringing in but by throwing out their lieads and necks. It is also very necessary to observe whether the mouth be fine and hard on both sides, or on one or the other. For horses which have not both jaws equally sensitive, are likely to be too hard mouthed on one si. ${ }^{2}$ or the other. And it is better that a horse should have prominent than hollow eyes, for such an one will see to a greater distance. And widely opened nostrils are far better for respiration tham narrow, and they give the horse a fierer aspect; for when one stallion is enraged against another, or if he become angry while being ridden, he expands his nostrils to their full width. And the lofter the erest, and the smaller the ears the more horse-like and handsome is the head rendered; while lofty withers give the rider a surer seat, and produce a firmer adhesion between the body and shoulders.

'A double loin is also softer to sit upon and pleasinter to look upon than if it be single; and a deep side, rounded town'd the belly, reuders the horse easier to sit, and stronger and more ensy to keep in condition ; and the shorter and broader the loin, the more easily will the horse raise 
lis fore-quarters und collect his hind-quarters under him in going. The joints, moreover, cause tho belly to appear tho smulier; which if it he lurge at once injures the mpenranee of the unimul and renders him wenker and less mungeable. The qunters should be broad and fenty in order to correspond with tho sides and chest, and, should they be entirsty firm and solid they wonld be the lighter in the gallop, and the horse would be the speedier. But if he should have his buttocks separated under the tnil by a broad line, with a wider space botween them, and so doing he will have a prouder and stronger gait and action, and will in all rewpera, be the better on them. A proof of which is to be had in mell, who, when they desire to raise uny thing from the ground attempt it by struddling their legs not hy bringing them close together."

\section{Front View of Fore-quarters, Showing Different Bad Conformations}

Explanation.-On page 191 the upper left hand figure shows the lext fuir to the knee, but from thence down, had, and with toes turned rery much out.

The next figure on the loft, is very bad, the knees turned out and the toes turned in ; a dangerous horse, and unfit for driving or riding.

The lower figure to the left is us unsightly as possible ; the legs spready, weak, straddling, and with the toes turned out. Such a horse may the tolerably sure-footed, if carefully managed, and not hard-driven, but one never to be depended upon.

The next figuro ut right of bottom, is bad all over, weak-limbed, kwowkkneed and splay-footed. A horse never to be depended upon and unserviceuble in the extrene.

Between these there aro muny grudations, which those who study theses pages may profit by examining and comparing with the front vien of a perfect shape given on page 187, and which carried fully in mind will go a great way in enabling one to form a pretty accurate opinion in fuying a horse.

\section{The Hind-quarters.}

It has been said that the fore-quarters of a horse are simply to hold him up, while the hind-quarters propel the machine. This in a sense is true. but a horse, however good his hind-quurters be, must not only have the fore limbs good enough to hold him up, but to keep him out of the way of the hind feet, and at the sane time assist in propelling the body. In fact, the whole animal should be composed of parts working harmoniously together, each assisting the other while doing its owu work; 
'ME HORSE, HOW TO HUX.
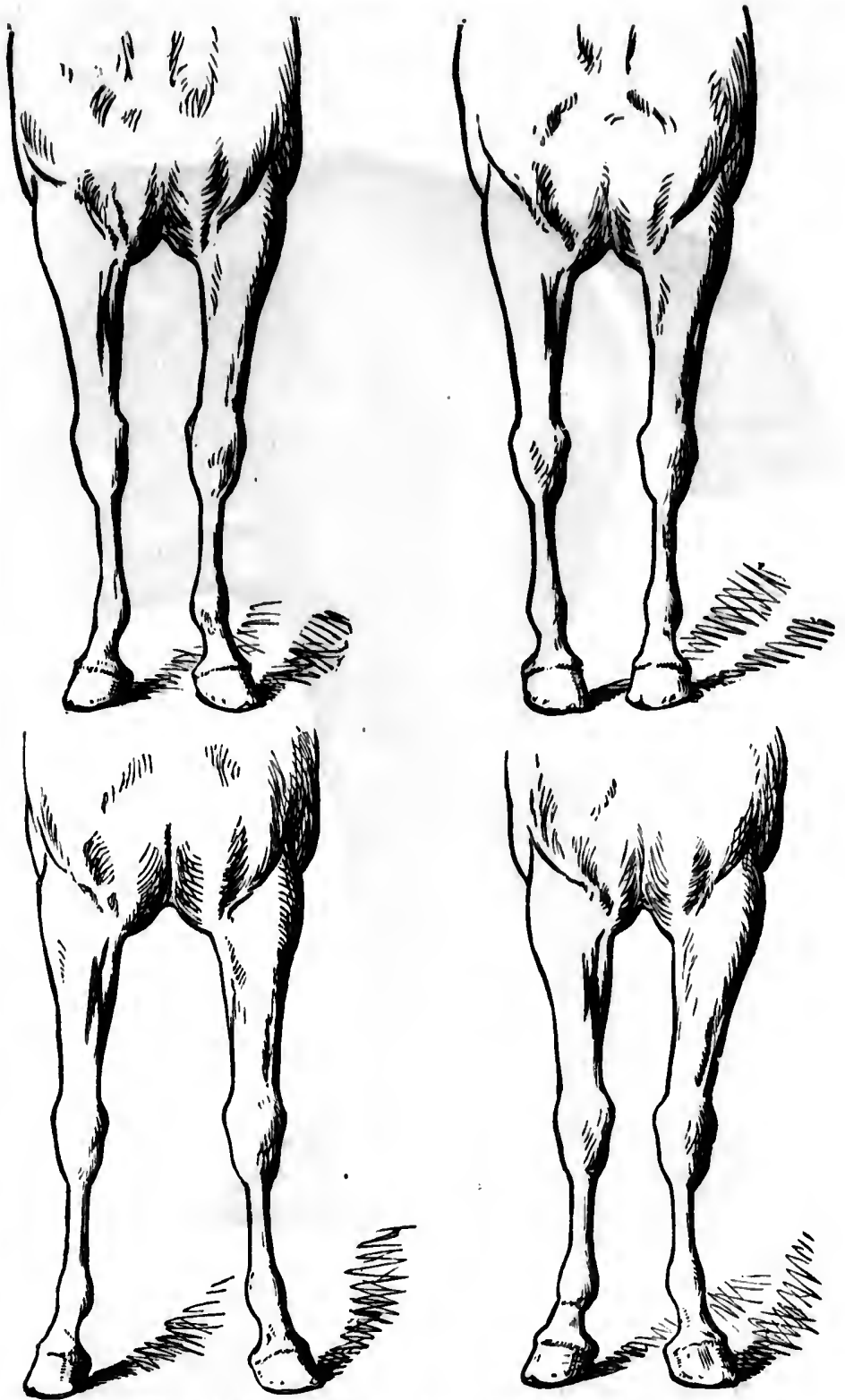

FRONT VIEW OF FORE-QUARTERS, BHOWING DIFFERENT BAD CONFORMATIONS. 
nevertheless the hind-guarters are the propelling power, especially when under the gallop. For then the motion is communicated by a succession of leaps, acting more in the nature of a balance than in walking or in

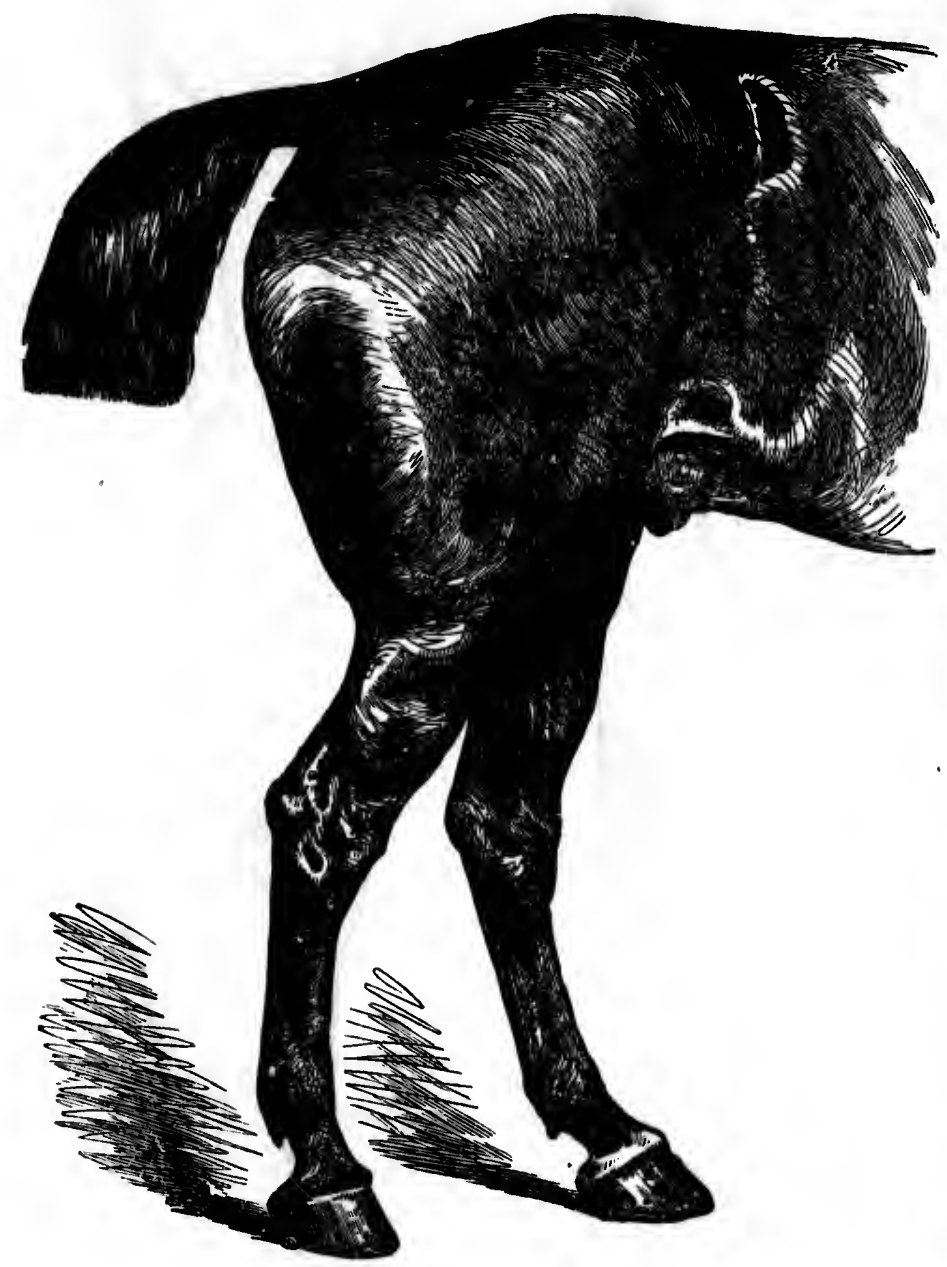

GOOD HIND-QUARTERs. (See Explanation.)

trotting. In order that the hind-quarters may do their work effecinviy, there must be a strong loin, anple and muscular quarters, great length of hip, strong and wide legs.

In order to at him from th leg alike. The neither should though he were square, and dis hind their true find if such a $p$ splints, damage and in the hind pin, as previous 192 , and if he "better.

Examine espe are nearly perl curvilinear prot there will be litt the hocks are dr as serious as it $i$ hind-legs are wi it may not weak some fast and st should be avoid goond hind-quarte

Oll page $194 \mathrm{t}$ in every way goc but lack this:acte

'The figure to hammed, with th also weak.

The figure to $t$ legs alle thrown $\mathbf{t}$ pasterus.

The figure to $t$ the position is er.

The view of th quarters, full and 
of hip, strong, dense bones, sinews like whip-cord, strong joints and flat and wide legs.

In order to determine this the purchaser should observe first, looking at him from the side, whether he stands resting perpendicularly on every leg alike. The legs should not be straddled outside of their true position, neither should they be gathered together, or in horse-men's phrase, as though he were trying to stand in a half bushel. He should stund straight, square, and distinctly on every leg. If lie stands with the hind legs behind their true position, induce him to move his fore legs forward, to find if such a position gives him ease. Examine him as before stated for splints, damaged back sinews, ring-bones or side-bones in the fore limbs; and in the hinder ones for bone blood or bog spavins, curbs or thorough pin, as previously described. If he stands as in the figure given on page 192 , and if he is free from blemish, one may go a long way to find a botter.

Examine especially whether the pasterns, outline of the hock joints, are neurly perpendicular or angular, or whether they present a convex curvilinear protuberance just above the union of the shank bone. If not there will be little danger of curb, or a tendency to throw them out. If the hocks are drawn in the horse will appear cow -hocked, a malformation as serious as it is ungainly, for thus the animal will be weak. If the hind-legs are wide apart and the horse straddles in going forward, while it may not weaken his stride it is not elegant. However true it be that some fast and strong trotters straddle - as going wide is termed - this should be avoided. The illustration on page 192 will slow aecurately gond hind-quatiters, as those on page 194 will show bad ones.

On page 194 the figure at the upper left side would be called fine and in every way good to the inexperienced buyer. The buttocks are round but lack chinacter, and the legs ure too straight and far behind.

'The figure to the right is bad in every respect-goose-rumped, cathammed, with the legs thrown far back to equalize the strain; the ankles also weak.

The figure to the lower left on same page shows a fair quarter, but the legs are thrown too far forward, and the animal stands too straight on the pasterus.

The figure to the right is really not badly formed as to the quarter, but the position is cramped and bent, and the limbs badly placed.

\section{The View from Behind.}

The view of the horse as seen from behind should show good squaro quarters, full and perfectly shaped gracilis, as those muscles are called 

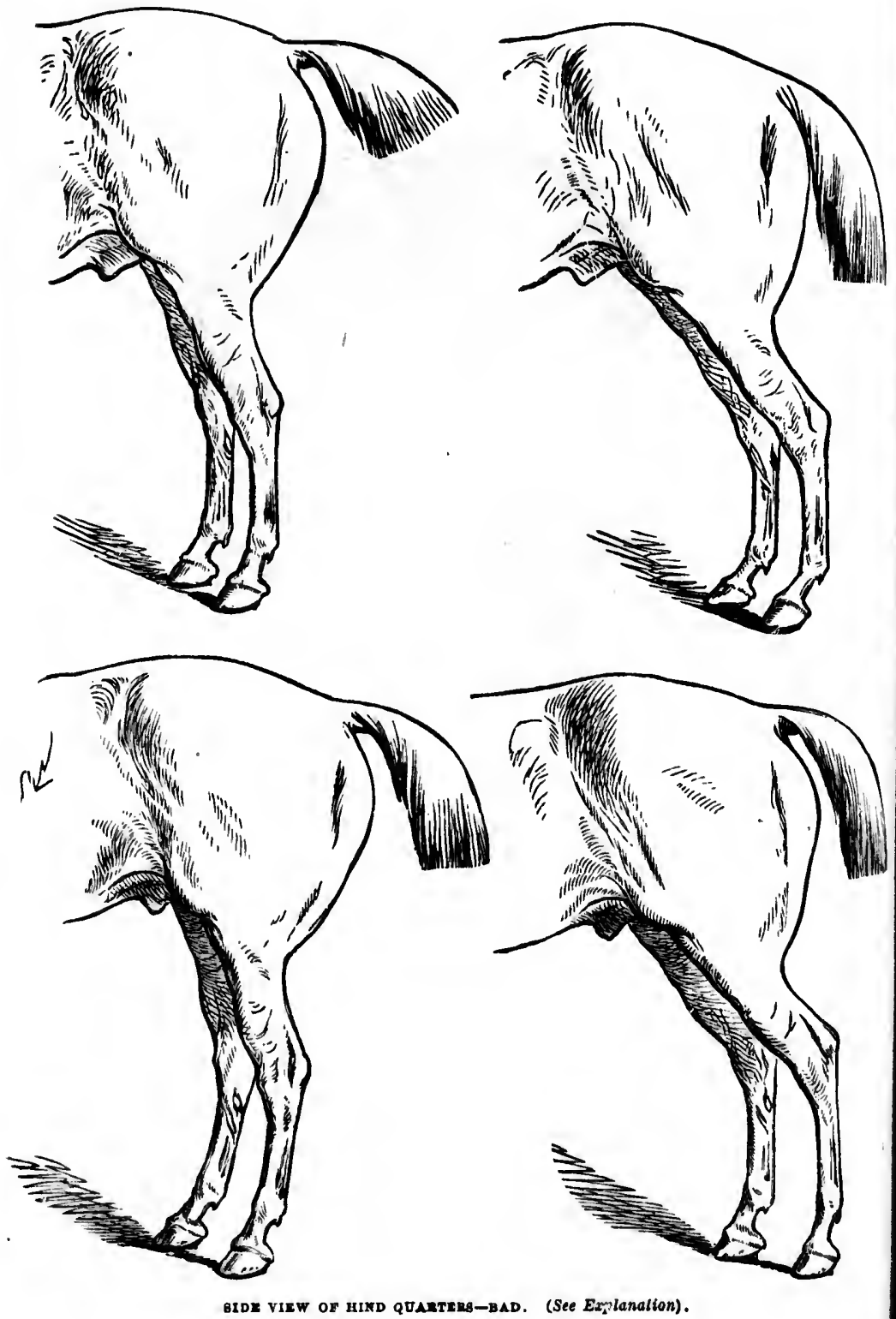

which give th be egg-shape gradually ded 
which give the peculiar swelling shape to the inside of thigh. These should be egg-shaped, or rather should swell from neasly a point below and them gradually decrease in size till lost to view near the rump bone.

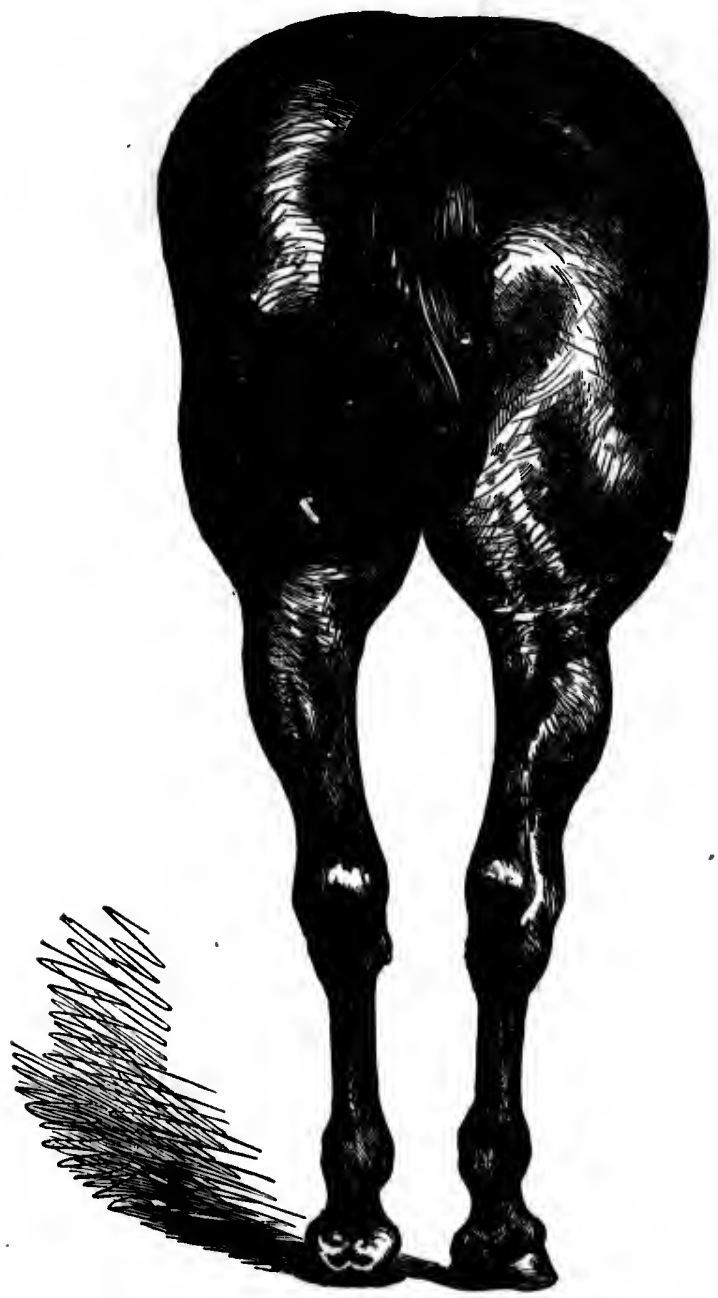

BACE VIEW OF HIND QUARTER8-GOOD. (See Explanation).

The outside muscle of the tibin, or grett bone of the leg above the knee, cannot well be too large. The tendons connecting with the hocks 

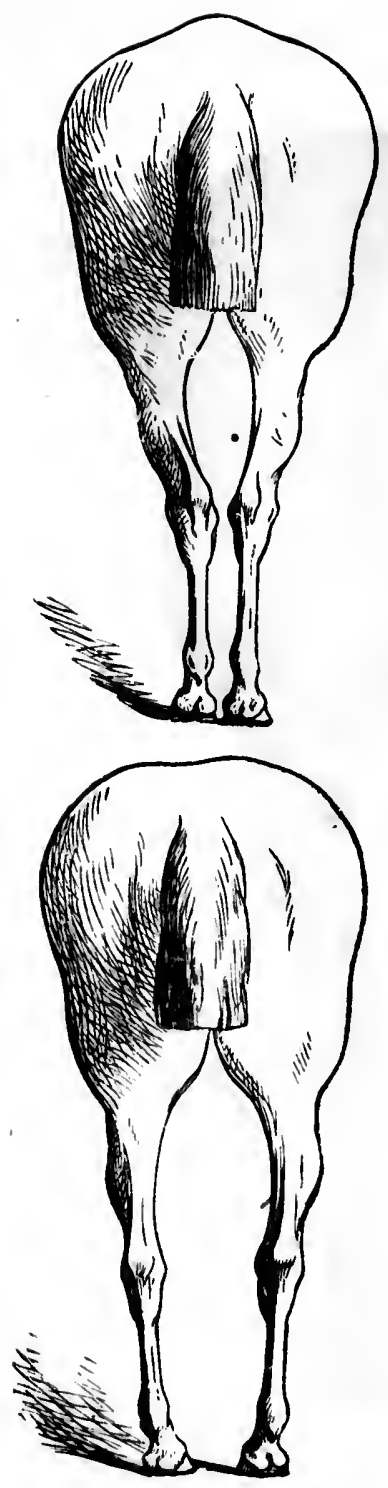

BACK VIEW OF HLND-QUARTERS-BAD. (See Explanation). should be str strong and we fetlock joints should never :

When the squarely, carri und the confor 195 , then if $y$ movement is $\mathrm{s}$ not filil you in As showing lind-quarters, which will enab how-legged or c

Never buy a 1 competent to $\mathrm{t}_{1}$ can depend. $\mathbf{N}$ remain so under to get him rid takes money. "very fat." A They are intend or pickled pork. weulthy and aged Never buy a he heavy drift. $\mathrm{Li}$ eleven hundred is ter than a heavien pounds is good o enough for any ci some brower's was Don't buy al $\mathrm{c}$ went together. $\mathrm{P}$ searce as to be enti They are seldom s in degree. A hor: quite defective for and expect to pay 13 
should be strong and well presented to view. The hocks large, firm, strong and well knit, but smooth and free from blemish, as should be the fetlock joints. If the horse is flat-footed he has a weak hoof, which should never go with a strong muscular horse.

When the animal moves forward, observe that the feet are lifted squirely, carried straight forward, without turning or straddling. If so, and the conformation is as presented in the rear view of the horse on page 195 , then if you have attended minutely to the other directions, and the movement is satisfactory, you need not fen to buy the horse. He will not fail you in time of need.

As showing defects, in various gradations and malformation in the lind-quarters, we refer the reader to the figures on page 196, a study of which will enable the observer to steer clear of splay-footed, pigeon-tred, bow-legged or cow-hocked brutes.

\section{What Not to Buy.}

Never buy a horse unbroken or half broken, unless you are thoroughly competent to train him, or else have some one to do so on whom you can depend. Never buy a horse overloaded with fat, expecting him to remain so under work. 'The first thing to be done with such a horse is to get him rid of the superfluous fat and water. This takes time and takes money. Besides you never can know the real defects of a horse "very fat." An ox or a hog perfectly fattened, is pleasing to the eye. They are intended for sueculent joints and steaks, or for hams, bacon, or pickled pork. A fat horse, except before the close coach of some wealthy and aged spinster or widow, is wocfully out of place.

Never buy a horse becauso he is big, unless you want hin for slow and heavy druft. Light horses are for light driving. A horse weighing eleven hundred is heavy enough for ordinary driving, and generally better than a heavier one. A pair of horses weighing twenty-four hundred pounds is good enough for any ordinary work that comes, and heavy enough for any eity teaming, except when wanted as show horses before some brewer's wagon, or as hor'ses of slow draft on heavy trucks.

Don't buy a cheap horse, expecting perfection. The two never yet went together. Perfect horses are not so plenty. Indeed they are so scarce as to be entirely beyond the means of any except the very wealthy. They are seldom seen even among this elass. In faet perfection lies only in degree. A horse may be measurably perfeet for our purpose, and yet quite defective for others. Therefore buy a horse for what you want, and expect to pay the honest price for what you get. Again, unless you 
are a judge, buy of some dealer who has a reputation to lose, and the means to back up any guarantee he may make.

\section{Buying for Blood.}

In buying for fast work, buy blood every time, whether the work desired is to be trotting to the wagon or carrying the owner under the saddle.

In buying blood, as a brecder, whether stallion or mare, never fool away any money on a half or three-quarters bred sire, expecting to get high caste horses. With a staunch thorough-bred of trotting action, you may successfully breed good trotters and workers on mares of cold blood, if they be of good size and form and are roomy. But for racing do not expect a cold-blooded mare to bring a very fist one, however good the size, except it may be by chance, and a rare chance at that.

In breeding for any purpose select the best of the elass. Staunch thorough-breds for finst work ; handsome thorough-breds for show horses.

For draft select from families that have been bred for generations for this work. Above all do not buy horses and nares that happen to strike your fancy, expecting to start a new breed. Life would be all ton short. It would be far more sensible to begin where the last man left off. 
the work devner under the are, nover fool xpecting to get ting action, you $s$ of cold blood, or rneing do not wever good tho at.

class. Staunch for show horses. generutions for happen to strike be all too short. an left off.
RACING, OR TURF HORSES.

RARLY HISTORY OF THE KNOLISH BLOOD HORBT. - HOW HE WAS IMPROVED, - THX AMERICAN BLOOD HORGY. — CEL BBRATED AMERICAN HORGES. — HISTORY OF THEIR PERPORMANCES.

The care taken in the breeding and training of horses for the chase and for racing in Great Britain, extends back, according to the best authority, to long before this people were converted co Christianity; in fact, to long before the Christian Era.

Just when and how horses were introduced into Great Britain is not certain, but it seems clear that they were well known there long before the Roman conquest, and that they bred horses not only for domestic purposes but also for war and for racing, secms true, from words in the ancient British language, as rhediad, a race; rheda, to run-from the Gaulish language rheda, a chariot, showing that these words applied to the racing of horses. Hence the inference that horses came by way of Gaul, and that chariot races were anciently one of the pastimes of the people.

The Romans found different vehicles in use in Britain, including the war chariot. Youatt infers that from the cumbrous structure of the car, the harduess of the roads, and the furious manner in which the driving was done, that the meient British horses must have been not only active, but powerful in 12 wonderful degree; and he says that Cesar thought them so valuable that many of them were carried to Rome, where they were much esteemed.

After the evicuation of England by the Romans and its occupation by the Saxons, increased attention was paid to the breeding of English borses, and after the reign of Alfred running horses were brought there 
from Germany, yet these should not be understood as meaning racing horses as the term is now used. They are supposed to have been light, speedy hor'ses, adapted to the chase or for the ronds, as opposed to the heavy war horse, capable of currying a man ut arms with his armor.

It does not appear that until the time of Charles I. horses were kept exclusively for rucing. Yet even before Athelstan's time English horses hud come to be prized on the continent, and in Athelstau's reign many Spanish horses were imported, showing clearly that so long ugo as this the English were fully alive to the importance of the continued improvement of their horse stock.

William the Conqueror is recorded to have used grent pains in improring the horse stock of tho comntry, after the conquest of Grent Brituin by the Normans, through the introduction of fine borses from Normundy, Flanders and Spain, and arecording to Beal it would sccm that as early as 631 people of rank distinguished themselves by often appearing on horsebark, and from which it would be natural to infer that thus early horses werc kept for pleasure riding, since saddle horses are known to have been used during the Roman occupation of Britain, and cavalry horses long before the Christian Ern.

The first Arab horse would seem to have been imported in the reign of Henry I., an Arab horse having, with his accoutrements, been presented by Alexander I. of Scotland, to the church of St. Andrew.

In the twelfth century a race course was established in London, at what was since called Smithtield, and which was also a horse market.

King John paid great atrention to the importation of horses; one hundred chosen Flemish stallions having been imported at a single time. Later it is recorded of Elward II. that he purchased thirty war horses and twelve heavy diaft horses.

Edward III., upon the occasion of buying fifty Spanish horses, made application to France and Spain for safe conduct for them, and so important was the horse stock of England considered thit the exportation of stallions was forbidden, and this prohibition was continued up to and during the reign of Henry VII.

In the reign of Henry VIII it was decreed that no stallion should be allowed to run at large on any waste or common where animals pastured, if under the height of fifteen hands, and that all foals, fillies or mares likely to breed undersized or inferior animals, should be killed and buricd.

All the nobility, gentry and higher orders of the clergy, were compelled by an act to keep a number of horses proportioned. to their rank, and even a country parson, whose wifo was entitled to wear a French hood or velvet bonuet (no person below a certain rank being allowed to wear such a hood) was of twenty $p$ deer park an mares and st mide in Eng or Suffolk, his reign the

11. W. I the whole ma the time of $C$

It is now pl or Alisb of th influence in re giving to it th day, to be este world.

In what deg strinin, is by ne of the early in

During the pelled by the Puritans, to for enruest promot chitsed of $\mathrm{Mr}$. 'Turk", -still r lomught into Es To him suceed to him Fairfax forght against 5

And to these time ehiefly ow specially inport justly-held th:

Of all succeed referred to, as h: begotten of super generations - hu We have, it is wood's White, th Cullen's Brown, Gray Arabians; it seems now to 1 
a hood) was obliged to keep an entiro trotting stallion, under a penalty of twenty pounds sterling. So, also, it was mado compulsory thnt every deer park and rural parish should muintain a certain number of full-sized umres and stallions. It is also interesting, ns being the first mention midde in English history, that Henry VIII. and Charles Brandon, Duke or Suffolk, rode a race in the presence of Queen Catharine, and that in his reign the first annual races on a regular race eourse were instituted.

H. W. Herbert, in his work, The Horse of Americn, thus sums up the whole matter in relation to the value of Oriental blood in Finglund, in the time of Oliver Cromwell:

It is now pretty generally admitted that, whether 13arb, Turk, Syrian, or Arab of the desert proper, all oriental blood has had its sharo and influence in reinvigorating the blood of the English thoroughbred, and giving to it those peculiar qualities which eause it, with justice, at this day, to be esteemed the best, completest, and most perfect animal in the world.

In what degree these animuls have ministered to our now dominant strain, is by no means to be aseertained; but it is to be noted that most of the early imported foreign stullions were not Eastern Arabs.

During the protectorate, Oliver Cromwell, who, though he was eompelled by the necessity of conciliating the absurd prejudiees of the Puritans, to forbid racing, was yot an ardent lover of the horse, and an earnest promoter and patron of all that belongs to horsenamship, purchased of Mr. Place, afterwards his stud-unaster, the celebrated "White Tink" - sitill recorded as the most beautiful south-eastern horse ever brought into England, and the oldest to which our present strain refers. To him suceeds Villiers, Duke of Buckingham, his Helmsley Turk, and to him Fuirfax's - the same great statesman and brave soldier, who fonght against Neweastle at Marston-Moroceo Barb.

Anl to these three horses it is thit the English race-horse of the old time chiefly owes its purity of blood, if we except the royal mares, specially imported by Charles II., to which it is - mythicully, mther than justly-held that all English blood should trace.

Of all succeeding importations, those, which are principally known and referred to, as having notoriously amended our horse-by proof of stock begotlen of superior qualities, and victorious on the turf through long generations - hut few are true Arabs.

We have, it is true, the Darley Arabian, the Leeds Arabian, Honeywood's White, the Oglethorpe, the Newcome Bay Mountain, the Damaseus, Cullen's Brown, the Chestnut, the Lonsolale Bay, Combe's Gray and Pell's Gray Arahians ; but what is generally ealled the Godolphin Arabian, as it seems now to be the prevailing opinion-his origin not being actually 
ascertained-was a Barb, not an Arab from Ambin proper. Agninst these, again, we find Plnce's White Turk, D'Arcey s 'Turk, the Yellow 'Turk, Lister's, or the Struddling 'Turk, the Byerly 'Turk, the Selalyy 'Turk, the Acaster 'Turk; Curwen's Bay Barb, Compton's Burb, the Thoulouse Barh, Layton's Barb Mare, greut-great-grandum of Miss Layton; the Royal Mares, which were Barbs from 'Tangier, and many other Barl, horses, not from the Eastern desert, hending the pedigrees of our best horses.

In this connection, I would observe that the very reasons for which the Murquis of Newcustle condemned the Murkham Arabian - viz., that when regularly trained he could do nothing against rnee-horses - on necount of which condennation he has received a sneer or a slur from every writer who has discussed the subject, are those which, at this very moment, prevent prudent hreeders from having recourse to oriental blood of any kind.

They emmot run or hist ugainst the Euglish hol'se. 'They huve not the size, the bone, the muscle, the shipe, if we except the benutiful head, tine neek, thin withers, long, decp and sloping shoulders, which are the inevituble characteristies of the race. Therefore, all men who breed with an eye to profit, - and howsoever it might have been in the olden times of the 'Turf, there are few now who have not an eye to it, either as hoping to win on the turf, or to produce salable stoek-prefer to put their mares to known Euglish wimning horses, proved getter's of wimners, of unquestioned bottom and stontmess, rinther than to try stallions of the desert blood, concerning which nothing is known beyond the attested pedigree, and the visiole shapes.

Further our anthority gives a list of all foreign, and the most celebrnted native stallions which were used for eovering in England in 1730, or just 150) years ago. They are as follows:

$$
\text { Foleigs stallions in } 1730 \text {. }
$$

The Aleoek Arabian, the Bloody Buttoeks Arabian, the Bloody Shouldered Arabian, the Belgrade Purk, the Bethel Arabian, Lord Burlington's Barb, Croft's Egyptian horse, the Cypress Arabian, the Godolphin Aribian, Hall's Arabinn, Johnson's Turk, Litton's Arabian, Matthew's Persian, Nottinghum's Aıbian, Newton's Arabiun, Pigott's Turk, the Duke of Devonshire's Ambian, Groyhound, a Barb, Hampton Court grey Barb, Strickland's Arıbiau, Wynn's Arabian, Dodsworth, a Barb. NATIVE STALLIONs in 1730.

Aleppo, Almanzer, Astridge Ball, Bald Galloway, Bartlet's Clilders, Basto, Bay Bolton, Blacklegs, Bolton Starling, Bolton Sweepstakes, Cartouch, Chaunter, Childers, Cinnamon, Coneyskins, Councillor, Crab, Doctor, Dunkirk, Easby Snake, Fox, Foxcub, Græme's Champion, Grey

Chiilder Blind I

Iewtru Shinflles bine, II

The Ameries astablist of the 1 with the Finglaur there we relebrate us is pro records aluies.

Sjork doek's d himself George 1 the fir'st

Other , old IIsut also impo land the blood of beating $\mathrm{C}$ a mare ow Nearly Crib, by posed to 1 Arabian, a Royil n good stoc hoger, by Barb, Dic Clilders, out of a d of a dangl of the Bus In about vertail by 
Clilders, Groy Crofts, Hampton Court Childers, Harlequiu, Ihurtley's Blind Horse, Hip, Hobgobling, Hutton's Blueklegs, Hutton's Huntor, Iewtrump, Jigg, Lamprey, Leedes, Murricle Oysterfoot, Purtner, Royul, Shufller, Skipjuck, Smule's Childers, Soreheels, Squuirrel, 'Tifter, 'Truehue, Woodcock, Wyndhum.

The importation of racing horses was, without doulst, first male to America in Virginin and Marylund. Arendy had ruce-courses been established there previous to 1753, and during the exodus from kinglund, of the Royulists, to tho South, it is undoubtedly true thut they biought with them desecudants of such horses ns were covering with suocess in Fingland. Certain it seems thit quite enrly in the eighteonth century there wero a eonsiderable number of thoroughbred hor'ses from the most relebrated English sires. That the perfect recorel has not couro down to us is probably due to the fact that, during the Revolutions.ry war the records were either lost or destroyed between the shock of contending armies.

Spark was owned by Governor Oglo, of Maryland, provious to Braddoek's defeat, having been presented to him by Iord Baltinore, who himself received him as a gift from the then Prince of Wales, father to (ieorge III. Spark was a most celelorited horse, and probably one of the first of high distinction brought to America.

Other ('elebrated horses early imported are said to have been, Wilkes' oh Hantloy mare, afterward known as Miss Colville. Governor Ogle also imported (Queen Mab, and about 1750 Col. 'Tasker brought to Maryland the celebrated mare Selina, the progenetrix of much of the mightiest blood of the country. In 1752 ho won, al sweepstake of 500 pistoles, beating Col. Byrd's renowned Tryall, Col. Taylor's Jemny Cameron, and a marc owned by Col. Cameron.

Veurly alout the same time, there were imported into Virginia, liouth's Crab, hy old Crub, dam by Counsellor, duughter of Coneyskins, supposed to lee in or about 1745. In 1747, Monkey, by the Lonsidale Bay Arahian, dam by Curwen's Bay Barb, daughter of the Byerly 'l'urk and a lioyal mare. He was twenty-two years old when imported, but loft good stock. In 1748, Roger of the Valo, afterwards known as Jolly loger, by Roundhead, out of a partner mare, Woodeock, Croft's Bay Balb, Dicky Pierson, out of a Barb mare. Roundhead was by Flying Childers, out of Roxana, dain of Lath and Calde, by the Bald Gialloway. sut of a daughter to the Acaster 'Turk. Woodeock was by Merlin, ont. of a daughter of Brimmer. Dickey Pierson by the Dodsworth Barb out of the Burton Barb mare.

In about 1764, was imported Fearnought, gct by Regulus out of Silvertail by Whitenose, grand-dam by Rattle, great grand-dam by the 
Dariey Arnbian, great great grand-dam Old Cirild mare, by Sir Thoman Gresley's Arubian, grent great great grand-dan, Vixen, by Heliusley 'Turk, out of Dodsworth's dam, a natural Barb. Regrulus was by the Godolphin Barb, dam Grey Robinson by the Buld Galloway, grand-alam hy Snake out of Old Wilkes' Hauthoy mure. Rattle was h. Sir II. Harpur's I3arb out of a Roynl mare. Whitenose was by the Hall Ambian out of dam to Jigg. Thus Fearnought is come of the very higheat and purest blood in England, and lans left his mark largely on the blowelhorse of Virginia. It is said that, before his time, there was little beyond quartor racing in Virginin, that his progeny were of uncomumon figure, and first introdueed the size and bottom of the English race-horse into Ameriea. This must be taken, however, cum grano sulis, at it is evident from what has been stated in regard to Selina, that four-mile racers were the fushion in Maryland at least fifteen yearw before that dnte, and it is only to be understood in the ease of second-rate racers, that quarter running was in vogue at this period.

'These enpital horses were shortly followed by Morton's Traveller, whos was probably got by Partner, a grandson of the Byerly 'lurk, and graws. sire of King Herod, dam by the Bloody Buttocks Arabian; yrand-dam by Cirey-hound, a Barb; g. grand daun by Makeless; g. g. g. dam by Brimmer; g. g. g. g. dam by the White Turk; g. g. g. g. ag. dasin hy Dodsworth, a Barb; g. g. g. g. g. g. dam Laydon Barb mare.

Makeless was hy the Oglethorpe Arub out of 'Trumpet's dam. She was a pure Barb by Dodsworth out of the Layton Barb mare. Brimmer was by the Yellow Turk out of a royal mare.

These were probally the hest early loores that were imported into Americal and to these, with the mares Selima, Queen Mab, deenuy Cam eron, Kitty Fisher, Miss Colville, and a few others of aloont the tame period, may be traced all, or almost all the families of rumiug burtes now existing in the United States, in n grenter or less degrese, and with nearly as much certainty as the English champions of the olden day may be followed up to imported Arab and Barb on both sides.

This being most interesting history, we quote from 'The Horme of America, to show how much the United States is indebted to the South for the foundation of its mighty racers of the present day, and owing undoabtedly to the great interest the old planters of the South and their de. scendants have taken in field sports. The record is as follows:

In Virginia, Col. John Tayloe, Messis. Hoomes, Selden and Johnon: in Maryland, Governors Ogle, Ridgely, Wright, Lloyd and Sprigg, who, ats it has been remarked, seemed by their practice to acknowledge that the keeping up of a racing stud was a portion of their gubernatoral duty; and in South Carolina, Messrs. Hanpton, Washingtou, MePber- non, Alston " constunt und Queensburys, "qually renow old English gu

Fromı so e champions, su Antonv, Rogu Nell, Bel Air, Maria, by Sh Amanda, Ball Bond's First C Tuckahos, and (an easily brin then, both wit recently Alabn riccers, to the of dolphin Arubia -ind when th of the whole $w$ derived that $t^{\prime \prime}$ rated, but in th try by the perf

As being of the most celeln' They are:

Finst Mnuld Aimindia by Silu by a soll of 13ay gro dam by Ho! two True Blue Grisc'wood's P:a l'uttocks, g. g. Betty.

Cripple was b. dam by Childers

Medley wus of Atalanta, Bel A lighter, the Opo: racers in a high Second Shan 
non, Alston and Singleton, were us eurly, und have continued to be as constunt und undeviating patrous of the Americun turf, ns hnve the Queensburys, Rutlands, Wyudhnms, Bentincks, Fit»willians, und othor cnually renowned turf names, becn supporters of this noble sport on the old Euglish greensward.

From so eurly a date us that of the unte-revolntionury crucks und champions, such us Celer, 'Truveller, Yorick, 'T'rynll, Ariel, l'urtuer, Mure Antony, Regulus, Flng of 'Truec, Goode's Brimmer, Butler's Virginia Sell, Bel Air, Calypso, Gray Diomed, Cincinmutus, Virago, Shnrk, Bhok Maria, by Shark, Levinthun, Gullutin, Fuiry, Cup--beurer, Collector, Ananda, Ball's Florizel, Post Boy, Oscalr, Hickory, Muid of the Oaks, Bond's First Consul, Sir Archy, Potomac, Pacolet, Duroc, IHanptom, Tuckuhoe, and others, the dames of which alone wonld fill $n$ volume, we (an ensily bring down in these Stutes - nnd the other's colonized from then, both with men and horses, such is Kentucky, Tennessee, and more recently Alubama-one uninterrupted and stainless succession of noblo ricers, to the day when the descendants of Sir Arehy, that verituble Ciodolphin Arabian of the 'Turf of America, began to show upon the course -and when the renown of American Eolipse began to call the attention of the whole world, und of the mother country most of atl, whenee was derived that trinscendent stcok, whirh in all other countries has degenerated, but in this has continued to rival the honors of its remotest nucestry by the performance of American race horses.

As being of value, we grive also the history and pedigrees of some of the most celelnnted horses of the dnys suceceding the revolutionity war. They are:

Finst Menley-Imported into Virginia in 17xi, by (iimeralek, dam A minda ly Sintp, out of Miss Clevelund hy Regulus; g. gr. dan Mage, by a son of Bay Bolton; g. g. ger. dam by lautlott's Childers; g. g. g. g. gr. dam by Honcywood's Aribbiun; g. g. g. g. gre. diun the dam of the two True Blues. Gimerack was by Cripple, out of Miss Elliott, lyy Grisewnod's Partues, gr- diun Celia l,y Pintner, g. gr. dim by Bloody Buttocks, g. g. gr. dam by Greyhound, g. g. g. gri'. dam Broekleshy Betty.

Cripple was by the Godolphin Arabian, out of Blossom by Crab, gr. dam by Childers out of Miss Belvoir, by Giantham.

Medley was one of the best sires ever imported into America. He got Atalanta, Bel Air, Boxer, Calypso, Gray Diomed, (iray Medley, Lamplighter, the Opossum Filly, Pandorn, Quicksilver, Virginia, and others-. racers in a high form, and themselves the getters of ricers.

Second Shank-Fonled in 1771, and imported into Virginia by 
Marske, out of the Sunp mare, gr. dam Wag's dam, by Marlborough, out of a nitural Barb mare.

Marske; sire of Eclipse, was by Squirt, dam by Foxeub, gr. dam by Conoyskins, g, gr. dam by Hutton's Gruy Barb.

Squiirt was by Bartlett's Childer's, dam by Snake, gr. dam Hautboy. Marlborough was by the Godolphin Arabian, dam large Hartley mare.

Shark's most distinguished progeny are: Americus, Amette, Black Maria, dam of Lady Lightfoot, Opossum, Shark, Virago, and many others.

Turo Dromen-Foaled in 1777. Imported into Virginia 1798. He was by Florizel, dam by Spectator, gr. dam by Blank, g. grt. dam by Childers, g. g. gr. dam Miss Belvoir, by Grinthim.

Florizel was by Herod, dam by Cygnet, gr. dam Cartouch, g. gr. dam Ebony by Childers, g. gr. gr. dim old Ebony Basto mare.

Herod wiss by Tartar, out of Cypron, by Blaze, out of Selima, \&e. \&e.

Diomed is probably the greatest sire of the greatest winner-gretter's ever bronght into this comntry. Had he got none but Sir Archy, out of imported Castianin-who hrought him to America in her belly-that renown alons would have been more than enough; for scarce a recent horse in England, unless it he Pot8o's, has so distinguished himself ats at progenitor.

Ile begot Bolivin, Diana, Dinwiddle, Duroc, Florizel, Gallatin, Gracchus, Hamlintonian, Hampton, Hornet, King Herod, Latdy Chestertield. Madison, Marske, Nettle-top, Peace-nial:er, Potomac, P'rimrose, Sil Ar(hy, Top-gallint, Truxton, Virginius, Wonder, and many others. Most of the horses named ahove were the grentest rumers of their day, and the getters of the greatest racers and sires to tho present time, Boston. probably the very best horse that ever ran on American soil, wals by Timoleon, grandson of Sir Arehy, the best son of Diomed; while lishion, the very best mare that ever lan on this side tho water, by her dam, Bonnets of Blue, daughter of Reality, was great-granddaughter of that same noble stallion; and by her grandsire Sir Chirles, sire of Bonnets and son of Sir Arehy, was also his great-granddaughter, a second time, in the maternil line.

Fourti Gabmenef-Foaled 1790, imported into Virginial, was got by Dorinunt, dam Suap mare, gr. dam by Shepherd's Crab, g. gr. dain, Miss Meredith by Cade, g. g. gr. dam Little Hartley nare.

Dorimant was by Otho, dam Babriham mare, gr. dam Chiddy by Hampton Court Aralsian, out of the Duke of Somerset's Bald Charlotte.

Otho was hy Moses, dam Miss Ver'non by Cide, grr. dam by Partner, g. gr. dau Bay Bloody Buttoeks, g. g. gr. dam by Greyhound, g. $\underline{g}$. g. gr. dam by Makeless, g. g. g. g. gr. dam by Brimmer, g. g. g. g. g. gr. dau by Plac $g \cdot g \cdot g \cdot g \cdot g$

Moses was gr. dam, the Anbian.

Grabriel w liorsies, very

He got $\mathrm{Os}_{\mathrm{s}}$ imp. Medley was a good $\mathbf{r}$ lions and mat

Fiftir $\mathrm{Be}$ got by Dungs Young Cade, Warlock Gall

Dungannor by Blamk, $g$. Godolphin A Childers, s. Sister to IIom

The year , ureat stallion States which He wis a sing on his rump, absolute defor transmitted to opinion ats to that it has con rather than a binther, Shitl' Bedford go Nancy Air, Sh

On the first State into the stoek from Vir Morton's Trav pereolates in $r$ has been alwa happy-the ra of the neighlyo the opportunit 
daun by Place's White Turk, g. g. g. g. g. g. gr. dam by Dodsworth, g. g. g. g. g. g. g. gr. dam Layton's violet Barls mare.

Moses was by the Chedworth Foxhunter, dam by the Portland Arabiau, gr. dam, the dam of tho Duke of Bridgewater's Stur, she by Richard's Arabian.

(iabriel was brought into Virginia, and becane, like the, preceding horses, very famous for splendor of his get and their great performane'es.

He got Osear, Post Boy, and other's. The former of whom, dim by imp. Meciley, bred by General Tayloe, is his mest celebrated son. He wis a good rumier, and his blood tells in miny of our best modern stallions and mares, espeeially in the Southern States.

Fiftu Benfond-Foaled in 1792, imported into Virginia. IIe was rot by Dungammon, dam Fairy, by Hightlyer, gr. dam Fairy Queen by Young Cade, g. gl' dam Routh s Black Eyes by Crab, g. g. gr. dam the Warlock Gallow:ay, g. g. g. gr. dam by the Byerly Turk.

Dungaunon was loy Eelipse ont of Aspasla, by Herod, gr. dim Doris by Blank, g. gr. dam Helen by Spectator, g. g. gr. dam Diphone by the Godolphin Arabian, g. g. g. gr. dam by Fox, g. g. g. g. gr. dim by Childers, g. g. g. g. g. g. gl'. dam hy Makeless, g. g. g. g. g. g. g. gr. gl. dam, Sister to Honeycomb Punch, by the Tiaffolet Barb.

The year of Bedford's importation is yot exactly known. He was a areat stallion, and there is bardy a family of horses in the Sonthern States which do not in some degree, more or less, partake of his blood. He was a singularly formed horse-a rich bay-with a peculiar elevation on his rump, amounting in appeanance to an unsightliness, if not to an alsolute deformity. This mark, known as the Bedford IIump, he hats transmitted to his posterity, and, whatever may have been the original opinion as to its beauty, it hias been worn by so many celebrated wimners, that it has come of hate to be regarded as a foreshadowing of excellence, rather than al deformity. It has heen worn by Eelipse, Black Maria, hel brother, Shark, Boston, Argyle, and many other horses of great note.

Bedford got; Nolus, Cup-Bearer, Firiry, Latdy Bedford, Lottery, Nancy Air, Shylock and others not inferior in repute.

On the first settlement in Temesse, previous to its admission as a State into the Union, the early settlers began taking with them excellent stock from Virginia and Maryland, and the blood of Janus, Joliy Roger, Morton's Traveller, Pacolet and other worthies of the olden times, still percolites in rich luxuriance through the veins of their noble steeds. It has been always a gallant and a sporting State; and I feel proud and happy-the rather that the history of the blood storek of Temnessee and of the neighhoring Stute of Kentucky is nearly identicul-to bo allowed the opportunity of presenting to my readers a most valuable memoir of 
the blood of its best equine fumilies, considerately and kindly compiled for me fiom his own memoranda of old times, and from personal recollection of events, even before General Jackson and his contemporaries were on the turí, by a veteran turfman and a hereditary breeder, Mr. William Williams-to whom I take this occasion of tendering my most grateful and respectful thanks.

\section{Race Horses at the North.}

Prior to the Revolution there was a course for racing, near New York, about the centre of the eounty, called Newmarket, and one at Junaiea ealled Beaver Pond. As etrly as the year 1800 courses wore established at Albany, Poughkeepsie and Harlem, New York. On these tracks purses of from one to four miles were contended for. In 1804 an organization was formed extending for tive years. 'The Newmarket course was remodeled, and regular races were held in May and October of each year, at which purses were contended for at four, three and two mile heats.

Among the celebrated horses of that time, some of which have left their impress to this day, were Tippoo Sultan, Hambletonian, Miller's Damsel and Empress. Among these, as worthy of especial mention, were Hambletonian, as the progenitor of mighty trotting stock, Miller's Damsel as the dam of American Eclipse, and Ariel, whose granddam was thin gray mare Empress. American Echipse was the king of the American turf of his day, and Ariel may certainly be said to hnve been the queen, since out of fifty-seven rices she was forty-two times the winner, seventeen of them having heen four mile heats. They both of them may be said to rank with the best race horses of any age or country.

The pedigree of Eelipse may be summed up in the language of Frank Forrester, as follows: Ameriein Eclipse, bred by Gen. Coles of L. I., foaled 1814; was got by Duroc, his dam the famed race mare Miller's Damsel, by imported Messenger, out of the imported Pot8os mare; her dam by Gimerack. Duroe, bret by Wade Mosely, lisq., of Powlatan comty, Virginia, foaled 1809 : was got by imported Diomed, out of Mr. Mosely's "extraoldinary rice mare Amanda," by Col. 'Tayloe's fumed gray I Iomed, son of imported Medley. Thus far Eclipse's pedigree is unquestioned; for the balance see Ameriean Turf Regrister, p. 50, vol. 4. Of Sir Charles Bunbury's Diomed, imported into Virginia 1799, laring filled the measure of his glory," nothing more need be said. Messenger, foaled 1788, imported about 1800 into Pennsylvania, was also a race horse of repute at Newmarket; he won some good races, and lost but few. He was a gray, of great substance; was got by Mambrino, a very superior stallion, his dan by Turf, son of Matehem, Regulus-Starling-Snap's dim. Sec English Stud Book, and American Eclipse's pedigree in full, Ameriean Turf Register, p. 51, vol. 4.
Of Ariel performances distinguished O'Kelly, that such eclat as Baltimore, w Terror-her' that was beat Medley-ilre been regarded the North. beat the fam heats, at Hitrl

Besides ('on Eclipse, it wil best English l, Partner, Crab ley, Pot8os, $N$ cent from the takes so much two, not very from imported tains her valua

Black Maria pitrt of the cel N. Y., and foil dam Laidy Lig] Shark; $\boldsymbol{g}$. gr. to Medley, hy

Of her diun, distinguishod it: races, the nitijo once, exrept in the Union Cont was foaled at $\mathrm{I}$

Among the w will alwitys be prowess and we Boston was $f$ Va. His sire Tuckahoe, by B mare by import 
Of Ariel we find the following: Ariel's pedigree is worthy of her performances. Her own brothers-Lance, a year older than herself, a distinguished runner that beat the famous Trouble, a great mitehO'Kelly, that beat Flying Dutchman, Mary Rimdolph, and others, with such eclat as to bring $\$ 5,000$ - and st. Leger in the great sweepstake in Baltimore, where he wals so unaceountably beaten, but has since beat Terror-her own sister Angeline, and half-brother Splendid, hy Duroe, that was beaten at three years old, in a produce mitch, by Col. .Johnson,s Medley-are all well known to fame. Her grandam Empress, has also been regarded one of the most renowned race nags and brood mares of the North. October, 1804, at four years old, she very unexpectedly beat the famons First Consul, for the Jockey Club purse, four-mile heats, at Harlem, N. Y. The first race he lost.

Besides combining the three valued crosses of Herod, Mateheni: and Eclipse, it will be observed Ariel's pedigree is "richly imbued with the best English blocil ;" to which she traces almost directly from Childers, Partner, Crab, Snap, Cade, Spark, Othello, Gimerack, Mambrino, Medley, Pot8os, Messenger, Baronet, Diomed, de. ; hesides deriving her decent from the best early importations. No other stock probably partakes so much of the Messenger blood-no less than four crosses; with two, not very remote, from English Eclipe, two from Gimcrack, two from imported Pacolet, and three from inported Spark. Her color sustains her valualle origin-ruming so mueh into the Arabian blood.

Black Maria was another of the wonderful performers of the early part of the century, having been bred by Charles Henry Hall, Harlem, N. Y., and foaled lune 15, 1826. She was sired by American Eelipse, dam Lady Lightfoot by Sir Archy, gr. dam Black Maria, by imported Shark; gr. gr. dam the dam of Ving't un, by Clackfast, a half-brother to Medley, by Gimcritck; g. g. g. dim Burwell's Mirria, by Regulus.

Of her dim, Lady Lightfoot, Frank Forrester says she was the most distinguished racer of her day, having won between twenty and thirty races, the majority at four-mile heats, and never having been beaten but once, except in her old age-her eleventh year-and then by Eelipse, on the Union Course. She was bred by the late Col. John Tiloe of Vat. and was foaled at Mr. Ogle's sent, Bel-ilir, Md., in June, 1812.

Among the wonderful racers of forty years ago, Boston and Fashion will always be remembered as the two mighty eximples of staunch prowess and well-deserved fume.

Boston was foaled in 1833 , bred by John Wicklan, Esq., Richmond, Val. His sire was the celebrated Timoleon, out of an own sister of Tuckahoe, by Ball's Florizel ; her dam by imported Alderman, out of a mare by imported Clackfast; her gr. dam by Symmes' Wildair, \&c. 
He was a ehestnut with white hind feet and a strip in his face, 15 1-2 hands high, rather short limbed, somewhat flat sided, but of immense substmuce, und his buck n prodigy of strength. From 1836 to 1841 he ran thirty-eight times and won thirty-five races, twenty-six of which were four mile heats and seven three mile heats. His winnings were $\$ 49,500$, and his earnings as u breeding stallion in $1841, \$ 4,200$, making a total of $\$ 53,700$.

Finshion was bred by William Gibbons, Esq., of Madison, N. J., and was foaled April 26, i837. Of this mare it is recorded that it would be difficult to sit down over the Stud Book and compile a rieher pedigree than hers, and the same remark will apply to Boston. Each is deseended from the most eninently distinguished racing families on the side of both sire and dam, that have figured on the Turf for a hundred years. Fashion was got by Mr. Livingston's Imp. Trustee, out of the eelebrated Bonnets o' Blue by Sir Charles, and she out of Reality-"the very best race-horse," says Col. Johnson, "I ever saw." Reality was got by Sir Arehy, and her pedigree extends back through the imported horses Medley, Sentinel, Janus, Monkey, Silver-Eye and Spanker, to an imported Sproish mare. Trustee, the sire of Fashion, was a distinguished racehorse in England, and sold at 3 yrs. old for 2,000 guineas to the Duke of Cleveland, after rumning $3 \mathrm{~d}$ in the race for the Derby of 101 subsoribers. He was subsequently imported by Messrs. Ogden, Corbin and Stockton. Trustee was foaled in 1829 , and was got by Catton out of Emmn, by Whisker, and combines the blood of Hermes, Pipator, and Sir Peter, on his diun's side, with that of Penelope, by Trumpator, and Prunella, by Hightlyer, on the side of his sire. Trustee is not a chance horse; in addition to other wimers of his family, in 1835, his own brother, Mundig, won the Derby of 128 subseribers.

In her three year old form she won three of the races she ran and lost one, being beaten by Tyler after winning the seeond heat. In her four year old form she ran and won three races, one at two miles, one at three miles and one at four miles.

Later, the pelan of victory rested upon horses bred west of the Alleghanies und south of the Ohio river. Among the celebrated ones were Lexington, got in 1851 by Boston out of Alice Carneal. Lecompte, by Glencoe, out of Reel. Pryor, by Glencoe, out of Gypsy, own sister to Medoc, by American Eelipse.

Still later, and within the last ten years, the laurels of soutinern bred racers on various tracks in America and Eigland, are too well known to need rec. nitulation.

As showing English and American views on the speed of race horses of twenty years ago, really the palmy dnys of the turf, and which con- tinued up to says :

By an exa it will be see rate of spee $7 \mathrm{lbs}$. carriec won the Der actly 14 seco reached; the failing by t furlong. Bt of Sir' Tattor 132 yards in rate of as ne tional year a by West Au w's on he defo furlongs in 4 seconds and modern days, will compare over the Beac manzor and 1 (ins. 40s., or allowing him which he car latter horse: Australian at performances the Ameriean lest our antag our laurels. Orleans betwe the latter, wh $3-4$ s., or as $n$ sidered by the creditable per: count, not so On the 14th of same course iu furlong ; the $f$ five years old, 
tinued up to the late war, Stonehenge, from an English point of view, says :

By an examination of the racing time-tables as recorded of late years, it will be seen that from $131-2$ to 14 seconds per furlong is the highest rate of speed attained in any of our races, above a mile, and with 8 st. 7 lbs. carried by three-yenr-old horses. In 1846, Surplice and Cymba won the Derby and Oaks, each running the distance in $2 \mathrm{~m}$. 48s., or exactly 14 seconds per furlong. 'This rate has never: since that time been reached; the Flying Dutchman having however, nearly attained it, but failing by two seconds-making his rate 14 seconds and one sixth per furlong. But the most extriordinary three-year-old performance is thut of Sir 'Tatton Sykes over the St. Leger Course, 1 mile, 6 furlongs, and 132 yards in length, which he ran in 3 minutes und 16 seconds, or at a rate of as nearly as possible 13 1-2 seconds per furlong. Witl an additional year and the same weight, this speed has been slightly execeded by West Australian, even over a longer course, as at Ascot in 1854, $w_{L}$ on he defented Kingston by a head only ; ruming two miles and four furlongs in $4 \mathrm{~m}$, and $27 \mathrm{~s}$., or as neirly as possible at the rate of 13 1-2 seconds and one.third per furlong. This performance is the best in modern days, considering the weight, the age, and the distance; and it will eompare very favorably with the often-quoted exploit of Childers over the Beacon Course in 1721, when, heing six years old, he beat Al. manzor and Brown Betty, earrying 9 st. 2 lbs., and doing the distance in fin. 40s., or at the rate of 14 seconds and one-third per furlong. 'Thus, allowing him his year for the extra mile in the course, and for the $2 \mathrm{lbs}$, which he carried above the Kingston's weight, he was outdone by the latter horse at Ascot by one second per furlong, and likewise by West Australian at the usual allowance for his age. Again ; eomparing these performances on the English Turf with the recently lauded exploits of the American horses, it will be found that there is no canse for the fear lest our untagonists in the "go-ahead" department should deprive us of our laurels. On the $2 d$ of April, 1855, a time-mateh was run at New Orleans between Leconte and Lexington, hoth four years old, in which the latter, who won, did the four miles, earrying 7 st. 5lbs., in $7 \mathrm{~m} .19$ $3-4$ s., or as netrly as may be, $13 \quad 3-4$ seconds per furlong. This is considered by the Americans the best time on record, and is undoubtedly a creditable performance; though when the light weight is taken into account, not so nenr our best English time us would at first sight appear. On the 14th of April, Brown Dick und Arrow ran three miles over the same course in $5 \mathrm{~m} .28 \mathrm{~s}$, or at the rate of 13 seconds and two-thirds per furlong; the former a three-year-old, carrying 6 st. $2 \mathrm{lbs}$, and the latter five yeurs old, 6 st. $12 \mathrm{lbs}$. Thus it will appenr that Kingston, of the 
same age as Arrow, and carrying 9 st. instead of 7 st. 12 lbs., ran 2 1-2 miles at a better rate than Arrow did his 3 miles, by one-third of a second per furlong. And it has been shown thit in the year last past, two horses exceeded the greatest performance of the olden times by a second per furtong, and beat the best American time of modern days by onethird of a second per mile. The assertion, therefore, that our present horses are degenerated in their power of staying a distance under weight, is wholly without foundation; since I have shown that, even tuking the time of the Childers' performance as the true rate, of which there is some doubt, yet it has recently been beaten very considerably by West Australian and Kingston. Many loose assertions have been made as to the rate of the lorse, for one mile in the kist century, but there is not the slightest reliance to be placed upon them. That any race-horse ever ran a mile within the minute, is an absurd fiction: and it is out of the question to suppose that if Childers could not bent our modern horses ner the Beacon Course, he could beat them a shorter distince. Stouta... vas undoubtedly the forte of the early race-horses; they were of s. ") niz:, very wiry and low, and could unquestionably stay a distance, an wis race month after month, and year after year, in a way seldom imitat ? hese days : but that they eould in their small compact forms $\because$ as fo $\quad \therefore$ chort spin as our modem thee-yen-olds, is quite a fal

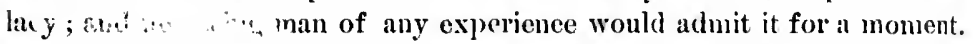

The size ata shape of the modern thoroughbred horse are superior to those of olden ditys, if we may judge by the portriats of them himded down to us by Stubbs, who was by far the most faithful animal painter of the eighteenth century. In elegance of shape we beat the horses of that day very considerably, more especially in the heauty of the heal and the formation of the shoulders, which hive been much attended to hy breeders. In size, also, there has been an immense stride made, the average height of the race-horse having been increased by at least a haul in the list century. This enlargement is. I believe, eliefly due to the Godolphin Arabian, who was the sire of Babrahim, the only horse of his time which reached 16 hands, and sire and grandsile of several which were more than 15 hands, much above the averige height of lorses at that time-as for instance, Feamonght, Genius, Gower, Stallion, In fant, Denmark, Bolton, Cade, Club, Lofty, and Amphion. Indeed it will be found, by an examination of the horses of that time, that out of 130 winners in the middle of the eighteenth century, there were only 18 of the height of 15 hands and upwards, of which 11 were by Godolphin or his sons, three descended from the Darly Arabian, two from the Byerly Turk, and two from other sources. It may therefore be assumed, witl some degree of probability, that the increase in size is in great measure due to the $\mathrm{G}$ the horse has and forcing $i$ unless there would lave placed at abo

In relation l'ace horses, and gives a li which we app

It will appe not much diff a century; a sides of the $A$ list two year: Australiun an than was eve four-mile heat land. "Ston "the absurd $f$ "not the sligh - such as the were a distanc they " could b authority, it a races, as won John, and We half to two mi bas been a littl no authentic re mimute and for Sominally of 86 lbs., Iuherit rite per milo siders the best four yours old, "defeated Kin 9 st._-i26 pou as possible, 13 of modern day compare very $f$ 1721, at Newm 14 
due to the Godolphin, in addition to the extra eare and attention which the hor'se has received during the same time. Nevertheless, all the cure and forcing in the world will not increase the size of some breeds; and unlese there was this eapubility of being forced, no amount of attention would have brought the horse to the present average, which may be placed at about 15 hands 3 inches.

In relation to the comparisons of speed between English and Anerican rice horses, the Spirit of the Times, New Yord, sums up the matter, and gives a list of the most renowned raeers of England and America, which we append:

It will appear, on a critical examinntion of the subject, that there is not much difference in the powers of the best race-horses for more than a century; a period during which they have been brought, upon both sides of the Atlantic, to the present high state of perfection. Within the last two years have been exhibited faster running in England, by West Australim and Kingston, and in this country, by Lexingten and Leeomite, than was ever before known. The two last have run four miles, and four-mile hents, faster, in either case, than has been performed in Englind. "Stonehenge," who has been well endorsed in England, has shown "the absurd fiction" of "a mile within a minute;" and that there is "not the slightest reliance to be placed upon the many loose assertions" -such as the reported accounts of Childers; and that he and Eclipse were a distance better than any other horses that have appeared, or thit they " could beat any other a half-mile in four miles!" On the sime authority, it appears that, in the fastest Derby, St. Leger, and Ascut cup' rices, as won by Surplice, the Flying Dutchman, Sir Tatton Sykes, Don Joln, and West Australian, the distance varying from one mile and a half to two miles and a half, that the fastest rate, with English weights, his been a little over one minute and forty seconds per mile. We have no authentic report that the mile has been run in England under one minute and forty-two seconds, the time of Henry Perritt at New Orleans. Sominally of the same age, three years old, and with the same weight, 86 llss., Inheritor, at Liverpool, ran two miles in 3.25 ; which is at the rate per mile of 1-42 1-2. " "Stonehenge," referring to what he considers the best race ever run in England, states that West Austrulian, four yours old, earrying the St. Leger weight, 8 st. 6 lbs._-118 pounds-"defeated Kingston by a head only," the latter five years old, carrying 9 st.-i 26 pounds-running two and a half miles in 4.27, "or ns nearly as possible, 13 1-2 seeonds per furlong." "This performunce, the best of modern days, considering the weight, the age, and the distance, will compare very favorably with the often quoted exploit of Childers, in 1721 , at Newmarket, when six year's old, carrying 9 st. 2 lbs. $-128 \mathrm{lbs} .-$ 
he did the distance, three and a half miles, in 6.40 , or at the rate of 14 scconds and one-third per furlong." "Thus allowing Childers his year for the extra mile in the course, and for the two pounds which he carried above Kingston's weight, he, Childers, was outdone by Kingston at Ascot, by one second per furlong, and likewise by West Australim, at the usual allowance for his age." "Kingston, of the same age as Arrow, and carrying 9 st. instead of 6 st. 2 lbs. -100 pounds-ran two and a half miles at $n$ better rate than Arrow, in his race with Brown Dick, did his three miles, by one-third of a second per furlong," But Arrow's was a rice of three-mile hents, the second heat in 5.43 1-2. Lexington, nominally four years old, carrying 103 pounds, run four miles, also at New Orleans, in 7.19 3-4. or, as nearly as may be, 13 3-4 scconds per furlong, at the rate, for four miles, of less than 1.50 per mile.

The often quoted exploit of Eclipse, of England, was that he ran four miles, earrying 168 pounds, in eight minutes.

With these data before them, it is left for others to draw their own deductions of the relative merits of West Australian, Childers, Eclipse, and Lexington, at the distances they ran, varying from two and a half miles to four.

Some anong us belicve that Lexington and Lecomte were about as fist and as good race-horses as have ever appenred in England. Undoubtedly they eould "stay a distance", nbout ns well as any horse that hits run anywhere, having run two heats, of four miles, in 7.26, and 7.38 , and the third mile of the second heat in 1.47.

It would be difficult to institute a fair comparison between the racehorses of England and Ameriea, the systems of racing being so different in the two countries. With the exception of the light weights, adopted by us for convenience, the modes and rules of our turf are nearly the same as they were in England the last eentury. In England, since that period, the mode of racing has been essentially changed; heavy weights, cren for two and three-year-olds, at short distances, rarely beyond two and a half miles; no longer raes of heats; the great events being for "baloy horses," two and three-year-olds, instead of horses, as formerly. They rarely, nowadays, reach maturity in England. Priam, Touchstone, Harkaway, and Rataplan, ale to be regarded as execptions to a rule. Childers and Eclipso wero not introduced upon the turf until five ycars old, an age at which the mcst distinguished horses rarely run in these diys.

The elistic turf and the straighter shape of the English race-courses, better adapt them to speed than our cireular "race-tracks," that are wholly denuded of turf. Therefore a fair comparison of English and American race-horses cannot be made by time as the test; one, too, that is not beld in as high esteen in Englind, but is frequently disregarded. 
Rather a long catalogue is here presented of the best race-horses of Englind and of this country, which might be extended. Those now or latcly upon our turf are omitted, as some doubts might be entertuined of their comparative merits. Of those furnished, who will agree as to the pre-eminence of any two of them; at least, to place any six above the rest?

\section{MOST RENOWNED ENGLISH AND AMERICAN HOHSES.}

1715*, Childers; 1718*, Partner ; 1748*, Matehem; 1749*, Regulus und Milza, by the Godolphin Arabiun ; $1749^{*}$, Spectntor ; 1750*, Sinup ; 1758*, Herod; 1764*, Eclipse, by Marske; 1771*, Shark, by Marske; $1773^{*}$, Pot8os, by Eclipse; — ${ }^{*}$, Siltrum, by Eclipse ; 1777* $\dagger$, Diomed; 1782†, Trumpator; 1784†, Sir Peter; 1790†, Waxy; 1792†, Ilambletonian ; $1796 \dagger$, Soreerer ; $1798 \dagger$, Eleanor ; 1798†, Orville ; $1807 \dagger$, Whalebone; 1816, Sultan ; 1822, Camel; 1827†, Priam, by Emilius $\dagger$; $1831 \dagger$, Plenipotentiary, by Emilius $\dagger$; 1831†, 'Touchstone ; -_ $\dagger$, Queen

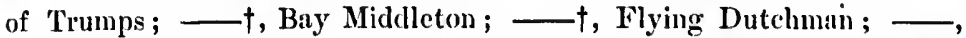

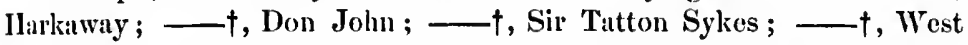
Australian ; - Kingston ; 1801*, Florizel ; 1812, Potomac ; 1813*, Sir Archy ; 1812, Lady Lightfoot, by Sir Archy ; 1812, Vanity, by Sir Arehy ; 1813, Reality, by Sir Archy ; 1813*, Timoleon, by Sir Archy ; 1814, Virginian, by Sir Archy ; 1815, Sir Charles, ly Sir Archy ; 1820, Bertiand, by Sir Archy ; 1801, Maid of the Oilks, by Imported Sprend Eigle; 1801, Floretta, by Imported Spread Eigle ; 1801. Postboy, by Inported Gabriel ; 1801, Oscar, by Imported Gabriel ; 1801, Hickory ; 1808, Duroe; —_, Sir Solomon ; 1814, American Eclipse ; 1820, Flirtilla; _- Monsicur Tonson; —- Sally Walker; —_, Aricl, by Ameriean Eclipse ; —-Medoc, hy American Eclipse; —_, Funny, hy Amcrican Eclipse; —_, Lady Clifden; —_, Doubloon, by Imported Margrave; -_, Blue and Brown Dick, by Imported Margrave; 1833, Boston ; 1837, Fashion ; 1839, Peytona ; —- Trifle, by Sir Charles ; - Andrew, by Sir Charles ; —, Wugner, by Sir Charles ; —, Grey Fingle.

Another view of the comparative merits of race-horses that were not contemporaries is presented by time on the same course, and with the same weight, or the relative weight for age.

It has been shown lately, that on the Charleston Course, at three and four-mile-heats, in the races won by Nina, Highlander, Jefferson Datvis, anck Frank Allen, nearly the sume time has been made; besides the com. parison between that of Bertrand and Floride. 
On the Union Course, New York, the fustest four-milo heats were us follows:

Fashion, 5 years, $111 \mathrm{lbs} .$, and Boston, 9 years, 126 lbs., 7.32 1-2 -7.45 .

'Tally-ho, 4 years, 104 lbs., and Bostona, 5 years, 111 lbs., 7.33-7.43. Fashion, uged, 123 lbs., and Peytona, 5 years, 117 lbs., 7.39-7.45. Eclipse, 9 yenrs, $12 f$ liss., and Henry, 4 yenrs, 108 lbs., 7.37 1-2 -7.49 .

Red-Eye, 8 years, 126 lbs., und One-Eyed Joe, 6 years, 117 lbs., 7.52 -7.39 .

Lady Clifden, 4 years, 101 lbs., and Picton, 3 years, 90 lbs., Picton winning first hent, 7.44-7.43 1-2-7.56 1-2.

\section{Principles of Breeding.}

In relation to the principles and practice of breeding for the turt and for general purposes, Stonchenge on British Rural Sports, than whom nono could bo more competent to advise, and although written from an English stand-point is applieable to nny country or conditions. The author, in an essay loolds the following:

TIIE PRINCIPLES AND PRACTICE OF BREEDING FOR TIE TURF AND Fon GENERAL PURPOSES.

Before proceding to enlargo upon the practical management of the breeding stud, it will bo well to ascertain what are the known laws of generation in the higher animals.

The union of the sexes is, in all the higher animals, necessiny for reproduction; the male and female each taking their respective share.

The office of the male is to secrete the semen in tíc testes, and enit is into the uterus of the female, where it comes in contact with the ovun? of the female - which remains sterile witlout it.

The female forms the ovum in the ovary, and at regular times, varying in different animals, this descends into the uterus for the purpose of fructification, on receiving the stimulus and addition of the sperm-cell of the semen.

The semen consists of two portions - the spermatozoa, which have an automatic power of moving from place to place, by which quality it is believel that the semen is carried to the ovum; and the sperm-cells, which are intended to co-operate with the germ-cell of the ovum in forming the embryo.

The ovum eonsists of the germ-cell, intended to form part of the embryo,- and the yolk, which nourishes both, until the vessels of the mother take upon themselves the task; or, in oviparous animals, till hatching takes place, and exterual food is to be obtained. The ovum is carriod dor ovary to th like the ser

Tho enul semen with former is al dency to it the nutrime attached itss sorbs its not

As the ma the embryo, it, which is $\mathrm{f}$ rutirely depe the offspring with her stat onc-hialf of $t$ generul chara

The ovum size of the $y o$ support the $g$ of the egrg un malia the plac niterus to the entrance of th nearly the wh called utero-go

In all the $\mathrm{m}$ dischinges in $\mathrm{t}$ in the male.

the deseent of strong desire $f$ times in them.

The semen re tained within $t$ fruitful if kept the time of he the ovun is re reaches the uter it remains there

The influence the fact that he 
carried down by the contractile power of the fallopian tubes from the ovary to the uterus, and hence it does not require automatic purticles like the semen.

The enibryo, or young animul, is the result of the contact of the

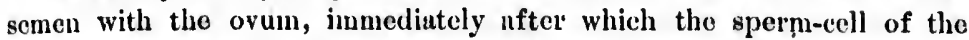
former is absorbed into the germ-eell of the lutter. Upon this $a$ tendency to increase or "grow" is established, und supported at first, by the nutriment contained in the yolk of the ovum, until the embryo has nttached itself to the walls of the uterus, from which it afterwards nbnorbs its nourishment by the intervention of the plucenta.

As the male and female each furnish their quota to the formation of the embryo, it is reasonable to expect that ench shall be represented in it, which is found to be the cuse in naturo; but us the food of the embryo pntirely depends upon the mother, it inny be expected that the health of the offspring and its constitutionnl powers will be more in accordance with her state than with that of the futher; yet since the sire furuishes onc-lalf of the original germ, it is not surprising that in externals and general character thero is retnined a fac-simile, to a eertain extent of him.

The ovum of mammalia differs from that of birds chiefly in the greater size of the yolk of the latter, beciuse in them this body is intended to support the growth of the embryo from the time of the full formation of the ergr until the period of hatching. On the other hand, in mammalia the placenta conveys nourishment from the internal surface of the uterus to the embryo during the whole time which elapses between the entrance of the ovum into the uterus and its birth. This period embraces nearly the whole of the interval between conception and birth, and is called utero-gestation.

In all the mammalia there is a periodical " heat," marked by certuin discharges in the female, and sometimes by other remarknble symptons in the male. In the former it is accompanied in all heulthy subjects by the descent of an ovum or ova into the uterus; and in both there is a strong desire for sexual intercourse, which never takes place at other times in them.

The semen retains its fructifying power for some days, if it be contained within the walls of the uterus or vagina, but soon ceases to be fruitful if kept in any other vessel. Hence, although the latter part of the time of heat is the best for the union of the sexes, because then the ovum is rendy for the contact with the semen, yet if the semen reaches the uterus first, it will still cause a fruitful impreguation, because it remains there uninjured until the descent of the orum.

The influence of the male upon the enibryo is partly dependent upon the fact that he furuishes a portion of its substance in the shape of the 
sperm-cell, but also in great measure upon the effect exerted upon the nervous system of the mother by him. Hence the preponderance of ono or other of the parents will, in great meusure, depend upon the greater or less strength of nervous system in each. No general law is known by which this can be mensured, nor is anything knowis of the laws which regulate the temperament, bodily or mental power, color of conformation of the resulting offspring.

Acquired qualities are transinitted, whether they belong to the sire or dam, and nlso both bodily and mental. As bad qualities afo quite as easily transmitted as good ones, if not more so, it is ne $y$ to take care that in selecting a male to improve the stock he be, irom lad points, as well as furnished with good ones. It is known by experience that the good or bad points of the progenitors of the sire or daun are almost as likely to appear agnin in the offspring, as those of the innediate parents in whom they mre dormant. Hence, in breeding the rule i, that like produces like, or the likeness of some ancestor.

The purer or less mixed the breed, the more likely it is to be tranto mitted unaltered to the offspring. Hence, whichever parent is of the purest blood will be generally more represented in the offopring ; lwat as the male is usually more carefully sclected, and of purer blood than the female, it generally follows that he exerts more influence than she dow; the reverse being the case when she is of more ummixed blowed than the sire.

Breeding "in-and-in" is injurious to mankind, and $r$ lways leen forbidden by the Divine law, as well as by most humay ivers. On the other hand, it prevails extensively in a state of nature with all gregrrious animuls, among whom the strongest male retains his daughters and granddnughters until deprived of his harem by younger and stronger rivals. Hence, in those of our domestic animals which are naturaily gregarious, it is reasonable to conclude that breeding "in-and-iu" i; not prejudicial, becuse it is in conformity with their natural iestinets, if not carried farther by art, than nature teaches by her example. Now, in nature we find about two consecutive crosses of the samo llood is the usual extent to which it is carried, as the life of the animal is the limit; and it is a remarkable fact that in practice a conclusion has been arrived at, which exactly coincides with these natural laws. "Once in and onee out," is the rule for breeding given by Mr. Smith in his work on the breeding for the turf; but twice in will be found to be more in accord. ance with the practice of our most successful breeders.

The influence of the first impregnation seems to extend to the sulnew quent ones; this has been proved by severil experiments, and is expecially marked in the equine geuus. In the series of examples presenred in the Museu quaggonil, wher three generut and they nre

When som ure in uccord in such a kinc hand, whẻn $t$ untitted for $\mathrm{tl}$

By $n$ caref horses, it will the greater pa It is difficult $t$ commence, fo sire and dum o execption-an which is the re find that his s through three to pige 215. direet a cross lyzed, the resu made up of $\mathbf{E}$ that a horse $\mathrm{g}$ through six or Ifence, it may are related, eit brecling, we $n$ $o r$, at the mos lie found that ton fur, and tl bied 111 this wa

By crossing of wholly diffo be obtuined of view. Thus, i same strain be diminishes the avoid this evil, 
in the Museum of the College of Surgeons, the mnrkings of the male quagga, when united with the ordinary mare, are continued clearly for three generntions beyond the one in which the qungga was the actunl sire; and they are so cleur as to leave the question settled without a doubt.

When some of the elements, of which an individual sire is composed ure in accordance with others making up those of the dnm, they coulesce in such a kindred way as to muke what is culled "a hit." On the other hand, when they aro too incongruous, an animal is the result wholly untitted for the tusk he is intended to perform.

IN-AND-IN BREEDING.

By n careful examination of the pedigrees of our most remarkable horses, it will be seen thut in all enses there is some in-breeding; and in the greuter part of the most suceessful a very considerablo infusion of it. It is difficult to suy whit is not to be considered such, or when to make it commence, for in all eases there is more or less relutionship between the sire and dum of every thoroughbred horse; at lenst, I cannot find a singlo exception-and again, for instunce, exumining the pedigree of Harkuway, which is the result of one of the most direct crosses in the Stud-book, wo find that his sire and dam are both descended from Eclipse and Herod through three or four strains on each side, as will be seen by referring to page 215. The sume will apply to Alu'm, who also is the result of as lirect a cross as is often seen; and, in fact, whatever pedigreo is annlyzed, the result will be that the bulk of it in the fifth or sixth remove is made up of Eelipse; Herod, and Matchem, or Regulus blood. It is not that a horse goes back to one of these stullions in one line only, but through six or seven, and sometines through neurly ull his progenitors. IIence, it may be fairly assumed that all the horses of the present day are related, either closely or,distantly ; but when we spenk of ir-and-in hrecding, we mean a nearer relationship than this, such as a first cousin, or, at the most, ono in tho second or third degree. But $I$ believe it will be found that even this amount of relationship is desirable, if not carried too fal', and that a vast number of our best modem horses bavo been bied in this way.

\section{OUT-CROSRTNG.}

By crossing the blood, we understand the seleetion of a sire composed of wholly different blood from that of the dam, or as different as esm be obtained of such quality as is suitable to the particular purpose in view. Thus, in breeding race-horses it is found that continuing in the same strain beyond two stages deteriorates the eonstitutional health, diminishes the bone, and lowers the height; hence, it is important to avoid this evil, and another strain must be selected which shull lead to 
the same results as were previously in existence, without the above deterioration; und this is called out-crossing, or more commonly, crossing. The great difficulty is to obtain this object without destroying that harmony of proportions, and due subordination of one part to another which is necessary for the race,horse, and without which he seldom attains high speed. Almost every individual breed has peculiar characteristics, and so long as the sire and dam are both in possession of them they will continue to reappear in the produce; but if a dam possessing them is put to a horse of different character, the result is often that the produce is not a medium between the two, but is in its unterior parts like its dan, and in its posterior resombling its sire, or vice versa, than which no morc unfortunite result can occur. Thus, we will suppose that a very strong muscular horse is put to a very light racing mare; instead of the produce being moderately stout all over, he will often be very stout and strong behind, and very light and weak before, and us a consequence his hindquarters will tire his fore limbs, by giving them more to do than they have the power of accomplishing. This is well seen in Crucifix, who was a very wiry and fast, but light mare, with a fore-quarter hardly capable of doing the work of her own hind-quarter. Now, she has severnl times been put to Touchstone - a horse remarkable for getting bad-shouldered stock, but with strong muscular propellers-and, with the, solitary exception of Surplice, these have been a series of failures. Surplice was also defective in the same way, but still he managed to get along in an awkward style, but somehow or other at a great pace. Cowl, on the other hand, was a better galloper, beeiuse there was a greater harnony of parts; but he was somewhat deficient in the stout qualities which Touchstone was intended to supply; yet he will prove, I fancy, a better stallion than Surplice, because he is more truly made, and by eonsequence more likely to perpetuate his own likeness.

\section{COMPARISON OF IN-BRED AND CRUSSED STALLIONS.}

The following list of thirty of the most immediately snccessful stallions of late years slows the proportion of in-bred to crossed horses of this class to be equal. I have omitted such as only became celebrated through their duughters as brood-mares, for instance, Defence, ete.

\section{IN-BRED STALLIONS.}

1. Priam. 2. Bay Middleton. 3. Melbourne. 4. Cotherstone. 5. Pyrrhus I. 6. The Baron. 7. Orlando. 8. Ithuriel. 9. Cowl. 10. The Saddler. 11. Sweetmeat. 12. Chatham. 13. Flying Dutchman. 14. Sir Tatton Sykes. 15. Chanticleer. 
CROSSED STALLIONS.

e deterossing. armony thieh is ns bigh ics, nud ley will $\mathrm{m}$ is put duce is ts dain, no more y strong produce I strong is bindian they who wis cetpable ral times ouldered solitary Surplice aloug int 1, on the harnony es which a better sequence

stallions of this through

tone. 5. wwl. 10. utchman.

1. Partisan. 2. Emilius. 3. Touchstone. 4. Birdeateher. 5. Sir Hercules. 6. Voltaire. 7. Plenipotentiary. 8. Pantaloon. 9. Lanercost. 10. Venison. 11. Alarm. 12. Ion. 13. Harkaway. 14. Velocipede. 15. Hetman Platoff.

\section{BELECTION OF BROOD MARE.}

In choosing the brood mare, four thing:s must be considered-first, her blood; secondly, her frame: thirdly, her state of health; and fourthly, her temper.

Her blood or breeding will mainly depend upon the views of the breeder-that is to say, what particulur class of colts he wishes to obtain, and according to his decision be will look out for mares of the particular kind he desires to reproduce, on the principle that "like hegets like," but subject to the variois considerations partly alluded to in the last chapter, and partly in this and subsequent ones.

In frame, the mare should bo so formed as to be capable of carrying and well nourishing ber offspring; that is, she should be what is called "roomy." There is a formation of the hips which is particularly untit for breeding purposes, and yet which is sometimes carefully selected, because it is considered elegant; this is the level and straight hip, in which the tail is set on very high, and the end of the haunch-bone is nearly on a level with the projection of the hip-bone. The opposite form is represented in the skeleton given with the article "Horse," which is that of a thoroughbred mare, well formed for this breeding purpose, but in other respects rather too slight. By examining her pelvis, it will be seen that the hauneh-bone forms a considerable angle with the sacrum, and that, as a consequence, there is plenty of room, not only for currying the foul, but for allowing it to pass into the world. Both of these points are important, the former evidently so, and the latter no less so on consider. ation, because if the foal is injured in the birth, either of necessity, or from iguorance or carelessuess, it will often fail to recover its powers, and will remain permanently injured. The pelvis, then, should be wide and deep-that is to say, it should be large and roomy ; and there should also be a little more than the average length from the hip to the shoulder, so as to give plenty of bed for the foil ; as weli as a good depth of baek-ribs, which are necessary in order to support this incrensed length. This gives the whole framework of the trunk of a larger proportion thun is always desirable in the race-borse, which may be ensily overtopped; and hence many good runners have failed as brood mares, whilst a great number of bad rumers have been dams of gond race-horses. Beyond this roomy frame, necessary as the egg shell of tho foul, the mare only 
requires such a shape and make as is well adapted for the particular pur. pose she is intended for; or if not possessing it herself, she should belong to a family baving it. If one can be obtained with theso requisites in her own person, so much the more likely will sho be to produce racehorses; but if not all, then it is better that she should add as many as possible to the needful framework, without which her office can hardly be well carried out. But with this suitable frume, if she belongs to a family which, as a rule, possesses all the attributes of a race-horse, she may be relied on with some degree of certainty, even though she herself should fail in some of them. Thus, there are many fine roomy mares which have been useless as race-horses from being deficient in the power of some one quarter, either behind or before, or perhaps a little too slack in the loin for their length. Such animals, if of good ruming fanilies, should not be despised; and many such have stood their owners in good stead. On the other hund, some good-looking animals have never thrown good stock, because they wero only exceptional cases, and their families were of bnd running blood on all or most sides. No mme could look much more unlike producing strong stock than Pocahontas, but being of a family which numbers Selim, Bacehante, Tramp, Web, Orville, Elennor, and Marmion among its eight members in the third remove, it ean scarcely occasion suplprise that she should respond to the eall of the Bitron by produeing a Stockwell and a Rataplan.

In health, the brood mare should be as neur perfection us the artificial state of this animal will allow; at all events, it is the most important point of all, and in crery case the mare should be very carefully exauined, with a view to discover what deviations fiom a natural stato have been entailed upon her by her own labors, and what she bas inherited from her ancestors. Independently of the consequence of accidents, all deviations from a state of health in the mare may be considered as more or less transmitted to her, beciuse in a thoroughly sound constitution, no ordinary trentment such as training consists of will produce disense, and it is only hereditary predispositions which, under this process, entails its appenrance. Still there are positive, eompanative, and superlative degrees of objectiontble disenses incidental to the brood mare, which should be accepted or refused accordingly. All accidentnl defect, such as briken knees, dislocated hipe, or even "hreaks down," may be passed over; the latter, however, only when the stock from whic's the mare is descended are famous for standing their work without this fraily of sinew and ligament. Spavins, ring-bones, largo splints, side-bones, and, in fact, all bony enlargements, are constitutional defects, and will be almost sure to be perpetuated, more or less, nccording to the degree in which 
they exist in the particular case. Curby hocks mre also hereditary, and should be avoided; though muny a one much bent at the junction of the os calcis with the astragalus is not at all liable to curbs. It is the defectje condition of the ligaments there, not the augulnr junction, which lends to curbs; and the breeder should curefully investigate the individunl case before accepting or rejecting a mare with suspicious hocks. Bad fect, whether from contraction or from too sat and thin a sole, should also be avoided; but when they have obviously arisen from bad shoeing, the defect may be passed over.

Such are the chief varieties of unsoundness in the legs which require circumspection ; the good points which, on the other limd, are to be looked for, are those considered desirable in all horses that are subjected to the shocks of the gallop. Calf knees are generally bad in the race hoise, and are very apt to be transmitted, whilst the opposite form is also perpetuited, but is not netuly so disadvantageous. Such are the general considerations bearing upon soundness of limb.

Th:at of the wind is no less important. Broken-winded mares seldom ireed, and they are therefore out of the question, if for no other reason; but no one would risk the recurrence of this disesse, even if he could get such a mare stinted. Roaring is n much-vexed question, which is by 110 means theoretically settled among our chief veterinary nuthorities, nor pricticully by our breeders. Every year, however, it hecomes more frequent and important, and the risk of reproduction is too great for any person wilfully to run by breeding from a roarer. As far as I can learn, it appears to be much more hereditary on the side of the mare than on that of the horse; and not even the offer of a Virago should tempt me to use her ns a brood mare. There are so many different eonditions which produce what is called "roaring," that it is difficult to form any opinion which shall apply to all eases. In some instances, where it has urisen from negleeted strangles, or from a simple inflanmation of thu lay the result of ecid, it will probuhly never reappenr; but when the genuine ideopathie roaring has made its appearance, appurently dependiug upon a disease of the nerves of the laryux, it is ten to one that the produce will suffer in the same why.

Blindness, "gain, may or may not be hereditary; but in all eases it should be viewed with suspicion as great as that due to rouring. Simple catarnct without inflamnation undoubtedly runs in families; and when a horse or mure has both eyes suffering from this disease, without any other derungement of the eye, I should eschew them earefully. When blindness is the result of violent inflammation bronght on by bad management or by influeuza, or any other similar eause, the eye itself is more or less 
disorganized ; and though this itself is objectionable, as showing a weakness of the organ, it is not so bad as the regular cataract.

Such are the chief absolute defects, or deviations from health in the mare; to which mity be added a general delicacy of constitution, which can only be guessed from the amount of flesh which she carries while suckling or on poor "kcep,"' or from her appearance on examination by an experionced hund, using his eyes as well. The firn, full anuscle, the bright and lively eye, the healthy-looking cont at all seasons, rough though it may be in winter, proclaim the hardiness of constitution which is wanted, but which often coexists with infirm legs and fect. Indeed, sometimes the very best-topped animals have the worst legs and feet, chiefly owing to the extrin weight they and their ancestors also have hat to carry. Crib-biting is sometimes a habit acquired from idleness, ns also is wind-sucking; but if not caused by indigestion, it often lends to it, and is very commonly caught by the offspring. It is true that it may be prevented by a strap; but it is not a desirablo accomplishment in the mare, though of less importance than those to which I have already allu. ded, if not accoinpanied by absoluto loss of health, as indicated by emaciation, or the state of the skin.

Lastly, the temper is of the utmost importance, by which must he un. derstood not that gentlewess at griss which inay lead the breeder's fam. ily to pet the mare, but such a temper as will serve for the purposes of her rider, and will answer to the stimulus of the voice, whip or spur. A craven or $n$ rogue is not to be thought of as the "mother of a family;" and if a mare belongs to a breed which is remarkable for refusing to answer the call of the rider, she should be consigned to any task rather than the stud-farm. Neither should a mare be used for this purpose which had been too irritable to truin, unless she happened to be an exeeptional case; but if of an irvituble family, she would be worso even thin a roarer, or a blind one. These are defects which are npparent in the colt or filly, but the irritability which interferes with training often leads to the expenditure of large sums on the faith of prirate trials, which are lost from the failure in public, owing to this defect of nervous system.

\section{CHOICF OF gTALLION.}

Like the brood mare, the stallion requires several essentials-commencing ulso like her, first, with his blood; secondly, his individual shape ; thirdly, his health; and, fourthly, his temper. But there is this difficulty in selecting the stallion, that he must not only be suitable perse. but he must also be adıpted to the particular mare which he is to "serve." Thus, it will be manifest that the tusk is more diffieult than the fixing upon a brood mare, because (leaving out of considerations all other points bu of good same attc to the me connected the subje breeding, adapted $\mathbf{t}$ their mind which dec upon whic liorse; th or the Fly blood and there is : mily be, h any horse show thit many priz am satisfic lottery ; b tempted to hare alreac by numer bo my obj instimees.

In choos impression in her pedi leer the bes it will hapl there happ superior st hand, the 1 then a cros the success hlood alrea more than therefore, I ocenrrence espaped ols supposing, 
a weak.

in the , which es while ation by scle, the , rough on shlich Indeed, and feet, atve had eness, is leads to it it may nt in the ady alluby cma-

st be uner's famrposes of spur. A fanily :" ng to ansk l'uther purpose an excepeven thin nt in the ften leads which are ystem.

$\mathrm{ls}-\mathrm{com}-$ ndividual re is this je persp. " serve." he fixing all other

points but blood) in the ora case, $n$ mare only has to be chosen which is of good blood for racing purposes, while in the other there must be the same attention paid to this particular, and also to the stallion's suitability to the mare, or to " hit" with her blood. Henee, all the various theories connected with generation nust be investignted, in order to do justice to the subject; and the breeder must make up his mind whether in-nnd-inbreeding, as u rule, is desirable or otherwise; and if so, whether it is adapted to the particular case he is considering. Most men make up their minds one way or the other on this subject, and act accordingly, in which decision much depends upon the prevailing fashion. The rock upon which most men split is a bigoted fuvoritism for some particular horse; thus, one man puts ull his inares to Orlando; another, to Surplice or the Flying Dutchman; although they may every one be different in blood and form to the others. Now, this cannot possibly be right if there is any principle whatever in breeding; and however good a horse mily be, ho cannot be suited to all mares. Some, again, will say that any horse will do, and thut all is a lottery ; but I think I shall be able to show that there is some science required to enable the breeder to draw many prizes. That the system generally followed of late is a bad one, $I$ sm satisfied, and with constunt crossing and re-crossing it is almost a lottery ; but upon proper principles, and with careful munugement, I am tempted to believe that there would be fewer blanks than at present. I hare already given my own theoretical views upon the case, illustruted by numerous examples on both sides of the question. It will now be my object to apply thes; views practically by selecting particular instances.

In choosing the particular blood which will suit any given mare, my impression always would be, that it is desirable to fix upon tho best strain in her pedigree, if not already twice bred in-and-in, and then to put to her the best stallion available of that blood. In some cases, of course, it will bappen that the second best strain will answer better, because there happens to be a better horse of that blood to be hud than of the superior strain, which would otherwise be preferred. If, on the other hand, the mare has already been in-bred to tho extent of two degrees, then a cross will be advisalle; but $I$ am much inclined to believe, from the success of certain well-known cases, that even then a cross into blood already existing in the mare, but not recently in-bred nor used more than once, will sometimes answer. $\tilde{U}_{\text {jon }}$ these principles I should, therefore, look for success. It is surprising to me that this very eommon oceurrence of in-breeding umong our best modern horses lins so generally escaped ohservation, and the only way in which I ean explain it is by iupposing, that having frequently been through the grandam on either 
side it has been lost sight of, because the knowledge of the sire's and grandsire's blood is generally the extent to which the inquiry goes. Thus, we find the most recent writer on the subject, who assumes the name of "Craven," usserting, at page 121 of "The Horse"-_There is no proximity of relntionship in the genealogy of the Flying Duteluman, 'Tonehstone, Melbourne, Epirus, Alarm, Bay Middleton, Hero, Orlando, Irish Birdcatcher, Cossack, Harkaway, Tearaway, Lothario, or others of celebrity." Now, of these the Flying Dutehman is the produce of seeond cousins ; Bay Middleton, his sire, being also in-bred to Willinmson's Ditto and Walton, own brothers; and Orlando, contnining in his pedigree Selim twice over, and Castrel, his brother, in addition. Melbourne slso is the produce of third cousins, both his sire and $\mathrm{dnm}$ being descended from Highflyer. But if to these four, which ho has specially named, be added the numerous "others of eeleiority" to which I lave drawn attention, besides a host of lesser stars too numerous to mention, it will be admitted that he assumes for granted the exact opposite of what is really the case.

The choice of partieular stallions, as dependent upon their formation, is not less difficult than that of tho mare, and it must be guided by nearly the same prineiples, except that there is no oceasion for any framework especially caleulated for nourishing and containing the fotus, as in her case. As far as possible, the horse should be the counterpart of what is desired in the produce, though sometimes it may be necessary to select an animal of a breed slightly exaggernting the peculiarity which is soughi for, especially when that is not counected with the preponderanee of fore or hind-quarters. Thus, if the mare is very leggy, a more than usually short-legged horse may be selected, or if her neck is too short or too long, an unimil with this organ particularly long, or the reverse as the case may be, should be sought out. But in all eases it is dangerous to attempt too sudden alteration with regard to size, as the effort will generally end in a colt without a due proportion of parts, and therefore more or less awkward and umwieldly.

In constitution and general health, the same remarks exactly apply to the horse as the mare. All hereditary diseases are to be avoided as far ns possible, though few horses are to be met with entirely free from all kinds of unsoundness, some the effects of severe training, and athers resulting from actual disease, occurring from other causes. With reard to futness, there is an extraordinary desire for horses absolutely loaded with fat, just as there formerly was for overfed oxen at Christmas. It is quite true that the presenee of a moderite quantity of fat is a sign of a good constitution, but, like all other good qualities, it may be carried to exeess, so as to produce disease; and just as there often is hypertro

plyy,

there perfo death overalso $t$ the or

In 1 relati be mo causec kept. does $n$ stable

It is mature will be out of Cressid Lottery Voltain Andove the othe in numl produce first foi Puta, S have all of super which I Ugly $\mathrm{Bu}$ two year foaled ; years old horse w parents. not carrid the follos believe, dogs, or 
plyy, or excess of nourishment of the heart, or any bony parts, so is there often a like superabundamce of fat eausing obstruction to the duo performance of the animal functions, and often ending in premuturo death. This is in grent measure owing to want of exereise, but ulso to over-stimulating food; and the breeder who wishes his horse to last, and also to get good stock, should take especial care that he has enough of the one and not too much of the other.

In temper, also, thero is no more to be added to what I have said relating to the mare, except that there aro moro bad-tempered stallions to be met with thun mares, independently of their running, and this is caused by the constunt state of unnatural excitement in which they are kept. This kind of vice is, however, not of so much importance, as it does not affect the running of the stock, and solely interferes with their stable management.

\section{BEST AGE TO BREED FROM.}

It is commonly supposed that one or other of the parents should be of mature age, and that if both are very young, or very old, the produce will be decrepit or weakly. A great many of our best horses have been ont of old mares, or by old horses-as, for instance, Priam out of Cressida, at twenty ; Crucifix, out of Octaviana, at twenty-two; and Lottery and Brutandorf, out of Mandane, at twenty and twenty-one; Voltaire got Voltigeur at twenty-one; Bay Middleton was the sire of Andover at eighteen, and Touchstone got Newminster at screnteen. On the other hand, many young stallions and mares have suceeded well, and in numberless instances the first foal of a mare has been the best she ever produeed. In the olden times, Mark Antony and Conductor were the first foils of their dams; and more recently, Shuttle Pope, Filho da Puta, Sultan, Pericles, Oiseau, Doctor Syntax, Manfred and Pantaloon, have all been first-born. Still these are exceptions, and the great bulk of superior lorses ure produced later in the series. The youngest dam which I ever heard of was Monstrosity, fouled in 1838, who prodiced Ugly Buck at three years old, having been put to Venison when only two years of age. Her dam, also, was only one year older when she was foaled; and Veuison himself was quite a young stallion, being only seven ycars old when he got Ugly Buck; so thnt, altogether, the last mentioned horse was a remarkable instance of successful lreeding from young parents. As in most eases of the kind, however, his early promises were not earried nut, and ho showed far better as a two-year-old, and early in the following yeir, than in his maturity. 'Such is often the case, and, I belicve, is a very general rule in breeding all animals, whether horses, dogs, or enttle. The generul practice in breeding is to use young stal- 
lious with old mares, and to put young mares to old stallions; and such appears to be the best. plan, judging from theory as well us practice.

\section{BEST TIME FOR BREEDING.}

For all racing purposes, an early foal is important, because the age takes date from the 1st of January. The mare, therefore, should be put to the horse in February, so as to foal as soon ufter January 1st as possible. As, however, muny mares foal a little before the end of the eleventh month, it is not sufe to send her to the horse before the middle of the second month in the year. For further particulars, see "Thoughts on Breeding," and the "Stud-Farm," in which the general management of the mare and foal is fully detailed.

It will be interesting that the reader have a pretty complete record of the best time at various distanees in racing. Such a record has been carefully compiled for Turf, Field and Farm. up to the close of the setson of 1879 ; and which we append:

Fastest and Best Time, and Most Creditable Performances on Record, st all Distanoes, to end of Year 1879.

\section{HALF A MILE.}

Olitipa, by imp. Lenmington, Saratoga, July 25, 1874, $0: 47$ 3-4. Pomeroy, by Planet, Louisville, Ky., May 23, 1877, $0: 49$ 1-4. Harold, by imp. Leamington, Saratoga, July 23, 1878, $0: 49$ 1.-4. Idalia, by imp. Glenelg, Jerome Park, June 8, 1876, $0: 49$ 1-2. Leona, by War Dance, Lexington, Ky., May 12, 1874, $0: 49$ 1-2. Blue Lodge, by Felloweraft, Lexington, Ky., May 10, 1879, $0: 49$ 1-2. Duke of Magenta, by Lexington, Saratoga, July 24, 1877, $0: 49$ 1-2. Idalia, by imp. Glenelg, Long Branch, July 4, 1876, 0:49 3-4. Sensation, by imp. Lenmington, Saratoga, July $22,1879,0: 49: 3-4$. Kimball, by imp. Buckden, Louisville, Ky., May 21, 1879, 0:49 3-4. Observanda, by Tom Bowling, Louisville, Ky., May 21, 1879, 0 :49 3-4. Grenada, by King Alfonso, Long Branch, July 5, 1879, $0: 49$ 3-4.

\section{FIVE-EIGHTHS OF A MILE.}

Bonnie Wood, by imp. Bonnie Srotland, Saratoga, July 20, 1878, $1: 02$ 3-4.

Grenada, by King Alfonso, Saratoga, Aug. 10, 1879, $1: 03$ 1-2.

Harold, by imp. Leamington, Long Branch, July 4, 1878, 1 :03 1-2.

Rachel, by imp. Bonnie Scotland, Long Branch, July 6, 1878, 1 :03 1-2. Palmetto, by Narragansett, Saratoga, Aug. 10, 1876,1 :03 1-2.

Rhadamanthus, by imp. Leamington, Saratoga, July 25, 1876, 1:03 1-2. Egypt (aged), by Plunet, Saratoga, July 19, 1879, 1 :04. 

Aristides, by imp. Leamington, Jerome Park, Oct. 7, 1874, 1 :04 1-2. Volturno, by imp. Billet, Sarutoga, Augr. 21, 1878, 1 :04 3-4.

THREE-QUARTERS OF A MILE.

First Chance, by Baywood, Philadelphia, Pa., Oet. 17, 187t, $1: 15$. Lady Middleton, by imp. Hurrah, Saratogu, Aug. 1, 1879, $1: 17$, 1:15 1-4. First was dond heat with Cheekmate.

Bill Bruce, by Enquirer, Lexington, Ky., May 12, 1876, $1: 15$ 1-2.

Connor, by Norfolk, Carson, Nev., Oet. 19, 1879, 1 :15 1-2.

Rhadamanthus, by imp. Leamington, Salatoga, Aug. 19, 1877, 1 :15 1-2.

Florence B., by Tom Bowling, Louisville, $\mathrm{Ky}$., Sept. 20, 1879, $1: 153-4$.

Madge, by imp. Australian, Surutoga, Aug. 21, 1874, $1: 15$ 3-4.

Alurm, by imp. Eelipse, Saratoga, July 15, 1872, $1: 16$.

Belle of the Meude, by imp. Bonnie Seotland, Nuslıville, Tenn., Oct. 9, $1876,1: 16$.

Enquiress, by Enquirer, Detroit, July 5, 1879. $1: 16$.

Egypt (aged), by Planet, Louisville, Ky., May 26, 1877. 1:17.

Milan, by Melbourne, Jr., Louisville, Ky., May 26, 1877, 1 :16.

Girofle, by imp. Leimington, Prospect Park, Sept. 13, 1879, 1 :16 1-4.

Spendthrift, by Australiun, Nishville, Oet. 8, 1878, 1.16 1-2.

Checkmate, by imp. Glen Athol, Saratoga, Aug. 15, 1879, $1: 16$ 1-4.

Kimball, by imp. Buckden, St. Louis, June 13, 1879, 1 :16 1-2.

Mistake, by Waverly, Louisville, Ky., Sept. 23, 1879, 1 :16 1-2.

Madge, by imp. Australian, Saratoga, N. Y., Aug. 15, 1876, 1 :16 1-2.

Glendalia, by imp. Glenelg, Louisville, Ky., Sept. 24, 1879, $1: 16$ 1-2.

Pigne, by imp. Leamington, Saratoga, Aug. 27, 1877, $1: 16$ 3-4.

Tom Bowling, by Lexington, Long Branch, 1872, $1: 16$ 3-4.

Bowling Green, by Tom Bowling, Louisville, Sept. 24, 1879, 1 :16 3-4.

Duke of Magenta, by Denington, Surutoga, Aug. 16, 1877, 1 :16 3-4.

Spartan, by Lexington, Saratoga, Aug. 16, 1877, $1: 16$ 3-4.

Sly Dance, by War Dance, Louisville, Sept. 22, 1879, $1: 16$ 3-4.

Bye and Bye, by imp. Bonnie Seotland, Louisville, Sept. 22, 1879 , $1: 163-4$.

McWhirter, by Enquirer, Louisville, Ky., May 15, 1879, $1: 17$.

Wallenstein, by Waverly, Lexington, Ky., May 15, 1879, $1: 17$.

Countess, by Kentucky,-Suratoga, 1873, 1 :17 1-2.

Beatrice, by Kentueky, Isong Branch, $1: 17$ 1-2.

Luke Blackburı, by imp. Bounie Seotland, Prospect Park, Sept. 6, 1879, $1: 17$ 1-2.

Oden, by Vauxhall, Saratoga, Aug. 7, 1879, $1: 17$ 3-4.

Idalia, by imp. Glenelg, Saratoga, Aug. 5, 1878, $1: 18$. 
Spartan, by Lexington, Sarutoga, Aug. 22, 1877, $1: 19$.

ONE MILE.

Ten Broeck, by imp. Phneton, Louisville, Ky., May 24, 1877, $1: 39$; 3 -4. Lennder (Semreher), by Euquirer, Lexington, Ky., May 13, 187\%, $1: 413-4$.

Redman, by Wu Danee, Lexingtou, Ky., May 13, 1876, $1: 42$ 1-4.

Danger, by Alarm, Baltimore, May 23, 1878, $1: 42$ 1-2.

Mahlstick, by Lever, Lexington, Ky., Sept. 20, 1877, $1: 42$ 1-2. Chas. Gorham, by Blarneystone, Lexingtou, Ky., Sep. 20, 1677, $1: 42$ 1.2. Dead hent.

Grey Planet, by Planet, Suratoga, Aug. 13, 1874, $1: 42$ 1-2.

Dan K., by imp. Bonnie Seotlaud, Louisville, Ky., May 24, 1×7\%, $1: 42$ 1-2.

Gooduight, lyy Enquirer, Louisville, Ky., Sep. 23, $1879,1: 42$ 1-2

Katie Pease, by Planet, Buffalo, N. Y., Sep. 8, 1874, $1: 42: 3$.

Ala'n, by inp. Eelipse, Saratoga, July 17, 1872, $1: 42$ 3-4.

Glenmore, by imp. Glen Athol, Detroit, July 4, 1879, $1: 42$ : 4.

Virginus, by Virgil, Saratoga, Aug. 4, 1877, $1: 42$ 3-4.

Cammie T., Ly imp. Glenelg, Louisville, Sept. 20, 1879, 1:4\%.

Mistake, by Waverly, Louisville, Sept. 26, 1879, $1: 43$ 1-2.

Edinburg, by Longfellow, Lexington, Mny 11, 1878, $1: 43$ 1-2.

Belle of the Mende, by imp. Bonnie Scotland, Louisville, Sept. 25, $1876,1: 441-2$.

Belle of the Meade, by imp. Bomie Scotland, Louisville, Senvt. 27 , 1876, $1: 44$ 1-4.

Spendthrift, by imp. Australian, Nashville, Oct. 12, $1878,1: 441-1$.

Clara D., by inp. Glenelg, Sacrumento, Sept. 27, 1877, $1: 44$ 1-z.

Astral, by Asteroid, Lexington, Ky., Sept. 12, $1873,1: 44: 3-4$.

Parole, by imp. Leamington, Saratoga, Aug. 10, 1875, $1: 44: 4$.

Aristides, by inup. Leamington, Baltimore, Oct. 22, 1874, $1: 443 \mathrm{3}-4$.

Susquehannu, by inp. Leamington, Saratoga, Aug. 8, 1876, $1: 45$.

Charley Howard, by Lexington, Saratoga, Aug. 17, 1876, 1:45.

Firework, by Lexington, Baltimore, Oct., 1874, 1:45.

Hamburg, by Lexington, Cincinnati, 1869, $1: 45$.

Battle Axe, by Monday, Sarntoga, 1873, $1: 45$ 1-2.

Spendthrift, (aged) by imp. Bonnie Scotland, Jer une 5 , $1876,1: 461-2$.

Tom Bowling, by Lexington, Long Braus MILE HEATS.

Kadi, by Lexington, Hartford, Coun, Sept. 2, I 475, fastest

he:

tud

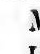

F

$1: 4$

Bob

Jane

Blue

War

Jack

Fadl

Picol

Him

Jils o

Fann

Roun

Konr:

Ben

heat, 1 :

Mollie

1879,1

Una,

Susqu

Exper 
heut, and fastest two hents ever run, $1: 42$ 1-2, $1: 41$ 1-4.

L'Argentine, by War Dance, Louinville, Ky., Sept. 27, 1879. Beatitude won first hent, $1: 42$ 1-4, $1: 421-3,1: 451-2$.

Mark D., by Monday, Sacrames'n sept. 19, 1878, $1: 43,1: 42$ 3-4.

Himyar, by Alarm, St. Louis, June 4, 1878, $1: 42$ 1-2, $1: 43$ 1-2.

Camargo, by Jack Malone, Louisville, Ky., May 20, 1875, $1: 42$ 3-4, $1: 431-4$.

Una, by Wur Dance, Prospect Park, June 25, 1879, $1: 42$ 1-4, 1 :45.

Tom Bowling, by Lexington, ran mile heats at Lexington, Ky., May, 1873 , in $1: 431.2,1: 431-2$.

Thornhill, by Woodburn, ran first two heats in $1: 43,1: 43$; Thad Stevens (aged), by Langford, won the third, fourth and fifth in $1: 431-2$, $1: 461.2,1: 45$.

Clara D., by imp. Glenelg, San Francisco, Sept. 13, 1878, $1: 43$, $1: 431-2$.

Brademante, by War Dance, Sarutoga, Aug. 9, 1877,1 :43 1-2, $1: 43$ 1-2. Brumble, by imp, Bonnie Scotland. Nashville, Oet. 7, 1878, $1: 43,1$ :44.

Lena Dunbar, by Leinster, Sacramento, Sept. 17, 1878, $1: 44$ 1-4. $1: 423-4$.

Springbok, by imp. Australian, Utica, N. Y., June 25, 1874, $1: 45$, $1: 4924$.

\section{ONE MILF AND ONE-EIGHTII.}

Bob Woolley, by imp. Leamington, Lexington, Ky., Sept. 6, 1875,$1 ; 54$. Janet Murray, by Panic, Brighton Bench, July 13, 1879, 1 :54 3-4. Blue Eyes, by Enquirer, Louisville, Ky., May 28, 1879, $1: 55$ 1-4. Warfield, by War Dance, Louisville, Ky., Oct. 1, 1878, 1 :56. Jack Hardy, by imp. Phaeton, St. Louis, June 4, 1878, 1 :56. Fadladeen, (aged) by War Dance, Saratoga, Aug. 19, 1874, $1: 56$. Picolo, Concord, Saratoga, Aug. 15, 1874, $1: 56$.

Himyar, by Alarn, Louisville, Sept. 20, 1879, $1: 56$.

Jils Johnson, by Longfellow, Lexington, Sejt. 11, 1879, $1: 56$ 1-2.

Fannie Iudlow, by imp. Felipse, Saratoga, Aug. 10, 1879, 1 :56.1-2.

Round Dance, by War Dance, Louisville, Sept. 27, 1879, 1 :56 1-2.

Konrid, by Rebel Morgan, New Orleans, April 26, 1878, 1 :56 1-2.

Ben Hill, hy imp. Bonnie Scotlund, Louisville, Sept. 25, 1879, dead heat, $1: 56$ 3-4.

Mollie McGinley, by imp. Glen Athol, Brighton Beach, Sept. 10, $1879,1: 57$.

Una, by War Dance, Prospect Park, Sept. 11, 1879, 1 :57.

Susquehanna, by imp. Leamington, Saratoga, July 24, 1877, $1: 57$ 1-4. Experience Oaks, by Lexington, Sarutoga, Aug. 20, 1872, 1 :57 1-4. 
Bramble, by imp. Bonnic Scotland, Suratoga, Aug. 17, 1878, $1: 58$.

Bramble, " " " " " “ $9,1879,1: 58$.

Kennesaw, by imp. Glengarry, Louisville, May 28, 1878, 1 :58 1-2.

Essillah, by Lever, Nashville, Apr. 29, 1879, 1 :58 1-2.

Gabriel, by Aların, Brighton Beach, Sept. 27 1879, $1: 59$.

Edinburg, by Longfellow, Louisville, Sept. 25, 1878,1 :59.

Diamond, by imp. Leamington, Ogdensburg, N. Y., Sept. 10, 1878, $1: 59$.

Lancerood, by imp. Leamington, Saratoga, Aug. 13, 1×7!9, 1 :59.

Belle, by Dickens, Saratoga, July 23, 1878, $1: 59$.

Rhudamanthus, by imp. Leamington, Sarutoga, Aug. 15, 1876, $1: 59$ 3-4.

Spendthrift (aged), by imp. Bonnie Scotland, Jerome Park, June 10, 1876, 2:00

Phyllis, by imp. Phxton, Louisville, Sept. 27, 1876, $2: 01$.

Spendthrift, (aged), by imp. Bonnie Scotland, Jerome Park, June 12, 1875,2 :03 1-4

ONE MILE AND A QUARTER.

Charley Gorham, by Blarneystone, Lexington, Muy 1४, 1877, 2 :४ 1-2.

Falsetto, by Enquirer, Lexington, May 10, 1879, 2 :08 3-4.

Grimstead, by Gilroy, Saratoga, July 24, 1875, 2 :08 3-4.

Frogtown, by imp. Bonnic Seotland, Lexington, Ky., May 1872, $2: 09$ 1-2.

Monitor, by imp. Glenclg, Prospect Park, Sept. 9, 1879, 2 :10.

Parole, by imp. Leumington, Saratoga, July 20, 1878, 2 :10 1-2.

Mate, by imp. Australian, Jcrome Park, Oct. 3, 1874, 2 :11 3-4.

Preakness, by Lexington. Jerome Park, June 13, 1874, 2 :12.

\section{ONE MILE AND THREE-EIGHTHS.}

Spendthrift, by imp. Australian, Jerome Park, June 10, 1879, 2 :25 3-4. Gov. Hampton, by Planet, Prospect Park, June 21, 1879, 2 :26 1-2.

Bramble, by imp. Bonuie Scotland, Lung Blanch, July 10, 1879, $2: 27$.

ONE AND A HALF MILES.

Tom Bowling," by Lexington, May 12, 1874, 2 :34 3-4.

Parole, by imp. Leamington, Saratoga, Aug. 14, 1877,2 :36 3-4.

Lord Murphy, by Pat Maloy, Louisville, May 20, 187:), 2 :37.

Daty Star, by Star Davis, Iuuisville, May 21, 1878, 2 :37 1-2.

Aristides, by inp. Lenmington, Louisville, Ky., May 7, 1875, 2 :37 3-4.

Glenelg, by Citudel. Iong Branch, Aug. 2, 1870, 2 :37 3-4.

Shylock. by Lexington, Jeromo Park, Oct. 31, 1874, 2 :38.

Baden Buden, by imp. Australiau, Louisvilln, May 22, 1877, 2 :38. 
10,1878 ,

$1: 59$.

$15, \quad 1876$,

, June 10,

k, June 12,

$77,2: 8$ 1-2.

May 1872,

$: 10$.

$1-2$

$3-4$.

2.

$79,2: 253-4$.

$2: 261-2$.

$1879,2: 27$.

$363-4$.

37.

$-2$.

$75,2: 373-4$

$7,2: 38$.
Vagrant, by Virgil, Louisville, May 14, 1877, $2: 38$ 1-4.

Peru, by imp. Gilengarry, Lexington, Ky., Sept. 11, 1879, 2 -38 3-4.

Belle of Nelson, by Hunter's Lexiugton, Louisville, May 23, 1878, 2 :39.

Imp. Saxon, by Beadsman, Belmont stakes, Jeromo Park, Juno 13,1874, $2: 391-2$.

Tom Ochiltree, by Lexington, Jerome Park, Oct. 14, 1877, $2: 43$.

Zoo Zoo, by imp. Australian, Saratoga, Aug. 21, 1877, $2: 43$ 1-4,

Duke of Magent:l, by Lexington, Jerome Park, June 8, 1878, $2: 43$ 1-2.

*'Tom Bowling was permitted to extend the run to two miles. He ran the first mile in $1: 413-4$; mile and a half in $2: 343-4$; one and threequarters miles in $3: 003-4$; and two miles in $3: 273-4$. The last two unofficial.

ONE MILE AND FIVE-EIGHTHS.

Ten Broek, by imp, Phaeton, Lexington, Ky., Scpt. 9, 1875, $2: 49$ 1.4. Monitor, by imp. Glenelg, Prospeet Park, Sept. 13, 1879, 2 :50 1-2. Springbok, by imp. Australian, Jerome Park, June 20, 1874, 2 :53. Brademante, by War Dance, Lexington, May 17, 1877, 2 :53 3-4.

Harry Bassett, by Lexington, Belmonte stakes, Jerome Purk, June 10, $1871,2: 56$.

Mintzer, by imp. Glenelg, Saratoga. July 23, 1879, $2: 58$.

Katic Pease, by Plant, Ladies' stake, Jerome Park, June 11, 1873, $2: 581-4$.

ONE AND THRFE-QUARTER MILES.

One Dime. by Wanderer, Lexington. Sept. 12, $1879,3: 05$ 1-4.

Irish King, by Longfellow, Sept. 25, 1879, 3 ;05 1-4.

Courier, by Star Davis, Louisville, May 23, 1877, $3: 05$ 1-4.

liefurm, by imp. Leamington, Saratogra, Aug. 20, 1874, $3: 05$ 3-4.

Mate. by imp. Australian, Long Branch, July 15, 1875, $3: 06$ 1-4.

D'Artagnau, by Lightning, Saratoga, July 24, 1875, $3: 06$ 1-2.

Gen. Phillips, by imp. Glenelg. Saratoga, Aug. 5, $1879,3: 06$ 1-2.

Emma C., by Planet, Louisville, Ky., Sept. 23, 1875,3 :06 3-4.

Frogtown, by imp. Bomnie Scotland, Lexington, Ky., May 26, 1872, $3: 07$.

Diunicheff, by Glenelg. Surutoga, Aug. 9, 1879, 3:07.

Gov. II:umpton, lyy Planet, Prospect Park, Sept. 9, 1879, $3: 07$ 1-2.

Kenny, ly Curles, Prospeet Park, June 25, 1879, 3 :07 1-2.

Leveler. by Lever, Lexington, Sept. 9, 1878, 3:07 1-2.

Neeey Hale, by Lexington, Lexington. Ky.. Sept. 14. 1876, 3:07 3-4.

Catesby, by imp. Eelipse, Saratoga, Ang. 15, 1874. $3: 07$ 3-4.

Parole, by imp. Leamington, Sarutoga, Aur. 11. 1877, $3: 08$.

Kemes:aw, by imp. Glengurry, St. Louis, June 5, 1878, $3: 08$. 
Duke of Magenta, by Lexington, Saratoga, July 20, 1878, $3: 08$.

Joe Danicls, by imp. Australian, 'Travers' Stuke, Saratoga, July 13, 1872, 3 :08 1-4.

Preakness, by Lexington, Baltimore, Oct. 21, 1864, 3 :08 1-2.

Viceroy, by Gilroy, Saratoga, Aug. 9, 1877, 3 :08 1-2.

Volturno, by imp. Billet, Brighton Bench, Sept. 16, 1879,3 :08 1-2.

Atilla, by imp. Australian, Travers's Stake, Sarutoga, July 25, 1874, $3: 09$ 1-2, $3: 08$ 3-4. The first was a dead heat with Acrobat.

Mintzer, by imp. Glenelg, Saratoga, July 28, 1879, 3 :09 1-4.

Falsetto, by Enquirer, Saratoga, July 19, 1879, $3: 09$ 1-4.

Zoo Zoo, by imp. Australian, Saratoga, Aug. 2, 1877, $3: 10$.

TWO MJLES.

Ten Broeck, by imp. Phæton, against time, Louisville, May 29, 1877, $3: 27$ 1-2.

MeWhirter, by Enquirer, Louisville, May 28, 1877, 3 :30 1-2.

Courier, by Star Davis, Louisville, May 28, 1877, $3: 31$ 3-4.

Katie Pease," by Planct, Buffalo, Sept. 9, 1874, 3:32 1-2.

True Blue, by Lexington, Saratoga, July 30, 1873, $3: 32$ 1-2.

Jack Frost, by Jack Malone. Cleveland, O., July 31, 1874, 3 :33 1-2.

Glenmore, by imp. Glen Atho!, Detroit, July 5, 1879, 3 :33 1-2.

Lizzie Lucas, by imp. Australian, Sarntoga, Aıg. 21, 1874, 3 :33 3-4.

Creedmoor, by Asteroid, Louisville, Ky., Sept. 20, 1876, 3 :34.

Geo. Graham, by Rogers; first heat; Louisville, Ky., Sept. 25. 1675, $3: 34$.

Lord Murphy, by Pat Mailoy, Louisville, Sept. 22, 1879, $3: 34$.

King Alfonso, by imp. Phæton, Louisville, Ky., Sept. 20, 1875,3 :34 1-2.

Hegiru, by imp. Ambassador, New Orleaus, La., Nov. 23, 1850,3 :34 1-2.

Littleton, by imp. Leanington, Lexington, Ky., Muy 23, 1871, 3 :34 1-2.

Monitor, by imp. Glenelg, Baltimore, Oet. 21 , $1879,3: 34$ 3-4.

Wilful, by imp. Australian, Prospect Park, June 24, 1879, 3 :34 3-4.

Charlie Howard, by Lexington, Saratoga, Aug. 10, 1876, 3 :35.

Vandalite, by Vandal, Breckinridge Stake, Baltimole, Oct. 23, 1874, $3: 35$.

Himyar, by Alarnı, Lonisville, Sept. 25, 187!, 3 :35.

Falsetto, by Enquirer, Saratoga, Aug. 14, 1879, 3 :35 1-4.

Volturno, by inp. Billet, Baltimore, Oct. 25, 1879, 3 :35 1-4.

Vandalite, by Vandal, Dixic Stake, Biltimore, Oet. 2(), 1874, 3 :35 1-2.

Harry Basset, loy Lexington, Saratoga, Aug. 16, 1871, $3: 35$ 1-4.

Vigil, by Virgil, Baltimore, Oct. 28, 1876, 3 :37 1-4.

"Katie Pease aame in first, but was disqualified, and race given to Lizzie Lucas. 
8. July 13 ,

8 1-2. 5,1874 ,

29,1877 ,

:33 1-2.

$1-2$.

$3: 333-4$.

34.

25. 1875 ,

34.

, $3: 34$ 1-2.

, $3: 341-2$.

, $3: 34$ 1-2.

-4 .

:34 3-4.

:35.

23,1874 ,

4.

, $3: 35$ 1-2.

5 1-4.

e given to
TWO MLE HEATS.

•Brademante, by War Dauce, Juckson, Miss., Nov. 17, 1877 (?) $3: 321-4,3: 29$.?

Willic D., by Revolver, Prospect Park, Sept. 11, 1879, $3: 34$ 1-2, $3: 35$.

Lottery, by Monday, Sacramento, Cal, Sept. 21, 1878, 3 :36, $3: 35$ 1-2.

Arizona, by Lexington, Louisville, Ky., May 18, 1875, $3: 37$ 1-4, $3: 351-2$.

Aureola, by War Dance, Lexington, Sept. 18, 1872, $3: 37$ 3-4, $3: 35$ 1-2.

London, by Lightning, Nashville, Oct. 5, 1872, $3: 36$ 3-4, $3: 37$ 1-4.

Bushwhacker, by imp. Bonnie Scotland, Baltimore, Oct. 22, 1878, $3: 36,3: 36$ 1-2, $3: 38$ 1-2.

lrinceton won second heat by head. Bushwhacker second; best average three heats.

Belle of Nelson, by Hunter's Lexington, Cincinnati, June 1, 1878, $3: 371-4,3: 361-4$.

Mollie Jones, by Roxbury, Galesburg, Ill., July 4, 1874 ; Rocket won first heat, $3: 36,3: 40,3: 37$ 1-4.

Eolus, by imp. Leamington, Baltimore, May 28, 1874; the fastest third heat, $3: 40,3: 391-4,3: 363-4$.

Laneıster, by Lexington, Lexington, Ky., Sept. 12, 1867, $3: 35$ 1-4, $3: 381-4$

Jack Sheppard, by Jack Malone, Nushville, Oct. 12, 1876, 3 :35 3-4, $3: 421-2$.

Irish King, by Longfellow, Baltimore, Oct. 21, 1879, $3: 37$ 3-4, $3: 37$ 3-4. Harkaway, by Enquirer, St. Louis, June 7, 1878, $3: 39,3: 35$ 1-4.

- Brademante's time very doubtful.

TWO MLES AND ONE-EItHTII.

Aristides, by imp. Lenunington, Lexington, Ky., May 10, 1876, $3: 45$ 1-2.

Mate, hy imp. Australian, Sarıtoga, July 31, 1875, 3:46 3-4.

Monmouth, by War Dance, Louisville, Miay 1!, 1875, $3: 48$ 1-4.

Big Fellow, by War Dance, May 15, 1874, $3: 50$.

Dave Noore, hy Longfellow, Lexington, May 16, 1879, 3 :50 1-2.

Ferida, by imıp. Glenelg, Prospect Park, Sept. 5, 1879, 3 :54.

Springbok, by imp. Australian, Saratoga, Aug. 3, 1874, $3: 56$.

Sultiust, by Lexington, Jerome Park, Oct. 7, 1876, 3 :56 3-4.

\section{TWO MILES AND A QUARTEIR.}

Preakness, by Lexington; Spriugbok, hy imp. Australian, dead heat, 3:56 1-4.

Hitry Bassett, by Lexington, Saratoga, July 16, 1872, $3: 59$.

W'anderer, hy Lexington, Saratoga, Aug. 13, 1874, 4 :00 1-2.

Kentueky, hy Lexington, Saratogn, Aug., 1865, $4: 01$ 1-2.

Fortuna, by Enquirer, Louisville, May 23, 1879, 4 :(01 1-2. 
Bramble, by imp. Bonnie Scotland, Baltimore, Mny 24, 1879, 4.02 .

Mollie McCarty, by Mondny or Eclipse, Chicago, June 25, 1879, 4:02.

Muggins, by Jack Malone, Larntoga, Aug., 1867, 4 :03.

TWO AND A HALF MILES.

Aristides, by imp. Leamington, Lexington, Ky., May 13, 1876, $4: 27$ 1-2.

Katie Pease, by Planet, Buffalo, Sept. 10, 1874, $4: 28$ 1-2.

Ballankeel, by Asteroid, Baltimore, Oct. 22, 1874, $4: 31$ 3-4.

Helmbold, by imp. Australian, Long Branch, July 30, 4 :32 1-2.

Tom Ochiltree, by Lexington, Jerome Park, June 18, 1877, 4 :36 1-2.

Edinburgh, by Longfellow, Cincinnati, June 7, 1879, 4:36 1-2.

TWO MILES AND FIVE-EIGHTIS.

Ten Broeck, by imp. Phneton, Lexington, Ky., 1876, 4 :58 1-2.

TWO MILES AND TIREE-QUARTERS.

Hubbard, by Planet, Saritoga, 1873, $4: 58$ 3-4.

Kentucky, by Lexington, Jerome Park, Oct. 3, 1866, 5 :04.

Tom Ochiltree, by Lexington, Jerome Park, June 17, 1876, 5 :09 1-4.

THREE MILES.

Ten Broeck, by imp. Phæton, Louisville, Ky., Sept. 23, 1876, 5 :26 1-2.

Monarchist, by Lexington, at Jerome Park, 1872 ; first mile, $1: 45$; $5: 34$ 1-2.

Tonı Oehiltree, by Lexington, Long Branch, July 6, 1876, 5 :35 :3-4.

TIIREE MILE HEATS.

Brown Dick, by imp. Margrave, New Orleans, April 10, 1865; the best second heat on record, and second best three mile heat race, 5 :30 3-.t ; 5 :28.

Mollie Jackson, by Vandal, Louisville, Ky., May 25, 1861 ; Sherrod won the second leat. The list two miles of the first lieat were run in $3: 35$ : the last two of the second heat in $3: 36: 3-4:$ the nintl mile in $1: 481-4$. This is the best three heats and the best third heat on record, 5 :35 1 -2 ; 5 -34 3-4 ; 5 :28 3-4.

Norfolk, by Lexington, Sacramento, Cal., Sept. 23, 1875 ; best avelage two heats, $5: 27$ 1-2; 5:29 1-2.

Vandal, by imp. Gleneoe, Lexington, Miy 26, 1855, 5 :36 1-2 ; 5 :33.

Whisper by Planet, St. Louis, June, 8, 1878, 5 :39; 5 :35 1-2.

FOUR MILES.

Ten Brocek, hy imp. Phaton, vs. Fellowcraft's time, Louisville, Ry., Sept. 7, 1876, $7: 14$ 3-4.

Felloweruft, by imp. Australian, Saratoga, Aug. 20, 1874, 7 :19 1-2. 
02. mile in record,

Lexington, by Boston, vs. time, New Orleans, La., April 2, 1855, $7: 173-4$.

Lexington, by Boston, beating Leeomte, New Orlenns, April 14, 1855, $7: 23: 3-4$.

Janet, by Lightning, Louisville, Sept. 27, 1879, $7: 29$.

Wildidle, by imp. Australian, San Frmeiseo, Oct. 28, 1875, $7: 25$ 1-2.

Idlewild, by Lexington, over Centreville Course, L. I., June 25, 1863, $7: 261-4$.

Thad. Stevens, by Langford, best second heat, Californin, Oct. 18, $1873,7: 30$.

Kentucky, by Lexington, Saratoga, 1866, $7: 31$ 1-2.

Silent Friend, hy imp. A ustralian, New Orleaws, April 21, 1873, $7: 30$ 1-2.

Kentucky, by Lexington, vs. time at Jerome Park, 1867; first two miles, $3: 36$; first three $5: 29$; $7: 313-4$.

Abd-el-Kader, by Australian, Saratoga, 1869, $7: 31$ 3-4.

Abd-el-koree, by imp. Australian, Jerome Park, Full 1871; best time for n three-year-old, $7: 33$.

Monarchist, by Lexington, Jerome Park, 1872 ; first two miles, $3: 39$ :3-4; first three, $5: 36$; $7: 33$ 1-2.

Tom Ochiltree, by Lexington, Jerome Park. Oct. 12, 1876, $7: 36$.

FOUL MLF IIEATS.

Lecompte, by Boston, at New Orleans, April 8, 1854, henting Lexington and Reube, $7: 26,7: 3 \times 1-4$.

Kupee, by Voucher, April 10, 1858, $7: 39$, 7 :35.

Miss Foot, by imp. Consol, at New Orleans, Mareh 26, 1×42, 8:02, $7: 35$.

Fashion, hy imp. Trustee, over Union Course, L. I., Mny 10, 1842, beating Boston natch, $7: 321-2,7: 45$.

Morgan Scout, hy John Morgan, at Lexington, Ky., 1870, best race ever run in Kentucky, $7: 321-2,7: 43$ 1-2.

(ieorge Martin, by Garrison Zinganzee, beating Hunnah Harris and Reol, March 29, 1843. Reel broke down in first heat, $7: 33,7: 43$.

Bushwhacker, by imp. Bonnie Seotland, Baltimore, Oct. 26, 1878. l'rinceton won seeond heat, $7: 31,7: 361-4,8: 29$.

(Glemmore, ly imp. Glen Athol, Baltimore, two and three heats, bent third heat, $7: 29$ 1-2, $7: 301-47: 31$.

T'ally-ho, hy Boston, ut Union Course, L. I., Oct. 8, 1849 ; Free Trude won the tirst heat, Boston the third, and 'Tally-ho second and fourth, $7: 331-2,7: 431-2,7: 52,8: 101-2$.

\section{HURDLE RACES.}

doe Rodes, hy Virgil, mile heats, over four hurdles, St. Louis, June 4, $1878,1: 503-4,1: 501-4$. 
Judith, by imp. Glenelg, mile heats, uver four hurdles, Prospect Purk, Sept. 11, 1879, $1: 52,1: 52$.

Lobelia, hy imp. Bonnie Scotland, mile heats, over four hurdles, Fashion Course, L. I., Sept. 11, 1869,1 :51 3-4, 1 :53 1-4.

Waller, by imp. Hurrah, one and a quarter miles, over five hurdles, Suratoga, Aug. 14, 1878, $2: 21$ 1-2.

Disturbance, by Chillicothe, one and a quarter miles, over 5 hurdles, Saratoga, Aug. 22, 1878, $2: 21$ 3-4.

Problem, by Pimlico, one and a half miles over 6 hurdles, Long Branch, July 5, 1879, $2: 50$.

Derlyy, by Eugene, one and a half miles, over six hurdles, Loing Branch, July 2, 1878, $2: 52$.

Judith, by imp. Glenelg, one and three-quurter miles, over seven nurdles, Long Branch, Aug. 28, 1879, 3 :36 1-2.

Tom Leathers, by Camps Whale, two miles, over eight hurdles, New Orleans, April 16, 1875, $3: 47$ 1-2.

Redman, by War Dance, two miles, over eight hurdles, Louisville, Ky., May 19, 1876, 3:48 1-2.

Captain Hutchinson, by Voucher, two miles, over eight hurdles, Columbus, O., July 3, 1875, $3: 50$.

Jonesboro, by Lexington, two miles, over eight hurdles, welter weights : Now Orleans, April 11, 1868, $3: 51$ 1-2.

Milesian, by imp. Miekey Free. two mi!es, over eight luurdles, welter weights; Long Braneh, Aug. 3, 1872, $3: 52$ 1-2.

Cariboo, by Lexington, two and a qunrter miles, over nue hurdles, Long Branch, 1875, $4: 33$.

\section{STEFPLE CHASES.}

Dead Head, by Julius, about two and three-quarter miles, thirty-six leaps, Saratoga, Aug. 26, 1878, 5 :33 1-2

Trouble, by Ulverston, about two and three-quarter miles, thirty-six leaps, Saratoga, Aug. 19, 1876, 5:34 3-4.

Duffey, by Hunter's Lexington, about two and three-quarter miles, thirty-six leaps, Saratoga, Aug. 5, 1873, $5: 48$ 3-4.

\section{FASTFST TROTTING TO WAGON.}

Oue mile, Julge Fullerton, San Francisco, Nov., 1874, time $2: 20$ 1-2.

Two miles, Geu. Butler and Dexter, each a heat, Iong Island, 1863, time $4: 561-4$.

Three miles, Kemble Jackson, June, 1853, time $8: 03$.

Four miles, I,ongfellow, Dec. 31, 1869, time $10: 34$ 1-2.

Five miles, Little Mack, Iong Island, Oct. 29, 1863, time 13:43 1-2.

Twenty miles, John Stewart, Iong Island, Sept. 22, 1868, time 59 :23. 


\section{TRAINING TO TROTIING.}

Fash-

urdles,

urdles,

Long

3ranch,

en nur-

s, New

le, Ky.,

les, Co-

reights :

, welter

hurdles,

hirty-six

hirty-six

miles,

$1-2$.

363 , time

2

23.

The idea of the averuge horse owner is that training means pampering the horse. Nothing could he further from the mark. It truly means the very best and most intelligent care, feeding and exercise for the work to to be performed, and this exercise must be in proportion to the distance.

The artificial care given the horse in eonfinement renders blankets necessary for all fast working horses. Doubly so for turf horses, whose pace is of the most exhausting kind. To get rid of superfluous flesh sweating and exereise is necessary. The superfluous flesh and undue moisture of the body having been properly reduced, then the pace of the horse should correspond to that expected in the final trial. Thut is for mile hents a faster pace will be required than for longer heats, lout the horse must be earefully worked up to the point, the improvement heing (arrefully and intelligently watehed, thit as the day of trinl approuches he may have a real trial of speed for the distance to be trotted. There is, however, no rule that ean be laid down as to the amount of work to be done before this trial takes place. It will depend upon his condition while at work and the manner in which he accomplishes his brushes, as spurts of speed are called for short distances. These are anong the most important parts of training, since they tend not culy to extend the stride of the horse and improvement in speed, but the manner of coming out of them will indiente the condition of the animul.

High-strung, enger, generous horses nust be handled in a very different manner from sterner tempered ones. In nny cuse, the horse must come to place implicit confidence in his driver. The first must be restrained; the second urged. The first named seldom lave the power to aceomplish all they would. The second must be made to know that it is speed and distance that is required, and that they must go the paee if it is in them.

Feeding is essentially important. Some horses crave much hay. Such must be restrained; some gluttons will eat their bedding. If so, they must be muzzled when not feeding, und alwnys so at night. If a horse is so light a feeder that be will not eat twelve quarts of onts a daty, he may hive a little Indiun com, but this only in exceptional cases. Sound, henvy outs, thoroughly cleaned and sifted, should constitute the feed of the trotting horse, or any horse of fnst work. The light feeder must be earefully watehed in his work. Some horses will eat fourteen to sixteen quarts of oats a day. Such should huve corresponding exercise; for in no event must fat be allowed to aceumulnte. We should prefer to limit any horse, however large and powerful, to fourteen cyuarts of oats per 
day, or rather to that number of pounds. As a rule twelve quarts or pounds should suffice for the averige horse.

Hirum Woodruff, than whom there is no better authority, in his work on "'The Trotting Horso of America," in relation to the preparntion which precedes the first triul, says :

During the preparation which preedes the first trial, it will be necessary to give the horse one or two sweats. Whether it ought to be one or two must be indicated by the condition and unture of the animal, the races in which he is engaged, and resolved by the judgment of the truiner. The amount of elothes in which he shall be sweated must be determined by the same considerations. Some may require a blanket and hood, and a wrapper round the neek to start the perspiration out of them: while there are others that will sweat freely with but little elothes, and scrape well when more have been thrown on at the end of the jog. One thing may certainly bo said, that a sweat obtained without the use of henvy clothing is more satisfactory and better than one with it, provided the latter method does not include a good deal more work to get the sweat. Only a moderate quantity of elothing and little work while the horse is going are the best for a sweat, if a good scrape can thus be obtuined. When the horse comes from the drive, and is taken out of the wagon, he will soon be ready to scrape. That done, he must be blanketed up again, and walked about out of the draft. A favorable day for the sweat ought to be taken advantage of, as a matter of eourse. Another light serape may probably be had after some little time spent in walking in the blankets; but, if the perspiration does not continue so as to give this second serape, it is not to be forced by more work in the clotles. To be of use in itself, and as a satisfactory indication that the condition of the horse is advaneed it must come of itself. During the time this seraping process is in course of operation, the trainer having the conduct of it should not be in a hurry. The same things that are said to cure a nun's cold-patience and a little water-gruel - will often do wonders in procuring a good sweat. Commonly, however, it is ensy enough to gret the sweat and serape, but more difficult to eool the horse out properly. In order to do this well, he is to bo elothed uguin, and led very gently about for a considerable period, so that he may become cool gradually, and the perspiration may dry away ly degrees. This walking is to be out of all draft as much as possible ; and it will not do to lemry it over, and go to the stable, until the horse has cooled off well and gradually. When the proper state has been retehed, the horse is to be taken into the stable and his body is to be well dressed. This done, he is to be re-clothed, and again led into the air.

A few sups of gruel, made of Indian meal or tiue shorts, from half s 
pint to a pint of the menl stirred into a bucket of water may now he given to the horse, or water with the chill taken off it may be used as a substitute for the gruel. When tuken into the stublo again, which will be after a little more walking about in the air, the logis me to be put in tubs of warn water, the body elothing being kept on. The legs are then to be well washed with the water and castile sonp, and when dried off to be bandaged. These bandages should be of light flumel, and it is inmaterial whether it is red or white. Thoy me not to be put on tight. The legs of a horse ought never to be bandaged tight, for such a eourse inpedes the circulation into the feet, where there is " grent necessity for it ; but losing sight of this, the bundages are sometimes pulled so that it looks as if they were intended to serve as a tourniquet, and stop the circulation of the hlood altogether. Neither can it serve nny useful purpose, that I ean see, to bind the suspensory ligament up to the bone of the leg. Nature intended that in the horse it should stand out from it, as we see in the fine fint legs of the best runners and trotters. Whatever support is required may be obtained with 8 nly a moderate degree of tightness ; and I have sonetimes thought that an elastic stocking, such us our best surgeons use in eases of bad strain to the nerves and muscles of the human foot and ankle, would be a very useful article in a training-stable.

DIRIVING.

The average furmer's boy supposes he can drive a trotting horse. Has he not seen the pietures of drivers sitting back, apparently holding to the reins with a grasp), as though the stronger the horse was pulled the faster he could go? Such driving never got speed out of a horse. The best drivers simply"allow the horse to pull on the bit with sufficient force to steidy himself, and this pulling force must be grinduated according to cireumstanees. It is true many fast horses are land pullers, and generally so from defects in training. The bit and reins are intended simply is the medium of communication between the horse and the driver, and the more intelligently the horse is trained to their use, the more will be got out of him. The horse should be tuught to take a firm hold of the bit, not for the purpose of pulling upon, iut that the driver may give the horse needed support and stendiness, and that intelligent action miny be exublished between the diver and the horse.

The object of kecping the horse well in command during fast work. on the road as well as on the track, is that he may instantly respond to the wish of the driver through the medium of the reins. Thus he may be pressed from day to day in his speed, until he at last comes to the full ineasure of his powers.

Although trotting speed does not come to the horse until some years 
after he is fully developed in growtl, the history of trotting shows that this incrense of speed continues to develop until the horse is from ten to twelve years old. Hence there should be no hurry to clevelop the animal while young. He should be driven from the time he is three years old, sufficient to eause hin to lengthen his stride as much as possible. He should be taught to listen quickly, never to frighten or shy at any object, and this by familiarizing him with whatever muy bo near. In his brushes, either on the rond or the traek, however sharp they may be, they should never be extended until the animal shows signs of distress. When he is being regularly trained for some public trial of speed, it will be time enough to find out if he cnn go the desired pace.

DRIVINA ON THE ROAD.

Road driving, like driving or riding a race, is a fino art. In road driving the object is not only to get good speed out of the animal driven, but he must also be made to go in tino style. With a horse of naturnlly fine action, this, if the driver understands his business, is not difficult. If not a horse of naturally fine style and action, he may be spoiled. For road work the horso should have been better flexed than when he is to be used for trotting a race. He must be able to turn out quickly and handsomely in passing or meeting other teums. When being driven slowly, he must curry himself hundsomely. Thus something must bo sacrificed to this end.

Every horse should have a perfect fitting bit. It should be of the proper size and length for the mouth, und this ean only be decided by trial. Keep trying different bits until you find one in which the horse works counfortubly. Above all, in handling a young horse do not injure the mouth with a eruel or rough bit. Above all, never be so cruel as to jerk his mouth with the reins. The bit is the medium of communication between the driver and the horse. If there is any speed in the horse. it is to be gotten out of him by means of the bit, and hence the nore sensitive you can keep the mouth, the more likely you are to succeed. If you render the mouth numb or callous through pulling, twitching, suwing ' $w$ other smart trieks of drivers, you do so to the pernanent injury of the horse. Therefore first aequire a niee touch yourself, and there will be no difficulty in imparting it to the horse.

Never lose your temper with the horse. If a horse does so that is 10 reason why you should. Never strike a horse with the whip for any fuult, and then jerk him back with the reins. If necessury to punish him, first assure yourself that you have him sufficiently well in hand so he cunnot " jump out of the harness." Have a definite object in view, for every use of rein or whip. Aloove all avoid a steady, rigid pull on the horse. Some horses will not trot without being pulled liard. It is 
ows that

an ten to 10 animal eurs old, ble. He my obIn his may be, distress. ed, it will

In road ial driven, naturally ifficult. If led. For on he is to nickly and ing driven g must be

be of the lecided by the horse not injure cruel as to munication he horse, it more sensceced. If hing, suwth injury of there vill

that is no ip for auy to punish (II hand so ct in view, id pull on ard. It is usually from defect in training. The perfect horse is truined to pull just sufficient to steady himself in hurness. How Hirum Woodruff drove, he tells in his "Trotting-Horse of Amerien." No one, during his life, or since his denth, was better unthority in such matter's. Hence, we cunot do better than to give it to our readers in his exact words.

In order that a fast loorse should be under eireumstances to do his hest, he should be as much at his ease in his lamess mod generul rig as possible. If he is not, he is pluced at almost as omuch disndvantage ns if sore or stiff, or suffering from some bodily ailment. You.mnay seo horses brought out of the stuble to trot with a very tight eheck to keep their hends up, and a tight martingale to keep them down. Such a horse is in irons ; and when to this is added a dead drag at the reins, and no movement of the bit from end to end, I e:unnot see how he could do his best. Peoplo talk about a steady, bracing pull ; but, in my opinion, that is not the right way to drive a trotter. There is a grent differenee between letting go of your horse's hend, and keeping up one dull, dendening pull all the time. 'The race-horse riders princtice what is called a braeing pull ; and, a grent many times, I hatve seen their horses tire under it without ever ruming their best. The stendy pull checked them. The pull should be sufficient to feel the mouth, and give some support and assistance, so as to give the horse conficlence to get up his stride. More than that is mischievous. To keep the mouth ulive, the bit must be shifted a little oceasionally. A mere half-tum of the waist, or less than lanlf $n$ turn, by which the thumb is elevated and the little finger lowered, is sufficient to shift the bit, keep' the mouth sensitive, and rouse the horse.

The reins are to be held steadily with both hands while this play with the wrist is made; and it is, of course, only done with one wrist at a time. The hands should be well down; and the driver ought not to sit all of a heap, with his head forward. Neither should he lean back, with his bodily weight on the reins, which, in that ease, are nunde a sort of stay for him. He should be upright; and what pulling he must do should be done by the muscular force of the arms. The head and the arms are what a good driver uses; but some hold their arms stringht oit, and pull by means of putting the dend weight of their bodies on the reins. If, instead of lying back, and putting their bodily weight on the reins, with which latter they take a turn round their hands, drivers would depend upon their muscular strength, they couid let up on the pull, graduate it, and so ease the horse from time to time instantaneously. The driver who depends upon the arms has command of the horse: he whorsubstitutes bodily weight with the reins strapped round his hands, has not half command of the horse, or of himself either; and, if the horse is a puller, he will soon take command of the driver. The reason of it is, that there 
is no intermission of the exertion, no let ul, either for man or home. Besides, in that way of driving, it is impossible to give those movements to the bit which seem to refresh nud stimulnte the horse wo much. When a horse has been taught the signitiennce of this movement of the bit, the shift by the turn of the wrist, he will uever fnil to answer it, even though he should seem to be nt the top of his speed. 'The moment he feols this little move of the lit in his sensitive month, he will eollect him. self, and make unother spurt; and the value of this way of driving is, that the horse is not likely to brenk when thus enlled upon, while a highstrung, generous horse, if enlled upon for a finul effort with a whip, is as likely to brenk the moment it fulls on him us not. I have won many a very close heat by pretising this movement, and therefore 1 have no hes. itation in recomnending it. It is not ditheult to acounre, and the horse soon conses to know whit it menus.

Let us eome now to the way of takmng nota of the reins. A wrap around the hand, such as running-horse riders take, is elumsy and bad. I do not know whether many people take hold of the reins as I do, of not. Perhaps not. Sim. Honglund is the ouly one who taken hold precisely as I do, so fur us I have observed. When we have heen jouging horses together at early morning, we hnve often talked over thest matters; and, whether our way wns the best way or not, we could never spe any other that suited us half so well.

I will try to explain how I hold the reins: I could show it in two sec. onds. Tnke, first, the right-hnnd rein. This, coming from the bit, passes between the little finger and the third finger, over the little: finger, then under the other three fingers, and up over the thumb. The lefthand rein is held in the left hand exactly in the same way ; but the bight of the slack of the rein is also held between the thumb and foretinger of the left hand. This gives some substance in that hand; but, if it is found ineonvenient to huve it there by those who have small hand, it may be dropped altogether. A tirn grasp on each rein, witl the back of the hands up, and without any wrap, is thus obtuined. It is if great point in driving to be able to shift the reach-that is. the length of the hoid yor take-without for an instant letting go of the horse's head. With this way of holding the reins, it is ensily done. If I want to fhorten the hold on the left hand rein (the near one), I take hold of that rein jort behind the left hand with the thmmb and forefinger of the right latud, and steady it. This is very ensily done; and it does not iuterfere at all with the command of the off rein with the right hand. 'The near rein being thus steadied behind the left hand, I slide that hand forward on the rein, which is kept over the little finger, under the other tlue tingers, and over the thumb all the time, and then shut the grasp again on the new reach. 
loophe.

emesits

musch.

of the

it, even

went be

et lim.

vilug is,

a ligh.

aiv, is as

maaty a

au hes.

be burse

A wrap aud bad.

I do, ot ald pre. jogging

yene inat-

neverer see

two aec-

the bit, llo finger, The leftthe hight forctinger , if it is 1.. it may ve of the $t$ proint in hosid yor With this orten the reiu just und, and t all with rein ining the rein. - and over aw reach.

A shift with the right hund is made just in the same way, by taking hold and steadying the rein behind that hand with the thumb and forefingor of the left hund.

"I have often observed, that, with other methods of holding the reins, there wis grent difficulty in shifting the reach. The driver tries to do it; but, for an instant, he has let go of the horse's head on one side altogether, and broken his stride. When this is found to be the case, the dead pull all the time is adopted; and this spoils the freedom and elasticity of the horse's stride, and chokes of his wind. I do not intend this to be takell as instruction for professional drivers. Every driver has a way of his own; and some of them have very good ways, for, as I have taken occasion to stato before, they drive well. But what I have set down above may be of service to gentlemon who drive their own horses, and to those young men who, having as yet no settled method of their own, may think it well onougb to try that which I have found to unswer. Anotber word about bits. I am opposed to the use of severo bits, and complicated things of that sort. Some of the inventors of such things say I am prejudiced; but $I$ don't think $I \mathrm{am}$. If a man has a horse that eannot be driven with a bar-bit or a snaffle, ho may as well sell him, except it is a very exceptional case. Where are these kinds of severe complicated bits most in uso? Why, in England; five hundred or a thousand of them are used thero to one that is used hero: and where do the horses trot the best? These bits are mostly invented by men who have had no practical experionce whatever as to what sort of driving a fast trotter requires to keep his gait square and bold, and induce him to $\mathrm{do}$ his best when it is called for. When $\boldsymbol{n}$ horse has a good mouth-and a bad one is almost always the fault of bad breaking and driving-the ensier the bit you use, the better be will act for you, and the more speed he will show you."

\section{Trotting Horses.}

It has often been said of Northern and Eastern men, that they'do not take kindly to the saddle. In a sense this is true, especially in the North. In England the passion for riding in the saddle grew up at a time when there were, so to speak, no roads. In the earlier settlement of Anerica, throughout the then vast timber region, the same state of things existed; but a peoplo who settle a new country have soinething else to think of than riding to hounds or other pleasure riding. So the country became seitled; the level or gently unduliting nature of the country rendered good rouds passablo at light cost, and the absence of preserves of game, $\boldsymbol{a}$ landed aristocracy, and the improvement in vehicles for pleasure and use, tended to force public taste in the direction of driv- 
ing. Hence the early appreciation of the trotting horse, and the wonderful dovelopment in speed in this direction.

In the South, raciug stock held its own, and does oven to this day; and nobly have they contested the palm of victory, and successfully, on many

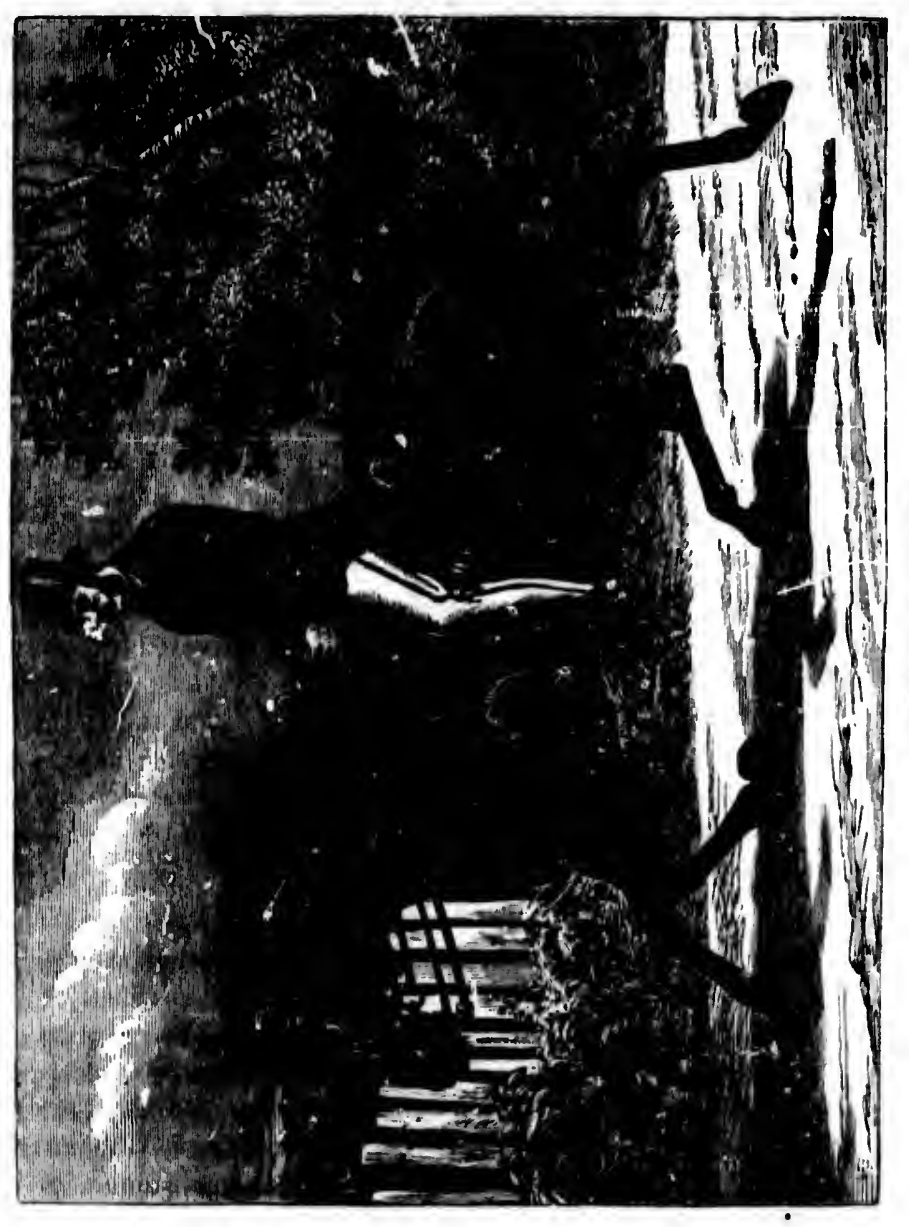

hard fought ficlds of racing blood in linglund and our own country. At the Nortl, however, the trotting horse now reigns supreme. It is the intention here to present something of tho wonderful inerease in siped und endurance of the trotting horse of $\boldsymbol{A}$ mericn, with information of the 
most celebrated horses that early gave fushion to this style of going, and a full list of animals and performances, that the reader may see at a glunce the growth of this passion for trotting horses.

\section{EARLY TROTTERS.}

Until 1823 we have but little authentic information that regular trottilly courses were established, and not until 1830 were fast trotting courses estublished. According to .Porter's Spirit of the Times, the first public trotting in Ameriea for a stake was a match against time for $\$ 1,000$.

In 1824, A. M. Giles trotted his horse 28 miles in one hour nnd fiftyseven seconds. The same year Topgallant and Betsey Baker were matched to trot three miles in harness for $\$ 1,000$ a side. The raeo was won by Topgallant by 40 yards, in 8 minutes, 12 seconds. Topgallant also trotied iz miles on tho road in 39 minutes. The "Albany pony" did a mile in 2 minutes, 40 seconds. The Treadwell mare did ono mile in $2: 34$; and Boston Bluo trotted 18 miles within the hour. Boston Blue is reported to have been the fit at horse that trotted a mile in three minutes; it huving been done in 1818 . So that it will bo seen that the Trealwell mare in 1824 had redueed the time to $2: 34$. Yet for many years after a 2:40 horso was considered extraordinary, as also was any lor'se capable of going on the roud in 3 minutes.

In 18:7, on the Hunting Purk Association of Philadelphia, Screwdriver won two heats at two miles, beating Betsey Baker in $8: 02$ and $8: 10$, the three hest time on reeord. Dutehman nfterwards acconiplished the same distance in $7: 321-2$, and Lady Suffolk in $7: 40$ 1-2.

In $1: 40$, on the Long Islund course, Jerry bent Whulehone in a three mile trotting mee, in $8: 23$ the first hent, and $8: 15$ the second. The best time for 2 mile heats that your was $5: 22,5: 21 ;$ for 3 miles, $8: 26,8: 27$, $8: 41, x: 56$. On long distances Sweetbriex accomplished six miles in $18: 52$.

In 1 1344 Edwin Forrest, us yet an unentered horse, trotted his inile in $2: 31$ 1-2, leating Sally Miller. The course was 1 mile and 10 yards in length.

In 1835 Dutchman mado four miles, under the saddle, in 11:19 and $10: 51$, and Dolly, by Messenger, out of a thoroughbred mure, fivo miles fo wagon, carrying two mon, weighing 310 pounds, in $16: 45$; and immediately was started again to do 10 miles more, which she accomplished in $34: 0 i$. The sane year the horse Duniel D. 'Thompkins, under the sincldle, trotted threo mile heats in $7: 59$ and $8: 10$.

In $1 \times 42$ liipton beat Lady Suffolk, at 3 miles in harness, in $5: 07$ and $3: 17$.

In 1843 Lady Suffolk made mile heats in $2: 281-2,2: 28,2: 28,2: 29$ 
and $2: 32$, which was not again equaled until 1854 , when this record wh. covered by Tacony.

In 1844 Cayuga Chief made the first half mile in a race in $1: 15$, the fast:st yet mude in public; and Fauny Jenks accomplished 100 miles, in harness, in 9 hours 38 minutes 34 seconds. The slowest mile was done in $6: 25$ and the fastest in $4: 47$. At the end of the race this mare was driven an extra mile in $4: 23$.

In 1849 Lady Suffo.' $z$ trotted 19 times and won 12, benting Grey Eagle and Mac twice, Pelham five times, Lady Sutton twice, Trustce four times; also beat Black Hıwk, Gray Trouble, Plumbay and other horses. This year a Canadian mare, Fly, is said to have been driven from Cornwall to Montreal, ninety miles, in 8 hour's and 15 minutes. Fanny Jenks made 100 miles in 9 hours 38 minutes and 34 seconds. Fanny Murray trotted one hundred miles in 9 hours 41 minutes 23 seconds.

In 1852 Tacony won 12 races, benting all the best horses of the day, making a single mile in $2: 26$; two miles in $5: 02$, und was beaten orily twice. As a 3 year Ethan Allen trotted this year in $3: 20$. Florn Temple this year won her first purse, on the regular turf, in $2: 41$.

In 1853 the entire sporting interest was centered in Florn Tenple and Tacony. Flowa this year beat all the best horses of the day, winning seventeen times. Her best time at mile heats was $2: 27,2: 28$, in $;$. mile hents 5:01 1-2, 4:59. This year Tueony trotted a mile in 2 .

In 1856 the contest lay principally between Florn Tempte and Flora nade 11 rnecs, wimning nine, beating Laneet four times in harness, and Tacony three times in harness, Tneony going under the saddle. This yeur Florn Temple lowered the one mile reeord to $2: 241-2$.

What the trotting horse of Amerien owes his great powers to the infusion of thorough blood, we have before stated. To Imported Messenger is this due in the greatest degree. Messenger's sire was M:unbriuo, his second sire Engineer, and his third sire Sumson. Thenee to Blaze, Flying Childers and the Darley Arabinn. Samson is reported to have been coarse and homely, and Engineer rough and conrse, but both of these hories were of extraordinary substance.

Asother grent trotting sire of America was imported Bellfounder. There has been inuch controversy over his breeding, first and last, but that he wiss a staurich trotter, and a getter of admirable horses, there is no dout t, griving splendid action to his get. Still, it must be admitted that, adnirable us was Bellfounder himself, his get was not equal to the deseendants of SFessenger in all that constitutes speed, endurance wid action.

Durne also hecame a valuable factor in our trotting blood. His strain of blood appears in the Medley's, Durne Messenger's, Mambrino Chief's and Gold Dust's. 


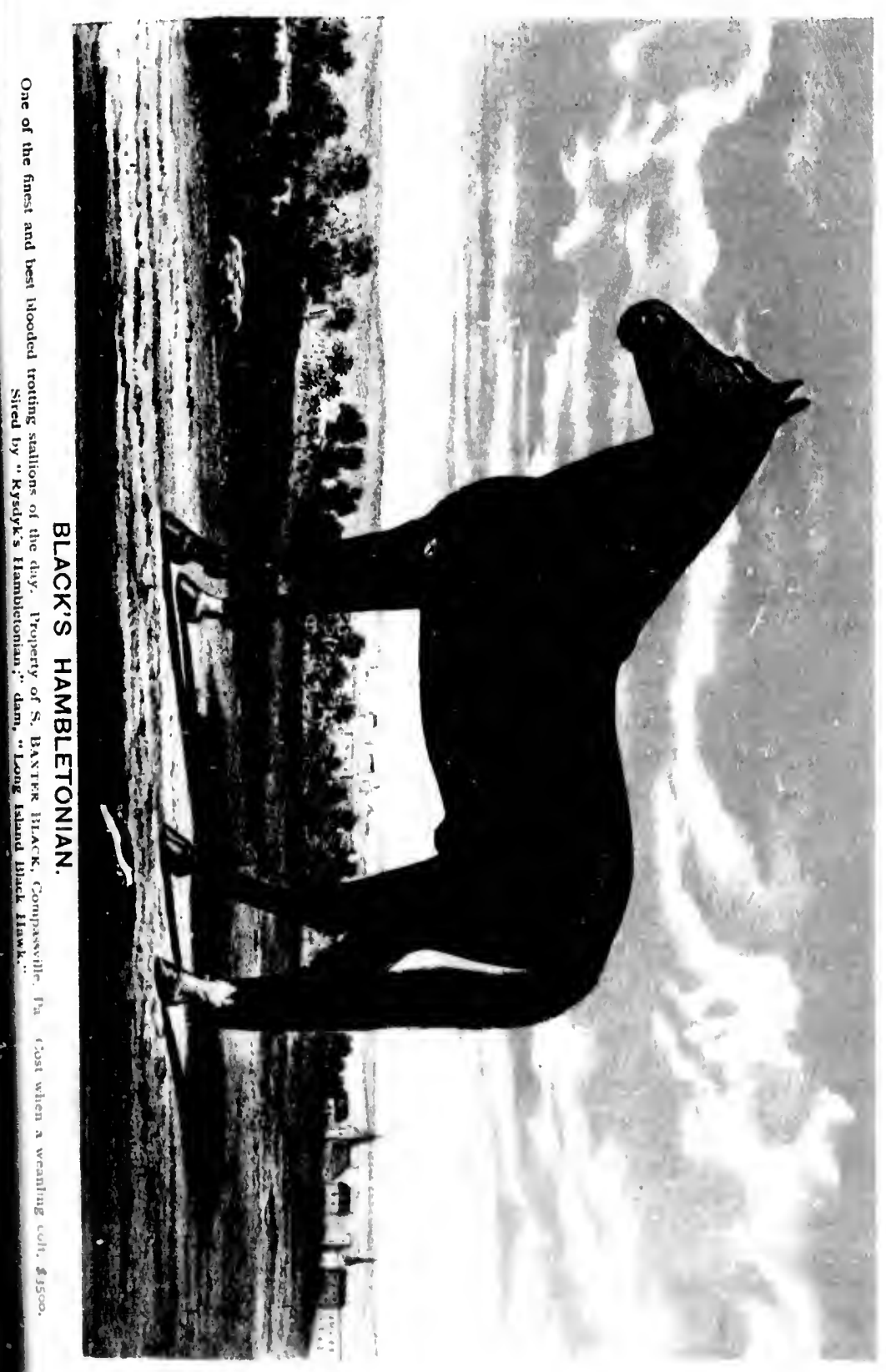


One of the sub-families of Messenger's blood, Hambletonian, who united the blood of Messenger and Bellfounder, has raised the trotting horse of America to the highest point of perfoction. He was not a handsome horse from a thoroughbred standpoint, if indeed bo was thorouginbred, which has been doubted. It has been given as follows:

Humbietonian was by Abdallah; ho by Mumbrina, a son of Messenger. The dum of Abdallah, the mare Amazonia. The dam of Hambletonian by imported Bellfounder; secoud dam by Humbletonian; third dam, Silvertail, said to have been by imported Messenger.

In all that constitutes stoutness and ability to perform, in freedom from tendency to disability, his stock has been wonderful. Noted for inmense and strong joints, length and strength of bone, magnificent muscular development, prominent, square, mussivo build, mighty hips and excellent barrel, all knit together to form a most admirable frame, united to a nervous constitution, that reproduced itself in his descendunts, in a most wonderful degree.

One of the finest specimens of the Hambletonian stock is shown on the preceding plate. This fine horse was by Rysilyk's IIambletonian, by Abdallah, by Mambrino, by Imp. Messenger. Dam Kitt, by Long Island Black Hawk, by Andrew Jackson, by Young Bushaw, by Imported Bashaw. Is half-brother to Dexter, time 2.17ł; Nettie, 2.18 ; Jay Gould, $2.21 \ddagger$; Gazelle, 2.21 ; George Wilkes, 2.22 ; Volunteer (who has eight trotters below 2.25); Elsall's Hamliletonian (Sire of Gohsmith Maid, 2.14); Elward Everett (Sire of Judge Fullerton, 2.18); Bruno and Brunette, that trotted double in 2.25ł. Foaled 1868 ; bright golden bay; two white fuct; star and stmall stripe on face; black legs, mane and cail ; $15 \frac{1}{2}$ hands high. A horse of fine finish, and shows his high breeding; remarkably strong and vell-backed; thick through the heart; game head; beautiful, strong eyee, set wide apart; clean, sinewy limbs, and sound feet; perfectly sound, excellent constitution, good temper, and very intelligent ; a natural trotter, with the big, open, fust, easy, stride of the Hanbletonians.

Of Goldsmith Maid, one of the truly great descendants of this bloor, Mr. H. T. IIclm, of Chicago, in 1876, wrote as follows:

\section{GOLDSMITI MAID,}

"The Qieen of the Trotting Turf, was fouled in 1857, and is now nmeteen yeurs old. Sho was bred by Johu D. Deoker, of Sussex county. N. I. Iler dam was one of those yellow-bay mares so common in the produce of old Abdullah. She was undersized, fretful, und of a nervous temperament, nnd up to the age of six years had performed no work of any kind, exeept to run occensional races about and on tho farm, for the amusement of the boys. In 1863 she was sold by Mr. Deeker for \$260: the purchaser selling her ngain, on the same day, to Mr. Tompkins, for $\$ 360$; und she was soon nfterward bought by Mr. Alden Goldsmith, for 8i00. The eye of the practical horseman discovered that she wis worth 
the handling. He discovered her ability, and soon brought the world to a knowledge of ber value. Under his careful and patient management, and the skillful drivers ensployed by him, she soon displayed such speed

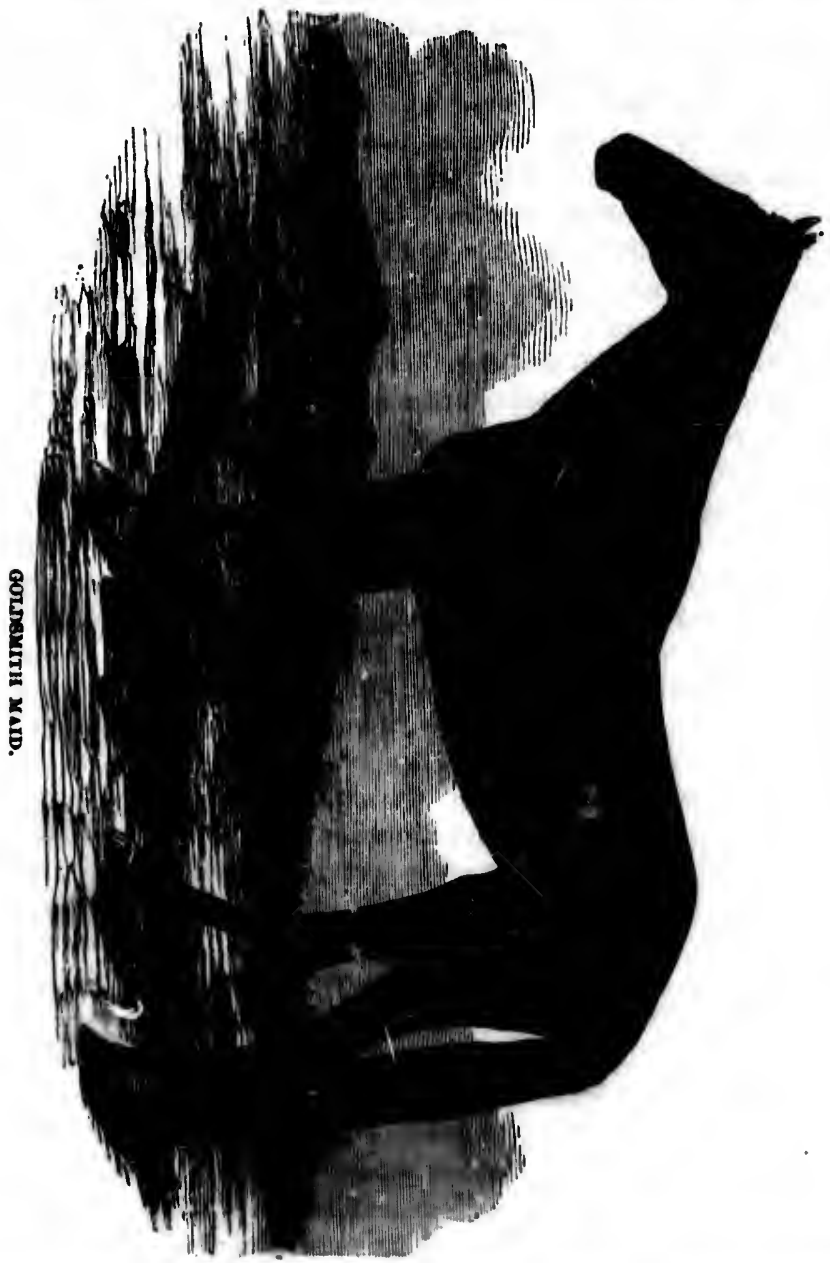

and extraordinary qualities of game and endurance, that he was ahle to sell her, at about the age of eleven years, for the sun of $\$ 20,000$. The purchasers were B. Jackman and Mr. Budd Dobie, and, under the guid-nce of the latter, she las steadily advanced in a eareer of fume that is 
without a parallel in the history of the trotting turf. She was subseyuently sold, by the two gentlemen last numed, to H. N. Suith, for the sum of $\$ 37,000$, and yet remains his property. She has been matched against all the great trotters of her period; and, while she hus ocensionally lost a race, she has ultimately vanquished all competitors, and stendily lowered the reeord for trotting performanees, and at the age of eighteen, murked the marvelous, and thus far unappronchable, reeord of at mile in $2: 14$.

"T'wice during the year 1876 she trotted in a race in $2: 15$, anil although in her first raco agninst the renowned Snuggler she was beitun, she by no means surrendered her queenly scepter, for again, at Buffulo, she nsserted her supremney in the three fustest suceessive hents on record. Proudly does she commund the sympathy and applnuse of all beholders when she hurls at her powerful ecmpetitor the defiant chullenge, "You many become King, but I am yet Queen."

"It were useless to mention the numes and performances of others; there is no name that can be compared with that of the little bay mare; the faume and the radiunce of all others pale before the brilliancy of $"$ renown thit followed her to the age of twenty years, and has been witnessed on every great course throughout the expmnse of a continent. I subjoin a description of the Trotting Queen, from the pen of one of our most necurite and capable writers:

"Goldsmith Maid is a bay mare 15 1-4 hands, no white. She appenrs, ut first glinee, to be rather delieately mude, but this conception is dinwn from the form, rather than the quality of her make-up. Her hend and neck are very clean and blood-like; her shoulder sloping and well placed; middle piece tolerubly deep at the girth, but so light in the waist as to give her a tucked-up appearanee, and cne would say a lack of constitution, but for the abundnut evidence to the contrary ; loin and coupling good; quarters of the greyhound ordor-broad and sinewy; her limlss are clean, tine-boned and wiry; feet rather small, but of good quality. she is high mettled, and takes an nbundance of work without flinehing. In her highest trotting form, druwn to an edge, she is almost deer-like in alypearance, and when scoring for a sturt and alive to the emergencies of the race, with her great flashing eye and diluted nostrils, she is a perfect pieture of mimation and living beuty. Her gait is long, bold and swceping, and she is, in tho hands of a driver nequatinted with her peculiarities, a perfect piece of machinery. She seldom makes an out-nndout brenk, but frequently makes a skip, and has been accused of losing nothing in either case. Aside from the distinction of hnving trotted the fustest mile on record, she also enjoys the honor of making the fustest three consecutive heats ever wor in a race, which renders any comments upon her staying qualities vnnecessury. 
She continued on the turf until past twonty years old, and after com. pleting that nge she closed her publio career with the year 1877 by trotting during that year forty-one heats in $2: 30$ or bettor, and making a time record of $2: 14 \mathbf{1 - 2}$. Hor record stands at thu close of her career at $2: 14$, with 332 hoats in $2: 30$ or bettor. Her record and her career are "the marvel of the age." Goldsnith Maid finally found a home at the Fashion stud farm, at 'T'renton, N. J., there to end her lluys.

DEXTER.

Dexter has been so often described, that the publio aro fumiliar with his appearance. A dark bay or brown gelding, with a whito stripe the full length und width of his face, and four whito logs; 15 hands, 1 inch high; his head as finely cut in its outline as that of Australian or Bonnie Scotland; an oye that does not stand out with the prominence of the Abdallah cye in Hambletonian, but one that sparkles with a glatice of fire that spenks of thut which is back of tho orb; his muno and tuil are medium in fulness, und in form and blood-like appenrunce he is hardly surpassed by that of any thoroughbrod of full age in the country. His rocord of $2: 17$ 1-4 is fumiliar to all.

\section{JAY GOUL.E.}

Jay Gould is a bright bay horse, of fine mould and finish, 15 hands 2 inches in height; rather light-nppenring in form, but of grent and powerfully formed quarters, and a tolerably fuir set of limbs. His hend is a fincly formed one, and he has a fuce that indicates the high degree of intelligence that in so great a mensure marks this branch of the family. Ho has trotted twenty heats in $2: 30$ or better, and reached a record of $2: 21$ 1-2, and in uddition is credited with one son, King Philip, a young horse only fivo yeurs old, that has trotted nine heats in $2: 30$ or beiter, and reached a record of $2: 21$.

\section{MAUD S.}

HOW SHE WAS RAISED AND WHAT BHE HAS ACCOMPIISIIED.

Mand S. was foaled on the Alexnnder stud farm, Kentucky, on the 28th of May, 1875. She is of Harold, dam Miss Russell by Pilot, Jr., second dam Sallie Russell by old Boston. She is 15 hands 3 inehes in height, $1 \frac{1}{3}$ inches higher vehind than in front; her weight is $\mathbf{9 6 5}$ pounds; she is a red-chesenut mare without a white spot. Until she was 4 years of age the mare was owned by Captain Stowe and was formed uuder his personal supervision. When she was a colt she wins gentle and affectionate, and a great pet with Captain Stone's daughter. Miss Stone became very much attached to her pet, and the mare seemed to be just as much attached to her. Captain Stone, therefore, requested his daughter to name her equine playfellow, and in compliance she gave it her 


\section{$\bullet$}

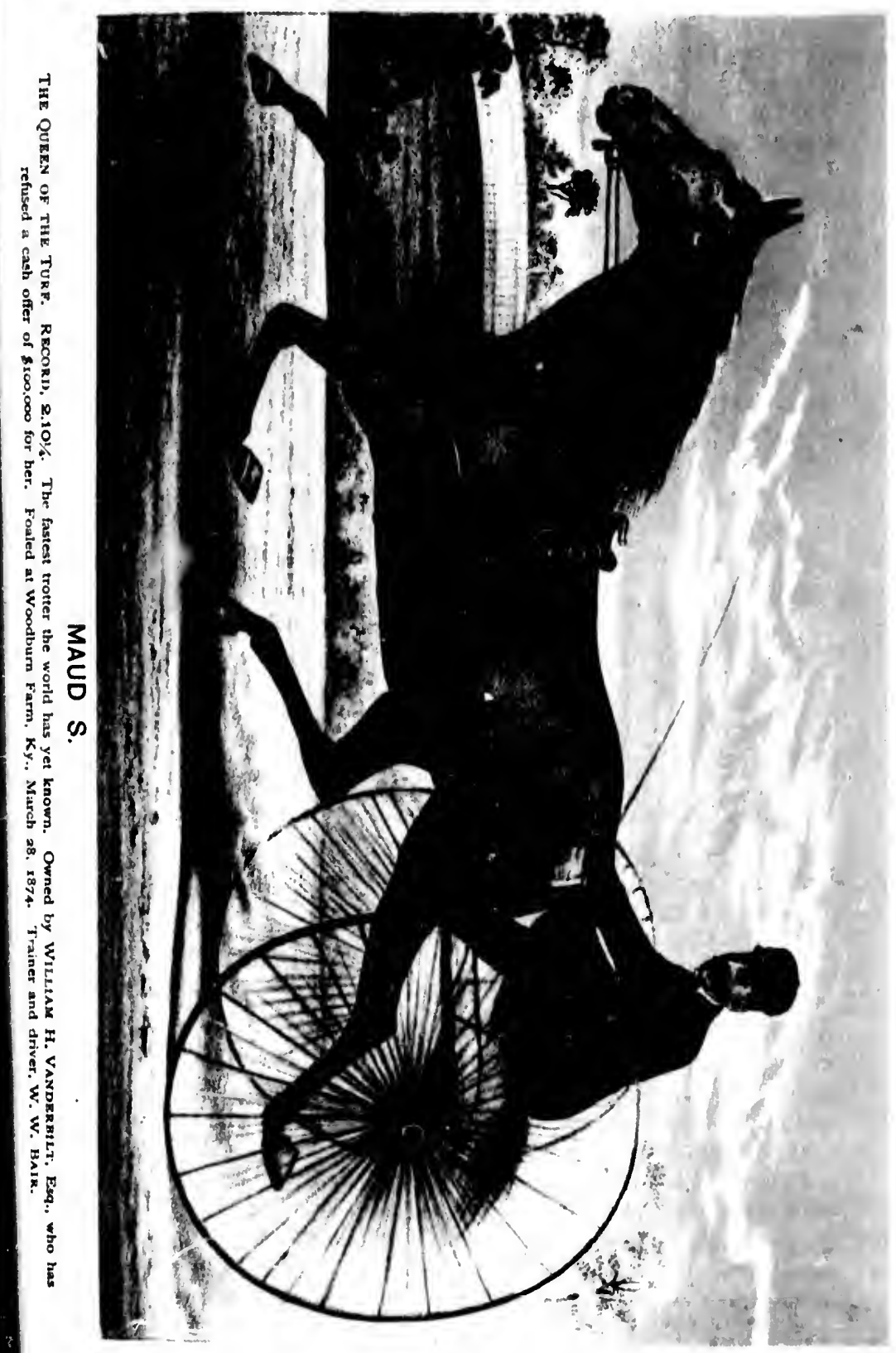



own name, Maud Stone, which was afterward ubbreviated into Mand S., a namo which hus since become celebrated throughout Eurojo and America. When Maul S. was 4 years old, however, Captnin Stone sold her to Willian H. Vanderbilt of New York. That gentleman sent her to a well-known Long Islund stud furm to be formed. When slie was 5 years old, however, he bemane dissutisfied with her handling, and sending for Captain Stone requested liin to take entirs charge of her future training. Captain Stone consented, aml the mare has sinee that time heen in his care. Wlien being speeded the mare wenrs a 4-ounce too-iveight, arljusted so thut it ean be removed when she is jogging, as at that time her trainer never allows it to be worn.

HER PERFORMANCES.

Mand S.'s first publie exhibition was given July bih, 1880, at Cincinnati. She wis entered in the 2.34 cluss. She won in three hents. 'Time, 2.23, 2.30 and 2.28 .

Her uext rnee was at Chicngo on July 24th for a special purse aguinst Trinkett. T'le mure won in three hents. 'Time, 2.19, 2.21 and $2.13 \frac{1}{2}$, in her second publie race thus surprising the sporting world by making a record at which oll turfmen held up their hunds in wonder.

Mand S. next appeared nt Clevelund on July 28 th in the 2.19 elass. She won in three heats; time-2.24, 2.18, 2.31.

At Buffalo, Augnst 4th, wins the next trot in the 2.19 elass. The mare liere lost the first hent to Charlie Ford in 2.17 and won the next three in 2.15 , $2.16\}$ and 2.16 ?

At Rochester was her next trot, on August 12h, against time to beat all records. The first quarter was mule in 321 , the half in 1.05, the three-quarters in 1.38 , and the mile ind $2.11 \%$.

Chicago was her next trotting place on an exhibition against time. In this the now widely celebrated little mare was successful. The first quarter was made in 334 , the half $1.04 \frac{1}{2}$, the three-quarters in 1.36 and the mile in $2.11 \frac{1}{2}$.

In her next race at Chieugo, September 18th, ngainst time, Maud S. still more astonished the work. She made the first quarter in 34 seconds, the half mile in 1.043, the three-quarters in 1.36 and the milo in the wonderful time of 2.103 , trotting the middle half in 1.02 .

After this she went into winter quarters at Cincinnati in the height of her glory. On the 1st of Jnunary, 1881, she was taken up and give her first exhibition at Columbus, Ohio, on June 30th, over a very slow track, agninst Rarus' best time over that track of $2.17 \frac{1}{2}$. She made the first quarter in 33 seconds, the balf in 1.06 , the three-quisters in 1.40 and the mile in 2.131 .

At Detroit, July 4th, ngainst St. Julien's best time over that track of $2.16 \mathrm{f}$. First quarter in $35 \frac{1}{2}$, the lialf in 1.08 , the three-quarters in 1.423 and the mile in 2.13 . 


\section{IMAGE EVALUATION \\ TEST TARGET (MT-3)}
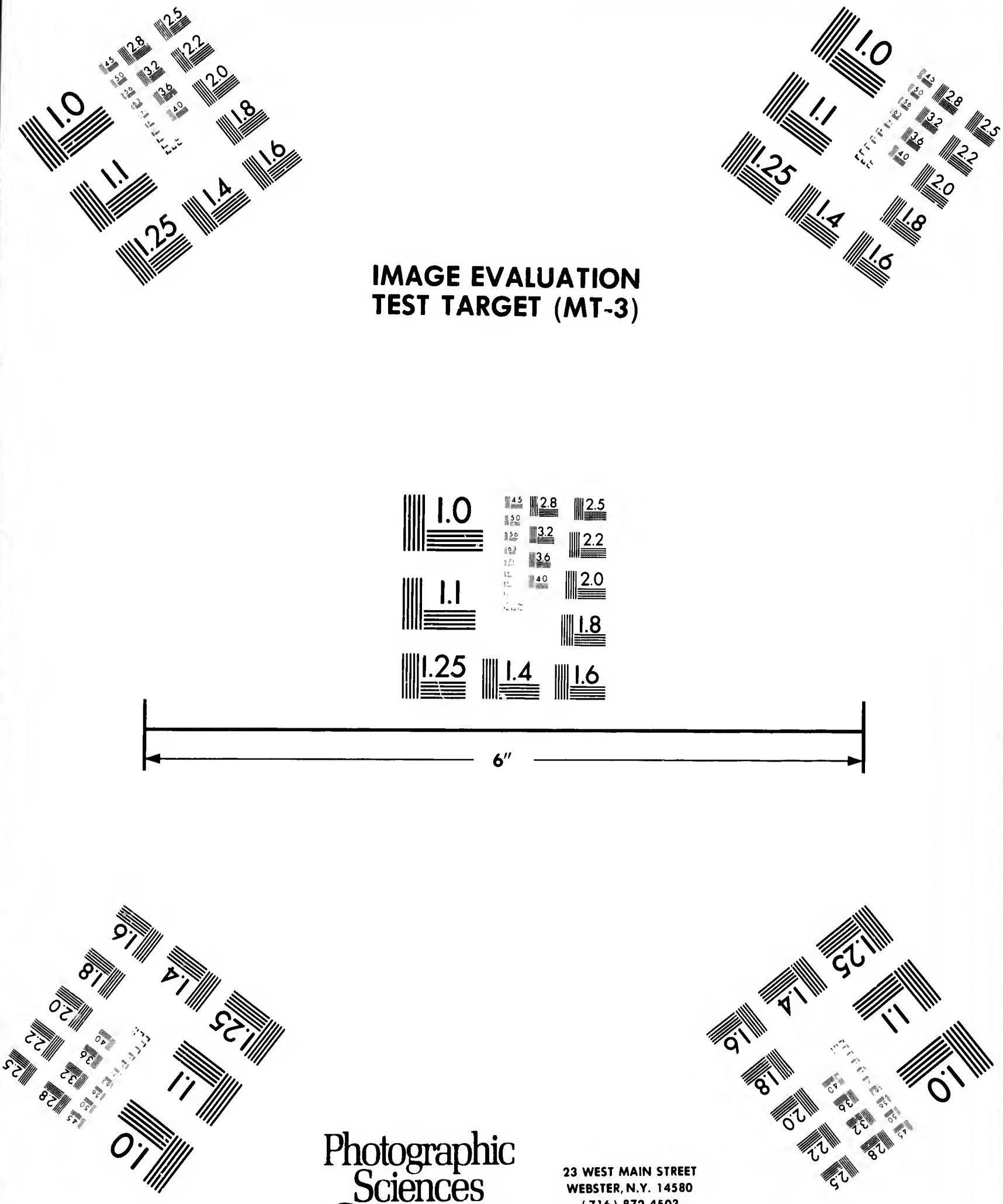

Photographic Sciences Corporation

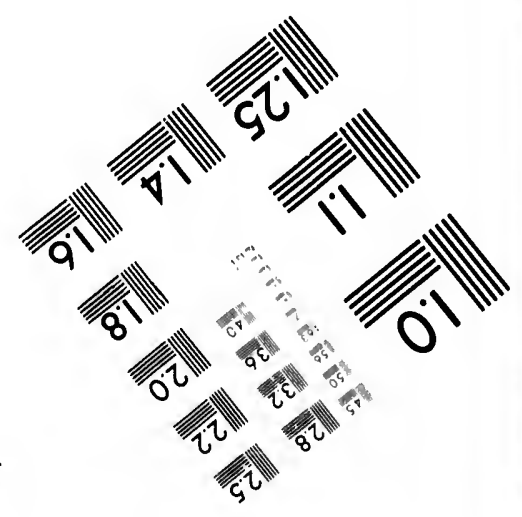

23 WEST MAIN STREET WEBSTER, N.Y. 14580 (716) 872.4503 

At Pittsburg, July 13th, first quarter 33 seconds, half mile $1.05 \frac{1}{2}$, threequarters $1.37 \frac{1}{4}$, and the mile in $2.10 \frac{1}{2}$, heating ber former recorl.

At Chicago, July 23, three lieats. The first mile, $2.21 \frac{1}{2}$. The second mile, first quarter, $34 \frac{1}{2}$, half mile in 1.06 , the three-quarters in 1.38 and the mile in 2.114. The third mile, first quarter, in 34 sconds, the half in 1.061 , the three-fourths in $1.37 \frac{1}{2}$, and the mile in 2.11. 'This was considered the greatest performance ever achieved by Maud S. Beside trotting the three fastest miles ever trotted by any horse, the truek over which it was done was believed by the best judges to be at least three seconds slow.

Her best reeord up to August, 1881, was made at Rochester (August 11 th), when she trotted the mile withont a break in $2.10 \frac{1}{4}$.

In short, she has put to her eredit in three years the best heat as a 4-yearold; the best heat as a 6-year-old; five heats faster than any other horse has ever trotted or paced, one of then when 6 yeurs old; the fastest heat in a race with other horses; the fastest first, second and third lieats; the fastest two consecutive heats, and the fastest threc conseeutive heats. Nothing more is needed to dernonstrate her superiority in point of speed and stay combined over any animal living or dear; but the publie las set its heart on her beating 2.10, and, until she does it, the public's cap will not be thrown up.

W. W. Bair is entitled to great credit for developing the wonderful speed of Maud S. She is a highly-bred mare, and wants to be humored. Her lieart is won by kindness. She will not stand harsh treatment; will not prove obedieut under rough usage. Both Bair and his wife made mueh of Maud S. They petted her and treated her to apples and lumps of sugar. 'The result is that she will eagerly respond to their call. When jogging on the track at Chester Park the presence of Mrs. Bair near the rail at any time would cause Maud to turn in that direction. During the winter the mare ran in a roomy box. In April she was put in front of a break-cart, and $\mathbf{M r}$. Bair drove her about the streets of Clifton and Cincinnati, and thus got her accustomed to the noise and bustle of the toiling world. He also harnessed her double, and tauglit ler to drive on either side. She always beluaved well to the pole. She does not like blinds to her bridle, but will trot with any kind of bit in her mouth. All she asks is that the driver shall not pull on the bit. She wears a 151ounce shoe forward and a 9-ounce shoe behind. Sle also carries 4-ounce toe weights. 


\section{PART II.}

\section{DiseAsES OF THE HORSE:}

THEIR CAUSES, IIOW TO PREVENT, HOW TO KNOW AND HOW TO CURE. 
TEFIR

The vario th. 8 afflicti common, di of the ligan to which the rance, and in over-weightiti lessness in withholding disease and should see by substance ; 0 and tendons, serious afflict rheunatism ; of the hoofs, faithful serva purposes of $p$ of the torture sake of the $\mathrm{fe}$ 
Diseases of the Horse.

THEIR CAUSES; HOW TO KNOW, AND HOW TO CURE THEM.

\section{CHAPTER I.}

I. INTRODUCTION.—-II. EXTERNAL MANIFESTATION OF DISEASE,

I. Troduction.

The various diseases to which the horse is subject, embrace nearly all th. \& afflicting the humau family, and including among them, as most common, diseases of the skin and its integuments, those of the muscles, of the ligaments, and of the bones, quite rare in the human family, and to which the horse might be conpletely exempt, were it not for the ignorance, and in very many cases the brutality. of the master in over-ciriving, over-weighting, leaping, beating, neglect in clothing when heated, carelessness in grooming, want of proper ventilation in stables, and the withholding of proper and sufficient food. Take away these causes of disense and the labors of the veterinary surgeon would be light. We should see but little of caries of the bones, causing degeneration of the substance; of spavin, curb, ringbone, splint; of injuries to the sinews and tendons, causing breaking.down; swellings and other of the most serious afflictions; poll evil and other fistulous diseases; of fractures; of rheumatism ; founder, including grease, inflamed glands and veins, cracks of the hoofs, quittor, hernia, and all that class of diseases attacking the faithful servant of man, and henceforth rendering him useless for the purposes of pleasure or profitable labor. Instead of ending the sufferings of the tortured animal by mercifully taking its life, many owners for the sake of the few paltry dollars received, transfer the once favoritc steed 
to some one else equally inhuman, who thenceforth drives and goads the sufferer to labor under the most torturing circumstances, until the animal economy, entirely disorganized, perhaps by years of such unmitigated torture, drops and dies.

The object of this trentise is to so enlighten the horse owner in the nuture of disease as to enable him to determine whether treatment can be made effective - if so, what to do; and especially is it the purpose to so acquaint him with the causes, that occasion for treatment nuy bs averted. By a study of the facts we give it may be ensily known whether eure is possible, and if not it is more merciful to kill and end the misery of the poor animal.

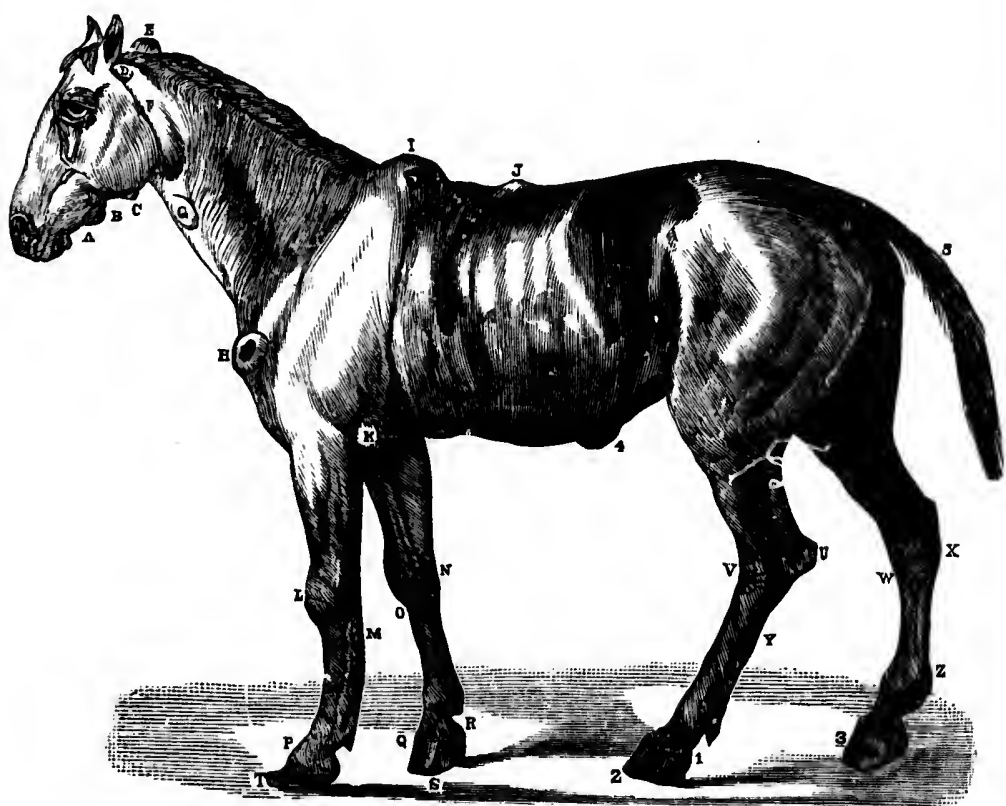

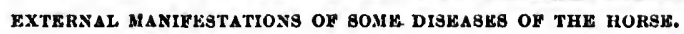

\section{External Manifestation of Diseaso.}

For all the diseases we have mentioned but littlo medicine is needed. Rest and nursing arc most needed-often months of rest and care, as in the case of spavin, commencing in inflammation and ending in the deposition of bony matter, stiffening of the joint, or, as in the case of exostosis of the heads of the bones, they in time become quite anchylosed, when la by their

That and liave the princ with a sh the prope $A-C$ in mortifi $B-F i$ undue com $C-B_{0}$ will produ increased $n$ $D$-Sue sometimes

$$
\begin{aligned}
& E-P o l l \\
& F-I n f l a \\
& G-I n f l a
\end{aligned}
$$
ness after bl

$I$ I-Fung galls and sul

I-Fistule J-Saddle sitfasts.

K-Tumo, in lying down L-Indura M-Clap and leaping, $x_{\text {-Mallen }}$ becoming erac O-splint, be dreatded as $P-R i n g b o x$ going up hill. $Q-$ Tread $u$ treading on the of the boof.

$R$-Quittor. roronet. 
when lameness censes from the suspension of action of the joints caused by their complete solidification or growing together.

That the reader may form a more correct idea of what we here write, and have it brought plainly to view, we present an illustration of some of the principal diseases of the bones and tissues, caused genernlly by abuse, with a short description of their origin. 'The trentment will be given in the proper place.

A-Caries of the eJaw. Ulceration of the lower jaw, sometimes ends in mortification. Caused by bruises from barbarous bits and curb chains.

$B$-Fistula of the Parotid Duct. Fistulas are caused by bruises or undue compression of the parts producing inflammation and abscess.

C-Bony Excrescence. (Exostosis of the jaw). A blow upon a bone will produce inflammation followed by exostosis (bony growth through increased nutrition) - that of the joints being fearfully painful.

$D$-Suelling by pressure of the bridle, causing inflammation, and sometimes tumors.

E-Poll Evil. A painful fistulous disease, often difficult to cure.

F-Inflamed Parotid Gland. Caused by a bruise or compression.

$G$-Inflamed Jigular Vein, caused in various ways, often by carelessness after bleeding.

II-Fungus Tumor, from compression of the collar. The result of galls and subsequent wint of cure, and inattention.

I-Fistula of the Withers, caused generally by pressure of the sadile.

$J$-Saddle Gall, caused by a bad fitting saddle; sometimes endin in $_{\text {¿ }}$ sitfasts.

K-Tumor of the Elbow, caused generally by interference of the shoe in lying down; sometimes by a blow.

$L$-Induration of the Irnee, caused by blows in fulling.

M-Clap of the Back Sinews, cnused by severe excrtion in rumning and leaping, destroying the integrity of the sinews of the leg.

$r$-Mallender's, scurfy manifestntions at flexions of the knee, sometimes becoming cracked and itchy.

O-Spliat, cuused by blows, kicks, etc., on the shins. They are to be dreaded as interfering with the action of the sinews.

P-Ringbone, caused by starting hoavy loads, or excessive pulling in going up hill.

Q-Tread upon the Coronet, the contusion of the shoe of one foot by treading on the other, causing laceration of the coronet and of the horn of the hoof.

$R$-Quittor, confined pus, from prick of the sole, corns, or injury to coronet. 
S-Quarter Sand Crack. Imperfect secretion caused by dryness or the hoof; rupture of the lamine.

$\boldsymbol{T}$-Contracted Hoof, or ringed hoof of a foundered horse. The result of Laminatis.

U-Capped Hock. Injuring the point of the hock.

$V$-Sallenders. Scurfy eruptions on the seat of flexion of the hock. Similar to mallenders.

W-Spavin. Inflammation causing painful bony enlargement, some times stiff joint. Caused by blows, slipping and hard work, often from weak limbs.

$X$-Curb. Inflammation and lameness of the posterior part of the hock, ending in bony formation. Caused by wrenching or straining the limb.

$\boldsymbol{Y}$-Swelled Sinews, caused by strains or bruises, producing inflammation, and ending in enlargement.

$Z-T h i c k L e g$, caused by various injuries to the joint. Any inflammation may result in a thickening of the integuments. In all inflammatory difficulties of this nature, including, spavin, curb, etc., cold water faithfully applied at the outset will be indicated, but often the trouble is not known until too late for cold water. The warm water fomentations will then be indicated. [See treatment].

1-Grease, caused by debility, excessive labor and neglect, filthy surroundings, from stoppage of the secretions. Scratches are from the same cause, as working in the mud without proper cleaning, etc.

2-Toe Sand Crack, caused by the same difficulty as quarter sand erack.

3-Quarter Cra' i. [See sand crack].

These are occasioned generally by severe labor of animals not strong in the feet, by which the walls are ruptured, by breaking the hoof witl the calk of another foot. False quarter is occasioned by the absence of the outside and harder portion of the hoof.

4-Ventral Hernia. Rupture by which the bowel lies next the skin. When hernia is accompanied with strangulation it becomes dangerous.

5-Rat Tail, loss of the hair of the tail.

Fuller facts as to causes and treatment of these disorders will be found in this appropriate place in this work. 


\section{CIIAPTER II.}

DISEASES OF THE SKIN AND SUB-CUTANEOUS TISSUEB.

I. SCRATCHES. - II. GREASE. - III. TIRUSH. - IV. SWELLED INKLES. - SWELLED LEGS. - VI. SURFEIT.—-VII. MANGE,-VIII. RING.WORM.—-IX. IIIDE-BOUND. - $X$. SADDLE GALLS, OR SITFASTS. - $X I$. FUNGOUS COLIAR TUNOR.-XII. WARTS.—XIII. VERMIN. —XXIV. JARVA IN THE SKIN.—XV. TETTER. - XVI. RAT-TAILS.- XVII. MALLENDERS AND SALLFNDERS.XVIII. POLL EVIL. XIX. FISTULA.

Of skin diseases there are two elasses: those resulting from negleet and general bad treatment, and those due to disorders of the internal organs with which the skin is in sympathy, or which influme it by unnaturil excretions or irritants in the blood. It is almost impossible perfectly to clissify them, since even some that are generally considered to arise from constitutional causes may be produeed by external eireumstances, and the reverse.

In the following seetions we treat the most important of both classes. Others of less moment will be found in our chnpter entitled "Miscellaneous Matters and Suggestions, Minor Disorders, etc."

\section{Scratches.}

Causes.-These are various; as, clipping the heels, which is sometimes done, and thus destroying nature's covering, so as to allow the parts to become chilled; washing off the legs with soip and water without subsequently thoroughly drying them, and then suffering them to be exposed to cold air ; standing in snow or snow-slush; standing in or upon hot and steaming mannre of any kind, while in stable; or being long in mud and filth while in service and not subsequently carefully cleaned. Anything that will produce inflammation of the skin of the heel, or in any way reaken it, may produce scratches.

As is the case with other local disorders, this is most easily and rapidly 17 
developed when the horse is not in a condition of good genernl henlth; but foul stables, while furnishing the irritnting tilth immediately to the sent of this disense vitiate the nir nleo, and thus tend to bring about a two-fold troulsle.

It is believed to be sometines due to the existence on the skin of par. asitic plunts and insects.

Tho sure preventive is to keep the horse, if possible, in good generil condition; and to confine him, when he must be confined at all, only in a dry, clean, and woll-ventilated stall. When he is forced to be worked during the day in mud or slush he should be neither stabled nor turned out to pasture until both his fect and his legs are well waslied and thoronghly dried.

How to know it.- Scratelies are said to be unknown to European horsemen; but it is so well known in the United States as to render a description well nigh unnecessary. It appears on the back part of the foot, generally of the lind foot; and extends from the heel to tho fotlock. It lits been known entirely to encirele the foot, and to extend upward to the hock and to the knee. The parts are sometimes hot, swollen and sensitive before any eracking or ulceration takes place; then they become dry and sealy, und erack open by ordinary motion. A horse thus affected is apt to manifest a disposition to walk stiffly, with his hind legs, (when the disease is seated in the hind heels), wider apart than ordinary, and to throw his foot rather violently forward when an effort is made to examine it.

It is often the case that at first there are littlo patches of a thick, dry, scabby covering of the skin; and these spread and inflamo until they form a solid mass of seal) and matted hair. These seals may be distinguished from those which sometimes appear in other skin diseases by this, that they have an unusual itchiness, which leads the horse to rub them as much as possible; and he often does this until they bleed and become raw. This disposition of the suffering erenture to seratch himself is said to have originated the name by which the disease is known.

What to do.-.-In cases where the patient is in good condition, and the disease is in its incipient stage, a thorough eleansing of the parts with castile soap and warm water, and applying an emollient or softening poultice for a day or two, with rest, will be sufficient. If there seems to be feverishness of the system, a dose or two of Epsom salts to move the bowels, given in doses of from one to three ounces at a time, well be beneficial.

The following is for ordinary cases a most efficacious and easily used remedy : 


No. 1.
1 Oz. powdered gum eamphor,
1 Fluid oz. nulphiturie acld,
1 Finld oz. splrits of turpentine,
1 PInt of lurd.

Mix thoroughly, und rub the ointment well upon the heels once a day. The legs and feet should be washed with sonp suds before every applications.

When the disense is chronie, and proud flesh lus uppeared, make a poultice of ground thix seed and lime-water; sprinkle burnt alum over the poultice, and npply. Use two or three poultices a day until the proud flesh his evidently distupened, then use the ointment. No. 1 an alhove directed.

Another course of treatment, to be ndopted when there is a disordered condition of general health, and evidenees of vitiated blood are manifested, is this:

First bleed; lout observe to regulate the quantity of blood drawn by the condition of the animal as to flesh and strength. If he is poor and weak, take from the neek vein about three pints, and nfter nine days a like quantity. If he is pluinly in poor general health, but not reduced in flesh and still strong, bleed once, taking from the neek vein three quarts. Then make careful and thorough appliention of ointment No. 1.

It may well be stated here that in our practice we do not often resort to bleeding, nor do we recommend it except in raro cuses. To the mun, however, who finds it both profitable and ngreenble to be his own stock doctor it is often the quickest, ensiest, and safest menns of removing vitrious humors, and bringing about a more natural and lienlthful cireulation. In some acute disenses of violent character, as pleurisy, mad stingers, and the like, it is frequently of the first importance, sometimes almost the only hope; but we would caution the reader against the indiscriminate hlood-letting of the old prinetitioners. Observe well the symptoms; consult this department of "The Stock Doctor" carefully; and you will not fall into the mistake of talking away gallons of blood when a little rest, some good grooming, and plenty of nutritious, lifegiving food, are the things mostly required. The manner of blood-letting will he found to have been treated of in our chapter entitled "Inplements : what to keep and how to use."

The foregoing methods will answer in all ordinary cases; but if the patient has not been taken in hand till the disease has become chronic ard obstinate, the following is a most execllent prepuration and may be used instend of No. 1. It requires care in the using, as it will discolor the hands and corrode the nails if it comes in contact with them, and it should never be entrusted to bungling and inconsiderate grooms; but in 
the lands of eureful horsemen it is a most valuable remedy for all obs: $\mathrm{i}$ nate wounds, bruises, gulls, tmonors, und sores. We shull refer to it in subsecpuent portions of the work us camphorated corrosive sublimate or

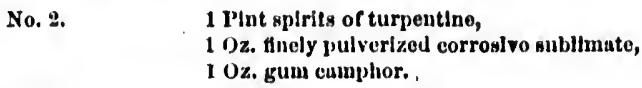

Inve the corrosive sublimate very finely ground in a druggist's mortar, (the eflicacy of the compound depends much upon this); pulverize the gum eamphor; put ull together into n good strong bottle, and shake thoroughly. 'Then let it stund for at lenst twenty-four hours-longer would be better, ns it becomes more min more valunhlo with nge and repented slukings-nd it will do to nse. In applying it, saturnte a small mop, made of soft rigs, nently and firmly tied upon n stick. Wush before making first appliention of No. 2, but afterwards, unless the foot becomes very foul, this need not be done. The liniment should be "lpplied once a day till cure is effected.

Keep the horse out of the wet during treatment, especially if the cumphorated corrosive sublimute is used. See to it, also, that his stable is not only dry, but airy. If it is pasture time, he will need no other food than grass, unless it is found necessiry to stablo him, to keep lim from rains and dows. In any event, he ought to be fed ruther lightly ut first, and with feod not calculated to influme. If the time is Winter give as much green, soft food as can be conveniently had, such as roots, chops, ete.

\section{Grease, or Cracked Heols.}

Causes. - This disense is but a modification of scritches and of thrush - partaking more of the nuture of thrush, however, thun of seratches, as it is confined almost exclusively to the hecl, the seat of the thrush, which is seldom attacked by the scratches.

It is occisionally the result of constitutional wealness or derangement. When the system abounds in morbid mutter, its tendency is towards the heels, and debility is felt in the distended vessels remote from the vital organs, ending in inflammation of the skin of the heels, distension of the sebaccous glands. a stinking deposit on the surface, and a purulent discharge through cracks.

Cutting away the hair of the fetlock, and thus exposing to sudden and protracted cold the parts which it is designed to protect, often cetuses this affection, even in animals of otherwise good condition.

Frequently, however, it may be regarded as most probably a secondary disetase, originating in some other, which has resulted from careless or :nhuman treatment, or from constitutional weakness.
It is 11 nearly al

How to thruslı, " linrity wl of thint $k$ horse is 1 stint sees under the fererish, pent-ui) oi As the flor and stinki become an

It somet out of a skin from coffin-bone ruently the in this case the healing

What to $\mathrm{d}$ ilar to that $f$ to it that th no longer op must be son mal should ereise is na eept in bad fine him, gi pure air.

conditions of other labor w physician.

If the disen the general cleanse the castile soap, : ated corrosive applications w If the hors effects of this 
It is not contagious; lut filth and want of nttention will produce it in nearly all horses similnrly subjected to their inflnences.

How to know it.-It munifests neurly the very sumo symptoms ns thrush, un given in tho following section; but thero is ono striking peculinity which distinguishes it from thrush, foot-ovil, and other disorder's of that kind-the heel cracks open. In a henlthy state, the heel of the lorso is moistened, and so kept from hecoming dry und hurd, hy a eomstant secrotion and dischurgo of an oily fluid from the cellular tissues under tho skin. When this is olstructed, tho skin becomes diy and feverish, and looks scurfy and hot. It soon therenfter crucks, and the pent-11p oily secretion, now turned to a foul, yellowish water, flows out. As the flow of matter increnses, it becomes moro and more thick, stickey, and stinking; and if not attended to, tho heol and sides of the foot become a mass of uleerated exereseenses.

It sometines munifests itself by tho oozing out of a thin matter through the pores of the skin from somo deep-sented disense of either tho coffin-bone or the navieular joint - most frequently the latter. The moro effoctive treatment in this case would of courso be that directed to the healing of the primary disorder.

What to do.-The treatment neecssary is similar to that for seritches. In the first place, see to it that the causes which huve indueed it slanll no longer operate. If the disense is secondary, it

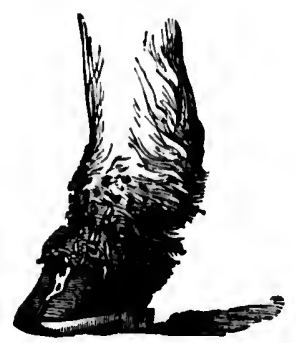

Fingt Stagic of Conptamed Griese Exupation.

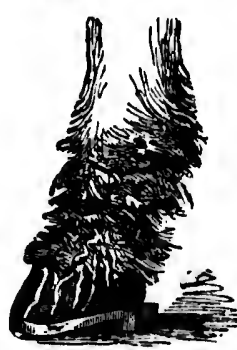

Brcond stagi of CoxFirumd Grabe Cuaclis. the general health of the animal has not suffered, cleanse the parts woll with tepid water and castile soap, and make occasional applications of No. 2, or the cumphorated corrosive sublinate, say once n day, till a cure is offected. $\quad$ few applications will generally bo found sufficient.

If the horse is thin in flesh, and in a low state of health from the effects of this disease, mix sulphur and rosin, in the proportion of two 
parts of the former to one of the latter, and give him a quarter of a pound of this every third day until he has taken three or four doses. Meanwhile, thoroughly saturnte the parts at least every other day with No. 2 till the disease is thoroughly eonquered.

If the liniment forms a scab upon the heel, so hard and dry that the remedial effects seem to ecase, omit the liniment for several days and keep the heel well greased. 'The seab will come off, and then the application of the liniment, (No. 2), nuy be resumed. This course must be persevered in till a cure is effected.

The liniment should bo applied at night; and the horse should not be turned into pasture when tho grass is wet with dew or rain-at any rate, not till six hours after the application has been made.

In Summer, pasturage will in general afford suffieient food; but in Winter it should be more nourishing, yet green and suceulent as far ats possible. Roots and good bran mashes ought to be given in reasonable quantity. Grain, as a regular diet in this case, is objectionable, on account of its tendency to produce inflammation.

After three doses of the sulphur and rosin have been given, as directed, the following mixture, given every night until all traces of the active diseaso have disappeared, will be found an excellent tonic or strengthening medicine, and having the effect; too, of giving healthy tone to the skin :

No. 3.

1. Oz. liquor of nrsenicalie.

1 Oz. tincture of muriato of iron,

y. Pint of water.

This constitutes a dose. Mix and grive as a drench.

When it is difficult to procure No. 2, the following may be prepared and substituted therefor:

No. 4. 8 Oz. tar,
1 Oz. becswax,
1 Oz. rosin,
1 Oz. alum,
1 Oz. taliow,
1 Oz. suiphate of iron,
1 Drachm carbolic acid.

Mix, and boil over a slow fire, stirring as long as dirty scum appears, und then add $2 \mathrm{oz}$. of the scrapings of sweet elder.

\section{Thrush.}

Causes.-This, like scratches, results for the most part from foul stables,- the horses being forced to stund in mortar of dung and urine,or from working in muddy and filthy places, without having his feet and legs well cleansed when he is unharnessed for the night.
It is : snatgging

It ma!

of tine $\mathrm{s}$

sound he

Agriil,

dung, as curing de

Lastly, superindu

How to

existence as the hoo this case deepened, when this

The pros no disposi becomes to discharge. its place; 1

In its ad by a contin If not reass the whole $f$

What to d disease are is to be st: moist excreu

If the dis to removing In its sim Clean wel cloth or strin of the frog nc.st morning evening), for effected.

Or, sprinkl and then fill all dirt. Rep 
It is sometimes caused by injuries to the frog of the foot, as bruising, snagring, and improper shocing.

It may arise also from a gross habit of body, producing inflammation of the sensitive frog, when a spongy substance is deposited instead of sound horn; and this breaks away and leaves the frog ragged and tender.

Again, it may come from too frequently stopping soft frogs with cow dung, as is the practice of some grooins, thus encouraging rather than curing decomposition.

Lastly, it miay be secondary, having resulted from other diseases, superinduced by want of cleanliness and eare.

How to Know It.-In some cases, the only means of detecting the existence of thrush is a peculiar smell, or hy very careful examination, as the hoof may show no ehange, and the frog may not be tender. In this eise the cleft of the frog will generally be found lengthened and deepened, the opening extending to the sensitive horn within, and this, when thus closely observed, shows discharge of matter.

The progress of the diseaso is often slow, though showing memw hile no disposition to heal; till after awhile the frog begins to contract, becomes tender, grows rough and brittle, and emits a more offensive discharge. The horny part disappears, and a hardened substance takes its place; thi: easily seales off and leaves the sensitive frog uncovered.

In its advaneed state, it is very ensily detected, as it is charueterized by a continuous diseharge of offensive matter from the eleft of the frog. If not reasonably attended to, proud flesh sprouts up ; and as this spreads the whole foot beeomes involved in canker.

What to do.-In the first place, if the eauses which have produced the disease are still in operation, remove these. In any cise, when the horse is to be stilbled, use dry litter, and see that the stall is kept clear of moist exerement, and that it is well ventilated.

If the disease is secondary, tho treatment must of course be directed to remoring the affection from which it has sprung.

In its simple stages, it may bo casily cured in the foliowing manner : Clean well with soap suds, and allow to dry. Then, wet a piece of cloth or string of tow with tho liniment No. 2, and press it into the eleft of the frog and the corresponding part of the heel. Remove the tow ncxt morning. Continue this treatment, (putting in the saturated tow at erening), for four days; then omit a day; and so on until a cure is. effected.

Or, sprinkle a small quantity of blue vitriol in the eleft of the frog, and then fill up the eavities with cotton, which so press in as to keep, out all dirt. Repeat until the foot is cured. 
When it has arisen from grossness and inflammation, rather than from filth or other local eause, give a dose of Epsom salts, from six to eight ounces, according to degreo of inflammution ; use less stimulating food, and give him regular, but not too severe exercise every day. Tho local applicution must not be of a stimulating character. Put the foot in a bran poultice, and let it remain for some days, till the inflammation is reduced. Be careful, however, not to use the poultice too much, as undue softening is injurious. Then dress the frog with tar ointment, a mixture of equal parts of tar and grease). If the frog is found not to harden by the application of the tar ointment, moisten it occusionally with a solution of $10 \mathrm{grs}$. of blue-stone to $1 \mathrm{oz}$. of water; or, (which is a somewhat more powerful medicine), 5 grs. of ehloride of zinc to $1 \mathrm{oz}$. of water.

When the disease has become chronic, it is hard to effect a cure, and the following course ought to be adopted: Clean away all the ragged portions of horn, so as to reach the sensitive parts. Then smear some tow with this ointment.

No. 5.

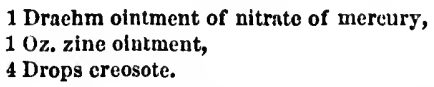

Mix well ; and having smeared the tow with the preparation, as directed, press it into the eleft of the foot and retain it there by a bar shoe, slightly tacked on. Apply this every day, observing its effects. If found not to do well, try a wash made of six grains of sulphate of zine, dissolved in one ounce of water. As the frog grows, it should be kept supple with tar ointment. The bar shoe should be kept on until the frog is fully developed. Some degree of pressure must be employed by metils of tow, and this pressure should be increased as the horn incleases in substance. When proud flesh is obstinate it may be burnt away at once by forcing a stick of nitrate of silver (lunir caustic,) into it.

In chronic eases, the horse should have, once a day, in his food, an alterative dose, (a mild improver of health), say a table-spoonful of sulphur and powdered sassafras, of each an equal quantity.

The following mixture is sometimes found valualolo when there is a tendency to proud fiesh. The ingredients are to be well stirred together and sprinkled into the eleft of the frog, where it must be confined in the same manner as directed for powdered blue vitriol alone:

No. 6.

$10 z$ powdered biue vitriol,

$10 z$. eopperas,

$2 \mathrm{Oz}$, burnt alum,

1-2 Oz. white vitriol. 


\section{Swelled Ankles.}

Causes.-This affection invariably arises from a diseased condition of the feet. Its origin may sometimes be traced to diseases of the navicular and lower pastern joints; but it is known to proceed for the most part from hoof rot. It seems occasionally, however, to result from a plethorie condition of the general system, a superabundance of blood, hard work, severe strilins, etc., etc.

How to Know It.-Confined alnost wholly to the ankle joints, it is not difficult $\therefore$ detection - the only point of importance being to determine whether the swelling is merely spasmodic and temporary, or whether it is the resuit of a primary disorder which requires attention. It is generally pereeptible of a morning, and distuppears during the day, because exercise restores healthful action; but when there is really a diseased condition of the bottom of the foot, the ferer caused therehy inflames the membrine of the joint, under the skin, while the horse is inactive, and the swelling again takes plare. If the ankles present a swollen appearance from morning to morning, attention should be directed to discover the real condition of the foot; and appropriate treatment must be resorted to before the disease takes the chronic and more adviunced form of swelled legs, eracked heeis, or scratehes.

What to do.-If the swelling proceeds from plethora, or too great fulness of the general system, give an oceasional dose of Epsom salts, to reduce the tendency to inflammation; and feed upon green and sueculent food.

If it proceeds from soreness of the bottom of the foot, apply No. 2 frecly every day for four days ; then omit for two days, and apply again. If there is any appearance of thrush or cracked heels, treat as directed for the removil of these.

\section{Swelled Legs.}

Causes.-Swelled legs, may be the result either of an undue deposit of scrum or watery particles of the blood, or of inflammation of the cellular tissue lying between the skin and bones in those parts of the leg most destitute of muscles.

A poor condition of the blood, or fecbleness from great loss of it, may cause the legs to swell, since the fluids conveyed to the extremities by the capillaries accumulate there, because, in the absence of museular activity, the veins have no power to return them. Diseased kidneys have a tendency to produce this disorder of the legs.

The influnmatory type may result from blows upon the lower leg; from concussion; or, in general, from anything that may arrest the 
action of the cellular tissue referred to, eausing it to become dry and at length acutely juflamed. It muy also arise from the shifting of inflammation from other parts, as from the lungs, kidneys, etc.

Horses of coarse fiber and full habit, accustomed to exereise, if allowed to stand idle several days, will have swelled legs from the accumulation of watery fluid; and, if uniteuded to, the parts may soon be attacked by inflammation, when the tissues become involved, and the disease assumes its more serious type.

It is oceasionally a mere extension of the effects of cracked heels, with its primary cause resting in whatever may have produced the primury disorder.

How to know it.-The leg becomes greatly swollen, and looks as though it was stretched to its utmost tension. Occusionally, the swelling appears almost suddenly, and then as suddenly subsides, in which case the cause may be considered as having but just begun to operate; and if now treated, it is easily mamaged. Again, it is sometimes sudden in its attack, and violent; the skin is hot, dry, and extremely tender, and the pulse is quick and hard, while a peculiar lameness speedily sets in. The swelling may extend to the sheath and along the belly, as far as the muscles of the breast.

In the more advaneed stage of the disease small eracks appear in the skin, and from these exudes a watery matter, of whitish-yellow color, simlar to that which is seen in cracked heels. In this case it must be taken for granted that no treatment, however skilfull, em speedily remove it; that the improvement must be slow, and consequently much time required.

What to do.-If the disense seems to bo inerely undue deposit of serum, owing to confinement, nothing more may be necessiry than to give the animal a doso or two of niter, daily, to act upon the kidneys; and to exereise him regularly, to induce alsorption. In the administering of a diuretic, however, even so simple as niter, eare should be taken that it is not left to ignorant and irresponsiblo grooms, since it may be given in excess, and result in disordering the kidneys, and thus ultimately inducing the very disease which it is intended to remedy.

When there is a tendeney to swelled legs which nunifests itself in the morning, but disappears during the exercise of the day, an excellent preventive is to stand the horse in cold water to his knees, half 'an hour, just before night, and then rub dry before stabling; lout care must he taken to dry the legs thoroughly, or the plan is plninly objectionable. If it should le found not to yield to this, administer the niter in moderition, as previously directed, and exercise the horse regularly, causing him 
to sweat, both of which have a tendency to diminish the accunuluted fluid, and to assist the veius and alssorbents in their functions.

In case the horse is in a debilitated eondition, and the swelling is manifestly owing to the sluggishness of the cireulation, he should be well fed, on nutritious diet, and the leg or legs should be firmly, but not tightly, bandaged. Then prepare the following-a tonic and somewhat stimulating medicine:

No. 7.

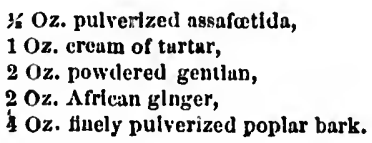

Rub these ingredients together in a mortar until thoroughly mixed. Divide this into six doses, and give one, in the food, every night till exhausted. The bandage should be removed from time to time, and the limb) subjected to a brisk hand-rubbing, or rubbing with a medium conrse cloth.

If the disease has become chronic, and the animal is much debilitated, the following more stimulating medicine should be used.

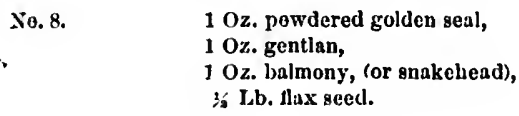

Mix well; and divide into six doses, of which give one night and morning in the food. Banduge and rub alternately, as previously directed. If the disease does not speedily show signs of yielding to this treatment, apply, every night, omitting the bundage, the following liniment :

$$
\begin{aligned}
& \text { No. 9. } \\
& \begin{array}{l}
1 \text { Oz. essence of cedar, } \\
1 \text { pint neture of cupsleum, }
\end{array}
\end{aligned}
$$

When crneking of the skin has taken place, so that matter exudes, and there is much fever, the following course has been found eminently suc. eessful, and must be at oneo adopted: First, take from the neck vein three quarts of blood. Mix fincly pulverized sulphur and rosin, in the proportion of two parts of the former to one of the latter ; und give daily, for three or four days, six ounces of this mixture. It should lec put into meal or bran, and the horse should be allowed no other food until he readily takes this: Meanwhile, apply No. 2 every morning to the parts most evidently affected, until the swelling hins entirely subsidel.

In these chronic eases, it is best not to feed on very nutritious, or at 
least, stimulating food, unless the horse is in low genernl condition. Ordinurily, pusturing will be best, when the senson admits of it. If it does not, he should have light, moist diet; nud his stable should he elem, dry, roomy, and so supplied with litter as to induce hm to lie down as much as possible.

\section{vI. Surfeit.}

Causes.-This disease, sometimes known as prurigo, has for its predisposing eause a thick and impure state of the blood, with deranged condition of the digestive organs. When the animal is in such case, any sudden exposure to chill, especially when he has been heated, will produce surfeit-pimples; and unless the general condition be attended to, a confirmed case of skin disense may be the result.

It generully appears in the Spring, at the time of sledding, when the skin is more exposed than at uny other time of year, and the hor'se is still exposed to sudden spells of cold and wet weather. The skin, thus bare, is easily affected; and if the chill is severe or too frequently repeated, inflammation sets in, and the cuticle or outer skin becomes hard and dry because the pores are so elosed as to retnin the oily secretions necessary to moisten the surface.

Some poisonous herbs produce this, or a similar, eruption of the skin, and musty hay has been known to have a like effect.

Quick surfeit, or thut which arises suddenly, even in animals in good general condition, upon being overheated and suddenly cooled by chill air or an over-draught of water, may disappear upon his being lnought to a sweat by exercise ; but that which is contracted while the lorse is in general ill condition is apt to become confirmed, and, unless timely attention is bestowed, may settle on the lungs and cause serious trouble.

How to know it.-No symptoms preede an attack of surfeit by which its approach may be known. The pimples or lumps, in quick surfeit, suddenly appear, and almost as quickly sulside. When a case of confirmed surfeit has set in, the skin is hard, dry, and feverish ; and pimples appear, sometimes confined to the neek, but more frequently sprend over the sides, back, loins, and quarters. Ocensionally, these are attended with great itching, while again they seem to cuuse no amnoyace. When they hive remained a few days, they discharge, in small quantities, a thin, whitish, oily matter. Small, scabby excreseenees, formed by the discharging sores, cover the parts. These come off, taking the hair with them, and leaving a small senly spot-sometimes, though rarely, in sore.

Surfeit is sometimes mistnken for button-farey; but it may be distilguished from this by the shape of the pimples: in surfeit these ure 
elevated in the center; whereas, in farcy the lumps are rather flat on top and have thick edges, like a button in the skin. Farey buds generally

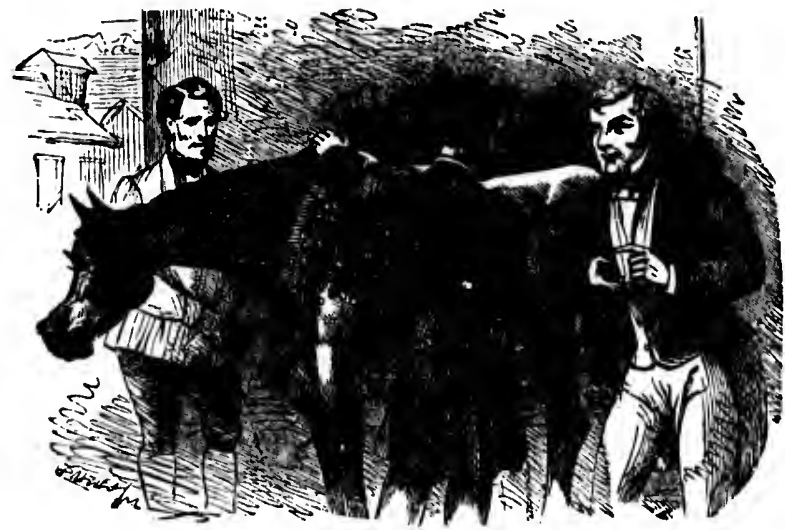

A IIORS AFFected with SUlFeit.

:lppear on the inside of the thighs and fore legs, while surfeit pimples are sctelom found in these places.

If not promptly and properly attended to, surfeit is likely to degenerite into mange, which it is sometimes taken to be, even in its early stages; but it may be known flom mange by trying the short luir's at the roots of the mane: if it is mange, they will be loose and come out; but if surfeit, they will show their natural condition.

What to do.-If the general condition of the horse is good, and the affection has evidently arisen from sudden exposure or some other imprudence on the part of the person having him in charge, little treatment will be necessary. Prevent costiveness and keep down fever by cooling food, such as bran mashes, roots, and other moist provender. Give arsenieal drink once a day, a pint at a time, to act on the skin, until eure is effected, being careful, meanwhile, if the weather is cool, to keep the horse comfortably warm-blanketing him if necessary; and a half hour's walking exereise should be given him daily. The arsenical drink consists of these ingredients in the proportions numed:
No, 10.
1 Fluid oz. arsenicalis, or Fowler's solution,
1 ty Fluid oz. tincture of muriate of iron, 1 Quart water.

If the disease has sprung from a thick and impure state of the blood, disordered digestive organs, and general ill condition, take from the 
neck vein from three to fivo quirts of blood, necording to strength, extent of eruption and degree of fever. Keep him from becoming costive by cooling und lixative food, as previously directed; see that he is comfortnbly stabled, if the weather is at all inclement, and gire, on several suecessive nights, the following alterative :

No. 11.

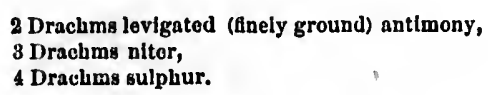

The food should be good - if possible, green and succulent; and it will he found advantngeous to take the chill from water given him, if the weather is at nll cold. If the uppetite is bad, place gruel in the manger, so thit he may use it instead of water till stronger food is relished.

If it is Summer, or Spring is sufficiently advanced to be mild, he may be turned to pasture; but in any event, he should be allowed to rest during treatment.

In the more confirmed eases a speedy cure is not to be expected ; but good food, not of a nature to induce costiveness and inflammation, and proper care as to warmth and eleanliness, together with a proper use of No. 11, will bring the patient round in time.

In very obstinate eases, oceasionally anoint those parts where the lumps appear with a mixture of sulphur and lard, in equal proportions.

\section{Mange.}

Causes.-This is sometimes brougrist about by the same causes as surfeit; or rither, it is indeed but an advanced or chronie stige of thit disense; though in some eases of the same kind, it is of a much more serious character in itself, and highly contagious.

When not a mere secondary stage of negleeted surfeit, its immediate cause is a parasite-the aearus-bred in the skin of the amimal when subjected to dirt and filth, and debilitated by hard living and ill usige, or by total neglect and lack of food. The acarus produces mange in the horse in the same manner as the human parasite produees itch in man; but it is of a different species, and frecuently so large as to be visille to the naked eye.

Neglect, starvation, and accumulated filth having induced a depraved state of the digestive npparatus, with which the skin sympathises, and the insect onee having obtained a lodgment, the horse, unless promptly taken in hand, soon becomes a louthsome object, and dies.

The disease once contracted in this way, may be communicated to cren sound animals, in good condition; in fact, the great majority of cases are thus contracted, as comparatively few animals are so utterly neglected 
or ex osed to filthy influenees us to become in themselves the generutors of these minge-breeding insects. It is regarded as one of the most contagions disenses to which tho horse is subject, nnd may be impurted not only to other horses, but to cattle, logs, and dogs, though it is asserted by good authority that none of these enn in turn communiente it to the horse.

The curry-comb, brush, collar, or blunket which has been used on a mangy horse will produce the infection in another ; and to lie in the same stall or to rul where a mangy horse has rubbed himself is ulmost certain to communicute it unless the unimal so exposed is exceedingly healthful and in active condition of loody.

How to Know It.-The skin is at first scabby, the hair comes off, and the outer skin loecomes broken into little seale-like pieces. These fall off, or are rubbed off, and leave the parts raw and sore. The general appentunce of the skin where the raw spots nre not too numerous is a dirty brown, and it is loose, flabby and puckered. The horse is inpelled by itehing to rub himself frequently and violently, and he thus leaves his scurf, dindruff, and in the more adranced stage, his parasites, at cvery plise.

Usually, where the disessso is engendered in the animal itself, it alppears first on the side of the neek, just at the edges of the mane, and on the inside of the quarters near the root of the tail. From these parts the auption extends along the back and down the sides, seldom involving the extremities, except in the very worst eases. Sometimes, though rarely, the ears and eye-lorows are attacked and left loure.

When it is the result of contagion, the horse may at first be in liealth ; lut the constant irritation makes him fererish, the hair falls off as in the first ease described, lenving the skin in those places almost bare; and little red pimples appear here and there. Each of these contains a parasite, and the pimples are connected by furrows along which the parasites have worked their way. In time they ircrease in number and size, and from them exudes a matter which hairde's into a scab. Under these s(a)s the parasites may be found, upon removing them and carefully examining in the sunlight.

In the enrly stage of the disease, where it may be suspected, but is not yet fully minifest, it may be detected by placing the fingers among the roots of the mane und tiekling the skin with the nails. The horse is so sensitive to titillation when in this condition that he will thereupon stretch out his neek and evince the most ummistakable pleasure as long as Che tickling continues.

What to do.-The most effectual preventive, it will be rendily inferred 
from tho preeding statement of eauses, is elennliness. In no cuse should a healthy mimul he nllowed to occupy n stuble whero a mugy one his been kept until it shull hnvo previously been washed with whter strongly impregnated with sulphur und chlorido of lime-sny linlf an pound of powdered sulphur and one pint of chloride of lime to ench gnillon of water. If the stuble is thoroughly cleminsed of loose litter and dirt, and all parts that may huvo been rublod ugainst by a mungy horse perfectly snturited with this solution two or threo times, on as many consecutive days, there can be no dinger in using it. Clothing, currycomb, hrush, etc., that may have come in contact with such animal, should be burned up.

If starvation, wenkness, and general ill condition lave caused the mange, a patent menns for its renoval will be found in giving him clem quarters and good nourishing food; which, however, should not be it first of a henting nuture. Generous pasturage, unless the weather is damp, will be sufficient; otherwise, a full supply of onts and chop food should be given. It eimnot be too much insisted upon that esprecially while treating a horse for disense his stable should be dry, well ventilated and properly supplied with litter.

In enses of full habit of body, where the disease is the result of contact, and the presence of high fever is noted, blecd once, taking from the neek vein from three to five quarts, aceording to the condition of the animal and the degree of fever' but if it is the result of porerty and debility, do not bleed at all.

Next, have him as thoroughly eleansed of seal, and dirt as possible, with a wisp of hay, and by softly and lightly using a curry-eomb. Then prepare a liniment of the following ingredients and in the proportions here given for greater or less quantities:

$$
\begin{aligned}
& \text { No. 12. } \\
& 1 \text { Quart nnimal glycerine, } \\
& 1 \text { Gill cleosote. } \\
& \text { 1/3 Pint turpentine, } \\
& 1 \text { Giil oil of juniper. }
\end{aligned}
$$

Mix all together and shake well; and with this saturnte the whole skin, as nearly as possible, rubling in woll with a soft cloth. Care must be taken to rub it in thoroughly. A little well rubhed in is better than much merely smeared on.

Leatve him in this eondition two days; then wash him well with warm water and soft soap; stand him in the sunshine if the weather admits, and rub with a wisp of hay or with suitalle eloths until he is diy; after whieh, anoint him pretty well all over with the mixture described, No. 12, and rub it in. This course should be pursued until a cure is effected.
Two to obstinite alterativ

Mix wi balls, and

Carre m dews whil

\section{Causes.-}

neons oric is usually apartments The latter, well as on parnsites in

How to k ippears on When not cruption of patches of ittended to,

The contin scales, and : scalss around hairs soon d characteristid the hairs in t

Occasional irregular ratl

Any attaek and scritchin objects outsid tom, since it

What to do closely as po iodine ; or, if with the follo 
Two to four applicutions will generally be found sufficient, even in obstinate cuses, if earo is taken as to food and drink. The following ulterative will be found beneficial :

$$
\begin{aligned}
& \text { No. 13. } 1 \text { Oz. tartarized antimony, } \\
& 2 \text { Drs. murlute of quicksitier, } \\
& 3 \mathrm{Oz} \text {. powdered ginger. } \\
& 3 \mathrm{Oz} \text { powdered aulse seeds. }
\end{aligned}
$$

Mlix with mucilage so as to form a consistent mass; divide into six balls, and give one every morning till the eruption disappears.

Care must bo taken that the patient is not exposed to ruin or heary dews while under this course of trentment.

\section{Ringworm.}

Causes.-There are two kinds of ringworm; one simple, of spontaneous origin, und non-contugious. Tho other contugious. The first is usually the result of indigestion or confinement in close and foul :partments, us in filthy and ill-aired stables, railroad cars or ship holds. 'lie latter, or contagous kind, is found on horses of good condition, as well as on diseased and negleeted ones, and is produced by vegetuble parasites in the hairs and hair-glands.

How to know it.-It is especially common in Winter and Spring, and appeurs on tho face, neek, shoulders, sides, and sometimes elsewhere.

When non-contagious, it may usually be known by its appenring as an eruption of small blisters, about the size of a wheat grain, on inflamed patches of skin. These assume a circular form ; and if not seasonably sttended to, the circlo enlarges and covers fresh portions of skin.

The contagious type appears in round, bald spots, eovered with white scales, and surrounded by a ring of bristly, brokes, or split hairs, with seabs around the roots, and some eruption on the skin. These broken luirs soon drop out, and a wider ring is formed. The most marked characteristic of the contagious or parasitical ringworm is the splitting of the hairs in the ring, and the perfect baldness of the central part.

Occasionally the patches, in either form of the disease, assume an irregular rather than a really circular form.

Any attack of this sort is usually marked also by the horse's rubbing and scrutching himself against the sides of his stable, or convenient objects outside; but this is not to be depended upon as a narked symptom, since it likewisc indicates surfeit and mange.

What to do.-If a simple, non-contagious case, shave the hairs as closely as possiblo from the affected part, and paint with tincture of iodine; or, if seratches or little ulcors have appeared on tha pateb, rub it with the following stimulating and healing ointment: 
No. 14.

10 Gruins nitrate of allver, $1 \mathrm{Oz}$ lard.

If it is a cuso of the contugious or scaly variety, wish the patches thoroughly with soft water' and soft soap, and then rub every day with the following ointment :
No. 15.
x. Drachm lodine,
1 Drachm todido of potash,
$10 z$. cosmollne.

If through neglect and long stunding it hus uleernted, uso this ointment twiec daily:

$$
\begin{aligned}
& \text { No. 16. } \quad \text { Oz. pyroligneous neld, } \\
& \text { 5 Oz. linseed oll, } \\
& 2 \mathrm{Oz} \text {. splrits of camphor. }
\end{aligned}
$$

If it has become obstinate-not yielding to the foregoing trontmentapply a blister direetly over the patch, and then trent as for $n$ common sore, using some simple ointment.

If there are signs of constipation und fever, care must be taken to keep the bowels open and regular, and to avoid stimulating grain food. A sensonable supply of cut grass und sliced potatoes, or of carrots, if they can bo obtained, should be allowed. If in Spring and Summer, and the horse is not in active use, put him to pasturo for a few days.

When the horse shows a tendency to weakness, as is sometines the case with young animals, and with those suffering from neglect, give good nutritious food, and tonic medicine ir moderation.

To prevent sprending the contagious form, clean the stable where a horse so ufflicted has stood, and white-wash its interior thoroughly. Wash the harness, collars, and whatever else may have covered the ringworm, with strong soap and water, and rub them over with a solution of corrosive sublimate, (one drachm to a pint of water.) If the horse has been blanketed while suffering with the disease, tho blanket should be well boiled.

\section{Zide-bound.}

Causes.-Strictly speaking, this is not of itself a discase, though the skin is in a peculiarly abnormal condition, but the result of a cliseased condition of the general system or of derangement of some specific vital function. With respect to the causes from which it arises, it is somewhat similar to mange; but, unlike mange, it is neither eruptive nor contugious.

Poverty and crual usage-the food being deficient in quantity or 


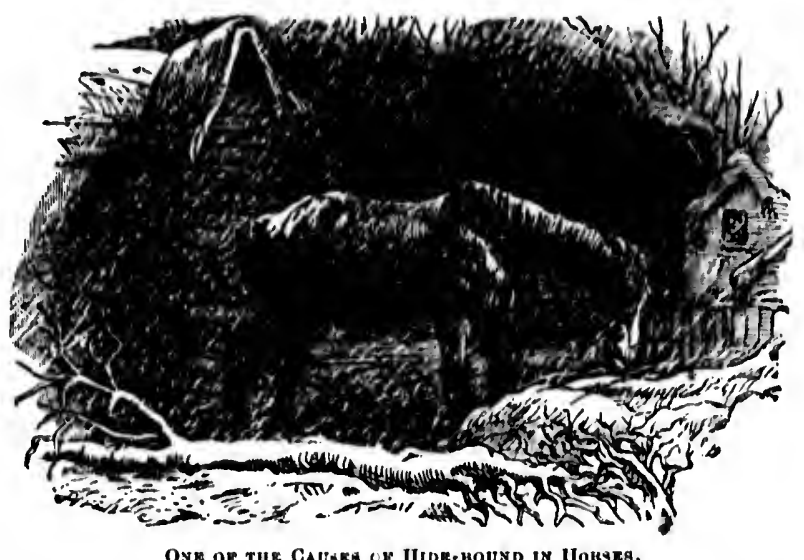

funlity, and the labor onerous-bring on impuired digestion ; the blood becomes thick, dark, and feverish, becunse the secretivo processes are slugrasishly performed; the skin symputhizes with these intermal disorders, and the lubricuting fluid through the pores is suspended; and then, insteat of remuining soft and pliant, it becomes dry and adheres to the hody. A disorelered stato of the stommeh, bowels, and minary and respinatory organs may be considered as having produed it when no specific form of disease ean be discovered as existing ; but it is an ulmost invurible acempaniment, in a greater or less degree of intensity, of big hend, glindel's, grease, farey, fomder, distemper, had enses of swimey, lige shoulder, lock-jaw, consumption, and chronic dysentery. The fever in these dries up the watery secretions and shrinks the hide.

Formerly it was supposed to be caused by worms in the stomach and "limentiny cumal; but this is erroneous. Worms may of course exist while the borse is in this state, but they are rather a consequence than at eatuse-the result of imperfect digestion and exeretion. The skin, as has been elsewhere stated, sympathizes readily with the vital internal organs, and in all obscure eases hiclo-bound slouls be considered a symptom of disorder in these, and treated aceordingly.

How to know it.-The skin is dry and harrd, and the hatir is rongh and rusty. Both are evidently destitute of that oil by which in health they are kept in soft, plimnt, and glossy condition. Adhering almost immovally to the ribs, legs, neek-almost every part of the body-the skin cannot he canght up in folds with the hand. At tines it appears scurfy, and the exhalants, (having the quality of giving out or evapornting), pour 
forth unusual qumtities of matter, the more solid portions of which form seales und give the horse a filthy appearance.

The exerement or dung is dry, hurd, und black.

What to do._Especial pains must bo taken to discover, if possible, what specific disease has given riso to this stato of the skin. If the cause is obscure, direct the treatment to restoring a healthy condition of the digestive organs. Begin by bettering his treatment in every way. Instead of hard labor, he should have only gentle exereise, and instead of being left exposed to the rain, snow, and mereiless winds, in barren passture land or filthy burnyard, he should bo well sheltered, and, in Winter, blanketed-using for this purpose two blankets joined along his back by tapes so that a pace of an inch or two may be left for the eseape of insensible perspiration. Instead of allowing the skin to grow elogged, torpid, and deat for want of cleanliness and frietion, ho should have regular daily eurrying and brisk rubbing with good brush or coarse eloth, which will materially aid in restoring healthy action of the skin.

If it is pasture season, give him a rum at good grass during the day; but stable at night in a clean stable, furnished with dry litter, and give him a generous feed of bran and oats, or moistened bran and ehopped hay, Mix with the food night and morning, the following alterative:

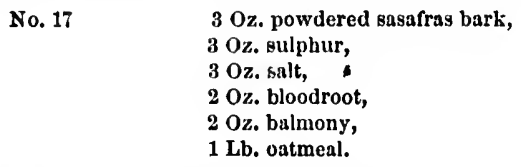

Mix, and divide into twelve doses.

If he appears in the begiming of the treatment to be filthy, fererish, and stiff, bleed him-taking from the neek vein thres quarts. If the stiffness continues, bleed again after seven days, taking a like quantity.

If the appetite is bad, mix with No. 17, (the alterative above deseribed), a spoonful of ground ginger; but in general you should avoid cordials, tonies, and aromaties, (that is, warm and pungent medicines). They may arouse fever that would otherwise fail to develop itself, and thus defent the object for which the mild laxatives and temperato alterutives preseribed have been given. Cordials may indeed arouse the vital functions to sudden action; but even if no lasting fever is created, the action soon subsides, rendering it necessin'y to eontinue the cordial or forego whatever seeming advantage may have heen derived from it. If excitment is continued by this means, the powers of nature are impaired and lasting injury done.

A good and sufficient tonic may be furnished, of which the horse will 
partake as much as the system requires, by placing a poplar pole in the stable, upon which he ean conveniently gnaw.

If the time is Winter, it will generally be found neessary to begin the course of treatment ly giving a purgative, say two ounces of Epsom salts, which may be repeated within seven hours if it fails to produce the desired action; and to feed him on laxativo food until constipation is orercome and a healthful action of the bowels restored.

Rener ber that one of the very first objects is to establish regular action of the bowels; and then gencrous diet, (let it he green and suceulent if possible, but at any rate nutritious without being inflammatory), with clcanliness and regular friction of the hide, will do more than medicine. Do not expect to effect a specdy cure; in any event, the very existence of hide-bound indicates chronic disorder, and all chronic diseases require time.

If it is known to be the result of a well-defined disease, as big-lead, fircy, etc., the treatment must of courso be directed to the removal of that, according to dircetions elsewhere given in this work; and the hidebound will disappear as its immediate cause is removed.

\section{Saddle Galls, or Sit-fasts.}

Causes._These are swcllings, sores, and tumors, caused by ill-fitting saddle or harness. Different names are applied to them according to their appearance and character. When a mere heated swelling on the horse's back or shoulders is unattended to, while he is kept in constant use, it sometimes assumes the appearance of a dead pateh of skin, and is then called a warble; when these ulcerate and discharge pus, and a leather-like piece of skin is firmly fixed upon the top of it, the name sit-fast is applied; and when, by the use of sadcle or harness before a warble or sitfast is thoroughly healed, a hard, callous lump is formed, it is called a navel gall-said to be so called because it is generally on that part of the back opposite the navel.

How to know it.-These swellings, sores, and tumors require no further description than has already been given.

What to do._-The first and most essential thing is, that the animal shall be allowed to rest; or at any rate be subjected to such labor only as will not require the same ehnfing, abrading saddle or harness which has produced the trouble.

Then, if it is merely a gall or scald-a heated, tender swelling, without either suppuration or havdness-batlie with cold salt and water two or three times daily. When the heat and tenderness are sensibly reduced, anoint oceasionally, until the lump has entirely disappeared, with a mixture of tar and olive oil, equal parts. 
If it has assumed the eharacter of a sitfust, do not uso the knife, nor try to tear the dry skin away, but bathe with warm soft water, and then apply a poultice. This must be repeated, if necessary, until the eallous skin is easily removed, and then anoint frequently, until the sore is healed, with the following:

$$
\text { No. } 18 .
$$

1 Dr. iodide of potash, 6 Drs. simple olntment, 2 Drs. glycerine.

When it has reached the stage of navel gall-hard, grisly, almost horny - apply daily the eamphorated, corrosive sublimate, No. 2. Shake the bottle well before pouring it out; use a mop with which to put it on ; then, when it is thoroughly saturated with this liniment, use a hot iron with whieh to dry it in.

When one finds his horse suffering in this way under saddle or harness, his own interests, as well as the promptings of humanity, denand that he shall at once remove the cause, if possible; but it is sometimes the case that this eamot be done-absence on a journey, military necessity, press of farm or road work, requiring regular service. Under these circumstanees the saddle or harness should receire immediate attention and subsequent watehfulness on the part of the rider or driver. The piddling must be taken out of the saddle or collar so as to obviate pressure on the part affected; or, as for the saddle, the blanket may be so arranged as to lift it from the spot. The sore place must be bathed well with salt and water as soon as possible after it is discovered; and then covered with a piece of adhesive plaster, heated, of course, until it sticks readily. If matter has formed, a hole should be cut in the middle of the plaster to allow it to escape.

Treated in this way, the horse may be ridden from day to day, and recover while in use.

Greasing collars and other parts of harness will frequently prevent that chating which results in sores and eallous tumors.

If the horse, through constitutional tenderness, is sulject to these swellings and sores, it is well to put the saddle on half an hour before using him; and leave it on, having slightly loosened the girths, for a half hour or an hour afterward, thus preventing sudden change in the temperature of the skin.

\section{Fungovs Collar Tumor.}

Causes.-This in its nature is essentially the same ns that described in the preceding section as saddle gall, or sitfast-differing, however, in location and specific cause. It is an inflammution and swelling beneath the larg by the e

How to tion of : point of or severit standing, detect as Where th and no cu there will

Under : it may for

\section{What to}

scar or lun quent use, order will use a breas is recent, a over the sh This must I

But if $\mathrm{tl}$ and contai smooth, ve the pus.

So. 1

If the wo diseontinue to promote

No. 20

\section{Causes.}

received as $t$ plethorie con rily to high be taken as auimals, of 
the large flat muscle that covers the front of the shoulder, and is caused by the chafing of the collar.

How to know it.-It is scarcely necessary to undertake farther description of a well-known, visible ariection. It is usually found near the point of the shoulder ; and the character of the tumor as to simplicity or severity can be readily determined by examination. If of considerable standing, it will be found so hard as to render it almost impossible to detect any fluctuation that would indicate the presence of matter. Where there is much swelling, however, there is almost invariably matter, and no cure can be effected until this is removed. In cases less marked there will be a small, hard or indurated lump without matter.

Under similar conditions as those mentioned in the preceding section, it may form a leathery patch in the center and become a real sitfast.

What to do.-.The tumor nust, if possible, be so treated as to leave no scar or lump, as this would be easily irritated by the collar upon subsequent use, and prove a source of constant trouble. The first thing in order will be to take the horse from work, if at all practicable. If not, use a breast-strap, so as to prevent all further chafing. If the sweiling is recent, apply cold water often, or cover the part with a wet rag hung over the shoulders in such a way as to remain in contact with the swelling. This must be kept constantly wet.

But if the tumor is large, and of long standing-already hardened und containing matter deeply hidden, open with a knife-making a smooth, vertical cut, and of sufficient depth to thoroughly evacuate the pus. Syringe the opening well every day with the following solution :

$$
\begin{aligned}
& \text { No. 19. } 30 \text { Grains chlorido of zlnc, } \\
& 1 \text { Quart water. }
\end{aligned}
$$

If the wound seems inclined to heal and leave a hard lump in doing so, discontinue the injection, and rub frequently with the following liniment to promote the absorption of the callous or gristly formation:

$$
\begin{aligned}
& \text { No. 20. } 10 z \text {, iodine, } \\
& 120 z \text {. sonp liniment. }
\end{aligned}
$$

\section{Warts.}

Causes._-It is difficult to point out anything that may be implicitly received as the cause of these excrescences. Generally accompanying a plethoric condition, they may be considered as owing their origin primarily to high feeding and insufficient exercise. This, however, must not be taken as conclusive, since they not unfrequently appear upon active animals, of meagre habit. 
The manuer of their formation seems to be this: Knots in the true skin are gridually developed, being surrounded with a covering of the scarfskin, something thickened and matted together; and this outer covering gencrally dries and splits into tibers towards the top, while blood, in greater quantitios than usual, is sent to the inner or vascular parts; and more nutriment is thus diverted to it than to the surrounding fiesh, so that an upward or outward growth is promoted.

Seed wirts usually make their appearance on the eyelids, the nose, the sheath and adjoining parts of the belly; the encysted or sac warts, on the pasterns, hock-joints, and knec-joints, and sometimes upon the sheath and neighlooring parts.

Unless warts appear upon the penis they are not injurious to health, and at first oceasion little inconvenience unless upon the shoulder or some part where harness or saddle touches constantly; but they should be removed, nevertheless - particularly the suc wart and those seed warts which manifest a tendency to enlargement. If the encysted or blood wart is allowed to remain it will almost invariably enlarge and spread.

How to know it.-There are two kinds of these formations, one of which is fibrous, white, and gristly or cartilaginous, but somewhat spongy lump, contained in a sac or cell which has uken its rise from the outer or scarf-skin; and the other is a somewhat cartilaginous sulstance, not inclosed, but adhering firmly to the skin - a hard excrescence, - the "seed wart," - which is too well known to require particular description. It is sometimes difficult to distinguish the blood wart, as the former is sometimes ealled, from the seed wart; but it generally presents a more rounded, smooth appearance, and sometimes hangs as by a little stem, in which last case it is readily known.

What to do.-If there is doubt as to the character of the wart, the matter may be speedily determined by running a sharp-knife through it; when, if a blood or sac wart, the contents will come out, accompanied by more or less copious bleeding; whereas, the seed wart will in this case be merely divided by the incision, each part retaining its firmmess or consistency.

When the blood wart is thus opened, nothing more will bo necessary than to touch the part with a solution of chloride of zine, one grain to the ounce of water, or lunar caustic. When these warts are attached to the skin by narrow bnses, or small stems, they may be clipped off with knife or scissors, and the part slightly burned over with caustic as previously directed.

If the growth is of the fixed kind, or seed wart, remove by menns of scissors or knife when standing singly; but if the stem or base is large, 
or if the warts grow in bunches, tno numerous and too close together to be cut away, pick off or otherwise chafe the rough outer surface so as to make it bleed; then with a stiff brush rub in yellow orpiment wotted with a little water, and in a few days they will come away, or mat be rubbed off, and leave a henlthy sore, which soon heals. If tho entire wart does not come off by reason of one application, repeat.

When the penis is wholly covered with warts, the best plan is to have it amputated, as the warts cannot easily be removed without destroying as much of it as it would be nocessary to remove entirely in order to be rid of them.

\section{Vermin.}

Causes._-Vermin a :e both a cause and a consequent of skin disease; and being also bred in the hairy covering, perhips in the very skin itself, they are pro, serly treated in this connection.

Every species of animal is nore or less troubled with his own peculiar inseet tormentor; and while no well-defined cause can be assigned as to their origin, they are almost always found associated with filth and squalor.

They sometimes, however, trouble animals of fair condition, and accustomed to reasonable care; but in this ease they are caught by contact.

Poor, ill-cared-for, mangy horses, colts in the Spring of the year, with long, uncurried coats, and old and feeble horses with like rough and shaggy covering, most probably breed them; and on these they are most frequently and plentifully found.

The itching torment to which they subject diseased animals doubtless intensifies whatever disorder may exist; and the very earliest opportunity should be taken to eradicate them from the sufferer.

When horses stand in proximity to a hen-house, they are often seriously annoyed with hen-lice, which are even more tormenting than those peculiar to the horse himself.

How to know it.-The horse infested with vermin will usually manifest his unensiness by biting und rubbing himself ; but their presence may be unmistakably detected by a more or less careful examination of bis coat.

What to do.-If the horse is suffering from some skin disease requiring treatment, the means adopted for this will almost invariably suffice of themselves to remove the vermin; but where no such disease exists, and it is a simple case of lousiness, anoint him with the following salve: 
No. 21.

1 Dr. earbolic acld crystals, 1 Quart fresh lard.

Pub it upon every part of the body thoroughly ; wash with warm soap suds next day ; repeat if necessary - at lust washing und drying.

Attention to his general health will also be demmoded and to this end he should be upon good pasture, or a liberal supply of nourishing but not heating food should be given.

If it is a case of hen-lice, the first thing to be done is to remove the horse from the place infested with these, and then to anoint and wash as before directed.

\section{Larva in the Skin.}

Causes.-The larva, which infests chicfly the back-that part of the horse upon which saddle or harness must press-is not only a souree of trouble to the animal, but of great inconvenience to the master, as the acute painfulness of a tumor raised by one of these grubs often prevents use.

The larva is the offspring of a fly which deposits its eggs upon the back and sides of the horse while he is out at pasture or roaming at large upon the common. This fly does not frequent the barn-yard and stable, so that horses which are confined to these when not in use are never annoyed with the larva.

The eggs ure hatehed by the warmth of the animal; and the creature burrows into the skin, where it remains and grows till Spring, raising menwhile, by its irrituting presence, a small lump, which is eventually developed into a painful tumor, upon the pus of which the insect prolongs a life that it began upon the natural juices of the skin and cellular tissue.

How to know it.-'The most unmistakable sign of the trouble, when it is not plainly discernible with the eye, is the restlessuess manifested by the horse when subjected to the saddle. When he does this, and $110^{\circ}$ well-defined occasion for his displeasure and his pranks is readily pcrceptible, examination will reveal a tumor or alssess if the larvn is present; for the horse will hardly grow restive at first, when there is a mere lunp in the skin. Upon the top of this alscess a black spot will be found, which is the point of entrance, and the opening through which the insect obtains the little air that it needs.

What to do.-The best thing to do, because both quickest and safest, is to open the top of the tumor slightly with a lancet, and then to squeeze out the larva. The wound should then be dressed a time or tro with a solu the trouble

\section{Causes.}

is difficult $\mathrm{t}$ habit of b Summer.

It is not c which it sor and horse.

There are reality what with other a

How to $\mathrm{kr}$ obselved to The neck, sh Upon exami times torn 0 be seen on $t$ These bliste1 surface moist

In its more distinguished iuvade all pa scabby portio

What to do iion. If the constipation, any crent let

Give, once affeeted parts hours ; theu seales. Then skin all round No. 22. 
with a solution of one grain of ebloride of zinc to one gill of water; and the trouble will soon be over.

\section{Tetter.}

Causes.-This seems to arise from some constitutional cause, which it is lifficult to point out. It appears on horses of different conditions or hal hit of hody. On some it breaks out periodieclly, Summer after Summer.

It is not contagious, unless neglected until it assumes the epizootic form, which it sometimes does, after which it is communicable to both man and horse.

There are said by some to be two or three forms of tetter, but in reality whatever different forms it may assume, when not compliented with other affeetions, they are indications of different degrees of severity.

How to know it.-The attack is usually sudden, and the animal is observed to rub hinself severely, as suffering from intense itchiness. The neck, shoulders, back, and thighs are the points ordinarily affected. Upon examination, the skin will be found red with inflammation, sometimes torn or seratehed by rubbing; and the blisters or pimples will he seeu on those parts of the inflamed spot not so torn or seratehed. These blisters break, nnd a watery fluid is diseharged, which keeps the surface moist.

In its more advaneed stage it may be taken for mange; but it may be distinguished from mange by its manifesting less tendency to spread and invade all parts of the skin; and by the absence of parusites under the scably portions.

What to do._First, see that the horse's bowols are put in good eondiinin. If there is any tendeney to plethor:a, (too great fulness), to constipation, or general feverishness, give him a purgative dose; and in any event let his food be of such eharacter as to prevent costiveness.

Give, once a day, an ounce of Fowler's solution of arsenic. Rul the affeeted parts well with sweet oil, and let it remain thereon for a few hours; theu wash with warm soapsuds so as to remove the seabs or sciles. Then cover the diseased surface and some portion of the healthy skin all round with the following ointment:

No. 22.

1/3 Lb. flour of suiphur,

K L Lb. carbonate of potash,

$1 \mathrm{Oz}$. enrbolic acid,

2 Lbs. lard,

2 Lbs. olive oil. 
Mix well with a gentlo heat. Allow it to remain on the skin for two or three dnys, and then wash off with strong soap and water.

Tar ointment, (equal quantities of tar and lard well mixed with gentlo heat), is an excellent exterual application, and may bo used when No. 22 is difficult to procure.

\section{Rat Tails.}

Causes._-Simple tetter, as also mallenders and sallenders, is sometimes allowed through neglect to beeome obstinnte; the skin thickens; ugly sracks are formed, from which flows in abundance a sort of purulent half-watery fluid; upon the thickened portion of the skin the seabs inerease, growing up into somewhat perpendicular layers, and the hairs growing from these are glued together by the exuding matter. Such bunches of matted hair aro called, by reason of their uppearunee, "rit tails."

The disease seems oceasionally to be produced outright, without the supervention of any other known disorder, by much exposure to wet ground of a chalky or loamy nature, or to stieky mud.

How to know it.-It appears chiefly upon the legs, one or all of which may be affected at the same time; but the hairs of the tail, especially near the root of the tail, are often found in the gondition deseribed, and for a like reason. Tetter, ringworn, or some other disurder. produees itching; the horse rubs the part till it becomes raw; matter exudes at length, and the hair is matted in bunches along the upper portion of the tail bone, as shown in the figure exhibiting exterual manifestations of disease.

If resulting from either neglected tetter, no matter what its position, or from mallenders and sallenders, it is aceompanied by itchiness; but this is generally less severe than is the ease with these disorders in their simplo form. When the disease is fully developed, the appearance of the bunches of hair upon the parts is a sufficient indication.

What to do.-As in simple tetter, attention must be directed to estiiilishing a good condition of the bowels; and to this end a purgative may be given-especially if there is any indication of constipation and greneral feverishness. The food must be regulated by the necessity of keeping down all inflammatory symptoms. Make a tonic powder as follows:

No. 23.

$$
\begin{aligned}
& 12 \text { Oz. sulphur, } \\
& 1 \text { Dr. arsenic, } \\
& 1 \text { Oz. brulsed coriander seed. }
\end{aligned}
$$

Divide into twelve parts and give one in the food night and morning. 
Dress the sores three times $\boldsymbol{n}$ day with the following lotion, applying with a soft rag:

No. 24.

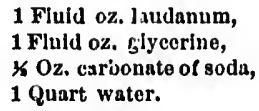

\section{Mallenders and Sallenders.}

Causes.-By thase terms are denoted oozy, scurfy patches upon the knee and hoek - thoso which appear back of the knee being called (for what reason nobody seems to know) mallenders ; and those which appear in front of the hock, sallenders. They spring from idleness and negleet -an impure state of the blood having been brought on by heating and unstiitable diet, and disorders of the bowels, liver, or kidneys.

Though of no serious importance as diseases, they are unsightly, and, if neglected, they result in troublesome sores.

How to know it.-They first begin as a moist tetter, apt to escape olservation until they appear in a roughened state of hair about the parts mentioned, under which the skin is seurfy, feverish and somewhat tender. Itching of such severity sometimes attends them as to render the horse restive and hard to keep under restraint.

What to do.-In the first place attend to the cleanliness of the horse and put him upon a regular course of moderate exereise. Give hmu twice daily, night and morning, a pint of the excellent alterative and tonic drink:

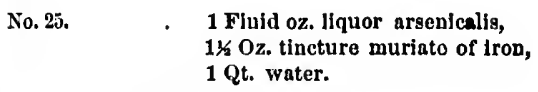

Rub the parts affected two or three times a day witis an ointment made as follows:

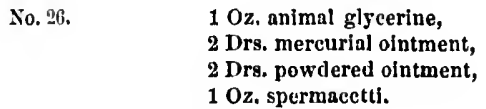

If the scurfy places have developed into suppurating sores, use, instead of the ointment, the following lotion, saturating them well twice a day :

No. 27.

13. Pint animal glycerine, $1 / 2 \mathrm{Oz}$, chloride of zinc, 6 Quarts water.

Be careful that his food is such as to keep him from constipation and ferer. 


\section{Pollevil.}

Causes.-Poll-evil is the name given to a deep abscess having its sent of primary inflammation between the ligament of the neck and the first bone which lies benenth without being attuehed to it; nnd it is serious in its nature by reason of this depth and of the difinculty with which the nutter formed finds its way to the surface through the strong tibrous membrune that envelopes it. If not attended to in its early stinges, the surface of the first bone from the head, or thint of the joint between the first two bones, becomes inflimed, and the joint or joints involved.

The discase may be said to owe its origin nlnost wholly to violence of some kind. $\Lambda$ blow upon the poll by a britul driver muy very rendily produce it; and much slighter enuses, often repeated, result in this affection; as, the forcing on of a tight collar day after day; hanging baek and so bruising tho poll with bridle or halter; and excessive rubling of that part because of itch produced by dirt nceumulated ubout the enrs and upper point of the neck and not carried awny by brush or enrryeomb. Striking the head against low ceilings and the benms of low doorways is doubtless responsible for very many eases of this dangerous and disigreeable disorder.

How to know it. $-A$ certain restlessness, a throwing back of the head and then returning; again, a drooping tendency, turning the hend from one side to the other; a dull appearance about the eyes; a sluggishness of movement - all these are sometimes observed before any symptoms of tise disease may be diseovered about the head.

fometimes no notice is taken of its existence until considerable swelling and even an unwholesomo discharge heve set in; but more frequently an oval tumor is discovered,-hot, tender, situated direetly in the region of the nape of the neck, but generatly inelining to one side. In the milder form this tumor is evidently superficial ; and the horse moves his herd with comparative ease and freedom ; whereas, in the more advanced stage he carries it stiftly, and every movement of it or the neek eauses great paill.

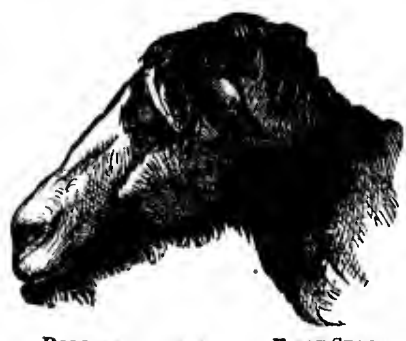

Poll-avil doring tuz First Stage.
Sometines the disorder is so depplyseated that the tumor is not dereloped sufficiently to make much outwilrd slow: It is much likeliej to discover itself plainly as a well-developed swelling when the hurt is supcrficial. In any ease, it must be examined with the fingers to determine this point. Place the fingers gently upon it, and give the animal time to recover from the little scare into which this touching of a sore at first gives him: then gra If the hut flineh qui will be co jing evides tion has a be known sort of fll fluetustion if the matt

What to no matter 1 ishness by condition ; diet. Then constantly $n$ siturated wi

No. 28.

If this do within a few though it ma bring it to a is pose a mixtu hog's liurd. shiup knife; p'erent strugrg the blade thre tho lower poin of mitter this tendinous ligat matter ippeirs: leare this lig: serered betwed head be not $m$ bone, and the is best to aroid ienced veterina use the knife. 
then gradually press upon the part. If the hurt is near the surfuce, he will flinch quickly; if deeply sented, he will be correspondingly slow in showing evidences of pain. If suppurintion has already set in, it can readily be known when near the surface by a sort of fluctuating feeling; lout this fluctuntion can scarcely bo felt at all if the mitter is deep sented.

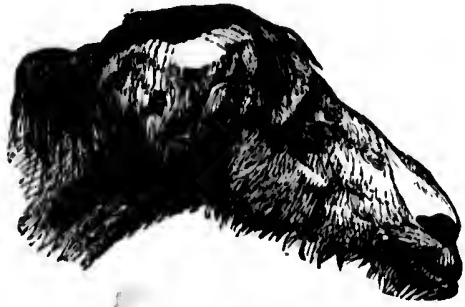

Polf-evil IN IT8 SrCOND StaOx.

What to do.-If discovered when there is nothing more thun a swelling, no matter laving yet been found, removo all tendency to general fere: ishness hy giving purgative medicine according to evident fullness of condition; allow the horse to rest; and put him on moderitely light diet. Then make the following cooling lotion, and keep the swelling ronstantly moistened with it hy having a small rag pad laid over it and saturated with the mixture from time to time:

No. 28.

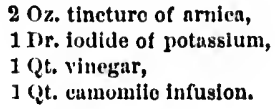

If this does not reduce the inflammation and remove the swelling within a few days, it may be inferred that matter is already forming, though it may have been impossible at first to detect it; nnd you nust bring it to a head as soon as practicable by poulticing. Uso for this purpose a mixture of ground flax seed, coln meal, oil of turpentine, und hog's lard. As soon ns matter ean be felt, have ready a large and very shurp knifo; cust the animal, and have some one to sit upon his neck to prevent struggrling; then open with a quick, steady, and strong sweep of the biade through the tumor-being careful to have the wound open at the lower point of the tumor, so as to provide for more easily draining it of matter that may hereafter form. 13o careful, too, not to cut the tendinous ligament that runs along the neck under the mane. If the matter appears to be on both sides, open the places separately, so as to leave this ligament undivided. It may, if absolutely necessary, be severed between the second bone and the head, and the support of the head be not materially weakened, since the main stress is on the second bone, and the divided ligament, if hoalthy, will soon heal again ; but it is best to avoid all risks; and if at all comvenient, tho aid of an experienced veterinary surgeon should be had when it becomes necessary to we the knife. 
'ilhe wound must now he cleansed by being syringed daily with it stimulating wash, (1-2 dr. chlorido of gine in 1 quart of water), until " lienlthy discharge sets in, and ovidences of healiug begin to manifest themselves. Nothing further will then bo necessary than to keep the parts cleim by daily sponging with warm sonpsuds.

It sometimes occurs that before remedial mensures are resorted to, not nlone the fleshy, but the tendinous, ligmmentary, and bony structures have become involved, and the disenso hins assumed $n$ desporite churanter. If further neglected, the spinal cord is likoly to become disensed, and the case hopeless. If, upon opening a tumor, the matter is found to flow in grent qunntities, resembling melted glue, with something of sun oily consistence, it may he known that the disenso is deep-sented und diugerous; and the probe should bo employed to find whatever cavities may exist. If any are found, the knife should again bo employed, and unother cut mide, smooth down, and in the sime direetion as the first, to prevent all rough and hacked walls, till the lowest depths are renched. Then cleanse the wounds with warm sonpsuds, using a good gum eompess syringe; and dress with a mixture of spirits of turpentine, honey, and tincture of myrrh. When a thick, light-colored mutter begins to appear, the dressing must be discontinued, and the parts must be kept clean, as previously directed, by sponging with wurm soupsuds.

It is sonetimes necessary to eut awny loose pieces of ligament till a healthy aspect is presented on the walls and in the depths of the incision.

In the more desperate cases, numerous openings are formed, and these discharge a matter resembling the white of an egg, which adheres to the surrounding parts, and gives to the animal a most repulsive appearance. In this case the knife should be used so as to take in at ono sweep the greatest number of openings, and then the other openings should bo connected ly cuts with this main chmmel; after which the wound should be cleansed as previously directed, and dressed with the mixture prescribed - spirits of turpentine, honey, and tincture of myrrh.

After matter has formed, the knifo is the only sure means of sariag the horse; and, in the hands of the skillful man, it is a mereiful means. The opcration is brief ; and the relief is moro speedy thun ein otherwise be obtained. Let no ono attempt it, however, who cumot operate as though for the moment divested of feeling, as there must be no hesitation, no awkwardness as to direction, no notehing and hueking.

A horse that has once had the poll-evil should never afterward hare a collar thrust over his head, or be hauled around with a halter or any other head-gear pressing upon the part. The poll will long remuin tender, and a return of the disorder is likely.

If it is necessary to treat during Summer, when the horse is apt to bo 
annoyed with tlies, keep tho wound covered with a rag moistened in a solution of tar.

\section{Fistula.}

Causes.-C'This is sometimes known as fistulous withers, to distinguish it from fistuln of tho purotid duct. It is similar to poll-evil and is generally cmined in like mmmer, by bruises. In the ense of fistuln, these bruises muy be caused by an ill-fitting collar; by a lady's'saddle, purtie. ularly if uwkwardly ridden; hy tho pressing forwurd of a mun's suddle, enpecially in case of high withers; by striking the withers ngninst the (10) of a low door-wny; by rolling und striking the withers against some hard sulstance; by the biting of other horses; and hy a blow of the biacksnith's hanmer. 'The points of the spinul processes, (littlo projections of the spino or buck bone, ) are hurt, inflammution sets in, and the fistulous tunor is produced. Its sito is tho spine nbove the shoulders; and it is more troublesomo than poll-ovil, because it is more exposed to repented injuries.

How to know it.- The first indicution will be a swelling on one or both sides of tho withers, generally rather brond and flut. Upon exam.. ination with tho fingers this will be found hot, tender, and appurently decp sented. If olsserved when first formed, it will be of uniform hardness throughout. If unattended to while in this state, the tumor soon becomes an abseess; and owing to the difficulty in the way of the matter's esenping, (its nuturnl outlet being ut the top of the shoulders), the pus sinks downward; und the abseess sometimes becomes cnormous hefore there is any well defined hend, and before there is any opening. When it breaks, or is opened, a largo ruantity of extremely offensive matter flows out. Ordinarily, tho tumor will come to a head in from one to two weeks. When the discharge has begun, the tumor does not begin 10 grow hetlthy and heal, but ho walls of the opening thicken, and continue to dischargo matter which becomes more and more offensive. The matter burrows between the shoulder blade and spinal points, and everything around seems to bo rotting away; and it is both difficult and dangerous to trace the opening. In process of time several holes will appear along the course of the muscles in contact with the original abscess, and from each issues n foul discharge, till the ulcerating process secms to extend itself to nearly all tho muscles of the shoulder.

The health of the animal may at first be excellent, and there may be no lameness; but as the inflammation extends, there is lameness of the shoulder, and he suffers generally-often greatly. He is averse to motion, and will suffer for food and drink rather than undergo the pain 
of trying to reach and partake of it. In its worst stages the bones extending into the sinus decay.

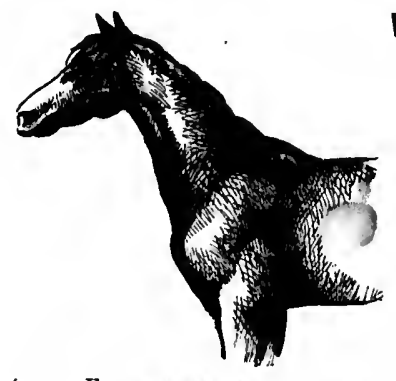

SLIOHT ENLARCEMENT WHCH MAY END in Fistulous Witukes.

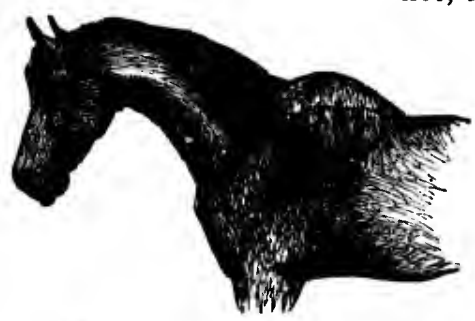

Fistulotg Withers-Worgt Stage.
What to do.-Be careful to ascertain, in the first place, whether the tumor has newly risen. The matter maty form in one, even while it is quite small ; and it is important to know when the knife may be used to advantage.

If matter has already formed, it ean bo detected by the somewhat soft and fluctuating fecling of the abseess.

If discovered while still a new formation, take the lorse from work, if possible; if not, take especial pains to protect the injured point or points from pressure. A bruise at that point of the withers where the collar rests will not unfit a horse for the saddle, unless considerable inflammation and extending soreness has already set in; nor will a saddle bruise, farther back on the wither's, necessarily unfit him for harness.

A recent swelling should be immediately treated with fomentations of bitter herbs.

Boil wormwood, or mullen stalks, or life-everlasting in soft water, to make a strong decoction; and apply it with large woolen cloths, as hot as can be borne, to hasten the formation of matter. When the tumor begins to soften and show signs of lieading, have a suitable, fine-pointed, sharp knife. Ascertain the lowest point of the aluscess. Then stand close to his side, near the middle, to avoid both lind and fore feet in case of kicking or striking, with the back of the knife to the shoulder; point upward and outward, stick at the lower edge, and eut open with a free incision. Next, syringe the abscess till it is as thoroughly eleansed as possible with a solution of carbolic acid and water, one part acid to two of water. Then dress with coal oil, or some convenient salve. After two or three days, the wound should be thoroughly cleansed by syringing with warm soap suds; then use the curbolie acid water, and repeat the oil or salve dressing; and so on till a cure is effected.

The patient must in no case be turned to pasture, since the eonstant motion of the neck and juws necessary to procuring and mastieating his food aggravates every symptom. Stable him comfortably, and feed aceording opportuni silall incl

When $t$ have appe course as ticularly b to press be out ; and $\mathrm{i}$ rotten, ni] reached.

matter and

After th deald bone, parts ; ther instead of $\mathrm{c}$

No. 2

The coppe thoroughly. set in, discor intervals, wi after each dr

Should th which takes reatson of abs from three to the intlammu

When the treatment, th disfigured.

In very des pensable, to $u$ ealled), the o tion, and ten ascertain the not answer, $u$ ter on medieil it a firm rap o the point thr 
according to his general condition. Let him have water freely ; and give opportunity each day for some exercise by allowing him the run of a small inclosure.

When the case has becone clironic, and holes in considerabre number have appenred, make a cut so as to reach the bones, and to include in its course as many holes as practicable. If there are other openings, (particularly below), eut from them into the main incision. Have an assistant to press back the sides of the greater opening till the matter is cleared out; and if the spinous processes or points are found to be carious or rotten, nip off with a pair of bone foreeps till the healthy bone is reached. If any of this decaying bone is left, the wound will inevitably matter and break again, though it may for a time appear to have healed.

After thus cleaning out the bulk of the matter and picking away the dead bone, use the syringe and warm soap-suds still further to clean the parts; then injeet the carbolic solution as previously directed. But instead of coal oil, use this ointment once a day ;

No. 29.

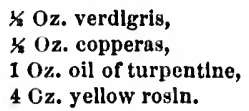

The copperas and rosin must be finely powdered-then mix all together thoroughly. When a kind of thick whitish discharge is observed to have set in, discontinue the ointment; but still wash or syringe thoroughly, at intervals, with warm soap-suds. To keep away flies, cover the wound, after each dressing, with a large cloth saturated with diluted tar.

Should the horse grow feverish from the effects of blood poisoning, which takes place in a greater or less degree in this chronic stage by reason of absorption, bleed him ouce, at least, taking from the neck vein from three to six quarts, according to general condition and severity of the inflammation.

When the disease has proceeded to the length of requiring this severe treatment, the recovery is necessarily slow, and the horse is inevitably disfigured.

In very desperate cases it is sometimes best, or, indeed, almost indispensable, to use the rowel. The pipes, (or sinuses as they are sometimes called), the openings whenee the matter exudes, take a dangerous direction, and tend from the withers to the chest. Use an elastic probe, to ascertain the direction and the deptlı; and if it is found that eutting will not answer, use the guarded setou or rowel needle described in the chapter on medicines, ointments, ete. Insert it as far as it will go, then give it a firm rap on the liandle, so as to foree out the cutting edge and drive the point through the flesh. Kunt one end of a long, sleuder tape, 
place the other through the opening near tho point of the needle and draw it through. Then tie a knot at the other end, and leave it. In this way, the sinus will have an opening below, and the tape will act as a drain, while tending also by friction to remove the hard lining of the pipe. As soon as a healthy looking matter is seen to be issuing from the lower orifice, remove the seton, but cleanse occasionally with warm soap and water. 


\section{CHAPTER III.}

DISEASES OF THE GLANDS AND NASAL MEMBRANES.

J GLANDERS, - II. FARCY.—II. DISTEMPER, — IV. NASAL GLEET, - V. NASAG POLYPUS.

\section{Glanders.}

Causes.-This scems to be primarily a disease of the lymphatic and ntasal glands, and confincd to them ; but upon this point authorities disagree, and it is contended by some that all the air passages are always affected-that it is a kind of phthisic, or incipient pulmonary disorderand that whether the uleers appear on the membrane of the nose prior or subsequent to the formation of tubercles in the lungs does not invalidate the proposition that the earliest exterual manifestations are but the effects of pulmoniry derangement. The most tenable conelusion, how(ver, is plainly this: that inflammation of the membrane of the nose, and eonfined to that membrane, at last results in ulceration; that the matter discharged from these is poisonous, and acts upon the glinds by mens of the absorbents with which it comes in contact, and is also inlinled into the lungs with the air as it passes through the nasal eavities, till at length both the circulatory and the respiratory systems are generally diseased.

Whence this poison is derived is not at all clearly defined. The disease is both spontaneous, (bred in the horse), and contagious ; but it is doubtless die far more frequently to predisposing cause than to contagion. It is found als it prevalent disease whero neglect, filth, and foul atmosphere exist ; and we may reasonably conclude that poisonous inhalations, acting upon the delicate and easily irritated membrane of the nose, produce that incipient ulceration from which the subsequent geaernl poisoning proceeds. In close stalls, the carbonic acid given off 1 rom the lungs, (which' gats is of a deadly poisonous chinneter), passes again and again 
into the lungs, mixed with other impurities of the stall itself ; this, actung perhaps more readily upon the nasul membrane than upon the other lihings of the nir passnges, produces inflammation. This inflammation may long exist, and unsuspected by the ordinary observer, till some intense action is set up, when uleeration takes place.

Or it may be produced by anything that injures and weakens the vital energy of this membrame; as vicient catarrh, accompanied by long eontinued discharge from the nostrils; a fracture of the bones of the nose; and the too frequent injection of stimulating and acid substimees up the nostrils. Everything that weakens the constitution, may, under peculiar circumstances, produce glanders. Among the hurtful influences thit may operate to this end wo may enumerate: hardships and an exhunsted constitution; any interference with the due elimination or throwing off of morbid and waste matter from the system ; want of regular exercise; sudden and violent exercise when the horso has not been previously prepared for it; placing a weak and worn-out horse upon a course of diet that is too nutritious and stimulating; and hereditary predisposition to certain forms of disease.

One point is deserving of special mention : it is sometimes present and contagious in animals apparently in fine bodily eondition; otler horses may contract the disease from such a one and die of it while it is still difficult to diseover ummistakable traces of it in the first. There may be inflammation, and minute nlecrs so far up the nasal passages as not to he seen ; these little hidden ulcers may discharge so small a quantity of matter as to escape notice, and yet the matter is so poisonous that when it comes in contact with any thin and delicate membrine, by which it mar be alssorbed, it will produce glanders. Weeks, and even months, miny intervene between the first existence of inflamed membrane and the development of the disease. In this case there may be counteracting tendencies, requiring some violent action or sudden change to determine the issue.

It nust bo observed that its infectious nature is not general, but particular-depending upon inoculation with the matter exuded from glanderou's ulecrs, or at least from poison received in some way from the glandered animal and communicated directly to a wound or to some delicate nembrane of another horse, an ass, or $n$ human being.

How to know it.-As may be inferred from the preceding, it is not always easy to detec the actual presence of this disease, though it is often a matter of paramount importanee that it should be known. Its dangerous character as an infectious disorder makes it essential that it should be known in its very earliest stages, that the proper precautions may be taken to prevent the infection from spreading.

There

appeninic thongh th extraordin

The tir's pyes are re them. 'Tl appearance immatural. larly if a c so alternat failing heal

These mi to this tim from the no serutiny, to mide by th drred condi After the diseresse, the dlfined, are muth resem imes to pal which has 1 nostril, and is the right, a peculiarit. diserase.

The secon lieenmes mor triluspiarent now to drip) stagere, now nt afferts the it alands within nowstril, only theso swelled look for some ence of gland surfice als $n$ rlanges, and center of the 
There are some symptoms that may be observed, even before the appearance of any dischurge whatever; and these mny be cleseribed, though they may sometimes prove fallacious, and are found to be but extriordinary indientions of some other diseuse.

The first signs are those of henviness, dullness, followed by fever ; the eyes are red and unhealthy looking, while the light is seemingly painful to them. The hair is one day dry, the next, perhaps, it resumes its natural appearance, and so alternating until after awhile it becomes staring and umatural. The flesh wastes away ripidly for a time; then, and particularly if a change of food is introduced, showing some improvement, and so alternating till at length he begins to show signs of permanently failing health and of a general debility.

These may be regarded as for the most part premonitory signs, and up to this time there inay be no appearnuee of tumors and no discharge from the nostrils; but the animal shouid be subjected to the most rigid serutiny, to discover whether there is anything to confirm the impression made by the symptoms enumerited as to the probable existence of glandered condition.

After these manifestations there may be said to be three stages of the discase, the peculiarities of each of which, in so far as they are distinctly defined, are generally as follows: In the first stage the discharge so much resembles that which attends some other nasil affection as sometimes to pass umoticed, but examination will disclose a curious fact which hals not been accounted for,-it will be found eonfined to one nostril, and that, in the vast majority of eases, the left. Oceasionally it is the right, very seldom hoth. This, however, must not he regarded as a peculiarity of the first only, ats it is common to every stage of the diserise.

The second stage is chatuctorized by an increased tlow, and it also lecomes more mucous and sticky, while its color chunges from an alnost trinsparent clearness to a whitish or yellowish tinge. It often begins now to drip from the nose in stringy clots. Some of the matter in this stage, now more actively poisonous, being taken up hy the alssorbents, affects the neighboring glands. If hoth nostrils aro discharging, the glinds within the under jaw will be enlarged on loth sides; if from one nestril, only the grhand on that side. As other discenses will produce these swolled glunds, as eatarrh, for instance, it becomes necessury to loik for some peculiarity in order to determine certainly as to the existence of glanders. At first the enlargement may be spread over so nuch surface is not to make any distinctly marked lumps; but this soon changes, and one or two sinall swellings remain, and these are not in the tenter of the channel, but adhere close to the jaw on the affected side. 
This may be regarded as an almost conclusive test. The membrane of the nose will now be found of either a dark purplish hue or a leaden color-- the lntter, unless there is some of the redness of inflammation; and uleers will probably appear upon the membrane, usually appronching to a circular form, and deep, with abrupt and prominent edges. When these uppear there ean be no further doubt, but enre must be taken to know that they are not spots of mucous. To thls end, try whether they may be brushed away. Notice particularly, too, that the orifice of the duct which connects with the tear glands is just within the nostril, and c t $t_{k}$ : ar side of it; otherwise, this, if foul, may bo mistaken for an ulcer. 'This orifice may be readily distinguished from an ulcer by observing that it is on the continuation of the common skin, while the glanderous ulcers are on the membrane of the nose.

When these ulcers begin to be visible, the general condition of the animu? sn... shows signs of change; his coat seems dend and staring, the huir coning of: easily ; his appetite is impaired; he loses flesh ; his belly contracts: et : $:$ nis nore and more debilitated there is more or less cough; the dischi"s; inr reases in quantity, and its increased poisonous chiracter eruses it innove the hair where it flows, while it seems tinged with $b 1,1,: ?: \ldots$. thensive to the smell.

In the third stage the ininve become larger and more numerous; and upon placing the ear to the horse's chest, a grating, choking noise will be heard at every aet of breathing. The nir passages being obstructed, every breath is drawn with difficulty. The skin of the forehead will he fonmd somewhat thickened, swelled, and peculiarly tender; the membrane lining the frontal openings of the nose will be not only uleerited but evidently inflamed ; the discharges are increased and become more sticky and of dirker color, though still soniewhat flecked with blood. The absorbents become more and more involved; it seems now that general nleeration has set in : and the additional symptoms are henceforth those of farey.

To prevent its being mistaken in its earlier stages for strangles, which is sometimes done, the following directions will suffice:

Strnngles is peculiar to young horses, and at the outset resembles cold with some fever and sore throat, accompanied generally by distressing cough and some wheezing. The enlargement which sometimes appears beneath the jaw in strangles is not a single small gland, but a swelling of the whole substance between the jaws, growing harder toward the center, and at length, if the disease runs on, breaking. In strangles the membranes of the nose will be very red, and the discharge from the nostrils profuse and mattery almost from the first. When the tumor has burst, the fever will abate and the horse will speedily get well. 
To distinguish it from catarrh, for which also it is sometimes mistaken, observe that fever, loss of appetite, coughing, and sore throat all accompany catarrh, wherens these symptoms are rarely if ever found together in glanders. In catnrrh, the horse quids his food, (drops it from his mouth partially chewed), and gulps his water. The discharge from the nose is profuse and sometimes mattery; the glands under the jaw, if swollen, are movable, whilo there is a thickening around them and they are hot and tender.

What to do.-The first thing to do, and in the first stage, will naturally sugrest itself to any one who has taken the pains to inform himself of the dreadful nature of the disease. Its contagious charaeter renders it dangerous, as has been said, not only to all of the horse kind but to man; and no time should be lost in removing a glandered animal from the possibility of communicating the disorder to another. If stibled, there should be no comnection whatever between his stall and those of other animals, as the discharge from the nostril, (in which lies the (amger), may be communieated through any opening sufficient to allow hores to bite or nibble at each other. If placed to pasture, it slould be kuown that no other horse is at all likely either to be turned in with him or to approach the inclosure. And this removil or separation should take place whenever it is observed that there is that constant discharge from one nostril whieh has been deseribed, even though it may seem but watery and natural, and the horse be in the very best apparent condition. Remember that a glandered condition may long exist, and minute ulcers, in the hidden recesses of the nose, discharge a sort of limpid or clear thid, without any of the active and violent symptoms being manifest; hut that all this time the horse may be able to communicate the disease to others; and that these may die of it while he is yet in reasonably fair eondition.

It can hardly eseape the intelligent horse owner that every known ciluse of the disense should, if possible, be promptly removed. Close, d:mup, dark stables, reeking with exhalations distilled from mingled dung, urine, and rain water, ought at any rate to begin to receive a little attention after the poor occupant has eanght what is more than likely to prove his death; if he is jaded and exhausted by labor, no hope of cure an be entertined unless he is promptly released from his toils and put upon moderate and health-giving exercise only, with sueh generous diet as will restore the wasted tissues; if, on the confrary, he is pampered and stimulated and grown unwholesomely plethoric for want of labor proportioned to his good keeping, his food should be gradually ehanged, and a regular course of moderately ircreasing exercise be instituted and 
persevered in till that point is discovered at which such exercise is recuperative rather thun exhaustive, and then unintained.

It muy be well, before proceeding farther, to cuution the reader against the advice of quacks, and point out what not to do. 'This may be summed up in the one single injunction, do nothing conel. All such printices as slitting the nose, seraping the cartiluge, searing the glands, firing the frontal and nasal bones, and injecting mustard, enpsicum, vitriol, and corrosive sublimate up the nostrils, are but the hurtful devices of ignor. ance combined with brutality.

If the disease is in its first stage when the horse is taken in hand for the purpose of employing remedial agencies, place him in a good, dry and airy stable, if in Summer, or in an open pasture where most of his food may be obtained by himself, observing the preenutions already lail down. If in Winter, he should still havo the diy stable, not too close, and supplied with elean litter, and eare should be taken to guard him against severe cold and exposure to any sudden change. The matter of food may be regulated by this: it must be nutritious without heing inflammatory ; and the condition of the animal as to previous treatment and present condition of flesh must regulate the quantity, as also to some extent the quality. Then prepare and administer the following medicine:

$$
\text { No. } 30 .
$$

1 Draclum powstered sulphate of camplior,

4 Fiuld drachnss Fowler"s solution of ursente.

Mix with linseed meal and syrup to form a ball, and give one of like quantity each day for three days; then onit a diy; then give the balls for three days again, and so ou till a ehange for the better is perceptible or its failure is minifest. Meamwhile, swab out the nose every day with a solution of pyroligenous acid-nsing warm water, (as warm as the horse can well bear), and putting in sufticient of the acid at first to make the solution of medium strength. It should be a little increased from lay to day; but eare must be taken not to make it too strong, als riolint acid injections or swabbing solutions are calculated to do harm rither than good. A good mop for this purpose may be made by attaching soft l'igs, (old cotton eloth is best), to a light stick, two feet in length-io arranging the cloth as to have it project beyond the end of the stick to be inserted, to prevent any roughness that might abride or serateh the nembrime, and fastening very securely, to prevent its slipping off.

If this treatment is found not to be efficacious, or if the disease has already developed into the second stage-the discharge more mueous, sticky, and stringy, with glands swollen and the menibrane of the nose of a dark purple or leaden color-adopt the following treatment, and carry it out energetically and persistently :
Take $\mathrm{f}$ ing as th very strol Put ellou bear), :ane mop as ju into at pil must he $n$ will produ and overen of the glan ditys, and the dischar

So for tl and atre ats earried out disetse hats confidently agencies w dently decl quickest and the possibili poisonous c England-si -and it is and man res stid, until I suffering wit rificed. It , to be spatre who would not alparen prisoin.

A horse a man who han a loathsome ordinary cir possible. I prescrilied fo

The reade been instind having taken 
Tinke from the neck vein from three to six quarts of blood, aceording us the horse muy appear feeble or plethoric. Muke "gallon of very strong decoction or ten of tobaceo lenves, which kecp rendy for use. I'ut enough of this into warm water, (ns warm us the horse can well bear), and swab out his nostrils with it, as high up as possible, using mop as just directed. Then put a gill of this sume strong tobaceo ten into a junt of warm water, and drench him with the solution. There must be no uneasiness on account of the dreadful sickness which this will produce. The tohace is necessury thoroughly to relux the system and overcome fixed or chronic tendeneies, and to counternct the influence of the glanderous poison. Swab out the nose every day for eight or ten days, and drench every third day for from two to four weeks, or until the dischnrge has ceased and the ulcers aro perceptibly healing.

So for the first two stages. If all theso directions, (those as to food and care as woll as for the administering of medicines), are faithfully carried out, a reasonable hope of success may bo entertuined. If the disease hats passed into the third stage, however, no treatment rum be confidently recommended. So doubtful is it as to whether any remedial agencies will arail, that most veterinarians in the United States contidently declare that the best thing to do is to kill the sufferer in the quiekest and most humane way, and bury him deep in the gromed, beyond the possibility of his eontaminating the atmosphere with his decaying and poisonoms carcuss. This is made a matter of legislative enactment in England-screre penalties attuching to the kecping of glandered horses -and it is contended by some that the general safety of boh animals and man require like legal enactments in this eomtry; but, as we have said, until he has passed into the third state, or where he secms to be suffering with both glanders and farey, a good horse ought not to be sacrified. It cimnot be toc strongly urged, however, that no effort ought to be spared to prevent the spread of the contagion; and the man who would expose a horse for sale, known to him to be glandered, but not apparent to a casual observer, ought to be confined in the State prison.

A horse affected with this disease, in any stage, is dangerous to the man who handles him; but he is doubly so, perhaps, when he has heeome a loathsome olject in limbs and body as well ns in head; and under ordinary eireumstances it is doubtless best to destroy him as quickly as possible. In case treatment is determined upon, nothing better thun that prescribed for the second stage can be recommended.

The reader's attention ought to be ealled to this fact: that there have been instances of a spontaneous cure of glanders-that is, of cures having taken place without the agency of remedial means used by man ; 
but all such cuses may have been apparent rather than real-a mere suspension of the active powers of the poison-and they ought to be looked upon with suspicion. These may be resumed at some future time and with fatul result.

It remnins now but to suggest some preenutionary mensures to prevent contagion, in addition to those which huve already been given. If a stable is known to lave been used by a glnndered horse, no other animal should be allowed to oceupy it until the trough, the rnek, and the walls have been thoroughly scraped and scoured with strong soap and warni water. Then tuke one pint of chloride of lime and dissolve it in two gal. lons of water, with which thoroughly saturate every part that the horse's nose may have touehed. Next, white-wash the walls inside. Then burn bridles, hulters, buckets out of which he has drunk-whatever may have been about his head-and if any blanketing has been used have it carefully cleansed by washing, or burn it up.

\section{Farcy.}

Causes.-In treating of glanders and farcy there is a great diversity of opinion as to the relations in which they stand to each other-which is the antecedent, which the consequent; but the most sensible view of the matter, and the one taken by the ablest veterinarians, is this: that the two are but different manifestions of the same disease, and that they might with propriety bo so trented. Regarding them separately it is diffieult to say which is the more acute form, which the more chronic, as it is now generally conceded that a horse aftlicted with what may secu at first a well-developed case of glanders may be presently laboring under confirmed farcy - the last state apparently worse than the first; again, a ease of farcy may assume the type to which the name glanders is applied, and in this ease also there seems to be a development of the first into a more hopeless disorder.

This would be a matter, however, of no special consequence to the intelligent horse owner were it not that the confused notions of. men concerning the two affections might chance to bring him face to face with this difficulty: that, unable to eliminate the truth from the tangled statements of some who, entertaining diverse views, may take it upou themselves to advise, he may find himself halting between two opinions when it is of vital consequence that he should be doing something. Let him be assured that it is wholly unnecessary to trouble himself with nice questions as to the priority of either disease or the real difference between them ; the one important point for him is to be able to detect in the incipiency of an attack of either that one of them is present. 
Speaking now of the furey us a distinct disense, it is to be regarded us a general poisoned condition of the horse-the poison huving its immediate origin in un ulcernted condition of the lymphutic glunds; and its remote origin in whatever tends to disorder these lymphaties. The remote enuses aro often found in constitutionnl or inherited tendencies, but more ficquently, no doubt, in neglect und abuse- some of the forms which these take on being overwork and under-feeding; luck of the curry-eomb and brush; exposure to the foul atmospliere of dark, damp stables, und their necumulations of filth.

The glands so affeeted are more numerous along the jaws, neck, and flanks th:u elsewhere near the skin. Some speeies of poison is taken into the system of the animal, which manifests itself by an enlargement of some of these glinds into the hurd, rounded lumps, called farcy-buls, or buttous, which presently secrete and discharge dangerous infectious matter. The alssorbents whose office it is to remove useless particles from the body, take up from beneath the skin some of this virus; they inflame with it and swell; and by their connection with the veins give the latter a corded, swollen appearance. The poison, of course, finally reaches the veins and is mingled with the blood; by the blood it is conveyed to every part of the system. Acting upon the valves of the reins-those little membramous saes which assist in giving the blood a uniform tendency towards the heart - the poison ereates new knots or bnttons, and thus they increase until many portions of the skin are covered with putrid ulcers

The first existence of an uleerous condition may not be upon any visible portion of the body. Minute poisonous ulcerations may arise in the recesses of the nose, and discharge so slightly as to escapo observation until the general system is thoroughly inoeulated with the virus.

It is, however, extremely eapricious in its manifestations ; probably owing more to the peculiarities of different animals than to any difference as to either immediate or remote causes of the disense itself. It oceasionally takes on a lingering form, and will continue for months and years; again it will ruu its course and kill the horse in an ineredibly short time.

It is extremely contagious in all its stages, and is communicable not only to other brutes, but to man.

How to know it.-It is difficult to give in few words such directions as enable the unprofessional and inexperienced reader readily to detect this disease in its incipieney, and to distinguish, in its somewhat advanced state, between it and some other diseases which have, oceasionally similar manifestations. It often perplexes by the different forms it assumes; but close attention to the following particulars and a wide-awake interest, 
that lends one to observe chmuges mud peculiar conditions will probubly suthice :

In some eases the horse will droop for mnny dnys before the ajpeurance of either buds or corded veins; the nppetite is impaired; the coat is sturing, or rough and unplensint to the sight; his mouth is hot; his thirst great and ditheult to quench ; the urine is highly eolored; the lair comes off easily; nud he evinces then the symptoms of a genemally derunged condition.

Sometimes the horse will "upenr to be perfectly well nt night, and $n$ morning one leg, usunlly the hind leg, will be fenfully swollen, ; with fever, and almost without the power of moving.

At other times the head will swell, the muzale, particularly, will be enlarged, and an offensive dischnrge proceed from the nose.

Again, this tendeney to the swelling of the leg is necompanied by crucks at tho heels, lending the inexporienced to mistake it for ordinary "swelled legs", or for "grense."

When taken by inoculation, (the poison hnving been received froul inother muimil or from trough, stable, or curry-comb), it is npt to mumifest itself in its earliest stages by shivering, followed by hent of body, a frequent and hard pulse, dullness, aecelerited breathing, and rapid elevation of temperature. These attucks miny speedily prove fatal.

In all these eases, the poison has been working, but is not yet outwardly manifest. Generally the first stuge of unmistaknble lo manifestation is a swelling of the lymphaties, a development of "farey-bud." A single bud will sometimes appear near the pistu. joint and run up in an uneven knotty form. They usually appear, however, along the sides of the neck or inside the legs, and are rounded, with an elevated edge, and a pale surface. 'These presently burst and discharge a watery fluid for some time, when a chunge takes place and the discharges become more mattery and offensive, and are mixed with blood. They frequently inerease in number until the neck, shoulders, and legs are almost entirely covered with them-sometimes almost the whole body becomes a putrid loathsome mass. In this last ense there are no longer any buds or knots, as the veins have beeome so generally injured as not to show special prominenees at the valvular points.

Ocensionally it will be found that the buds will not ulecrate, but become hard and difficult to remove. This indicates that the progress of the disense is suspended; but the poison is in the system, and if steps are not taken at once to eradieate the seeds of the malady, it will in time break out and destroy the horse.

When it rises along the spine, as it occasionally does, it is to bo considered malignant and very dangerous, particularly to those horses 
that are fut and full-blooded-the disense in this case heing most probubly the rescilt of infection.

To cimble one to distinguish it from those disonses for which it is sonnetimes mistuke'n, the following directions, if closely observed, will bo -ullicicient :

It differs from surfeit in this: thit the buds ure genernlly highor thun the surfeit tumors, more knotty, not so brond, and are found principally on the inside of the limb and not on the outside.

The sudden swellings of the legs, hend, or cliest are charnoterized by lisit and tenderness that do not necompany other enlurgements; and tho furcy may be distinguished from grease or swelled legs by this: that in arense there is usually n peculiar tightness, glossiness, und reduess of the skin, with scurtiness, dischurging crucks, and a singuhr spasmodie cutching up of the log. In furcy the swelling is more sudden-tho leg that is ipparently somnd at night is found in the morning swollen to an ('normous sime. It is owing to a simultmeous inflammation of all the absorbents of the limb ; but insteal of the redness and glossiness of surfeit there will be burning heat without outward manifestution, and the l'a will be jeculiarly tender, while the body will be generally feverish.

It uay be known from that locil dropsy of the cellular membrane producing in enlargement benenth the thorax called watcr-farcy, by simply observing thit in water-farcy there is general weakness unacempanied by intlammation.

What to do.-The treatment must of course be directed primarily to the removial of the blood poison and to the re loring of the assimilative jowers of the digrestive and circulating organs. It must be both general and lowal ; as the vitul functions are to be restored to their normal eondition at the sine time as the outward manifestations of the poison are removed. The buds must be dispersed and the ulcers healed by netive rxternal applications, since the powerful internal remedies must be more or less inoperitive while these reecptaeles of poisonous matter furnish a constant supply to the absorbents, to be earried by the various organs of circulation to all parts of the body.

The first and most necessary thing to do is to exercise a wise discrimination as to the stage of the disease. If found to be in its incipiencyfew buds laving appeared, and being slow to spread; no foul discharge fron the nose; no sudden swellings and violent heat-the following treatment may be adopted with every hope of success :

Pay particular attention to feeding, and to keeping the stable, (if noeessary to have the animal confined), clean, dry, und comfortable. The food should be easy of digestion, but nourishing, and especially of such 
a character as to keep tho bowels regular. Bran, oats, long forage, (green if possible), are good; and an occasional mush of boiled carrots or turnips mixed with bran or shorts, to which a table-spoonful of salt is addea, will be found beneficial. He should hnve moderate daily exercise; and as much good pure water as he will take should be given him. If the food given does not have the effect of keeping the bowels open, give an occasional mild purgative compounded as follows:

No. 31. Drachms finely powdered aloes,
1 Druchm ground ginger.

Stir these ingredients thoroughly together; then use sufficient soft soap to make a paste that can be rolled into a ball. Wrap this in thin puper, and give by elevating his head and thrusting it into his throat.

Give the following tonie, to stimulate the digestive and secretive functions :

No. 32. 6 Oz. powdered sulphate of iron,
6 Oz. rosin,
3 Oz. gentian,
3 Oz. ground ginger.

Mix thoroughly, divide into twelve powders, and give one night and molning. When these powders are exhausted, make up the sane mixture, with the exception of the rosin, which, by too long continuance is apt to affect the kidneys unduly, and give as before, night and morning.

To remove the buttons and ulcer's, take a large stick or pencil of lunar saustic or of caustic potash, and with it bum out the central portion of each bud, and cauterizo each ulcer. When convenient to obtain what is called a farrier's "budding iron," the work maty be more expeditiously done by heating the iron to redness, and, after rubbing it on something to elear off the scales, inserting the point into every bud and ulcerremembering that it must be done moderately, and not so as to destroy the tissues. When these burnt places begin to slough out, and look pale, foul, and spongy, with thin matter, wash them frequently with a solution of 1 drachm of corrosive sublimate in $1 \mathrm{oz}$. rectified spirits. When the wounds begin to look red, and the bottoin of them is even and firm, while they discharge a thick white or yellow matter, use some simple ointment.

If the disease is plainly in an ndvanced stage-the buttons and ulcers numerous and widely spread over the body; the thirst great and hard to satisfy ; signs of glanderous ulcers on the mucous membrane of the nose; the hair, where the sores have not invaded the skin, staring and sasy to 
come off ; the general ippearance filthy and loathsome-the following severe treatment should be adopted and perseveringly carried out:

In the first place, observe all the precautions as to diet and the state of the bowels previously recommended, heing careful to guard against cxtensive purging, for this will tend rather to reduce the discaso to a lower stage, and to retard recovery.

Bleed at once, taking from two to four quarts of blood from the neck rein, according as the body is moro or less inflamed.

Take a gill of very strong solution of tobaceo and pour it into a pint of warm water, and adrench with it. Repeat this dose every third day until a chimge for the better his evidently taken place. If the feverish state continues he should be bled again, taking a like quantity as at first, within a week or ten days. The practice of bleeding, as insisted upon ly some veterinarians, cannot be recommended; but there are eases in which it may be employed with the greatest advantage. In farcy, it cunnot be suid to removo the poison to any great extent, though it does in some mensure have this effect; but the vitiated endition of the fluid seems to render it turgid and slow, and to produce an unnatural distension of the veins and capillaries, which bleeding partially relievespossibly by both diminising the quantity a little and by a reaction which follows the shoek given to the organs of eireulation by the act of bloodletting.

The tobaceo drench is a powerful medicine in counteracting the poison in the system ; and while the dose recommended will make the horse very sick, from its well-known nauseating properties, its effects are not to be feared.

On those days which intervene between the doses of tobaceo tea, the tonic powder, No. 32, may be given as directed for tine milder stage of farcy, omitting the rosin.

When the poison has been long at work without betraying its presence, till all at once the horse becomes lame, his legs swell, violent general leat sets in, large and vicious looking buds appaar suddenly and presently lreak, while a stinking discharge takes place from the nose-corded veins and buttons appearing in some instances along the spine- the ease may well be looked upon as hopeless; and if there me other animals that are in dunger of taking the affection from him, it is doubtless best, as is generally recommended by English veterinarians, for even much milder forms, to kill the horse and bury him beyond the reach of all danger to others. In this stage of the disease he is dangerous to man, and no one ought to be requirea to take the risk of handling him.

Lastly, every precaution should be taken to gund against the sprenci of the contagion. Whon a horse is known to be affected with farey, 11 " 
time should be lost in cleansing the stable where he has been confinedwashing the trough, rack and walls thoroughly, - saturating them after that with a strong solution of chloride of lime, (one pint of chloride to two gallons of water), and then white-washing the walls inside. Curry. comb, blanket-whatever may have the poison adhering to it-had better be burned.

\section{Distemper}

Causes. - This is an epidemic disease, occurring in young horses, generally, and when it once breaks out all the animals in the stable are likely to be infected with it, unless they have already had it. Colts and young horses will take it from older ones more easily than older ones from the young.

If it is not actually generated by filth and uncleanness in the stables, the disease is certainly aggravated by causes producing miasma and bad air in the stables. Therefore cleanliness is essential not only as a means of preventing the disease, but in rendering it of a mild type when it breaks out

Horses will contract the disease from others when at a considerable distance. It is supposed to be communicuted both by actual contact and also from germs proceeding from the breath. Hence when once it breaks ont, at the first symptons, isolate the sick animal or animals, fumigate the stable thoroughly and daily.

To do this fill the stable with tobacco smoke, both the stable from whence the sick horses have been taken, and the place where they are confined during treatment. Let the smoke be so thick as to become quite inconvenient. Make all the animals inhale as much as possible. Wash every part of the stable, and especially the feeding places and hay racks, with a strong decoction of tobacco stems, using for the purpose cheap, rank tobacco. Keep powdered tobaceo leaves in tho mangers of all the horses. This beinc early attended to its spread may be generally arrested.

How to know it.-The disease has three stages. In the early stage of the disease there is a dry, hacking cough, and there will be noticed a discharge from the nose, first of a thin, watery fluid succeeded by a thicker, purulent discharge of a whitish color.

The next stage of the disense shows itsclf in a swelling of the throat. The salivary glands, which at first were inflamed, are now closed, and pus is being formed. At length an abscess is formed.

The third stage is the suppurative stinge, in which the abscess breaks; sometimes to mend, bad cases it may con

From fir

The appeti fever inere lic close, lo the whole:

What to o ever, shoul veteriuary s dicutions of taken from in a thoroug light, but it oats; out-m following:

No.

Mix, and down the th throat.

Let all dri there is consic tartar in the to promote cir

No. 34.

To be mixed ounces of sulp two or three ti will bear it. they will often then every me then be dangen the contents of 
sometimes there are two. From this time on, the animal is in a fair way to mend, and every means should be taken to promote the discharge. In bad cases the suppuration may continue for weeks, and in extreme cases it mily continue for months.

From first to last there is a fever. The pulse is quickened and hard. The appetite fails, both from the fever and inability to swallow. As the fever increases the eyes become dull and glassy : the hair is dry, will not lie close, looks dead; and the animal stands with its head drooped, and the whole appearance is stupid.

What to do.-In some cases, bleeding will be indicated. This, howcver, should not be allowed except under the advice of a competent veterinary surgeon or physician. If the animal is fat, or if there are indications of blood poisoning, from a quart to three pints of blood may be taken from the neck vein. The animal must be warmly clothed and kept in a thoroughly well ventilated but comfortable stable. Let the food be light, but nourishing. Mashes made of oat-meal and bran ; also boiled oats; oat-meal gruel, and hay-tea should be given for drink. Give the following :

No.33.
1 table-spoonful pulverized gum myrrh,
1 table-spoonful gun powder,
1 table-spoonful lard,
1 table-spoonful soft-soap,
2 table-spoonfuls tar.

Mix, and put a spoonful of this mixture on a long, narrow paddle down the throat twice a day, so it will lodge about the glands of the throat.

Let all drink and food have the chill taken off before giving it. If there is considerable fever and the tongue is coated, give a little crean of tartar in the drink. If the limbs are cold, bandage them and hand rub to promote circulation. Give once a day in the food the foliowing :

$$
\begin{aligned}
& \text { No. 34. } 2 \text { or three ounces flower of sulphur, } \\
& 1 \text { ounce resin. }
\end{aligned}
$$

To be mixed in the food if it will eat, or in the drink. Give also threc ounces of sulphur per day, if the animal will take it. Wash the neck two or three times a day with a decoction of tobacco as hot as the auinal will bear it. If these remedies are taken in time and faithfully applied, they will often prevent any tumor from forming. If the tumor forms, then every means must be employed to cause it to suppurate. It will then be dangerous to scatter it. If the bowels aro obstructed, remove the contents of the rectum by the following injection : 
No. 35.

\author{
4 Drachms powdered aloes. \\ 1 Drachm common sait, \\ 2 Drachms hot water. \\ Mrix, and inject when blood-warm.
}

Use every possible means to promote the formation of pus and its dis. charge. Common distemper and strangles are similar in sume of their symptcms, and one may run in the other. Stimulate the swelling with the following:

No. 36.

Two parts splrits of turpentine,

One part laudanum,

One part spirits of camphor.

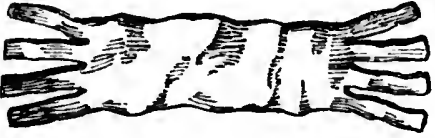

EIGHT-TAILED BANDAGE.
Apply this three times a day with a brush until soreness is produced. Af. ter each application keep the parts warm with folds of flannel, kept in place with an eight-tailed bandage, a piece of flannel having three slits cut in the ends for tying, and long enough to go round the throat and tie over the top of the head.

If this does not cause the tumor to form, prepare a poultice as follows:

No. 37.

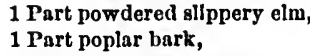

1 Part ground flax seed.

Moisten with vinegar and water equal parts, quilt between two folds of cloth and apply to as large a surface as possible. When the tumor las formed pus and is nearly ripe, which may be known by a soft place where it is working its way to the surface, open it with a knife with a roundpointed blade, and if necessary increase the opening with a button-pointed bistoury, to allow free exit of matter. It will give almost immediate relief. Then apply to the swollen glands night and morning, the following:

No. 38.

4 Ounces spirits of camphor,

3 Ounces pyroilgneous acid,

1 Pint neat's foot oll.

Mix. If the acid is not to ie easily obtained use strong cider vinegar. Prepare the following powders :

No. 89.

2 Ounces powdered gentian,

1 Ounce powdered golden seal,

1 Ounee powdered pieurisy root.

1 Pound powdered liquorico root.

Mix, and divide into six powders, to be given in the food night and morning.
Causes.

is one of sometimes is caused : nicating $\mathbf{b}$ the semi-li chronic gle is in one 0 facial sinu. which may chcapest $w$

\section{How to $k$}

Sometimes a thick yell rolor of tl tinged with and in gland cious, elasti enlargement of the jaw, for the pron by which a treatment.

\section{How to $\mathrm{Cu}$} if found, ren by bruises. be light, but nasal passage No. 4

When cool daily.

Prepare the

No. 41 


\section{Nasal Gleet.}

Causes.-This afflietion sometimes follows distemper and strangles and is one of the attendants on glunders, sometimes running into it. It is sometimes caused by a chronic affection of the schneiderian surfaces. It is caused sometimes by the relaxing and enlarging of the ducts communicating between the cavities of the mouth and nose by disease, allowing the semi-liquid food and its juices to pass into the nostrils. This is true chronic gleet, and the discharge is tinged with what the animal eats. It is in one of its forms a suppuration of the mucus menbrane lining in the facial sinuses, producing distortion and a terribly offensive discharge, which may have been produced by a blow on the face. In bad cases the cheapest way is to end the animal's misery by killing.

How to know it.-Discharge is not always present, neither is it uniform. Sometimes during fair weather it will be discontinued. The discharge is a thick yellow mucus tinged with green, if the food be grass, or with the color of the food. If it becomes purulent, that is pus, matter, and tinged with hlood, it may end in ulceration of the cartilages of the nose, and in glanders. If the discharge is confined to the left nostril, is tenacious, elastic, accumulates around the edges of the nose, if there is enlargenent of the lymphatic submaxillary gland, under and on the side of the jaw, it is cheaper to kill the horse, or else call in a surgeon, since for the proper treatment of the disfase the trephine should be used, by whieh a cireular piece of the bone may be taken out to facilitate treatment.

How to Cure.--In mild cases look for decayed molar (grinding) teeth; if found, remove them. Look for swelling of the frontal bone, produced by bruises. Put the horse where he may be comfortable, let his diet be light, but soft ; fresh grass in Summer, with good food. Inject the nasal passages thoroughly with the following: No. 40.1 Ounce bayberry bark,
1 l'int boiling water.

When cool strain through a close linen or white flannel cloth, and inject Whily,

Prepare the following:

No. 41.

1 Part Grains of Paradise,

1 Part white mustard seed,

1 Part powdered suiphur,

1 P'art powdered charconl.

Mix, and give one ounce daily in the food. 
Give occasionally in gruel the following:

No. 42.

3. Ounce balsam copalba,

2 Druchms sweet spirits of niter.

This with warm clothing and nutritious food will suffice for mild cases. Where the trephine is not to be used, treatment must be persisted in until the animal is cured.

\section{INasal Polypus.}

Polypus may form upon any of the cavities of the body which eommuniente with the air, being peculiar to the mucous menbrane. These grown to such size as seriously to impair breathing, are accompanied sometimes by discharge of mucus which is pure. That is, it is thrown out as soon as formed, and therefore it is not fetid.

What to do.-If the polypus which is gencrully pear-shaped and at tached to the membrane of the nose, by a small neck, can be made visible by causing the horse to cough, it may be removed by a ligature or a pair of polypus seissors by any physieian, if no veterinary surgeon is at hand.

When the polypus is entirely concealed from view, tracheotomy may have to be employed before an examination can be made, since the polypus may have gone so far as to oppress the breathing. Thus in all eases of polypus, unless it be so low that a ligature can be employed to strangulate it at the neck, it is altogether better to call in the aid of a veterinary surgeon. 


\section{CHAPTER IV.}

DROPSICAL AFFECTIONS.

4. DROPSY OF THE HEART. - II. DROPJY OP THE BRAIN. - - IIT. DROPSY OF THE CHEST. - IV. DEOPSY OF THE SKIN OF THE chest. — V. DROPSY OF THE SCROTUM.—VI. DROPSY OF THE ABDOMEN.

\section{Dropsy of the Heart:}

Causes.-The pericardium or membranous eovering of the heart is subject to inflammation; by this inflanmation and consequent obstructed circulation in the minute vessels that supply it an effusion tukes place, and either thickens the walls of the pericardium itsolf, and thus contracts or compresses the heart, or it is deposited in the eavity of the pericardium in quantities varying from a pint to a gallon. This diseased condition is generally found in connection with dropsy of the chest or abdomen.

How to know it.-In the early stages of the disease there is a quickened and irregular respiration, with a bounding netion of the heart. As the fluid increases the action of this organ becomes feeble and fluttering. There is a peculiar expression of anxiety and aiarm on tho eountenance of the animal. If he does not die of the disease before the pericardium is filled, violent palpitations and throbbings characterize the advanced stage. The breathing becomes difficult, and when the head is raised there is a tendency to faint.

What to do.-If it is ohserved while there is yet a painful state of the pericardium by reason of influmınation-profuse effusion not having taken place - the first thing is to reduce the inflammation and allay the pain, and thus forestall the further accumulation of the fluid. For this lurpose relieve constipntion, which is usually found as an aceompaniment, by moderate doses of salts, or of oil. Then give the following draught: 
No. 43.

1 Oz. nitrato of potash,

15 Drops tincturo of aconite,

1 Pint of wuler.

The animal must be kept comfortuble, according to the season, and have a plentiful supply of fresh air and cold water.

If there are no indieations of relief within four hours, give the following draught :

No. 44.

\author{
4 Oz. solution of nectale of ammonla, \\ 10 Drops tineture of uconite, \\ $120 z$ of wuter.
}

Repeat this after eight hours, and then leave off the aconite, lut eontinue to give, at intervals, the neetate of ammonia in water.

If the disease has reached an advanced stage, and the cavity of the perienrdiun is largely filled with water, it is scarcely to be hoped that the animal may be saved; but even in that case the course here prescribed should be adopted, unless there is some more general disorder under such treatment as will render it unnecessary or objectionable.

\section{Dropsy of the Brain.}

Causes.-The remote cause of this disease (known also as hydrocephalus), is some constitutional disorder of the brain, or of its membranous covering-chiefly, as is believed, a scrofulous tendency. The immediate causes, or the excitunts to its development, are various, as custration, foot puncture, staggers, acute diseases of the stomnch, defective nutrition, etc.

How to know it.-At first an unnatural sleepiness will appear, with apparent unconsciousness and a tendency to reel when moving on foot. The pupil of the eye is perceptibly dilated; the animal breathes in a hard and grunting way; he tosses his head about and throws it upward or backward, us though in much pain. When down, with neek lying prone, as is often the ense, he will sometimes raise his head, then dropp it spasmodically, beating it upon the ground. If unrelieved, convulsions finally set in, and death ensues.

What to do.-If the head is hot with fever, denoting an acute attack, sponge frequently with cold water, and see that the bowels are kept moderately open. If there is decided constipation, as is sometimes the ease, use an injection of soap-suds at intervals, until the bowels are moved. Then give the following in doses of 2 ounces, morning and evening:

$$
\text { No. } 45 .
$$

$40 z$. fluid extract of buchu, $2 \mathrm{Oz}$. iodide of potassium, $6 \mathrm{Oz}$. water.
Contin until all the unnat

Causes. sequel of surfaces 0 adequito filled, the

How to legs which to assume tite returns and his ma first appare muscles qu with the ls stretched or brought int small, irregr again. His dies, someti

The disea horse has st chest, near $t$ will detect $n$ up tho shoul at the point made on the splashing nd longer any $d$

What to of that the vari fluid. For $t$ No. 4

Mix the po tincture, and 
Continue this, keeping the horse from lubor and ns quiet us possible; until all symptoms of feverishness disappear from about the hend, and the unnatural torpor no longer manifests itself.

\section{Dropsy of the Chest.}

Causes.-This disease, (called also hydrothorax), is frequently the sequel of pleurisy, and is the result of the inflamed condition of the large surfaces of the covering of the heart and lungs. The ubsorbents are inadequate to the taking up of the abundant effusion, so that the ehest is filled, the lungs are pressed upon and death by suffocation follows.

How to know it.-The impaired appetite and ehilliness of the car's and legs which eharacterize the last stage of pleurisy, elange when it is about to assume a dropsieal form, and the horso becomes moro lively, his appetite returns, his legs and ears become warm, the eyes look more cheerful, and his manner is every way more encouraging. A fow hours after this first apparent improvement, however, the brenthing becomes libored, the museles quiver and twitch, and the nostrils flap. The animil stands with the legrs wido upart, hend low, or resting upon something, neck stretched out, eyes staring, and the motion of the flunks increased, even brought into foreible hearing action. The pulse is more frequent, but small, irregular and fluttering; and the nose, ears and legs become cold again. His weakness rapidly increases, and if not relieved the animal dies, sometimes within a week, though he may linger much longer.

The disease may be detected in its early stage, or immediately after the horse has shown signs of relief from pleurisy, by placing the ear to the chest, near the breast bone. If the dropsical effusion has set in, the ear will detect no sound, nor will any bo detected until tho ear is placed high up the shoulder or flank, past the middle of the ribs. Holding it here, at the point where the breathing is first audible, and directing a slap to be made on the other side with the open hand, the examiner will hear a dull, splashing noise as though of disturbed water: and there need be no longer any doubt as to the nuture of the ease.

What to do.-In the first place adopt the use of diureties and lixatives, that the various organs mny be assisted in carrying off the accumulated fuid. For the first day give every six or eight lours, the following :

No. 46.

4 Draebms powierel nilrute of potash,

1 Fluid ounce tinclure of cardianoms,

$10 \mathrm{Oz}$. water.

Mix the potash and water, und when a clear solution is formed add the tincture, and give from the bottle twice or thrice in the tiventy-four hours. 
On the second day, two or three times a day give:

No. 47.

2 Fiuid ounces solution of acetate of ammonia, 1 Oz. nitrous ether.

Mix with water and administer from the bottle.

If this treatment does not seem to be giving relief at the end of three to fivo days, draw off the liquid by tapping the chest. It is a simple nud safe operation and will give relief unless trentment has been too long delayed, so that there is an accumulation of substances that will obstruct the mouth of the canula and prevent the flow of the liquid. The instrument to be used, the trocar, armed with a stylet, must not be large, as drawing off the water too suddenly would prove fatal. The smallest of those macle for human practice is large enough, but it must be of greater length. Having the instrument, and that in good condition, select a place behind and about on a level with the elbow, and tuke a small portion of skin, between the eighth and ninth ribs, which must be pulled forward. Then make a narrow slit with a sharp knife upon the place which the skin originally covered. Still holding the skin gathered forward, insert the armed trocar into this opening and press it with such force as suffices to push it gradually onward until resistance ceases. It is then within the cavity of the thorax, and the stilet must be withdrawn, whereupon the water usually begins to flow out. Take all the water you can get if the horse will suffer so much to be withdrawn; but if at any time during the operation he shows signs of faintness, withdraw the trocar and lot the skin fly back. It is necessary always to have the skin drawn forward so that on returning it may cover the wound lest the air may enter the chest from the outside, which would prove quickly fatal. In an hour or two after the first attempt a second may be made but the trocar must he inserted in a new place, as the first wound might be irritated by an effort to re-insert the instrument.

There is sometimes apprehension lest this operation may injure an artery by appronching too near the posterior border of a rib, but this is groundless, as the artery is protected by the groove through which it travels.

If the trocar is properly inserted, and no water fiows, the case may he regarded as well nigh hopeless. A whalebone may be inserted to break away the pus or whatever substance may line the thorax, but this is not known to have ever resulted in any good.

If there is fluid on both sides, it should be drawn off on both sides at the same time, to prevent pressure upon the delicate divisions of the shest. The fluid is generally confined, however, to one side.

The operator should stay by the animal during the slow abstraction of the water and preve

After t patient a sume; all morning $f$

Causes.and it is a itself only likely to oc changing th

How to $k$ between the yielding to 1

What to o the first thin if the fluid: trocar; and and moderat

Diureties : good. It is nutritious fo regularly, al gentiun every

It must be case there is

,

Causes.-T men, and aris followed by e the generul all

How to Kno part, except $v$ 
the water, so that upon any sign of faintness he may withdraw the trocar and prevent denth through sudden collupse.

After the water is pretty thoroughly druwn off, be careful to give the patient as much nourishing and carefully prepared food as he will consume; and the following tonic ball should be administered night and worning for several times on alternate dnys:

No. 48.

1 Drachm fodile of iron,

* Orain strychnia,

* Drucbm sulpisale of zinc.

4 Druchens extract ne gentian.

\section{Dropey of the Skin of the Chest.}

Causes.-This is an effusion of fluid underneath the skin of the chest; and it is a sequel to various disenses-beginning generully to manifest itself only after the animal is reduced to a debilitated state. It is most likely to oceur in the Spring and in the Fall of the year, at the time of changing the coat.

How to Know it.-A swelling appears on the chest and somewhat between the forelegs; and its dropsienl character may be known by its yiclding to pressure of the fingers with a fluetunting feeling.

What to do.-If it is the accompaniment of any more general disorder the first thing, of course, is to remove that primary disense. Meanwhile if the fluid aecumulates in any considerable quantity, draw it off with the trocar ; and if there is not too mueh soreness, subject the part to regular and moderately vigorous frietion oecasionally for some days.

Diuretics are always good in these dropsical complaints. No. 45 is good. It is important that the bowels be kept regular, and that good nutritious food, as boiled onts or boiled barley, with wheat brun, be given regularly, and in sufficient quantity to nourish well. Give 4 drs. of gentian every other day for a week or two.

It must be remembered that these medieines are to be given only in case there is no treatment in progress for a more general disorder.

\section{v. Dropsy of the Sorotam.}

-

Causes.-This is usually found in connection with dropsy of the abdomen, and arises from either local injury and consequent inflammation, followed by effusion, or by sympathy from that eause which has produced the general abdominal trouble.

How to know it.-It is readily known by a chronie distension of the part, except when mistaken for scrotal hernia or rupture, from which it 
muy loe distinguished by its not pussing lonck with n sudden movement, when pressed with the lingers, hut with n stendy current and grindual diminution.

What to do.-If it is associnted with dropsy of the abdomen treat that first, und until it is relieved, without which being done it is unnecessary to attempt the cure of the more locul and dependent disorder. In any event, find out, if possible, and remove the primary cause. Next see to it thint the bowels of the patient are kept moderntely active; nud us in the ease of dropsy of the abdomen, give sufticient of diuretic No. 45, to act freely upon the kidneys.

If the fluid lins acemulated in any considerable quantity, so as to render the scrotmm painful by distension, draw it off with a fine urmed troear, or a hypodermic syringe, and support the parts with an elastic bandige.

\section{Dropsy of the Abdomen.}

Causes.-This is a collection of water in the nbdomen which is generally the result of chronic inflammation of the peritoneum, a tough, white membrane which lines the abdomen and embraces the bowels in its folds. When this inflammation has assumed a ehronic eondition, the peritoneum secretes a watery fluid, because of long obstructed eirculation, which fills the eavity, and unless nttended to will finully cause death.

Frequently it follows injuries of the abdominul walls, when the peritoneum has been subjected to violence, and is associnted with local inflammation of the muscular tissues, from which effusion is direeted inward.

Sometimes it arises from obstrueted eireulation eaused by diseases of the liver, lungs or heart, and again from n poor, watery stnto of the blood, superinduced by exhaustion or by seanty and immtritious food.

It is more frequently found in old than in young and vigorous amimils.

How to know it.-Generally, a low state of health preeedes the more unmistakible manifestations; there is thirst and loss of uppetite; the pulse is hard and small; the membrane of the nose is pale; the mouth is dry; the head droops; there is a condition of weakness and langun: and there are some signs of heart and liver disenses ; pressure" abdomen is so painful as to cause a groan. Sometimes the dropsy of the sheath, legs and breast, as well ns , bowels are apt to be constipated, but are sometimes: gular; the cont is loose and sturing.

When the water has begun to fill the cavity, the horse manif to a desire to lie down and res.in long in one position; there is a gradual enlargement of the abdomen, and as the fluid increases there is inereased diflienlty $\mathrm{i}$ is slow; b stances the tho skin at

The pre: tity, may l. one slap th

In mine: joregnant co feeling whi fluid motios

\section{What to} disenses of of treatmen but when it results from tho horse in and give hin

$$
\text { No. }
$$

Mix with suticient firn It is impor ug dinretic ?

$$
\text { No. } 5
$$

Melt the so ents while th with linseed IIp a somewh If at any ti hy means of jallt of the di. 
diflienlty in brenthing. In the chronic stikges of the d jease, the progress is slow; but the belly becomes more mod moro bue $y$; and in some instunces the hatr of the tuil comes nway casily or drops out, showing that the skin and cupillary glunds of that part of tho body mo affected.

The presence of water, when it hins collected in any considerable qunntity, may bo detected by plucing tho ear to the ubdomen and heving somo one ship the horse on the opposite side with the open palm.

In unures, this enlurgement of tho belly is sometimes mistaken for a pregnant condition; but it muy be readily distinguished by a fluctuating fecling which follows a pressure upon the purts with the fingers, it sort of fluid motion, as of water forcibly displaced.

What to do.-If it is known to proceed from local injuries, or from discesses of the vital orguns, it is sciucely necessury to adopt any course of trentment, unless, indeed, tho primury disense cun itself bo removed; but when it depends upon inflammation of the peritoneum, or when it results from bad or defieient food and unwholesomo surroundings, place the horse in a good, dry and well-rentilated stall, feed him generously, and give him the following tonic ball, night and morning :

$$
\begin{aligned}
& \text { No.49. } 1 \mathrm{Oz} \text {. powilered digitalis, } \\
& \text { 3: Uz. nuiphatu of iron. }
\end{aligned}
$$

Mix with mucilage and a spoonful of linseed meal to form a ball of qut'icient firmness for handling.

It is important that the kidueys should be kept aotive, and the following dinretic must be used for that purpose :

No. 50.

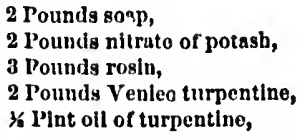

Melt the soap and rosin slowly together, and stir in the other ingredi-. ents while the former mixturo is eooling. Make it into 2-ounce bulls with linseed meal, and give ono at a time as often as necessary to keep up a somewhat copious nction of the kidneys.

If at any time the water nceumulates in a great quantity, draw it off ly means of a fine trocir, plunged into the most dependent or lowest purt of the distended abdomen. 
CHAPTER V.

DISEASZS OF THE THROAT, CHEST AND IUNGS.

1. CHRST-FOUNDER. — I1. BRONCIITI. - III. PNEUMONIA, OR TNFLAMMATION OF THE

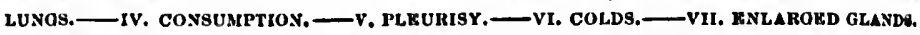
VIIt. BWELLED THROAT, OR LARYNGITIS. - IX. CIRONIC COUGH. - X. MaLIGNANT HPIDEMIC, - XI. DIPFICILTY OF BREATHING. — XII. BROKEN WLN, - BELLOWg, HEAVE8. - XIII. INELUKNZA. - XIV. BPASMODIO ACTION OF TIIH GLOTTIS AND EPIGLOTTIS.-XX. CROUP. - XVI. BLEEDING FROM TIE NOSE.—XVII. BTRANGLES.

\section{Chest-Founder.}

This when it is not soreness of the muscles from hard work, is rheumatism in its acute form. Sometimes it is caused by lesion, or straining of the museles or the tendons conneeted with them.

Causes.-It may be brought on by suddenly allowing the horse to become chilled after heating, giving large drafts of cold warer when warm, or driving him into cold water up to his belly when heated.

How to know it.-The horse is dull; his coat may be sturing; he is stiff, and moves unwillingly. Sometimes the soreness extends to the limbs; usually does from sympathy. Thero is fever in the parts affected and accelerited pulse, the latter from 70 to 80 beats in a minute. Also, sometimes profuse sweating and heaving at the flanks, but the legs will remain wirm. The parts affected may be more or less swollen, but always tender to the touch.

What to do.-Clothe the horse warmly, und put him where he nuy be kept so. If the animul is fat, and full of blood; if there is evident determination of blood, bleed moderately, say a pint from the neck rein. 320
We never, physician $w$ water. Re suds, if the does aiocs. to form a $\mathrm{m}$

No.

Mix and horse being blister.

No.

Heat to $b$ breast, wash When the bli

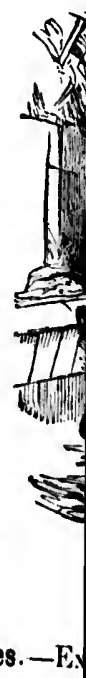
excrtion, and I relaxed. Ridi the owner is in glands and sw 
We never, however, advise bleeding, except by a veterinary surgeon or physician who knows his business. Wash the throat in warm salt and water. Relieve the bowels as soon as possible by an injection of suap suds, if the rectum be impacted. Give as a laxative 4 drachms Barbadoes aioes. Pulverize and mix into a ball with molasses and linseed meal to form a mass or give the following:

$$
\begin{aligned}
& \text { No. 51. Oz. ground ginger, } \\
& 1 \text { Draciun tariar emetle, } \\
& 1 \text { Pint sult und water. }
\end{aligned}
$$

Mix and give as warm as the horse can swallow it. As a rule the horse being thoroughly physicked will get better; if not, apply a mild blister.

No. 52. 1 Oz. powdered cantharides, 8 Oz. lard oil.

Heat to blood heat and mix thoroughly. Shave the hair from the breast, wash with warm vinegar and apply the mixture rubbing it well in. When the blisters rise dress with a plaster of mutton tallow.

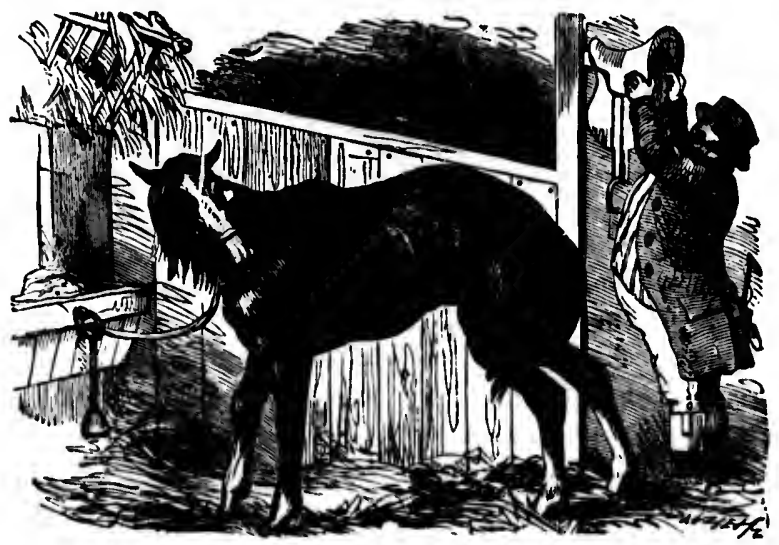

A FIT SURJECT FOR FOUNDER OR BRONCHITIS.

\section{Ir. Bronchitis.}

Causes.-Exposure of a heated and steaming horse to chill, or over exprtion, and leaving the horse in the stable, when the system is quite relixed. Riding to town and leaving a lorse in the cold and wind while the owner is making hinself comfortuble. There is first a cold, enlarged glands und swelled thront. The inflummation extends down from the 
lurynx through the trachea into the bronchial tubes and air passages of the lungs, and ends sometimes in confirmed and incurable bronchitis.

How to know it.-In the acute stage there is difticulty and rapidity of brenthing, from the filling of the membranes with blood and the consequent diminishing of the size of the tube. After a time mucus is formed and increnses the difficulty of breathing and causes a cough. The : pulse will be 60 or 70 beats per minute ; the cough will become hard and dry, and the sound in the throat will be rattling, and after the secretion of mucus a gurgling sound will be given similur to that made in blowing soap bubbles. In extreme cases the breathing becomes extremely liborious, the cough is constant and distressing, the legs are extended, and at lenigth the animal dies of suffocation.

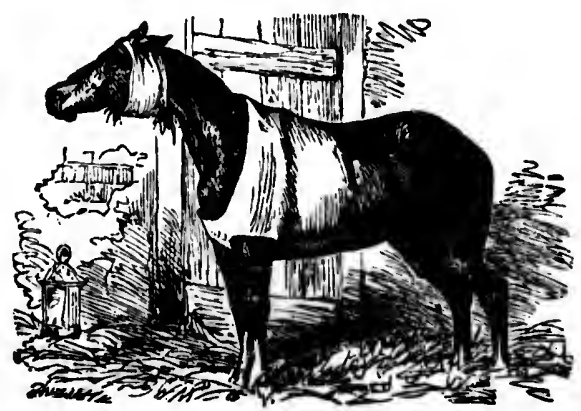

A HOREE DRESSED FOR BRONCHITIS.

What to do.-The first step is to find the extent of the inflammation. Never bleed. Clothe the animal warnly and give un injection of warm water to relieve the bowels. Avoid all strong purgatives. In fact, give none unless the bowels are decidedly bound up. Let the food be soft and laxative, green grass in Summer, or mashes and gruels in Winter. For the thront, sealded soft hay, fastened by means of the eight tniled bandages, will be good. Wrish the neck and ehest with a weak decoction of tolsace as hot as it can be borne. When dry, shave the hinir from the chest and apply a blister of better strength than that adrised for chest founder The following will be good:

No. 53.

1 Ounce powdered cantharides,
1 Ounee powdered restn,

4 Ounces lard oll.

Melt the resin and lard together, with just sufficient lieat to melt the resin.

chest anc

Shave

For the two piece also four pieces wit on each sic and linid at to hold all immedistel mity be, at recovered.

In rery a pulse regiai once al diay,

At the thi give the foll

$$
\text { sio. }
$$

Rub dow every hour 1 the inudinum onnmended. potutoes, inc dirty food. grass and ha given moistel If the dise tremulous. ing difficulty tint with fro 
resin. Add the canthurides and stir until it sets together. Apply to the chest and throut if the case is desperate. If only irritation is desired the following will be good:

$$
\begin{array}{ll}
\text { No. 54. } & \text { 1 Ounces lard oil, } \\
& \text { O Dunco turpentine, } \\
& \text { Draetms powdered cuntharides. }
\end{array}
$$

Shave the hair and apply by rubbing in.

For the body prepare a strong cloth as shoirn on preceding page. Get tro pieces of flimmel three yards long and the full width of the fabric, also fonr piees half a yard long and a foot wide. Saturate one of the pieces with cold water, fold, and apply near the top of tho back, equally on each side. Two of the sunaller pieces are to be saturated with water and laid along the sides of the chest, fasten the jacket at the back so as to hold all snug. When the flamels are warm remove them and replace immediately with others. So continue for two or three hours as the case nity be, and then allow them to remain until the animal is pretty well recovered.

In very aggravated cases of congestion give every half hour until the pulse regains its tone, and then at longer intervals, reduced at last to once a day, the following:

No. 55. 1 Ounce sulphuric ether,
1 Ounce laudanum,
1 l'int water.

At the thirl dose discontinue if the effect required is not produced and give the following:

$$
\begin{aligned}
& \text { 3o. 5. 34 Ounce of aconite, } \\
& \text { 36 Drachm of extract of belladonna. }
\end{aligned}
$$

Rub down the belladoma with an ounce of water. Mix. Give this every hour until the pulse is better, then withdraw the aconite and half the laudaum, and ada half a draehm of belladomn to the drink first recommended. (No. 55.) Let the food be thick gruel of oatmeal, boiled potitoes, and oatmeal and bran mashes. Give no dry, and especially no dirty food. When the nuimal begins to recover so as to eat whole grain, grass and hay, let them be especially freed from dust, and let them be given moistened, until the horso be perfectly recovered.

If the disease is to terminate fatally, the pulse will grow quick and tremulous. In drawing the breath the body will quiver, showing increasing difficulty and prin. The membrune of the nose hecomes of $n$ bluish tiut with frothy blood and purulent matter about the nostrils. The 
respiration, will become more and more difficult, and the cough most distressing, and continuing until a quantity of fluid matter is ejected from the nostrils, only again and again to be resumed. Thus the animal suffers and dies, or else slowly recovers, remaining through life with the cough of incurable bronclitis.

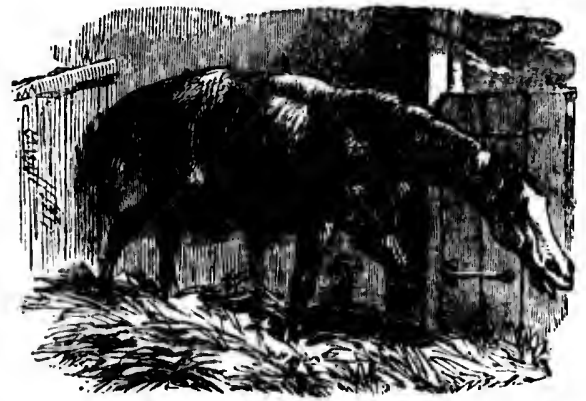

A covau of Ixcurable BRoNCHItIs.

\section{Pneumonia, or Inflammation of the Lungs.}

This may follow acute congestion of the lungs, this being really its lirst stage, though often not notieed, by the ordinary observer, ats sueh. But congestion may occur in its sudden and fatal form from overtaxing a fat horse, or one otherwise ont of condition. Suppose from lurrl driving or hind riding he hangs heavily on the bit; droops and staggers:

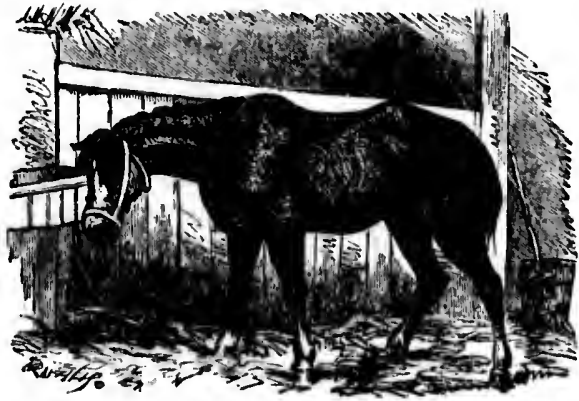

a CAsr of CONgestion.

if not pulled up he may fall; or getting to the stalble he stands with dilated nostrils, extended head, quick, convulsive or labored breathing, eyes staring mid hloodslot, his nasal membrane deep red or blue, ant palse ripid respirntory if the henrt the limbs :I the body, th the neek rei bitel calses.

liemove e allow him pl he had ; whi witer. If $t$ of witer, or witcr. Give antive bind $r$ while the bo covered witlı treatment the

How to kno have just desc shivering, and There will be hut opplesesed loe red, and as rome firom the illostrt ; so will and the latter piration of $t$ the ox will lie rrepitation of seat of the dis nornill murmu ear. By prereu ferted parts, at:k cien groant seat of the dis tain its healthy eased piorts will Thus, ly the e the hand, the fication of the 1

What to do. !lood may be dr 
pulse rappid and weak ; if in putting the ear to the chest there is a loud respiratory murmur with crepitation (a peculiar slight eracking sound); if the henrt, as felt behind the left elbow, is beating tumultuously ; if the limbs are cold, with perspiration brenking out on different parts of the body, there is no time to lose. In extreme cises bleed at once from the neck rein. The blood will be turbid, dark, almost jelly-liko in very batl cisses.

Remove everything from the animul thit may impede breatling, and allow lim plenty of fresh air. Give an active stimulant, the easiest to he hat ; whisky, four or five ounces, or a tumbler full in a half pint of witcr. If this cammot be lund give an ounce of ground ginger in al pint of water, or a half ounce of oil of turpentine in half a tumbler of water. Give also warm water injections to relieve the bowels, and also active hand rubbing of the legs to promote cireulation to the surfice, while the londy is enveloped in blankets wrung out of hot water, and covered with dry ones. If the patient does not soon recover under this treatment the ease will be one of pneumonia.

How to know it.-If the disease does not suceed to the symptoms we have just described, those of acute congestion, there will be a ehill with shivering, and generally a dry cough, but deep as though from the chest. There will be a hot skin, indicating fever, quick-labored breathing, a full hut oppressed pulse. The membrunes of the eyes, nose and mouth will he red, and as the discase advinees a yellowish or whitish matter will come from the nostrils. The horse will always stand with the legs wide alpart; so will the ox in bad cases, and the latter will monn with each expiration of the lureatl. Generally the ox will lie down. There will be irepitation of the lungs aloout the seat of the disease, and a more thin normal mumur upon applying tine eall. By pereussion, striking the nfferted parts, there will be flinching atol even groming, but execpt at the seat of the disease the chest will retain its heslthy sound, while the diseased jarts will sound dull and solid. Thins, by the ear, and sounding by the hand, the progress of the solidi-

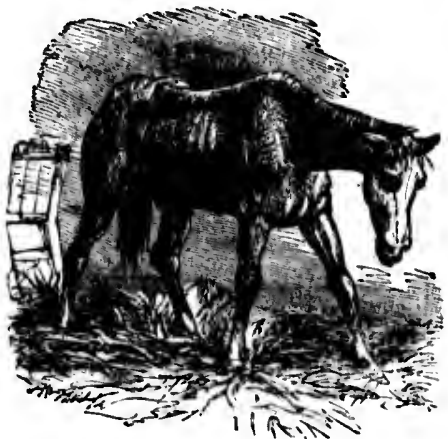

TIIE POSFTIOX ARETHED BY TIE nOIESK DEUING AN ATTACF OF l.NETYUSTA. fination of the lungs may be followed from day to day.

What to do.-Conder the advice of a veterinary surgeon or physicjan, !lookl may be drawn. If none such nre near, if the anianal be young and 
plethorie, blood may be drawn in the earlier stages. Place the animal in a loose box stall, with plenty of ventilation to the stable. If the bowels are costive, loosen them by injections of warm water. Bandnge the limbs to keep them warm, and give the body such elothing as the neces. sities of the case seem to require. Let the food be simple, lixitive and cooling. Bran mashes, boiled earrots, linseed meal, soft sweet hay. Do not check diurthen or profuse staling; it is an effort of nature to relieve the system. If there is fever, givo plenty of water. If thero is swift pulse and oppression of the lungs, give 20 to 30 drops of tincture of aconite in half a pint of water, or 1 to 2 drachms of tincture of veratrum in water every two hours. If under this treatment the system becomes depressed, and it must be watched, discontinue. If the pulse falls-if there is trembling sweats, and a peeuliar anxious expression in the eyes, discontinue. If there is great exhuustion, give moderate doses of whisky, but discontime it unless good effects are seen. If thero is much weak. ness, give two druchms ench of enmphor and of carbonate of ammonia, made into a ball with molasses and linseed meal, twice a dny. In the case of considernble congestion, strong mustard poultiees will be indieaterl, to be applied to the chest; or in extremo cases, blister.

In the case of cattle, the samo general treatment should be followad. Double the quantity of aconite and ammonia should be given. As a rulc, cattle require more than the horse; and in giving medieine to cattle it must trickle down the throat, in order that it may not pass into the first stomach.

In this disease symptoms must be watched. Good nursing is of espeeial value, and as the unimal begins to recover, give soft and easily digestible food, and assist the system if necessary with wine, ale or whisky in very light doses.

\section{Consumption.}

This hereditary affection is nuch more common in the West than is generully supposed. More common in cattle and cven in sheep and swine thun in horses. In horses it is comparatively rare. The disease may bo communicated to healthy mimals by inoculation, and hy eating the raw flesh of diseased animals, and it may also be saperinducel in animals predisposed to the disease by local inflummation ; so also the germs may be received in milk, when the disense has invaded the mamnary grlands of the cow. Deep milking enttlo with narrow horns, thin necks ind narrow chests are especially predisposed to the disease. Tulperdes may be developed in any purt of the body, even, in rure eases, the bones and muscles; the lungs, the spleen, the liver, the pancreas, the orarics and the kidneys are the usunl sents of the disease. 
Causes.-Badly construeted and illy ventiluted stubles; moving from a wirm to a cold climate; exposure to cold and wet; or any thing which tends to lower the health in a predisposed animal will bring on the disease.

How to Know it.-The disease may he aeute, carrying off the animal, sometimes, in $n$ few weeks. It is genemlly chronic. The nttack is insiclious, tubereles often being formed before danger is suspected. There is a generul dullness and loss of spirit, tenderness of tho withers, back, loins, and of the walls of the chest. In eattle the nose will often be dry, showing fever; tho ears and horns will he hot; tho skin loses its elusticity and pliant quality. The heat of the body muy go up to 102 degrees; the pulse is weak lunt accelerited, and there is n slight, dry, but not frequent cough ; the lymphatic glunds about the thront may be enlurged and there muy be swelling of the joints. If the chest is sounded there may be hesurd a murwuring sound hoarser than natural, if it he listened for just orer the lower end of the wind pije or in the chest. As the clisense adrunces, the eyes become more and more sunken, the skin becomes more and more hide bound, the hair is diy and erect. If the lowels are involved there will be more or less scouring, and if tho lungs are principally affected there will be swelling and lameness, labored hreathing, exhinstion and profuse perspirution oceurring upon the slight est excreise. There will he temporary windy distention of the stomach after feeding, and the appetite fails. The congh increases with rattling, the dischinge at first light, increnses. There is crepitation (a rattling or smapping sound) of the lungs, with a whirring or grurgling of the chest, and pereussion gives a dull sound, with wineing when the parts eovering them are handled. So if tuhereles are formed in the liver, pancreas, or kidney's it will show the involvement of these parts. Recoveries are rare. Oecalsionally calcitication of the tubercles oceurs in mimals naturally of a strong constitution, but the discaso usually ends in death.

What to do.-A rure is seareely ever accomplished. The symptoms may be mitigated. The animal must have dry, puro nir, plenty of smishine, Summer and Winter, and be protected from sudden changes, and must be kept wim. The food should he light and digestihle, good grass in Summer and ground food with linseed meal mul roots in Winter. In the early stages of the disense four to tive dachms of gentian may he giren daily in the food, at two or three doses, alternated with two slachus of sulplate of iron as a tonic. As an expectorunt, and diaphoretic, give necensionally three to four ounces flowers of sulphur every other day, or once in three dias, or to net on the skin and as a diuretic, the following:

Xo. 5i. 2 Ounces of nowers of sulphur.

2 To 3 three drachms powdered resin. 
Mix and give a dose daily until the effeet is produced; and afterwards as needed. As an antiseptic (to counteract putresence) the fumes of burning sulphur would be indicated.

How to Prevent.-From what we have written the owner will understand the difficulty attending the treatment of this disease, and ulso its dungerous clunructer in the caso of cattlo. The flosh and milk it is better not to use at all, although dauger can be destroyed by the most thorough cooking. Using consumptive animals as breeders, or selling the milk of consumptive animals should not bo thought of. Druinage, good pasturage, a warm, sumny location for the stables and yards, care against all chronic and debilitating disenses, good, liberal feeding, especinlly when animals are giving milk, the prompt removal of all consumptive unimals from pastures and buildings, und the thorough fumigation of the latter is recommended.

\section{Pleurisy.}

This is an inflammation of the membrane lining of the chest and covering of the lungs. It is common to all domestie animals, in exposed situations and those liable to rheumatism. The pleura is one of the serous membranes, those lining close cavities, as tho ehest, abdomen and joints. In health they are insensible to us, lout under the effects of inflammation the most sensitive and painful possible. Since every inspirntion and expiration of the breath moves these membrunous linings upon each other, we ean at once see the extreme muguish it must oceasion. If relief is not soon obtained the disease quickly ends in death.

How to know Pleurisy.-There will bo some alternations of shivering followed by heat of the skin, sometimes extending to the limbs. There will be localized sweating and eongestion of the muscles. If confined to one side the foot of that side will bo extended. The animal will look at the flank, lie down, rise again. and there will be general uneasiness indieative of pain. The pulse will be quick and hard, secming to strike the finger under the compression. There will be inclination to cough, but which tho animul will fenr to exercise. The cough is not always present, but when so, is always suppressed, short and haeking. The breathing will be hurried, but appirently confined to the abdominul muscles, the inspiration short and checked, but the expiration slow and prolonged. In pnoumonia and hronchitis there is often intense redness of the nose, in pleurisy less. 'There is no nasal discharge and the hent of the breath is not so great as in pneumonia. After effusion of serum (fluid matter or water) into the cavity of the chest ensues, which may be in 24 or 36 hours, the pulse becomes soft, and the animal secms better. If the effus

loses its again dif ind liead l'le puls the anim

An att: disense $\mathbf{f}$ to the an ment, anc artery is short.

What to of the lus pletely in When rem If taken is

This wil For an ox strong mu maly be alp (opell. If potissa on found exee and a rapic

$$
\text { so }
$$

The effu trochill. rib and nea off only a have the atd mil should in witter, wi It is absol the urine sh following wi 
the effusion is re-absorbed the mimul will recover. If not, the pulse loses its full tone, and ngain becomes hard and quick. The breathing is again difficult und attended with lifting of tho thuk und loin. The nose and heal is extended, the nostrils aro dilated, with signs of suffocution. The pulso at length becomes weik, thrilling at each beut until at length the animal wavers, stinggers, falls and dies.

An attack of pleurisy is often tuken by those unacquainted with the disease for spasmodic colic. This error, if mnde, will prolnbly be fatul to the animal affected. In colic the pulse is natural at the commoneement, and the puroxysms of pain are of short duration. In pleurisy the artery is thin, the pulsations seem to strike tho fingers, but the stroke is short. The pain is continuous, the hody hot, but the feet generally cold.

What to do.-The same general care as in bronchitis and inflammntion of the lings is to be observed. If there is a ehill, wrap the horse completely in blankets wrung out of hot water, and cover with dry ones. When removed,do so a little at a time, rubbing dry, and re-clothe warmly. If taken in its earliest stage, give :

$$
\begin{aligned}
& \text { No. 58. } \\
& \text { 3: Ounce landanum, }
\end{aligned}
$$

This will often prove effective; if not, repent the dose in a few hours. For an ox, give double this dose. If the symptoms inerease, apply a strong mustard poultice to the side of the chest, or a blister. No. 53 may be applied to the chest. The bowels should be kept moderately opell. If effusion of water tukes place, give 6 clachms of neetate of potassa once or twice a day in a pail of water. The following will be found execllent in place of the last named remedy, if there is weakness and a rapid pulse ( 70 to 80 ), and seanty urine:

$$
\begin{aligned}
& \text { No. 59. } \quad 1 / 2 \text { Ounce tincture of chloride of Iron, } \\
& \because \text { pall water. } \\
& \text { Give as a drink twico dally. }
\end{aligned}
$$

The effusion of water not yielding, the chest may he tapped with a troehar. Divide the skin with a lancet, between the eighth and ninth rib and near the lower end. Be careful the air does not enter. Draw off only al part of the water if it produces a shock. In this, one should have the advice of a veterinarian. Repeat in 24 to 48 hours. The animal should be kept up with sulphate of iron, two drachms, twice a day, in witer, with stimulants and easily digestible and nutritious food.

It is absolutely necessary, after effusion of water has taken place, that the urine should be passed freely to ussist absorption. To this end tho following will be indicated : 
1 No. 60.
1 Drachm carbonato of ammonla,
ri Ounce powdered gentian.

Give twice a day as a drench in a quntr of water, or as a ball mixul with linseed meal und molasses.

\section{vI. Colds.}

Colds in horses, as in the human fumily, are usually the result of im. proper care or undue exposure. Thking a horse from a hot, illy ventilated stable, and ullowing him after driving to become cold, is one prolific cause of colds. 'There are so many mens of enusing this disalility that it would be impossible to enumerate them. If the nttuck is light, all that will be necessary will be to clothe the animul warmly und relux the bowels with a warm mash, and give rest for a few days.

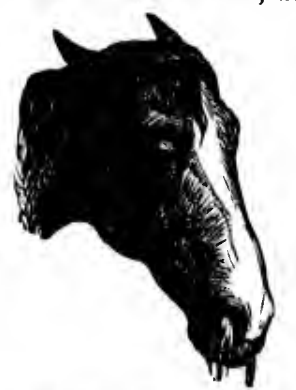

Sometimes, however, the attack is prolonged and severe. The appetite ceases, the coat roughens, parts of the body are hot and others coll, the membrane of the nose at first dry and pale, with the facial sinuses clogrged, at length termimates in a diseharge more or less great, but without improving the henlth of the horse.

What to do.-Keep the animal warmly clothed, in ample box stall, with plenty of bedding. If a nonse's mead witu cold. the cold does not give way in a few days after the first attack, and the symptoms are as we have indicated, or if the membrunes of the nose nre dry, make a sack of coarse gunny cloth, large enough so it may fit the nose properly, but enlarging to the hottom, nud two feet or more loug, with a slit covered with in flap in the side, half way down. Put into the bag laalf a peck or more of coarse pine sawdust with which half an ounce of spirits of turpentine has been thuroughly mixed. Place the bag on the nose as shown in the cut on next piage.

Turn two gallons of hot water in the slit, and every twenty minutes repeat, nllowing the bag to remain on an hour ench time, use this six times a day until the discharge begins. When water runs freely from the nose, three times daily will bo enough. Iet the food be good senlded oats or other like food, with mashes if the howels are constipated.

An animal with this kind of a cold should not be put to steady work until entirely recovered. The result of protracted cold is grent weakness. and work before reeovery often leads to disense of the air passages and lungs. If there is much fever give the following:
Mix $\ldots$ is involy mixcel. the пр)

Form t piarts and in eatiureh following

Mix into every thiee ic cold the platic orlan ders miuy

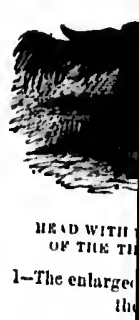

(not by al ill

There are from disense This result i bility. Goit producing in Mortions of 
So. 61. 2 Drachmn eplrlis of ammonla, 2 Jrachums ether.

Vlix and give in it little gruel, (suy 1-2 pint,) twice a duy. If the throut is involved poultice it with linseed menl in which a little mustard hats been mixud. When the symptoms give way and improvement hegins, or if the uppetite is not good prepure the following :

$$
\begin{array}{ll}
\text { No. 62. } & 2 \text { Ounees powderel pen?lum, } \\
& 2 \text { Ouuces earbonuto of ummonia. }
\end{array}
$$

Form this into a mass, with linseed oil and molasses, divided into cight parts and erive one twice each day. If the eold becomes chronic it ends in eaturrh. When there are enturrhul symptoms und sore throat give the following :

No. 63.

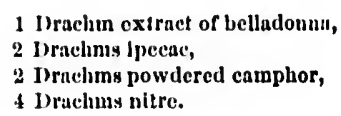

Mix into a ball with linseed oil, and give one crery three or four lours. In inveterate or chronic cold there is diseharge, and swelling of the lymphatic gland. We have uleesdy shown how glineders mily be known.

thed, If after have ck of ut ellwith more entine wn in inutes is six from ruldcad work kness. es and

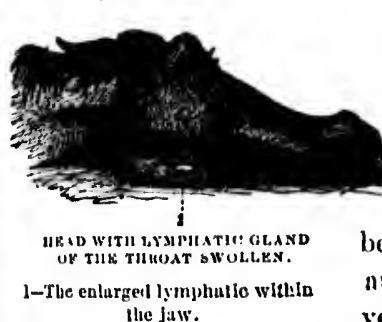

We give a cut showing tho enlargement of the lymphatio gland in clironic cold. In ease the horse gets cold it is better that he lise exnmined by a competent veterinary s u r g c o n,

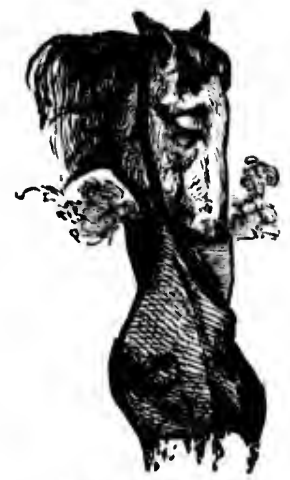

NOSE JAO FOII STRAMNO MULSE WITH COLD. (not by a cunck,) in order to be sure the disense is not glanders.

\section{Enlarged Glands-Goitre.}

There are various glands in the throat that are subject to enlargement from disease, and which remain permanent after the disense is passed. This result is generally more unsightly as a blemish than as a real disilbility. Goitre, however, is a disense peculiar to some limestone regions, producing in animuls us in man a swelling of the thyroid gland. In some wortions of the Eist it is quite prevalent, producing extensive enlurge- 
ments in lumbs. It ulso attucks enttle and swine. In solid-hoofed mi. mals, us in the horse, there may bo a swelling on either side; in others it is in the center just bolow the roots of the juws. For all enlurgements of the glunds, fincture of iodine will disperse the swelling if it muy be possible. In bronchocele or goitre, rainwater only should be given to clrink; iodine in doses of ten gruins duily muy be given on mu empty stommeh, and the swelling maty bo painted with the tincture. This to be persisted in for months. Another remody thut has been suceessful, is the following:

$$
\begin{aligned}
& \text { No. 64. Drnelim lollde of potasslum, } \\
& 1 \text { Draclim llquor potassa, } \\
& \text { 36 l'int raluwater. }
\end{aligned}
$$

Mix, und give as a dose niglit and morning, using the tincture of iodine on the goitre.

\section{Swelled Throat, or Laryngitis.}

Causes,-Foul stnbles or any cause producing colds, catarrhs, etc. It is sometimes divided professionally into laryngitis and pharyngitis, but practicully they ure one-inflammution of the air and food passuges of the neck, generally accompanied with cough, difficulty in swallowing and fever.

How to Know it.-The animal is dull. The head is carried in a peculiar momner, us though the neck were stiff. There is a short, frequent congl, the breath is hurried, tho pulse full and throbling, and the membrines of the nasal passages are high colored, almost scarlet. There will be $n$ hoarse sound, :lpproathing to a grunt, at ench breath taken, if the ears are held aguinst the animal's wind-pipe. Exterually there is more or less enlargement over the region of the laryux, the enlargement of the windpipe next the throat. Handling the thront seems to produce extreme puin.

What to do.-Reduce the pulse at onee by doses of tineture of aconite in a wine glass full of water, repeated every half hour. Plice the steming-lang on the nose, as recommended for colds. Keep it employed almost constantly, for there may be dinger of strungulation. If the steaning seems to distress the animal, omit it, or use it only ocensionally, and sonk soft hay in boiling water and apply to the throat as hot as can be borne. Bandage and fasten with the eight-tailed bandage previously described. Or, ferment the throat with cloths wrung out of hot mustard water. If there is difficulty in swallowing, put $n$ tenspoouful of the following well back on the tongue several times a day:
Do not i gently ais 1 give three

In eise throat will 1

$$
\text { No. }
$$

Mix, shuk dily. If this

$$
\text { No. } 6
$$

¿lix, and n

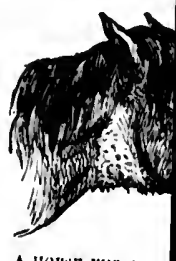

A HOUNE WIII TH

When the sy nose becoming more free, or appearinec of iu the thront, More the seto one of the kno food-liay and stoncs or grit a ing. In this, a horse may quid 
No. 65. 1 Ounce powdered gualacum,

4 Onines powdered chloruto of potush,

Yi l'lut of molassos.

Do not in administering anything, foree the juw's wide mpart. Act as gently as possible. If the mimul is feverish und the throat hot and dry, give three times a day, in a pint of cold linseed ten, the following:

$$
\begin{aligned}
& \text { No. 60. } \\
& 1 \text { Drachm powile solutlon of acetate of ammonla. }
\end{aligned}
$$

In cuse the disense bccomes chrouic, the following exeitant to the throat will ho indicated:

No. 6\%.

1 l'urt oll of turpentlice,

1 P'urt solutlon of ammonia,

1 Iurt ollvo oll.

Jlix, shake the bottle before using, and rub well in on the thront every day. If this does not relieve, apply the following blister:
No. 68.
1 Drachm croton oll,
1 1)ruchun sulphurle cther,
10 Draclims alcohol.

:Iix, and nplyly ly rubbing with considerable friction.

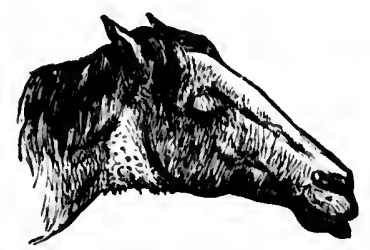

A HUHS WHU THE THLAT MLISTERED.

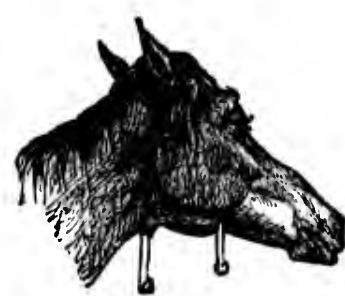

A BETON IN THE THHOAT or A HOHSE.

When the synptoms become more favorable, by the membrunes of the nose becoming pale or more natural in color: by the cough becoming more free, or louder, easier and with less violent breathing, and by the nppearance of a white mind thick discharge from tho nostrils, put a seton in the throit, (see cut,) and allow nothing but moist and succulent food. Nove the seton daily until healthy pus (matter) is formed. Then eut one of the knots and withdraw it, and as the horse recovers allow drier food-liny and grain-but that entirely free from dust. See that ne stones or grit are in the oats, and soak for five or six hours before feeding. In this, as in diseases where the throat is more or less sore, the horse may quid his food. This is not a symptom of laryngitis as is some- 
times supposed, but known to all disenses where there is obstruction in swullowing.

\section{Chronia Cough.}

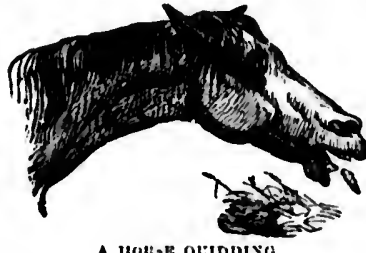

There ure many cases of long standing or chronic cough. Cough is an attendant upou so mamy lisonders of the air passuges, from the most trivial difficulty in tecthing to chlander's, that a cough should not be overlooked in the dingnose of disenses. And so many diseases leave the patient with chronic congh, that its symptomutic stages should be cire-

fully observed.

Coughiug tends generally to a thickening of the membrines. When the membrano eovering the laryux becomes thickened, and eonsequently morhidly sensitive, the cough becomes fixed or what is termed chronic.

The sense of smell in the nose is peculiarly acute, mul the membrines of the nose und thront, as a mutter of course, are fully as sensitive. Wo have said, "the linils and feet are half the horse: the lungs the test of nis endurunce." Yet nine in ten of the stubles in which horses are kept are offensive to man and irritate the air passages when first, entered. Yei the sense of sme!! in m:m is not very neute, except in a few directions. A stuble therefore, offensive to man is not a fit pluce for horses to be kept, where the lungs constitute one of the principal excellencies of the animal.

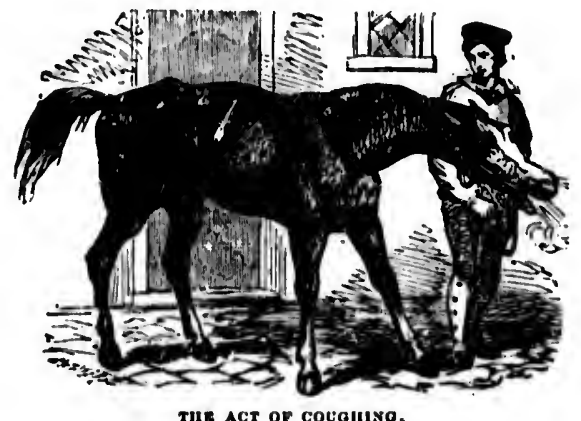

The cough which accompanies the several disenses of which this rolune treats, will be described in the trentment of the disenses themselves. In this articlo chrouic eough will he treated, the congh that is always present in enting, drinking and inhaling a cold driught of air, or from any causo cure. 'Th For this, sround the

Give twi

If this di cough, the

$$
\text { so. }
$$

iive one week or ten wr I first d

No.

(iive in al to he valuals following : No.:

If the couse xo. :

Mix in 11 three times a

Lixpector:al to theire natu farm animuls. 
any causo of excitement, requiring long and eareful nursing for their cure. The chronic cough, resulting from colds, is himd und metullic. For this, tho following will be good, to be rubbed on the throat and wround the windpipe, once in ten days :

$$
\begin{array}{r}
15 \text { Drops eroton oll, } \\
1 \text { Uunce glycerlne, }
\end{array}
$$

Give twice a day, for a week, the following:

$$
\begin{aligned}
& \text { So. 70. } \\
& 1 \text { Drops dlinted prussle acld, } \\
& 1 \text { Ounce nlter, } \\
& 1 \text { Quart waler. }
\end{aligned}
$$

If this does not give relief, the following, valuntule for irritalble chronic cough, the result of influenzil or sore throat, may be used:

$$
\begin{aligned}
& \text { Xo. 71. } \\
& 1 \text { Ounco Fowior's solution of a senle, } \\
& 1 \text { Innco chlorate of potash, } \\
& 1 \text { Iruchu belludona. }
\end{aligned}
$$

Give once a day in water or gruel und note results, censing after a week or ten days, if no improvement ensues. For cough and sore throat, wh I tirst discovered, tuke:

$$
\begin{aligned}
& 1 \text { Drachm powdered enmphor, } \\
& \text { 1 Drachm extract beliadona, } \\
& 2 \text { Uunces sweut spirlts uiter. }
\end{aligned}
$$

(iive in a pint of cold gruel three times a day. Tar-water is well known to he valuable in obstimate coughs. Give every norning as a drink, the following :

$$
\begin{aligned}
& \text { Nis. 73. I Drachn powdered squlls, } \\
& \text { * l'lut tar-water, } \\
& \text { Y. Plut lime-water. }
\end{aligned}
$$

If the congh is violent, use as $n$ sedutive, the following:

$$
\begin{array}{ll} 
& 1 \text { Drashm dilute prussic ach, } \\
\text { 2 Drashms powilered opium, } & \\
& 4 \text { Drachms niter. }
\end{array}
$$

Mix in a pint of linseed tea ard givo from tive to six tuble-spoonfuls three times a duy.

lixpertormits, culculated to loosen the cough and restore the secretions to their naturul eonditions, do not nct so kindly as could be wished on farm animals. For « long standing cough, try the following : 
No. 75.

\author{
1 Druchm aloes, \\ 1 Drtebm rqullity, \\ 2 Druchms gum ammonineum.
}

Mix into a ball with meal and give once a day in the morning. If the congly is irritable and ensily excited, and the bowels natural, onit the aloes and substitute for it one drichm of opium.

For a cold settled in the chest, with cough, give every morning the following :

$$
\text { No. } 70 .
$$

1 Drachm ipecac,

1 Druchm lienorico powder,

If Ounce nilrate of anmonit.

Add tar, the size of a hazel-nut and mix with molasses to form a ball. All coughs resulting from indigestion or worms, and some of those resulting from irritation of the passinges of the throat, are often cured by turning the horse out in Summer where lie may liave free runge on the prairie, where resin weed grows plentifully. A long stunding congh, however, requires time, and the operator must use judgment in administering medicine. If he be a veterinary surgeon he will make up his mind from various symptoms. The farmer should endeavor carefully to do the same.

\section{Malignent Epidemic.}

Under this hend the older veterinurians were aceustomed to torm several diseases that sweeping over a country became unusually previlent or fatal. Thus Dr. Lalyard and Ohmer long ago wrote of milignunt epiclemic, probably a severe form of caturrhal fever, or epjelenic atartar, and also known as influenza distemper, malignnut epidemic, mun'ain, pest, etc.

Yount deseribes a malignant disense oceurring in 1714 in lingland, imported from the continent and destroying in tho course of a fow month 70,000 hor'ses und cattle. Professor Bruquon, of Turin, silys of this disease, that it commenced with loss of appetite, staring coat, at wild sud wanelering look, mol it staggering from the very eommenement. Tho horse would (ontianaliy lie down and get up agan, as if tormented hy, colic ; and he gazed alternately at hoth dhuks. In moments of compur ative ease there were mircrsal twitchings of the skin and spasms of the limbs. The temperinture of the ears and feet was vinisble. If there lanpened to be about the animal any old wound or sear from setoung n: tiring, it opened afresh and discharged a qunntity of thick and hlack blood. Very shortly afterward the flanks, which were quiet before, hegan to henve, the nostrils were dilated, the head extended for breath. The horse had could rise ing, and tongue wh proeceded of the dis animal ling serotum fo

Blitek s] tissue of a mesenteric The memb. were tilled The brin :

From wh ization, or c eres the ob can be don with judgm closing or ol not piss aw: be mitigrited dust, griving disty. Ma: "rily open, : linaring li in the United duced by ob: the linivix a minates in ro

\section{Causes.-I} violent exerti the disense. uniluly contin dares and wec unless his lun known in tho heares, cithes 
horse had, by this time become so weak that, if he lny, or fell down, he could rise no more; or, if he whs up, he would stind trembling, stnggering, und threntening to fall every moment. The mouth was dry, the tongue white and the breath fetid; a discharge of yellow or fetid matter proceeded from the nose and fetid matter from the anus. The durntion of the diseuso did not exeed twelve or twenty-four hours; or if the animill lingered on swellings of the head and throut and sheath und scrotum followed, and he died exhausted, or in convulsions.

Black spots - extravasation - wero found in ec!lnlar membrune, in the tissue of all the membranes, and on the conts of the stomuch. The mesenteric and lynuphatic glands were engorged, black and gangrenous. The membrane of the nose and pharynx were highly injected, the lings were filled with blnck and frothy blood, or with black and livid spots. The brain and its meninges were unaltered.

\section{Difleulty of Breathing.}

From whatever source this may arise, whether from some disorganization, or change in the lungs, or obstruction in the air passages; whaterer the obstruction be, it must first be traced to its cause before grood cum lie done. This is sometimes not ensy to do; the owner must act with judgment. Thiek wind often follows pueumonia, and is caused by elosing or obliteration (hepatization) of $n$ portion of the lungs. If it rlocs not piss awity after the disease which preceded it is entirely cured, it may be mitigated by feeding the animal on sound oats, entirely freed from dust, giving hut ittlo hay, that moistoned, and nvoiding any food that is dusty. Mashes and earots in Winter sufficient to keep tho howels properly open, and turning on pruirio pasturo in Summer will bo indicuted.

lioaring hats rendered uourly useless many valualblo horses in Engrland; in the United States horses me not subject to it. It is saicl to bo pro. duced hy olstruction in some part of the respirat ory canal, most often 1 , the larynx and next in the trachen. Thus chronic eough sometimes terminates in roaring. In this country heaves is the most usual termination

\section{Broken Wind; Bellows; Heaves.}

Causes.-Brohen wind is the result hoth of disonse of the lungs mat violent exertions. Feeding on dusty hay and grain are prolifie somrees of the disense. Where no clover hay is used, the disense is rine. It is mainly contined to horses that have nrived at maturity. 1 horse fed for days mul weeks on dusty hay, and then driven hard, will cxhibit lowves, unless his lungs and digestion are extmordinnry. This disense in usunliy known in the south muder the name of hellows, and in the 1, wth ins heares, either of them expressive of the disease. 
How to know it.-Brokm wind is nearly allied to asthma in man, but is more continuous in its action and less liable to occur in paroxysms. At ench brenth there will be a two-fold motion of the flank, citused by a fulling in of the abdominal walls, eausing the lank to lift, then after a perceptible interval a rising of the loak part of the belly assists in frecing the lungs of air. There is a short, dry cough, sometimes almost inaudible, followed by whirring. When the horse is moved suddenly, or driven luurd, when a draught of cold water is given, or the animul is suddenly brought into the cold air, the spells will oceur. Indigestion is almost nlwiys present, and as a consequence of flatulency of the bowels. The ippetite is ravenous and umatural ; eating the litter given for bedding, is one of the many exhilitions of it.

What to do.-There is no permunent cure for this disibility. The symptoms and distress may bo alleviated loy giving only sounc' grain and hright, hard stalked hay, freo from dust. Prairio hay with plenty of resin leaf in it is the best; next, elcan cured corn-stnlks. But little water should be allowed at a time, and not more thun 6 to 8 pounds of hav, daily, and this given at night, tho provender being confined ns much as possible to grain and grinss in Summer, and grain, bran-mashes and carrots on potatoes in Winter.

This will enable many brolsen-rinded horses to do a fair amount of work with comparative eomfort. In nuy event, a horse inclined to be thi-in-winded in any degree, should never be ighty checked up, nor :hove all, bo driven by pulling in tho head, causing vndue bearing cither of the enirl or snafle on the jaw.

The animnl should bo sillowed to hold its head

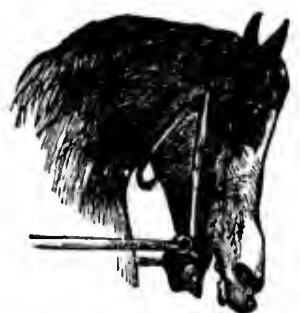

BIT HEAMYO UPON JAW.

$$
\text { No. }
$$
in tho ensiest position, since its work must be nee. essurily slow. One of tho most usual palliative mems of the animal appeatiang for a time sound, is to gire 10 to $1 \vec{i}$ gratins of ansenic a day for: weck or ten duys. A better preparation to give relief-afterwards, the anime! to be turned out on clean, short griss, is the following:

Give once a dity, in the molning, in one pist of water, and eontmue for four to cight weeks, us circumstancos may dietnte.

This ep countries i stood. Its complicatec rheusnatic:

How to $\mathrm{kn}$ and weikne the gritit will be no alpeti with scinty membinano o le deep and somctimes $\mathbf{t}$ [pon applyi times it halrsi dischialiges a ter; but whe rense. As a jnisent.

What to do. of air. I) 110 by watching the keep the lowel nil. Relief m rusing must be A good tonic an 


\section{Influenza.}

This epiznotic, which first mad last lass been prerulent in nearly all countries where the horse is used, is, as to its origin, but little understood. Its symptoms, howover, are well known, but these may bo complicented by inflamuatory symptoms of all the ail passiges ; also by rhenanatic swellings, pambsis, delirinn and intlammation of the eyes.

How to know it.-The attack may he sudden. There will be stupor and weakness, the hend will he held low, the cyes dall and half closed, the gait will be weak, with eracking of the joints sometimes. There will be no alpetite, and fever ; the month hot and el:mmy, the bowels eostive, with semity mine; the pulso quick and weak, hut sometimes hard; the mombrane of the nose may be piuk, or a deep lenden hue; the coughl will be deep and harsh; tho cont rough and staring; the skin tender and sometimes tremblingr, mod tho ears and limbs alternately hot anci cold. Ipon applying the ear to tho lungs crepitation will be heard, or sometimes a harsh blowing somm. Is tho disense progresses, and the nose discharges a white, yellowish or greenish water, the animal may get better; lut when the lungs are seriously involved, tho syuptoms will inrease. As a rule there is constipation, although purging is sometimes present.

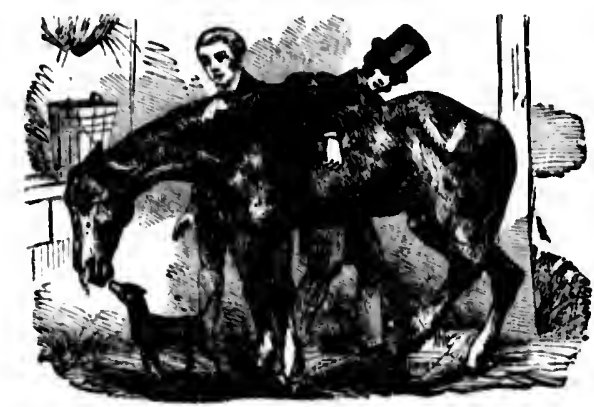

CoxrikMEA INTLURNZA.

What to do.-Place the animal in a well littered stall, free from drafts of air. Do not depend upon strong physic. The cure must be effected by watehing the symptoms und combating them. If there is costiveness keep the bowels open by injections of two wine glasses full of linseed nil. Relief must be hud by menus of stimulants and tonies. Food masing must be constant, with clothing enough to keep the animal warm. A good tonic mod stimulant is : 
No. 78

Form in eight doses and give one night and morning. If the cough is distressing prepure the following:

$$
\text { No. } 79 .
$$

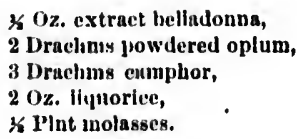

Mix thoroughly and spread a table-spoonful on the tongue twice a day. If, with the cough, there is sore throat and catarrh, prepare the following:

$$
\text { No. } 80 .
$$

20 Gralna iodine,

1 1) rachm iodide of potassium,

2 Ounces sweet spirits of niter,

1 l'int water gruei.

Give this as a dose twice a day. If the animul should begin to improve it will be about the fifth day.

Sometimes recovery is complicated by various disabilities. If there is dropsy or swelling of the legs or sheath, prepare the following:

No. 81 .

$10 z$ iodide of potnssium,

1 Oz. carbonate of unınosin,

1 Oz. powdered gentian.

Form into eight halls and give one morning and evening.

If a spasmodie cough follows the nttuck the following wili be indicated:

No. 82 .

1 Drachm exIrnet of belladonna,

1 Drachm chloroform,

10 Druchms alcohol.

Mix in a pint of gruel and let it trickle slowly down the throat, in order $t$ produce a full locul effect.

As recovery ensues, the food should he rourishing and ensily dipested. The animal should be induced to take food during the disense, especially in the form of nourishing gruel. When the pulse changes, and especially when it loses its wiry character: when the dischauge from the nose becomes stendy and copions, a pint of sle occasionally is a good stimnlant. In any event, good, ensily digested food should be given, and the animal must be nursed until entirely resovered.

\section{Spasmodic Action of the Glottis and Epiglottis.}

This may be oceasioned rarely by food sticking in the resophagus. It is sometim gums shou rrowing ins to say that animal.

This dise in colts than

Causes.or much exp'

How to kn There will । sometimes i d. the disen boty rumming lumdred. II in the throat, dies of suffoc

What to do. and where th clolling. Giv quitrt of warm

As an antis every hour in disease warm $f$ If later, use th

ง. 82

Ruls well on throat do not $\mathrm{g}$ the following :

No. 83.

Wix and swal of a small pien jireer of whaleh of foals and on lamls not more the avoilled. 
is sometimes attendant upon cutting the teeth. In the latter case the gums should be cut. Spasn of the glottis passes away by a peeuliar rrowing inspiration. It is so rare in horses thit it will only be necessary to say that its cause must be looked to in the goneral health of the animill.

This disease is generully confined to young unimals, and is more rase in colts thun in culves or lumbs.

Causes.-Being (onfined to damp, low lying ground, or in cold, damp, or much exposed loenlities.

How to know it.-The first symptoms are like those of soro throat. Thre will he a dry whirring breatling and a hard metnllic cough. sonuctimes it will be hend only when spusm of the larynx comes on. d: the disense progresses the fever increases, the temperature of the bndy rumning to 107 degrees, and the pulse from ninety to over one hundred. White films or pellicles (albuminous false membrunes) form in the throat, which come away from time to time, or if not, the animal dies of suffocation.

What to do. - Place the animal where it my have free air but no clrafts, and where the temperature ma be kept eonfortable. Allow sufficient dothing. Give as a laxntive twelve ounces Glauber sults dissolved in a quart of warm water.

As an antispasmodic give two or three drinchu doses of laudunum every hour in a decoction of narsh mallow. In the early stage of the disease warm fomentations persistently applied may scatter the disease. If later, use the following:

$$
\begin{aligned}
& \text { No. 82. } \\
& 1 \text { Part oll of turpentine, } \\
& 1 \text { Part lard oil, } \\
& 1 \text { Part solution of ammonin. }
\end{aligned}
$$

Rub well on the affected parts of the thront. If the membrane in the throat do not give way, and there is increased difticulty in breathing use the following :

$$
\begin{aligned}
& \text { No. 83. } 10 \mathrm{Grains} \text { nitrate of silver, } \\
& 1 \text { Ounce rainwater. }
\end{aligned}
$$

Yix and swab the throut well over the forming membranes, by menns of a small piece of soft sponge tied over the end of a smooth, flexible pirce of whalehone and saturated with the nitrate of silver. In the ease of fouls und enlves, only hulf the doses named must be used, and for lanls not uore than one quarter. In any case damp, exposed stubling must tere arvidenl. 


\section{Bleoding froln the Nose.}

This often oecurs from various injuries to the mucus membrune of the nostrils, from hard pulling up hill, too tight a collur, and from ciner causes, especially if the animul be full of blood. In these eases, $t^{2}$. bleeding is from one nostril and in drops, necompanied ly sneezing. If the bleeding comes from the lungs, it will bo bright red and frothy, and there will be a cough. If from the stomach, it will be black, elotted, sour und accompinies: by retching.

What to do.-In simple ('ases tie the head up us high as possible, bow strong alum water from a tubo into the nostril at ench inspiration, and if obstinate, plug the nostril with pledgets of tow. Give internally onle seruple of acetate of lend, to be followed in half an hour with another if necessitry. In the ease of an ox, two struples may be griven at a dose.

If hoth nostrils aro involved, and the llow is continuous, only one no:tril must be stopped at a time, unless tricheotomy is performed, since the horse eamnot mreathe thromigh the mouth. The ox, however, can do so. Therefore both nostrils mity he plugrared if meessing.

In performing this operation (tracheotomy), on the horse, sometimes necessary in varions obstructions of the throat and windpipe, a ring of the windpipe should not be severed, but only pints of two. That is, a circular flip) should be excised. It shonld nlwiys be performed by a veterinary surgeon, exeppt in a case where death from stringulation is imminent. In this case do not hesitate, take the laneet or shan knife and, holding the horse's hiad high, eut in in foot above the breast-bone and in the center of the neck, denen to and into the windpipe. The opening through the skin should be about two and a half inches long or even three inches, and through the windpipe from onc-half to threc-puarters of an inch. If a surereon performs the operation he will be provitud with a tricheotomy tube; if not, any smooth metal tube which may he inserted will do, as the spout of a tei-kettle; this must be held to its place by proper fastenings, and until the wound is healed the horse must not be allowed to put his head to the ground.

\section{Strangles.}

This is a disease lont little known in Amerien. Our distemper takes its place. It is thus described in English works: It usually oceurs in young horses, highly-bred horses being more subject to it than enld blooded ones. When the animal is "loreeding stmungles," there is a gen. erul though slight indisposition. After a few dnys the neck beconse stiff, the throat swells, the tumor being hard, hot and tender. A $d *$ charge fro olplpessed, with half-c opened, as ('ise is real same thing

The gener: applicution $t$ recommended

No.

Mix, and al strangles or d ing drinks, as take should 1 possible mean portant. Unt it should have 
charge from the nose takes plice, the throat beeomes sore, the breathing oppressed, the hair is sturing, the uppetite is gone, and the animal stands with half-closed eyes. At length the tumor hecomes ripe onough and is opened, as is usual in distemper. It is more than probable that the disease is renlly the sume, and that strningles and distemper are one and the sune thing, only modified by conditions and elimate.

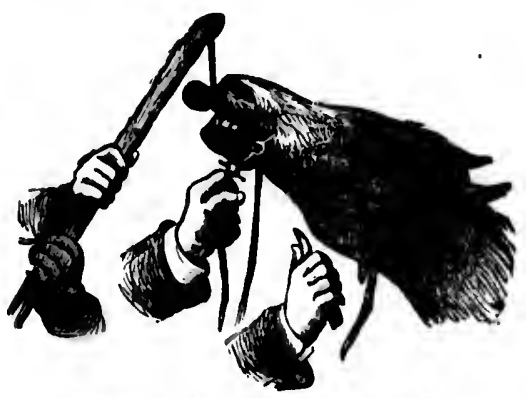

OPENIXO THE AHECEss OF STILANGLES.

The general trentment is the simus as we give for distemper. As an application to the swelling to produce suppuration, the following is reconmended:

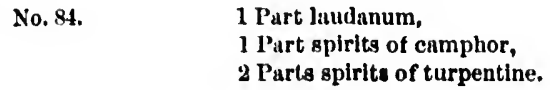

Mix, and apply with a paint brush to the swelling. In treating either strangles or distemper, no physic should be given. Good nursing, soothing drinks, as much nourishment in the food or gruel as the animal cul take slould be allowed, and the strength must be kept up by every possible means, and to induce the ripening into pus of the tumor is inportunt. Until the animal he again entirely recovered and in good heulth, it should have no work. 


\section{CHAPTER VI.}

\section{DISEASES OF THE ETOMACH AND BOWFLS.}

\begin{abstract}
1. sour stoyach. - II. colic. - III. THE BOT. - IV. INPLAMBation AND RUPTURE OF TIR COLON. - $\mathrm{V}$. INFLAMMATION AND BLEEDING OF THE REC. TUM.—-VI. BPONTANEOUS BALIVATION.—VII. INFLAXMATION OF THE STOY.

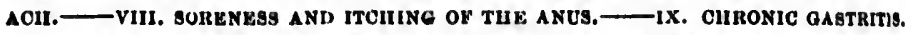

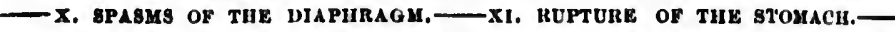

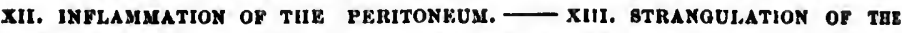
INTESTINES, - XIV. FUNCTIONAL DISEAGES OF THE LIVER, -XV. PARASITES WHICH ATFECT THE LIVRR.—XVI. DIAIRIEA.
\end{abstract}

\section{Bour Stomsch.}

Animals living upon vegetable food, where the mastication or the grinding down of the substances taken into the mouth is imperfectly accomplished, or where a greedy animal is allowed to overload the stomach with food, since it thus is imperfectly moistened with salis:t. ure subject to acidity of the stonnch, fermentution of the food, and the disenses attendunt thereupon. Curbonic neid gas is evolvel, und if not checked in time will sometimes cuuse violent and extreme distension and inthummation of the stomach, the result of decomposition, or spasmodie colic, with puroxysms of extreme agony, and sometimes the most violent rupture of the stomach ending in denth.

We often see violent distension of the stomach in cattle when turned into $n$ field of flush clover when hungry; the remedy in this ease is thrusting a trochar or knifo into the stomach to allow the escape of the gases. When in the horso intlanimatory netion has been set up it may lend to many disenses, each of which must be treated according to the symptoms exhibited.
In the $\mathrm{i}$ time, trent gastritis, il

Causes.londing the in slow fee this cinse th may occiur thus winkhit ulso ensue from cuting

How to $k$ or ferment quickened, there is in violent sym

\section{What to} Evacuste th helly with there is grip

$$
\text { No. }
$$

If the we relief.

In the ens quarter to o which give tl

This muy the result of tendeney to tendency to

How to kno ing., st rikingy lying down at an instant : 1 pain intermit. gone throught. 
In the first stage or that of simple neidity of the stomuch, if taken in time, treutment is compurutively eusy. It is culled sour stoniach, neute gustritis, indigestion, tympuny, etc.

Causes.-Suspended digestion und consequent fermentution from overloading the stomuch with improperly chewed food. This will never occur in slow feeders that fully grind und snturate the food with salivn, sinco in this cuse the appetito is fully satistied before overlonding ensues. Colic may oceur by giving large drauglits of water immedintely ufter feeding, thus washing forwarl the food heyond the stomach. Sour stonach may ulso cusue from indigestible and ensily fermented food, and inflummation from cuting plunts thut irritute the stomnch.

How to know it.- - The first symptoms are nour stomach, simple colic, or fermentution. There is fulluess, causing undue distension; then quickened, deep, but oppressed brenthing; the animnl is dull und stupisl ; there is inerensing puin, and ut length, if relief is not obtaned, more violent symptoms set in.

What to do.-Give immedintely one or two ounces of magnesia. Evocunte the bowels by menus of injections of warm water. Rub the helly with considemble friction one winy, from the forclegs back. If there is griping give the following :

$$
\begin{aligned}
& \text { No. 85. } 15 \text { to } 20 \text { Drops oll of pepper...lnt, } \\
& 1 \text { Ounco ol lautlanum. }
\end{aligned}
$$

If the weather is cold, blunket and walk the horso to ussist in giving relief.

II the case of the ox, give double the dose mentioned; sheep onequarter to one-third the dose for the horse, except of luudamam, of which give the sheep, 2 to 3 dinchms.

\section{Colic.}

This may be of two kinds, spasmodic, or flatulent colic. The tirst is the result of crimps or spasmodic controtions, eausing severe pain with tendency to inflummation. The other of distension of the bowels with teudency to inflammution and rupture of the conts.

How to know Spasmodic Colic.-'There will be spasms of pain, with puwing, striking of the belly with the hind foot, lonking round at the flanks, lying down and suddenly getting an instant: then suldenly rising, the horse will shake himself us the pain intermits. Agni the pain retmrns and the same performunes ne gone through. There may be frequent small dischurges from the bowels 


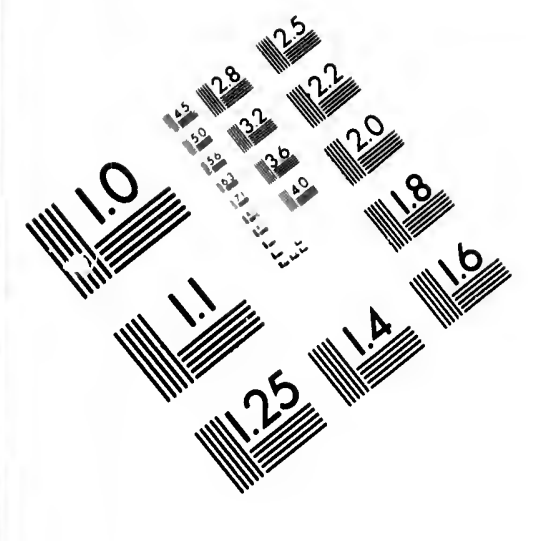

IMAGE EVALUATION

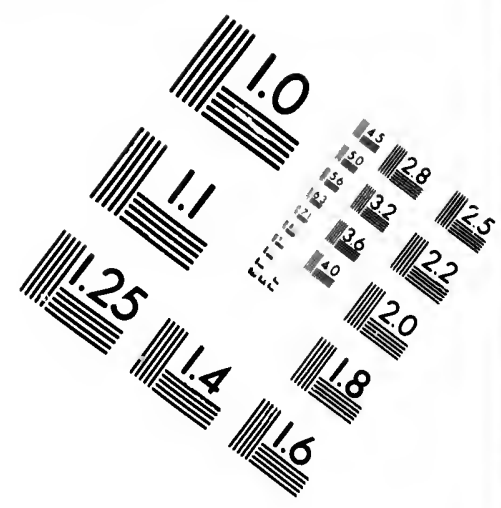

TEST TARGET (MT-3)
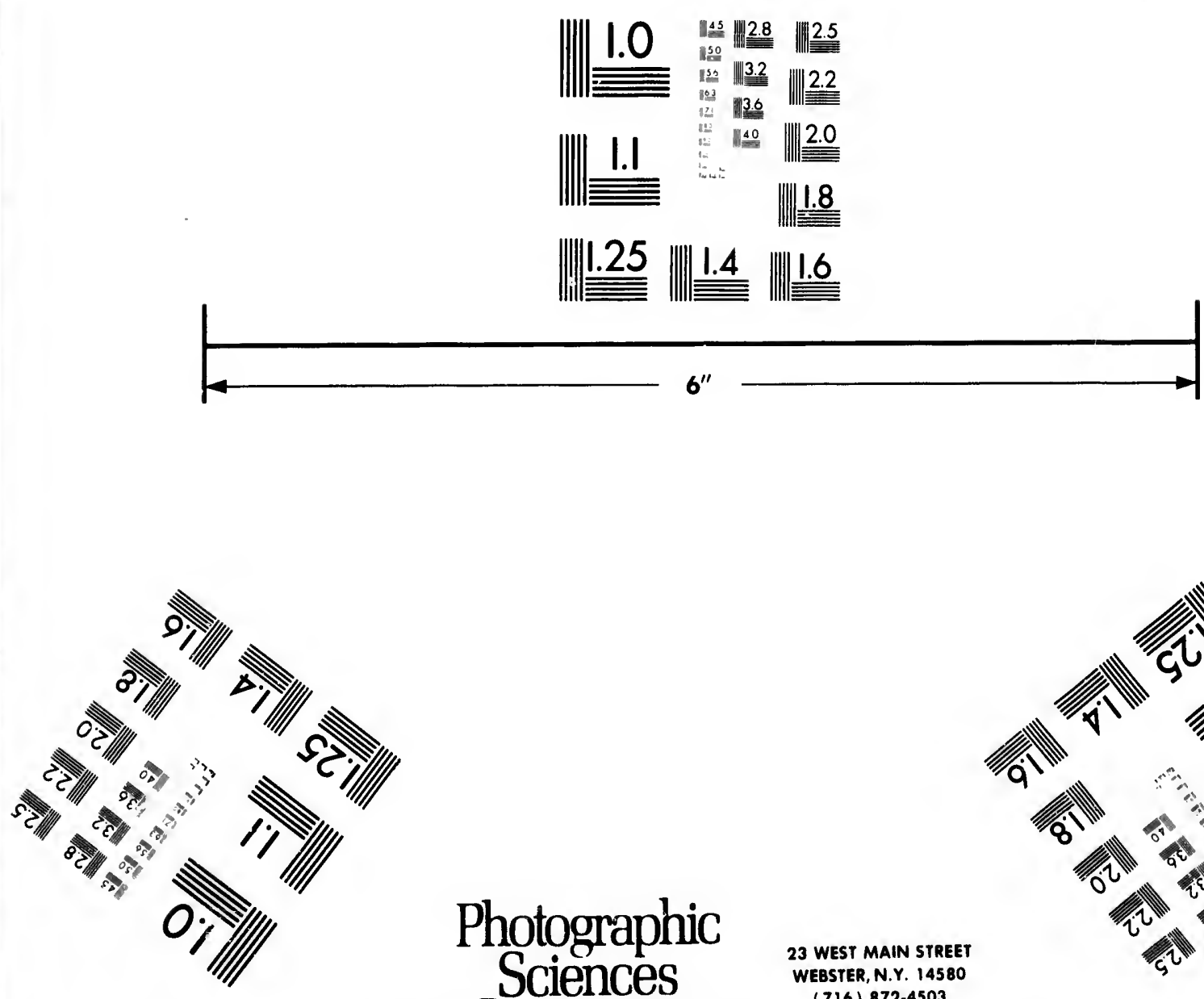

Photographic Sciences Corporation
23 WEST MAIN STREET

WEBSTER, N.Y. 14580 (716) 872-4503

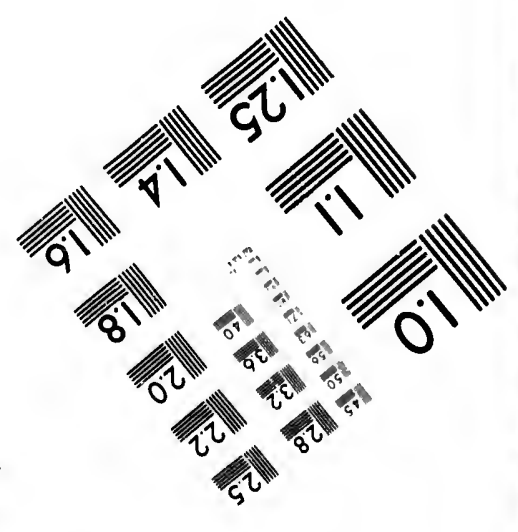


and bladder, and during the attacks the pulse and breathing are accelerated.

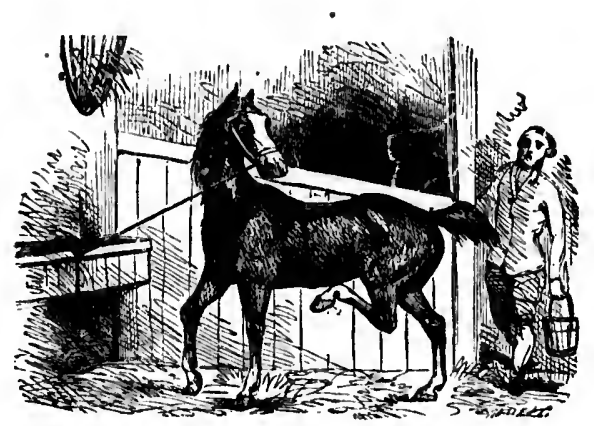

THE FIRST BTAGE OF SPABMODIC COLIC.
Mix followi

Mix, $p$ the other give as a

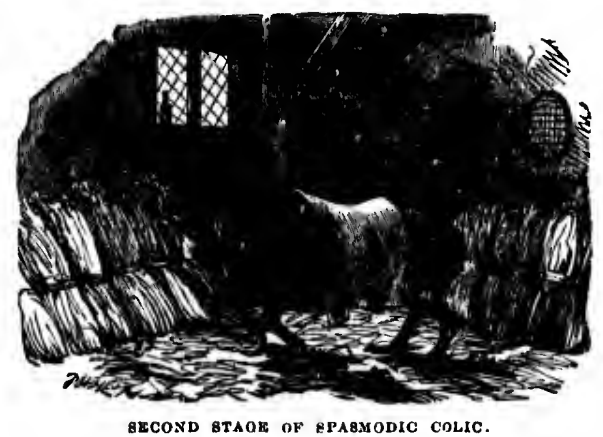

Pulverize the aloes and dissolve in the hot water. Cool as quickly as possible and add the laudanum, and give as a dose. If there is abunoant formation of gas, give the following promptly :

No 87.

* Ounce powdered aloes,

1 Ounce aromatic aunmonia,

1 Ounce willphuric ethar,

1 \% Ounce warm water.

What to do.-Relieve the pain by means of an opiate, and cause movement of the bowels. To do this in mild eases the following will be good in eonnection with injections of warm water :

No. 86 .

1 Ounce of laudanum,

4 to 5 Drathmy aloes,

1 Pint hot witter. 
Mix and give at once. Another colic drench in good repute is the following:

Yo. 88.

4 Draehms aloes,

1 Ounce sulphuric ether,

1 Ounce laudanum.

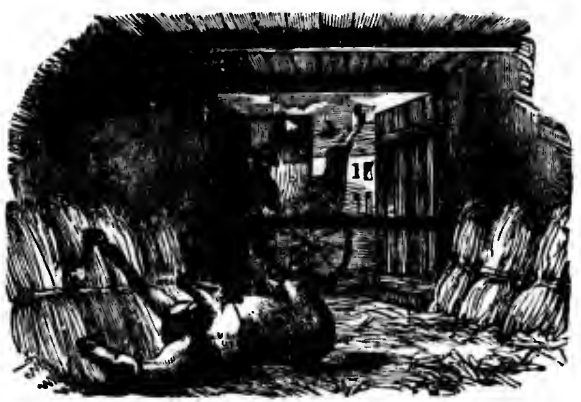

THIRD GTAGE OF BPABMODIC COLIC.

Mix, pulverize the aloes in a pint and a half of hot water; cool, add the other ingredients and give immediately. If relief is not obtained, yive as a second dose the following:

No. 89.

16. Ounce sulphuric ether,

1/2Ounce 1:แndanum,

3/. Omeo spirlts enmphor,

te Outuce essence ol peppermint.

Mix in a pint of gruel and turn down. The symptoms in cattle are uneasiness, shuffling of the hind legs when standing. When lying down they will kick with the outer limbs. There will be monning and twisting of the tail. The same treatment is advised as for the horse, except that one pint of linseed oil should replace the aloes. Give the doses by allowing the liquid to trickle down the throat very slowly. The doses should be doubie that of the horse. Swine should have castor oil one ounce in place of the linseed oil ; and sheep three-quarters of an ounce. Otherwise the doses should be about one-quarter to onc-fifth those ordered for the horse.

Flatulent Colic.-This disease is dingerous, and is generally the msult of a chronic distension of the bowels, with tendency to inflammation and rupture of the conts.

It may be the result of some other disease, or appear as a consequence of the spasmodic form; or, may be produced by the same causes as those assigned to the acute form. 
How to know it.-The expression of pain is constant but not so acute. The pulse is rapid and feeble, with difficult breathing; the feet and ears are cold: the abdomen is tense and swollen, and it sounds drum-like when struck. The animal is weak and sometimes delirious. The intes. tines are painful (sore) as is shown by the cautious manner of lying down: if, indeed, the horse lies down at all.

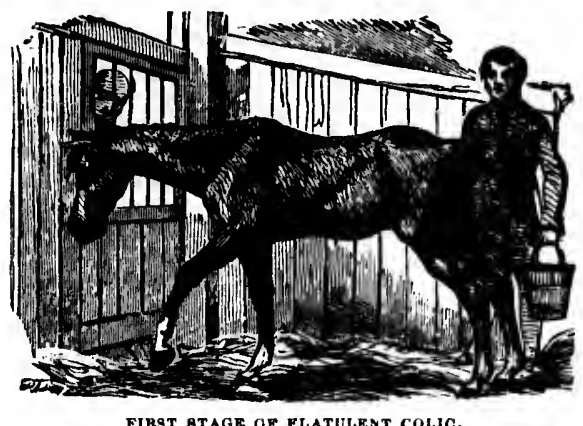

What to do.-Be careful about giving purgatives. Act by injections of soapsuds and oil of turpentine; removing the contents of the impacted rectum with the well oiled hand. Give the following injection:

No. 90. 34 Pint oil of turpentine.

1 Quart of soupsuds.

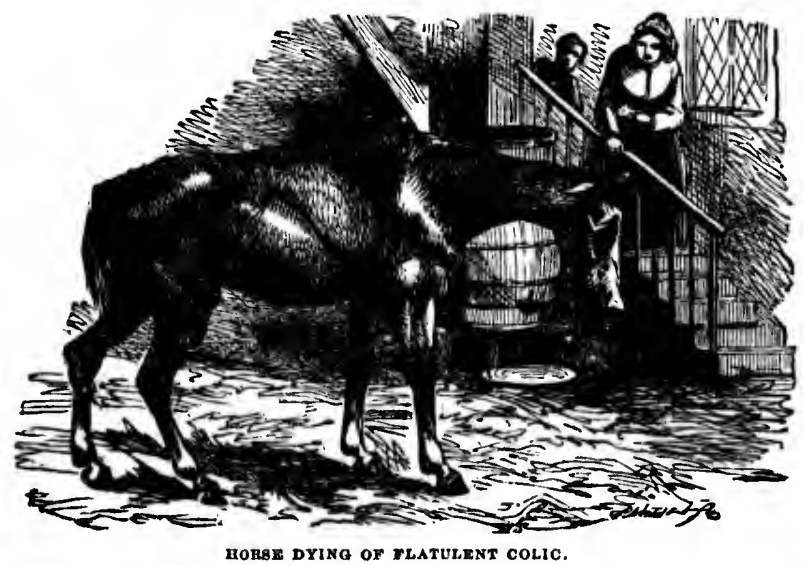

Repeat in half an hour if necessary. If there is great distension puncture the large intestine, or, where the sound when tapping with the 
knuckles is most dru n-like, plunge in a trochar and allow the gas to escape through the canula. Give the following according to cireumstarces :

No. 91. $\quad 3$ to 1 Ounce laudanum,

2 to 4 Ounces tincture assafoctida.

Mix in a pint of gruel.

If the colic is the result of disease and exhaustion, with wilch swelling of the belly, try the following:

No. 92 .

1/3 Ouuce chinrate of potash, 3/. Ounce suiphuric ether,

$1 / \%$ Pint wuter.

To be given in a half pint of gruel.

Later in this disease when it is required to act moderately on the bowels the following will be found useful :

No. 93.

2 to 3 Ounces aloes.

Powder the aloes and dissolve the whole in a pint of warm water, and give when cool. During reeovery, the health of the animal must be attended to. Give easily digested food; avoid large draughts of water, and over feeding. Give good grooming; blanket if necessary, and teep the circulation active by hand rubbing of the body and limbs.

\section{The Bot.}

The female bot fly, Astrus-equi, is too well known to need deseription. They lay their eggs on the legs, flanks, and other portions of the horse's body easily reached. The animal in licking its body takes the egg into its mouth and being swallowed they liatch, and the young fasten themselves by means of their hooks to the mueous membrane of the stomach. Here they live and grow and the next season become mature and are passed from the animal, and undergo their transformation to the perfect fly in the earth. So long as the animal is in perfect health they do little if any harm. But in case of disease or insufficient food they hecom? troublesome. Or if they exist in great numbers when nearly or full grown and they are passing from the animal, they sometimes cause severe injury by attaching themselves to the sensitive lining of the bowels. This irritation is not easily distinguished from other forms of indigestion or colic.

In the Spring when the animal is hungry, and there is indication of intestinal difficulty, they may be suspected. If the horse turns up his upper lip, and if the edges of the tongue are red and fiery looking, it 
will be evidence of their existence At this time physic will hasten them away. A usual remedy is to give once a dny for three days, 1 drachm sulphate of copper, to be followed at the end of the time with 4 drachms of Barbadoes aloes, and repeat at the end of a week if necessary. Or the following will be found safe and effective:

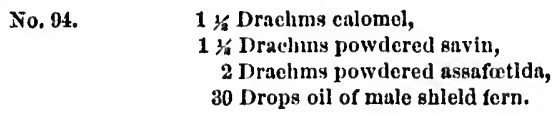

Make into a ball with molasses and linseed meal, to be given at uight and followed next morning with 4 drachms of aloes.

In the South, Azedarach (pride of China) is grown around stables for its supposed efficacy in destroying bots by being eaten by horses. If so, it can only be whise the bots are quito young. Since, after acquiring some age and becuming fastened to the stomach, they resist alike, stroug acids, alkalies, irrespirable gases, nareotics and mineral poisons.

Colics, etc., arising from bots, $r$ ay he trented by anti-spasmodies as given under that head. As a preventive against bots, keep the long hairs of the jaws, breast and fore-limbs trimmed close, and apply a little oil daily ; and brush off any eggs that may be found. Animals kept in stables and well groomed are seldom troubled with bots.
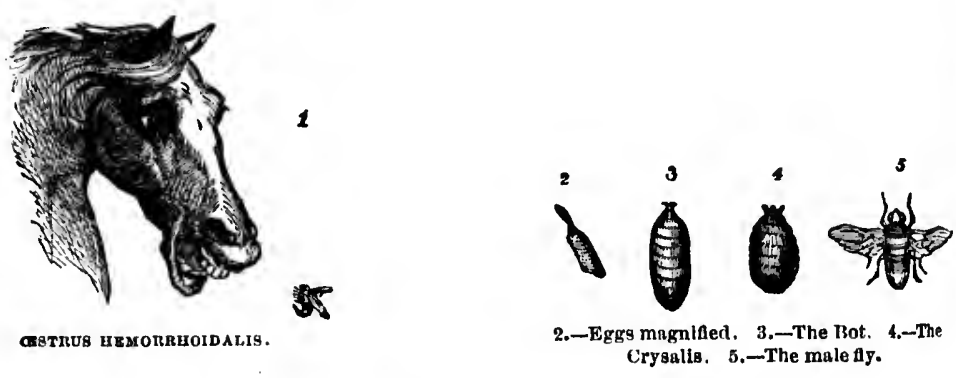

Another bot fly (Estrus Memorrhoidalis) resembles the oestris equi quite elosely, and deposits its eggs upon the lips and upon the hairs under the jaw. Dropping into the food, they are swallowed and fasten t.o the stomach in dense clusters. The larve are somewhat longer in proportion to their bulk than the speeies equi.

When ready to pass away they sometimes cause irritation of the bowels and anus by sticking there. The same means must be used for this species as for the other.

Intestinal worms.-There are various intestinal worms that inhabit the horse, ux bias wol'in : followir

Mix $t$ ether, :II condition For rom are foul following

Follow For thre: week, of

Inject tion. $A$. an injectic

This dis one part will die. ginning at by the rig spleen, the $S$ to the u and this $p$

How to will be fev fering. I 
horse, at least three species of tupe worns und seven of round worms. The ox hits two tape worms and seven round worms. The sheep one tape wor'm and seven round worms. A good vermifuge for tape worm is the following:

No. 95.

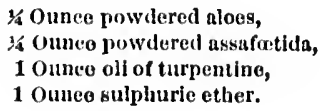

Mix the two first in hot water and when cold add the turpentine and ether, and give in gruel as a drench. If the animal is weak and out of condition, give an ounce of areen nut, and follow with nourishing food. for round worms, if suspected, givo 4 drachms of aloes, and if worms are found in the dung, grive immediately on an empty stomach the following:

No. 96.
$\begin{aligned} & 2 \text { Drachmoll of male fern, } \\ & \text { 3a l'int linseed oil. }\end{aligned}$

Follow this for three days with a dose of 1-2 drachm sulphate of copper. For thread-worns in the rectum give an injection every two days for a week, of the following:
No. 97.
2 Drachms oll of turpentinc,
1 Pint linseed oil.

Inject every day for a week, a purgative dose to precede the first injection. A strong decoetion of wornwood is also al good vermifuge used as an injection.

\section{Inflammation and Rupture of the Colon.}

This disability is usually the result of colic. If through constriction of one part and expansion of another rupture actually oceurs, the animal will die. The colon is the largest division of the intestinal canal. Beginning at the ceecum, (the commenement of the large intestine) it ascends by the riglit kidney, passes under the hollow part of the liver to the spleen, thence descends by the left kidney and passes in the form of $1 \mathrm{n}$ $S$ to the upper part of the os sacrum. It thence runs straight to the anus and this part of it is called the rectum.

How to know Rupture.-The sides of the flanks will be distended, there will be fever and heat, and the animal will give evidenee of its severe suffering. The pulse will be hard. wiry and quick, the belly tender, the 
ears cold ; the pain will be constant, and medieine will inerease it. There will be great and rapidly increased weakness. The symptons are directly opposed to those in colie.

What to do.-In the first stages of the disease give the following, in lime water, every hour or two until three or four doses are given :

$$
\text { No. 08. } 20 \text { Drops tinclure of aconite, }
$$

3á Ounce laudaunm.

In very severe cases a hypodermic injection of 40 grains of chloral hydrate, to be at once followed by one of 3 grains of morphia, to be repeated in an hour; this, however, must he performed by a competent surgeon. The following may be given by the mouth:

$$
\begin{aligned}
& \text { No. 99. } 10 \text { Gralns morphla, } \\
& 1 \text { Ounce cliloral hydrate. }
\end{aligned}
$$

Give in sweetened water, and repeat every two hours until three or four doses are given, or until the symptoms abate.

Extensive fomentations to the bowels will be beneficial. This may be done by folding a blanket inside a rubber eloth which is fastened over the back. Keep the blanket soaked with water as warm as ean be borne.

If the disease be influnmation of the bowels, or enteritis, whether it does or does not follow an attack of eolic, among the symptoms will be stretching of the lips upward. This may however be done when there

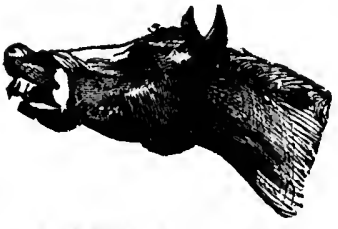

NOSE BTRAINED UPWAHD. is abdominal irritation of any kind. If the inflimmation be severe, so shown by increased heat and fever, an ammoniaeal blister may be applied. Dilute strong liquor of ammonia with six times its bulk of cold water, saturate a cloth with it and lay it on several folds of blanket, to be held to the belly by four men who will not mind the fumes. The manner of holding it is shown in the eut on next page.

Watch the action of the ammonia. It may blister within ten minutes, or it maly take twice that time. Do not allow it to eat the skin, else a bad sore will be the result. When the proper effeet is produced remove it at once. It should really be applied only under the direction of a veterinary surgeon. They are, unfortunately, not always near. In this case, to save life, something must be risked. The worst inflammatory symptoms being stayed, give every two hours until three or four doses are given, or a favorable result is obtained, the following:

No. $100 . \quad 30$ Grains calomel,

$$
1 \text { Ounee Jaudanum. }
$$

Mix

slowuld

Cooked

them br

drink it

This is the bowel

How to protrusiol

What to and also u this do no golden se:

\section{Causes.-} other afficic White elor dentition, intation of horses in frothy n and genera

What to the mouth 
Mix in half a pint of gruel. As the animul begins to take food it should have bran and oatmeal mashes, mixed with tea of slippery elm bark. Cooked food should be given, and if earrots are at hand, give a mess of them boiled every day. Skimmed milk is excellent if the animal will drink it.

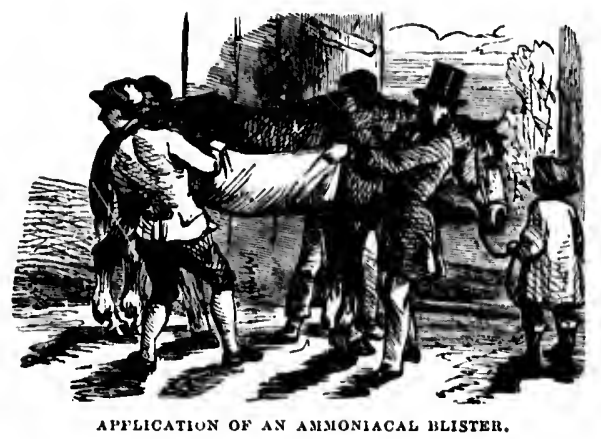

\section{Inflammation and Bleeding of tho Rectum.}

This is a difficulty that often accompanies or follows inflammation of the bowels.

How to know it.-There will be heat and swelling, with or without protrusion and bleeding of the rectum.

What to do. - Wash the parts with a weak solution of salt and water, and also use injections of the same as often as may seem necessary. If this do not give relief add a slight infusion of chlorate of potash and golden seal.

\section{Spontaneoug Salivation.}

Causes.-This infirmity is generally the result of or symptom of some other afliction. It is often produced by something the animal has eaten. White clover will produce it. Caries and other diseases of the teeth : dentition, paralysis of the lips, ulcers of the mouth, irritating food, irritation by the bit, and especially from medicaments attached to the bits of horses by ignorant stable men. It oceurs as a free diseharge of saliva in frothy masses or in stringy filaments, with frequent swallowing, thirst, and generally indigestion.

What to do-Remove the cause. If the cause is from alkalies, wash the mouth with weak vinegar. If from acids, use lime water. If from 
caustie salts, use white of egg, or tea of slippery elm burk. If there in inflanmation with costiveness, open the bowels with injections of warm water, or soapsuds, and wash the mouth frequently with vinegar and honey. If this do not effect a cure wash the mouth with alum water. If there ure ulcers touch them with a fenther wet with the following:

$$
\begin{aligned}
& \text { No. 101. } \\
& 10 \text { (iralns lunar caustic, } \\
& 1 \text { Ounce distilled water. }
\end{aligned}
$$

If there are tumors with pus, lanee them. If there is sloughing wash with the following:

$$
\begin{aligned}
& \text { No. 102. Drachin kolution of permanganate of potassa, } \\
& 1 \text { 1'int rainwater. }
\end{aligned}
$$

Give plenty of cool water, so the animal may take it at will, and feed with soft or boiled food, and if there is much swelling, k'ep the head tied up.

\section{Inflammation of the Stomach.}

Causes.-This disense is not common in horses, and oceurs larely from eating vegetable poisons, and more generally from poisoning ly arsenir given in the food by ignorint stable-men, to make the horse earry a shining coat and form at the bit. It is also produced by the licking of external corrosive applications, thus producing acute gastritis.

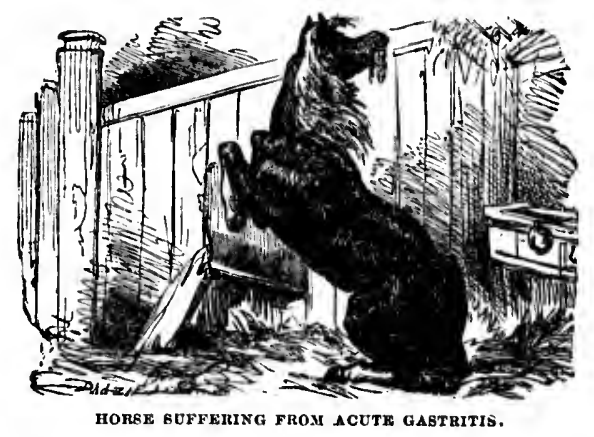

The symptoms are various in unison with the causes producing them. These are, refusing food, extreme thirst, redness of the nasal and conjunctival membranes, discharge of ropy saliva, frequent eruetations with fetid smell, colic, rolling on the ground, pawing, striking at the abdomen. ctc., s tucked up flanks, heaving, panting, small, quick pulse, viole it

striinis timl of rulsion

What trouble

Mix a drachm low, tik of the $t$ through sice alrtic fact whe liv frecly

This is and also 'becones : itching th lirely wor What to
bowels in
keep the
goldenseal
the anus,
that article

Causes.this diseas ordinary $\mathrm{fo}$ eign substa litter and $b$ How to $\mathrm{k}$ i and nostril 
struining, passing of mueus in lnrge quantities, protrusion and inflnmmation of the opening, glances at the nhdomen, prostrution of strength, con rulsions, madness and death.

What to do.-Tho tirst thing, if possible, is to find out what caused the trouble. If this cannot be found, give at oneo:

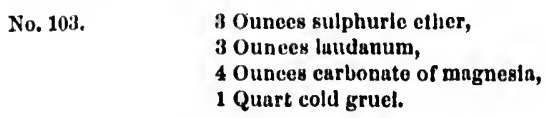

Mix and give as a dose. If the nulso be low, ald to the above one drachm carbonate of ammonin. If the animal is wenk, but able to swallow, take plenty of time, do not use violent means. If there is paralysis of the throat, or the horse is in delirium, the doso must be injected flurough the nostril, by means of a pump and pipo, or horse eatheter. see article tetanus. $\Lambda$ s soon as there is evidence of recovery, and in fact whenever the animal will take it, thin stareh or gruel of flour should 1. freely given to sheath the mucus surfaces.

\section{Soreness and Itching of the Anus.}

This is a disense following inflammation and disease of the rectum. and also produced by other causes. The anus or orifice of the rectum becomes sore. There is a peculiar dryness with seurf, and to relieve the itehing the horse sometimes rubs the roots of his tail until the hair is enlirely worn awily.

What to do.-Attend to the general health of the horse, to keep the howels in a natural condition. Mix a littlo fino salt with lard oil, and keep the parts well oiled, with friction. If the trouble be inside, a little goldenseal well rubbed down with salt butter and passed earefully within the anus, will give relief. If the difficulty is oceasioned by worms, see thit article.

\section{Chronic Gastritis.}

Causes.-Anything which impairs the digestive functions may produce this disease. It is, however, in its chronic form, extremely rare. The erdinary food will be refused, and the animal will persist in enting foreign substanees-old lime mortar, the wood work of the stable, earth, litter and bedding.

How to know it.-There is a dry cough ; the membrane of the mouth and nostrils are dry and pale; the breath is tainted;: the evacuations 
smell badly; the eyes are sunk, the cont dry nud migged; the horse loses condition and becomes pot bellied; the anus is lux and prominent.

What to do.-The cure will take time. Prevent the unimal from in. dulging its unnatural appetite. The following made into a ball will be indicated.

No. 104.

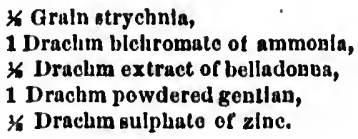

Give this as a ball once $\boldsymbol{u}$ day. If after continuing soveral days there is no improvement, give the following:

No. 105.

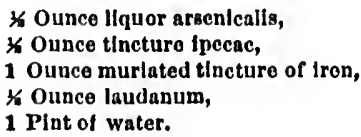

$\Lambda$ s the animal gets stronger give an ounce of sulphuric ether daily in a pint of water.

If the animal has simply chronic indigestion, that is, the discase docs not show in the severe form we have depicted, to improve the general health the following will be indicated :

No. 106.

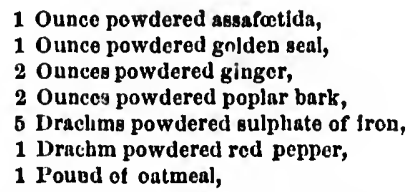

Mix, divide into sixteen messes, and give one every night in the food. In addition to this the following will make a good appetizer :

$$
\begin{aligned}
& 1 \text { Quart brandy, } \\
& 1 \text { Ounce salt. }
\end{aligned}
$$

Mix and give a wine glass full night and morning in gruel, just before the food. The food given must be of the very best, and that which is easily digested. Boiled oats, shorts and carrots, with sufficient good hay to disteud the stomach. Keep the animal muzzled during the intervals of feeding, to prevent foul feeding. That is, cating litter or other injurious substances. If acidity of the stomach be shown, moisten the hay given, and sprinkle it freely with maguesia. 


\section{Spasm of the Diaphragm.}

Causes.-Hard riding or dnving of " horse constitutionally weak.

How to know it.-If the horse is being ridden, there will be a sensition to the rider as though a sudden blow was given inside the hor'se. This is from spasmodie action of the diaphrugm (the midriff or musch । separating the (hest from the abdomen) in drawing the breatl. If the minual is still driven forward it sometimes suddenly fulls and dies of suffocution.

What to do.-There is no eure. Relief may be given by elothing the animal. Lead him to the nearest stable or shed and give the following:

\section{No. 10s. 3 Drnchms aromatio spirits of ammonia, \\ 3 Drichms tincture of ginger \\ 8 Ouuces lautanum, \\ 14 Ounces ether.}

Mix in a pint of oil or gruel and give as a dreneh, or give the following:

No. 109.

3. Drachm camplior,

1 Drachm powlered ginger,

1 Drachm carboute of nmmonia.

Mix with sufficient linseed meal and hot water to form a ball. Repeat at an interval of three hours if relief is not afforded by the first dose.

A horse subject to this affection should have only slow work. The diaphragm may be strengthened by giving for some time a daily dose of one drachm of powdered sulphate of iron in the food.

\section{Rupture of the Stomach.}

he food.

Rupture, when it ensues, ends pretty surely in death. Rupture of the stomach is produced By working or driving a horse until he is very hungry and then feeding and watering unduly. The only symptoms which show, are violent colie, and the tenseness of the tissues. There are many ruptures where animals die, and the owner does not know what is the diffi 'ulty. If the mischief has proceeded to rupture, the animal muy as wel!' be killed.

One of the positions assumed by a liorse suffering from abdominal injuries, is this: He will persistently sit on his haunches. Animals will assume this position and yet occasionally recover. Another position assumed is, for the animal to kneel and support himself uporn his hind 
legs. Such unnatural positions show the intense pain which leads to such attitu des to get relief.

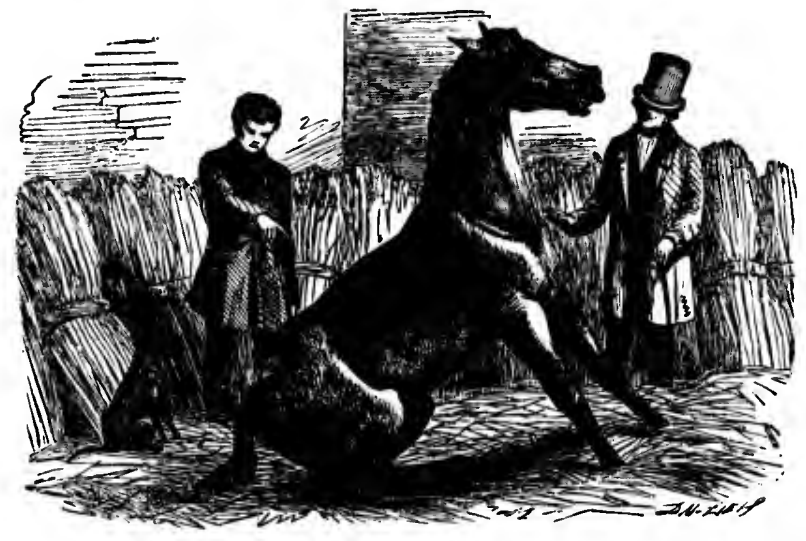

UNNATURAL ATTITUDE INDICATIVE OF ABDOMINAL INJURY.

\section{Gorged Stomach.}

When this occurs from over feeding, the bowels should be immedittely relieved by removing the contents by repeated injections of warm water. Let the animal be gently wilked abont, and wirmly elothed in cold weather. The operator must ant according to circumstames. If discor-

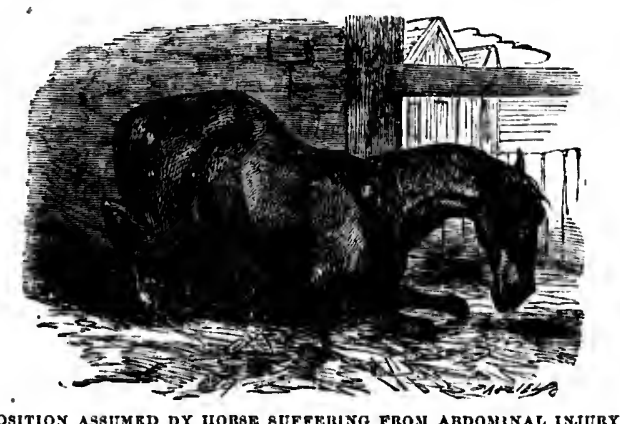

ered early, or before colic sets in, give the following to eracuate the bowels after having relieved them by injections:

No. 110.
6 Irachums powilured aloes,

1 Onnee sirup of buekthorn.

1 Uunce tincture of ghiger.
Dis: ger, al

Infla in all d the ani

\section{Cause} from in an exhit

\section{How $t$}

acute $\mathrm{wl}$ altermatc the breat iug will ent, and

What ounces, at Apply $m$ if :al bli cooked gi toms are disease $\mathrm{pr}$ Oat or ryc soft bransound oat. In cise place, whic potassa mi manded, 9

This is being the 1 tion of $f_{\text {:I }}$ rupture of it is cutirel nuinjal wil Rupture of better to $\mathrm{ki}$ 
Dissolve the aloes in a pint of warm water, add the buckthorn and ginger, and give as a drench.

\section{Inflammation of the Peritoneum.}

Inflammation of the lining membrane of the abdomen is likely to oscur in all domestic animals. In ruminants the right side is most affected, and the animal will stand with its feet well together.

Causes.-Injuries either from rupture of the stomach or intestines, $\omega^{*}$ from injuries to the abdominal walls, exposure to chill or eold, or giving an exhausted horse a wet bed to lie on.

How to know it.-There, may be colic, or steady pain. This will be acute when the affected parts ure pressed. There may be chill and fever ulternately, and loss of appetite. The pulse will be rapid and hard, and the breatl quick and catehing, but when effusion takes place the breathing will be deep and easier; the pulse will soften, the belly will be pendcot, and there will be fluctuations when handled, from the water contained.

What to do.-In the early stages, give full closes of landanum; 1 to 2 ounces, as may be needed, to allay pain and keep the bowels inactive. Apply mustard poultices to the abdomen, or in extreme eases the amno1: al blister as previously described. Frequent injections of thoroughly cooked gruel may be thrown into the rectum, but until the worst symptoms are past the animial should take nothing into the stomach. As tho disease progresses farorably, great care should be exercised in feeding. Oat or rye meal gruel may first be given. If these agree well, give warm soft bran-mashes, with a little oat meal added, and at length hay and sound oats.

In ease alssorption of the effusion of water in the eavity does not take place, which may be known by regular and ample stuling, give 6 drachms potassa nitrite, daily, until the kidneys aet. If tonics seem to be demanded, give duily doses of 1-2 drachm oxide of iron.

\section{Strangulation of the Intestines.}

This is produced by various causes, the result of colic and rupture being the most frequent. Strangulation may be produced by the formation of false membrumes, by the involvent of the intestines, by the rupture of the mesentary, or by the rolling on itself of the intestine unitil it is entirely strungulated. In this as in other abdominal difficulties, the animal will often assume unnatural positions, as shown in the article Rupture of the Stomach. If it be a ruminant, and in good flesh, it is better to kill the animal at once. Some forms of strangulution in eattle 
of sufficient value, may be remedied by a veterinary surgeon. In this case, give laudanum in 2-ounce doses to keep tho animal quiet until the doctor arrives. Relief is obtained by cutting into the side and releasing the intestine. For the horse give opium in one or two drachm doses as the nature of the ease may seem to require to relieve the pain, and trust to nature to effect a cure by relensing the parts naturally.

\section{Functional Diseases of the Liver.}

The liver of the horse is not particularly subject to disease. It was formerly supposed to be aimost entirely exempt, but later researches show it to be an agent, through obstruction, und the prineipal local seat of various disorders, as diabetes, blood poisoning from imperfect oxygeration of the albuminoids, ete.

How to know it.-In active congestions of the liver, which is the disease most usually prevalent and this principally in the South, there may be sluggishness, irregular bowels, abundant liquid discharges of

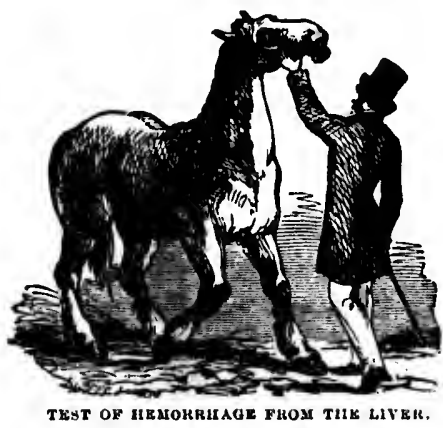
deep yellow or orange colored duug. There will be extreme and painful prostration, the eyes will be sunken, the pulse exeited, and the limbs will tremble. There may be colicky pains. If the last ribs are struck with some force, extreme pain will be shown. If the horse faints and there are patlid mucus membrane, with quick and weak pulse, it may be conjectured that rupture of the liver has taken place. In this ease, the end is death. The illustration we give will show the test alike for ruptured liver and spleen.

What to do.-In the beginning, that is when the pulse is strong, free bleeding will often eheek the disease. When the pulse is weak, blood must not be drawn; or, if the blood does not flow freely, elose the orifice at once.

Apply mustard poultices to the limbs. Give one pound of sulphate of soda dissolved in a quart of water, to deplete the portal system and liver. Apply ice to the last ribs to eheck effusion. Apply a blister over the region of the liver. Continue the sulphate of soda in doses of one to four ounees ditily.

During the attack and recovery the animal must have pure air, and soft, es cise mu

Infla inflanum be quic bowels The be membri

What purge a walm w: doses of If the $\mathrm{h}$ fresh $g \mathrm{I}$ Peruvian

The go general il dry and will bec bellied; $t$ but vora brenth, di with the of itehing an the passa eggos will ! will raise against :un and bite it limbs. TI good gene ing from w

Besides are those headed and

What to o nature, and pected, and 

blood e orifice

bhate of d liver. ver the one to air, and

soft, easily digested food, and as recovery ensues, daily moderate exerciso must be given.

Inflammation of the liver is rare. If congestion has procecded to inflammation the region of the last rib will be very tender. There will be quickening of the pulse. The mouth will be hot and elammy; the howels may be at first loose, yellow and bilious, but soon become costive. The heat of the body is raised; patehes may appear on the mucous membranes; and the limbs, especially the hind ones, will swell.

What to do.-In this case all bleeding should be aroided. 'Give as a purge a pound of sulphate of soda (glauber salts) aided by injections of warm water. After the bowels are opened, keep them so with small doses of glauher salts, six ounces, or, cream of tartar four ounces daily. If the horse eat anything it must be very light mashes, pulped roots or fresh grass. As the horse improves, give twice a day two ounces of Peruvian bark or two drachms twice a day of gentian.

\section{Parasites which Infest the Intestines.}

The general symptoms for intestinal worms, in large quantity, are general ill health. The animal will lose condition : the skin will be scurfy, dry and often itching; the animal will become hide bound and pot bellied; the appetite will be irregular but voracious; there will be fetid brenth, diarrhea, passing of mueus with the dung, colicky pains, swelling, itching and puffy anus, and especially the passage of the worms or their eggs will be certain proof. The horse will raise the upper lip and rub it against anything near. Colts will pick and hite the hair from the body and limhs. The annexed cut will give a good general idea of an animal suffering from worms.

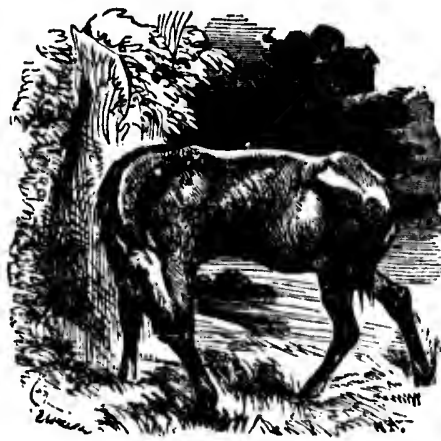

Colt plckiso fain from its LEo, GIVINO phoOY of wolks.

Besides the bot, already trented of, which inhabits the stomach, there are those of the intestines proper. These are the tape worm, round headed and flat headed, and five species of round worms.

What to do.- Vermifuges are without number, some general in their nature, and others specific for partieular clnsses. When worms are suspected, and the owner of the animal is not sure of tho reality, it is safe 
to give a purge and watch the droppings. The following is a good vermifuge drench :

$$
\text { No. } 111 .
$$ \\ 4 Drachms aioes, \\ 1 Ounce powdered male fern, \\ 20 Drops ofl of worm seed.
}

Give this in a pint of warm gruel an hour before feeding in the moruing.

If it be found that there are tape worms, if the horse is weak, give an ounce of areen nut fasting and follow with 4 drachms of aloes. If the animal is strong, give an ounce of oil of turpentine in an ounce of water. In four hours give another dose and follow in an hour with 4 drachms aloes. In the case of common pin worms, (Sclerostomuin Equinum) and all worns inhabiting the bowels except the tine worm, the following vermifuge will act kindly:

No. 112.

1 Drachm tartar emetic,

\% Drachm powdered ginger.

Mix with enough linseed meal to form a ball, then moisten with hot water and give a dose daily for a week, before feeding. Follow with a dose of one pint of linseed oil, wait another week, and repeat as before. Then give good generous diet, with tonics daily, say 2 drachms sulphate of iron, or 4 drachums gentian in the food.

For worms lodging in the gut near the rectum, give an injection of a strong decoction of wormwood or tansey. The prevention of worms is to pay attention to the water the animal drinks, to be careful of dog's droppings in the pasture, and to give sound grain and hay as food, since libcral feeding and good general care will often extirpate the parasites. For other vermifuges see article 3 of this chapter.

\section{Diarrhea.}

Diarrhea is a condition of frequent watery discharges from the bowels, and may be produced by so many causes, as irritating and indigestible food, worms, severe purgation by medieines, disorders of the liver, or constitutional tendency, that no general rule can be given. The owner of the animal must find the cause before proceeding intelligently to give relief. The most we can $d o$ is to give some general indications.

Sometimes diarrhœa is an effort of nature to rid the body of injurious matter; then the effort should be aided. Early in tho effort give the horse a pint of linseed oil, or if an active purge be required, a pint of castor oil. If the diarrhœa does not cease check it with ounce doses of laudanum and follow with tea of slippery elm bark, or linseed. If the

difficult or, dose require: daily, o caused giving it cases $m$

For s twice or

For so

Form i

If the fcllowing

Iake in

When $t$ following :

Mix, and and contin

Astringe 
difficulty refuse to give wiy, doses of 2 scruples of tannin may be given, or, doses of 3 drachms of cutechu every hour until checked. The ox requires double the dose. Follow with tonies, say 4 drachms of gentian daily, or one ounce of peruvian bark, with sound, easily digested food. If caused by bad water, throw a handful of charcoal in the water before giving it to drink. The following will be found beneficial in the several cases mentioned.

For sour and fetid discharges mix the following ingredients in the food twice or thrice daily.
No. 113.
1 Ounce powdered chalk,
1 Ounce bisulphate of soda.

For sour discharges with griping, take :
No. 114.
1 Drachm powderell opium,
1 Drachm powiterel chaik,
20 Drops carbolic aeid.

Form into a ball with linseed neal and molasses.

If the bowels are simply in an irritable, relaxed condition, use the fcllowing :
No. 115 .
1 Ounce powdered chalk,
1 Ounce catechu,
1 Ounce ginger,
1 Drachin opium.

II:ke into a ball with linseed meal and molasses.

When the diarrhœa is the result of violent medical purging, try the following:
No. 116.
2 Onuces laudanum.
2 Ounces powdered chalk.

bowels,

gestible

iver, or wher of to give

jjurious give the pint of loses of If the

Jix, and give in a quart of thin starch, or flour gruel. For excessive and continued purging, give at one dose the following:
No. 117.
1 Ounce laudanum,
1 Ounce sulphuric ether,
20 Grains tamic acid.
Mix in a pint of thix-seed tea.

Astringent injections may be given as follows:
No. 118.
2 Ounces laudanum,
2 Drachms acetate of lead,
1 Quart starch wuter. 
Inject half of this and follow with the remainder in three hours, if nec essary, or give at one injection the following:

No. 119.

4 Drachms tannio acld, 1 Pint starch water.

In ease of cattle the same quantities may be used, but when given by the mouth it must be made to triekle slowly down the throat.

I. JalNDIC NkYs. GLAVEL THON OF XIII. sp.

The hol yellows, is (if it be not by non of bile alr

Causes.the bowel: fullness of hepatic ast of congest: In solid animals it : ance of the

How to The mucou olstruction from being 


\section{FHAPTER VII.}

\section{DIBEASES OF THE IIIVER, URINARY ORGANS, FTC.}

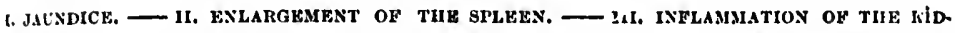

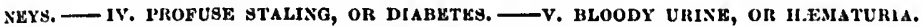

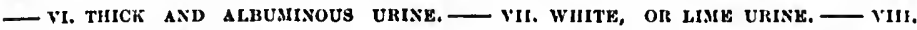
GRAVEL, OR STONE IN THE BLADDER. - IX. SUPPRRSSION OF VRINE. - X. INFLAMMA-

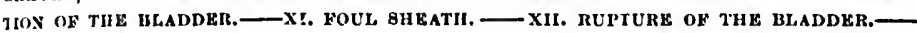
XII. SPASM OF THE URETHRA.-XIV. INYLAMMATIOY OF THE ORGANS OF GENERATION.

\section{Jaundice.}

The horse is subject to but few diseases of the liver. Jaundice or the yellows, is a condition in which the visible mucous membranes, the skin (if it be naturally white) the urine and the tissues are stained yellow, not by non-secretion of the bile from the blood, but by the re-absorption of bile already secreted.

Causes.-Obstruction of the bile duct from any cause. Obstruction of the bowels hindering the proper diseharge of the bile. Diminished fullness of the eapillary vessels of the liver from obstruction of the hepatic artery or aorta. And from undue secretion of the bile in cases of congestion of the liver.

In solid hoofed animals the blood is casily dissolved. In flesh-eating animals it is not so. Hence, although there is often a jaundiced appearanee of the membranes in horses, it is comparatively harmless.

How to know it.-There will be a general colorntion of the tirsues. The mucous nembrane will be yellow. The urine will be yellow. In obstruction of the bile duet tho dung will be fetid, and of a clay color from being deroid of bile. 
What to do.-No general rule con be laid down. The following is 1 good remedy for torpiclity of the liver, when there is general dulhess and biliousness.

120.

\author{
1 Pound Epsom salts, \\ 1 Pound Glauber saits, \\ 1 Pound common salt, \\ 1 Ounce essence of ginger, \\ 1 Gallon warm water.
}

Mix and give a pint from one to three times a dny until a gentle but full purgation is produced. Follow this up with daily doses of one seruple of podophyllin.

This remedy will also be indicated for eattle, except that they should have the following formula as a purge instead of No. 120:

$$
\begin{aligned}
& \text { No. 121. } \\
& \text { 3/2 Pound sulphate of magncsla, } \\
& \text { 2 Ounces powdered gluger. }
\end{aligned}
$$

Give this dose in two quarts of water once a day until a free cvacuation of the bowels is produced, giving also daily one scruple of podophyllin.

Saline purges do not always act kindly on horses. If so the following will be indicated if there is considerable congestion :

$$
\begin{aligned}
& \text { No. 122. } \\
& \begin{array}{l}
30 \text { Gralns calomel, } \\
1 \text { Drachm alocs, } \\
2 \text { Drachms soup, } \\
4 \text { Draclims powdered rhubarb. }
\end{array}
\end{aligned}
$$

Mix with mblasses into a ball and give twice a day until a moderate operation of the bowels is had.

If the disease occurs in the Spring, turning upon sueculent gras, especially where dundelion is plenty, will generally effect a cure.

\title{
II. Enlargement of the Spleen.
}

The pancreas and the spleen are subject to a variety of disenses, very difficult to determine. The pancreas is a gland which secretes the pancreatic juice, by which emulsion takes place with the fatty aliments by means of a duct leading into the intestines. The presence of fitty matter in the dung will imply a suppression of these juices. If there are sharp, eolicky pains without fever, obstruction of the duet by calculi may be suspected. If there is general fever, with pain and tenderness behind the last rib on the right side, inflammation may be suspected.

For calculi use fomentations of hot water over the parts affected, and 
give anti-spasmodics, chloral hydrate in hnlf ounce doses daily, or hyoscyamus extract two drachm doses, or belladoma two drachm doses, is the case may be.

If there is inflammation give laxitive medicines, one and a half ounces dandelion; blister the right side, and eonfine the nuimal to light diet.

For suppressed secretion give one ounce doses of sulphuric ether.

So far as affections of the spleen ure concerned, it is an involvent in disenses of the liver and other glands. In highly fed animals enlargement ensues; in badly fed ones degeneration or whsting. Obstrueted circulation through the liver will engorge the spleen almost to rupture sometimes. In tuberculosis, cancer, glanders and blood poisoning it is affected. Anthrax and other fevers tend to enlargement of the spleen, sometimes to rupture. So little is renlly known of the spleen and its true functions, that but little can be done except by giving general attentiou to the health and by menns of tonies nnd good nursing to build up the hetlth.

III. Inflammation of the Ridneys.

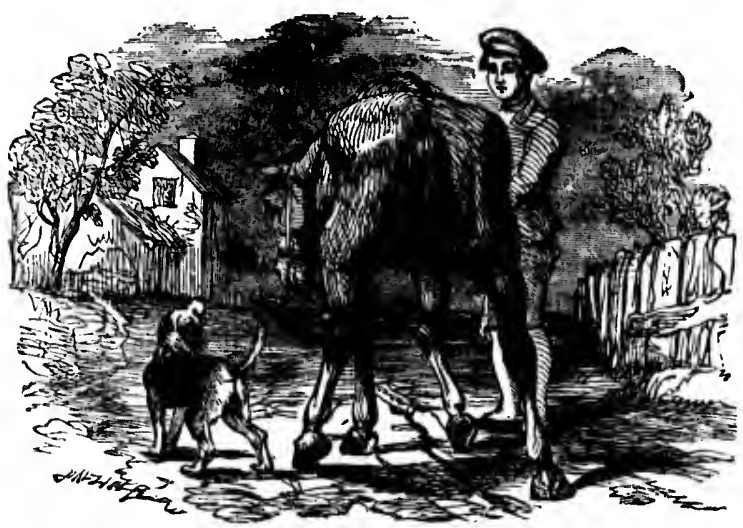

BYMPTOMS ATTENDING DISEASES OF THE URINARY ORGANS.

Causes.-Inflammation of the kidneys, Nephritis, is produced by at varicty of causes. Blows on, or sprains in the region of the loins, callculi, the excessive use of diuretics to which some stalblemen are prone, musty fodder, or that which eontains irritunt plants, ete.

How to know it.-There will be more or less fever, sometimes a high fever; colieky pains; looking at the abdomen; the borse will lie down with extrene caution; frequent passages of urine in small quantity, but 
very high colored, sometimes containing blood and even pus; the legs swell uniformly from the hoofs up; the pulse is rupid, the bowels costive and the breathing exeited; the horse straddles in his gait; this, however, is a genernl charucteristic of all diseases of tho urinury organs, but in severe inflammation it amounts almost to helplessness.

There is, however, one test that is constunt: there is extreme tenderness of the bony processes about six inches from the spine in the loins, pressure over the kidneys will show the terrible pain from the crouching nttitude the horse issumes.

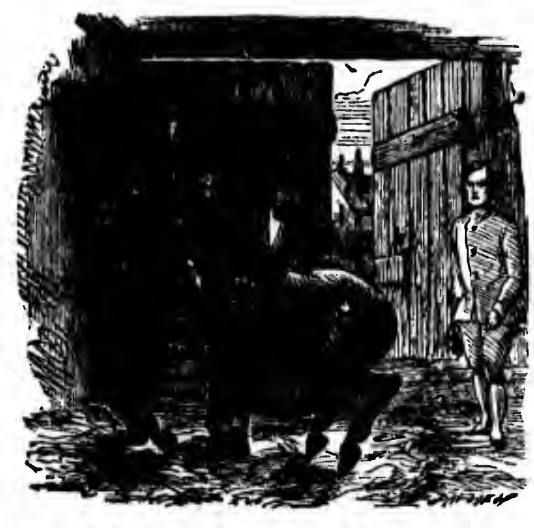

TEST FOR INFLAMMATION OF THX KXDNEYS.

If the urine is examined under a microscope, the fibrinous casts of the kidney tubes will be found. In ehronic cases, stocking of the legs, casts in the urine, moro or less tenderness upon pressure of the loins, and general ill health, may be all that will be observed.

What to do.-In acute cases, if there is a strong pulse and the animal is full of blood, bleeding mey assist $\boldsymbol{\Omega}$ cure. It is not always safe, except under the advice of a veterinarinn of modern practice. Bleeding should never be practiced except in the earliest symptoms. Give an active cathartic.

No. 123.

1 Drachm calomel,

4 Drachms powdered aloes,

Make into a ball with linseed meal and molasses.

Wrap the loins in woolen blankets and foment thoroughly with an infusion of a handful of digitalis leaves in a pail of boiling whter, putting it on as warm us the hand will beat it; or wring a sheep skin out of hot water and apply the flesh side, changing as often as may be necessury.

To one qu if possi with la: proves, or nn o

This polurit, flesh, wc breakiug

Causes favorite also proc dinretic 1 stimulati

How to staliug, o nud spirit the pulse ing noxior

What to with liuse from thir: one of thr formula, $t$

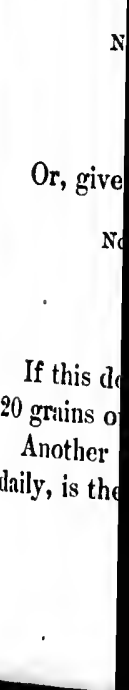


To nssist the evacuntion und ease the pain give injections of linseed ten, one quart, to which un ounce of luudnmun is udded. Get up a good swent if possible. 'This will relieve the kidneys. Kecp the howels gently open with laxatives und relieve the puins with modynes, and as the mimnl improves, give bitter tonics, 3 ounces of Peruvinu burk dnily in three doses; or an ounce of gentian in two druchm doses three times a day.

\section{Profuse Staling, or Diabetes.}

This disease, ealled by various names, as diuresis, dinbetes insipidus, poluria, ete., is simply an excessive secretion of urine, cuusing loss of flesh, weakness, und ut length terminating in exhaustion und " general breaking down of the system.

Causes.-The most common cause is dosing with quack medicines, a farorite pastime of ignorant stablemen, especially for "the water." It is also produced by musty hay and grain, new outs, distillery slops, acid diuretic plants, or any eause irrituting the stomach and at the same time stimulating the kidneys.

How to know it.-There is excessive thirst, profuse and frequent staling, of pale colored urine, thin, and with little odor; loss of conclition and spirits ; the appetite fails; the skin is havd and dry ; the hair harsh: the pulse will be weak, whether fust or slow; depraved uppetite for lickingr noxious sulsstnuces.

What to do.-Change the food at once, well seasoned hny and grain, with linseed tea griven freely in the drink. 'The loorse must not suffer from thirst, but inordinate drinking should not be allowed. Iodine is one of the chief speeifies in this disease. The following will be a good formula, to be given three times a day in water:

No. 124. 20 Grains iodine,

1 Drachn iodicie of potassium,

4 Dracims carbouate of soda.

Mix, and give in waler.

Or, give daily the following :

No 2 Drachms phosplate of iron,

2 Drachms iodide of potassium,

4 Drachms Peruvian bark.

Mix, and give once a day in water.

If this does not soon show a disposition to eheck the disease, add 15 to 20 grains of ereosote daily.

Another good formula, to be given once a day, or in bad cases twice daily, is the following : 
No. 126.

$$
\begin{aligned}
& 30 \text { Gralns lodine, } \\
& 2 \text { Drielums mulphate of irou, } \\
& \% \text { Ounce powdered geutlan. }
\end{aligned}
$$

This ,

Give as a bull, made with molnsses and linseed menl. If four or five doses do not show decided effect discontinue. Six or seven days should effect $n$ cure.

\section{Bloody Urine, or Hæmaturia.}

Causes.-Sprnins or bruising of the loins, stone in the kidneys, urinury passages or bladder ; blood poisoning.

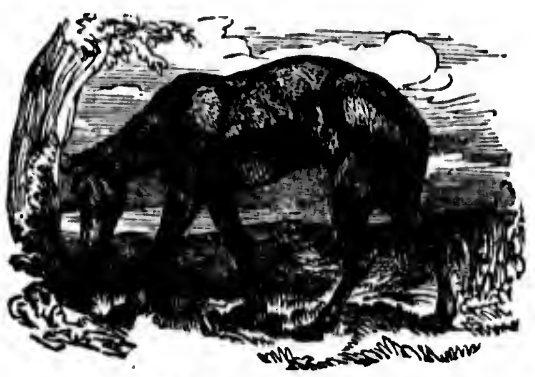

HORSE BUYYERING FROM BLOODY URINE.

How to Determine the Condition.-If from local irritution, the blood heing in a healthy state, there will be clots of blood passed, and fibricious casts of the urinary tubes entangling blood globules. These may be seen with a good lens. If there is gravel more or less gritty matter will be passed. If from blood poisoning, the tests must be made by a reterinary surgeon, from the urine, who can then preseribe the proper treatment.

What to do.-The general practice is to give sound food, grood shelter, mucilaginous drinks, as linseed or slippery elın tea, or marsh mallow ter. Also acid astringents, vinegar, buttermilk, a weak decoetion of white oak bark. If the passages are profuse apply cold water to the loins. If there is inflammation foment with warn water (cloths suturated with hot water) and follow with a mustard plaster. If the bowels are inactive, give the following:

\section{No. 127.}

\section{Drachms aloes,} 1 Ounce cream tartar.

Mix in one and a half pints of warm water and give when cool, aiding the operation by an injection of one quart of soap suds and four ounces oil of turpentine. dischiturg :ust on fevers, it allt on i with degr tining the

How to $k$ suffering $f$ out positio In its mild begins to $\mathrm{fl}$ rondition, commencin thicker, $m$ smell. It in Bright's

What to warmly. I skin wrung digitalis (F recommend urine, not a and exercise 


\section{Thiok and Albuminous Urino.}

This disnbility in horsos, charneterized by n thick, ropy, albuminous

shelter, ow teil. hite onk ins. If ith hot mactive,

, aiding ounces discharge of urine, is quite common in its milder forms, being wn nttendant on extensivo inflummution of importunt orguns, on rheumutism, fevers, und some conditions of blood poisoning. It is especinlly attendant on inthummation of the kidneys, both neute and chronie, attonded with degenerition and shedding of tho epithelium (the hyers of cells) lining the kidney tubes.

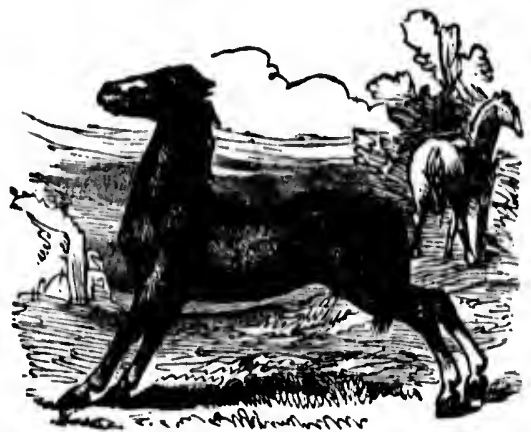

POSITION ASBUARD BY HORSE HAVING aLBUMINOUd URINE.

How tn know it.-'There are two specinl posilions assumed hy horses suffering from severe secretion of albuminous urine. One is the stretched ont position. In the other the back will be roached, as seen in the cut. In its mild stages the urine is thick, ropy, mucilaginous; when it first hegins to flow, of a reddish-brown color, but changing to a more natural condition, ending with a whitish, miky fluid; sometimes the reverse; commeneing white. When the disease is farther adranced the urine is thicker, more deeply tinged, and sometimes offensive to the sense of sunell. It may degenerate into a number of forms, and finally terminate in Bright's disease of the kidneys.

What to do.-Place the animal where it may be comfortable; clothe warmly. If there is inflammation of the kidneys, foment with a sheep skin wrung out of hot water; or better, with an infusion of a handful of digitalis (Foxglove) in a pail of sealding water, and use other measures rcommended in this article. If it be thought necessary to liquify the urine, not always beneficial, prepare the recipe given on the following page, aud exereise great eare in the attendant treatment as there prescribed. 


\section{No. 128. \\ 1 Ounee powdered assafectidn,
2 Ounces powdered juulper berries,
8 Ounces powdered poplar bark.}

Mix, divide into eight parts, and give one night and morning in thr food.

The real animus should be to remove the cause, which, as we have stated, is various. Attend to the general health of the animal, keep the bowels open by a free use of bran mashes and other food of an opening nature. Give a laxative if necessary-say, 5 ounces salts, and Peruvian bark 1 to 2 ounces daily at two or three doses.

\section{White, or Lime Urine:}

The urine is one of the agents used by nature to pass awiy the excess of calcareous or other stony matter from the body. So long as the conditions are normal, even when limy secretions are excessive, it may be nature's means of removing this excess. When the urine beeomes alluuminous, the calciferous matter unites with the albumen, and the result is calculi.

How to know it.-A white matter will be passed at the end of each urination, or the urine may become decidedly limey.

What to do.-Attend to the general health of the horse, give none but sound oats and Indian corn, and swect elean hay from upland meadows.

Sand-like Deposit in the Bladder.-Sometimes a sand-like deposit, or soft magma is made in the bladder, and to such an extent that the urine flows involuntarily and constantly by drops. The remedy is by means of a stomich pump and catheter, to fill the bladder with water. Shake up the contents with the hand introduced through the rectum, and allow the water to flow through the catheter. So proceed to again pump full and empty until all the deposit is clemed.

When an animal is inclined to this disability, 1 drachm of caustic sodia given daily in the water will correct the secretion.

\section{Gravel, or Stone in the Bladder.}

The existence of urinary calculi, whenever found, is dne to the deposit of mineral mutter around some body as a nucleus. This may consist of mucus, fibrine, blood-clot, or even of a erystal deposited f:om oversaturated urine.

Causes.-They are so various that it would be useless to enumerate then. Impaired brenthing, whether from weak or diseased lungs, imperfect action of the liver, or impaired functions generally, are anong the promi bring

How

domest will es be pas: by intr may bo

What lithatrit male is operatio it invols by the :

Preve (Dalure formatio fecd eve give the

Form Animals meadows

Causes. especially severe col ignor:int of the eats

What to severil tin be given i

Give as 
prominent causes. Any cause favoring concentration of urine might bring about the formation of calculi.

How to know it.-Cistus ealculus, or stone in the bladder, oceurs in all domestic :mimals, producing straining in the effort to pass the urine. It will escipe in driblets, often drop by drop, or not at all. Blood will often be passed in elots, and crystals of microscopic calculi will be passed. By jutrodueing the oiled hand into the rectum up to the bladder the stone may be felt. Sometimes there are a number of them.

What to do. - In the case of a female the stone may be broken with a lithatrite. In the ease of a male the operation is ealled lithotomy. The male is operated on standing, or else thrown on the right side. The operation must in any event be performed by a competent surgeon, since it involves cutting and the use of instruments that may not be attempted by the novice.

Preventive Measures.-The seed of Jamestown weed, or thorn apple (Datura stramonium) has been given with good effect in preventing the formation of large caleuli. Give an ounce of the powdered seed in the feed erery other day until six doses are given. In comnection with this give the following:

No. 129.

1 Ounce oil of sassufras,

4 Ounces sweet spirits of niter.

Form into four doses and give one morning and night for two days. Animals predisposed to gravel should be fed on sound hily from old mendows, sound grain, and watered only with soft water.

\section{Suppression of Urine.}

Causes.-Retention or suppression of urine is due to so many causes, especially in old horses, as paralysis of the bladder, meningitis, lockjaw, serere colic or other acute disease, or from irritating drugs given by ignorant stablemen, that the operator must be informed as to the nature of the case.

What to do-If it be caused by paralysis the urine must be drawn of several times a day with a entheter. The following will be indicated to be given internally :

No. 130. 1 Pint winter.

Give as a drench twice a day. 
Another remedy, if one has a hypodermic syringe, would be :

No. 131.

4 Drope sulphuric acid, 2 Grains stryehuine, 3á Ounce alcohol.

Throw one-half of one grain twice daily under the skin.

If the difficulty is due to general weakness of the bladder, give the following stimulant:

$$
\text { No. } 132 .
$$

\section{Gralns powdered cantharides,} 1 Drachn powdered digitails.

Make into a ball with soap.

If there is an accumulation of hard frees in the rectum it must be removed by full injections of strong soap suds, and if necessary removal of the partially softened dung with the oiled hand.

If there is inflammation of the neck of the bladder, as shown by heat, swelling, tenderness, give injeetions of one drachn extract of belladomna in a quart of warm water, thrown repeatedly into the rectum of lorses and into the vagina of mares. To relieve pain give from one-half to two drachms of opium as nay be needed.

\section{Inflammation of the Bladder.}

Causes.-A disease very rare in animals, and when oecurring the effect of violent external injury, or the result of irritating medicines, as croton oil, cantharides, administered by the ignorant. It is quite rare, and may be known by the frequent passing of urine, with great pain and difficulty. As a sure test grasp the horse by the mane half way between the head and shoulder with the left hind; place the right hand under the flank when all nervousuess is passed, press more or less strongly on the abdomen. If inflammation be present the animal evinces intense pain. If the museles be tense and hard there is no inflammation.

What to do.-Give full doses of opium, two drachms, to relieve pain. Give linseed tea, milk, and white of eggs beaten up with water as drinks. As a laxative to relieve the bowels give one to two pints of olive oil as nay be needed. Inject into the bladder the following if you have an instrument :

$$
\text { No. } 133 .
$$

1 Drachm opium,

1 Drachm gum arable,

1 Pint blood warm water.

In severe cases the ammoniacal blister may be applied, as given on the next page, if there is paralysis of the parts, with or without fomen copaiv seem ti clus, gi

A hol difficult

What removin protrude there be washed, salt. E cure is e

This di tion. $\mathrm{Th}$ rousded $n$

What to ounce of fully, by i The diffici There will judgment renewed st

Stricturd gravel, or urination, effected by the normal

a.-In st caused by 
fomentations. The acute symptoms having subsided, give small doses of copaiva, one to two drachms, or buchu, two to three drachms, as may seem to be needed. Give soft or sloppy diet, with linseed tea, slippery clil, gum arabic, or other mucilaginous drinks.

\section{Foul Sheath.}

A horse with a foul sheath is unfortunate in his master, unless the difficulty occurred before purchase.

What to do.-Clean the sheath of all foul matter witl warm soap suds, removing all lumps. To wash the sheath, take hold of the yard when protruded, and without undue violence hold it with gentle pulling until there be no resistance when it may be pulled out its entire length. When washed, oil thoroughly with lard and salt, three parts of lard to one of salt. Every other day or every three days wash again and oil until a cure is effected.

\section{Rupture of the Bladder.}

This difficulty occurs only in the female, the result of difficult parturition. The animal strains violently, and on examination a red, tunid, rounded mass is shown between the lips of the vulva.

What to do.-Wash the parts earefully with tepid water, in which an ounce of laudanum has been mixed with each quart. Then return carefully, hy pressing the center of the mass inwards to correct the eversion. The difficulty will be in returning it through the neck of the bladder. There will be more or less inflammation and softening, thereforo care, judgment and time must be used, not to tear the tissues. If there is renewed straining, place a truss or compress over the vagina.

\section{Stricture of the Urethra.}

Stricture of the urethra is the result of local irritation, the results of gravel, or of strong astringent injections. The symptoms are difficult urination, with great pain and frequent erections. The eure must be effected by the use of eatheters, gradually increasing them in size until the normal condition is reguined.

\section{Inflammation of the Organs of Generation.}

a.-In stallions, there is occasionally inflammation of the testicles, caused by external injury and other caiuses. It may be known by the 
swelling of the parts, a stladdling gait, with drawing up and again let ting down of the testicles.

What to do.-Give a purgative, 4 drachms aloes in $11-2$ pints water. Foment the parts twice a day with warm water. Then dry and apply extract of belladonna or laudinum. If pus (matter) slıould form, known by fluctuation of the parts, open at the soft part. If the gland is involved, and there is threatened destruction of the part, castration had better be performed.

\section{b.-Inflammation of the Womb.}

Causes.-Bruises or other injuries at the time of giving birth, or in getting rid of the afterbirth; retained afterbirth, or exposure to wet or cold after parturition.

How to know it.-Two, three or four days after parturition, there will be an attack of shivering: pains, with looking at the flanks, similis to those in colic; shifting of the hind feet; the loins and abdomen tender, with aching of the loins; the vulva red and swollen; there is frequent straining with fetid discharge. 'L lio oiled hand being introduced into the womb, the neck and body will bo found filled with fluid; the belly will be tense and swollen; the respiration and pulse will be increased, and the temperature of the body hot. There will be grinding of the tecth, great thirst and loss of power in the limbs.

What to do.-After having drawn out the contents of the womb with a eatheter, fill it agrin with tepid water, introduced through the tube, and wash out thoroughly. Then inject one drachm permanganate of potassa in a pint of lukewarm water, adding four ounees of glycerine and half all ounce of laudanum. Give a purgative dose to move the bowels freely, 4 drachms Barbadoes aloes for a mare; (for a cow, 1 pound of glauher salts). Follow this with 20 drops tineture of aconite four times a day for the mare; (for a cow, 30 drops). Give also once a day 5 drachns nitratc of potassa, and also once a day 1 to 2 drachms chlorate of potassa. Apply a blister of mustard to the right flank of the mare, or for a cow, mustard and oil of turpentinc. If there is a weak pulse, prostration and stupor, use stimulants; quinine in 15 to 20 grain doses, camphor and whisky : also antiseptics, chlorate of potassa, 1-drachn doses, or carbolic acid 1-2 drachm doses in a pint of water.

\section{c.-Leucorrhoea, Catarih of the Womb or Vagina.}

The same general treatment is to bo observed as in the foregoing. It may be known by a whitish discharge from the vulva if caused by retained afterbirth. Repeat the injection recommended for inflammation of the womb, daily, and keep up the system with tonics and good food. 
THE HORSE, ITS DISFASES.

The following will form a good tonic, appropriate in any enfecbled condition of the mare, but especially so in the forms of disease just treated.

No. 134

2 Drachms sulphate of iron,

1 Drachra black pepper,

$1 / 2$ Ounce ginger,

\% Ounce gentian.

Divido into threc doses for each day.

or in

iet or

ce will

lar to

ender,

equent

ito the ly will and the , great

with a be, and potassa half an freely, glauher lay for rachns botassit.

a cow, hon and tor' and carbolic

ng. It by remation food. 


\section{CHAPTER VIII.}

\section{DISEASES OF THE TEFTH AND MOUTH.}

1. TEETHLG, OR DENTITION. - II. SHEDDING TEETH. - IIY. BLIND TEETH.—W. DECAY OF THE TEETH.—-V. SCURVY. — VI. STUMP SUCKING, OR CHIB BITING. - VII. LAYPAS.- VIIY. INFLAMMATION IN AND AROUND THE MOUTH. - IX. SLAVERING, - $X$ INFLAMNATION OF THE TONGUE.—XI. SHARP AND PROJECTING TEETH.-XII. SCALD MOUTH. - XIII. APTHA. - XIV. INFLAMNATIIN OF THE PAROTID GLAND. - XV. FISTULA OF THE PAKOTID DUCT.

\section{Teething, or Dentition.}

Dentition in the horse has already been written of and illustrated in the map given in this work. In teething, all animals suffer more or less from irritation and fever of the parts, probably as much so as the human family. In puppies :nd in kittens it often causes convulsions between the third and sixth month. Cattle are principally troubled between the second and third year, and horses from the third to the fourth year, since in the third year they cut four front teeth and eight back ones, and in the fourth year four front back teeth, eight back teeth and the four tushes Hence the reason why it is advised that at this period of their lives they be not hard worked.

In both eattle and horses the rising teeth are sometimes entangled with the teeth that are being shed. There will be redness, swelling, tenderness of the gums, and the inflammation sometimes extends to the thront, causing coughing and general fever.

What to do.-If there is slavering; if the animal seens to chew hard food with pain, or bolts soft food with haste, examine the mouth. Extract the loose teeth; lance the gums to allow easy dentition; wash the gums with tincture of myrrh : relieve the bowels if necessary with gentle 370 laxativ the six require

In th for loos they at straight grow $\mathrm{pl}$ rounding proper ' pain, eve be given such mar of myrr uceessilly

Supern When so unmerary to notice given the even apo: in horses be extriet not broker

The teet subject to sometimes,

Causes.strong min tecth by bit

How to mouth; sla acute form. 
laxatives, and give as mueh rest and soft food as possible. Swine from the sixth to the twelfth month usually cut thirty-six teeth, and sometimes require attention.

\section{Shedding 'Peeth.}

In the shedding of the teeth the mouth should be examined frequently for loosened teeth, to find if the new teeth are growing properly. If they are likely to become erowded, calusing twisting, they should be straightened, and if necessary one of them extrneted to allow them to grow properly. Sometimes there will be disense of the membranes surrounding the roots of the teeth, eausing loosening, deviation from the proper course, suppuration, and even shedeling of the tecth with much pain, even to inflammation and other diseases of the grum. Relief is to be given ly careful examination, keeping the bowels open with soft food, sucl manipulation as may be necessary, sponging the gums with tincture of myrrh, laneing the gums, and extraction of the loose tecth when necessary.

\section{Blind Teeth.}

Supernumerary teeth may occur anong the nippers and grinders. When so they should be extracted. Blind, or wolf teeth, are not supernumerary, bat natural as they are insignificant, and would not be necessary to notice here were it not from the fact that ignorant pretenders have given the impression that they are the cause of blindness, big head, and even apoplexy or staggers. These teeth are certainly useless, and occur in horses (not in mares) immediately in front of the grinders and may be extracted without difficulty or injury, eare being taken that they be not broken and thus irritate the gums.

\section{Decay of the Teeth.}

The tecth of horses under an artificial system of management, are quite subject to decay. Usually this is found in the grinders, although it sometimes, but rarely, oceurs in the nippers.

Causes.-Anything that will destroy the enamel or corrode the teeth, strong mincral medicines, fermentation in the stomach, breaking of the teeth by biting hard substances, or natural eauses from increasing age.

How to know it.-The horse will suddenly drop the food from the nouth; slivering and exhibition of pain. This means toothache in its acute form. The general symptoms are imperfect chewing of the food,

hew hard th. Exrash the th gentle 
and cousequent finding of whole gruin in the dung; indigestion, uas. thrifty state of the hair and skin, irritubility, loss of condition, generally.

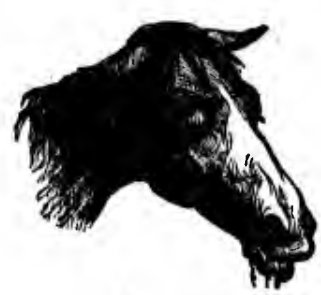

A IIONSE WITIL TOOTIACIIE. with swelling of the legs; swelling of the jaw-bone about the earious tooth, quidding of the partially ehewed lay , accumulation of food around the tooth, and between it and the eheek.

What to do. - Put a balling iron in the horse's mouth, and eximiue the jaws for broken or decayed teeth. If suspected, tap it gently. If there is inflummation, lauce the affected pirts, and sponge with tincture of myrrh. If the tooth is ulcerated, it is better to extract it at once; if not, it may be elened and the eavity filled with gutta-perehil. If tender from exposure of the nerve, it must be relicred or deadened with erystalized earbolic acid and powdered opium, before filling. As a rule, in extensive earies, the tooth may be extracted. If so, the opposing tooth must be oceasionally rasped down. The extracting of teeth, however, should only be undertaken by a veterinary surgeon, exeept in the ease of loose teeth, which may be extracted with a large pair of forceps.

\section{v. Scurvy of the Teeth.}

Old horses are subject to deposit of calcarcous matter, by which the teeth become ridged with a white scurf, extending down upon the gums, inflaming them and keeping them sore. This is generally confined to the front tecth. Young horses also sometimes suffer from this disability.

Causes.-Imperfect digestion and sour stomach, orolving gases, or any cause injuring the enamel of the teeth.

What to do.-First, find if his system is in good condition, or put it so. Put a twitch on the animal's nose and with proper instruments remove the incrustations. Files, serapers and fine emery paper are the means to be used, the teeth afterwards to be oiled. In ordinary cases, a stiff brush and a mixture of tartaric acid and salt will do it; rubbing afterwirds with clean, hard wood ashes. Keep hard wood ashes and salt where the horse may take it at will.

\section{Stump Sucking, or Crib Biting.}

Stump sucking is when a horse rests its teeth against any projection, arches its neck with spasmodic action of the throat, chest and flanks. Crib-biting is when the horse seizes the crib or other hard substance bo,

tween

sucking

its laetl

modic a

witls sw:

What

of the te

examine any disal ered witl of the in iron bars orel" ind pare win neck wil] at roaner.

Laimpas of the bin tion in you chewing $\mathrm{fl}^{\prime}$

What to slighit cutt or lancet w tion to the only about third bill an Ilence the the roof of cident the a cord around to the gums possible. oifice :itld s for the gum

No.

Sever bur 
tween the toeth and pulls, with or without spusmodic action. Wind sucking is when the horse suddenly seizes any hard, firm substance with its treth, pulls back, sucking in the air, sometimes with so loud a spasmodic action, noise mol groms that it may be heard for a long distanee, with swallowing and eructintion.

What to do. - It is probably more generally comected with disense of the teeth than is generally suspected, and these should be immediately eximined for enuse. At length it becomes a contirmed vice. Relieve any disabilities from the tecth. The remedy is to allow no surface uncorered with sheet-iron where the horse may reneh it. Smearing the front of the manger with aloes has been recommended. A muzzle with two iron bars projecting from the lower jaw over the mouth and extending orer and between the nostrils, will prevent the vice. If the disense be pure wind-sucking, .. strip) fastened tightly about the upper part of the neck will prevent the effort, but there is danger of the horse becoming at roarer.

\section{Lampas.}

Lampas is congestion of the palate; a redness and swollen condition of the bars of the mouth behind the upper front teeth, caused by dentition in young animals, and in old ones from indigestion, causing pain in chewing from the protrusion of the tender pirts.

What to do.-If in young horses, the means advised in dentition, with slight eutting (scarifying) of the roof of the mouth, with a sharp knife or laneet will suffice. In old horses, scarification, with a general attention to the health of the minul will be indieated. In scarifying, cut only about an inch back of the teeth, and never deep. Just behind the third bar an artery lies near the surface, difficult to manage if cut through. Hence the eare required in bleeding in the roof of the mouth. Sliould, by acecillent the artery be severed, put a strong cord around the upper front teeth close to the gums, and strain it as tightly as possible. This will generally close the oifice :nd stop the bleeding. As a wash for the gums, the following will be good:

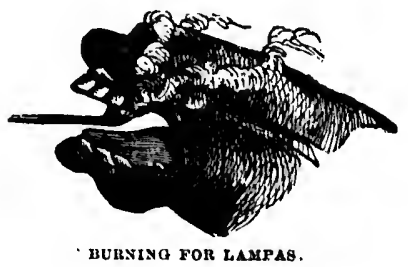

Never burn the bars of the mouth for lampas. It is as senseless as it 
is brutal and eruel. Never use caustics. The hars of the mouth are useful to the horse, as the palnte is to man, nud may not be tampered with with impunity.

\section{Inflammation in and Around the Mouth.}

Causes.-Irritation from wounds, bruises, nerid or poisonous plunts, savage bits, injuries from the bit, twitch or rope around the under juw and tongue, medical irritunts, hites or stings of reptiles or inseets, the use of ealomel and otles salivating drugs, fungus growths, specitic fevers, etc.

How to know it.- There will be difficulty in feeding and drinking, slivering with or without fetid saliva, swelling and rigidity of the lips, cheeks or between the hones of the lower jaw, blisters or sores within the mouth, swelling of the glands, ete.

What to do.-Find the cause, whether from mechanical injury, irritating food or irritant drugs. If injured by alkalies wash with vinegill and water, equal parts; if by acius use lime water or a weak solution of bicarbonate of soda; if eaused by caustie salts use mueilige of slipyery elm, or white of egg; if from venomons bites apply ammonia and give one-half ounce of liquid ammonia internally to the horse, and one-linff to one ounce to the ox. For bite of venomous suakes, tmintulin, ete, eauterize the wound in addition and give whisky in full doses. If there is simple inflammation, open the bowels with a gentle laxative, two onnee doses of magnesia, and wash with vinegar and honey. Give plenty of cool water and soft food. If there are ulcers, touch them with a feather dipped in

No. 136.

10 Grains lunar caustic,

1 Ounco raln water.

If there is much swelling keep the head tied up. If tumors resolving into matter (pus) appear, open with a laneet or knife. If there is sloughing of the parts (separation of dead flesh) wash with the following:

No. 137.

1 Drachm permanganate of potassa,

1 lint of water.

\section{Slavering.}

Causes.-The result of mereurinl salivation, symptoms of various affections, as apthous fevers, epilepsy, cutting teeth, ulcers of the mouth, irritating food, alkalies, acids, bad fodder, ete. White clover will often cause undue secretion of saliva by the glands.
It $111 \mathrm{a}$ indigesti

What

atld soun for the and hour slightly. and atter

How to tongue wi

What to the mouth sulsstince hatugs fron extendingr retiet' maly

The reme a twitch on the tectls un and with as

Causes.ritreless or sometimes lead, and d distressing 11

Kow to knd motion, movi puin the anin

What to do and soft food the animal wi 
It miny be known by the free discharge of saliva, great thirst and often indigestion.

What to do.-Find tho eause and remove it. Give eold water to drink, and sound grin, grinss and hiny. Use as washes for the nomth, vinegar and water or vinegur and honey. If the saliva is offensive, use water slighltly tinetured with earbolic acid as n whsh, and attend to the general health of tho animal.

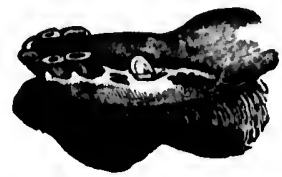

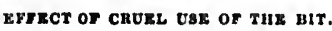

\section{Inflammation of the Tongue.}

How to know it.-There will be difficulty in enting and drinking. The tongue will be swollen and inflamed, sometimes lunging from the mouth.

What to do.-Use the same means reeommended for inflummation of the urouth, first having thoroughly searelied for wounds from any shmr? sulstance laving punctured and remaned in the tongue. If the tongue himes from the mouth put the end in a bag, and support it with tapes extending from the corners of the nouth and tied behind the ears. Gireat reliet may be atfurded the suffering animal by this means.

\section{Sharp and Projecting Teeth.}

The remedy for this disability will be obvious. Secure the animal, put a twitch on its nose, if a horse, and a balling iron in the mouth and file the tecth until smooth and even, using a rasp made for this purpose, flat and with a slightly crooked bandle.

\section{Scald Mouth.}

Causes.-The ignorant use of acid drenches or corrosive drugs by (areless or jgnorant stable men. Medicines of unusual strength are sometimes sent with directions for diluting. If labels were carefully read, and dircetions implicitly followed, there would be less of this distressingr malady, often ending in chronic disease of the stomach.

how to know it.-The mouth is red, often raw ; the lips are in constant motion, moving up and down; the saliva flows continually, showing the puin the animal endures.

f rarious he mouth, will often

What to do.-Give well-mide cold gruel, either of corn or oatmeal, and soft food if the horse can take it. Boiled carrots are excellent if the animal will eat them. Prepare the following lotion: 
No. 138.

5 Ounees of powdered borax,

2 loundy of honey,

1 Gallon of bolling water.

Mix, let it become quito cold; hold up the horse's hend moderntely and pour half " pint into the moutlı. At the expirntion of half n minute allow the hend to gradually drop so the fluid may flow over the inflamel surfices. This should bo repented severul times a diy. Beyond this nothing can be done except to attent to the generul heulth of the animil, which should do 110 work until entirely recovered.

\section{Aptha, or Thrush.}

$\Lambda$ disense incident to sueking animals and young horses, grenerally occurring in the Spring and Fall.

How to know it.-Red patches will nppear on tongue, checks and lips,

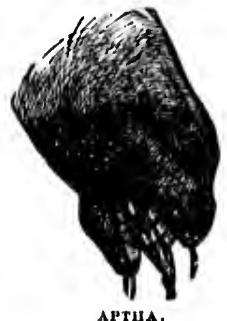
which assume a whitish color, caused by a fungus growth (aelium albieans). The lips swell; the tongue lang; out of the mouth; vesicles form contuining a clear, gelatinous fluid. At length these burst; ertists form and recovery ensues.

What to do.-Give the animal soft food as recommended for other moutfi diseases. Wash the mouth with the lotion prescribed for scald mouth, or prepare equal parts of honey and powdered litylherry bark into a paste, with wheh guoint the affected parts every night.

To purify the blood and promote the general healih give the following:

No. 139.

1 Ounce flowers of sulphur,

1 Ounco powdercd sassatras bark,

2 Ounees powdercd golden seal.

Mix, divide into four portions and give one every night in scalded shorts allowing it to get cold. Or give it in eold gruel as a drink. This prescription will be found valuable in any case and for all farm stock when the blood is thick and inelined to humors. Givo fully grown swine half the dose prescribed, and full grown sheep one-third the dose; that is, divide into eight doses for swine and twelve for sheep.

\section{Inflammation of the Parotid Gland.}

Causes.-This gland, which lies in the hollow that extends from the root of the ear to the angle of the lower jaw, sympathizes with inflammation of the upper part of the throat, and becomes hot, tender and swollen in almost ever case of cold. It is liable to influmunation also 
from mechunicul injury, and from obstruction of its duct. In bud enses of strumgles or distemper, it will sometimes swell to great size and will brenk, a fistulous sore being the termintion.

How to know it. - When the glund hus hecome swollen, it is ensily discernible by sight or feeling. There is a hurd und pminful lump beneath the enr, with a softer feeling nbout its edges. 'The horse carries his head stiflly, chews slowly and with difficulty, nnd hus some geneml ferer.

What to do. $-\Lambda$ s this stute of the glind is almost nlwiys precederl by cold, and is accompunied hy it, the trentment must bo first directed to the removal of the exciting cause. Place the animul in comfortable surroundings, attend to the state of his bowels, giving 3 ounces glituber's or (p)som sults, in case of constipntion, and $n$ few wa'm mashes. Menuwhile, cover the uffected gland with in good poultice until the inflammation is subdued.

If inflummation results from mechanicnl obstruction, that obstruction must of course be removed before my permunent relief can be obtuined; and this may recuire the removal of a ealculus ol stone from the parotid duct, which can be safely done only by an experienced surgeon.

If attention is not directed to the swelling until matter is forming, nllow it to approach the surferee and come to a liend before attempting to open, to avoid cutting any of the ducts, which might result in a fistula. If the tumol becomes, hard, use iodine, almost to the extent of blistering.

Any wound inflicted mechanically, as a cut into the gland, or a prick with a stable-fork, must be treated externally according to its naturethe main point being to close it so effectually that the salivary fluid which it is the oftice of this grand to secrete cannot escipe through the wound.

\section{Fistula of tho Parotid Duct.}

Causes.-The parotid duct, which is formed by a union of the smalles ducts of the parotid gland, enters the mouth after it letves the gland, in front of the large misseter muscle of the ehceks-having passed for some distance upon the inner side of the jaw, and then turned under the lower border of the bone. The saliva secreted by the parotid glimd, which lies at the spot where the neck joins the jaw, is poured into the wouth by this parotid duct, to be mingled with the food during the process of mastication. If the mouth of this little tume is closed in any way, so as to prevent the free egress of the saliva, distension of the duct takes place, and the confined secretion causes suffering, inflammation, and finally rupture. This stoppage is sometimes cuiused by luyseceds or other particles of food that enter the mouth of the eluanel while the 
animal is feeding. The presence of food in the mouth and the motion of the jaw stimulate the aetion of the gland, and sinee the saliva thus secreted cannot escape by its natural opening, there is constantly more and more pressure until some outlet is found. This, as we have said, may be by bursting, or it may be by external aceident. A wound inflicted on the jaw with any pointed instrument, as a hay-fork, has been known to penetrate this chamel. The saliva thereupon pours through the opening, and by its constant flow it prevents the healing of the wound, so that its edges speedily become hard and without that liveliness essentiil to the closing of punctured or gatshed flesh.

The stopping of this passage into the mouth is stid to have been sometimes caused by calculus or stone in the cheeks of the anima. These, of a size exceedingly large in proportion to the size of the duct in which they lodge, have been taken from the jaw.

Every wnund which penetrates this or any other duct of the salivary glands soon becomes a fistulous and offensive sore; the fluid secreted by the gland finds its way out through the false opening, while none of it enters the month to perform its naturnl function in preparing the food for the stomach, so that the horse soon begins to lose flesh, and fintly assumes a wretched and loathsome appearance.

The opening of the parotid duct occasionally occurs, perhaps, from the opening of abseesses attending strangles or distemper.

How to know it.-The digestion necessarily beeomes deranged when the process of mastication is carried on for any considerable length of time without the foods being moistened by that secretion which the parotid duct in a healthy condition furnishes; but the oritice in the skin under the jaw or on the check at the large muscle, discharging a liquid somewhat resembling the white of an egg, is the munistakable indication of the disorder under consideration. During the act of feeding this fluid is freely clischarged, even sometimes squirting from the wound, and especially so if the food is dry and hard to chew. It will be noticed that in chewing the horse uses the opposite side of the mouth from that son which the opening occurs, and that the process is slow and difficult. The edges of the wound soon become callous, the rumning of the strem dorn the eheek destroys the hair, and the whole part has a fistulous and ilthy appearance.

What to do.-In the first place, especial care must be taken to keep the animal, during the period required for effeeting a cure, upon fool that requires no chewing. It should be sufficiently plentiful and nutritious to prevent the uneasiness of hunger. Soft mashes and gruels alone should eonstitute the diet. Another precaution is necessary when he is

left $t_{t}$ from of th ciently the tri

If $t$ rought collodi round

If th first cill betwees a new o must hit other ou shortene way the tirm, anc being op must be mistic wi -njphnivic and flesh surtoundi vily secret an adhesiv las stopp rnbber, an the adhesi that is dry edge. Co some of $t$ thoroughly mimal as il may ealt, ho Iround.

This one hitt if it $f_{i l}$ still feedin! rubber, cot uffected. 
left to himself - that is, to tie him up in such a way as to prevent him from rubbing the wound. This can be done by having a rein at each side of the halter, and tying it up, one to each side of the stall, and sufficiently back and high up to keep him from putting his jaw against either the trough or the wall against which it stands.

If the wound has recently broken, shave the edges so as to remove all roughness and bring them closely and evenly together. Then cover with collodion, putting on coat after coat until it is strong enongh to keep the wound from bursting.

If the sore is of long standing, and the case evidently obstinate, the first care must be to determine whether the chamel has become rlosed between the wound and the mouth, as sometimes happens. If so, make a new one and keep it open by passing a thread through it. This thread must have a that button affixed to each end, onc inside the mouth the wther outside the round, to retain it in place. It should not be so closely shortened by the buttons as to prevent its being slipped a little, first one way then the other, until the walls of its passage have become callous or tirm, and not likely to adhere. It must then be withdrawn, and the way ineing open for the secretion to escape into the mouth the outside wound must be closed. To do this, make an adhesive fluid by saturating gim mastic with the strongest spirit of wine, or by dissolving India rubber in mlphuric ether. Pare off the edges of the wound till the healthy skin and flesh are laid bare, which may be kinown by hleeding. Now wash the surrounding parts thoroughly with warm soap suds, so as to remove the wily secretion from the skin and hair, and render the latter dry, so that an adhesire preparation may the more readily stick. When the bleeding lass stopped and the hair is dry, hay over the orifice a pice of India rubber, and over that a cotton cloth. Fix the cotton firmly by means of the adhesive fluid above mentioned, first attaching one side, then, when that is dry and firmly fixed, stretching and fastening down the other elge. Continue to fasten on these strips one after another in this waysome of them aross-ways-until there is a good borly of them; then thoroughly saturate the whole with the adhesive fluid and tie ul the animal as already directed. Winen his reins are loosened in order that he may eat, he must be watched to see that he does not rub and re-open the womnd.

This one covering, as described, is gererally sufficient to effect a cure; hut if it fills off before the orifice is entirely closed, wait a day or two, still feeding on soft food, and then put on another coat of the India rubher, cotton, and mastic solution; and so continue until a cure is effected. 


\section{CHAPTER IX.}

\section{DISEASES OF THE HEART, BLOOD, ETC.}

\begin{abstract}
I. THUMPS. - II. SCROFULA. - III. HEVER, OR GENERAL INFLAMMATION. - IV. RNLAKGEMENT OF THE HEART. . FATTY DEGENERATION OF THE HEART. MENT OF THE ARTrRIrg, -VI MATION OF THE ABSORBENTS.
\end{abstract}

\section{Thumps.}

Palpitation of the heart, or thumps, as it is usually called, may occur from fright, in highly fed, irregularly worked animals, but is not as a rule comnected with struetural disease of the heart.

Causes.-Indigestion, some blood diseases, sudden excitement or fright in animals predisposed to nervousness.

How to know it.-The action of the heart will be violent and conrul. sive; the beatings can be seen, felt and heard. The disorder comes on abruptly, generally from excitement, has perfeet intermissions with allrupt jarring thumps, and a jerking motion of the abdomen, and unacconpanied by redness of the mucus membranes; excited eyes, rapid breathing and a more or less sudden diminution of the palpitation. If signs of temporary excitement are not present ; if the attack comes on slowly, is constant with aggravated intervals ; if there is a heavy, prolonged, unequal beating, with red nucus membranes and swelling of the limbs, it may be inferred that the difficulty is connected with structural heart disease.

What to do.-Avoid sudden excitement and over-exertion, but giri regular but gentle exereise, stimulants and tonies. The following woull be indicated as a stimulant, either whisky, or 1-2 ounce liquid ammonia. Give 15 to 20 grains digitalis twice a day in the feed, for some weeks.

\section{If} the $\mathrm{d}$ water be inc

For

The animals more $r$ gernis c ulcers Thus it eruptive

What weed, is seed, brt daily. and swin attended icine, Gl:

Then Alimulator the organ: becomes $g$ on the mir the result In fuct, a disense of cease. II ment of th In inter? stage. Tl is in a mo organs eml fevers the 
If there is a full, strong pulse, and inereased size of the heart, add to the digitalis 20 drops tincture of aconite, twice a day, or drop it into the water given twice a day. If there is general debility, the following will he indicated, to be given twice a day for several weeks :

No. 140 1/: Drachm powdered nux vomica, 1 Drachm extruct of belladonna.

Form into a ball with liquorice powder and molasses, and give.

\section{Scrofula.}

The horse is not subject to scrofula, as is man, and the lower farm animals. Swine are essentially scrofulous; sheep are often so; cattle more rarely, and horses least of all. Yet that this noble animal has the germs of this dread disease in his system, would seem to be indieated by uleers on the liver, tumors in the glands, and tubercles of the lungs. Thus it may be found in connection with other diseases, or show itself in eruptive skin, or of the organs.

What to do.-Stramonium, known to farmers as Jamestown or Jimson weed, is a specific. Give every other day half an ounce of the dried seed, bruised, or 20 to 30 grains of the stramonium of the druggists, daily. The ox may have from 1-2 to 1 drachm; sheep 5 to 10 grains, and swine 4 to 6 grains daily, the state of the bowels being cairefully attended to by giving laxative food if costive, or if neessity occur, medicine, Glauber salts in light doses.

\section{Fever, or General Inflammation.}

When from any cause injury is done to any part of the frame, or inflammatory action is set up either in the tissues, membranes, or any of the organs of the body, heat is produced, and this is fever. This often becomes general from sympathy, thus in a measure relieving the pressure on the more closely affected parts. Fever is not the disease itself, but the result of disorganization, a symptom of disease, or internal disorder. In fact, a symptom of disease arising from sympathy of the system with disease of the animal economy. Remove the cause and the fever will rease. We may do something to alleviate it in connection with the treatment of the disease itself, but we must not lose sight of the latter.

In internittent fevers there is a cold stage, a hot stage and a sweating stage. These may vary in succession and degree, but the real difficulty is in a morbid state of the viscera, but warticularly of the liver and orgais employed in the formation of bile, and of the mesentery. In fevers the tongue is couted. Yet no quack is so igmorant as to suppose 
the fever ean be eured by scraping the tongue, and yet this is fally as sensible as to suppose fever to be the disease itself when it is an effect of discase.

In the horse fevers often manifest themselves through inflammation of the mucous or serous membrames, producing catarh or influenza. When it affeets the mucous surface of the stomach and bowels it produces extreme languor and debility. In pleurisy there is inflammation of the scrous membranes within the thorax. The ferer is the manifestation of the discase. In typhoid fever there is inflammation of the brain and viscera and especially of the stomach, intestines and peyers gland. The fever is the attendant simply upon the cause of the inflammation.

Fever in horses has been deseribed by the author of IHippopathology to be 1st. Common fever-a general diffuse inflammation. 2d.Idiopathicarising without any apparent local injury. 3d. Symptomatic-arising from some local cause or irritation. The late Dr. Dadd, V.S., very truly says :

"A rational system of veterinary medicine contemplates, in the treatment of febrile symptoms, nothing more than a kind of expectancy. If the patient be in the cold stage, alminister warm diffusible stimulants and diaphoreties, aided hy wamth and moisture externally; friction on the extremities, and, if necessary, stimnlating applications to the chest and the extremities. In the hot stage, and when the superficial heat of the body is great, cooling drinks are indicated: water acidulated with cream of tartar, makes a good febrifuge. The patient may be occasionally sponged with weak saleratus water. The alkali has a beneficial effect on the cutameous ressels, while the water lessens the temperature of the body. No treatment, however, can be of any rational use, muless it contemplates a restoration of the healthy equilibrimm of the whole system. Let the doctor treat the disease, and a good, attentive groom can mange the ferer."

In treating general fever or inflummation, therefore, we must first find the cause, and in eat, giving such agents as have been indieated throughout this work, for the felmile symptoms as they occur. As a rule we do not advocate bleeding, but in the horse in the early stages of acute inflammation, especially of the brain, and all that dass of diseases which inrolve the general system, and when the blood is thick and dark, sometimes: almost brown, bleeding may be practiced with suceess. It is never well however to bleed blinclly. In apoplexy and that class of diseases, bleed. It is a ase of life or death. For fevers in general there can be no specific. In disenses of the blood, accompanied by fever, alteratives will be indicated both as a preventive and corrective of the diseased functions. Sometines the condition of the alssorbents are so inactive that alteratives 
cannot act. Here bleeding would seem to be indicated. Yet it is better unless in the case of life or death, that it be not resorted to, except under the advice of a competent veterinarian or physician.

\section{Enlargement of the Heart.}

Hypertrophy or enlargement of the heart is an increase of its muscular sulstance and may be confined to one side or one ventricle. Sometimes disease of the valyes leads to enlargement much beyond its usual size. Enlargement of the heart also accompanies broken wind and other impediments to the free netion of the lungs and breathing tubes.

Causes.-Long eontinued hard work; chronic incligestion, or some obstruction to the cireulation.

How to know it.-There is palpitation, the beats forcible and prolonged, the intervals of silence shortened. The first sound is low, muftled and prolonged, the second loud, and if only one ventricle is affected sometimes repeated. The pulse is as a rule regular, except under excitement of the unimal, and, the, excitement removed, soon returns to its usual state. The breathing is often hurried, and exertion increases the general symptoms in a marked manner.

What to do.- Simple hypertrophy is seldom the enuse of imminent danger. It is not unusual for horses with an enlargement of the henrt to do steady, slow, moderate work, and live to be old. If there is dilatation, weakness, blowing murmurs with the first heart sound, spells of oppressed and difficult breathing, if the nasal and other visible mucous nnembranes are livid, there is dimger of sudden death at any time.

Keep the animal quiet, and at ouly slow, moderate labor; never over. loul or put him to speed. Let the diet be of good, easily digested food; never allow the stonach to become orerloaded. Give twice a day from 20 to 30 drops tineture of aconite root as the case may need. If there is broken wind or other serious impediment to breathing, 3 to 4 grains of arsenie in the food has been found useful. If the case, however, be of long standing, or due to permanent olsstruction, treatment must be simply alleviation. The ease will eventually end in death.

\section{Fatty Degeneration of the Heart.}

This disease is oceasioned by a change of the museular substance of the heart to a fatty state, by which the organ is weakened, at length leading to rupture of its tissues. It is not uncommon in high-bred stock, including cattle and swine. 
Causes.-High feoding, inactivity, want of exercise, and the result of such diseases as purpura scarlet fever, and disenses the result of profound alteration of the blood.

How to know it.-Debility in the circulation, irregularity and weak. ness in the pulse, lessening of the heart sounds, swelling of the legs and sometimes a general dropsical condition, dilatation, a wunt of correspondence between the heart beats and the stroke of the pulse, appetite irregular and capricious, and the membranes of the mouth and nose a rusty red color.

What to do.-Humor the appetite with sound, easily digestible food. There is no remedy. Attention to the general health, and an ounce of chloratr of potash twice a day in the food may mitigate symptoms when more violent than usual. In all heart or arterial diseases give rest, and in fattening stock, do so as quickly as possible.

\section{vI. Enlargement of the Arteries.}

iliat ition of the arteries (Aneurism), is rarely found. It is a thinning and $n$ ening of the coats of the vessels, sometimes to bursting, causing \& nulsii, $\because$ mor containing blood.

Causu:.- - strains in the vicinity of an artery, blows, kieks, stabs, or weakening from overstretching, as in fatty degeneration. In the mesenteric arteries of horses, they are common from immature worms (Sclerostomum equinum) in the circulation.

How to know it.-There is a soft, fluctuating, visible tumor if near the surface, which may be reduced by pressure, but which instantly reappears.

What to do.-Treatment is not successful except when near the surface. Then steady pressure by a pad if taken early will sometimes cause its disappearance. An animal with enlargement of the arteries is unsound and should never be bought. The same rule applies to all diseases of the heart.

\section{Inflamed Jugular Vein.}

Causes.-This is due, for the most part, to bleeding, and the treatment to which the horse is subjected, or rather lack of treatment immediately after blood-letting. It is not to be attributed to any particular maner of bleeding, or to any awkwardness in its execution and in the elosing of the wound. Some horses have a constitutional predisposition to iuflanmation upon any occasion of punctured veins, and the most skillul phlebotomist eannot avoid throwing them into this state unless care is taken 
after the operation to see that there is as littlo exciting cause as possible. Inflammation may, indeed, result from bruising the vein in the act of bleeding, but this must be of so rare occurrence as to be scarcely worthy of notice. The same may be said of a large and ragged wound made by a bungling operator.

The motion of the animal after bleeding, and rubbing so as to displace the pin and tow by which the wound is usually closed, may be set down as the great sources of danger. If the horse is turned loose and ullowed to graze about, hanging down his head and kecping it down at will, with his jaws in almost constant motion, inflammation of the vein is apt to result. So, if he is allowed access to food in a trough or stable. When allowed his freedom he is apt to rub the wound whenever itehing sensittions supervene, as they are apt to, and the trouble is thus easily induced. If put to the saddle immediately after blood-letting from the neck, the bridle reins may rub the wound, and especially irritate it loy disturbing its fastenings; and if put to harness the collar may press the blood too violently and constantly against the orifice, and so bring on inflammation.

How to know it.-The earliest indication is a slight opening of the lips of the wound, whenee exudes in small quantity a thin, watery diseharge. A slight swelling appears; this is followed by a hard, cord-like enlargement of the vein, which feels hot; and there is some visible swelling at the angle of the jaw. The swelling takes place albove the orifice, and the inflammition tends almost wholly in that direction.

If neglected, the second stage of the disorder soon sets in. Ahscesses form along the vein, and these flnally hurst and dischinge a thin but filthy puss. These tumors are united at their bases by sinuses in the interior of the vessel.

It may be reckoned as a third stage of the disease when the vein feels hard under the skin, and the abscesses disclarge a dark, impure and stinking pus, resembling rotten blood. At this stage the horse grows dull and stujicl ; then at last the inflimmation extends to the brain, and a madness similar in violence and fatal effects to the rabies may supervene.

What to do.--In the first place, "an ounce of prevention is worth a pound of cure," and whenever it is necessary to bleed an animal, let it the done in as neat, skillful and expeditious manner as possible; then Whose.the wound with care, leaving no part of the fastening pin to project over the suture or winding of tow or cord by which the lips are drawn "lose; and at once tie up the horse in a stall. If the stall is contracted in width, it is all the better, as he will be less likely to stir unneeessarily.

Tie the halter above and something hack from the manger, so that he cannot rub his neck against the trough nor anything pertaining to that part of his stall. Give him no food that will necessitate dhewing- 
nothing but a sufficiency of thin, cool gruel, having in it no inflammatory ingredients, to prevent the absolute gnawings of hunger. Water may be given in as great quantities as he will take.

Allow him to remain in this position twenty-four hours. Even then, do not turn lim into a ficld, as the traveling to and fro, with the head often pendent und the juws in motion as he grazes may yet cause inflammation. He may now, however, be ullowed a more roomy stuble; but the food should be for mother day only such as will necessitate no considerable ehewing. This precuution will in ull probability wholly prevent inflammation, even in those eases where the animal, has a strong constitutional tendency to it.

These direetions, however, ure not to be understood us applicable to every case. When a horse is bled to relieve some sudden or acute local trouble, there is really but little danger of inflammation of the jugular, especially if the acute trouble is attended with marked loeal fever.

When inflammation has actually set in, from whitever cause, the eure is easy and speedy, if steps be promptly taken to this end. If begun while in its simplest stage, place the horse at once in a stall, as previously indicated, and tie his head up during the day-giving him food and drink by raising a bueket within easy reach for tho time. Then sponge the inflamed part very frequently with the following lotion, as cool as it can easily be made:

No. 141 .

3 Ounces tincture of arnica,

2 Ounces muriate of ammonia,

4 Ounces methylated spirits of wine, 3 l'iuts water.

It will be more effectual if some soft padding is confined along the whole extent of the inflammation, and this kept constmitly saturated with the cold lotion.

After the inflammation has subsided, inix biniodide of mercury and lard in the proportion of 4 drachms biniodide to 4 ounces lard, and rul the vein well with this, if it remains enlarged, every night until the new deposit has been absorbed, which will be known by its having produced a free watery discharge.

The treatment thus laid down is intended to apply strietly to the first stage of the disease. When the second stage has set in before treatment is begun-that is, discharging abscesses along the vein-begin by remoring the pin and suture, if not already done, and then blister along the whole extent of the inflamed and tumorous surface by rubbing in effectuilly the oil of eantharides, or liquid blister. One blister must succeed another till every sign of the disorder has disnppeared. If the case seems to he violent and to yield slowly, one blister must not wholly ceasc to 
act until another conting of the oil hus been applied-though this is not necessiny exeept in very obstimate cases. If the liquid is to be applied over an old one, still raw, use at fine brush with which to lay it on, and then cover over with an applicution of some unctuous oil to soothe the severe smurt that presently sets in. Be eareful always to luve the blister cover every spot where there is indication of inflammation.

If the discase has progressed to that stage in which there is a foul and black discharge, the abscesses must all be joined by slitting up the intervening sinuses. Cut the whole extent of the hardened vessel except a little st ench end, which must be left to prevent eopious bleeding. Enfhoy a small, suitable probe, calefully and patiently, and cut along the truck indicated, from alscess to abscess. Then upply the liquid blister as directed, regindedess of sores or ents, and continue to do so until the part is but one hlister sore and not a lot of discharging tumors.

The vein will of course be destroyed. Whenever the corded and suppurating state sets in this is inevitable, as no human agency can restore its functions ; but this will not seriously interfere with the eircnlution, since the smaller vessels that ramify every part of the neek (as, indeed, of the whole system ) soon accommodate themselves to the new order of things, and the life-current flows regularly on. It requires much time, however, to bring him to that condition in which he will not need more than ordinary attention. Thronghout the day his head must he tied up to the rack, while at night he may be loosened so as to permit hin to lie down. The floor should be covered with tan, as he would chew straw, and thus render eure more difficult by that motion of the jaws which is to be guarded against. He should be kept this way for from four to seren weeks, according to progress of recovery. Meanwhile his food should be hay tea, sloppy mashes, and cooling gruel moderately thick. No solid food should be allowed-no corn nor oats. Potatoes, marrots, turnips, boiled, reduced to pulp, moistened and mixed with bran, form the best diet.

At the ciose of the time designated begin regular daily exercise-very little at first, but gradually increasing it, which may be continued for two or three months, during which time he should not wear a collar, or be in any way subjected to pressure about the neek. After three months he may be restored by degrees to the use of solid food; but much eare should he observed during a whole year, after which he may be considered measurably sound.

Inflammation miay follow bleeding from leg veins, and those elsewhere, but it is most common in the jugular and most troublesome. The treatment were prescribed is of course applicable in its general principles to other reius. 


\section{Inflammation of the Absorbents.}

Inflummution of the absorbents (Lymphangitis), has a variety of names, among which tre Weed, and Shot of Grease, and may be a constitutional ease, or a mere local affection. In its constitutional form, it is found in heavy lymphatic, fleshy-legged lorses that, hard worked on heavy feed, are left in the stable for days together.

In its local form it is the result of wounds, bruises, injuries of various kinds, putrefying mitter in and around the stable. It may occur from the specific poison of glinders, furey, ete., and in the constitutional form may go on to abscess, sloughing and unhealthy sores, and death; or the horse may be left with the limb permanently thickened. In the loeal form there may be ubscess, diffuse suppuration, induration of the gland, and even the vessels and surrounding pints.

How to know Constitutional Lymphangitis._-There will be more or less shivering; in bad cases severe, quickened breathing: rapid, hard pulse; a general feverish state, and fever in one or both hind limbs. Enlargements may be detected high up in the groin, by the side of the sheath in the horse or udder in the mare, and grent tenderness of the inguinal glinds. The shivering fits will be sueceeded by fever with burning sweats, swelled limbs, exudation and filling, sometimes to the body.

What to do.-In mild eases, give moderate and daily exercise, pay attention to diet, ventilation, and cleanliness. If the case is more severe, give from 4 to 6 drachns of aloes, apply warm fomentations continually to the limb, with walking exercise. The bowels having been thoroughly moved, give diureties, an ounce of siltpeter in a gallon of water tro or three times daily; or 10 grains of iodine. In very bad eases, when the subject is plethoric, bleed from the jugular vein until the pulse softens, and proceed as before directed. For "thick leg," a chronic thickening of the limb, handage from the foot up when the animal is in the stable, and apply tincture of iodine for four days, giving daily exereise; or rub the limb with iodine ointment, and give the following once a day:

No. 142.

3/. Ounce powdered resin, $3 / 6$ Ounce niter, 10 Drops oil of juniper.

Mix into a hall with liquorice powder and molasses.

If abscesses form, open them with a sharp knife, and dress with the following :

No. 143.

1 Ounce carbolic acid, 1 Pint distilled water. 
In the local form there will be slight swelling of the cords, and redness in white skins. The lymphatic glands will be enlarged nlong their course, and become nodular or knotty. There will be pasty swellings of the parts, and even erysipelas.

What to do.-Give rest, and a purge of aloes as recommended for the dironic state. Wash the diseased limb with the following:

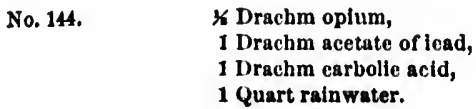

In case of excessive inflammution, poultice with flax seed or bread and mulk to hasten suppuration. Open the suppurating parts to let out the matter, and dress with the carbolie solution as in the other form of the disease.

\section{Scarlatina.}

Causes.-This disease, called also scarlet fever, is not considered contagious in its milder forms, but in a malignant stage it would doubtless be as much so as the same disease in the human family. It is sometimes regarded as but a mild form of acute anasarea, and rot entitled to be treated as a distinct affection; hut we cannot dwell upon the niceties of elassification, and where the neessities of the case (the knowledge requisite for treating certain manifestations of disease suceessfully) ar'e met, it is not importint that we should.

It generally follows influenza and other affections of the respiratory organs; and may le justly said to have its origin in colds, and in some (alses, perluaps, in the breathing of vitiated air in close, dark, ill-ventilated stables.

How to know it.-The patient exhibits great thirst, with a failing appetite, and evident weakness. He is more or less unsteady in his gait ; his breath is hot and stinking, and all the limbs are swollen. But the most unmistakable sigus are elevated blotehes on the skin ahout the neek and fore limbs, and scarlet spots, of variable size, on the membranes within the nostrils.

What to do. - First, remove the animal from its fellows, for fear the disease may develop into that putrid form which is found so contagious among children, and prove infectious. Give an occasional watery bran mash to keep the bowels open and allay fever. If this is not found suffeiently laxative, give a dose of Epsom salts, or linseed oil. Guard against too active and violent purgatives. Mix three ounces liquor acetate 
of ammonin with three ounces of cold water, and drench, with this once or twice : d duy, necording to the violence of the fever, for three days. Mennwhile, sponge the elevated spots on the skin with a tincture of muriate of iron mixed with warm water; or, if found more convenient, put two ounces of hartshorn (nqua ammonin) into a qunrt of soft water, and use that.

There is a tendency in this disense to dropsical offusions, and the limbs become very much swollen, even during the treatment preseribed; und by the third or fourth day a whitish mucus will begin to run slightly from both nostrils; the scarlet spots will have spread a. 1 hecome redder. Give now, night and morning, onc-half fluid onnce swe rits of niter, for four or five days. Discontinue to sponge the elevated spots, but rub the limbs closely and often; and blanket the unimul if necessary to keep him comfortable. The niter acts as a diuretic, and the dose and Iength of time it is given must be regulated by the effect upon the kidneys. If urine is voided too often and too freely, lessen the dose, or discontinuo it altogether. - Follow this up with a daily dose of twenty grains of sulphate of quinine for from three to six days, and continue to rub the limbs. When there are signs of returnmg appetite, give hum, in addition to the bran mashes, a few oats and a daily small allowance of hay; and place him in a small inclosure, where ho may have such moderato excreise as he may be prompted to take. Do not fail to supply him from the first with all the pure water that he will drink. 


\section{CHAPTER $\mathrm{X}$.}

\section{DISEASES OF THE BRAIN AND NERVOUS SYBTHM.}

I. HYDROPROIBIA, OR RABIKS. - II. MAI) STAGGERS, OR PHRENITIS. - III. BLIND STAGGERS, MESiRIMS, OR VERTIGO, - IV. APOPLLXY, OR SLERIY STAGGERS, - V. ABCESS WITHIN THE MRAIN.

\section{Hydrophobia, or Rabies.}

Causes.-This is the name given to a madness which generally arises from the bite of a dog, though wolves, foxes and cats me also sulject to it by a spontaneous generation, and this hite is as fatal to another animal and to man as thut of the dog. It is believed by some anthoritios tinat in rare cases hydropho', an arises spontaneonsly in the horse ; hut of this there is no proof; ard since it mathe been communicated by something of the dog or cat kind, even in those cases where all the outwand signs are lacking, it is safe to say that the horse takes it only by inoculation. He need not be absolutely litten. The licking of hridle-lit sores at the corner of his mouth by a mat dog is sufficient to introduce the poison by absorption; and if the horse by any means ehanees to take into lis month and stomach, with his food, the saliva or spittle of a mad animal, he vill very probalhy be attacked, and especially if the amimal so tropping the spittle is suffering with the disense in its violent stage. The poison is known to reside in both the spittle and the blood of its rictim.

When once the virus has been generated in or communicated to any ammil, hot weather, abuse, want of water, want of good food, will produce that fererish state which is so favorable to its development; and the greater or less time in which it manifests itself decidedly in horses after inoculation, is probably due to these conditions or the absence of such. The poison remains in the system, without producing the positive symp399 
toms, from three to eight weeks. Somo declure that a longer period than even eight weeks sometimes intervenes between inoculation and positive madness; lout such eases, if there are such, must be extmemely rare. They form the exception, and contrictict the great inass of testimony on this suloject.

The remote cause-that which produces it in animals of the dog and cat kinds-wo need not attempt to discuss, as it ean have little if any practical bearing on the subject in hand. It mny be well to observe,

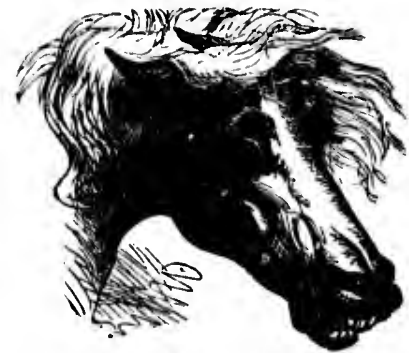

COUNTEN ANCE OF A HORgE W!TH RARIES. however, that most of the lower animils contract the disease when bitten lyy dogs that are violently mad, whereas annong men it is widely different. Statistic: seem to show that less than fifty per ent. of the latter take the disease. It has been offered in explanation, that the bite is generally through clothing, that serves in many instances to cleanse the teeth of the virus before the skin is reached: In the ease of horses, the bite is generally on the lip-a sensitive and vascular part, where the absorbents are readily reached.

How to know it.-Blood on the lips, or elsewhere, with marks of violence, are of course to be regarded as symptoms of dog bite, if an! known oceasion for such a thing has existed; an' for a few days these will be the only indieations. If the horse is high iad and full of blood, and the weather is hot, tho poison may hegin so produce outward effects in from tive to ten days by a swelling of the hitten pants, and by a dittculty manifested in swallowing. In from twelve to fifteen days there is perceptibly increased pulsation; inflanec thront, with thickening of the membrane that lines it: from the tifteenth to the twentieth diy the stomach inflames, and perhaps rejects food,-but nothing certainly (an he stated as to this point, since here the symptoms vary greatly with different animals: in some cuses the appetite is voracious, and so morbid that the sufferer will devour his own excrenent and urine. Sometimes he will exhibit burning thirst and drink freely, while again water will cause spasmodie movements and be avoided with horror. But in gencrat. the appetite is destroyed, and that dread of water which characterizes the disease in mat is present in the horse.

In a very short time the indications increase, and usually (us te have said, with full blooded, feverishly disposed horses, at a time of high temperature) before the twenticth diny, absolute madness sets in. He 
d than

ositive

- rare.

ony on

og and

if any

bserve,

animals

by dogs:

anong

tatisties

ifty per

asce. It

that the

ng, that

anse the

skin is

, the bite

itive and

marks of

le, if any ays these of blood. rd effeets oy at diththere is ig of the 1 dask the tainly ('tul eatly with (o) morthid Sometimes water will In general. uracterizes

lly (us we ne of bigh s in. Ile

nw rubs the bitten part ngninst anything convenient with increased violence; sometimes instead of rubling he will bite and tear the wound; the eyes assume a wilder and more unnatural appearance; some patients neigln squeakingly, shove out the tongue, or gnash the teetl. The progreses of the disease is now very rapid; genernlly there is profuse swenting; there is suppression of the urine, and intammation of the parts of reneration; his countenmec changes from a look of anxiety to one of cumning and a sort of grimning ferocity, and there is an irrepressible desire to bite man or animal - whatever living thing may be within reach ; he silzes sometinins at an imaginalry object and springs and suaps mally at racancy ; his propensity to destroy grows with his pain, and at last he wreaks his fury upon inanimate oljects-the manger, or trough, the rark, whaterer is seizeable in his stall is torn to pieces with his teeth or smashed with his feet; if not eontined he dants ferocionsly at whatever object of attack may present itself; plunges about like a demon of destruction, snorts, foams, sometimes uttering a kind of crying neighl, and perhaps beats himself to death before the last and comparatively helpless stage eomes on.

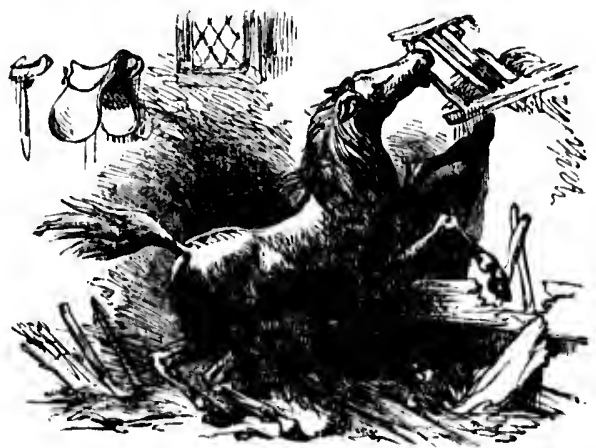

DERTNUCTIVE IMPULEY OF HYDIOPIOMIA.

If not destroyed before the disease has r'un its course, paralysis, nsually contined to the loins and the hinder extronities, sets in, and involves with it all those organs which depend for their nervous intluences upen the posterior portion of the spinal corel. Vnable to stand upon the limol leges, the animal will sit on his hannches, and strike and paw with his fore fect. The sufforing is sometimes rendered more terrihle by tenesmus or "etrhing of the bowels, which seem drealfully oppressed hut have lost the power to net, while the kidneys are fevered and torpid and the urine c:annot be voided. 
It sometimes happens that the disease is developed by exertion and heat, when no previous indications have been manifest, and shows itself in a peculiar manner. The horse stops all at once in his work, heaves, paws nervously, trembles, staggers and falls. In a monent he will be up, and may, if put to it, proceed for a few moments, when he will stop, stare about, and lie down again. This stage is sometimes mistaken for blind staggers, but it may be distinguished by observing that in blind staggers the horse loses his senses, while in hydrophobia he is always conscious, often acutely intelligent and observing.

What to do.-.This is a disorder of so dreadful and dangerous a character that some of the ablest veterinarians do not hesitate to advise the instant killing of the sufferer; and they refuse to give any directions for attempting a eure. When the furious stage has come on there seems to he a sort of demoniac maliciousness and treachery, with a watchful cullning, that makes it hazardous for friend or stranger to trust hiinsclf arywhere within reach. It is extremely doubtful, too, whether recovery ever takes plice after the madness is developed.

Yet, it is not improbable that much may be done in the way of prevention after the bite has been inflicted. The first step is to check the thow of blood from the part, if possible, to prevent the rapid spread of the poison over the system. If a limb has been bitten, this may be done by tying a handkerchief around it, above the wound, and twisting with a stick until a sufficient degree of compression is hatd. Then caluterize the wound thoroughly, making sure that the very deepest recesses of every tooth print or lacerated place is reached. Lunar caustic is best, becalue most easily and surely handled; but if impossible to get a stick of this, any convenient eaustic may be applied, as oil of vitriol, nitric acid, callstie potash, butter of antimony, etc. : or, a small iron, not too shillp. heated to a white heat and cleaned of scales, will answer if the animil can be kept still enough to apply without danger of injuring him otherwise. The handkerehief should be left on tight until the cauterization is effected.

Cauterizing thoroughly, even two or three days after the injury, mily result in saving the animal, as the absorption does not always spectily take place.

If the wound is upon a part that forbids the use of the handkerchief. it may be cut open to its depth, and a freer flow encouraged, both by the larger opening and by squeczing und wringing-soaking, meanwhile, with warm water. Then use the lunar caustic wherever a sign of tooth mill'h can be seen.

But when unobserved till the virulent stage has come on, it is not eren known to science that anything can be done to save; and the best, the 
most mereiful thing to do is to shoot at once. When there are strong symptons of madness, but still some donbt, put him by himself in a stahle, bare of everything destructible exeept food and water, which must be placed where he can get it, and barricade the door. Leave a window open for observation, and keep him here until the symptoms disappear or hydrophobia is unnistakable-then act aceordingly.

\section{Mad Staggers.}

Causes.-This disease is sometimes known by the more learned term of phrenitis (the delirium of fever ; frenzy, raving); but it will be by practical men most readily recognized when treated of under its old and fitmiliar name.

It is an inflamed condition of the brain and its covering, with effusion of the small cavities and the spaces between the membrane and the brain itself. Sometimes both the brain and its membranous covering are involved in this inflammation, sometimes but one, and that most frequently the membrane.

It Ii:ly be caused by coneussion of the brain by reason of blows upon the head. The brutality of a driver, which finds its gratification in using the butt of his whip upon the head of the horse, may result in a fractured skull, to be followed by slight pressure upon the brain, a speedy ferer and the eonsequent determination of too much blood to the head, which, combined with tho burning inflammation, brings on this madness, perlinps deatll.

Among the causes other than violeneo we may name the following: The slugging of the vessels of the brain with elots formed elsewhere in the system by some abnormal nction; the growth of tumors upon the brain or upon its eovering, from some remote and probably hidden cause ; sudden and great changes of temperature in the body brought alsout by instantameous exposurc to extreme heat or cold ; over-exertion in plethoric or full-blooded animals, especially in hot weather; congestion from dose collar, short-drawn cheek, or iight throat-lutch ; congestion from internal compression, as by over-loading stonuteh and bowels; feeding on parasitic grasses or smut, of which rye grass may bo noted as the most hurtful; infection of the blood by poisonous animal matter or fluids; imprudent over-feeding nnd insufficient exercise.

How to know it.-The symptoms often differ but little from apoplexy, comparing the first stage of each, but they may generally be distinguished by this: that in mad staggers the horse is not so comatose, or sleepy and insensille, as in apoplexy. Light affeets his eye a little, and he is sensitive to the whip, whereas the horse laboring under $n$ genuine attack of 26 
apoplexy seems blind, deaf, and without bodily feeing. In somo instances in mad staggers, it is true, the animal may sleep till he drops, but on recovering himself ho will manifest the sensitiveness above described.

Oceasionally, the brain alone is involved, in which ease he is stupid, dull, and awkward of motion, the nerves of senation and of motion being both affected; and during this stage ho will somotimes bore bis head against some object; at others he will rest his haunches upon his trough or anything else convenient.

When the membranes covering the brain nre inflamed, which is most generally the ense, there is restlessness rather than stupor; the horse trembles; his genoral temperature is elevated, while there is grent heat about the upper part of the head; his pulse is excited, his breathing quick; his eyes glare; his movements are irregular; he paws, stamps, ehamps his tecth; an interval of stupor may oceur, but even when just aroused from this condition of repose he is extremely excitable and trembles violently.

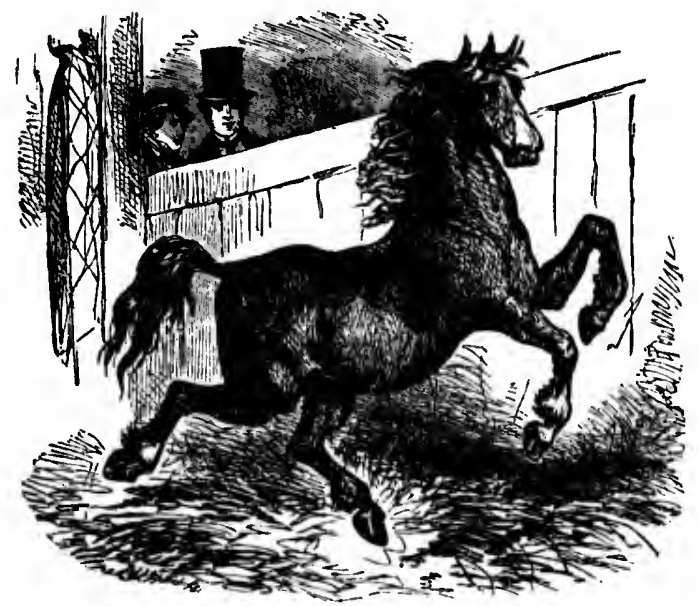

HORSE DURING THE MAD gTAGE OF gTAGgers.

When the worst symptoms are rapidly developing themseives he begins suddenly to heave at the flanks ; his oyes brighten and his nostrils expand: the pupil of the eye dilates to the utmost, and stares wildly and vacantly; his brenthing becomes shorter and quicker; sometimes he will neigh uneasily; his ears are erect and bent forwurd; the membrane of the eye reddens and contrasts strangely with the clearuess of the cornea or ball; he becomes more and more excitable, and trembles at every sound, and 
delirium sets in. He 1. $v$ dashes himself about with fury; his motions are sudden and violent, but without uny disposition to mischief, as he is evidently unconseious. He sometimes becomes ferocious, and dingerous to all who may eome within rench; he then bites and strikes at those who come near him ; he plunges, rears upon his hind legs, whirls round and round and falls with drendful force. He will now lie awhile exhausted, and his pulse and breathing are slower.

At length the mighty anguish returns, and he becomes again a terrifying and dingerous animml. The second paroxysm is worse than the first ; he darts furiously at everything within reach; sometimes bites and tears himself ; and this eontinues until his former stupor, returns, or until he hai; worn himself out and deith puts an end to his sufferings. Each snceeding attaek increases in intensity, and brings on increased weakness, so that his periods of stupor beeome longer and longer till at last he dies.

In those cases where at first only the brain is involved the premonitory symptoms may continue a day or two, when the membranous coverings may become suddenly intlamed and delirium speedily set it. Whenever the membrames are attacked the discase reaches its erisis in a few hours there must be speedy relief or death will quickly follow.

This diseise may sometimes be mistaken for colic or for hydrophobia; lout to distinguish from the former, notice that in the colic the horse rises and falls with less violence, and that though he sometimes plunges, he more frequenty rolls about. He looks frequently at his flanks with an expression of pain, ancl he is all the time conscious. To distinguish it from hyotrophobia, oloserve that while there is violence in the latter, and generully an inclination to do mischief, there is ulways conscionsuess.

What to do.-If the enlier symptoms-stupidity, sleepiness, awkward, staggery motions-ire observed, apply ice cold water to the head, hoth by pouring and by means of a sponge or rags secured between the ears and along the forehead; and bleed severely-not enough, however, to sender the horse faint. Then give an netive purge, as the bowels will almost invariably be found to be torpid and constipated. Use at first:

No. 145.

$$
\begin{aligned}
& 7 \text { Drachms alocs, } \\
& 4 \text { Drachms castile sonp, } \\
& 6 \text { Drops oil of caraways. }
\end{aligned}
$$

Mix with mucilage or syrup to form a ball, and give this quantity for one dose. If this is found, ufter four hours, not to have produced the desired effect, give one scruple of croton meal in water, if he will drink it; if not, he must be drenched. This is a powerful medieine; but it is of the utmost consequenee that his bowels be free, and no effort must be spared to effect that object. If the croton cannot be had, resort to the clyster (of willm soap suds), or to back-raking. 
The bowels having becn opened, give two or three times a day, the following compound, the effect of which is to decrease the action of the heart and prevent the tendency of the blood to the beid, as also to pro. mote the activity of the urinary organs:

No. 146.

1 Drachm digitalle,

1 \% Drachm tartar emetle, 3 Drachms niter.

Keep him in a enol, airy stall, and feed with the greatest moderation, giving such green and moist food as has a laxative tendency, and such quantity only, for a few days, as will prevent gnawing hunger.

But if the paroxysm hins already come on when remedial means are to be adopted, seize the first opportunity, during an interval of stupor, or of comparative stilluess, to bleed him till he falls, or, if down, till he grows fnint and weak. Open the vein on both sides of the neck, if possible, as the quickness with which the blood is diawn away from the bruin is of almost as much consequence as the quantity. The operitor must observe great caution, as the fury may return suddenly and with much danger to himself.

If successful in bleeding, the next step to take is to purge in the least possible time. To affect this, use half a drachm of croton meal. Sometimes the horse will drink readily and freely, in which case the meal cau be well stirred in water and given in that way ; but if necessary, pour it down him according to directions for drenching. If the meal of croton cannot be had instantly, give an ounce of aloes dissolved in hot water. If this does not act within four hours, give a quarter of an ounce more, and so continue till purging is produced. The next step is to give as a sed:tive the digitalis or powdered foxglove, etc., us previously directed. It may be necessary to back-rake and then give a clyster of warm soap-suds.

All this will of course leave the creature in a dreadfully depleted and weak condition; but the only hope of saving him lies in the uss of powetful means, especially when delirium has already set in. It may not be possible in every case to bring him back to fullness of life and usefulness, even with the best of care. At all events, he must be treated gently thereafter, and guarded from excitement, as the attuck is otherwise likely to recur.

\section{Blind staggers.}

Causes.-This disorder, by some called megrims, by others vertign, and still by others dizziness, is not well understond; and there is a difficulty in determining whether some of the forms it assumes ought not to be set down as separnte diseases. The causes, however, that will produce 
certuin manifestations in one horse will produce differcnt ones in another, so that it may be readily inferred that the varying symptonıs do not mark different types of disease but mere difference of degrees; and thit the same general eauses act throughout.

The immediate cause is elearly pressure on the brin, resulting from unusual flow of blood to the head. This is doultless in some instances the result of a constitutional tendency - a predisposition to epilepsy that is brought to manifest itself on occasion of excitement, over-exertion, or general ill condition of the digestive apparatus. In others it is most probably a watery suffusion of the brain - the blood being subjected to some sort of decomposition in its passage through the head and leaving the serun or watery portion to collect there.

The brain requires a proportionately far greater amount of blood than any other organ; but while ample means are provided for supplying it, mature guards against doing this with that velocity which would endanger it by overloading and rupturing. The arteries make their way through the head in a peeulialy circuitous manner, and they enter through minnte bony holes that will not admit of much distension. When the horse is overheated, lowever, or when the return of the blood is impened, this fullness takes place. In great heat the arterial passages are cularged to their ntmost capacity, and the rapidity with which the now uncommonly heated and the thinner fluid makes its way into the brain is not comnterbalanced by a similarly rapid return, and the effect is produced to which the various names referred to have been given. Impeded return of the blood from the extremities, through the veins, is cansed by a tight collar, pressing, during the act of pulling, upon the large or jugular vein, on one or both sides of the neck; by a tight throat lateh, producing a similar compression of the jugular; or hy a check-rein drawn so short as to lring down the head, and bend the neek to the extent of crowding its purts together and interfering with the circulation. By this compression, though the blood may not be foreed to any undue arterial activity, the latre veins will be too long distended by reason of the sluggishness of return, and the small veins rumning through the substance of the brain will be so inereased as to press upon the nerves at their points of origin and produce loss of power and of consciousness.

The immediate enuse, or pressure upon the brain, is doubtless sometimes to be fornd in tumors, arising from blows on the head, as well as in congestion, or too great fulluess.

Other remote causes besides those already named may be found in a diseased stomach and intestines. Inflanmation of all the organs of digestion and secretion may he brought on by the retention of great masses of indigestible food, and this clogged state superinduces conges- 
tion by a sort of internal compression, and this tendeney is of courso increased by rapid exercise und the consequent hent. That this is one of the primnry cuuses is evinced by the fact that colistipntion atiends nealy every case. Indigestion und foul stomach are the natural. results of eonfinement in hot and badly uired stables, unwholesome food, or fool in excess of the quantity required by the mmount of daily exercise, of extreme cold, of extreme hent, and of great fatigue. Hot weather, when the horse is of full habit, will sometimes derunge the digestive functions, and undue exereise will then quiekly develop a case of blind stingrers.

Draft horses, and particularly those that are young and of a plethorie or full blooded tendency, are most subject to it, though it is not confined to any age. It is rarely the ease that a horse under the saddle is attacked with it.

The dread of the whip, combined with the consequent fretting and interference with both the cligestive and cireulatory functions, is thought to produce it in sensitive horses.

It is ordinarily regarded as an incurable disease. If there is an organic predisposition to eprilepsy, entire recovery is of course out of the ques. tion; and when a horse has been once attacked, though previously free from any snch tendency, he is subject to a return of the complaint because the vessels have been weakened by violence, and offer less resistunce to the rapid flow of blood in the arteries, or the abnormal gathering of it in the small veins of the brain.

How to know it.-In its final manifestations it is unnistakable; but the eareful and intelligent owner ought to be able to deteet some symptons of an appoaching attack in time to guard against its most lyurtful effects. That condition of body which superinduces congestion by internal compression and derangement is not difficult to detect, and attention to this may be the means of warding off a violent attack. This is indicated by an offensive breath; somewhat impeded respirntion, or expelling of the air from the lungs ; chewing food slowly, perhaps letting some of it fall from his month only partly masticated; a foul tongue ; a dry and clamm! mouth; disposition to plunge his head into the water above the nostrils when drinking; freces (or dung) hard and difficult to pass; and urine ejected in small quantities.

As previously observed, the attack very seldom comes on while the horse is ridden, but while he is being rapidly driven, or after he has been subjected to a long, lot pull under a tight collar, a elosely-drawn eheck rein, or a thront-lateh buckled almost chokingly.

Oceasionally the attack will be sudden and without the slightest waming; he will fall almost as though shot, or make an effort to run around 
and then fall ; usually he will first exhibit some signs of uneasiness, as shaking the head and twitehing the ears, and the eyes, if observed, will be found to have a wild, staring and bloodshot appenrance. Sometimes he will stop and stare abont-look wild and irresolute-nud then go on as though nothing were the matter. Again, he will rear up or stagger like a drunken man, and then fall. He often becomes stubborn, and will go only his own way-evidently unconscious-and then come convulsions, followed by insensibility.

When down, it oceasionally huppens that ho lies in this insensible state at first, but he usually strugrgles violently, then becomes quiet; gralually recovers himself, and gets up, ready to proceed on his way-being yet dull, howerer, and evidently affeeted by what has happened.

What to do.-When it is diseovered in time thit he is suffering with disordered digestion and is constipated, relieve him from work, if possible, and lessen the quantity of dry food.

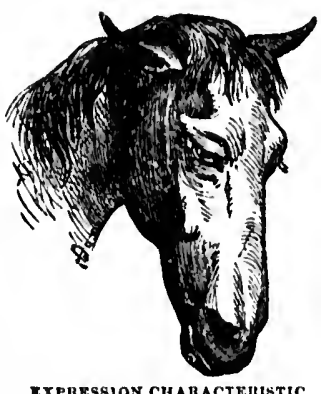

EXPRESGION CHARACTEMSTIC OI MEOUMA.

Turn him out at night, at any rate, even if found imperatively necessary to have his services during the day. If he (an have some continued rest, and the run of a good pasture, or elso bo well fed with food suitable to his condition, and well watered, while oceupying a loomy, dry und well-ventilated stable, his chances for restoration to health and escaping violent attacks altogether, will be greatly increased. Of course he should have sufficient exercise, but in moderation. If the animal is young, and of full habit, yet fallen into this disordered state, l'estrict his diet, increase his exereise by degrees, or turn him out to pasture until his normal condition of stomach and bowels has returned. In the beginuing of this treatment as to diet-what may be called the preventice treatment - give him the following purgative:

No. 147 .

7 I) rachms aloes,

4 Drachms cistile soap,

6 Drops oil of curaway.

Nix with mueilage or syrup sufficient to form a ball. This amount constitutes a dose. It may be repreated after twelve or fifteen hours if the first does not produce proper action.

But if these premonitory symptoms pass unobserved, or if it is a ense of sudden attack owing to violent exercise, great heat, or development of epileptic tendencies, stop him, if driving, upon his showing any of the indicutious described, and go to him ; eximine collar, check-rein, throat- 
latch, und see that all is right; pat and sootho him, and nllow him to staul for $n$ fow moments in quiet. Where it is found that the collan lists been pressing the neck veins seo that it is nltered without more adoeither by eutting or by pressing in ngainst the lienst on the lower pitrt of the collar a cloth of sufleient size to provent its tightoning 11 pon the sides of the neck. If he recovers sufticiently to bo driven, allow him to move at a very modernte puco; if not, remove him from the vohicle and land him home. When there he must lave rest and quiet, and care must be taken, as provionsly directed, to loring him, by food and laxutives, into a good state as to stomach mul bowels.

When the nttack is so violent that he rears, plungess, and falls, hacel as soon ns he becomes composed enongh to allow it - taking from the neck vein from three to six quarts, aceording to the violence of the fit, and the weight, fullness, and fleshiness of the patient. Dming the first paroxysus of his attack dash eolal water over his head, if it ean he had; and it wet sponge made fist between his ears will he found useful.

From these violent attacks, entire recovery is doubtful, even though he may not die outright; hut every chanee of oven a partial return to health and usefulness is incrensed by rest. $A$ horse once nffectorl in this way should really not ho driven again, thomgh apparently rocovered, for the tit is likely to recur, and the driver may himself be therely seriously endingered.

The necessary steps as to feeding and eare, and tho administration of laxative medicine have alrendy been pointed out.

\section{Apnplexy, or slcepy Stnggers.}

Causes.-The different stages of this disease are sometimes treated is thongh they were two different types; and we tind even professed reterininrians, who ought to ho more discriminating, so reganding them. Apoplexy is the term by which alone it should be known-the stite of slecpiness and staggering being but premonitory symptoms, or rither the eatriest stage.

The immediate causo of this disorder, as in blind staggers, merrins, vertigo, giddiness, dizziness, 01 by what other name the disense previously treated may be known, is undue pressure upon the brain, and their romote eauses are generally identieal also-the difference in the diseases being simply a difference in the modes of their manifestation.

Post mortem examinations of horses that have died of apoplexy, have sufficiently indicated the enuse. The vessels of the brin are found to be peculirly blonted or distended with black blood. Sometinies there may be no inflammation of the membranes of the brain, but the stomaeh is found loaded with undigested food or the intestines with foul matter. It 
is clear thant congestion of tho bunin, porhups of tho venous system gencrally, is the condition thut prevuils when the disense manifests itself in its netive mul violent stuge. And this too grent fullness of hloorl is in most rases owing to disordered digestion, which may be bronght about in two wiys: the horse may bo overfol mal subjocted to insullicient exerrise, so that the stommeh hecomes wouk, mod lacks tho powere te digest of expol the food; or he muy sudilenly gorere himsolf when elhancing to

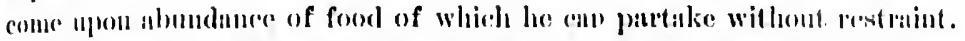
The fulness of the stomatel and bowels produees thint intermal eompression which preceludes the regular flow of hlood throngh the veins, and reakens tho venous system, and the bran soon beemes overelatined, :and that, too, with a thist in a degree poisonoms for waut of perfoct oxy-

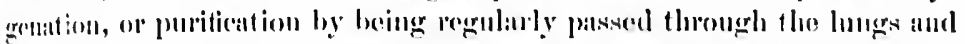

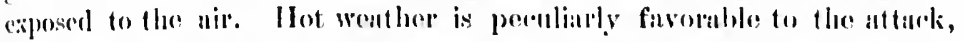

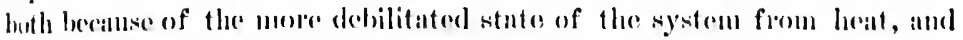

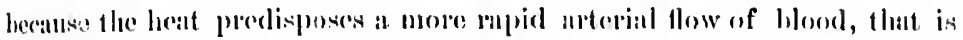

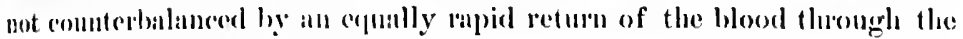
veins te. the heart and lungs.

Inxintiant pasture, warm wentler, and the dependent posture of the

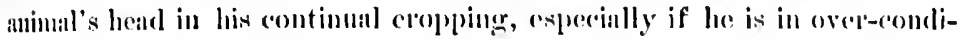
tion mol full of blood, maty readily produce apoplexy-the immediate and the remote (amse in this anse seeming to atet simultanemsly. II poor endition may be attaked after laving been orelworkol and reduced to a debilitated state though want of care and of nourishing foorl. Put upon rich pasture, with a ravenous appotite, they are apt to gerge and bringr on indigestion and its attendant constipation.

There is sometimes a softening of the brain, lather than effusion or too great fullness, and this may arise from tumols, cansed by blows, or by the plugring of the vessels with clots of tihrous matter.

How to know it.--This differs from blind staggrers or megrims in this, at laist, that the prevailing symptoms foree themselves npon the attentinn of the ordinary olsserver while the horse is at rest. Ho exhihits at first a want of appetite, and is more thata ninally dull. When he walks his movements are slow and mustealy. Examination will discover his pulse to be slow, heavy and dull, yet full. When he is cxercised a little these symptoms go off, but they soon return when lie is left to himself, and more unmistakably. In the open air he balanees himself as though about to fill, and stands with his head depressed. In the stall he bears upon the trough or the wall, and $\|$ good deal of his weight seems to be supported in this way. Sometimes lie grets his head aguinst some rest, stunds for a length of time, and then drops as though shot, but presently gets upon his feet again, to relapse into the sime sleepy listlessness. 
When in this condition it is dangerons to be nem him, or to attempt tu move him. "When monsed from this mpment sleep he looks vatutly mound, glnres unmenuingly, and sometimes the oyes will not closo when mu object is noved before them - and the indications are that he neither sees nor hears. If food is within reach he will sometimes take n mouthful, but lose conseiousness while it is yet but half chewed; and if he attempts to drink, the power of swallowing seems to be partially lost, and the water will return through his nostrils. As he grows worse he will twist his legrs over ench other when trying to go struight forward. In the last stage he hegins to foam at the mouth; his breathing becomes loud and laborions; the pulse is depressed; the jugular veins are distended almost to bursting : the muzzlo is cold. and sometimes he discharges feeces nlmost involuntarily; he grinds his teeth; twitehings stcal over his face and limbs; and at last he falls into convulsions and beats himself about ill a terrible mamer. There is no disposition to do mischief - ho is evidently well nigh unconscious. All the power's of life me wrought upon, and death speedily results unless some powerful means ean be brought to benr to bring instaint partial reliof.

It is well to cantion the reader agrinst mistaking for an apoplectic sign a certain slecpy, listless, stupid expression of eomntenunce that is brought on by repeated attacks of morgrims. A little examination will generally disclose that all the other symptoms of apoplexy are wanting.

What to do.-That treatment which will most speedily relievo the overloaded ressels of the brain is clearly best. If anything is done before the violent stage of the disense comes on, bleed freely from the neek vein - so freely, indeed, that the horse falters or begins to blow. If the ease has been neglected until tho violent stage is upon him, heed, if possible, until he falls. It mily sometimes huppen that a lull in the paroxysus ensues, and even at this late hour it is well to milke the attempt to save by diawing blood.

Next, determine, if possible, whether the cause is a present-existing gorged stomalel, and constipated, torpid bowels. If so, use the stomach pump promptly. Foree warm water into bis stomach till the food is so thinned that it may eseape by the pylorus and by the mouth and nostrils. When this extreme fullness of the stomach is overcome, give a purgative bolus us follows:

No. 148.

7 Drachms aloes,

4 Draclims cistilo sn'

6 Drops oil of cara"

Mix witl mucilage or syrup to form a will, whic is give as a dose.

If the constipation is obstinate, and does not violl to this purgative,

stir a

lisis ho

I'li

uluted

Disso

Attel

quantitity mity he

food ud

free itce

In the

in quieti

ine eold

Cntil ! pasture,

comes on

int inl op

Compl

once sere

go throus

As int $\mathrm{t}$

reuders :I about by and shortsubstitute agrilinst.

Apoples. than one 1 be assured are remov

This $n 0$ by external substance, similar cau 
stir a hundfull of fine sult in ono gallon of warm water, and inject it into lis howels. This fuiling he must bo buck-raked.

When tho system is once relieved the rigestive functions may loe stimilated by giving, overy four hours, for two duys, a winc-glass-full of

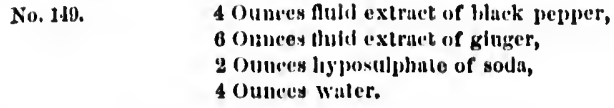

Dissolve the soda in the wator ; then ndd the ginger mal pepper.

Attention must now be paid to diet, at first reducing it to a small quantity, and to such in quality as will have $n$ laxative temdency. Hu may be turned upon $n$ prosture, if it is not too rich, hut lie should have food alninistered morning and evening in moderation. Ilo should have free alceess to witer.

In the heginning of the puroxysm it is sometimes foumbl anlvintugeous in quicting lim somewhat to apply ice to his head, or to pour an stream of ice cold water stendily between his enrs.

Intil he is so fur recovered as to render it sufe for lim to go to pasture, keep him comfortalsle. If the weather is lot-and it usually comes on during hot wenther-keep him in a cool, well-nired pluce, or iil all ope'n place well shaded.

Complete recovery is seldom to be hoped for. Generully, the horse once severely affected, is useless for Summer work, though well able to go throngh that of Winter, if properly eared for.

As in the blind staggers, the unnutural distension of tho blood vesside renters a recurrence of an nttack very probuble; and it may bo brought ahout by external compression, so that tight collars, tight throat litches, and short-draw oheck-reins, should be avoided. A breast-strap should be sulstituted for n collar, and overwork should be specially guarded :II:iunst.

A poplexy is not contngious, though it has been so regarded. If more than one hor'se on the same farm or in the same stalle is affected with it, be assured that the same causes me present for both, and that when they are removed the danger of now cases ceises.

\section{Abscess Within the Brain.}

This not unusual and terrible affection is produced almost invariabiy by extermal injury. From being struck or striking agrinst some hatrd substance, as in lunning away, striking the head in the stable, or other similar cause. It is possible the owner may know nothing alont it. A 
wound, perhaps a trivinl looking one, is found on tho head, from which perhaps only a little watery fluid issues. Soon the horse becomes dull, and from day to day gets worse, refuses his food, and at last falls and commences knocking his head against the floor or on the ground; thus he continues until at length death eomes to his relief.

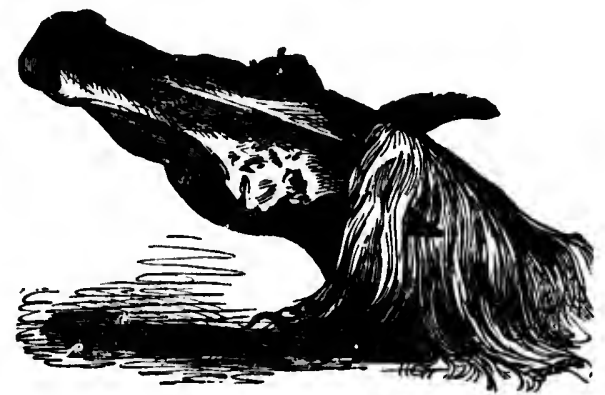

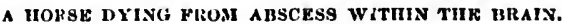

What to do.-There is nothing to be done once an abseess forms within the brain. The only means of cure is to allow the matter to escape. The thick muscles covering the cranium of the horse would prevent the use of

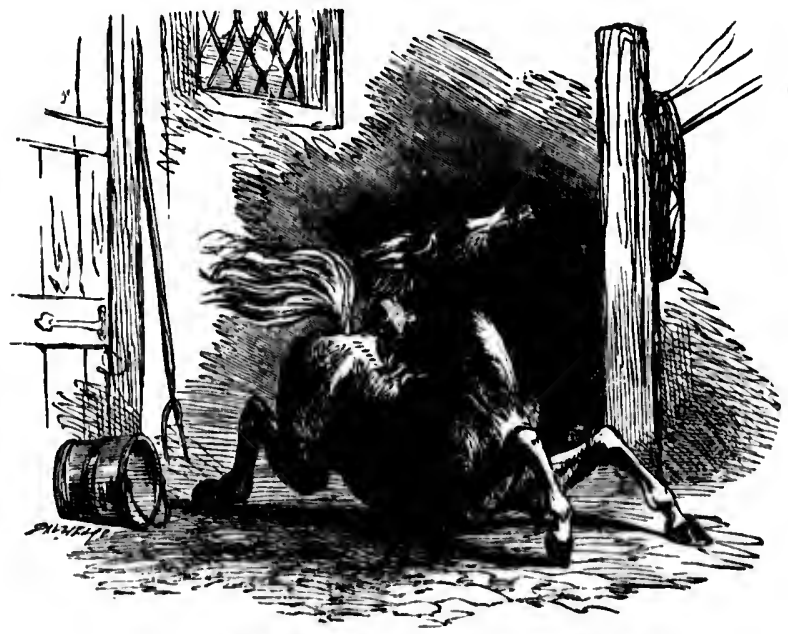

A IIORBF, MAD FROM INFLAMMATION OF TIIE BRAIN.

the trephine, and if, indeed, it hole wis mude through the skull to the hrain and perehance the abscess cured, who would want the horse?
There is cry at or

Anoth flammati exhibitio successft

If dise mily be $h$ flow unti sinks. $\mathrm{P}$ at the en the pulse tincture o pint of $h$ be given cases out 
There is but one sensible way: kill the suffering animal and end its misery at once.

Another terrible affliction of the brain, fortunately not common, is inflammation of the brain, or phrenitis. It is indeed madness, with the exhilition of terrible strength, which no humm power enn ecpe with to sucecssfully relieve, in its frenzied stute.

If discerned in its earliest stage, hefore violent frenzy attacks it, resort mily be had to bleeding. Open both neck veins and allow the blood to How until the dull, heavy, listless expression brightens or the animal sinks. Bleed agnin if necessary. Give 8 drachms of aloes, and repent at the end of three hours, if the bowels are not thoroughly relieved, or the pulse changes for the better. Afterwards give 20 to 30 drops of tincture of aconite, or half a drachm of the powdered root infused in a pint of lot water, or a drachm of digitalis, infused in the same way, to he given cold every half hour until relicf is obtained. In ninety-nine cases out of a hundred, however, relief will come in death. 


\section{CHAPTER XI.}

\section{DISEASES OF THE MUSCLES AND TENDONS.}

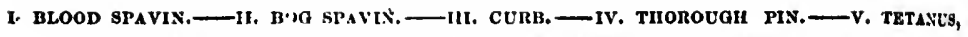
OR LOCKJAW. VI. CHA.MI'S VII. KHEUMATISM. — VIII. STRING HALT.

\section{Blood Spavin.}

This may be defined as a distension, or enlargement (dilatation) of the veins of the hock joint, and overlying the seat of bone and bog sparin; a local venous congestion, eaused generally by swelling, impeding the flow of the blood, and often connected with bog or bone spavin. It is harmless; in fact it may be considered as accompanying, or the result of other disease of the joint.

What to do.-In the early stage cold water perseveringly applied, followed by cooling lotions, equal parts of aleohol and rain water, or one pint of bramly to one-laalf pint of water, applied as a lotion. If this does not relieve the difficulty, use a strong infusion of bayberry bark, using considerable friction by hand rubbing with either of the renedies named.

\section{Bog Spavin.}

Common bog spavin is technically (as is windgall) an enlargement of the Bursa Mucosa, just as a distension of the sub-cutaneous (beneath the skin) veins in the region of the hock is called blood spavin. These cause an undue secretion of joint oil and a dropsical effusion into the joint, producing swelling having ull the charucter of inflammation of the true hoek joint. This inflammation of the upper or principal lock joint is true bog spaviu.
Cause

fracture inflamm

How $t$ ating sw or prine a swelli forward, below an

What $t$ timued pr with cold

In case of witer, In the lat is a bad o may be ap even to bo and $161 \mathrm{fc}$

This is: the hock jo shinpe of $t$ the hock.

\section{Causes.-} the sheatll hock when

How to and a tencle

What to of will generis disease. If following :

No.

Apply nig daily with vi 
Causes.-Overwork, sprains, injuries either from punctured wounds, fractures or bruises: also fiom the effects of rheumatism. All produce iuflanmation of the structures of the joint.

How to know it.-In its acute early form there is a tense, puffy, fluetunting swelling of the front and inside portion of the hock at the upper or principal point just where usually there is a depression. There is also a swelling behind, where thorough-pin occurs, but it can be pressed forward, the anterior (front) swelling filling up; but there is no swelling below and behind the hock as in thorough-pin.

What to do.-Absolute rest and the use of a high-hecled shoe. Contimued pressure on the swollen parts, by means of a truss or compress, with cold water applications, or brandy and salt.

In ease there is much inflammation reduce it by means of fomentations of water, and if there is pain let the fomentations be an infusion of hops. In the later stages use tincture of nrnien diluted with water. If the ease is a bad one, when the extreme heat and tenderness has subsided a blister may be applied, sinee it sometimes goes on to uleeration of the joint, and even to bony deposit destroying all movement of the joint. See No. 160 and 161 for hlisters.

\section{Curb.}

This is a swelling in the middle of and just behind the lowest part of the hock joint. At first it is soft and dougloy, or retaining for a time the shipe of the pressure, producing an enlarement about two inches below the hock. Curloy hocks are also sometimes eongenital and hereditary.

Causes.-A blow, but more frequently a sprnin of the truclon, or of the sheath through which the tlexor tendon passes. The ligament of the hock when injured increases the gravity of the disense.

How to know it.--There is beat, inflammation, tenderness, lameness, and a tendeney to knuekle forwind at the fetlork.

What to do.-Absolute rest, a high-heeled shoe, and cold water bandages will generally renove the difficulty if applied in the early stiges of the disease. If, from neglect, the lameness becomes decided, apply the following:

No. 150 .

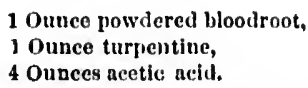

Apply night und morning for a week or ten days and nfterward bathe daily with vinegar 
If coagulable lymph forms, threntening callosity, (a hard swelling) daily and long-continned friction - hand rubbing downward-and the application of a more decicis stimulant will be indicated. If so, prepare the following:

$$
\begin{aligned}
& \text { No. 151. } \\
& 1 \text { Ounce oli of eedar, } \\
& 1 \text { Ounce ofl of majoram, } \\
& 1 \text { Ounce ofl of sassafras, } \\
& 1 \text { Pint soft soap. }
\end{aligned}
$$

Use this daily, rubbing always downwards.

\section{Thorough Pin.}

Causes.-This is a sprain of the flexor tendon behind the hock, and which has a large sheath which extends both above and below the jointa dropsical enlargement of the sheath of the tendon, so the fluid contained may be pressed from one side to the other. Hence its name.

How to know it.-Pressure on one side will enuse bulging on the other, and pressure on both sides will enuse fluctuation along the tendon below and behind the hock.

What to do.-Use the same treatment as for curb; eold water handages, or hot fomentations in the early stages of the clisease; also absolute rest and a high-heeled shoe. When tenderness censes and lameness is gone, apply a spring truss, so the pads will clasp and cover the puff on both sides, and exert a pretty firm and steady pressure. Success in removing the puff has occasionally been had by puncturing the lower part of the swelling, into the sack, and injecting a solution of the following strength :

$$
\text { No. 152. } \quad 10 \text { Grains suiphato of zinc, }
$$

$$
1 \text { Ounco rainwater. }
$$

Inject one or two tea-spoonfuls, as the ease mny require. Then hring the walls of the sack elosely together and hold them so for a week iy means of a firm flannel bandage.

Another plan is to npply with gentle rubbing, the following ointment every day until the skin is inflamed:

$$
\begin{aligned}
& \text { No. 15. } \\
& \text { i Part biniodilio of mereury, } \\
&
\end{aligned}
$$

Rub together, either in a mortar or with a spatuila on glass, until intimately incorporated, and use as directed, observing regularity and slumming violent lundling. 


\section{Tetanus, or Lockjaw.}

This terrible affliction, which consists of persistent and often acutely painful drawing together (cramps) of the volunt:lry muscles, causing extrene rigidity, drawing together the whole musculur system, and elosing or locking the jaws.

Causes.-Often a wound in the leg or foot, seemingly of the most trivial chitricter, us the prick of a nail. It is also produced by castrittion nicking and docking; by hard riding or driving, and leaving the animal slivering in the night air. When it proceeds from a wound, it is called trumatic: when from no apparent cause, it is called idiopathic. It rarely occurs from wounds until they are well advanced toward being healed; though it may display its symptoms immediately upon or at month after the hurt, but generally from the sixth to the fourteenth diny.

How to know it.-In the enrliest stages there will be stiffness and rigidity of the muscles near the injury, and the limb will be moved with. difficulty. There will be excitement, the ears will be pointed forward, the head elevated, the legs stiff and stretehed out; the horse will seem exeited and yet obstinate to move; the tail will quiver and the skin and tlesll will feel hard like a board. The lower jaw being taken in the hand and the head raised, if the haw projects over the eye, you have a cuse of lockjaw, See cut.

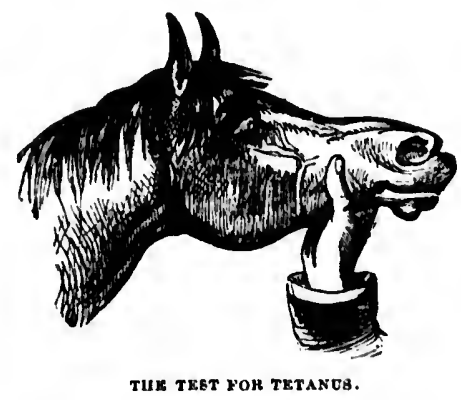

What to do.-Give the animal a loose or box stull, and in the most iniet place possible, and where it will see no one exeept the attendant. l'lice slings beneath him so ho can stand elear of then or rest in them at will. Remove all straw, litter or other sources of excitement, and avoid all noise or unusual movement. Keep the stable datkened und without ither animals present. If tho disease is produced by a wound exumine it, and if contracted or containing pus (matter) widen it, and cover with 
a bread and milk poultieo containing lnudanum or extract of belladonna.

Give a powerful purgative, as the following:

No. 154.

6 to 8 Drops eroton oll,

4 to 6 Drachms powdercd aloes.

Dissolve in a pint and a lulf of water and give as a drenels. If it cannot bo given ly the mouth administer it through the nostrils by means of a stomach pump and the horse eatheter, to be hereafter shown, in feeding; or prepare tho following, if the horse can swallow a ball :

$$
\text { No. } 155 \text {. }
$$

\author{
4 Drachms powilered aloes, \\ 4 Drachms extract of genilan, \\ 1 Scruple croton furina. \\ Mflx with llnseed meal and molasses Into a ball.
}

Follow this up with three doses datily of anti-spasmodies, as, one to two drachms belladomna, or one-half ounce ehloral hydrate, or onc-half to one ounce dose of tincture of lobelia in a pint of wates. Give ly the mouth if the animml can swallow; if not, ats an injection. Feep the howels open with one drachm podophyllin and two drachuns extract of helladonni, smeared on the barck of the tongue.

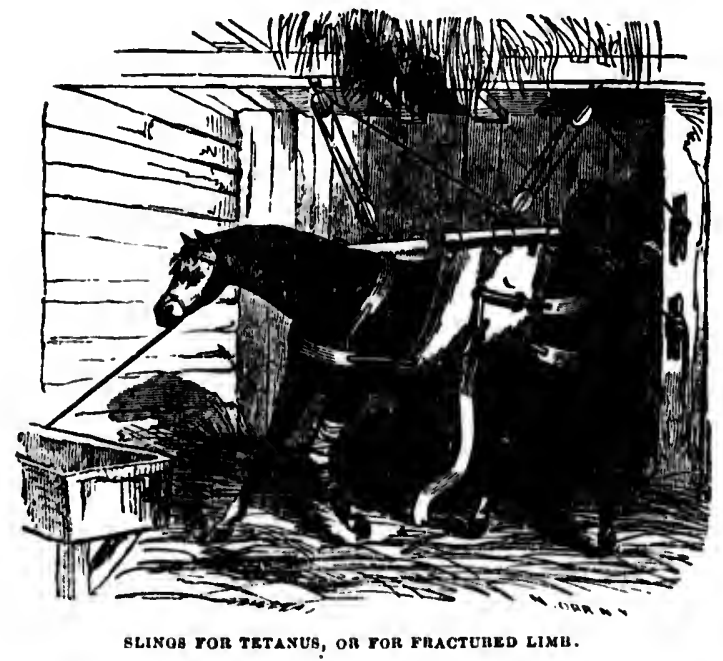

If the animal can bear it, a thorough sweat with a blanket wrung out of hot whter, and covered with dry blankets will do good. Feed with nourishing gruels if the animal can swallow; if not, feed as next described.
At1

the $n$ draw

slarming his fist This, ho form (it: waty be 1

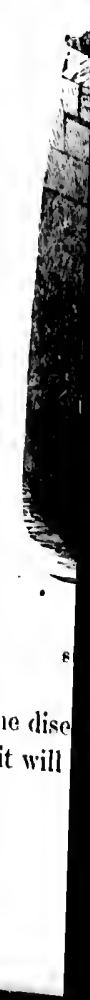


Attach a horse catheter to a stomateb pump, puss the end carcfully up the nostril and into the gullet as shown. If coughing is produced, withdraw the catheter and commence anew. If two feet ire inserted without

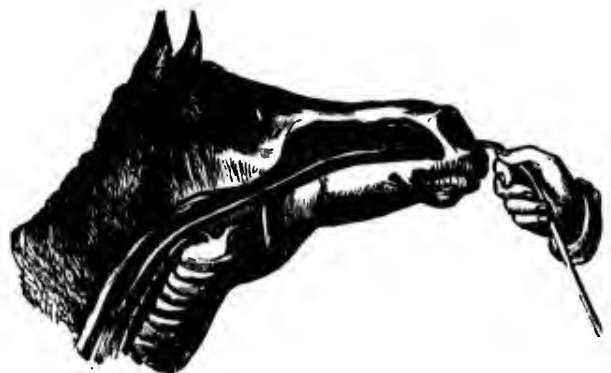

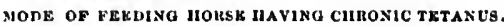

alarming symptoms, pump in only a quart of linseed gruel, if the iorse has fatsted for some time, and as the stomach ean beal it, give more. This, however, must not be attenuted while the discuse is in its acute form (its earlier stage), but after the disease assumes a chronic forn it maly be resorted to.

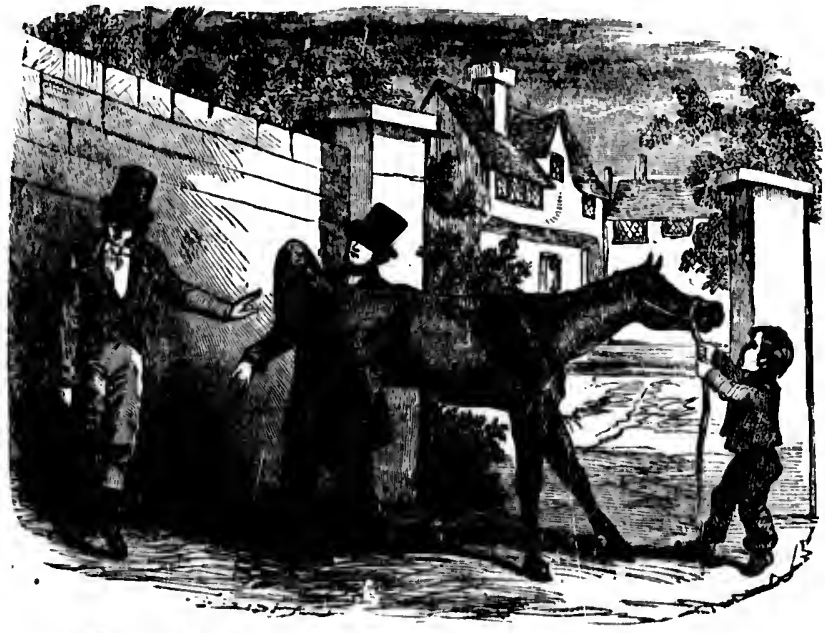

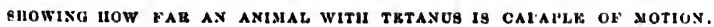

vrung out Feed with escribed.
The disense is apt to leave the animal in a most deplorable condition, and it will be a long time before it becomes serviceable, if indeed it ever 
does. Six weeks or even two months may be required before the unimat regains the use of its powers. The cut annexed will illustrute the condition of a horse with tetanus.

It will thus be seen that in a decided caso it will be policy as well as humnnity to seriously consider whether it may not be better to reileve the sufferings of the poor animal at once by shooting through the brin.

\section{Cramps.}

Some horses are quite subject to eramps of the museles and tendons, It may be an irritalbility or spasm of a particular musele or set of musw (les, which refuse to act, becoming stiff and inflexible. They (rimp amu sometimes twiteh excessively. This is ngain sueceeded hy another stige in which the muscles relax and are restored to their normal condition.

Causes.-Strins, bruises, or orer-taxation of the powers. In many eases it is undoubtedly allied to rheumatism, a disorder nttacking horses much oftener than is supposed; rheumatism very often being attributed to bots, founder and various other eauses by the ignorant. Both diseases aro quite painful, and leave the unimal verysore, and rheumatism often for montlss.

What to do.-Clothe the body warmly, find the scat of the difficulty by feeling of the parts until the sore plice is touched. Wash the parts with salt and water, and rub dry. Then apply the following liniment:

No. 156.

$$
\begin{aligned}
& 1 \text { lart solution of ammonia, } \\
& 1 \text { Purt spirits of camphor, } \\
& 1 \text { Purt olive oll. }
\end{aligned}
$$

Rub it in well, and hold a hot iron or brick to the parts to heat it thoroughly.

\section{Rhoumatism.}

This is a peculiar form of inflammation attneking the fibrous structures of the body, such as the joints, tendons, ligaments and museles, and is accompanied by stiffness, exceeding tenderness und pain, shifting from place to place, often implicating the valves or other structures of the heart, and when so usually results in death.

Causes.-Exposure to cold, wet or drafts, especitlly when the system is overworked. There is usually a constitutional predisposition in the subjects, and in such it is ensily hrought on by diseases of the respiraton? or digestive organs, especially in horses of a full, gross habit.

How to know it.-In its acute form there is dullness, followed by ex. 
treme lameness in one or more of the limbs. There is tenderness and then swelling of the joint, tendon or museles, at first soft, then hard. There maty be fluctuations from excess of synovia (joint fluid). With the inflammation there is fever. The pulse is full and hard; the mouth is dry and chumny ; there is hurricd breathing, scanty urine and costiveness.

In the chronic form the symptoms are the same as in the acute, but not so pronounced, and in this form it is unitended witl fever. It may appenr only upon undie exposure, or in dump, lowery wenther, and disappear again upon the recurrence of fine weather. Chronie rheumatism is also less inclined to shift from place to place.

What to do.-For rheunatism in its early acute stnge relieve the howrls by lixative medicines, say four ounees of aloes. Put the amimnl in slings, as for tetanus, and clothe him from the hoofs to the eurs in flannel. If priteticalle the first thing is to fill the box in whicls the horse is kept with stetun, keeping it up for an hour. If the pain is extreme lessen it with ounce doses of landunum.

Give the following three or four times a day as a drench in a pint of gruel:

No. 157. 1 Ounce blenrbonate of sodi,

If this c:mnot be obtained, give the following, at it dose, night and morning:

No. 158.

$$
\begin{aligned}
& \text { 3. Ounce powdered saltpcter, } \\
& 1 \text { Dracim powdereil coichicum, } \\
& 1 \text { Ounce oil of turpentine, } \\
& \text { Mix in haif a piut ol linseed oll. }
\end{aligned}
$$

Leat it

For rheumatism in its chronic form the following will be found to be valuatle, used internally :

$$
\begin{aligned}
& \text { No. 159. } \\
& 1 \text { Ounce powdered earbonate of potash, } \\
& 2 \text { Draclins iodide of potash. }
\end{aligned}
$$

Give in one and a half pints of water.

As a liniment for the joints and other affected parts, to be afterwards mrapped in flannel, the following is excellent:

$$
\begin{aligned}
& \text { Vo. } 160 . \\
& \text { 1 Pound compound soap linlment, } \\
& 2 \text { Ounces ilquor ammonia, } \\
& 2 \text { Ounces tincturo cantharidey, } \\
& 2 \text { Ounces iaudunum. }
\end{aligned}
$$

Rub in with as much friction as the horse can bear, and apply until 
signs of blistering are upparent. If this does not produco the desired ef fect, use tho following :

$$
\begin{aligned}
& \text { No. 161. } \\
& \text { 16 Ounce laudanum, } \\
& \text { 1 Ounce tincturo cantharldes. }
\end{aligned}
$$

Apply to the joints with a soft brush, but without friction.

$\Lambda$ soothing and stimulnting ombrocution, when so severe measures as the foregoing nre not considered necessury, may be mude as follows:
No. 102.
1 Part spirits of camphor,
1 Part solution of ammonia.
1 Part ollvo oll.

Mix, and apply by rubbing it in.

\section{String Halt.}

String-halt is the sudden jerking up of $a$ hind limb, sometimes both in succession. Sometimes several efforts will be made bofore the muinul can progress at all. In other cases the spmsmodic netion of the hind ley is shown in starting off, und the mimal becoming warm, it will nearly of quite cense. An exceptionnly bad case is shown in the illustration griven below.

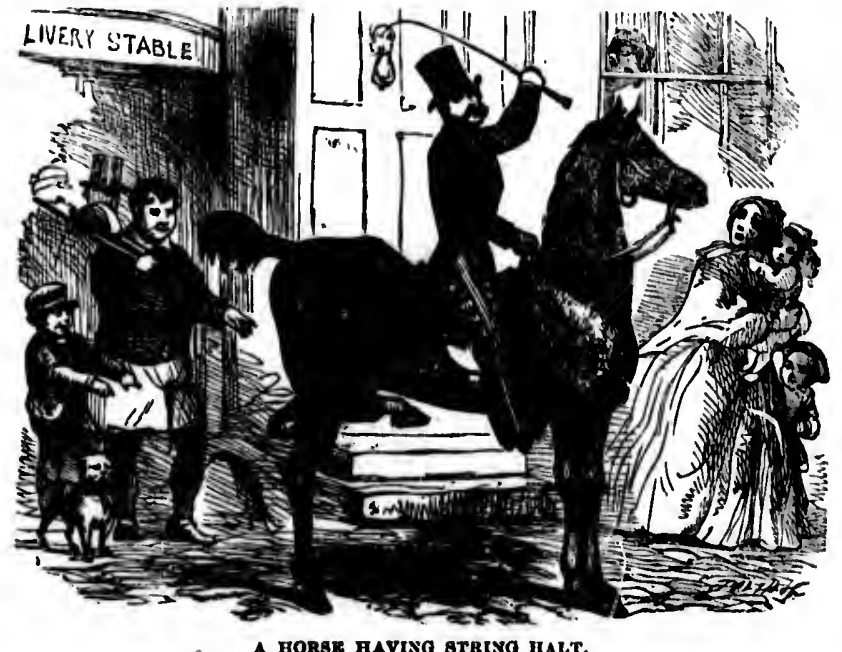

Sometimes the action is so slight as to be alinost unnoticed, and aguiu it may be so strong that tho hind log will strike tho belly. 
Causes.-The causes are unknown. It is supposed to be produced by a variety of injuries, but principully as a reflex nervous netion. It increases with ago and hurd habor, und nervous exeitenent, and is a positivo unsoundoess.

What to do.- There is no cure. Rest, keeping the bowels open with 2 arachm doses of belladonn dity, will lessen the spasms for a time; but fatigue or nervous excitement is sure to bring on a recurrence of the nttack. A careful driver will often prevent the disthility being much shown by being careful not to excite or overwork tho horso. 
1. NATURALLY WFAK FYYS, - II, BORE RYE-LIOS, - III, MOON FYES, - IV, CATARACT - V, INYLAMMATION OF TIIE HAW, OR HOOKS, vi. DIMNESS ON vision. - r.t. WORMS IN THE EYE.- VIII. PURULRNT OPIITIALMT. IX. FUNGOID TUMORS IN TIIK

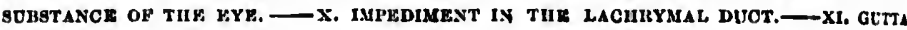
BERENA.

\section{Naturally Woak Eyes.}

Very many persons, otherwise well informed, when from any cause the eyes of horses become wenk, inflamed, watery, or drop tears, suppose the cause to be from a natural wenkness of the sight. So "blind tecth" are supposed to cause serious trouble, and even blindness in hoises. Nothing could he further from the truth. It is exceedingly rare that horses laive naturally woak eyes; it can almost always be truced to some local cause. Thus, watering of the eyes is ctused by a stoppage of the lachrymul lucts leading from the cyes into the nostrils, the natural ehimnels $f(n)$ carrying off the superabundant moisture of the eye. Inflammation of the eyes is not uncommon from a turning in of the eye-lashes. The remedy is to snip them off with the scissors.

"Blind teeth," or "wolf teeth," as the immature supermmerary tushes are called, do no injury whatever. If it is feared they may, it is casy to take them out with a pair of forceps, or to knock them out with a punch and hammer.

Occasionally a supernumerary tooth mily be found growing in the upper jiw, between the first and second teeth, and lapping over loth of them. This is considered by many persons as producing inflammation of the eyes. It is true that if pain results, the eyes may be affected by sympathy. This tooth should always be removed, and may be done with a strong pair of forceps. It may cause distress from pain in the jar; nothing more.
Colt
during
recoves

Ii) th

is comin thammiat other di

There inge and lave spe

What not in a

Form i

To red oughly at mixed ; to sulpluste c rurd over The clear lent for so timers a dis In agrgr: risw und c c'nrial oint tact with 1

During the rear 1 ) from a nos

This is o weeks, it m

Causes.low, damp 
Colts $n$ ro often suliject to intlammution of the eyes in a slight degree, during teething. Examine the teeth, lance the gums, and the eyes will recover. It is a ease of symputhy.

\section{Sore Eyo-lids.}

In the outset of more serious disense, soreness of tho lids of the eyes is common. It is also produced by irritution of vurious kinds. In inHammation of the eyes, soreness of the lids is nlways juesent. If from other disense, it is sympathetic, and will puss awny with the disense itself.

There is one form, howerer, that is chnracterized hy a redness, swelling and itching, the edges hecoming raw and exuding matter. This must have specitic trentment.

What to do.-The horse should have a laxitive elese if the lowels are not in a muturnl state. The following will ho indicated :
No. 163.
1 Draclum flowers of sulplunr,
2 I) rachms powdered mandrake,
3 Dr:uchms powdered aloes.

Form into a ball with honey, and give as a dose.

To reduce the inthmmntion, muke a curd, by benting three egres thoroughly and then stirring them with a quat of filtered minwater until mixed ; let it come to a boil, stirring oceasionally. Adlel lalf am ounce of sulphate of rinc, and continue the looling for $n$ fow minntes. Bind the (mrl orer the eyes, by plucing a portion between lisyers of thin muslin. The clear water strained through several thicknesses: of tine linen is excellent for sore or influmed cyes of any kind. Wret the licls three or foir times a day.

In aggravated cases that will not yicld to treatnent, and that remain riw and exnde matter, tho edges should be curcfully tourhed with mercurial ointment, the utmost earo being talken that it does not come in contalet with the eye.

During the whole trentment the horse must. be tied up hy two lines to the rear posts of the stall, so he eannot rub the eyes, and must be ferl from a nosc-bang.

\section{-}

\section{Moon Eyes.}

This is ophthalmy, recurring at periodic times, or at intervals of thee weeks, a month or more, and not, as is often supposed, at the full moon.

Causes.-Hereditury predisposition ; from malarial causes; herling in low, damp situations; rheumati: affections; irritution (onsequent on 
teething, and in fact, where predisposition occurs, from any cause tenu. ing to lower tho general stute of the health.

How to know it.-There will be a sunken look to the eye; the haw of the oye will protrude; the whits of the eye may be of a pinkish east; the eye will ine watery; the pupnl of the eye will be eloudy, nt the edges, and dull and ciiseolored at the conter; there will be haziness, milkiness, or a whitish spot may appear, which will continue to overcast the eye. In the intervals between the attneks the trimspurent cont of the eye will have a hazy, bluish cast about its horder, and the iris will lnck its natural lorightness; the upper lid or eyebrow will be wrinkled or furrowed.

What to do.-Look first of all for carious or defective teeth, and if found extract them. Tliere is a streng sympnthy between any diflienlty with the teeth and the eyes, though unsound or "wole teeth" do not, is was once :upposed, cuuse blinduess.

Place the animal in $n$ darkened stable; givo four dracbus aloes, and apply the following lotion twice a day :

$$
\begin{aligned}
& \text { No. 101. } \\
& 20 \text { Grains acetate of lead, } \\
& 20 \text { j)rops belladonna, } \\
& 1 \text { Quart liltered raln water. }
\end{aligned}
$$

Alternate this twice a day with the following:

$$
\text { No. } 105 \text {. }
$$

20 Grnins sulphnte of zine, 20) Drops tincture of Malabar bean, 1 (Quart flltered raln wator.

The physie having acted, give two or three times a day the following:

$$
\text { No. } 168 .
$$

1 irrachm suiphate of irom, yá ounce powderecs P'ruvian bark.

Mix in one quart of warm water, or give in the feed if the horse will eat it. When mother attuck is experted double this dose.

Sometimes an ounce daily, for severnl weeks, of Fowler's solution of arsenic will be sorviceable, intermitting a fow dinys oconsionally. If, how. ever, the attacks recur, and at lessened periods, the trouble may be expected to end in enturnct and blindness.

\section{Cataract.}

As a rule, cataract is the result of inflammation of the deep structures of the eyeball (interual ophthalmy or tho periodic form). It also oeeurs ocensionally from dinlıetes nud other constitutioni disabilities.

How to know it.-Put the horse in a durk place. Take a ligrlted candle. Three images will bo reflected, one from tho surface of the ere, one frot the lent cliangined in other

What be crent and ulso digitalis six to cis diark roo following

Mlix the linen cloti Apply:

Mlix and stypler.

The hatw colner of $t$ pilss overe $t$ froun the es the inction. illempting

Causes.pirrts of the illy from it. some perso: from " geini

What to for oplithall use the land

If the inf eye, or eyes 
one from the front surfice of the lens, and one from the rear surfile of the lens. If in moving the light either of the posterior images are changed into a white hazo; there is exudation into that part of the lens; in other words, a cutarnct is forming.

What to do._Unless the enturact is only just forming the horse will he erentually blind. Give uloes as reommended for moon-blindness, and also the preseription for lotions in that case. Follow this up with digitalis in doses of fifteen to twenty grains duily, alternited duily with six to rient drachms of niter in the water taken. Keep the nnimal in :: dark rom! ; apply blisters to the cheeks and behind the enrs, using the following, well rubbed in:

\section{Sio. 16i. 2 Drachins powdered cantharides, 3 Ounec lurd.}

Jlix thoroughly and rub well in, treating the blisters when formed with linen clotiss covered with mutton tallow to keep them running.

Aply ulso to the eye dnily for several months the following:

No. 168.
2 Grains phosphorus,
1 Ounce almond ofl.

Mix and keep in a dink, cool plnee, in a bottle with a ground glass stoplper.

\section{Inflammation of tho Haw, or Hooks.}

The haw is a trimgulan shaped eatilage situnted just within the innecorner of the eye. In henlth lout little of it cim le seroll. Its use is to pass oree the ball of the eye to remove dust or os a offensive substances from the rye. This is dono so quickly that it is diflicult to distiaguish the action. Its play muy be seen by opening the lid of the eye, or ly antempting to touch the eychall with the tingers.

Causes.-This is often produced ly inflammation or swelling of other farts of the eye: It may end in producing a hard, bony state, protrucling from its pluce is a whitish lump. When it presents this mpentunes some persons are foml of "utting out tho "hooks" to keep the hosese from "goilig blind." Our ndvico is, "Dom? do it."

What to do.-If there is inflummation and swelling, trest the eye as for ophthaliny (inflnmmntion). In all eases of inflummation of the eyes use the bandage as shown in the eut on next page.

If the inflanmution is slight, hut netive, keep " linen cloth orer the eye, or eyes, siturnted with the following: 
No. 169.

1 Quart raln water.

Let it stand three or four hours, and apply cid, straining it as usei. If the inflammation is more pronounced, use the following as a lotion:

No. 170.

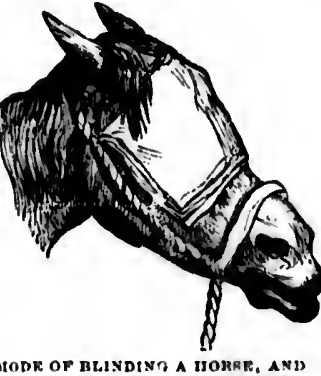

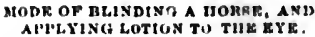

4 Draclsms luudanum,

2 Drachms extract bellacionia,

1 Quart rain water.

Also raise the eyelids and swab the inflam. ed haws occasionally with the egg and sulphute of rine lotion recommended for sure eyes. If the lichrymal duct is closed, thit is, if water runs from the eyes, swab out the ducts well up the inside of the nostril: with weak tobacco wates, finishing with clean water, or use the sulphate of zine in the form of a lotion.

If the blood ressels are overloaded, leceling the lids of the eyes will be heneficial, and in extreme eases half a gallon to one grallon of hlood mily be tilken from the neek vein, to he repented at the expiration $c^{\circ}+{ }^{\circ}$ dars, if necessary.

The inflammation having subsided, the haws will resume in ituril place and appearance, and again become almost invisible.

\section{Dimness of Vision.}

Very many horses lave defective vision. Some do not see well at light ; some are ne:ar-sighted ; some are far-sightel, as in man, from ton frreat couvexity of the eye, or the reverse. Old horses gradually anyine dimuess of vision.

There is no spreitic for lefeetive cyesight. Sprectucles would reliere the ditliculty, but, spectacles that might be worn by a horse have unt yet been inveriteil, nud for the reason that they are not practical. HI must get on as best lie may.

\section{Worms in the Eye.}

This is oesasioned hy a worn (Filaria Oculi), and may be extrated hy a skiliful puncture. It shonld only be undertaken hy a competent veterinary or other surgeon, the horse being first securely hampered an he cannot struggle.
Purt of the sweilin the me trituspis inilamm stible.

What eres we inition c

Lise th continuec

The bo (II" with s forms of If the prepane a

Mix. int

This is duce it all iffretion. affection $\mathrm{i}$ bill mis hasese of the If it be pitted. 'T and slightit mutil it ne knife ordis straiglit, tı 


\section{Purulent Opisthalmy.}

useu.

inflams. nd sulfor sore ed, thit wab) out nostrils ag will f zinc in

d, leedieneficial, tily he tildavs, if atural

well at f from tom Ir acentuite lit relient ve not vel minst get on

extrated emmpeterit impered in

Purulent Ophthalmy confined to the conjunctiva (mucus membrane of the eye), and it is in this membrane that the redness and ordinary swelling of the eyes have their seat. The oyelids are much swollen, and the membrane rises up, puffy and red above the level of the cornea (the trmspirant dise), sometimes in fungoid exerescences. This species of intummation is epidemic, and when occurring often, groes through the stible.

What to do.-Place the animal in a moderately dark stable, kcep the eres wet eonstantly-by means of the cloth shown in the cut with inflammation of the hooks-with the following:

$$
\begin{aligned}
& \text { No. 1i1. Drachms sulphate of zinc, } \\
& 20 \text { Grains morphin, } \\
& 1 \text { l'iut ruinwuler. }
\end{aligned}
$$

Usc the water tepid if possihle, but if used cold at first, it must he so contiuned, mul vice versar.

The bowels should be kept moderitely open with physic if necessary, or with soft feed, and the same general treatment used as for the other forms of ophthalmy.

If the disease does not yield to this treatment, and becomes chronie, prepare a watsh as follows:

No. 172. $\quad$ G Grains nitrato of allver,

1 Ounce distllled water, or ralnwater fittered through sharp washed sand.

Vix. and drop a little into the eye, daily, from a quill.

\section{Fungoid Tumors in the Substance of the Eye.}

This is a rare affection, and fortunately so. The causes which produre it are obseure, but probably the same as in any other eancerons affertion. The end will probably be deatll, for the taint of the cuncerons. affection is probably in the system. Upon close examination, the eye hall may be clear, but a brilliant yellow substance may be seen at the bise of the interior.

If it be not deemed hest to destroy the animal, the eye must he extirpated. 'Two knives are required, of a peenliar shipe, one of small size and slightly hent to one side: the other larger and eurved to one side until it nearly reaches the slmpe of a semi-nirele. $A$ sharp sealpel (tho knife ordinatrily used in surgieal operations) will also he iefuired. Two straight, trimgular pointed needles threaded with strong waxed twine, a 
curved needle, similarly threaded, water, a sponge, lint, injecting tube ind a bellows.

Cast the horse, and fasten him so he cunnot pve. Pierce each eyelid with one of the straight needles and tic " sccure loop for raising and holding the lids us shown in the cut.

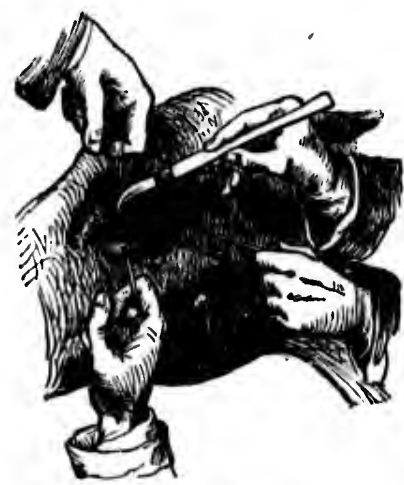

EXTIMPATIOS OF THE EYz.

Let an assistant then hold tho lids wide open. The surgeon with the straight knife quickly descrilies a circle around the globo of the cye, severing completely the conjunctiva mueous membrane of the sye. He then takes tho small, eurved blade, and pessing it through the divide! conjunctiva it is carried around the eyeball close to thu bone, severing the levator and depressor museles. The cornea is then piereed with the curved needle, in and out, the thread drawn and a loop tixed. 'Then the eye being drawn out as fur as possible the curved knife is pissed anound the rear of the eye with a sawing modion, the integuments are severel, and the eye is drown forth.

It is quickly done when all things ure rendy, but should not he at. tempted except by a compotent surgeon. Some bleeding will follow. Inject eold water ; if this do not check the hemorrhuge, force cold air into the eavity with the hellows. If this do not avail, phug the eavit: softly with lint, bandinge the womnd to sceure the dressing, and lears the result to the natural process of henling.

\section{Impodiment in tho Lacbryma! Gland.}

The lachrymal ducts of the ayos wre small anuls leading from the eyes into the nose. Their use is to eonvey away the superfluous mosture (tears of the eyes). Whes: it is closed by inflanmution or other tempor rury ct

subjoit

Occa

manent

the no.

bacco

If th

trials, $t$

The $\mathrm{c}$

the tern

inner ro durk ski nostrils,

A deli long, the to introd mostril.

the point

The oper

This is understoo the pupil white lins simply for

'line gil the neivot disense of sometimes it is inculy:

Causes.Also by in inflamımat $i$ or duringr

How to $k$ only partia of the cyes variation in dilatation ; steppling ai 
riny eause, the water of the eyes flow over the face as shown in. the subjoined cut.

Oeeasionally, however, the duct becomes permanently closed. The usual remedy is to swab the nostrils where the duct enters with weak tobacco water and afterwards with clenr water.

If this do not effect a curo after two or three trials, the duet must be opened with a probe.

The duct commences by minute openings near the terminations of the upper und lower lids at the inner corner of the eye. It comes out upon the

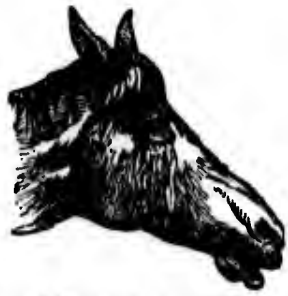

ODSTRUCTION OF LACHRYMAL CLAND dark skin which lines the commencement of the nostrils, lying on the inner membrnue.

A delicately thin elastic probe must be used, and about twelve inches long, the horse being east nnd securely fustened. It may be neessitry to introduce the probe both from the corner of the eye and from the nostril. Next charge n fine pointed syringe with tepid whter und plneing the point into the nasal termination of the duet, force the witer through. The operation should only be performed by a surgeon.

\section{Gutta Screna.}

This is sometimes eallel ginss eye, ineorrectly, however, as the term is understood in the West and South. In glass eye, ns understood there, the pupil is sound and perfect, the iris distinct and natural, hut has it white ring around the cornea. It may injure the sale of a horse, hut simply from the singular expression it grives the cye of the ramal.

'True gutta serenat, or Amecoros:', is pialsy of the nerve of sight, or of the nervous expansion called the retina, and due to functional and organice disense of the optic nerve. In the early stages of the disense it m:ly sometimes he relieved, but is likely to oecur ngatin. In the later stalges it is incurithe.

Causes.-Congestion, tmmors, droply or other diseases of the lumin. Also ly injury to the nerre of sight, ly pressure or other eame, from inflammution, excess of light, and may be symptomatic, from indigestion or during gestation.

How to know it.-In the enrly stages the insensilility of rieglit may he only partial; the pupil will he momaturally lange; nyon alowing the lids of the eyes, and opening them in a strong light, there will he little or no variation in the pupil; the eyes will bo munturally clear from extreme dilatation; the animal will he partially or totally blind, as shown hy high stepping mid fnilure to Alinch when the fingers ure suddenly boint od close 
to the eyc; the ears will be in constant motion as a compensation for the want of sight.

What to do.-If from overloading the stomach, indigestion, gestation, etc., turn the animal upon grass, if in the senson; or elothe warmly und

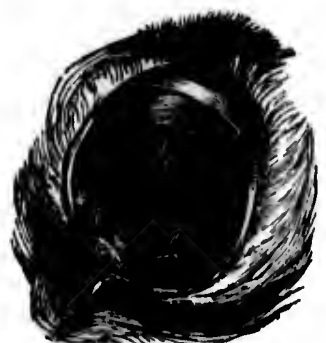

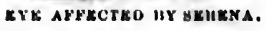

feed upon easily digested food, as mashes and roots. If the attack is recent und from such cause as inflammation of the briin, bleed to the extent of a gallon, and put a seton close to the eye. In fact the cause must he found and removed, if it be duo to one that can be removed. Success is sometimes liad by blisteriug as for ophthaluny. Use in connection with this nerve stimulants. Of these stryelsnia, in ono to two grain doses, according to

silver may be given.

Sympathetic mmaurosis may ndmit of cure. As wo have said, the deringed function must he restored.

If medicine is required to deplete the system the following will be good:

No. 173.

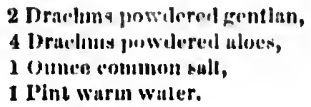

Give as a drench, und keep the animal on light mashes with an oces. sional injection of salt and witer if necessary.

If there is delility alteratives and tonics will be indieated:

\begin{tabular}{|c|c|}
\hline No. 174. & 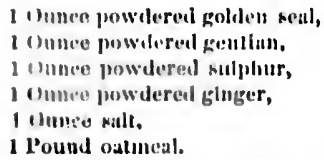 \\
\hline
\end{tabular}

Mix, divide into twelve parts and give one in the feed-of gootl, getlo epous diet--night and mornine

As a lotion for bathing the eve the following is recommended as a gowd astringent :

$$
\text { No. } 175 .
$$

10 unce powilerel baybersy bark, 1 I'lat boillng water.

Let it stand until cool. Struin through a close linen cloth, add a table-sjoonful of tincture of bloodroot and bathe twiee a day.

It

X. ROT

Causes.an enlarger and the ey pus, and at the hone. formed as structure of interstices : and tendous: dislocations these suppon The prim. helieved to is generally asseculs nist infrequently The innnedi want of tha the houes wi It masy be 


\section{CHAPTER XIII.}

\section{DI8EA8F8 OF THE BONGS.}

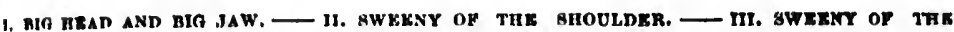
IIIP.—IV, BONK EPAVIN, — V. KNLAROKD JOCK. — VI. RING-HONE.—-VII. STHFL. —VIII. APIJT, — IX, RORK SIINS (INFLAMMATION OF TIIE METACARPAI, BONR), X. ROTTEN BONB. — XI. INYIAMMATION OF THE KNEEJOINT. — XII. CARIES OF TIE LOW VK-IA W.

\section{Big Hoad and Big Jaw.}

Causes.-This disouse, called also exostosis of the bones, is manifested in an enlargement or bony tumor on the face, on a line hetween the nostril and the eye. It timully breaks out in smull holes, which discharge a thick pus, and at last ends, if not treated opportunely, in a eomplete decay of the bone. The bone continually enlarges, and cells or channels are formed as the minute bony plates become thinner and thinuer, till the structure can he ensily cut with a knife or crushed with the fingers. The interstices are filled with a red, blondy mass. In some 'uses the ligaments and tendous are separated by decomposition of the hone, and crumblings, dislocations and fructures take place for want of firm attachment for these supporting ligaments.

The primary enuse of the disorder is not known; hut the tendency is helievel to be trmusmitted. A horse manifesting signs of the big head is generally diseased not alone in the bones of the face, but the whole asseous systom seems to be to some extent involved, so that there is not infrequently soreness of the limbs and a lameness accompanying it. The immediate exeiting cause is most probably defective nutrition - a want of that power of assimilation which is necessary to the supplying of the bones with their phosphute coustituent.

It may be developed by both over-feeding and ly deficiency of food, as $\because 8$ 
the digestive functions are deranged by either exeessive burdens imposed upon them or want of sulticient nutrition in that food which is digested.

It is difficult to nssign nuy renson why the general predisposition should be determined primurily to the fuee.

It hus heen observed to prevail nostly in those regions where Indian corn is constantly fed, and in those, whatever be the predominant food, where the mimal uses only, or ehicfly, free stone water-a fluill lacking in that phosphinte element so essential to bony structures.

Hard lahor and abuse, poor food and bad stuble mungement, doubtlen do much to precipitute the disease.

How to know it.-Before the visible swelling of the face there will arencmally be evident weakness, loss of appetite, lariness; a slight suffusion of the eyes with tenrs-one ur both necording us ane or buth siden of the fucial bone is affected; then $n$ swelling, ahout lualf wny between the eve and the nostril, smull and hard, but grndually incrensing in size. If the swelling is pressed upon with some force the horse will wince with pain, but grentle rubbing seems to give ense. The lower jaw, under the chin, will next "pprar thickened; " degree of general stiffuess sots in: at last the joints are swollen, and seem fmefed " rapidly fatils in flesis; and the hearl becomes enormously swollen, ind timully lneaks into little openings which dischnege all offensive phis.

What to do.-It is well, perhapss, to warn the realer in the nutset mit to do any of those foolish things which characterized the old prative, such as boring into the disensed part und injecting corrosive poison; lay. ing open the juw and silwing out a portion of the hune; blistering, burn. ing, ete. The disense is not lowal, but constitutional, and thomgl perhalp having no other visible manifestution than on the fuce, it has extensive comnection witl virious portions of the frime, so thet punely locul tre ite ment is of little consequence.

The tirst step) will be to sec that the patient is woll stubled or other wiso enred for areording to the season of the year. amol put upou a sp.temntir course of food, drink, and moleme exepreiso in the siln. Give him from five to seven cunts of outs per any, and if these are hoiled and mi-ed with a little whent hran, all the better. When green vergetaho enn he had, they should be fed liherally, to counteract a sort of seorinti or seurvy tendency which mneks this disorder. Apples, beets, eurrot, turrips-whintever fruit or vegetuble you can get him to take is good. When sensonible, put him upon a bountiful pusture.

Give the following iose night and morning in such food as he wil! most reudily cut : 
No. 176.

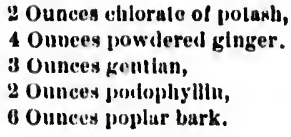

Give also with the food, once daily, 2 onnees phosphate of lime. kub upon the swelled face with inoderute vigor, twice daily, the following prepuration :

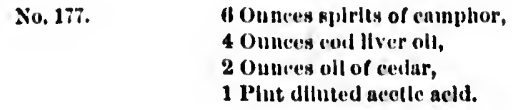

If the ense has been neglected until there are alrendy breaks in the ekin, and exudation of matter, mopt the previously described eourse, with this exeeption, that the part must he thoroughly elemed with wirm soip and witer, and then, instend of No. 177, npply the emmphomed (orrosive sublimnte every other dny for six or cight times, then omit three days, and begin again, and so on until the skin shows signs of henling. Apul: the sublimate with a little mop of soft rags, and dry it in with a hot irous helel near the part, or pressed smoothly over a layer of intervening eloths, thick enongh to prevent actunl burning.

\section{Bweeny of the Bhoulder.}

The common effeet of all lameness and disease of a limb is a wasting of the unseles commected therewith. 'Therefore in ull sprains entailing inflammation and continued disense of a limb, and in ull injuries entaiing chronic, long-continued munifestations, there will he wasting or atrophy of the muscles, and in extreme cases sometimes permanent contraction, ("en of the corts of the limb. This is popularly called swinny or sweeny. It is the result of disense nud mot the disense itsolf. The amse of this wasting must therefore he looked after in order to olsviate the difficulty.

Thrre is, however, from sprain of the muscle outside the shoulder blade, a tendency to waste of the muscles, to such a degree sometimes, that they are so shrunken us to enuse the skin to be drawn tight to the shoulder biade.

Causes.-Sweeny is usunlly aequired by young horses, when first put to rork, from over-strain; or, it may occur in horses of any nge, from hard pulling on uneven ground, by stepping into holes, ete., thus chusing injury to the muscles of the shoulder, and particulurly those supporting the joints. 
How to know it.- Sometimes the horse may be able to walk or eren trot without serions ditliculty. If one stand directly in front of lins there will be seen that the affeeted shoulder is held in an unuatural position, seeming to be rolled outword forther thun is naturnl. There will be a peruliar motion in the genit, and hent, tenderness and swelling on the outside of the joint.

What to do.-By pressure on the parts diseover the seat of the inflammation by the tlinching of the mimal. This found, reduce it by contisued applicution of cold water to the purt, if in the eurlier stanges. This mas be done ly folding a long blanket and hanging over the shoulder so as to cover the uffected part. (Orer this keep a cloth continually wet with cold! water, until the acute symptoms have sulssided.

After these have subsided, exereise must be given every day, either by driving on a smooth rond or using at uny light work on sinooth ground. Every effort should be male to inerense the cirvulation over the fallen museles hy active rubbing. If the case do not yield to trentment, and there is decided wasting, the muscle being hard, use the following:

$$
\begin{aligned}
& \text { No. 178. } 1 \text { Pint ammonla, } \\
& 1 \text { Quart oil. }
\end{aligned}
$$

This should be rubbed in with considerable friction, until nearly the excitement of a blister is produced. This with subsequent friction and an oceasional use of the blister, will effect " cure; but it may take monthe of perseverme to bring the shoulder back to its perfect shape. Light exercise should be given every duy.

\section{Sweeng of the Hip.}

The wasting of the museies of the hip are due to analugous causes with those of the shoulder. It is, however, far more rare, since the jower of the horse being in the hind-1juirters, the enormons museles of those parts act as eushions to protent the parts from injury. As a rule, the rause of the wasting of the muscles of the hij must ho looked for lower down. unless the injury is known to proceed from a fall on the side.

A cureful eximinution of all the muscles will enable the owner pretty generully to tix the sent of the disense, from the hent and tenderness of the parts. This disewvered, use the mens preseribed for shoulder swopn. In old and ditheult cases, either of the shoulder or hip, it may be neepse sury to resort to active blistering and subsequent stimulation by means of the gulvanic battery. In old and confirmed sweeny thut has come with a horse bought, or from negled at the proper time, a cure will probably not be effected; but a partial restoration of tho parts may be made. 
Sweeny his been placel mmong the diseuses of the lones becuuse it monctimes proceeds from injury to tho bones and joints. The ditheulty itself, lowever, is conlined to the muscles.

\section{Bone Spavin.}

The definition of hone spuvin may be given as un inflammution, uleeration and bony deposit of the smoll flat bones in the lower and imer part of the hock joint; or of both the outer und inner ones, or from intlummation of the cuniform mod metulursal bones, terminuting in unchylosis (a lony union of the parts) rendering the joint stiff.

rly the onl and $y$ take shape.

es with wer of e parts ulse of down.

pretty hess of weent. neceseans of with s roluably le.

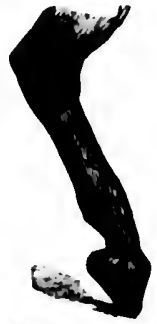

Yoot, Incupalite of belnus raisel from ground by reason uf souvin.

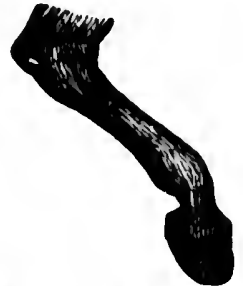

Natitral poaltion of the liruliby foot when ralaed from (he ground iluriug wi eugy trot.

Causes.- - Injury to the joint by concussion, squnins of the ligmnents, the use of shoses with high heols or culks. Hereditury predisposition to forin is eommon from weakness of the joints, bones and ligaments.

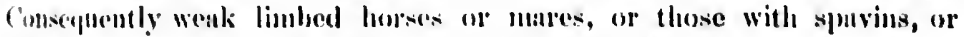
uther diseases of the bones should nevere be bred froms.

lane spavin in really one of the most formidables disenses with which the horsentan hats fo denl, and the aftacels is sometimes so slow and blind that jonkeys are often enahled to pus off a spavined horse on the unwary, the horse ofterwinds going dead lame. Severtheless it will sheow itself If the borse is allowed to cool, or is ridelen into the water and allewed tor stand awhile, for a herse with spavin combing an as he beeomes warmed the liganents hecome freer in their action, and an amimal lame at tirst, will gu well enough sfterwurds: yot, in the ent the horse hecomes peremanemly lane, until the deposit alout the hone, alled nnehylosis, becimes soliditied, when the joint is stiff and the lamenoss ceases.

Causes.-The emuses produring spavin may be varoms. Hereditary wenkness of the limbs is undoultedly one of the principial cillsess. Thus a blow, a spmain, or muy injury produe ing intlanmation will muse spavin in such an animal, when in a strong muscled and tine honed mimal it 
No/I

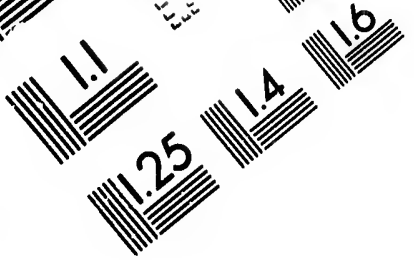

IMAGE EVALUATION

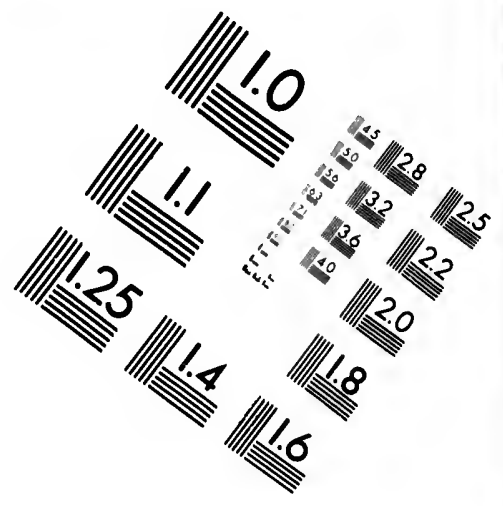

TEST TARGET (MT-3)
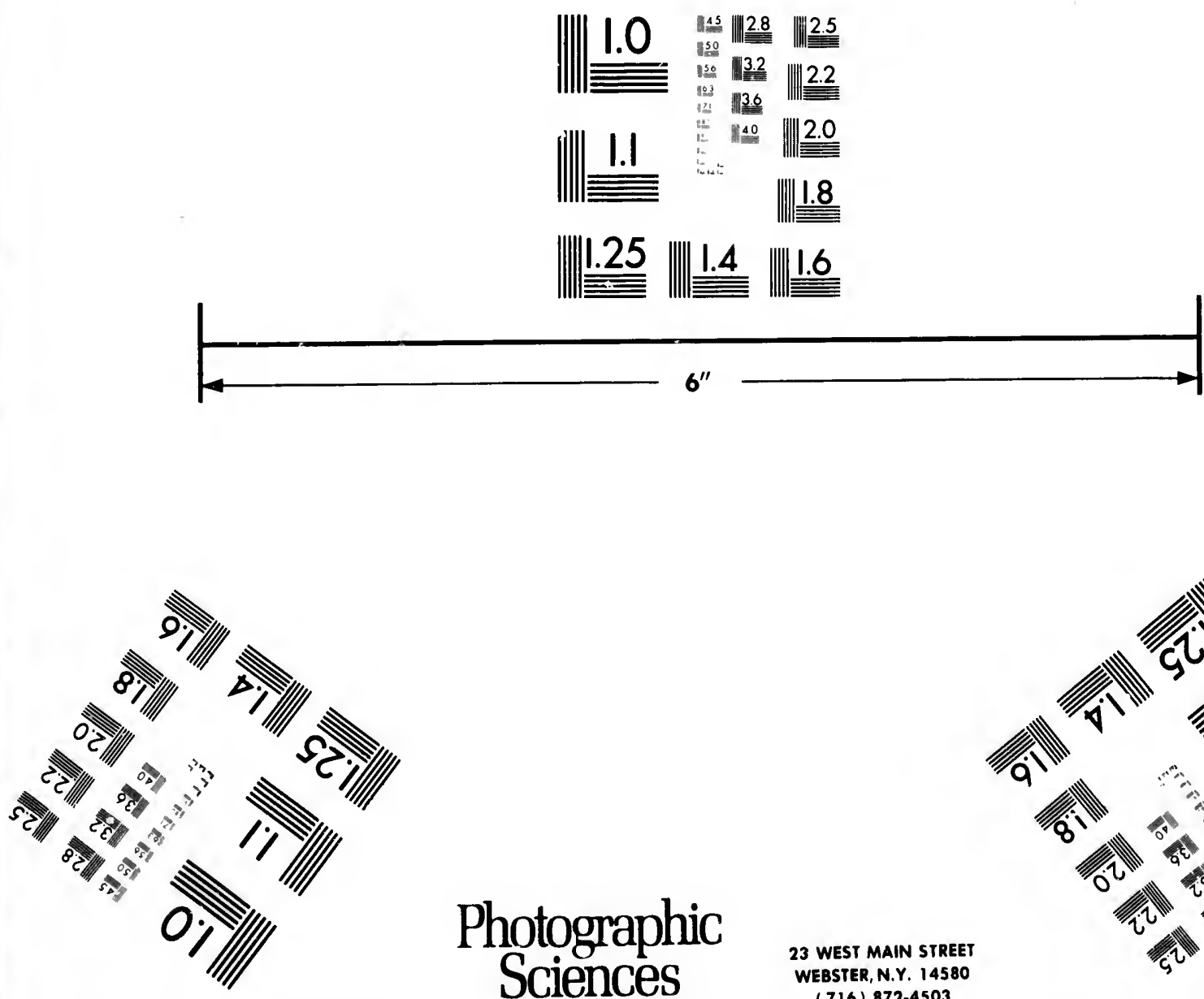

Photographic Sciences Corporation
23 WEST MAIN STREET

WEBSTER, N.Y. 14580 (716) 872-4503

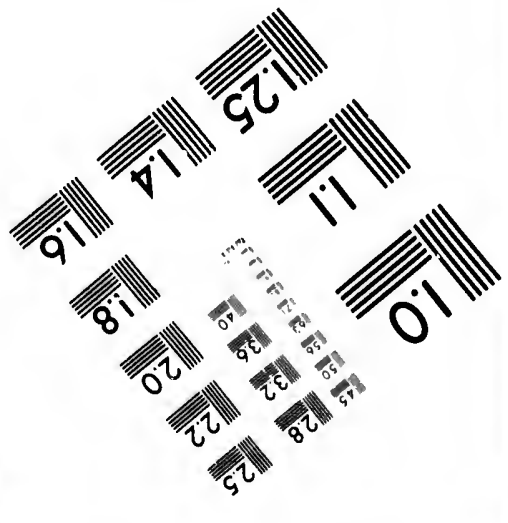



would yield readily to treatment. The reason is, a feverish and unhealthy condition of the membrane secreting the synovial fluid is produced, and the firm membrane affording no outlet, it settles into the spongy bone, and a diseased condition ensues, which the weight and motion of the animal intensifies until confirmed spavin is the result. When only the plint bone is affected there is chance for recovery, but when the cube bone is affected there is but little chance for relief until the disease has run its course, and ended in a joint more or less stiff.

How to know it.-Sprains do not invariably causo lameness. There may be little or no local swelling as in occult spavin, as ulceration is called, in the center of the joint between the flat bones. The swelling, when it does exist, is in front and on the inside and on the lower part of the joint, and may best be seen by standing about midway of the body so as to get a side view of the front of the hock. When the swelling is in front of the hock it is most to be feared. It is hard and is to be distinguished from the tense but elastic swelling caused by sprain of the flexor tendon, or from the flexible and fluctuating swelling of bog spavin.

The swelling of bone spavin may be more to the front or farther back on the inside of the hock, $r z$ even shown prineipally on the outside, and in case it extends to the true hock joint, it may end in bony formation to such a degree as to close the articulation (play of the parts) and produce a stiff joint. The animal if turned from side to side in the stall will move stiff and on the toe. This same stiffness is also seen when the animal first starts off, but which may nearly or quite disappear when the animal becomes warm. The horse will sometimes jerk up the limb as though he had string-halt. By turning him quickly in a small circle he will carry the limb more or less stiff, or rest on the toe only.

What to d0.- In any case rest and a high heeled shoe should be allowed. In the acute stage or early in the development of the discase, place the horse in slings if pessible. Foment thoroughly with hot water in which an ounce of laudanum is mixed to each two quarts of water. Give four drachms of aloes if the bowels are costive, and give half an ounce to an ounce of saltpeter in the water, morning and night, until a free flow of urine is had. When the inflammation has subsided blister. The following will be effectual :

No. 179. 1 Part corrosive sublimate.
12 Purts oil of turpentine,

Mix thoroughly and rub in. Firing with a white hot iron is still more effectual, yet the iron and the corrosive liniment are apt to leave a blemish. A nilder preparation is :
Grind tl

If there with olente come bone he passed Anoint the

Before $t$ thrusting a parts. In bony parts them. It is rases will al yield kindly be given in cure is diffic

Nature h: injury under cumstances, ous bruises fomentation however, the the contrary,

How to kn tendons and fomentations using the $\mathrm{pr}$ a severe blow investing me torn loose, gi matter on th parts are of diffleulty the 
No. 180 .

2 Drachms oll of rosemary,

1/. Ounce powdered cantharldes,

4 Ounces mercurial olntment.

Grind thoroughly together and rub on heating it in with a warm iron. If there is simply swelling, in old cases, thorough and frequent rubbing with oleate of mereury will dissipate what swelling las not actually become bone. Setons are also most valuable in spavin. The needle should he passed for a considerable space under the skin, over the seat of spavin. Anoint the tape with the following:

No. 181.
8 Part powdered rhite hellebore,
Mix with gentie heat.

Before the application of either blister or seton we would advise thrusting a narrow-pointed bistoury under the sprain and scarifying the parts. In no event, however, should resort be had to cutting away the bony parts which have formed, with mallet and chisel, as we have seen them. It is harbarous, inhuman, and can do no good whatever. Some cases will absolutely resist all and any means for cure; others again will yield kindly in from one to three months. In young horses if treatment be given in time, a cure may generally be effected. With old horses the "ure is difficult.

\section{Enlargement of the Hock.}

Nature has protected the locks in a most ample manner, to prevent injury under ordinary circumstanees, and in fact, under exceptional eircumstances, except those of an accidental or violent nature. Fron various bruises or strains, inflammation and lameness may ensue. Rest and fomentations will generally set this right if taken early. Sometimes, however, the enlargement will continue to grow in spite of all efforts to the contrary, and until the entire joint is involved.

How to know it.-There are two forms of this disease. In one, the tendons and cartilages only are affected. This will generally yield to fomentations and a few applications of oleate of mereury. If not, blister, using the preseription No. 180. Another form is more serious. From a severe blow or other cause, there is a bruise of the bone, by which the investing membrane, called the periosteum, is either severely striined or toru loose, giving rise to inflammation and formation and deposit of bony matter on the surface of the bone, sometinies to such a degree that the jarts are of excessive size, and the leg so lame that it is only with great diffleulty the unimal can walk. The animal may, indeed, as in the easo 
of bad spavin, be capable of doing farm work even with a stiff leg, but is totally unfit for driving on the road.

What to do.--Precisely the same treatment must be pursued as in the ease of bora spavin. Fomentations, while in the stage of fover or illflammation, and blistering, firing and setons to assist absorption. It nust be remembered, however, that either in spavin, or any other disease of the bones, joints, cartilages, or muscular tissues, that straining of the parts is likely to ensue again, and consequently eare must be taken about overworking or injuring by fast driving, especially on rough grourd.

\section{Ring-bone.}

This is a deposit of bony matter above and below the coronet of the foot, just where the hair begins above the hoof, or of the bone of the boof, as the coffin bone is ealled, or bony growth on the pasterns.

Causes.-It is caused by heavy work, hard pulling. by draft horses, bruises of the bone by pounding of the feet on hard loads and pavements, generally beginning as inflammation of the menbranes covering the bones, and at these points griving attachments to the ligaments at the side of the lower or small pastern bone, or of the lower end of the upper or large pastern. Sometimes the bony formation proceeds to such an extent, involving and et vering the whole surface, as to produce a kind of club foot.

How to know it.-There may be lameness or not, exeept on hard ground, or upon binding the limb, in old-seated ring-bones. During the begimning of the evil, or while there is inflammation, and a tender, elustic swelling, and a more or less doughy state (engorgement) of the soft parts. In the course of the disease this matter becomes hard, from being turned into al soft or spongy bony formation. The swelling may be scarcely seen and confined to the sides of the pastern bone, or there may be creat enlargement of the whole surface. If the trouble occurs in a fore-leg, the heel is put down first; if the ring-lyone is in the hind-foot, and in the sides or back part of the pastern, the toe will be put down first.

What to do.-For the fore-foot, put on a thin-heeled bar shoe. If in the hind-foot, a high-heeled shoe. 'That is, if the animal walks ou the toe, use a high-heeled shoe; if on the heel, a thin-heeled shoe. If there is inflammation, known by heat and tenderness, use fomentations of hot water, perseveringly applied until it is reduced. Then blister severely with the following: 
No. 182.

\author{
10 Drops muriatic acid, \\ 20 Grains corrosive sublimate, \\ 20 Grains camphor, \\ 1 Ounce oil of turpentine.
}

Jix, and apply until a sufficient blister is forned: then wash off to prevent blemish and keep the blister running as long as possible, by covering with a rag well smeared with mutton tallow. Blister again if necessary. Or, use the metns pursued in spavin, oleate of mercury, if the ase is not difficult.

If the ring-bone has been of long standing, the only relief. will be the growth of bony matter over the joint. There will be more or less stiffness in the joint, but the horse may do slow work. Old horses are more difficult to cure than young ones, and in any ease to avoid blemish, the euse must be taken at the first indieation. Then thọrough fomentations, slight blistering, a proper shoe and rest will accomplish a cure. If there is simply a lurdening of the integuments, oleate of mercury, in developed ring-bone or spavin, will reduce so much of it as is not already bony growth.

\title{
VII. Stifle.
}

Any difficulty of the stifle joint, by which the animal is more or less disabled from the use of the limb, is by the generality of horsemen terned stifling, it being supposed to be a dislocation of the stifle bone, corresponding to the knee-pan in man. Dislocation, however, is extremely rare. The displacement of the whirlbone of the stitle joint when it occurs, will eatuse the animal to throw the limb straight out behind. This form often becomes chronic ; that is, oceurs, and the habit is fixed from apparently slight causes, or any cause that shall compel the animal to throw the leg back farther than is usual in going at a slow gait. It is often produced in the first place by catching the hind leig or hoof in some. thing which forcibly holds it.

How to know it.-The horse will hold the leg extended out behind, the head will be raised and the animal will go on three legs; there is erery evidence of extreme pain, but no heat nor swelling. Cpon examining the stifle bone, the patella, corresponding to the knee pan in man, will be found outside those against which it should fit. When the disloeation is inward, the limb will be drawn upward.y

What to do.-Get the animal into a close place; have him held firmly by the head; pass a rope about the fetlock and over any projection, so the limb may be drawn forward. Bring the limb forward and upward, and standing behind and against the hip, press the bone toward and into 
its place. Hold it there firmly until the museles regain their original contractibility in some measure, and use an infusion of bayberry or oak bark, cold, freely, for some days.

In addition to this it is better that the horse be made to stand on the injured limb. 'To do this it is usual to tie a cord tiglitly about the other hind leg. 'This is apt to nake a blemish. Tie the other foot so it cannot be thrown back.

In nine eases out of ten when the owner supposes his horse to be stifled the difficulty will be found to be from injury to some other part of the limb, as sprain of any of the ligaments of the leg, of the fetlock, a prick of the hoof, ete., elusing the animal to hold the limb in such a way as to cause the stifle bone to seem displaced.

Horses often injure the parts around the stifle joint by running, leaping, or from bruises or other hurts. In this ease the treatment is to be the same as in any other sprain or bruise. In mild cases the following will be found good to bathe the sprain or bruise. with :

\section{No. 183.}

1 Ounce tiucture of arnica, 1 Pint rain water.

Bathe the affected part freely $、$ ith this from time to time. If the difficulty is severe, fomentations of hot water must be perseveringly used until the inflammation subsides, and then resort may be had to blistering if necessary, or a seton may be placed under the affected part to get up counter irritation. In severe cases the cure is slow and the animal must have absolute rest.

In any difficulty in or about the stifle joint, it is well to examine carefully for wounds or bruises.

A wound of the parts will often cause intense pain, and to the uninitiated, apparently all the symptoms of dislocation. The veterinurian is ncver deceived, and no one need be if he brings common sense and a careful examination to bear upon any wound, bruise, strain or other injury. There will be blood, matter, swelling or heat in the part affected. This found, use the remedies prescribed in such cases.

\section{Splint.}

Causes.-The name is given to a peculiar enlargement generally found on the outside of the sinall bones of the fore leg, and inside the leg. The causes are not well defined. Splint may be caused by violent blows or other injuries, but it seems to be more a consequence of weight and strain. The inner splint bone, or small bone of the leg, is placed nearer the center of the body than the other, and there is at almost all times greater weight upon it, while on certain oceasions it may also be subjected to more vi deposit rest centributes 'llie term st pear on the as this part

How to $k$ forming, the brane; there you can dise with the thus two small bo pressed upon

When the erally attendo comnodated consequent se splint will oft easily seen at In cases of resting the to great heat nat nearest the spl Sometimes $t$ put to a walk, coneussion pro will disclose tl

What to do.do nothing, un will disappear provided there unskillful atten of the splint.

If it is a rec whether the irr the part, and s inflammation, frequent applic from over and lowing mercuri:

No. 184. 
to more violent strain, whence inflammation may set in, and a bony deposit result. Raising the outer heel of the shoe more thin ordinarily, contributes in some degree to produce an unnuturnl strain upon this bone. The term splint is mplied also to those bony tumor's thnt sometimes appear on the outer shank bone. These are more readily accounted for, as this part of the leg is peculiarly liable to blows and other injuries.

How to know it.-In the first stage of the disease, while the splint is forming, there is inflummation of the periosteum or bone-covering membrane; there is lameness ; und though no swelling may yet be visible, rou can discover it by passing the open hand down the side of the leg, with the thumb on the small bone, or rather in the groove formed by the tro small bones. A small, hard swelling will be fourd, which, being pressed upon, will cause the animal to flineh.

When the tumol is well-developed and plain to the sight, it is not generilly attended with lameness, from the fact that the periosteum has necommodated itself to the new formation, and the inflanmation, with consequent soreness, has subsided. Then it happens that a very little splint will often cause more lameness than one which is so large as to be easily seen at it distance.

In cases of much inflammation and extreme soreness, the horse stands resting the toe upon the ground, with the leg slightly bent; and this great heat mily extend itself hy syinpathy to the soft parts of the leg nearest the splint, but this is seldom the case.

Sometimes the animal is apparently free from all trouble when merely put to a walk, but will discover extreme lameness in trottin? - the extra concussion producing much pain, and examination, as previou: ? directed, will disclose the seat of the trouble.

What to do.-If the protuberance is small, and there is no lameness, do nothing, unless the horse is valuable and the tumor is unsightly. It will disappear by natural absorption as the animal increases in years, provided there is no direetly exciting cause constantly at work. An unskillful attempt to cure will sometimes lead to lameness and an increase of the splint.

If it is a recent formation, and treatment is thought necessury, observe whether the irritation is such as to have produced extreme tenderness of the part, and swelling of the soft parts of the leg. If so, lessen the inflammation, and thus also the soreness, by cool, softening poultices, or frequeut application of cold salt and water. Then shave the hair off from over and around the protuberance, and rub in, at evening, the following mercurial ointment:

No. 184. 1 Drachm binlodide of mercury, 1 Ounce lard. 
Continue this until a free watery discharge is produced from the surface. As a general rule this is suffieient, for even though it may not directly disappear, it will gradually do so from this time, unless the tumor interferes materially with the ligaments or tendons.

If it is large, or near the joint, or extends so as to destroy the motion that naturally exists between the two small bones, cast the horse, and secure him from violent struggling-then scarify the periosteum or membrane covering the bone, over the splint. For this purpose, have a small, probe-like knife, shaped like a scimiter, with the cutting edge on the convex side. Make a small opening about an inch below the splint, turn the little probe knife flat and insert it into this opening and urge it forward until the point has passed over the protuberanee. Now turn the cutting edge down, and scarify the periosteum well, making several cuts across the splint, and with such force as to reach the naked bone every time. Withdraw the knife and insert a soton needle, with tape fixed as usual ; pass the point up past the splint, send it through the skin, and draw the tape through. Slightly enlarge the upper end of the tape, so that it camnot eome out below, and the work is done. Suppuration will ensue in from seven to fourteen days; absorption will follow, and the splint will almost invariably disappear.

During treatment the horse should be kept from work, as any considerable exercise, particularly any straining in haruess, or concussion by rapid motion, will increase laneness and render cure more tedious and diffcult.

\section{Sore Shins-Inflammation of the Metacarpal Bones.}

This is an infiammation of the membrane covering the shank bones, anc is not confined to any particular classes of horses, though racing or other fast worked horses are more subject to the affection than are dratt horses, the difficulty generally occurring before the animal becomes mature.

Causes.-The cause is undoubtedly over-working and abuse before the bones and integuinents become fully developed.

How to know it.-The lameness resembles that of splint. There is swelling over the shin bone, which is tense as though stretched, elastic, and doughy to the touch. There is heat and tenderness, and sometimes the swelling becomes excessive, and breaks, but always preserves its elartic feeling. Or the swelling may not be extensive, but gradually hardens through the formation of bony matter, until at length the pain disappears.

In these slight cases, the matter thrown out between the bone and membrane, is generally converted into a bony formatiou and the skin remains permanently thickened. In severe eases the throwing out of

This is calle and caries whe

Causes.-De ble to oceur is inflammation of

How to knov or more absces form fistulas (1 smell, but afte of decayed bon

What to do. decayed bone, with chloride of

No. 180.

The wound $\mathrm{m}$ 
matter (lymph) may separate the membrane and the bone, and eventuate in necrosis, or dentl of the bone.

What to do.-If the difficulty is not severe, cold water faithfully applied during the inflammatory stage, und later, blisters, will be all that will be necessary. In fuet, treat it precisely as is recommended for splint.

li very severe cases, where there is great tenderness, and decided doughy swelling, make a series of incisions with a bistoury or narrowbaded knife, carrying the blade a short way beneath the skin, and then cutting down to the bone. This is done to let the contents escape. Use as a fomentation hot water containing half an ounce to an ounce of laudanum to a pint, and afterwards with cold water. If the healing is not prompt, apply a blister. In a mujority of eases it should yield by applying the following astringent lotion :

$$
\begin{aligned}
& \text { No. 185. } \\
& \text { 36 Drops carbolic acid, } \\
& 2 \text { Quarts rainwar of lead, }
\end{aligned}
$$

It may be necessary, in fact it will be better, to give a purgative, 4 or 5 drachms of aloes, to be followed by 20 drops tincture of aconite, three or four times a day. The animal should have perfect rest and be kept on sound hay and bran mashes.

\section{Rotten Bone.}

This is called necrosis when it attacks the shaft or body of the horse, and caries when it is confined to the ends at its joints.

Causes.-Death and decay of the bone, from inflammation. It is liable to occur in poll-evil, founder, from cracked or broken bones, and inflammation of the membranes.

How to know it.-There will be severe inflammation, followed by one or more abscesses, which break and discharge. They do not heal, but form fistulas (pipes). The discharge at first may be thin and without smell, but after a time there is a peculiar and fetid odor, characteristic of decayed bone.

What to do.-The proper thing to do is to cut down at once to the decayed bone, scrape it clean, remove all loose portions, wash the wound with chloride of zinc lotion, made as follows:

No. 186.

40 Grains chioride of zinc, 1 Ounce distilled water.

The wound made in cutting is to be treated as is any wound. If the 
cutting be extensive enough to warrant it close with stitches, cover with lint steeped in oil to which a little carbolic acid is added. If heuling $d_{n}$ not progress satisfuctorily, that is if the granulations at the edges do not contract fast enough, stimulate by washing with tincture of aloes and myrrh. So far as this cutting and scarifying is concerned it should he done by a surgeon. If this cannot be done, open the fistulas clear to the bottom and wash out once a day with the following:

$$
\text { No. } 187 .
$$

36 Ounce sulphate of zine, 3. Ounce sulphate of copper,

1 Ounce solution of sub-ucetate of lead,

6 Ounees pyroligeous aclil, (or better, whlte wine vinegar).

To one part of this use ten parts of water, and injeet with force from a syringe once a day for two weeks if neessary.

\section{Inflammation of the Knee-joint.}

Inflammation of the knee or other joints may occur in all stages, from the most simple form to those most violent, with ulceration, and the formation of destructive abseesses.

Causes.-Jarring on hard roads; various injuries, such as bruises, strains, ete.

How to know it.-In light cases the horse in starting forward will do so from the knee and with pain. There will be excessive flinching if the knee is extended by force. The animal stands square on his feet, and without inclination to raise the heel. In walking he takes a fair step, but carries the knee joint as much without bending as possible, and in putting down his foot exerts the greatest pressure on the heel.

What to do.-Take off the shoes. Treat the inflammation as directed in other cases ; first by hot water embrocations perseveringly upplied, using laudanum as direeted if necessary to relieve pain. There must be perfect rest, and if the animal will use the limb put him in slings, and apply splints and bandages to the knee. The inflammation having beea cured, blister the parts, to promote absorption of the fluids. When the animal is better let him have the run of a quiet pasture until entirely sound, or keep him in the stable with gentle walking exercise every day.

\section{Caries of the Lower-jaw.}

Causes.-Caries, or ulceration of the lower jaw bone, hetween the tushes and grinders, is cuused almost wholly by the barbarous use of bits and curb-chains. Injury is also sometimes inflicted upon the bony plate of the roof of the mouth by pressure of the curb, when a tight 1050

baud kee often hur in this ulc must slou astinkinger bone and attended no

How to $k$ trouble wl color diffe the animal ing sore, it beginning, stantly goir of blood a the hor'se is nothing else in that case, (avity, a ma very offensi

What to o itiveness to of matter, 1 made ought grating of $t$ gle with mon derness of $t$ as to the am the sealed by bone forceps

Upon eutti taken to see injured bone, uleer.

When the fensive to the making an ef syringe, sever

No. 18 : 
er with ling do do $110 t$ oes and ould be ur to the band keeps the month shut down. The gums of the lower jaw are very often hurt, and not infrequently the bone itself is so bruised as to result in this nlceration. When this is the ease, the gum, unless forcibly opened, must slough, so thut the injured portion of the bone can be enst off. Thus "s stinking sore is made, and one of long continumee, us the sculing of the bone and the escape of the loosened particles is a tedious process, and attended no little suffering.

How to know it.-Examination of the gums is necessary to disclose the trouble when it exists simply as a bruise. The spot will appear of a color different from the adjacent purts, and pressure upon it will caluse the animal to wince with pain. Even if neglected till there is a discharging sore, it is not always detected at once, as the discharge is, in the begiuning, of a watery eharacter, and is lust in the suliva, though constantly going on. On contact with the bit, however, there is a mixture of blood and watery matter, and some of this esciljes constantly while the horse is in use. This ought to attract the attention of the master, if nothing else has, and lead to thorough exumination. There will be found, in that case, a depression in the gum, and, fixed to the bottom of the arity, a mass of proud flesh. The discharge will be characterized by a rery offensive stench.

What to do.-If the bruised place on the gum, accompanied with sensitiveness to pressure, is discovered before there is any break or exudation of matter, have a strong, keen knife, and cut to the bone. The incision made ought to correspond with the extent of the bruised bone. The grating of the knife upon this sore portion will cause the horse to struggle with more or less violence, owing to the exceeding soreness and tenderness of the injured part; and this may in some sort furnish a guide as to the amount of incision necessary. If the opening is too small for the sealed bone to be ensily east out, it will be necessary to employ the bone forceps with which to grasp and withdraw it.

Upon cutting it, a thin, watery fluid will flow out. Care must now be taken to see that the incision is not allowed to close over and retain the injured bone, as this would ultimately result in a foul and troublesome ulcer.

When the discharge has somewhat thickened, and is peculiarly offensive to the smell, showing that the bone is decaying and that nature is making an effort to cast off the injured portion, wash it out with the syringe, several times a day, with the following solutiou:

No. 188. 1 Scrupie chloride of zinc,

4 Drachms essence of anise seed,

1 Pint water. 
If treatment is deferred, however, till there is an open, ulcerous gum, with the existence of proud Hesh, push a stick of lunur caustic deep into the unhenlthy granulation in the envity, so us to destroy it. Then keep down the fungous growth by the use of the caustic, day after day, until the stinking discharge has ceased. This will not be until the bone has ceased to scale awny; und the wound mny now be safely left to heal.

A cure affected, the next thing to do is to select a bit that shnll press upon another part of the moutl, or there miny be a repetition of the evil. The snaffle muy be used with comparative safety where the curb has inflicted serious hurt.

1. ULCEHATIO
RUT.-
RIES TO
BAND CRA
PUMICR
-XVIII.

Between forms the $p$ This bone is the surface the synovial One of the connection b to cuable the coffin bone, In high bre peculiarly lia inflammation The difficult passes over i

Causes.-I animal to th limbed anims they are not would do, e violent exerti 
DISEAGES OF THE FERT.

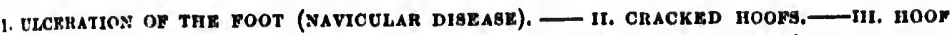
RUT. - IV. CORNS. - v. CONTRACTION OF THE HOOF (NARROW HERL). - VI. INJU-

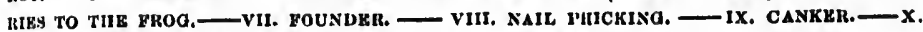

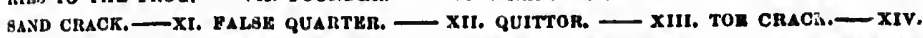
PUMICR FOOT.-XV. BREDY TOK.—XVI. OSSIYIED CARTILAGKS.—XVIT. GIDL BONES. - XVIII. INCISED AND PUNCTURED WOUNDS OF THE GOLE.

\section{Ulceration of the Foot-(Napicular Disease).}

Between the coffin bone and lower pastern there is a small bone which forms the projection of the heel and rests upon the frog of the foot. This bone is called the shuttle or navicular bone. The inflammation of the surface of this bone is called the navicular disease. It may implicate the synovial sac, the ligaments and the flexor tendon which plays over it. One of the uses of the navicular bone is to give increased strength to the connection between the coffin bone and the joint above. Another use is to enable the flexor tendon, which passes over it and is joined to the coffin bone, to give increased pliability, strength and motion to the foot. In high bred horses, and all those used for fast work, this bone is peculiarly liable to injury and consequently to disease. This disease is inflammation and subsequent ulceration of this highly organized bone. The difficulty may extend to the interior of the bone, to the tendon which passes over its surface and even involve the adjacent parts.

Causes-It is thought that a rheumatic constitution predisposes an animal to this disease. Certain it is that highly organized and weak limbed animals most usually suffer from it, probably from the fact that they are not able to withstand an injury that a stronger limbed animal would do, especially when carrying a bad fitting shoe, or subject to violent exertion or ovar strain of any kind. Other causes than bad shocs 
and concussion of the bone may exist, injury from nails pieked up on the rond, impaired nutrition, by which the bones are not sufficiently nourished aeting to ussist injury to the bone.

How to know it.-The foot will feel hot, yet particular heat is not always present. The toe will be pointed, in the statble, eight or ten inches before the other, and with the beel slightly raised. This peculiarity inay indeed be noticed often for a long time before any particular lameness is noticed. By-and-by the animal will be observed to step short, and on the toe, with liability to stumble when first taken out of the stable. This will disippear as the animul gets warm, but will show again when cool. The toe of the shoe will become more woin than other parts. As the disease progresses the hoof will decrense in size, particularly in the quarters and heels. Trying the edges of the hoofs will not milie the animal flinch unless there be corns, but by tapping the sole on each side of the body of the frog with a hammer, or upon the walls of the hoof about the quarters, will give pain. By bending the foot back and pressing with the thumb in the hollow of the heel on either side of the flexor tendon, with considerable force, it will eause intense pain. These are all characteristic tests. There may be sweeny of the shoulder from disease of the muscles. 'This is an effect of the disense and not a discase in itself.

What to do.-If the injury is new, the first thing to be done is to reduce the inflammation. Do this with eold water applications or auy of the remedies advised for ring-bone, spavin, or other inflammation. Give in luxative dose, 4 drachms of aloes; have the shoes taken off and let the horse stand during the day time in pure wet clay up to the top of the hoof, and at night poultice the foot. If there is much inflammition, bleed in the arteries above the coronet. The coronet is the lowest part of the pastern, where the hair grows around the hoof. Keep the horse perfectly quiet, and if he has a fast pulse, give an ounee of salt petre in the drinking water night and morning. At the end of two weeks, or sooner if the inflammation is gone, blister the coronet all around. 0 . use the following:

No. 189.

$$
\begin{aligned}
& 1 \text { Ouuce cnmphor gum, } \\
& 1 \text { Ounce corrosive sublimate, } \\
& 1 \text { Pint oil turpentine. }
\end{aligned}
$$

Grind the sublimate thoroughly in a mortar, and put into a strong bottle ; pour on the turpentine and shake oceasionally. It should he fit for use in from 20 to 30 hours. This is to be applied every other dny to the heel and bottom of the foot, first paring away all sculy, ragged part.
Heat it i power an

If pref To do th quick ; $\mathbf{p}$ pierce the tween the the hollor The utm tendon or No. 189 ,

Shake $\mathrm{t}$ sionally fo at the sam running of

If, in sp degenerstic ing to the (1). pter.
Causes.-
horses, and
brittle hoo
hoof, whatr
or other ea
causes are
uncen ben
wounds or
may extend
the time it

What to haring an a relieve the d over the inju If the cru 
the

shed

not

ches

may

ss is

d on

'This

cool.

is the

is the

e the

side

hoof

press-

flexor

ile all

lisease

ase in

to le-

any of

Give ill

et the

of the

nation,

it part

horse

etre in

oks, or

$\mathrm{Or}$.

ig bottit for to the parts.

Heat it in with a hot iron. This preparation is of great strength and porrer and must be used enrefully.

If preferred, a seton may be put in the bottom of the foot at the frog. To do this, first pare the scale as thin as possible without reaching the quiek; provide a sharp, short, well-curved needle threaded with tape; pierce the sole about an inch from the toe, and bring out midway between the two parts of the frog and the holow of the heel; or enter nt the hollow of the heel and bring out the needle at the hody of the frog. The utmost care must be had not to pierce decp enough to injure the tendon or bursa which lies close there. Tie the tape, and wet daily with No. 189, or the following:

\section{No. 190. 1 Purt powdered cantharldes, 1 Part oil of turpentine, 8 Parıs Canada balsam.}

Shake the two first well together and add the balsam, shaking oceasionally for 24 hours, and apply to the seton tape every day, turning it at the stane time. The object in this disease is to produce suppurative ruming of the parts. This done, the cure is only a question of time.

If, in spite of all that has been done for relief, the disease proceeds to degenerition of the bone, resort must be had to cutting the nerves leading to the foot, (Neurotomy) whieh will be described in the proper 1...pter.

\section{Cracked Hoofs.}

Causes.-This is not an unusual occurrence in horses, and arises, as a rule, from weak and brittle hoofs, produced by a dry state of the hoof, whitever mitly be the cause, whether fever or other causes of degeneration. The prolific causes are drying of the wall of the hoof, uneren bearing of the shoe, ealking or other wounds or injuries of the coronet. This crack may extend down from the coronet according to the time it is allowed to run.

What to do.-If taken early, a bar shoe,

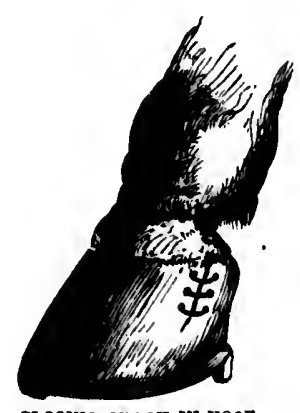

Czosino cracx in roof. haring an even bearing all round will genernlly relieve the difficulty. In connection with this, apply a plaster of pie: in over the injury.

If the crack becomes determined, as in the cut given, it must be kept 
closed together by elinching a thin nail on each side of the gap near the bottom and top, or else with thin wire as shown in the cut.

Also burn a groovo just below the crack about an inch long nearly down to the quick. It is also well to slightly blister the coronet at the top of crack. An efficient and stimulating liniment will be the oil of eautharides, made as follows:

No. 191.

Mix in a strong bottle and set it in water kept near the boiling heat for three or four hours, and filter through close linen. Apply ouce a day with friction until the part is tender. Let the horse have rest, or turn into a pasture until cured.

\section{Hoof Rot.}

This difficulty, sometimes called tender feet, arises from diseases of various kinds, spavin, ring bone, chronic founder, navicular disease. There is a dry, feverish state of all the parts, and the hoof, and especially the sole, becomes decayed and sometimes perishes entirely.

How to know it.-The bottom of the hoof is dry and chalk-like, so that it may casily be dug away with the point of a knife, or even easily seruped away. The frog of the font diminishes in size, and the ankle joints are apt to swell. The hor'se steps short and goes lame, if in one foot, or if in hoth, eripples in his gait. The affected foot will be pointed forward to enahle the animal to rest on the sound foot, or if botlo are affected, first one and then the other will be placed forward. Sweeny or wasting of the muscles of the leg and shoulder result simply from disense of the limb.

What to do.-Remove the shoe, pare awaly all unsound portions of the hoof until all the pumiced parts are got rid of ; also the frog and the sides of the hoof. Stimulate the bottom of the hoof by washing with $\mathrm{N}$. 189 once a day for three days, lenting it in with a hot iron. Then omit for two or three days and commence again. During the treatment the animal must be kept in tho stable and the feet should be kept dry. When hoof rot is due to other disenses; as ulceration of the navicular joints, it will do no good to follow the ruie laid down until the cause of the difficulty is removed.

\section{Corns.}

Corns are in very many cases the result of other disenses, tending to weakening of the solo rather than the result of a bruise to a sound hoof.
Thus a b bones of

Causes producin Sometim which wo formation either sid

\section{How to} and sole which sid at rest, a short and be so extr' there is a by the evi erack.

\section{What to} traction a corns will bruise, ren so there $\mathrm{m}$ than the of rest in colo a soft spon to fit. $\mathrm{Tb}$ on the part and sole sn mote healt

Use the If the di matter), th awaly all th away all th with a linse the surface leather sole. 
Thus a horse with corns should be thoroughly examined for injury to the bones of the hoof, rotten hoof, ete.

Causes.-A bruise on the sole below the bars and the wall at the heel, producing a horny tumor or hardening, which presses on the quick. Sometimes there is inflammation, owing to the formation of matter which works' out either at the top of the hoof or at the toe, from the formation of a fistula. Then it is Quittor. They may be found on either side of the heel, but usually on the inner or weaker side.

How to know it.-There will be flinching when the walls of the hoof and sole are seized and strained with the pincers; thus revealing on which side and the locility of the corn. The toe will be pointed, when at rest, and with the heel slightly raised. In notion the gait will be short and stumbling. If it has proceeded to suppuration, the pain will be so extreme that the horse will fear to put the foot to the ground. If there is a horny tumor forming, it may be known upon paring the hoof by the evident appearance of a white, spongy, horny formation, as in sand crack.

What to do.-If the corns proceed from other disease, causing contraction and other disabilities of the hoof, remove these eauses and the corns will disappear. 'If the eorns proceed from a simple and recent bruise, remove the shoe and rasp down the bearing surface of the heels, so there nay be no pressure. That is, the leels should be rasped lower than the other bearing surfaces. If there is inflammation, let the hoofs rest in cold water, or keep them moist with a wet eloth and the sole with a soft sponge, or the whole hoof may be enveloped in a large sponge cut to fit. The animal should wear a bar shoe, arrunged to avoid pressure on the parts uffected. When the foot ceases to be tender, keep the hoof and sole smeared with the following ointment, to render it soft and promote healthy growth:

No. 192.

Ya Ounec tallow,

1 Ounce oil of turpentine,

4 Ounces beeswax.

Use the horse at light work until entirely recovered.

If the difficulty be found to be a suppurating eorn (one containing matter), the hoof must be eut down to let all the matter escape; cut aray all the horn that has beeome separated from the quick, and pare away all the horn around the parts to a thin edge. Poultice the part with a linseed poultice, renewed until there is no longer tenderness, and the surfice is smooth and healthy. Then put on a bar shoe with a leather sole, and fill the spaee from behind with tar held in place with a 
stuffing of tow. Give entire rust and no pressure on the heel until the sole of the foot has grown out naturally.

If the corn has become a tumor it should be cut out, and the same treatment pursued as advised for a corn that has formed matter.

Old corns sometimes result in disorganization of the parts, or death of a portion of the heel, disease of the bone of the foot, or ulceration of the cartilage. In this case they must be treated as advised for Quittor or for navicular disease.

\section{Contraction of the Hcof, Narrow Heel.}

In a healthy condition the hoof of a horse should be neurly round. Whatever shape the hoof may assume, it is not a disease in itself but the result of disease or of some disability. It is generally the result of fever in the feet from injury to bones, ligaments or frog, or the effect of founder, etc. Contraction of the hoof exists in nearly all diseases of the feet, and may occur from standing idle in the stable. So it may result from undue paring of the heels, the bars on the frog, from a shoe remaining on so long that the foot is prevented from taking its natural growth.

What to do.-The only thing is to remove the shoes and round the edges of the hoofs to prevent their being broken or split, and keep the affected hoofs standing every day from early in the morning until late at night in puddled clay reaching well up the hoofs. Continue this for two, three, or four weeks as the case may be. Then use prescription No. 192 as a hoof ointment until the hoof is brought back to its natural shape as near as may be. In shoeing let the shoe be without bevel on its upper side, and let the bearing be equal on all parts of the wall of the hoof.

\section{Injuries of the Frog.}

The frog of the horse's foot is especially liable to injury from heing bruised upon projecting stones, pierced by nails and splinters. It is also liable to inflammation of the secreting membrane, resulting in the formation of matter, and io canker.

What to do.-In all bruises with soreness pare away the frog carefully until the difficulty is found. If bruised, treat it by using the liniment No. 189. If pierced with some sharp substance extract it and inject tincture of aloes and myrrh. If the difficulty be thrush, caused by exposure to wet and filth, bruise of the frog, hard substance lodged in the cleft, or other cause, there will be soreness of the skin behind the cleft 
of the frog, and a bad smelling discharge from the cleft with more or less limmeness.

Wash the affected parts thoroughly. Cut away all ragged surfuces and press into the cleft or wound dry calomel, or tinely powdered sulphite of copper.

\section{Founder.}

Founder, or inflammation of the feet, called by veterinarians laminitis, consists in fever, inflammation of the sensitive parts of the foot, including the laminæ, and of the foot bone, but is most severe in the forward portion, where greatest strain occur's when standing. Acute inflammation of the foot, or founder, differs but little in its physical manifestations from other inflammatory symptoms, except that it seems more complete aud permanent. Acute founder is generally produced by overwork or overheating and exhaustion and sudden cooling, while the sub-acute form . may be the result of diseases of the respiratory organs, suddenly leaving those parts and inanifesting itself in the extremities.

Causes.-The disease may be brought about directly from hard work on dry, solid roads, and consequent strain on the lamine (scale of the bones), from over-feeding or drinking cold water when warm, especially when the predisposing cause already exists. So it may be brought about by other diseases, as inflammation of the lungs. Heavy, fat horses are espeeially predisposed to founder, and so are those with small and deformed or large, flat feet.

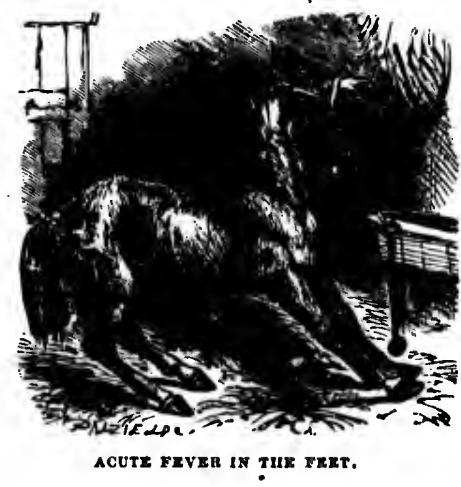

How to know it.-There will be general fever and stiffness, and soreness ; there may or may not be shivering. Soon extreme tenderness of the feet follows, generally most severe in the forward part, but soon in the heel; the pulse is strong, full nnd rapid; the breathing quickened, 
with dilated nostrils ; the intensity of the pain will often cause the animn to groan and to break out into a sweat. If pushed backward the lorso will elevate the toes and throw his weight on the heels by a peeuliar motion. The hoof and frog will be hot and very sensitive to pressure, and the arteries of the pasterns will beat with violence.

When the inflammition is in the hind feet, the fore feet are carried as fur under the body as possible to support the weight, while the hind feet are thrown forward to bring the weight upon the heels. In either ease, the animal will often lie stretched out for hours to relieve the intense pain of the feet.

Founder has sometimes been mistaken for a disense called myositis, an inflammation of the muscles of the limbs, especially of the hind quarter's and loins. They should never be so mistaken, as an observation of the several symptoms will show.

Founder.-First one foot and then the other is lifted from the ground.

Lying down lessens the pain and the fever of the feet.

The diffieulty usually occurs in the fore feet.

Mrositis.-Both feet are kept on the ground with refusal to move either.

The animal will not lie down, and if thrown down the pain is increased.

Generally in the hind quarters.

In many cases the symptoms are not so aggravated as we have showl, but the symptoms, whether one or nore of the feet are affeeted, are the same, and often, especially when repeated attacks have been suffered, leave the animal with seedy toe, pumiced feet, corrugited and otherwise distorted hoofs, and always more or less liable to recurrence of stiff spells during life.

What to do.-In light cases, when discovered early, clothe the animul warmly, give twenty drops of tineture of aconite every two hours, pre. ceded by a gentle laxative, suy

\section{No. 193. 2 to 3 Drachms powdered aloes, \\ 1 Ounce bicarbonate of Boda.}

Mix in a pint of water and give as a drench. If there is severe paln give ounce doses of laudanum every hour until an effeet is produced.

As an application to the feet keep them in large warm poultices of linseed meal and water, or let the feet be placed in whter kept as hot as the animal cun bear. Put him in slings by all means, if they ean be procured. Have the shoes carefully taken off as soon as the sedatives girell will allow him to bear the pain. As early as possible the animal should be bled in the veins above the coronets of the affected feet. The bleeding will be assisted by the feet being plaeed in hot water, and for this reason, if for no other, the slings should be used as quiekly as possible. 
If there is much thirst make the drink slightly sour with eream of tartur. If at the end of two days the fever and tenderness does not get better pare down the soles and open them at the toe to let out any watery matter that may exist, for fenr the horn may separate from the quick, keping on the poultices afterwurds as before. When the inflummation subsides blister the pasterns and apply the corrosive liniment No. 189 to the soles of the feet, and keep the horse standing on soft elay, or if in Summer time tmrn him into a moist, soft pasture.

As a rule, neither bleeding from the neck or active purging should be allowed in founder. There are, however, enses occasionally in simple founder, from overfeeding when tired, or giving cold water when warm, when a gallon of blood taken from the neck and an active purge of a quart of linsced oil has acted like a charm, the patient recovering almost inmediately. In this the operator must be guided by circumstanees. If the loorse is fit and full of blood it will tend to reduce the inflammation by drawing the blood to another part of the system. If so the blood should be allowed to flow in a full stream.

\section{Nail Pricking.}

The prick of a nail in shoeing, or from having a nail enter the foot in traveling often leads to the most serious eonsequences if allowed to proceed, such as ulceration, ending in quittor and other disabilities. An animal being lame without swelling, inflammation or other indieation of strain or bruise, the feet should be carefully exumined, and the nail or other substance be eut out, at whatever pains it may take. Then dress the parts with hot pitch, cover with tow and give the animal rest for a few days.

\section{Ix Canker.}

This is one of the disenses that muy arise from the prick of a nail or bruise. Again it may oecur without apparent cause.

How to know it.-It is a disease nıost prevalent in heavy, coarse-boned horses. The frog will become large, spongy, and covered with a fungous growth of a cheesy texture, and throwing out an alundant colorless, lad smelling fluid. If eut away it will agrin quickly spring into growth. The discharge is more offensive than in thrush, and the disense more ohstinate, often resisting treatment for a long time.

What to do.-The horse must be kept in a elean, dry, well-rentilated stable. All diseased portions of the hoof must he carefully pared off so far as the knife may be able. The cure consists in destroying the fun- 
goid granulations. Thus in cutting do not be alarmed at the sight of blood from the canker. Over the well portion of the hoof spread the following:

No. 194.

\author{
4 Grains chlorido of zinc, \\ 1 Ounce tlour. \\ Mlix, uud apply dry.
}

Cover tho diseased parts with the following:

No. 195.

$$
\text { 16 Ounce chlorido of zinc, }
$$
4 Ounces 1lour.

Tack on the shoe lightly, pad the parts within the shoe well, and secure good pressure by cross pieces driven firmly within the shoe. The second day after remove the shoe und padding, cut away everything that appears to be in a slonghing condition; repent the dressing every two days until the parts are sound. As soundness begins to appear in portions of the surface, dress these with the following; thit is, when fungoid granulations have ceased to sprout :

\section{No. 190.}

2 Gruins chloride of zinc, 1 Uunce llour.

As the canker improves, the dressings may be extended to the third or fourth day, and during the whole time of treatment the horse should be liberally fed, and be exercised gently for four hours every day.

\section{Sand Crack.}

These are of two kinds, quarter crack, occurring in the inner quarter of the fore foot, and toe crack, oceurring in the toe of the hind foot, both being eracks and fissures in the walls of the hoofs, begiuning at the coronet and extending downwards.

Causes.-Defective quality of the hoof, causing brittleness; bad shoeing, or splitting of the hoofs from hard driving on solid ronds.

How to know it.-When the horse leans his weight on the hoof, the crack will open; when the foot is lifted the crack will close. Sand nud dirt work into the parts, causing excessive pain and lameness, often ferer and the formation of matter.

What to do.-In recent eases, before there is much inflammation, all that will be necessary to do will be to remove the shoe, clcunse the crack thoroughly, cutting into it if there is dirt or sund lodged inside, drawiug the hoof together elosely again, by the means of two thin elinch hore shoe nails, one at top and one at the bottom, and filling: with the follow. ing composition .
Melt to

The foot $\mathrm{s}$ to pasture jured hoof.

If the er: be pilled a cleansed of fomented $\mathrm{t}$ bealthy upp means of $c$ on, and a ne

This diffic deficiency in onct to the s

Causes.power, owing

What to o a bar shoe. mild blister, with weak (") old cisses, all protect the w

Causes.-T inflamed, sup openings upo in shocing, b bad tread or crack and fills fitt-footed ho which leads tr tion of pus in a nail, or whe 
No. 107.

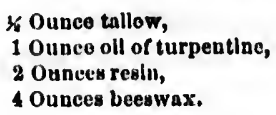

Melt together, and fill the craek with it quite warm, and let it cool. The foot should be protected so no dirt can enter, und the horse turned to pasturo until a new hoof is grown, plaeing a bar shoe on the injured hoof.

If the ernek is un older one, and there is inflammation, the edges must be pirred and the fissure sufficiently lnid bare so it muy be thoroughly deansed of all grit and dirt. The erack must then be thoroughly fomentel to reduee the inflammation, und poulticed until it issumes a bealthy appearunce. The parts must then be brought firmly together by means of elinch nails; covered with ointment, No. 197 ; a bar shoo put on, and a new hoof allowed to grow.

\section{False Quarter.}

This difficulty differs materially from sand erack, inasmuch as it is a deficiency in the growth of the horn of the hoof extending fiom the eoronet to the sole. It is a gap in the wall of the hoof rather than a crack.

Causes.-It is produced from a deficient secretion of the horn making power, owing to previous quittor, frostbite or other injury to the coronet.

What to do.-The principal means to be used is eareful shoeing with a bar shoe. If the injury has been reent, stimulate the eoronet with a mild blister, or if there is a wound, eut the edges with a knife and dress with weak carbolic acid water, to induce a henlthy growth of horn. In old eises, all that can be done is to fill the fissure with gutta percha, and protect the weak hoof with a bar shoe.

\section{Quittor.}

Causes.-This fistulous condition of the fibrous eartilage of the footinflaued, suppurating, penetrated by canals in various direetions, with openings upon the quarters and beels of the coronet-is caused by prieks in shoeing, by threads, by suppurating corns or bruises, by neglected bad tread or over-reach, hy negleeted thrush, by irritation from sanderack and false-quarters, by bruised sole that sometimes takes place when fint-footed borses are ridden over stony ground; in short, by any injury which leads to inflammation of the cartilage of the hoof and the formation of pus inside. When the sensitive portion of the foot is piereed iy a nail, or when inflammation has followed a bruise, suppuration speedily 
follows, and the acenmulating matter presses in every direetion, and, finding no rendy outlet, the little fleshy plntes of the eoffin bone uro forced from the horny ones of the crust, or it may burrow between the horny and fleshy sole, and fur towards the very central portion of the foot. Pipes und sinuses are then made in every direction; but the outlet is generally by nbscess of the coronet, or that portion of the hairy skin running immedintely down upon the hoof.

How to know it.-A recent wound or ordinary abscess of the coronet may be mistaken by the inexperienced for quittor, especially if any lame. ness attends it; but a little examination will readily disclose the true nature of the ense. From $n$ simple wound, there is not upt to be a fetid discharge of so unwholesome a charaeter as that which oozes from the simuses of the quittor, and the parts must be more or less swollen, and yielding to pressure, whereets, in quittor, the surrounding tissue is hard, though it has taken on a peculiarly moliealthy action, and probing with the flexible probe, or bougie, will discover the presence of a simus or of sinuses, of more or less depth. There is almost always lnmeness, which is sometines excessive, and of a halting eharaeter; the coronet is somewhat swelled into a ridge around the top of the hoof, and nbout the center of which one or more small orifices are found, that discharge in small quantities an offensive matter-sometimes rather thin and watery, again, thick and having a curdled appearance. The probe, as wo have said, will disclose sinuses, and these genernlly tend dowuward into the foot. The quantity of matter discharged is often very small at first, so much so as to be out of all proportion to the very serious nature of the trouble, and the difficulty attending a cure. Even when the openirg or openings will scarcely admit the small bougie, there may be much mattel, and this may have penetrated under the cartilages and ligaments, and to the cofin-joint itself. Wherever it has gone, it has formed fistulous pipes, or ulcerations that are difficult to heal. There is usually increased heat, as well as much tenderness of the foot.

What to do.-The first step is to discover, if possible, the cause; and if this is still opernting, to make every effort in your power to remove it Sometimes there is such swelling around the hoof, and such excessive tenderness, that the animal cannot bear to have the foot handled except in the gentlest manner. In this ease, apply a good softening and cooling poultice, and keep him as still as possible-renewing the poultice as often ns it begins to grow dry and hot-until the inflammation is something reduced, and the extrene tenderness overcome. Then, remove the shoe and withdraw every nail if it enn be done. If the trouble has been caused by a nail, and the nail can be removed, there is already something of $n$ depon and this of to reach $\mathrm{tl}$

A smull to the lowe the foot, $\mathrm{t}$. meet it, 11 bruise, or i ing establis foot will re in which ca

If tho di sinuses hats injected wit zinc to onc drachnıs.

This treat dependent o of the sinus riously direc channel or p

No. 1

Do this th subsequently simply kecp

If it is for: adopt this i corrosive sub sublimate). felt the caust charge a whit but if thorou, be expected.

Sometimes hetween the s be ascertained appearance, $\mathrm{h}$ down so as to to discover an 
of $n$ dependent opening made by which the accumulated pus may escape, und this opening may be enlurged by farther paring awny the hoof, so as to reach the softer purt, that can be nore readily cut with a keen knife.

A snull probe, or bougie, should be inserted from nbove, and worked to the lowest depth of the sinus. If this extends far towards the base of the foot, the prime olject should be to get an opening from below to meet it, no matter what may have been the cause-whether a prick, a bruise, or irritation caused by other foot diseuses. This dependent opening estublished and kept open, the pus will in time be evacunted, and the foot will return to its heulthy state, unless the joints have been attacked, in which case a cure is scurcely to be hoped for.

If the discase is of long standing, the internal surface of the sinus or sinuses has become more or less callous, and a stimulating lotion must be injected with a syringe every dny, composed of one drachm chlorido of zinc to ono pint of water-increasing the chloride gradually to two drachms.

This treatment will suffice. The main trouble, however, is to make the dependent outlet. In case this camnot be done, owing to the shallowness of the sinuses from above, reduce the infinmmation by poulticing, as preriously directed, and then inject this somewhat caustic solution into each channel or pipe :

No. 198. 5 Grains bichloride of mercury,

1 Ounce spirits of wine,

20 Drops muriutic acid.

Do this three times the first day, twice the second day, and once a day subsequently. When the discharge has ceased, stop the injection, and simply keep clean by the use of warm soap suds, used asnecessary. If it is found impracticable to inject this solution into the openings, adopt this instead: Insert, by means of a wet probe, a mixture of corrosive sublimate and flour (three purts of flour to one of corrosive sublimate). Persevere until you know that gvery part of the sinuses hus felt the caustic. In two or three days thereafter they will begin to discharge a white, curd-like matter. It may be necessary to repent this, but if thoroughly done, and there is no affection of the joints, a cure may be expected.

Sometimes the trouble rises from a gravel having insinuated itself betwcen the shoe and the sole, and creating a bruise or corn. This may be ascertained by removing the shoe and seeking for a spot unnatural in appearance, hot, and tender on the sole. If found, it ought to be pared down so as to reach the more sensitive part of the foot, and, if possible, to discover and liberate matter. 
In making examinations preliminary to trentment, the greatest eare should always be exercised, as tho trentment, to be suecessful, must be specially udupted to the exigencies of tho casc. It sometimes happens that the trouble is critical, and that only an experienced pruetitioner ought to be intrusted with it. When the probe indicates thut the direction of the siunses is backwurd, the chances aro in favor of recovery; but if it shows the direction to be forwurd, the inportunt and compliented parts of the foot uro in dunger, und tho result of even the best trentment is doubtful.

In uny event, a complete curo requires much time, and a more than ordinaly exercise of patience and care.

If the patient, in moving about, strikes the swollen parts above the fore-foot with the toe of the hind-foot, or if he hurts it in lying down, some steps ought to be taken to obviate these additional causes of irritation and pain.

If the general health of the mimal is serupuously attended to: it will materialy assist in the managenent of the local disorder.

\section{Toe Crack.}

A hoof with crack in the toe should be trented precisely as though the difficulty oceurred in another portion of the wall of the hoof. The diffeulty in all eraeks of the hoof, is the difficulty in healing, for the renson that when tho animal steps, especially on uneven gromnd, the walls are struined apart. In sand-crieks, the principal carre must be to extirpate the grit and dirt, whatever the amount of paring and cutting it may take. If granulations appear, they nust be eut out. Then wash with a solution of chloride of zinc, made as follows :

No. 109 .

1 Grain chiortde of zinc,

1 Ounce of water.

Whatever the quantity made, let it be in this proportion. Cleanse the whole interior of the crack fully. In cutting away the hoof, it should present an oval shape when finished, the points at top and bottom.

Having cleansed the iuner portions, if the crack does not extend completely from the coronet to the toe, with $n$ firing iron, just hot enough to eause the horn to smoke, the iron not at a red, but at a black heat, soften the crust and continue the cutting until the disensed portion is all exposed. If granuiations (proud flesh) show, cut it out and let the parts bleed. Then continue the application of the chloride of zinc lotion three times a day until a healthy reaction is produced. The crack may then be stopped with piteh or tar and tow, or gutta percha; a bar shoe put oll with $t$ in a clear parta liei stunce lin

Situd-c ensure $\mathrm{ft}$

Pumice of soft, s together: above 'I costen bone the sole it instead of pled. Thi weak limbs

What to to ulleviste the furmu. the rreb ho fuce and th shoe be nls

The looof tar. If lie have the st time to tim pasture. I never be ex

The wall harder and t and lighter i coronet, the intimately u bearing the

Causes.tegrating the just as in the ces seedy to 
on with two elips in front to hold the purts togethor, and tho animul kept In a clean, soft pusturo until n new hoof is grown. An examinntion of tho parts lieing made from time to time to see that no grit or foreign substunce has entered to inerense the difheulty.

Suid-eracks, quarter-eracks, and false-quarters, will require time to ensure full recovery, und the time so consmmed should not be grudged.

\section{Pumico Foot.}

Pumice foot, tho effect of chronic luminitis, is an excessive growth of soft, spongy horn in pluee of the henlthy loof, forming rings ruming together ut the toe, cuusing a lrulging nt that point and a depression above. This growtl in front of the lanine of the toe separntes the costu bone from the wull of the hoof, und ullows the bone to press upon the sole and even to piere through it. Thus the sole beecomes convex instend of eoncave, the animul becoming groggy, and in time quite eripplel. This state is almost entirely confined to animals with flat fect and weak limbs, weak and brittle crusts to the feet, with large, prominent frogs.

What to do.- In bad eases there can be no eure. Much may be dono to nlleviate distress, and enable the horse to do slow work, especially on the furm. Put on n thick, brond webbed bar shoe, a dished shoe having the web hollowed out, or beveled toward the inner side on the upper surface und thinned down fiom the toe to the heel. It is better that the shoe he also assisted with a benring of leather next the sole.

The hoof should be smenred dnily with equal parts of glycerino and tar. If heated in slightly so much the better. The sole should also have the same application. Apply n mild blister to the coronet from time to time to stimulate action, and turn the lorse into a soft, damp pastmre. Thus in time a fuirly smonth hoof nlay be grown, but it can never be expected to be entirely sound.

\section{Seedy Toe.}

eanse the it should n.

end comnough to at, soften is all exthe parts tion three may then shoe put

The wall of the foot is composed of two layers, the outer one darker, harder and thinner than the inside one; the inner liyer thicker, softer and lighter in color thun the outer. The outside layer is seereted by the coronet, the inner one from the sensitive laminx. In health these are intimately united, forming the thick, tough, elastic hoof, capable of bearing the shocks of the body in tratveling.

Causes.-If from any cause, inherent weakness, undue shocks, disintegrating the laminx, or other enuse, the separation begins at the toe, just as in the human nail the separation begins at the margin-it produees seedy toe. 
How to know it.-If a seedy toe be struck with a hammer it will give a hollow sound, showing that it is disunited. Remove the shoo and " sepn'ution will be found between the two couts of the hoof.

What to do.-Find the extent of the separation with a thin probe. Cut awny such portions of the erust as muy bo disunited, and to where there is firm ndhesion of the parts. If these is a powdery substance clean it out. Keop the cavity tilled with wum tur, properly held in pluee, und shoe so as to give a uniform bearing, and support tho weak purt with a clip if necessury. This dressing must be repeated from time to time as recuired, until the eavity is entirely filled with a new and healthy growth.

\section{Ossifled Cartilages.}

Ossification of the cartiluges is sometimes called falso ring-bono. It is $n$ disense to which muny horses are sometimes subject, and often exists in connection with ring-bone and side-bones.

Causes.-Tarring, by hard driving over rough roads, or pounding on hatrd pavements, or any of the cuuses producing ring-bono or inflammation of the purts.

How to know it.-When the difficulty is new, there may be fever in the parts. Luter there will he nore or less enlurgement of the lnck of the coronct and the heel, the parts feeling hard, irrogular or lunpy. The horse is not ulways lame, but if driven over hard roads, the horse will show soreness and truvel short after cooling off.

What to do.-In old stunding cases, but little can be done; rubbing the patrts with olente of mercury will reduce so much us is not already bony substauce. In comnection with th:s put in a seton under the affected part. In more recent enses, if there is hent, bleeding from the foot will give rolief. Then mply choths dipped in cold water to ever! qualt of which has been ndded a half pint of tincture of arnicu. The inflammation being reduoed, apply repented dressings of biniodide of mercury. 'This will promoto absorption, but a completo curo muy not be expected.

\section{Bido Bones.}

Side-bones ure ossifientions from the heels of the coffin-bone into the luteral curtilages. In houvy horses, side-bones mny occur in connection with ring-bones. In fuet, ring-hone hus its sent in the os suffraginis, and side-bone in the parts about; the first being in the pasteru; the latter lower, or about the coffin-bone. 
How to know it. - The enlargement is just ahove the coronet and imnedintely below, when ring-bone exists. Side-bone uny be found at the back and laterul purts of the coronet. There will be more or less soreness ancl laneness, but after ossitication bony formation of the parts has been completed, the joint is either stiff or nearly so.

What to do.-The trentment should be precisoly identicnl with that preseribed for ring-bone.

\section{Inoised and Punctured Wounds of the Sole.}

Ineised wounds are those mude with a shurp instrunent; punctured ones are those made with a blunt one, us a nail. If the eut be a clean one, all that will be necessary to do will be to pare away the sides to be sure that no foreign substance is lodged there; wash out with tincture of aloes und myrrl, und keep the wound elosed with tar and tow, and give rest until healed.

If the difficulty be from a nail, care must be taken thut it is all extracted. This anust be done at whatever cost of cutting. Then dress as prescribed for the incised womil. In old cases, where suppuration has taken pluce, the matter must be let out by emlarging the oritice. Then the same means for cure may be ndopted as in quittor or other naturated sores.

rubling alrenty - the at. from the to erert The inodide of may not

into the oumection ginis, nud the laster 
CHAPTER XV.

WOUNDS AND INJURIES AND THEIR RESULTS.

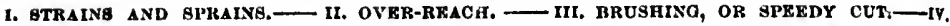
BHOKEY KNEKS. - V. CAPPED KLBOW,-VI. FROST BITE.—VII, BURNS AND ACALD, - VII. RUPTURE, — IX: CHOKIYG. — $\mathrm{X}$, WOUNDS PENETRATING THE ABDOMINAL CAVITY, - XI, CONTUSED WOUNDS.-XII. LACERATED WOUNDS, - XIII. PUNCTURRD WOUNDS, - XIV. BROKEN HOCK.-XV. DISLOCATIONS, - XVI. VARIOUS FRACTURES. XVII. VARIOUS DETORTIONG.—XVIII. DISKASES OW THE EAR.

\section{Strains and Sprains.}

In the human subject, a strain is simply a wrench, by which a fiber, a ligament or tendon is stretehed beyond its proper eapacity, and followed by pain, lameness, and inflammation of the parts.

A sprain is an incomplete luxation (dislocation) in comnection with stretching, with more or less laceration of the ligaments of a joint, and even rupture of the tendon. In veterinary pratice the word stein i* used. It is far more difficult to handle thm in man, and for the reason that it is often difficult to prevent an animul from using the parts.

Replacement of the parts as near as may be, and rest, are the surest means of cure. Thorefore in every case the intelligent horseman will use the best means to ensure this ; consequently it will be simply necessary to lay down certain rules of guidance to bo followed.

Strain of a joint._- In a joint that is easily flexed, (moved back and forth) the parts should be held firmly by means of a stareh bandage, if there has been suftieient stretching to produce loss of continuity.

How to make a starch bandage. - Provide a long strip of strong unbleached muslin, and of a width proportioned to the part injured. Soak this in strong starch, and bind on while wet, making a half turn of the cloth in passing about the limb, so it will form a figure eight. Allow 469 this to oceur: strain solme, by ill met $w$ the ear water. day, in

If thr affected sary. hefore

This, of crean calso of :

Lauses fails to li the hind higher, of

What to keep the parts witl the slougl of arnica the same s

This is the shoe of It is more once is mo that is res don'n out

What to confined to the lorse t thus throwi 
this to dry without movement and it will hold the parts firm. If the strain oceurs in the fetlock, hock, or knee, this will be indieated. For a lighter strain, a simple cold water bandage will sufti"e.

In all struins, rest must be given, the diet should be light but wholesome, and if the bowels become costive, they must be stimulated to action hy alterative medicines. Strains of the ligiments or museles must !n met with cold water bandages. In all strains, however, dependence in the early stage must be upon arnica, equal parts of the tincture and rain water. Bathe the parts thproughly and carefully two or three times a day, and then apply the cold water bandige, keeping it wet.

If the strin is in the shoulder or loin, lay a wet blanket over the part affected, and eover with a dry one, changing as often as may be neeessary. Sponge the affeeted parts with the tiluted tincture of arnien, as beforr recommended.

This, with rest, a light diet, keeping the bowels regular, and an ouncer of cream of tartar to the bucket of water, ought to subdue any curable case of strain.

\section{Over-reach.}

lauses.-A tired horse, especially when going at a fast paec, sometimes fails to lift the fore feet quick enough. The result is tire immer part of the hind foot strikes the outer side of the coronet of the fore foot, or higher, often producing a severely lacerated or contused wound.

What to do.-The only remedy is to clip the torn portions away, and keep the parts washed with ebloride of zine, (No. 195), first cleansing the parts with water if at all dirty. The healing must take place through the sloughing of the torn parts, and by granulation. If slight, tineture of arnica will be sufticient as a lotion. Treads from ealking may receive the same general treatment.

\section{Brushing, or Speedy Cut.}

This is a bruise, abrasion of the skin, or contused wound, produced by the shoe of one foot striking the opposite fetlock ankle, or even the knee. It is more owing to weakness than other causes, though a horse striking ance is more liable to the same injury therenfter. It is really the foot that is resting on the ground that eauses the hurt, from its being put down out of the proper line.

What to do.-For horses of slow or moderate driving, the difticulty is coufined to striking the ankle and below. The usual remedy is to cause the horse to set his foot in proper line by raising that side of the shoe, thus throwiug the inside of the ankle slightly up. Any common sense 
blacksınith should know how to do it. For fast horses, the limbs must be further protected ly means of pads and other appliances to be found it all saddlery establishments.

\section{Broken Knees.}

This is a common disability of stmmlyling horses, and of saddle horses kept for riding, leaping, or hunting. A horse with the scurs of broken knees should never be used as a saddle horse, unless it call be clearly shown that the hurt was done accidentally in leaping upon a foul landing place.

What to do.-The first thing to do is to find the extent of the injury. It may be thit it is only a slight bruise with or without abrasion of the skin. In this ease, using the timeture of arniea two or three times a day, and a cold water bandage, if there is hent, should ensure reeovery.

Sometimes, however, there is an ugly, heerated wound tilled with dirt and gravel. In this case the parts must be well washed by repeatedly filling a large sponge with olean, warm watcr, and squeering it dry against the limb above the hurt. Never, under any circumstances, put it anginst the hurt. It only soils the sponge and presses the particles of dirt farther into the wound. If there is a sac below the ent containing dirt it must be carefully probed, and opered from the bottom with a keen, sharp pointed knife. The object is that no grit may remain in the wound to prevent its healing. A seton should be tied so the sale may be emptied of its contents in the process of suppuration. If the grrmulations bevome soft and flabby, showing proud flesh, they must be touched with nitrate of silver. In three days after the establishment of sulpuration the seton may be withdrawn. The wounded parts must be kept wet with cold arnica water, the proper proportions being one ounce tincture of aruin to each pint of water used.

Copious suppuration laving been fairly established, discontinue the use of the arnica, and use instead the lotion made by dissolving in eath ounce of water used a grain of chloride of zinc. Use no bandages. Cleanliness of the parts is necessary. These moans should curry the knee to a favorable issue.

Sometimes, however, the injury is so severe that the ligaments and even the joint is injured. It then beeomes a most serious case. In this event the animal must be put into slings, the joint brought together, after being thorougly eleansed as before stated, the pirts must be banduged and ustringent washes used to promote the uniting of the parts, while the same general treatment is pursued with the laceration as advised before. In case the injury be so severe as to involve the joint, if a veterinary 
surgeon enunot be hud with proper applianees for caring for the horse he had hetter he killed nt once.

Besides injury to the knee hy falling, it is sometimes injured by having some sharp substance driven foreibly into the ligaments or even between the joints. These should be earefully looked for and removed, since old running sores, fistulas and other disabilities may result, completely destroying the usefulness of the animal. Joints other thun the knee muy be similarly injured. If so, the general trentmen' should bo the sume. First reduce the inflammation, and then use means for cure. In ordinary rases, as a healing agent, in wounds, either lacerated or contused, we lave never found anything better for promoting healthy granulation or healing of the pints than a free use of tineture of aloes and myrrh.

\section{Capped Elbow.}

Causes - This tumor at the back point of the elbow is generally er.used by a bl" ase inflicted by the calkings of the shoe while the horse has slept with 1 s leags doubled up under him. Inflammation of the sub-cellular tissue is established, and that condition sets in which gives rise to enlargement ly incleased deposit near the part. 'The tumor is eircumseribed, heing woufined to the clbow, hut it sometimes grows to an enormous size, and liangs lomerly from the back point of the ellow, amd interferes with its artion.

It may be produced also lyy long heels, as well as calkins, by striking witl the shod hiud foot, by a blow, and by lying on uneven surfaces.

How to know it.-A slight swelling of the point of the elbow is first perceived, and muless the cause is removed this will gradually develop into a harge-sized tumor. When of any considerable size, it will contain serum, or a watery matter, and has a fluctuating fecling to the fingers. This fluid is contined in tough, tibrous walls, and may remain for a long tine, or it may at last be absorbed, and lenve a hard tumor. At this stage there will of comrse be no thetuation.

What to do.- If discovered in its carly stage, and serum is evidently present, let it out by opening the sac at the lower edge with a keen knife, or a thumb lancet. Press upon it so as thoroughly to remove the fluid. Then, with a small rubber syringe, inject a mixture of equal parts of pyroligneous acid and water, Next, moisten it externally, morning and night, with the camphorated corrosive sublimate, No. 2, which will have the better effect if dried in at once with a hot iron hold near. Before the horse is nllowed to lie down again, make a soft pad, covered with chamois skin, without a sean on the outer sicle, of such thiekness as to keep the shoe from striking the elbow when the legr is doubled under him, 
and tie it securely round the pastern. 'This should be on every night, and even after cure is effected it will be necessary for the animal to wear this pad, to prevent reeurrence of the bruise, or else to have the she shortened. The pad must be at least two and a half inches thick.

If it is in its new state (a simple swelling without matter), it can be assuaged by using frequently, at moderate intervals, some cooling lotion.

If large, watery, somewhat pendant, and unsightly, have an experlienced surgeon remove it entirely; and then dress as an ordinary wound.

If, after it his been opened, and the fluid pressed out, it heals with hard substance left behind, rub frequently with acetnte of merculy until the natural state is restored.

If treatment is undertaken only when there is no watery matter, no fluctuation, remove it absolutely by making a vertical slit, of suttirient length, and dissect the lump; after which treat the wound with simple cerite, or any healing ointment.

Care must always be taken to gourd against having the elbow injured again while treatment is going on, and to prevent rehruising the part after cure is effected.

If there is constipation or otherwise feverish tendency in the animal, the cure of tumor's or other local troubles will always be more ditficult unless this tendency is removed by suituble purgatives and carrefully regulated diet.

\section{Frost Bite.}

Injury from the effeets of frost is more common in the North and West than is generally supposed, and in many cases rheumatism, foumder and other "stiff complaints" may undouhtedly be attributed to this as the predisposing cause.

Causes.-Loug exposure to eold, either standing in the open air or confined in cold stahles; standing in half melted snow and slush; kecping young animils in exposed yards, where they cannot take exereise and with insufficient food.

How to know it.-The skin of the injured parts in light eases, turns purple, inflames, cracks and exudes a hloody scrum; or if severe, the skin and tissues beneath lose color, and become dead and eventually shrivel. The skin, particularly of the heel, will crack, often from one side to the other, refusing to heal.

What to do.-If the limbs are simply elilled, friction will be all that is necessury. If uctually frozen, the animul should be warmly clothed and the frozen parts be rubbed with snow until cireulation is partly restored. Then put the parts in eold water and continue rubbing until wurmth doths ar

If the ance, $\mathrm{pr}$

Rub tl or ulcerit cers ocen Rub all v

Burns on the ro are enplo founderie

What to for a fre baking so and bind $i$ rover a la white ical bind on $\mathrm{cl}$

Strong scalds, the ralin-water with thes

Sonnetit should be mixture d

Mix int moisture comes per

Rupturd 
wurmth and circulation are entirely restored. Then dry thoroughly with athe and hurd rubbing.

If the frosting has been neglected and raw sores make their appearance, prepare the following:

$$
\begin{aligned}
& \text { Yo. 200. } 2 \text { Draehms belladonna, } \\
& 1 \text { Ounce petroleum, } \\
& 1 \text { Ounee lard". }
\end{aligned}
$$

Rub the whole thoroughly together, and apply twiee a day to the raw or ulcerated places. If this does not promote reeovery, and decided ulcers occur, add to the above prescription 2 ounces red oxide of mercury. Rub all well together and apply once a day to the ulcerous parts.

\section{Burns and Scalds.}

Burns and sealds seldom oceur in horses kept on the farm or employed on the roal. They are, however, of frequent oceurrence when horses are eniployed about mills or factories where steam is used; or in iron founderies and in cities.

What to do.-One of the best and most easily obtained applications, for a fresh burn or seald, is to dredge bicarbonate of soda, common baking sodil, thickly on the part, or moisten with water into a thick paste and bind it or lay it over the injury. For slight burns, which sometimes cover a large surface, there is uothing better than several coats of thick white iead paint laid on with a brush; cover the whole with cotton and bind on close.

Strong alum water is also an excellent remedy for fresh burns and scalds, the proportions being 2 ounces of powdered alum to each pint of rain-water. Keep the parts well soaked with it, and wet cloths saturated with the same constantly over the surface.

Sometimes indolent sores follow burns and scalds. If so, the ulcers should be well and cirrefully wished with tar wier, and the following mixture dusted over the parts :

$$
\begin{aligned}
& \text { No. 201. } \\
& \text { 2 Ounce oxide of zinc, } \\
&
\end{aligned}
$$

Mix intimately and dredge on thickly to form a crust. Wherever the moisture appears through, keep adding the mixture until the crust becomes permanent and fixed.

all that clothed ittly reng until

\section{Rupture.}

Rupture or burst (Hernia) is the displacement of an internal organ 
through an opening, eitler muturnl or otherwise. monly seen is of the bowels and omentum. membramous covering of the bowels or the caul.

The rupture most eom The omentum is the through the caul by rupture, or the bowels and involved caul min, it is possible, pass through the mesentary, the membrano retnining the intes. tines in their proper position.

If the rupture is into the chest, it is enlled diaphramatic, and may oecur from a violent shock, as in letping,or in 'bucking,' as jumping stifflegged is called. In bad cases death is sudden from suffocation. In the slight forms there may only be difficulty of breathing, with lifting of the flanks, as observed in heaves. The only remedial means to be used are to give anodynes and rest. Thus slight cases may at length take ou the ehronis form, but will never be cured.

Hernia of the mesentary and omentum is diffienlt to know, and no remedy can avail, except rest, with anodynes if there is pain.

Naval rupture, and that through the serotum, is most common. The only means of cure in muval rupturo is where pressure can he had by means of a bundage or truss and taken in the carlic'r stages. The intestine must first be carefully pressed hack and pressure made over the parts by menns of a soft prad, securely fastened, and to be worn until the orifiee is closed or at least permanently contracted. Of course an animal with rupture of any part is not capalble of violent exertion.

Rupture of the scrotum is also common in males. In cases of colic in entire animals, an examination should be male for serotal rupture, since there may be colickey symptoms. There may be a swelling of the bag eontaining the testicle, the eontents being movable, and disippearing upon pressure. In the smaller animals, eastration may be employed, the gut returned and the wound sewed up.

Ventral hernia is known by the contents being movable and gurgling, and ensily pressed back to their place. If recent, the animal should be thrown on its back, using ether or chloral to keep quiet, returning the protrusion, padding the orifice, and eovering with strong factory muslin wound round the abdomen and laced along the back, the bandage being kept in place by bands fastened in front and carried to a collar worll on the neck. Except in the ease of valuable animals, treatment seareely pays, unless a veterinarian can be employed who understands anatomy.

\section{Choking.}

Choking oecurs in two distinet forms. The high ehoke, when the sulv. stance is lodged in the throat or neek; and the low choke, when the substance is lodged in that part of the gullet lying low down within the chest. In choke, there

How to $\mathrm{kr}$ is slavering,

What to d neek for the tingers on eae into the mout the throat an out in a strai olsstruction is oil it thoroug duce the prol endeavor to $\mathrm{n}$ into the stom:

If the sulss mass must be side of the ne of a shan'p kni an anple cut, them with fine difficulty hero: therestfter pree semi-liquid for aninal seens

In desperite tracheotomy ni insertingr a bre TiIe Low $\mathrm{C}_{1}$ or in the thoral In this form saliva rinus frol if the animal at breathing is lal animal shows s

What to do.between these

$$
\text { No. 2)2. }
$$

Use the prob 
chest. In high choke, the muimal may die in a few minutes; in low choke, there is not such special need of haste.

How to know it.-There is intense distress; the head is raised; there is slavering, violent coughing and continunl efforts to swnllow.

What to do.-Examine carefully the furrow on the left side of the neck for the sulustunce. If solid, enclenvor to press it upwirds with the fingers on euch side. If not, endeavor to extract it by putting a balling iron into the mouth to hold it open; pull out the tongue; pass the hand into the throat and endeavor to dislodge it with the fiuger, the head being held out in a straight line with the neck. If this do not succeed, and the olstruction is in the gullet and is clear of the windpipe, procure a probang, oil it thoroughly, east the horse, put the balling iron in the mouth, introduce the probang and by steady pressure for a few seconds at a time, endeavor to move it. If it moves continue the pressure until it is pushed into the stomach.

If the substance is "o firmly held thit the probang will not move it, the mass must be cut down upon and tuken out. Let an assistant press the off side of the neck to get as much bulge as possible. Then with a bold ent of a shap knife, cut through skin, tissues and gullet, to the mass, with an anple cut, and remove; bring the edges of the gu!llet together, stiteh them with fine centgnt, or strong silk, and then the wound in the skin. The diticulty here mily cause subsequent strieture of the gullet, which may thereafter prevent the animal swullowing solid food. In any event onlysemi-liquid food should be given for ten days after choking, or until the animal seems well.

In desperate cases, where there is instant diungere of death from choking, tracheotomy must be enployed. This is contting into the windpipe and inserting a breathing tube and will he treated in its appropriate place.

TuE Low Cuoke.- This is where the obstruction is low in the gullet, or in the thoracic portion of the resophagus.

In this form there is great distress but the head is not held so high, saliva runs from the mouth, and the discharge is copious from the nose; if the animal attempts to drink, the water is east forth from the nose; the breathing is laborious, the flanks tueked up, the back ronehed, and the animal shows symptoms of general distress.

What to do-Give a gill of linseed oil or lard oil onee an hour, and between these doses every hour the following anti-spasmodic:

$\begin{array}{ll}\text { Xo. 202. } & 2 \text { Ounces sulphuric ether, } \\ & 2 \text { Ounces laudanum, } \\ & \text { 1/2 Pint water. }\end{array}$

Use the probang carefully after each :anti-spasmodic. If the whole of 
the dose is apparently returned, administer chloroform from a sponge, by inhalation, until entire insensibility is produced. Then extend the head, insert the probang, well oiled, und nse stendy but constunt pressure, until the substince moves. It may trke ten to fifteen minutes, or more, When the substance moves do not use inuch violent pressure, but move it earefully until it enters the stomach, care being taken not to force the instrument too far and thus wound that organ, remembering always that sudden violence may bring on spasmodic action, in which case efforts must cease. Violence may also rupture the resophagus.

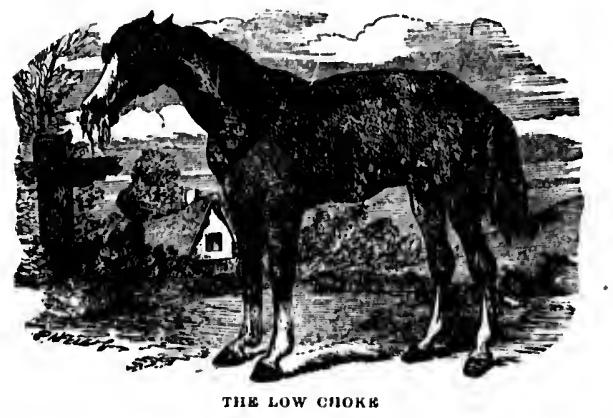

X. Wounds Penetrating the Abdominal Cavity.

A penetrating wound of the walls of the abdomen is gencrally followed by protrusion of the bowels. Sometimes it is so extensive as to allow a large portion of the intestines to escape. If so, they should be supported by a sheet fastened over the back to prevent injury by the feet and the admission of dirt until relief is given.

What to do.-The horse should be cast, the bowels washed with tepid water, the horse turned partly on his back, the intestines properly returned to their place by pressure, and the wound sewed up with catgut, well soaked in warm oil, and at intervals of an inch apart, bringing the edges nicely together. Then encircle the belly with a strong bandage properly fastened, by being laced along the back. Empty the rectuin, if necessary, by meins of injections of warm water or soap suds, and kcep the bowels open by feeding seulded shorts pretty well salted.

\section{Contused Wounds.}

A contused wound is one occasioned by injury from some blunt instru- ment, as a leave a gap

What to edges. If keep the bo mashes, usi tincture of dressing fo is follows:

$$
\text { No. }
$$

Mix, keel filter throug with water i appear, if $\mathrm{p}$ and use the a place that the grinulat touch them Then dress :

A lacerate a lacerated leaving at tlat

What to d of pulverize moderate $\mathrm{pu}$ In the ca shreds, brin white waxed other wound

A nail, th mobstance, $n$ wounds, fron 
ment, as a hook, wagon shaft, or other similar medium. They often leave a gaping wound with torn and bruised edges.

What to do.-Clip away all torn and bruised flesh that present ragged edges. If the injury is not extensive all that will be necessary will he te kep the bowels of the animal in health, and modentely loose, with brun mashes, using the following lotion daily. This is known ns the compound tincture of aloes and myrrh and should be kept in every stable as a dressing for wounds, galls and other injuries of that nature. It is made ins follows :

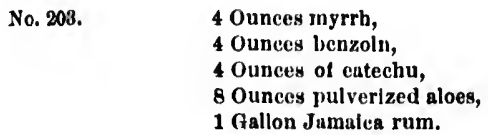

Mix, keep in a warm place for two weeks, frequently shaking it, and filter through linen. If the wound assumes an unhealthy eharicter, wash with water in which a little earbolic acid is mixed. When granulations ippear, if pus,anutter, forms, wash duily with a syringe and warm water, and use the carbolic acid wash for dressing, or, if the wound is in such a place that it may be done, eover with tow saturated with the wash. If the grumulations are soft, flabby and projecting, showing proud flesh, touch them with a stick of lunar eaustic, and expose to the air until dry. Then dress as before directed.

\section{Lacerated Wounds.}

A lacerated wound is a torn wound. The wound by treading, ealking, is alacerated wound. The tearing up of the skin and sub-cellular tissues, lexving a flip, is a lacerated wound.

What to do.-In :ny wound, if feverish symptoms occur, give an ounce of pulverized saltpeter in the drink night and morning, and administer a moderate purge, unless the bowels are open, say 4 ounces of aloes.

In the case of any lacerated wound, if extensive, clip away all torn shreds, bring the edges nicely together and sew them with fine entgut, or white waxed silk, and let the subsequent treatment be as direeted for other wounds.

\section{Punctured Wound.}

A nail, the point of a fork, a splinter of wood, a thorn, or any similar mabstance, makes a punctured wound. They are the most dangerous of wounds, from danger of internal poisoning, or fistula, lockjaw, etc. 
What to do.-First, exmmine carofully by menns of a probe for any foreign substince lodged inside. If so, remove it, even if a clenu cus has to be mude. A clean cut is not dungerous unless mu artery is sev. ered. If the instrument inflicting the wound was dirty or rusty, syringe the wound thoroughly with weak embolie water. If the wonnd heals kindly, use the tincture of myrrl dressing, No. 203. If inflummation sets in, and mutter forms in a deep, nurrow wound, it muy be neessary to enlarge the opening to let out the pus. Then treat as directed for contuged or lincernted wounds.

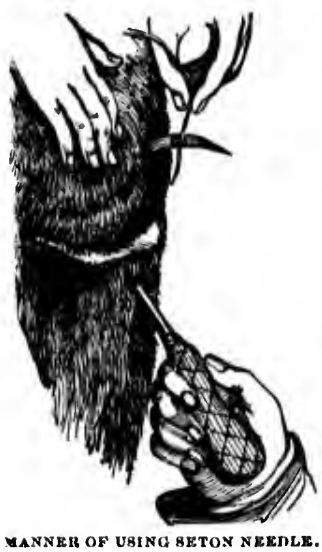

Dislocations in the horse nre rare, and when they occur are difficult to manage, except with the aid of a veterinary surgeon. Dislication of the lower joints, and of the hip, is most common, from eatehing the foot, twisting and pulling thereon to get free. In fuct, dislocation of the lip is scircely ever seen exeept in connection with fracture, but is sometims, met with in lenn, under-fed, young cuttle and horses. Dislocation of the shoulder is most seldom met with.

What to do.- In iny ense of dislocation the first thing to do is to put the joint in place, not always an easy matter. The memns we liare indicated for dislocation of the stifle will serve to show the manner of operation. A veterinary surgeon shonld be employed if possible in auy case of dislocation. If such canmot be had, any humane surgeon should he willing to give advice as to how to operate. The means to be employd are so different, varying with each particular ense, that it would be inpossible to state them except in a general way.
If influs discovered hot wilter hrouglit to will not be

When n to hold the padded, or always be rooling lot will ensure beaves the 1

Th fructu a nitture, iil for bredin! rases, lowes though the I Softening, ls stable, the is the leag is (all harness, or $f$

What to do having :ilply)i, will he nece. hovels nittur. annica, and t strengthen t] stall until rece

\section{A distortio} be cured.

by which the lronght strai norilial tone. ducing a dist produced by the cure of animals, as 
If inflammation and considernblo swelling has set in before the hurt is discovered this must be first reduced hy cold witer applications, or better, hot water fomentations, if persistently applied. 'Then the joint must be brought to pluce by traction and force. If there is no intlammation this will not be diflicult.

When a stureh bandnge muy be employed, this should alwnys be used to hold the purts togother. If not the dislocition must be splintered or padded, or both, to keep the parts intact and in place. 'The slings slowuld always be employed to rest the horse when they may be had. This with rooling lotions to suldue inflummation, rest, proper rore and feeding. will ensure recovery in the end. A bad dislocation, however, nsually laves the hor'se out of condition for anything but farm or slow work.

\section{Various Fractures.}

T'o fructure a limb (ompletely, so the log hangs loose, is of so serious a nature, in the hol'se, thint unless in the cise of at very valuable animal for breding purposes it had better be killed at once. In very many mes, however, one of the bones of the leg is fratured or split part way, though the horse may not exhibit extreme pain, may even travel upon it. Softening, however, sets in, and sometime after, in setting up in the stable, the hone grives way entirely. So the tibulit, as the smaller hone of the leg is rilled, maty be fractured. If there is lameness after fulling in harness, or from a blow, with tenderness, it is safo to treat for fracture.

What to do.-Place the horse in the slings and splinter the limb, tirst. having applied a sturch bandige, when it may be made to act. All that will be necessary further will be to feed and water regularly, keep the howels naturally open, reduce inflammation and soreness by the use of arnica, and trust to time for a eure. A month or six weeks ought to so trengthen the bone that the animal can eat grass, or be fed in a box stall until recovery is perfected.

\section{Various Distortions.}

A distortion arising from fracture or from any chronic difficulty eamnot be cured. In cise of severe recent strain of the ligannents of the neek, by which the head is thrown to one side, and held so, the neek should be brought straight, splintered, and held so until the ligaments recover their normal tone. Poll evil often leaves the animial with a stiff neek, produeing a distorted manner of holding the head. Distoctions are often produced by injuries of various kinds. These must he attended to during the cure of the superindueing eause. Distortions often oceur in young animals, as knuekling, turning the fetlocks from weakness, ete. The 
remedy is starch bandages and splints. Distortions of the tail by whioh it is eurved uwry, are remedied by wholly or purtially severing the tendons which are constricted or drawn. This, however, should never be attempted by one who does not understand the anatomy of the parts, else mischief may be done. As a rule, however, any distortion, except it be old and ehronic, may be cured loy taking proper measures, splintering, bandaging, and the use of fomentations where relaxation is necessary. These means the intelligence of the operator will readily suggest.

\section{Diseases of the Ear.}

Causes.-Injuries to the car are generally caused by brutal treatment. 'Twitehing them, nipping and pulling upon them with the blacksmith's plyers, and blows upon the hend with cudgels, sometimes result in troublesome bruises, uleers and tumors that elose the auditory passare.

Deafness may be an organic defeet, or it may be the effect of some disease which has disordered the head, and, by sympathy, the anditory nerve; and the sense of hearing is no doubt dulled hy old age, even when the horse may have been well used and reasonably free from disease; but it results in most cases from pulling the ears, eutting or rlipping either them or the surrounding skin to remedy supposed defects and from beating upon the head.

Sometimes seably or mangy eruptions make their appearance upon the tips of the ears and spread downward, eovering them entirely; but this is most probably the accompaniment of some general skin disease.

How to know it.-The euts, breaks in the skin, or sutures, that result from pulling, pinching, and twitohing are readily discernilste, as are allin the ulcers or suppurating sores in which they sometimes end. When the tendons which sustain the ear in its upright position are broken, there is no difficulty in perceiving it, as the enr drops down and flapss abont with the motions of the head and neek.

Rumning sores, similar to the poll-evil, sometimes result; but these raay be distinguished from that disease by their being contined more closely to the enr, either inside or out.

When denfness is suspected, un eximnination of the internal ear will be necessary ; and if the swollen purts or ulcers are not perceptible, some artifice must be resorted to to find. whether the hearing is netually destroyed. Deafness may be only temporary, as is sometimes the else with man, and the matter ean be decided only by making a series of examinations.

What to do.-A simple lneeration of the skin, and even of the curtiluge, if small, will require no special attention : but if it is so great that the 
by whind the tell. never be he parts, , exceptit lintering, cecessary. it.

reatment. ceksmith', result in i palssige. t of some a auditory age, evell from dis10 or elipdefectis,

e upon the ; but this ase.

that resulf as are also When the u, there is ibout with but these fined more al tur will tible, some ctually doos the ease a series of e cartilage. at that the edges do not come in contaet, they must be brought together and sewed, after which the trouble will soon be over.

But it occusionally happens that ulecration of the skin and cellular tissue and a rotting away of the cartilage sets in. 'This is past all remedy, and necessitates tlıe cutting away of the ear.

When there has been no laceration of the skin, an $n$ tumor is forming, apply camphorated corrosive sublimate, No. 2, occasionully, till it entirely subsides; but if matter seems already forming, aply May-ipple liniment, made hy taking one gallon of May-apple roots and boiling them until a thick syrup is formed; then, having removed the roots, udding an much lard as there is syrup, and stirring well togrether while the syrup is still boiling. This liniment will draw out the fever and bring the matter speedily to the surfuce.

Sometimes an absecss forms on the outside, which will need lancing in order to afford the most speedy relief. In this case, cut at the lower extremity of the rising. and let the laneet slant upward into it.

Deafness, unless simply a temporary result of some provailing disorder of the head or neck, is beyond the art of the veteriuary practitiouer. 


\section{C.HAP'TER XVI.}

\section{POISONING.}

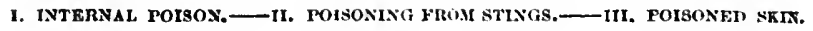

\section{Interna) Poisoning.}

The eases of internal poisoning are more frequent, espeeially with horses, than is generilly supposed. Among the most common are those arising from drastic or powerful doses, blindly given by the ignoram. either in disease, or from some effect sought to be produced upon the greneral health-to make the coat blooming, eause champing of the hit and frothing at the month, or to excite the animal spirits. Of these strong purgatives, diuretics and arsenic are the most common.

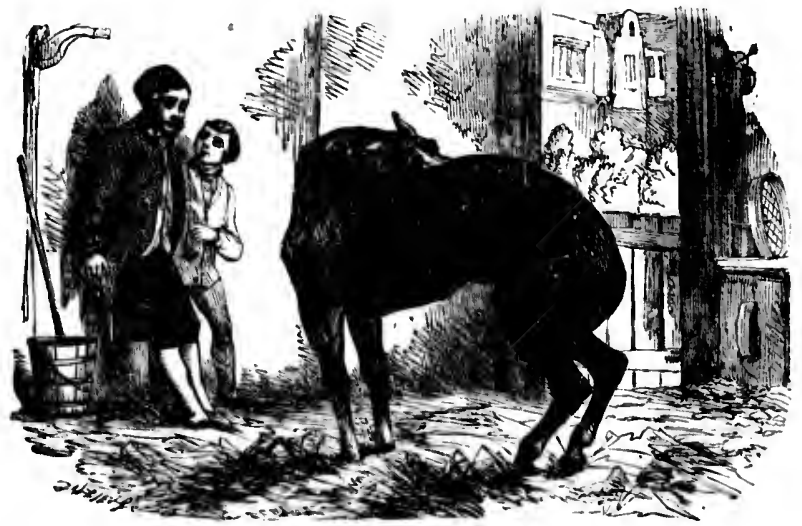

A HORgE SUFFELING FHOM DHASTIC HOJBON

Other causes are from eating poisonous plints, either in the hay or in the pasture, the ergot of rye and other grain; crgot sonetmes at tacks the 482 grasses-t

stlinmoniu

le mentio muriatic : irritant po dote to the ln the abs and follow

Alkalies ol washing :Ind follow

llorses t show alcol for disease

Forty gr this'st, quic times, irre Give full a earbonite

Corrosiv a horse.

hlooly diss and death. witel. Fit elm. Lith staring cos stilergeringer, of pulogitiv potash clail

Strychisi alwiys kill. and jerking rition, suce ly a slight mmimal puic oil. Follo the bownls ensues rive Tartar e lolser. 'l] colice, suliva Give stru. 
grasses-thus,smutty grain, eastor beans, hellebore or poke root, laurel, strumonium or Jumestown weed, und eured tobaceo, among plants, may be mentioned as common. Among minerals, sulphuric, nitric mud muriatic acid, and all the concentrated vegetable acids are caustic and irritant poisons. They are never taken unless forced down. The antidote to these is large doses of powdered chalk, whiting or lime water. In the absence of these give weak lye (white lye) until relief is obtained atud follow with a full dose of linseed oil.

Alkalies destroy the tissues. If quick lime, caustic potash, strong lyc or washing soda has been taken give vinegar and water to neutralize it. and follow with a dose of oil.

IIorses that are dosed with whisky to "give them strength" sometimes slow alcoholic poisoning. Never give it except as a stimulant as advised for disease.

Forty grains of arsenic will kill a horse. The symptoms are, intense thirst, quick, feeble pulse, great pain in the bowels, with purging sometimes, irregular breathing, faintness, paralysis, convulsions and dentb. Give full doses of oil, in which is mixed two, three or four spoonfuls of. carbonate of iron as the case may soem to demand.

Corrosive sublimate is a fatal poison. A quarter of an ounce will kill a horse. The symptoms are violent pain, intense thirst, effusion, anci booly discharges from the bowels, trembling, salivation, ending in stupor and death. Give the whites of a dozen eggs, stirred in a little warm water. Follow this with linseed tea, or hetter with mucilage of slippery dim. Litharge and sugar of lead are poisonous. The symptoms are sturing coat, arehed hack, a protruding tongue aind forming at the mouth. stargering, and sometimes dashing wildly to and fro. Give large doses of purgatives to be followed by from one to two ounces of iodide of potish daily for seven or eight days.

Stryehuno is a quick and potent poison. Eight to ten grains will always kill. The symptoms are violent trembling sueceeded by stiffnesand jerking of the limbs, spasms, rigicl limbs, arehed back, difficult respiration, suceceded by intervals of quict; but which are again bronght ou hy a slight noise or even a touch. Soon the animal dies. Keep the amimil puict and in a dark place, and give a quart of sweet oil or linseed oil. Follow with powdered chareoal mixed with thin mucilage. Move the howels by means of injections as quickly as possble, and if exhunstion ensues grive stimulants (whisky) freely.

Taltill emetic in doses of two to fom" ommees will sometimes kill a horse. The symptoms are, thirst, romiting and purging, staggering, colic, salivation, convulsions and paralysis.

Give strong tea, followed us soon a d yon ean get it, with a decoction 31 
of white oak bark. For the vomiting and purging, if they continue, give ounce doses of laudanum in a little water.

Poisoning from aloes, castor oil or croton beans, known by excessive bloody purging, and straining, cold ears and legs, hot, dry mouth, und bloating. Give two ounces of luudanum in a quart of linseed tea, and if necessary give a like dose by injection.

In poisoning from ergot or other disensed and injured foods, give full doses of linseed oil, both by the mouth and as injections, with stimulants afterwards; and tonics, say eight grains of quinine three times a diy during recovery.

For poisoning by white hellebore or Indian poke, give whisky in pint doses. The same means may be used in poisoning by laurel, followed by injections of salt and water, and also by linseed oil given as a purge. In case of poisoning by opium or laudanum, pour cold water on the head from a considerable height, and keep the animal in constant motion. For poisoning witlı J:mestown weed (jimson) known by faintness, giddiness, followed by convulsions, pirnlysis and stupor, give a quart of linseed oil with two ounces of laudanum. Give also an injection and subsequently stimulate with pint doses of whisky.

Tobacco poisoning is shown by purging, offensive dung, colic pains, weak pulse, prostration, convulsions and stupor. Give a purge of oil, and follow with pint doses of whisky in slippery elm or linseed tea.

\section{Poisoning from Stings.}

It is not infrequent that animals are badly stung, or bitten by venomous serpents or insects.

For the stings of insects, as wasps, hornets and bees, wash the stings repentedly with onion juice, or anmonia three parts to one part of oil. Washing with salt and water is also an excellent remedy.

In some portions of the West and especially in the South, gnats and certain species of venomous flies come in Summer. The remedy against this is to use petroleum. When these insects are very bad it is usual to

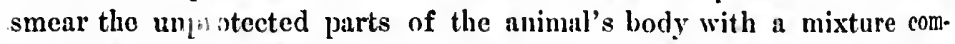
posed of one part of tar to two parts of lard. We prefer equal parts of petroleum, lard oil, and tar. Bicon drippings may be substituted for the lard oil or lard. For the stings of centipedes, scorpions, tarantulas and other venomous spiders, give the following:

No. 208.

1 Tea-spoonful of ammonia, 1 Pint of whisky, ti Pint of warm water.
Wash t therewith 1

Bites by wound sho a white he half this $q$ until relief as a first 0

There ar poisoning 0 apply some oak, poison golden seal ing wash as again. As ing of the 
Wash the bitten part with ammonia frequently, and keep it soaked therewith by means of a sponge.

Bites by venomous serpents are to be treated in the same way. The wound should be well cauterized when first discovered with an iron at a white heat. The doses of whisky we have given are full ones. One half this quantity of proof spirits given every hour with a little ammonia until relief is obtained will be proper, but in bad cases give the full dose as a first one, and always with water.

\section{Poisoned Skin.}

There are many weeds and plants that sometimes cause irritation and poisoning of the skin. The means of cure is to move the bowels and apply some soothing wash to the irritated parts. For injury from poison oak, poison ivy, hemlock, St. John's wort, etc., wash with a decoction of golden seal three times a day, oiling the surface at night. In the morning wash away the oil with soap and warm water, and use the golden seal again. A solution of sugar of lead is also a specific for vegetable poisoning of the skin. 


\section{CHAPTER XVII.}

\section{VETERINARY SURGERY.}

I. CASTRATION, —II. BLEEDING,-III. TRACREOTONY, - IV. PERIOSTEOTOMY, -V, XBC. ROTOMY. - VI. DIVISION OF THE TENDONS.

Ghaneral Remarks on Surgery.-Every person who has the care of .n stuck, or who has the care of horses, should understand some of tiv mpler means used in veterinury surgery. The castration of animals, for: : ace, is exceedingly easy and safe if a few simple rules are ob. in done in a bungling or improper manner, the chances, except in the ca $\therefore$ ery young animals, are agninst recovery. Bleeding is sometimes absolutely necessury to save life. When necessury it should be promptly performed. Tracheotomy also, as cutting into the windpipe is ealled, must sometimes be performed before in surgeon could possithy reach the animal. Periosteotomy, as operating upon the -membrame of the bones of the leg is called, had better be left to the veteriniry surgeon entirely; so again, neurotomy, the division of the nerve which supplies the hoof of the fore leg with sensation, had also better be left to the surgeon. In all clivision of tendons, fractured limbs and various disaliliities to which animals are subject; every horseman ought to know what to do. The diseases of animals have been pretty tholoughly treated of in this work. Some of the operations of surgery must therefore receive the attention their importance deserves.

\section{Castration.}

Calves, lambs and pigs should be eastrated when quite young, always before the sixth week of their life. Lambs and pigs should be eastrated at from one to two weeks old. Colts are not usually castrited until one year old, since thus they retain more of the natural vigor and style of the entire horse.
In the cords str one end $t$ so tight $t$

How to everythin the serotu testicle, in line dividdi near intace the testicl (dimp) witl with a wax then be all are to be $\mathrm{r}$

Another is after fre the artery for the pur let go, and beeding. strings to $h$ pincers, is

In cistrit leave the ee mation ens push up the ation with estublished Wash the 1 the work hi ence, and $n$

The best May to the the young

There are are hrain di lar vein is $t$ systerı, six. the blood il 
In the case of colts and old horses the structures are tough and the cords strong, consequently clamps (grooved sticks) so twined together at one end that when pressed together and tied firmly the cord will be held so tight that circulation is entirely stopped ure generully used.

How to do it.-Cast the colt or horse and fasten him securely, having everything rendy, a keen, round-pointed knife, clamps and cords. Seize the scrotum making a clean eut through the integuments and well into the testicle, and in a line so the eut shall be parallel to the median line, or line dividing the scrotum. Clen the envelop of the testicle, leaving it as neir intact as possible, as the envelop must remain with the animal. Draw the testicle out, put a clamp on the cord and seizing the other end of the (dimp with a pair of pincers press it strongly together, and tie seeurely with a waxed thread. So proceed with the other side. The horse may then be allowed to get up. In thirty-six to forty-eight hours, the sticks are to be removed by cutting the strings.

Another mode, and a most excellent one, especially in the case of colts, is after freeing the testicle of its envelop and exposing the cord, to seize the artery beyond where it is to be secured, with a pair of pincers made for the purpose, cut the cord and twist the artery seven or eight times; let go, and with its retractive force it will retain the twist and prevent all bleding. Another way is to tie the artery and allow the ends of the strings to hang out of the orifice. The plan by torsion, twisting by the pincers, is the plun to be preferred.

In castrating, do not be afraid to make an extensive cut, and do not leave the cord too long, else it may he strangulated, and fever and inflimation ensue. If this should unhuppily occur, enlarge the opening and push up the cord. If there is formation of matter, hasten it by fomentation with warm water. When a free exudation of cream-like matter is established, the animal will go on to recovery as granulation progresses. Wash the parts daily with tineture of aloes and myrrh. If, however, the work has been properly done, the animal will suffer little inconvenience, and nothing more need be done.

The best time for enstriting eolts and horses is from the middle of Iny to the first of Jume, in the North, and in the South about the time the young grass is a full bite.

\section{Bleeding.}

There are cases where bleeding must be resorted to to save life. These are brain disorders and some forms of inflanmatory disease. The jugular vein is the one to be bled from, and when the object is to deplete the syster, six, seven, and even eight quarts should be taken. Always eatch

the blood in a ressel, as it is neccessary to know how mueh we take. 
By pressing on the jugular vein along the neek, below the spot select. ed for the incision, it will soon rise up prominently. In bleeding, always make the incision in the line of the vein, never across it. Make the ineision lnrge, but never through both walls of the vein. When sufticient blood has been taken, raise the lips of the vein between the fingers, thrust a pin through and wind some thread dipped in the blood about it to hold it.

In staggers and diseases of the brain, it is usual to bleed in the roof of the mouth.

Whenever a horse is to be bled, it is better to blindfold him, since it prevents his starting, and thus causing a miss with the lancet or fleam in the hands of an inexpert person.

\section{Tracheotomy.}

The operation of traeheotony consists in cutting down into the windpipe, in all desperate eases where the animal is likely to suffocate for want of breath. In bad cases of strangles, or other obstruction to breathing, it is sometimes necessary to save the life of the animal, and there is no time to wait for a surgeon.

How to do it.-Have an nssistant hold the horse's head high, with the nose extended, so as to best streteh the skin of the neck. Then feeling along the neck for that part least covered with flesh, make a bold illcision with a sharp knife--one with a round point, and thin, being preferable. Make the incision about four inches long, and along the eentral line of the windpipe, and down to it. Then with a sharp-pointed knife pieree one of the upper exposed rings of the windpipe, eut downward along the central line, dividing two or three of them; introduce a tracheotony tube, which has a movable collar to prevent going in too far, and fasten its strings around the neck to hold it in place. The spout of a ten-kettle has been extemporized as a tube, and with good effect. This tube must be allowed to remain until the animal can breathe through the nostrils, when the wound may be sewn up and treated as any other clean cut.

\section{Periosteotomy.}

This is cutting down to the bone, and through the periosteun, the nervous vascular nembrane immediately investing the bone, and which in health has little or no sensibility, but which in disease of the bones is exceedingly sensitive. It is sonetimes performed in inflammation of the shank bone, when exudation has taken place between the membrane and bone, giving rise to thickening and the formatlon of bony matter. 
How to do it.-Pass an extremely narrow-blinded knifo througl the skin half an inch below the swelling, and curry the point carefully up orer it, dividing the periosteum or membrane. 'Then corer with a wet b:udage, or put in a seton.

A better wny is first to make a snip above and below the tumor with a pair of roweling scissors. Then with a blunt seton needle fixed in a hollow handle by means of a screw, and armed with a tupe knotted nt the end, force it in at the lower snip and curry it up and out at the otlicer. breaking down the cellular tissue of the tumor. A probe-pointed knife is then introduced slieing the tunor. The knife is withdrawn, and the needle, released from the handle, is passed in at one opening and out of the other, the end withdrawn from the needle and thus the seton is fixed. The operation should be performed by a surgeon. The first operation, simply cutting through the periosteum, is altogether the better course.

\section{v. Neurotomy.}

This is the division of the nerve of the hoof in navicular disease when other means fail. It will give relief from pain, but it is no cure, and generally the disease goes on advaneing uritil the animal becomes worthless. We should never advise the operation upon an animal with a weak hoof. The operation must of necessity be,performed by a competent surgeon who understands the anatomy of the foot and leg.

\section{Division of the Tendons.}

There are some disabilities, as bad eases of knuckling over, earrying the tail awry, or only the toe of the hind leg may be able to be put to the ground, from contraction of the perforans tendon. Relief is obtained by division of the tendons, but it should always be done under the advice of and by a competent surgeon and with proper instruments. 
CHAPTER XVIII.

\section{MISCELLANEOUS MINOR DISEASES}

I. PIGMENT TEMORS. II. RPITHRLIAL CAXCFR. III. DROPSY OF TnE LeNas. - IV

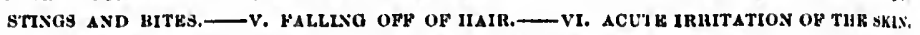
VII. HARDENING OF THE SKIX.—_ VIII. KXOSTOSIS OF THE LOWEIS JAW.—_IX, SHELL. INA BY PRESSUKE OF THE BRIDLE.-X. BORE NOSK. - XI. ROARING, OK IIIGH-BLOK. ING. - XIR. WIND-GALLS. - - XIII. RUPTURE OF TIL HAMSTRINO. — XIV. INTKRXAL

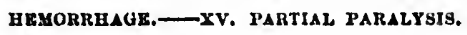

\section{Black Pigment Tumors.}

Those black pigment tumors known by the learned name of Melanosis, and which are so common in gray and white horses, attacking the bare parts of the skin, as the anus, the vulvis, the sheath, the udder, the lips, the eye-litis, ete., are ocetsionally cancerous, but for the most part quite harmless. If they ate deemed objectionable, as disfiguring the animal, remove then with the knife.

\section{Epithelial Cancer.}

This is a nipple-like eaneer, which sometimes appears on the lips of horses. It should be promptly removed with the knife, after which the part should be burned over with lunar caustie.

\section{Dropsy of the Lungs.}

This results from valvular and other diseases of the heart. When the ear is placed to the ehest, and the horse struck on the other side with the open palm, the sound heard is nearly the same as that heard in pneumonia ; but it may be distinguished from pneumonia by the entire absence of fever which characterizes lung dropsy. It is usually beyond medieal reach, as the diseased heart, its original eause, is generally incurable. 490
So trentr cun be re

Hornet: the'll seris following Solution 0 witter); 1 solved; ol

Cases itI of bees. will be suf with lime ble, use a in equall p:l To plueve balk of the bites of bu cover the 1 ) -tiro piart

1.or' that learned ter falling off the animal the state no

$$
\text { so }
$$

Mix, and

For that which som solution of borse is esp $\mathrm{N}_{0}$ 
To trentment, in addition to that already prescribed for heart disease, ('un be recoummended.

\section{Stings and Bites.}

Hornets, wasps and bees often attack horses, and sometimes cause them serious injuries. 'To relieve a cuse of this kind, wo use one of the following remedies, with which the coat must be thoroughly suturated : Solution of ammonin; weak curbolic acid wush, (1 ounce to a quart of water); 1 pint of lime water, in which 1 drachm of carbolic acid is dissolved; or oil of lobelin.

Cases are recorded of horses laving died in consequence of an uttnck of bees. In ordinary (aises, the preceding direction properly curried ont will be sufticient; but in more aggravated ones, sponge the whole body with lime water, and then smenr with linseed oil. If lime is not necessible, use a weak solution of soda. Spirits of turpentine and laudanum, in equal parts, will give relief.

To prevent the stings of gad-flies, make a strong infusion of the green bark of the elder, and wash the flunks before going out. To prevent the bites of buffalo-gnats, that are so troublesome along the lower Mississippi, pover the parts most likely to be attucked with a mixture of tar and lard -two parts of lurd to one of tar.

\section{v. Falling Off of Hair.}

1. or that unwholesome state of the skin and hair glands known by the leurned terms of humid exanthema and dry exinthema, that causes the falling off of the hair, the following is an excellent locul remedy when the animal is not under general treatment for some disease primary to the state now under consideration :

No. 209.

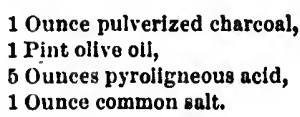

Jix, and rub upon the parts daily with a sponge or a soft rag.

\section{Acute Irritation of the skin.}

For that acute jrritation of the skin consequent upon clipping, wits which some horses suffer so much, wash twice a day carefully with a solution of soda ( 2 ounces of soda to a bucket-full of water). If the horse is especially feverish and sore, givo the following purgative :

No. 210.

2 Ounces tincture of aloes,

2 Drachms essence of peppermint.

When the with the pneumoe absence d needical incurable. 
In grooming, use a soft brush, and discurd the curry-comb until the soreness and tenderness are gone.

\section{Hardening of the Skin.}

For that hurdening of the skin which takes place in conserpuence of the pressure of some portion of the humess, from cutting the integunents ancl suh-collular tissne, from tho calkings of the shoes, from cauterized fungi, ete., use the acetute of cuntharides as an nppliention to the in. cluritions:

No. 211.

1 Onnce ncelate acld,

b Ouncea wulur,

1 Ounce pulverized cumbarides.

Mix, and let the mixture stand fourteon clays to soften. Then filter through linen or hlotting pener, and add one ounce of spirits of wine. Apply it oceasionully by menus of a hit of sponge. Or, use expal parts of oil of turpentine and olive oil applied in the samo way.

VIII. Exostosis of the Lowor Jaw.

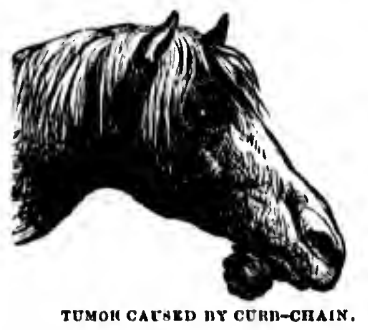

That unnatural enlargement or hony excrescence of the loiver jaw, known by the ahove name, is gencrally cansed by a tight curb-chatin used with a curb-bit of such lereriage an to enable the rider to inflict injury by violent jerking. Tho : w-hone is bruised, and soom enlarges. " injured portion must exfoliate, or scale ; ie presence of this unnaturnl substmec under the flesh and tendons gives rise to a foul ulcer, unless steps are taken to give relief while the hurt is comparatively recent.

Nature makes a constunt effort to heal, however, and unless tho tumor is irritated by passing particles of hone, it partiatly heals, so that an ol. stacle is interposed from time to time to the escape of the scales; and in this way in unnatural bony structure is formed and matured hefore the bony tumor is entirely healed. To prevent this, open with a keen kuife, as soon as the bone is found to be injured, and keep the wound open by using the elastic syringe and warm water, until the discharge has assumed an offensive odor-then syringe into it severnl times daily, this solution:

No. 212.
1 Scruple chloride of zinc,

4 Drachms essence of anlse seed, 1 Pint water.
If take

without d

When

skillful ve

These, 1 nectsional or rublinge lelow and recent, ren (No. 2) แI 'l'his must luring trea He suture tI

If the to luarned aw land to the siuple cor:a

The nose chinges, frr ertaking nen poison the impunity. it to herom in which eq effect a cul rahbed in at

This is w: simply be $t$ the shan'p but a more glottidis. precedes w atrophy or dilate the lis Thick wil 
cen filter of wine. ail parts

lony ex'n by the y u light such lerlict iujury a is bruised portion resence of f flesh and yive relief

the tumor hat an ol. $\mathrm{es}$; and in before the een kuife, d open by is assumed solution:
If taken in time, and treated in this way, the healing may tako place without deformity.

When once the bony excrescence lans estublished itself, no one hut a skillful veterinnry surgeon should bo entrusted with its removul.

\section{Swellings by Prossure of tho Bridlo.}

These, as the designution indicates, mro swellings, sometimes sores, and orensionally, when of old stunding, cullous lumps, mude by the pressure or rubhing of the bridle upon that littlo prominence on the neck just hew and lunck of the root of the eur. If tho swelling is simple und recent, renove hy suturnting it with the cumblornted corrosive sublinato (No. 2) mnd drying in with in loot flut iron, held close without touching. I'lis must he uttended to once a dity, and the bridle must be kept off luring treatment. If there is a sore without fungous growth (joroul flesh) the smme trentment will be found effective.

If tho tumor is of old stming and fungous, the proucl flesh must bo burned awny with lunar enustic. If it is old mul horny, resort must be had to the knife, ufter which the wound nny be healed hy a dressing of simple cerate, or of any of the unctuous oils.

\section{Bore Noso.}

The nose sometimes becomes sore from long-continued purulent discharges, from uny irrituting substunce introllued, but genernlly fiolı gritzing near some irrituting weed or vine. Jumestown weed will oftell poison the uoses of hores, yet the lenves, buds and pods are eaten with impunity. So-called "sneeze weed" will also irritute the nose and couse it to become sore. As a rule rubbing the nose with mercurial ointment in which equal parts of sulphur and lard hus been intinntely mixed will effect a cure. Apply with a mop, if out of rench of the hand, to be rabbed in as well as muy be possible.

\section{Roaring and High-blowing.}

This is when a horse emits any unnatural noise in truveling, whether he simply be thick winded, or emits the peculiar noise when hurd urged, or the shan'p sound denominated whistling and piping, similar to roaring, but a more enfirmed type, ocensioned by a strong closing of the rinua glottidis. Whistlers are simply chronic or confirmed roarers, and roaring precedes whistling. Both impediments to Frenthing are produced by atrophy or wasting or degeneration of the muscles whose office it is to dilate the larynx.

Thick wind is from an influmed and thickened condition of the smaller 
and lower branches of the breathing tubes, whistling from a narrowing or constrietion of the windpipe. Roaring, again, is of two kinds, acute and chronic. The first is, in comparison with the chronic and contirmed state, light and trivial. Fortunately it is comparatively rare in the United States, but quite common in England, and essentially a disease of ligh or well-bred horses.

True high-blowing, as understood by English horsemen, is not considered a disease or impediment. There is no sound made during inspitition. The air is expelled during and after hard exertion, with force and a peculiar vibration of the nostrils, causing the sound.

Causes.-Any and all of these impediments are produced by various affections, and some of them, as thick wind and rouring, are considered by some as hereditary. Laryngitis, distemper, bronchitis, pneumonia, tumors, diseases of the nasal menbranes, and tight reining. Roiring and whistling nre decided unsoundness. So also should thick wind be coussidered, if the horse is to be used for any other than slow work.

How to know it.-One of the means used is to go into the stall, take the horse by the head, and make a motion as though to strike him across the side with a stick. The animal will probably spring towards the manger, and if a roarer, the peculiar grunt accompanying the habit will be made. Yet it must be admitted that some horses, under the impulse of sudden fear, will grunt. The best test is to put him to speed inore severe than usuul. If the trial is objected to, be sure there is something wrong, and be sure also that there are no strnps about the neck to prevent or ease the habit. In addition to the ordinary sound made by roarers, they often, indeed usually, have a loud, hard, sharp cough, between a cough and a roar. If occasioned by laryngitis, this cough will be indicative of the chronic stage of that disease. So a thick-winded horse will have a short, hard, dry cough, which he will give upon making any sudden movement, or upon being struck shurply ajon the al)domen.

What to do.--Remedies are of but little nvuil, except as palliatious. In slight cases, and during the earlier stages, swabbing the lurynx with a solution of nitrate of siiver has given relief. It is prepared by dissolving at the rate of ten grains of nitrnte of silver to each ounce of distilled water, and is applied by means of a small, soft sponge fixed on the end of a piece of whalebone, the sponge having a cord attached and longer than the handle, so as to be recovered if it comes off. Pads hatve been attuched to the nose-band of the bridle, so as to lie on and compress the false membrune of the nose. These have given relief if the horse is not required to make extra exertion. Firing or blistering about the region of the larynx has nlso been successfully used as a means of relief. 
When roarng is caused by paralysis of the muscles of the larynx, hypodermic injections of strychuine every two or three dinys in half grain doses has given relief.

Relief is also sometimes given by rubbing on daily, or once in two days, the following:

$$
\text { No. } 213 .
$$

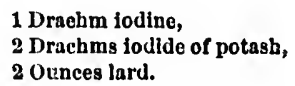

Nix at a heat little more than to melt the lard, by placing in a vessel of hot water.

In all of the diseases mentioned. good, easily-digested food should be given, and only sufficient water to satisfy the actual demands- of the system, and the animal should not be put to work within an hour of eating lis fcod.

\section{Thiok Wind.}

This may be alleviated, and sometimes cured, by giving the following hall once or twice a day for several days in succession, as the animal nuy seem to need it :

$$
\begin{aligned}
& \text { No. 214. } \\
& 1 \text { Drachm powdered camphor, } \\
& 1 \text { Drachm powdered niter, } \\
&
\end{aligned}
$$

Or' if preferred, to be given once a day, until five or six doses are taken, the following:

$$
\begin{aligned}
& 1 \text { Drachm powdered niter, } \\
& 1 \text { Drachin extract beliadonua. } \\
& \text { sgrains arsenic. }
\end{aligned}
$$

\section{Wind-galls.}

Causes.-Windgalls may arise either from strains, over exertion, or dropsy of the parts. As a rule they are elastic, round swellings on each side of the tendons, rarely becorning solid from coagulation of the lymph, unless as is occasionully the cnse, the strain is so seyere as to cause inflammation of the bone, ulccration and bony deposit. They do no injury whutever, and do not cause unsoundness.

What to do.-If the puffs, windgalls, are just appearing they may be scattered sometimes by a strong decoction of white oak bark and alum. They my be reduced by blistering from subsequent contraction of the skin; so the liquid lympl may be drawn out with a hypodermic syringe, after which a wet bundage should be applied over the part. 
If there is heat and tenderness in connection with the windgalls it must be treated with fomentations and a high-heeled shoe as recommended for such disabilities. As a rule simplo windgalls being so common, often appearing on colts, and doing no injury, had better not be meddled witl unless there is inflummution attending them.

\section{Rupture of the Hamstring.}

Not only the hamstring but other sinews are subject to rupture or even division. In this ease the parts should be brought together and held so by stareh bandnges or splints or both, when fibrous tissue will form and the ends will unito in three, four, or five weeks. If inflammation occurs it must be treated as heretofore advised.

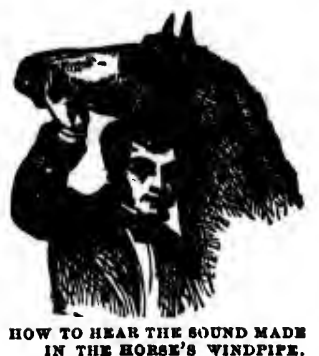

XIV, Broken Wind.

A horse with broken wind is in pretty much the same condition as a mm with the asthum. It is said often to occur suddenly, as after unusual exertion, or after severe work upon a full stomach. The facts are, these may luave aggravated and suddenly made apparent symptoms not noticed before. There is no eure, but much may be done to alleviate the distress and enable the animal to do ordinary slow work.

How to know it.-There is often, for a long time previous to a serere attack, more or less cough-a short dry hack, and occasioned by irritability of the larynx. The appetite is often ravenous and morbid, the thirst excessive. As the disenso progresses there is flatulence, a pendulous belly, a ragged cont, and a general dejected and unthrifty appearune.

In brenthing there will be $n$ three-fold effort. The inhalition will be quick, the expiration slow. Then the abdomen will rise as in an effert to drive forward the diaphragm, and thus empty the half expired lungs. The two last efforts seem lnborious, and the double effort is often only partially completed when the animal is again foreed to gasp for breath.

In the earlier stuges the peeuliar sound made is in the windpipe. The cut given will show the manner of listening to sounds for throat difficulties. Every horseman should accustom himself to recognize not only the sound indicative of healthy breathing but also those given out in various diseases of the thront. No horse with heaves or broken wind should be driven inmedintely after enting. The food should be sound, and water should be given only in small quantities.

Inter'ina some of $t$ being obs they can 1 not bleed traction o (ausing w eil be eut

Rupture exertion, a lungs maly ressels. the blood it is from specifie di bleeding $f$ clieck the ! mily be giv probably ti

If the b] nose, a stro 피 the nost drachm of

Chronic 1 in hemorrh ure, the mo rellow. usuilly lies diseaso pro pupils of $t$ attempted $t$

What to the bowels and as muel following :

No.

Mix, and 


\section{Internal Hemorrhage.}

Internal bleeding or hemorrhnge is rare unless made by puneture of some of the deep-seated blood vessels. The orifice leading to the surfnce being obscure and high, wiit of course oecusion internal bleeding. When they enn be got at the remedy is of course tying. Punctured wounds do not bleed much, the clot usually closing the orifice, assisted by the contraction of the vessel. In transverse or oblique clean euts of an animal causing wounds to the important arteries death must follow unless they can be cut down upon and tied.

Rupture of the blood vessels of the lungs sometimes occurs from over exertion, and is also common from the nose. Or hemorrhage of the lumgs may arise from any pulmontry conpluint involving the blood ressels. In this case it must bo determined. If the blood comes from both nostrils nud is frothy, it is from the lungs. If the horse has no specitie disease of the lungs, and is in full flesh, lleeding from the neck vein, a full stremm, mny check the blood. Digitalis in fifteen grnin doses may be given. It may give present relief, but probably there is no permanent cure.

If the bleeding is from the blood vessels of the nose, it strong solution of alum may be syringed

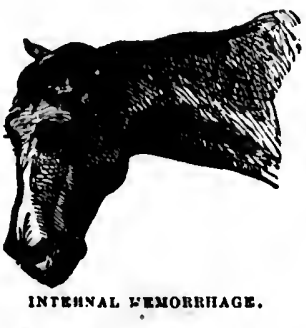
iㅣ the nostril. If this fails, pour half $n$ pint of boiling water on a drachm of mutico leaves, and when cool strain and injeet it up the nostril.

Chronic hepatitis, congestion and infiammation of the liver, often results in hemorrhage internally. The symptoms contirming this state of things ure, the mouth cold, nasul membranes pallid, the eyes ghastly, sometimes rellow. The horse will look for the seat of puin on the right side, and usually lies on the left side when down. The head is depressed. As the disenso progresses there is increased wenkness with staggering. The pupils of the eyes aro dilated; the sight is bad, and if the heal is attempted to be raised high the animal instantly shows signs of falling.

What to do.-Put the animal in a roomy stall, or loose box. Keep the howels regulated by grass and bran mashes uniy, with nutritious food and as much gentle exercise daily as the animal can take. Prepare the following :

No. 216. 2 Ounces iodide of potassium, 1 Quart ilquor potassa.

Mix, and give two table-spoonfuls twice a dny in a pint of water. 


\section{จ. Partial Paralyais.}

This is a disease principally confined to fust driven horses, or those used to extreme exertion. It is ulso occasioned by ergot in the hay or gruin and then is known as ergotism. An injury to the bruin may cause paralysis of the opposite side of the body. So paralysis of the face, body or limbs may arise from pressure on the brain. Paralysis of one side of the hody, called hemiphlegia, may result from disordered brain or spinal cord. So parnlysis of the fuce, ear, eyeiid, lip, tongue, laryux and tril may arise from local causes. A current of cold ai: continully striking a part, bald fitting bridles, collars, 0 : other parts of the huruess, Paralysis of the hind limbs is the most common form and may result from injury to the loin or back, from indigestion, from tumors, parasites, inflammation or softening of the spinal cord, from eating freshly ripened seeds of some of the grasses (the loliums) as darne!l, flax rye grass, and perennial rye gruss.

What to do.-The cause must first be found. Sec articles on inflan. mation, poisons, indigestion, etc.

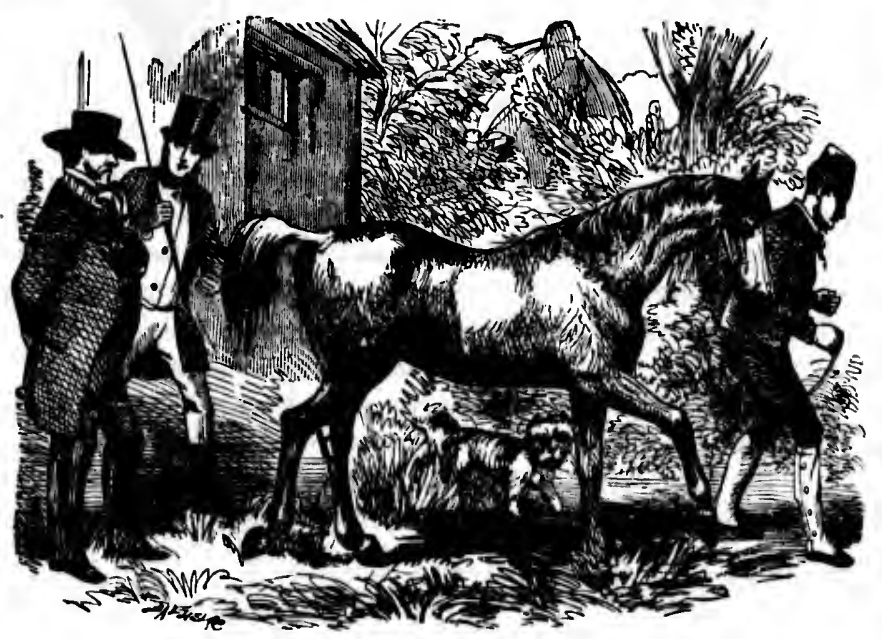

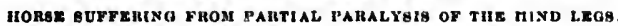

If the paralysis proceeds from an incurnble disease it is to be trented by cold water shocks and subsequent friction by rubbing. Among the best means is a current of electricity drily.

The following ball has resuited in relieving the difficulty when it was partial paralysis of the hind limbs:
Work thi daily, gradu at the end effects are 1 five or six $w$

Paralysis relief, but e strengthenin careful thut labors. Du must be giv inereasing $\mathrm{t}$ ) muscles are with the sma 
No. 217 .

\% Grain strychnine, 3. Grain lodine.

Work this up into a ball with powdered quassia and molasses and give daily, gradually increasi.. the strychnine according to its effects, so that at the end of three weeks one grain will be given daily, and, if good effects are produeed, a grain and a half may be given daily at the end of five or six weeks.

Paralysis is, however, past cure. Something may be done for present relief, but each recurring attack is mole and more severe. The most strengthening food should be given and the best of eare, always, being careful that the animal be not subject to cold drafts, or extraordiuary labors. During the recurrence of the attacks, absolute rest and quiet nust be given. In the giving of nerve stimulants, as strychnine, wher increasing the doses gradually, if twitching or slight cramps of the muscles are observed, eease giving for a few days and then begin again with the smallest dose. 
CHAPTER XIX.

MEDICINES.

What to Keep, How to Obtain, How to Prepare, and How to Give Them.

I. ALTBRATIVRS.-II. AN ESTHETICS.

THARTICS.— VI. CARMINATIVES.

III. ANTISEPTICS. - IV. ASTRINGKNTS.-V. $C_{A}$ IX. DIAPHORETICS. - X. DIURLTICS, - XI. DENIULCENTS. - XII. DISINFKCTANTS AND DEODORIZERS. - XII. EMETICS AND EXPECTORANTS. - XIV. NARCOTYCS, ANODYNES, AND BEDATIVKS. - XV. RELAXANTS.—X XVI. STIMULANTS. - XVII. TONICS. - XVIII. VERMIFUGES. —XIX. IMPORTANCE OF SYMPTOMS.—XX. DISSECTION. - XXI. SURGICAł AND OTHER INSTRUMENTS.— - XXII. MEDICINES TO BE KEPT.—XXIII. DOSRS.

It is not necessary that every farmer should keep a large quantity of medicines on hand. A few simples will suffice, except in the case of those who, having " large stock of animals, require medicines to meet cases apt to arise. The great point we lave insisted on, and here reiterate, is good cure and nttention, in henlth, and good nursing in siekness, as being most important in the care of farm animals. The day has past for bleeding and purging for every ill that even horse flesh is heir to. Good nursing, attention to the general health, and to symptoms, with the prescriptions we have given, will enable any one to carry an animal through an ordinary sickness.

Every person who has carefully studied this work will see the necessity of keeping some medicines on hind, since there is no reason why, with the aid of what we have presented, he may not be able to treat nine in ten of the disenses to which farm animals are subject, and without the aid of a professed veterinary surgeon. The very full glossary which will he found as a part of this work, should be consulted for medical terms used when the definition does not immediately follow the use of the term. In naming the medicines and their effects in this chapter we shall give definitions that may be found in the glossary, since in the division of the subject of medicines it seems proper that we should follow the rule adopted of defining the meaning of terms in the body of the work. The operations of medicine may be defined as follows:

\section{Alteratives.}

Medicines acting generally and continually on the system, especially on the blood and glandular system. Among the alteratives are, antimony, 500 piter, sul sulphite, c Antimo Given in $\mathrm{c}$ Ginger.

Calomel mereury, drachms ex in obstinnt

Arsenic. direction Fowler's sc best form $i$

Iodine.-

Iodile o rheurnatisn sorption in

$B i-s u l p h i$ $1-2$ to 1 ous

These ren in destroyin that will be

Chlorofor lowing :

No.

Cast the sponge and $I$ it, since if nd pulse, and if horn to the sciousness is again from completed.

Sometimes istration, wit cold water on pair of bellor in natural ro 
niter, sulphur, ginger, calomel, arsenic, iodine, iodide of potassium, sulphite, or bi-sulphite of sodis.

Antimony.-Bluck sulphuret of antimony. Dose 1 to 2 drachms. Given in connection with sulphur, 1 to 2 ounces, and niter 4 to 6 drachms. Ginger.-Given as an alterative only in connection with other medieines.

Calomel.-Give in broken doses, say 1 seruple. Another form of mercury, sulphuret, give 3 drachms once a diny in connection with 4 drachms cream of tartar in a pint of water. This has been recommended in obstinnte cases of surfeit, und other affections of the skin.

Arsenic.-Dose 5 to 10 griains daily. It should only be used under the direction of a veterinurian. Its action is principally on the nerves. Fowler's solution of arsenic contains 4 grains to the ounce. It is the best form in which to administer the mineral.

Iodine.-As an alterative give 10 to 20 grains.

Iodide of potassium.-Dose 1-2 to 1 drachm. Valuable in chronic rheumatism, chronic cough, scrofulous enlargements, and to cause absorption in plcurisy, and inflammation of the lungs.

Bi-sulphite of soda.-This must not be confounded with sulphate. Dose 1.2 to 1 ounce relieves tymphany.

\section{Anæsthetics.}

These remedies benumb the senses, relieve pain, and are used largely in destroying sensation in performing prineipal surgieal operations. All that will be necessary to notice are :

Chloroform and Ether. The best and safest preparation is the following:

No. 218.

1 Ounce alcohol,

2 Ounces chloroform.

3 Ounces ether.

Cast the animal to be operated upon; pour a table-spoonful on a sponge and hold to the nostrils so that the animal can take some air with it, since if not mixed with air, it is fatal to life. Keep the fingers on the pulse, and if it censes, or internits decidedly, discontinue, and hold hartshorn to the nose, and commence agiin more lightly. So soon as unconseiousness is produced, suspend the use of the incesthetic, and renew again from time to time, until the operation for which it is given is eompleted.

Sometimes the animal will continue low for some time after the administration, with failing pulse and irregular breathing. If so, pour pails of cold water on the body, and if necessary, gently inflate the lungs with a pair of bellows, at the same time pressing upon and releasing the ribs, as

in natural respiration. Also press pieces of ice into the rectum, or 
vagina, according to the sex, as an alditional menns of restoration, if necessary. As the natuml functions again act, clothe the hody and rub) dry. From two to four minntes should be suflicient to produce complete insensibility in either the horse or ox.

\section{Antiseptics.}

These are used to arrest mortitication and putrefaction. The principal agrents are chareoal, creosote, pyroligneous acid, sulphate of zine, and yeast. They should be applied directly to the parts affected.

\section{Astringents.}

These are agents used to stop or lessen discharges, either of the bowels, nose, blood vessels, kidney's or glands, and ure applied both internally and exterually. Among those usually employed, are, acetate of leard, alum, catechu, ergot, kino, opium, per sulphate of iron, tamm, the mineral acids, and gallie and tunie acids.

They should not bo used when there is eonsidertble inflummation; nor for diarrhea, in the begiming of $n$ dificulty, since this flux is often an effort of nature to relieve the body by natural means.

Acetate of lead.-Dose, 1 to 2 scruples. As a wash, use a saturated solution.

Alum.-Dose, 2 to 3 drachms ; useful in sore throat and dysentery. lin powder, used for stopping the flow of blood.

Catechu.-Dose, 2 to 5 drachms. Useful in diarrhoea.

Ergot.-Dose, 1-2 to 1 ounce. Checks bleeding from the lungs, nose, stomach and howels. As an astringent, for this purpose, it is better to give it by hypodernic injections, using ergotine in solution in five grain doses.

Fino.-Dose, 1-2 ounce to an ounce. Given in diarthœe.

Opium-Laulanum.-Dose, powdered opium, 2 drachms. Lauds. num, 2 to 4 ounces. It is a well known agent in relieving the spasms of colic, dysentery, lockjaw and other convulsive ailments. In diseases of the lungs and breathing tubes, if the respiration is short and quick, it should not be given. So, if there is much fever it should not be given until these symptoms abate.

Per sulphate of iron.-Dose, 1 to 2 drachms. Useful for arresting bleeding or hemorrhage.

Tannin.-Tannic acid is the best form. Dose, 10 to 20 grains. I powerful astringent in diarrhœa or mucus discharges.

\section{v. Catharties.}

These are medicines acting strongly and directly on the bowrels as a purge, in from 3 to 12 hours. Strong purgatives should not be given except it be necessary to thoroughly evacuate the bowels, and deplete the animal sys

linsecd oil,

Alotes, B

aloes, whic

croton

(oul-tij)ition

ish. Dose

Linseed

1 quatrt.

Polophyl

both purgat

is not so 11

excellent.

Sults.-S

gative effect

sulphate of 1

every three ?

These are medicines.

gillger, peppe

Black pepp)

is required gi

Carauay.infusion.

Claces.-D and given wan mucilige of a

Peppermin the heating he

These aro skin to redne sores on the on the surfite interual orgur anod in influe low fever; as washing it off when fever or in old rluronic 
animal system. Tho prineipul agents employed are aloes, eroton oil, linseed oil, podophyllin and snlts.

Aloes, Barbadoes.-This should always be used in preference to Cup? aloes, which is more griping. Dose 4 to 8 druchms.

Croton oil.-A powerful and sharp purgative, valuable in obstinate (omstipations. Applied extermally it is apt to irritate and produce blemish. Dose interuilly 20 drops.

Linseed oil.-A safe, and pretty sure, mild purge. Dose 1 pint to 1 inuiurt.

Pollophyllin.-This is the active principle of the May apple. It is both purgative and sedative. Dose 1 to 2 drachms. Its cffect on animals is not so marked as on man. In the eommencencint of ferers it is exiellent.

Salts.-Sulphate of soda or Glauber sults is generally used when purgative effects are required. The dose is 1 to 1 1-2 pounds. Epsom salts, sulphite of magnesia, dose 1 to 2 pounds, or 8 to 12 ounces, and repeated every three or four hours until an operation is had.

\section{vI. Carminatives.}

These are used in colic, grriping, ete., and are often given with griping medirines. The principal agents are black pepper, caraway sceas, cloves, ginger, peppernint, suge, etc.

Black pepper.-Dose 2 drichms. When a quick and powerful remedy is required give 2 drachms red (cayemne) pepper.

Carauray.-Dose 1-2 to 1 ounce of the seeds, as a powder, or as an infusion.

Clores.-Dose 1-2 to 1 ounce of powdered eloves steeped in hot water and given warm, or 30 to 60 drops of the oil of eloves given in thin mucilige of grum alrabic.

Peppermint (oil).-Dose 15 to 30 drops in mucilage. Sage or any of the heating herbs may he given as a tolerably strong infusion or tea.

\section{Counter Irritants.}

These are divided into classes: Rubefacients, which simply excite the skin to redness ; vesieants, which hlister, and suppurimts which produce sores on the surface. They are serviceable by setting up inflammation on the surfape near the seat of disease, in congestion and inflammation of internal organs; also of the lones, joints and tissues. Rubefacients are food in influenza, and other attacks of a gencral nature, where there is low fever; as, for instmee, rubbing a paste of mustard on the legs and washing it off in ten or fifteen minutes. Vesicants should not be nsed when ferer or inflammation is high, and suppurants are eliefly of value in old chronic complaints. 
Rubefacients.-Aleohol, anmonin, mustard, turpentine.

Vesicum/s._-Cantharides, scalding water, and a hot iron at 212 degrees, Fahrenheit.

Suppurants.-Croton oil, ointment of tartar emetic.

\section{Caustios.}

Agents which burn and destroy the flesh. Used to kill the virus in poisoned wounds, ent out proud flesh, destroy sloughs, and stimulnte old ulcers ; to produse henlthy action in fistulas, and remove warts and other excrescences. Among the best agents are butter of antimony, caustic potnsh, chloride of zinc, lunar cuustic (nitrate of silver), nitrate of mercury, nitrie acid, and the hot iron at a white heat. Chloride of zine and nitrite of silver come in pencil shnped sticks. Nitric acid must be used with care. It is powerful and intensely eating, causing extreme pain, but which soon ceases. It may be used by dipping a suitable slip of wood in the acid and applying. The hot iron is the most powerful caustic, as it is the most efficient. It however requires nerve and judgment to use it properly and efficiently.

\section{IX: Diaphoretics.}

These are medicines to cause sweating or to incrense the insensible perspiration, and thus relieve pressure on other organs. Acetate of anmonia in solution, Dovers powder, jpecac and cantharides are mainly employed; the animal being covered quite warm. Warm water is also useful, but steaming the most prompt of all.

Acetate of ammonia.-Solution. Dose, 2 to 3 ounces.

Dover's powders.-Dose, 3 drachns.

Ipecac.-Given in 2 to $3 \mathrm{draehm}$ doses in warm water, until the effect is produced. Not especially useful for horses.

Cantharides.-Dose, 4 to 5 grains.

\section{Diuretics.}

These are medicines used to act on the kidneys. Saltpeter, sweet spirits of niter, cream of tartar, turpentine and digitalis are principally used.

Saltpeter.-Dose, 6 to 8 drachms.

Sweet spirits of niter.-Dose, 1 to 2 ounces.

Cream of tartar.-Dose, 1 ounce.

Turpentine (Oil).-Dose, 1 to 2 ounces.

Digitalis.-Dose, 15 to 20 grains.

Both diureties and diaphoreties are similar in their action. If swenting is intended, it must be assisted with warmth and friction. If operation oul the intern used.

These are $\mathrm{g}$ fumed surfac the throat, sto ble conditions aralhic water, mallows muke soothing to th

The most vi bolic acid, ehlo etc. The che: solved to ench disinfectant, th

No. 219. -

Mix with a $\mathrm{g}$ Carbolic acid pure form, is it any wood, iron. and hanging up

The following No. 220.

Mix into ball pools.

Collins' disin two parts of $\mathrm{c}$ mass, and set in

The following No. 221.

Pour the oil ive disinfectant

The followin! To make it take 
on the internal organs is required, warmth and friction should not be used.

\section{Demulcents.}

These are gummy or glutinous substinces, used to soothe and eover inflamed surfuces, or those in an irritable condition; ins inflammation of the throat, stomach and bowels; in disenses of the kidnoys, or for irritahe conditions genermlly. Those most in use are: Jinseed tea, gum arabic water, slippery elm bark tea, sturch water aud olive oil. Marsh mullows mukes one of the most valuable agents known, being especially soothing to the bowels.

\section{Disinfectants and Deodorierss.}

The most valuable of these are, sulphate of iron, chloride of zine, carbolic ucid, chloride of lime, used for disinfecting and deodorizing drains, etc. The cheapest is a solution of sulphate of iron, a good handful dissolved to each bueket of water used. As an atmospheric fumigant and disinfectant, the following is cheap, and one of the best known :

$$
\begin{aligned}
& \text { No. 218. } \quad \text { Pound flowers of sulphur, } \\
& 2 \text { Pounds pine tur. }
\end{aligned}
$$

Mix with a gentle heat, saturate tow with it and burn without flame. Carbolic acid in weak solutions, or crude carbolic acid in its liquid, inpure form, ats it cones from the gats works, is valuable for brushing over any wood, iron, brick or stone work. Also valnable for wetting cloths, and hanging up to destroy diseatse germs, keep away flies, etc.

The following formulas will be found valuable disinfectants :

$$
\begin{aligned}
& \text { No. 220. } \\
& 1 \text { Part sulphate of zinc, } \\
& \text { 2 Parts suiphate of Iron. }
\end{aligned}
$$

Mix into balls of proper size and place in drains, sink-holes and cesspools.

Collins' disinfecting powder is made by adding 1 part of burnt alum to two parts of chloride of lime. Pour on water to thoroughly wet the mass, and set in shallow pans about the stable.

The following is a powerful disinfectunt

$$
\text { No. } 221 .
$$$$
2 \text { Pounds common salt, }
$$$$
1 \text { Pint oll of vitriol. }
$$

Pour the oil of vitriol gradually and slowly over the salt, and the active disinfectant, muriatic gas, will be evolved.

The following, known as chloralum, is not poisonous, and has no smell. To make it take, 
No. 222.

\author{
1 \% Ponndn chlorlde of aluminum, \\ 1 Gallon water. \\ Dissolve.
}

A most effectual, powerful and cheap disinfectant, but poisonous, if taken, is made as follows.

$$
\begin{aligned}
& \text { No. 223. } 8 \text { Ounces ehloride of zine, } \\
& 16 \text { Ounces sulphate of iron, } \\
& 1 \text { Gallon water. } \\
& \text { Dissolve. }
\end{aligned}
$$

A pint mixed in a gallon of water will be quite strong enough for use.

\section{Emotics and Expeotorants.}

What would act as an emetic on man, would be simply a nauseant with the horse. The lorse does not vomit, nuusemts act to loosen a cough, and to loosen the mueus in the air passiges, and thus facilitate its expul. sion. Nauseants ulso net as a substitute for the old practice of bleeding. Tnrtar emetic, blood root and sulphate of zine are among those usually enployed.

Tartar emetic.-Dose, 1 to 1 1-2 drachms, in connection with lobelia and saltpeter.

Blood root.-Dose, from 2 to 4 drachms of the powdered root.

Sulphate of zinc.-Dose, 1 to 2 drachms.

Tartar emetic.-This is often employed in connection with saltpeter and lobelia. Dose, tartar emetic 1 drachm; saltpeter 1 ounce; lobelia 1 drachm.

\section{Narcotics, Anodynes and Sedatives.}

These run one into the other, and are used to soothe pain, allay the irritability of the system, and quiet excessive nervous action. Nareotics quickly quiet the system, induce sleep, and if taken largely, produce death. When given simply to allay pain, they are ealled anodynes. The action of a sedative is to lower nervous foree, reduce the pulse and abate febrile symptoms, especially in the beginning of acute inflammation.

Narcotics.-Opium, or its preparations, laudanum and morphia, belladonna, tobaeco and Indian hemp.

Opium is generally given as a tincture, in the form of laudanum. Dose, 1 to 2 ounces.

Morphiu.-Dose, 3 to 5 grains.

Belludonna.-Dose, 2 ounces.

Indian hemp.-The dose of this drug 1-2 to 1 drachm.

Sedatives.-Aconite, tincture. Dose, 20 to $30 \mathrm{dm}$

Veratrum viride.-The dose of this is $1 \mathrm{scr}^{\circ}$ lnte
These c

be given :

These : gin ind : twe dose 3 ounces ounces ; c 1 to 2 oum a teis.

Stimula from exhit must not 1

Tonics s prove the ("onditions tonics cont healthy ani mot henetic rallyring. light doses. few ding, : The miner: more netir ete., thoug

These and For roul hest itgents drachins an sion, and $f_{1}$ hest direct

Tape veon fern, 1 oun of fontr hor I ounce.

In using giring it, at 
XV. Rolaxants.

These deprive the museles of their power. Of this class lobelin should be giren in doses of 1 to 2 drachims.

\section{Stimulants.}

Trese are, alcohol, and ure given in the form of brandy, whisky, rum, gin and nle. The latter when $m$ animal is exhunsted by hard driving. lue dose of brandy, whisky or gin is 3 to 6 ounces, and of nlcohol 1 to 3 ounces diluted with witer. Other stimulants are: ether, dose, 1 to 2 ounces ; carbonate of ammonia, dose, 2 to 4 dmolims ; turpentine, dose, 1 to 2 ounces; and ginger, dose, 1 ounce. The ginger to be given as a teis.

Stimulants are used when it is necessary to quiekly raise the animal from exhustion. In nervous exhaustion its effects are murked, but it must not he given in inflammation or fever.

\section{Tonios.}

Tonics sharpen the appetite, incrense tho nervons vigor, and thus improve the condition of the patient. Mnuy horsemen ure fond of giving (ondition powders, the main value of which lies in the nlterutives and tonic's contaned. In this they suppose that they ane heneficial to already healthy animals. Nothing could be farther from the truth. They ure wot heneficial unless the animal is out of condition and the system needs mallviug. 'To get the best effect from tonics, they should be given in liglit doses, and continued for a considerable time. Then intermit for a few duys, and if necessiry, commence agrain, or substitute mother tonic. The mineral tonic's, sulphite of iron, sulphate of epper and mrsenie are more active than the vegetable ton'es, Peruvian hark, gentim, quassia, ete., though often the two forms combined act with greater efficacy.

\section{Vermifuges.}

These are medicines supposed to be useful in expelling worms.

For round worms, common salt, to be licked at will, is one of the lest agents to expel them. Oil of turpentine 1 ounce. Tirtar emetic 2 drahms and sulphate of iron 2 drachms; give five or six days in succession, and follow hy a purge. Four to 6 drachms of aloes is one of the hest direct vermifuges.

Tape rorm.-Oil of turpentine 1 ounce doses; or root of male shield fern, 1 ounce of the extract. Give all vermifuges fisting, and at the end of four hours give a purge of aloes. For weak animals give areka nut 1 ounee.

In using a vermifuge it is always better to clear the bowels before giring it, and in ease the worms are in the intestines give injections as well 
as a purgative by the mouth. It should be remembered that vermifuges that destroy by mechanical irritation, as iron filings, pounded glass, etc., should never be given.

From the foregoing the action of the different classes of medicines will be learned. Some of the more common we have given as exumples. In the vast list of drugs used in medicines, nnd which are drawn alike from the animal, vegetable and mineral kingdoms, and some of them, the most valuable, being deadly poisons, must not be given in too large doses, the practitioner cannot be too careful in their use. The doses we have given in this chapter are froin medium to large. If there is any doult in using those, espccially the strong poisonous extracts or crystals use the smailer.

There are really but few medicines out of the large list that are of real and well known value in common practice. The druggist in preparing medicines, 'tses delicate scales and weighs aceurately. It is always better that they compound the preseriptions if possible; yet, $\mathrm{a} z$ it is not always convenient to seek the druggist, especially when a stock of medicines in ordinary use is kept, it is better to huve a pair of scales and a liquid measuring glass. We therefore append a table of weights and measures as used hy vetcrinarians :

\section{WFIGHTS AND MEASURES. \\ Apothecaries' Weight. \\ 20 gruins make 1 scruple, \\ 3 scruples inake 1 druchm, \\ 8 drachms mako 1 ounce, \\ 16 ounces make 1 ponnd.}

Wine Mear re.

60 minims, or Jrops make 1 drachm,

$8 \mathrm{~d}$ achms make 1 ounce,

16 ounces muke 1 pint,

2 plnts make 1 quart,

4 quarts muke 1 gallon.

Sufficient accuracy in fluid measure for anything not violent in its action, will be the following:

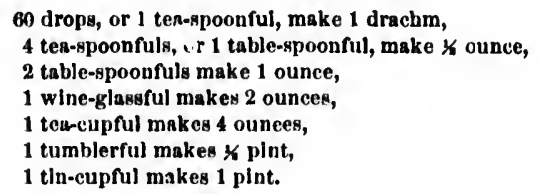

A handful of flixseed, or other seed, usually innocent in their nature, will weigh about 2 ounces; a landful of leaves of dried herhs will weigh about 1 ounce. 


\section{Importance of Symptoms.}

The importance of understanding symptoms in disease, not only of the horse, but of all furm stock, is generally underrated by farmers and stock men, and yet it is the key to ull remedial menns. Unfortunately, dunib animals cannot tell how they feel, und thus the practitioner must judge by outward signs, which, by the wity, are pretty ample to the c."eful observer. These are difficult to describe in print, yet they have been so described as fully as possiblo in the list and trentment of discases.

Every horse owher, and especially every stock-rniser, should eduente himself to understand symptoms in such diseases as he must necessarily have to deal with. This will not be found difficult, if the render will use the neans we have presented in this work. 'The pulse is one of the most important agents in this direction; through this, we may get a pretty accurate indicntion of the state of the system in relation to fever, plethorn of blood, or the reverse. It cunnot well be kescribed, und yet it is sona learned by use and observation. In the horse, the mouth is hot and dry in fever, and moist and cool in health. In health the nose of the ox is especially cool and moist, and in fever hot and dry. The full or smult pulse, depends upon an excessive quantity of blood in the vessels indieuting a full or a weak nutrition. A thready or wirey pulse is inclicative of a small quantity of blood in the vessels, rombined with in inereased or diminished contractibility of the henrt. A slugrgish or oppressed pulse will indicate unusual fulness of the vessels, the vitul powers of contractibility and sensibility not being incrensed, or, it may even be one or both of them being diminished. Among the internal eauses operating on the pulse are irritability, and nervousness. Outside causes are temperature, other atmospheric eauses, and manner of feeding. The stock man who will habitnute himself to feeling the pulse of his mimals, will soon come to understaul how slight causes will sometines affect this agent, and thus will soon learn to detect disease, often by this indication ulone. This and attention to the outward symptoms we have given in diseases enumerated, will soon enable him to dispense with the services of the practiced veterinarian, except in critical cases.

\section{Dissection.}

If a farmer would, when an unimal is sick, in addition to attendiug to studying the symptoms as they appear, tuke the trouble, in cuse it dies, to open it, with a view of studying the altered structure, knowing as he may, how they look in health, this would assist him grently in understanding disense generally ; for hy this mens he may find just whon and how the parts affected are changed. Ho will thus, also, como to understand the importance of grood care nut nursing in the prevention and elinination of dișease, more fully thun by uny other one means. 
XXI. Surgical and Other Instruments.

With all our care it is necessary to meet disease and accidents when they come, and to this end we must be provided at least with a few simples, and the means of arriving at quantities.

To this eud we have advised the purchuse of a pair of scales to weigh grnins, drachms, ounces and pounds; certain surgieal instruments, also, and a small store of the medieines such as are in common use.

In the horse stuble a balling iron should be kept. This is an iron riug through which the closed hand may be passed; on the top and bottom are two bars, which placed between the front of the jaws cnable the mouth to be kept open while the hand passes the ball of physic to the root of the tongue. Sponges of severul sizes should also be kept. A roomy nose-bag and an atomizer will be useful. The little India rubber bottle with which the wife sprays her plants, will answer very well in place of a better, for spraying the external surfaces.

Means for giving injections should be procured. This may be the regular horse or eattle syringe, though the pail and India rubber pipe, deseribed in another part of the volume, will be found simple and effectual.

A drenching horn or bottle is another implement that should not be neglected. A probang should always be kept. A troear will he found useful in ease where the stomach is to be punctured to permit the esenpe of gras. A knife will, however, answer in its place very well, if the blade be sufficiently long and pointed. An outfit larger or smaller aceording to the necessities of the stock owner, may be bought in any store where surgieal instruments are kept, and in fact in any of the larger drug stores of eities.

A convenient one which we have used contains: 1. A hlunt-pointed bistoury, an instrument for making incisions. When only one is to be used we recommend the slightly eurved form, with the sharp edge on the inside.

2. Thumb laneet. We are opposed to the old time fleam. It secms to have been iuvented for ignorant persons ; certainly none such should ever operate, even on an animal. A little judgment will soon enable the operitor to use the lancet properly and with effect, gauging the depth properly to which the puncture is to be made. It is better than the spring lancet.

3. A spring foreeps, most valuable in dressing wounds, catching arteries for tying, for removing foreign substances in wounds, and for a variety of other purposes.

4. An ancurismal needle-a long blunt needle. It can be used as a probe and for introducing small setons.
5. A silver sharp at the 0

6. A frog edged hook at hoofs, ete.

7. A pair o cising ragged

8. A struig sresses, castr: broad-bladed, have always nurserymen is 9. A setoll 10. A few gut. These 1 purpose, ind send them at $t$

The followi bottles, well stoppers. Th ties of these $t$

1. Aceticac ox, 2 drachms

2. Timcture ox, 30 to $40 \mathrm{~d}$

3. Alenhol. 3 to 6 ominees

4. Bartiando

5. Ahm . sheep, 1-2 to

6. 1 mmoni diuretic. $\mathrm{H}$

7. Carlion anti-acid, diun 1-2 to 1 drach

8. Anise se tive. Horse,

9. Armica drachm ; shee

10. Asafar 2 drachuns; 0 
5. A silver probe, for exploring wounds. It is blunt at one end and sharp at the other, and is indispensable.

6. A frog knife, a narrow straight blade, sharply curved into a strong: edget hook at the end, and used for puring and cleaning the frogs of the hoofs, etc.

7. A pair of curved scissors, for trimming the edges of wounds, excising ragged flesh, clipping the hair, and for other purposes.

8. A straight, broad scalpel (knife), used in dissecting, opening abseesses, castrating, and various other surgical operations. Any straight, broad-bladed, keen-edged knifo will do. In eastrating, however, we have always preferred a round-pointed blade, similar to that used by nurserymen in budding.

9. A seton needle for threading and introducing tapes or other setons.

10. A few surgical needles, white thread and silk, or better, thin catgut. These may all be carried in a neat moroce case made for the purpose, and can be afforded, wholesale, at ten dollars. (In fact we will send them at that price, delivered with this book.)

\section{Medicines to be Kept, and Doses.}

The following drugs will bo found handy. Keep everything in white bottles, well corked. Corrosive substances must have ground glass stoppers. The druggist, if so instructed, will arrange things. Quantities of these to be kept should be about ten doses each. 1 dose is :

1. Acetic acid-Antidote to acids, cooling astringent. Horse, $1 \mathrm{drachm}$; ox, 2 drachms; sheep, 1 scruple.

2. Tincture of aromite.-Sedative, diaphoretic. Horse, 20 to 30 drops : $0 x, 30$ to 40 drops: sheep, 3 to 5 drops.

3. Alcohol._Stimulant, diuretie, nurcotic. Horse, 1 to 3 ounces ; ox, 3 to 6 oumess ; sheep, 1-2 ounce. Iocally, cooling astringent.

4. Barbarloes aloes.-Purgative. Horse, 4 drachms.

5. Alum.-Astringent. Horse, 2 to 3 drachms; ox, 3 to 4 drachms ; sheep, 1-2 to 1 drachm.

6. Ammonia, liquid.-Diffusihle stimulant. anti-spasmodic, anti-acid, diurctic. Horse, 1-2 ounce : ox, 1-2 to 1 ounce; sheep, 1-2 to 1 drachm.

7. Carbonate of ammonia.-Diffusible stimulant, anti-spasmodic, nnti-acid, diuretic. Horse, 2 to 4 drachms; ox, 4 to 6 drachms; sheep, 1.2 to 1 drachm.

8. Anise sepd, caraway, cardamon, fennel seed.-Stomachic, carminative. Horse, 1 ounce; ox, 1 to 2 ounces; sheep, 2 to. 4 drachms.

9. Arnica tincture.-Stimulant, diuretic. Horse, 1 drachm; ox, 1 drachm ; sheep, 1 seruple.

10. Asafatida._Diffusible stimulant, carminative, vermifuge. Horse, 2 drachms; ox, 4 drachms; sheep, 1-2 to 1 drachm. 
11. Balsam of Peru.-Dtimulant, antispasmodic, expectorant. Horse, 1 ounce; ox, 1 to 1 1-2 ounces; sheep, 2 drachms.

12. Borax.-Nerve sedative, uterine stimulant. Horse, 2 to 6 drachms; ox, 1-2 to 1 ounce; sheep, 1-2 to 1 drachm.

13. Blackberry root. - istringent. Horse, 2 to 4 drachms; ox, 1-2 ounce; sheep, 2 seruples.

14. Camphor.-Antispasmodic. Horse, 1 to 2 druchms; $0 x, 2$ to 4 drachms; sheep, 1 scruple.

15. Carbolic acid.-Sedative, anodyne, astringent, antiseptic, disinfectant. Horse, 1-2 to 1 drachm; ox, 1 drachm; sheep, 10 drops.

16. Cherry bark, vild.-Expectorant. Horse, 1-2 ounce; sheep, 2 to 3 scruples.

17. Copaiva. - Stimulant, diuretic, expectorant. Horse, 2 to 4 drachms; ox, 3 to 4 drachms; sheep, 1-2 to 1 drachm.

18. Cream of tartar.-Diuretic. Horse, 1 ounce; sheep, 4 to 6 drachins. Laxative: horse, 5 ounces; ox, 5 to 8 ounces, sheep, 1 to 2 ounces.

19. Ergot.-Checks bleeding, parturient. Horse, 1-2 to 1 ounce; ox, 1 ounce; sheep, 1 to 2 druchms.

20. Iron, peroxide.-Tonic. Horse, 2 to 4 drachms ; ox, 4 drachms; sheep, 1 drachm. An antidote to arsenic.

21. Lime, chloride.-Checks tympany, disinfectant. Horse 2 to 4 drachms; sheep, 1 to 2 drachms.

22. Linseed oil.-Laxative. Horse, 1 to 2 pints; ox, 1 to 2 quarts; sheep, 1-2 pint.

23. Lobelia.-Sedative, antispasmodic, expectorant. Horse, 1 to 2 drachms; ox, 1 to 3 drachms; shecp, 15 grains; swine, 5 to 15 grains.

24. Mallow.-Demulcent. Give freely of cold infusion.

25. Mentha piperita (peppermint). -30 to 60 drops.

:26. Oak bark.-Astringent. Horse, 1 ource; ox, 2 to 4 ounces; sheep, 4 drachms.

27. Olive oil.-Laxative. Horse, 1 to 2 pints; ox, 2 to 3 pints; sheep, 3 to 6 ounces.

28. Opium.-Narcotic, sedative, anodyne, antispasmodic. Horse, 1-2 to 2 drachms ; ox, 2 to 4 drachms; sheep, 10 to 20 grains.

29. Opium, tincture laudanum.-Narcotic, sedative, anodyne, antispasmodic. Horse, 1 to 2 ounces : ox, 2 ounces; sheep, 2 to 3 drachms Of the powdered drag, give: horse, 1-2 to 2 drachms; $0 \mathrm{x}, 2$ to 4 drachns ; shrep, 10 to 20 grains.

30. Peppe:, Jlack.-Stomachic, stimulant. Horse, 2 drachms; ox, 3 drachms; sheep, 1 to 2 scruples.

31. Pumpkin seeds.-Vermifuge, tæniafuge. Horse, 1 pint. 
32. Rhubarb.-Laxative, tonic. Horse, 1 ounce; ox, 2 ounces ; sheep, 1 drachm.

33. Resin.-Diuretic. Horse, 4 to 6 drachms; ox, 1-2 to 1 ounce ; sheep, 2 to 4 drachums.

34. Soup.-Diuretic, antacid, laxative. Horse, 1 to 2 ounces; sheep, 2 to 6 diachms.

35. Silver nitrate (lunar caustic).-Nerve tonic. Horse, 5 grains ; $0 x, 5$ to 8 grains; sheep, 1 to 2 grains.

36. Sweet spirits of niter, Spirits of nitrous ether.-Stimulant, antispasmodic, diuretic, diaphoretic. Horse, 1 to 2 ounces; ox, 3 to 4 ounces; sheep, 3 to 6 drachms.

37. Tobacco.-Sedative, antispasmodic, vermifuge. Horse, 4 drachms ; ox, 4 to 6 drachms; sheep, 1 druchm.

38. Tar.-Expectorant, antiseptic. Horse, 1-2 to 1 ounce ; ox, 1-2 to 2 ounces: sheep, 1-2 ounce.

39. Turpentine oil.-Stimulant, antispasmodic, diuretic. Horse, 1 to 2 ounces; ox, 1 to 1 1-2 ounces; sheep, 1 to 2 drachms. Vermifuge : Horse, 2 ounces; ox, 2 to 3 ounces; sheep, 4 drachms.

40. Valerian.-Diffusible stimulant, antispasmodic, vernifuge. Horse, 2 ounces; ox, 2 to 4 ounces ; sheep, 1-2 ounce.

41. Wild cherry bark.-Expectorant. Horse, 1 ounce; ox, 1 1-2 ounces; sheep, 3 drachms.

42. Zinc, sulphate.-Astringent, tonic. Horse, 1 to 2 drachms; ox, 2 to 3 drachms; sheep, 15 to 30 grains.

\section{Graduating Doses.}

In the administration of medicines the following statement of ages and doses will be found valuable in deternining quantities. The doses mentioned in the preceding list being full ones :

A horse of 3 years, ox 2 years, sheep 1 1-2 years and swine 15 months old, should have a full dose.

A horse 15 months to 2 years; cattle 1 to 2 years, sheep 9 to 18 months, and swine 8 to 15 months, 1-2 of a full dose.

A horse 9 to 18 months, cattle 6 to 12 months, sheep 5 to 9 wonths and swine 6 to 8 months, requiro 1-4 of a full dose.

$A$ colt 5 to 9 months old, calves 3 to 6 months, lambs 3 to 5 , and pigs 3 to 6 months old, may have 1-8 of a full adult dose.

Colts 1 to 5 months old, calves 1 to 3 months, lnmbs 1 to 3 months, and pigs 1 to 3 months old, may have 1-16 of the dose.

Servous, excitable animals require less than others. The continued use of medicines renders their action slow and decreases their power. The influence of disense also ehecks or modities action. In diseases of the brain, und spinal cord, and in impaction of the stomach, double 
quantities must sometimes be given, while in low fevers one-hulf the usual (juantity ma produce evil, and sometimes prove fatal.

As a rule, anodynes, nurcoties, sedatives, stimulants mand anti-spasmodirs may be repented once in four hours until the required effect is produced.

Twice daily may be given as the rule for alterutives, refrigerants, tonics, diaphoreties and febrifuges.

Emeties should be repented every five or ten minutes and their aetion indueed by opening the moutin and irritating the thront with a fenther. If the animal will drink, give large cliaughts of slightly wam water. Emeties are not given to horses.

Purgatives shonld not be given the serond time until the first has had full time to operate. In the horse not hetore 36 hours; eattle and sheep 12 to 15 hours; swine in 7 to 10 hours.

Draughts of tepid water, or warm gruel assist the operation of purgatives.

A ball is not to be made round, but longer than it is wide and not larger than a walnut for horse or ox. It must be small enough so an animal may swallow it easily. Balls are made of drugs in powders mixed into a semi-solid stato with houey or molasses and linseed meal, and corered with oiled tissue piaper.

Drenches (liquid medicines) are made as infusions, with warm or cold water, or as decoctions with boiling water. Powdered substances not solvent in water are mixed with thick gruel or mucilage.

A ball is best given with the aid of a balling iron. This has been previously described. Put the iron between the front of the jaws, and place the ball well back on the tongue with the hand. Hold the head well up until swallowed. This may be aided by stroking the throat next the jaws.

Liquids are given from a horn or thick quart bottle with a pretty long neek, such as a champagne bottle. No liquid or irritating medicine should be given until sufficiently diluted with water so that it will not injure the mouth if held therein some minutes.

Oil of turpentine, eroton oil, and other strong irritating substances that will not mix with water, should be mixed with paln or olive oil, milk beaten with eggs, or it may be given in mueilage as the ease mar require.

Powerful agents, that do not irritute, aet promptly injected under the skin with a hypodermic syringe. A surgeon's advice should be used in administering them.

Injections are given with a horse syringe. There are patent injectors that pump in the liquid continuously. We have deseribed an implement that works well, by gravity, nnd is easily mude. Snall syringes are used for injecting abscesses. Also the hypodermic syringe for injecting under the skin.

Catheter. ther rounded the water wh introduced int of a syringe. and slowly pu

Drawing $k$, sniths; a thi used in euttin

Firing iron times used for Valuable in sl

Forceps.splinters, piec

Innives.-1 round-pointed. opening deep

Lancet.-T cet and the fld lancet by a sp make the inci:

Ligatures.should be usc other, pass it

Probes.-I

They are use

Rouel.-T 


\section{IMPLEMENTS AND APPARATUS.}

\section{What to Keep, and How to Use Them.}

Catheter.-This is a round gutta pereha tube, with one end open, the other rounded and near the end with two openings. Used to draw awny the water when the horse is unable to pass it naturally. They are also introduced into deep ulcers, and liquid injected through them by means of a syringe. In using the catheter, it should be well oiled and carefully and slowly pushed along the orifice or camal.

Drawing knife.-Frog knife. The knife in common use by blacksniths; a thin blade with a sharply-curved end fixed in a handle, and used in cutting into and paring the hoof.

Firing iron.-A heavy, blunt-edged blade fixed in a handle, and soinetimes used for blistering when the actual cautery is considered necessary. Valualle in skillful hands.

Forceps.-These are pincers with long jaws, and used for extracting splinters, pieces of bone, or for scizing arteries in order to tic them up.

Knives.-These should be always keen and should be both sharp and round-pointed. A heavy bistoury is ॥ loug, narrow-bladed knife for opening deep wounds and abseesses.

Lancet.-These are of three kinds: the thumb lancet, the spring lancet and the fleam. The thumb lnneet is guuged by the thumb, the spring lancet by a spring, and the fleam is struck by a hard wood stick. Always make the incision lengthwise of the vein.

Ligatures.-Cords for tying arteries, and in tying, a surgeon's knot should be used. Instend of passing the end of the cord once round the other, pass it twice around befere drawing tight. It will hold securely.

Probes.-These ure made of silver wire, with the ends slightly knobbed. They are useful in exploring wounds.

Rowel.-This is a ring of leather, an inch or so in diameter, the rim 33 
being about a qunrter of an inch wide. It is wrapped with flax or thread moisteued with turpentine, and pushed down into a pocket made in the skin, to induce a ruming sore. They are little used now; setons accomplishing the object fully.

Setons.-A cord or liguture of leather thrust in, under and out of the skin, and tied. It is sonked with turpentine or sucared with irritating compounds, and turned every day, the object being to promote and keep up a diseharge of pus, and reduce inflammation.

Seton needles.-These ure broad, curved blades, with a round shaft eighteen inches long, and with an eyc at the blunt end. Used for thrending setons of tupe, cord or lenther into wounds made. Needles for sewing up wounds are of several sizes, curved, squure needles.

Tents.-These are pledgets of tow, lint or other substances introduced unto wounds to cause them to form matter. They should be moistened with Venice turpentine.

Twitch.-A loop of leather or strong cord, fastened securely upon a stout handle two feet long. Used for holding refrnctory horses, or during surgical or other operations. Pass the upper lip tlirough the loop, and twist until sufficient force can be used to keep the animal still.

Hopples.-Ropes for easting a horse. They should be each twentyfive feet long. Have two strong straps of leather double, with a two inch seam between, and so they may be buckled tight to the fetlock. Fasten both ropes securely to the bottom of a collur placed on the horse's neek. Or if the rope is long enough, loop the middle to the collar; buckle a strap securely to each hind pastern, pass the ends of the rope through the rings, and back through the collar. One man nanages the .head to bring the horse down properly and easily, while assistants pull forcibly on the ropes ahead. A horse should never be cust except upon a thick, soft bed of straw or tan bark. If it is simply wished to hopple the horse, fasten the ends of the rope to the collar, and of such a length that the horse cannot kick.

Slings.-These are an apparatus to suspend a horse's weight in case of fracture, rheumatism, or otber diseases when the animal cannot bear full weight on the limbs. First a broad strip of leather or strong cunvas tro feet wide and six or seven feet long, stiffened at the ends by being sern around smooth billets of wood. To this a breeching is attached to pass around the buttocks, and others to and about the breast, to hold it securely. Loops must be fastened to the billets at the ends of the girdle of sufficient strength to bear the weight of the animal. Double blocks and pulleys are attached to these, suspended ait proper points, and thus the animal is lifted and suspended so as to bear much or little weight on his limbs. 


\section{PART III.}

\section{A T T L E;}

\section{HISTORY, BREEDS, CHARACTERISTICS}

AND MANAGEMENT. 



\section{CATTLE.}

\section{CHAPTER I.}

\section{NATURAL HIBTORY OF OATHLF.}

HEIR ORIGIN - EARLY DOMESTICATION - THE DIFTERENT KINDS AND THELR PECULIARITIES - MMPROVED BREKDS—DEVONS-SUSSEX - - - DORT HORNS-ALDERNEYS AYRSIIIRES - HOLSTEINS - POLLED CATTLE-KERRY COWS-THE CHEROKEE OR TEXaS CATTLE, BTC., BTC.

The native country of the genus Bos is not known, and the wild type bas long since passed away.

The Urus is regarded as the parent of domesticated cattle, and is described in its wild state, as an animal of enormous size, of great fierceness, and fable has thrown around it an air of mystery, as is common in all legends that have come down to us from the far past.

\section{Domestication of Cattle.}

The domestication of cattle is also a matter of conjecture.

Our earliest record comes from scripture. . Jubal, the son of Lamech, who lired in the lifetime of Adam, is recorded as being "the father of such as have cattle."

Noah certainly had cattle, and wherever the sons of Noah migrated, they carried eattle with them.

Cattle were worshipped by the earliest Egyptians, and among the ancient nations of Judea, they were, and still are, held in great veneration.

In the days of Abraham, eattle certainly were regularly bred, and in the days of Jacols we have an account of systematic breeding to color, and probably to type. 
In every civilized nation, the keeping of cattle forms smong the earliest productive industries recorded, und every Celtio nation has at one time or another ropresented them ns divinely given, or else, like the Hindoos, held them in the grentest veneration.

\section{Boientiflo Nomenolature.}

According to naturalists cattlo belong to the crass Mammalia; that is, having manmo or tents ; their maturn order is called ruminantia, from their hulit of ruminating, or ehewing the cud.

Their rmus is termed bovide, menning the ox kind. The anest is bos, the $\mathrm{ox}$; the horns growing, from the erest, projecting at first sideways, and porous or cellular inside, with a film of true hom eneasing the cellular bony strueture inside; the sun-cisus, which will form the subject of what we lave to sily, is termed bos taurus, or tho domesticnted ox.

Of these there aro mauy fumilies, or sub-fumilies; each distinetive breed being a fumily. Mixed breeds, grades, and crosses, muy be termed sub-families.

\section{Tho Teeth.}

Cattlo are distinguished as to their teeth by having eight lower incisore, and none upper; these are the cutting teeth. They have no eunine teeth or tusks, but have twenty-four molars or grinding tecth; six on ench side of the lower jaw, and six on each side of the upper jaw. The upper juw has no incisors; but the skin upon which the lower incisors meet in the upper juw is thickened, hard, and in aged animals almost horny. The teeth may be represe'nted as follow's; the figures ubove the line representing the upper, and the figures below the line representing the lower jaw :

$$
\begin{gathered}
\text { Cattle, lucisors, } \frac{0}{8} \text {, caniues, } \frac{0}{0} \text {, molars } \frac{6}{6} \frac{6}{6} . \\
\text { Total, } 32 \text { teeth. }
\end{gathered}
$$

We annex a cut of a section of the lower jaw showing the eight incisors, of a mature ox, or at the age of five years. Before and after this age the teeth vary very materially, as other portions of this section

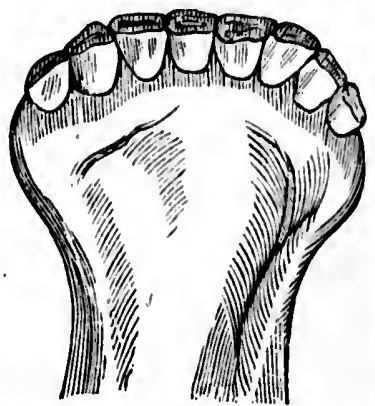

Teeti OY Ox at Age of Five Yrang.

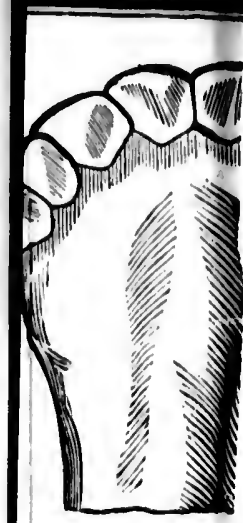

Fig. 4

at one month or al s or the full set.

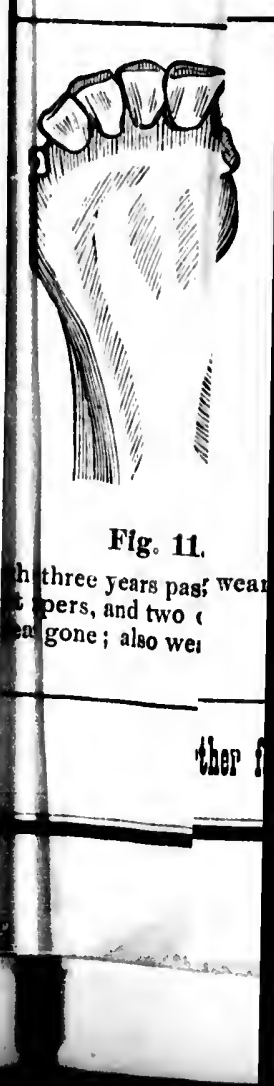




\section{IMIT:}

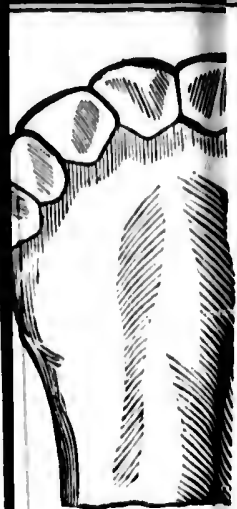

Fig. 4

at one month of abso $\beta$ or the full set.

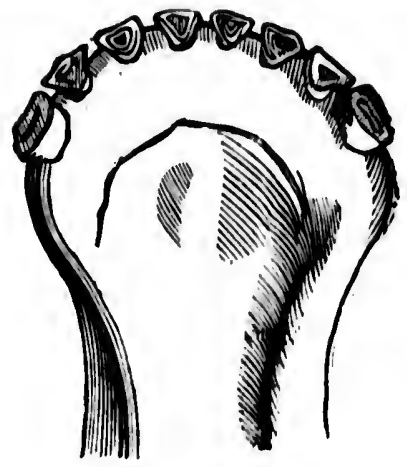

Fig. 7.

Teeth at twelve montho old, showing ab. sorption in all the nippers, except outside pair, and wear in these.

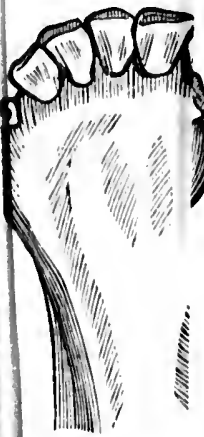

Fig. 11

h three years pas; wear and pers, and two fai gone; also wer 


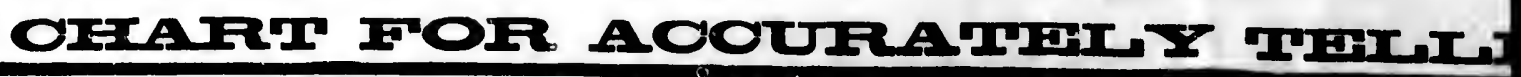

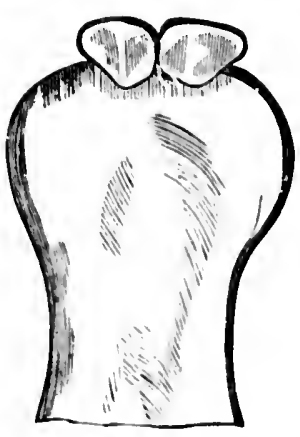

Fig. 1.

Teeth of Cali at Birth, showing the first two incisors, milk teeth.

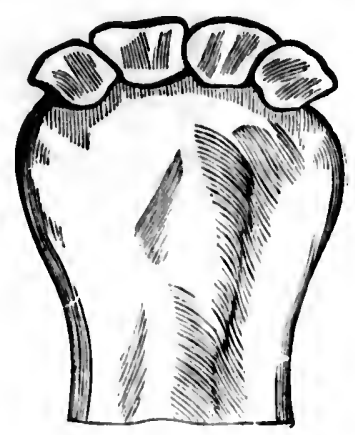

Fig. 2.

Teeth at two weeks old, showing four temporary inclsor?.

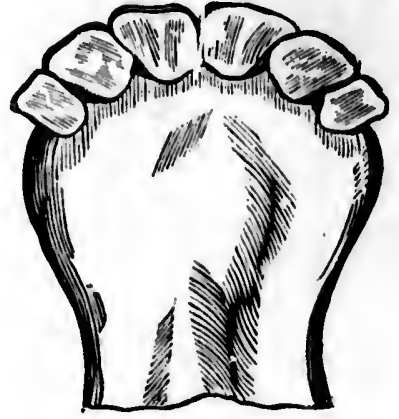

Fig. 3.

Teeth at three weeks old, showing sis Incisors.

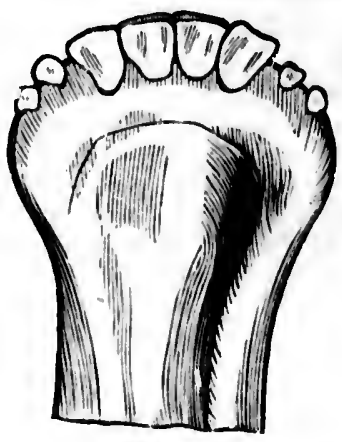

Fig. 10.

Teetk at two years old p.st, showing four rig. !.

Teeth at eightcen montins old, thowing two firs: permanent incisors $(1-1)$, nid next two pairs $(2-3$ and $3-3)$, growing and push. ing unwards towild the surface: alio $4-4$, 5-5 and 6-6) showing absorption. At $8-8$ )

is shown the alveili, or cells for the teol.
Pur temporary ones, atsorption nearly complete; also marks of wear on two first pairs.

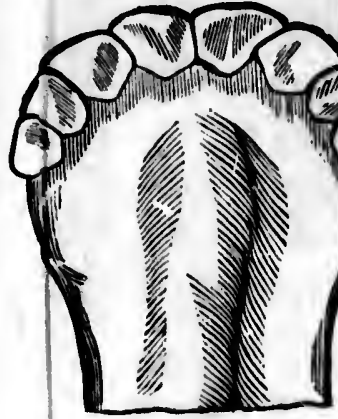

Fig. 4.

Teetr. at one month old, show incisora or the full set.

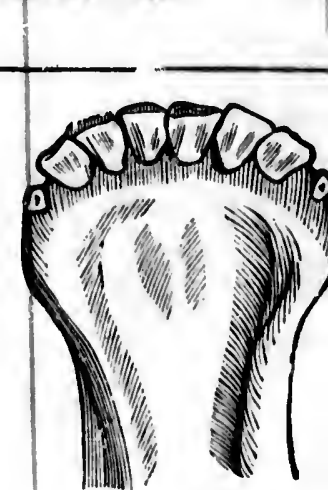

Fig. 11.

Teeth at three years nast, showln manent nippers, and two outslde te ones neark gone; also wear on tw pairs.

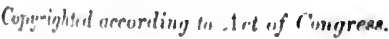




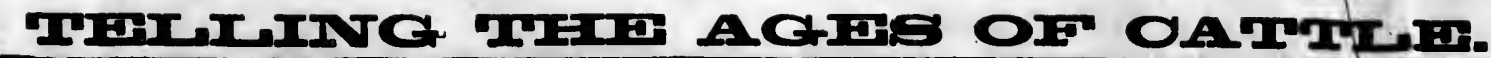

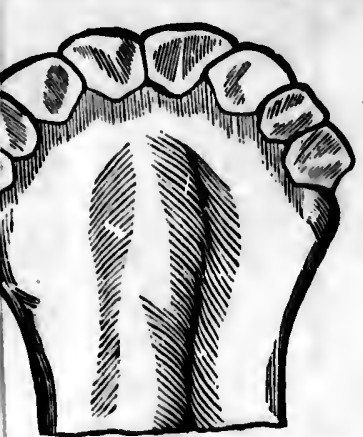

Fig. 4.

at one month old, showing elght or the full set.

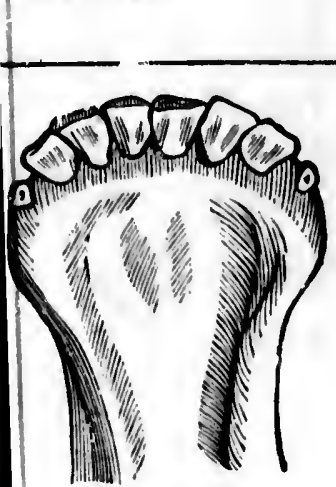

Fig. 11.

at three years past, showing six perippers, and two outslde temporary gone; alao wear on two central

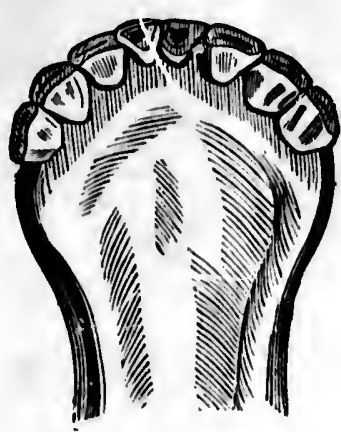

Iig. 5.

Teeth at six to eight months old, showing wear on first two, or central teeth.

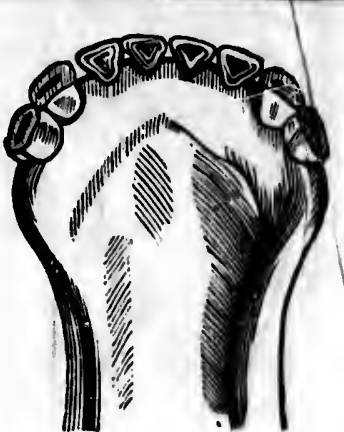

Fig. 6.

Teeth at ten months old, showing absorp. tion in first tro pairs of teeth, and wear of two outside pairs.

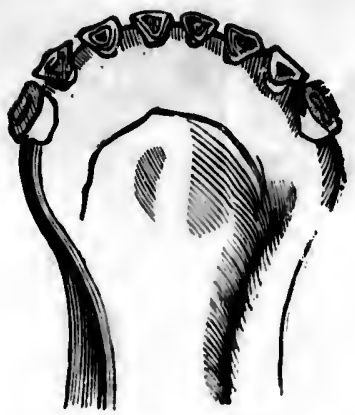

Fig. 7.

Teeth at twelve montho old, showing ab. orption in all the nippers, except outside pair, and wear in these.

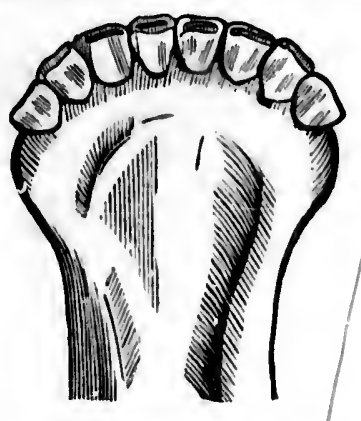

Fig. 12.

Teeth at four years past. shwing eight complete complement; also werr on all but outside teeth. pormanent inclsors - the full wouth - and

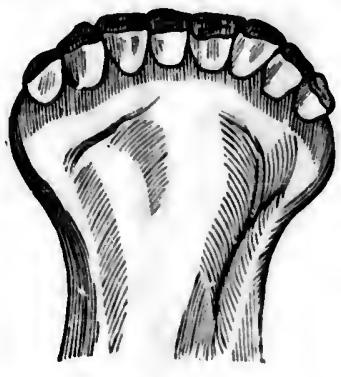

Fig. 18.

Teeth at five years past, showing wear and dark marks.

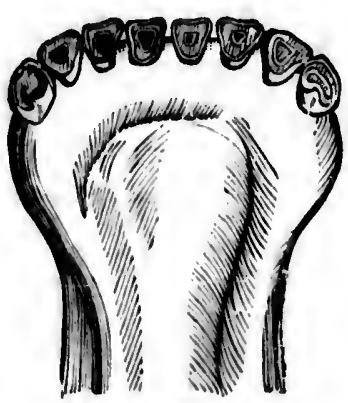

Fig. 14.

Teth at tei years old, showing permanent spack between them; and also sha $v$ from natual wear by use.

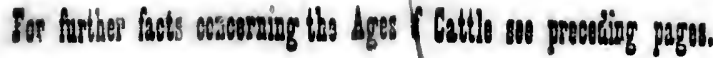


1320
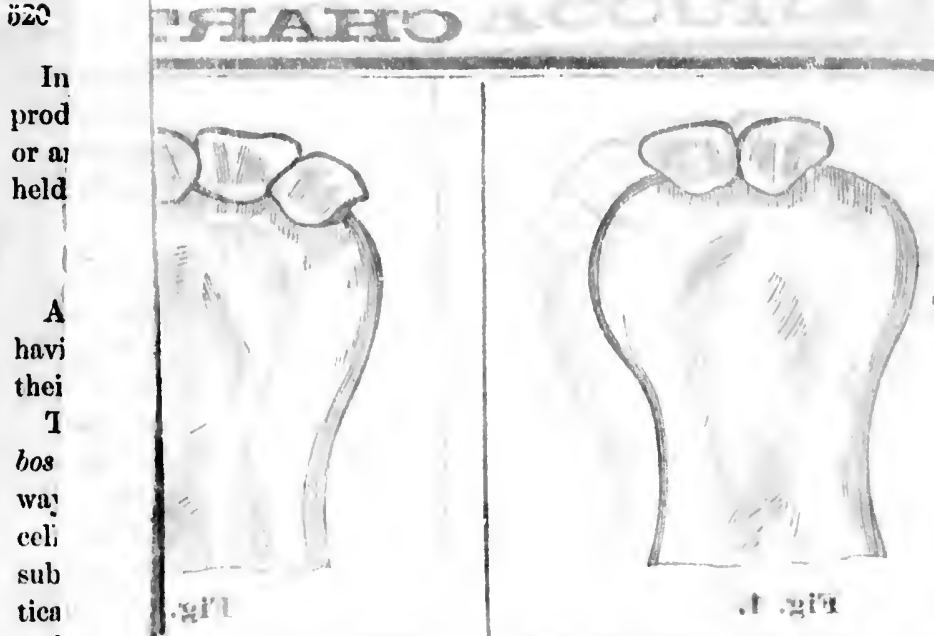

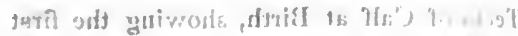

C
bre
sub

C Nuar ows the dysas?

C

and

teet

eacl

upp

sors

harc

The

the

upp.

resel

C、

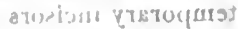

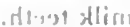
confined to but

The Devons retained their $p$ ity as to eolor, mueh so as the of the original

We a jaw 8 l ox, or and $a$ materi. show.
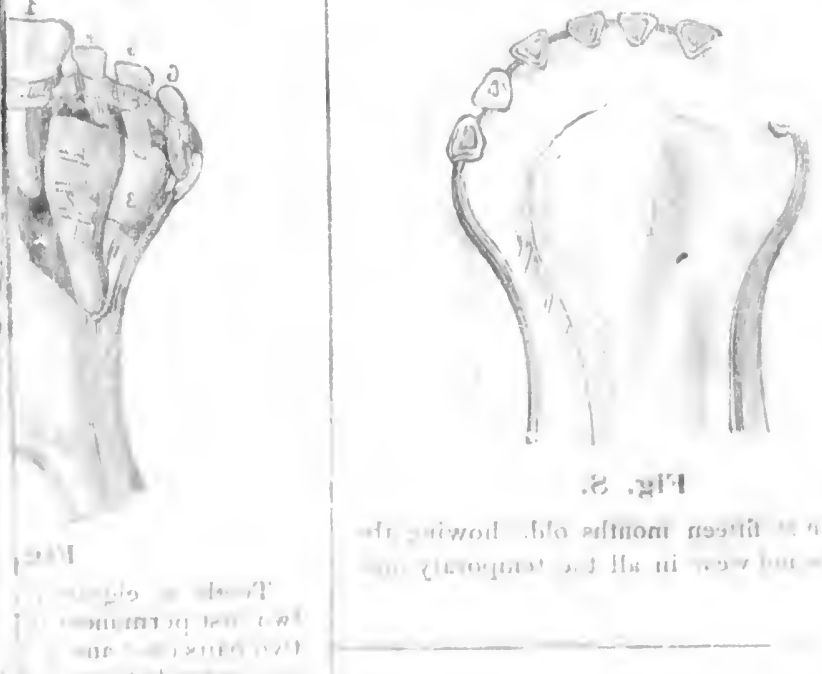
The annexed cut of section of the head of an ox will show the molars, or grinding teeth, and also the terminal bone of the upper jaw, corresponding to the lower . face jaw, and destitute of teeth.

Explanation. $-a-$ Molars or grinders. b-Superior maxillary bone-its - palatine process. c-Cells of the palatine bone. $d$-Anterior maxillary bone, destitute of incisor teeth.

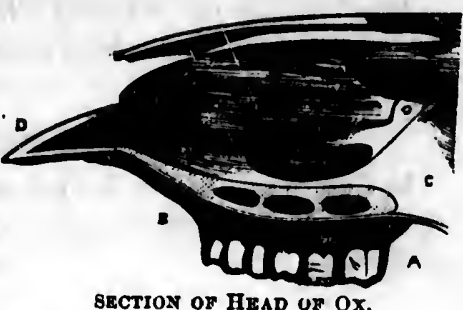

Breeds of Catîle.

The brceds of cattle which have acquired favor in the United States are confined to but few.

The Devons are the typical race of England, as ainong those that have retained their purity, through long generations, breeding with entire uniformily as to color, symmetry, horns, and other general characteristies, fully as much so as the Chillingham white cattle, which are regarded as descendants of the original or aboriginal cattle of the British Islands.

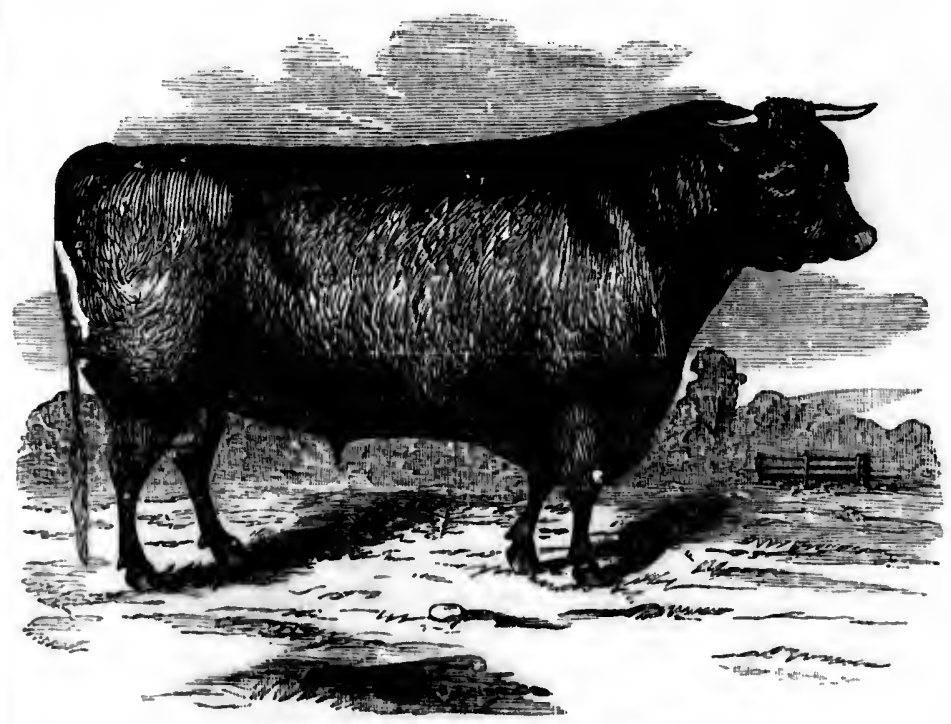

First Praze Devon Beli, "Wilsot."

Two Years Old.

The Property of Mr. George Rudd, Guclph, Ont. 
The foregoing; cut is a good illustration of a Devon bull as he appeared when but two years old. Such an animal may be regarded as a most admirable specimen.

\section{Claseifleation of Races.}

In England cattle are divided into beef and duiry cattlo. Beef cattle e again are divided into long-horns, middle-horns, short-horns, and polled or ho:mless cattle.

\section{Long-iIorns.}

Of the long-horns; the old Irish long-horn 3 showed a striking peculiarity, which was, that their horns turned directly downward.

In Craven, England, has long existed a breed of cattle peculiar in themselves, broad in the chine, quick. and easy to fatten, und noted for making excellent beef. .

Under the scientific breeding of Bakewell, a hundred years ago, and his inmediate successor, Leicester, long-horns acquired a wide celebrity. This was undoubtedly attained by breeding in-and-in. He was known to have done so to a remarkable degree:

With the death of Bakewell and his immediate successors, excessive delicacy of constitution began to tell, and they began to lose caste years ago, as a race.

They have.left their impress, however, and, most decidedly, I yon the whole family of long-horns. They became better feeders, better handlers, and mado better beef than before the infusion of this blood.

They have iong been superseded by the short-horn and the Herefords, and are only noticed here, as forming a part of the mixed blood of cattle, of the United States anit Canada.

We occasionally see by reversion, arimals among our so called nutive cattle, showing strong chas acteristies of Leicester, Hereford, Devon, the old Teeswater, the Dutch and polled cattle.

\section{Middle-Horns.}

Of the Middle-IIorns the only cattle valuable in the United States, are the Devons and the Herefords, bnth wonderful fumilies, in their muke up, and valuable whether for beef or working oxex.

In fuct the Devon is the best working ox in the world, and as beef maker's their fiesh is superior to that of any other breed, except the Scoteh, or West Highiland eattle.

Besides the Devons the other fanilies of tive Middle-Horns, are the
Sassex, Peml Highliurd catt for many gen tion.

Their princ to fatten whes Above, as s tion of a West

The celebrit and working $q$ bred, in North to distinguish rior cattle, eith

The Devons noted for their

It is only wi been made to $i$ than one hund to the improve fecders. The such high per. high caste entt uny other brec

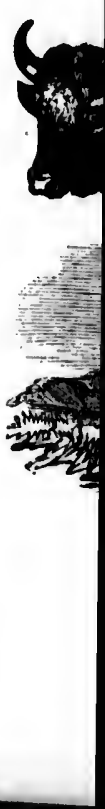


Sassex, Pombroke, Glamorgan, Angelsea, and, in Scotland, the West Highlind cattle, noted for the superiority of their flesh, and which have, for many generations, remained unchunged, or improved except by selection.

Their principal value, after all, is their extreme hardiness, and aptitude to futten where other animals would starve.

Above, as showing the characteristics of this breed, we give an illustrution of a West Highlund ox, in good feeding flesh.

\section{The Devons.}

The celebrity that the Devons long ago attained for their superior beef and working qualities, is wholly due to the fact that they bave long been bred, in North Devon, pure. Hence, they are often called North Devon, to distinguish them from the South Devons and the Sussex, both inferior cattle, either from a feeding or working standpoint.

The Devons are undoubtedly an original and puro race, and havo been noted for their high excellence for muny generations.

It is only within the last two hundred years that systematic efforts have beeu made to increase the excellence of English cattle, and it is not more than oue hundred und fifty years ago that Devon furmers were waked up to the improvement, that might bo made in these ligh strung, generous feeders. They have within the last seventy-five years been orought to such high perfection, that they do not suffer in comparison with other high easte cuttle, and they would certainly suffer by intermixture with any other breed.

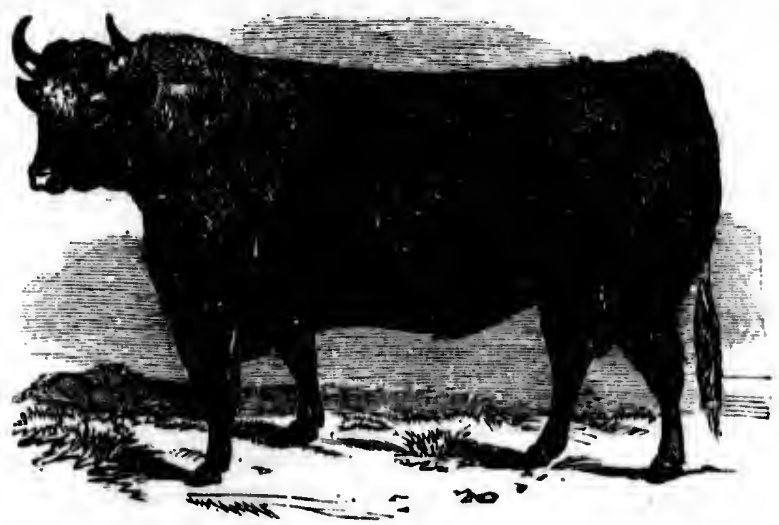

Thz Standard Devon Bult. 
Where Devons Thrivo.

They cannot compete with the Short-Horns and Herefords, on flush western pastures.

They lack size, and early maturity, but on hill, or broken pastures, and in climates too cold for these breeds, and especially in climates unsuitable to Short-Horns, they are the best eattle ever kuown.

On the previous page, as showing the extraordinary symmetry and style of this remarknble breed, we present a likeness of a Devon bull, remurkable for eminent charactoristies of the breed.

\section{Devon Cows.}

The bulls of this breed are inclined to be vicious as they get old. The cows are gentle, and if gently used, kind in the extreme. Both mules and femnles, however, are so high strung that thoy will not bear abuso. A brutal master they will fight, but if manged with a firm, yet gentle hund, they are the most fumiliur, as they ure the most intelligent, of hisued cuttle.

The cows give exceedingly rich milk; and many of them fair quantities.

The mules are suid to eross kindly with the Guernseys, and these make valuable dairy enttle.

There are however now so many excellent pure breeds of milker's that it would be futile to experiment with the cross, sinee it will surely redure the value of the animul either for work or beef.

As workers, milkers and beef makers eombined, for the anount of food taken, they have no superior, if they have their equal. As beef maker's alone, in the West, the Short Horns and Hereford are superior. As milkers the Jersey, the Holstein and Ayrshire take the palun. Is working enttle the Devons are superior to all known breeds.

The cut on the fo!lowing page is a good illustrution of a high caste Devon cow.

\section{Characteristics of the Devon Cow.}

This we give as follows :

There are few things more rearkable about the Devon cattle than the compurative smallness of the cow. The bull is a great deal less than the ox, and the cow snaller than the bull.

This is some disadvartuge, and the breeders aro aware of it: for, although it muy not be necessary to have a large bull, und especially as those of an extrnordinary size are seldom handsome in all their joints, sut somewhere or other present coarseness or deformity, it is almost impossible to 1 roomy cow.

Theso cows, projection of $t$ romy than a $\mathrm{c}$

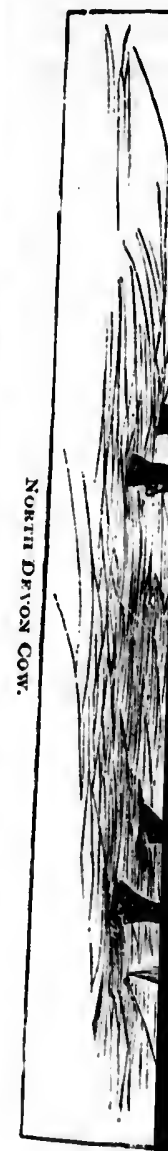

The cow is part gold-eolored circle of the ear.

The countenance 
impossible to procure largo and serviccable oxen except from a somewhat roomy cuw.

These cows, however, although small, possess that roundness and projection of the two or three lust ribs, which nuke them actually more roomy than a cureless examination of them would indicate.

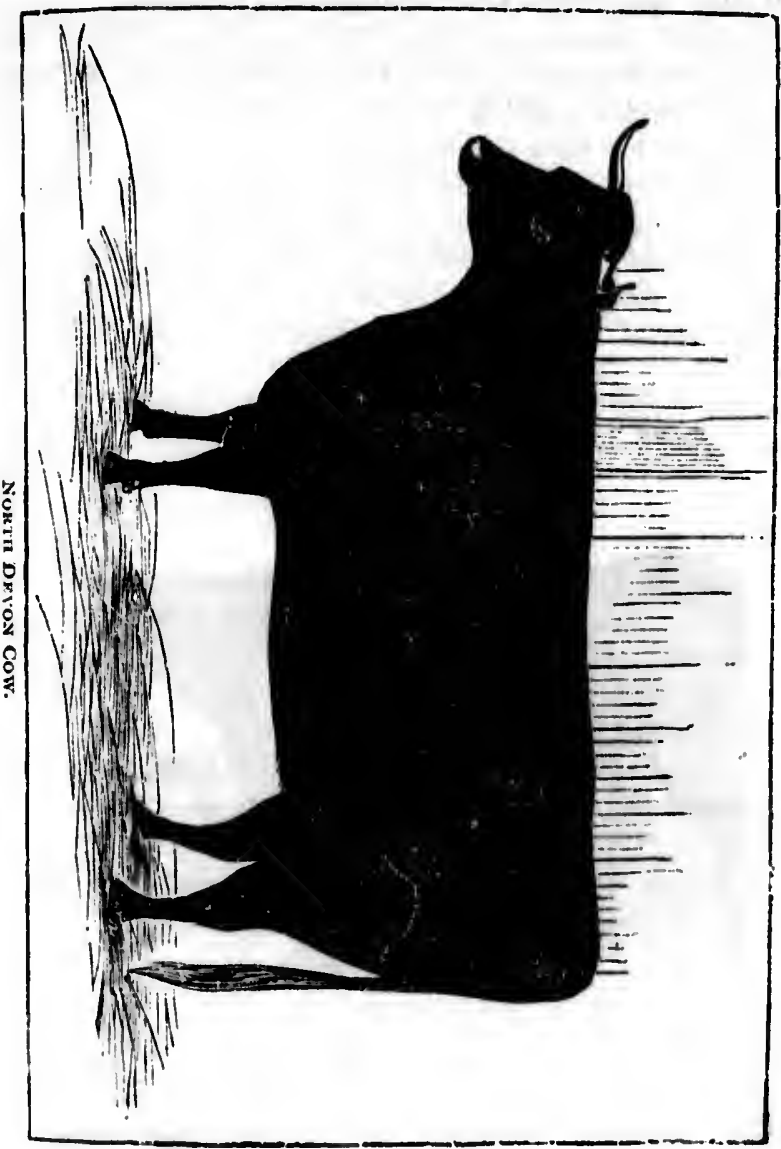

The eow is particularly distinguished for her full, round, elear eye, the gold-eolored circle around the cye, and the same color on the inside skin of the ear.

The countenance is checrful, and the muzzle orange or yellow. 
The jaws are free from thicknoss, and the throat from dewlap.

The back, the barrel, and the hind quarters differ from those of other breeds, having more of roundness and beauty, and being free from angles.

\section{Point of the Devons.}

Yountt, than whom none have written more intelligencly on domestie animals, describes the characteristics of tho breed as follows:

The more perfect specimens of the Devon breed are thus distinguished:

Tho horn of the bull ought to be neither too low nor too high, taperiug at the points, not too thick at the tip.

The eye should be clear, bright, und prominent, showing much of the white, and have around it a circle of dark orange color.

The forehead should be flat, indented, and small, for, by the smallness of the forehead, the purity of the breed is very much estimated.

The cheek should be small, and the muzzle fine; the noso must be of a clear yellow.

The nostril should be high and open; the hair curled about the head.

The neck should be thick, and that sometimes almost to a fuult.

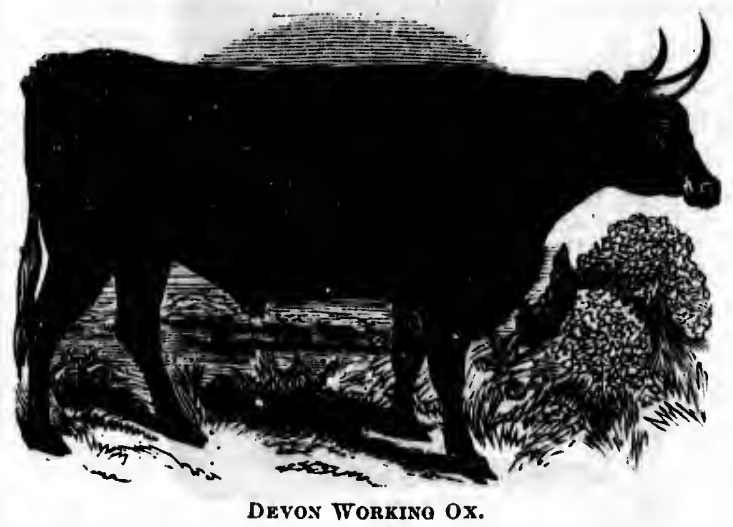

Excepting in the head and neck, the form of the bull does not materially differ from that of the ox, but he is considerably snialler. There are exceptions, however, to this rule.

The head of the ox is small, very singularly so, relatively to his bulk; yet it has a striking breadth of forchead; it is clean and frec from flesh about the jaws.

The eye is very prominent, and the animal has a pleasing vivacity of countenance, breeds.

Its neck is 1 more common

It is account of the week fro that of tho bac In the Devon reminding us of and quick action It has little o1 The horms are the base, and of The animal is breast deep, anc with the finchess The fore legs : a great weiglit.

The point of $t$ tion of bone, but

Angular bony $p$ tlesh and fat.

The fineness of the broad and ope

A narrow-chest grazing.

With all the ligl liked in the blood drauglit-the legs far and wide befor of slow draught, on in catching tim stumbling.

The lightuess of heaviness there.

The legs are stra or crooked in the $f$ tive iacapacity for behind the withers, takes away so muc 
countenance, distinguishing it from the heavy aspect of many other breeds.

Its neek is long and thin, admirably adapting it for the collar, or the moro common and ruder yoke.

It is accounted one of the characteristics of good cattle, that the line of the neek from the horns, to the withers, should scarcely deviate from that of the back.

In the Devoll ox, however, there is a peculiar rising at the shoulder, reminding us of the blood-horse, and essentially connected with the free and quick action by which this breed has ever been distinguished.

It has little or no dewlap depending from the throat.

The lorins are longer than those of tho bull, smaller, and fine even to the bise, and of a lighter color, and tipped with yel!ow.

The animal is light in the withers; the shoulders a littlo oblique; the breast deep, and the bosom open and wide, particularly as contrasted with the fineness of the withers.

The fore legs are wide apart, looking like pillars that have to support a great weight.

The point of the shoulder is rarely or never seen. There is no projection of bone, but there is a kind of level line rumning on to the neck.

\section{Charaeteristies and Important Points.}

Angular bony projections are never found in a beast that carries much flesh and fat.

The fineness of the withers, the slanting direction of the shoulder, and the broad and open breast, imply strength, speed, and aptitude to fatten.

A narrow-chested animal can never be useful either for working or mazing.

With all the lightness of the Devon ox, there is a point about him, disliked in the blood or riding horse, and not approved in the horse of light draght-the legs are far under the chest, or rather the breast projects far and wide before the legs. We see the advantage of this in the beast of slow draught, who rarely breaks into a trot, except when he is goaded on in catching times, and the division of whose foot prevents him from stumbling.

The lightness of the other parts of his form, however, counterlualances heaviness there.

The legs are straight, at least in the best herds. If they are in-kneed or crooked in the fore-legs, it argues a deficiency in blood, and comparative incapacity for work; and for grazing, too, for they will be hollow behind the withers, a point for which nothing can compensate, becauso it takes away so much from the place where good flesh and fat should be 
thickly laid on, and diminishes the eapacity of the chest and the power of creating arterial and nutritious blood.

\section{The Ilmbs of the Derons.}

The fore-nrm is particularly large and powerful. It swells out suddenly above the knee, but is soon lost in the substance of the shoulder, which is specinlly full and round.

Bolow the knee the bone is small to a very extraordinary degrec, indioating a seeming want of strongth; but this impression immediately oeases, for the smallness is only in front-it is only in the bone; the leg is deep, and the sinews are far removed from the bone, promising both strength and speed.

It may be objected that the log is a little too long. It would be 80 in an animal destined only to graze; but this is a working animal, and some length of leg is necessary to get him actively ovor the ground.

\section{The Body of the Devone.}

There is some trifling full bohind the withers, but no hollowness, and the line of the back is straight from thenee to the setting on of the tail. If thore is any seeming fault in the beast, it is that tho sides are a little too flat. It will appear, howovor, that this does not interfere with foeding, while a deop, although somowhat flut chest is best adupted fur speed.

The two last ribs are particularly bold and prominent, leaving room for the stomach and other parts concorned in digertion to be fully developed.

The hips, or huckles, are high up, and on a level with the back, whether tho benst is fat or lean.

The hind quarters, or the space from the hip to the point of the rump, are particularly long and well fillod up - a point of importance both for grazing and working. It leaves room for flesh in the most valuable part, and indientes much power behind, equally connected with strength and speed. This is an improvement quito of modern date. The fullness here, and the swelling of the thigh below, are of much more corr sequence than the prominence of fut which is so much admired on the rump of many prize cattle.

The setting on of the tail is high, on a level with tho back, rarely muct. olovatod or depressed. This is nuother great point, as connected with the perfection of the hind quarters.

The tail is long and small, and taper, with a round bunch of bair at the bottom.
The akin o. elustic. Gra this. When $t$ is rooin to sot

The skin is from tho curl the condition ples on water. should bo fine fatten more ki

The favorite hreed; but ther of intermediate

If the eye is bear hard work and hard under worker, and un

Those of a yo These ure the perhupss as man too rippidly behii hip bones and th und strong soils.

A selection fro small und tho ne knees, and not a the strength and degree his activit

The IIerefords originnlly red or bred to brownish within the last hu It was finally $\mathrm{n}$ dewlap, brisket a tail aro now fashi They ure a very they very much re: 


\section{OP the Binin and Hair.}

The skin of the Devon, with his eurly hair, is exceedingly mellow and elastic. Graviers well know that there is not a nore importunt point thun this. When the skin can be ensily raised from tho hips it shows that there is room to set on fut bolow.

The skin is thin ruther than thick. Its appenrunce of thiokness arises from the curly huir with which it is covered, and curiy in proportion to the condition and health of the animal. These curls run liko littlo ripples on water. Some of these cuttle have the hair smooth, but then it should bo fine and soft. Those with curled hair ure more hurdy, and fulten more kinüly.

The favorite color is blood red. This is supposed to indicato purity of hreed; but there are many gonl cuttle approaching almost to bay, and others of intermediate hues.

If the cyo is clenr and good, and the skin mollow, the palor color will bear hird work, and futten as well as othors, but a benst witl pule hnir, and hard under the hand, and tho eyo dark and dead, will be a sluggish worker, and in unprofitablo foedor.

Those of a yellow color nre suid to be subject to dinrrlicen, or scouring.

These ure tho principul points of $\boldsymbol{n}$ good Devon ox; but he used to be, perhups as many are yet, a littlo too flat-sided, and tho rump narrowed too rapidly behind the hip bones; there was too much space between the hip bones und tho last rib, and ho was too light for plowing in tonacious and strong soils.

A selection from the most perfect animals of the true breed-the bone snall and the neck fine, but the brisket deep and wide, and down to tho knees, and not an atom of fintness all over the side-theso have improved the strength mudbulk of the Dovon ox, without imparing, in the slightest degrec his activity, his beuty, or his propensity to fatten.

\section{Tho Horefords.}

The Ilerefords, namied from the county of Hereford, England, were originally red or brown, with no white about them. From thint they were hred to brownish or yellowish red, some fow oven being brindle. Only within the last hundred years lave they been bred to whito faces.

It was finully mado to extend along the top of the neek, along the throut, dewlap, brisket and fore legs, belly and flanks; and whito hind fect und tail are now fushionable.

They ure a very ancient breed, and undoubtedly allied to the Devons, which they very much resemble. 


\section{IMAGE EVALUATION TEST TARGET (MT-3)}
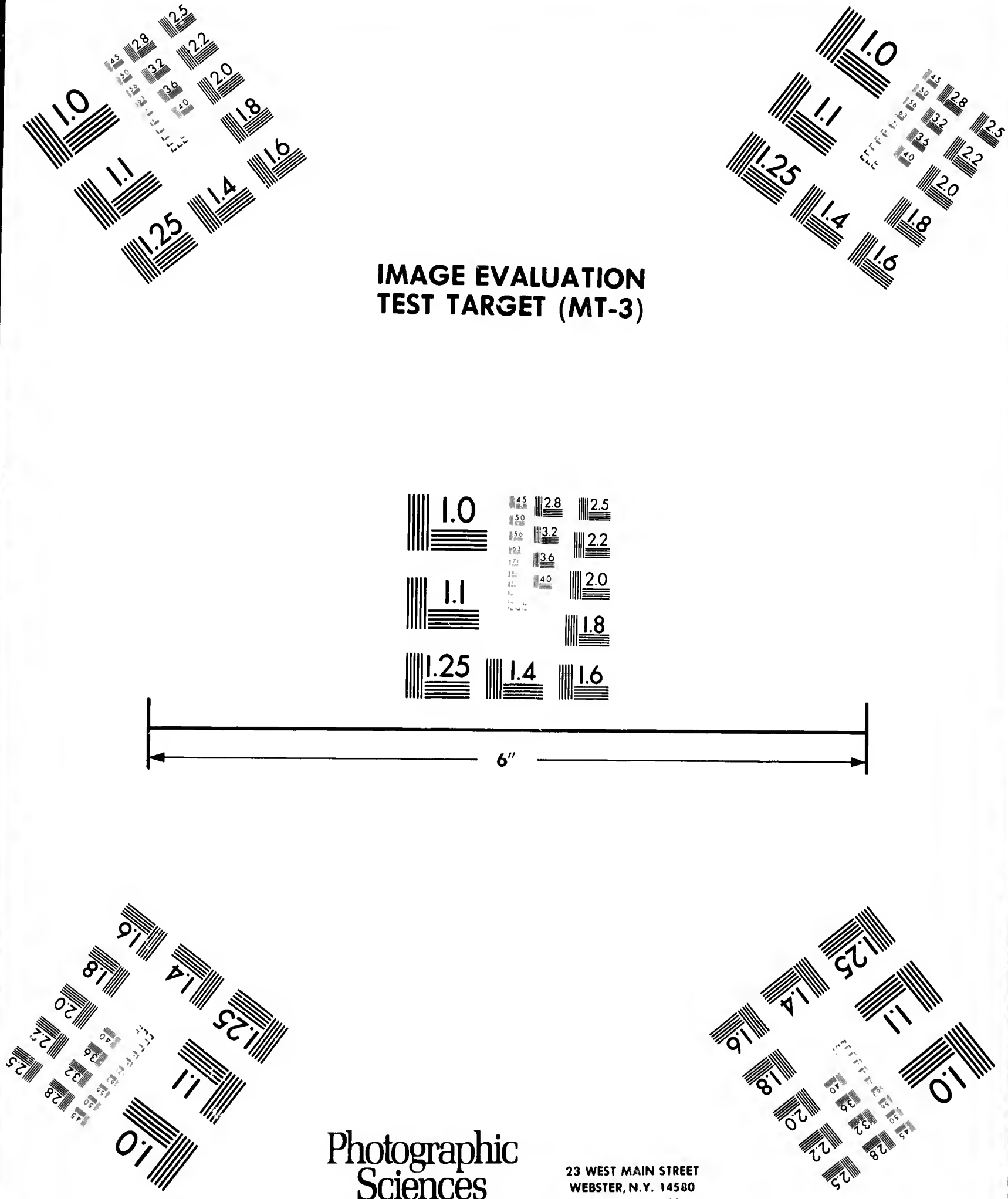

Photographic Sciences 23 wss mans sherr Corporation

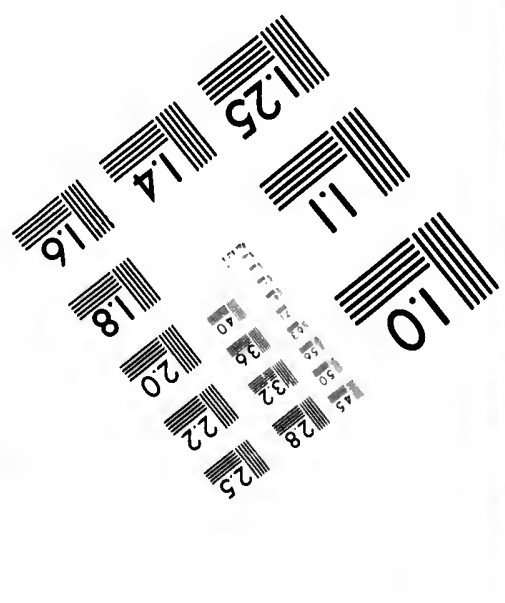





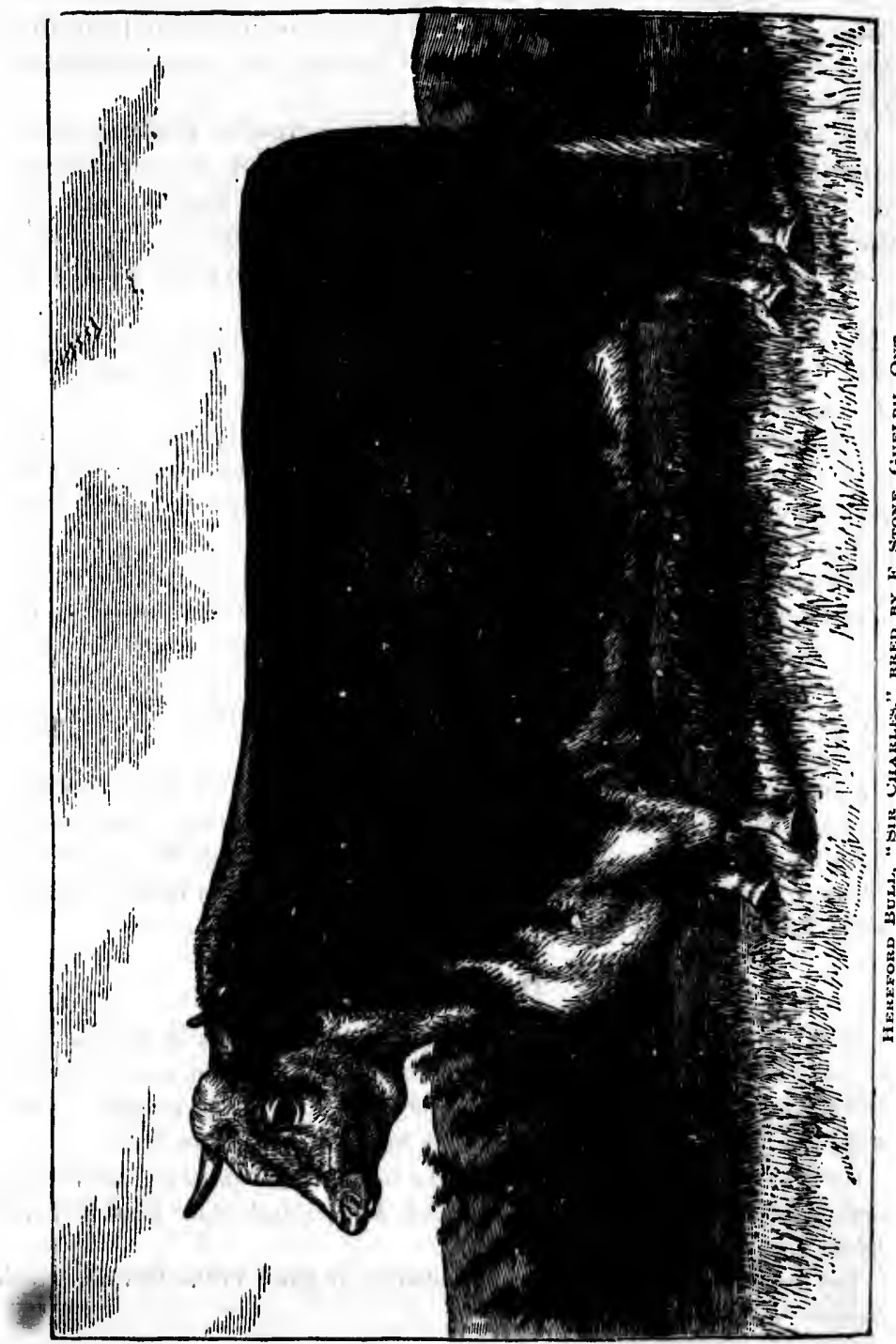

Mr.

of the

"Th

full an lean; 11 forward and me with the level of haired; spread; a smoot bones sil right and flank lar: touch, es supple, 0 neatly he face, is $\mathrm{c}$

The He always ha Here a Deron. breeding, oider that inside.

With th large or $d$ even from fatten earl When $t$ the owner and this to The $\mathrm{He}$ livod. Th parts, and t Their $m$ working ox 


\section{Herefords Fifty Years Ago.}

Mr. Marshal, a most competent authority, gives the following account of the improved Hereford as it was known tifty years ago:

"The countenanco pleasant, cheerful, open; the forehead broad; eye full and lively; horns bright, t:uper, and spreading; head small; chop lean; neck long and tapering; chest deep; bosom broud, and projecting forward; shoulder-bone thin, flat, no way protuberant in bone, but fulf and mellow in flesh ; chest full ; loin broad; hips standing wide, and level with the chine; quarters long, and wide, nt the neck; rump even with the level of the back, and sharp above the quarters; tail slender and neatly haired; barrel round and roomy; the carcass throughout deep and well spread; ribs broad, standing flat and close on the outer surface, forming a smooth, even barrel; the hind parts large and fuli of strength; neck bones suug, not prominent; thigh elean, and regularly tapering ; legs upright and short; bone below the knee and hock small ; feet of middle size : flank large ; flesh every where inellow, soft, and yielding pleasantly to the touch, especially on the chine, the shoulder and the ribs; hide meilow, supple, of a middle thickness, and loose on the neck and huckle; cont neatly haired, bright, and silky; color, a middle red; this, with a bald face, is characteristic of the true Hereford breed."

\section{The Hereford Cow.}

The IIcreford cow compared with the ox is small and delicate, and not always handsomely made, to the superficial observer.

Here again this breed would seem to slow their relationship to the Devon. She carries but little flesh, in breeding condition, and when breeding, should not be fed sufficiently to nccumulate nucle fat; for, in onder that the young be superior, the dim should have plenty of room inside.

With the Herefords, experience has shown that the dum may not be too large or coarse but she should be roouy. Then the breeder will get, even from apparently inferior cows, large, handsomo stecrs, that will fatten early, and kindly, and to grent weights.

When the cow is done breeding, and rendy for fatting, it will please the owner to see how she will sprend out, and accumulate flesh ind fat, and this to a greater degree, than if not allowed to breed.

The Hercfords are a hardy, gentle rnce, muturing early, and are long lived. The flesh is superior, handsomely marbled, heavy in the prime parts, and they fatten to weights fully as heavy as any kuown breed.

Their massive strength, honesty and gentleness make them the vorking oxen known, and the potency of the bulls, when crossed apren 84 
red or nearly red cows of the country, renders the steers easily matched in color, as they will be easily matched in general characieristics of the progeny.

\section{Herefords in America.}

Herefords were first brought to America for systematic breeding in 1816 or 1817, by the great Kentucky statesman, Henry Clay. 'T.'ey were soon, however, allowed to run down and were at length entirely lost sight of there. Admiral Sir Isaac Coffin, a few years after, sent out from England a Hereford bull to his friends in Massachusetts, which was used in crossing upon the native cattle of the State. He made a very marked impress there, and for many years the good result was seen in the cattle of the State.

About the year 1840 there was a large importation made into the State of New York, from England. They went principally to Jefferson county and some to Vermont.

About the year 1852 there was another considerable importation of Herefords into Ohio-very fine animals, where they, in connection with later importations, have been successfully bred.

In 1860 and 1861 two importations were made into Canada, consisting of two bulls and eleven cows and heifers, From these there have come down many most excellent animals, which have left their impress fur and wide. Since that time there have been various importations, prineipilly in Illinois and Maryland, the produee of which have fought their way against the opposition of the Short-Horns, until now they may be said to fairly divide honors with this famous breed in America as they are well known to do in England.

\section{As Milkers.}

The cows are not very deep milkers, in fact they give but little milk. They were never large milkers, and a course of breeding for many generations as beef makers, while it has brought up the animals to great weights and such wonderful symmetry that they fairly dispute the palm in the showrings with the best Shor Horns, the milking qualities have gradually become less and less. It is but another exemplification of the fact, that all goodness cannot be combined in one animal.

It is enough that the science of breeding within the last fifty years has hrought all our domestic animals far toward perfection, in the two great classes needed in cattle : that is, superior excellence as beef makers, or else superior excellence as deep and rich milkors. It is obvious that it must be so, for the animal superior as a milker must necessarily be ogether different in her conformation from one destined to produce a maximum weight of prime beef at the earliest age. 
atched

tics of

ding in

'T':'ey ely lost ut from ras used marked de cattle he State n county ation of ion with onsisting ave come is far and rincipally their way be said to are well

ittle milk. for many $s$ to grent e the palm hities hare ion of the years has two great makers, or pus that it essarily be produce \&

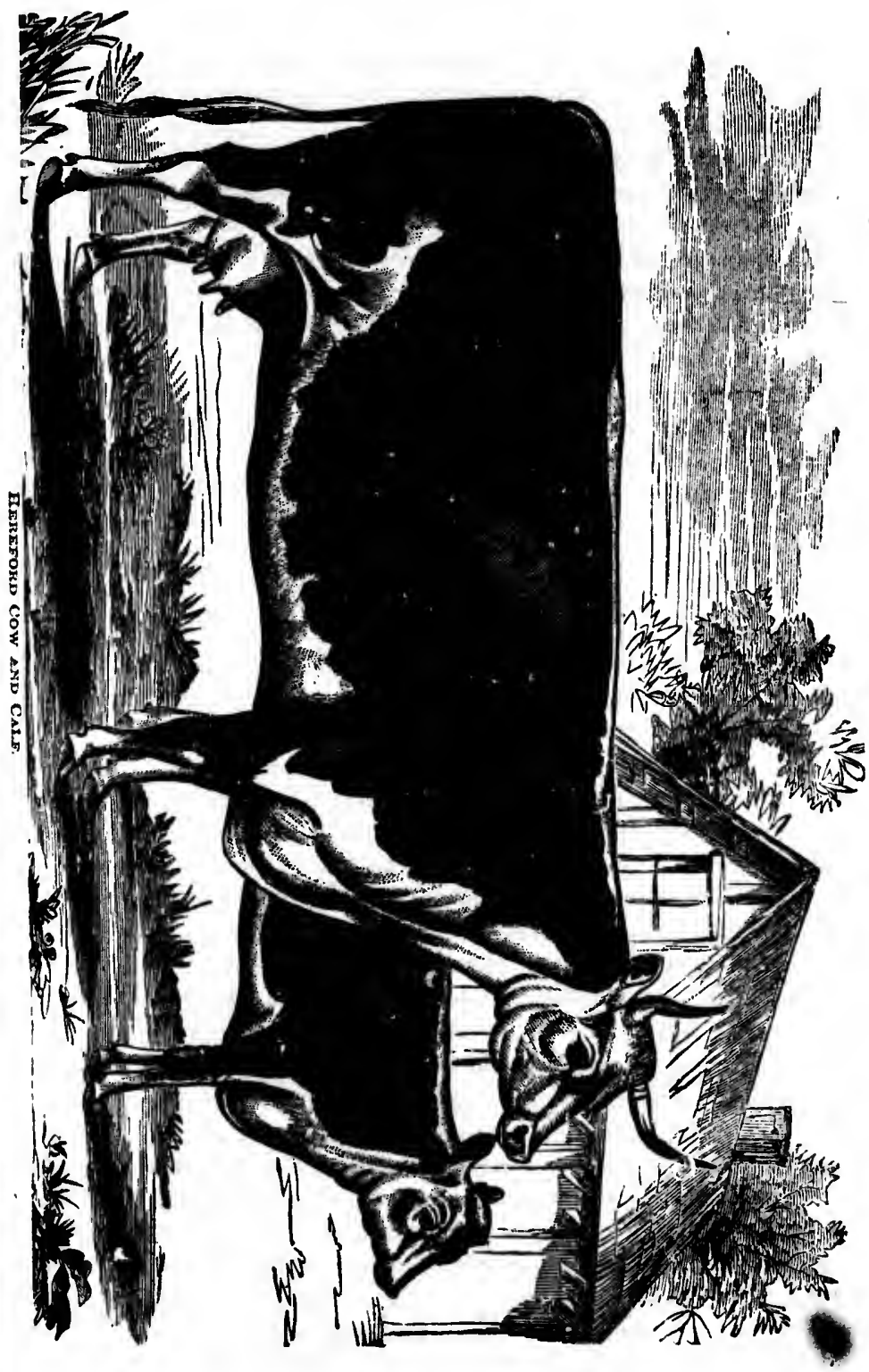




\section{The Hereford Ox.}

Whether we consider this remarkable breed either in their adaptability to heavy draft, or in their wonderful fattening qualities, it is the steers that make the money for the feeder.

Their capability of standing fatigue and constitutional adaptability in resisting winter weather, has of late made them great finvorites with the runchmen on the plains.

So, while we see them winuing honors in the show rings at home, the young iulls are cageriy picked up for trunsportation to Colorado, New Mexico, Montana and Wyoming, to put with the herds there, for the purpose of breeding grades.

Thus two valuable ends will be conserved: That country will send East most superior cattle for feeding fat, in the great corn region of the West, while at the same time they will bo ruising up steers admirably adapted to the heavy freighting business in the mountains and mining districts.

\section{The Hereford of To-day.}

As showing the extreme care that has been exercised of late years in improving this comparatively rare breed in England, to such great perfection as to fairly claim honors with the very best Short-Horns, the following extracts from leading agricultural jouruals, relating to one of the great show rings there in 1878, the Bath and West of England, the Maric Lane Express speaking of the Hercford exhibit says :

"They are not so numerous as the more fashionalle breed, but the quality throughout is excellent. In the aged bull elass there are five animals of which the Hereford men need not be ashamed.

"The heifers in milk or in calf numbered only three, but two of them were such animals as it was worth while coming to Oxford on purpose to see. Mrs. Sarah Edwards, of Wintercott, took first and second, leaving Mr. Lutley the reserve; but Mrs. Edwards' Leonora is one of the most perfect animals that has been shown for years. It was first last year as a yearling at Liverpool, and will likely be first wherever it gocs. The champion prize given ly the Oxfordshire Agricultural Society was also awarded to this heifer as the best female horned mimal in the yard. The companion heifer, Beatrice, is also very hundsome, and took seeond to Leonora's first at the Royal last year, as it did last week at Oxford. Mrs. Edwards may well he proud of such stock as that; if Leonora had been a Grand Duchess Short-Horn a poem would have been composed in 5 honor, and translated into several langunges by this time. But no Siwort-Horn that we have ever seen was cast in such a mould.
In the

"Thi

dampic

declared

year old

Buth, ats

She is

instumce

"The

mukers

The Tee:

locul eirc

white-fac

The $C$

"The

Aarom Ro in 1876 , 1

IIe has m is is prow and has $\mathrm{s}$ leen put as the be champion: competito IIereford distinction capital loi very level flesh with one-half columns, a well supp consisting Edwards a "In the second prir at her fore grand fian prize cow, Buth, und The two-yd were, of ed 
In the Agricultural Gazette (London) we find the following:

"This breed enjoyed the remarkuble distinction of producing both the dampion animals at Oxford. Mr. Aaron Rogers' Grateful being declared to be the best bull, and Mrs. Sarah Edwards' Beatrice (a two year old heifer) being declared to be the best cow or heifer in the yard. Both, as may be supposed, were very good, tho heifer pre-eminently so. She is a diughter of the famous bull, Winter de Cote; and another instance of hereditary merit.

"The yearling leifers and calves indicate that this breed is, ns beef makers at an early age, quite up to tho highest Short-Horn standard. The Teeswater may milk better, and be more ready in adapting itself to local circumstances; but where the pasture is good, it is hard to beat the white-fuces for grazing."

The Chaniber of Agriculture Journal (London) also says :

"The old bull Hereford class produced an extraordinary animal in Mr. Aaron Rogers' Grateful, who secured the reserve at the Hereford Show in 1876, but did not make his appenrance at Bath or Liverpool last rear. IIe las made wonderful development since, appenring as a two-year-old, as is proved by the fact that Thoughtful, who was then placed above him, and has since taken firsts at Birmingham, Liverpool and Bath, has now heen put second to him ; and that not only was he selected by the judges us the best Hereford bull on the ground, but in the contest for the championship succeeded in earrying it .off against such a Short-Horn rompetitor as Sir Arthur Ingram. This is no slight honor to the llereford breed, and of course any animal counted worthy of such a distinction must be a first-class one. Gratejul, at four years old, has capital loins and chines, with great thickness and depth of frume, and is very level all over; lout his grand feature is the astounding mass of flesh with which his frame is covered. His girth is eight fect ten and one-half inches. Thoughtful has frequently been deseribed in these columns, and it is sufficient to state that he is a massive, grand bull, who well supports his merit. The next class was a very weak one, only consisting of two, and those not so good as the herds of $\mathrm{Mr}$. H. N. Edwards and Mr. Philip Turner are accustomed to supply.

"In the cow class the late Mr. Warren Evans' Lady Blanche, which took second prize at Bath, now came to the front position. She is marvelous at her fore flank, and displays a great mass of flesh on a well-shaped, grand frame, which, however, fell off slightly at the rump. The second prize cow, Mr. E. J. Lewis' Little Betuty, had a highly commended at Bath, and wonderfully retains her show-yard merit at eleven years old. The two-year-old heifers of Mrs. Surah Edwards, Leonorn and Bentrif. Ivere, of course, sure to win. Beatrice has recently reared a calf, which 
is slightly against her for showing; but Leonorn is in full bloom with her beautiful head, symmetrical form, and all that loveliness which is so taking to the eyg. After being selected as the best Hereford female on the ground, she carried off the champion prize against a remarkably

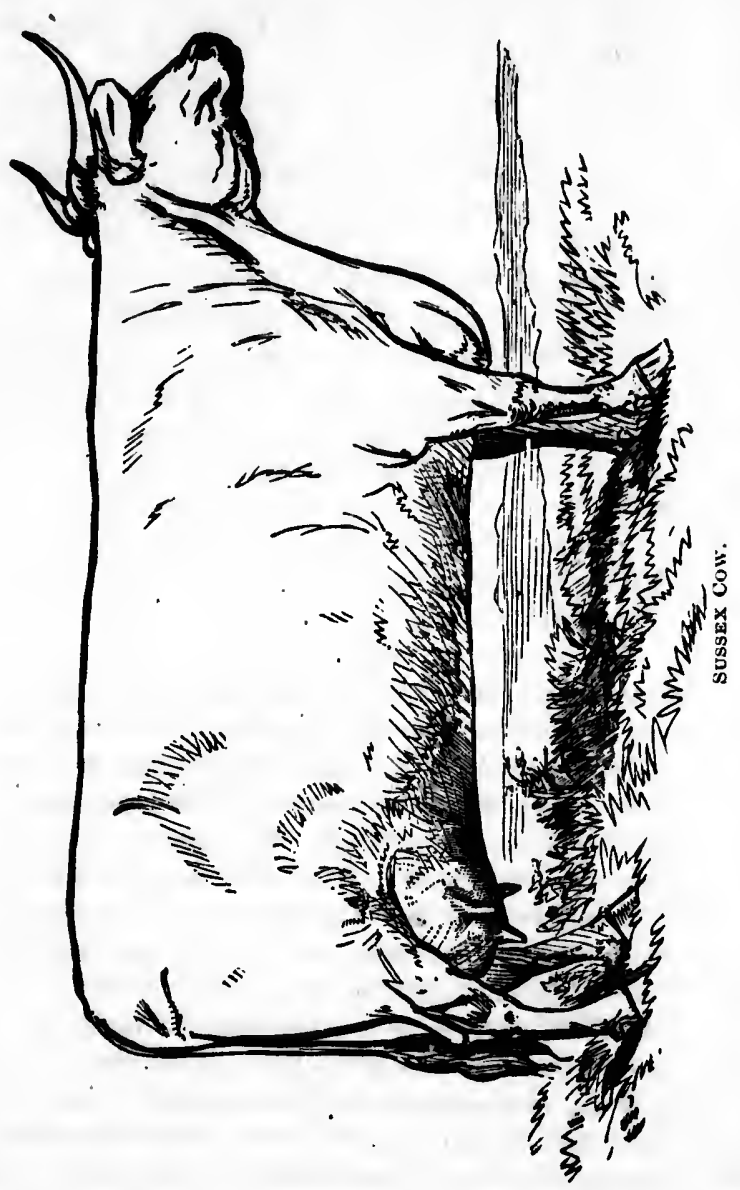

aty Short-horn heifer, and one of the best Devons that has appeared for years, so that both cups were awarded to Herefords."

This

The

up mo mitd $\mathrm{i}$ clem : should top of much round the mu belly a are wid and th and thi straight above. be strai In co all light

The $\mathrm{c}$ borns $\mathrm{f}$ and tur straight at the $p$ Hips cass larg The $c$ and as $b$

They even exh

This a bay Der in other

The S Yorkshil 
Eussex Cattle.-Distinguishing Marise.

This breed is closely allied to the Devons, but coarser. Their distinguishing marks are :

The horns are more tapering, pushing farther forward, and turuing up more. The head is small and well formed, the eye full, large and nild in the ox, but rather wild and unquiet in the cow. The throat is cleni and the neck long and thin, but coarser than in the Devon. The shoulder is wider and rounder on the withers; straighter from the top of the withers towards the back, and carries much flesh, giving too much weight to unprofitable parts. On the other hand, the barrel is round and deep, the back straight, and the back-bone entirely hidden by the nuscles on each side. The heart and lungs are full and large, and the belly and flank eapacious. The barrel is well-ribbed home. The loins are wide, the hip-bone low, free from raggedness, large, und well spread, and the space between the hips well filled up. The tail, which is fine and thin, is set on lower than in the Devon, yet the rump is nearly as struight, for the deficiency is supplied by a mass of flesh and fat swelling above. The hind quarters are cleanly made, and if the thighs appear to be straight without, there is plenty of fullness within.

In color the Sussex is a deep chestnut red, or blood bay. They are all lighter in color than the Devon, but in color they are fully as uniform.

\section{The Sussex Cow.}

The cows have fine hair, a mellow, rather than thin skin; a small teat; horns fine, clean, and transparent, which reach forward from the head and turn up at the tips; the neck is thin and clean; back and belly straight; ribs round and springing out well; shoulder flat, but projecting at the point.

Hips and rump wide; the tail set on level with the rump, and the carcass large; the legs are rather short and fine.

The cows are not good milkers; they are often uneasy in the pasture, and as before stated, unquiet in temper.

They have been, 'some of them, imported to the United Stutes and even exhibited and sold as Devons.

This description of the Sussex is given for this reason: Those who bay Devons should be careful that they have no stain of this blood; in other words, their pedigree should be perfect.

\section{Short-Horned Breeds.}

The Short-Horn breeds of England are represented by the Durham, the Yorkshire, the Lincolnshire, the Teeswater and the Holderness breeds. 


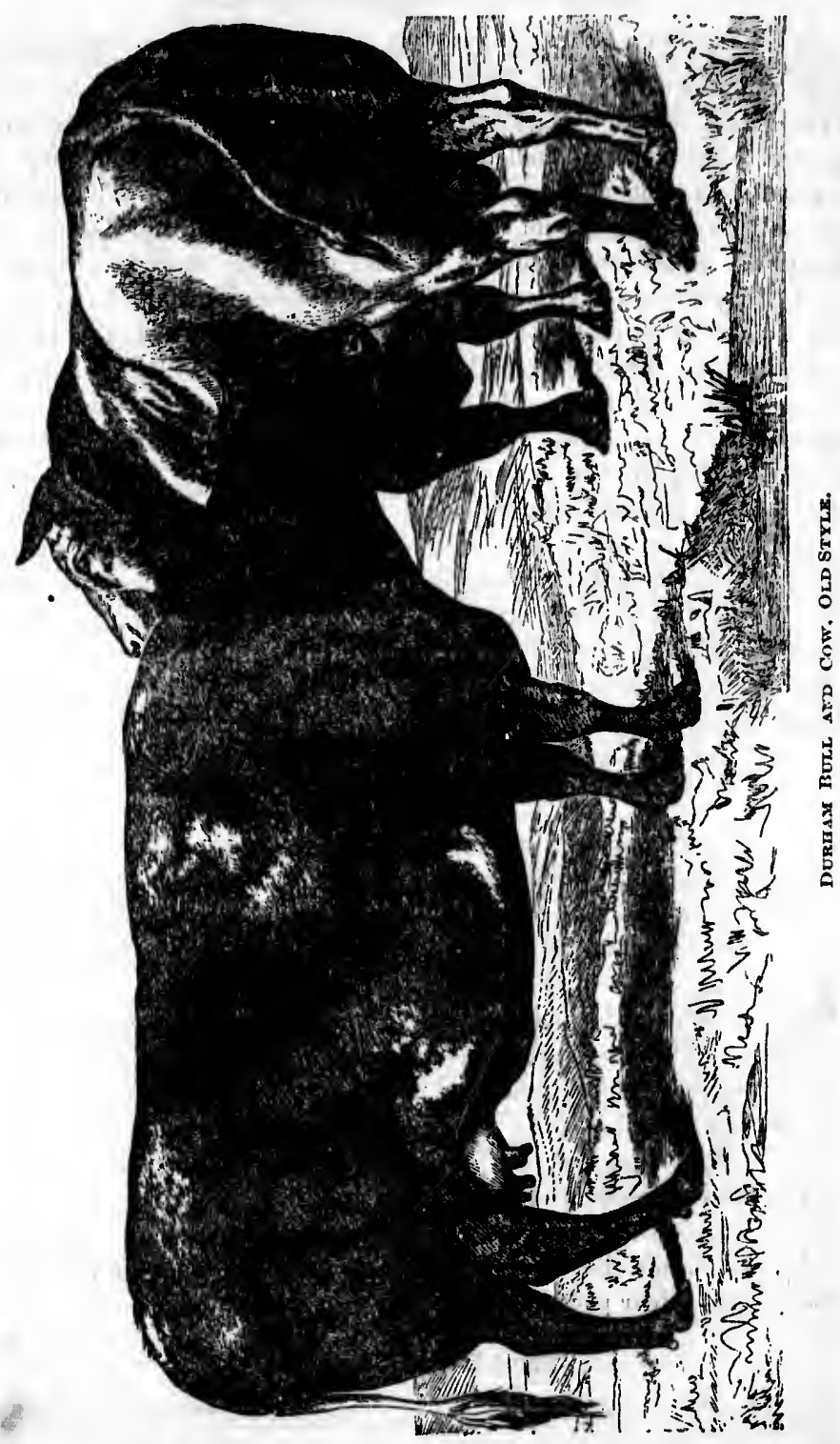

seded the nial

'Thei hum :II

The deseenc in the These ordinar As 1 rither e defectir of a ditı Excel early 11 and tift (and he chaructc

What descend is enoug ficiently eminent Amon early pit Robert), In the Bates, an. aninals. of extra Bates.

Since steadily i thousand: so fashior large fifty 
The Yorkshires and Lincolnshires are now but little known, being supersoded by the improved breed now generally known and recognized by the ntme of Short-Horn, or the crosses thereof.

Their chameteristics wero those in a modified degree of the old Durhaun and Teeswater cattle.

\section{Short-Horns Propor.}

The only representation of this class worthy of notice here, are the desendints of the old Durhmm or Teeswater enttle, which have existed in the counties of Durham and York, from the earliest historieul periods. These uniformly had short horns, were of large size, and were extraordintry milker's.

As to their characteristies, they were thin-skinned; sleck-haired; ruther delicate in constitution; not mellow to the toueh ; course in offul ; defective in girth forward; slow to fatten ; the ment inferior, and often of a dark line.

Exellence in the uptitude of the Short-Horns of latter yenrs to fatten, early maturity, and mellowness of hide, go bick nlunost one hundred and hifty yeirs, when the Short-Horns, on the binks of the river Tees, (and hence ealled the Teeswater breed), began to assume the distinctive characteristics of the Short-Horns of a later period.

\section{Short-Horn History.}

Whatever may have been the origin of the cattle from which have descended the present rice of Short-Horns, it is not of moment here. It is enough to know that they had been for many generations bred sufficiently pure to establish certain characteristics that attructed the most eminent breeders of the day.

Among the breeders of the latter part of the last century, and the early part of the present century, were the Collings, (Charles and Robert), Sir Henry Vane, Col. John 'Trotter, and Mr. Mason.

In the early yenrs of the present century, Mr. John Stevenson, Mr. Bates, and Mr. Booth, each became eelebrated for the eminence of their animals. Earl Spencer also aequired a grent reputation, as the possessor of extraordinary animals, and for prices received by himself and $\mathrm{Mr}$. Bates.

Since the death of the latter gentlemm in 1849 , Short-Hor'ss have stendily increased in price for fashionably bred aminals, ruming far into thousands of dollars, of late years, for a single animal, while those not so fashionably bred were equally sought at prices that would have seemed large fifty or sixty years ago. 
Bolow inay be found an outlino representation of a fat Short-Horn cow.

It will be obscrved that this animal carrios grent size, a square body of great substance, while the legs are sufficient for locomotion, although from the fullness of the carcass they seem short, and that there is abundance of meat in the prime parts, including the thighs, which carry their

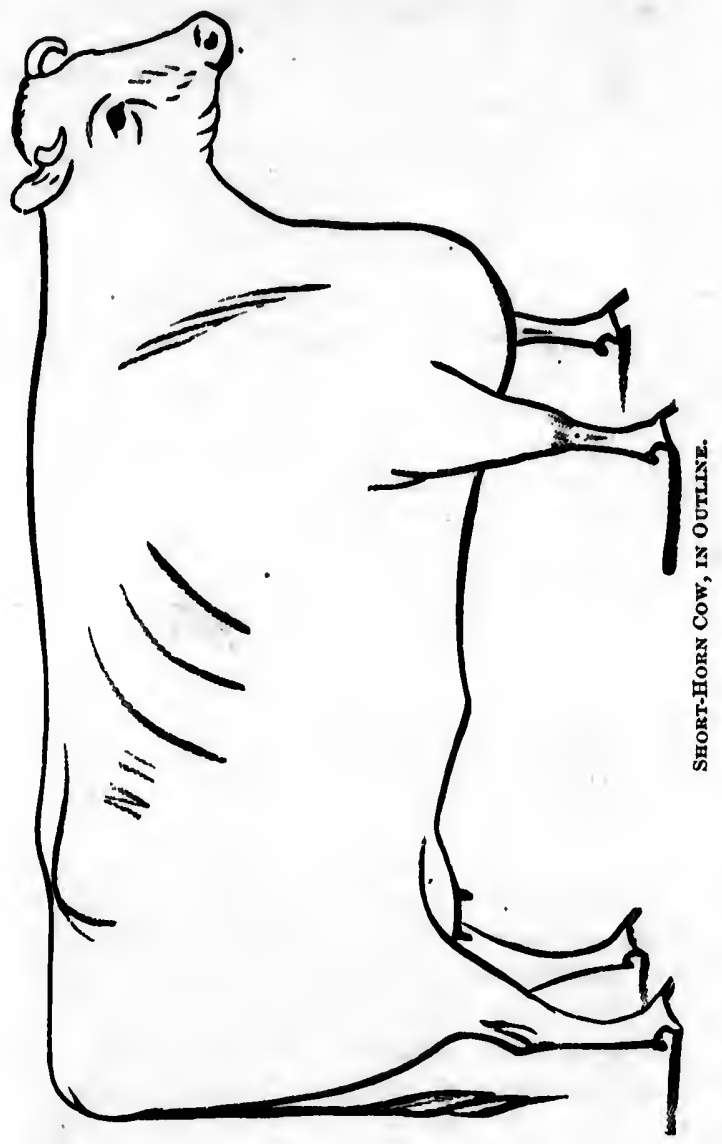

fullness well down to the hocks. It will be seen that she is characterized by massiveness, smoothness, and that she shows the appearance of carrying light offal. The brisket is deep, the udder small, but compact, and 
extending well forward. The rump is smooth, but brond, and without patchiness-that is, great lumps of fat standing out like blubber. The hips are broud and well covered with flesh and fat; and tho loins, and indeed the whole top, exceptionally good. In fuet, she is an animal carrying beef all over, where tlesh may be laid on, and full of fat inside. She is a grand representative of the breed, and one that muy be futtened to a great weight.

\section{Ehort-Forns in Amerios.}

Mr. Allen, the editor of the Ameriean Short-Horn Herd Book on American cattle, from a very exhaustive researeh of importations in relation to the introduction of this most valuable breed into the United States, silys :

Soon after the termination of the Revolutiocury war with England, a few cintle supposed to be pure Short Horns, were brought iito Virginia by a Mr. Miller. These were snid to be well fleshed animals, and the cows renurkable for milk, giving as high as thirty-two quarts in a day. Some of the produce of these eattle, as early as 1797, were taken into Kentucky by a Mr. Putton, where, as little was known of "breeds," they were called, after the gentleman who brought them, the "Patton stock." They were well cured for, and.mado a decided improvement in the cattle of the "blue gruss country," where they were first introdueed. Some of this early Virginia stock also went out to the "south branch of the Potomac," in that State, a fine grazing country, which, fifty year's aro, was famous for its good cattle. In the year 1796, it is suid that an Englishman, named Heaton, brought two or three Short Horn cattle from the north of Englund to New York. They were taken to Westchester county, near by, and bred, but no results, in pure blood, have been traced to them.

Iu 1815-16, a Mr. Cox, an Englishman, imported a bull ond two heifers into Rensselær county, New York. Theso were followed in 1822 by two bulls, imported by another Englishman named Hayne. Descendants from this Cox stock were said to be bred pure, and afterwards erossed by Mr. Hayne's bulls. The stock now exists in considerable numbers and of good quality, in that and adjoining counties.

In 1817 Col. Lewis Sanders, of Lexington, Kentucky, made an importation of three bulls and three heifers from England. They were of good quality and blood, and laid the foundation of many excellent herds in that State. In 1818, Mr. Cornelius Cooledge, of Boston, Missachusetts, imported a yearling heifer,- "Flora"-and a bull"Cicero"-into that city, from the herd of Mr. Mason, of Chilton, in 
the county of Durham, Englaud: These were carefully bred, and mny of their descendants are now seattered throughout several States. About the same year Mr. Samuel Williams, then a merehunt in London, but a native of Massachusetts, sent out a bull-"Young Denton"- - and some cows of the same and later importations, and their descendants are still numerous among well bred Short Horns of the present day.

The same year, Mr. Gorham Parsons, of Brighton, Massachusetts, imported a Short Horn bull-“Fortunatus"-bred by Geo. Faulkner, of North Allerton, Yorkshire, England. He was used considerably on the native cows of his State, but we have never traced any thorough-bred pedigrees to him.

In 1820, Mr. Theodore Lyman, of Boston, Massaehusetts, imported a bull, which he sold to Israel Thorndike, of that city, and he sent him to bis farm in Maine. Of his produce we hear nothing.

About the year 1820, and during a fow years succeeding, "scveral spirited gentlemen of Boston, and its neighborhond, inported a number. of cows and bulls from some of the best herds in England. They were Messrs. Derby, Williams, Lee, Prince, Monson, and perhaps others. These were all fine eattle, and of approved blood in the English ShortHorn districts. Their descendants are still numerous in New England, and some other States.

About the year 1823, the late Admiral Sir Isale Coflin, of the British navy, a native of Massachusetts, sent out a cow-"Anabella"-and a bull-"Admiral" - as a gift to the Massachusetts Agricultural Socie:They were good animals, and bred with the other Massachusetts importations.

Shortly previous to 1821 , the late Jolm S. Skimmer, of Baltimore, Maryland, imported for Goveruor Lloyd, of that State, a bull- "Champion" - and two heifers_-Whito Rose" and "Shepherdess" - from the herd of Mr. Champion, a noted English breeder. From these, several good aninals deseended, some or which are now known.

In 1823, Mr. Skinner also imported for the late Gen. Stephen Van Rensslær, of Albany, New York, a bull- "Wushington"-and two heifers_"Conquest" and "Pansey"-from the same herd of Mr. Champion. Conquest did not breed; Pansey was a suceessful breeder, and many of her deseendants are now seattered over the country.

During the years 1822 to 1830 , the late Mr. Charles Hemry Hall; of New York, imported several Short-Hor bulls and cows, from some of the best English herds. Several of these he sold to persons in the neighborhood of that eity, soon after they arrived, and others he sent to his farm in Rensselær county, near Albany, and there bred them. Their descend. ants are now scattered through several good herds. 
many About , but a id some ure still

husetts, aulkner, rably on igh-bred ported a thim to , several , numiber. hey were $s$ others. sh ShortEngland, 1e British '-and a Socic:- " ts imporBultimore, - Cham-from the e, several bhen Van -and two of $\mathrm{Mr}$. breeder, $y$

Hilli, of some of neighborhis farm - descend.

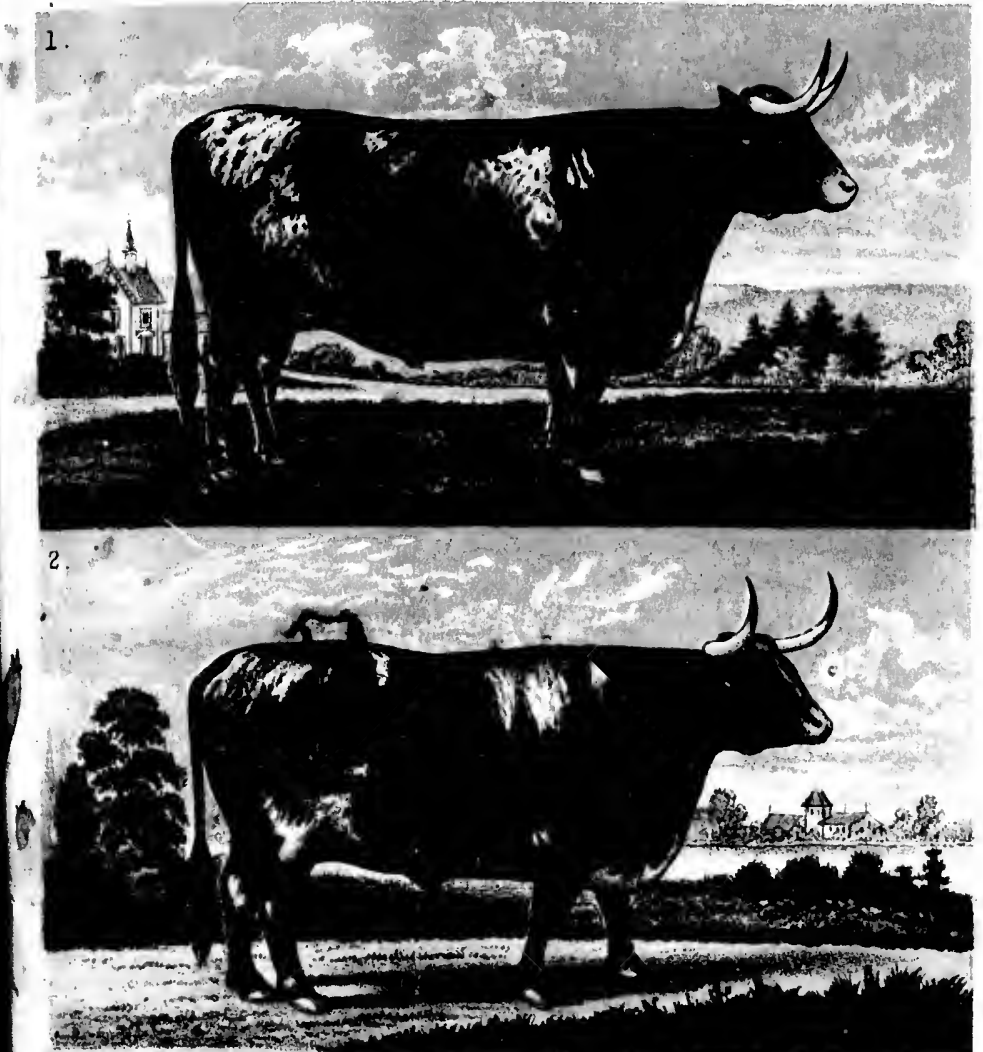




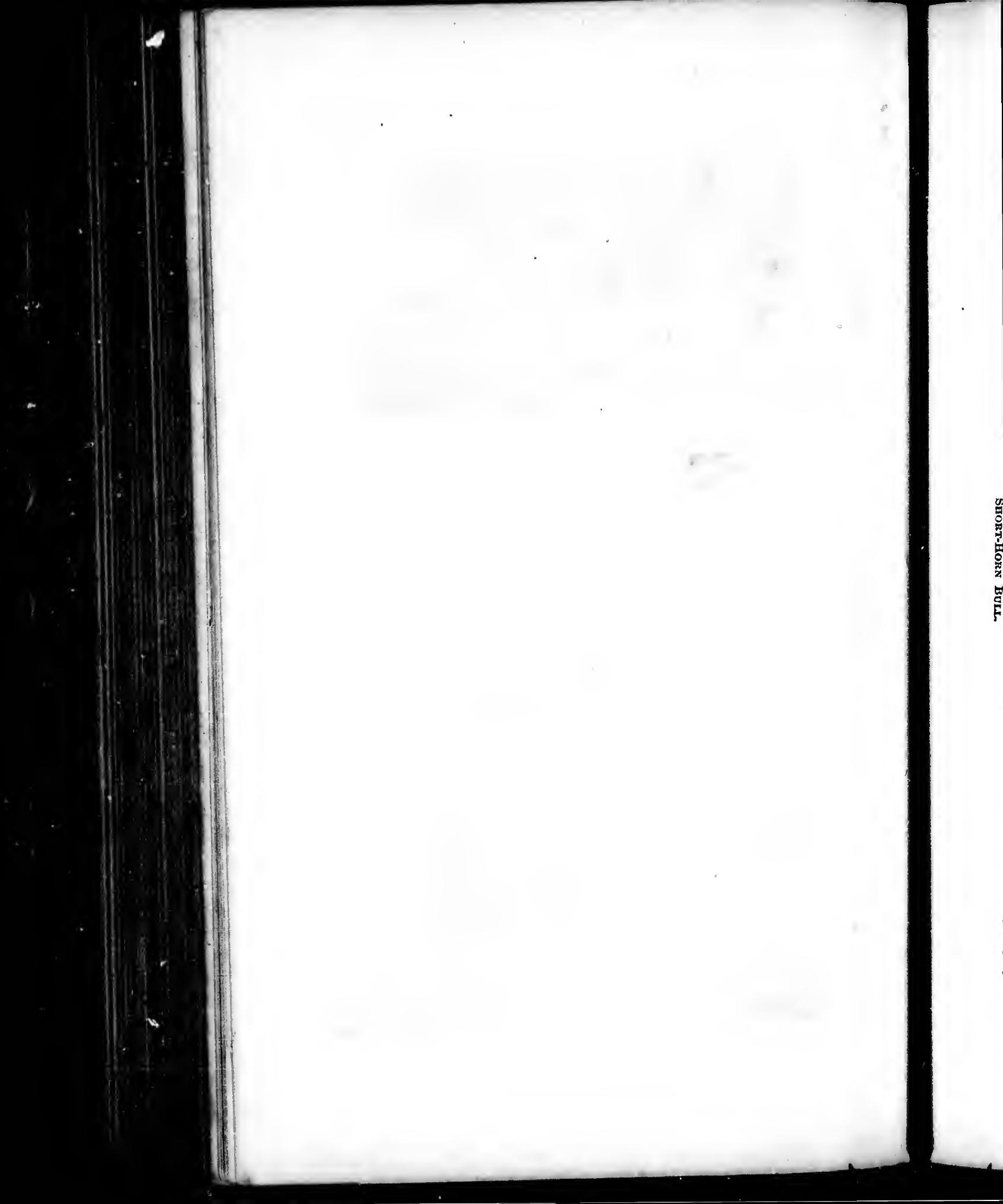




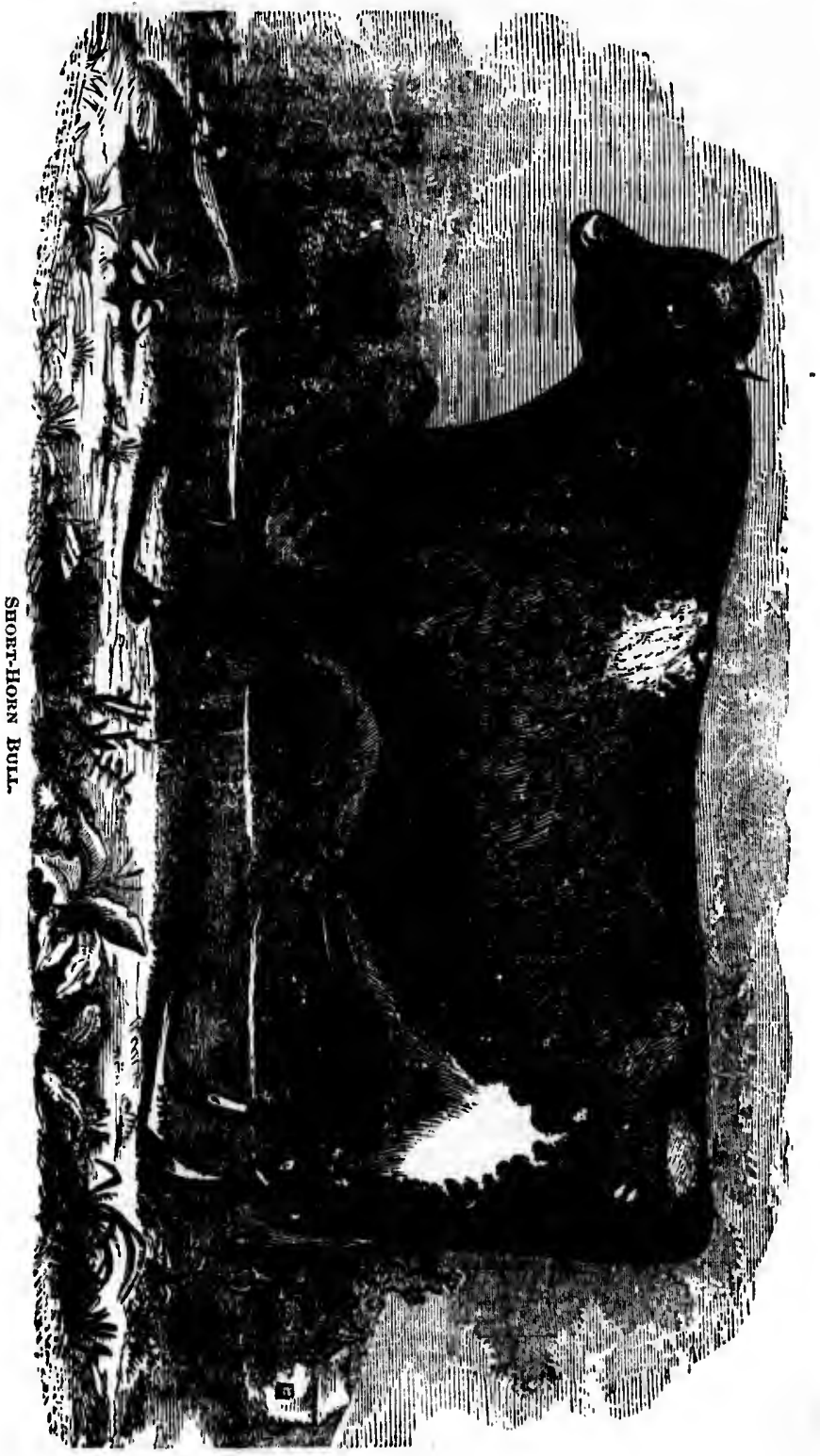


In 1824 the late Col. John Hare Powell, of Philadelphia, Pa., commenced iniportations, and for severul years continued them with much spirit and judgment. His selections were principally from the herds of Jonas Whitaker, of Otley, in Yorkshire, England. He bred them assiduously at his fine estate at Powelton, near the city, and sold many to neighboring breeders, and to go into Ohio and Kentucky, where may of their descendants still remain.

About the year 1828, Mr. Francis Rotch, then of Neiv Bedford, Mass., . selected from the herd of Mr. Whitaker, and sent to Mr. Benj. Rodnan; of New Bedford, a bull and three heifers. They were afterwards sold to other breeders, and their descendants are now found in several excellent herds.

In the year 1833, the late Mr. Walter Dun, near Lexington, Ky., imported a bull and several valuable cows from choice herds in Yorkshire, England. He bred them with much care, and their descendants are now found in many good western herds.

But the first enterprise in importing Short-Horns upon a grand scale was commenced in $\mathbf{1 8 3 4}$, by an association of cattle breeders of the Scioto Valley, and its adjoining counties, in Ohio. They formed a company, with adequate capital, and sent out an agent, who purchascd the best cattle to be found, without regard to price, and brought ont nineteen animals in one ship, landed them at Philadelphia, and drove them to Ohio. Further importations were made by the same company, in the years 1835 and 1836 . The cattle were kept and bred together in one locality, for upwards of two years, and then sold by auction. They brought large prices- $\$ 500$ to $\$ 2,500$ each-and were distributed chiefly among the stockholders, who were among the most extensive cattle breeders and graziers of the famous Scioto Valley.

In 1837-8-9, importations were made into Kentucky, by Messrs. James Shelby and Henry Clay, Jr., and some other parties, of scveral wellselected Short-Horns, some of which were kept and bred by the importers, and the others sold in their vicinity.

In 1837-8-9, Mr. Whitaker, above mentioned, sent out to Philadelphia, on his own account, upwards of a hundred Short-Horns, from his own and other herds, and put them on Col. Powell's farm, where he sold them at auction. They were purchased at good prices, mostly by breeders from Pennsylvania, Ohio, and Kentucky, and distributed widely through those States.

From 1835 up to 1843 , several importations of fine stock were made by Mr. Weddle, an Eng.ish emigrant, to Rochester, N. Y., and by American gentlemen, among whom were Messre, E. P. Prentice, of Albany, N. Y., Mr. James Lenox and Mr. J. F. Sheaffe, of New York city,

with mud herd on widely d herds. 
Messrs. LeRoy and Newbould, of Livingston county, the late Peter A. Remsen, of Genesee county, N. Y., and Mr. Whitney, of New Haven, Ct., Mr. Gibbons, of New Jersey, and some others, not now recollected, -all valuable animals. They were bred for some years by their owners,

ly to

wy of

Lass., -

linan;

old to

sellent

im-

sshire,

e now

d scale

Scioto

mpilly, it cattle imals in Further a 1836. fards of $s-\$ 500$ ers, who famous

$\therefore$ James al wellporters,

delphia, his own old them ers from gh those re made y AmerAlbany, ork city,

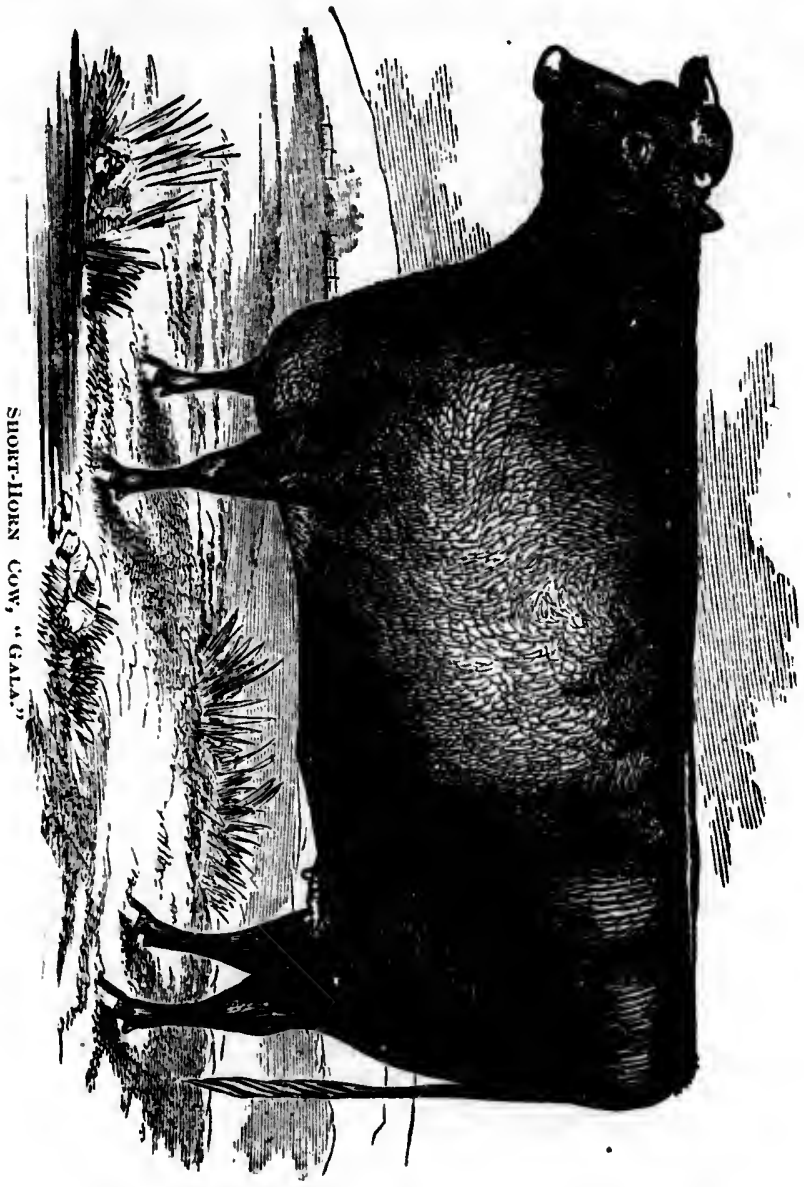

with much care. Mr. Prentice, for several years, had a large and excellent herd on his home farm. After some years all these herds were sold and widely distributed. Their descenc ants still remain among our valuable herds. 
In the year 1849-50, Col. J. M. Sherwood, of Auburn, and Mr. Ambrose Stephens, of Batavia, N. Y., imported from the herd of Mr. Bates a bull, and from Mr. Jno. Stephenson, of Durham, England, three bulls and several heifers, all choico animals, and sticcessfully bred them during several years. The stock became widely distributed, and well known among stock dealers.

About the yemr 1839, Mr. George Vail, of Troy, N. Y., made an im. portation of a bull and heifer, purchased of Mr. Thomas Bates, of Kirts. leavington, the first cattle from that particular herd which had been introduced into the State. A few years later, he purchased and imported several more cows from the herd of Mr. Bates, crosses of his "Duchess" and other families. He bred them with success and widely distrilunted their blood. Mr. Vail made a final sale of his herd in the year 1852.

A period of some years now occurred, in which few more, if aly, Short-Horns were imported. Cattle, as well as all kinds of agriculturit? produce, were exceedingly low; but as things grew better, the demand for "blood" cuttle revived, and the spirit for their breeding was renewed. Mr. Thomas Bates, a distinguished Short-Horn breeder in England, died in 1849. His herd, fully equal in quality to any in England, was sold in 1850. The choicest of then - of the "Duchess" and "Oxford" tribesfell mostly into the hands of the lite Lord Dacie, at Fortworth Park, alreudy the ownor of a noble herd, to which the Bates stock was added. He was a slillful breeder, and of most liberal spirit, and during the brief time he held them the reputation of the Bates stock, if possible, increased. Within three yours from the time of the sale of Mr. Bates' lierd, Lord Dacie died. In 1853, peremptory sale of his stock was widely advertised. Allured by the reputation of his herd, severnl Ameriean geitlemen went over to witness it. The attendance of English herders was very large, and the sales averaged higher prices in individual animals than had been reached since the famous sale of Charles Colling, in 1810. Mr. Simutel Thorne, of Duchess county, N. Y., bought several of the best and highest priced animals, of the "Duchess" and "Oxford" tribes, and added to thein several more choice ones, from different herds. Messrs. L. G. Morris, and the late Noel J. Beear, of New York, bought others of the "Duchess", and "Oxfords," to which they added more from other chnice herds. These were all brought over here, and bred. Mr. Ezra Cornell, of Ithacn, and Mr. James O. Sheldon, of Geneva, N. Y., soon nfterwards made some importutions, nnd obtained some of the "Bates" blood also. The late Gen. James S. Wadsworth, and other gentlemen of the Genesee Valley, N. Y., also made importations. These "Bates" importations have since been bred so successfully hy their holders here, that several young bulls and heifers, bred by Mr. Thorno and Mr. Shel. 
don, have been purchased by English breeders, and sent over to them at good prices, where they are highly valued.

rose

bull,

and

uring

mong

im.

Kirk.

intro-

orted

hess"

ibuted

2.

f any, ultura! lemand newed. $\mathrm{d}$, died sold in wibesPark, added. he bricf creased. d, Lord ertised. en went $y$ large, ad been Samuel highest dder to L. $G$. of the $m$ other Ir. Ezra Y., 8001 - Bates" emen of "Bates" ers here, Ir. Shel.

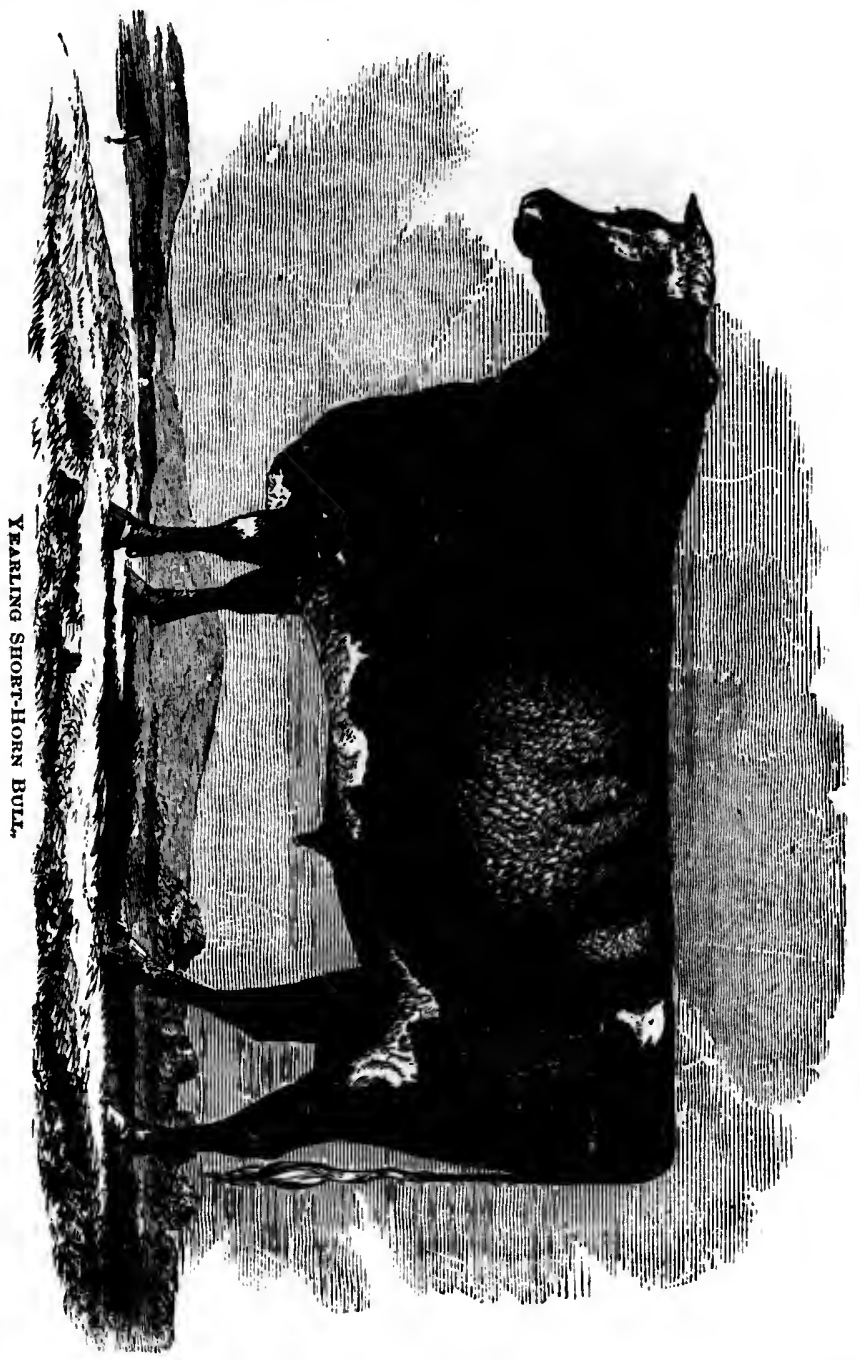

In 1852-3-4, several spirited companies were formed in Clinton, Madison, and other counties in Ohio, and in Bourbon, Fayette, and some 35 
other counties of Kentucky, and mnde importations of the best cattle to be found in the English herds, and after their nrrival hore, distributed

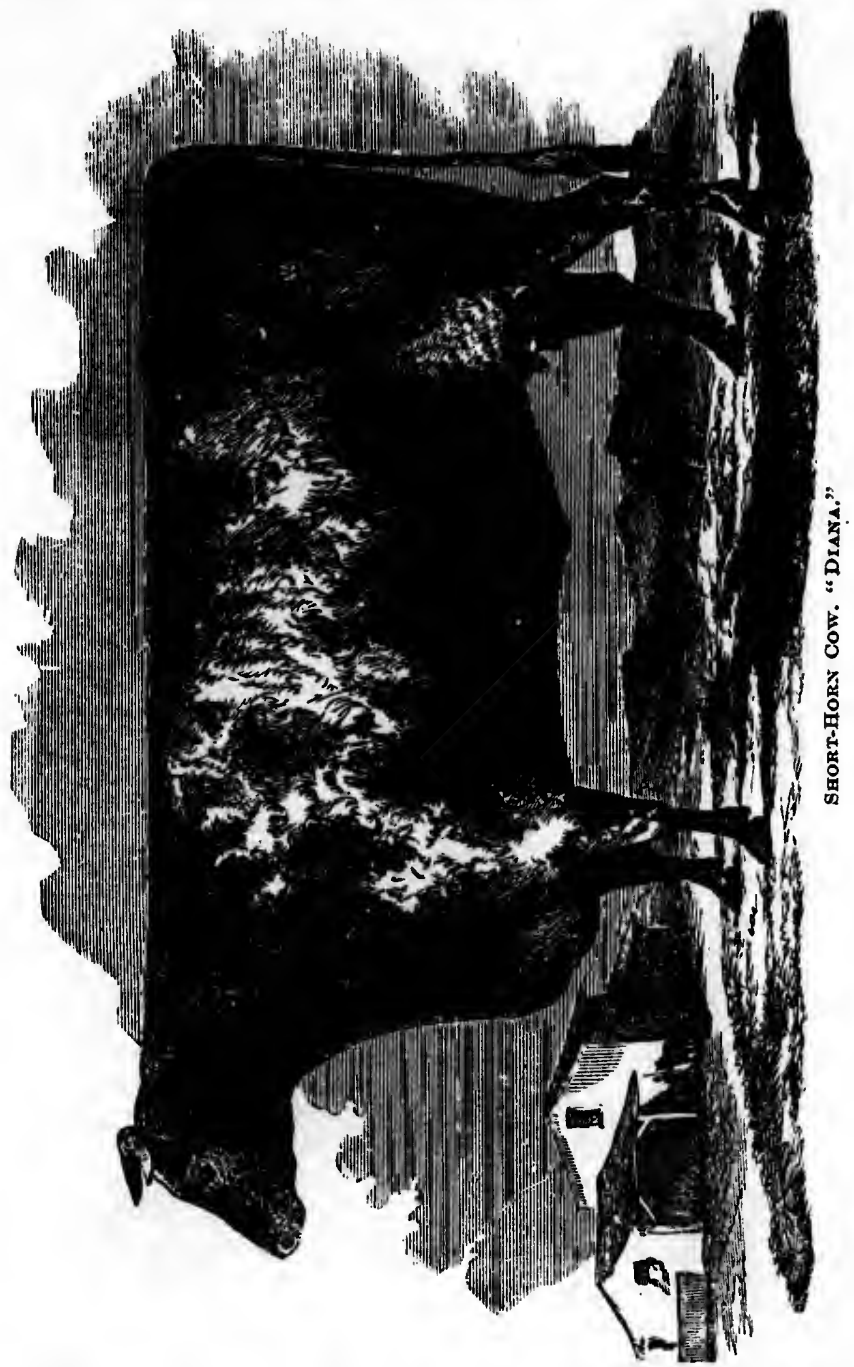

among their stockloolders. Mr. R. A. Alexander, of Kentucky, also, during those years, made extensive inuportations of choice blood for his 
own breeding, so that in the year 1856 , it may be said that the United States possessed, according to their numbers, as valuable a selection of Short-Horns as could be found in England itself.

Keeping pace with the States, a number of enterprising Canadians, since the year 1835, among whom miny be named the late Mr. Adam Fergusson, Mr. Howitt, Mr. Wade, the Millers, near Toronto, Mr. Frederick Wm. Stone, of Guelph, and Mr. David Christie, of Brantford, in Canada West, and Mr. M. H. Cochrane and others, in Lower Canada, have made sundry importations of excellent cattle, and bred them with skill and spirit. Many cattle from these importations, and their descendants, have been interchanged between the United States and Canada, and all may now be classed, without distinction, as American Short-Horns.

\section{Short-Horns in the West.}

In the Northwestern States the first importation of Short-Horns direct from England was by the Illinois Importing Company, in 1858. This was an association of gentlemen, a part of them members of the State Board of Agriculture, in connection with prominent breeders of the State. They returned in July of the same year with twenty Short-Horn cows and seven bulls, of approved blood, which were sold at auction on August 27th, at Springfield, to breeders throughout the Statc. They also brought over two stallions, three Cotswold rams, nine ewes, four Southdown rams, eight Southdown ewes, five Berkshire boars, four Berkshire sows, and ten boars and sows of Irish breeds; also Cumberland and Yorkshiro boars and sows. From this time on, various States in the West have taken up the breeding of Short-Horns as they have inereased in wealth and population, until now no finer herds can be found in any other locality; and, the fact that at the New York Mills sales individual animals brought prices all the way to over $\$ 30,000$, for exportation to England - prices which before this time would have been considered fabulous - shows conclusively that Short-Horns, as bred in the United States, have not suffered in comparison with those bred in their native land. No such prices were ever reached before in any country in the world; nor have they been since. To-day they are found wherever civilization extends. As beef producers they have no superiors ; as milk producers there are families eminent in this respect, and they have left their impress upon the stock of the country wherever introduced.

\section{Short-Horns for the Dairy.}

It has been held that the Short-Horns are as good for milking as they are for bcef. That they once were most excellent dairy cows there is no 
doubt. That Amorican Short-Horns of the present are not, as a elass, even decent milkers, there is as little doubt. The carly importations of Short-Horns were of the milking struins. For the last thirty years, however, they have been bred with such special reference to beef points and early maturity that it is now difficult to find a decent milker in any of the more fashionable strains of blood, and very many of the eows will not give milk enough to properly raise a calf. Once in a while, however, a very superior milking unimul appears, showing, by reversion, what the eapabilities of the breed might be in this direction.

That the early importations of Short-Horns were uniformly good in this direction, as well as admirable beef cattle there is no doubt. That they have left their impress upon the nutive cattle in this direction is unquestioned. That they exist to some extent in England and America, in particular herds, is cortain. We have seen them here and know they are there. They huve grown less, year by yeur, as the improvement of other dairy breeds becamo more and more manifest, until of late years little has been claimed for them as nilkers. Their great value as early maturity beef makers, - attaining great weight-luving superceded their purely milking churacteristics. Anong the better milkers may be nuned the descendants of the "Patton breed," the "seventeens," or the importation of 1817 , and some descendants of the Ohio importation of 1834. In fuct, this latter importation was made solely with a view to beef and flesh points, and since this time milk has been ignored by the more fashionable breeders both in England and America.

\section{Short-Horns for Beef.}

Throughout the whole West, especially, beef was the object sought. 'The land was eheap, fortile, and the pustures flush. Until within the last few yeurs, butter and eheese was not an exportable product, beef was. It is not strange that a class of nuimals was sought that would produce the most beef in the least possible tine. How this has been developed, the great herds of Ohio, Kentucky, Tennessee, Indiana, Michigan, Wis. consin, Illinois, Missouri, Iowa, and later, Minnesota, Nebrnska, and Kan sas, give ample proof.

In breeding there are no superior cattle in the world. Their usefulnes; as beef producers will continue to grow with the settlement of the country. The value of the bulls for erossing upon the ordinary stock of the country is becoming more and more appreciated every year. It will continue to be an inereasing integer for many years to come.

On the next page, as showing a modern bred Short-Horn bull, combining exccllent beef points, with great stamina and constitution, we give an illustration of "Hiawatha." . 
The modern Short-Hom has grent thickness of eareass, squnrish-sotund shape, rapid growth, carly maturity, and a ripeness at two, three, four, or five years, that is attained by no other breed. Many nro also the hand-

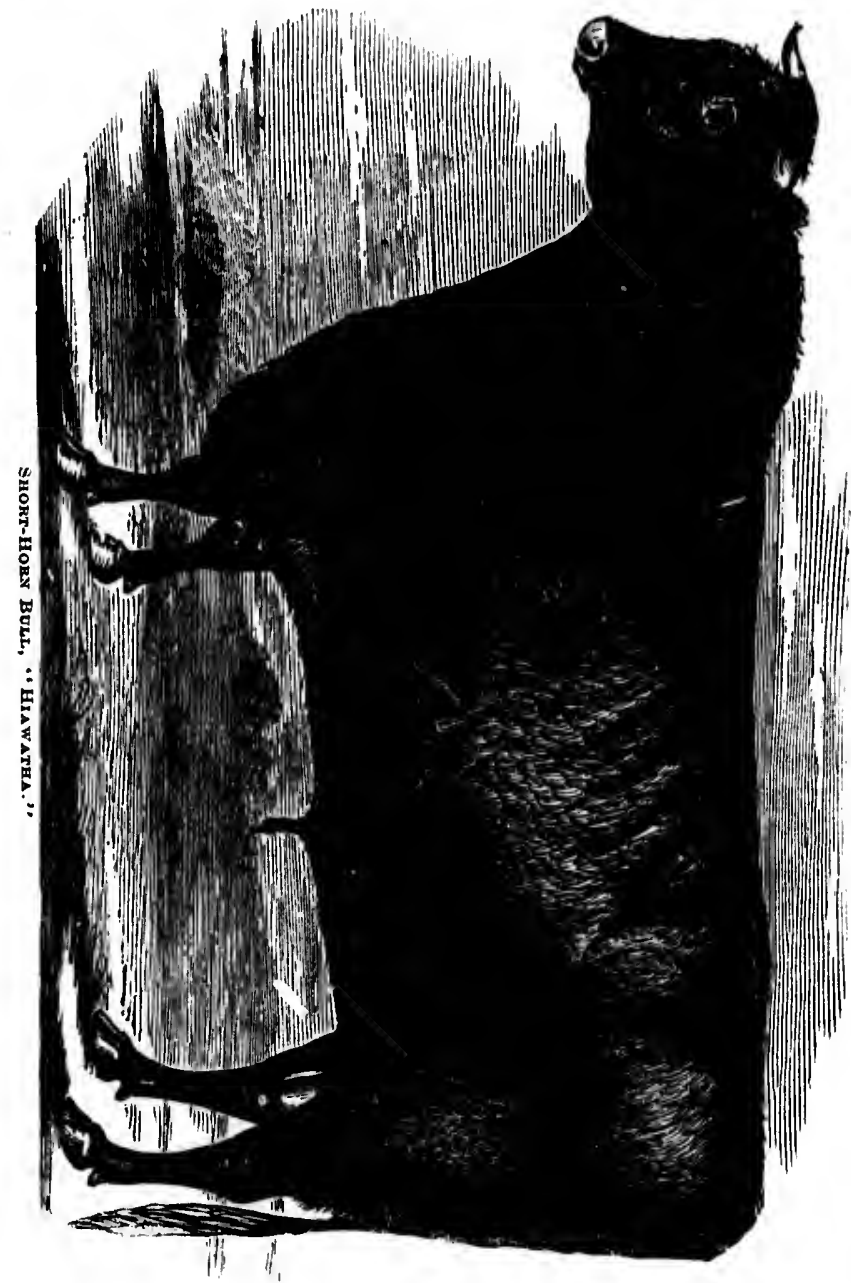

somest eattle to look at of any known breed-weight, substance and style being taken into consideration. 'There is a wonderful fullness in the carcass, extending to every part. The ehoice flesh is put on in part 
where ordinury cuttlo fuil ; the offul is exceptionully light, as light as it would be among common nutive enttle of two-thirds the weight. In the milk-yiolding Short-Horns thero is "I lendency to lomness. Muny avo

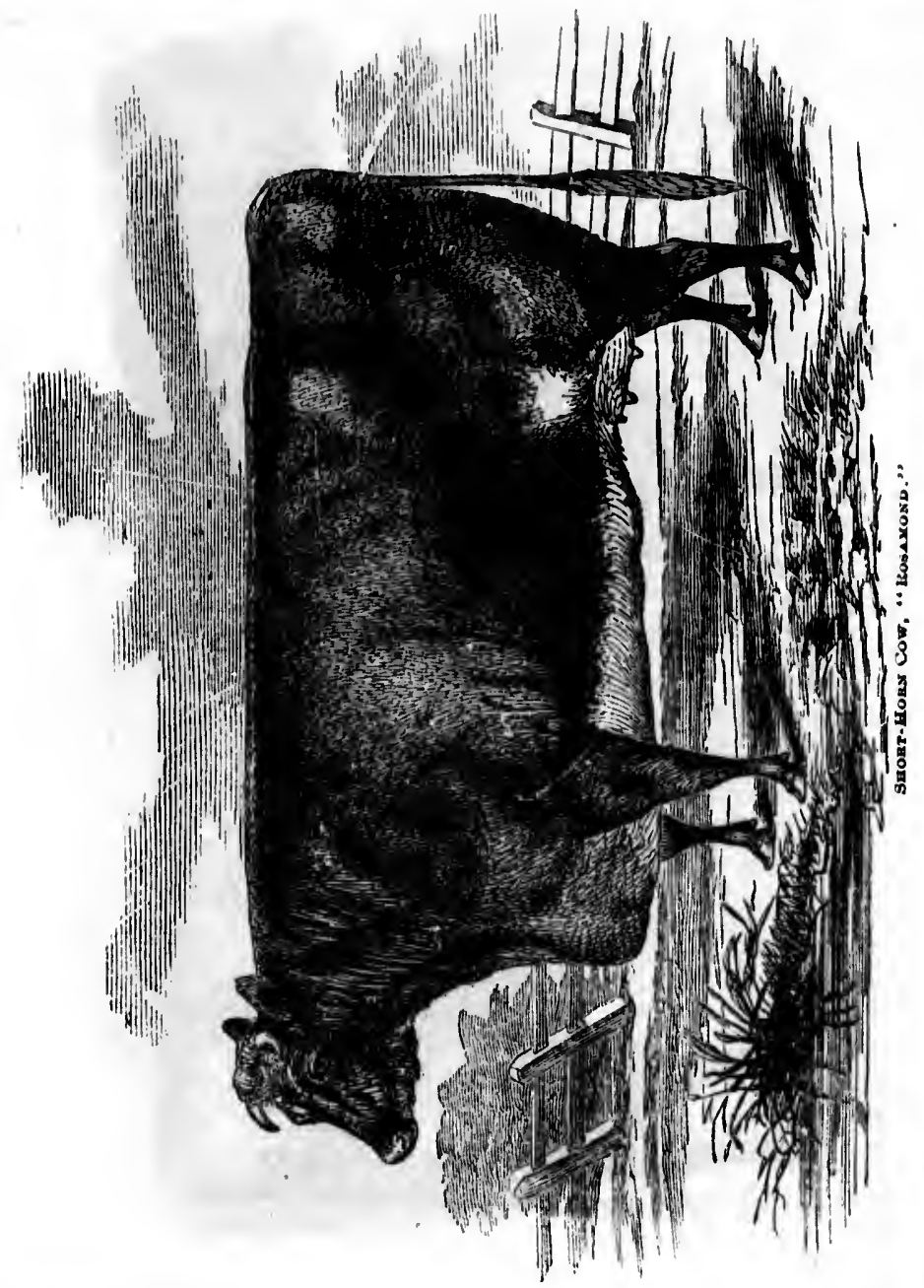

lighter before, flatter in the side, hut yot exceedingly firm ull over, from a dniryman's standpoint. In the beef animals there is a rotund fullness, a smoothness, a majosty, no whero else seen. 
As showing beof in the Short-Horn cow, in an eminent degree, wo give a portruit of the cow "Rostumond," showing not only good beof points but milking quulities us well.

\section{Points of Bhort-Horns Desoribed.}

Tho points of Short-Horns_-and which will upply in judging all beef nuimals, with slight vurintions, to lo herenfter described-are worthy of a somowhint minuto description. 'The points ure of two elnsses-those observed with the eye and those felt hy the touch. By the eyo ono ohserves the generil contonr of the animnl ; size, length, brendth, thickness, fineness of body, hend und limb; the loin, bnck, thigh, the spring of the rib and tho muner in which the animul is ribbed up elose to the hip boncs. 'The touch-thut is, the feeling under the touch-shows length and quality of the huir, thiekness and elnsticity of the skin. The eyo and expression of comntenunee is indientivo of disposition und temper. An elnstic, mellow und yet firm hide, of medium thickness, is an indieation of well marbled flesh, while a flonting, soft skin will indicate blubbery fat, und often dark colored flosh.

\section{The Butcher's Profit.}

The buteher in buying an unimal for beef has now-ll-duys but a single plject in view - the animal that will turn ont tho greatest anount of lem ment in the prime parts, with the lenst offil, mind only a modernto unount of fat; for fat is now one of the eheapest portions of the animul. Years ago, in the dnys of tallow candles, the revorse was the case. The back, loin, and ribs ure the choice bits; next the rump and thigh; then the shoulders; whilo the neck and hend are comparntively worthless. The sugicious breeder, whilo keeping this constantly in view, seeks to idd early maturity to good flesh. He who comes nearest to this has tho best animal, whatever the breed, or tho pedigreo of the purtieular breed. The buteher's block is the final, the erucial test.

A description of tho points of the Short-Horn was so carefully and admirably given by Dr. A. C. Stevonson, President of the Indiann ShortInorn Breeders' Association, at the first convention thereof, that we append a synopsis, accompanied with $n$ m outline of a Short-Horn, to which reference can be made, illustrating the prineipal points.

In this it will bo seen that $a, b, c, d, f, h, m, j, k, x, y, z$, represent tho inferior parts ; from the girth $p$, back, including $r, s, t, u, v$, the superior parts. From this it will be easy to understand the points and the respective numbers ns given in the scale.

Tho Hend.

"The head should be small." This is a vely imperfect deseription of 
the head, but in too many accounts, all that is given. If the size of the head were all that was of consequence, a pound difference in any case

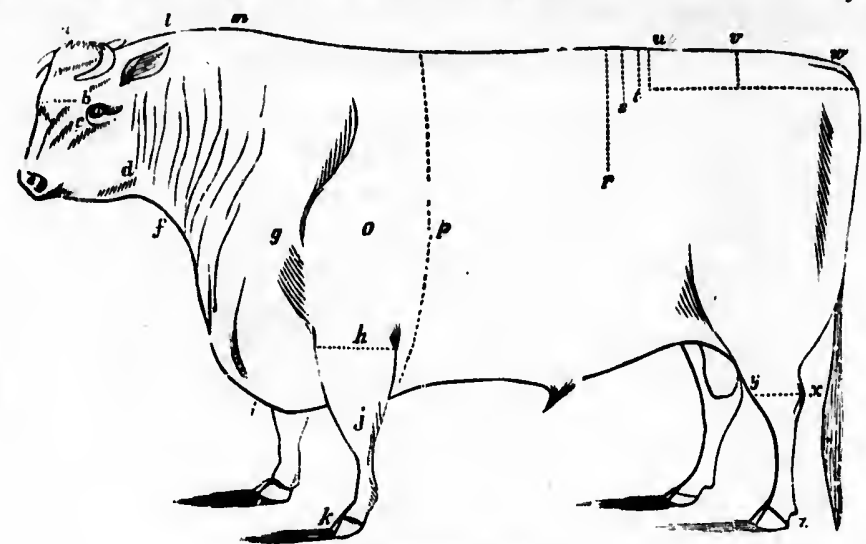

PonNts of Short-HoRn Bull.

would be of little consequence in the sale of a bullock. It is the form of the head that becomes of so much interest to the breeder. The head above the eyes should be wide, giving space for large cerebral development. The intelligence of the animal depends upon a well-developed brain and nervous system; upon which, also, so much depend the vigorous and healthy action of the organs of digestion and assimilation; the circulation and the vital functions generally; the intelligence and temper of a cow depends much upon a well-developed brain. It will be found by observation that most vicious beasts have small upper heads, an $\dot{\alpha}$ are large below the eyes. Again, the upper head should be wide, to give width to the articulations of the lower jaw. It is necessary that the part of the mouth where the food is to be masticated should be large, that the supplies required for the stomach may be well masticated and re-mastica ted in chewing the cud. There is another reason for width at the base of the head and betwecn the angles of the lower jaw : it is here that the very important passages have their entrance, which supply food for the stomach and air for the lungs. Close at hand, also, is the important connection of the spinal marrow and the brain, to say nothing of many large and important blood-vessels that find their wny to the head. These considerations we think conclusive as to the necessity of size of head.

The portion below the eyes, the face, should be comparatively small. Its principal office is to gather food and air. Thin lips and elastic nostrils are wanted. The eyes should be large, bright and lively, and yet quiet. The physiognomy of the ox is as clearly indicative of his character 
as that of a man is written upon his face; and the reason that less is indicated in the face of an ox is because he has fewer vices, and has been guilty of fewer transgressions. A small dark eye, set in a dark circle, with a large face below and a narrow head above, will indicate an animal that is bad tempered, wild, and consequently a poor feeder. The circle around the eye should be of a bright yellow color, the nose the same. These considerations may seem trifles, yet this color is the result of a peculiar secretion, and the inference is a probable one, at least, that other secretions will be apt to rescmble it in color. Hence, the sccretion of milk will be apt to resemble it in color, and a bright colored flesh is belokened by these peculiar secretions as indicated in the color of the nose and circles about the eyes. As a very large ear mostly indicates sluggishness, one of medium size is preferable. A bullock of fine organization will manifest very clearly his impressions by the movement of his ears. If he flees from danger his ears are erect, or a little inclined backward, that he may be the better warned of danger behind. If he is in haste to mect a kind master, who is bringing him a desired meal, the eur is presented forward. The horns should be clear, without black tips or any black marks whatever-some say of a waxy color, some again, claim that they should be flat in Short-Horns. But these matters are, most of them, non-essentials. We dismiss the head, after attaching it to the neck in its proper position-not at right angles, but at an angle of so many degrees that, with the under part of the neck it forms an arch. This gives a better throat and a freer passage for the food and air to the stomach and lungs, and is graceful withal.

\section{The Neek.}

The neck expresses very much less to the breedor than the head and face. The neck should be just long enough to enable the taking of food easily from the ground. It should be strong and well muscled upon its sides, covering at its base the points of the shoulders well, and at its junction with the head it should be small and round, with its skin fitting it pretty much as a well-fitting stocking does the leg-the under line of the neck with the under line of the jaw. A thin, broad neck, is sure to indicate weakness and poor feeding and fattening qualities. Animals baving such may well be avoided as breeders.

\section{Contour of the Body.}

The butcher, the breeder and the stock dealer, may now meet and consult profitably on the general contour of the body. Here the opinions of the former may be a lopted, as he fixes the price of all 'butchers' stuff.' The ox of givea weight that will sell for most in mar- 
ket possesses the points that must be adopted. These points are now, however, well established, and wo have ouly to refer to them and notice the reasons on which they are founded. We proceed to name then before we give their rationale. In general contour the body should be nearly a square. The crops should be wide. The line of the back should be straight; the line of the belly nearly so, swelling a little behind the ribs; the flank low; the ribs barrel-shaped; the loins wide, and the rump long and wide; the back should be wide, and tho thigh should be long and wide; the legs short and comparatively small, or at least not coarse; tail light; hair soft and fine. The color should bo red or white, or a mixture of the two, as roan or pied.

As has already been said, the body should be nearly a square. The vital currents moving in short lines are moro effective than when moving in those of great length. The blood moving from the heart along very extended channels, flows with much less force as it recedes from the cause that set it in motion. The same is probably truo of the nervous currents. The great vitalizing organs aro located near the center of the system - a provision of nature by which the vital currents are shorter than under any other arrangement. Here is the heart sending out its great currents of arterialized blood in all directions, to supply and nourish all the members of the body. Sitting over it is that wonderful air machine, tho lungs, receiving the entiro venous currents - an atmospherie bath - by which they are so renovated and changed as to make the blood again fit for the heart's use, to which it is returned by the shortest possiblo route. Theso organs lie enensed together, and never eease their operations night or day. But just here in this great center is another great vitalizer of fully equal importance-the stomach. Here the food is received and changed into chyle, which is at once thrown into the circulation, where its office of supplying the system is performed. Now, the nearer a body is compacted around these great vitalizing systems the more effectual will be the supplies. Observation fully sustains these views. A very lengthy bulloek never fattens so readily as a short one. The breeds of hogs with long bodies are known not to fatten so readily as those of short, square forms, as the Siamese and Chinese. The samo is trne of sheep, and also of the horse. And evelt in man, wo rarely find a corpulent man who will mensure six feet. Obesity will generally be found under six feet. Health and vigor is equally confirmed by observation, as a result of the square structure. Longerity may also be claimed with the greatest propriety for the same proportions. A bullock with a square frame will be sure to possess all the qualities of health and vigor, and will feed and fatten as well or better than a long one. 


\section{Broad in the Crops.}

The animal broad in the crops has a better back; but it is also evidence of a better rib beneath the shoulder-blade, giving greater width to the chest within, and consequently greater play to the lungs. This position of the shoulder-blade enables the legs to be brought more gracefully under the chest beneath. There aro some beasts whose fore-legs stand so wide apart that they very mueh resemble two stieks stuck into a large pumpkin. Such animals are considered awkward and inconvenient at least.

\section{The Back Should be Straight and Broad.}

A broad back affords valuable roasting bits, and will be the delight of the butcher. The straight back affords a better spinal column, and gives the proper space to the cavities beneath, which, as we have just seen, aro occupied by the most important organs. A straight line also gives to the ribs a more graceful as well as more convenient attachment.

\section{Ribs Should be Barrel-Shaped.}

The ribs rising well from the spine, giving to the body a round or barreled shape, gives much more room to the organs within - the heart and lungs - than there would be if the ribs descended in such a manner as to give a fint side. A beast with flat sides, and consequently a narrow throat, will lack greatly in vigor and health, and all the essential qualities that constitute a good bullock. A bad rib gives poor space to the abdominal organs which lie immediately behind those of the chest, unles. the belly is greatly sagged, which is generally the case.

\section{The Loin Should be Wide.}

This is an interesting point to those who love choice bits and are willing to pay well for them. The butcher makes large estimates here, and is sure to suit liberal purchasers. But nature is ever true to herself, for here, as elsewhere, beneath a broad loin she has provided large space for important organs, as the bowels, kidneys, and the organs of the pelvis. The rump of a good Short-Horn is n very nice point. The back should extend out straight to the setting on of the tail. The thigh should pass up to this point nearly straight, so as to make the junction a right angle. This point, in many beasts, will be found to be a circle, which is unsightly and causes a loss of prime bcef.

\section{The Legs.}

The legs should be short. There are preeisely the same reasons for 
objecting to long legs that there are to long necks or long bodies. Observation proves a leggy animal to be not so good a feeder as one with short limbs. The bone of the leg should be fine and smooth, and not too large. The legs should stand well under the animal, and the hocks directly in line with the body, so that in moving, the hocks will be well separated, or about as far apart as the hind feet. The fore-legs should be straight and stand well under the chest, that the animal may have an easy and frec movement. The inner side of the fore-legs, as it passes the sternum, presents a beveled appearance, to bring the limbs to their proper position beneath. Upon the proper position of the limbs depends that case and gracefulness with which a bullock should move. It may be thought of no conserquence how a bullock moved so that he is able to get to the market, but be assured there is much in it, it evinces strength and health, which are indispensable in feeding. I have seen Short-Horns carrying two thousand pounds and upwards, with limbs so perfect that their movements were as nimble as if they were carrying but a thousand.

\section{The Touoh.}

By this the butchers ascertain beforehand the quality of the flesh. By it the breeder ascertains the aptitude to fatten as well as the quality and quantity of flesh that the animal will carry.

Of all the qualities $o^{f}$ the $o x$, this is probably the most difficult to understand. It is the peculiar sensation of softness and elasticity that is produced by the pressure of the hand on different parts of the body. This sensation depends, in part, upon a large cellular development benesth the skin and between the muscles, and part upon the muscular structure, adapting. itself to the laborious duties it has to perform. It is, therefore, to the cellular and muscular tissue that this sensation of touch is to be attributed. It is very common to find a softening of the muscular fibre as an accompaniment or a precursor of disease that may mislead. The same may be observed in the aged of both man and beast. What is 'touch,' or what is it to 'handle well?' How is it to be distinguished from that which portends bad health and old age? By its elasticity-its power to replace the parts when pressed-a springy sensation. Mellowness from disease has a sluggish feel and moves slowly when under the hand; to a less extent, it is true, still something of the same that is manifested in the pressure of the fingers on a dropsical limb as compared with a healthy one. In the one the indentions replace themselves sluggishly, whilst in the other with a ready elasticity.

It will require much practice to become an adept in this knowledge. Still many useful lespons may be duily had by the examination and hantling of one's own stock. Comparative handling will afford much 
assistance. Take those animals that are known to accumulate fat readily and largely, as the opossum or the bear, or any other known to take on fat readily, and you will find a peculiarly soft and mellow 'touch.' Those breeds of swine, as the Chinese or Siamese, that are known to accumulate fat largely, as compared with some of the poorer wood breeds, will offer good and ready illustrations. But probably the most ready illustration will be found in man himself. All that class of persons disposed to corpulency will be found to have a soft mellow touch, while those disposed to leanness will be found rigid and hard. This may be readily recognized in shaking hands. A very delicate lady may sometimes be found to have a hard hand as well as a sharp tongue. Smooth, soft skin will also be found belonging to this class of persons.

\section{The Skin.}

The skin should be thick, soft and elastic_fitting alike either a poor or fat ox. A lean animal, with an inelastic skin stretched upon him, could not fatten for the want of space to expand in. But with an elastic skin he may be swelled to great dimensions in what seemed to be but a covering for his bones. The skin performs very important functions in the animal economy. It is not only a covering for all the parts beneath it-a protector against cold and heat, and all external causes of danger, but it is the seat of a vast system of minute blood vessels and capillaries, of exhalents and absorbents. A vast nervous tissue centers here that renders the skin sensitive in the highest degree. The great viul worth and importance of the skin may be readily appreciated by any injuries done it. The rapidity with which extensive burns destroy life, may serve as a sufficient illustration. 'Destroy my skin, and you shall have my bones also.'

The Eair.

The hair should be thick and fine, forming a protection against inclemencies of weather. It is not sensitive, and is, therefore, a proper shield to the whole body, and it is an evidence of the wisdom displayed in the creation of this family of the animal kingdom, that its hair-its outer garment, against which all injuries must first come-should be without sensation-a complete cdat of mail, injuries to which cause no pain. Fine hair is also an evidence of a finely organized skin, a skin exquisitely finished in its whole structure of minute vessels and tissues. A skin thus delicately organized is also evidence that other organs are alike constructed. Nature, in all her parts, undoubtedly produces a correspondence, so that if one part is of a peculiar structure, either fine or coarse, other parts are apt to correspond. Parts seen may be cousidered indica- 
tive of parts not seen. It may be permitted to add that in all the scrub cattle that I have grazed and fed, I have never found (ne with fine silky hair that did not fatten well and make a desirable bullock.

Color.

Short-Horns are red or white, or these colors blended as roan or pied. Fashion, for the time, may make one or the other of these colors popular. This is probably so now with the red color. It may be so of another color in'a few years. A caprice that excludes all but the red color is injurious. It limits improvement and confines it to a limited portion of the breed. It encourages the use of inferior auimals just to obtain a fashionable color, and rejects better ones because they are of different color. There is, in consequence, great danger of deterioration of this noble breed of cattle as a result of such puerile practices. If the breed is to be kepi up to-its past high standard tho very best selections should he bred regardless of color, provided it is the one peculiar to the breed. We would admonish breeders and lovers of this noble race of cattle to give no encouragement to such departures; they are evil, and that continually.

\section{Perfection.}

Both ignorant and cultivated alike; the ordinary breeder and the scientific one; the practical man and the visionary one; each will establish in his own mind an ideal of what any object should be. When this ideal is required to stand the test of practical experience, to be defincd by a scale of points, not one in ten, even among those who think themselves competent to establish a standard of excellence can do so, point by point. The reason is he has never read, nor has he educated himself in any other way to that exactitude of judgment required in matters of such nicety; in other words we have not the scientific iden of what is necessary in the premises; no absolute rule to go by, and so the whole inounts, after all, to something very like mere guessing. For dairy purposes the udder of the cow is the strong point. In animals bred for their flesh, the meat is the essential thing and also that it be laid on in the prime parts.

To enable any person to judge more or less correctly according to the study he gives, and the manner in which he has educated his eye and touch, we append the scale of points for judging Short-Horns, as found in the American Herd-Book.

In studying this scale it will do quite well for all beef breeders-always bearing in mind the difference in make up of the breed. Thus the ShortHorns will be found full in the rump behind, the Devons and Herefords more pointed, and essentially different in other respects ; yot these very 
all the scrub with fine silky

rom or pied. f these colors may be so of Il but the red it to a limited mimals just to ise they are of of deterioration e praetices. If very best selece one peculiar to this noble race ; they are evil,

der and the scienwill establish in When this ideal be defined by a think themselves o, point by point. mself in any other s of such nicety; necessary in the mounts, after all, oses the udder of flesh, the meat is ie parts. according to the cated his eye and -Horns, as found breeders-always Thus the Shortns and Herefords 5 ; yot these ver?
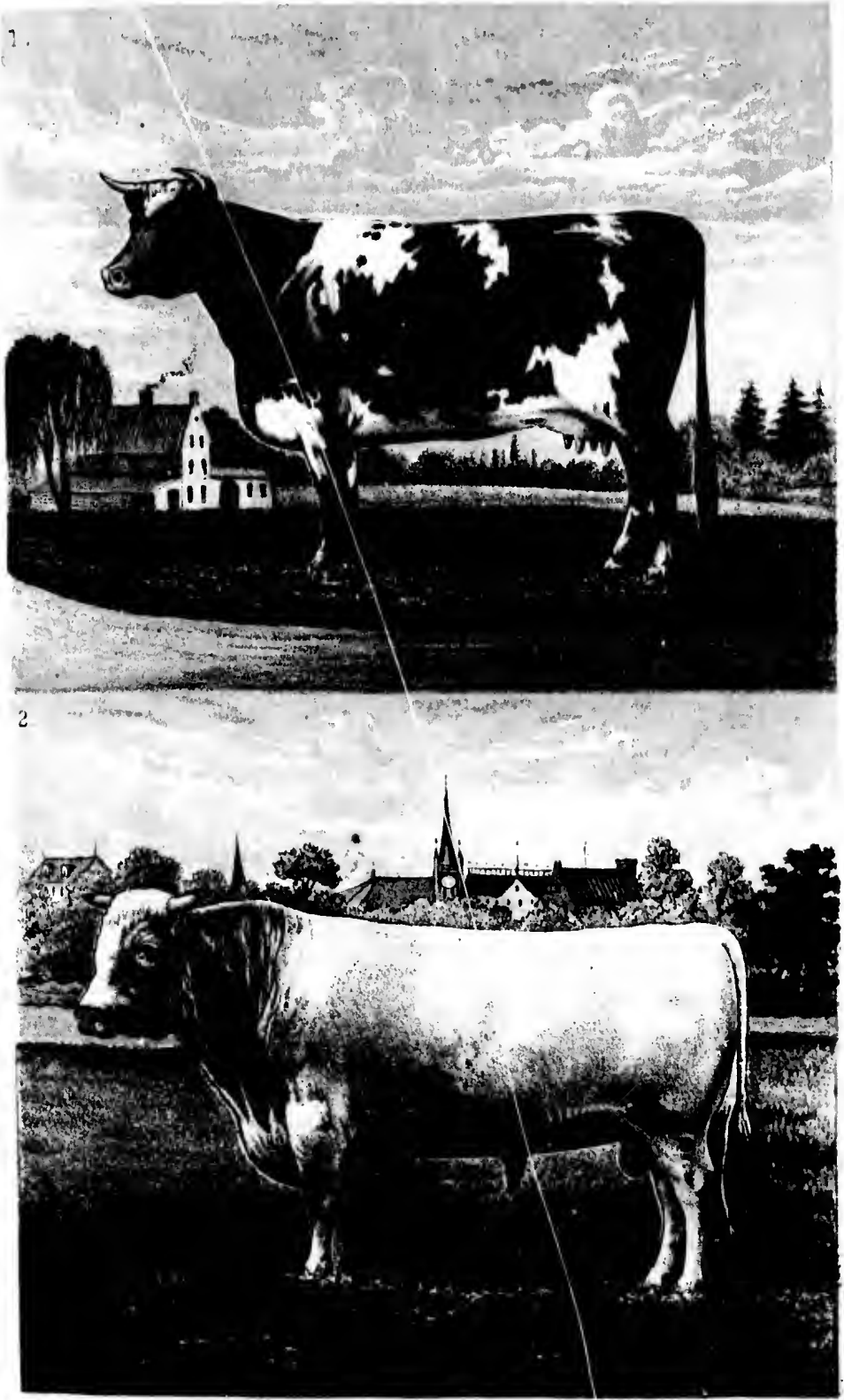

\section{SHORT HORN STOCK.}

Fine specimens of the breed of Short Horns. No. I, the celebrated animal, "Baroness the Seventh;" No. 2, the noted $\$ 25,000$ bull, "Star of the Realm." Property of A. J. ALEXANDER, Woodburn Farm, Ky. 
differen of the such thi near it have but too ferw,

ArT. 1.repu to $f$ givin maki ART, 2.dimir tha b color and $t$ ered - short, eyes $b$ a yell and $w$ of a c open ; ART. 3.-N head roundi ART. 4.-C line th Art. short fore-ar full abd strong; the hoo ART. 6.-Bi ART. 7.-Ba setting bones of the bael without with 
differences constitute their value; their beef is certainly better than that of the Short-Horn; but still they fail in other particulars. There is no such thing as absolute perfection in any thing finite. We simply come as near it as possible. The Short-Horns, in all their attributes, certainly have but little more to be desired as beof makers, and some families, alas too fow, are deep and excellent milkers.

\section{Bcale of Points for short-Eorn Bulls.}

ART. 1.-Purity of breed on male and female side; sire and dam Pornts. reputed for docility of disposition, early maturity and aptitude to fatten; sire a good stock-getter, dam a good breeder; and giving a large quantity of milk, or such as is superior for making butter or chaese.

ART. 2.-Head muscular and fine; the horns fine and gradually diminishing to a point, of a flat rather than a round shape at twe base, short and inclined to turn up, those of a clear, waxy color to be preferred, but such as are of a transparent white, and tinged with yellow, admissible; ears small, thin and covered with soft hair, playing quick, moving freely; forehead short, broad, especially between the eyes, and slightly dished; eyes bright, placid, and rather prominent than otherwise, with a yellow rim around them; lower part of the face clean, dished and well developing the course of the veins; muzzle small, nose of a clear orange or light chocolate color; nostrils wide and open; lower jaw thin; teeth clean and sound. - - -

ArT. 3.-Neck fine and slightly arched, strongly and well set on the head and shoulders, harmoniously widening, decpening and rounding as it approaches the latter point ; no dewlap. - .

ART. 4.-Chest broad, deep and projecting, the brisket on a lower line than the belly.

ART. 5.-Shoulders broad, strong, fine and well placed; fore-legs short, straight, and standing rather wide apart than narrow; fore-arm muscular, broad and powerful, slightly swelling and full above the knee; the bone fine and flat; knees well knit and strong; foot flat, and in shupe an oblong semi-circle; horn of the hoof sound and of a clear waxy color. $\quad-\quad-\quad-\quad-2$

Art. 6.-Barrel round and deep, and well ribbed up the hips. - 4

ART. 7.-Baek short, straight and broad from the withers to the setting on of the tail ; cropss round and full ; loins broad; huckle bones on a level with the back; tail well set, on a level with the back, fine and gradually diminishing to a point, and hanging without the brush an inch or so below the hock, at right angles with the back. 
ArT. 8.-Hind quarters from the huckle to the point of the rump well filled up; twist well let down and full; hind legs short, struight, and well spread upart, gradually swelling and rounding above the hock; the bone fine and flat below; legs not to cross each other in walking, nor to straddle behind.

ARr' 9.-Skin of medium thickness, movable and mellow; a white color is admissible, but rich cream or orange much preferable; hair well covering the hide, soft and fine, and if underconted with soft, thick fur in winter, so much the better; color, pure white, red roan, bright red, or reddish yellow and white. (A black or dark brown nose or a rim around the eye, black or dark spots on the skin and hair decidedly objectionable, and indicative of coarse meat and bad blood.)

Ars. 10.-Good handling.

Arr. 11.-Sure stock-getter.

ART. 12.-Stock, when made steer, certain to feed kindly for beefers at any age, and make prime beef.

ART. 13.-General appearance.

Perfection.

Bcale of Points for short-Horn Cows.

Arr. 1.-Purity of breed on male and female side; sire and dam reputed for docility of disposition, early maturity and aptitude to fatten. Sire a good stock-grtter. Dam a good breeder; giving a large quantity of milk, or such superior for making butter or cheese.

ArT. 2.-Head small and tapering; long and narrower in proportion than that of the bull. Horns fine and gradually diminishing to a point; of a flat rather than of a round shape at the base; short, and inclined to turn up; those of a clear waxy color to be preferred; but such as are of a transparent white, slightly tinged with yellow, admissible. Ears small, thin, and well covered with soft hair; playing quick, moving freeely. Forchead of good breadth between the eyes, and slightly dished. Eyes bright, placid, and rather prominent than otherwise, with a yellow rim round them. The lower part of the face clean, dished, and well developing the course of the veins. Muzzle small; nose of a clear bronze, or iight chocolate color-the former much preferred. Nostrils wide and well opened. Lower jaw thin. Teeth clear and sound. 
ART. 3.-Neck fine and thin, struight, und well sot on to the head and shoulders, harmoniously widening, deepening, and slightly rounding in a delicnte feminine manner as it approaches tho

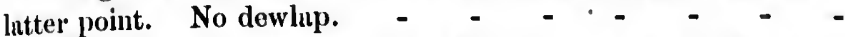

ART. 4.-Shoulders tine and well placed. Fore-legs short, straight urrl well spread apart. Fore-arm wide, muscular, slightly swelling, und full above the knee; the bone fine and flat below. Kines well knit and strong. Foot fint and in the shape of an oblong semi-cirele. Horn of the hoof sound, and of a clear wixy color.

Акт. 5.-Chest broud, deep and projecting-the brisket on a lower line thin the bolly.

ART. 6.-Barrel round, deep and well ribbed up to the hips. -

ART. 7.-Back short, strong, straight from the withers to the setting of the tiil. Crop round and full. Loin broad. Huckle bones on a level with the back. Tail well set, on a level with the back or very slightly below it; fine and gradually diminishing to a point; and hanging, without the brush, an incl or so below the hock, at right angles with the back.

ART. 8.-Hind quarters from the huckles to the point of the rump long and well filled up. Twist well let down and full. Hind legs short, straight and well spread apart; gradually swelling and rounding above the hock; the bone fine and flat below. Foot flat, and in shapo of an oblong semi-circle. Horn of the hoof sound, and of a clear waxy color. Legs not to cross each other in walking, nor to straddle behind.

ART. 9.-Udder broad, full, extending well forward along the belly, and well up behind. Teats of a good size for the hand; squarely placed with a slight oblique pointing out; wide apart; when pressed by the hand the milk flowing from them freely. Extra teats indicative of good milking qualities, but should never be milkeu, as they draw the bag out of shape. Milk veins large and swelling.

ART. 10.-Skin of a medium thickness : movable and mellow; a white color is admissible, but a rich cream or orange much preferable. Hair well covering the hide; soft and fine, and if undercoated with soft, thick fur in the Winter, so much the better. Color pure white, red, ronn, bright red, red and white, spotted roun, or reddish and yellow and white. (A black or dark brown nose, or rim around the eye, black or dark brown spots on the skin and the hair decidedly objectionable, and indicative of coarse meat and bad blood.) 
AnT. 11.-Good hundler.

AkT. 12.- Suro and good breeder.

Arт. 13.-Generul ирpenranco.

Perfection.
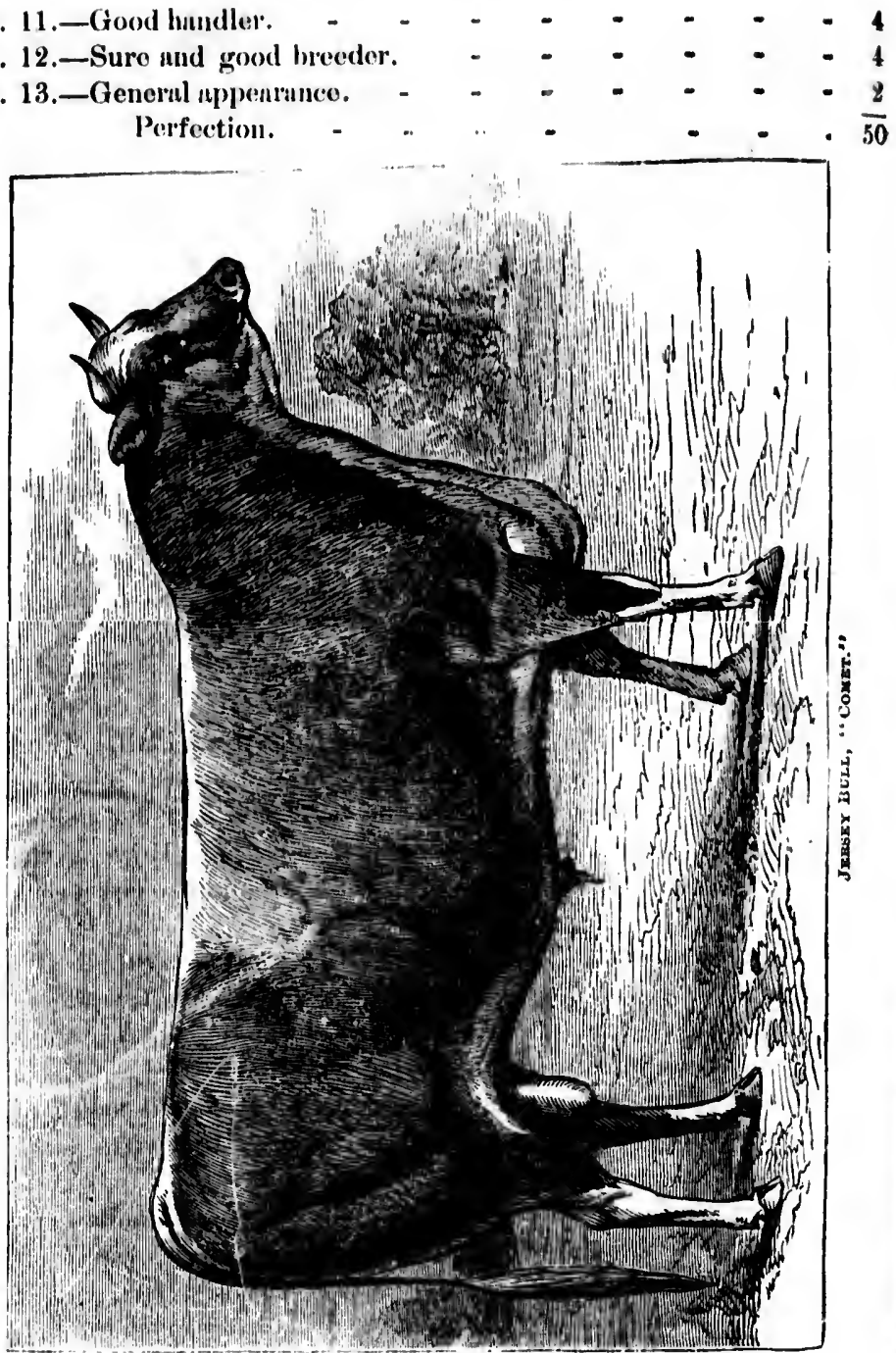

\section{The Alderneys.}

In the British Chammel, between Great Britain and France, are in number of islands noted for their salubrity of climate and fertility of soil. Many years ago these islands, particularly Jersey, were noted for their 
superior fruit, und large qunutities of cider and perry were mumully minde there.

Of late yeurs these islunds, Alderney, Jersey, und Guemsey, huve hecome celebrated throughout England und America, for their loreed of cuttle; the cows of which give milk of unsurpussed richness.

These cattle are undoubtedly of French origin. The Normundy enttle ure larger than the Jerseys, and Youatt says, huve a grenter tendency to fatten. He passes then by, in his admiruble work on cuttle, with senreely more than a mention; this is to be regretted, since he was so rureful and conscientious a historian. He says :

"'They are found mainly in gentlemen's purks and pleasure grounds, and they maintuin their occupaney there, purtly on account of the richness of their milk, and the grent qunntity of butter which it yields, bnt more from the diminutive size of the animuls. Their real ugliness is passed over on these accounts; and it is thought fushionalle that the view from the breakfast or drawing room of the house should present an Alderney cow or two grazing at a little distance.

"'They are light red, yellow, fawn or dun colored; short, wild-lorned, deer-necked, thin, and small-boned; irregularly and often very awkwardly shaped."

\section{A Prejudiced Btatement.}

Qnoting from Mr. Parkinson, who, Mr. Youatt says, seems to have ind in determined prejudice aguinst them, he writes:

"Their size is small, and they are of as bad a form as can possibly be described; the bellies of many of them being four-fifths of their weight. 'The nock is very thin and hollow; the shoulder stunds up, and is the lighest palt; they are hollow and narrow behind the shoulders; the chine is nearly without flesh; the hucks are narrow and sharp at the ends ; the rump is short, and they are narrow and light in the brisket." Mr. Youatt adds for hiniself :

"This is about as bad a form as can possibly be described, and the picture is very little exaggerated, when the animal is analyzed, point $b y$ point; yet all these defects are so put together, as to make a not unplewsing whole."

Mr. Youatt, however, compliments chem with giving exceedingly rich milk, and with fattening in a surprising mamner when dry.

We have quoted the above for two reasons: one as showing probably what may have been nearer the truth than we might naturally expect from seeing the best specimens now, and the other as showing that this breed has mado a grent advancement since his day, both in quantity of milk given, and in symmetry and perfection of form. 


\section{From an American Standpoint.}

Mr. Lewis F: Allen, the best known historim of American cattle, says:

"Beginning with the hend-the most characteristie feature-the muzzle is fine, the nose either dark brown or black, and occasionally a yellowish shade, with a peculiar mealy, light-colored hair running up the face into a smoky hue, when it gradually takes the color of the body; the face is slightly dishing, clean of flesh, mild and gentle in expression, the eye clear and full, and encircled with a distinct ring of the color of the nose; the forehead is bold, horns short, curving inward, and waxy in color, with black tips ; the ear is sizable, thin, and quiek in movement. The whole head is original, and blood-like in appearance, more so than in

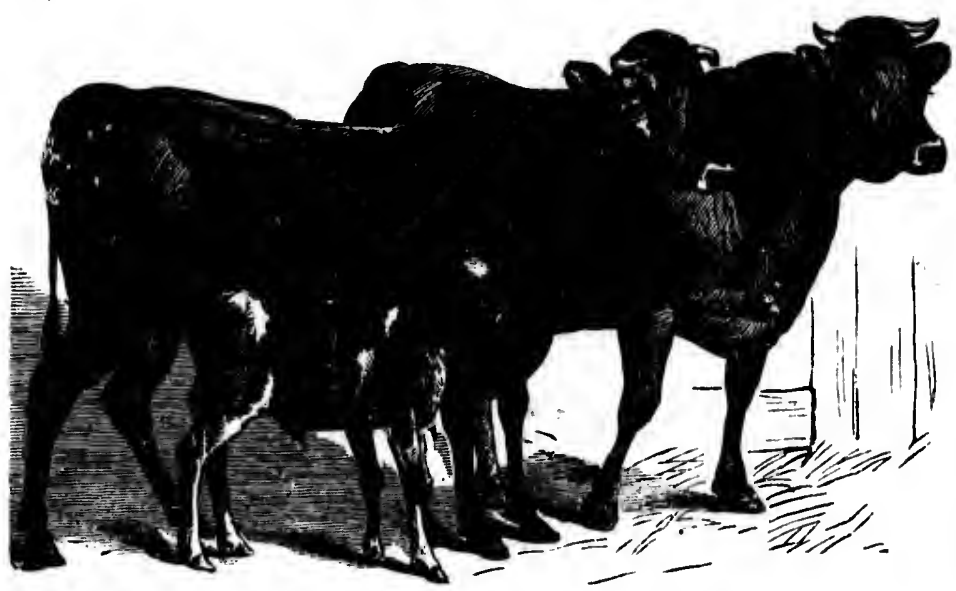

A Trio OF JERseYs.

almost any other of the cattle race-reminding one strongly of the head of our American Elk. The neck is somewhat depressed-would be called ' ewe-necked,' by some - but clean in the throat with moderate, or little dewlap; the shoulders are wide and somewhat ragged, with prominent points, running down to a delicate arm and slender legs benenth; the fore-quarters stand rather elose together, with a thinnish, yet well developed brisket between ; the ribs are flat, yet giving sufficient play for good lungs; the buek depressed, and somewhat hollow, the belly deep and large, the hips tolerably wide, the rump and tail high, the loin and qunrter medium in length, the thigh thin and deep, the twist wide, to necommodate n good sized udder, the flanks medium, the hocks or gambrel joints crooked, the hind legs small, the udder eapacious, square, 
set well forward, and covered with soft, silky hair ; the teats fine, standing well apart, and nicely tapering ; the milk veins prominent."

\section{Charaeteristie Colora.}

The colors are mostly light red ur fuwn, and black, mixed and plashed with white ; the solid colors are, we think, generally fuvored, and, to our mind, the best cattle, as showing careful breeding, though we have seen the most superior cattle among all these colors. So we have seen some distinctly roan, with round, quite smooth forms, called pure; they should always be avoided, as there is more than a suspicion that such have Short-Horn blood in them, which can do this breed no good, but on the contrary, harm.

The breed is distinctly a milk breed, and is of 110 value whatever except as yielding fair messes of exceedingly rich milk-giving largely of the most superior cream, producing hard, and most delicately fluvored butter. Thus any cross on this ancient and carefully bred stock must necessarily injure them in the points where they excel other cows. These are: Superiority of the milk, creain and butter, golden in color, delicate in texture and flavor, and commanding prices in the market, from wealthy eitizens, that no other nake can reach.

\section{They are. Milking Cows.}

Whichever of the three varieties may be chosen, they should be bred for this and nothing else. Whether they be from Alderney, Jersey, or Guernsey, no infusion, of other blood can improve them, neither can they improve any other breed. The bulls may improve our native cows, if the cows be good milkers, the hereditary milking qualities of the race being pre-potent in the progeny. For this improvement, however, none but pure blood bulls should be used, and this rule will hold good in all breeding.

The pure animal is pre-potent, the grade is not, and pure bred animals of all the superior races are now so plenty that it will not pay to use grade bulls for the improvement of stock.

\section{The Value of Purity.}

To show the value of purity, we will perhaps, find no more appropriate place than this.

A thorough-bred animal upon native stock produces in the first succeeding generation an animal partaking equally of the blood of the sire and dam, or what is called a half-blood. The next generation, or the produce of a full-blood and $n$ half-blood will give a three-quarters-bred animal. 
The young of a pure-bred and three-quarters-bred will give a seven-eighthsbled. Following in the same line the next generation will give an animal possessing fifteen-sixteenths of pure blood.

In renlity it will be far more thun we huve stated, for the pre-potent element of pure blood, constantly present, will continually be an increasing integer in the progeny. Hence animals from seven-eighths to fifteensixteenths-bred, cannot be distinguished from one purely bred, except by a most critical, and at the same time expert judge. For all practical purposes they are fully equal to an animal purely bred, that is to say, as dairy cows, bit here the comparison must end. A taint of impure blood once in, cannot be bred out for many generations-never in fact. There is always danger of reversion. One may, theoretically at least, breed grindes up for a thousand years, and yet not have purely bred animals. Hence the extraordinary prices paid for stoek, the pedigrees of which have been kept absolutely without taint of admixture.

\section{The Value of Points.}

So important is the question of symmetry of form, and points of excellence, in stock, viewed as integers in the make-up of an animal-real value being udaptation to the necessities required-that, of late years, all animals are judged thereby. As a study of these we give a figured portrait of a model cow, illustrating perfection.

These points may be adopted in judging any cow, so far as general characteristics are concerned, devintions being only in matters of form, color, peculinr markings, shnpe of horns, and general contour: The Guernseys, for instance, are lirger, somewhat coarser, and have of late years been placed in a family by themselves.

The scale of points given are those adopted by the Royal Jersey Agricultural and Horticultural Society, in determining the merits of animals to be passed upon :

\section{Scale of Points-Cows and Feifers.}

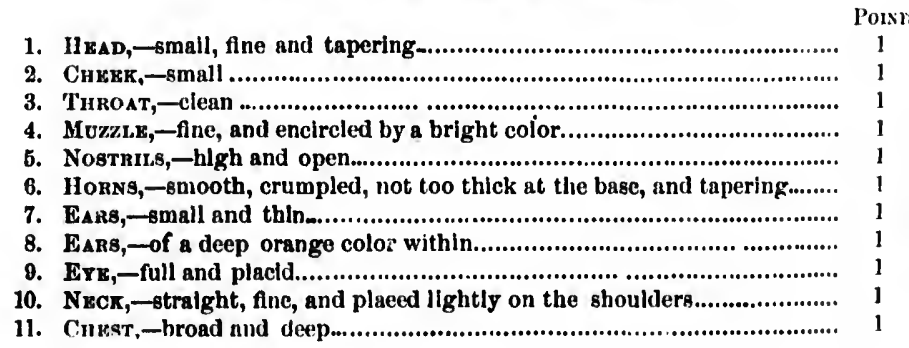


12. BarreL, - booped, broad aud deep

PoIntr.

13. Well ribbed home, having but little spuce between the last rib and the hip.

14. BAck, - straight from the withers to the top of the hip.

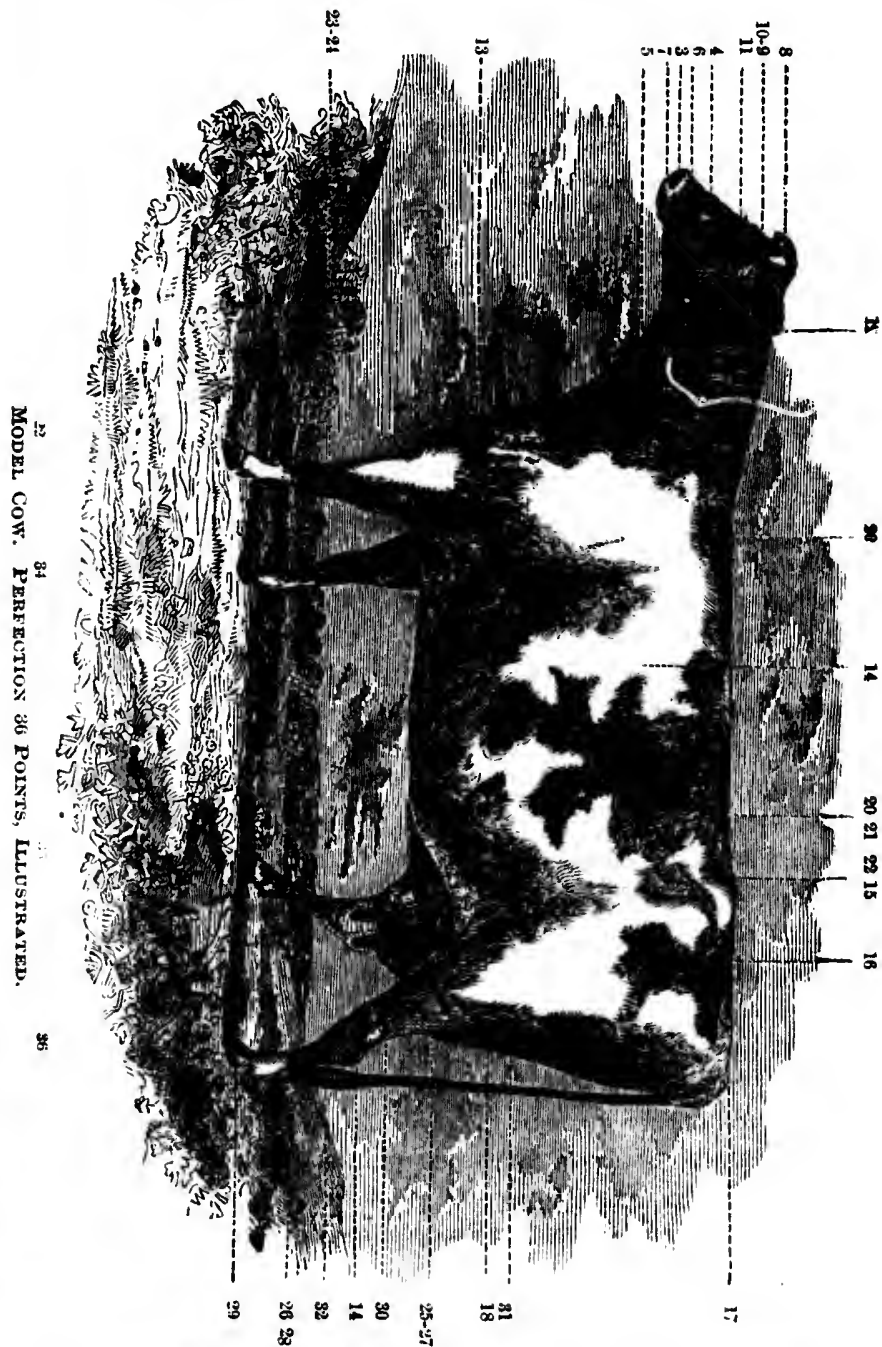

15. BACK,-straight from tine top of the hip to the setting on of the tail, and 16. TAI the tail at right angies with the back 
17. TAIL,-hanging down to the hocks....

Points.

18. HIDE, -thin and movable, but not too loose.....................................

19. HIDk, - covered with fine, soft hair... ...........................................

20. Hidk, $\rightarrow$ of good color.

21. Fork-LEGs, - short, straight and fine

23. HIND-QUARTERs, - from the hock to the point of the rump well filled up.

24. Hind-LLos,-short and straight (below the hocks) and bones rather fine.

25. HIND-LEas, squarely placed, not too close together when vlewed from behind.

26. HIND-LkGs, - not to cross in walking.

27. Hoors, $\rightarrow$ mall.

28. UnDrk, - full in form, i. e., well In Jlne with the belly

29. UDDRR, - well up behind.

30. Tears,-large, squarely placed; behind wlde apart.

31. MiLK-verns, - very prominent.

32. Growth .

33. General appearance.

34. Condition

Perfection

No prize shall be awarded to cows having less than twenty-nine points.

No prize shall be awarded to heifers having less than twenty-six points.

Cows having obtained twenty-seven points, and heifers twenty-four points, shall be allowed to be branded, but cannot take a prize.

These points, namely, Nos. 28, 29, and 31-shall be deducted from the number required for perfection in heifers, as their udder and milkveins cannot be fully developed: a heifer will, therefore, be considered perfect at thirty-one points.

To this we add :

One point inust be added for pedigree on male side.

One point must be added for pedigree on female side.

Again, the size of the escutcheon, or milk-mirrors, is a point of especial attention. This, however, will be treated in another chipter, for the escutcheon is now coming to be accepted as an indication of the milking qualities of a cow, and whatever the breed may be, strongly relied upon. And those who discard it, that is, refuse a cow with a stroug escutcheon, will surely go astray.

In judging bulls, many of the same points will serve. The head will not be so small, and the forehead must be broad; the horns must be tipped with black; the neck, arched, powerful, but not too coarse and - heavy; hide thicker than in the cow - certainly not thin - and mellow; fore legs short and straight, fore arm large and powerful, full abovo the knee and firm below it. As in cows, pedigree must have two points, one for purity of blood on the male side, and one for purity of blood on the female side. 


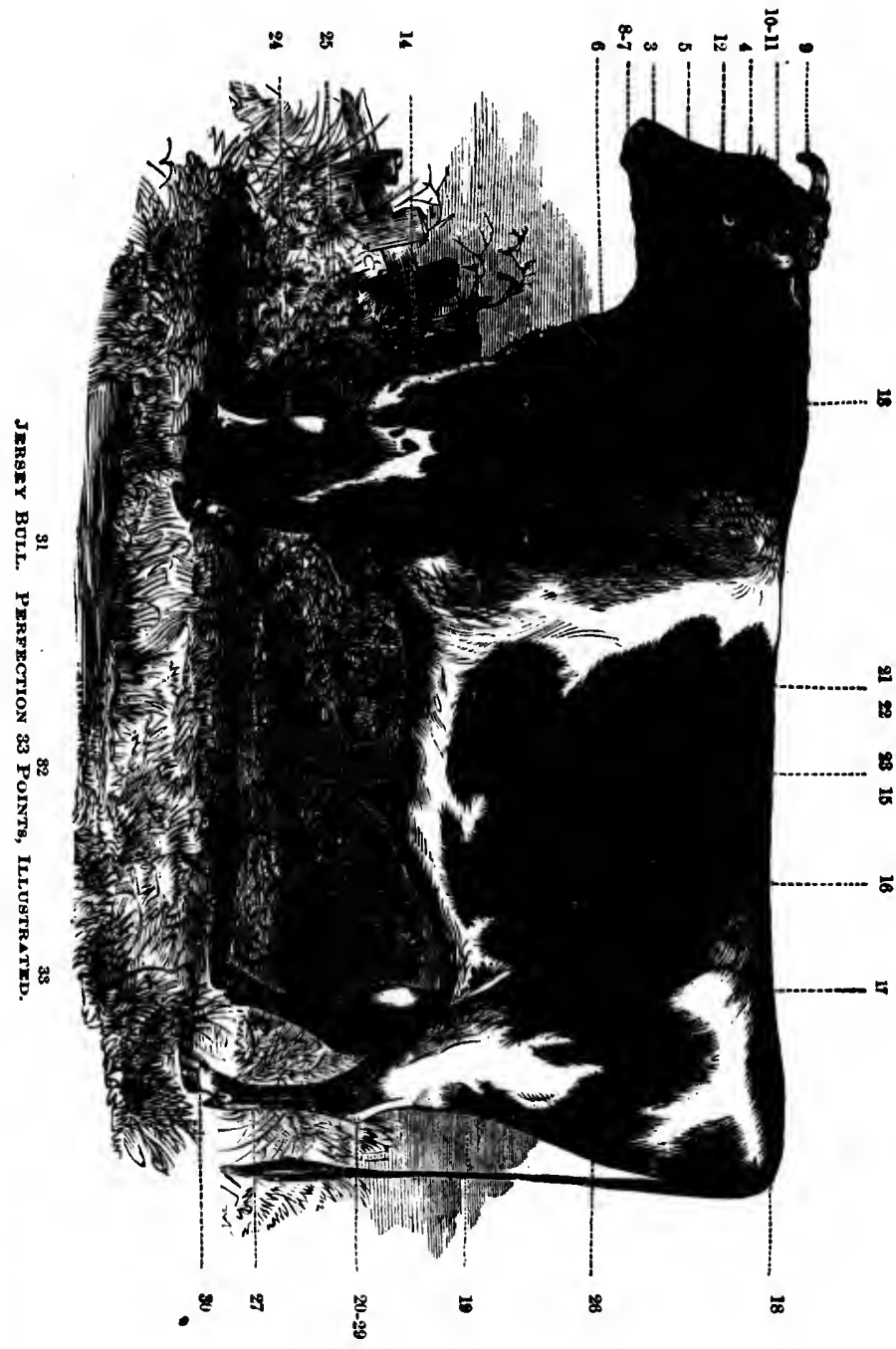

point of apter, for $n$ of the strongly a a stroug head will - must be oarse and mellow; abovo the oints, one od on the

The portrait of a bull given above illustrates the "points" adopted by the Royal Jersey Agricultural Society, and continued after an experience of ten years without alteration. Through it the reader will easily become conversant with the points by which Jersey bulls are judged. By refer- 
ence to the figures given below, und corresponding in tho illustration with the points the reader will understand the following

\section{Scale of Points for Bulls.}

ArTICLE.

1. Yroviones on male slde

2. Provarer on female side

3. HraD,-fine and tapering

4. FORKBKAD,-brond

5. Cherk, - small.

6. 'Throat, -clean

7. Muzzex, - -fine and encircled with light color.

8. NoBtrils, -high and open.

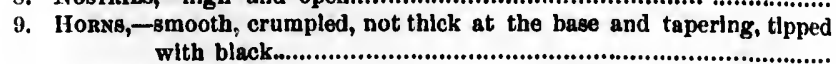

10. EARs, $\rightarrow$ small and thln

11. E ERs, - of a deep orange color within.

12. EYre, - - tull and lively

13. NrCK,-arched, powerful, but not coarse or beavy

14. Cisst,-broad and deep..

15. BARRKL, -hooped, broad and deep

16. Well ribbed home, having but little space between the last rib and the hip.

17. BAck, - straight from the withers to the top of the hlp..........................

18. BACK,-straight from the top of the hips to the setting on of the tall,

3i. TAIL, - fine and the tall at right angles with the back.

PaIL,-hanging down to the hocks.

2i. Hidx, - thln and movable.

22. Hint, -covered with fine and sott balr

23. HiDe, - of a good color.

24. F'onE-LEGs,-short, stralght and flne

25. Fork-ARM, - large and powerful, swelling and full above the knee and fine below it.

26. HIND-QUARTRRs, - from the hock to the point of the rump long and well filled up.

27. HiND-LEGs,-short and stralght (below the hocks) and the bones rather fine.

28. Hind-LEGs, - squarely placed, not too close together when viewed from behlnd

29. HiND-LEGs, - not to cross In walking

30. Hoofs,-small

31. Growth

32. General appearance

33. Condition

Perfectlon

Judging by Points.

The highest excellence of any milking cow lies in the udder. This must not only be full in form, that is, in line with the belly, but it must not bs cut off square in front, like thit of a goat. It should be rounded, full, 
presenting great brendth behind, and carried well up between the thigh. The milk veins should be full and curried well forwurd toward the fore legs. If knotted and with curves, so much the better.

The tail is another essential point. Whatever its size at the root, it must be large and tapering, and have a good switeh of hir.

The chest should be brond and deep: this shows good respiration, essential to feeding and health. 'This, however, must not be taken in the sense in which we view it in the blood horse. It is then one of the essential points, neeessary to fast and long continued exertion.

In the dairy cow, especially when viewed from before, there will be no appeat:unce of massiveness. On the contrary, she will give an appearance of delieate fineness, and will look large behind, swelling gradually from behind the shoulders. She may not be closely ribbed, in fact should not

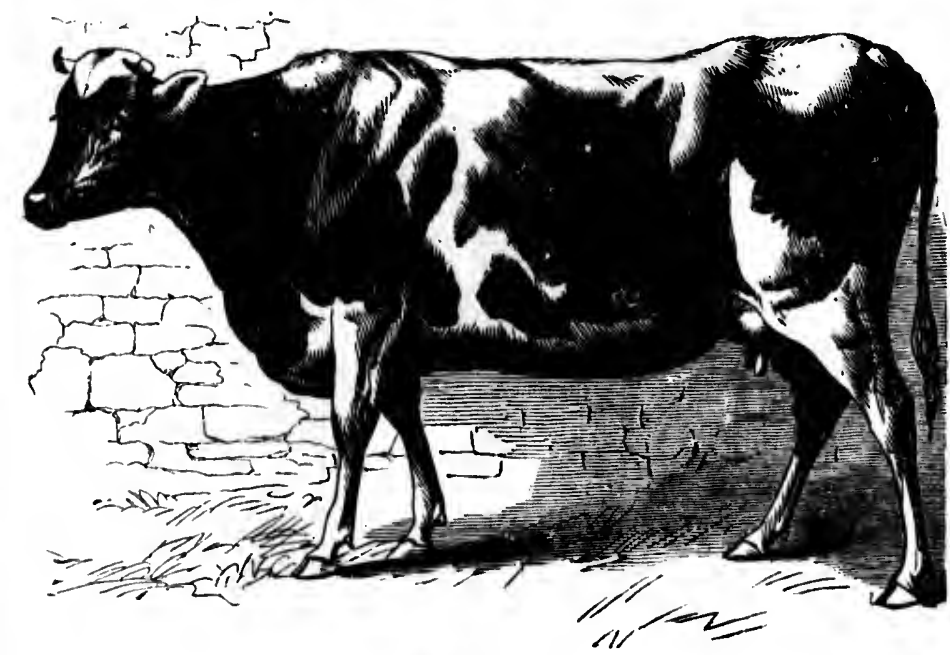

JERSEY COW.

ve (lose, only comparatively so. The best milkers, every where, will bo found to be rather loosely put together between the last rib and the hips, and good milkers must be roomy in the flank.

The hind quarters must be long from the point of the rump to the hock, and well filled up; yet this does not mean rounded and massive in flesh ; on the contrary, the best milkers will be rather lean and perhaps high boned. Nevertheless, the same animul, when out of milk and fat, may fill up, and perhaps, present a fully rounded contour, while yet possessing all the delicacy of points eharacteristie of the high bred dairy eow. 
A cow may have large and heavy ears; her back may not be fully straight from the withers to the top of the hips ; her rump may be sloping: her tail may not reach the hocks; - all these are defects - the latter a serious one-yet, if the milking organs are super-excellent it will outweigh all these.

A phenomenon may show absolute perfection in all the points: we have never yet seen suel an one. In judging, the essentials are to carefully consider each point of excellence with reference to its bearing upon the animal as a dairy cow.

A high open nostril would count but little as against a poor milk vein; a very delicate ear, nothing as against a very superior udder.

The Jersey, to the uncritical eye, when in full milk, is lean, scrawny, and misshapen ; are so, fat or lean, from the standpoint of a Short-Horn

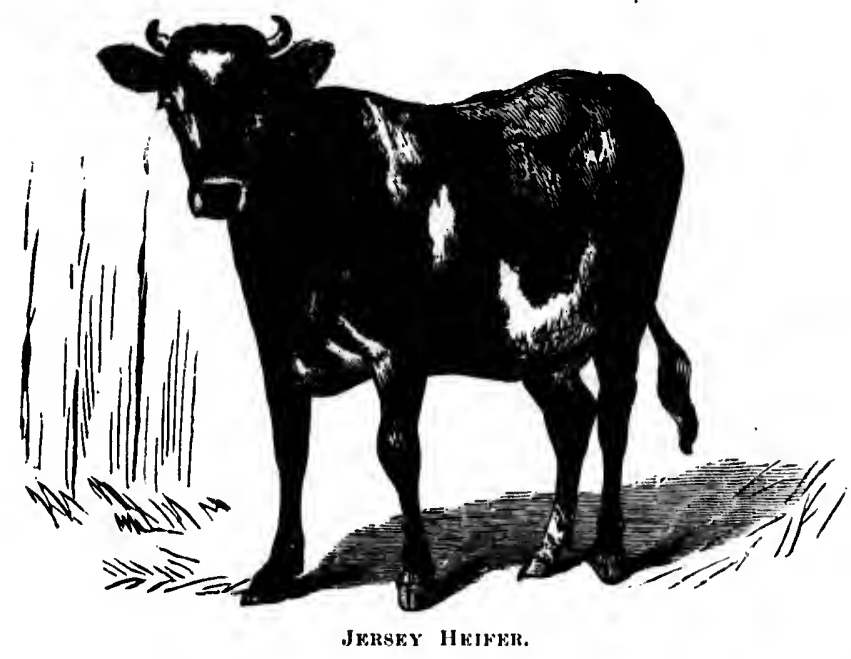

or Hereford breeder. 'The Short-Horn, or Hereford, is a gross, lubberly, disgusting, mountain of fat in the eyes of a Jersey breeder.

\section{Color, Temper, and Size.}

Do not be too particular about eolor ; solid colors, and black points look well in the show ring. The animal that will turn out well at the pail, that is doeile and gentle, be she what eolor she may, so long as she adheres to the distinguishing color-marks of the race, is the one for the milking yard. 


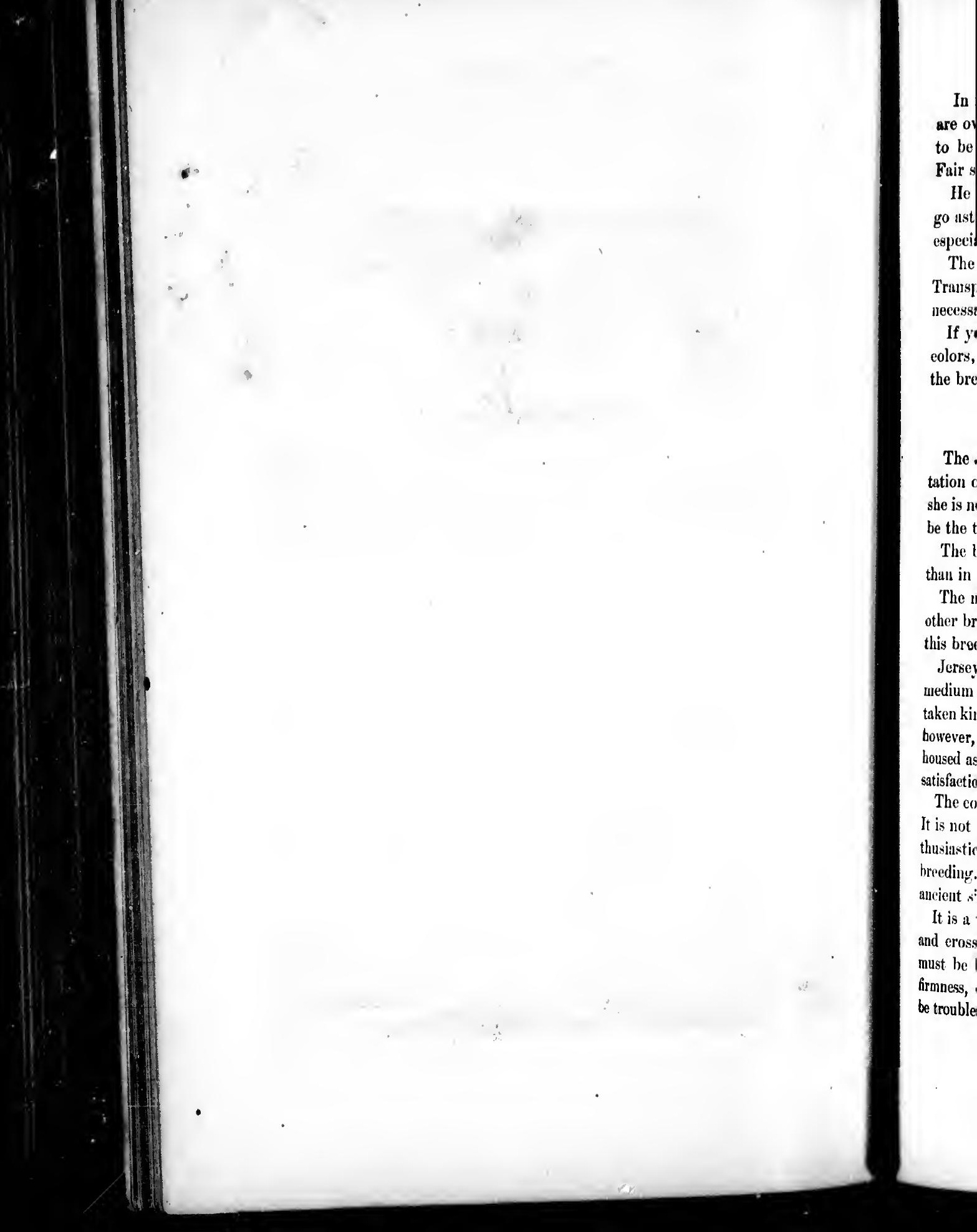


In relation to size, the Jerseys are a small rice of cattle. In no breed are overgrown animals the most valuable. With the Jersey it is especially to be avoided. So, in undersized animal is not to be countenanced. Fair size, however, is desirable.

He who seeks to increase the size of the Jersey unduly, will certainly go astriy. They have been curefully bred, for many generutions, with especial reference to milk.

The Jersey is the product of islunds peculim in soil, elimnte, and people. Transplanted to our flush pastures, with good shelter in winter, they will necessarily increase in size This is to be expected.

If you funcy "solid colors," "nnd enn get plenty of rich milk, with solid colors, well and good. If not, loreed to whitever color, charneteristic of the breed, which will give you this desirable result.

\section{As a Dairy Cow.}

The Jersey cow can hardly be ealled a dairy eow, in the general aceeptation of the term. She lacks size to give quantity; as a cheeso maker, she is not a succes's as butter makers, they stund withont equals, if quality be the test.

The butter glotiules of the milk are larger, and with a weaker covering than in other breeds; hence it churns quicker than the milk of other cows.

The inilk, sream, and butter, of the Jerseys are yellower than that of other brewds. This is due to the excess of orange pigment seereted by this breed.

Jerseys are especially adapted to the villager, or family, requiring a nediun quantity of rich milk, and superior cream and butter. They have taken kindly to our summer climate, from Maine to California. In winter, however, and in the early spring and late fall, they should be as carefully housed as Short-Horns, else they will fail to give even a moderate degree of satisfaction.

The cowis are always docile, gentle, and tractable, when properly treated. It is not to be denied, however, that the bulls are often vicious. An enthusiastic writer has attributed this to their long lineage of aristocratic breeding. The Short-Horns are far more aristocratic in their linenge of ancient sires and dams; they are also notably peaceable.

It is a fact that animals kept in confinement are apt to become surly, and cross. The breeder of Jerseys must accept the fact that the bulls must he kept under strict diseipline, and this by the exhibition of both firmness, careful handling, and gentleness. Otherwise, they themselves will be troublesome, and their off'spring also will bear thesc characteristics. 


\section{vI. Ayrohire Cattle.}

The origin of these cattle emnnot be distinetly truced. That Ayrshire, in Englund, has long been noted for "1 very superior breed of milking cows, is indisputuble; yet unything like what were known as Ayrshires, fifty years ngo, did not exist ono hundred yeurs prior to that time.

Thit the present breed was' not produced loy a cross of Alderney, on the mutive enttle of Scotland, ns has been asserted, is evident enough from their form and characteristies; that they were not produced in selection, is equally as well grounded. They may have originated in it hippy cross, and enreful breeding therenft"

That the Ayrshire owes much of its sup aty to crosses of the better milking strains of the old Short-Horn ruce, would seem to be borne out, not only hy tradition, but particularly by unmistnkable characteristics of both these breeds.

Ayrshire indeed is eminently adapted to the production of superior milking cows. The climate is moist, with plenty of soft ruins; constquently, the grasses would nnturnlly be succulent, and tend to produce the greatest flow of milk of which a eow might be eapuble.

Of the three divisions of Ayrshire-Carriek, Kyle, mul Cuminghmthe latter is regarded as the true home of this most valuable breed. Indeed, they once went by the nume of Cumningham enttle.

\section{Ayrshires of the Last Century.}

Mr. Aiton, an old English writer, who intelligently thm perhilps any one elso of written more largely and reed, has given much villuable information concerning then as they existed in Aylshire early in the last eentury. Spenking of them, he snys :

"The cows kept in the districts of Kyle and Cunninghmm were diminntive in size, ill-fed, ill-shaped, and they yielded but a scanty return in milk; they were mostly of a black color, with large stripes of white along the chine or ridge of their back, nbout the flunks, and on their faces. Their horus were high and crooked, having deep ringlets at the root, the plainest proof that the eattle were but scantily fed; the chine of their backs stood up high and narrow; their sides were lank, short and thin ; their hides thick, and adhering to the bones; their pile (skin) wals con'se and open ; and few of them yielded more than six or eight quarts of milk per day, when in their best plight ; or weighed, when fitt, more than from twelve or sixteen to twenty stone avoirdupois, sinking offal."

The Husbandry of Ayrshire, published in 1793, states upon the anthority of $\mathrm{Mr}$. Bruce Campbell, that the introduction of the improved breed was made by the then Jate Earl of Marchmont, and Mr. Youatt thinks that it must have happened between 1724 and 1740 . 
There then were suecessivo introductions of improved blood mong them, the Dunlup struin of Short-Horn about 1780, or one hundred yeurs ago. This breed heenme well established in reputution, and in the enrly part of the present eentury became regularly known us Ayrshire, and was widely disseminnted in Englunel.

ney, on enough need by ted ill :

the lortbe borlie intructer-

superior ; conseproduce inghitul1le breed.

rgely and inuch val- early in

ere diminreturm in of white I on their ets at the te chine of short ind skin) was ght quirts fat, more ig offill." upon the improved Ir. Youstt

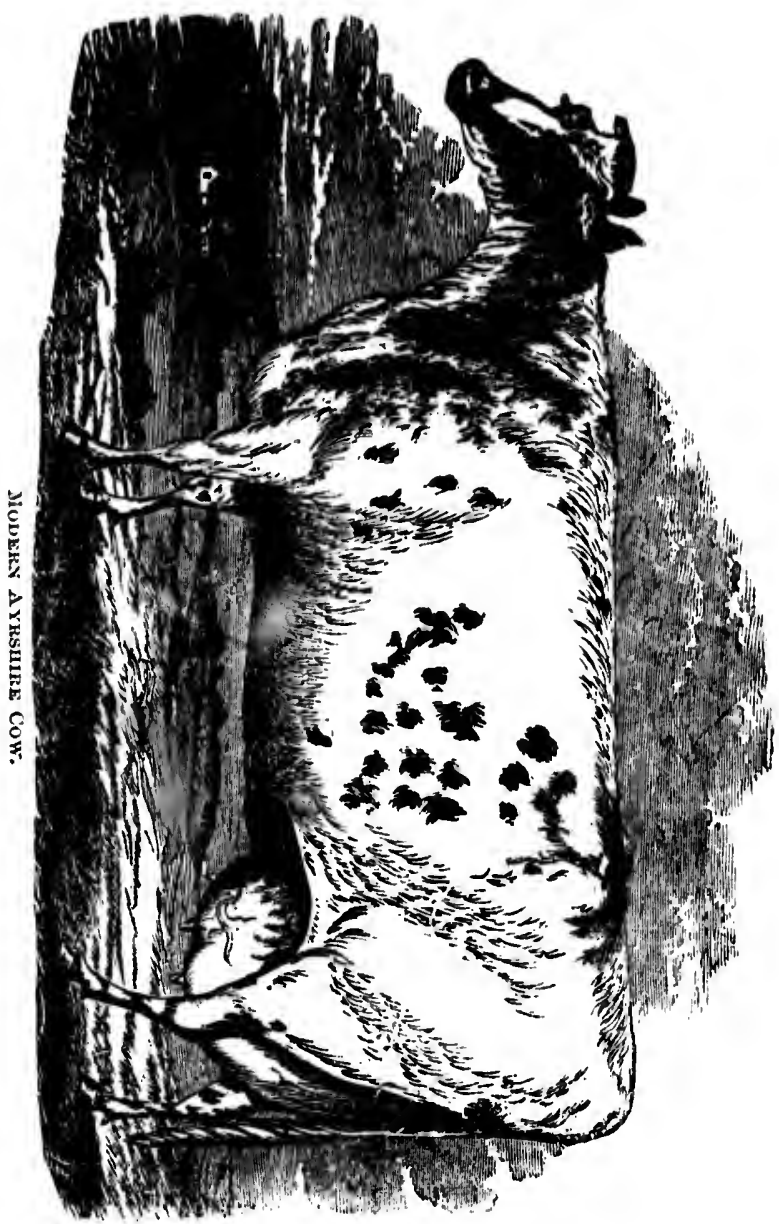

The above likeness is a good one of the improved or modern Ayrshire cow.

Mr. Aiton deseribes the breed in its improved form, or as it existed late in the last century, and early in this, ats follows: 
"The shapes most approved of, tre-head small, but rather long and narrow at the muzzle; the eye small, but smart and lively; the horns small, clear, crooked, and their roots at a considerable distance from each other; neck long and slender, tapering toward the head, with no loose skin below; shoulders thin; fore-quarters light; hind-quarters large; back straight, broad behind, the joints rather loose and open; carcass deep, and pelvis capacious, and wide over the hips, with round fleshy buttocks; tail long, and small; legs small and short, with firm joints; udder capacious, broad and square, stretching forward, and neither fleshy, low hung, nor loose; the milk-veins large, and prominent; teats short, all pointing outward, and at considerable distance from each other ; skin thin and loose; hair soft and woolly. The head, hones, horns, and all parts of least value, small ; and the general figure compact and well proportioned."

In this comnection, it should always be remembered that the Ayrshire cows were always noted for their thighs, and in fact a general thinness of body, as compared with beef breeds. The bulls were always selected for their feminine appearance, especially about the neck and head; they were not required to be roomy behind; they were required to be broad in the hook bones and hips, and full in the flanks.

Tameness and docility of temper, hardiness, a sound constitution, plenty of spirit and life, and the capability of giving large messes of milk, rich in butter and cheese, are noted characteristics of this breed in an eminent degree.

Mr. Youatt says of them: "They yield much milk, and that of an oily, or butyraceous, or cascous nature; and that after she (a cow) has yielded very large quantities of milk for several years, she will be as valuable for beef as any other breed of cows known; her fat will be much more mixed through the whole flesh, and she will fatten faster than any other."

As far as milk is concerned, it is true of the Ayrshire of the present day.

In America, the breed has not yet been sufficiently disseminated to determine whether the quality of beef shall be borne out by the statement of the anthor quoted.

Mr. Youatt agrees that the breed has much improved since Mr. Aiton described it; that it is short in the leg, the neck a little thicker at the shoulder, but finely shaped toward the head; the horns smaller than those of the Highlander, but clear and smooth, pointing forward, turning upward, and tapering to the points; they are deep in the carcass, but not round and ample, and especially not so in the loins and haunches.

Some, however, have suspected, and not without reason, that an atten- 
tion to the shape and beauty, and attempt to pioduce fat and sleek cattle, which would be admired at the shows, has had a tendency to improve what is only their quality as grazing cattle, and that at the certainty of diminishing their value as milkers.

\section{Yields of Mrilk, Butter, and Cheese.}

Experiments made early in the century, to determine the relative value of different breeds for milk and butter, we find as follows:

"In some experiments conducted at the Earl of Chesterfield's dairy at Bradley Hall furm, it appeared that, in the height of the season, the Holderness would yieid seven gallons and a quart; the Long-Horn and the Alderney, four gallons three quarts ; and the Devon, four gallons ons pint, jer day. When this was made into butter, the result was, from this Holderness, thirty-eight and one-half ounces; from the Devon, twentyeight ounces ; and from the Alderney, twenty-five ounces."

The Ayrshires average five gallons per day, and from that is produced thirty-four ounces of butter.

This shows the degree of superiority the breed has obtained in $\mathrm{Mr}$. Youatt's time.

Mr. Aiton, indeed, asserted that 3 3-4 to 4 gallons of this milk would yield a pound and $a$ half of butter, and that 27 1-2 gallons of milk would yield 21 pounds of full milk cheese ; and that Ayrshires in their best condition and well fed would yield 1,000 gallons of milk in a year.

With respect to yield in the United States, we have the record that the first Ayrshire cow imported by the Massachusetts Society for the Promotion of Agriculture, in 1837, yielded 16 pounds of butter a week, for several reeks in succession, on grass feed only.

Mr. Rankin, a most reputable English authority, reporting upon a Kylo farn in Ayrshire, holds that Mr. Aiton's estimate is too high. In relation to two farms visited, upon one of which was kept from twenty to thirty cows, and on the other from thirty to forty very superior cows, he says of the first, that, "at the best of the season the average milk from each cow, is 9 Scots pints (4 1-2 gallons, ) and in a year 1,300 Scots pints ( 650 gallons,); that in the summer season, 64 pints ( 32 gallons,) of entire milk will make an Ayrshire stone ( 24 pounds) of cheese ; and 96 pints ( 48 gallons) of skimmed milk will produce the same quantity ; and that 180 pints (90 gallons) will make 24 pounds of butter." Of the other farm, he states that "the average produce of eaeh is 1,375 pints (687 1-2 gallons) ;"' and adds as his belief, on the whole, that although there may be Avrshire cows capable of giving 900 gallons in a year, it would be difficult to bring half a score of thein together; and that in stocks 
of the greater number, most carefully selected and liberally fed, from 650 to 700 gallons is the very highest produce of each in the year.

Upon his own farm, the size of which, he says, is of an inferior nature, his cows produce only 550 gallons in a year

\section{Ayrshires in Amerioa.}

The Ayrshires were first imported to the United States in 1831. They were different in appearance from what they are now, the colors being either deep red, or brown flecked with white, many of them laving black noses. They have been materially changed since then, and vary mueh in color. The most of them, however, retain the characteristic colors of the breed, and whether they be dark red or black, they are generally more or less pied, mottled or blotehed with white.

Mr. Allen, himself a Short-Horn breeder, in his work, "American Cattle," sums up the Ayrshires as follows;

"Their thirty-six years' trial here has been successful. They are hardy, healthy, well fitted to our climate and pastures, and prove good milkers, both as to the imported originals and their progeny. Their flow of unilk is good in quantity and fair in quality ; yet, we must be permitted co say, that in this eountry they do not yield so much in quantity as is alleged they have produced in Scotlnnd. The chief reason for this is obrious. Ayrshire has a moist climate-in almost continuous drizzle of rains, or moistute pervading it-making fresh, green pastures; a cooler and more equable temperature in summer, and it is warmer in winter than with us.

Our American climate is liable to extremes of eold in winter, heat in summer, and protraeted droughts, for weeks, drying up our herbage. These differences alone aceount for a diminished yield in milk from Scoteh to the American Ayrshires. They have softer grasses for hay, and plenty of root-feeding in winter, which latter we have not. This fact of a diminished yield of milk on this side of the Atlantic is acknowledged by those most conversant with them in both conntries.

In the year 1837, we visited the Ayrshire herd of the lute Mr. John P. Cushing, at Watertown, near Boston, Mass. They were of the choicest quality, imported by himself, on an order sent out to an experienced dealer in Ayrshire eattle, "without regard to price, so they are the best." Two or three of the cows were "prize" milkers at home, and eertificates, duly verified, were sent with them of the quantities of milk they hind made. They had then been a year or more nt Mr. Cushing's farm, and had the best of keep. We questioned the manager as to the quantities of milk the cows gave sinee their arrivnl, eompared with the certificate. His answer was, 'about one-third less, on an average. The best 'prize' cow gave 33 quarts per day when at her maximum in Ayrshire, and 22 quarts 
bere, and the others in about like proportion, but they are all good milkers, and Mr. Cushing is satisfied with them."

We uote the fact of the declension in milk of the Ayrshires in this country, knowing the same to have occurred with cows of other breecis from England. It is neverthcless true, we think, that the milk produced bere is richer in the eonstituents, as it is undoubtedly true that cows on flush, soft pastures, or those fed on soft, sloppy food, give far poorer milk, although more in quantity, than when fed on shorter rich herbage, or upon other rich food.

\section{Ayrshires in the West.}

In the West the Ayrshires have not gained the celebrity that the Jerseys or the Holsteins have. The probability is that the Jerseys owe much of their popularity to the fact that they are par excellence the family cow, where quality of milk has greater weight than quantity. The latter are hard keepers; that is, they consume $n$ large amount of food for the quantity of milk given, and probably more than either the dryshires or Holsteins for the quantity of butter and cheese produced. The Jersey must have rieh food to enable her to sustain herself. Nevertheless, the texture, solidity, hardness and delicacy of the butter amply compensates for this. The Holstein has grown in favor in the West rapidly within the last few years. Our albundant pasture and sheap forage and grain in winter, has made them prime favorites with all that class who must have a large quantity of fairly rieh milk. As a cow for making cheese they are unsurpassed, as is the Jersey for butter. For a great flow of milk, rich in butter, our experience is that the Ayrshire carries off the palm, especially on pastures not good enough for the Holsteins.

\section{Deseription of Ayrshire Points.}

In judging cattle of any description, reference must always be had to the charicteristies of their breed. Thus, while all cattle are judged by certain undeviating standards as respects feeding and assinilation, beef cattle must be judged from a beef-making standard, and dairy eattle from their milk-producing powers. It is more than probable that, weight for reghth, the Ayrshuro being a cow of medium size, will produce more milk than any other breed. In selection no surer test ean be had than a careful study of her points. Dr. G. Lewis Sturtevant, of Snuth Framingham, Massnehusetts, who has given the Ayrshire particular attention, and who is one of the most eareful farmers and breeders in the East, thus describes the Ayrshire, and the same principles may be applied to the whole race of dairy cattle. 


\section{Usefulness.}

The usefulness of the dairy eow is in her udder, and toward the udder, its shape and its yield, all the eapabilities of the cow should be directed. We may first view it as a reservoir for the milk. As such, it must be large and enpacious, with broad foundations, extending well behind and well forward, with distinct attachments ; broad and square, viewed from behind, the sole level und broud, the lowes even-sized, and teats evenly distributed; the whole udder firmly attached, with skin loose and elastic. Such a form gives great space for the secreted milk, and for the lodgment of the glands, while allowing the changes from an empty to a full vessel. The glands should be free from lumps of fat and musele, well set up in the body when the cow is dry, and loosely covered with the soft and elastic skin, without truce of flabbiness. Such a covering allows for extension when the animal is in milk, while the glands are kept in proximity with the blood-vessels that supply them. The necessities of the lacteal glands are larger supplies of blood from whieh milk can be secreted, and this harmonizes with the demands of the udder as a storehouse. For broad attachments means broad belly or aluundance of space for the digestive organs, from which all nutriment must originate. The blood is furnished to the glands of the udder by large and numerous arteries. As seeretion is dependent on the freedom of supply of blood to the part, and u copious flow, we find branches coning from different arterial trunks and freely anastomozing with each other. Although these arteries are internal anci out of sight, yet fortunately the veins which earry the blood from the ndder pass along the surface, and from their size and other characteristics indicate the quantity of blood not only which they carry away, but which must have pussed through the glands from the arteries. These retum veins pass both bnekward and forward. Those passing forward are known as the milk veins, and the size of these superficial veins on either side of the belly, and the size of the orifices into which they disappear, are excellent points to determino the milking probability of the cow. Still better is it to find, in addition, the veins in the perineum, which also return from the udder, prominent and eircuitous.

\section{Escutcheon.}

The escuteheon is now generally conceded to be a good indication of milk in the cow. This mark is sufficiently well known not to require deseription in detail. I think a broad eseutcheon is fully as good a sign as a long one; that quantity or quality mean more than slape, yet I would not discard the shape entirely. One elror nust, however, be avoided. It may be well to compare the size of escutcheon of cows of one bred, but ne

I think

Holste

it in th

to ado

breed $\mathrm{h}$

dairy.

The

mark, $n$

fluence

The mil

on eithe.

breadth

flunks.

loin here pustion. continuor so to spe fucilities hold the

"To g: yet no he required $\mathrm{f}$ is nceded. from the and speed cleunse its to a health yield of $m$ tion must luugs. In

"The re broad pelvi. Defects liere "Thus the wedge s from above

The point Soeiety, und up as follow 
but never to compare the size of escutcheon in cows of different breeds. I think thi point means more relative to size in the Ayrshire than in the Holstein or Dutch; and I an certain that while it may be safe to follow it in the Ayrshire in the majority of instances, it would be equally unsafe to adopt it in selecting a Short-Horm, for the obvious reason that that breed has been bred for generations for other purposes than those of the dairy.

The udder and its dependeneies, the milk veins, and the escutcheon mark, may be considered the foundation of the Ayrshire cow. . These influence profit, and also the shapes of the body and the form of the animal. The milk vessel is placed in the pubic region of the cow, and is protected on either side by the hind limbs. The breadth of its attachments secures breadth of body, and the weight requires also a depth of quarter and of flanks. The breadth below requires breadth of hip above, and length of loin here appears related to length of pelvis. So much for the physical purtion. The physical function of milk-producing demands a great and continuous flow of blood, for it must not be forgotten that milk is blood, so to speak. This flow is dependent on the supply of food, and on the facilities of digestion. To gain this, a large body is required in order to hold the suitnble digestive organs.

"To gain further room for these, we desire to seo arched ribs, depth, yet no heaviness, of flank, and breadth of hips which we see was also required for the broad udder. To sustain this body, a strong, firm back is needed. To gain the most of our blood after it has absorbed the chyle from the digestive organs, reason shows that it should find its way freely and speedily through tho system on its lnbors of supply and removal, clemse itself in the lungs, and again pass on to its duties. All this points to a healthy heart, not eramped, and lungs of sufficient capacity ; for the yield of milk drains much nutriment from the system, and the constitution must needs have the vigor given by healthy and active heart and lungs. In this way the chest is correlated with the udder.

"The reproductive functions requiro hock bones of good size, and a broad pelvis is desirable, as underlying within are the generative organs. Defects here are to be shunned.

"Thus the necessities of tho body of a good milking cow require the wedge shape, and this not only from the flanks, but also when viewed from above."

\section{A summing Up.}

The points of the Ayrshire cow, as given by the Ayrshire Agriculturn? Society, and the New York State Agricultural Society, have been summed up as follows : 
The Body.

"The whole fore-quarters thin in front, and gradually inereasing in depth and width backward, yet of sufticient breadth and roundness to insure constitution; back should be straight and the loins wide, the hips rather high and well spread; pelvis roomy, long, broad and straight, hook bones wide apart; quarters long, tolerably muscular, and full in their upper portion, but moulding into the thighs below, which should have a degree of flatness, thus affording moro space for a full udder; the flanks well let down, but not heavy ; ribs, behind, springing out very round and full, affording space for a lurge udder-the whole carcass thus acquiring increased volume toward its posterior portion.

"We see that the points as given are those of utility, and that at this stage the udder-points and body-points are correlated.

\section{Tho Skin.}

"In connection with the body and the udder, the skin is of great value in assisting our judgment. Between the portion of the external covering used for leather, and the muscle, there occurs a layer of cellular tissue, which contains a larger or smaller amount of fat cells, and the mellow handling caused by these cells indicates a free circulation throughout this meshwork.

"'The skin varies from a thin, papery hide, covered with silky hair, ti a thick, supple, elastic hide, well coated with hair, on the one hand, anci a similar variation, with harsh hair and coarseness, on the other. The thin, papery hide indicates quick fattening and a delicuto constitution; the thick, elastic hide cushioned on fat, and which on the flank comes into the hand almost without grasping, indicates the height of ngor, accompanied by the fattening tendency, and the possessor of this handling endures climntic changes, low quality in his food, and neglect, with remarkable hardihood, and quickly responds to tull feed and good care. The harsh handler is a dull feeden, consumes much food, and generally contnius more than a just proportion of offal or waste. In the Ayrshire cow we desire weither of these extremes, for it is in the milk product that we wish the food to be utilized, and it is almost an unchanging lar of nature, that deficieney in one direction must be compensated for by excess in another direction, and vice versa. At any rate, the cow that lays on fat too quickly is seldom a first class milker; and how well known is it that the cow of large yicld milks down her condition! I cow that has n moderately thin, loose skin, of sufficient elasticity and suppleness of touch, without being fat-cushioned, as it were, with bair soft and mossy, or woolly, if of correct form otherwise, will usually mill neck of tapering firm.

If the extra foc derelopn

"The 1 in the for the breed an expand gencrul st more freq teristic ; a rell-lored and such Scotland.

"The e eye is a $\mathrm{n}$ cow; a fre disappoints physiognon 
a large quantity, and when she becomes dry, will rapidly come into condition. In truth, the haudling of the Ayrshire cow must be good; it cannot be too good; but it must not be of exactly that quality sought for in the gruzing breeds.

"There, as everywhere, the dairyman must keep to his line; milk, not fat, is his profit; and in seeking excess of both, he will be liable to fall below the average of either."

\section{Relating Fspecially to Milk.}

It is an axiom of breeders to diminish the useless parts of an animal as mueh as possible, or, in other words, to reduce the proportion of those parts not conductive to profit to as great extent as possible. Applying this rule to a dairy breed, we should desire a small neck, sharp shoulders, smiall brisket and small bono. Moreover, small boue usually accompanies thrift, and is universally found in improved breeds. We thus have a reason for these other Ayrshire points, which I now quote :

"Shoulders lying snugly to the body, thin ut their tops, small at their points, not long in the blade, nor loaded with muscle; brisket light; neck of medium length, clean in the thront, very light throughout, and tapering to the head; tail long and slender; legs short, bones fine, joints firm.

If the dairyman's policy were otherwise, he would have to supply extra food for the support of parts useless to him, and whose larger development is of no especial value.

\section{The Head.}

"The heald should be small, in shape either long and narrow, or broad in the forehead and short, according to the type of animal preferred by the breeder, generally preferred somewhat dishing; the nose tapering to an expanded muzzle, with good clean nostrils. Opinions differ as to the general shape of the head. A broad forehead and short face oceurs more frequently in bulls, and is genernlly esteemed a masculine characteristie; a more elongated fuce is called feminine. Yet some families of well-hred and good milking Ayrshire cows huve the broad and short head, and such were, at one time, if not now, the favorite in the show-yard in Scotland.

"The eye should be moderateiy full, lively yet placid looking. The eye is a mirror of the disposition, and interprets the character of the cow; a fretful, irritable animal is seldom a quick fattener, and usually disappoints at the pail. It also gives expression to the features, and physiognomy aids our judgment. 
"The ears should be of a good size, but thin, and their skin of rich yellow color. Coarse ears are usually found on ill-bred animals, and these may be considered, to a certain extent, indicative of general coarseness. The color of the skin, as shown inside the ear, is usually considered indicative of the richuess of the milk in butter.

"The horns should be of medium size, of fine texture, with an out-. ward and upward turn, or inclining upwards and curving slightly inwards, according to the taste of the breeder. They should be set on rather widely apart. A coarse horn may indicate a coarse and thick hide, us there seems an intimate relation between the composition of the horn, hair, and hide, and the influence of climate on horn and hair gives an appearance oftentimes of correlation between the two.

\section{The Top Points.}

"The neck should be of medium length throughout, and tapering to the throat, which should be clean or free from loose, hanging skin. Yet too thin a neck is not desirable, as it usually indicates a delicate animal. A thiek-set neck, well covered yet not overladen with muscle, accompanies hardiness and vigor of constitution.

"The junetion of the neck with the body and over the shoulders is called the crops; on a horse it would be called the withers. A hollow behind this point is a never-failing sign of weakuess. The crops should blend in easily with a thin shoulder, lying snugly to the body. This shoulder and a well defined spine produce the shirpness of shoulder so much admired. The back should be straight, with spine well defined, especially forward. The tail long, firm in the bone, and set on $\|$ level with the back, without depression or notch. A fine tail usually accompanies fine bone, and the fine bone is not only decrease of offal over heavy limbs, but accompanies early maturity, and a tendency to thrift. The limbs should be fine-boned, flat-boned, and with joints of moderate size. On the forward limbs the cow should stand low. Large joints and round bones are found very frequently on dull feeders and on unimals of little profit.

\section{The Teats.}

"The teats should be of medium length, evenly set, and project slightly outward when the bag is full, of even thickness throughout, and of fine texture. They should be placed about one-third of the length of the "vessel" apart in one direction, and about one-lialf the other. When the udder is not distended, they should hang perpendicularly. Large teats, however desirable to the milker, are usually accompanied by 
conrseness of build in the cow. They aro scldom found on well-bred animals, yet exceptionally they occur, and are much liked. A tent should be large enough to grasp, sny from two to two and a half inches in length. A shorter one would be an objection; with larger, I should fear coarseness.

\section{Color and Carriage.}

"In color the Ayrshires vary greatly. Brown, red, and whito appears to good advuntuge, and is fashionable. A good quantity of white, well distributed, adds style and showiness to the animal. Yellow and white is frequently seen, yet whilo this color is sometimes stated as inclicating lack of hirdiness, I ain not aware of any proofs of argument hiving been brought forward to support this view. Color is as yet a matter of taste, for its correlations are hardly guessed at; and from almost puro black, through the reds to almost pure white, are colors found on the best eows. Black spots on the skin, burely perceptible through the hair, oftel occur on the best cattle. Strawberry-blotched and red and white are perhaps the more common colors. A self-colored animal, or a roan, or animal with white on the ears, the writer has never yet seen umong the Ayrshires in Scotland or in this country, when the pedigree was unquestionable.

"The carriage should be light and active, the head well up, and the hind legs should not cross in walking. The condition should be neither fat nor lean, but that average which a good cow holds when in good flesh at calving, liberally fed while in milk."

\section{Holstein Cattle.}

Duteh cattle were undoubtedly among the first cattle ever brought to America. Canada was visited by the French in 1808, when they founded Quebee. Soon after colonists arrived and brought with them the littlo Normandy cattle. The English first settled on the James river, in Virginia, in 1607, and New York was settled by the Dutch in 1614. In 1625 the first cattle were imported from the mother country, and they were undoubtedly the Dutch cows noted for milk, or a race nearly allied to what are now generally recognized as Holsteins. That this supposition is correct is probably true, since these cattlo were considered valualle for milk and labor. It would naturnlly follow that these two qualities should be eonsidered of prime importunce by the practical Dutch settlers, in a country where game in abundance might be had by all who knew how properly to aim a gun. Rearing cattle for the sake of meat would be a secondary consideration there. 
History of H.olsteins.

In the adaption of breeds to special purposes we must always hear in mind that feed, climate, cure, and careful breeding must be tuken into considerntion. Thus for the most excellent dairy cattle, wo must look to countries noted for dairy products. In such districts will always be found tolerubly uniform and excellent milkers. Really scientifie breeding has not been practiced until within a very few yeurs. It was more experiment than anything else. Yet so long ngo as 1625, Englind, Holland and Switzerland were hoted for dairy products, and also for breeds of deep and lasting milkers. As educution increased, and wealth became more general, improvement by selection wus supplemented by a curoful study of certain points and characteristics that miglat be expected to perpetunto themselves. Thus we now have the Jerseys, the Ayrshires, the Swiss cattle, and Holsteins, each specially adapted to the soil and requirements of their respective localities. The Holstein cattlu, or those of North Holland, are noted for large frames; for being of two distinct color's, black and white mixed. They lelong to the great short-horned division of eattle, which race, from the best accounts extant, would seem to huve been peculiar to the transient inhabitants of Germany from time inmemoriu!, and to have been carried with them in all their migrations.

The size, ndnptation to districts yiclding strong, plentiful herbage, and extraordinary milking qualities, have mado then universal favorites in the West, and wherever introduced in all that great country of the Northwest that of late years has so suddenly become celelorated for its dairy products. Within the last century this breed, like all other pure breeds, has been wonderfully improved by the astute and practical Hollanders, so that it may now be called as distinctly a breed as uny other of the more reputalle families. Like the Durhan and Teeswater eattle of a hundred years ago, they were then noted for a fair uniformity in appearance, and ns deep milkers, good at the yoke, and as muking heavy weights of fair beef when ready for fattening. The general charncteristies of these two breeds would seem to point conelusively to the fuct that originally they had a common ancestry in cattle belonging to the ancient races inhabiting the north of Europe, and that they were earried wherever these people, in their wanderings, migrated.

\section{Improvement.}

We have no definite' knowledge when this wonderfully enstituted short-horned race of eattle first becume broken up into the various fumilies that have of late years become celebrated both as duiry enttle and as beef cattle. It is probably within the last three centuries that 
systematic attempts huve been made to breed them with a viow to their cureful improvement und toward fixing their clurncteristies - in Englund with the Durhams, now known as Short-Horns, and in Holland with the Duteh enttle, now known in the West through the importution of the Holstrins, from the fuct that in this district more eare seems to have been taken to breed their enttle, not only to type, but nlso in line as duiry cuttle. It takes long generations of such breeding to fix undevintingly peculiar traits and characteristics, so they may be trumsmitted with grent fixity to the resulting progeny. The Holsteins of the present century have presented uniformity, und to-dny they muy be ealled as persistent in the transmission of quality as the other grent families of the genus Bos in uny country.

These have superior excelleneo in their milking qualities. They are dairy cows noted for giving enormous quantities of fuirly rich milk. They have massive compact frumes, and make good beef; us working oxen, from their strength, doeility, patience, und fuirly active habits, they should make excellent workers. The horns of the Holsteins are short. The hair short, soft, nnd fine. The hides me of modernte thicknesi, of good texture-that is, meilow. The color should be ulways black and white, either in bauds, or else pied, nottled or spotted over the body. The udders of the cows are capneious, of great breadih and depth. The teats vell shaped und stunding well apart. The milk-veius prominent, large, and ruming well forward.

\section{Holsteins in Amerioa.}

As we previously stnted, the old Dutch settlers of New York brought over with them this valualsle breed of eattle. 'They have, however, become entirely lost, except that they have left thoir impress in resultingr generitions of mixed blood.

Since the time noted, there probably were none imported until the present century. In the eurly part of the century, at the time of the importation of Merino sheep, by Mr. William Jarvis, of Vermont, in one of bis royages he brought over a bull and two cows. They remained on his farm for some years ; the bull wis bred to the common stock of the country, producing a decided impress, but at the end of a few years the pure blood was lost.

It is recorded, that, somewhere between 1820 and 1825, Mr. Herman Le Roy, a public spirited merchunt of New York city, imported some improved Dutch eattle which were sent to his farm near the eity. Between 1827 and 1829 , some of the produce of this herd were sent to the furm of bis son, Edward Le Roy, on the Geuesee river. Mr. L. F. Allen de-

onstituted jo various airy enttle turies that 
scribes this herd in 1833, as he then saw them, as being large, well-sprend cnttle, black and white in color, and romurkable for their uncommon yield of milk, and of grent value as dairy animuls; their qualities in that line were universally acknowledged wherever known.

\section{About Duteh Cattle Generally.}

In treating of Dutch enttle we have adopted the name Holstein, and for the renson thit in the West certuinly the importer's seem to have filucied the enttle found in Holstein, and to have imported more lingely of them than any other of the Duteh enttle. That the right nume for all those families of ancient linenge, bred in Nortl-Holland, and recognized as luving been for many generntions great milkers and as making heavy beef cattle, of good quality, when dry, should be Dutch cattle, there is, from the testimony, little doubt. So also it would seem that the Holstein cuttle are n sub-rnce of the older Dutch, ns the following letter from Prof. J. G. Hengwold, of the Netlerlands Royal Veterinary Institute, to Mr. Charles Muller, United States Consul at Amsterdam, would seem to show. This is dated Utrecht, November, 1872, nnd published in the Report of the - on Duteh Cattle in Agriculture of Mussachusetts, second series, 1873-74. From it wo extract us follows:

Quoting from Low's Agricultural History of the Domestic Enropen Animals, etc., he says: "In comparing these varieties of eattlo to the breeds of the Continent, there is an analogy found on the one side between the great breeders of the marshes and the black cattle, natives of the plains and marshes of Holland; and on the other, between the more various kinds on the north of the Humber and those of Holstein and Jutlind, whence the best cattle of Northern Europe hnve sprung." It is not unreasonable to suppose, that these latter breeds may have been introduced during the first period of Saxon colonization by the Jutes and Angles, who settled down in that part of England. But at a more approximate period to us, it appears that cattle were frequently imported from the neighboring continent, and that they were mixed with native breeds.

It was especially the Dutch cows that were considered the best milch kinds of Northern Europe.

There is here a very clear and evident difference mude between the excellent Dutch cattle and the Holstein n... $+H_{1}+$ ' breeds whose origin Low traces to a Saxon colonization.

can make the Dutel cattle fow lines further oll, -from which lines the 'herd in the Holstein cattle in the French version, 'whence tw hest Dich ch races themselves originate')is incomprehensible; and it is evident Low orrs, or is not sufficiently ac

quai

befi [II) furt

E of $\mathrm{T}$ ble ti roufi "Du

Thi speak It giv the tir 1857 , ahound of sily belong

Tlio that th the Net edly do patge !, rejultat strunge

1st. thin th: 2n11. $3 \mathrm{rd}$. for a pe taining of whicl Acror origin of probubly Empreron mouth of Accordin 
quainted with the history of both countries. For nlrendy soven centuries before the colonizution in Englund, of the Jutes und Angles, the Friesinns [Hollanders] were known for the grenter number of their cattle, as will further appeur.

Wery Spring, thousands of Holstein heifers nre driven to the fields of Northern Germuny and Hollund, where people find it is more profitnhe to buy heifers than to ruise them; and the numo of the breed got confused, so that the name "Hollund cow," was here trunslated into "Dutch cow," etc.

\section{About Herd Books.}

The "herd-book" takes the unwurrinted liberty, whenever it should spenk of Dutch enttle, of adding immediately after, the word "IIolstein." It gives to Holstein cuttle purchased in North Holland-and of which the fir'st inportation took place in Massachusetts in 1852, afterward in 1857 , etc., but the greatest in 1861-ill the honor the Dutch cattle so abundantly deserve, and nppenrs to have made the geogruphicnl blunder of supposing North Hollund, Frieshund, Groningen und Oldenburg as belouging to Holstein.

The thesis so arbitrarily adopted and set forth by the "herd-book," that the large black and white cuttle imported into North America from the Netherland provinees of North Hollund and Friesland have "undoubtedly descended from the originnl stock of Holstein," as it proclaims on page 9, rerguires a most decided denial and refutation for the honor and reputution of Dutch cattle; and, without being led astray by the most strungely jumbled-up referenees mentioned, I wish to point out,-

\section{True History.}

1st. That the history of the Duteh or Holland eattle dates further back thin that of IIolstein.

2ull. That the Holstein enttle deseended from the Dutch; and

3rd. That the name of "Holstein eattle" is only a local uppellution for a peculiar indigenous breed, constituting only one of severil appertuining to the same group, numely, to the groups of the Lowland rnees, of which the Dutch breed is the fundamental type. To this I now proceed. According to the "Allgemeine Deutsehe Real Encyclopedia," the origin of Holstein Schleswyck lies buried in obscurity, and Holstein was probally visited by the Cimbri; while a century after, the Roman Finperor, Cesar Tiberius, arrived with his army and fleet before the mouth of the Elbe, without, however, setting foot on the Holştein shore. According to Tacitus, it may be stated, that the Holstein Baltic coast was 
inhabited, as fur as Mecklenburg and Schleswyck, by seven petty German tribes, of whom the Angles and Warnes have preserved their names down to the present time; while the others have been melted down iuto that of the Saxons. In the fifth century, the Saxons and Angles united with the Jutes and Friesians, and migrated to England. (This is Low's colonization.) Subsequently, the Holstein Saxons, who dwelt to the north of the Elbe, were called by the name of Normans; while the nume of Holstein is not mentioned in history before eight hundred yenrs after Christ. In 1128-64, the Holstein provinee Ungrien was conquered and converted to Christianity, and partly peopled with strange colonists from Friesland, Holland and Westphalia.

It appears that, with regard to its fitness as a grazing and eattle-breeding country, Holstein is of later date thun Holland; which fact will appear the more prominent after some necount has been made of the oldest inhabitants of Holland and their pursuits.

\section{What History Bays.}

For this purpose $\mathbf{I}$ at onee direct the attention of the reader to the coming of the Friesians and Batavians. The former were the oldest inhabitants of Holland, and were known as herdsmen, hunters and fishermen. Their history in this country goes as far back as 300 years before Christ. The Batavians cume 200 years later ( 100 years before Christ) down the Rhine; and, although they were likewise herdsmen, they occupied themselves more particulawy with hunting and fishing.

The lands of the Friesians comprised the whole country to the north of the Rhine as fa as the shore of the North Sea, to which West and East Friesland belonged, composing the present Dutch provinees of Groningen, Friesland, Dreuthe, and North Holland, besides the provinees of Utrecht, Overyssell, and a part of Gulderland and South Holland. Of all these provinces, Groningen alone appertained to East Friesland.

Tracitus says of the Friesians and Batavians: "They owned eattle, not excelling in beauty, but in number." He further states, as docs nko Julius Cesar, that the Fri, sians and Batavians paid each other in eors, sheep and goats, and gave likewise to their children as dowry, oxcn adipted to the yoke and plough, cnttle and horses. When they were subducd ly the Romans in the first century of our era, the conquerors derived nurh advantage from this wealth in enttle, and imposed upon the Friesians an anmul tribute, consisting of cow-hides and meat; while they chose their most valient warriors from among the Batavians.

The Friesiuns and Batuvinus applied themselves to the druining of their marshy lands and their islunds, created meadows on the reclaimed soil, which $\mathrm{tl}$ and dik through regurdiin color in juus, wh the nortl Scandina after-cen as far as unite wit tion to w and not $Y$

The Fr. Elbc, bot inclemenc vial swam these local to land th It can 1 make sure racies com people fro no means whose land ing their pe penetruting where givi was betwe these stintel brief, it ent existed a lo It is also Westplalia, largely eons Hence w descent than originated $\mathrm{f}^{\prime}$ lian enigran

After thi remarkable cultivation. 
which they first protected against inumdations by raising hills, lreakers and dikes, of which the traces are everywhere discernible along the coast throughout West Friesland and Groningen. Something is even known regarding the color of their enttle, namely, that thev held those of a white color in religious veneration. It is a very plausible theory that the Fries- ' jans, who, at as early a date as three hundred years before Christ, peopled the north of the present Netherlands, and wrought those alluvial plains of Scundinaviun clay into soil fit for the requirement of their cuttle, did, in after-centuries, sprend themselves in more northerly and ensterly directions as far as the Elbe-as we alrendy know they did, in the fifth century, unite with the Jutes and Anglo-Saxons in emigruting to England ; in addition to which, we must observe that theso wore probably East Friesians and not West Friesians.

The Fricsians, from Oldenburg and the country near the mouth of the Elbe, both south and north of that river, were compelled, through the inclemency of those regions-then in their original condition of low alluvial swamps, inundated at every tide-to desert them. It was owing to theselocal circumstances that the Romans were prevented from endenvoring to land their army.

It can be shown that the inhabitants of this territory were unablo to make sure provision for their own wants because of the robberies and piracies committed by the Normans, dwellers on the west coast of Denmark, people from Inlstein and Schleswyck, Jutes and Angles. These were by no means peaceful breeders of cattle, as were the Friesims and Batavians, whose lands they constuntly plundered and luid waste, burning and ravaging their possessions, massacring the inhabitants, making them pay tribute, penctrating far inland to the mouths of the Rhine and Yssel, and everywhere giving unbridled vent to their ferocity and love of plunder. This was between the eighth and eleventh centuries. Giving due weight to these statements, which, from the nuture of the case must be necessarily brief, it cumot be doubted that the cultivation of cattle in the Netherlunds existed a long time before such a thing could be thought of in Holstein. It is also quite as certain that the colonies from Friesland, Holland and Westphaliil, carried with them their cattle into Holstein. Their wealth. largely consisterl in their herds.

Hence we see that, first, the Dutch rare of cattle date from an older descent than those of Holstein; while, probably, second, the Holstein cattle originatel from the Friesian brced and from that of the Duteh and Westphalian enigr'ants.

After this colonization, we have our attention directed to another remarkable particular in the rapidly advaneing history of the Dutch sattle cultivation. 


\section{Regular Markets Established.}

From the fourteenth on till the eighteenth century, a large number of Dunish oxen were annually turned for pasture into the grassy meadows of North Hollind-formerly West Friesland, and sold ut the weekly North Holland cattle murket. The oldest of these eattle markets is that of tho eity of Hoorn. This market was alrendy established in 1311, and in 1839 the Danes and the inhabitants of the Eyder were allowed by Albrecht, duke of Bavaria, to hold $n$ weekly market there. In 1605 , the Danish eattle market was removed from Hoorn und transferred to Enkhuyzen, when, in 1624 , the number of 1,179 oxen were sold. There wis also in Amsterdam a lenu-cattle murket, begiming in the Spring, in the month of April, but held at irregular periods, depending upon wind and weather, when cattle were ullowed to be conveyed from Denmark and Holstein hither to grazo. These wero mostly brought by vessel. Mr. Hengeveld says :

"These importations of Danish mud IIolstein cattle into North Holland, to which the 'herd-book' might refer, did not consist of 'heifer's' but of lean oxen, which were pastured on the fertile meadows of the Polders, und afterwards sold ut the murkets of IIoorn, Enkhuyzen and Amsterdam as fat eattle. As to heifers, either then or now, having been imported from IIolstein into Frieslind und North Holland for the purpose of breeding, no such thing is known."

To withloold nothing, and to put nothing in a distorted light, I may add, that in the middle of the 18 th century severnl importations took place into Friesland of Dinish cattle, consisting of young calves. This wass at the time of the raging of the cattle-plague, which desolating disense curried off thousands of the finest cattle in Friesland and Holland.

For the purpose of kecping the cattle trade alive, and to fill the phaces of those destroyed by the plague, small Dimish hreeds and German cors of diminutive size were substituted and crossed with the remaining and recovered natives.

"They were," says Scheltma, “Danish, IIolstein and small German cows, of which the greater part were smaller in size than the native race." In the same work we find, "that one was reduced to the neessity, in 1769, of purchasing the needful cuttle in the county of Bentheim. in the district of Oldenburg and Munster, in Hanover and other parts of Germany.",

In the work, "Present State of Friesland," it is mentioned that, " owing to the cottle-plague, the people were compelled to in port from abroad all kinds of small cattle, chiefly Danish. But, what wis remarkable, however small and ill-favored these animals might be, when com- 


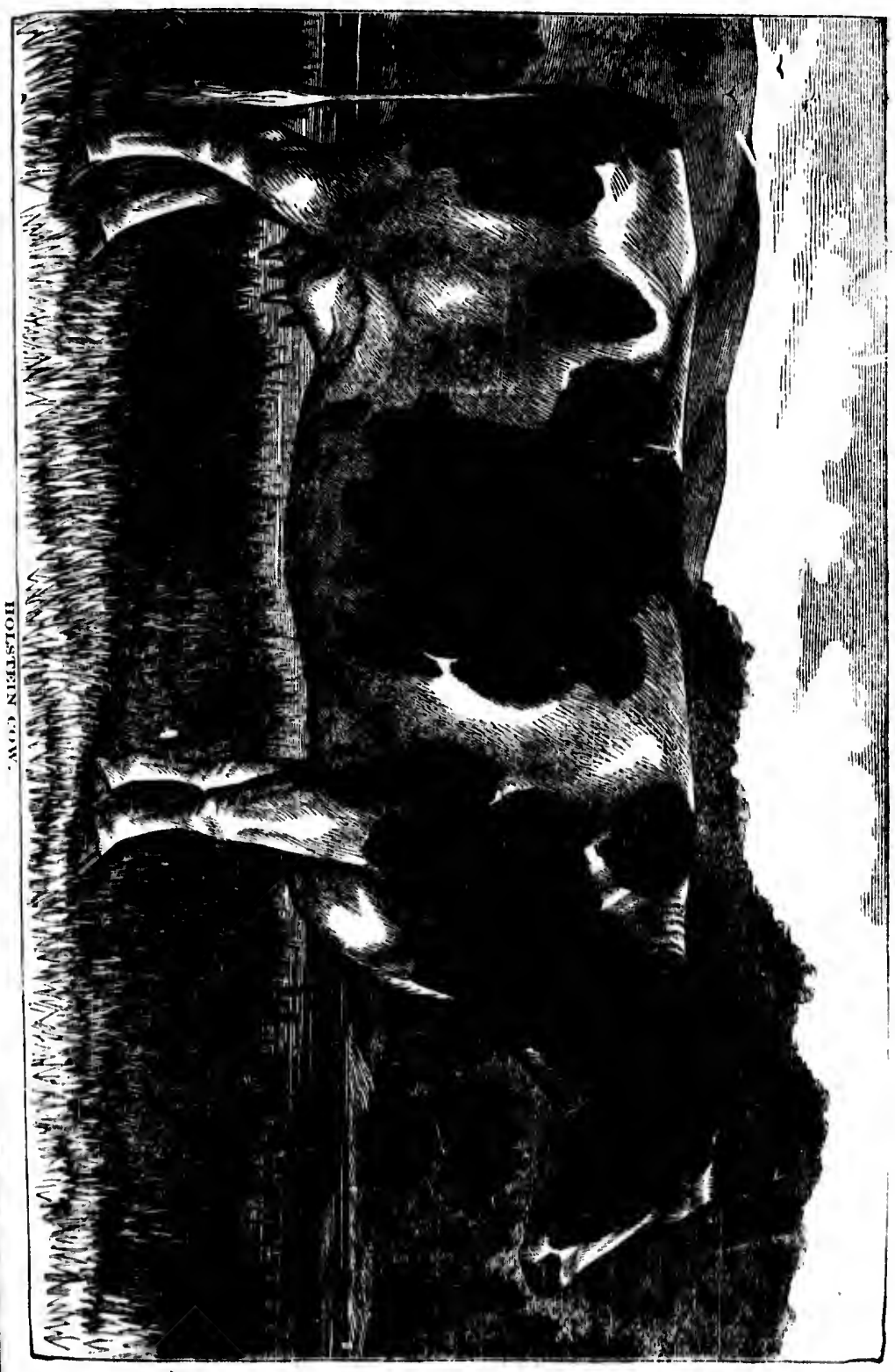


pared with the handsome Friesian horned cuttle, as a natural consequence, an improvement of food induced a favorable development of body, and, from the mixture of the two breeds, good and choice milch-kine were uttrined within tro or three generations of the introduction of the foreign blood, no mattor how much the race hud in the beginning deteriorated through the process, and, oventually, the type of Danish and German cattlo was quite lost." This is, lowever, ulready one hundred years ngo.

A fuir considerution of what has been thus far stated will lenve nc justification of tho "herd-book's" imputation upon the antiquity and purity of descent of our Friesian or Duteh cattle; or its assumption that they are of Holstein origin. No ; the genealogy of Netherland cattle is pure and unadulterated, and it is at least two thousand years old.

Feote as to Dutch Cattle.

Our authority continues as follows:

"I come now to the present time, and the question whether it is tenable to give to one varicty of cattle the name of an entire group, and to reckon as appertaining to it all its several varieties or breeds, - as, for instance, the Dutch, Friesian, Oldenburg, Holstein, etc., - and would it not he imperative in such a ense to give it the purely historieal name by which it is generally known? If it could be desirnble to give a general name to the eattlo of the just mentioned districts, then that of Holstein 'attle would not be appropriate, and for it should be substituted that of Friesian cattle, whence all the varieties originuted.

"'The chief characteristics of this Friesian breed-its eminent milk. giving and fattening qualities-wo find in nil the just mentioned districts, and extending still further southward; with this difference, however, thit wherever the land is more fortile, the elin. ate milder, and the tending, foeding and breeding of the cattle olsseryed with more care, in that meisure, and according as theso requisites stind to each other in the rlosest proportion und harnony, they are more developed, attuin lirger sime and are of $\boldsymbol{n}$ finer texture.

"If the intention be to convey a correct understanding of the trun qualities of the severul varieties or breeds mentioned in their own dwelling places, it is better that each breed should retain the name by which it is knowu, and that no collective nane, though a historicul one, should be given them.

"In order to be nble to rendily elassify $n$ group of cattie of great exter:, possessing the same chief qualities in form and productiveness, Sturm* proposed, so long as fifty years ago, to give to a group, subject

"Dr. Sturm: " Of Races, Croseing and Improvement of Indigenou Domestic Animala." Fiberfield, 1825. 
ence,

und, were oreign orated erman 's ligo. une no. ty and mpltion ud eaturs old.

temable , and to - as, for would it name by - general Ilolsteil $d$ that of ent milkdistricts, however, e tending, e, in that er in the iin larger

the true alwelling hich it is should be of great ctiveness, p, subject ic Animala."

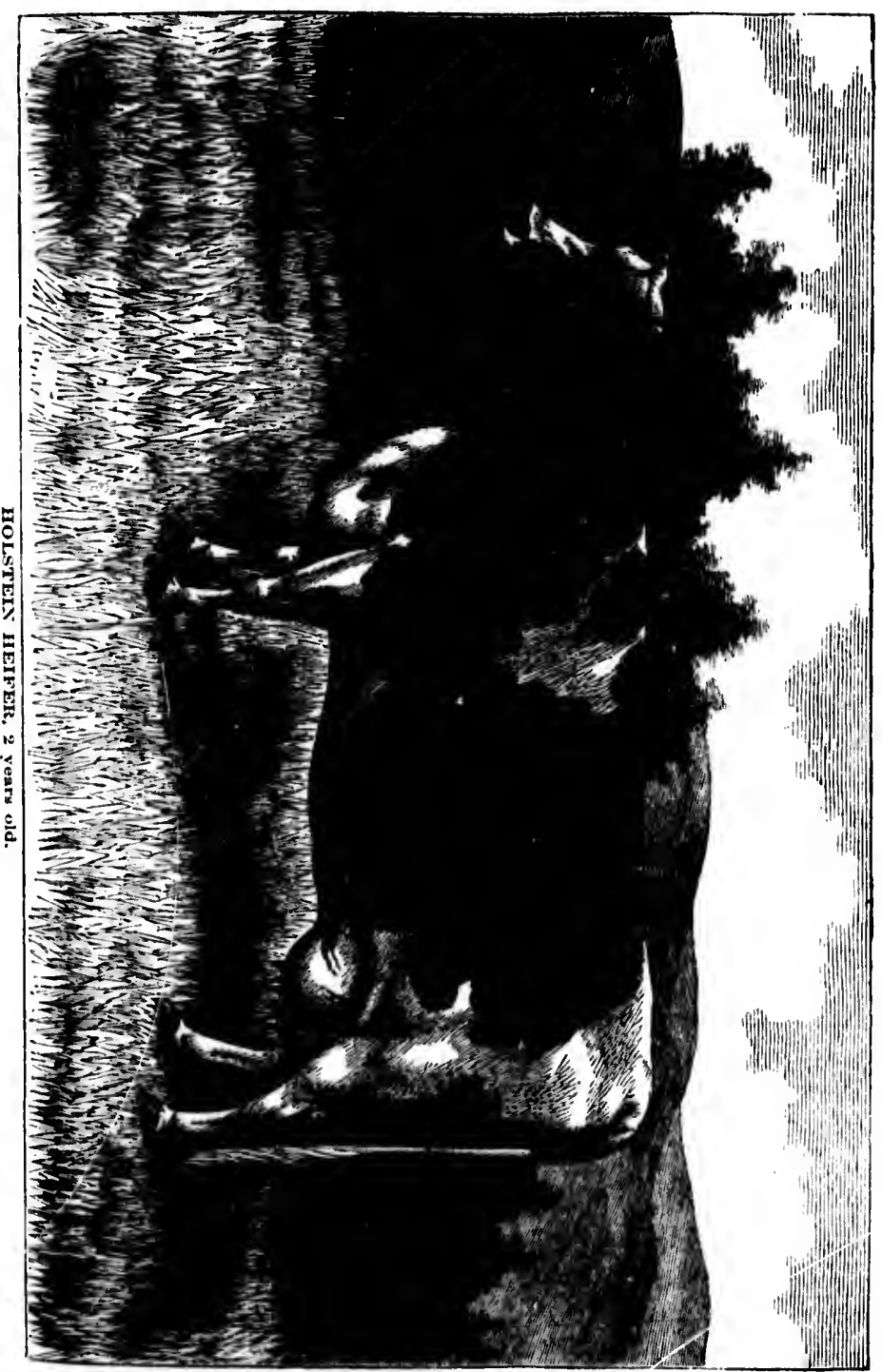


to the sume conditions of soil und clinute, $n$ nume indicuting those conditions, and thus origiuated Mosntuin Cattle, Highland Cuttle, and Lowlund Cattle. He also heads each of these divisions by the breed best representing the distinctive fenture of its elass, as its type. It is under the denomination of Lowlund, Cattle thit he places the different breeds of the coast lands along the North Sen. Schmulz, Palst, and muny subsequent writers, adopt this classification; some with a few modifientions, but all in the physienl eharneteristics of the country to which they are indigenous, the general denominntion of the collective group, according to Schmalz's statement, cattle, adopting Sturm's classificution, may be distinguished in the following munner :

\section{Races of Dutoh Cattle.}

"A. Lowland Race.-Primitive cow ; Duteh-Friesiall cow.

"B. Mountain Race.-Degenerate, quite tho contruly of A; Swiss cow.

"C. Middle Raee.-Highland race; forms the trousition from $A$ to B ; Finukish cow.

"Schmalz says, "To the race A belong the Dutch, as representatives, the Friesinn, the Oldenburg, and chiefly nll Lowlund rnces benring the peculiur churacteristics which identify it with the pluee of its sojomm.'

"This is a purely natural division, and there is not the lenst arrogunce in usserting, what history points out, thent the Duteh cuttle constitute the type of the oldest, purest, and best loreed. All other varietics are of less intrinsic vulue; they are coarser or smaller, possess less productive qualities, though of locnl excellence in their nutive places. 'If carlle of' the genuine breed are bought, imported elsewhere, and there bred, why i* it not called by its native name, and why must an appellation be given "" it quite foreign and unknonon to itg'

"One hears in Europe of 'Lowland enttle,' lut purchases of then for' the purpose of improving other brecds have, for the last hundred years, been only mude in the ehief Netherland provinces, where the choicest enttle of the Lowlunds are found. Thus, thousands of Duteh and Friesiut cuttle nre unuully sent ubrond under the nume of Dutch cattle."

\section{Dr. George May's Testimony.}

Finally, I beg to ndd quotutions from Dr. George May, director of the ngriculturul estalslishment "t. Weihensteplun, who visited Hollaml nbout ten yenrs ngo.

"The Dutch eattle constitute the type of the properly so-culled Lowlund

-Dr. George May: “The Cattle.” Munich. 1803. Vol. III, p. 338. 
race, which extends throughout Netherlands, Flanders, Normandy, Oldenburg, and Denmirk. The Oldenburg enttle descended from the Dutch rice, und are likewise distinguished ns Eust Friesian cattle, us still partially found in Hanoverinn Friczlind. In the adjacent purts of Bremen it is enlled Bremen enttle." "The Holstein nnd Breitenburg cuttle in the Wilster and Rempuer markets are equnl to **; but with respect to their squure build, the Breitenlurg cattle are in their properties more like the finer Duteh enttle."

Other writers of repute mny be quoted, but enough his been given to show that the name of "Holstein" is only n local, and not a collective name, and muy not bo given to cattle bought in North Holland. To do so is to underrite the Duteh enttle ruce.

\section{Mr. Klippart's Testimony.}

In relation to the native cuttle of Holstein, the lamented Klippart in his Ohio Agriculturnl Report of 186is, siys:

"The native attle of Holstein ure the Angle cattle, which are far mor" numerous than my other. kind or mee. They me small mimals, with fine bones, short legged rather thm otherwise; a very fine, smgll hend, and delicately formed neck. The predominating color is red or brown, but there are many dme, black, or spotted ones. According to the umount of food consumed, this race give a more almudant supply of milk than iny other in tho dnchies. It is a very highly esteemed rnee-is much sought after for its milking qualities and kindliness in tuking on flesh. The flesh is very fine, tender and juicy. On account of the great demand for stock of this rice, eattle dealers have not unfrequently gone into Jutland and other points, and made purchnses, which they represented us being genuine Angles; but in recent years a law has been pussed that every breder of Anglo stock must hrund the enlves with the letters A. R. (Angle Race, ) in order to prevent impositions.

"In these marshes aro fonnd a rnce of cattle much larger and henvier than the Angles, lurger boned, and of a dink, recldish brown, and known as the Marsh race. This race scems to bo ndapted to the marshes, but does not do well on the higher ind elyer uplands. Upon the rich pastures of the marshes, for i time nfter culving, the best cows will give from forty-eiglit to sixty-four pounds, (from six to eiglit gallons), of milk daily. But the milk is not near so rich us that of the Angles;-in fact, I was shown : statement, mppmently well muthentiented, to the effect that milk of the Mursh race contained no more thun two per cent. of cream, while that of the Anglo rue eontuined sixteen per eent. One thing is very certain, mumely : the luntter of the Marsh mee is not near no swect or 'nutty' as that of the Angle mee. 
"In Sohleswig, ruther than in Holstein, wre found many of the Jutland race of cuttle. 'These havo very fino bones, and nro long in proportion to their height, and ure, as a rule, short-legged. Tho prevailing color it gray, bluck, or gruy and bluck mixed with white, but very micely red or brown. This raco is moro highly esteemed for its eurly maturity and readiness $t$ ( futten than for its milking qunlities."

In the trinsnction of the Ohio Bond of Agriculture, 1872, in an article on Dutch enttle, by Plofessor Furstenturgr, we find the following: "The breeds of cattlo in Holland miny bo divided according to their locality as follows: 1. The breeds in tho provincos North and South Holland and West Friesland. 2. 'The breeds in the provinces Groningen, Guelderlund, Utrecht, and Overyssel. 3. The breeds in the provinces of Seelund. Although these breeds ure closely relited, still they show difference resulting from keeping and the various purposes for which they aro bred.

\section{Breeds in the Provinces North and South Holland and West Friesland.}

"Tho broed most renowned in the kingdom for its milk-producmeg qualities is found in theso three provines. But North Hollund in particular is noted for the mumer of keeping eattle, which are known by the name of Amsterdam race, being no less remarkable on necount of size than for the great production of milk. The pastures of North Holland are saicl to contain 100,000 morgen ( $158-100$ morgen to an aere) ; every acre furnishes nourishment for 49-100 head of enttle. The pensints are engaged aluost solely in eattlo breeding, and the kecping and eare which these animuls recoive here has almost become proverlial on account of its perfection.

"Tho eattle here are mostly spotted black and white; however, brown and blue or gray mixed are found. The height is considerable, being not undor two Amsterdim ells (4 51-100 fect) ; the length of the hody in proportion to the height, the midcllo part of which is particularly developed, the quarters fleshy, neck rather short than long, with a strong dewlip); heid nurrow and long, with tho forehend slightly depressed; fine horns crooked forward, and large projecting ears. The withers are often narrow ; the back, on the other himd, broad across the hips, whieh are not very prominent; the tuil fine and long, with " good tuft of hair; the position of tho hind legs strong und struight (not knock-kneed), tho hind-rinarter: brond and roomy, and the ling well developed. The lower part of the legs alove the hoofs is inrmialoly white, which is regarded as a sign of the pure mumixed breed. The live weight of the eows is 1,200 to 1,400 pounds ; that of bulls renehes 2,000 pounds when full grown and fitted. The cows are unusunlly productive of milk, and give an average of 3,000 quarts and over per annum.

"A

cow st: natiou: Nethor 1865. quantit quarts $i$

"To

IIollind are larg to their keeping mamufice stock it which st for the b

"Holl aecustom when its ! essary. on a sean a light soi care and received $f$ as yours has shown

"Three cows of $\mathrm{T}$ Scotland,

"The yi

"1. Fou quarts, or 2,345 quar

"2. Thr 2,86+2-3 :nilker gavd "3. Thr quiluts, or 4 2,249 quart 
"A very excellent milch cow of tho 'Amsterduu race, from the royal cow stable in Eldenu, which wiss brought with a few others to the Interuational Exhibition, took the first premium for mileh cows of the Netherland race at the International Exhibition of live stock at Stettin in 1865. This cow, fed in the stull only, gave in one year the grent quantity of 6,142 quarts of milk, and kept up afterwards to 4,000 quarts in un equal length of time.

"To the breed of North Holland are neurly reluted those of South Holland and West Friesland, and differ perhups only in that the lattor are larger boned, and in general of not so pleasing a form. In regurd to their milk-producing qualities they are about equul. Tho manner of keeping the stock, und the use of the milk, is also the sane, viz.: tho manuficture of cheese, while the calves are ruised and sold as young stock at high prices. Froin these three provinces, the former two of which suffered so much lately from rinderpest, milch cows are bought for the best dairies in Germuny.

"Holland cattle are well adapted to soiling, although ut home they are aecustomed to pasturage. They are kept profitably on the latter only when its abundance fucilitates grazing nnd makes corporal exertion umecessary. Thorefore a great error would bo mado in placing these mimals on a scant pasturage, and they are not at all adapted to the pasturage of a light soil. The result of stall-feeding is more favorable, because proper enre and fodder cun be given the stock without its exertion. We lisve received from no other race an equal quantity of milk with the same feed, as years of observation in the cow stable of the Academy at Fldena has shown.

"Three years ago (in 1865), different ruses were kept here, vi $\%$ : milch cows of Toudern and Breitenburg, in Sehleswig-Holstein, of Ayrshire, in Scotland, and of Holland.

\section{Yields of Millk.}

"The yield of milk this year of these races was :

“1. Four Toudern cows gave 9,337 quarts, or an averuge of 2,334 quarts, or 6 3-10 quarts per day for the year. The largest milker grave 2,345 quarts, the smallest 2,020 quarts.

"2. Three Breitenburg cows gave 8,594 quarts, or an average of 2,864 2-3 quarts, or $785-100$ quarts per day for the year. The largest: :milkel gave 2,946 quarts, the smallest 2,820 quarts.

“ 3 . Three Ayrshire cows gave 5,386 quarts, or an averuge of 1,795 1-3 quirts, or 4 92-100 quarts per day for the year. The largest milker garvo 2,249 quarts, the smallest 1,415 quarts. 


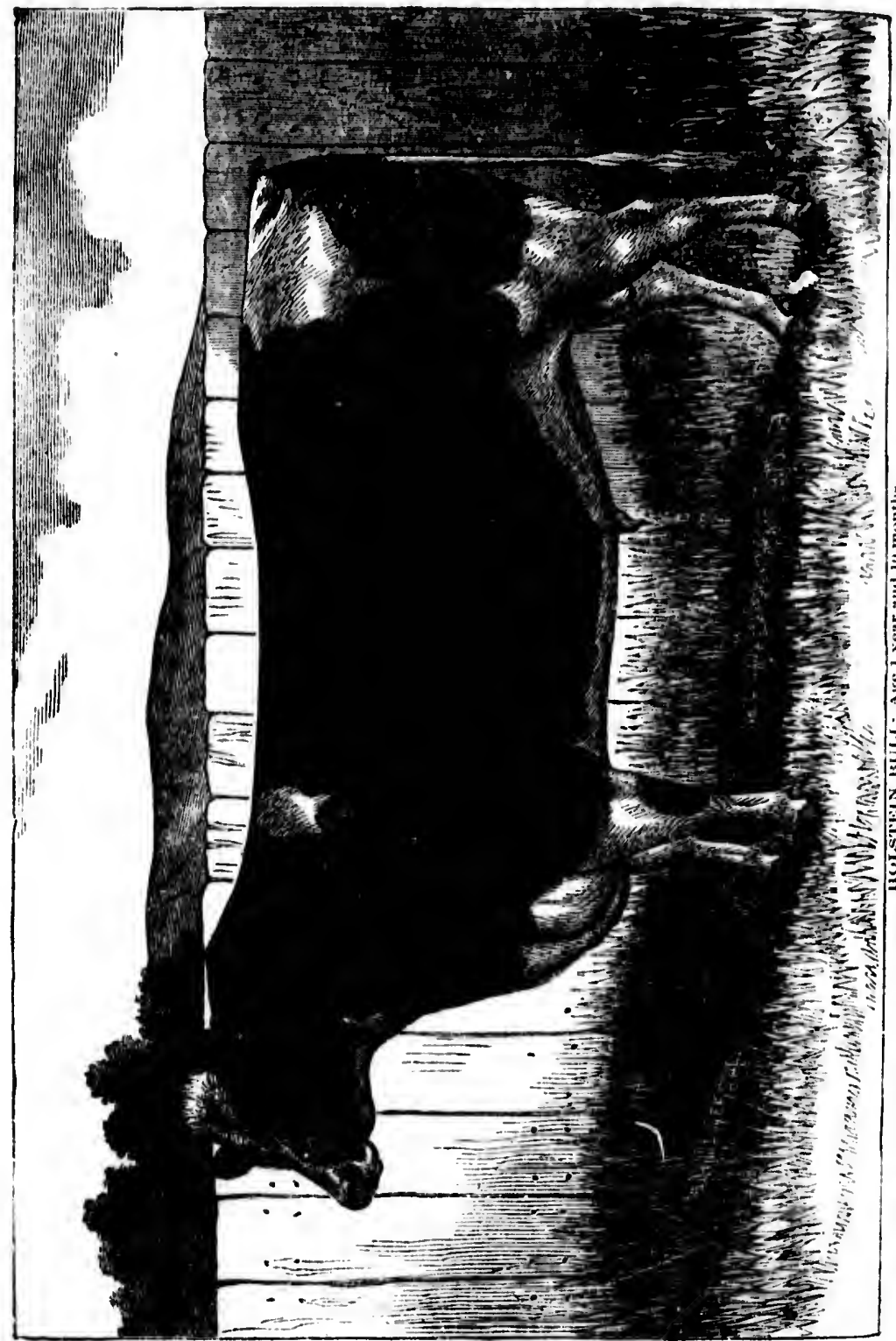

3,550

"Tho mer str beets ; 1 pounds pounds I

"Duri green foo and threo

"Altho ally, thin weighed o compariso greuter min viz. : Ninc mother of The propor of hay, tho "From $t$ 5 pounds w $625-100 \mathrm{po}$ of hay. preferable.'

"Le Roy, scattered and tion to the 1 from the rec ward, none b "The first those of $\mathrm{Mr}$. four cows, w previous to tl importations four more cov to import ple 
"Twenty-two Holland cows gavo 78,100 quarts, ol an averuge of 3,550 quurts, or $973-100$ quirts per day for the yenr. The largest 'milker gave 6,142 quurts, tho smullest 2,526 quarts.

"Tho averngo feed per hend in the Wintor was dnily-10 pounds Summer stmw, out fine: 2 1-2 pounds ont and whent chuff; 25 pounds beets; 10 pounds hay; 8 pounds refuse mnlt from beer brewery; 3 pounds rye bran. This food is considered nbont equnl to 12 9-10 pounds liny.

"During the Summor the cows were fed daily per head 135 pounds green fodder, viz., clover und vetehes (of the latter very little wus used), and threc tiues a day 8 pounds of hay."

\section{Feeding Qualities.}

"Although there is no doubt that the Hollund cows eat more, generally, thun the smuller Ayrshire and Toudern (for the fodker was not weighed out for each animul separntoly), this is of minor importunce in comparison with the grenter amount of milk given by the former. 'The greater umount of feed eonsumed by the Holland cows can be estimnted, viz.: Nine of them steod at one crib, while ten of the smaller stood ut amother of equnl size; the fodder was, however, divided the same in enel. The proportion is as nine to ten, or when the smuller eows eit, 45 pouncls of hay, the larger ones ont 50 pounds.

"From the quantity of milk given, the Holland eows nsed in trifle over 5 pounds weight of hay to produce one quatrt of milk; Breitenhurg used $625-100$ pounds of hay; Toudern 7 pounds of hay; Ayrshire 9 pounds of hay. By these results it cannot remain doubtful which race is preferable."

\section{Early Importations Retained Pure.}

"Le Roy, father and son, should not have allowed their herd to heeome seattered and lost as a pure breed, when they subsequently turned nttention to the breeding of Short-Horns. Thut this was the fuct is evident from the record, that at the sale of the furms of these gentlemen, afterward, none but grades were found in the herd or in the adjacent country.

"The first importation of animuls that have been retnined pure, were those of Mr. W. C. Chenery, near Boston, in 1861. This was a bull and four cows, which were suceessfully bred and kept pure. Mr. Chenery, previous to that tinse, in 1852 , imported $n$ single cow ; in 18.57 he made importations of a bull and two cows, and in 1859 a further importation of four more cows. With this latter importation he was so unfortunnte as to import pleuro-pneumoniil. The ravages of this dread disease extended 
to the entire breed, und with the exception of 1 single young bull they were entirely destroyed. In $1861 \mathrm{Mr}$. Chenery mude mother inportation of "bull and four cows, which came over sound. 'These and their doscendunts were the only pure bred herd in Amerien for years. That they were the best representatives of their breed is certain from the fuct that they were selected with care from the best dairy herds of North Holland, and were so certified to by the official unthorities of the districts wher they wero bred."

\section{Holsteins as Milkers.}

As being interesting history und also as a means of comparison with their descondants and also with later importations, we give somo interesting data :

The four year old bull girted 7 feet 10 inches. His length was 8 feet 7 inches ; height, 4 feet 11 inches, and his weight was 2,465 pounds. Ilis color was jet black and clear white, the white being confined to the forchead, with a large patch on the withers and top of the rump; the linibs, brisket, belly, and flunks being also white.

In relntion to yield and quality of milk, Mr: Allen says :

"'The fout imported cows, ench seven yenrs old, hnve mu nverugo weight of 1,325 pounds. The weight of a past two-year old heifer is 1,240 pounds. A past yeurling heifer weighed 960 pounds; nnd the weight of six calves at an nveruge of eight months, renred in the usual why, without forcing, was an average of 576 pounds ench.

"The milking, qunlities of the breed may bo judged by the following. memornuda: One of the imported cows, when six yen's old, dropped s calf on the 15th of May, weighing 101 pounds; and from the 26th of May to the 26 th of .July, by n eareful and exact record, gave 4,018 pounds 14 ounces of milk. The largest yield in any one day was 76 pounds 5 ounces (35 1-3 quints). In ten duys she gave 744 pounds 12 onnees, or wn nverage of 74 47-100 pounds per dny. She gave a good flow of milk during the season, continuing to the 24th of May following, and on the succeding dity dropped twin heifer calves, which weighed 155 pounds. The anount of erenm produced from this cow's milk, in n vessel specially prepared for mensuring it, produced 22 70-100 per cent of the milk, as tested by an accurate examination.

"The nutritive qualities of the milk wero also tested by a thorough chemical analysis, and found to be excellent. It is also rich in its caseine, or cheese-making properties. Six days' milk of this cow was set for cream, and the produce was 17 pounds 14 ounces of good butter-netrly 3 pounds per day; aud it is clained by the owner that she is not the very best cow of the herd. 
"These results slow not only the remurkable productions of the cow, bat the uccurate und pains-tuking care of the proprietor of the herd in testing their ability at the puil. Of what the food given to the eow was composed, we are not informed. Wo aro to presume, however, that it was of the best, us every cow should have, to test to the utmost her liceteal faculties."

\section{Weighte and Milk Products.}

The Ilolstein bulls weigh from 2,000 to 3,000 pounds, and are kind, tractuble, grood tempered. A half-blood Holstein steer is recorded that weighed 1,900 pounds, and some two-year olds that averaged 1,300 pounds.

II a lurge number of tests that have been made with Holsteins and nutires ut vurious factories in the $W$ est, the results reported showing as follows: Nutives runge from 5.000 to 8,000 per year; Holsteins, from 8,000 to $12,000 \mathrm{lbs}$. per yemr of milk.

In a comparison of IIolstein and Ayrshires, the following is the report of three herds of $\Lambda$ yrshires, including Dr. E. L. Sturtevant's herd. The Dr. gives the reeord as follows: General average with 13 Ayrshires for four yeals, 5,543 lbs. The best year was 1872-13 Ayrshire cows (no heifers), 6, 047 lbs. Mr. E. F. Miles, of Massachusetts, gives the following yichl of Ayrshires: Best yenr's average ont of five yeurs wus 6,292 lis., from a dairy of 11 cows ; general average for five yeurs, 5,614 lbs. Mr. F. II. Appleton, of Mussuchusetts, gives the following record of three Ayrshire cows for one your, avernge, 7,055 liss.

It is quite safe to say that these enttle will give from 8,000 pounds up to 12,000 pouncls n yeur. Mr. Hubble, of Onarga, Ill., gives the record of our cow, which gave 14,000 pounds in less thm one year, and another which, in 1878, gave 15,960 1-8 pounds of milk.

\section{Herd Records.}

As showing the grent value of any pure breed in the production of milk. heeping in mind uwnys thint the Jerseys give exceptionally good milk, and the Ayrshire and Short-Horns the next in richness, we append a list if herds $f(r)$ a series of yeurs, showing the number milked, tho average yielded per eow and the avernge of all given breeds, which is tabulated on next paige.

As milking cows the Holsteins are wonderful, as cheeso-maker's they are superior, as butter-mmkers they do not stand the test so well. In fact, Holstein breeders nlways tell how much milk their cows will give; the Ayrshire men, how much milk, and butter, and cheese their cows will 
AVRAUIRE URRDS

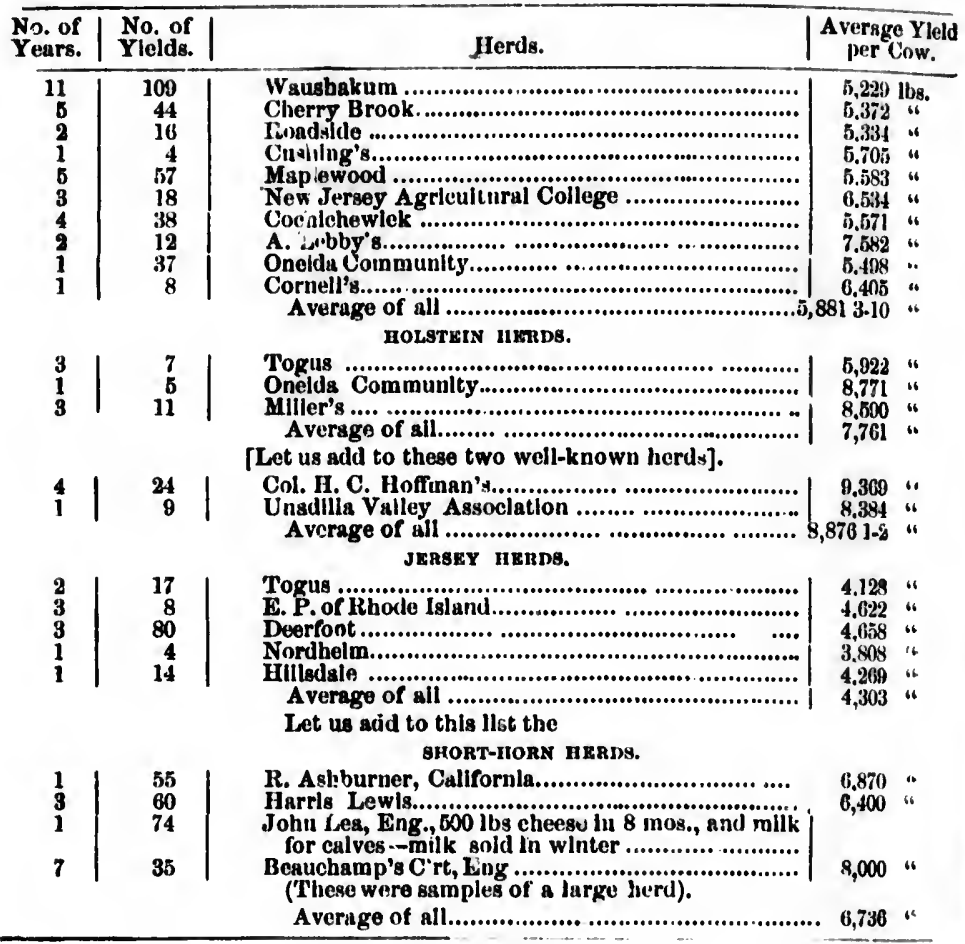

make; the Jersey owners, how much butter and cream to the quart of milk. To show that the Holstein is not a butter cow, the following dedueer from a table published by the London Agriculture Journal, the results of tests made by $\mathrm{Mr}$. Amersfoordt, of Badhoeve, in the Lake of Haarlem, Holland, a most competent authority, who tested the milk of 46 eows in June, and 49 cows in November, with Prof. Tesse:'s lactoscope, which is elnimed to give a close upproximation to the netual fat in the milk.

In the table made by Mr. Amersfoordt, the yield of each "ow on the 15th of Jule and the 24th of November is given with the per centage of fat. The average yield of 46 cows in June, is 13.87 litres, or 31 lis. each, and the per centage of fat 5.217. Six of the largest milkers gave 20.2 litres, or 46 lbs. per dny, with 5.2 per cent. of fit. 
November. So considering the noble milking powers of this breed, und their well-known ability as cheese-makers, their outcome in butter should be considered satisfactory.

\section{The Eerry Cow.}

In Ireland, from time immemorial, there has existed two distinet races of cattle that were valuable in their day and time; one a long-horned breed, and the other belonging to the middle-horns and considered an abrriginal breed. Of the long-horns we have already made what mention is necessary here, except that we may add that from their resemblance to the English long-horns, they have been supposed to have had the same origin; but whether the English family came from Ireland, or vice versa, is not known; history is silent on the subject, and it matters but little to this generation. The middle-horns and the short-horns are the valuable cattle of the present day, and they will be the cattle of the future.

The other representative branch of the genus Bos in Ireland, the enttle of Kerry, or as they are now termed, Kerry eattle, are worth more than a passing mention, because there lave been representative animals imported to the United States, and they may have valne in some mountrinous countries of the United States, and the fur Northwest, for their extreme lardiness, their facility in shifting for tismselves, and their adnptubility in fattening when not in milk. As: 2,4 ' d they are rare, and even in the last century were not to be fou is s.s.p. inland on the mountains. They are deseribed by Yountt as small, light, active and wild.

\section{The Kerry at Home.}

The head is small, nlthough there are exceptions to this in various parts ; and so numerous, indeed, ure these exceptions, that some describe the native Irish cattle as having thick hends and necks; the horns are short, as compared with the other breed, all of then fine, some of them rither upright, and frequently, after projecting forward, then turning lackward. Although somewhat deficie:.: in the hind-quarters, they are high-honed, and wide over the hips, yet the bone generally is not henry. The hiir is coarse and long; they are black-brinc'led, black, or brindled, with white faces. Some are tiner in the bone, and finer in the neek, with n good eye mnd sharp muzzle, and great netivity.

They are exceedingly hardy; they live through the winter und sometimes fatten on their mutive mountuins and moors; nid when removed to a better climate and soil they fatten with ull the rapidity of the aboriginal 
cattle of the Highlands and Wales. They are generally very good milkers, and many of them are excellent.

The cow of Kerry is truly a poor man's cow, living overywhere hardy, jielding (for her size) an abundance of milk and fattening rapidly.

These cattle usually are small, and are confined to the hilly and moor grounds. Some are of considerably size, elscwhere, and are improved in form as well as weight. The horns, usually of middle length, turn up, as do the horns of those on the mountains; they are shorter in the leg, shorter in the body; their loins and haunches are heavy and wide; although the hair is thick, the hide is mellow, and they thrive with rupidity. This is as they were known many years ago. They have since been bred with care. The London Stock Journal of a late date says of them now: "These characteristic points of the breed are unmistakably well marked. The size is small. The legs in most cases are very short in proportion to tho size of the body. The head is somowhat small, though tho muzzle is long and clean. The lips are thin; the expression of the countenance is pleasing, and the oye is particularly clear and fairly prominent. A symptom which is most indicative of purity of breed is the "turu up" of the horn, which is of medium length. Occasionally, however, the horn will, nfter turning up, turn backwards. The nicety of the horn and the manner in which it is set on adds inmensely to the style. The neck is not massive at the junction with the head, but it thiekens gradually, and affords reasonable covering to the shoulders. The latter are flat and thin. Tho dorsal vertebre rise more than in other eattle, which sometimes gives the back an irregular appearance. The ribs spring well, especially the last of those appronchng the hip); this makes the body very compact. The loins are of medium width, and the hip not prominent. The distance between the hip and the setting on of the tuil is not considerable; the latter hangs nently, and is well concenled by talo adjoining bones. The chest is full and deep, and the hind-quarters long, but rather light. The favorite color is black, though black and white, brown, and red, are by no means uncommon. The coat is iuvariably fue and thick, and the hide elastic and mellow, showing great capacity for the production of flesh and fut.

"Sixteen quarts of milk per dny may be regarded as the maximum quantity the best specimens of the breed will grive, and twelve quarts may be regarded as a good average for the entire seison. Tisis is, of colirse, on good keep. The milk is rich in erenm, and the butter delicnte in flavor, superior in color, and, us in the ease with the Jersey cows, one or two Kerries will give the milk of ten to fifteen other cows in the production of butter. As an indication of the richness of milk of the Kerry cow, eight to nine quarts are said to produce a pound of butter." 
In relation to their udaptubility to futten, it is said to be a remarkable peculiarity of the breed, but they take a long time to mature. At three to four years of age they will not dress more than three to four hundred pounds of beef to the fore quarters. They are not however beef cattle, nor nre they ndupted, in this country, to dairying, except by mixing, to improve the messes. In fattening, however, when of mature age, they thrive inost rapidly, and the beef in point of being well marbled, in flavor, and tenderuess, is not excelled by that of any other breed.

With proper cure and breeding, there would scem to be capabilities in this breed well worth perpetuating and inproving, especially now that dnirying as n distinctivo brr.nch of ngriculture is assuming such proportions in the United States, and particularly in the West.

In relation to constitution, hardiness, etc., the authority last quoted says : "It is nlready observed, the hardy constitution of the Kerry most enhances its value; for duiry purposes especially a remunerative yield is obtained on what would be to other animals 'starvation fare.' In the depth of the winter season I huve not only known the animals to live jumping from rock to rock, and from cliff to cliff, picking a coarse scanty bito from anong the mountains, but with very small additional keep at the furmsteading, whither they come to be milked morning and evening, to actually thrive under the circumstnuces. Fow people think of nousing the Kerry, either night or dny, at any period of the year. When not giving c.ny milk they remuin for months nway concealed in the ravines of mountinin passes, secking the best shelter they can from the excessive rain und snow storns with which their abodes are perio ically visited. The hair is thick bnt fine und long $\rightarrow$ provision of nature typical of cold latitudes.

"What, however, is far more singular in the constitution of the breed, is the readiness with which it adupts itself to circumstances of a wholly reverse charneter. In acclimating breeds of cuttle, sheep, or pigs, the trumsition mist be gradual ; but with the Kerry we have it suddenly and indiseriminaty transferred from it:s home in the mountains to the richest grazing villeys which our island ean bonst of without experiencing the wlightest change in regard to henlth. Not alone this, but we have seen the bensts ushered nt once into tho diniry sheds, und there confined for ycurs, in the (losest bonduge, without any "1) ur ont effect on the constitution. They further enjoyed the full benetit of the change as well as if the new ubode was their native labitation. It wus for a time believed that the frame of tho breed was impregnabje to pleuro-pneumonia, of other contugious disenses. Recent experiments which have been conducted have fuiled to establish this view." 


\section{0} e ad , to cy or, in hat ons ted nost $d$ is the live santy ep at ning, using n not hes of e rin The cold oreed, wholly $s$, the $y$ and richest ng the e seell ed for nstitu1 as if dieved nia, or con-

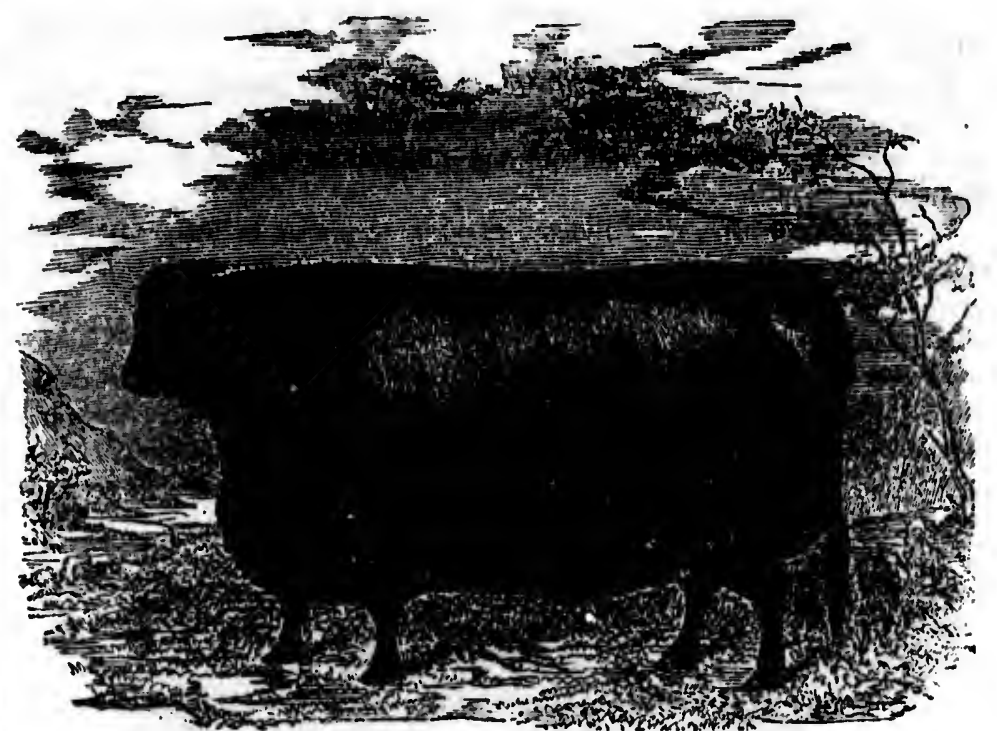

Hollkd Axous Cow.

\section{Angus or Aberdeen Polls.}

There are but three prominent heefing breels in the world: the Short Horn, llereford, and Angus or Alerdeen poll.

Several others are eminent both in quality and nelaptability to particular circumstances, but wone of them liave proved equil to these three in all that goes to make the modern moilel ox on pasture or in the stall. Angus, or Forfirstire, in Sentlund, some fifty years ago, took up the important question of the improvement of its nutive cattle upon the principles then well known through Hic sucresses of Short Horn breeders, and ere long immense progress resultel. Hugh Watson, of Keillor, was the principal agent and worker-up of all this. Ile was unquestionably the fither of not only this turanch of these polls, but necessarily, as we shall see, also of that of the Alserdeen line. These enttle were horuless, black, good milkers, somewhut stiff fitteners and good at living nn "wothing" upon the somewhat bleak rolling pastures of Angus. The stamp of animal now on hand by Mr. Watson's skill and perseverance is conrequently very hardy, grand graziers, fattening and ripening early on pasture, and, as a natural result of man's interference, also good as stall feeders.

The men of those parts and times were not indifferent to the illustrions Durham, as several purchases were nlready in possession of the more choice farms of the north of Stotlanl, but, in view of securing the more valuable charaeteristics of Funglumel's fumous beefer, nlong with " hardier constitution, ?9 
or one then supposed to be more suituble to the district, this Angus, or "Keillor Doddlie" was established.

The growing importance of the Angus breed led the farmers of Aberdeenshire to consider the improvement of their own boruless black cattle, and in order to render this more certain and rapid, they made use of the larger and best specimens of the Angus.

William McCombie, of Tillyfour, stood pre-eminent in this work. His olject was to secure a larger frame, and, if possible, a better stall feeler than the "Watson" type, in short, a "Sootch Durham," and he succeederl beyond all expectation.

These breeds had their separate herd books until three years ago, when, in consicleration of their essential oneness, in history, points and chnraeteristics, they were joined, and hence the new name, Angus or Aberdeen polls.

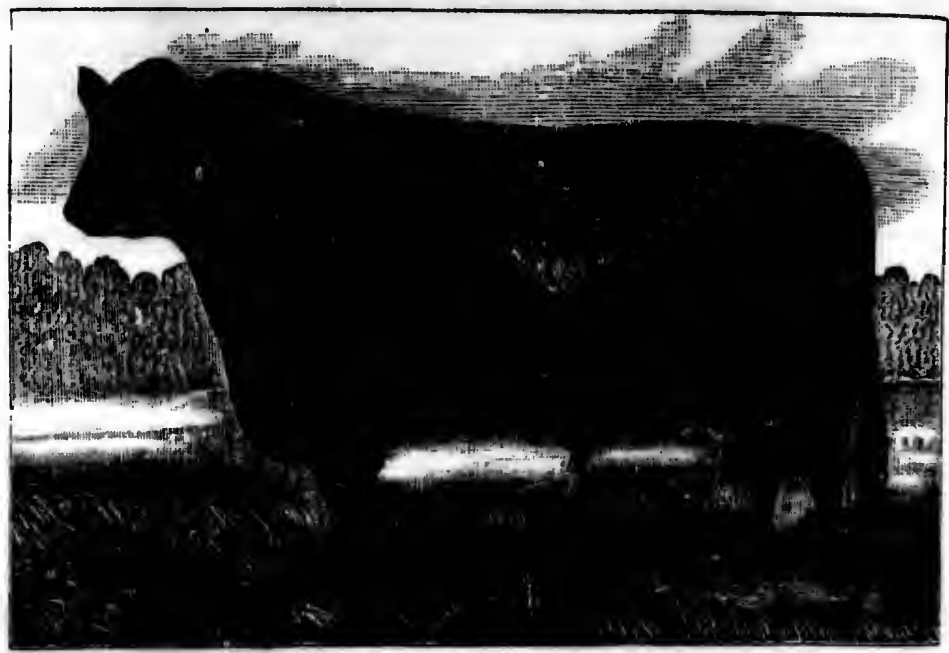

Polled Axaus Bulz.

At the present diy, therefore, we have a polled or hornless breed of cattle, entirely blaek, with cernsional spots of white on the belly anci ndder, a deep square frame, laving all or nearly all the detnils that make up the molern Short Horn. With the exception, then, of the color and horn, the Augus or Aberdeen poll, is practically a Short Horn, but more able to do well on indifferent pastures, is as a whole benter built behind the shouller and arm, and decidelly better in quality of milk and producing goxd innrbled flesh, thangh not so deep at the pail as the average Short Horn, nor probalily so heavy when matured.

It is evident from the eircumstances under which this breet lins been established-those of hill-side grazing, little grain, and plenty of hay, straw, and turnips, with severe winters and moclerate summers, that for many parts of 
the world they are superior to the Short Horn and Hereford. They have every year during the last quarter of a century so successfully competed with all other breeds that their extension in Britain and importation to most civilized countries is becoming a thing of common occurrence.

The Ontario Experimental Farm has had a herd of them for five years, and as we write (April, 1881) we read of other purchases for other parts of Canada, as well as for the United States and Anstralia.

In view of the great field now open for the raising of cattle upon the prairies of North America, several importations are being made of the best animals of this breel for the purpose of improving the common herds :

\section{Gallowas Oattlo.}

The Galloways we have seen have proved to be most admirable cattle, thick-meated, deep-fianked, short-legged, fino-haired animals. That they were considered most valuable cattle, and worthy. of being brought here in the early settlement of the country, is evident from the fact that forty yenrs ago these hornless or muley cattlo, as they were termed, wero not extromely rare, often breeding back by reversion entirely hornless or with but tho rudiments of horns, as gentlo and good milking eattle. Gentleness is a charneteristio of the pure Galloway. Even the bults are noted for their docility and quiet tempers. For tho reason that this breed of eattlo hnve of late years been growing in favor in the West as grazing and milking eattle, and for the further reason that it is thought, that erossing the Galloway on the half-wild Texan will bo most valuable, we append the following general characteristics of tho breed.

The Galloway cattlo are straight and broad in the back, and nearly level from the head to the rump; are round in the ribs, and also between the shoulders and the ribs, and the ribs and the loins, and broad in the loin, without any large projecting hook-bones. In roundness of barrel and fulluess of ribs they will compare with any breed, and also in the proportion which tho loins bear to the hook-bones or protuberances of the ribs. When viewed from above tho wholo body appenrs bentifully rounded, like the longitudinal section of a roller. They are long in the quarters and ribs, and deep in the chest, but not broad in the twist. There is less space between the hook or hiph-bones and the ribs than in most other breeds, a consideration of much importance, for the advantage of length of carcass consists in an animal being well-ribbed home, or as little space us possible lost in the flank.

The Gallowny is short in the leg, and moderately fine in the flankbones-the happy medium preserved in the leg, which secures hardihood and disposition to fatten. With the samo cleanness and shortness of 
shank, there is no breed so large and musculur above the knee, while there is more room for the deep, broad and capacious chest. Ho is elean, not fino and slender, but well proportioned in the neek and ehaps; a thin and delicate neck would not correspond with the brond shoulders, deep chest and close, compuct form of the breed. The neek of the Gallowiy bull is thick almost to a fuult. The hend is ruther henvy; the eyes aro not prominent; and the eurs are lnrge, rough and full of long hairs on the inside:

The Galloway is covered with a loose mellow skin of medium thickness, which is clothed with long, soft, silky hair ; tho skin is thinner than thit of the Leicestershire, but not so fine as the hide of the Short-Horn, although it hundles soft and kindly.

The prevailing and fashionablo color is black; a fow are of $n$ durk lurindle brown, and still fewer are speckled with white spots, nnd some of them ure of a dun color. Dark colors are uniformly preferred, from tho belief that thoy indicate hurdiness of constitution.

The Galloway cows ure not good milkers; but although the quuntity of milk is not great, it is rich in quality, and yields a lurge proportion of butter. $\Lambda$ eow that gives from twelve to sixteen quarts per day is considered very superior, and that quantity produces more than a pound and a hulf of butter. The average, however, of a Galloway cow cannot be reckoned at more than six or eight quarts per day, during the five summer months, after feeding lier ealf. During the next five months she does not give moro than half thut quantity, and for two or three months she is dry. Thero is, perhnps, no breed of cattle which ean be more truly said to be indigenous to the country, and ineapable of improvement by any foreign cross, than the Galloways. The Short-Horns almost everywhere else have improved the cattle of the districts to which they have traveled; at least in the first cross produced manifest improvement; but even in the first cross the Short-Horns have dono little good in the Galloway, und, as a permanent mixture, the choicest southern bulls lave failed. The intelligent Galloway breeder is now perfectly sutisfied that his stock can only be improved by adherence to the pure breed, and by enre in the selection. While this is undoubtedly true of all pure or thorough-bred stock, it seems especially so of the Galloways to-day. It does not however follow that pure breeds may not improve the mixed stock of a country. They must and do, as the magnificent Short-Horn, Heroford and Devon grades amply testify in all our grent markets. That the Galloways have many valuable points cunnot be denied. One of these is their absence of horns; another is their extreme docility. If by crossing Galloway bulls with Texan cows their homs enuld be toned down their wildness tamed, their frumes thickened with superior flesh, 
their milking qualities improved, and the whole animal amoliornted, it would seen as possible.with the Gulloway as by any other means we know. It is certainly well worthy of trial.

\section{Toxan Cattie.}

Within the last fow yeurs certain theorists have harbored the idon that the immenso herds that cover tho great plains of Texas, Mexico, and Americi are a race native to the soil, and that havo existed there from time immemorial. Such lowever is well known not to be tho fact. As well in:y the groat droves of horses that occupy the same region be said to bo is native and wild race. On the contrary, theil' well known characteristics, and similarity to the Spanisl cattle and all that country including Austria, Hungury, and other regions bordering the Mediterraneun, Bluck and Cisspian seas, points distinctly to their origin, if, indeed, it were not well known that they were introduced by the Spanish settlers about the year 1500 and succeoding years. In fact, ncither cattle or horses were known in Anerica prior to the Spanish invasion, and that they havo multiplied so amazingly since is due to the genial climate and abundunt unturage, so that the original cattle brought by the Spaniards succeding the diseovery of the various countries along the Gulf of Mexico and south America, has eaused them to spread over all the region from Culifornin to a latitude south, bound only by a line beyond which the coldness of the elinute precluded constant Winter and Summer herbage.

Unlike the wild buffulo, n ruce indigenous to Americu, cuttle are not migrutory to any considerable extent. Not so much so as horses. Hence whilo the buffulo is found in Summer fur north, even into the British possessions, cuttle have never been found beyond the linits of abuncunt Summer und Winter pasturage, and they have never been brought into suljjection by the wild Indians of the plains as were the horses, that escaping from domestiention gradually increased and occupied in a wild state many valleys to which cattle nevor renched.

\section{Characteriatios of Bpanieh Cattle.}

This race of cattlo should thereforo be called Spanish enttlo-what they really aro; gaunt, bony, long-horned enttle, semi-wild, eapuble of great endurance of hent, and adapted to the dry but fertilo regrions they have gradually overrun. So vast has become their numbers that ten yeurs ugo these cattlo wore estimated at $4,000,000$ in Texas and New Mexico, being in point of numbers about one-seventh of all the norned cattle in the Union. Somi-wild, impatient of restruint, ican and lank in body, high-boned, furnishing but littlo meat, and that of an inferior 
quality, giving little more milk than wild buffulo - searcely enough for a fow months Sunimer support of a calf - they wero for generations run down like wild bensts and sluughtered for thoir hides and senuty tullow. The grudunl settlement of the country, und the incrensing denand for beef, both in Europe and Amerion, at length caused then to be moved north into Kunsas for summer pasturuge, whonce they were driven to the nearest ruilwuy stution, shipped enst and sluughtered, oither for paeking, or sold at an inforior price for consumption of flesli.

Vurious attempts have been made to reduce them to subjection to man so they might bo divided into smull herds to be confined in pastures or fod in wintor. It lus been in overy instunce unsuccessful. They remuin shy, wild, irrituble, and refuse to futton kindly. Tho writer, immedintely

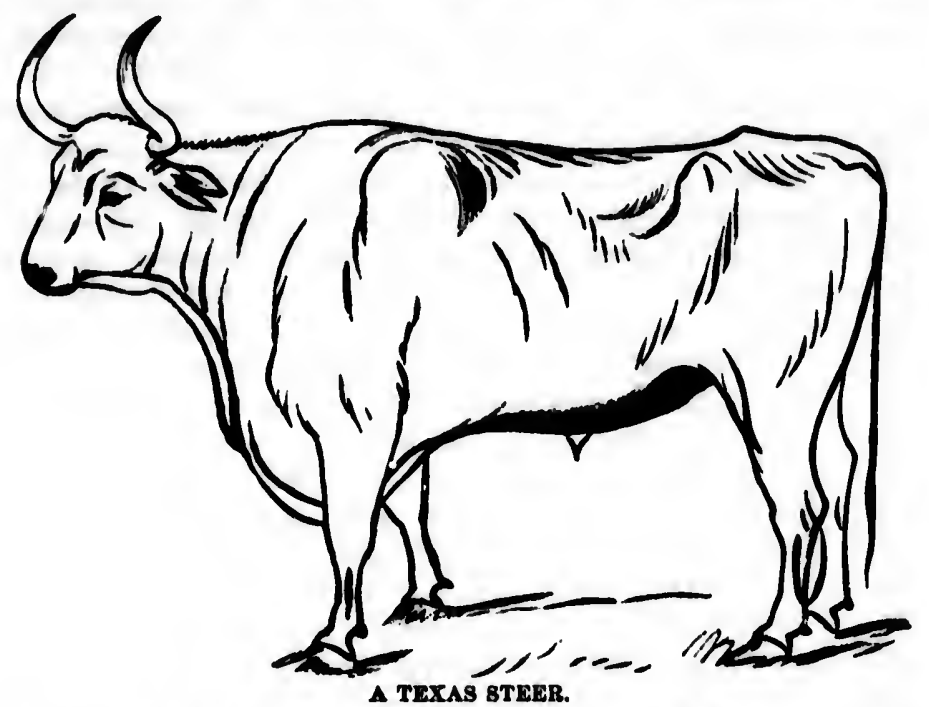

after the close of the war, huving a large quantity of forage and futtening muterial, with mills for grinding corn, and stubles for the accommodation of 450 cattle, on account of scarcity of stock was obliged to put ${ }^{\prime}$ in Texans.

\section{Foeding Texans in Confinemurt.}

They were bought in Kansus and were known as Cherokee cattle, a modified form of Texans, bred by the civilized tribes of the Indian reservations oceupying tho torritory botween Kansus and Texas. They had to be lasseed and dragged into the stables and made fust to the stanchions, from Spring grount to thes The st to feed months the so $f$ cattlo is unfit fo meul-fe take kiı could be feed, an of ten $y$ Neverthe have bee At that $t$ ledger ae care to tr off of $\mathrm{gru}$ wo have

The av grass in $\mathrm{t}$ tho averay except the Of late ye distillery They aro r Other's angu of hilusas, They really other, and IVinter, we borhood of From whe in breeding rast outlying, able. In T, 
from which they could not bo allowed to escupo until turned off in the Spring. Underground pipes conveyod their drinking water, the foed, groumi corn and hay, togethor with residuum from a mill was conveyed to them lyy cars on trumwuys runuing between onch two lines of cuttle. The stalles were kept only light enough so that the workmen could see to foed and clous; good ventilation wus providod, and at the ond of six inniths they wore turned out, and shlppecl to New York,-good ripe cattle so fur us Texins could be made such, - and brought the price of fut cuttle in the murket there. Of this lot ouly two cur-louds were culls or untit for the Now York market. They were strictly corn-fed, or ruther meal-fed. For the first inonth they wero sulky und anvage, refusing to take kindly to their rutions. They never becume so qulot that strungers could bo allowed in the burns without danger of throwing them off their feed, and yet they wore ultogether superior to the ordinary Texun cuttlo of ten yeurs ago in point of docility, for they had beon closely herded. Nerertheless, the one experiment was sufficlent. If other cattle could have been had at a fuir price it would not have paid to have fed then. At that time good cattle were high and scarce, Texans wore cheap. The ledger account came out all right in the Spring, but the writer did not care to try the experiment a second time. As to how they looked when off of grass and rendy for the stuble in the Fall, the full page illustration wo have prepared will show:

\section{Woight of Teran Cattle.}

The average weight of full grown Texan steors as usually sold from grass in the Western markets, muy bo strited at 1,000 pounds; of this the average beef and bose will be 400 to 450 pounds; of the lulance, exeept the hide, it is protty much offul, the tullow being exeeeding light. Of late yeurs very muny Texus cuttlo are yearly bought for feeding in distillery stables, on the slop mide in the musufacture of high wines. They are roped und fustened and remnin there until sold to the buteher. Others agrain aro bonght in the Autumn und shipped to the vast corn-fields of Kunsus, lown and Illinois, and fed in the fiolds during the Winter. They really tako more kindly to this latter system of feeding than any other, and they will gain about two hundred pounds of flesh during the Winter, weighing an average of 1,200 pounds, and making in the neighborhood of 700 pounds of beef.

From what we huve stated it will readily be seen that there is no profit in breeling Texans, when other cattlo may bo kept. There are, however, rast outlying territories where tho herding of these cuttle is found profit. able. In Texus, New Mexico, the Indian Territory, Westeru Kunsus and 


\section{IMAGE EVALUATION TEST TARGET (MT-3)}
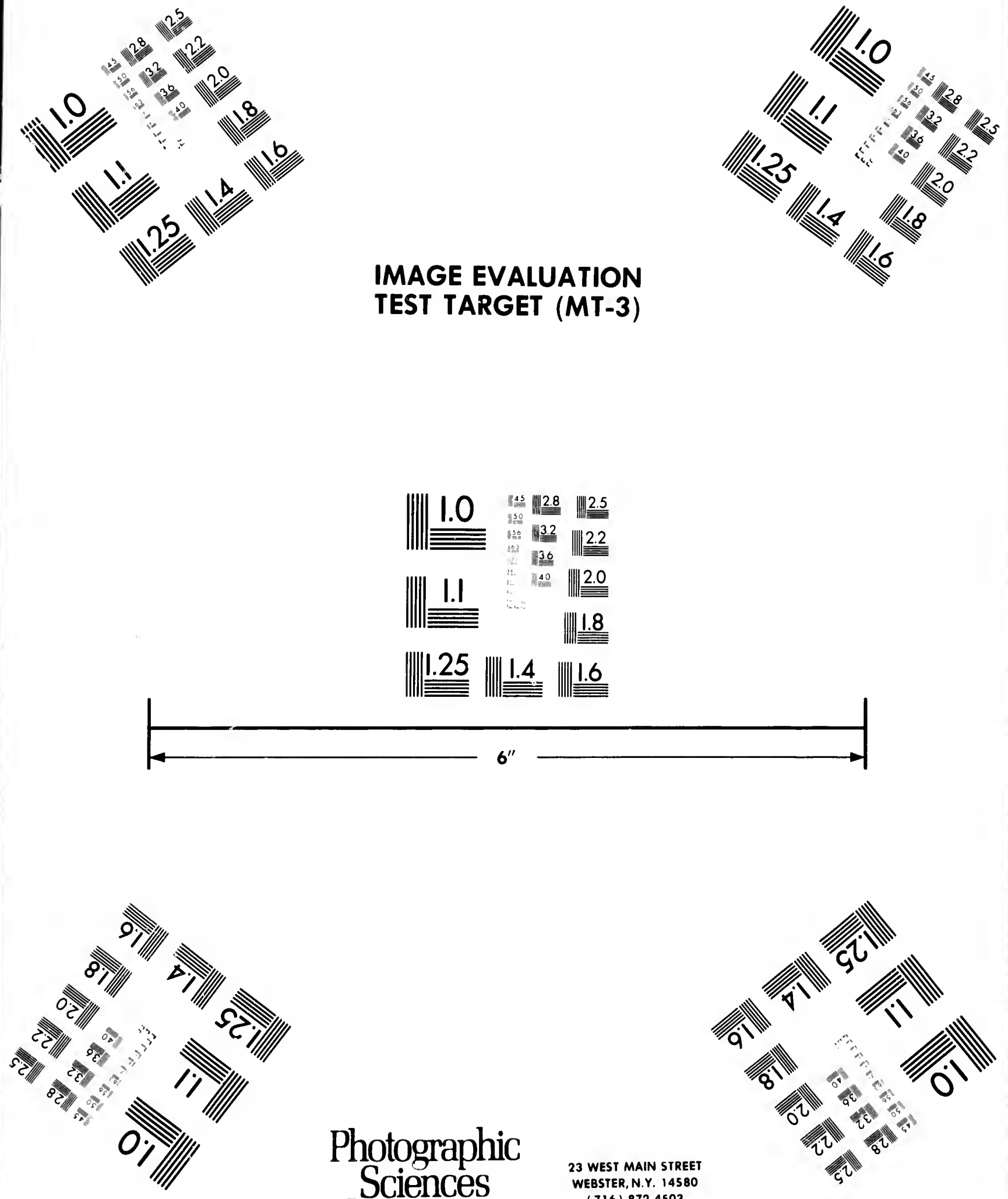

Photographic Sciences Corporation

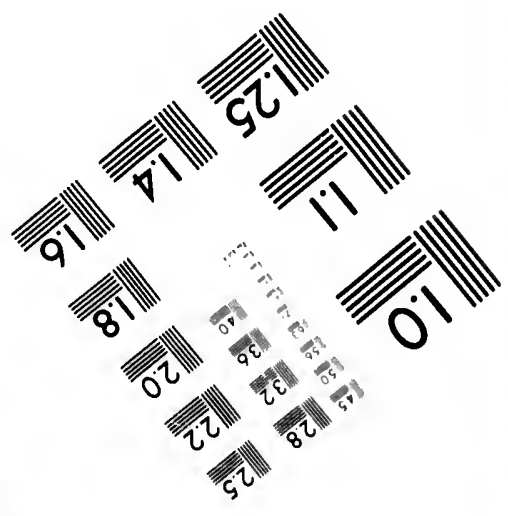





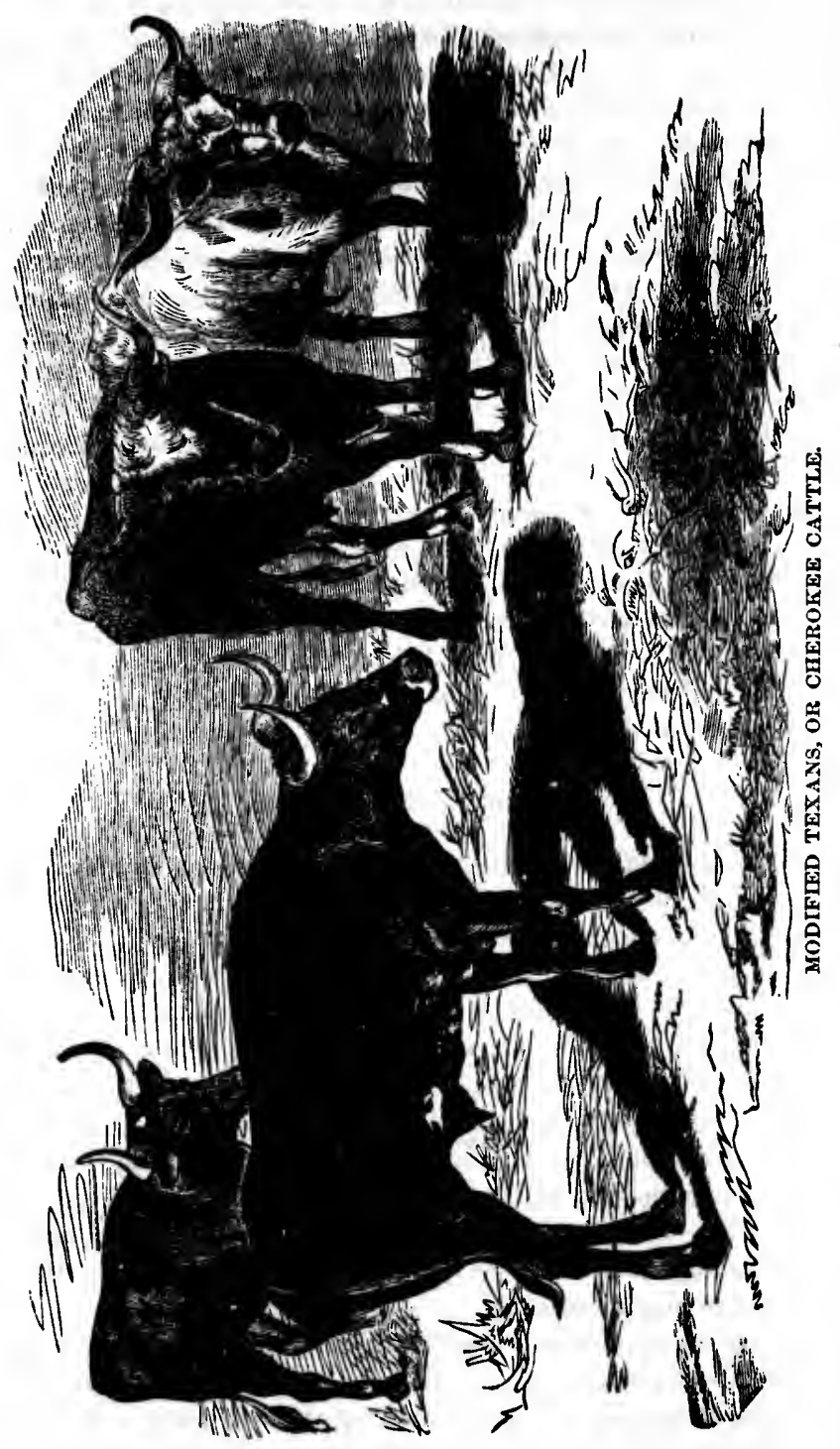

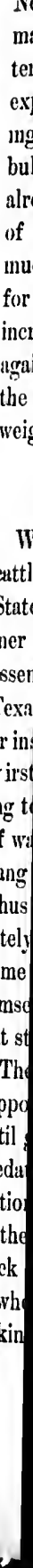


Nebrasika and Dakota, in the valleys of Montana and Wyoming, they may lave unlimited range, and enjoy their semi-wild condition, and fattened on grass may be shipped east to be slaughtered and barreled for export, or fattened as we have previously stated. Of late years enterprisIng herdsmen have bought great quantities of Short-Horn and Hereford bulls to be used in the improvement of their stock. The effects are already apparent. It is well understood now that the produce of either of the bulls we have mentioned, in the first eross, produce an animal much superior to the dam, and which will sell at three or four years old for nearly double what the natives will. The cows give a largely inereased quantity of milk, they make better and fatter calves; and hero ugail is a conclusive illustration to the breeders of cattle everywhere, of the utility of improved breeds in inducing early maturity, increasing the weight and improving the quality of the beef.

\section{Proflts in Breeding Grades from Texans.}

Within the last ten years fortunes have been made in herding Texas cuttle, not only in that State, but in various Territories of the United States. There are two essential requisites ; plenty of good grass for Summer and Winter pasturage, and abundance of water. The latter is the essential. Many persons have failed in their efforts to profitably breed Texas cattle on the.plains, for the reason, that water was either not near, or insufficient in supply. The cattle must go long distances to slake their $\forall$ irst, and consequently become very dry and uncomfortable before starting to the watering place. Then they drink such immoderate quantities of wat:r, us again to be uncomfortable for some time, and will, if allowed, hang about the water, on scant grass, until again forced to take the range. Thus they cannot gain in flesh uniformly, but on the other hand, absolutely lose condition in the constant travel necessary to get water. Perhaps some epidemic sets in, and they die by hundreds, and the owner finds himself the loser, simply from entering into a business hastily, and without studying carefully the absolute necessities in the case.

There is another class of failures. These have been persons who have supposed they could take fifty cows, and make money by herding them until grown up. In all that wild region inhabited by Indians more or less predatory, the force about a runch must be strong enough for some protection. The profits must come principally from the increase in cattle. If the small herder has water privileges, he can make money if he has stock enough. If he has but few, the expense of herding will be the same as when the herd is larger. Owners of other and large herds, or those seeking to become such, will not take kindly to the appropriation of water 
privileges, for so small a drove. There will bo quarrels; cattle will be stampeded, and get mixed with other herds, and at last the owner will be obliged either to leave, or take a partner with sufficient capital to properly stock the ranch.

The yearly increase in value of cattle on the ranch will be all the way from 25 to 50 per cent. according as the business is managed. In northwest Texas the value of cattle on the ranch is for yearlings $\$ 6$; two year old $\$ 10$; three year old $\$ 13$; cows $\$ 12$ to $\$ 15$; beeves $\$ 15$ to $\$ 20$.

\section{The Cattle Interest of Texas.}

To give some idea of the vast numbers of cattle in all that region where there is abundant pasturage and water, it has been estimated that, from the Red River, in Clay county, west to the Pense River, and south to the Colorado, embracing a territory of perhaps twenty-five thousand miles, the whole region is now stocked to its fullest capacity, and in the better portions thereof, it is estimated that an average of one head nay be kept to eight acres. The loss in cattle may be estimated at about four or five per cent. per year, and the expense of herding 300 head and their produce, has been given as follows:

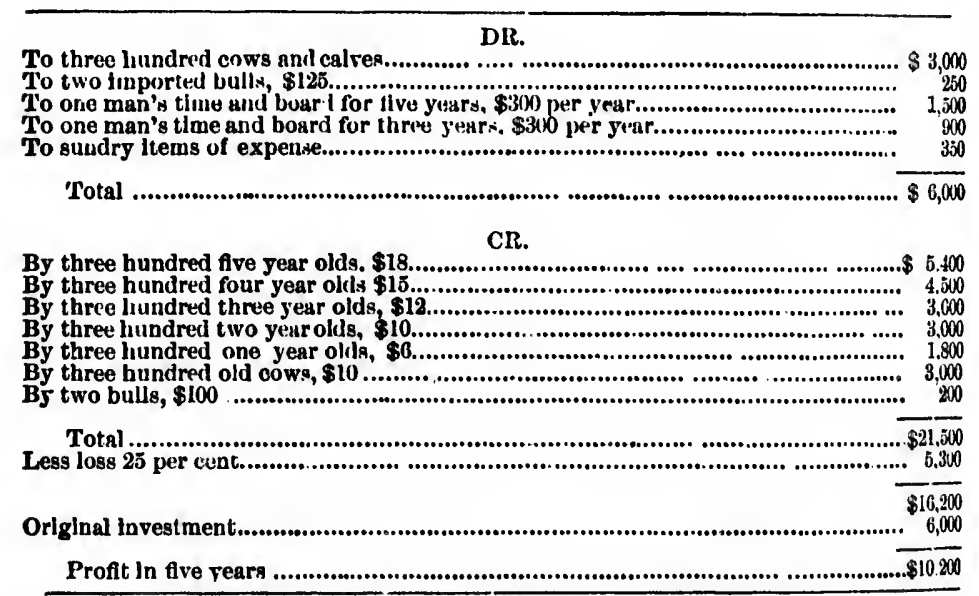

This is approximately correct, except as to the value of the bulls, if by these are meant acclimated thorough-bred bulls of Short-Horn, Herefr,rd, or Gulloway blood. It is well known that it is useless to take mature bulls or other cattle raised in the North, to Texas. They die off with Texas fover before they have timo to leave their impress to any 
cousiderable sxtent. An acclinated bull two years old past, should be worth $\$ 250$. Not less thar three such bulls should be used in the herd of 300 cows. The second year 150 heifers will be in breeding condition, and the increase will then be increasingly fast. The fourth year two more bulls must be bought, and at the end of the five years; the three first bulls will be practically of little value. With these exceptions, the figures may be taken as correct.

\section{Acclimating Improved Bulls.}

The serious losses that have constantly occurred from the death of thorough-bred bulls sent to Texas for the purpose of infusion of blood has prevented, to a great extent, the improvement of the stock. In all the plains regions of the West this difficulty has not been so severely felt. The improved breeds take kindly to the Summer climate and only require protection in Winter, and if put with $a$ herd in which the germs of Texis fever have been eliminated are healthy. Not so those taken to Texas. Whatever the cause of the disease, it is certain that nearly every animal taken there has succumbed to this dread disorder, if placed immediately in the herd, and generally before they have had time to serve more than from twenty to forty cows, and from weakened condition the impress they have left has been deficient in vigor to that of either the sires or dams.

\section{Select Your Bulls.}

To obviate this a thorough system of acclimation must be established. And above all none but very young animals should be taken. In every case they should be calves of early Spring, bought when they are eight months old. The sars in which they are earried should be carefully prepared, to provide for the comfort of the animals. Pay particular attention to feeding and watering regularly so as to keep the bulls rigorcus and strong.

Buy none but animals of parents and families of known soundness and vigor of constitution. Avoid all fancy or highly in-bred families. Abjurt excessive style and fineness, and look only to the single points, constitutional soundness and vigor, and thick beef. It is better that they be a little rough from having been bred out of doors, and with out-ofdoor care, rather than stable bred, pampered animals. Such are not even fit to put with the breeding herds of the plains. To carry them to the very home of Spanish, or as it is now called Texas fever, can only result in loss. When they arrive establish them in good, well ventilated stables,

the bulls, if Short-Horn, seless to take They die off apress to any 
and under the supervision of a keeper who fully understands both breeding and raising, and do not allow them to mingle with the native cattle unti? they are ut least two years old; and, no contact should be allowed with stock that are known to show indications of the malady. One more sug. gestion: the bulls should not be freely used as breeders until they are twenty months old. In acclimating the bulls, watch for the first symptoms of the fever, and give prompt treatment at the first discovery of the disease. This mny be known by the restlessness of the animal. The eves will be dull, the movements constrained and moping, there will be more or less straining in the attempt to urinate ; that voided will be scanty, high colored, and of bad oder; and the bowels may be costive or very much relaxed. Treatment, said to be nost successful, is to give at the first indication of the disease one tablespoonful of finely pounded charcoal, and one teaspoonful of ground ginger, to be followed in an hour with a quart of strong decoction of marsh mallow, and one quart of camonile tea. This to be repeated in ten hours if the animal does not get relief. If marsh mallow can not be obtained, salt peter is recommended. This remedy, however, had better be given under the direction of a veterinary surgeon. Above all, endeavor to keep thi pores of the skin active by brushing and friction. By proper care in this direction it is stated that ninety per cent. of the cases treated can be saved.

In all this, eare of course nust be taken in regard to the food of the animal. Bran, boiled oats, and corn, or corn meal, may be given ; if roots, carrots, parsnips, or sugar beets can be had they will be excellent. In fact they should always be kept in supply on breeding farms. Grass in plenty and of good quality should also be supplied freely.

\section{A Texan's View.}

An intelligent and educated correspondent of the Live Stock Journal, gives the following excellent advice in relation to the transportation, care, and feeding of stock bulls to be carried to Western Texas. He advises that care should bo used in the selection of calves of stout, robust frumes, the offspring of sires and dams of good constitutions. Calves cropped in the early Spring will be found most suitable for shipment say about the last of November or early in December. Plenty of milk from birth until September should be given them ; then they should be fed on wheat brin, boiled oats, and crushed corn, until dato of shipment ; and if kept in stables during the day they should have a good grass lot to graze in during the night. They should be handled, made very gentle, and well broken to the halter. The cars for transportation should be well bedded, and food for the eutire trip transported with the stock. 
Arrangements should also be made for through trip when starting. Food, water, and careful watching by the herdsmen will land them at the place of disembarkation but little damaged by the trip. Caro should be taken not to crowd too many in one car-thirty head can be taken if they are properly eared for-yet twenty-five head would do much better. The calves designed for shipment in one car, if more than one is to be sent, should be permitted to run together for some time previous to starting.

After reaching the terminus of their wearisome journey by rail, a week's rest, in dry lots, should be granted them, with the same kind of food as was usel before shipment. When taken any distance slow and easy travel should be given them. If either costiveness or its opposite is exhibited, simple remedies should be given to prevent the too activo purging or relieve the constipation. The preparation for their reception at their Texas home suould have been completed before their arrival; and in addition to a supply of corn, onts, and wheat bran, pure running water and free access to a growing onts or barley pateh, which should have heen sowed in early Antumn for their benefit, should be allowed. Suitable protection must be provided to guard them from the cold blasts of the " northers ;" then, by prompt attention to any symptoms of fever and the inmediate use of charcoal and ginger, one table-spoonful of charcoal and one tea-spoonful of ginger will relieve them.

If December and January are passed without ferer you can feel safis from its ravages until the rains of Spring, followed by the heat of June, when the ticks and vermin menace them. Then avoid exposing a vem to either rain or sun, and destroy the vermin by a free use of coal oil and lard, using two parts of the latter to one of the former. If only Spring calves are brought there will be less of fever than if older animals were brought.

\section{Tom many speculators, who bring young stock to Texas, stint and half starve them, thinking that to keep them in good growing condition increases the chances of disease. My observation teaches the reverse to he true. To secure a complete development of bone, flesh and growth, and early, profitable maturity, a calf must have generous care, plenty of sutritious food, good water, and kind treatment. I have heard men complain that Texas Short-Horns are not thrifty and handsome, like those exhibited at Northern fairs. The reason for the dissimilarity is readily found on investigntion to be that the one had excelient feeding and growing, while the other-in addition to a long winter, starvation, and acclimation, with a Spring and Summer with rain and hot sun - had his ritality almost destroyed by ticks and vermin. Cattle from the North cannot be acclimated unless generous food, comfortahle quarters, and \\ tation, care, He adrises bust frumes, s cropped in ay about the m birth until 1 wheat brin, cept in stables in during the ell broken to ed, and food}


kind treatment are given to them during their first year in Texas; and unless this treatment be kept up they are worthless when acclimated. They will be weak and sickly in spite of the best efforts to the contrary. Care as to condition of animals will always pay. That which osts us the greaiest pains in cattle raising will always reward us the best. 


\section{CHAPTER II.}

\section{BREFDING AND FERDING.}

In the breeding of animals, ono must have a definite object in siew. We have already stated that in this age of civilization, where industry is divided und subdivided, so that each set of workmen have separate und distinet lines of labor in the make up and finish of the most simple nrticles, so in stock breeding, the farmer must understand the nature and ndnptation of his soil, and its adaptability to certain crops and animals. In rocky, hilly, and comparatively barren regions, or where the soil suffers under drought, the farmer cannot compete, either in the raising of beef cattle, or in dairying, with the more farored well matured countries of deep soils and flush pastures. Again, in a country noted for its short, sweet perennial pastures, and cold springs of water, tho stock brecder cannot compete with the dairyman. The stock feeder of cattle and hogs must be in a region where corn, or other fecding grains can be chenply and abundantly raised. Fortunately, such countries are well adapted to the meadow grasses, producing heavy crops of hay and pasture.

\section{About Grasses.}

Here again, the grasses cultivated will be somewhat different. Tho, stock feeder will depend shiefly upon bluo griss, timothy, red top, orchard grass, and clover, and where blue grass is natural to the soil, he will depend almost solely upon this grass, for late fall and wiuter feeding, as ho will upon blue grass and orchard grass for spring feeding, depending later on clover, timothy and red top. The dairyman, while he will depend upon clover, timothy, red top and orehard grass for hay, will not use these tor pasture exclusively. He must have in his permanent pastures a great 
variety of grasses. His pastures, to produce the greater quantity and best quality of milk, must be permanent ones, and the older the better. This with a moist climate is what has made some sections of England, and especially Ireland, Holland, and Denmurk so celebruted for their dairy products. 'This, also, with the peculiar' eare given in fecding, has mado England nnd Scotland celcorated throughout the world, not only for the heavy weight, and superior qunlity of tho beef, but it has resulted in such superior beef eattle as the world has never hefore known. Some of these breeds, transplanted to the United Stntes, lunve taken kindly to our soil und climate. The wonderful fertility of the lund lying west of the Alleghanies and north of the southern line of Tennessee, and cspecially those States bordering upon tho Mississippi and Missouri rivers, and principal tributaries, mnd, also, the grent Southwest - this tecming fertility of soil has made all this grent recrion of country the true home of the most celebrated breeds of cattle-where they have reached weight, and richness of milk given, no where else attuined except in very confined areas,

\section{What Breeds are Best?}

This becomes a most important question. In all that great region of the West, of gentle undulnting prairies or grassy plains, Short-Horns and Herefords will be found the very best eattlo to breed from, when only beef is the object. If labor and beef are wanted, the Devons and Herefords will be found most valuable. If beef and milk ure to be the products, the Duchess and Princess families of Short-Horns, and the IIolsteins will give the best returns. If dairying is to be the chief industry, then, for butter, the Ayrshire, with a few of Jerseys intermixed will produce the best results. If for butter and ebeese, Ayrshire or Short-Horns. If cheese alone, the Holstein, and for quantity of milk given this latter breed will certainly carry the palm. If milk and butter, without reference to quantity, be required, the Jersey is the cow. All the breds except the Jerseys will make good weights of beef and fatten readily when dry - the Short-Horns, Holsteins, und Ayrshires making weight in the order named. For milk, wo have not included the Devons; occlsionally a cow will be found giving a large mess for her weight. Devons, however, are not dairy cows, at lenst, now-i-dnys; having been bred most exclusively for their superior quality of mabled beef, and their uniform excellence, courage, and kindliness in the yoke.

\section{How to Breed.}

All farmers cannot become breeder's of highly bred, pure stock. For this the animals must be isolnted from all other breeds of the same race. 
It least the males must be strietly eonfined, so tliey may not intermix with others. Where furms join, divided only by fences, this will not bo found pructicable in a mujority of cuses. One's neighbor may fancy scrub stock. They are notoriously breachy. Once they intermingle with a pure breed, the taint of their blood is not only found in the calves, but in the dums themselves. In the ealves and their progeny, it may never be bred out. We see the Kyloo eross in some fumilies of Short-Horns, even to this day, cropping out in single individunls after a lupse of nearly a century. The writer so saw it at the last fat-stock slsow in Chiengothat of 1879. Tho animal was a most excellent specimen ; fully as perfeet us many of the very lighest breceding, yot tho taint of the family was there and the breeder of "ligh easte Shurt-Horns" would not have bred from such a cow or to a bull showing the taint, at any prico.

\section{About General Utility.}

Just here is where the differenco comos in, as between breeding for general utility or absolute purity of blood. The breeder for general utility cares not so much about a particular strain of blood, as he does to get certain climacteristics that will furnish him, at the lenst expense, either the most beef, the best working oxen, or the most and the best milk. Those who undertake breeding, or in fnct any other business, in a haphazald way, always fail ; the only exception to the rule being pure luck. Luck is not a good business integer to depend upon. Liko lightning, it nerer strikes twice in the same place.

There is another thing in connection with luck that it is well to bear in mind. It is as apt to nur as to mark. The farmer, therefore, who undertakes the breeding of stoek, with a view to the money they will briug from the butcher, or from the sale of dairy products, must be gruided by an entirely different set of rules from that of the breeder who breeds solely with a view to selling sires and dams to other breeders of pure stock. So particular, now-i-days, have breeders of this class become that some of them will breed only particular families. Some will not allow a Booth cross, others abstain from the Bates blood.

Many high caste breeders are pretty well agreed that a top cross of what are known as seventeens, and some other sub-families of later importations, and also of particular bulls of pure breeding, but which hare been considered more or less coarse, must be rigidly excluded. Ther have their particular fancies. To gratify this fancy they will pay extraordinary prices, while the great mass of really superior and really pure Short-Horns will be passed unnoticed. It would be unadvisable for the ordinary farmer, or even the Short-Horn breeder to buy these 40

re stock. Foi the same race. 
"terribly bred cattle." And the furmer must enrefully discriminte. Let him get staunch henlthy enttle to start his herd, if beef be the olject, und animuls with good milk points if milk be the object, rother thun to strive for color. So long as the color of the animal is elaurateristic of the rnee, the beef points and the milk points nre what he should seek. The body in the beef animal, and tho udder in the duiry cow, is whut ho wants.

\section{Brecding in Iine.}

Breeders of pure stock uro especiully particular in the selection of sires; so much so thet muny of them breed solely with reference to the strain of blood particulur fumilies contrin, the selection often bing without reference to the uniformity or qunlity of the animuls selected. Really, however, breeding in line menns the selection of minles of a common type, and belonging to the sumo fimily. Thus in breeding in-the-line, the expert, w'uile he objects to going out of a sub-finuily, nevertheless seeks to couple unimals together whose uniformity is identical, or, when one is wenk in some essentinl, to improve it by coupling therewith an animul of superior excellence in this particular. Thus, if the head nnd horns he rather eoarse in m animul, it is lored to one fine in hend and horns, but not lacking in other essentinls. It is one of the most futal mistnkes that enu possibly be made in lorceding, that to aequire one essential other disabilities be allowed to enter. Miny breeders have committed irrepurable injury to their stock by not understanding the necessity, while trying to improve one essentiul, of kecping all others intact. Therefore the sagneious breeder will paly more attention to those points indicative of henvy sueculent beef laid in the primer points and without an undue proportion of fat, if combined with general symmetry, rather than style and earriage, connected with deficient eharacteristics in flesh. The one animal may be striking to the eye, while the other will bring the butcher's money. This is really all there is to beef cuttle.

\section{Form as an Index to Quality.}

Whatever the animal, its form, organization and general make up, will be an indication of its true type and eharacter. It is a fixed law of nature that this should be so. A few illustrations will suffice, and which will easily commend thomselves to the render.

The thorough-bred horse, is courageous, high strung, active, sinewy, impatient under restraint, and not given to carry much flesh or fitt. The heavy draft horse, carries much flesh, is docile, honest at the collar, pos- 
iminute.

o olject,

than to

neteristie

uld seek.

, is what

lection of cee to the ten being solected. mles of a 2 breeding ub-fumily, $y$ is identioy coupling Thus, if one fine in one of the nig, that to ter. Irany not underof kecping pary more laid in the nbined with neeted with ling to the is really all

aike up, will iw of nuture d which will

ive, sinerry, or fut. The collar, pos- sessing grent bone and sinew, and is on the whole more sluggrish. The horse of all work should be a modification of hoth these churneteristics. All horses huve grent chests, und consequently grent lung power, fitting them for severe and long continued musculur exertion. They must bo judred ly a standiard where muscular exertion is the important integer. Cattlo have been bred so long with reference to their bodies, ns heef or milk producers, that they lane becomo so distinct from tho supposed will type ans to possess but littlo in common therewith. The hend, neck and limbs, luve heen refined, the lunges havo less power, since it is only neces. sary that they supply suflicient oxyen to the blood to keep up a uniform animal hent under exercise, never violent. Tho loin and rump are broadmod, the ribs spring ont more to give eapacity for a stomach of size to digest a largo quantity of fool. In swine the diminution of lung power is particularly secn. They are essentially slow in all their movements, nud arerse to exertion. Their forto is simply enting, slecping and laying on fit. No one would mistake a hog for either an ox or n horse. The intelligent breeler so educntes his eyo and his tonch, that he ean distinguish between numuls of any given race as to their enpulsilities for the purpose intended. The external conformution comes at length to be so kecoly associated with the correluted structural affinities, that he tels at one, and exactly, the inportant points that would entirely escape the unedueated eyo and touch.

\section{Practical Suggestions.}

As the greatest excellence in the production of meat, milk or labor in rattle; of wool and curcenss in sheep; and of hams, loin, side meat and lard in hogs, involves peculinrities of structure and function-aldupting the animal to the special purpose for which it was intended, and ats all tirso require close study of matomy, physiology, and the correlations existing in the different forms of production; and since scientitic breeders have for the last lumbled years been seeking to estabiish a higher and ligher exeellence, the intending breeder wonld he unwise to undertake to breed up from the eommon herds of the country. It would he time ill spent. He should first inform himself of the practical necessities within his reach, and breed from types already existing rather than create one. This will simplify his study, he must educate his eye by points and the ohservation of the best animals, and his touch by feeling them according to the rule heretofore given; and this brings us to

\section{Breeding Grades.}

At the mecting of the American Association of Short-IIorns, at India- 
napolis, 1872, "pure-bred," "full-blood," and “thorough-bred," wero defined as being synonymous terms, and to indicate "animals of a distinct and well-defined breed, without any admixture of other blood." The following definitions were adopted by the association.

"“Cross-bred'-Animals produced by breeding together distinct brecds."

“'Grades'-The produce of $a$ cross between a 'pure-bred' and a 'native.",

" 'Iligh grade'-An animal of mixed blood, in which the blood of a pure-bred predominates."

The produce of a Devon and a Short-Horn would be a cross hred animal. In-and-in breeding is considered to be the coupling of muimals of the elosest relationship, as the produce of one sire and dam, ete. Close breeding is the breeding of animals together that are closely related; as animals one or two removes from the parent stock, in relationship. High breeding is sometimes incorrectly used in this connection; it is wrong. Many of our most highly bred horses are not elosely related. and the same may be sitid of our pure eattle. High breeding properly signifies the selection of the breeding stock, within the limits of some particular family, and within a definite stnudard of excellence and characteristics.

\section{How to Breed Grades.}

Select the best eows you ean find, that is, those that come the nearest to the standard of excellence for the purpose wanted; then select a lull combining in the most eminent degree possible the points of real excellence for the outcome expected, not in fancy breeding but in adaptability to the end sought. Thus, if for heef, he should be of fair size, not too large, certainly not too small, but of excellent fineness combined with great loins, rumps and thighs, round-ribbed, and well ribbed to the hip bones,-in other words, what a breeder would eall a well-bred, servicable animal.

If for milk, the bull must have come of a line of uniform milkers, for here the udder and milk-reins are the essential part. In fact, the male must possess the peculiarities eharacteristic of the breed, and better if from a family of extraordinary excellenee. Why? Such animals are prepotent; that is, they will impress upon their progeny the distinguishing characteristics and excellence of their race. By following the directions we shall give, in ten years one may have grades bred to such excellence that none but the most eritical judges of stock can tell them from pure bred cattle. 


\section{Start the Ferd}

With one yearling bull for each ten two-year-old heifers, selected as we have stated, and which have not been bred. Keep them from contact with other cattle, and espeeially keep their own bull as much in their sight as posible. The next year's produce should be ten ealves, onehalf of which should be heifers. Geld the steers, and make what use muy be desired of them. Rear the heifer calves in the best manner possible, and with their sire and dans when in the pasture, and at other times do not allow them to see strungely marked animals, especially when in heat.

At the age of two years breed them to their sire. He will now be four years old, and should be kept simply in good flesh, not really fat, certainly not lean ; but strong, vigorous and healthy. When these ealves are two years old, breed again to the same sire, and so on to the fourth generation, if he last so long with vigor.

Thus this produee will inherit 15-16 of the blood of the sire, being the fourth generation from the original sire and dann. It may be formulated thus: it one year from starting the herd, you have the first generation ; at four years the second; at seven years the third; and at ten years the fourth gencrition. They will grade as follows: First, one-half bloods ; second, three-quarter bloods: third, seven-eighths bred; and fourth, fifteen-s...teenth bred.

Besides these you will also have generations successively from the original cows, or seren-eighths, three-fourths and one-half bred heifers corresponding with the succeding years from the first. If these ngain have been bred to the same bull, or another pure bred bull, their produce will be respectively fifteenth-sixteenths and seven-eighths bred.

\section{Ten Years' Produce.}

Let us now figure how much stock, young and old, will be the produce of this system, allowing that none have died. In one year, from the ten eows and one bull, we have ten calves, ive heifers und five steers; the second year, ten calves, the third year ten calves, the fourth year ten calves. This year we have also five calves, the produee of the first yeur's calres. The sixth year we will have twenty-five ealves, the seventh year thirty, the eighth year thirty-five, the ninth year forty, and the tenth year forty-five calves as the produee of the original eows and their progeny, making in all two hundred and forty animals ranging in age from calves to thirteen years old, of which one hundred and twenty-five should be females. 


\section{Seleotion.}

Just here selection may come in. Some of the cows and their progeny will have proved superior beef makers or milkers, according as they were originally chosen. Their progeny should be carefully raised and bred. It may seem dreadful, this incestuous breeding, but please emember, it is animals that are the subjects. The records of the improvement of animals and their erection into fixed breeds, will show very much closer in-and-in breeding than this. The object is not only to throw the good qualities in a lump, but to fix them by concentration. Thus a cow bred during her whole breeding life to one bull, never laving had contact with another, will bring her calves nearer and nearer to the sire year by year, through the infusion of the blood of the sire into the dam, through intercirculation by means of the fotus, during its growth.

As showing close in-and-in we find in the first volume of the Amorican Herd Book a diagram of the breeding of Comet from Hubback, and Lady Maynurd. It is explained as follows :

1. Bull, Hubback.

2. Diun of Hutughton.

3. Richard Barker's Bull.

4. Cow, Haughton.

5. Bull, Foljambe.

6. Cow, Young Strawberry.

7. Bull, Dalton Duke.
8. Cow, Lady Maynard.

9. Bull, Bolingloroke.

10. Cow, Lady Maynard.

11. Cow, Phonix.

12. Cow, Young Phœnix.

13. Bull, Favorite.

14. Bull, Comet.

In relation to Favorite or Lady Maynard, Mr. A. B. Allen says : It was conceded by a company of old breeders in 1812, in discussing the question of the improvement of Short Horns, that no stock of Mr. Colling's ever equalled Lady “Maynard" the dam of Phœnix, and granddam of Favorite (by Foljambe) and of young Phœuix (by Favorite, her sou, upon his own mother,) the dam of Comet 155) so celebritted as having been sold for 1000 guineas $\$ 5000$ ) also by Favorite, a specinen of as close-in-and-inbreeding as can perhaps be found on record.

To show wonderful depth of in-breeding with eontinued good results, the cow Clarissa may be mentioned; she possessed sixty-three sixty-fourths of the blood of Favorite. Her pedigree runs thus : "Cow Clarissa, roan, enlved in 1814. Bred by Mr. R. Colling, got by Wellington (680) out of-by Favorite, (852)-by Favorite,-by Favorite,-by Favorite-by Favorite-by Favorite-by a son of Hubback.

Wellington, the sire of Clarissa, was also decply inbred with the blood 
of Favorite. Taking the two pedigrees - that of Clarissa and Wellington together - they will read thus :

\section{Bull, Hubback.}

2. Son of Hubbaek.

'3. Cow', by son of Hubback.

4. Bull Favorite.

5. 1st cow by Favorite.

6. 2nd eow by Favorite.

7. 3rd cow by Favorite.

8. 4in cow by Favorite.

9. 5th cow by Favorite.
10. 6th cow by Favorite.

11. Clarissa.

12. Bull Wellington, sire of Clarissa.

13. Bull, Comet.

14. Cow, Wildair.

15. Cow, Young Phœnix.

16. Cow Phœuix.

4. Same bull Favorite on the side of Clarissa's sire as on the side of her dam.

17. Bull, Bolingbroke.

18. Granddaughter of Hubback.

\section{Exercise Common Bense.}

In breeding so closely as we have advised it will be necessary that intelligent judgment be used. The effect of in-and-in breeding is to refine and render delicate the constitution. Animals closely in-bred, in fact all highly bred animals require better cure than those of a coarser nature. They are not as able to take care of themselves, to shift for themselves; are in fact artificial. But on the other hand they will repay the care and attention bestowed, in inereased profits for the food given. In in-and-in, or other very close breeding, care must be taken to give the animals an out eross as soon as you find they are suffering in constitution and hardiness; in fact when you find they are no longer getting better and better seek another sire, and so continue until you have got animals fully equal to any thorough-bred for all practical purposes, and that shall at the same time be marked with vigor as well as the characteristies wanted, whether they be for beef or milk, or both.

Once having begun, however, with pure sires on native stock, never by any chanee allow a grade animal to become a sire, no matter how good he may be. It can only result in loss, whatever the attempt at improvement he in animals of any kind. In swine in-and-in breeding may not he earried so elose as in other animals. They are serofulous and weak lunged at best, and elose breeding soon shows in the progeny. As a rule one-half or three-fourths bred are good enough to bring enhanced profits over those usually denominated land-pikes, a pieture of which may be found in auother part of this work.

ays : It was the question olling's ever upon his own een sold for se-in-ind-itl-

rood results, sixty-fourths lanrissa, roan, on (680) out Favorite-by ith the blood 


\section{Gestation of Cown.}

There has been much surnised first and last upon the subject of the length of time of gestation, and its effect upon the sex of animals produced. It is a prevalent idea that if an animal goes over her time a male will be the result. Let us see how careful records kept by scientifie mon will tally with this.

Mr. Tessier, a most accurate and acute observer for over forty years, embracing vurious animals, gives results of over 575 cows and these subsequently having been extended to 1,131 cows the extremes were not changed but results as to averages are as stated below.

Upou the 575 eows the results were as follows: Twenty-one ealved between the 240th and 270th diys, the mean time being 259 days.

Five hundred and forty-four calved between the 270 th and 299 th days, the mean time being 282 days.

Ten ealved between the 299th and 321st days, the mean time being 303 days.

Earl Spencer has also carefully tabulated the period of gestation of cows as we find in the table on the following page.

In these 766 cows the least period was 220 days; the mean 285 days; the longest period 313 days. He states that he was able to rear no calf produced at an earlier period than 240 days. Thus it may be accepted that, according to Tessier, a cow may carry a calf 321 days and produce it sound; and from the fact that Tessier und Earl Spencer agree almost exactly as to the meantime of gestation, (1,895 cows being observed), 285 days or nine and a half months may be taken as the average time of gestation of cows, slight variations being allowed from this for different breeds.

Earl Spencer was inclined to the belief that a cow would carry a bull calf longer than a cow-calf. In stating the case, he says :

"In order to try this, the cows who calved before the 260th day, and those who calved after the 300th, ought to be omitted as being anomalous cases, as well as in cases in which twins were produced; and it will then appear that, from the cows whose period of gestation did not exceed 286 'days, the number of cow-ealves produced was 283 , and the number of bull-calves 234 ; while, from those whose period exceeded 286 days, the number of cow-calves was only 90 , while the number of bull-calves was $152 . "$

The author, however, omitted to notice th at all the enlves born after the 299th day were females, and of those born before the 260th day, 10 were females and 15 inules. And again, omitting the twin-calves, 340 were females and 401 males-a largo excess of bull over cow-calves. It 
TABLE RELATIVE TO THE GESTATION OF COWS.

of the

animuls

time a

ientific

y years,

and these

were not

ne calved

s.

9th days,

me being

station of

285 days; ear' no ealf e accepted nd produce ree almost observed), ge time of fol differarry a bull

th day, and anominlous it will then exceed 286 number of 6 days, the bull-calves

born after (0th day, 10 -calves, 340 -calves. It

\begin{tabular}{|c|c|c|c|c|c|c|}
\hline Number of Days of Gestatlon. & Cows. & $\begin{array}{c}\text { Cow } \\
\text { culves }\end{array}$ & $\begin{array}{c}\text { Bull } \\
\text { culves }\end{array}$ & $\left|\begin{array}{c}\text { Twin } \\
\text { cow } \\
\text { ealves. }\end{array}\right|$ & $\left|\begin{array}{c}\text { Trwin } \\
\text { bull } \\
\text { ealvez. }\end{array}\right|$ & $\mid \begin{array}{c}\text { I'wlin cow } \\
\text { asul bull } \\
\text { culves. }\end{array}$ \\
\hline 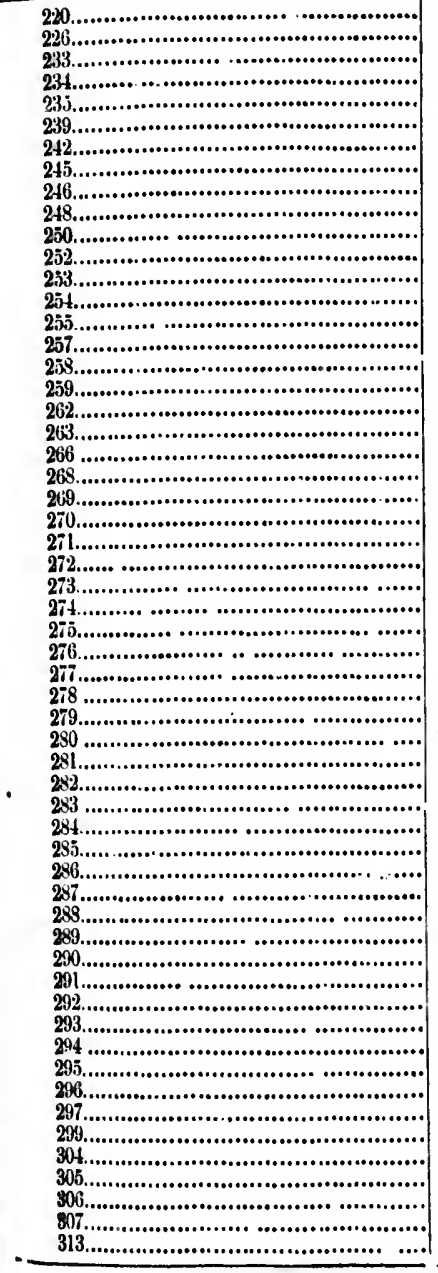 & 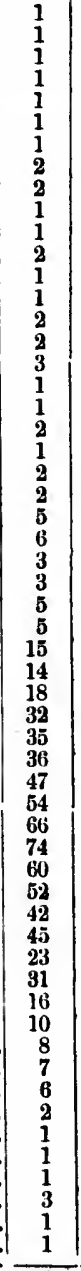 & 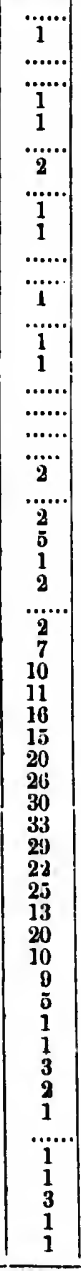 & $\begin{array}{r}1 \\
1 \\
1 \\
1 \\
1 \\
5 \\
2 \\
6 \\
2 \\
4 \\
11 \\
20 \\
18 \\
20 \\
24 \\
33 \\
\mathbf{4 3} \\
38 \\
27 \\
28 \\
25 \\
13 \\
22 \\
11 \\
9 \\
7 \\
4 \\
4 \\
1 \\
1\end{array}$ & 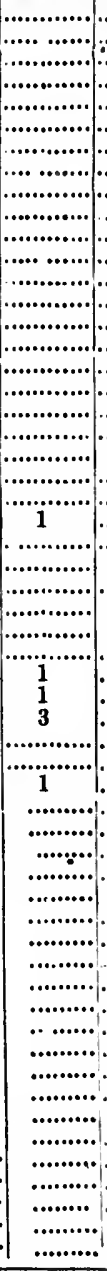 & 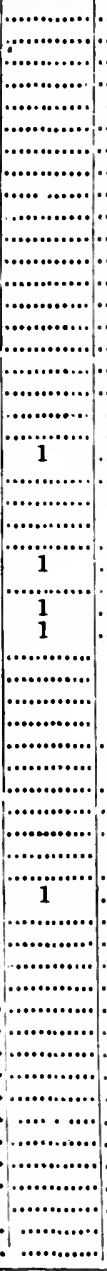 & 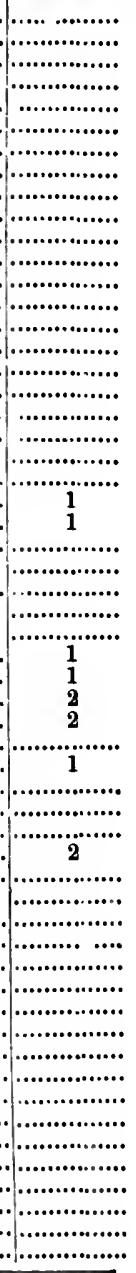 \\
\hline
\end{tabular}


is also curious in this connection to note, that of the 764 cows, 23 produced twins, or one cow in $331-3$ of these ; 7 cows had twin females; 5 , twin maies, and eleven had twin male and female calves. Those in the twins produced their owner 18 female calves and 16 male calves.

From the many facts collected in various races of animals, it is quite safe to conclude that the sex of the young has no particular influence on the period of gestation. It is more probable that heredity, sires, early maturity, and various other integers in the problem, may control the tendency to long or short gestation.

\section{Food vs. Product.}

The value of an animal depends upon the profit it will give in comparison with the care and expense in rearing and fattening, in the case of beef cattle, and, of the cost of feeding, in comparison with the milk yield, in connection with dairying. In this we may safely conclude that an animal will produce less and less gain the longer it is kept, and thus early mutuxity becomes the most important integer in the breeding of stock, whether it be for beef or milk. The reuson why the mature animal consunes more in proportion to gain than the younger one is, that it takes a certain amount per pound of live weight to supply waste. The animal of a given age, according to breed and adaptability to fattcuing, can only arrive at a certain weight. Hence this ultimate weight reached, it will not increase. Long before this ultimate weight is reached, the animal will increase only in fat. Thus the flesh-forming element in the food is wasted, save that which supplies the daily waste in the animal economy. Thus from the data which we now present it will be seen how much may be considered necessary as food, under various conditions. .

\section{Conclusions from Experiments.}

Prof. W. S. Johnson, in his report of the Connecticut Agriculture Strtion for 1877, gives the following translations from Dr. Wolff, a German experimenter. These, of course, must only be considered as approximative. They, however, will show as being the result of practical experiment-principles upon which ratios may be made up of other naterial.

Dr. Wolff, in illustrating the standard for a milch cow, says that 30 lbs. of young clover hay will keep a cow in good milk; that this contilins of dry organic substance $23 \mathrm{lbs}$, of which is digestible-albuminoids 3.21 , carbo-hydrates 11.28 , and fat 0.63 . This is $71 \mathrm{lbs}$. albuminoids more, and $.22 \mathrm{lbs}$. of carbo-hydrates less, with $.13 \mathrm{lbs}$. of fat more, than the standard. The richest and best meadow hay contains in $30 \mathrm{lbs}$., of organic substance 23.2 lbs., having digestible albuminoids $2.49 \mathrm{lbs}$, carbo-hydrates $12.75 \mathrm{lbs}$. and fat $.42 \mathrm{lbs}$. This comes very near the feeding standards. 
23 pronales ; 5 , se in the $t$ is quite tuence on res, early ontrol the

in comparhe ease of the milk nelude that $t$, and thus jreeding of mature ani10 is, that it vaste. The o fattening, ght reuched, reached, the ement in the n the animal be seen how nditions.

riculture Staiff, a German s approximaetical experither material. says that 30 this contains albuminoids albuminoids at more, than in $30 \mathrm{lbs}$. , of $2.49 \mathrm{lbs}$., carar the feeding
Feeding 8tandards.

PER DAY, AND PER 1,000 LB'S. LIVE WEIGHT.

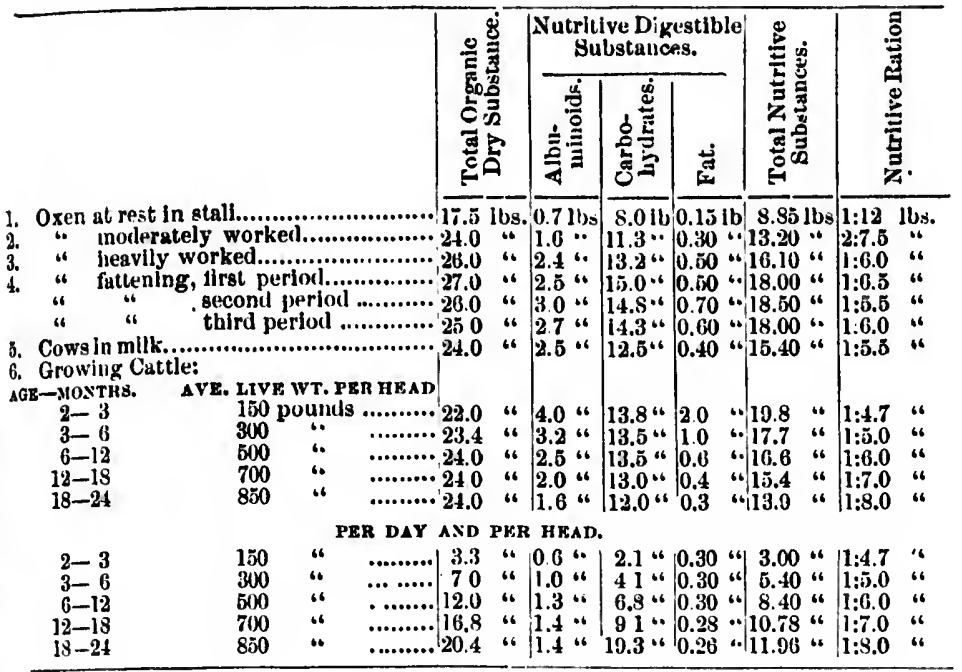

To show how a ration for milk cows may be arranged of various material, he gives the following:

\section{Ration for Milch Cows.}

\begin{tabular}{|c|c|c|c|c|}
\hline \multirow{2}{*}{ " } & \multirow[b]{2}{*}{ 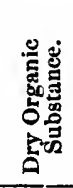 } & \multicolumn{3}{|c|}{ Digestible. } \\
\hline & & 竞咅 & 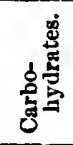 & 苛 \\
\hline 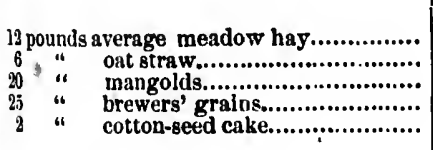 & $\begin{array}{c}\text { lbs. } \\
9.6 \\
4.9 \\
22 \\
5.6 \\
1.0\end{array}$ & $\begin{array}{l}\text { lhs. } \\
0.65 \\
0.08 \\
0.22 \\
0.98 \\
0.62\end{array}$ & $\begin{array}{c}\text { lbs. } \\
4.92 \\
2.40 \\
2.00 \\
2.70 \\
0.36\end{array}$ & $\begin{array}{l}\text { Jba, } \\
0.12 \\
0.04 \\
0.02 \\
0.20 \\
0.24\end{array}$ \\
\hline 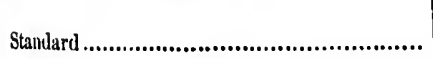 & $\begin{array}{l}23.8 \\
24.0\end{array}$ & $\begin{array}{l}2.55 \\
2 . \tilde{0} 0\end{array}$ & $\begin{array}{l}1238 \\
1250\end{array}$ & $\begin{array}{l}0.62 \\
0.40\end{array}$ \\
\hline
\end{tabular}

Prof. Johnson gives the following rations, calculated from the table:

\begin{tabular}{|c|c|c|c|c|}
\hline 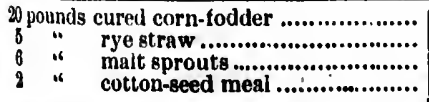 & $\begin{array}{r}13.7 \\
4.1 \\
50 \\
1.6\end{array}$ & $\begin{array}{l}0.64 \\
0.04 \\
1.16 \\
0.62\end{array}$ & $\begin{array}{l}8.68 \\
1.82 \\
2.70 \\
0.36\end{array}$ & $\begin{array}{l}0.20 \\
0.63 \\
0.10 \\
0.24\end{array}$ \\
\hline Standard.............................. & $\begin{array}{l}24.4 \\
24.0\end{array}$ & $\begin{array}{l}2.46 \\
2.50\end{array}$ & $\begin{array}{l}13.56 \\
\text { I2.50 }\end{array}$ & $\begin{array}{l}0.56 \\
0.40\end{array}$ \\
\hline
\end{tabular}


Or, again :

\begin{tabular}{|c|c|c|c|c|c|}
\hline \multirow{2}{*}{\multicolumn{2}{|c|}{ 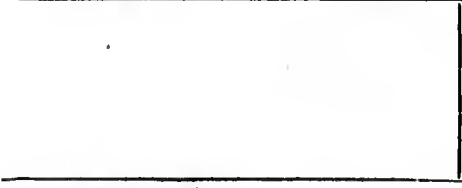 }} & \multirow[b]{2}{*}{ 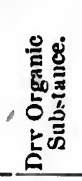 } & \multicolumn{3}{|c|}{ Dlgestlble. } \\
\hline & & & 窇泀 & 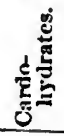 & $\stackrel{\dot{\varpi}}{\dot{E}}$ \\
\hline \multirow{2}{*}{\multicolumn{2}{|c|}{ 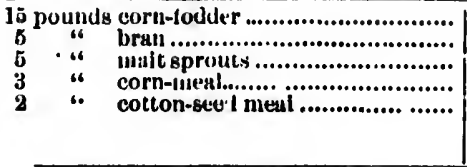 }} & $\begin{array}{r}12.1 \\
4.1 \\
4.1 \\
2.5 \\
1.0\end{array}$ & $\begin{array}{l}0.16 \\
0.50 \\
0.07 \\
0.22 \\
0.62\end{array}$ & $\begin{array}{l}5.55 \\
2.21 \\
2.25 \\
2.05 \\
0.38\end{array}$ & $\begin{array}{l}0.04 \\
015 \\
0.08 \\
0.07 \\
0.24\end{array}$ \\
\hline & & 24.4 & 2.50 & 12.42 & 058 \\
\hline
\end{tabular}

A correspondent of the National Live Stock Journal gives the following as a practical ration which he used to feed forty steers, weighing an average of $900 \mathrm{lbs}$., and gaining $21-2 \mathrm{lbs} .$, per head, per day :

\begin{tabular}{|c|c|c|c|c|}
\hline 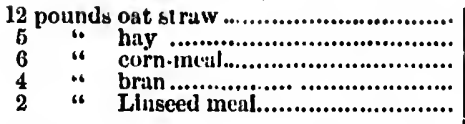 & $\begin{array}{l}0.80 \\
\mathbf{3 . 0 8} \\
\mathbf{5 . 0 4} \\
\mathbf{3 . 2 2} \\
\mathbf{1 . 6 1}\end{array}$ & 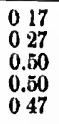 & $\begin{array}{l}4.81 \\
2.05 \\
\mathbf{3 . 0 4} \\
1.70 \\
0.70\end{array}$ & $\begin{array}{l}0.08 \\
0.05 \\
0.28 \\
0.10 \\
0.18\end{array}$ \\
\hline Standnri for fattening cattle of this weight & $\begin{array}{l}23.65 \\
24.30\end{array}$ & $\begin{array}{l}1.01 \\
22 . j\end{array}$ & $\begin{array}{l}12.90 \\
13.60\end{array}$ & $\begin{array}{l}0.69 \\
0.45\end{array}$ \\
\hline
\end{tabular}

This corresponds quite closely with the German standard. The albuminoids are slightly less, and the fat more. One gallon of cheap molasses added to the rations of hay for forty head, would nearly bring up the carbo-hydrates to the standard. Again he says: The following is a practical ration fed to $\mathbf{1 0}$ steers for $\mathbf{9 0}$ days ; their average weight for the 90 days being $1,348 \mathrm{lbs}$; and this was the average ration fed-the average gain being 3 lbs. per head, per day:

\begin{tabular}{|c|c|c|c|c|}
\hline \multirow[t]{2}{*}{ 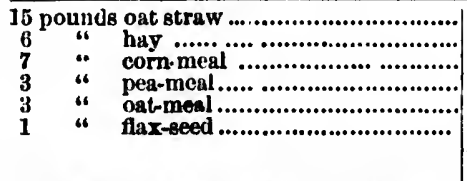 } & $\begin{array}{r}12.25 \\
4.77 \\
586 \\
2.48 \\
2.48 \\
0.86\end{array}$ & $\begin{array}{l}0.21 \\
0.32 \\
0.59 \\
0.51 \\
0.29 \\
0.17\end{array}$ & $\begin{array}{l}6.01 \\
2.46 \\
4.24 \\
1.32 \\
1.29 \\
0.18\end{array}$ & $\begin{array}{l}0.10 \\
0.06 \\
0.33 \\
0.05 \\
0.14 \\
0.29\end{array}$ \\
\hline & 28.70 & 2.09 & 15.00 & 0.97 \\
\hline$-3 i 1$ period.......................................... & 33.70 & 3.63 & 19.95 & 0.80 \\
\hline
\end{tabular}

This seems a wide departure from the German standard; but that all the conditions may be understood, it is stated that the coru, pease, oats and flax-seed, in the proportions stated, were mixed and ground together, and then $14 \mathrm{lbs}$. of the mixed meal was mixed with the $15 \mathrm{lbs}$. of oat straw, cut into inch lengths, and all well cooked together; that is, 420 lbs. of the ground meal was mixed with $450 \mathrm{lbs}$. of cut oat straw, placed in a steam-box and well cooked with steam, and this served for three 
days' rations for the 10 hend, except that 6 lbs. of long hay was given to each at noon. Perhaps the explanation is, that the cooking rendered a so much larger per centugo digestible, that it was, in effect, equal to the German stundard. These steers weighed $1,210 \mathrm{lbs}$. when the experiment beg:ul, und $1,485 \mathrm{lbs}$. nt the end of 90 days ; so that $1,348 \mathrm{lbs}$. was the averige weight during the period. The meal ration was but $10 \mathrm{lbs}$. during the first two weeks, and increased gradually up to $16 \mathrm{lbs}$, at the cud of 60 days; making the avernge ration 14 lbs, per day.

As supplementary to this we give three rations applicable to the East, South and West, in the order named:

ClOVER AND CORN RATION FOR FATTENING CATTLF OP 1200 Lhs.

\begin{tabular}{|c|c|c|c|c|}
\hline \multirow[b]{2}{*}{$\cdot$} & \multirow{2}{*}{ 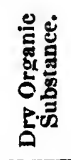 } & \multicolumn{3}{|c|}{ Digeatible. } \\
\hline & & $\frac{\stackrel{2}{\frac{2}{2}}}{\frac{2}{3}}$ & 造悹 & 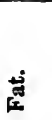 \\
\hline 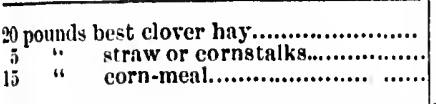 & $\begin{array}{r}11.3 . \\
15.20 \\
4.10 \\
11.77\end{array}$ & $\begin{array}{l}16 \times . \\
214 \\
0014 \\
1.17\end{array}$ & $\begin{array}{l}113 . \mathrm{s}, \\
7.6 \overline{2} \\
1.82 \\
848\end{array}$ & $\begin{array}{l}\text { lha. } \\
0.42 \\
0.02 \\
0.50\end{array}$ \\
\hline 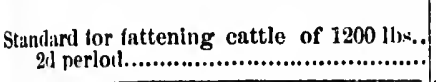 & $\begin{array}{l}31.07 \\
31.20\end{array}$ & $\begin{array}{l}3.35 \\
3.60\end{array}$ & $\begin{array}{l}17.82 \\
17.70\end{array}$ & $\begin{array}{l}0.06 \\
0.84\end{array}$ \\
\hline 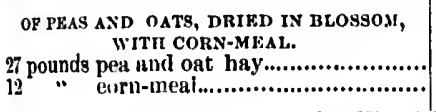 & $\begin{array}{l}2090 \\
10.09\end{array}$ & $\begin{array}{l}2.16 \\
1.00\end{array}$ & $\begin{array}{l}961 \\
7.27\end{array}$ & $\begin{array}{l}0.48 \\
0.07\end{array}$ \\
\hline \multirow{3}{*}{ 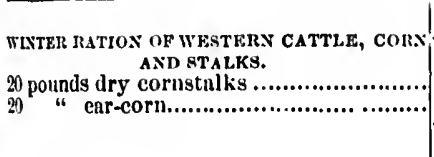 } & $30 \mathrm{tid}$ & 316 & 17.48 & 1.05 \\
\hline & $\begin{array}{l}16.52 \\
16.82\end{array}$ & $\begin{array}{l}0.10 \\
068\end{array}$ & $\begin{array}{r}7.30 \\
1: 12\end{array}$ & $\begin{array}{l}0.18 \\
0.96\end{array}$ \\
\hline & 3314 & 1.84 & 19.42 & 1.04 \\
\hline
\end{tabular}

It will be of interest now to show the chemical composition, digestibility and money value, according to the German standard, for 2,000 lbs. of clover hay, meadow hay, corn fodder, oat straw, oil ake, wheat bran, corn meal and oats. These foods, used more in the United States than any like number of others, are also complementary to each other : (Sce table on following page).

\section{Comparing Values.}

The comparisons of values by the ton of these very dissimilar foods is as follows: We find clover hay worth $\$ 17.82$ and oat straw $\$ 9$ per ton; but it cannot be inferred that oat straw would be as cheap at that price as clover hay to make an entire food for cattle, or other animals, because clover hay is a well balanced food for cattle and oat straw is only a 
RELATIVE VALUE OF DIFTERENT KINDS OF FOOD.

\begin{tabular}{|c|c|c|c|c|}
\hline - & $\frac{\ddot{g}}{8}$ & $\frac{\stackrel{4}{0}}{\stackrel{5}{0}}$ & 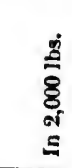 & 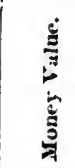 \\
\hline 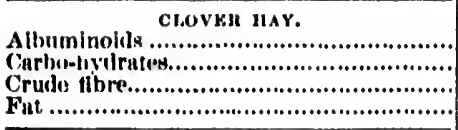 & $\left.\begin{array}{l}153 \\
\begin{array}{l}35 \\
25 \\
23.2 \\
3\end{array} \\
2\end{array}\right\}$ & $\begin{array}{r}10.7 \\
37.6 \\
2.1\end{array}$ & $\begin{array}{l}164 \\
214 \\
752 \\
42\end{array}$ & $\begin{array}{r}\$ 024 \\
670 \\
182\end{array}$ \\
\hline 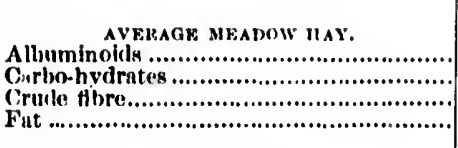 & $\left.\begin{array}{c}9.7 \\
41.6 \\
21.1 \\
25\end{array}\right\}$ & $\begin{array}{r}5.4 \\
40.1 \\
1.0\end{array}$ & $\begin{array}{r}1008 \\
180 \\
820 \\
20\end{array}$ & $\begin{array}{r}\$ 1782 \\
\$ 408 \\
738 \\
87\end{array}$ \\
\hline 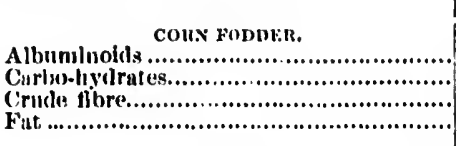 & $\left.\begin{array}{c}44 \\
37.0 \\
25.0 \\
1.3\end{array}\right\}$ & $\begin{array}{r}3.2 \\
43.4 \\
1.0\end{array}$ & $\begin{array}{r}0 ! 8 \\
60 \\
808 \\
20\end{array}$ & $\begin{array}{r}\$ 1293 \\
\$ 286 \\
781 \\
87\end{array}$ \\
\hline 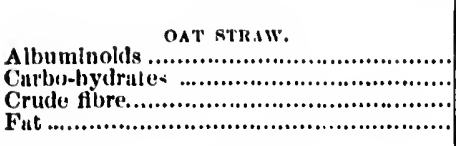 & $\left.\begin{array}{c}4.0 \\
3(6.2 \\
3 ! 1.5 \\
2.0\end{array}\right\}$ & $\begin{array}{r}1.4 \\
39.5 \\
0.7\end{array}$ & $\begin{array}{r}1134 \\
28 \\
802 \\
14\end{array}$ & $\begin{array}{r}\$ 115 t \\
8121 \\
72 t \\
61\end{array}$ \\
\hline 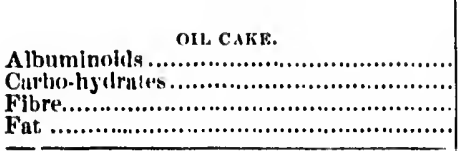 & $\left.\begin{array}{l}28.3 \\
32.32 \\
100 \\
10.0\end{array}\right\}$ & $\begin{array}{c}23.77 \\
3517 \\
9.0\end{array}$ & $\begin{array}{l}844 \\
47 \% \\
703 \\
180\end{array}$ & $\begin{array}{r}\$ 961 \\
\$ 1900 \\
632 \\
61\end{array}$ \\
\hline 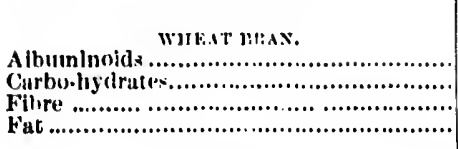 & $\left.\begin{array}{l}150 \\
612.2 \\
10.1 \\
3.2\end{array}\right\}$ & $\begin{array}{r}12.6 \\
426 \\
2.6\end{array}$ & $\begin{array}{r}1358 \\
252 \\
852 \\
5+2\end{array}$ & $\begin{array}{r}\$ 3{ }^{2} 12 \\
\$ 1092 \\
767 \\
225\end{array}$ \\
\hline 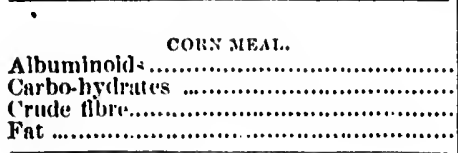 & $\left.\begin{array}{c}10.0 \\
62.1 \\
5.5 \\
6.5\end{array}\right\}$ & $\begin{array}{r}8.4 \\
60.6 \\
4.8\end{array}$ & $\begin{array}{r}1156 \\
168 \\
1212 \\
96\end{array}$ & $\begin{array}{r}\$ 2084 \\
5728 \\
1090 \\
416\end{array}$ \\
\hline 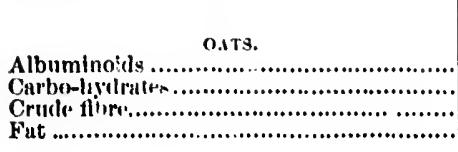 & $\left.\begin{array}{c}12.2 \\
5.5 .0 \\
9.3 \\
6.5\end{array}\right\}$ & $\begin{array}{r}9.0 \\
43.0 \\
4.7\end{array}$ & $\begin{array}{r}1470 \\
180 \\
860 \\
94\end{array}$ & $\begin{array}{r}\$ 2234 \\
5780 \\
774 \\
407\end{array}$ \\
\hline & & & 1134 & 81981 \\
\hline
\end{tabular}


partiul food, contuining so little albuminoids and fat that enttle would starve to death upon it if fed long enough. The muscles and nerves could not be nourished upon it; and yet a good urticle of oat straw is worth the price umed, becuuse of the digestible heat and fut formers it contuins. Now, put a ton of the best out straw with a ton of the best clover huy, and you hive a fuirly bulmeed food. It compares well with common meadow hay. The digestible albuminoids in elover 10.7, in straw 1.4, making the two added 12.1, and the average per eent of the mixture is 6.05, whilst mondow hay is only 5.04. The digestible carbohydrutes in the mixture is about 39.0 to 41.0 in hay, and tho fut is 1.4 to 1.0 in meadow hay. The parullel is very close; and as the mixture hus slightly moro albuminoids und fut, it may be considered the better rution. These valuations of tho different elements simply ineun that each is worth the relative price named when fed in due proportion with the other elements. Oil-enke, for eximple, is ns fur from loing a balauced rution as ont straw, for it contains ns mueh too large $n$ proportion of albuminoids as straw does too smull. It has also oil in excess. Like straw it must be fed with other foods. If $400 \mathrm{lbs}$, of oil-cake be mixed with a ton of oat straw, the mixture will muke a ration equal to mendow hay.

\section{Fecding Where Corn is Cheap.}

When stock of any kind is kept and fattened in stables, on ground or cooked food, these tables will bo found valuable. So far ns our own experience goes we have found that for growing animals there is nothing better than equal weights of corn and oats, or corn and barley, with what good hay or shocked corn fodder they will ent. We have also found that when corn was less than 30 cents per bushel it did not pay for grinding even for eattle, if it could be fed in the ear or in the husk, the experinents being based on the toll taken, and the cost of hauling ten miles to mill. For sheep, horses, and hogs it will not pay for grinding when it is less in price than 40 cents per bushel.

In all that great scope of country in the West known as the corn zone, the most economical mamer we have ever found in fattening cattle was to feed, first, shock-corn ; next, snapped corn ; und, third, husked corn • in the ear. In feeding the two latter, the animal weighing 1,000 pounds should hive about 25 pounds of corn and 10 pounds of best hay.

In feeding shock corn the animal will eat no more than it requires, and it should have twice a day whatever it will eat up clean, of ears. In feeding in this manner in the fields or di'y yards with abundance of water, allowing hogs to run after the cattlo after they have finished the ears, to pick up wasted corn and droppings-if the cattle are sheltered from wind and storm, they may be most economieally fed and to very heavy weights. 


\section{Raising Young Cattle.}

Here again the breeder must be guided by sound judgment. It will not pay to sturve even the commonest stock. A culf, to use $a$ common expression, "knocked in the hend with a pail of skimmed milk," will never muke a first class steer or cow. Neither is it necessary thut they suck the cow. In fuct, in the case of dairy cows or heifers intended for the duiry, they should not suck, for it surely tends to diminish the flow of milk, except the calf is turned with the cow at stated intervnls, and the cow milked clean at the same timo. In tho caso of heifers, they should be milked as soon ns the calf hus drawn the first milk, both us a menus of training and to develop the flow of milk us much as possible; besicles this, a calf taken at two or three dnys old is ensily taught to suck the finger or an artificial teat attached to a reservoir.

\section{The First Two Weeks,}

They sloould have nothing but new milk. It should be as warm as it comes from the cow, and the enlf should bo fed four times a day. Then they may have milk twelve hours old, from which the crean has been taken, ndding four ounces of finely ground menl made into thoroughly cooked mush, to each meal, for strong, hearty calves. Thus they may be fed for two weeks more, ehanging to oat-meal or wheat flour if the calf is inclined to scour. Some feeders add a tenspoonful of linsced meal once a day. It is not $a$ bud plan. When the calf is four weeks old it need be fed but twice a day, giving milk wurmed to about ninety or ninety-five degrees, which lnst is the nutural unimal heat. From this time on more and more mush, or its eyuivalent may be added as the calf increases in size and strength, until it begins to eat grass and threshed oats, which it should be encouraged to do.

\section{Feed Early.}

At ten weeks old it should eut freely, and at three months old it mar he gradually weaned from milk and taught to subsist on grass and onts. During all this time the calf should be sheltered from the hot sul and rain, by providing a shelter to which it may retire, well ventilated, dry and clean, and sufficiently dark to kecp out green-head ind other biting flies. In the autumn its rations of grain should be incrensed, and as grass fails the finest meadow hay should be substituted-whatever it will eat, clean of both. Offer it water ocensionally after it is a month old, and whon weaned see that it never lacks for water. 
Figuring Profts.

It will

common k," will that they anded for the flow $s$, and the cy should imeans of ssides this, o finger or

warm as it day. Then $\mathrm{m}$ hins been thor'oughly us they may flour if the linsoed meal weeks old it it ninety or From this d as the ealf and threshed

hs old it may ass and oats. hot sun and entilated, dry other liting , and as grass er it will eat. onth old, and
During the winter kocp the calves in the warmest qunrters possible; feed libernlly with grain and hay, and in the spring yon will huve tho sut. isfuction of knowing thint you lune received the best profit that you will ever reilp from the mimal at nny subsequent age; but upon compuring debit and credit with your neighbor who has fed skint-milk alone in sumner and poor hay in winter, you will tind that the loss on his enlves hats grone in the slinpe of profit in yours.

From this time on feed libernlly of grain in the winter, and give n little all summer when they will ent it. Jet them in winter be so wim that they never beeonre chilled. So continue until the animal is within six months of being ripe for the hutcher. Then feed the best you can, and rou will he rejoiced to find that you may get two to three cents a pound gross weight more than your neighbor who has only half foel and has turned off his sattle totally unripo for the butcher.

The same rule will hold good for those eslyes intended for cows. 'To mike a reod cow, she must be fed well to bring enrly development ant maturity. She may thus be brought forward strong and lusty, and in hatter condition at two years past to hring you a perfect calf, than those of your neimhlor at twice that age, whose policy lans been to grudge them feed and nllow them to shift for themselves.

\section{Castration.}

When the bull ealves aro three weeks old, if in good health, they shonld he atsinted. It should certuinly be done before they no four weeks old. Many of our best stoek raisers incline to the opinion that as soon as the enlf begins firirly to gain size and flesh, say at two wecks old, is the proper time. We have never had better success than at this time. Every person who purposes to breed cattlo should know how to do this. Tho operation is quite simple, and easily performed.

Secure the culf so it may remain standing on its feet, but cammot struggle severely. Hive a knifo ready with a keen-edged blade. The blado of a ludding-knife is the proper shape. Seize the scrotum from behind, and with two light, swift, sharp strokes cut through and into the testicle. Soparate the membrano where it unites, pull the testicle out until the cord stors from four to six inches, and cut it with a pair of nippers or rather dull shears. It will savo loss of blood. So operate with the other, and the work is done. If from any cause severe bleeding ensues, inject a little tincture of muriate of iron :nto the cavities, and wet a soft rag with the tincture and press it well into the eavity. If these be not it hand, push a little snlt and lard into the cavity. If the operation has been care41 
fully performed, nothing will genorally be required. The calf should bo kept free from interference by other animals

\section{Until the Parts are Healed,}

which will usually oceur in $n$ week. If they have been used to the company of other calves, they should not be deprived of it now, else they will pine. One renson why wo advise early gelding, is, it should be done beforo the oulf is taken off of new milk, and it slould not bo deprived of the r.utural milk until it recovers from the shock. Care must be taken that flies do not get nenr, to deposit their eggs in the parts operated on. To prevent this, if there are flies, keep the calves in a pretty dink, but well ventilated place. Most persons will find it awkward at first to geld as we 'anve directed. A little practice, however, with tuct and firmess, will render all easy, especinlly if one can have the advantago of seeing un expert opernte once.

\section{Sometimos Buppuration Fnsues.}

In this case recourse must be had to mild palliative measures. Keep tho parts washed clean, twice a day, with warm ruinwater and castile soap, and inject $\Omega$ small qunntity of tincture of aloes and myrrh. If tho parts becomo unhealthy, or ulecrated (for moro suppuration is healthy action), wash with a weak and clear solution of sal soda, or hard wool aslies. If proud flesh should arise (a raro occurrence), burnt alum, pounded very fine may be applied, or tho parts may bo touched with lunar caustic. 
should be

o the comse they will we done beleprived of st be taken perited on. ty dark, but first to geld nd firmness, of sceing an

ssures. Keep d castilo soan, If tho parts ealthy action), ood ansies. If pounded very ii) cuustic.

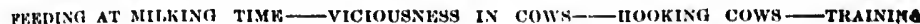
OXEN-THAIN STOCK YOUNG-SUMMING UP-MANAGING A KICKING COW.

\section{Training Cattlo vs. Brcaking.}

The word "broaking" horses or steers to work, or breaking a heifer in to milk, has now-il-diays becomo pretty well obsolete. Brenking by brute foree maty make a kind of a machine of an animal; it may do stupidly

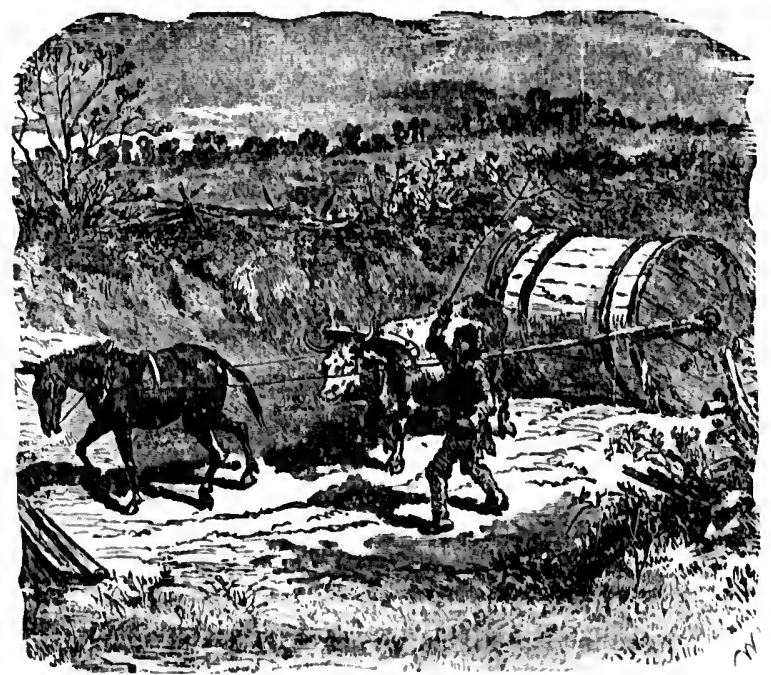

WORKING HY MAIN FORCE. 
what is desired, and yet not do it to the best advantage. Intelligent persons now do not break an animal by destroying its will, they simply make it subservient to that of man, hy letting it know at the first hampering for training that it will not be hurt, if it does not resist. All domestic animals are naturally subservient to the will of man; they require to be taught what is wanted, and the individual should know that no good 'an come out of any system of training which compels the use of the vhip constantly. The whip is necessary only as a means of correction. when an animal is refractory after understanding the will of the master. An intelligent trainer wii: oasily distinguish between stubborn antagonism and a want of eomprehension. We have never seen young animals stul, born, exeept that they did not understand what was wanted of them; and in animals that have at length been made to work in the yoke, or to stand 'quietly to be nilked, hut which have "froaks," as they are called, when they seem wild or stubborn, it is usually the result of bid treatment in "breaking," and the animal is actuated almost solely by fear. If, in the struggle which ensues, the animal becomes master, it is there. after of but little use. It is better in training that the struggle be not made necessary.

\section{Training thn Calf.}

If the ealf has been raised by hand, that is, fed with milk from the pail, it will, or should have, become so gentlo and familiar as to allow itself to be approached readily, and to respond to the call of its master. Many persons at this time name every ealf, and thus they soon come to know their names when called. If firmuess and at the same time gentleness have been used, so that the calf will understand that there is nothing to fear ; if no struggle is made, it is well on the way to understund what is further expected of it. It should be rubbed and curried occisiontlltr, especially on those parts of the body that itself camnot reach, as the head, neck and shoulders; or, if kept in the stable constantly, it slould be brushed all over at least once a day. Here is one of the first and most important lessons. At first, tho calf does not know what is intended. If the master gets angry and beats it, it will ever after as: ciate curryiug and brushing with a beating; and when it gets older and stronger; in the constant successions of struggles to escape punishment, it will at length find it is the stronger animal of tho two. Thereafter itself and not the man is master. The olject of currying is not to gire pain. It is an operation of cleaning that the animal cannot perform for itself, because confined in a stcble. If the animal is turned out during 
the day, and confined only at night; or if it have the range of the yard and sheds day and night, the cleaning is not needed. Animals ean. and do perform these offices for themselves and for each other by licking, so far as is necessary. The accumulating scurf in an out-door life is a provision of nature for the protection of the animal. It should not be touched. In the stable, however, it is different. The laek of exercise tends to a sluggish movement of the blood, and hence a elean skin becomes one of the most aetive integers in preserving the health of the animal. In using the comb or brush, or, in the ease of cattle, the eard and brush, a light hand with the comb and card will do better work than at heavy hand. It should be unneessary to say that about the bony parts the card or eurry-comb should never be used.

\section{Haltering.}

The first thing a calf should be taught is to stand quietly when tied, and under all eircumstances. If it is taught this by being tied up immedistely upon being taken from the eow to be fed inilk, or at from three dils to a week old, there will be no difficulty. If the ealf has l'un with the cow, it wil! be strong and lusty. In this easc, the lot if they are to be stabled, should he put into a close pen, and a strong halter fistered to the head, of one of them, using discretion and time so as not to frighten the animal. Once secured, two men will easily place it in position in the ttille. So proceed until all are handled. Here they may be gently handled until quieted, whatsoever the manipulation.

The next step will be teaching it to lead. Take it into a elosely fenced rard, having the ealf haltered at the end of a ten-foot rope : stand in front of it and utter the word "come." Of course, it will not move. Utter the word again, and at the same time let an assistant tap it lightly with a bugey whip on the legs, from hehind, or hold the whip yourself and tap it on the forelegs at the utterince of the word. The animal will soon understand what is wanted and come forward. It should then have something $i$ likes, the least possible liek of salt, for instance. From this time on you will have no difficulty in teaching the ealf to follow quietly ; in fact it may be taught to do many things : to back or come forward at tho order ; to turn to the right or left. In fact, it should be half broken to milk before it has had n ealf, or should be half broken to labor before the yoke is put on.

To illustrate the difference between this plan of uniting firmness with gentlensss in the training of cattle, one has only to observe the difference in eattle on different firms. The stock of the brutal farmer will never willingly allow the owner to come near them. If a master's animal be in 
a corner and he approaches, thero is a dash to escupe, and perhaps some young. animal is miimed. Such stock soon acquire the habits of their master : they are morose, ugly, often vicious; for in in herd under bid management animnls sometimes get the better of the master, and are apt to become breachy, tricky, and generally unmunageable.

\section{Training to Milk.}

In vraining to stand quietly while being milked, the udder should be often handled while tho heifer is growing up ; the bag should be rulbed; it. should be pressed and the tents gently pulled. This need take but very little time." The real work comes when the nnimal is to be milked. There are many things to be taken into consideration here. 'The heifer must be put in a pen where she cannot hurt herself, and where the mulker ean operate easily; a pen just long enough and just wide enough for the heifer to stand in, five feet high and tight enough so there will he no danger of the heifer injuring herself, and with an opening for the milker to operite through, will thoroughly sulsdue the wildest. Generally, all that is needed

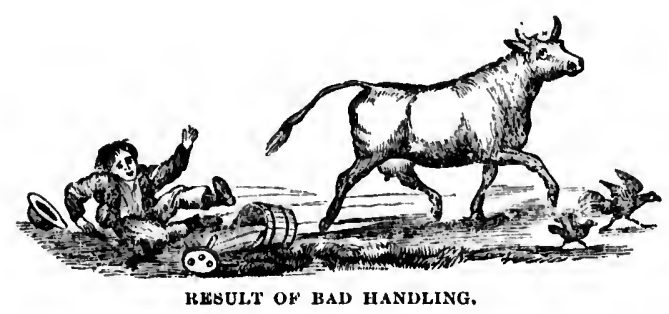
will be to tie the heifer by the head, and then patiently show he" that she will not be hurt. She will soon come to associtite the ant of milking as easing the udder and thenceforward will stind quietly, unless the lag or teats hurt her. If so, seek the eause of the difficulty and eure it.

If the animal has never been tied up, but has been haudled in tlie yard, one person may take the heifer by the horns, while another milks. If she be very rofractory she may have to be " nosed." Seize the off hom firmly with the right hand, and thrust the two first fingers and thumb of the left hand into the nostrils, clasping the membrane tightly if she struggles severely. So soon as the struggles cease, ease the pressure of tiue fingers in the nostrils. If she again struggles, again tighten the grasp. Let the milker use gentleness. It does no good to .kick ill animal ; it may do much hurm. If the heifer kick, it is probibly beeuse she is hurt. A person of ordinily strength need not bo kicked while milking, unless in the ease of a eow of extraordinary strength and vicousness. The wrist of the loft hand holding the teat, if kept well ngainst the stifle, and pressed firmly back when the foot is raised, will

\section{wt \\ ret \\ cal \\ likt \\ sen \\ by \\ ther \\ ous \\ plac \\ go t}

A

bad

give

madc

bad 1

cow u

and $g$

The ${ }^{\prime}$

concele

best s

Son

dowin $t$

and if

tented.

and pr

hand, i

at case

whole :

retdy $f$

think tl

tomed

salt fro

you lied

Silk fa 
aps some of theil andel' lad d are apt

should be te rubbed; se but very ad. There fer must be ker can 0- the heifer o danger of $r$ to operite lat is needed ie the heifer al, and then how her that not be hurt. soon come to the ant of is easing the d thencefor11 stind quiess the hag cure it.

din the yard, ar milks. If the off horn nd thumb of irghtly if the pressure of n tighten the d to kick an bably because kicked while strength and if kept well is ruised, will generally cause it to be set down in place again. Use soothing words when the animal is quiet, and low but tirm words of command. when refructory. If the udder is isflamed, as is very often the case soon after calving, batlio it carefully with cold water, so ns not to shock the animal. She will soon come to associate a feeling of relief with the operation and like it. In fact, the whole art of training may be summed up in the sentence: Use discretion and judgment, and show yourself superior to the brute-in truth, its friendly master. The conquering of brute forco by brute force is a relic of barbarism. There are vicious animals as there are vicious men; there are dangerous animals ns there are dangerous men. Both muy have been bred or educited thus. Vieious men are plicel where they eannot injure their fellows; vicious animals had better go to the butcher - they are as unprofitable to breed from as they are useless for what may be got out of them.

As showing tre effects of bad and good 'alndling, we give the pict are of a cow made wild and vicious by bad litudling, and that of it cow used to lind treatment and gentle but firm handling. The reader can draw his own conclusions as to which is the best systcm.

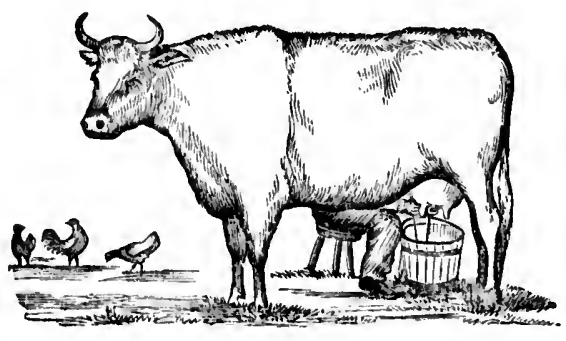

RLSULT OV GOOD HANDLING.

\section{Feeding at Milking Time.}

Some persons, to induce gentleness, givo the cow a mess before sitting down to milk. This is a bad plan. It leads the animal to expect it, and if it is not given, even if sho is gentle, she is restless and discontented. The very act of feeding induces moving about more or less, and prevents standing as quietly as she otherivise would. On the other hand, if she be fed after milking time she will stand quietly and enticly at ease. Many good handlers feed before milking. By the time the whole are fed and the stable cleansed the cows will have finished and be reatly for milking. This is the plan we have alwitys pursued, and we think the better one: Before sitting down to milk we have been aceustomed to have the milker give the eow to be milked the slightest lick of salt from the hand, or a single mouthful of extra nice soft hay. When you begin milking do not intermit until the cow is milked entirely clem. Milk fast. Slow milking not only worries the cow but tends to dry her 
up. If the milk is not drawn as fast as it is given down it is apt in the end to be withheld.

\section{How to Milk.}

Supposing the cows to be in the stable, after feeding, und cleming the stable and the animals themselves, carefully wash the udder and teats, if they are dirty, or thoroughly brush with $n$ soft brush, or wipe with a eloth if only dusty. Sit down quietly on the off or right side of the eow, the face slightly to the rear; take hold of the rear teat furthest from you with the left hand, and speaking the word "hoist," slowly and in a low but firm tone, press the arm against the leg, to carry the foot in place slightly behind the other. In milking, grasp the upper portion of the forward teat nearest you, so the hands operato the tents diagonally. In grasping the teats, do so well up towards the bag, aceording to the length of the teats, with the thumb and forefinger, and pulling gently down, at the same time, close the other fingers, thus foreing out the milk. So proceed, first with one hand and then with the other, until the milk is pretty much drawn. Then change to the other teats and finish them.

In stripping do not uso the thumb and finger, pulling the teat from the root to the end. It is a senseless plan. Every drop can be hal by pressing the top of the hand well up under the big, gathering the milk with the thumb and forefinger, and drawing ine milk with the others.

\section{Viciousness in Cows.}

Sometimes a person will have a cow that is given to viciousness from bad training, and whieh may be so valuable in other respects that the owner may not wish to part with her. She may bo a kieker. If so, and she be strong and decidedly ugly, use the following apparnatus, which will explain itself, and which, by the lever and notches, may be made to grip tightly into the flank. Another plam is to draw a strong cord quite tightly around the girth. The most usual plim, in tho stable, is to buckle a strap around the legs and to fasten it to a ring in the wall behind, so the cord will be loose when at rest, and yet so tight that the cow cannot get her leg forward to do mischief. The cut we give will slow the first device mentioned and the manner of fastening:

\section{Cows Sucking Themaelves.}

Sucking themselves is another bad habit which cows sometimes acquire. There are two objections to such cows. The first is, we lose their milk, and not rarely other cows will aequire the habit from them. It is a well 
in the

ring the tents, if e with a the eow, from you in : low $t$ in place on of the natly. In the length down, at milk. So he milk is h them. it firom the al hy presia millk with is.

isness from cts that the If so, and , which will hade to grip r cord quite is to buckle 1 behind, so cow cilunot Low the first

mes acquire. their milk, It is a well

known fnet that self-sucking cows : rro generully good milkers. It is quite certini that they aequire the habit from the fact that the milk pressure in the bigg hurts them, and in rubbing the udder with the nose they at length get a taste of the milk, and thus become fixed in the habit. IIence the ne'essity of regular milking, and often enongh to keep the udder from

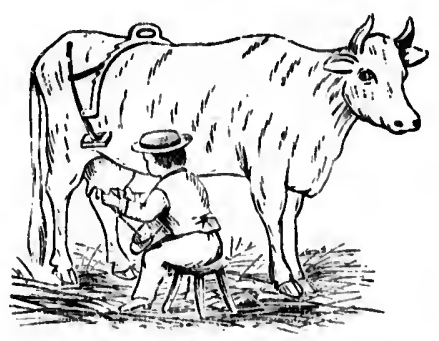

TO PREVENT A COW FUOM KICKING. being unduly strained. There are various devices for preventing this vice. One is a halter and nose piece, with spikes, similar but linger than those used upon calves to prevent sucking. It is given below, but hesides hitmpering the immal to a considerable extent in whthering lier food, it is not alwalys effectual.

A rery simple, and silid to he effective means, is to take a tough lickory stick, fourteen inches long, three-fourths of an inch thick in the center, shimpened to a point at each end ; ent a grovo aromel the center, half an inch wide, and hitlf the depth of the thickness of the wood. Whittle eich end nicely to a point, or lenve it somewhat blunt, and insert at shripened pieco of wire in each end. Itake a loole in the animal's nose, in the soft portion, but close up to the hard membrume of the nostrils, as you would for ringing a bull, and small enough so it

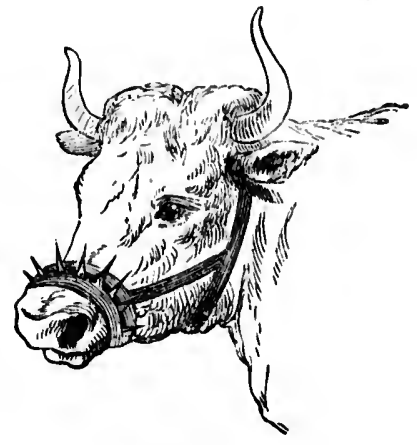

TO Pl:Evit slelisii. will require ('onsickerable pressure to slip) the bulge of the stick untul it reaches the middle notch, when it will remain fixed. This does not prevent the animal from feeding, nor being fistened in stanchions, and it must be an inveterate sucker that will druw her milk with this jewel in her nose. Still another but more complicated yet quite effectual plan is given in the cut on next page.

\section{Hooking Cows.}

Another vicious habit sometimes acquired by otherwise excellent cows, is the vice of attempting to grore every animal that comes near, that they can master, and even individuals. Various dovices have been recommended to prevent this. One is a bar across the horns, to which is 


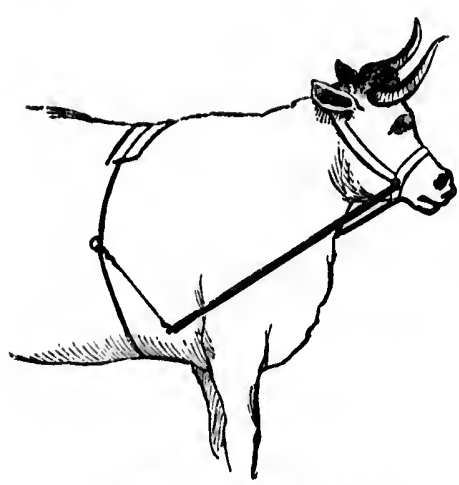

HARNESS TO PREVENT GUCKING.

fastened a slender, springy piece of lickory to reach a position just above the nostrils and armed with a sharp peg underneath, so that the slightest pressure will cause it to wound the nose. In a majority of cases balls placed on the tips of tho homs, and which may be purehased at any hardware store, will suffice, if the animal is not vicious to mankind.

These are made to screw on. To do so fasten the cow securely, and if the horn is too large to take the ball pare it down till it will fit. Stick a large potato baked soft, and thoroughly hot, on each tip, of the horn. It will soon soften it, when the ball may be easily serewed on with the proper tool, and will never eome off. In the case of animals vicions to man, the following device, which the cut fully explains, will prove entirely effectual.

\section{Training Oxen.}

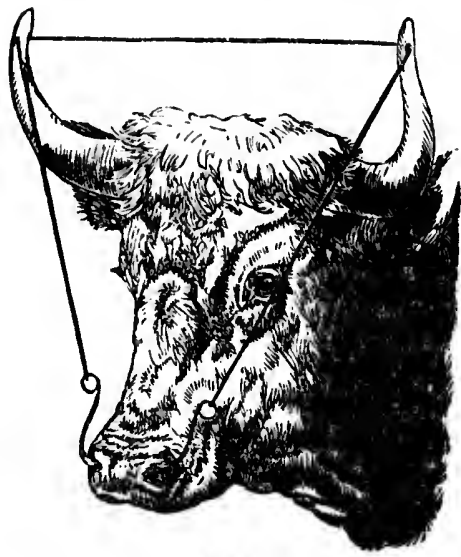

TO PREVENT HOOKING.

The value of a working ox lics not only in its ability to draw a heary load forward; to be thoroughly good in mud, or on roads; to be able to back whaterer he can draw forward, und to be quick-paced. It is true you cannot make a slow breed fast, nor a lazy ox active; neither can you make an ox that lacks muscle do heavy work. If the reader lials studied the characteristics of the Derons as wo have presented them, he will be pretty well able to judge whether an animal under inspection will be fit for the yolie. If not fairly perfect in tho principal points, discird him. It will not pay to train an inferior steer. If he is to be used for very heavy work, agility must to a considerable degrec be sacrificed to weight and muscular power. As a rule, however, it is better that you use $t$. ee 
yoko of medium sized nctivo steers in the term rather than two yoke of, heavy, lubberly, snail-paced brutes that are always vexing the driver.

Select such as will walk evenly, look as nearly alıke as possible so that they may be hitched together : lirst, for disposition, carringe, and pace; and sccond, for color and general appearance. If they are three years old, and to bo put to work immediately in a breaking or freighting team, select a pair of mates, hamper by first roping and tying, and then yoking together. So proceed until you have the teum, whatever the number, made up Once yoked, they should not again be released until they cease struggling, and work quietly in the team. Fasten them together, three, four, or five yoke, as the case may be, putting a well broken stendy yoke of oxen on the lead. Thus you may have a team in a few days that will learn to pull stcadily forward and turn "haw" or "gee"

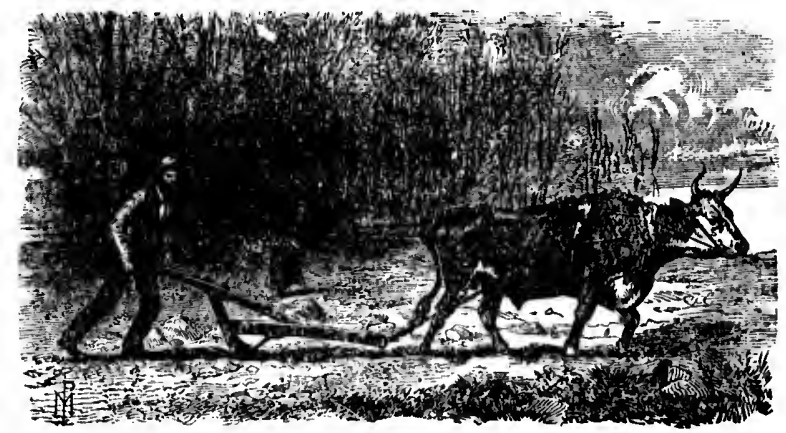

A PRIMITIVK TACKLE, BUT GOOD TRAINER.

-to the left or right--as is wanted. They, however, will never become a team, in the sense of the word, as used by those who know what a trained yoke of oxen are.

To properly train steers, they should be taken when quite young. Selecting one at a time, halter-hreak him as heretofore directed, cause him to come eloso to you by tapping him on the forelegs with a light rhip. Teach him to walk quietly, but at a quiek pace, at your side, you holding him lightly by the halter, neither before nor behind, but directly and closely at your side. Make him turn to the right or left at will, and teach him to stand quietly when so ordered. In all this do not hurry. Be quiet, low-voiced, patient but firm. Angry demonstrations and outcries may produce some spasmodic results, but the real, patient, working force of the animal will not be brought into effective operation by any such means. 


\section{Train Stock Young.}

Let the steer, which should not exceed one year old-eight months is better-be taught one lesson ut a time, und that thoroughly. It will render the next lesson easier. When they me quiet und will do your bidding in the yoke without halter or strup, they may be left until three years old before being worked, though it is better to begin at two years of age, especially if they are to be used on the wigon. 'They will not pull muel, but they may thus be taught to walk fast, to do then share of the work, and to become thoroughly "way wise."

Tho greatest difticulty in tramming oxen, as a single yoke, is tenching them to back promptly and well. 'To do thes requires patience. Never overload then. Make them back promptly twelve to fifteen feet at a time, and then come forward, stopping instantly at the word, with heads up ready to back again. In traveling along tho road never allow them to flag, nor exert them so long at any one time as to seriously weary them. Patience alone will secure the end sought. When you have oceasion to speak sharply to them, do not let it be in a very loud voice, but let it he accompanied by a touch of the goal or a blow of the whip sufficiently slarp so the auimals feel it. To touch both animals so near together thit it seems almost simultaneous, is a fine art. It is acquired by always touching the slow ox first, for scarcely ovor will two animals be found so evenly matehed as to be exaetly alike. When you find them you have a prize. When not so, we have always found it best to have the slower ox on the near side.

\section{Summing Up.}

In summing up the whole matter of training, the individual must keep the points aimed at steadily in view. First, the animal must be rendered entirely subservient to man, and this by showing it that man is its friend; that under no crrcumstances is it to be injured. A well trained yoke or a team of oxen will command a fancy price as easily as a well traned span of horses. There will be, for many years to come, uses to whuch neither horses nor mules are so well adapted as aro oxen. In lumbering, especially in breaking prairies, in much of the wor's of the film, and for teaming in wild regions generally, where there is nothing but rank, wild grassy feed, they will be indispensable. In these cases the trained team will do one-third more work than the untrained team, and do it casier for themselves, and much more satisfactory to tho driver. Here agam the driver should be himself trained. A brutal driver will soon rum a good team, yet cannot entirely destroy their value. 
An intelligent driver will neconplish what he wants without undue severity; his voice und signs are the potent powers. In starting a henvy load etch ox is culled by name, however latigo the team be. They undelstand thit they aro to place themselves in position for action; overy chain is straightened, every musclo is brought into tension ; they get well into the yokes, and at the signal all start together. With such a tean the lont must come.

So with cows. The training of the heifer is hegun in enlfhood: she leurns to rely entirely upon the master. 'They know his voice either in the yard or field, and come clustering about him, expecting some "ticl-bit," or at least a kindly word or earess. Whan the first calf is chropled there is no fear of the master ; ho may take it anel do with it what he willonly fond solicitude is shown. Let a strunger come about, and instantly this solicitude is changed to fear. If a person who lits benten them or otherwise ill-used them approatehes, the fear is intensitied, and if he offers to haudle the ealf, a battlo for the mastery is likisy to ensue.

We hatre never hitd any trouble in feaching a heifer to stand to he milked. If the udder is tender, as in mue ches out of ten it will be, they will gently submit to the means used for relief and secm grateful for tho effort. If strunge heifers are to he operinted on, the tirst thing to teach then is, that you are a friencl whatever llo time it takes, whether half an hour or half a day, do not untermit the effort until the aninual is sulpdued. If refinctory it is better that the heifer or cow ho tied up at once and kept thero until entirely quiet and without fear. Then fully half the work is done aud the subequent work is only a question of time and of patience.

must keep o rendered its frend; led yoke or cell triuned es to which lumbering, rom, and for rank, wild raincd team it easier for e agaul the rum a good

\section{Managing a Kicking Cow.}

We once subdued an unusually refinctory and kicking eow, hy having ber held firnly by tho head while we seized the teats firmly one with each band. There was no attempt to milk. The lesson to be given was that she could do no mjury by kicking. It took three-quarter's of m lour to accomplish the object. When she kicked the grusp was tightened; the wrist was brought back firmly nganst tho leg above the hock. When she censed kicking the grasp was relaxed, and the motion of milking was performed so fur as pulling gently on the teats swhen she kicked, or ruther attempted to do so by bringing her foot forward. She soon found it wins invariably brought down again nearly in its proper position m the rear of its mate. In the end sho gave up and sulmitted to bo milked. One nerr lesson she had to learn, to stand without holding. The was necomplished by following her about until she was content to stund, which she 
did after three or four breaks. Within a week, there was no more quiet cow in the yurd than this heretofore incorrigible vixen.

\section{A Inppy Family.}

As showing the benefits of suporior earo and training, it ean be dem. onstruted how nicoly ull furm stock will get along together in pence, when owned by a sinall farmer who camot ufford to sepurate into distinet herds on account of senrcity of numbers. If rilised together in the sume yard each will find its propor lovel. 'They will agreo kindly in a small pusture, ind if tho pigs uro ringed thero will be no diffeulty about rooting up the soil ; and of the different classes of animals each will eat grasses and plants not relished by the others. The fuct well illustrutes tho aduge, "A merciful man is merciful to his beast." 


\section{HOW TO SHELTER.}

\section{Necessity of 8helter.}

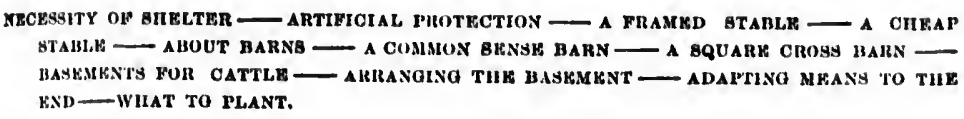

In all climites where cattle have to be fed nearly half the year, the question of shelter becomes of the first importnnee. In the miclllo corn region of the West, cattle must be fed from four to five months ; and farther north, from fivo to six inonths. If the pusture in Octolner be only sullicient to supply the unimal waste, then sueh feeding is entirely lost so fur as profit is concerned. The object of keeping enttle is to get growth and weight. The extra food given over and above the natural waste, represents tho protit. Hence in the artificial feeding of cattle the question of slueler comes in. A cold storn will often seriously reduce the weight of stock. They will begin to fall away, and before they got realy to agan inerotse in weight they will have had a season either longer or shorter when they will perhaps neither have gained or lost. The nitural heat of the animal must be kept to about 100 degrees. In fact, tho natural heat is 96 degrees whatever the temperature of the air. If it falls below this the animal begins to chill, and the body is ealled on to furnsh additional heat. So long as this can be supplied the animal lives. When it is exhausted the animal dies.

The foot given may be compnred to the fuel used under the boiler of a stenm engme. So long as the witer stands at 200 degrees no ste:tm is produced; above 212 steam accumulates, until at length enough power is raised to sturt the wheels in motion. Thus it is with stoek. Food must be given in proportion to the animal waste. With the thermomoter at zero, and air stirving, whatever the fecding may be the animal camot

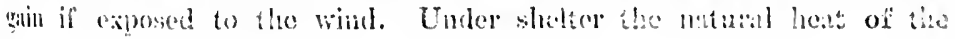


animal is conserved, and it remains comfortable. If the temperiture of the stable em be kept at 60 degrees, the minimum of food only will be required. Just here two integers come in; the cheapjess of food as agninst shelter, and the cost of labor. It is possible for food to he so cheap and libor so dear, and the price of cattle so low, that the interest

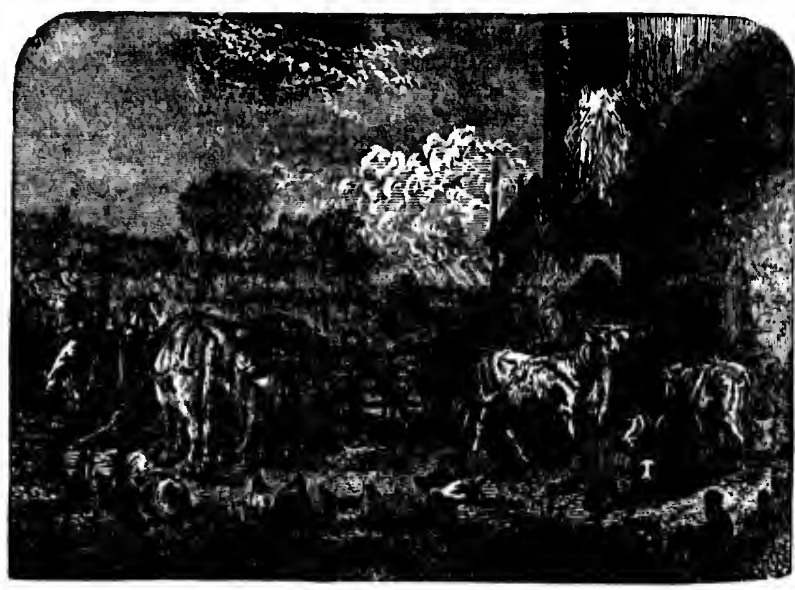

OLD STYLE FARM YARD.

on the shelter and the cost of labor woulel eat off the profits. It has been so in erery section of the West first and last, and is so still in some new seetions; lut nowhere so low that cattle could be profitaly fed without the protecting influenee of gullies or timber to break the force of the wind. This is nituril protection, and is the groundwork upon which sll other is to be built.

\section{Airtificial Protcction.}

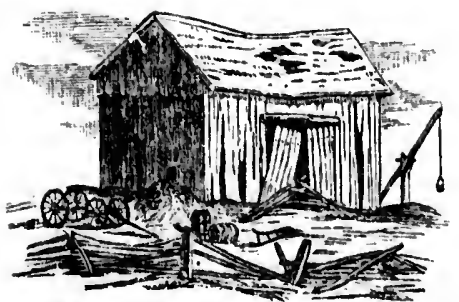

FIRMER THRIPTLES9' MODE OF PROTFCTION.

If the stock hreeder his not timber, then the sooner leo plunts wind-brealss to protect his rald and furm luildines the sooner will he reip profit therefrom.

This is the crudest of artificial protection and yet or of great importince, both in Winter and Summer. In Irinter it brenks the force of storms of wind, rain, sleet, and snow, and in Summer furnishes shinde.

The next crudest means of shelter is a shed of posts and poles, und 
covered with slough hay or straw, and slabs, or poles, filled in between with such litter as stock will not ent, the whole firmly pounded down to milke it wind proof.

This, if well made and so low as just to admit a minu to wall under, is both chesp and warm.

Another chenp form

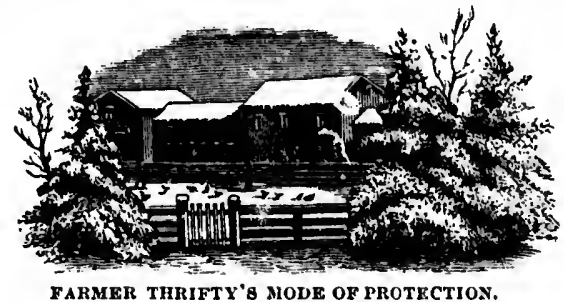
of shed or shelter from storms is made lyy setting posts firmly in the ground in two lines, sawing the tops level, fastening on plute pieces, laying on scantiing for the peak, supported temporarily, und nuiling on boards, for a roof, at one-quarter pitch, up and down from the plates to the peak, covering the joints with wide battens and bonrding up the side from whenee the prevailing winds come. If twelve feet boards are used for the roof, a shed may thus he made over twenty feet wide, that wiil furnish good shelter for stock cattle where for:tge is cheap.

\section{A Framed Shed.}

A still better shed may be made ly ruming the posts up eighteen feet, friming in cross-ties to support a floor. In the upper twelve feet of this shed a good deal of fodder mily be stored, to be fed from when the weather is too inclement to allow it to be handled on wagons. From this we may go on to more and more elaborate structures until we come to the birn'n proper.

On all well ordered fin'ms the owner fully appreciates the importance of shelter. Henee we see the feeding yands with one or two sides protected with more or less serviceable shed, until upon some fan'ms we tind the feeding yards entirely surrounded with this means of Winter protection.

In all this the owner must be guided by his pecuniary means. If he have not money enough to put up the better cliss of buildings, it hy no means follows that he is to leare his stock without shelter until he is able to louild.

So fir as the simplest sheds are concerned, it is almost cutirely a ques. tion of lithor. In the ease of simple sheds of lumber, it is simply a ques. tion of the cost of boards and nails. Auy intelligent farmer, assisted

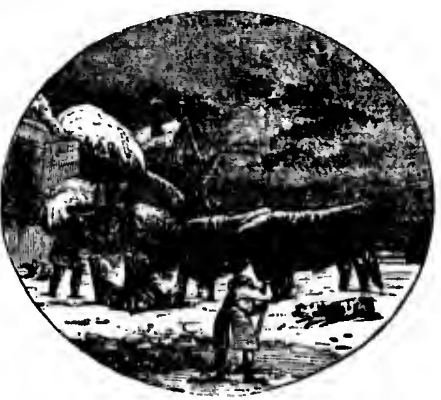

PRIMITIVE PROTECTICN. 42 
by his hired help, can do the work. It is true, however, that few persons, the first time they build, do so economically. Let us see how this may be fairly accomplished. Suppose the structure is to be a simple roofed shed affair. Deeide upon the length. The width should not be more than twelve feet for a single pitch roof. Allow that it is to be ninety-eight feet long. Set four heavy posts for the corners, three feet in the ground, and of the required heighit. The lower it is the warnier it will be, so it be high enough for the cattle to walk under the plates. Between the two end posts set, exactly in line, six posts each fourteen fect apart, and five and one-half feet high from the average ground line. Proceed in the same manner with the front, the posts to be nine feet above ground. At the back, now set seven lighter posts in the fourteen feet spaces. Saw them all off to an equal height, spike on four inch scantling from post to post in front, and two by four for the bick. It is now ready for the roof, which is to be firmly nailed from front to reall. Board the front down to within five and a half feet of the ground, and the ends and back entirely to the ground. Thus the shed is complete, except banking up. This is important and will add fully onc-lalf to its warmth. A good way to do this is to lay a line of sods one foot from the rear, and fill in with earth or old litter, carrying the banking at least four feet high; or, posts may be set two feet from the wall, with sufficient strips nuled thereon to hold the litter, and the wbole filled in and r:ummed tight.

\section{A Cheap Stable.}

Do you prefer a stable, take the form given for a hip or double-roofed shed. Board the whole tight all around, leaving space for doors and windows; batten the cracks, lay the floor, put in stanchons or upriglits for fastening the cattle, leaving a feeding place in front, and the whole i; complete.

Ve prefer rings to slide up and down, upon standards three inches thick, to stanchions. Now this style of stable will not be strong enough to allow their beng fastened to the floor nbove. Set strong posts seven feet apart and four and a half feet lugh, sawed off square on top, and three feet out from the wall. Prepare six-ineh seantling to be pinued firmly to the posts, twelve inches from the ground, and on the inside next the wall ; the scantling hored, each three feet, with two-inch holes. This will be wide enough for cow's. Larger cattle must have three feet, three inches. Prepare otlier scantling bored in slintlar manner for the tops of the posts. Tuke three-inch smooth saplings ; sharpen the lower ends just so they will drive firmly into the holes in the lower scuntling when it is 
pounded in place below. Shave the upper ends so they will fit the holes in the sciutling above. Drive them solidly into the holes below, pinning each one fast with a half-inch pin. Slip a four-inch iron ring over each stake. Lay the upper seantling on top, entering the standards as you go. It is better that they have some play. Lower the scantling on top of the posts, and pin and spike them firmly to the posts. Cut stout rope six feet, six inches long, splice a four-inch loop on one end, whip the other end with small cord so it will not unravel; pass the rope through the ring and back to the loop so the end of the loop will be eight inches from the ring; pass the end of the rope through the loop, draw tight and make fast with two half hitches, or, hetter, whip the two portions of rope together as far as the loop. The cattle are then ready to be tied up, by pissing the rope about the neck and through the loop, and drawing just tight enough so the animal eannot slip it over the horns. Iron chain bails that will last a life-time are kept ready made by agrieultural implement men, and are much the eheapest in the end. Tied thus, eatthe cun easily reach their food, ean lick themselres, can rest perfeetly, but cannot reach to injure each other. A six-inch board nailed along the standird at a proper height, say aloout six inches below the tops of tho shoulders of the cows, will prevent their reaching too far into the feeding passage.

\section{About Barns.}

'the sirst thing to do in the ereetion of any building is plamming to a certilinty what accommodations are wanted and the probable cost. The farm biu'n, if there is to be only one, must be made to inswer a vitricty of purposes. It must contain stables for cattle and horses, calf pens, shelter for sheep, a threshing floor, hays or mows for hay and grian, room for rehicles and many tools, harness room, granary, and, if the barn is a lurge one, room for placing a horse-power.

Years ago barns were seldom mado higher than eighteen-feet posts. In these days of improved machinery it is ns easy to fill $\boldsymbol{n}$ barn twenty-five or thirty feet high as one that is lower. The nearer squaro or octagonal a harn is and the higher, the less its relative cost, so that now barns are huilt of two or three stories when a slight declivity may be had for the site. If of two stories, the basement is cut up into stables for cattle and sheep, storage for henvy tools and machinery, calf pens, etc., etc.

The main floor will contain bays for hay and grain, threshing floor, a harness room and granary. Practically there is no ndrantage in tho third story. The barn may be as high as is needed, the bay continued to the roof ; the stable, harness room, granary, etc., may be floored over, and a 
mow be had overhead; so; a floor may be carried over the threshing floor, and this space utilized in the sume way. Practically you have the space at less expense.

\section{A Quarter Section Farm Barn.}

In the West and South, the farmer of 160 to 200 acres may get along very well with a side-hill barn forty-two by sixty feet. It will give anple room for a bay 16 by 60 ; a foor 13 by 60 ; horse stable 13 by 60 , containing 5 single and 1 douhle stall, or 2 single stalls and 3 double stalls; a room for implements 10 by 13 ; a granary 12 by 13 , and a tool room half that size ; while the basement may be devoted entircly to the stabling of cattle, with calf pens, a sheep pen, and, if necessary, a shed enclosed on threo sides. The granary will hold over 600 bushels of grain, and may be divided into bins for Winter and $S_{p}$ ring wheat, oats, barley, and ground feed for stock. The basement may contain two rows of cattle stalls, with passage way between, six feet wide, with shoots leading to the upper part of the barn for delivering hay, grain, and other feed. This will leave a space 12 by 60 , which may contain calf-pens and a place for sheep, and it may be so arranged by means of sliding doors that it mar be entirely closed in inclement weather. This basement will contain stalls for thirty-two eattle, and the manure may be thrown directly into a cart or wagon and hituled directly where it is wanted.

This barn may, of course, be enlarged by adding on, to accommodate any required amount of stock; but, if a much larger ban than this is wanted, the square or octagonil form should be used. It will give largely increased room in proportion to the cost.

\section{A Common-sense Barn.}

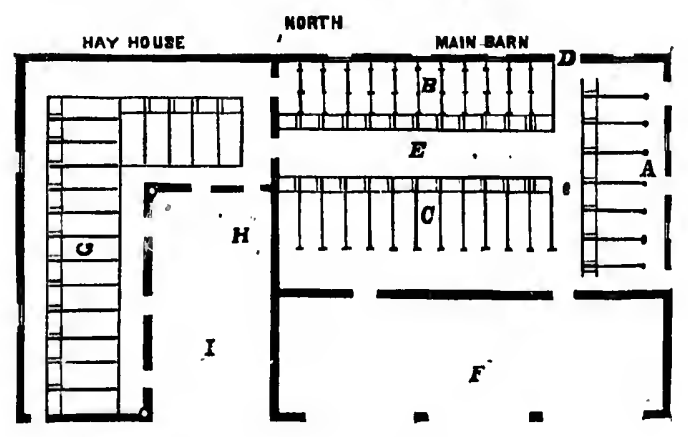

MAIN FI.OOR OF DAIRY BARN.

Above we give an outline of the basement of a barn forty feet wide and ixty feet long, with a lean-to overshot extending twerty feet in front. 
This barn will contain about 100 tons of hay. The barn would be better facing the South if the lay of the land as to declivity will allow. The hay-house may extend twenty feet in width and height in the form of an $L$ and of such a length as may be wanted for storage, say forty feet. This barn, if the space below the hay-house is utilized, will stable six horses and forty cattle.

The basement of the main barn may be divided into stabling as follows. $\triangle$, horse stables 12 feet deep, with mangers two and a half feet wide for hay, with suitable troughs for grain and manger for hay. $B$ and $C$ are cattle stalls. Those in $B$ hung with swinging gates, opening side ways, $G$ the same, but each stall having a separate gate entering direct from the yard. E is the main entrance eight feet wide and may eontain feed chests ; $e$ is an entry five feet wide, with steps up to door D, and having an entrance into the horse stables at each end. $F$ is the overshot or shed. G is the portion under the hay-house to be utilized in stalls, if the hay is not desired to run elear to the ground; and $\mathrm{H}$ is the yard connected therewith. If neessary this may be roofed over making additional shed room.

\section{Square and Octagonal Barns.}

In the square or octagonal barn the bay is in the eentre, in which a rast compact mass of hay can be kept, and this will run from the basement to the peak. The basement will be used as a stable, and if desired the main floor maty also be so used; modern builders understand perfectly the art of making a floor proof against the leakage of liquids.

One especial advantage in the oetagonal shape for barns, when a large number of cattle are to be fed, is, the roof is easily supported and contains more economy of space for its size than any other form except the circular. In this the hay will be in the center, and the cattle next the wall, faeing inwards. Above the cattle will also be a mow for hay, except such portions as are wanted for granaries, grinding machinery and other conveniences. At the peak may be a windmill of sufficient power to do the pumping of water for the stock, unless it be feasible to conduet water by its own gravity. In this case it may be used for grinding and cutting fodder.

Le. us sce what an octagonal barn sixty feet in diameter will hoid. The width of the stable will be twelve feet, and the feed next the bay six fect, making eighteen feet in all. This running elear around will have a central cre of twenty-four feet, besides the entire area, from the floor ahove the stoek. The stable will be one hundred and eighty fect in circumference, and, allowing three feet, six inches to each steer, will necommodate fifty head of steers, or if cows, a still greater number.

feet wide and fet in fronts 
Below we give the plan of tho duiry barn which will explain itself. We have represented a eistern and also the ineal room, protected by an earth embankment, so it may be used for roots and other feeding material that would be injured by freezing.

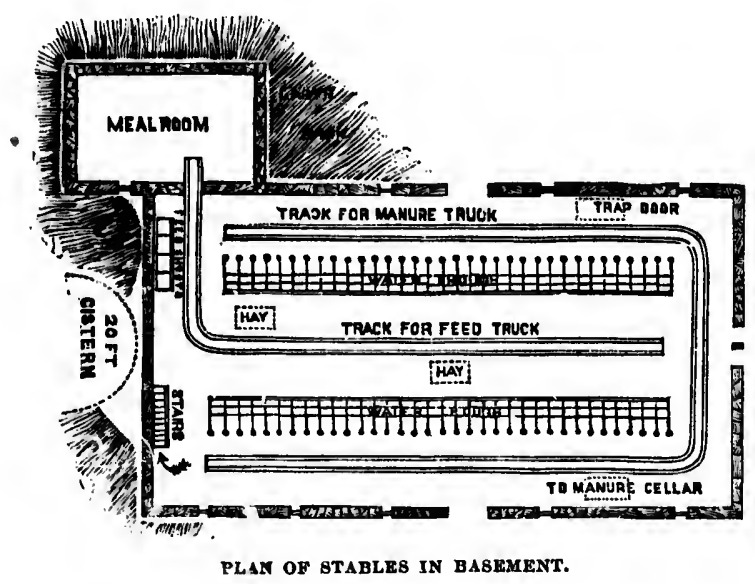

The following diagram will show a compact basement for a Bank Barn for feeding cattle and also accommodating a limited number of horses and milch cows, to be seventy by one hundred feet square.

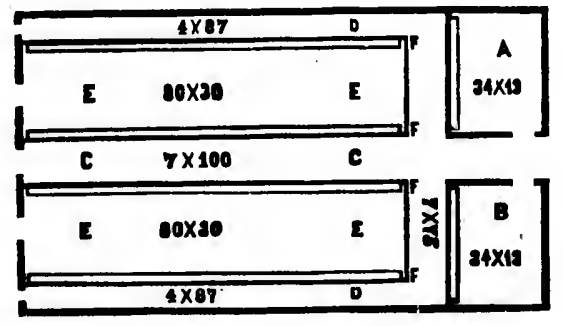

CATtLe-FERDING BABEMKNT.

$A$ is the horse stable with six stalls ; $B$, cow stable for six or eight cows; C C main entry; D D two snall entries, running on eitber side of the 
cattle stables; E E E E are the cattle stables, 80 by 30 feet each; and if the cattle are placed 4 fect apart, will accommodate forty head of steer: for futtening.

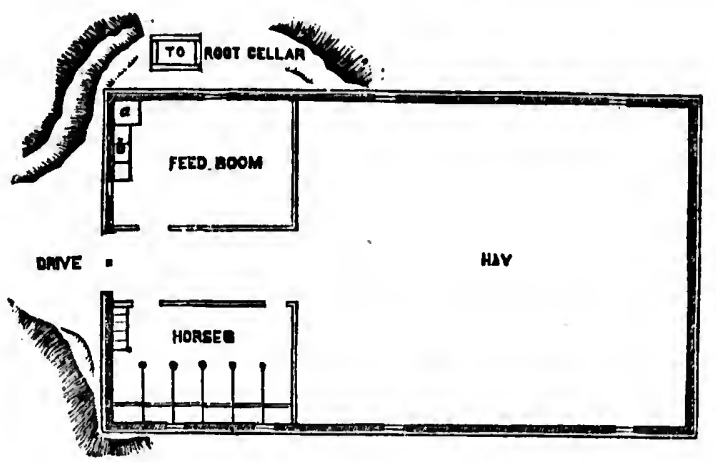

MAIN FLOOK OY DAIRY BARN.

To slow another plan we give a diagram of a dairy barn fifty by one hundred feet. In the plan of the main floor $a$ is a ventilating shaft, and $b$ feed shoots to basement through trap door which will be shown in the plan of the basement.

\section{A Square Cross Barn.}

For a large number of cattle we know of no better form than a square barn for the center, with four wings ruming therefrom, ench 30 feet wide by any desired length. In this arrangenient the cattle might be place with their heads to the wall, leaving a passage-way between each two rows, by which the manure might be taken up and carried away in carts. In some parts of the West cattle-feeding is carried out on an immense seale. Feeders are already beginning to ask, how best they nay build stables to save cost in feeding, and at the same time place the cattle in the best possille position for economical feeding.

A writer in the National Live Stock Journal, under the signature of "Alimentation," gives data for a barn to feed 1,000 hend of eattle. The principal objection to the plan is the concrete wall advised for the basement. In a building of this size and weight, it will be found to be quite unreliahle in the West. The basement should be built of good solid stone, or the best hard burned brick. In lien of this, if concrete must he used, the weight of the building should be on stone piers. The details 
for building the barn are given as follows, the wings being 30 feet wide and 200 feet long :

"This square cross barn will have all its extreme parts equi-distant from the center. It will be the same distance from the quadrangular eenter to the extreme animal in either wing as from the octagonnl center. By doubling the width of the wings, we dispense with eight long sides 200 feet each, or 1,600 feet; and as the ends of the four wings are the same length as the eight wings, the saving in outside wall is 1,600 feet. And if these sides are 20 feet high, und boarded up and down with a twoinch batten, it will tuke 36,933 feet to cover these sides thus dispensed with. It will also save all the ontsicle and interior posts of the four wings dispensed with, as it will require no more posts in a wing 60 fect wide than in one 30 feet wide. This will make a saving of about 22,000 feet; and the outside sills and plates on these long sides will bo saved, amount-

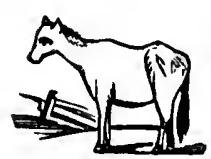
ing to 24,000 fect, besides girths and braces - umounting in all to a saving of 100,000 feet. The

WINTERED WITHOUT DULLTKE. roofs and floors will cover the same number of square fect as in the eight wings, and cost the same.

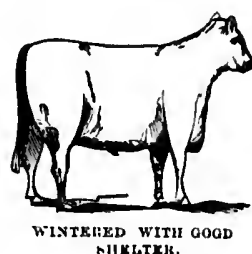

"It would also save 14,400 cubic feet of wall. The whole saving by building the wings 60 feet wide could not be less thin two-fifths of the whole cost of the barn; and the convenience and economy of labor must be even greater than with the eight narrow wings. This square cross barn has the capacity to feed conveniently and comfortably one thousiud head of eattle; and it now remains to notice some of the details of construction.

"The quadrangular center, 60 feet in diameter, may be built with large corner posts, say 14 by 14 inches square, 37 feet long, and the plates and girths of the wing may be framed into these posts; but it probally would be better that the wing should have separate corner-posts, and they be bolted to the posts of the center. 'The quadrangular center should be high enough above the wings to clear the ridge of its roof. This would require the posts of the center building to be 17 or 18 fect longer thin the wing posts, as the ridge of the wing roof should rise at least 17 feet in 60 fect, and come up under the cornice of the center building; as these wings will cost about the same money with posts 20 feet, and the latter height will hold about 40 per cent more, and as this storage room will be wanted for so many animals, it will be better to provide room in abundance, and make the posts twenty fect long. 
"The floor in the wing above the basement will run lengthwise of tho building, and it will be 16 feet wide, so that the posts on either side of the floor, running up to the cross-benm over the floor, may stund on a sill running lengthwise over the basement, and eight feet from the center, supported by the stunchion timbers. These two sills will he strongly supported the whole length by the stanchion posts, placed only 38 inches from center to center, and will consequently hold the whole interior structure above. The bays on ench side of the floor will be 22 feet wide; there will be no loss in so wicle a floor, as the hay may be mowed one or two fect upon ench edge of the floor if more room is desired. There will be 42 bents, the outside posts being about 18 feet 2 inches from center to center. The top of the cross-beams, rumning from side to side of the barn, will bo 13 fect above tho sill, and will be spliced nt the post, or between the posts, on either side of the floor. On three of the bents the cross-beams should be carricd up nearly to the plates, and the posts at the side of the floor must also be cirried up to support the beam. The three bents (every third one) will tio tho barn together, and being so far apart, will not obstruct pitching with a horse-fork. These high beams, besides being pinned to the outside posts should have a stirrup around the post coming back ten inches upon the heam, with a three-eighth inch bolt through the stirrup and the beam, turned up tight with a nut, and if the beams are well spliced in the middle, this will hold the barn firmly from spreading at the plates. Now, to prevent this long wing from rocking or: swaying by a strong broadside wind, these bents with the high beams should have long stiff brace ruming from the foot of the post on the side of the floor to the outside post just under the high beam. Such a long brace on each side will hold the barn rigidly from rocking. And while spenking of braces, let it bo rcmembered that a brace is valuable just in proportion to its length. The ibraces from the outside posts up to the plates show a four-foot run. They will assist rery much in sustaining any weight upon tho plates.

"It is not intended to have any purlins in these wings to support the roof, eren though they be 60 feet wide. The brace on top of the bean will have a run on beam from post of 8 or 9 fect, ruming up the post just under tho plates and fastened by a bolt. This will hold the plates absolutely rigid, and the roof will not spread them. The rafters should not he placed more than two feet apart, and the collar-beans should be 1 1-4 by 5 inches, and placed six feet below the ridge, with every other puir of rufters donble collar-benmed; that is, with a collar-beam nailed upon each side of the rafters. This will make a strong shingle roof. The collarbeanss will be some 20 feet long, and will be about as good a support to the roof as purlin-beams. The collar-beams should be as high as the 
barn would be likely to bo filled, so thint no room will be lost, and the burn will be prenctically free from obstruction to pitching with u horse-fork.

"In the bents, where the cross-bemns me rised nearly to the plates, there must be a heam framed into the posts on ench side of the floor, 18 feet nbove the sills, to correspond with the other beams over the floor, upon which scuffolding min be placed for using tho room over the floo:" It remains only to be mentioned that the interior sills aro four cross-sill , 40 feet npart, to tie the bun together at the bottom, mul two sills rumin;" lengthwise, one on each side of the flool-thit is, the centre of each of these long sills is placed 8 feet from the centre of the barn. The joists for the bays will run from these long sills on each side of the floor to the outside sill-allout 21 fect. Each of these long sills come over a row of stanchion timbers in the basement below."

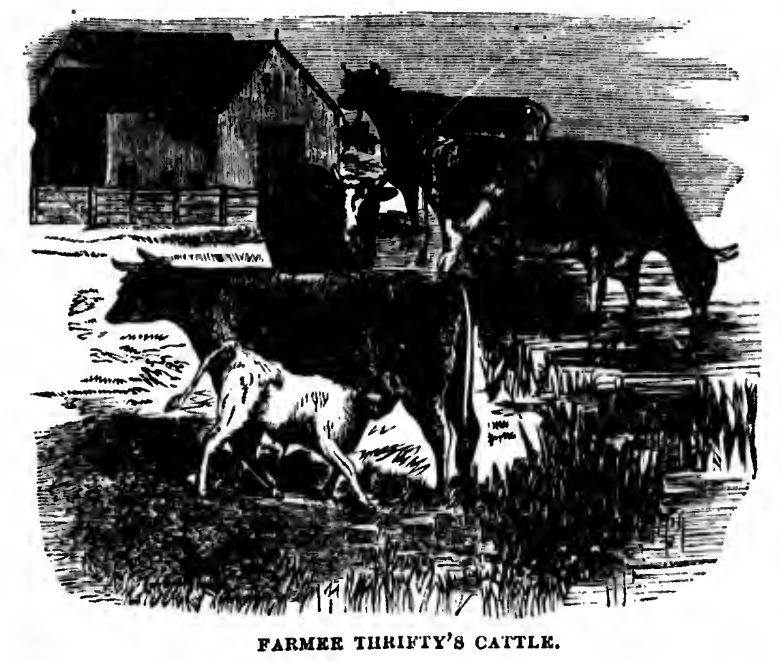

The reader will see that these wings above the basement are built in the simplest mumer, using no surplus material, and as cheap as my lie consistent with strength and durability.

\section{Basements for Cattle.}

"We will now examine the construction of the basements of these iong wings. The wall under ench of these wings, if built of concrete, 15 inches thick at botton, 12 inches at the top and eight feet ligh, being 460 feet long, would contuin 4,140 cubic feet, und could be built in most

plentyc crete bi so is to air shou bunneds through conerete ten feet to the in 
places for 10 eents per culie foot, or $\$ 414$ per wing. The wull under the center would be 1,440 cubic feet, and cost $\$ 114$. The wull under the entire squure cross bitri would cost $\$ 1800$. The long sides would require something to stiffen the wall sidewise; lut a pier built ngainst the wall on the inside would be in the way, nnd on the outsicle would look un:ightly; so to nroid the necessity of such piers, let a $T$ be mude of strong iron, sily threc-fourths by two inches. The long end of the $T$ would bo abont 20 inches, and built into tho wall, and the cross lie across the top of the wall directly under the sill. The end of the $T$ should project beyoud the sill on each side far enough to huve a threc-quarter incle holo punched, into which to insert a piece of the sume flat iron, six indes long, rounded at ono cnd. This will nttach the wull to the sill. There shoult bo four of theso $T$ 's for each side-one neur each cross sill 40 fect "lutt. This will hold the whole will to the benm, and prevent iny swiving.y. These long sides will give room for inserting

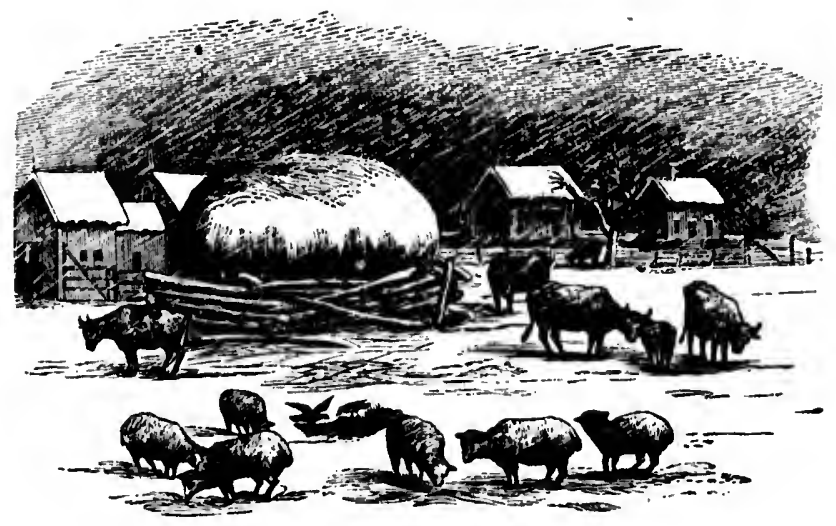

FARM KR SLACK'S BIIELTER.

are built in bas may lo

plenty of windows for light, the frames being into the boxes, and the concrete built over them. The sash may be hung on a pivot in the centre, so as to open easily to give ventilation at certuin seasons; but the fresh air should be introdnced throngh the wall near the bottom, through hard burned earthen or pottery pipes, 1 -inch bore, just long enough to reach through the will. These pipes may be laid in the boxes, bedded in the conerete, and the eoncrete timped down upon them. They may be pliced ten feet anpart, and will not weaken the will. Close covers may be fitted to the inside, so as to shut them out at will; and with proper ventilators

of these iong concrete, 15 high, being built in most 
to dischurge the heated and vitated air through the upper part of the barn, there will he a constant circulation of fresh air through the lasement.

One other point must be mentioned in reference to the wall. A concete wall contains a lurge muount of moisture, and if the sills are to he pluced on before the wall becomes quite dry, which is usunlly the ense, the moisture will pass up into the green timber of the sill, form a coiting of lume on it, and prevent the sup from esenping, and the result is a rapid decaly of the timber. To prevent this, take well-seasoned pino boards, 12 inches wide, cont one side with gas tur, and bed this tarred side in the mortur on top of the wull. The sills aro laid on this leveled bourd, nud no moisture can come through this board into the sill to rot it.

\section{Arranging the Basement.}

These long stables must be laid out so as to render the labor as courenient as possible. There must be easy access to every animal in the stable, and this becomes more important when one thousand cattle are to be provided for. Cattle are most easily attended when pliteed in double rows with their heads turned towards one feeding floor.

It the long basement, the first row of stamehion posts will he placed seven feet from the first wall, on the side of the first feeding floor, 14 feet wide. On the other side of the feeding floor is the second row of stanchion posts, coming up under one of the long sills, as described before. Two and onc-half feet being occupied by mangers on ench side of this Hoor, will leave nine feet for a drive-way. Along this flo' 'nay pass a cart or wagon, with green food in Summer, or fodder it er. The third row of stunchion posts will be 16 feet from the linst, un the second long sill, on the side of the second feeding floor; and the fourth row will be fourteen feet from the third, on the other side of the second feeding floor, and seven feet from the other wall. Here two rows of cattle stind, with their. tails to the walls, and the two middle rows stund tail to tail, facing upon opposito floors. The largest animals chould be placed in middle rows, as there is the most room. These stunchion posts are placed 3 feet 2 inches from center to center, und tho cattle nre best fastened to the center of a chain stretching from staple to staple driven iuto each stanchion post. These chains slide up and down on staples. The mangers may be placed 20 inches from the ground, and, with long staples, the cattle may lio down comfortably. One of the liest ways to feed cuttle, with plenty of bedding and nuck for deodorizing, is to let thens stand three or four months on tan manure, and, the mangers being plaeed high. the manure may accumulate two feet deep under them, and they may keep quiet clean, with the bedding and muck, and the manure 
he barn, nent.

concreto be placed cuse, tho costing of is a rapid 10 hoards, side in the board, and

as eourena tho stable, e to be prodouble rows

ll be placed ing floor, 14 eond row of lescribed beeach side of is flo' 'uny i) er. st, Uise tho ad the fourth ff the second two rows of c rows stand lis should he anchion posts attle are best staple driven n on staples. nd, with long best ways to ing, is to let natugers being der them, and d the maure will be trodden so hard as to ferment very hittle. Whon a lot of entele are sold, then wigons may be lriven through to carry off numure, I lane seen cattle fed in this munner, carded duily, and kept quito clenn, stimding on their munure for four months.

Theso feeding floors, ns described, stretch through the whole length of the barn. A feeding cur passes through two wings, mol, having a turntalhe, mity pass through any wing. Feed miny be dropped through a chute on the side of the upper floos into the enr wherever pluced on uny feeding floor. This fom of burn gives every fucility for exttung und conking the food-a larger engine, placed in tho conter, eutting, grinding and cooking all the food; und this also offers tho best fucility for soiling three thousind head in Summer, if such should he necessury. In the West, hewever, where only the feeding of such largo numbers of cuttle would be probitable, soiling is out of tho question.

\section{Adapting Means to the Find.}

Lo person ean possibly know so well what mn individunl wants as limself, if ho be a reflecting mun. The urchitect scureely ever gives attention to the planning of bilus. The best barns in a country ure those of intelligent farmer's who have curefully observed tho conveniences of various kinds in the barns of then friends in the localities visited, and who when in building their own raried them to suit their own wants. For this reason wo have simply given outlines of those illustrated with descriptions of others ndnpted to varions mumbers of enttle. See plp. 588, 590, 591. To givo tho eost would be a waste of space that may be better employed. This will vary with locality and tho price of miterial, and any mastrer capenter or mason will quickly estmate them. As a rule, the diborite and well furnished structure is not the most convement our, but those which lave the greatest number of permunent convenjunces, and in which the space is most thoroughly economized. Hence within the last few years, or since the greneral introduction of improved machnery, farm barns have undergono a complete change in the mumer of consiruction.

Formorly birns were comparatively low struetures where everything had to he dono by manual labor ; it wis not economy to pile up laty, grain, or other firm produce, story after story; the labor of lifting, or cirrying did not pay. Since the invention of hostiug machines and hay carriers, the invention of modern windmills, grinding mills, horso powers and other labor-siving machinery, twenty-five feet posts are not unuscal, and no barn shonld be built of less than two stories. The gain thes secured is abindantly worth what it costs. 
There are few farms where the drainage is so poor or the land so level but that a declivity sufficient for a basement harn may be had, by throwing the excavated portion up to assist in forming the trackway or rise to the main floor. Windmills are now so nearly automatic in their working that they may very safely be trusted to pretty much tako care of themselves. Therefore, in all the more pretentious farm barns, they should be built with special reference to the erection of a windmill on top. This may be used for a variety of purposes, cutting fodder, griuding grain, pumping water, being its principal work. If tho water is collected in a reservoir in the center of the mow it will not freeze, and the pressure will always he equal, and thus the water may be carried in pipes any distance, to the house or the duiry, and become a most valuable economy.

In the building of barns of superior size we have given descriptions of all but the circular barn, which can hardly be called a practical or economical structure, and the octngon barns will come under the same category ; for while economical in respect to space, they aro more eostly to build, if for no other reason than that they are unusual. We thercfore recommend the square harn in every case when the width is to be forty or more feet, with not less than twenty fect posts. This, with the the basement, will give two or three stories as necessity may require. The basement of course will be used for the stables, and if additional room be needed one or two wings may be added, and when farther space is needed two more. The diagrams showing the internal arrangements may easily be obtained to suit such a structure while pursuing the general features of economical and labor-saving utility.

\section{Summer \$helter.}

While the question of Winter shelter is of the first imporiance, it is necessary that Summer shelter be provided, and also for protection :gainst the inclement storms of Spring after stock has been put ulion pasture. During the feeding senson the sheds and barus will suffice; hefore pastures are flush the Winter sholter cun be utilized, for some food must he given night nnd morning. During the prevalence of storms the stock will of conrse be kept up und fed. Later, however, it will not be found practicable. What is wanted is a range where stock may not only be secure froun the winds of driving storms, but where they may retire for shelter during the extreme heat of Summer days.

We do not believe in shnded pastures. They are poetic but not practical. The object in keeping stock is to make them cat as much as possible. The pasture should be devoted to grnss. If shaded by single trees here and there, stock will very often haunt these when they should be 
ad so level by throwor rise to ir working c of themthey should ill on top. re, grinding $r$ is collected $z e$, and the ried in pipes ost valuable

escriptions of practical or der the same more costly We thereIth is to be Chis, with the may require. $\mathrm{d}$ if additional farther space arrangements ng the general

porianee, it is for protection been put upon as will suftice; for somo food of storms the it will not be may not only they mity retire

c but not pracmuch as possiby single trees they should be feeding. While in motion in the act of grizing they do not suffer from leat. Therefore it is better that they be obliged to do some travel to rench the shade, and this shade if natural will generally have water near. If not, the artificial shate should be given at such places where water may be had from mills or ponds most cheaply.

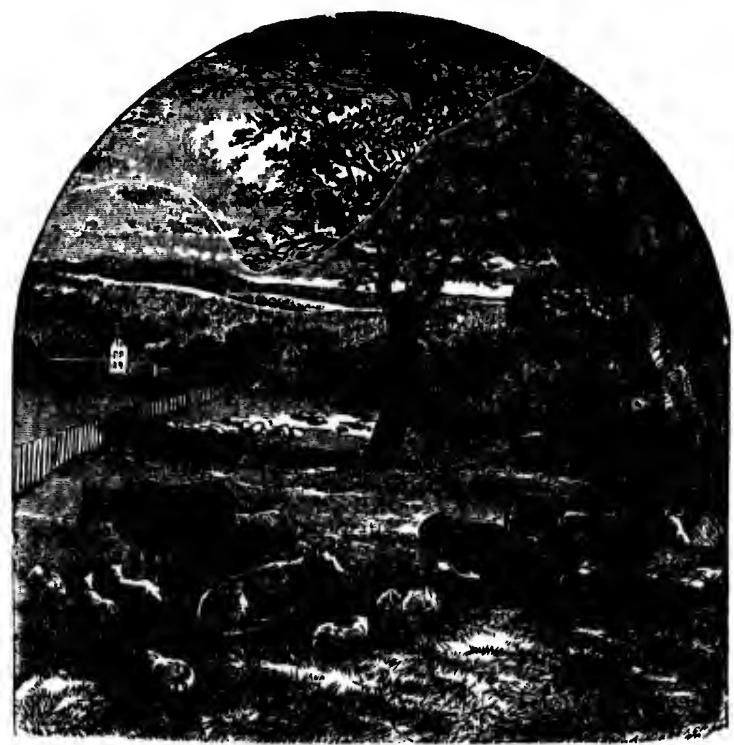

a Pastohal scene.

The accompanymg cut will show how this artificial shelter is accomplished both by isolated trees in the pisture and hy clumps and groves in the distanee. As previously stuted, tho single trees wo condemn, and they have been introduced to illustrite the point, and at the same time give effect to a most pleasant pastoral scene, and which any farmer may oltain in a gently undulating country.

\section{Where to Plant Shelter.}

This shelter should be planted along the crest of ridges, ahout gullies and ravines, and in fact whererer tho soil is not adapted to cultiration. These points will be especially sought during the hent of Summer, and the timber will crentually more thin pity the cost of plinting in any prairie country. Ai: high points are gcherally free to a great extent from biting insects. The ravines will nfford sheiter from winds and driving 
stor ms, and also will be vuluable as places where permanent water may be hnd either naturally or artiticially by druning. In lieu of this plant shelter belts and groves near the low places where water may be had, or neur natural water holes on the farm.

What to Plant.

For dry soil, anywhere south of 42 degrecs, the Catalpa (Speci osa) will be found hardy. The vuriety Big nonioides is not hardy in the West north of about 38 degrees. Blnek walnut is valuable, so are all the maples, the eotton-wood does well almost mywhere, and if care is taken to proeure cuttings of the male variety, (this tree bears male and female flowers on separate trees), you will have no trouble with the blowing about of the cotton during seeding time. Evergreens may be planted almost anywhere if the soll be moderately dry. The Norway spruce is most valuable, and next to this the white pine. For low lands, cottonwood, the soft maples, and the white, the black and the golden willow will be indicated. Thus the furmer will find that this question of shelter, while one of the most important of the many conuected witlı firm economy - the points relating to Summer shelter - will in the end prove one of the best paying investments in a prairio country of any in the whole category. 


\title{
CHAPTER V.
}

\author{
HOW TO PASTURE, FEED AND WATER.
}

\begin{abstract}
LBOUT PASTURAGR. -CLOVERS THAT DO WELL. - UNDESIRARLE CLOVERB. - ALFALFA.

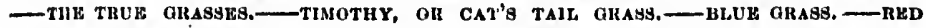

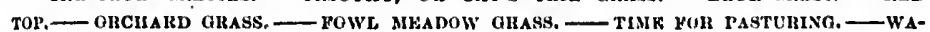

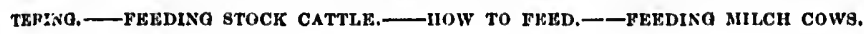

\section{About Pasturage.}

The subject of pasture and meadow is one of the most important with which the farmor has to deal. It mukes feed in Summer and forage in Winter. Yet, in the United States, nearly all our meadows consist of one clover and one grass; in other words, timothy and elover are our great meadow plants, and the addition of blue grinss to this forms the inlk of our pasturage, always excepting, of course, the vast arens of wild grasses that still cover the great prairies and vast plains of the West, yet to be brought into cultivation by man.

Until within the last few years, or until the dniry interest began to nssume such gigantic proportions, farmers got ulong well enough with these; for, where stock rilising for beef is the sole object, and wild grasses are plenty and gruin easily rnised, and consequently (heap, a very few grisses will suffice; but the inpetus gyiven to dairying within the last few years, has fiirly shown that the best results, nay, that even fair sucress eamot he had with a few grasses. This the dairymen in New York State eame to understand years ago, and yet so little was known of the adiptahility of varieties to soils and climate, that our best farmers workal blinlly in experimenting, and unfortumately, our botanists could do little more than furnish long strings of mere elassienl names of varieties as they were known in hooks, und could give almost no information as to their adiptability. 
Practically, the clovers are confined to three species. First, red elover, natural to all soils that are adapted to the cereal crops, as wheat, rye, barley, oats and corn, or such rich soils as do not heave under the frosts of Winter and Spring. If so, elover is apt to be thrown out, or at least to be so heaved as to be practically worthless, especially so from the fast that it is really a biennial plant ; that is, dying out at the end of the seeond year if allowed to seed.

The next clover in general use is Dutch, or white clover. This does well on soils somewhat moist, although it will not stand flooding. It is not especially relished by cattle, and at some seasons is apt. to give horses what is termed the slobbers; that is, it causes them to form saliva to sueh a degree that it drops from the mouth freely. Cattle do not relish it, and it can hardly be called good feed for horses. A sumall portion of it in a permanent pasture does not come amiss, yet it is so natural to miny soils that, like the plantain, which the Indiuns have termed the white man's foot, white clover they have called the white min's grass.

The only other variety of clover that we can recommend for cultivation, is Alsike, sometimes called Swedish clover. This does well on moist land, and even bears some flooding. We consider it the next in valus ro red clover, and altogether better pasture than white clover. It also makes good hay on soils too wet for red elover.

\section{Undesirable Clovers.}

There are a number of other species of elover, some of them indigenous to the West, which we only mention as a caution nganst their being sown. These are; two species of so called Buffulo elover; the upright and the running Buffalo clovers; the upright or yellow clover; and the low hop elover, a half-creeping variety. There is only one more variety worth mentioning, and this simply as a warning to farmers not to sow it, except for bee pasturage, and then only when it may not become a troublesome weed. We have reference to the tree elover or Bokhara elover, specifieally the white-flowered melilotus. It has been recommended as valuable for soiling; that is, for cutting green for feeding to stoc's in stahles. We give the same udvice about sowing this elover that the erabbed lawyer did to a young client who asked his advice about getting married-Don't.

\section{Alfalfa.}

The case is different with alfalfa, the Spanish name for a plant kmown botanically as medicago, and, in English by its French name Luzerne
This

freer

foring

be $f(1$

Amel

and $\mathrm{i}$

it, sil

It is

the fe

tant o

less th

barley

It w

and the

Our re:

import:

of thei

hay, an

The fi

describi

known i

lot too

it is amo

is that jo

as horse:

will not

This is

ties, $\mathrm{K}_{\text {in }}$ north latio Ifinnesot: it is ealled remains $\mathrm{g}$ grasses.

Blue g1 
This is valuable in soils adaptrd to it, deep dry soils not sulject to hard frezing in Winter. In Calnornia it has beeome one of the standard forage erops. In some of the far west plains country it will undoulotedly be found to stand well, as it will in Texas and New Mexico. In South Ameriea, in the vast grazing region, it has become thoroughly naturalized, and is well worthy of trial wherever the Winters will not be too cold for it, say south of forty degrees north latitude.

\section{The True Grasses.}

It is to these that we must really look for our pasture plants, outside the few elovers we have mentioned. It is a vast, as it is the most important of plants to man, comprising some 230 botanical genera, and not less tham 3,000 speeies, and includes all our cereal grains, as wheat, rye, birley, oats, corn, etc.

lt would not be in pliace in this work to enter into a history of grass. and the characteristies of the several species, viluable as they may he. Our readers must therefore be content with a list of some of the more important vurieties, as they have been tried, and their seasons, and some of their characteristics; and this more for their value as pasture than hay, and for reasons previously given.

\section{Timọthy, or Cat's Tail Grass.}

The first in importance is timothy; a better nime, as more perfectly describing its characteristies, would be eats-tail grass, by which it is kuown in England. It does well in all elnyey or clay loam soils that are not too wet, and makes the best hay of any of oul grasses. For pusture it is among the least valuable, if we except cattle, sinee one peculiarity is that just at the ground it forms a bulb, which if bitten in close grazing, as horses, sheep and hogs are apt to do, it dies. It is also a grass that will not bear hard tramping.

\section{Bluo Grass.}

This is the great pasture grass of the Western States, in its two varicties, Kantueky blue griss, which flourishes hest south of forty degrees north latitude, and wire grass, which is found well $u$ into Wiscomsin and limesota. Here again is confusion of common names. In Penusylvania it is called green grass, and this is really a suggestive name. It really remains green early and late, longer thin any other of our cultivated grasses.

Blue grass forms a tough, firm sward, springing early in the Spring, 
growing late in the Fall, and holding its substance well in the Wiuter. So thit after being patstured in Spring if nllowed to grow on through the Summer and Autumn, cittle and other stock nity be wintered on it udmirably, when deep snow does not cover the ground. Both varieties are found in their best perfection in linestone soils, although they do well according to latitude on all strong, rich, and even on some rather thin soils if well dinined. Neither variety is adnpted to wet soils. It cannot be ealled a hay grass, its great value being for pasturage.

\section{Red-Top.}

The next grass in importance, beeause found to do well on a great variety of soils, is red-top. It mukes good hay and is valuable for pasturage. It should be more genemlly cultivuted then it is, being idapted to a very considerable range of soils, neither very wet nor very dry. As before stated, in Pemnsylvania this is called herd's grass, and we may add in Rhode Island it is known as Burden's grnss. While red-tip hiss a goodly range of soils to which it adapts itself firiry, it does best on a rather moist soil, flowering rather late, or ubout the same time or later than timothy. It dries out considerably in curing into luy, and is not very rich in sugar, gum or stureh, three important elements in feeding. It is a strictly perennial speeies, and forms a pretty dense sod, when well established.

\section{Orchard Grass.}

This is really one of the most valuable grasses for extensive trial us a first-class pasture griss in the whole list of enltivated griasses. The wonder is that a grass so generally regarded as excellent in Europe, should have made its way so tardily in this grass country. This is probally: from its habit of growing in tufts where sown thinly. It is one of the earliest of the grasses to stint in the Spring, is strictly a peremial, starts freely after being grazed or mown, and if sown thickly makes excelleut hiy. It thrives better than most of the grisses in a partial shade, and hence its common name, orchard grass.

For pasture it should be sown at the rate of not less than two bushels of seed per acre,--three bushels is better. It is very light, weighing only fourteen pounds per bushel. When sown for huy we have had excellent success by seeding at the rate of sixteen pounds of orehard grass, and ten pounds of elover per acre. It is excellently adapted to sowing with red clover, since it blossoms more nearly with clover thin almost any other of the grasses. 


\section{Fowl Meadow Grass.}

This is another most valuuble grass, considered especinlly so for hny, and to our mind quite valuable for pasturage, purticulurly for dairy stoek. Like pritirie hay it is quite free from dust, and at the sume time it possesses all the essential elements of nutrition in a high degree. In all new countries the first dependenee must be on the wild grasses. The real diffieulty is, farmers do not undertake the cultivated grasses until forced to. If a trial of the important vurieties here noticed shall lead to the testing of still other sorts, the time will soon come when our farmers will wonder how they could have gone on so long without appreciating at their true value many varieties, that the ain and scope of this work precludes even the mention.

\section{Time for Pssturing.}

It is important that eattle be not only fully fed but that they huve their feed at regular intervals. Where stock are driven to and from pasture they should be turned on soon after dnylight in the morning, and not taken ont until sundown. It is especinlly necessnry that they get the grriss while yet it is covered with dew. So, where stock are kept and fed in stables, the tirst feed should be given early in the morning, just what they will eat cle:m. This should be supplied not less than three times a day ; and at night, to insure full stomachs, somo extra feed as meal, shorts, ete., should he added.

Salt should be kept where the animals can get it at will. They will thus get enough for their wants, and just as they want it, und will ent less than where supplied nt the stables, or out-of-doors, at irregular tines. Irregular feeding of salt is one of the worst possible practices. Salt is " cothartio when given in large doses, and this danger should be avoided.

In Winter, whether the animals nre kept in stables, in sheds, in feedingyarde or in the shelter of groves, the same regularity of feeding should he observed. Stock should also be graded, if possible, so there will be no very strong and very wenk ones together. And those of a given nge should be fed together. Where animals are fed in groves or in fields a much larger, and, in fact, more irregialar drove, as to age and strength, mily be kept together, than under open sheds or in close feeding-yards. Feed early always, as soon after daylight as the animals can see to feed, and let the last mess at night he given so as to be well finished just before dark. When fed in stables the snme rule should he observerl. Eurly and lnte feeding of good fodder, and in such quantities as they will ent tolerably clean, is what keeps growing animals going right along. This 
is what the wise feeder secks, for thus he secures the best possible gain, with the least loss in daily natural wuste of the physical system.

\section{Watering.}

Whether it be Winter or Summer, it is absolutely necessary that cattle have an abundance of water. Without this, given at regular times, there ean be no protit to the feeder. Cattle may be driven to it twice a dily, if the eonditions are such that they cunnot be fed in the same range where the water lies. When eattle aro kept in stubles, it is altogrether better that the water be conducted there in pipes so as to run directly into their drinking troughs. It will be found ehenpest in the end. If there is no living water, do not depend upon holes eut in the iee of ponds. It is not only dangerous to the enttle, but will cost more in the end than any other plun of watering. If the water is to be taken from wells, or ponds, erect a good windmill, with suitable tanks, with pipes so they will not freeze, leading to ample troughs. Let these bo in the yards where the stock tuke their rest, or else in the feeding runge. Then see that they have plenty of it, und plenty of salt where they can lick it at will. If the cattle are to be fed out-of-doors on ear eorn and hay, see that proper troughs are provided for corn and rucks' for huy ; let them be large and ample. Where this is done, close yards should be provided with warm shelter and water.

\section{Feeding Stoek Cattle.}

In wintering stock eattle the main dependence will be hay or corn fodder. These, if good, are perfect food, that is fed together, or hay fed alone will keep cuttle growing, if they do not suffer from the cold. In feeding the same rule should be adopted as in fattening cattle. See that they are not given enough to waste, but do not force them to eat rough, coarse, stalky or weedy hay elean. No unimal ever did well oul food it did not like. To make money in growing cattle they must not go hungry Winter or Summer. If the fodder is prairio hay see that the best and softest is reserved for the calves, and next hest for the cows. The oxen and steers will do fairly well on hay somewhat coarser.

\section{How to Feed.}

Calves should have some grain daily ; oats are best, one quart each, or the equivalent in other grain. Cows expected to calve the succeding Spring, should have from four to six cars of eorn daily, or its equivalent in some other grain; and oxen when not working, about the same. 
When working, give the sume ns to $n$ fattening steer, or about a half bushel a dny.

Cattle intended for futtening the succeeding ycar should have especial care the previous Winter. They should have feed enough to keep them growing right along, sny about lanlf the qunntity of grain given to futten- ing steers, that is, allowing the feeders do not helieve in forcing the mimul from calfhood constuntly, until realy for the butcher. The best and most suceessful feeders do forre, and none that we know who have over tried it could ever bo induced to go back to the old way of letting stoek mako a gain in Summer, to lose half or more of it in Winter.

\section{Feeding Milch Cows.}

Whatever the plan of feeding or sheltering cattle for the butcher-of course, fattening cattlo will have more attention given them, so far as food, water, and shelter are concerned-nileh eows must have soft food. No dirymun ever male any money by feeding cows in milk on dry hay, ear corn, or diy grrin ; for cows it must be ground.

In feeding, the owner will, of course, be guided by the relitive value of food in the market. If possible, a little ground oil-wike should form a daily portion, ahout half a pound per cow. In all the West, corn-meal is the cheapest food, exeept in the neighhorhood of large merchant flouring mills. One great difficulty with corn-meal is it is henting. It should be fel almost mensure for measure with bran; ten pounds of this with the addition of half a pound of ground oil-cake, with plenty of good hay, will be liberal feeding. If the cow will eat fifteen pounds of menl and bran, it will be wise economy to give it to her. She will not ent so much hay, and in a corn country hay is dearer than corn, and as a rule an acre of corn is raised fully as cheap as an acre of hay.

hay or corn etlier, or hay on the cold. cattle. See tinenı to eat - did well oll - must not go sec that the or the cows. itser.

fuart cach, or te succeeding jts equivalent ut the same.

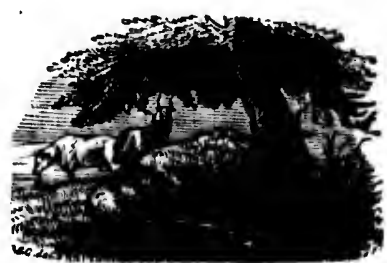




\begin{abstract}
FERDING FOR PROFIT, — AS BETWGEN WELL AND ILL KEPT STOCK.—-IIEAVY WEIGHTS. PROHIT IN RARLY MATURITY.—-MAKL BEHY YOUNG.-DABY BEEF.—- FELDING; COST IN KNGLAND. - SUMMER FEEDING. - - ANIMAL WASTE. - ANHMA HEAT. - ADVAY. TAGES OY SUMMER AND WINTER FEEDING.
\end{abstract}

\section{Feeding for Proflt.}

It should require no argument to show the benefits of kind and considerate trentment in the rearing of live stock of any kind, and in the treatment after they beeomo mature. One reason why so many persons fail to be successful in fattening stock is that they do not use due eonsideration in their treatment. The man who kicks and clubs his stock, or allows his hired help to do so, never yet produced a prize steer, and never will. Obesity und aetivity do not go together, neither will undue excitability allow of a steady inerease in fat. Hence the feeder, for the sake of his poeket, should seo that fattening enttlo aro.kept entirely quiet. To insure this the sagacious breeder avoids not only eattle naturally irritable, but thoso raised by persons of known bad or brutal temper. We have kuown a stablo of eattle thrown off their foed for days by a sudden fright. Those frights are quite apt to occur from the slightest causes. Where strange cattle, ruised half wild, are confined together-and this is not rare among stock that have been pieked up indiscriminately, and what are known as woods or prairio cattle-the first effort of the sagacious feeder is to get the confidence of the stock. This is only accomplished by gentleness, not by any means ineonsistent with firmness. The cattle must know and obey their master. Their knowledge of him must be that they receive food and kind treatment at his hands, and not stabs with the for
wit
mal
licl mus

As

stoch

are $n$

perfe

cerne

chen!)

most

and ec

bis st:

regula

sleets

slelter

The

be gent

stecis i

the reas

weight

His stee

nerer f:

1300 to

does not

off of $g^{\prime}$

half cent

for the $b$

or $\$ 27$ to

of our w

than the

and $\$ 8 \mathrm{i}$

the enlian

put on be

bare parti

daily anin

ducert exe

jected to

of sufficien 
fork, nor bentings with tho handle, or kicks, hecause they happen to stmud within rench of some brutul feeder. The inference is that the humme man is apt to have humano help; the brutal stock mun will hinve brutal help, and the stock will be very upt to partake of the character of their master.

\section{As botwoen well and ill-kept Stock.}

Aside from some wenlthy professionul men, having suburban farms, stock is kept solely for the profit it will bring. The stock of amateurs are not only earefully housed and fed, but they are kept at the leight of perfection, so far as costly appointments and careful grooming is concerned. The prictical mun arrives at the same results in u different and cheaper way, hut none tho less certuinly. His shelters may be of the most homely kind, even mude with poles and slough hay, but are wirm and eomfortable. Ho camot afford iron mangers and water pipes through his stables, but his troughs me tight and solidly built, and his animals are regularly fed and watered. He will not have blankets in winter and sheets in summer, but his animmls will be well and carefully fed, and sheltered from the earliest age until ready for sale.

The humate man will get ten dollars more for a eow beenuse she will be gentle and well trained to give down her milk without resistmee. His steers will bring from one to two cents per pound extrn in market, for the reison that the constant care given them will have resulted in extrin weight and condition. Let us see what two eents per pound anounts to. llis stcer of a given age, sny three years, is fed from birth so that it has nerer fallen in condition, but has eonstantly gained, and will weigh from 1300 to 1600 pounds, nceording to the breed. The steer of the mun who does not believe in feeding nor properly treating his mimals, will weigh off of gratss 900 or 1000 pounds. The good feeder will get five-nnd-athalf eents per pound gross weight, or $\$ 71.50$ for the $1300 \mathrm{lb}$. steer, und $\$ 88$ for the heavier one. The poor feeder will get, say three cents per pound, or $\$ 27$ to $\$ 30$. One muy see this every day of the year at the stock-ynrds of our western cities. It does not eost $\$ 20$ more to make the good steer than the poor one; so the enhanced profits are nearly $\$ 25$ in the one rense and $\$ 18$ in the other; in other words, the grood and humane feeder gets the enhanced price on the poor feeder's 1000 pounds, and on what he hat: put on besides by his considerate eare and constant good feeding. We hare partially shown this in unother part of the work, in alluding to the daily animal waste. That is an integer. This animal waste may be pro- • dueed exessively, whatever the system of feeding, if animals are subjected to frights and bruises, as well as by exposure to storms and lack of sufficient food. 


\section{Heavy Weights.}

- Until the inauguration of the Chiengo Fat Stoek Show, under the auspices of the Bourd of Agriculture of Illinoss, very little reliuble duti could be hud as to gain in feeding unimnls of various nges. It wis well understood, however, that the young unimul gained fuster in proportion to the amount of food consumed, thm the mature animul, and thit the older and futter the animal becmue, the less the duily gnin. As showing actual fucts we append the stutements of exhibitors, sworn to in some of the more important elasses shown there, and the reports of committee thereon :

"Among the henry cuttle were the following, and credited to weigh, ns taken from the pasture and feeding yurds, ns follows: The steer Gor. Morton, 3,190 liss; Burnside, 2,870 ; Hoosier Boy, 2,640; Nels. Mlorris, 2,840 pounds. The following are the actual. weights us given by the committee, on animals 1 year to 4 yeurs old :

Messrs. Graves \& Co., one steer 4 years old, 2,445; one steer 3 years old, 2,060 .

A. F. Moore, one steer 2 yenrs old, 1,786.

J. D. Gillett, ono steer 3 yenr's old, 2,139.

Wing \& Thompson, one steer, 4 years old, 2,240; one steer 4 yeurs old, 2,166; one cow, 1,525; one eow, 1,610.

John B. Sherman, one steer 3 years old, 2,019 .

J. N. Brown's Sons, one stecr 2 years old, 1,446; one stecr 2 yeurs old, 1,449; one steer 2 years old, 1,636 ; one steer 2 yen's old, 1,31l; one steer 2 years old, 1,246; one steer 1 year old, 1,338; one steer 1 year old, 1,24? ; one steer 1 yenr old, 1,193.

Dexter Curtis, one cow, 1,833 ; one cow, 2,042 ; one cow, 1,936."

In this, of the interesting facts shown, is the great weight uttined ly one, two and three-yenr-old steers, as well as the great ultimate weiglits attained by maturo oxen, viz. : Best one-yenr-old, weight 1,338 pounds; best two-year-old, weight 1,786 pounds; best three-year-old, 2,1:i9 pounds; and the henviest 3,190 pounds. The crueinl test in erery examination being simply the value of the animal for the butcher. The - recerds given below will repay the study, nnd the reports of the collmittees, as given, will show the points upon which the several decisions lave been made:

The conmittee on Short-IIorn steers, 4 years old and . following report on ages, weights, and gains per dav. an I which are appended: 
CLAS8 A-CATTLE. SHORT-nONNG-THOROUGHBREDS.

[TABLE 1].

cr the

le dititi

Ils well

portion

bat the

showilig

some of

mumittoce

weigh, us

cer fior.

s. Inomis, is by the

er 3 yenrs

er 4 years

cer 2 yents

old , 1,316;

me steer 1

$1,936 . "$

nttained by inte wrights

338 pounds;

-olil, 2,1.29

st in erery

tehere. The

of the colm-

lecisions lave

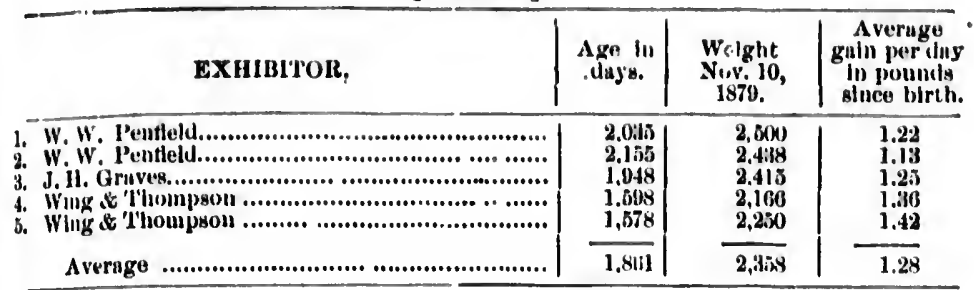

The committee in their report on this ring say :

The ring wiss mude up of u remurkubly fine bunch of well-developed deurs; ull wero uniformly fut, with flesh well distributed in the most valuable portions of the curcuss.

The animuls reflected grent credit upon the States in which they were fed, nimoly : Olsio, Kentucky, and Illinois.

The first-premium steer whs dee pred in eolor, smooth and even throughout, with stringht top and bottom lines; broncl, deep loin, well filled out; romad, smooth, compract bnrel; short in leg, with tino bone and smull hend.

This steer excelled the others in the ring in having more good flesh on the lack and loin, with a small portion of cheap, unsaluble fut ment, with sfunire, decp, symmetrical quarters, well covered down to the knce and gambrel joint.

'The second-premimu steer was a deep red steer of superion quality, mnd in choice rondition for the block, and, in the main, as gool as the firstpremium steer, but was not as frec from bunches of fit, especiully on the rinus).

The remuning steers in tho ring, while worthy of special commendation, rare coilseser and older thim the prize-winners, and not as well filled out in the shonlder nnd thigh, und were pontehed.

The first-premium steer was the youngest in the ring, and showed tho langest avernge gain por day since birth.

The sreond-prenium steer stood second in this respect.

SHORT-HORSG-THOROUGHBREDS. COWS TIIREY YFARS OR OVFR. REPORT OP COMMITTEE.

The ring consisted of eight cows of unusual exeellenee as a lot, showing great difference, however, in the matter of age, type, form and mode of . baudling.

The aged animals were uneven, and carried too large n portion of meat of inferior quality; too gross ; somo were very badly patched. 
[I'ABLE 2].

\begin{tabular}{|c|c|c|c|c|}
\hline No. & EXIIIBITOR. & $\begin{array}{c}\text { Age In } \\
\text { duys. }\end{array}$ & $\begin{array}{l}\text { Wolght } \\
\text { Nuv. 10, } \\
1870 .\end{array}$ & 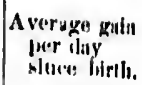 \\
\hline \multirow[t]{2}{*}{$\begin{array}{l}1 . \\
2 . \\
3 . \\
4 . \\
5 . \\
3 . \\
7 . \\
8 .\end{array}$} & 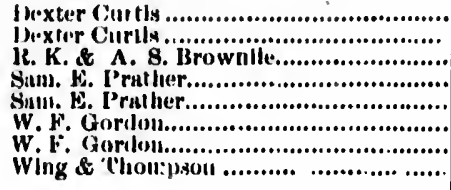 & $\begin{array}{l}2.5600 \\
3.617 \\
2.006 \\
2.731 \\
1.180 \\
3.064 \\
2.241 \\
1,428\end{array}$ & 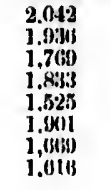 & 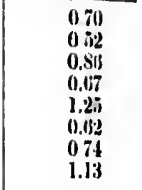 \\
\hline & 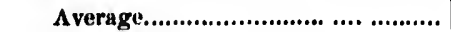 & 2,364 & 1,786 & .81 \\
\hline
\end{tabular}

The cows nveruged over six yenrs in age, and some were over ten yours old. Some of the old breeding cows were very undesirable for the hlock, and the meat would not le rnted as even medium.

The first-premiun cow was a deep red und of the lot the finest in bone, head und neck, the smoothest und best proportioned throughont, with an extrin well-filled fore and hind quarter. In the gi ent depth und even distribution of solid, mellow flesh, straight top and bottom line, brond lack, and thick loin, this cow excelled.

The second-premium cow was somewbit coarser in hend and not ns smootlı or evenly fatted, and rather deficient in back und loin; otherwise as good us the first-premium unimal.

BHOHT-JORNS-THOKOUGHBRED. BTERRS TWO AND UNDER TIREK YBARS

['ABLE 3].

\begin{tabular}{|c|c|c|c|c|}
\hline No. & EXIIHI'IOR. & $\begin{array}{c}\text { Age In } \\
\text { dilyk. }\end{array}$ & $\begin{array}{l}\text { Wolde.1l } \\
\text { Nov.10, } \\
1873 \text {. }\end{array}$ & $\begin{array}{l}\text { Avoruge } \\
\text { gaiu pererlay } \\
\text { silue: hirtli. }\end{array}$ \\
\hline \multirow[t]{2}{*}{$\begin{array}{l}\mathbf{1} . \\
\mathbf{2} . \\
\mathbf{3} .\end{array}$} & 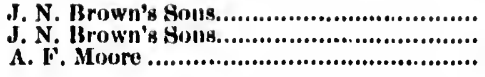 & $\begin{array}{l}845 \\
814 \\
0.53\end{array}$ & $\begin{array}{l}1 .(3) 316 \\
1.449 \\
1,786\end{array}$ & $\begin{array}{l}1.93 \\
1.78 \\
1.87\end{array}$ \\
\hline & A vernge $\ldots \ldots \ldots \ldots \ldots \ldots \ldots \ldots \ldots \ldots \ldots \ldots \ldots \ldots \ldots \ldots \ldots \ldots \ldots \ldots \ldots$ & 871 & 1.624 & 1.86 \\
\hline
\end{tabular}

The committee reported on this ring as follows:

This ring was composed of three very superior steers, showing unusuil development und ripeness for age. In size, symmetry, and distribution of meat in the best euts, they would pny the butcher the most protit, and furnish the consumer with the best qunlity of first-cluss ment.

The fir'st premium steer wis red in color, hud the best buck mod loin of the three steers, min showed the greatest development for age. Was the smoothest steer, with smaller head und lighter in horn; smull, unit, slint neck, with the widest and deepest breast; better in width of buek and 
thicker in loin. This steer wis smooth and free from bumebes, with firm, solid and mellow flesh. The quarters were henvy and well propor: ned and well filled down to knee und gambrel joint. The shortmess in leg and the fineness of bone is worthy of special mention.

The serond preminm steer wis a rich roan, not as avenly fatted ins the first promim steer-more uneven top and bottom: line thm the first premium steer.

STELHS THIEK AND UNDER YOUIR YEARS.

[TABI,E 4].

\begin{tabular}{|c|c|c|c|c|}
\hline Yo. & EXIIIHITOR. & $\begin{array}{c}\text { Ayo: ln } \\
\text { dayss. }\end{array}$ & $\begin{array}{c}\text { Welght } \\
\text { Nov. 10, } \\
1879 .\end{array}$ & $\begin{array}{l}\text { A vernge } \\
\text { gain per iluy } \\
\text { sluee birtli. }\end{array}$ \\
\hline \multirow[t]{2}{*}{$\begin{array}{l}1 . \\
2 .\end{array}$} & 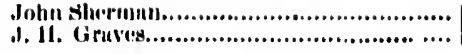 & $\begin{array}{l}1.311 \\
1.3 \% 35\end{array}$ & $\begin{array}{l}2,010 \\
2060\end{array}$ & $\begin{array}{l}1.63 \\
1.45\end{array}$ \\
\hline & A trerilge & 1.3203 & 2.039 & $1.5: 31.2$ \\
\hline
\end{tabular}

The committee's report on this ring is as follows:

"l'his ring consisted of two very superior, well-developed and evenlymatched stres's in point of nge mul weight.

The superiol quality of the tlesh and the proper distribution of the ment in the best parts of the eareuss was particularly noticeuble in hoth stecrs.

The first premium stecr, a light rom, wis perfectly smooth and free from bunches, and n good liandler. IIs was straghter on the back than his compretitor, with betier hind-cuarter's. This steer was a low blorky,

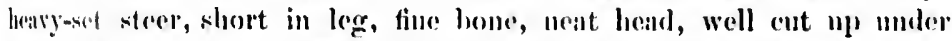

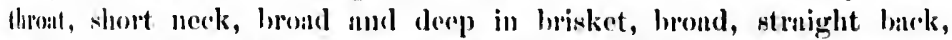
hespy loin, with thick round, well meated down to the knee and gambrel joint.

The ment was firmer and more suidd than on the first preminu aninal, which was fitter, and from all appeinrances would ent to better ndvintage and furnish moit of a superior quality.

The secouml premium steer wiss an extra well futted red eteer of great merit; was rither more legrgy mind comrser in hend and bone than the other steer."

\section{Proft in Early Maturity.}

In the foregoing reports it will be notiecd that the best gain wns in steer one year old and under two; the next best gnin wiss in steer two yeur old and under three, 1.93 pounds per dny ; the next best gain riss in steer three yenrs old and under four, 1.54 pounds per diy. Then 
in following the gain in eows over three years old, the average will be a diminishing qumtity, until in the case of the eow ten years old, tille 2, No. 12, the daily gain is lout 0.52 of a pound; and in the case of the oldest steer, nearly six years old, table 1, No. 2, the daily gain was 1.13 pounds per diay. These great results were arrived at by warm slicter, careful feeding, and as careful care from birth - most potent fictors in any case when money is to be unde in enttle, either for beef or the duiry.

As a rule, a yearling, as it is ordinarily wintered, will weigh much less in the Spring than in the previous Autumn. The next Spring and Summer it must first regain the flesh lost, und then add to growth and weight. The next Winter it again loses flesh, und at two years old often will not weigh as much as it did at eight months old. So it goes on gaining a little in Summer nnd losing as constantly in Winter, until at the end of the fourth yenr the minat will weigh 1,000 pounds-less than the same animal would have been made to weigh at eighteen months old with good common shelter and feed. There are cases in new countries where feeding, except hay, cammot be had; where this is plenty, and the range good, enttle may be raised at a minimum cost - simply salting and herding in Summer, and feeding in Winter. Hore anain the question of shelter nust be considered and will be found to pay, and without which no protit can be realized.

This-system of feeding, however, is no longer fensible except in linited areas. The grent West is fast settling up and incrensing in wealth. Herds are yenrly improving through attention to breeding and feedingthe resuit of the cultivation of vast areas in corn, the seeding of meadors and pastures, and in superior buildings for wintering stock. 'The history of the thickly settled portions must be the history of the newer regions in the future. The profits, in furming in the West, wre in the stock sold. Pustures and meadows ure the groundwork of good furming everywhere. Thus verifying the Belgian maxim: No pasture no cattle; no cattle wo manure; no manure no crops.

\section{Mako Beef Young.}

The time has gone by when it would be believed that an animal must rench the age of four or five years hefore it could nuke good leef. The time has also passed when the mere tallow in an unimal would sell it. The reason why we have so little beef fit for export to the English manket, and which will bring in Wesiern markets from five to six eents per pound gross weight, is that very few western furmers have adopted the Euglish standard of foreing a calf from the time it is born until it is killed, the age never exceeding three years. This tendency of English breeders and

feeders 1 that bee comprom eattle wer found that two-year attained a was sold, I Royul $A g$ farmers or, as they

Among o haring sold high-grade s

One elev(n)-mon One thiriet'l-mic l'bree soistre(c) Three fllteren-mo

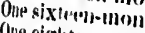
One eightrean-mo Oule cigheretis-and Tro elghteth-ind

The weight: price is stated -meaniag, w steer must hai quirters to hiar allowince for $s$ the best stcer, pear old and ur show fully as e. fully gond weig III relation rrites:

"The above is. a week fron Those Short-Ho mill'ket, and tho: bull, out of his 
feeders lus ieen the growth of years. They had tirst to combat the idea that beef must have age before it could be healthy meat. First, they compromised on three years; the beef was pronounced good. Then the cattle were pronounced at thirty months fully as good and ripe: they also found that they got enbaneed profits from this manner of feeding. Then two-yetr olds were foreed to the same weight that had previously been attained at threo years. Lnst year beef fyom eleven to twenty months was sold, und from an article prepared by Mr. Henry Evershed, for the Royal Agricultural Journat, in which the experience of some eminent farmers given, we find interesting mutter in relation to very young beef, or, as they term it,

\section{Baby Besf.}

Among others, Mr. Stanford, of Charlton Court, is eredited with haring sold the following heifers and steers in 1878, the animals being high-grade Short-Horns, at ages and prices given below :

One elev(n-months-old steer.

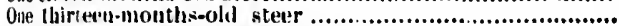

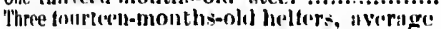

l'lire filteen-months-old heifers, averugre............................

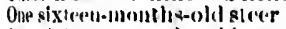

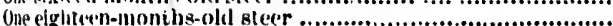

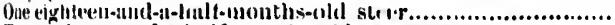

Tro dightexil-and-a-hnlf-inouths oli steers, averitge.

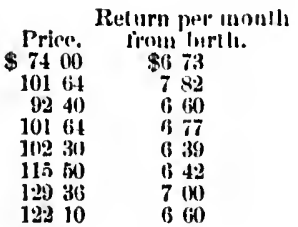

The weights of these, some of them were calves, is not given, hut the price is stated at from 16 to 18 cents (our money) per pound, net weight -meaning, we sulpose, the four quirters. The hest 16 months old steer must have weighed something like 1,200 lbs. alive, allowing the qualters to bave been 65 per cent. of the whole weight-a not very large allowance for such young cattle. In the last Chicago Fat Stock Show, the best steer, 28 months old, weighed 1,636 lhs. The best strol one pear old and under two 1,338 lbs., showing that our best feeder's not only show fully as early moturity as English feeders, but likewise as wonderfully good weights.

In relation to the English animals mentioned above, Mr. Evershed Irrites :

"The above figures show that tolerably-lored Short-Horns will return is, a week from birth on this sistem, at from 13 to 18 months old. Those Short-Horus which afforded the least return were bonght in the unket, und those which gave the highest were by Mr. Stanford's pedigrese bull, out of his well bred, but not pedigree cows. The best feeder's of 
conntry-lored eattle in Sussex mnd Surrey inform me that they consider a fair averige weight for minals, well fed from hirth, 100 Sinithield stone at one hundred weeks, giving a return of one stonc (8 los. dressed weight) per week, or $6 s .(\$ 1.32)$ per week."

Our authority mentions in steer killed thant dressed 132 stone at one humdred weeks, equivulent to $1,760 \mathrm{H} / \mathrm{s}$. live weight. Some sixteen months steers dressed, in the qunrters, $600 \mathrm{lhs}$., having 120 lis. of rough fat, und a very smull proprortion of offul. He stutes that the hest feelers ure able to rench un avernge of $\$ 1.43$ per week at sixteen to twenty montlis, from a Short-Horn cross on common cows.

\section{Foeding--Cost in England.}

The English feeder is content with the mimure resulting from this manner of feeding stock, if indeed he can get this for his trunble. As to the cost of making what is termed a "baby bullock" of seventy-one weeks, the following is griven, reduced to cur standard of dollars and cents :

Purchase of calf.

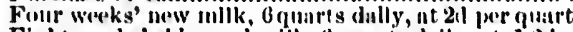

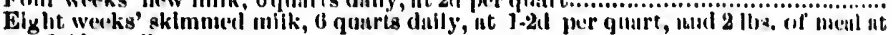
$1.4 \mathrm{tl}$ per lb.

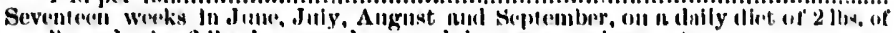

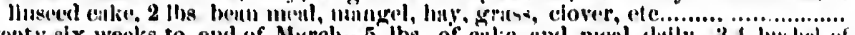

Twonty-six weoks to end of Murch-5 lbs. of cate and nanl dinily, 34 busliel of rools, hay and struw for focleker..

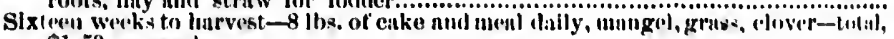
$\$ 159$ pere werk

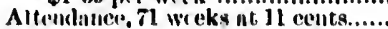

Insurunee, interest, andl rent of sliex).

Totul.

Our unthority estimates the value of tho mamure ut 20 per cent. of the cost of the food, $\$ 85.12$, or value of manule $\$ 17.02$. Ilis ateount stauds tlius :

DR.

A liullock 71 wreks olll. I'roflt.

'I'otul \$125 04

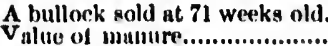

CR.

Totnl

I,et myy feeder take a calf at five dollars ut birth, figure the cost of everything fed in rnising, new milk, skim milk, oil-cnke, und ground food if raised by hand, or the interest on the cow if nllowed to run, care,

insuril side of

feeder: steers younge yeills o is fount longer $t$ of cittl grilss :III

From we are a have gir premises. the proper setson, w nuly foede the shorte Under $t$ in the fact that lorutes his his row

It is only incested paist for years. lighlest pos. prodece full jurirticablo pastures will they heugin t the animals o they will eat of younger gro teins of the on griss only when on snce liag at such t modifies tho from seventy 
insurance, etc., it will, if enrefully munuged, show figures on the right side of the leclger. Unfortunately there is no duta to show, but our best feeders for eurly mnturity seem perfectly sutisfied with the outeome on steers of from two to three years of age, und probubly might be so with younger ones if it were not the fuct thint uninuls do so well until three years of uge that they dislike to kill them younger; besides, in the West it is found cheaper to grow the enttle rather slowly and give them somewhat longer time. It is a question of chenp food as nguinst hubor in the curo of eittle in stables, in Winter, and soiling; thnt is, feeding in stables on griss :mol other food, urtiticinlly prepured, in Sum!mer.

From what we huve shown, the reader will come to the conclusion that wo are a firm believer in shelter and humane trentment. The furcts we hare given will, we think, fully sulsstuntinte the correctness of these premises. No sensible person will, we think, doubt the somdness of the proposition that the animnl should be kept growing during the cold senson, when both feeding and shelter are necessiry. The object with iny feerler is to get the grentest net guin for the food consumed, nucl in the shortest time.

Under this system of feeding the protit was seen. The humnnity lies in the fact that the animuls had during their lives the greatest enjoyment that lirutes are capable of - that of feeding and quiet rest. The owner has his roward both in a pecuninry and eonscientious sense.

\section{Summer Feeding.}

It is only within the last fow years that our best feeders have supplemented pustmrage in Summer with grain. In England this las been done for years. The rational of the matter is this. To keep animuls in the highest possible condition, the pastures must be flush, that is, they must produce full feed nt all times. Hery master-feeder knows this is not purcticable during some of the Summer months. The July and $\Lambda$ ugust pistures will not carry what the May and June pustures will. Gradually they beran to adopt the practice of fully srocking the pastures and giving the amimis what grain they would eat in comnection with grass. At times they will ent very little, especially when pustures nre in their full sucrulenor of young greenuess: hut a little mesl will be eaten every day. The systems of the enttle thus remain in betfer average condition than when fod on glisss only, in Summer, and on huy and grain in Winter. Animals when on snceulent pastures require some dry food; they will often ent hay nt such times. The menl or sonked corn, if mimmls are used to it, molifies the succulence of the grass and elover, contuining us they do from seventy to eighty per cent. of water. Full gruin feeding, with hay 
in only small quantities, tends to the creation of unnatural heat and ferer. Food gro ad, and fed moist with considerable hay, obviates this tendency somewhat, and the more the stomach is distended with fodder the les the tendeney to fever.

\section{Natural per cent. of Water in Food.}

The proportion of water to flesh-forming and fat-forming substance in natural food, (herbage), will rango from seventy to eighty per cent. The proportion of water necessary with dry feed may be stated at about sixty per cent. in Winter, and more in Summer, varying with the heat and humidity of the atmosphere. Upon succulent herbuge in Summer the animal tissues will contain more fluid thm in Winter, on dry fond; hence the necessity and economy in Winter-feeding to keep the animals fully supplied with water, so that certain portions of their systems will not be obliged to abstract the natural fluids from other parts of the bodly. Upon turning cattle to pasture in Spring they often seem to fitten suddenly. Much of this is due to increased assimilation of water in the tissues. The advantage of pasturage in Summer is that it tends to ameliorate the condition of the animal by reducing the feverish state of the system, acquired during the Winter feeding on dry food. Henee the vulue of roots, where easily and chenply raised-turnips in Englınd; turnips, carrots, and beets, in the Eastern States ; and leets and culrots in the West. In the West, roots are not given so much for their fittening 'quality; but when these are fed at the rate of one quarter bushel or less per day, they uet as a digestive element to tho other food, cansing more perfect assimilation. When these are not to be had, bran should constitute a portion of the food given.

\section{Animal Waste.}

It is generally considered us true that alout two-thirds of the food consumed goes to supply the animal heat and waste. All gratss-feeding animals that have to sustuin themselves for long periods in the wild state, on seanty food, accumulate large unasses of fat in the Summer montls. During the Winter this is gralually dissipated (consumed) in the effort to keep up the animal hent, and by Spring the animuls are thin and weak. Precisely the sume thing oceuls in the ordinary way of wintering stock on hay out-of-doors. They become thin, often emaciated, and sometimes die, in the effort of the owner to see upon how little food le ean bring them through alive. Not only all the food given has been consumed, burned up, in the effort to keep warn, lut also all the fint, where necumlulated in masses about the body. Not only this; before the animal finally 
succumbs, the fat mingled with the muscles and other heat-forming substances, will have been consumed. Yet mnny per'sons who consider themselves humane and Christian men, follow this plin year after year. It is true they suffer in purse and in vexation. Is it possible to be supposed that their depleted pockets will compensute for the suffering of the poor brutes under their care? It is hardly a supposable case that it should be 80 .

\section{Animal Heat.}

The natural temperature of the body is $\mathbf{1 0 0}$ degrees. If the tempera. ture go above thnt it indientes fever; if below it is a chill; either condition, if not counteracted, will be futal to life. The advantnge and cconomy of full feeding in Summer, as well as in Winter, will bo under stood when we remember, that, whatever the temperiture of the air, the animal heat will be 100 . When the temperature will average 60 to 65 degrees; as it will during the season of pasturage, it will require only food enough to raise this temperature by 35 to 40 degrees to bring it to 100 . All else the animal eats goes to make weight. If during the Winter the arerage temperature be 30 degrees, it will require food enongh to be eaten to raise the tempernture by 70 degrees to reach blood heat and keep up the animul integlity. Here again all food taken in excess of the animal waste is gain. But another integer here steps in. It requires less proportionate food to keep the animal force intact with a high thermometer thin with a low one; that is, it requires more than double to supply the waste with the thermometer at 20 than it does with the thernometer at 60 .

There is a limit of cold beyond which neither animul nor plant enn endure. In other words, when the cold becomes so intense that the eapacity of the stomach to digest is counteracted by the animal waste, death ensues. Thus we often hear of whole droves being destroyed, where exposed to the force of strong ehilling winds, as the "Blizzurds", of Ximnesoti, "Northwesters" of the plains, and "Northers" of Texas. In a still atmosphere the animals would have withstood $n$ much greater degree of cold. for the reason that they would have carried an atmosphere of heat ahout them. In the wind the heat was blown away, and in the atlempt to supply heat as fast ns destroyed the animal economy gave way and refused longer to exert itself.

\section{Advantages of Full Summer and Winter Feeding.}

From what we have written the reader will have learned that there is no economy in scant feeding of animals either in Summer or Winter. 
The facts are, those feeders make the most money who not only give the warmest shelter in Winter, with liberal feeding, but who earry their stock fully up to the feeding point in Summer. Where corn is as easily raised as it is in the West, muny of our best farmers will tell you they ean produce an acre of corn for less than an acre of hay. We have cultivated 65 acres to the hand in a field of 1,500 acres, and at a cost of ore and one-third days' work for teain and man per acre, up to the time of, but not including, the husking.

One advantage of feeding grain the year round is that you may stock your pastures so fully that the grass will bo kept evenly grized, thus enabling you to earry moro eattlo in Summer on a given area of pasture, and enabling you to produe more corn for Winter feeding. Another advantago is, the animals become fatter, and thus do not lose so much animal heat in Winter. Still another advantage is, you hasten maturity, and thus save interest on eapital, insurance and other items of cost.

These facts should be enough to convince the sensible man of the value of high feeding in connection with shelter, aside from the animus of this chapter, that the humane feeder-he who treats his unimals most kindly and feeds best-is really the one who makes the most money. 
CHAPTER VII.

\section{HOW TO BUT AND HOW TO BHLL.}

IHE TALUE OF GOOD CABE. — ESTIMATING WEIGHT. — ESTIMATINO BI MEAGUREMENT. - BUYING TO TEED.—-HOW TO BUY BREEDELS. - WHERE OOOD BEEF 3.IES. - BUYING FEEDING STOCK. - ANALYZING THE CARCASS.PROPER SIIAPE OF WELL-BRED FATTENING STOCK. — HOW TO BUY, — BUYING MILCII COWS. - BUYING DAIRY MILKBRs, - MILK MIRRORS, - THE TRUE VALEE OF MILK MIRRORS._-VALUE OF ESCUTCHEOK MARKS. - MILKERS IN ALL BREEDS.—HEREDITY.—DIOESTION, —RESPIKATION.—-SYMMETRY.

\section{The Value of Good Care.}

There are very many farmers who, by caro and attention to details in feeding their stock, and by kindly trentment, have done so with profit to themselves. They have raised them from ealfhood. Let them undertake to buy cattle for feeding their surplus grain and fodder, and they are very apt to overrate the weight and true value of the cattle purchased. One point should always be kept steadily in mind: Never buy an old steer or cow for fattening. They never repny the cost and trouble they give. Thin cattle, ready for grass, if healthy, may give good returns on flush Summer pasture, if bought at the price per pound that you expect to get in the Full. You will not only get the price of the flesh put on, but the cattle being thin and the museles dry, your profits will be added to in the fluids absorbed, and the loss will lio with the former owner in making mere frames to be built upon. So animals bought in the Fall in common grass flesh, will increase wonderfully with good feeding and shelter. If you buy at $\$ 2.50$ por $100 \mathrm{lbs}$., and so add $200 \mathrm{lbs}$. in flesh, and sell at $\$ 4$ per 100 lbs., you not only get $\$ 8$ for the flesh put on, but the difference between $\$ 2.50$ and $\$ 4$, or $\$ 1.50$ per $100 \mathrm{lbs}$. on the original weight. That is, you buy steers at 1,000 lbs. each, feed 50 bushels 
of corn per hend, and sell them weighing 1,200 lbs. average. They eost $\$ 25$ und sell for $\$ 48$, leaving $\$ 23$ as the value of the corn fed and care given. The manure in any eountry will pay for the care taken; so, your corn will have netted you near forty-six eents per bushel. From this, knowing the cost and price expeeted when fut, it will be easy to figure ou profits, fluetuations and aceidents excepted.

\section{Fstimating Weight.}

An expert judge will estimate from seeing and hindling steers often within ten pounds of their live weight. The buyer will always underestimate weight, and in nine cases out of ten convince the inexpert owner that the guess is right; in fuct, more than half the time the seller will be couvinced that he has the best of the bargain. The ouly safe way in such euses is for the seller to weigh. Every man who makes a busiuess of fattening cattle should own a proper scale. He may save the eost in a single yeur. The merchunt, the manufacturer and the builder, who work by guess, always end in bankruptey. The only reason why furmers do not, is, they have that generous bank, mother earth, which never fails to respond, even to indifferent munagers.

In weighing cattle noto carefully why certain ones weigh out of proportion to others, and study whether the weight is in the prime parts, a broad loin und hips, and good barrel, or in heavy fore-quarters, witl thick neek and big head and hor'ns. Study carefully the points as given in detail elsewhere in this book, and as earefully remember them for future use. Thus you may in time becomo yourself an expert judge of stock. If an animal is to be killed, estimate his weight alive, how much he will shrink in offul and hide. When tho quarters are weighed, if the record is not as you expect, examine carefully wherein the diserepancy lies. It is an especiully interesting study for the young man, who expeets himself to become a breeder and feeder of cuttle. If a breeder, he must know how to sell ; and if a feeder, he must know both how to buy and sell.

\section{Estimating by Measurement.}

Many breeders have rules of estimating the weight by measurements. There is no rule that comes nearer than good guessing, and all guessing should be avoided, especially when the guessing is to lie on the part of the buyer; that is, the seller should avoid trusting to the guess of the buyer, based upon measurement. No two animals will weigh alike according to measurement.

One rule, perhaps as good as any and for this reason given, is to find the superficial feet by multiplying the girth, just behind the shoulder- blude, 1 of the $t$ length w gruss fut

$$
\begin{gathered}
\text { Girth } \\
\text { "6 } \\
\text { " }
\end{gathered}
$$

Thus th

or 1,441 l twenty qin calveś, án little oren account of ing or selli

In buying young, thint If to bo kep and Devolls Buy uo ove should they for money, meek-eyed, through the the twist wel fatten kindly concerned, th has carefully

If the inten buying steers. and it is bette not the first es amount of $\mathrm{mil}$ foundation of young ean ma naturally will b 
blude, by tho length from the fore purt of the shoulder-blade to the root of the tail. 'Thus an ox girthing 7 feet 9 inches and measuring 6 feet in length would contain $73-4$ times 6 , or 46 1-2 superticiul feet. For cuttle griss fat the following is given us the weight per superticiul foot:

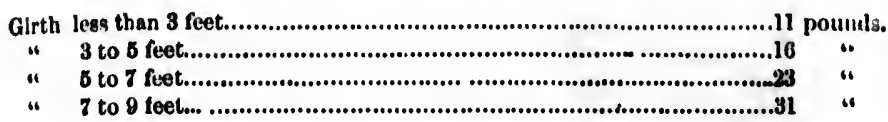

Thus the steer as per above measurements should weigh 46.50 by 31 , or 1,441 lbs. gross. Under this rule it is usual to deduct one pound in twenty qu half-fatted cnttle, from 15 to $20 \mathrm{lbs}$. on a cov hiving had calves, and if not fint an equal umount. The, rule as above stated is of little oreno value, except to those having no other means. In tuking account of stock, this nuy come somewhit neur the weight. For buying or selling the scale is the only true staudurd.

\section{Buying to Feed.}

In buying cattle either to graze or to feed fat, choose cattle that are young, that is, that will not have become muture before ready for sale. If to be kept a year, three year old past to four year old for nutives and Devons, and one yenr less for Short-Horns or Hereford gindes. Buy no overgrown, leggy animuls; they are hard feeders. Neither should they be undersized, as this indieates want of thrift. The cattle for money, whatever their breed, are compact, smooth, fine boned, meek-eyed, soft huired steers, with skin of medium thickness; thick through the heart, round barreled, well ribbed, with broad rump, and the twist well down to the hock. Such cattle, whatever their breed, will fatten kindly and the meat will be of excellent quality. So far as age is concerued, the teetl must be the test. In this no person can err who has carefully studied the chart of the teeth in another part of this work.

\section{How to Buy Breeders.}

If the intention is to raise beef cattle the same rule will apply as in buying steers. In no case should the cow be more than three years old, and it is better that she never had a calf. In breeding for beef, milk is not the first essential. It is necessary, however, that the dam give a fail amount of milk, since the proper sustenance of the calf is what lays the foundation of the future value of the steer. No calf starved when young can make a valuable cow to breed from, and as is the dam so naturally will be the produce. Whatever is to be the outeome, avoid at 
any price a vicious cow, or one with n wild eye or having a dished face. Her progeny will be sure to give you troulle, und will not give you cuttle that will futten to the standurd of the pieture wo givo you of Earl

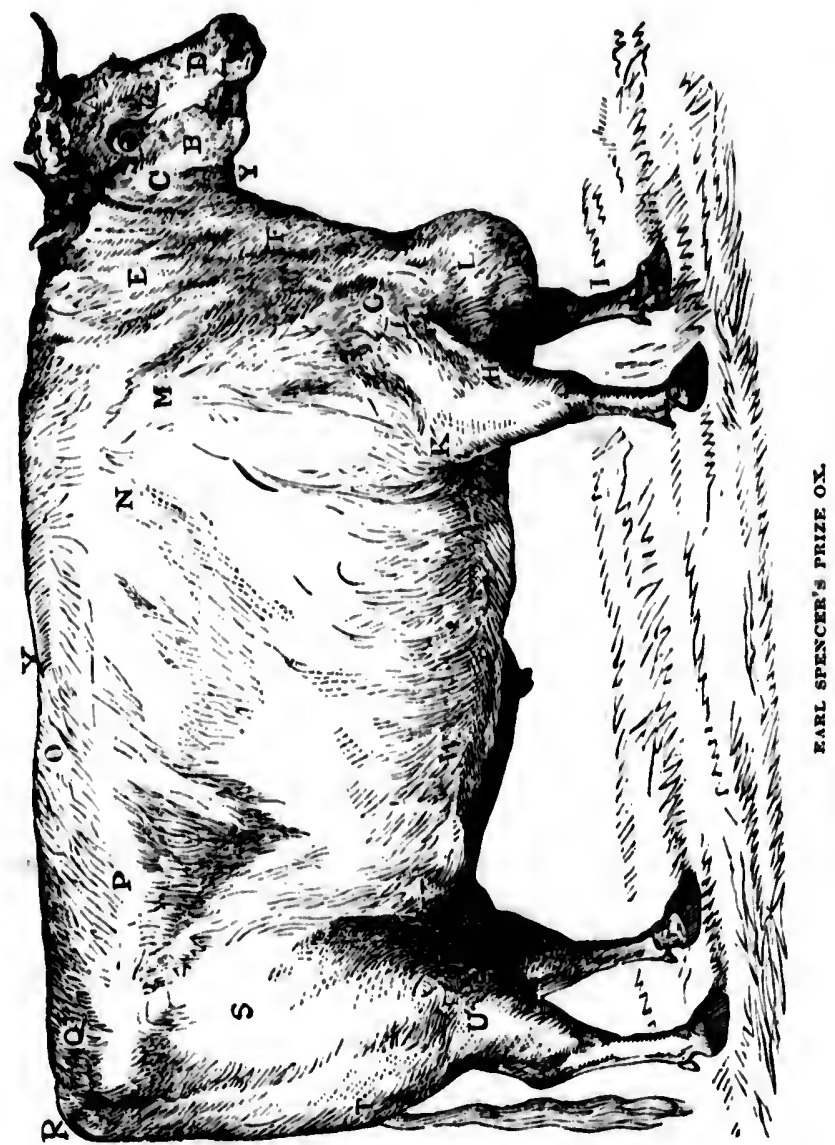

Spencer's prize ox; given not only as showing what Short-Horns were fifty years ngo but ns illustrating the terms to be used in deseribing the various beef points and other uutwurd portions of the bullock.

\section{Explan \\ $C-$ Nec}

Gambrel

Crops.

bone, thin

W-Plute

The prit

$S$, and bin second bes valuablo pi the flinks I will bo seer very large I thirk riblec below the to

The novic up. To tho rorse than tl and for this $r$ this, however may seem fiti will know that decides the $v$ smoether, and der to the rine stecer is piurtly are now spe:ik that have ehint of points for: fitt "attle show ox will show w miay lo taken al

In all first-cle: tallow, und offit corming pieces w 
Explanation.-A-Fordiead. $B$-Fueo. $C$-Cheek. $D$-Muzzle. $C$-Neck. $\quad \boldsymbol{F}$ - Neck-vein. $\quad G$-Shoulder-point. $\quad H-A r m . \quad I-$ Gambrel or hock. $\quad I$-Elbow. $L$-Brisket, bosom or brenst. $N$ C'rops. $C$-Loin. $P$-llip. Q-Rump. $R$-Pin-bone. S-Roundbonc, thurl or whirl. $T$-13uttock. $U$-Thigh, or gasket. $V$-Nlank. W-Plutes. $\boldsymbol{X}$-Back, or chine. $\boldsymbol{Y}$-Throut. $\boldsymbol{Z}$-Chest.

\section{Whore Gond Boef Lies.}

The prime parts of the ox lie, as shown in eut, from $N$ to $R$, thence to $S$, and hack to $N$. Botween $P, Q$ and $V$ are the primest parts. The

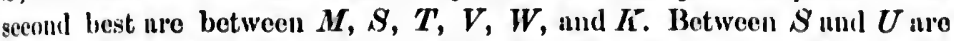
valuablo pieces for smoked or dried ment. The ribs between $M$, and $S$; the flanks $V, W$, and thence to the brisket $K$ are good corning pieces. It will be seen that this animal has a very small proportion of offal, and a very large proportion of valunble ment, being full and brond in the loin, thirk riblsed, with tho rump massive, square behind, and earrying beef below the twist, or junction of the thighs, well down to the hocks.

\section{Buying Feeding Stock.}

The novice in buying stock should carefully noto the shape and make up. To the superficial oyo the superior animals when thin will uppenr worse than the inferior ones; the bony parts will appear more prominent, and for this reason their breadth, when thin, will seem to bo exiggernted; this, however, is only appurently so. An :unimal of no purticular chancter may seem firily smooth to tho eye. Those aceustomed to handling stoek will know that superficial observation goes for little. The touch is what decides the vilue of an mimul. The well-bred animal enries softer, sunother, and finer hair than the ill-bred one; its brendth from the shoulder to the rump gives it a bony appenwuse when thin, that in the scrub steer is partly concealed by the higher backbone and eourser hair. We are now spenking of no particular breed, but of all breeds and erosses that have characteristic points enabling then to lay on flesh. The seale of points for Short-Horns will make a good stuily. 'Tho illustrations of fit cattle show what they should be when fat. The picture of the Devon ox will show what a good feeder should look like off of good grass, and may be taken as the type for our best native cattle.

\section{Analyzing the Carcass.}

In all first-class steers every part of tho nuimal, except tho bones, hide, tallow, and offal, will be gooul cousumihble flesh. The ronsts, steaks, and corning pieces will be of the best, so that when the four quarters aro hung 
up there will be no loss except bosis. Let us now see what such an ox as we have shown will give. In the first place, his quarters will dress sixty-five per cent. of his gross weight. The loin above $\boldsymbol{P}$ nnd from thence to the top of the shoulder above $N$ will give most sujerior stenk and roasting-pieces. The shoulder-pcint or neck-vein back of $T$ and the thigh at $S$ muke the best smoking-piece:s. The plates $W$ will make the richest of corned beef, while $R, \mathbb{S}$, and $L$ (the rump, round and brisket) make the best pieces for packin - geod thiek, juicy meat, and in large qunntities. In fact such un animal will convert the food he eats into good beef, and plenty of it.

\section{Proper Shape of Well-bred Factening Steok.}

Cut off the head, neck, legs, and tail, and well-bred beef cuttle will present the uppearance of an oblong square. Thus there is ample room
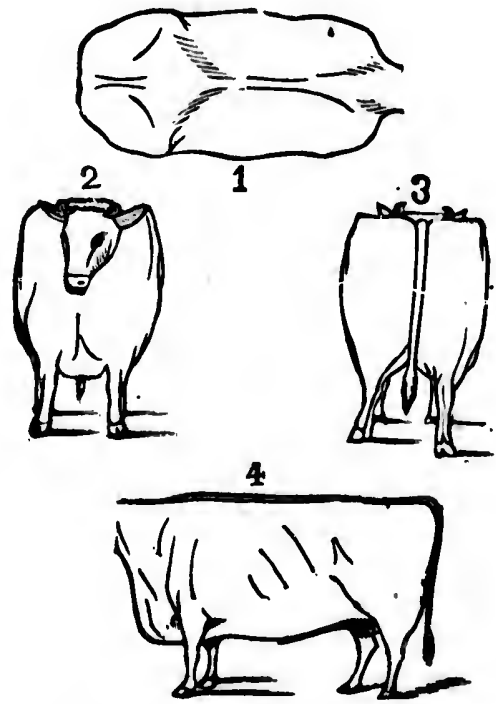

OUTIINA OF PRIZE FAT BULLOCKS.

for the legs ard viscera through the width of the bosom and spritig of the ribs, and this carries corresponding brendth behind, giving a broid loin and massive rump. Such in animal will feed heartily and kindly, satisfy the butcher when brought to the block, and be profitable to the feeder. Above we give four outlines showing animals made very fat, and 
cut square to show the shape. There is no profit, however, to the fceder in cattle futtened to obeso or immense weights; they aro mere mountains of fat, and contain no more lean meat than animuls fattened fairly ripe. There ure few people who do not like well-fattened beef. Few, however, care to eat any but the lenu. An animal, therefore, that is fattened just ripe is the heaviest in muscle, well marbled with fat. This is what the consumer wants, and what the feeder should seek to make. Smooth, finehorned, medium cattle, according to the breed selected, are what give profits in this respeet.

\section{How to Buy.}

In buying ordinary (that is native) cattle for pasturing and feeding fat during the Summer and Fall, always buy in the Spring. If tho grass is good at the time of purchase, as it should be, no matter how thin the stock, if healthy and henrty. The thin stock will weigh less, und you will havo to paty less for it. The loss will be with the farmer who grudges his animals sufficient to eat in Winter, rather than with the buyer. Generally all this class will sell eheuper in the Spring than in the Fall, and as a rule yeurlings may be bought for less money in the Spring than the same calves would huve brought in the Fall. If they have been fairly wintered they will be profitible to feed; if ludly wintered, it will be questionable, unless the price paid is low enough to warrunt the purchase. In any event the feeder must usually depend upon buying steers off of common keep. Good fecders are not apt to sell half-grown steers, nor those that one more season's keep will make ripe. The best moncymaking frends of the sagacious buyer aro, after nll, those who never rend, and will not believe that anything in print relating to ngriculture in any of its various departments ean be of vnlue. The do not know that as great adva'eces have been made in ugricultural art within the last thirty years as in any other industry, and that the best practieal talent in Europe, and within the last few years in America, have been euruestly engaged in elucidating and applying practical science to agriculture.

In selecting milking cows the following doggerel verses from an old English magazine are as true now us when written as to what constitutes a cow for both milk and beef :

Siue's long in her fnce, she's fine in ser horn, She'll quickly get fut without cake or corn; She's ciean in her jaws, and fuil in her chine, She's heavy in flank, and wide In ler loin.

She'a broal in her ribs, and Inng in her rump; A strilght anil 1l:tt back, without e'er a hunip; She's willo ful hir hips, antl culen in her eves; She's tise In ler shoulders, and ulu In her thighs. 
She's llght in ler neck, and small in her tall;

She's wide in her breast, and good at the pail;

She's fine in her bouse, alld sllky of sklil -

Sle's a grazlur's without, and a butcher's withln.

\section{Buying Milch Cows.}

In selecting cows for milk, or heifers from which to breed milking stock the hreeder must be guided by the same general principles as in buying beef-muking steers. Thut, is to say, the animuls must be fine, with mellow though rather thin skin, und mossy hair ; the head smnll, but fuce struight und ruther long; tho horns should be fine, short, and if somewhit curved it is a good indication. The eye must be bright and yet placid. The barrel, pelvis, ramp and thighs should bo roomy ; and, for obvious rensons, nvoid a dish-faced, and especiully a wild-eyed cow, or one with a dull, henvy eye. The first shows viciousness, tho last stupidity - both dangerous nnd both unprofitable.

In buying for milk, the ohjeet being to hreed your stoek, select heifers of three yenrs old renly to come in, provided the stock bulls were suitnble ; if not, huve nothing to do with them. In this case buy heifers of two years old thit have never been bred. Then, by attention to what we have said upon breeding, you camnot go amiss.

\section{Buying Dairy Milkers.}

When the buyer is selecting eows simply to wear out in the dairy, without any reference to retuining or improving the breed, all he has to look to is an mumal that will give a good tlow of milk, und hold the flow for a long period. Miny eows will sturt ont with lurge messes, and at the e.d of three montlss will hardly give cnough to keep a cilf; others will continue in milk for six months; others, again, will eontinue in milk well up to the time for again dropping a ealf. These latter are the rows to hny. Select them necording to the rules heretofore given, and of from three to five yen's oll, bat not unless they nro well along in calf. A dairy cow will continue to improve in her milking qualities until she is six yeurs old, sometimes until she is seven or sight; they will continue to give umple retu: us until ten years old, und often until eleven or twelve.

\section{Milk Mirrors,}

Besides the rules already luid down, there is an infallible sign in the mit: mirror - or "escutcheon," ns it is now called-in cows, heifors, calves, and also snown distinetly in the bulls of milking breds. Ife have studied and bred hy it since its first publieation in tho United States. It is the rosult of years of study by M. Francois Guenon, a prictical 
farmer of Libourne, France, and first reduced to in system in 1822. In 1828, at a public test and careful examination by the Agricultural Society of Bordeaux, the committee made an absolute und exhnustive report, in which they used this strong language: "This system we do not fear to say is infullible."

The society decreed Mr. Guenon a gold medal, made him a member of the society, ordered fifty copjies of his work, and distributed one thousand copies of their full report among all the agricultural soeieties of Frunce.

This system was tirst made kuown in the United Stntes, if we remenber uriglit, between 1838 and 1840, and has been studied, believed, and acted on ly many practical men; yet, curiously enough, it hins never attracted general attention until within the last few years, sinco which time dairying and the breeding of dairy cows has come to be a regular profession. While we should not rely entirely upon the muny classes and their variations, including a bastard escutcheon to ench class, the signs us given by the author are most vuluable in connection with other matters which nre given. In the Guenon theory there are twenty-seven cuts or diugrams to illustrate his iden, vacying from the fuilest dovelopment in the growth of hair turned upward, to ns nenr nothing, as is ever shown in the eow, but all having more or less of this peeuliur develop)went of huir on the parts named; this hair, to indicate n good milker, should turn upwurd, be short, fine and close; the skin ensily raised, and with peculiar oval marks and scurf spots.

\section{The True Value of Milk Mirrors.}

So far as ve have studied these signs, we have found them while not constant marks by which the quality and flow of milk could be necuritely julged, yet most valuable iu comeetion with other chinacteristic signs and contigurations, which we hnve given for judging accurntely what should constitute a good dairy eow. We luve found it a most valuable nid in judging the milking qualities and timo of continunnce in milk. That in itself it does not constitute an infullible test is no proof of its being an unsound theory. That it is correct, as a rule, is sufficient to cause it to le given cureful study and attention.

We do not hesitate to say that he who will study carefully the illustrintions we give, and the statements made, while he will find muny varying signs, will not only be convinced of the accuracy of the system, hit will be able, either in the cow or calf to select with judgment. The milk sign also follows in the bulls as we sh:ll show.

Mr. Charles L. Sharpless, of Pennsylvunia, a close observer and good 
breeder, in relution to the value of the eseutcheon, us seen in Jersey cattle, gives his experience, which wo condense us follows:

There is mo point in judging a cow so little understood as the escutcheon. The conclusinn of nlmost every one is, that her escutcheon is gool, if there be a broad band of up-running hair from the udder to the vulva, and around it.

Fra. 1.
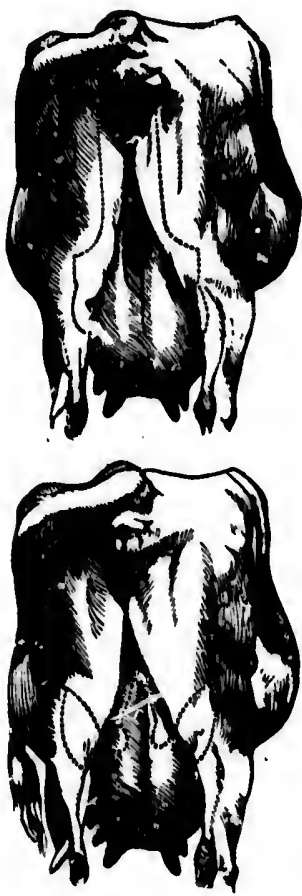

Fro. 3.
Fia. 2.
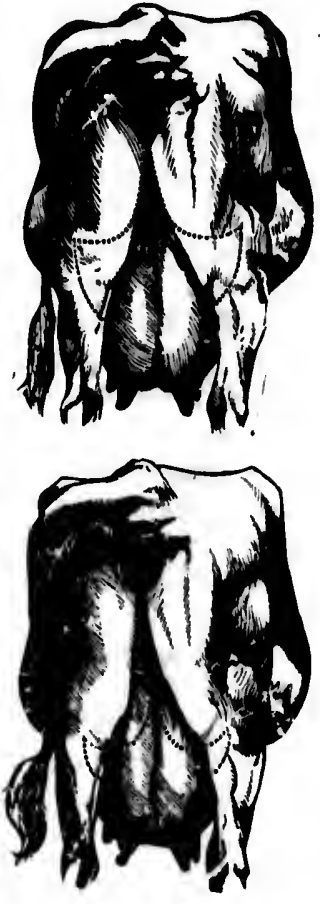

Fia. 4.

MILK MIRROR OF JERSEY

These cows with the broad rertical escutcheon are nearly nlways paralle! cows; thut is, with bodies long but not large, and with the under line parallel with the hack. Their thighs are thin, and the thigh eseutcheon shors on the inside of the thigh rather than on its rear.

Next eomes the wedge-sluiped cow, with the body sleorter hut very lurge, deep in the flank, and very capscoous. This form does not usually

exhith

thigh

thus -

In 1

on the

daun:ay

dowin,

leer us

Ther

4 will !

always

the udd

The c

timuing

The ?

or'n:men

2 is best

IThent

of the ut

So far

sints the

just as in

the body.

"unlucity,

This $\mathrm{fr}$ or bull, an luir monder of the esce that the amimil, wl forward is at the mitr

The bre: unpreity, it some cases is in others: This exil distunce np) It is marke ally age bet 
exhibit the vertienl eseutcheon running up to the vulva, but with a broader thigh may exhibit a thigh escuteheon, which is preferalsle to the other, thus-see Fig. 2.-Milk nirror of Jerseys.

In both vertical and thigh mirrors, where the hair runs down, intruding (oil the udder (as low as above the dotted lines) as in Figs. 3 nnd 4, it damages the escutcheon. If you find a cow with the hair all ruming down, and between the thighs-that is, with no up-running hair-stamp her us a cipher for yielding milk.

There are times when the udder of a cow with an eseutcheon like Fig. 4 will be enlarged by non-milking, for the purpose of deception. It is alwilys safer to judge by the eseutcheon rinther than by the large size of the ulder.

The escutcheons of the best cows - those yielding the most and continuing the longest - will be found to be those which conform to Fig. 2.

The vertical eseuteheon of Fig. 1 would not injure it; lut if thut oriumental fenture has to be at the expense of the thigh escutcheon, Fig. 2 is hest as it is.

Whenever an eseutcheon is accompanied by a curl on ench hind-quarter of the udder, it indieates a yield of the highest order.

So fill, we have noticed only the rear escutcheon, or thit which represonts the two hind quirter's of the udder. The two front quirters me just as important, and should be eapacious and run well forward under the hody. If the udder in front be conenve, or cut up, indicnting small (alpucity, it represents redueed yield.

This front or level escuteheon is distinetly ma.ted in the young heifer or bull, and enn be seen by laying the animal on its back. The udder birir undere the body all runs baekward, commencing th the forward line of the escuteheom. This dividing line is very pereeptible, fion the fuct that the hair in front of it all runs forward townrds the head of the :nimal, while the escutcheon, or udder hair, all runs backwind, over the forwird rinurter's of the udder, around and beyond the tents, and ceases at the murkings of the renr escuteheon on and between the thighs.

The brendth and extent forward of this front escuteheon indientes the anmeity, in the mature animul, of the front qunrters of her udder. In sume cases this front eseutcheon will be found of twice the extent that it win others, and is evidence of that much more yield.

This examination enables one to sec the size of the teats and their distance npart, nnd to test the looseness and softness of the udder skin. It is marked precisely the same in bulls, and can be easily examined at any age between one and ten months. 
Many think that the escutcheon of the hull is of little moment, so that he has a good look. So fur is this from being the case, that a bull with a mirror like Fig. 4, or worse, will stamp his escutcheon on, and to that extent dannge, his daughters out of cows with escutcheons as choice as Fig. 2. In this way the duughters of some of the best cows come very ordinury, while, if you use a hull marked like Fig. 2, he will muke a poor escutcheon better, nnd will improve the lest. His injury or henefit will be doubled according to the escutcheon markings under the hody in front of his scrotum. Hence the importance of the dnm of a bull being unexceptionnble in her udder and escutcheon. Her qualities inherited by her son will be transmitted to his daughters.

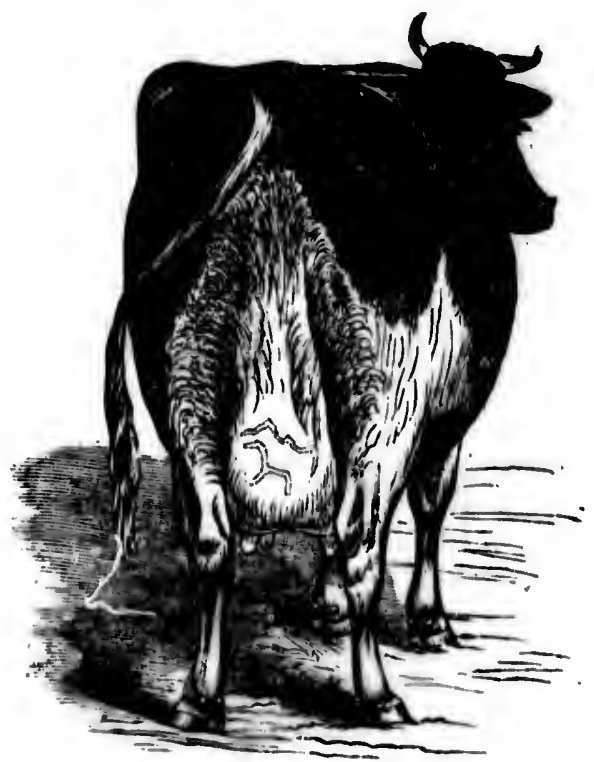

GREAT MHKK M,RHORS ON MOLGTEIN COW.

While careful as to escuteheons, we must not neglect the other essential fentures of a good cow-the back. skin, hide, the rich colored skin, and the fine bone. Let the hair be soft and thickly set, and let the skin he mellow. This latter quality is easily determined by grasping between the thumb and forefinger the skin at the rear of the ribs, or the double thickness at the base of the flank that joins the stifle-joint to the hody, or that on the inside of the rump-boue ut the setting on of the tail. Let the

tents

enoug

thum l

yielde

Pro

yeurs

the mi

gives $\mathrm{t}$

" $\mathrm{Tl}$

a large

face of ply the

couvey

per tuft

genernti

give gre

is agitin

glands, 1

"In

the cow,

developed

After t

observed,

more the

shape is of

Still, w!

duction of

certain as

In fuct,

the form an

ticular ma

and ellergy

influenee of

the anumtit

of the escu

tan always

often see co

and placed , 
tents be well apart; let thom yield $\mathrm{a}$ full and freo stream, and bo large enough without the necessity, in milking, of pulling them between tho thuml and forefingers. And lot us over koep in mind that the large yielder must be well fed.

Prof. Migne, V. S., of the Veterinury School, Alfort, somo thirty years ago, us to the relations below the escutcheons and the functions of the milky glands, and as difforing from M. Guenon in somo of the details, gives the following explicit informution :

"The direction of tho har is subordinate to that of the artories; when a large plate of hinr is directed from below, upwards, on the posterior face of the udder, and on the twist, it proves that the arteries thit supply the milky system aro large, since they pass backwards beyond it, courey much blood, and consequently givo activity to its functions. Upper tufts, placed on the sides of the vulva, prove that the arteries of the generative organs are strongly doveloped, reach even to tho skin, nud give grent activity to those organs. The consequenco is, that after a cow is again with ealf, it draws off the blood which was flowing to the milky glands, lessens, und even stops the secretions of milk.

"In the bull, the arteries, correspondiny to the mammary arteries of the cow, being intended only for coverings of the testicles, are very slightly developed; and there, accorlingly, the escutcheons are of small extent."

\section{Value of Esoutcheon Marks.}

After the explanation, which accords very well with all thut has been observed, it is ensy to conprehend the value of the escutcheons. The more the lower ones are developed, the greater the quantity of milk; but shape is of consequence.

Still, whatever be the cause of the relations existing between the production of milk and the escutcheons, these marks cannot furnish data so certain as some hive aftirmed them to be.

II fact, the quantity of milk, and its quality, do not depend solely on the form and size of the escutcheon; they depend on the food, the particular managemont, the climate, the season, the temperament, the size and energy of the principal internal organs, the capacity of the ehest, the influcuec of the generative system, etc. All these circumstances cau-s the quantity of nilk to vary, without muking any change on tho extent of the escutcheon; consequently, it is impossible that the same relation an always exist hetween the escutcheons and the quantities of milk. We often see cows equally well shaped, having exactly the same escutcheon, and placed under the same hygienic conditions, yet not giving equal quan- 
tities, or equal qualities of milk. It could not be otherwise. Assuming that a given tuft has the same value at birth, it cammot be the same in adult ugo; since, during life, un intinite number of eircumstmes oceur to diversify the uctivity of the milky glunds, without changing the figure or size of the tuft.

Is it not sufficient to refer to the inequality of milk given by the rame cows, according as they have had one, two, or throe calves, in order to make clear that M. Guenou has assignod too much value to the mark which ho has discovered?

It often happens that two horses, having exactly the same construeture, and the same external forms, lave not the same energy, the same fituess for work. The difference is owing, evidently, to the temperament, and the activity of the principul externul organs; in other words, to conditions which it is often impossible to estimute loy any direct method.

Now, sceing that temperument has an influence on muscles and bones, the action of which, however, is partiy mechanicul, resembling that of a lever, and exerts this influence so powerfully as to render their movenents unequal in respect both of power and promptness, can wo suppose that it hats no influence on the entirely vital, or, at least, the entirely molecular working of the mammary glaud?

It might, therefore, have been argued a priori thut the mathematical precision assigned to a classificution of cows is contrary to the most generil laws of physiology; to propose a mark indicating that it cow will give so much milk daily, and for so many days, is to deceive ourselves, or to attempt to deceive others : the study of the phenomenn of life proves that the action of the orguns depends not merely on the size and their form, but on the general condition of ench individual

We are able not only to oppose argument to the assertion of M. Guenon, but we cun appeal to the difficulties hitherto experienced in applying his clussiticution to prnctice. M. Guenon has not yet found a single pupil worthy of him. And among the thousands of persons who occupy themselves with his method, is there a single one who has aequired sufficient skill to justify the clnims which the author makes for it?

It may be uffirmed that, to form pupils as skillful as himself in judging of cows, ${ }^{*}$. Guenon would not only have to tench them that a certain firure for the tuft corresponds to a cortain number of pints of milk, but he would huve, ahove all, to communicate to thein his perspicuity, his talent for observation, und his grent experience; he would, in fine, have to fit them for estimating, in addition to the direction of the hair of the trist, the whole of the marks usunlly employed in making choice of milch cows.

All the attempts made on the Guenon method, not excepting those of 
the author himself, prove the soundness of our opinion. The most skillful, when ealled to decide on the qualities of cows, whose yield of milk was well known, erred seven times on eight cows, and tifteen times on twenty-one. And, lest these error's may be attrilsuted to chance, on account of the sinall number of cows submitted for trinl, wo should mention that other estimutes proved erroneous 152 times on 174 cowy, and 321 times on 352, and thut the error umounted to 121 pints of milk on 1 total of 2,683 pints; in other words, there wins error in regurd to almost ull the cows; and error amounting on an nveruge, on ench, to more than 1 third of the yield. On some individunls the estimntes were wrong to the extent of from $171-2$ to 21 , and even from 26 to 28 pints $n$ diny.

Such is the truth ins to the perfect niecty elnimed for the escuteheon system. The system camnot do moro thun furnish an approximale estiinite of the quuntity of milk, and that in regard not to nll, but only to the majority of cows.

What, then, has led so miny persons to put confidence in M. Guenon's discovery? 'The great tulents and knowledge of the nuthor. The system has obtained the creclit lue to the experienee of him who applied it.

By his discovery M. Ginenon has rendered great service to ngriculture; the esenteheon has the advantage of fumishing a mark which cun bo easily discerned, and estimated even hy persons of no great experience in the selection of cows - a mark perceptihlo on very young animnls, and on bulls as well us heifers - 12 mark which, when diseneunbered of the compliented system in which it has been wrapped up will be in common use and facilitute the increase of good cows, by not ullowing any but those of good promise to be reared.

\section{Milkers in all Brceds.}

Professor Minge also gives the following eoneise directions in relntion to choosing $n$ good cow, where he snys:

"We find good milkere in all breeds, but they are rave in some and rery common in others. It could not be otherwise. Milk properties, depending on the conditions which determine the formation of breeds, are due partly to the elimute, the soil, the air, and the plants of the countries where the breeds huve originuted; und must therefore vury in our different breeds of horned cattle, with the hygrenie conditions peculiar to ench locality.

"Nilkers, and more especinlly animals intended for breeding, must be selected unong breeds celelorited for abundance of milk. Not that wo can hope to import into our department, with a dry and warm elimate, 
nll the qualities of the excellent milking breeds possessed by eountries in which the soil is fertile, the nir moist, and the sky often eloudy; but as the influence of climate, though very marked, tukes effect only in the long run, the properties of the uninuls imported ure mnintained-though sulject, doulttess, to gradual deteriorution - during a period which varies with the precnution taken to preserve them; and for several generations the descendants of a good imported breed givo more milk thnn individuals belonging to a breed found on the spot, where hygienic circumstances ure not fuvorable to milking properties.

It is not to be forgotten, moveover, thut under the influence of particular circumstances, which it is sometimes impossible to call into existence, aninuls manifest properties which we ennnot produce directly. This explains why it is ofton more advantageous to import qunlities possessed by forcign stock than to try to develop thom in nutive stock.

As milking qualities are in a great nonsure dependent on structure and temperament, which are more or less hereditayy, descent exereises a grest influence.

\section{Heredity.}

In ench breed, therefore, we should choose individuals belonging to the best stocks, mud the offspring of parents remarkmble for their milling qualities; for it is certain that good milch cows produce others which resemble them.

But it is especially necessary . when selecting stock for the purpose of breeding milch cows, that particular caro slıould bo taken to select indjvidunls belonging to good families. A cow of a bad milking fumily, or cven breed, may occasionally be nn excellent milker, and more than this is not rimited when it is not meant to breed from her. The same camot be sitid when breeding is intended, becanse there would he little chance of her transmitting the accidental or exceptional qualities possessed by her; wherens the quulitics forming the fixed and constunt characters of the stock would almost to a certuinty be transmitted to descendunts.

'These remarks, with regurd to breed and parentage, apply to the selection of the bull, which, as experience demonstrates, acts like the cow in trunsmitting the milking quulities which distinguish the breed and stock.

\section{Digestion.}

The digestive ol'gans have a great influence on the exercise of all the functions, and particularly on the seeretion of the milk-glands. Where the digestive organs aro defective, good milch cows are rarely met with.

Good digestive organs are known by a belly of moderate size, with 
yielding sides, freo from tightness, (in nged animuls tho belly is often large, though the orguns whleh it contuins ure in good condition); u lurgo mouth, thick and strong lips, a good appotito, easy und quick digestion, glossy hair, supplo skin, yot firm, and somewhat vily to tho touch. Animals possessing these chnructoristics may bo expected to feed and drink heavily, and, if they are proporly fod, make much blood, and yield large quantities of milk.

\section{Respiration.}

The respiratory organs complete the systom of nutrition. The lungs bring the air breathed into contust with the blood, and render the system of nourishment complete. Henee, a good form, quick digestion and "henlthy condition of the lungs uro necessury to the production of a large tlow of milk.

\section{Milk Vains.}

If the veins which surround the udder are large, winding, and varicoso (dilated at intervals), they show that the glands receive much blood, and, consequently, that their functions are netive, and that the milk is nbundant. The veins on the lateral parts of the belly are most ensily obscrved, and all authors decide them to be among tho best tests for usecrtuining tho activity of the glunds.

These veins issuo from the udder, in front, and at the outer angle, where they form, in very good cows, a considerublo varicoso swelling. They proceed toward the front part of the body, forming angles, more or less distinet, often divide towards their anterior extromity, and sink into the body by several openings.

We can make the size of the milk veins prominent by compressing them in their passage, by pressing them at the place where they penetente into the body. If we press the thumb strongly into the opening through which the vein passes: the width of the opening represents the dinmeter of the veiu, and the thicknoss of the thumb which stops it, represents the volune of blood whose place it occupies. Sometimes the veins uro divided. It is then necessnry to examine all the openings by which they juss, in order to form a correct estimate.

\section{Veins of the Udder and Twist.}

The veins of the udder and twist are ahle to furnish valuablo inäications. They should, in both enses, be highly doveloped, lurgo und vuricose; that is, appear swollen and knotty. The veins of the udder have 


\section{IMAGE EVALUATION \\ TEST TARGET (MT-3)}
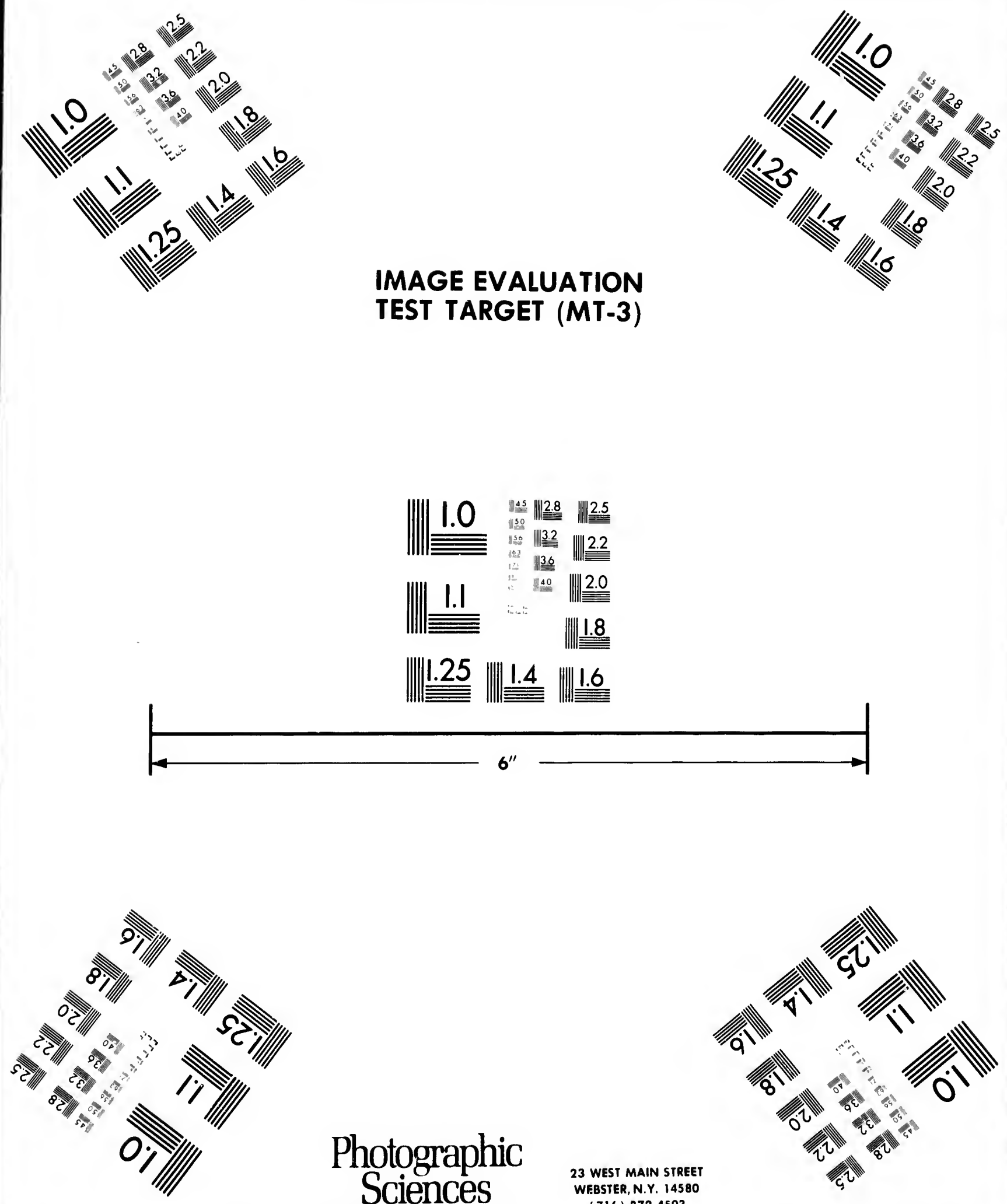

Photographic Sciences Corporation
23 WEST MAIN STREET WEBSTER, N.Y. 14580 (716) $872-4503$

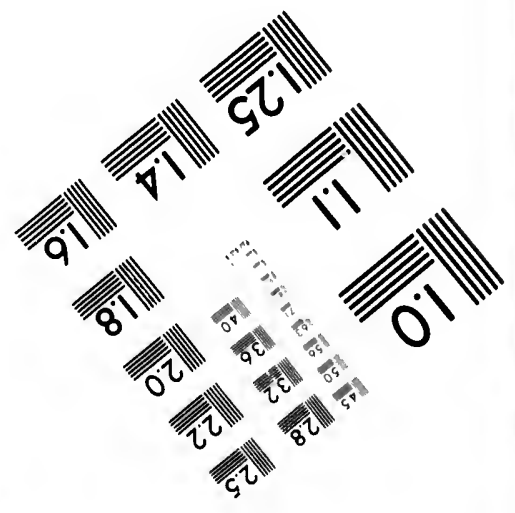


5

$\lim ^{3}$

$1 / 10$

18 
no difinite direction. They present themselves, irregularly, with zigzag liues, knotted, and more or less oblique. They are never of very large size, except in cows that give large quantities of milk.

The veins of the twist direeted from above downward, forming a winding line, interspersed with knots, resemble those of the udder in not being visible either in heifers or in cows of only fair milking quality. We cannot ascertain their presence in any but very good cows.

Of all the marks of abundant milk secretion, the best, and in fact the only infallible marks, are furnished by the veins of the twist and of the udder. To estimate them correctly it is necessary to take into account the state of the cow in respect to flesh, the thickness of skin, food, ability to stand fatigue, heat; all the eircumstanees, in faet, which cause variations in the general state of the circulation, and in the dilation of the veins. It is neessary, moreover, to recollect that in both sexes all the veins are larger in the old than in the young; that the veins which encircle the udder are those which, if the cows are in milk, vary most according to the age of the animal. Small when the auimal is young, they continue to inerease in size until after the cow has had several calves, when they come to their full development.

This proportion between the size of the veins and the milk secreted, is observed in all females without exception. The size of the veins and their varicose state being due to the blood attracted by the increased activity of the nilk-glands, is not only the sign, but also the measure, of this aetivity-this conneetion. In fuct, this connection is so elose that, if the glands do not give an equal quantity of milk, the larger veins are on the side of the udder which gives the largest quantity.

The length of time during whieh milk is given corresponds with the activity of the organs which supply it. Cows which give most milk a day, also give it the longest; and hence, if no special mark is pereeived, we cun judge mueh of the duration of milk by the marks which determine its quantity. It may therefore be accepted that as a rule an abundant milker may be expected to give a long continued flow of milk.

\section{Judging Age by the Teeth.}

For the reason that the age of cattle can only be approximately jugiged by the hor'ns, and in eonsequence of the liability to error, and especially - the doctoring of the horns by the use of the file, sand paper and oil, wo give a chart, showing from the cuts presented, the ages of cattle, from birth until they are five years old, when the teeth are fully developed, and also the appearance of the teeth at ten years of age. Thus at birth, it will be seen, there will be but two central teeth, figure 1 ; at two weeks it will have four teeth, figure 2 ; at three weeks it will have six teeth, 
h zigzag

ery large

ga wind-

er in not

ality. We

fact the

and of the

to account

ood, ability

eause vari-

tion of the

exes all the

which encir-

aost accord-

young, they

reral ealves,

secreted, is

he veins and

the increased

measure, of

close that, if

veins are on

nds with the most milk a is perceived, ch determine an abundant k.

hately jugiged nd especially and oil, we cattle, from ly developed, Thus at birth, at two weeks ve six teeth, figure 3 ; at a month old the jaw will contain eight incisors, and present the appearance as in figure 4 . The mouth is then called full, as contrining the ultinato number of incisors. These are not permanent, but temporary, or milk teeth, as they are called. At six to eight months old the central teeth begin to be worn, and show smaller than the others, sce figure 5. At ten months absorption and the widening of the jaw will have carried the two central teeth still farther uway from each other, and two other teeth, one on each side, will have begun to diminish, in fact will have distinct spaces between them, see figure 6. At twelve months absorption will have continued to two more teeth, leaving intact only the two outside teeth, figure 7. At fifteen ' months the whole of the teeth will present the nppeurance as seen in figure 8. At this time the true or permanent teeth will have been growing in the jaw, between and back of the mills teeth. Figure 9 shows the appearance at fifteen months of age, the two permanent central tecin appearing in the place of the two first milk teetl which have disappeared, and the other permanent tecth are shown in their several stages of growth. Figures 10, 11 and 12 show the teeth at two, three and four years past. At the age of five years the animal will have a full mouth, as shown in figure 13, and at ten years the incisors will present the appearance as in figure 14.

Thus any person by the use of the chart, and by examination of the tecth of cows, of ages known to correspond therewith, may easily become an accurate and prompt judge of the age of cattle, up to the age of four years. It will be seen, however, that in the four year old mouth, the two central pairs of teeth are beginning to be worn down at the edges, and in a flat direction, or inclining slightly to the inside; yet the animal has not a full mouth - that is, the incisors are not all fully up until it is five years old. See figure 14.

At five years old the teeth are all fully grown, and the peculiar mark on the teeth, called the cup, is shown in all. At the same time all will have become flattened, while on the two center ones there begins to be a distinct darker line in the middle, bounded by a line of harder bone. From this time on we may depend both on the incisors and the grinders. At six years old the animal will have acquired the last grinding tooth. This is the sixth molar and is, from the beginning, a permanent tooth. From this time until the cighth year, and indeed thereafter, in determining the age of the animal, the nature of the soil upon which it has been fed must be taken into account. Gritty, close fed pastures will wear them faster, and flusli pastures slower. Thus in all the pasture regions of the West, and Southwest, the wear will be light. As a general rule, but admitting of many exceptions, at seven years old this line is becoming broader and more irregular in all of the teeth ; and a second and bronder, 
and more circular mark appears within the center of the former one, the most distinct in the central, or two central pairs - and which at eight years has spread over the six central incisors.

At eight years, a change takes place which cannot be mistaken. The process of absorption has again commenced in the central incisors; it is slow in progress, and is never carried to the extent seen in the milk teeth, but is sufficiently plain, and the two central teeth are evidently smaller than their neighbors. A considerable change has also taken place on the surface of the teeth; the two dark marks are worn intu one in all but the corner teeth.

At ten the four centrnl incisors are diminished in size, and the mark is becoming smaller and fainter, as shown in figure 14. The six central incisors are smaller, and at twelve, all of them are very considerably diminished; but not to the same extent as in the young animal. The mark is now nearly obliterated, except in the corner tecth, and the inside edge is worn down to the gum.

From this time on they continue to diminish in size, and it is difficult to accurately determine the age. In fict except in the case of valuable blooded cows, bulls, or extra trained wosk oxen, and occasionally extra milkers in the dairy, few steers are now kept in the West past six yeurs old, and few cows over nine or ten years of age. 
one, the at cight ken. The sors; it is milk teeth, tly smaller lace out the all but the

the mark is six central considerably nimal. The ad the inside

it is difficult of valuable sionally extra ast six years

\section{CHAPTER VIII.}

\section{THE DAIRY.}

ROSHING INTO NEW INDUSTRIES, - THE IMPORTANCE OF DAIRYING. - ESTIMA-

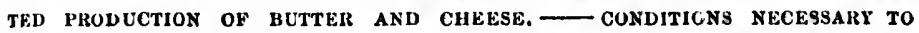
DAIRYING. - HOW TO BUILD.—- SUB-EAITTI VENTILATION. — CARE OF MILK, TEMPERATURE.-VARIOLS METHODS OF IRAISING CREaM. — MAKING DalRY BUTTER. - SALTINA BUTTER. — WASIING UR WORKINo BUTTER. - PaCKING bUtTer. - Preparing PaCKages - KIND OF SALT TC USE. - CheEse HAKING-CHEDdAR CHEESE.—CHESHIRE CHEESE.—HOW TO SELL BUTTER._- UTILIZING WASTE Products.

\section{Rushing Into New Industries.}

The impetus given to dairy farming within the list ten years, caused by the increasing export demand, and the large price which superior products both of butter and eheese brought in the markets at home and abroad, eaused many persons all over the West to r'ush into the business, supposing that flush pastures and eheap grain were the sole conditions of success. Unserupulous persons also made eheese of skimmed milk adulterited with olen-margarine. Butter makers adulterated their products with oleo-margarine, and extensive factories East and West, backed by large expita!, entered into tle manufacture of oleo-margarine ; vast qumitities of which were sold as butter. In addition to this many per'sons supposed it wus only necessary to stock their furms with eows, milk then, secure the eream, churn it, salt the butter and thus get rich. The result was, the markets were glutted with grease butter and skim or grind-stone cheese, as they were aptly termed, eausing the degradation of really good cheese of American make in the English market, for the reason that the markets being flooded with dishonest eheese, and the industry being in its iufancy here, but few makers had established a reputation, considered 
good beyond doubt in foreign markets. During 1878, especially, the price of cheese went so low as to eause much money to be lost in its manufacture. The consequence was, many, who went into the business hastily and witn few untural facilities for the manufacture, or knowledge of the business, ats hastily went out of it. In 1879 a reaction took plice, and both butter and eheese during the latter half of the year again paid the manufacturers large profits. These variations are not peculiar to this business alone, but they belong to every branch.

\section{The Importance of Dairying.}

Within the last ten yeurs, Ohio, Michigan, the northern half of Indiana and Illinois, southern und central Wisconsin, central Iowa, and later some portions of Missouri, Kansas, lind Nebraska have beeone great butter and ehecse prodvcing States, and the premiums awarded to Wisconsin, Iowa, and Illinois for dairy products at International and Inter-State fairs, show conclusively that there is plenty of territory in the West, where the conditions ure of t've highest order for the manufacture of first elass butter and cheese.

As showing the worth and importance of this industry in the West, we need ouly show the reeeipts and shipments, at two principal markets, Chicago and Milwaukee, the first for butter from 1869 to 1878 , inclusive, and Milwaukee for butter and cheese for the year 1878. That of Chicago was as follows :

\begin{tabular}{|c|c|c|}
\hline 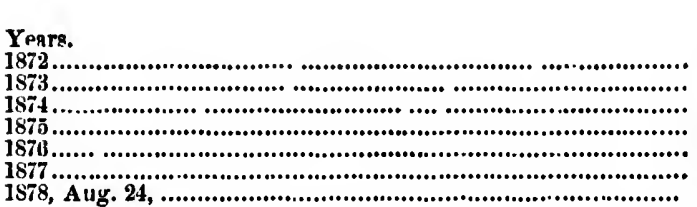 & $\begin{array}{r}\text { Receipts. } \\
\text { Ibs. } \\
\text { 14,574,777 } \\
\mathbf{2 2 . 2 8 3 . 7 6 5} \\
\mathbf{2 8 , 7 4 3 . 6 0 6} \\
21.868,091 \\
\mathbf{3 3 . 9 4 1 . 5 7 2} \\
\mathbf{4 2 . 2 3 6 , 3 6 6} \\
\mathbf{3 1 , 7 1 4 , 3 1 8}\end{array}$ & $\begin{array}{r}\text { Shipments } \\
\text { Ib. } \\
11,497.537 \\
12,851,303 \\
16.029,100 \\
19,249.081 \\
34,141,600 \\
36,514.983 \\
29,263,586\end{array}$ \\
\hline
\end{tabular}

For the regular butter season-May, June, July and to August 24, 1878, inelusive, the receipts have aggregated $21,414,520$ pounds, against 16 , 493,031 pounds for the same time 1877 -an increase of $4,921,489$ pounds. - The shipments for the same period-Muy to August 24th inclusive, aggregated 19,821,660 pounds, against 14,495,864 pounds for the corresponding time in 1877-an increase of $5,325,796$ pounds.

In Milwaukee the receipts for 1878 were :

Recelpts of Butter.... 6.111.286 lbs

Shipments of Butter. 5.739 .041 "

Recijptis of Cheese.... 13256.809 " 
ially, the $n$ its maness hastily dge of the place, and in paid the this business

If of Indiana d later some at butter and consin, Iowa, te fairs, show there the conit class butter the West, we cipal markets, .878 , inclusive, hat of Chicago

Shipments. Ib.s. 11.497 .637 $12.851,303$ 16.020 .190 $19,249,081$ $34,141,600$ $36,514.963$ $29,263,586$

ugust 24,1878 , $\mathrm{ds}$, against 16 , 921,489 pounds. inclusive, aggree corresponding 6. 111.2001 13256.809 $12,865.110$
The exports of butter and cheese from the United States, and value, for 1877 and 1878 are given by the Chief of the Bureau of Stutistics at Washiugton as follows:

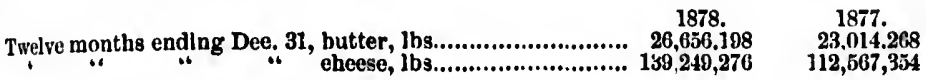

\section{Fstimated Produotion of Butter and Cheese.}

The value of land and cows in the United States employed in furnishing milk, butter, and choese, is not less than $\$ 1,300,000,000$, or the sum of nearly half the uational debt at its highest point. Over three thousand factories are engaged in the manufacture of these articles.

The production of cheese is estimated at $350,000,000 \mathrm{lbs}$. per annum, and of butter about 1,500,000,000; of the former, 130,000,000 lbs. will be exported this year, and $25,000,000 \mathrm{lbs}$. of the latter. The value of the two is about $\$ 350,000,000$ or $\$ 50,000,000$ more than the wheat erop of the ecuntry : three times more than the oat crop ; four times more than the potato crop; one-seventh more than the hay erop; one-third more than the cotton crop, and bat one-fifth less thun the corn crop. The number of cows in the United States is over 13,000,000, which is six times the number in Great Britain, over twice the number in France, two and a half times more than in Prussia, and more than in the countries of England, Ireland, Scotland, W as, Denmark, Norway, Sweden, Russia, Finland, Austria, Hungary and Svitzerland combined-although these countries together contain four times the population of the United States. The proportion of cows to the inhabitants here is twenty-three to each one hundred persons.

The production of cheese and butter increased thirty-three per cent. in 1877 and the exports have been in like proportion.

The eheese and butter exported in $\mathbf{1 8 7 8}$ have puid freight to the amount of over $\$ 1,000,000$ to the ocean commerce, or a sum almost sufficient to support a line of ocean steamers. These articles pay to the ruliroad companies over $\$ 5,000,000$ annually for transportation, and the article of milk pays nearly as much more. Loaded on railway cars, ten tons to euch ear, the butter and eheese produced in the United States in one year Trould fill 22,000 cars, and make a compact line 135 miles long.

It is estimated that Grent Britain, with a population of $32,000,000$, consumes about $260,000,000$ pounds of eheese annually, while the United States, with 50,000,000 inhabitants, consumes about 200,000,000 pounds annually. It is claimed that when only a good quality is put into the home market Americans will become as great cheese eaters as Englishmen. 


\section{Conditions Necessary for Dairying.}

There are three natural conditions necessary for the successful prose. cution of dairying: abundance of pure water, plenty of grnss and cheap grain. There are also three essentials in its munufacture without which no person ean sueced. These are, good cows, proper buildings and fixtures, and absolute eleanliness, from the stable to the package in which it is sold. Of course a thorough knowledge of the business must be possessed or acquired. If the dairy is conducted on the factory, associated, or co-operative system, only one person, the superintendent, need be an expert. Cold water is absolutely essential. In the West recourse must be had to ice for cooling purposes, except for the family dairy, and it is better there. The great drawback to dairying in the West has been the absence of cold springs and spring brooks. Deep wells, with windmill pumps, fully supply this need when there is an abundunt flow beneuth the surface, and when there is not, ice is used for cooling purposes. In fact, no large dairy, where butter is made, is complete without an ice house of sufficicnt cupacity, not only for cooling the milk, but also, to afford cold storage for butter. Whatever the size of the dairy, whether large or small, no person can make money in the manufacture without facilities so that the temperature of the milk and butter can be kept at 60 degrees or less. It is not our purpose to enter into details as to the minutia of dairy work on a large scale. The person undertaking the business must employ a competent dairyman as superintendent. The owner will have plenty to do in attending to the farm, the business details of manufacturing, shipping, selling, etc. To enable those haring grood facilities for the business to get an idea of the building, we give an illustration showing ground plim of model creamery.

The cut given is a model in every respect, not only in arrangement, but in cheapness. The main building is two stories, 52 by 26 feet, with two annexes as shown, and cost all told, including all the fixtures and apparatus, only $\$ 2,500$, the building itsclf costing $\$ 1,800$. The arrangements are made with special reference to economy of space, lubor aud travel ; to securing an equable temperature, and to the isolation of the creain and butter from odors that may arise in the manufacture or euring of cheese. The walls have three air spaces, one between the clapboarding and sheathing, one between the sheathing and building paper, and one between the building paper and plastering, thus making most perfect isolation. The windows are doublo. The milk, as received and weighed, is strained directly into the clieese vats, or into the deep cans, for the pool. This is about 20 inches deep, and is made by laying a brick wall to that height, and cementing it on the inside. It is supplied with water 
from a well near the rear of the building, pipes being so arranged that the stemu-pump can deliver either hot or eold water or stenm whero needed. Iee is used for this pool as needed. The press-room joins the manuficturing-room, and from tho door of this a stairwny leads to tho curing.room, which oceupies nenrly all the second floor; the front stairway leading to an office and to a bed-room for the attendant, in front of the enring-room, which is designed not only for the eheese made here, hut as a curing and storing-room for thint from severnl factories in the ricinity. The eheese is delivered, as sold, from a door in the rear of the curing-loom.

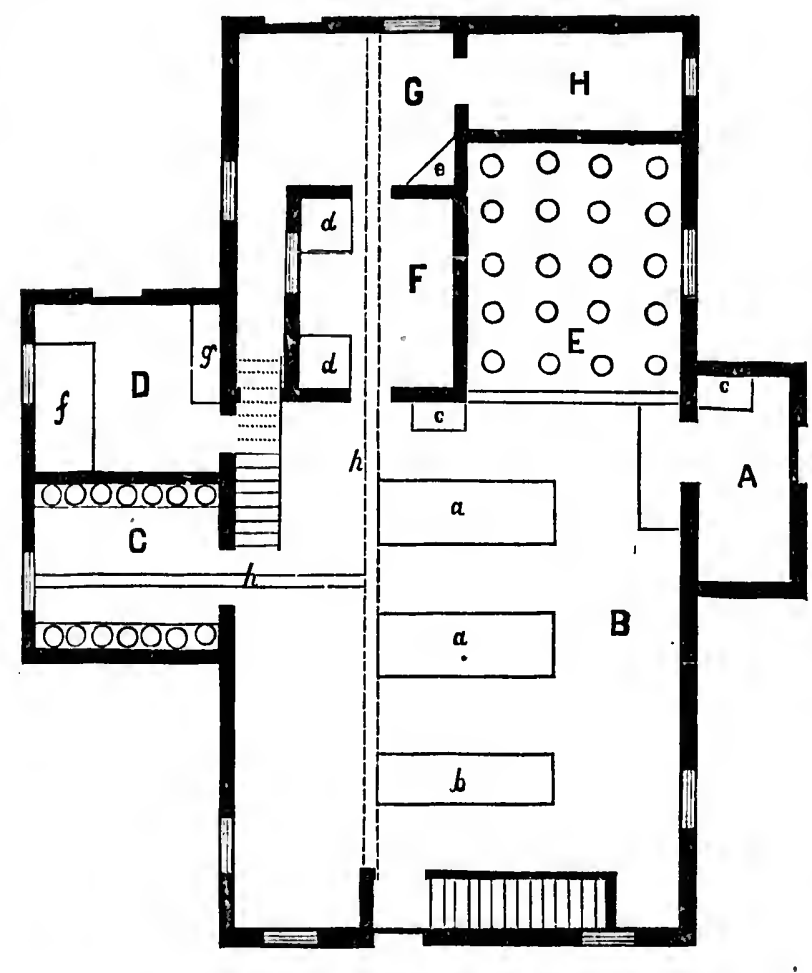

GROUND PLAN OF MODEL CREAMEKY.

Explanation-A-Milk receiving room. $B$-Cheese manufacturing room. C-Press room. $D$-Engine room. E-Pool. $F$-Crenm and churning room. G-Butter working and delivering room. II-Refrigerator $a$-Cheese vats. $b$-Curd sink. $c c-$ Wash vats. $d d$-Churns. $e$-Butter worker. $f-$-Boiler. $g-$ Engine. $h h-$ Whes drains. 
It will be seen that the cream und churning-room $F$ is a separnto enclosure within the main building, and which may bo entirely enclosed from the main room, so that when the crean is placed it may bo entirely isolated and kept so until churned and stored in the refrigeritor. Those contemplating erecting a creanery eannot well improve upon this plin, one of the most modern known, except it be in some minor details to suit local wants.

\section{How to Build.}

Where the drainage is good the lower story may consist of a bisement sunk three feet into the ground, of stone or brick, and it will be better if the whole building be of brick. The system of drainage should be mapped out, and a chart made. The drains should bo laid in the most perfect muner, and with full enough so they will not $\operatorname{cog}$. Besides the factory druins leading to the waste vats, there should also be tile drains to calry off surface water. The foundation of the floor of the fictory should, if possible, have a thin coating of tin shavings, or broken glass, say six inches thick well pounded down, and covered with water lime cement. Upon this a flooring of flugs or bricks maty be laid, covered with eement of water lime, which in time will become entirely hard, and the tin or glass below will prevent all burrowing of rats. The pipes, leading to and from the eisterns, etc., should be placed before the floon is laid, and the mortar carefully fitted to them. The jee-house should be plastered with water-lime, and a little vacancy left between the ice and the bottom of the house, to allow the water a small space. The top and side walls of the dairy-house should be finished with plaster, by which means a uniform tempernture, indispensable to curing cheese, is more perfectly secured.

\section{Sub-Earth Ventilation.}

Of late years Mr. J. Wilkinson has ndvocated a system of sub-earth ventilation, simply by a six-inch tile, laid six feet deep and 300 or more feet long from the building. Two of this length, -or better, one of twice the length, with a wing, and vane connected with the out-door end, to catch air and eonvey it to the tile-will keep the basement well ventilated, and of the earth temperature of the depth at which the tile is laid.

\section{Care of Milk.}

The first requisite is absolute and unqualitied cleanliness. Wo have already given directions as to cleaning animals before milking. The least 
rute encloosed from ntirely isool'. 'Those this plan, r details to

a basement 1 bo better if c should be in the most Besides the se tile diuins if the fuctory broken gliss, h water lime laid, covered rely hard, and t. The pipes, efore the floor -house should etween the iee pace. The top th plaster, by ring cheese, is

11 of sub-carth d 300 ol mole er, one of twice at-door end, to well ventilated, $o$ is laid.

hess. We hare ing. Tho least sloveuliness in the help, in this respect, should be soverely reprimanded, and if this does not avail, disclatrge hin, or her, at once ; it is as necessary as kind trentment of the cows.

If the milk is set in shallow pans, see that there is good ventilution to the dairy rooms, and that the paus are regularly sculded, and with hot, bubbling water-slight scalding will not do. Wipe dry, and sun, when possible. Allow no land odors to accumulate nenr by from garbage or other causes. For this renson the family dairy should never be in the house, since the stem and odor from cooking, the dust from sweeping, ete., will taint the milk, cream and butter. English dairy women ure many of them so particular that they will not allow the men who carry the milk from the yard to enter the dairy house. It is poured into a receiver outside and conducted in through a pipe, regularly scalded each time used, and covered tight from dust.

\section{Modern Home Dairies.}

One plan of setting milk is by the "Hardin system." By this system the milk is strained, immediately after being drawn, into deep pails and covered with a well-fitting lid, to exclude both air and water. It is then pliced in a refrigerator, with ice above it. The drippings fall upon the pails of milk and form a pool of water, in which they are allowed to stand.

When at cold spring of lumning water ean bo had the milk may be jumersed in deep open pails, in the cool waters. Unfortunately, in the Nest, springs are searce.

Another excellent plan for small dairies is that known as the Cooley system, setting the milk in deep cans; a medium sized refrigerator box, contuining spatee enough for from ten to twenty cows. These cans have close fitting covers, and are surrounded by ice cold water, and thus, if the heat and animal odor be expelled before putting in, there is no tainting or souriug. The cream is taken perfectly sweet, in from twelve to twenty-four hours. It is very compact, and may be economically used even in suall fumily dairies, of from ten to twenty cows, if the furmer cares to pay the royalty, the system being patented.

\section{Animal Odor.}

Expelling the animal odor is most important. To do this the milk is poured into a receiver, in the botton of which are a few sinull holes, through which the milk is allowed to drop into a tank, large enough and bigh enough to catch all without spattering. This tank stands in cold water neurly to its brim; in this the milk may remain about fifteen min- 
utes, when it may he set in ally of the ways we have mentioned. An. other plun is to heat the milk to 100 or 110 degrees and then allow it slowly to cool.

\section{Temperature.}

Good butter ean he mude, if the tempernture of the duiry-room does not go ubove 60 degrees. This is the proper temperature for churuing and working the butter. The tempernture for milk muy he much lower; it should not he higher from the time the milk is brought in unti? the butter is enrried away. So fur us storing the loutter is concerned, if the tempernture le kept at 40 degrees, so much the better. 'This, howerer, camnot be done without ice.

\section{Various Mothods of Raising Cream.}

G. C. Cnldwell, Professor of Agrienltural Chemistry, in Cornell Uni. versity, located at Ithaca, N. Y., iu relation to some Europonn methods, Bays :

"Among the different systems prevalent in Europe, we notice the Dutch method in which the milk is cooled down to 60 degrees in a witer tank, which requires usually from one and a half to two hours, and the milk is then set to the depth of four or five inches in a room where the temperatuse ranges from 54 to 60 degrees, and remains ahout twentyfour hours; the Irolstein method, in which the milk is set at ahout the same temperiture, without being first cooled in water, to the depth of one and one-hulf to two and one-half inehes; the Devonshire method, described us long ago as 1784 , where the milk is put in a conl room, standing at a deptli not greuter thun from threo to four inches for twelre hours; the vessel containing it is then set over the fire and heated till blisters begin to appeur in the eream, or to about 200 degrees, when it is set aside agnin for twelve hours; the cream is very firm in consistency and can he mude into butter loy simple kneading, and has a sweet, pleasant tuste. Mueller stutes that the skimmed milk does not retuin more than one per cent. of erenm; the Gussander method makes no account of tempernture, except that it shall not exceed 61 degrees, so that no milk cellar or but only a light, dry and airy room is required; the milk is put in lurge shallow pans, filling them to the depth no more than from ane to one and one-half inches; the milk is skimmed after twenty-three hours; in such a thin layer the milk is so well reruted that it remains sweet to the end, and the cream is swect and very rich in fat."

These various experiences should be very suggestive. 
innel. An. low it slowly

y-room does for ehuruing much lower'; in unti? thic erned, if the his, however,

\section{Cornell Uni.} openn methods, we notice the grees in n water hours, and the oom where the nhout twentybet at about the to the depth of onshire method, in a cool room, nelies for twelve and heated till grees, when it is in in consistency s a sweet, pleas. not retain more akes no accoult , so that no milk the milk is put thin from ane to nty-three hours; remains sweet to

\section{Making Duiry Butter.}

Mr. C. C. Buell, ono of the makers of high-easte dairy butter in the West, stated his modo as reported by the Secretary of the Illinois Duiryman's Associntion :

"Cows were common stock-Durham grades and sprinkling of Jersoy. Fed by running in fresh corn stalks during day timo, on timothy and clorer at night; in stable, with two messes of meal daily, consisting, by measure, of two parts corn and one purt onts, togethor with the grenter part of the sour milk and buttermilk from the dairy room. Number of cows, forty. The milk was strnined through an iron strainer into deep pails, ns soon as drawn, stunding in open air until the milking was finished. It was then strained agnin into the samo pails thruugh a double thickness cloth struiner. The milk was set in a room without fire, temperature being between 40 and 50 degrees, Fahrenheit. During a part of the time, the temperature heing above 50 degrees, the milk was set in water for twelve hours. The milk wus skimmed after standing twelve to forty-eight hours, it heing eonsidered desirablo to mix the newer and older eream, for the suke of flavor ; but the whole stood mixed together from two to four hours after the last skimming and during the process of warming to proper temperature for churning. Most of tho milk was skinmed a second time, the eream being included in succeeding churning. The churn (a dash chu'n with solid dasher, surface under neatlu concave), was started at n temperiture of 62 degrees; as the buttermilk began to appear a coujle of gallons of tolerably strong brino was added at in temperaturo of 58 degrees, and the churn stopped a moment afterward,-ns with the addition of the brine, at the proper temperature, the butter separates very rapidly. As much brine as necessary was used in washing down sides of churn, eover and dasher. The butter was then dipped into a bath of not more than two gallons of brine; a churning of forty or fifty pounds being washed in four purts, in the same brine. Remored to a worker with rolling lever; the butter was so handled as to mix with the proper amount of salt with the least working possible. It was then placed in a tub slightly packed, covered with brine and allowe: to stand three or four hours, when it was again placed on the worker, lightly worked and packed for market."

\section{Care of Milk.}

We have given the modes of some of the best butter-makers in the world. Now the prineipal points to be ohserved are: warm shelter, perfect quiet, fur the animals, absclute ejeanliness in all operations connected 46 
with the miik, from the time it is drawn until it is made into butte: Just as the butter is forming in little grimules, suddenly reduce the tein. perature to 56 or 58 degrees, so the butter will not mass together. is should never take less than half an hour to churn; quicker churning causes the butter to come salvy.

\section{Coloring Butter.}

The best coloring for butter is plenty of succulent grass in Summer, and rich feed in Winter. For home consunption we should nerer color butter. For sale it may be advisable. If so, use any of the pure preparations of annotto. It is perfectly hainuless. If used, stir it in the cream. As to quantity, this cannot be stated. It will rary with the season. Every person must experiment, only do not use too much.

\section{Salting Butter.}

Take the butter from the churn in its granular state, and salt at the rate of twn-thirds of an ounce to the pound of butter. Do not work it more than enough to fairly distribute the salt; and this by folding and pressing; let the grains of silt dissolve. It may stand from 12 to 24 hours before being worked the list time. Butter, through all the time and process of working, from the time it is churned until paeked, shoud be kept in a pliable, waxy condition, ahout 60 degrees Farenheit is right, so as to work easily, and the salt all the time be in a dissolving condition. It is utterly impossible to work butter well that is operated upon while either too warm or too cold, or that is allowed to beeome so between times of working. The benefit derived by standing after the first salting, awaiting the second working, is to dissolve the salt by the moisture in the butter, and so set the butter-milk free, that it maly be the more casily pressed out. The amount should not be more than will dissolve entirely, and this moisture should be well worked out before adding more. After this add salt sufficient to season to your taste, working to mix it erenly throngh the butter; then leave it there to cure and preserve.

A good average is about one ounce of salt to a pound of bitter: some tastes prefer less and some more. Three-fourths of an ounce to the pound is light salting, while one and one-fourth oune's to the pound is heavy silting. Wo use to the first salting just two-thirds of the smonnt, and after the second working add the balanee. Nerer go by gruess, but use the seales, and in this wily insure uniformity. No one can ancquire a reputation for good butter, who does not make a nniform article. It never yet was made by giressing. If on a churning of butter you guess

miny

good conil they it is t with of the ing a air. mith $t$ butter 
nto buttei. ce the tellgether. is ar elurning

in Summer, nevel color 10 pure prejstir it in the ary with the o !uuch.

nol salt at the o not work it by folding and from 12 to 24 gh all the time pucked, should renheit is right, lving condition. ated 1 poum while ome so between the first salting, the moisture in the more eisily dissolve entirely. ig more. After o mix it erenly rre.

of butter: somi in omnce to thic to the pound is s of the amomit, go by guess, but ne cim arquirc a form article. It butter you guess it three pounds less than it is, and on the salt three ounces mole than it is, you will make it far too salt. There should be a slight allowanee of salt made for the condition of the butter, for when it comes soft it usually contains more butter-milk than when it comes hard, and a greater percentage of the salt will be carried off in the extra whey.

\section{Washing vs. Working.}

Equally good results can be obtained by washing or working the milk from butter, when skillfully done muder favorable cireumstances. In either case the only 'object is to free the butter from the milk, with as little injury to the flavor or grain of the butter as possible. In washing butter, the datiger is mostly in injuring the flavor by introducing foreign mutter in the water, while in the other case, there is more danger in over-working and so injuring the grain. In localities where pure water eamot be obtiined, washing should not be resorted to, for butter is always sure to tike up the impurities contained, as it will the taint of any decaying regetalle or animal matter that may be near. Many wells and springs which the owners of, or users fron, believe to be pure and good, have in them decaying substances which render them entirely unfit for any use, much less to wash butter with. Decaying orgauie matter so introduced into butter acts very much like yeast in dough; at least, it starts a fermentntion, so to speak, which soon destroys the butter. Allow no surface water to get into spring or well, or any filth to remain in them, and if they are not highly eharged with lime, mineral or salts of any kind, there is no better or ensier method than to wash the milk out quickly and thoroughly before salting.

\section{Packing Butter.}

If for sale pack in good, strong, oak packages, whaterer the size that mily be decided on, and let them be uniform, clean, and nice looking. A good package will not sell poor butter, but a slovenly package will often coudem the best. Never use the round woocien hoxes, with handles, they are an abomination. In packing have the butter still at 60 degrees, it is then firm and yet not hard. First rub the package, hott om and sikes, with salt, just what will adhere. Put a quantity of butter in the midule of the package, and press down firmly-do not rub, but press, thus causing a perpendicular and lateral pressure ; thus you make all firm and exclude air. Then what brine remains in the butter will work to the sides and mith the salt prevent it from sticking to the wood. So continue mutil the butter is within an inch of the top. Lay on a cloth eut half an inch lurge:

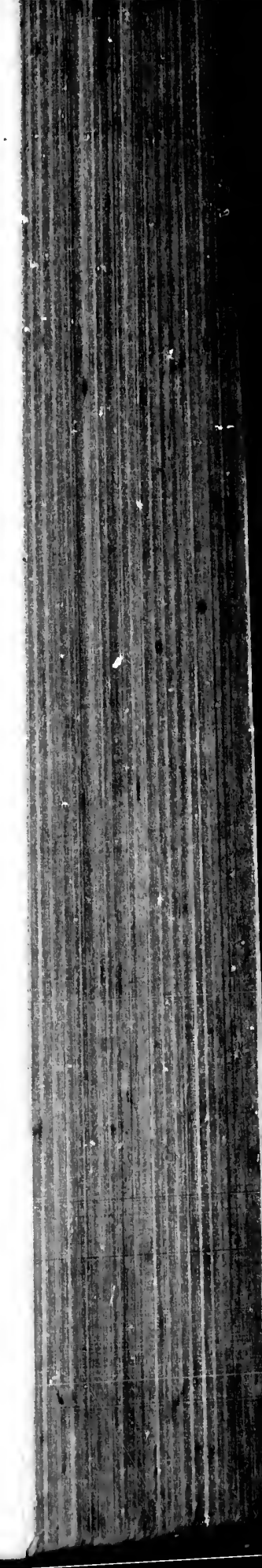


than the package, and wet with brine, working the edges down smooth, cover with a quarter inch of salt, cut another cloth an inch larger than the package, lay this on the salt, working smooth, as before. Head tight, bore a small hole through the head, fill full with brine, cork tight, and if kept level, and the butter has been properly made, it will come out all right when wanted.

\section{Preparing Packages.}

Use nothing but white oak; scrub them thoroughly inside and out with hot water and a clean brush; fill with clean, pure water; let them stand forty-eight hours in a cool place; turn out, scrub again with hot water, rinse thoroughly with cold water, and, while wet, sprinkle with . salt, what will adhere. It is then ready for use.

\section{What Kind of salt to Use.}

None but absolutely pure dairy salt should be used. So far as the manufacture is concerned there seems little to choose between the best American or English nuke. There is one thing about English goods, if warranted good they are so-laws against adulteration being very strict in England while they ure very lax in the United States. At a butter test some years ago before a committee of experts to decide if it could be discovered whether the samples were salted with English or American salt, the committee were very much at sea, guessing sometimes one way and sometimes another. Price being equal, we should use the best English dairy salt. Yet in all the best dairy salt, whether English or American, the impurities are so slight that in the salting of either butter or cheese there could be no taste whatever. If the impurity be sulphate of lime it would amount to nothing. It requires 400 times its weight to dissolve it, and there is almost no moisture in good butter. Another impurity is sulphate of magnesia, (Epsom Salts) which if present in sufficient quantity would give butter a peculiar but not a bad taste. Chloride of calciuml would give butter a sharp, pungent taste. and which would seriously depreciate the value both of the butter and cheese in which it was used.

\section{Cheese Making.}

The making of butter is both chemical and mechanical. It has this advantage, that any person can make butter as good as the best if absolute cleanliness is used; if there are no foul odors about the premises; if 
the temperature of the dairy be kept equal, and if pure water be used. This is all that is required, besides attention to a few simple rules. These we have givell, and there leave the subject.

The making of cheese depends almost entirely upon chemical action. Unless the conditions are right, good and uniform cheese cannot be made. These conditions can hardly be obtained in a farm house. Hence cheese so mude is never uniform, except in rare instances now and then in the hands of a perfect cheese maker. Such, if this strikes their view, should lose no time in building a factory, or engaging one already built. Hence it would be a waste of space to enter into the details of cheese making even in a general way. Yet many will want to make some cheese and we append an account of the process of some celebrated English brauds from the pen of Mr. John Chalmers Morton, of Eugland, who has written upon the subject in tho following concise yet comprehensive manuer :

\section{Cheddar Cheese.}

"The Cheddar cheese shall be described as it was carried on upon the farm of the late .Mr. Harding, of Marksbury, Somersetshire, who was oue of the best makers in England, and who did good work for cheesemaking in Ayrshire and other counties and districts which ho and Mrs. Harding visited on the invitation of agricultural societies and others for the purpose of giving instruction in the manufacture of this kind of cheese.

"The morning's and evening's milk are together brought to a temperature of 80 degrecs Fahr. If the night has been warm, a temperature of 78 degrees will give as great effectiveness to a given quantity of retuet as one of 82 or $84 \mathrm{dcg}$. would give if the milk had been at a lower tcmperature for some hours of a cold night. The evening's milk having been placed in shallow vessels during the night to cool, and having been stirred at intervals during the evening is skimmed in the morning, and the cream, with a portion of the milk, is heated up to $100 \mathrm{deg}$. by floating it in tin vessels on the boiler. The whole of it is then poured through a proper sieve into the tub - into which the morning's milk is being also strained as it arrives - so as to raise the whole, as I have said, to from 78 to $82 \mathrm{deg}$. Fahr. This tub may be a large tin vessel, capable of holding 150 gallons, and provided with fulse bottom and sides, enabling hot or cold water to be passed under and around its contents. The rennet, made from two or three dozen vells, in as many quarts of salt water, and allowed to stand three weeks, is added-half a pint to 100 gallons - and the curd sets in about half an hour. The small vells of

al. It has this he best if absothe premises; if
Salts) which if the butter and

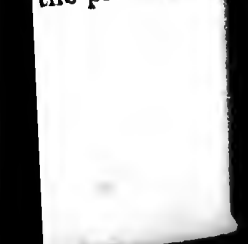
but not a bad de and out

So far as the een th the impurity be s 400 times its in good butter. 
Irish calves, which are killed at about a week old, are preferred, and they should be eighteen months old before use. The curd is slowly cut with a single long blade to and fro throughout its depth, in lines forming a 4-inch mesh upon the surface, and the whole mass is gently turned over from the bottom with a skimming dish and the hand. The whole is then agnin worked throughout with a "shovel breaker," a four-fingered paddle with wires across the fingers - great care being taken to do it gently, so that the whey shall not become too white. The curd is thus broken up into pieces not much larger than peas, and at least half an hour is taken in the process. Hot water is then let into the space around and below the cheese tub, and the whole is raised to $100 \mathrm{deg}$. Fahr.; and this, too, is done gradually, so as to raise the whole by degrees, not heating any portion to excess. This also takes half an hour. The hot water is then drawn off, and the curd is stirred by the land and a skimming dish for another half hour in the midst of its hot whey, being at last reduced to a mass of separate bits the size of small peas. The whey, after settling for half an hour, is then removed-ladled, syphoned, or drawn-to its vat, where it stands about six inches deep, and is skimmed next day, vielding a butter, which should not exceed in quantity six to eight ounces per cow per week.

The curd stands half an hour after the whey is drawn off, and it is then cut in four or five pieces, turned over and left for half an hour, after which it is ngain cut and left for a quarter of an hour. After this, it should be in the slightest degree acid to the taste. If allowed to become too acid, it will not press into a solid, well-shaped cheese, but will be apt to sink broad misshapen. It is now torn into pieces by hand and left to cool: and thereafter it is packed in successive thin layers in the vat-a cylindrical or wooden vessel twelve inches or more wide and twelve inches deepwhence, after being pressed for half an hour, it is taken out (it is then probably midday,) and broken up by hand, and allowed again to cool. Then, when cool, and hard, and sour, and dry, and tough enough, (all this, of course, being left to the judgment of the maker), it is ground up in the curd mill ; two pounds of salt are added to the ewt. of curd, and the whole is allowed to cool, and as soon as cold, it is put in the vat, und taken to press. It is then probably $3 \mathrm{p} . \mathrm{m}$. The pressure on the cheese may be $18 \mathrm{ewt}$. The cloth is changed next morning. A ealico coating is laced on it the second dny, and the third day the eheese may be taken from the press, placed in the eheese room, bandaged, and turned daily, and afterwards less frequently. The cheese room should be kept at nearly 65 degrees Fahr. The checse will not be ready for sale for three months.

The process lasts nearly all the day, but it is believed to produce the best cheese in the world; and its use is everywhere extending. Taking 
1, and they

cut with a

ing a t-inch over from $s$ then ugnin paddle with tly, so that ken up into is taken in $d$ below the this, too, is heating any water is then ing dish for it reduced to after settling rawn - to its ed next day, o eight ounces

, and it is thell ur, ifter which is, it should be come too acid, be apt to sink d left to cool: -a eylindrical inehes deepout (it is then again to cool. th enough, (all it is ground up t. of curd, and in the vat, nun e on the cheese calico coating is may be taken d turned daily, e kept nt nearly $r$ three months. to produce the nding. Taking its name from a single parish, it now prevails all over North Somersetshire, and is gradually extending into Wiltshire. Many dairies in Gloucestershire adopt the system; and some of its churacteristie details are followed in Cheshire; and it is well known in Laucushire, Ayrshire, , und Galloway.

The Cheddar cheese is made of various sizes, generally twelve inches wide and a foot high, but sometimes larger in both dimentions, and from 70 to 100 pounds in weight; the object being to make all the milk of one day on a farm of thirty to forty cows into a single cheese.

\section{Cheshire Cheese.}

Cheshire cheese, like the Cheddar, is made only once a day. The evening's milk is placed, not more than six to seven inches deep, in tin ressels to cool during the night, on the floor of the dairy ; it is skimmed in the morning, and a certain portion is kept for butter-in early Summer, only enough, perhaps, for the use of the house, but in Autumm more, and in some dairies at least, nearly all the morning's cream is thus tnken for churning. The skimmed eream, with a portion of milk, is heated up to 130 der. Fillu. by floating the tins which hold it, on the boiler-sufficient quantity being taken to raise the whole of the evening's and morning's milk together to $90 \mathrm{deg}$. or thereabouts. The rennet is made the day before it is used; 12 or 14 square inches of "vell" (rennet skin) standing in a pint of salt water, kept in a warm place, making rennet enough for 100 gallons of milk. The Irish vell (rennet skin) is used, as it is obtained from very young and milk-fed calves.

The curd is set about 50 minutes; it is then cut with the usual curdbreaker, a sieve-shipped cutter, very slowly. The whey is syphoned, pumped, or lifted out as soon as possible; but before it is all removed a portion is (on some farms where the Cheddar system is followed), heaicd and returned to the tub, and the curd is left in this hot whey for half an hour. The whey is then drained away and the curd is left to get firm. When firm enough to stand on the hand in cubes of about a pound weight -this is an intelligent indication-without breaking asunder, it is lifted out on the drainer (a falso bottom of rods), in a long tub with a stop-cock to it, and there left covered up for 45 minutes, after which it is broken up and well mixed with the hand with 3 1-2 to 4 1-2 llbs. of salt per ewt. It is then allowed to stand with a light weight upon it for about threequarters of an hour longer, and is turned over once or twice during the time, being eut for the purpose into squares with a knife. It is then twice passed through the curd mill, and at length put into the vat, a cloth being first pressed into placo by a tin hoop, and tho salted ourd being packed

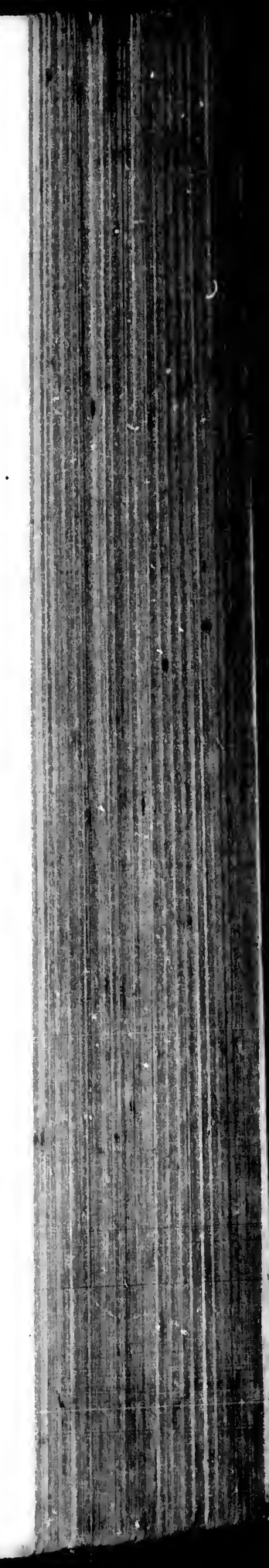


gently by hand within it. The vats will hold a cheese of 70 or 80 up to $100 \mathrm{lbs}$; and tin hoops, placed within them, are used to eke theu out, and give capacity for a larger quantity of curd if necessary. After standing in the vat, with a weight upon it, from one to two hours, according to the weather, it is turned over and put, still in its vat, into the oven,a warm chamber in or near the brickwork of the dairy chimney-where it remains at a temperature of $90 \mathrm{deg}$. to $100 \mathrm{deg}$. during the night. Both when in the press and here the cheese is skewered, skewer's being thrust iuto it through holes in the vat and every now and then withdrawn, so as to facilitate the drainage of the whey. The cheese is taken out of the vat in the morning and turned upside down in a fresh cloth. It is in the press three days, and it is turned in the press twice a day, being diyclothed each time. It is then taken out dry-clothed, bandaged, and removed to the cheese room, where it is turned daily, and at length only occasionally, until it is ready for sale. In some dairies all skewering is dispensed with, and no pressure is used at the time of making, nor for two days afterwards, but the whey is allowed to run out of its own aceord. Cheese manufactured in this way requires from 5 to 7 days in drying, but afterwards matures nore quickly for market.

The cheese varies considerably in qunlity throughout the year, the earlier make of March and April being considerably less valuable than that of Summer and early Autumn. Some of this varying quility is owing to the quality of the milk, the cows being house-fed; but more of it is, in all probability, owing to the necessity of holding a portion of curd over from day to day, when the quantity is insufficient to make even one, or it may be two, full-sized cheeses daily. In such cases it is conmon to make one full-sized cheese, and hold the remainder of the eurd over till the next day, keeping it wripped up on the drainer or pan, and grinding it up in the curd-mill along with the curd of the next morning.

\section{How to Bell Butter.}

There is never any difficulty in selling good butter at a liberal price in any market, however low grease butter may be. The maker of prime butter need never be in a hurry to sell. The butter once made, wiLl KEEP. But it will not be necessary to keep it. There are always purticular people in every town, however small, who are ready to take good butter at good prices. Thus it is usual for makers to contract to supply during the year at a stipulated price. During the flush season of grass, butter is packed down, to be drawn on when needed. Thus the manufacturer always has a supply on hand, and the customer is more than satisfied to have a good, sweet lump of butter on his table every day in the 
or 80 up to them out, fter stand, accordiıg the oven,$y$-where it ight. Both being thrust lrawu, so as in out of the It is in the , being dryaged, and ret length ouly skewering is king, nor for s own accord. in drying, but

the year, the valuable than ing quality is ; but more of a portion ol $t$ to make even ases it is conler of the curd er or pan, and next morning.

liberal price in haker of prime ce made, whL o always partic$y$ to take good triact to supply season of grass, Thus the manumore than satisovery day in the year, and does not grudge the extra five cents above what he would have to pay the grocer, for what those who do not know the difference might suppose was good.

If a lurger quantity is made than will supply the family trade of the village, the large markets are always open, and there good butter will always bring a good price. All that is wanted to know is that the butter is mude by one whose reputation is established and who would not sell a bad article, and all that ean be made will be eagerly taken. It is simply a question of cleanliness, attractivo package, careful attention to the details in making, and as careful a determination never to ship when there is danger of the thermometer going below 60 degrees. The rest is all plain, clear sailing, with large profits accruing. To insure large profits from dairying, the muster must be about carly and late, night and day, and Sundays as well.

\section{Utilizing Waste Products.}

The skim milk, buttermilk, and whey, must be fed either to calves or hogs. As far as whey is concerned, there is not much good in it for the nourishment of ealves, unless it be supplemented largely with meal and oil-cake. A shoat will fatten on the waste products of the dairy, one to each.cow, by using a very little corn. Some dairymen prefer to feed the waste to the cows. This is probably not the best use to which it could be put. Skim nilk and buttermilk is worth more to feed to calves, we believe, than disposed of in any other way. Here again we will give the experience of Mr. I. H. Wanzer, of Illinois, who believes with us that to make dairying permanently profitable, the raising of dairy cows must be a part of the business. To close the chapter we append his statement:

I tried the experiment, last season (1875), of raising calves upon the skimmed milk from my creamery; and as the result of this experiment may interest some of you, I will give you a few figures kept in comnection with the experiment, from which you may draw conclusions as to whether it pays to raise calves in connection with a creamery or not.

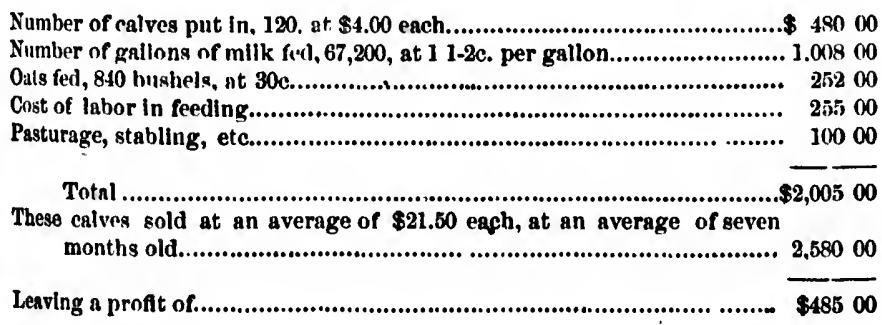


This amount passed to the credit of the milk would bring it up to two cents per gallon, which is equal to six cents per pound for cheese, and this kind of eheese would not have brought three cents per pound at the season I fed it, for it will be remenbered that this milk set thirty-six to forty-eight hours, and all the cream was taken out.

I am so much encouraged in this way of raising calves that $I$ expect to stock ngain the coming senson. I have now fifty-five young calves and ten older ones. Many of my neighbors and patrons ure bringing their best heifer calves to me, and marking them, expecting to bid them in at my sale next Fall, I paying the market price for them when received 


\section{PART IV. \\ Diseases of Cattle;}

THEIR CAUSES AND PREVENTION ; HOW 'TO KNOT THEM; WHAT TO DO. 



\section{DISEASES OF CATTLE.}

THEIR CAUSES; HOW TO KNOW THEM; WHAT TO DO.

CHAPTER I.

Diseases in General-Recognizing and Distinguishing Them.

PARMERS SHOULD UNDERSTAND SYMPTOMS - OF DISEASEg IN OENERAT.- - USR COMNON SENSE. - GRADUATION OF DOSEs. - FREQUENCY OF ADMINISTERING.- PORMS OF DOSES. - nOW TO GIVE MBDICINE. - INJECTIONS. VAPOR, SPRAYINO AND FUMIOATION. — ANESTHETICS. - TO DEPRIVE OF SENSATION. - BLISTERING. - FIRING. - SETONS. — ROWELS. - SEWING UP WOUNDS. — FOMENTATIONS.—-OPEHATION OF BLEEDING. — RECOGNIZ-

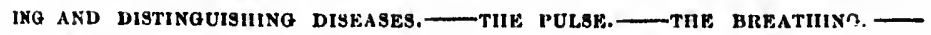

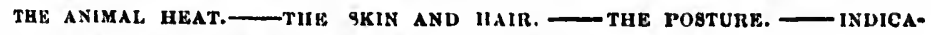
tIoNs on pain. - SPECIal signs hN cattle.

\section{Introductory.}

The immense value of the stock interests of the United States and the frequent outbreak of introduced contugious plagues, and of enzootic, eqizootic and various epidemic disenses, that at intervals have visited locilitics of swept over whole continents, would seem to call for special traiuing in veterinary science and art in every agricultural college in the United States; yet, until within the last few years, but little nttention bas been paid to this profession, and to-day the subject is not given that attention its importance demands, except in a few instances. Veterinary surgery has heletofore been flippantly termed "horse doctoring" by professors, and heads of too many of the colleges, endowed with the people's money "to teach such branches as relate to agriculture and the mechanic arts." 
Of late, however, n more enlightened course has been pursued, Mnay of the ngriculturul eolleges mre puying uttention to this importmit study, especially since the violent outbreak of splenic fover over the West mil Liast from the introduction of l'exus cuttle, and still more lately from the outhrenk and sprend of contagious pleuro-pmeumonit in a numiler of the Atlantic Stutes. Owing to the low state of veterinary science ar(n)ernlly, and the disdain with which the few highly educuted und thoronghly scientific investigntors in the United Stutes - mostly French and Ginim graduates - have been looked down upon by those who should have been too glnd to weleome them to the profession of medicine, and the esterm in which mere quacks and leeches huve been regurded by the eonmmity two notnlle fucts are made putent: First, the exclusiveness of ed inin puffed up "college Dons," who suppose that all knowledge must come from elissic soures. Serond, thint the people at lurge, furmers and stock ruisers, who from their halits and truining could not be supposed to understand surgery or medicine, except in its simplest forms, have been thrown into the clutches of mere pretenders to anatomical knowledge and the trentment of disenses. Of lute there have been many honorible exceptions, until now nemly or quite all of these people's collougs, foreed thus in muny instances by public outery, are taking strong means to foster veterinary science, and mnke it what it should be, and really long has locen in other enlightened countries, an importunt, as it is an honorable branch of humm seience.

There are mally valuable works extant in various languages, upon veterinary science and practice. They will be of little value to farmers and stockmen; all that this cliss ean denl with must necessurily be only those symptoms that can readily be disecrned, and remedies so simple in their niture that they cim be easily proeured and applied. In falct great care and attention should be given to first symptoms, as also to good nursing. Diseard all strong physics, und heroie trentment by purging, bleeding, and the surgery of main strength. Good care and nursing in the treitment of animals is now regarded (as it is in the treatment of human patients) as among the most important menns of cure. Indeen with animuls it is of the greatest importa.ce, since brutes are only alle to indicate the region of pain and disease by mute signs, entirely unintelligible in the mijority of cases to the ordinary observer.

\section{Of Diseases in General.}

In the deseription of symptoms, and the treatment of diseases, it would be out of plice here to go into learned discussions on the uature and pathology of diseases; so also it would be futile to dilate upon the 
al. Mimy

unt study,

West mind

litely fiom

numblocl' of

cirince gr(1)-

thoromghly

und Gormun

1 hisio been

the estrous

mumity two

astuin puffel

come fiom

's and stock supposed to

s, liave been

al kinowledge ny homorible theugses, forced ing means to d really long 3 an lonomble

guages, upou e to farmers surily be only s so simple in In fuct great also to good t by jurging, ad mursing in treatment of curre. Inderel are only alik' entircly unin-

of diseases, it on the miture late upon the symptoms and treatment of disenses. Only those most common, or futal, will be specially noted. Fortunitely veterinury art is congenial with tho medicul trentment of the humu fumily, and the same paths thut lend to " knowledge of humun disenses will indicute to uny intelligent local physician the menns to be used with brutes. Humune pliysicti:ne, now-il-dilys,-to their credit he it suid,-me not slow in coming to thr relief of the furmer mnd stockmm in preseribing and giving ndvice in the ahsence of regular veterinury surgeons. Such are verituble benefuctors, imismuch ns they grently ulleviate distress und do much to diseourage quatekery ; und when found, they should be frecly consulted. 'This deviition from tho regular medicul proctice, owing to the sparsely settled niture of many portions of the country, seems very necessary and eren inperntive.

In the prescriptions for cattle, we shall use the most simple formulns possible, wherever found, und whitever simple medicines will arail, aspecially those compounded of herlss, as better ndupted to the trentmont of domestic animuls. In connection with these, ofler ngents, both mineril and mechumienl, must be employed. In short, whit wo have nimed at is to stite symptoms and remedies for sueh disenses as may be treated withont the advice of a regular veterinary surgeon, and in such langunge as any intelligent person muy under'stumd.

In this, whil : we shall not attempt originality, except it may he in the matter of presentation in some instances, we shall use and quote from tho very latest anthorities in veterinary science in the United States, England, France, Germany, Austris, Belgimm, Hollund, Sweden, Italy, and other minor countries, where veterinury seience hus been necorded thut respectability whieh should accrue to $n$ lahor having for its aims the saving of life, and the amelioration of suffering, in $n$ direction second in importance only to that of the human family; and in preventing loss, so far is it mity be possible, of live stock, the mising of which is of arenter importance to mankind than any other single human industry. Thus, in presenting symptoms, we shall use and quote freely from the lntest works in reformed practice. What we present will not be as secking so much to aid the reterinary practitioner, as the farmer himself; not a work to supersede other authorities, but a substitute, in a limited sense, as to the treatment of certain diseases, so that the intelligent reader may comprerhenrl; advising, in every ease, when the operator does not understand the symptoms clearly, to seck the advice of the professional reterinarian, if such mity be had. If such be not within reach, then censult the best physician in the neighborhood. Diseases are substantially the same in canses, symptoms and treatmont, whother men or beasts be their subjects. Remembering this may suggest a helpful eourse of treatment in many cases. 


\section{Use Common Sense.}

Why, in the sickness of animals, the owner should try random remedies, and go from one to another, at the suggestion of each different adviser, as the matter may seem to strike them, is inexplicable. In nine cuses out of $t \mathrm{n}$, with proper nursing and care the animal will recover, simply by keping the bowels moderately open by mild physics and injections (which will be indicated) when costiveness and impaction is present; or by sedatives, stimulants-and astringents when the reverse condition is exhibited.

Such conditions as are often fatal during the gravid state of female animals, and succeeding delivery, abortion, false presentation, etc., and the means of relief; contagions and epidemic diseases-these from their special importance will receive due prominence. Of the non-contagions and local diseases every farmer should seek to make himself familiar with the symptoms, so that ready means may be used for the relicf of suffering animals.

In all this detection and treatment the operator must he guided by intelligence and use the least possible exhibition of force. It may be necessary to hamper an animal for the performance of some operation. When necessary, it is not merciful to use half-way measures. The humane man, however, will do so with as little pain to the animal as possible. If necessity should require killing as the best means of dealing with the ailment, the humane man will be actuated by no sentimentality about taking the life of an animal. He will kill promptly and surely, as the best meaus of alleviating the suffering of the aninal, or of preventing the spread of infections and contagious diseases. Prompt measures under these conditions will often save the loss of many lives.

\section{Graduation of Doses.}

A. a zule cattle require one and a half times as much as horses; sheep and pigs require one-third as much. Professor James Law, of Cornell University, in his work, Veterinary Adviser, has presented the mumer of graduation, frequency, and form of administering doses, in the following concise language :

The doses given may be held applicable to full-grown animals of medium size, therefore some allowance nust be made in any cases in which the patient exceeds or comes short of the avernge of his kind. A similar modification must be made as regards young animals, not only on account of their smaller size but also of their greater susceptibility. The following table may serve as a guide : 
TABLE OF DOSES FOR DIFFERENT ANIMALS.

im remedies, ent adviser, a line cases over, simply ad injections preseint; or condition is

ate of female ion, etc., and sse firom their non-contagious mself familiar - the relief of

be guided by iay be necessary elation. When e lumuane man, le. If necessity the ailment, the ng the life of an ins of alleviating of infections and is will often save

s horses; shicep Law, of Cornell ted the manner doses, in the

own animals of in any cases in of his kind. A nals, not only on ceptibility. The

\begin{tabular}{|c|c|c|c|c|}
\hline Horses, etc & Cattle. & Sheep. & Sivine. & \\
\hline $\begin{array}{l}3 \text { yenrs. } \\
11-4-3 \text { years. } \\
0-18 \text { wowths. } \\
5-9 \quad \text { " } \\
1-5\end{array}$ & $\begin{array}{l}2 \text { yeurs. } \\
1-2 \text { " } \\
6-12 \text { months. } \\
3-6 \\
1-3\end{array}$ & 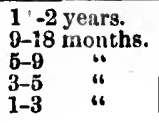 & $\begin{array}{l}15 \text { inonihs, } \\
8-15 \\
6-8 \text { " } \\
3-6 \\
1-3\end{array}$ & $\begin{array}{l}1 \text { purt. } \\
1.2 \text { part. } \\
1.4 \text {. } \\
1-8 \text {. } \\
1.16 \text {. }\end{array}$ \\
\hline
\end{tabular}

Al!owanco must also be made for a nervous temperament, which usually randers an animal $m$ re impressiblo; for habit, or continued use, which tonc's to decrease the susceptibility for individual drugs ; for idiosyncrasy, waich ean only be discovered by observing the action of the agent on the naticular sujject, and for tho infuence of disense when that is likely to iffect the action. 'I'hus, in most diseases of the brain and spinal cord, and in some impactions of the stomnch, double the usual quantities of purgative medicine will be necessary: while in influenza, and other low ferers, half the usual doses may prove fital. In acute $\mathrm{c}$ ngestion of the brain, stimulating narcotics (opium, belladomna, hyoscyonnus) would aggravate the symptoms, etc.

\section{Frequency of Administering.}

Anodynes, antispasmodics, narcoties, sedatives, and stimulanta, may generally be repented once in four or six hours in order to maintain their effect. Alteratives, diaphoreties, fel)rifuges, refrigerants, and tonies, may be administered twice duily. Purgatives should only be given when necessary, and should never be repeated until from the lapse of time we are assured that the first close remains inoperative. Thus, unless in urgent need, a horse should not take a second dose of physic under thirty-six lours after the exhibition of the first; and in all cases, until the medicine has worked off, he should be kept at rest and allowed only warm bran mashes and water with tho chill taken off. In ruminants a second dose may be rentured on in twelve or sixteen hours, and in carnivora (dogs, ete.) and omnivora (swine, ete,) in from seven to ten hours. Emeties should be given in full doses, and repented in five or ten minutes if they fail to take effect, their action being further provoked by copjious draught: of tepid water and tickling the roof of the mouth with a feather.

\section{Forms of Doses.}

Drugs may often be given as powder or solution in the food or water; they may be made into a soft solid with syrup and linseed meal, rolled into a short cylinder and covered with soft paper ; they may he enverted into an infusion with warm or cold water, or into a decoction by boiling; 47 
or they may be powdered and suspended in thick gruel or mucilage. They may be given, in a liquid form, from a horn or bottle; or, as a short cylinder or pill, which may be lodged over the middle of the root of the tongue; or, as a sticky mass, they may be smeared on the baek of the tongue ; may be given as an injection into the rectum; or, finally, in the case of certain powerful and non-irritating agents, they may be injected under the skin.

No agent should be given until sufficiently diluted to prevent irritation, if retained a few minutes in the mouth, and irritants that will not mix with water (oil of turpentine, Croton oil, etc., ) should be given in a bland oil, in milk, or in eggs after being thoroughly mixed.

\section{How to Give Medicine.}

Few things are so awkwardly done, as a rule, as giving medicine to farm animals. In the hands of a careful and expert person, il strong glass bottle is good. A better instrument is a flattened bottle of block tin, which for eattle should hold two quirts. The most usual instrument, and on the whole the best for ordinary operations, is the horn. Select one of which the point turns down and the lange end up; form this of the proper size and fashion so the opening will be oblique.

Drenches should alwitys be thoroughly mixed, and well shaken before they are given. If a fic of coughing ensues, free the animal at once and until it be ended. In operating with cattle do not irritate the animal unduly. Alnays operate from the right or off side. Pass the left hand over the head, and in front of the horn, seize the upper jaw firmly in front of the grinders, turn the heid firmly hack, the operator standing well braced, the back firm against, and as well forward of the shoulders as possible. Thus having the mimal with one side against a wall, or the side of the stall, it must be a very vicions ('ow or bull that a strong, expert min cannot handle. If, however, the operitor does not stand well forward and well braced, he may be severely kicked, since an ox, like a deer, can reach well forward with their hind fect. The usual qumity for an ox is from one to two quarts at a dose, if liquid, of ordinary decoctions and solutions.

\section{Injections, or Clysters.}

A large number of medieines, both liquid and solid, may he as easily administered per rectum as by the mouth. In administering injections, it is not necessary that much pressure be used. The intestinal canal of animals is lower than the opening. Thus fluid substances will fall by 
muciłage.

e ; or, as a of the root un the back or, finally, hey may be

it irritation, vill not nix in a bland

medicine to soll, a strong ttle of block ll instrument, horn. Select rint this of the

shaken before al at once and the animal unthe loft hand jaw firmly in pator stiluding the shoulders a wall, or the strong, expert tand well foran $\mathrm{ox}$, like a nsual yuntity f ordinaly de-

ly ive as easily ing injections, timal cantal of es will fall by their gravity. A good instrument for use may be a pail, with a tube cxtending from the bott me connecting with a half-inch rubber hose, of suitable length, so that the pail may hang just high enough above the animal to be out of their reach in unoving about. Oil the end to be in. serted into the reetum, and the fluid niay be passed into the gut, as much or as little as may be desired, and with much better effect than when strong pressure is brought to bear on the fluid.

When solid substanees are administered per reetum, they are ealled suppositories. They are often useful and simple, as in the ense of a smill cylinder of soap, for young calves, to encourage the action of the bowels and ducts: and in the ease of cows, in the use of disinfectants, to purify the discharges and lessen the danger of puerperal fever; suppositories are made into form by means of soap, starch, lard, ete.

\section{Vapors, spraying and Fumigation.}

These are medic:ments drawn in with the breath. Chloroform and other maly be administered by means of it sponge filled with the agent and

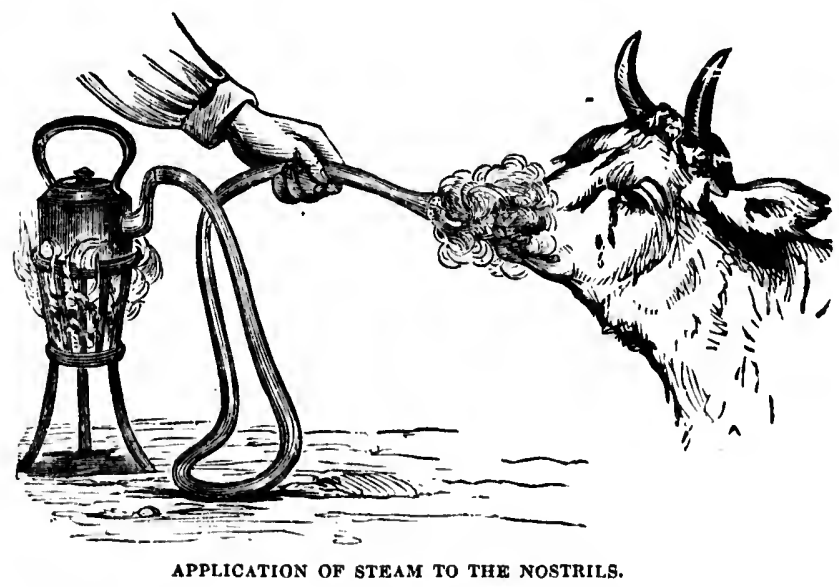

held to the nose. Vapors are easily produced from liquid substances by means of an atomizer, sold by all druggists.

Steaming is often of grent henefit. Hot water, either plain or medisated, may he held under the animal's nose, and the steam strongly driven off by plunging a hot iron into it at intervils. A hot hran mash, in a nose hig, readily gives off steam. A better form for steaming the nostrils would be that given above. 
For the promotion of discharge of the nostrils, the nose-bag will be indicated; its form and fastenings are shown in the annexed cut.

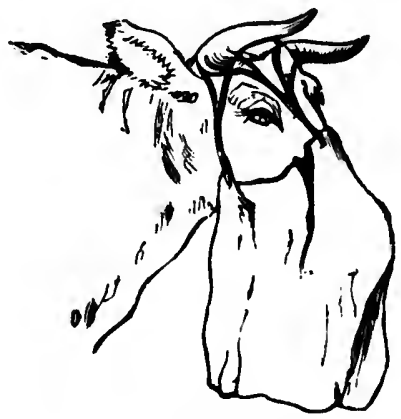

NOSE B.AG FOR ETEAMIXG.

Powders for easing the expulsion of the secretions of the nostrils, or for local application to diseases of the inmer surface of the nose, may be a simple tube of tin in two parts, which may be taken apart and put together like the joints of a stove-pipe, with a rubber tube on one end and a mouthpiece on the other. Charge with the powder, and blow with sufficient force to carry the agent where wanted.

When an anssthetic is used. it should not be held to the nose er itinuously, since, if undiluted wi.h air, it is fatal. Watch carefully and suspend the use of the anrsthetic as soon as unconsciousness is proluced, to be renewed from time to time as may be necessiry. They should not be used unless under the adrice of a surgeon or physiciun, since the need can hardly be cxpected except for the performance of some intricate surgical operation. The following is endorsed by high veterinary authority :

No 1.

$$
\begin{aligned}
& 10 z . \text { nleohol, } \\
& 20 z . \text { chloroform, } \\
& 30 z \text { ether. }
\end{aligned}
$$

Shake the bottle well before using it ; pour a teaspoonful or more at a time on a sponge; hold it to the nostrils. Two or three inoments should be enough to overpower the strongest ox.

\section{Blistering.}

Blistering is a valuable remedy, when it is required to ease the absorption of deposit, to stimulate the vessels to effect organic change, is hastening the ripening of an abseess, or the reduction of an enlarged gland; they should be entirely confined to cases where the acute inflummatory symptoms have ceased. Blisters do no good in deep-seated inflummations. Yet the quack, if he suspect internal inflummation, claps on a blister, which only agonizes the dumb brute, and generally leaves a permunent blemish. When a blister is found necessary, before applying, always as 
an ointment or fluid, and never as a plaster, cut or shave the hair from the part, wash and dry thoroughly, and apply with strong frietion for several minutes. The following, if thoroughly applied, will raise a blister, and will not leave a blemish :
No. 2.
1 Oz. Powdered Cantharides,
$12 \mathrm{Oz}$. Lard heated to $212 \mathrm{deg}$. Fahr.
Mix well together and stir untll cool.

A sweating blister of medium strength to be used to produce irritation and a watery discharge without raising a full blister, and which may be applied separately to the same spot and without removing the hair, is made as follows :

No. 8. 1 Oz. Powdered Cantharides,
1 Pt. Alcohol.

Add neither corrosive sublimate, arsenic, acids, nor turpentine to blistering agents. They are not useful, are often injurious, and always give unnecessary pain.

As a rule, sufficient irritation can be produced on cattle by mustard and Lot water, well ribbed in, and this form should be used except in particular cases. The following rules should be curefully remembered:

1.-Never blister more than one or two spots at the same time.

2.-Be careful about blistering in hot weather.

3.-Never blister an inflamed part when there are symptoms of mortification.

4.--There is always danger of produeing strangury in horses from blistering.

5.-When a blister causes great nervous irritability, loss of appetite, or mole at a ments should or difficult urination, wash the blistered surface with strong soapsuds of soft soap, dress it with sweet oil, and give a full dose of opium.

6.-The second day after a blister has been applied, foment the part with warm water, and dress it with lard or oil.

7.-An animal that has been blistered should be prevented from biting, rubbing, or otherwise irritating the blistered part.

\section{Firing.}

The actual cautery is most valuable in bone diseases, or chronic lameness. In certain diseases it cannot be successfully replaced by any other counterirritant. The iron should be at a full red or white heat, and used with a light hand, so that a distinct impression is made. More than one leg 
should not be operated on at one time. It should never be perforn ed by inexpert hands. The hair must be closely shaved, and the animal securely fastened. A better way for the novice is to cut n piece of bacon rind with some of the fut attached. The iron, which should be flat or slightly hollowed, is to be heated to a dull red heat. Place the bacon rind on the sprain or tumor, and apply the iron firmly for two or three minutes, and afterwards more lightly, until the rind is dried or burned. This may be repeated at intervnls of two or three days. The influence will be potent, and will leave no senr. It should never be used on cnttle, exeept in the case of a tumor, where the auimal is valuable.

\section{Setons.}

Setons are used in eases of bone disenses, in the healing of old fistulas, by producing a new and healthy inflammation in its sides. They should be inserted the whole length of the canal.

Setons are composed of tapes, threads, or fine wires, pushed just underneath the skin by means of a seton needle, entering at one point and coming out at another. Fasten the ends, to prevent dropping out, smear with irritant salve and turn every day or two to keep up a constant irritation and discharge. The following will be found good ointments for smearing the setons :

$\begin{array}{ll}\text { No: } 4 . & \text { Part powdercl cantharides, } \\ & \text { 8 Parts oil of turpentine, } \\ & \text { 8 Parts Cunada baisam. }\end{array}$

Put the two first in a bottle and keep warm for two days and add the balsam

A simple ointment would be :
No. 6. 3 Parts eitrine ointment,
1 Part oil of turpentine.
Mix.

\section{Rowels.}

These are wounds made with rowel seissors or a bistoury, and kept open with a pledget of tow or other substance, smeared with ointment, as used for setons. They are rarely used now by good surgeons, and are not to be recommended, sinee their aetion is that of the seton.

\section{Sewing up Wounds.}

The bleeding of wounds having been cheeked and properly cleaned, the edges are brought together and held in position by means of stitches 
be perforned by de auimal sceurely ece of bacon rind the flat or slightly bacon rind on the three minutes, and ned. This may be ince will be potent, inttle, except in the

aling of old fistulas, sides. They sliould

wires, pushed just tering at one point event dropping out, to keep up a constint und good ointments

ro days and add the

a bistoury, and kept ured with ointment, as od surgeons, and are the seton.

und properly cleaned, by means of stitches or sutures. The interrupted suture is made by enrrying a suture needle armed with white silk or white linen thread, through the two edges of the wound and cutting off, lenving about three-inch ends on each side of the ent ; bring together and tio. So proceed until you have the wound nicely closed, the lijs of the wound or skin being carefully brought together.

The twisted suture is better in inexpert hands when it ean ho used. Bring the edges of the wound together, pass a strong pin through to hold in place, and twist a fine wire or lace a strong thread across the protruding ends of the pin to hold the edges of the wound firmly together. So proceed at intervals of threc-eights of an inclintil the wound is closed.

The wound thus sewed, dress with a plaster or ointment and bandage to prevent threads or pins from being torn out. Remove them as soon as the surfaces have united, which should be in four or tive days.

\section{Fomentations.}

These are applied by wrapping the part to be treated with flamel bandages ol woolen eloths, and keep the wrappings constantly wet with hot or cold water, or mixed with any appropriate addition as vinegar, laudanum, ete. They are used to elemse or soothe irritable wounds, to reduce internal inflammation, or relieve external inflammation. Unless persistently used for hours and kept constantly wet, they had better not be attempted. After the operation is finished, rub dry and elothe warmly, to prevent chill, which will surely oceur. As an additional precantion, a little mustard rubbed in would be beneficial. When it can be appiied, a sheepskin with the wool on, wrung out of hot water, makes a good ggent for fomentation.

\section{The Operation of Bleeding.}

There is no operation in veterinary practice that has been more alused by quacks and other persons ignorant of the true necessity, than bleeding. It slould never be performed except by those who hive been instructed in the operation, and only in those eases where by common consent of the profession it is allowed. If a decided impression is to be made, as in apoplexy, from five to seren quarts should be talien from an ox, according to the conditions. If the jugular vein is pressed upon just helow where the incision is to be made, it will soon show prominently. Use a thumb laneet in preference to a fleam. When sufficient has been taken, raise the two lips of the wound, and lring them together between 
the thumb and finger, pass a common sumall pin through tho edges and weave thread across and over to keep all in pluce.

\section{Rocognizing and Distingulshing Diseases.}

The following explicit and detailed rules for recognizing diseases in animals, should be earefully studied: Anyone who would become expert in recognizing diseases in animals, must study them carefully in the heulthy state, and make himself thoroughly familiar with their habits, appearunce and general physiology. Ho must practice feeling their pulse and the heart, listening to the sounds of their lungs in breathing, and taking their temperature, by feeling the skin and also by using a properly constructed thermometer. He should wateh the appeurnes of the eyo and tongue, and note the positions assumed when nsleep and awake. He should observe the character and frequency of their appetite. For it is in the viriations from health in these particulars that the veterinarian diseovers the guides which lead him to the recognition of the particular discase be las to treat. We will examino each of these items separately, and assure our readers that if they will verify our statements by practice on the living animals, they will soon be in a position to take churge of them when sick, quite as well and often a great deal better than the averagc farrier, as he is to be found in this country.

\section{The Pulse.}

The pulse differs very much in the domestic animals. In the full grown horse at rest, its beats are about forty per minute; in the ox from fifty to fifty-five; and in the sheep and pig, about as in man, that is, averaging seventy to eighty beats in the minute. In calves and colts, and in animals well advanced in years, the pulse increases, in health, to about twice these figures; and it is also increased by hot, close stables, full feeding, and the condition of pregnancy.

The pulse may be felt wherever a considerable artery passes over a bone. It is usually examined in the horse on the cord which runs over the bone of the lower jaw, just in front of its eurved portion; or on the bony ridge extending upward from the eye, or inside tho elbow. In eattle conveniently reached over the middle of the first rib, or beneath the tail. There is a marked difference of foree in the pulse of the two species; that of the horse being full and rather tense, while in the $o x$ it is soft and rolling.

When the pulse differs materially from these conditions' in any direction, it is a sign of discase. If rapid, full and hard, there is high fever 
or acute inflammation; if rapid, small und weak there is low fever, loss of blood, or weakness. If very slow we muy suspect brnin disease; if irregular, now fust and in a few seconds slow, we should look for a disensed condition of the heart.

In the sheep, the pulse if felt by placing the hand on the left side, where the bentings of the heurt can be felt; or at about the middle of the inside of the thigh, where the femoral artery passes obliquely across the bone.

\section{The Breathing.}

The breathing is next in importance. If the ear is applied to the throat of a healthy horse or ox the nir will be heard passing through the windpipe with a regular, stendy, blowing sound; if applied to the chest a soft rustling murmur will be heard, like'a gentle breeze in the tree tops, caused by the air passing in and out of the fine tubes and vessels of the lungs. But where the lung or throat is diseased, these sounds are rery much changed and in many directions, which it is not necessary to dwell on here, but which will ut once indicate the presence of something aniss with these important organs.

If the foretinger of the the left hand is placed firmly on the ehest and smartly tapped with the ends of the three first tingers of the right hand, the sound will be noticed to be more resonant and clear tham when the same procedure is practiced on the solid thigh. This is because the lungs are not solid, but are always in health well expanded with air. Bat in rarions diseases, as pneumonia and pleurisy, they fill up with fluid and become solid, then the sound given out, by thus pereussing them, as it is called, is like that on any other solid part of the mimal. Hence this is another very important indication of disease.

By prictice on healthy animuls the character and boundaries of these sounds can be learned so closely that any variation from them will be at once detected, and will sometines reveal the presence of an unsound condition when nothing else will.

The rapidity with which the act of breathing is performed can easily be counted by the heaving of the chest. In health in the adult horse at rest it is from eight to twelve times a minute, and in the ox a little faster. Any great increase without obvious cause, is a positive sign of diseased condition.

The Animal Heat.

The temperature of animals can be ascertained, to a slight extent, by 
the feel of the skin, the eurs, und the legs. A hot, dry skin in a horse gencrally accompanies $n$ feverish eondition. Cold enrs und lears are a sign of serions disense. But the only scientitic, that is, n'cur'ate plan, is to nse what is called a "clinieal thermometer";" that is, one, the bull of which can be bared and inserted into the rectum. After it hus remined there two or three minutes, the mereury will accurately indicate the temperature of the bloot. This in health is 98 degrees, and nuy deviation from this, even of a few degrees, is a certnin sign of disense. 'Those rite. erinarians who have pranticed sufticiently with this instrument to berome skilled in its use, declare it invaluable in their business, us affording them gromnds for opinions nbout disenses which no other symptoms could.

Thus it has been found thint every disease has its own degree, n temperature at which it is either favornblo or fatal. For example, if in that sometimes prevulent epidemic among horses, cerehro-spinal meningitis, the thermometer rises as high ns 104 degrees, it is a certuin indiention that the horse will shortly die; while in such a disense as inflammiation of the lungs, the mercury will register 108 decrress, or 109 denrees, and the horse recover. If in gnstric or typhoid fever the heat his been 103 degrees, and fills to 100 degrees, and then suddenly rises agnin to its previons figure, the chances are terribly against the patient, no matter what the other appearances may scem to say. These few exmuples will serve to show how valuable the instrument may become in the hands of an intelligent per'son.

\section{The Skin and Hair.}

The skin in its general feeling and appearanco is an important gride to the condition of an animal. A dry, scurfy appearance is a system of indigestion, ind liability to joint affections. What is ealled "hide bound" is a symptom of a genernl state of poor nutrition, arising fiom indigestion, improper food, worms, or a wunt of proper exercise. The skill feels stretehed and hard, ns if too small for the body. The condition kuown as "stilling cont," when the hairs stand out like bristles, is often the only symptom of a low stute of health. Whenever an animal is dis- posed to shiver, with shedding of the coat, when exposed to moderate cold, or without such exposure, it is on the edge of some lisease. A persistently staring eoat, without other symptoms of disease, often iullicates the approach of an attack of farey or glanders; and when with this are repeated shivers or chills, we may expect the strangles, weerl, ol' other diseases with suppuration. When in an attack of disease the skin heromes eovered with a cold sweat, the life of the animal is in great danger. 
The Posture.

The position of nu nnimal, its mode of stmeling and lying down, are all sgnificint. Lying persistently on one side, or obstinately maintuining one position, shows thint any other is painful. Horses stand as long as they possibly can, ns they breathe much ensier in the upright position; and if they once lie down, they soon despair und die. Hence the rule is with a horse to sling him up, in various ailments. With cattle it is different, and it is much less important to keep them erect. When animals camot rise, it mity be from weakness, or from palsied limbs, or from severe injuries or sprains.

\section{Indioation of Pain.}

The feelin ${ }_{i}$ of pain in animals is indiented by their flinching when the painful part is touched; by the eare which they take in lying down, walking oi standing to "fuvol" the part, and by the appearance of the eye. Distress and suffering are genernlly plainly apparent in the face of siek horses and cattle.

\section{Special Bigns in Cattle.}

In (attle, the hol'n at its root yields, by the seusation it impurts to the band, a rough idea of the temperature of the blood, and the cow-leech generally feels it as the doetor does the pulse, as a part of the indispensable programme of a professional visit. If the temperatme is natural, be conchudes there is no fever ; if cold, and the tips of the ears also cold, it is a sign of some serious internal congestion ; the blood no longer eirculating in matural fore through the extremities.

The muzzle is another part he takes note of. In health this is moist, covered with "dew," as the saying is ; but in disease, especially fever, it is dry, hotter or colder than natural, and sometimes chnnged in color, paler' or injected with blood. By looking at the flunks, the regularity of the respiration is noted, rapid and irrecular heaving there betraying the disturb:une of the important function of brenthing. In ruminunts also, the second mastication of the food is among the first of the vital proresses to become disturbed in disense. When a cow or an ox "loses the eud," as it is ealled by herdsmen, that is, conses to ruminate withont apparent cause, there is sme to be a fecling of sickness about the animal which is thus interfering with one of its processes of digestion. No animal can thriec in this condition, it needs attention. eat danger. 
CHAP'TER II.

GESTATION, DISEASES AND ACCIDENTS THEREOF.

PLUKAL AND MULTIPLE gestation. - TREATMENT DURING GESTATION.—-BIRTH. - PROLONGLD LABOR. - LARGE PRESENTATINN. - UNATURAL PUSITIONS OF THE CALF, - FLOODING. - PRESENTATION OF AFTER-HIRTH.— - INVERSION OF THE WOMI3. L LANGUID LABOR. IRRITABILITX AND STHAINIXG. -TeMporalzy paralysis.-ABORTION.-ISOLation.

\section{Plural and Multiple Gestation.}

Fleming, in his work on Veterinary Obstetrics, gives a lucid and aceurate account of single, plural, and multiple gestation in animuls.

Among the domestic animals there are species which are naturally uniparous-produce only one at a birth; und others which, in a normul or physiological manner, bring forth two, three, or more, at a time, and are therefore desiguated gemelliparous or multiparous gestation, being known us double, triple, quadruple, de.

It is seldom that twins are produced by the larger domestieated animals, and particularly by the mare and ass, though instances are recorded of these ; while in the cow, sheep, and goat, the occurrence of twins, triplets, or even more young ereatures at a birth, are not so searce.

The causes of multiparity are not well ascertained. It may be due to simultaneous ripening of two or more Graafiun vesicles, which, rupturiug at the same time, allow the escupe of the ovules they contuin, and which may become impregnated at a single coitus. Or a Graafian vesicle myy contain two or more ovules, as Brisehoff has witnessed in women; and these arriving together in the uterus, may be fecundated at one time. Or it may even hrppen that the vitelline membrane contains two yolks, as sometimes occurs in the fowl's egg; and as the vitelline mass is the essen- 
tial part of the egg, it is evident that when this eontains two of these misses, they ought, if fecundated, to prodnce two embryos.

In the tirst case, as Sinint Cyr points out, each foetus has ordinarily all its annexes distinct and completely independent; or it may he that the two chitrions are fused togrether, in which circunstance the two fortises will then have " common envelope. In the second hypothesis, this fusion of the churions appenrs to be the rule, althongh the onvelopes may also be independent; and in the third ense-thut of the two vitelluses contained in the sanne vitelline membrine-not only the envelopes lut nlso the fretuses miy hecome united more or less closely and thus give rise to doulle monsters.

Fintly, it is also possible thint two ovules may become detached from the ovarian eluster, though not simultancously, but suecessively, and be feeundated, one after another, nt two suceessive eopulations within a brief period. Occurrences of this kind are by no metns rare, yet linve heen wrongly udduced as instunces of superfotution.

\section{What to Do During Gestation.}

As a lule the cow should be dried about the sixth or serenth month when stock breeding is the object. When milk and not ealves is the olject the flow may be continued to within six weeks of calving.

Graxing should always be allowed as mueh as possible, the exercise and griss both being furomble to henlthy gestation. In Winter the food given shonld be nutritive, ensy of digestion, eooling, and of such quality as not to induce either 'constipation or undue laxity. Water should be especially pure and plentiful, and not excessively cold ; in fact, all frozen food is to be avoided. Cleanliness is essential. Harsh or eruel treatment, rmuning by dogs, all danger of fright must be avoided. Surgical operations and severe medication is to be avoided, especially drastics. Suitable diet is to be used as a regulator of the bowels; powerful tureotics, sedatives, and other strong physics, if they do not impair the dim may imperil the life of the fotus. The veterinary anomalies in gestation are fully treated in Fleming's work on Veterinary Obstetric, to which we are indebted for much valuable information.

\section{Births.}

As a rule in natural parturition there is nothing gained by undue haste. The animal should have quiet and be left to itself so long as everything is gring on tolerably well. In the majority of enses nature will assist herself to a safe delivery. A roomy stull, in Winter well warned, should 
be provided with rather thin lout compact bedding. In Summer, or other mild weither, let the cow be out-of-doors by all means; in a smill griss lot is best.

\section{Prolonged Iuabor.}

When the labor is prolonged from excessive size of the fortus, and this is suspected beforehand, or if time do not press and there is 110 specian excitement in the cow, and there is delay in the descent of the calf, oil the hand and arm and feel for the neck of the womb in the vagina. If it be rigid carry extrnet of belladonna up the vagina and smear the neck of the womb for a few times. This should cause relaxation of the parts. If the time is passing earry a nilrow-bialed, blunt-pointed knife in the hand in the vagina; find the mouth of the womb with the forefinger, slip the knife along the finger until it enters the neck of the womb about a quarter of an inch, and make a slight cut in all four sides of the neck hy tmining the knife. A slight nicking will suffice, since the mouth once loosened in its contraction, the neck will give way, and the bag of water will accomplish the rest. The utmost ("ire is needed in such work, however.

\section{Large Presentation.}

Sometimes the calf is so large that the muscular efforts of the cow can not force the mass forward. In this ease do not resort to strongr means until all others fail. Let a small-handed man introduce both hatuds, well oiled, up the vagina, carefully working forward beside the calf, gradually pressing apart the oritice; pass elosely to the calf with the hands, and as the pains commence, pull forward as strongly ly pressure against the fotus. When a main effort is made pull forward, and at the same time slip the hands slowly back, and the ealf will often follow. Repent this again and again as the pains are renewed. We latve never failed in but one case in so delivering the calf, and in this ense the ealf had to be dissected in the body. This no person unskilled in surgery should attempt.

\section{Unnatural Positions of tho Calf.}

These are various, and, except in the six eases we mention, and in the order of their frequelicy, resort should be had to a veterinury surgeon. The following manner of relief is endorsed by various relinble and wellknown nuthorities:

Chuntural Positions of the calf.-The natural position of the culf on 
ner, or other small grass

he fortus, and $d$ there is 110 secent of the womb in the he vaginat and l cause relaxarrow-bladed, mouth of the until it enters make a slight slight nieking etion, the neck st. The utmost

rts of the corr esort to stroner introduce both vard beside the o the eilf with ats strongly by e pull forwird. calf will oftell renewed. The calf, stud in this erson unskillew

tion, and in the rinnry surgeon. blinble and wellof the calt on its exit from the womb, is with its bead and fore-feet first, the head between the feet and the back upwards. Six unnatural positions are enumerated by writers, which demand the assistance of the surgeon. We give them in the order of their frequency, with the appropriate treatment they reiguire.

First-Position with tail first. Press the hammehes back with the pralm of the hamd, tike hold of the bend of the hough of one leg, pull at it and rench the foot; seize the other foot in the sume manner, bring them forth and deliver the body.

Second-Position with fore-feet appenring without the head. Push the feet back until the head eam he seized either by the jaw or nose, and pull it down between the feet. No further aid will he required. This needs a long amon, and prompt action between the pains.

Thirt-Position with belly upward, head over one shoulder, fore-legs first. Gently push the calf back between the pains, and bring the head down hetween the legs.

Fourth-Fore-feet first, with hend under the hrisket. Push the calf hack, find the head, and draw it down between the fore-feet.

Fifth-Head alone, or only one fore-foot with it. Push the ralf hatek and seireh for the fore-feet, or foot, under the belly; when found, lning forward one at a time, by placing the hand under the knee and using gentle pressure.

Sixtl--belly upwards, the fore-legs folded and against the mother's mols, the hend, side or hind-leg appearing. If the hind-leg appe:ar, put it lark; seek for the head, and if possible turn the calf, to loring the fure-feet and head to the mouth. When this fails, thow the cow, put her on her bitek, and with a rope and pulley, or two or three stont assistants, latise her hind-quarters considerably ligher than her shoulders. In this position the calf can be casily pushed back in the uterus, so that it ean he turned and brought to the natural position.

Inany surgeons make it a rule to fasten the part presenting with a cord and slip-knot before going in seareh of the part they desire to bring to the nouth. The cord is held by an assistant, and serves as at maide.

The principal obstetrie instrument in the cow is the hook. This is made of wronght iron, four inches long, with a loop for the cord at the stright end. When by no other meins the ealf ean he delivered, or when renoring a dead fotus, this hook is fistened in the sorket of an ere, under the jaw or in an ear, and hy gentle and steady tratetion the resistunce is overcome.

Finally, the fotus may have to be taken out piece-meal, an operation which requires considerable skill on the part of the operator, to aroid rounding the womb and vagina when he is dissecting tho ealf. 
In all such operations certain general rules should be observed, as follows:

First-Thoroughly anoint the hand with lard, or oil, before introducing it into the vagina.

Second--Make the examinations while the cow is standing, and between the pains.

Third-In pulling at the feet, enclose the claws in the hollow of the palm, so that they will not tear the delieate coats of the womb.

\section{Flooding.}

Sometimes after a natural birth which has been rapicl, and often after an abortion which has been brought on by violence, there is a severe attack of "flooding," or bleeding from the womb. It may escape from the vagina, or it may be indicated by paleness of the mouth and nose, weak pulse, great weakness and coldness of the surface, and the womb be found to be filled with elotted blond.

Treatment.-The hand should be introduced into the womb, the clots and any remaining portion of the after-birth seized and extracted, and a sponge dipped in hot vinegar and water, or very hot or very cold water alone, be wrung out in the uterus. A full dose of fresh ergot of rye, one to two ounces, should be given without deliy.

If these mensures fail, a piece of ice the size of a walnut shonld be carried into the womb and left there; or a tea-spoonful of powdered alum should be stirred in a tea-cupful of milk, and a sponge of this be wipeezed out in the womb. Internally, Prof. Gangee recommends, for either the mare or cow,

No. 6

$3 \mathrm{Oz}$. Compound tincture of cinnamon,

$5 \mathrm{Oz.}$ Diluted suiphurlc acld.

Mix and give two table-spoonfuls for a dose every one or two hours, in a quirt of water.

\section{Retention of After-birth.}

There are many causes leading to this. The most common of these are hurried deliveries, adherence of the after-birth to the walls of the womb, and poverty of the animal. Retention for two or even three days under ordinary circumstances is not especiully serious. If left to putrify, fetid diseharges will exhanst the animal. The blood is poisoned, and the animal either dies or remains unhealthy for life. After forty-eight hours, if trouble still exists, the hand and arm well oiled should be introduced, 
observed, as

re introduc-

and hetween

gollow of the

mb.

id often after

is a severe atescape from uth and nose, and the womb

omb, the clots stracted, and a ery cold water rrot of rye, one should he carbovderent alum his be squeezed , for cither the

- two hours, in a

mmon of these e wills of the even three days left to putrify, bisoned, and the rty-eight hours, be introduced, and the after-birth carefully separated from the walls of the womb by picking with the fingers and nails, and gradual but firm pulling. The thole having been completely removed, syringe the vagina thoroughly with the following :
No. 7.
1 Oz. Chloride of lime,
1 Qt. Soft water.

Give the following as a physic :

No. 8.

8 Oz. Epsom salts,

3/. Oz. Ginger pulverized,

$1 / 4$ Oz. Caraway seed pulverized,

2. Drachms Copavia.

Give as a drench. If there is a tendency to biseding, give the following :
No. 9.
2. Oz. Ergot of rye, powdered.

\section{Inversion of the Womb.}

This occurs from long-continued and excessive straining, and there bangs from the birthplace a large red or violet colored bag. Clenn the

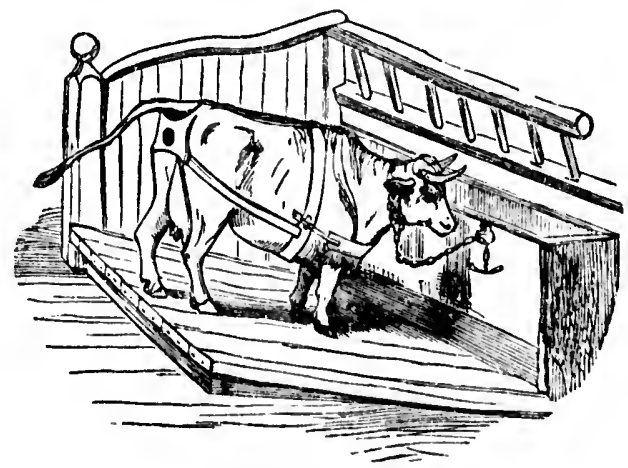

TO PREVENT INVERSion OF THE VAGINA.

bag thoronghly by the free use of warm water. If it is much swollen and enlarged, puncture slightly with the lance in several places to lot ont engorged blood. When sufficiently reduced, stop the effusion with cold water. Stand the cow so that her head will he permanently lowest in the stall. Let two assistants place a cloth undermeath the hag and raise it to the level of the vagina. The operator with his right hand well oiled, 
after oiling the surface of the big, places his hand against the point of bow of the bag farthest fro $m$ the vagina, presses it steadily but gently back: and as far up the vagina as possible. With the left hand, also oiled, he now presses in the depencient portions in and up in a similar manner. The assistants follow the retracting bag until $i^{t}$ is restored. A ball of tow is introduced to keep it in place, and a harness (as shown in the foregoing eut), which includes a raised stall. In any event the howels should be restrained for a day or two by doses of laudanum. After twenty-four hours, if the pains have ceased and tho animal is quict, the Jail of tow may be removed, and later the hurness. A simplitication of the harness will easily suggest itself to the operator.

\section{Languid Labor.}

If the presentation is all right and there is no obstruction, and the mouth of the woub is dilated but the labor pains are infrequent and weak, careful mechanical assistance should be given with the hands as heretofore stated, or try first full doses of ergot , : rye, one to two ounces. It is often ineffieient in eows and must be given in large doses.

\section{Irritability and Straining.}

If this is seen after birth, unless it subsides promptly, or if it show itself by repeated spasms and convulsions, give the following in al quat of warm milk: Chloroform and landanum, each half an ounce. If the muzzle is dry and the horns hot, showing tendency to fever, the following will be better :

No. 10. $20 \mathrm{Oz}$. sweet spirits of nitre,

$2 \mathrm{Oz}$. landumum,

$4 \mathrm{Oz}$. solution of aectate of ammonla.

This dose to be given in a quart of tepid milk every hour until relieved.

\section{Temporary Paralysis.}

Cows are frequently paralyzed in their limbs before parturition. If they does not regain the use of their limbs soon, or if they improve slowly, give the following:

No. 11.

2 Drathms powdered nux romlea, 2 Draclums sulphate ol iron.

Give in a pint or two of gruel twice a day. Aroid all so-called cleansing drinks; they are generally injurious. When there is unusual debility the following will be indicated: 
point or t gently so viled, manner. A ball of wn in the te bowels 11. After quiet, the ficution of

n, and the cquent and e hands as one to two large doses.

$r$ if it show in al quart nce. If the the following

until relieved.

rturition. If they improve

called cleansusual debility
No. 12.

$$
\begin{aligned}
& 1 \text { Oz. pow (lereil anlso seed, } \\
& 10 z \text {. " myrrh, } \\
& 10 z \text {. " ulisplee, } \\
& 1 \mathrm{Oz} \text {. " cummin seed. }
\end{aligned}
$$

To be stirred in a quart of warm gruel as a drench.

If constipation is strong and persistent give:

No. 13.

$$
\begin{aligned}
& \text { 3a Lb. sulplate of magnesia, } \\
& 1 \mathrm{Oz} \text { ground anise seed, } \\
& 6 \mathrm{Oz} \text {, ollve oll. }
\end{aligned}
$$

Give in a pint of gruel, and repeat daily if needed.

If there is strong relaxation with continued diarrhea, the following will be indieated :

No. 14.

$$
\begin{aligned}
& 2 \text { Draebms powdered eatechu, } \\
& 1 \mathrm{Oz.} \text { “g ginger, } \\
& 30 \text { Drops sulphurle acid, } \\
& 1 \text { Oz. laudanum. }
\end{aligned}
$$

Give in a quart of gruel, ale or weak whisky and water.

Or,

No. 15.

10z. nowlered ginger,

$1 \mathrm{Oz}$. bicarbonate of soda,

$1 \mathrm{Oz}$ laudanum,

J Oz. decoction of oak bark.

Give several times a day in gruel or ale. Half this dose suffices for six months' calves, in similar conditions of the bowels.

Antiseptic washes for cleansing the vagina when the discharge is foul:

No. 16. 1 Quart elean wood tar,

Stir, settle and pour off.

2 Quarts boliing rainwater.

Another,

No. 17. 1 Lb. ehloride of lime, 2 Gallous cool soft water.

Let it settle and pour off elear. A pint or two of either may be injected twice a day.

\section{Abortion.}

Abortion may be said to take place in cows when the fotus is expelled thirty-five days before the normal period. It may oceur from a variety 
of reasons, and is much more common during the first half of the normul period than in the latter. It may he sporidic, that is, induced hy areidental or loeal causes, as atmospherical ilifluences, such as bad weather, and irregular sensons-severe suddenly sueceeding mild weather. Coll storms, etc., tre especially to be guarded against. As extermai causes, aceess by the male, explorations in vagina, surgical operations, throwing the animal down, bleeding, and bad or improper food, are among the most common of external causes. Excitement, fear, surprise, certain odors, contagion, are eredited with playing an aetive part in this disability. Various diseases are also active parties in this direction. When cases oceur simultaneously over wide extents of country and without known causation, it may he enzontie or epizootic. Ravages of this kind are not uneommon, and have attracted the attention of veteriuarians.

\section{Milk Fever.}

This fever oceurs from the first to the third day after calving; rarely later than this time. Select breeds and good milkers seen speeially liable to attidlis from this disorder.

The primary trouble in this disease is inflammation of the lining membranes of the womb, extending sometimes to its substance and adjacent parts; and in some cases involving the bowels themselves. Among its more remote offerts are affections of the brain, congestion of the spinal cord, apoplexy, blootpoisoning and deatls.

Causes.-Injury to the womb in calving; the retention of the after-birth; exposure to chill and eold by sudden changes of temperature, poor management, etc., may cause milk fever. At times a contagious eharacter seems to attaeh to the disease, and many cows of the same herd suffer. It is also regardel as quite eertain that a cow having onee had the fever, will have it with her next calf: Over-feeding as the time of calving approaches is also prominent anong the the supposed canses of the disease.

Anthorities differ somewhat as to whether "milk fever" is identical with inflammation of the womb. Some think it is not identical; others, that it is the satme disense in different st'yges, or different degrees of violenee.

Symptoms.-CThe suspension of the milk secretions is one of the earliest indications of this trouble. 'The eow hangs her head, negleets to feed, censes to elnew the end, moves her hind feet restlessly, staggers if she attempts to wall, looks wild, fulls and eannot rise, sways her head from side to side. In this stage of disease the head is intensely hot. Power to see and to swaliow is lost enrly in the disense; paralysis of the hind-quarters sometimes ocenrs; if not relieved, the breathing becomes hard and rapid; the pulse becomes faint and quick; and sometimes the animal dies in convulsions, or sinks slowly away in stupor. 
Usually the bowels do not move, and the bladder ceases to act. The turn of the disease for the better usually comes in thirty or forty hours, when the animal becomes rational, is able to arise, and the secretions all begin to resume their functions.

Treatment.-When trouble of this character is anticipated, preliminary treatment is strongly recommended for about a weols before calving. This may consist in a purgative of

\section{Li. Epsom salts, \\ $\frac{1}{2}$ Lb. table salt, \\ $\frac{1}{2} \mathrm{O}$. ground ginger,}

Mixed with suitable quantity of cold water, and sweetened with molasses.

At this time the cow's food should be of the lightest kind also, avoiding meal and grain. The cow should be carefully sheltered also. After calving, if fever be anticipated, give twenty-five drops of tincture of aconite in water, repeating the dose every six hours, till four doses have been given. This has a very direct effect upon the heart and circulation generally.

If the disease has set in clearly, but exhaustion is not apparent, free-bleeding is recommended by good authorities. W'uen the pulse is weak and thready, however, and when exhmustion is apparent, bleeding is not called for, hut a stimulant is required. Whisky may mect this case, or

\section{Oz. carbonate of ammonia, \\ 1 Pint of water.}

If the cow be unable to swallow, a ball may answer better. It should be well oiled and pushed far back into the gullet. Active purges are always an advantage, and injections of soap and warm water may be used frequently when swallowing is impossible.

To relieve a heated head, cold water may be used. Carbonate of ammouia given as a ball may relieve swelling of the bowels. When the attack comes on, the following formula may be used as a laxative and sedative.

\section{$\frac{1}{2}$ Drachm calomel, \\ 2 Oz. laudanım, \\ 1 Lb. castor oil.}

Mix with hot water and molasses, and give in four doses at iutervals of four hours.

For the exhaustion following the more acute stages of the disease, the following is lighly commended:

1 Oz. epirits of turpentine,

$13 \mathrm{Oz}$. carbonate of ammonia.

To be given in a quart of cold gruel. 


\section{Mammitis.}

This disease is known as eaked-bag, or garget, and is sometimes erroneonsly called milk fever. It is a disease of rare occurrence in the mare, but is commonly met with in eattle and sleep.

Definition.-It consists in acute inflammation of the whole or part of the mammary gland (udder).

Cuses.-These are numerous; sometimes it is the result of extermal injury, such as blows of any deseription. Another eommon souree of this clisease is the cruel practice of "over stocking," which eonsists in the preparation of the cow for show or market, by allowing her to go mmilked until the udder becomes enormously distended with milk. This is done to give the gland a fine appearance. Cows giving no milk, when being fattened for the butcher, sometimes undergo a modified form of this disease; this is caused by some of the milk remaining in the gland and acting as an irritant.

Symptoms.-This disease seldom attacks the whole gland, but is usually confined to one or two quarters. The affeeted parts become hot, lard, swollen, tender, and red; the milk is curdled and whey-like, aud usnally mixed with llood. The constitutional symptoms depend upon the severity of the attack, the disease being often ushered in with rigors (trembling), followed by increased heat of the skin; the bowels are usmally eostive, but are sometimes numaturally loose. The muzzle more or less dry, appetite slightly impaireul, pulse quickened, together with general fever.

Trectment.-The first thing is to determine the eausc, which must be at onee renoved. If the bowels are costive, a brisk purgative must be given-such as one pound conmon salt mixed with one pound Epsom salts and half an ounce of ginger-the whole stirred in a quart of boiling water and given as a drench when cool-for sheep, about one-third of the above will suffice-for mares, alrout eight drachms of aloes with a drachu of ginger must be substituted for the salt, ete. $\Lambda$ fter the purgative has done operating, diuretics in the shape of salt-petre, may be given night and morning, for about three day's-dose, cattle, two Jrachms ; mare, one drachm; shcep, half a drachm, in say a pint of water.

The loeal treatment, which is of great importance, consists in fomenting the part thoroughly with warm water, for half an hour at a time, three times a day, drying and hand-rubbing; after which, the parts may be smeared with olive oil, or goose grease. Ponltices of various deseriptions are also alvantageonsly applied to the part, and may be made of spent hops, marsh-mallows, or some such substance, bearing in mind that the heat and moisture must be kept up, for the poultice to be effectual.

The aninal must be fed upou food which is not calculated to produce milk, such as bran-mash, and the like. The milk must be frequently removed for a week or ten days. In serious cases, the nearest veterinarian should at ouce be consulted, as individual cases differ so nuch. 


\section{CHAPTER III.}

\section{INFECTIOUS, CONTAGIOUS AND EPIDEMIC DISEASES.}

P.EUMONIA. — IISTORY. - ITS MALIGNANT CONTAGIOUSNESS, - DEFINITION HOW THE INFECTION ENTERS TIL SYSTEM. - HOW IONQ IS A BISEASBD ANIMAI INFECTIOUS.- HOW TO KNOW IT.-WHAT TO DO.—TEXAS FEVER. — HOW TO KNOW IT.—- BLOOHY MURRAIN. - ITS MALIGNANT CILARACTER.

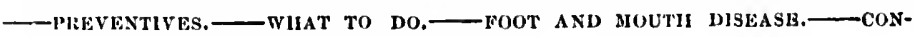
TAGIOUS PLEURA - MILK FEVER.

\section{Infectious, Contagious and Epidemic Diseases.}

Among the most terrible of the diseases ever imported into the United States is plento pneumonia confagiosa known scientifically by a large mumber of names, lyt now grenerally designated as Bovine P'nemmonia Plague, and the Lung Plague in eattle; Texas Fever, known also ats Spanish Fever and 'Texas Cattle Disease, and scientifically as Splenic Ferer; Bloody Murrain, also known as " Black Quarter" (Quatran) and "Quitrter Ail," is known among veterinarians by its French name Charbon, and also as Contagious Anthrax. Thus these will be all that it will be necessary to treat at considerable lengtlı ns among eontagious diseases.

\section{Contagious Pleuro-pneumonia.}

This disease which has lately excited so much attention in the United States from its violent ontbreak in the Atlintic States, and the well grounded fear that for the lack of national legislation it might overrun the whole country, is the most malignant with which the farmers of the country have had to deal. Onee fuirly established in the West there 
will be no possiblo menns of erndienting it. It will remun a fixturo forover.

History.

This diseaso has been known in Europe and Asin from the remotest eivilization, and has been trented since the first gathering together of eattle in lurgo herds. Aristotle, evidently writing of this disense three hundred year's beforo Christ, describes the symptoms accurately, intsmuch is he says: "Tho cattle which live in herds are subject to a malady during which the brenthing becomes hot and frequent; the ears droop and they camnot ent. They die rapidly, and the lungs are found spoiled." Greek and Roman writers nlso describe whit appears to be the sume diseaso, and Valentine particularizes a fatal lung plague which evidently corresponds to this malignant and terrible seourge.

\section{Its Malignant Contagiousness.}

Unfortunately veterinary science has never yet discovered a renedy. Its attack is so insidious, and often oecupies so long a time in the stage of incubation, that a whole lierd may be infected almost before it is known. As in the ease of all Germm plagues, nothing is known of its origin; but just as soon as it is apparent that a case is being well developed, the only safe plan is prompt killing, deep burying of the carcass, skin and all, and the freo uso of quick-limo (n barrel to the carcass) before being covered up.

\section{Deflnition.}

This disease is defined as follows:

A specific contagious disease peculiar to cattle, and manifested by a long period of incubation (ten days to threo months) by a slow insidious onset, by a low type of fever, and by the occurrence of inflammation in the air-passages, lungs and their coverings, with an extensive exudation into the lungs and pleure.

That the infection is carried by the animals wherever they go is certain. That it is carried in the air to a very considerably extent seems altogether probalble. That it is earried by inoculation is well demonstrated; and also by contact of diseased portions of an animal with the membrimes of a well one, is as certain as that the contagion is carried by attendants on sick animals and is proved almost beyond controversy. That the contrgion will hold in stables for months even after being thoroughly cleaned and washed with disinfectant liquids; is proved just as clearly as that it 
a fixture

remotest ogether of sense three ately, inasubject to a $t$; the ears 3 are found pears to be lagne which

d a remedy. in the stage ; before it is known of its g well develthe carcelss, the carcesss)

unifested by a slow insidious flanunation in ive exudation

yo is certain. oms altogether minstrilted; and membrames of attendants on hat the controughly cleaned arly as that it may be carried by the many. That it may be taken in pastures und with fodder is toa well nuthentieated to leave room for doubt.

\section{Vitality of the Virus.}

There is much difference of opinion with regard to the power of the rirus to resist ordinary destruetive influences. In many cases the freo exposure of an infected place for three or four months to the netion of the air has puritied it so that fresh stock have been introduced with impunity. On the other hand, instanees cun be nddueed in whieh enttle have been infected by being placed in stables in whieh eattle had not been kept at least four months previously. Other things being equal, it will be jreserved longest where it has been dried up and envered from the free necess of the air. Thus in very dry and elose buildings, in those haring rotten wood-work, or deep dust-filled eracks in the musonry, and in those with a elosed spatce benenth a wooden floor, it elings with tho greatest tenacity. Again, when the buildings contain piles of lumber, litter, haty, fodder, or clothing, the virus is covered up, secreted and preserved for a much longer time thm if left quite empty. In these last it is preserved just as it is in woolen or other textile fabries, and carried from place to place by human beings.

As earried through the air, the distance at which the virus retains its infecting properties varies mueh with varying conditions. The aluthor has seen a siek herd separated from a healthy one ly noe more tham fifteen yards and a moderately elose hoard fence of seven feet high, and in the absence of all inter-communieation of attendants, the exposed herd kept perfectly sound for six months in suceession. On the other hand, infection will sometimes take place at a much greater distince without any known means of conveyance on solid oljects. Roll quotes 50 to 100 feet, while others claim to hatve seen infection at at distallice of 200 and 300 feet. But it may well be guestioned whether in suen eases the virus had not been dried up on light oljects, like fenthers, paiper, sttaw, or haty, which could be borne on the wind. This, from being in thicker layers, would esenpe the destruction that would have befallen it had it been eurried in the air only as invisible particles.

\section{How the Infection Enters the System.}

The seat of the disease, its progress, and the result of all attempts at moculation, favor the presumption that the virus is usually taken in with the air breathed. Not only are the lesions eoneentrated in the lungs, but they begin with eloudiness and swelling of the smaller air-tubns and surrounding connective tissues. 
The exudution into the interlobuhr tissue, the congestion of the lung tissue itself, and the implicution of the lung covering, ure setondaly phe. nomenn. In other words, the disense begins where the inspired nir nust lodge the germs. 'Thus the inoculution of the virulent lung products on distunt parts of the body of $n$ sound benst rmely determines the chanturteristic lesions in the lungs, in lieu of which it induces in the seat of inoculation an exudation less ubundunt, ns might bo expected from the greates deisity and resistance of the integument, but which can, like the morbid lung products, be inoculated on sound animals with protective effect. It scrms probable that the poison is multiplied in both onses, but that the sperial loose and suscrptible texturo of thi renders its production incounparubly more almudant, as the continu,us ingress and egress of air through the disensed orgun renders it inmensurably more infecting.

\section{How Long a Diseased Animal is Infectious.}

Proof is wanting as to the infectious nature of the disease during the incubative stage. If negative evidence were of any value in a case like this, it womld be easy to alduce eases in which the removal of $m$ andunal as soon as it slowed symptoms of the plagre hat apparently sarem the rest of the herd. In other ases, the malady has becn eradicated from an herl by careful watehing, and the prompt removal of every animal as som as sickness appeared. The period of grentest virnlence is that at which the forer runs highest and when the lung is being loaded with the morbisl cxudation.

But it must not be inferred $t^{\prime}$ dangere is removel. It is a mat'

ith the subsidence of the fever the which have passed through the fever, that are now thriving well, or wiving a free supply of milk, and to ordinary observers would alpear in perfert health, retain the power of transmitting the disease to others. This may continue for three, six, nine, twelve, or, nccording to some, even tifteen months after all signs of acute illness have disappenced. 'This is easily explained. The tendency of the clisease is to interrupt the cireulation in the most severely affected parts of the lungs ; the exudation uround this becomes developed into a tough fibrous envelope, which closes off the . deal mass from the adjacent lung and from all communication with the external air. The dead and imprisoned muss now undergoes a process of breaking down, liquefaction, and absorption, commencing at the surface. and slowly advancing towarls the eentre. The encysted portion of the dead lung is one mass of infecting material, and as it undergons no ehange except that of liquefaction, and exhules at no time any putrid odor, it re mains infectious so long as it retains the solid form. At the outset nove than half a lung may be thus encysted, and five or six months after alleged 
of the hung andiry phe. ed :ilir must prodiction on 10 rhanimerf inoculation enter density morthid lung ct. It seems at the sperial ion incomparof uir through

ease during the 10 in a case like al of on animal pontly satrol the arlicatted from a every animul as mence is that at londed with the

of the feres the tion that animals ug well, or coiving :1)pear in perfect thers. 'This: maty ome, even tifteel 1. This is ensily the circulation in lation around this ch closes off the unication with the rgoos a process of ing at the surfine, ed portion of the dergoes no ehange putrid odor, it nt At the outset mote ouths after alleged recovely we still find musses of from one to two pounds weight wniting for the sow process of solution. Whenever there are indientions of the existence of such encysted musses, tho mimul should be looked on as infertions, and disposed of as summurily us if in the acute stuges of the divise. Mr. Law gives the following rules when the disense is susperted:

1. Romove all litter, manture, feed and fodder from the stahles; scrupo the walls and flool-wash them if necessury ; remove all rotten wood.

2. Take rhloride of lime one-latf th., crude cmbolic neid, a oz., and water, 1 gal ; ndd freshly-hurued quick-lime till thick enongh to make a gool whitewash; whitewash with this the walls, roof, Hoors, posts, mangers, dratus and other fixtures in the eow stables.

3. Wash so us to thoroughly clemuse all pails, buckets, stools, forlss, shorels, hrooms and other mosublo articles used in the hildings; then wet them all over with a solution of earbolic acid 1-2 lb., wuter 1 gal.

4. When the empty building has been clemsed and disinfected as alove, close the doors and windows, phee in the renter of the building it metallie dish holding $1 \mathrm{ll}$. Howers of sulphur ; set fire to this and let the cow-shed stand closed until tilled with the fumes for at least two homrs. The above should sutlice for a close stable appable of holding twelve cows. For linger, or very open buildings, more will be required.

5. The mimure from a stuble where sick cattle luve been kept, must le turned orel and mixed with quidkline, two bushels to revery lond ; then hiuled by holses fo fields to which no eattle have alecess, and at once plowerd undere by loorsess.

fi. The pits, where the manure has been, must be cleansed and washed with the disinferetent buid ordered for the bulding.

i. The surviving herd should be shut up in a close building for half an hour, ome o. wire a disy, and marle to breathe the fumes of hurning sulphur. Close doors and windows, plice al piece of piper on al rean shovel, lity a few pinches of llowers of sulphour upon it, and set it on fire; adding more sulphur, pinch by pinch, as long as the eattle can stand it without conghing. Continue for' a month.

8. (iive two drachms powdered copper:as (green vitriol) daily to ench corr in meil or grains : or, divide $1 \mathrm{lh}$. copperas into 50 powders, and give one daily to each adult amimal.

9. Do not use for the surviving rittle any feed, fodder or littor that bas been in the same stables with the sick. They may safely he used for horses ind sheep.

What to Do.

There is only one remedy-entire isolation of the herd infected. The prompt killing and slashing of the hides of diseased animals, deep burial, 
and covering the bodies with quick-lime. It may be stamped out only by the free use of the poll-axe, and the thorough disinfection by the most severe means of the premises, utensils and attendants. It is one of those cases where heroic treatment is of supreme value.

\section{How to Know It.}

The symptom most easily known in the early stage is an increased temperature of the body. If a clinical thermometer be introduced into the rectum of a beast in an infected district, mol an abnormal heat is ascertained, it is safe to suspect the disense; therefore send for a veterinarian at once. Next a slight cough will show itself; the hnir will be erected along the back; there may be shivering and always tenderness of the back when pinched; the brenthing and pulse is accelerated; the bowels are costive, rumination is irregular. The urine is seanty and high colered, the appetite fails, the milk-flow is diminished, the nose will be altenately moist and dry. The horns and other extremities will be alternately hot and cold. In the field, the sick animals will separate from the herd. All the symptoms become more and more apparent until the animal remains in a fixed posture, the head rigidly extended, the mout hopen, it every inspiration a moin, until at length the animal succumbs, a lonthsome and noxious mass of contagion.

\section{What to Do.}

A resort to remedies should not he had unless the animals are tikell early in hand, and ean be isolated in a building far from any lierd. It will not paty except in the case of thorough-bred or otherwise valuible stock. This is especially the ease in the West, if that section should be unforiunate cnough to import the disease. Prof. Gimgee, who made an elaborate report for the Government in 1871, strongly and wisely colldemns purgatives and bleeding, but believes the disense may be checked, if taken in time, by isolating the whole herd, and depending on active internal astringents. He ndvises duily doses of sulphate of iron, one-half to one drachm to the bullock, mixed with an equal weight of linseed and coriander seeds, given in bran to disguise it; this lie has found to mitigate the cough, followed by the disalppearance of the disense.

In the second stage of the disease, he ndvises light but nutritions food, copious warm, water injections, and the following stimulant:

No. 20 .

3 $\mathrm{Oz}$ carbonate of ammonin,

1 Qt. Inseed oil. 
ed out only tion by the 3. It is one

ncreased temueed into the heat is ascera veterinutuian vill be erected derness of the d; the bowels and high eolse will be alterll be alternately from the herd. ntil the animil mouth open, at scumbs, a loath-

nimals are taken in any herd. It herwise valualle ection should be cee, who made all and wisely contmiay be checked, ending on active of iron, one-luilf ist of linseed :Ind is found to mitise:tse. t nutritious food, lant :
Mix, and give this dose two or three times a diny. When only one lung is involved, recovery oecasionally takes place; when both are inrolved, there is little or no hope. For cough and debility during conralescence, he advises the following tonic:

No. 21.

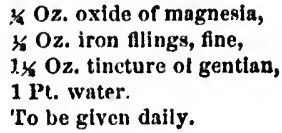

Another prescription is recommended-

$$
\begin{aligned}
& \text { No. :3. } \\
& 1 \text { Drachm ctrbolic acid, } \\
& 1 \text { PInt water } \\
& \text { To bo given as a dose three times a day. }
\end{aligned}
$$

The reader will see, upon a careful study of the foregoing, that but nue prescription-killing-is the only safe plan.

\section{Teras Fever.}

This disease, now called Splenic Fever, resembles in some of its phises the terrible Rinderpest of Asiatie Russia, but it is far less malignant and los contagious. It also disappears with the first frost, being effectually stamped out during the Winter, not to be again seen until again reintroduced by the passage of Texas cattle. So again it is not given by on Vorthern cattle to other bensts. The disense has its home on the coist of Texas, but how it originated is not clealy known. After deatlu the spleen is found greatly enlarged and softened, the kidneys broken, dung and the blood fluid.

\section{How to Know It.}

The period of incubation extends over four or five weeks after the poison has been introduced. The fever will at first be moderate, the temperiture as shown by a clinical thermometer, introduced into the rectum, will be 103 to 107 degrees. Then follows dullness, congh, trembling, jerking of the museles, drooping of the head, arehing of the back. The horns are lot, rumination ceases, and the appetite not good. The eyes hecome glassy and watery, the urine deep red or black from the blood continined the dung is hard and conted with blood; the mouth and rectum will be a dink red or copper color; and the animal dies in a stupor or courulsions.

Gimgee always found present in the examination of nearly 5,000 animals thit the fourth stomach was distinctly inflamed and the spleen 
always enlarged and of a purplish eolor-on eutting the pulp oozing out soft like currant jelly. Henee the name, "Splenic Fever."

\section{What to Do.}

Put the animal in a roomy stable with good ventilation, and give soft food. As an internal remedy give

No. 23.

\author{
1/2 Oz. ehlorate of potash, \\ $1 \mathrm{Oz}$. tincture of chloride of iron, \\ 1 Quart water.
}

Mix and glve us a dose to to be followed two or three times a day.

The most dingerous symptoms being passed, give plentiful food and the following tonic.

$$
\text { No. } 24 .
$$

$$
\begin{aligned}
& \text { 3. Oz. sulphate of iron, } \\
& 1 \mathrm{Oz} \text {. tincture of ginger, } \\
& 1 \text { Qt. water. } \\
& \text { Thls amount twice daily. }
\end{aligned}
$$

Professor Gamgee does not regard medieal trentment as being hopeful. In addition he advises that the limbs be well rubbed, and the bowels moved by injeetions. During the first two or three days he reeommends ounce doses of laudanum, and later as a stimulant the following:

$$
\text { No. } 24 .
$$

Ya Oz. sulphuric ether,

$4 \mathrm{Oz}$. ol acetate of ammonia.

Give in a quart of linseed tea three times a day.

\section{Bloody Murrain.}

Contagious Anthrax, known ulso as eharbon, black leg, likck quarter, black tongue- is so called beeause the parts attacked turn black, owing to decomposition of the blood. It arises undoubtedly from contagion, eating bat food, pasturing on swamp lands in summer, drinking staginut water, ete. Whatever the poison, certain it is it has wonderful tenacity of life; every part of the animal will ear'y it, even the excrement. Flies will enry it, a yoke worn by a discased ox retains it. Eren aleohol is stid not be able to kill the poison. Fortunately it rurely oceurs in its truly malignant form. There are many types of the disease attacking partieular parts. In ine tongue it is known as black tongue, or blain; in the throat as putrid sore throat. When it attueks the bowels it is called bloody murrain.

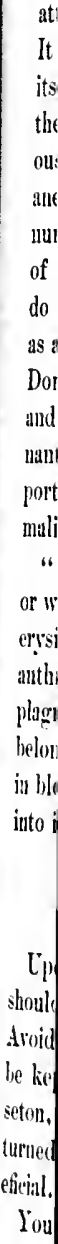

Rece 
oozing out

ad give soft

three times a day,

iful food and

being hopeful. id the bowels e recommends owing :

black quarter, d tur'il hlack, ally from commuer, drinking hats wonderful ven the excretains it. Even it rarely oceurs of the disease lack tongue, or ks the bowels

\section{Its Mulignant Character.}

In this disease it must be renembered that in its malignant form it attncks not only eattle and horses, but all the herbivora, swine and birds. It is communicable to other and different animals by inoculation, showing itself in different forms, but all characterized by the breaking down of the blood globules, rupture of tissues and letting out blood und albuminous fluids, with gangrene, yellow or brown mueous membrane, enlargement and sometimes rupture of the syieen, and a very high death rate. Immense numbers of human beings have died first and last from eating the flesh of diseased animals. This is especially the ease among the Tartars, who do not refrain from eating even the flesh of authrax horses. As many as a thousand persons are reeorded as having died in six weeks in San Doningo from eating the flesh of such diseased animals. Mosquitoes, and other biting insects are supposed to cause breaking out of the maligwant pustule in man, from the fact of its always arising on exposed portions of the body. In relation to the various manifestations of the malignant anthrax Professor Law says :

"Malignant anthrax may be manifested by externul disease, or swelling or without such appearances. To the first class belong the carbuneular, erripelas, of slieep and swine, malignant sore throat of hogs, glossmithrix or black tongue, black quarter or bloody murrain, the boiled plague of Siberia, and the malignant pustule of min. To the seeond helong all those forms of disense in which there are the specitic changes in blood, with engorgenent of the spleen, blood-staining, and exudations into internal orgaus only.

\section{Preventives.}

Lion the first intimation of the disense the well animals of the herd should he removed to elean, new pasture, where there is pure water. Aroid all bleeding, purging, and lowering medicines. The animals must le kept up. So all local applieations to the swellings seem uscless, A seton, composed of a yard of broad coarse tape, inserted in the dewlap turned cvery day and smeared with irritating ointment might prove beneficial. This should remain in from four to six weeks.

Yountt and others advise the following:

$$
\begin{aligned}
& \text { No. 25. } 2 \text { to } 4 \text { Druchms ehloride of lime, } \\
& 1 \mathrm{Oz} \text {. preparetl chalk, } \\
& 2 \text { Drachms lauds anum. }
\end{aligned}
$$

Mix and give in a plut ol warm griel every two or three hours.

Recent Freneh authors, in treating the malignant form of the disease, 
recommend quinine, one or two drachms, repeated every two or three hours in severe cases. Also lyppodermic injections of a solution of iodine as follows :

No. 26.

\author{
2 Grains lodine, \\ 5 Grains iodide of potassium. \\ $1 \mathrm{Oz}$. water.
}

Use a syringeful every lour in severe cases. In extreme ones, it is advised that this be thrown directiy into the veins; also that the strength be kept up by stimulants; among those recommended most strongly is carbonate of ammonia.

\title{
Blain.
}

When bloody murrain attacks the tongue it is called blain. In the case of blain it is recommended to open the pustule freely from end to end, with a sharp lancet, before the poison has been alosorbed. Treat the same surface freely with the following:
No. 27.
20 Grains chloricle of lime, $10 z$. water.

Mop the parts frecly.

Sulphuric or nitric acid, nitrite of mereury, lumar caustic, and other strong canstics, are equally good. When it may be alccomplished, burning with a hot iron is adrised.

\section{Foot and Mouth Disease.}

One other contagious discase will be necessary to be treated of hice, as begimning to be of common occurrence, having prevailed more or less since its introduction into the United States in 1869. This is cpizontic aptha, generally known as foot and mouth disease. Although a contagious febrile disease occurring in cattle and sheep, and commmuicable hy transmission to swine and even man, it is fortunately rarcly fatill, and is characterized in animals ly an eruption of small blisters in the mouth, and between the clefts of the hoofs, and along the upper margin of the coronet. It is a specitic poison of obscure origin, remuining in the system from one to four day's before producing its characteristic symptoms.

\section{How to Know It.}

There is an increase of tempcrature in the body, followed by an eruption of small blisters, of the size of a dime, situated on the tongue, the roof of the mouth, inside the lips, and occasionally on the udder. The 
blisters in the cleft of the hoofs and around the coronet and heels, are identical with the others, but smaller.

When the disease is mild, it is easily cured by daily applications of a portion of the following, applying by means of a swab or sponge :

$$
2 \mathrm{Oz} \text {. powdered golden senl, } \quad 1 \mathrm{Oz} \text {. tincture of matico, } 4 \mathrm{Oz} \text {. honey. }
$$

When the disense is violent and of long standing, it is apt to extend through the whole course of the alimentary canal. The method of curc, in this event, is by tonics and astringents. The remedies are tincture of matieo, golden seal, and sulpluur, in the following proportions:

\section{4 drachms tincture of matico, 2 drachms powdered golden seal. \\ 2 drachms sulphur, 1 pint water.}

The patient's diet shonld consist of oatmeal gruel, slightly alkalized with hyposulphite of soda.

\section{Malignant Catarrh.}

Caused by feeding in damp, cold situations, aul feeting on marshes in peculiar sensons. Low, wet river bottoms are most subject to give it to stock. The disease somewhat resembles the Russian catthe plague, but is not usually contagious. Professor James Ialw gives symptoms and - treatment as follows :

A slight diarrhea may be followed by mitiveiess, the dung being black, firm anl scanty. The hair is rough and erect; shivering ensues; the head is depressed; the roots of the horns and foreheal liot;

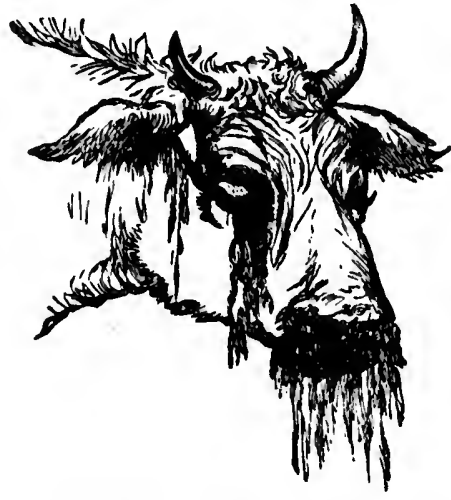

MALTGNANT CATARRI-SLOUGHING epes sunkes, red, watery, with turbiclity in the interior and intolerance of light; muzzle dry and hot; mouth lint with much salival ; the menbranes, month, nose and vagina bluish-led; pulse rapid; impulse of the heart weak; breathing hurried; eongh; urine seanty and high cullorel, and surface of the body alternately hot and cold. In twenty-four hours all the symtoms are aggravated; the nose discharges a slimy fluid ; forehend is warmer and duller on perrussion; the mouth eovered with dark red blotelies, trom which the enticle soon peels off, leaving raw sores; appetite is eompletely lost; dung and urine passed with much pain and straining, and there is generally stiffuess and indisposition to move. From the fourth to the sixth day uleers appear on the nose and muzzle, swellings take place beneath the jars, chest and abdomen, and on the lega the skin may even slough off 
in patches; a fotid saliva drivels from the mouth and a stinking diarrhœa succeeds the costiveness. Death usually ensues from the eighth to the tenth day, preeeded perhaps by convulsions or signs of suffocation.

The treatment is to clean the bowels with the following:

No. 28.

1 PInt ollve oll,

$10 x$. laudanum.

Mix.

In eight or ten hours, if it do not operate, give another. Follow this with diuretics, sweet spirits of nitre in half-ounce doses, and also with antiseptics, potassa chlorate, in doses of one-quarter drachm. Wet cloths should be kept on the hend; the mouth and nose sponged with quite a weak solution of carbolic acid. Give as food only soft mashes.

\section{Isolation of Infected Cattle.}

When abortion is about to occur in a stable, at the very first symptom the animal should be entirely separated from the others, and the stall thoroughly disinfected with carbolic acid. In relation to measures preventive and remedial, these will be found in the list of properly labeled drugs to be kept for tbat purpose ; they may be referred to at will. Isolation, however, is of absolute importance, lest the cause extend to other or perhaps all the cows in the stable. Ergot or other fungus spores in the food may be the cause. All possible causes should be curefully examined and remedied. $\Lambda$ thorough eleansing of the stables should be made, and disinfectants and fumigunts used. The following in the form of powder is good as a disinfeetant in any case.

No. 18.

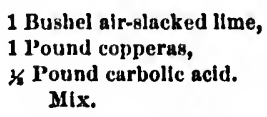

A liquid form :

No. 10.

1 \% Pounds chloride of aluminum, 1 Gailon water.

Dissoive. This ls not polsonous. 


\section{CHAP'TER IV.}

Follow this d also with Wet cloths ith quite a

st symptom and the still neasures preperly labeled at will. Isoxtend to other grus spores in carefully exbles sliould be ig in the form

1. Dissetion.- II. ACTION OF MRDICINES. - III. MEDICINES TO BE KEPT, AND DOSEs.

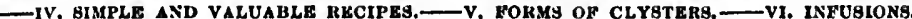

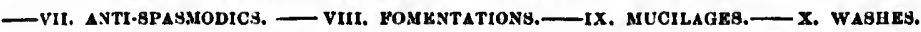
-XI. POULTICES. - XII. FUMIOATION8.—XIII. TINCTURE POR WOUNDS.

\section{Dissection.}

In the dissection of eattle the axe and meat saw, and butcher's knife must be largely depended on, in the hands of farmers, since all that is necessary is to get at the diseased parts to note their appearance and the seat of the disease, the symptoms having been previously carefully noted. This matter bas been treated of in diseases of the horse, chapter XIX., article Dissection, to which the reader is referred.

\section{Aotion of Medicines.}

The action of medicines, doses for horse, ox, sheep and swine is also trested of in chapter XIX., of the horse, together with much other vilualle matter applicable to animals generally.

\section{Medicines to be Kept, and Doses.}

It will not be necessary to keep more than a small stock of the medicines in most common use, or such as may be required in an emergency. Those adapted to the horse, will, as a rule be also adapted to other stock. ln elhipter XIX. a pretty full list will be found, with the appropriate doses for cattle, sheep and swine, as well as the horse; also the proper proportionate dose for animals of various ages up to the adult. It will not be necessary to repeat them here. 
For the purpose of enubling our readers to become familiar with the bony structure of cattle we give an illustration of the skeleton of the ox with the correct names of the various parts as known in vetcriuary science. It will be found valuable for reference, not only to the student in veterinary art, but also to every one who proposes to keep and breed cattle.

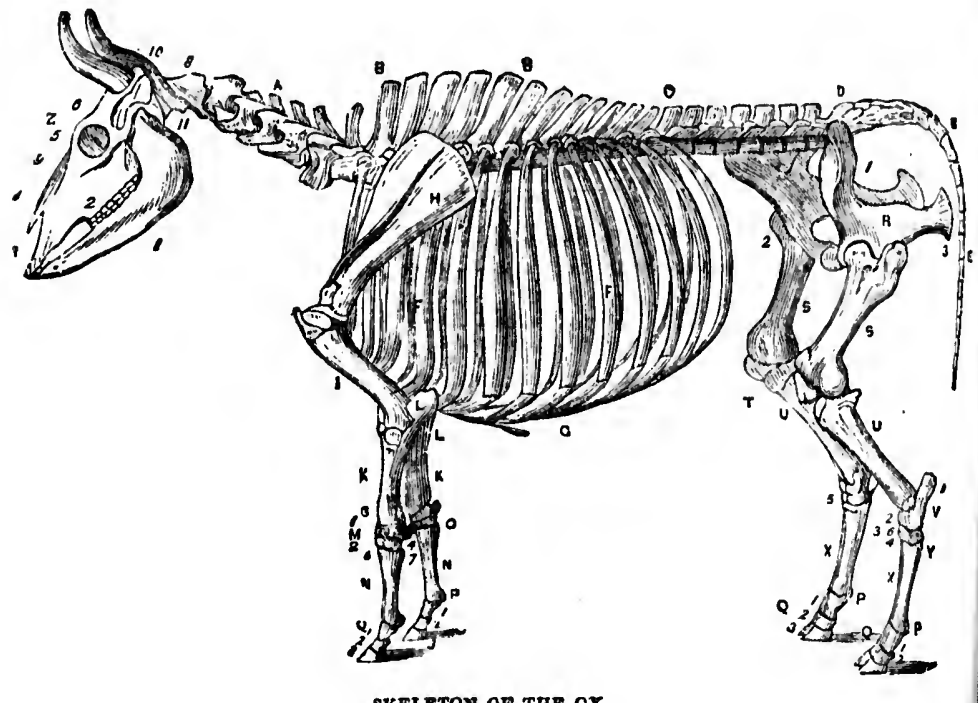

Explanation of Cut.- $A$-Cervical Vertebrac. $\quad B B-$ Dorsil Tertebrae. $C$-Lumbar Vertebrac. $D$-Sacrum. $E$ E-Concygeal Bones. $F F$ -Ribs. G-Costal Cirtilages. II-Scapula. I-IIumerus, II liRadius. $L$-Ulua. $M$-Carpus or Linee. 1-Seaphoid. 2-Semiluntr. 3-Cuneiform. 4-Trapezium. 5-Trapezoid. 6-Os Magnum. iUnceiform. 8-Pisiform. $\quad N$-Large Metacarpel or Caumon. 0Small Metecarpel, $\boldsymbol{P} P$-Sesamoid Bones. $Q Q$-Phalanges, 1-0s Suff rnginis or Pastern Bone. 2-Os Coronac. 3-Os Pedis. $R$-Pelris, 1-Illium. 2-Pubis. 3-Ischium. S-Femur. T-Pitellis. $\quad-$ Tibia. V-Fibula. W-Ioeks. 1-Os Calcis. 2-Ostragulus. 3Cuneiform Magnum. 4-Cuneiform Median. 5-Cuneiform Parrum. 6-Cuboid. T-Largo Metatarsal. 1, 2, 3-Phalanges. $Y$-Small Metatarsal. Z-Head. 1-Inferior Maxilla. 2-Superior Maxilla, 3Anterior Maxilla, 4-Nasal Bone. 5-Molar. 6-Frontal. 7-Parietal. 8-Oceipital. 9-Lachrymal. 10-Squamous. 11-Petrous. 
In compuring the skeleton of the ox with that of the horse, we ean readily perceive the difference in the length of the linb and neck possessed by the latter. Speed seems to have been an object at the creation, and as the body was elevated the neek needed proportionate leugth in orler to feed. The body of the horse corresponds to a square, while that of the ox to a long rectangle. The limbs of the ox are struighter than those of the horse, much less speed being demanded. The ribs of the former are both longer and larger than those of the latter, greater protection with sluggardness of movement being required. In the head of the $0 \mathrm{x}$ we find tho two plates or tables noticed in the horse; in the latter, however, they lie elose together, while in the former, as in all horued animals, there is considerable space between them. This diversity creates a number of cells, having bony ridges passing from the imer to the outer plate, which secures the firmmess of the parts. These cells form roomy and strong sockets for the horns. The cavity containing the brain of the $0 x$ is about one-fourth the size of the other parts of the skull ; the organs of mastication and those of smell taking up the remaining portions. In eattle the frontal bones extend from the nose to the superior ridge of the skull, presenting a flat, irregular surface, totally bare of any muscular or tleshy covering. The weapon of defense and offense employed by cattle is the holn and nuture has securely based it and rendered it effective by this expanse of the frontal bone. There is the same division in the center of the frontal sinuses as in the horse, but the perfection of division between the nostrils is wanting. Commencing about half way up the nose, the septum is wanting at the lower part, and the two nostrils are, as it were, thrown into one; the frontul sinuses connect with the nasal, thus forming a continuous carity from the muzzle to the horn, and from one muzzle to the other. In polled eattle the frontal bone holds the same situation-reaching from the nasal bones to the parietal ridge-but as they were not designed for tho base of horns, they narrow off towards the poll. The temporal bones in cattle are small, deep in the temporal fossil and destitute of the squamous structure. The occipital bone is, in the ox, deprived of almost all the importance attuched to it in the corformation of the horse. The sphemoid and itlumoid bones are in the sume relative position.

\section{Simple and Valuable Medieal Recipes for Cattle.}

Dr. G. II. Dildd, M.D., V.S., n medical practitioner of repute, and celebrated as a veterinary surgeon, up to the time of his death, some fifteen years ago, attributed much of his suecess to not being bound by any rigid rules of practice. Thus he, while having heen bred under the Allopathic system of medicine, used largely of botanical agents, as in 
finet do ull our best physicians now, more lingely thin formerly. In the appendix to his work on the diseases of cattle he gives a series of recipes under appropriate hendings, which we reproduce in a somewhat different and condensed form, as being at the sune time simple and efficucious. In his observations on the uetion of medicine, and external agents on the animal body, he says, that warmth and moisture always expnud it, and bayberry bark, tannin, and gum catechu always contract it; and that these ngents have these effects at all times (provided, however, there be sufticient vitality in the part to manifest these peculiar changes) and under all circumstances. If a blister be applied to the external surface of an animal, and it produces irritation, it always has a tendency to produce that effect, whatever part of the living organism it nuy be applied to. So alcohol always has a tendency to stimulate, whether given by the mouth or rubbed on the external surface, it will produce an excitement of nerves, heart and arteries, and of course the museles partake of the influence. Again, marsh mallows, gum acacia, slippery elm, etc., always lubricate the mueous surfaces, quiet irritation, and relieve inflammatory symptoms.

It follows, of course, 1st. That when any other effects than those just named are seen to follow the administration of these articles, they must be attributed to the morbid state of the parts to which they are applied; $2 d$. That a medicine which is good to promote a given effect in one form of disease, will be equally good for the sume purpose in another form of disense in the same tissue. Thus, if an infusion of mallows is good for inflammation of the stomach, and will lubricate the surface, and allay irritation in that organ, then it is equally good for the same purpose in inflammation of the bowels and bladder. What we wish the reader to understand is this: that a medicine used for any particular symptom in one form of disease, if it be a/sanative agent, is equally good for the same symptom in every form.

The medicines we recommeud owe their diuretic, astringent, diaphoretic and cathartic powers to their dromatic, relaxing, antispasmodic, lubricating and irritating properties; ard if we give them with a view of producing a certain result, and they do not act just as we wish, it is no proof that they have not done gogd. The fact is, all our medicines act on the parts where nature is making the greatest efforts to restore equilibrium; hence they relieve the censtitution, whatever may be the nature of their results.

\section{Forms of Clysters.}

Laxative clyster :

No. 29. 
Another :

In the of recipes $t$ different effiereious. ents on the and it, and ; and that r, there be ) and under iface of an to produce e applied to. given by the , excitement rtake of the , ete., ulways inflammatory

jan those just les, they must $y$ are applied; t in one form other form of is is good for ace, and alhy me purpose in the reader to $r$ symptom in good for the nt, disphoretic dic, lubricating of producing no proof that ct on the parts librium; hence ff their results.
No. 30.

\author{
4 Quarts warm water, \\ 1 Gill solt boap, \\ × Table-spoourul tine salt.
}

Useful in obstinate constipation, "stoppage," or whenever the excrement is hard and dark colored.

Emolliont clyster :

No. 31. 2 Or.nces slippery elm bark,

Simmer over the fire a fow minutes, strain through a fine sieve, and inject, when nearly cool. The following articles may be substituted for elm : fluxseed, lily roots, gum arabic, poplar bark, Iceland moss.

$U_{3 e}$.-In all cases of irritation and inflanmation of the intestines and bladder.

Stimulating clyster :

No. 32. 8 Quarts of thln mucllage of alippery elm or llnseed tes, 1 Teaspoonful African cayenne, pure.

Another :

No. 33. * Table-spoonful powdered ginger, 3 Quarts bolling water.

When cool, inject.

Use.-In all cases when the rectum and small intestines are inactive and loaded with excrement, or gas.

Anodyne clyster :

No. 34. 1 Ounce lady's sllpper (cypripedlum),

1 Ounce camomlie flowers,

3 Quarts bolling water.

Let the mixture stand a short time, then strain through a fine sieve when it will be fit for use.

Use.-To relieve pain and relax spasms.

Diuretic clyster :

No. 35. 8 Quarts llnseed tes, 1 Table-gpoonful oll of juniper.

Or, substitute for the latter, cream of tartar, half an ounce.

Use.-This form of clyster may be used with decided advantage in all acute diseases of the urinary organs. This injection is useful in cases of red water, both in cattle and sheep; and when the malady is supposed to 
result from general or local debility, the addition of tonies (golden seal or gentian) will be indicated. 'Their active properties may be extructed by infusion.

Astringent clyster :

Take an infusion of hardhack, strain, and add a table-spoonful of finely-pulverized churcoal to every three quarts of fluid.

Another is an infusion of witch hazel.

Another :

No. 80.

1 Table-spoonful powdered bayberry bark, 3 Quarts bolling water.

When cool, it is fit for use.

Use.-Astringent injections are used in all cases where it is desired to contract the living fibre, as in scouring, dysentery, scouring rot, diurrhen, bloody flux, falling of the womb, fundument, ete.

Nourishing elysters :

Nourishing clysters are composed of thin gruel made from flour, ete.

Injection for worms :

Make an infusion of poinegranate (rind of the fruit), and inject erery night for a few days. This will rid the animul of worms that iufest the rectum : but if the animal is infester with the long, round worm (teres), then half a pint of the above infusion must be given for a fow wurnings, before feediug.

Another for worms :

No. 87.

1 Ounce powdered lobelia,
1 Handful wood ashes,
3 Quarts bollng water.

When cool, it is fit for use.

\section{Infusions.}

These are made by steeping herbs, roots, and other medical substances in boiling water. No particular rules can be laid down as to the quantity of each article required. It will, however, serve as some sort of a guide, that we generally use from one to two ounces of the aromatic herbs and roots to every quart of fluid. A bitter infusion such as wormwood or camomile requires less of the lierb. All kinds of infusions can be rendered palatable by the addition c c " " uantity of honey or molasses. As a general rule, the humnn sion be too strong or

An infusion of eit 4 is ood eriterion; for if an infuflatulent and spasmodı, in all cusses of animals : caraway, peppermint, $i$, it is unfit for cattle or sheep. 
golden seal vo extructed

-spoonful of

is desired to rot, diarrhen,

om flour, ete.

ad inject every thint infest the worm (teres), fow L:urnings,

lical substanees to the quintity sort of a guide, atic herbs and wormwood or uns can be relley or molasses. for if an infucattle or sheep. le in colie, both $y$, peppermint, spearmint, fonnel seed, angelicu, borgamot, suake root, aniso seed, ginseng, ete.

\section{Anti-spasmodios.}

By anti-spasmodies are meant those urticles that assist, through their physiological action in relaxing tho nervous and muscular systems.

\section{VIIr. Fomentations.}

This class of remodies is usunlly composed of relaxants, etc., of several kinds, combined with tonies, stimulants, and anodynes. They are very useful to relieve pain, to remove rigidity, to restore tone, and to stimulate the parts to which they are applied.

Conmon fomentation:

No. 38.

1 Part wormwood,
1 Purt tunsy,
1 Purt hops.

Ioisten them with equal parts of boiling water and vinegar, and upply when blood wa'm.

Use.-For all kinds of bruses and sprains. They should be confined to the injured parts, and kept moist with the superabundant fluid. Whero it is not practicable to confine a fomentation to the injured parts, as in shoulder or hip lameness, constant bathing with the decoction will auswer the same purpose.

Anodyue fomentation:

$$
\begin{aligned}
& \text { No. 39. } \\
& 1 \text { Handful-of hops, } \\
& \text { Equal purts water and vluegar. }
\end{aligned}
$$

Simmer a few minutes.

Use.-In all painful bruises.

Relaxing fomentation:

No. 40. 2 Ounces powdered lobelia, 2 Quarts boiling water.

Simmer for a few minutes, and when sufficiently cool, bathe the parts with a soft sponge.

Use.-In all cases of stiff joints, and rigidity of the muscles.

Cedar buds, or boughs, any quantity, to which add a small quantity of red pepper and ginger, with boiling water sufficient. 
Use.-Etficacious in chronic limeness and paralysis, for putrid sore thront, and when the glands are eularged from cold and catarrh.

IX. Muoilages.

1 Mucilages are soft, bland substances, made by dissolving gum arabic in hot wuter; or by boiling numsh mallows, slippery elm, or lily roots, until their mucilaginous properties aro extracted. A tuble-spoonful of eitler of the above articles, when powdered, will generally suffice for a quirt of water.

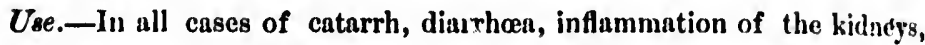
womb, bladder, and intestines. They s!licld tho mucous mombranes, and defend them from the action of poisons and Irastic enthurtics.

\section{Washes.}

Washes generally contnin some medical agent, and are principally used extermully.

Wash for diseases of the fect:

$$
\text { No. } 41 .
$$

4 Ounces pyroligenous acld, 8 Ounces water.

Use-This wash exeels any other in point of efficacy, and removes rot and its kindred diseases sooner thun any other.

Cooling wash for tho eyo :

$$
\text { No. } 42 .
$$

1 Pint raln water,

20 Drops acelic wead.

Use.-In ophthalmia.

Tonic and anti-spasmodic wash :

$$
\text { No. } 43 .
$$

\section{K Ounce camomile forern,}

1 IInt boiling water.

When cool, arain through fine linen.

Use.-In chronic diseases of the cye, and when a weeping remains after an ucute uttuck.

Wash for unhealthy or ulcerinted sores :

A wenk solution of soda or wood ushes.

Wush for diseases of the skin :

Tuke one ounce of finely-pulverized charcoal, pour on it one ounce of pyroligenous acid, then add a pint of water. Bottle, und keep it well corked. It may be applied to tho skin by means of $\|$ sponge. It is also an excellent remedy for ill-conditioned ulcers.
Phy

Mix.

Anot

Dissol

Anoth

Here a bilitite th surface as purges are

Mild ph

Aperient

$\mathrm{N}$

Mix.

Another

Mix.

A sheep

Stimulati

No.

$\mathrm{U}_{\mathrm{se}}-\mathrm{F}_{\mathrm{O}}$

Another: 
Physic for cattle :

No. 44.

\$. Ounce extract of butternut (Juglans cinerea),

1 Tow-upoonful cream tartar,

2 Quarts bolling water.

Mix. When cool, administer.

Another :

No. 45. K Ounce extracl of blackroot (leptandra virginica),

1 Ounce Kochelie aalth,

$x$ Tearupooniul powdered gloger.

Dissolve in two quarts of warm water.

Another :

No. 16. 1 Table-apoonful powdered mandrake,

1 Teaspoonful eream of tartar

2 Quarts hot water.

Here are three different forms of physic for cattle, which do not dobilitate the system, like aloes and salts, because they determine to the surface as well as the bowels. They may be given in all cases where purges are necessary. One-third of the above forms will suffice for sheep.

Mild physic for cattle:

No. 27 . 2 Onces ayrup of buck thorn, K Table-spoonlul sulpbur, K Tea-spoonful gluger, 8 Quarts lot water.

Aperient :

No. 48. 1 PInt linmeed oll, Yolk: of 2 egge.

Mix.

Anotlier :

No. 49.

1 Pint sweet oll, * Tearupoonful powdered cayenne.

Mix.

remains

ounce of it well It is also

A sheep will require about one-half of the above. Stimulating tincture:

\$o. 60.

1 Pint bolling vinegar,

2 Ounces llncture of myrrh,

2 Teaspoonfuls powdered crpslcum.

Use.-For external application in putrid sore throut.

Another: 
No. 51.

4 Ounces tineture of cumphor,

* Ounce oll of celur,

1 Outces tincluru of eapsicum (hot drops).

To be rubbed around throat night and morning.

Stimulating tincture for chronie rheumatism :

No. 62.
1 Ounces tlncture of capsicum,
1 Ounce oil of cedur,
1 Ounce oll of wormwood,
\$ I'int vinegar,
1 Gill goose grease.

Mix. To be applied night and morning. The mixture should be kept in a well corked bottle, and shaken before being used.

\section{Poultices.}

If a foreign substance enters the flesh the formation of matter is a part of the process by which nature rids the system of the eneny. A poultice relaxing and lubricuting will then be indieated. If, however, the foreign body shall have entered at a point where it is impossible to confine a poultice, then the suppurative stage may be shortence by the application of relaxing fomentations, and lastly by stimulants.

Mr. Cobbett says of marsh mallow plant: It is among the most valuable that ever grew. Its lenves stewed, and applied wet, will cure, and almost instintly case, any cut, or bruise, or wound of any sort. Poultices made of it will cure spratius ; fomenting with it will remove swellings; applications mude of it will cure chafes made by saddle and harness; and its operation, in all eases, is so quick that it is hurdly to be believed. Those who have this weed at hand need not put themselves to the trouble and expense of sending to doctors and furriers on tritling occasions.

If the use of this weed was generally adopted the art and mystery of healing wounds, and of curing sprains, swellings, and other external maladies, would very quickly be reduced to an unprotitable trade.

Lubricating and healing poultices:

No. 63.

1 Part powdered marsh mullow rooth,

1 Part marah mallow leaves.

Moisten with boiling water, and apply.

$U$ se.-In ragged cuts, wounds and bruises.

Stimulating poultice:

No. 64.

1 Part Indlan meal,

1 Part slippery elm.

Mix them together, und add sufficient boiling water to moisten the 
mass. Spread it on a cloth, and sprinkle a small quantity of powdered cayenne on its surface.

Use.-To stimulate ill-conditioned ulecrs to healthy action. Where there is danger of putrescence add a small quantity of powdered churcoal.

Poultice for bruises:

Tothing inakes so good a poultice for recent bruises as boiled carrots or marsh mallows.

Poultice to promote suppuration:

$$
\begin{aligned}
& \text { No. } 55 \text { A sufficient quantity of Indian meal, } \\
& 1 \text { II Iutful of linsecd, } \\
& 1 \text { T'easpoonfnl of cuyenne. }
\end{aligned}
$$

To be moistened with vinegar and applied at the usual temperature.

Styptics to arrest bleeding :

Witch hizel, (Winter bloom,) bark or leaves, 2 ounces.

IIske a decoetion with the smallest possible quantity of water, and if the hleeding is from the nose, throw it ul) by means of a syringe; if from the stomach, lungs, or bowels, add more water, and let the animal drink it, and give some by injection.

Styptic to arrest external bleeding:

Wet a piece of lint with tineture of muriate of iron, and lind it on the pirt.

There are various other styptics. such as alum water, strong tincture of nutgalls, bloodroot, common salt, fine tlour, ete.

Absorbents :

Aborbents are composed of materials partaking of an alkaline character, and are used for the purpose of neutrilizing acid matter. The formntion of an acid in the stomach arises from some derngement of the digestive organs, sometimes brought on by the improper quantity or quality of the food. It is useless, therefore, to give absorbents, with a riew of neutralizing acid, unless the former are combined with tonics, or arents that are capalibe of restoring the stomach to a healthy state.

A mixture of chulk, salisitus, and soda is often given by furmers ; yet they to not afford permmment relief. They do some good by correcting the arility of the stomach, but the animals are often affected with diariliea or costiveness, loss of appetite, colic, and convulsions. Attentim to tho dict would probably do more good than ull the medicine in the romll. Yot, if they do get sick, something must be done. The best forms of ahsorbents are the following which have heen very carefully selected. They restore healthy netion to the lost function, at the sume time that they nentralize the gas :

Forms of ubsorbents : 
No. 56.

1 Table-spoonful powdered charcoal, 3. Table-spoonful powdered snakeroot, 1 Tea-spoonful powdered caraways,

1 Quart hot water.

M: . To be given at one dose for a cow; half the quantity, or indeed one-third, is sufficient for a calf, sheep or pig.

Another:

No. 67.

1 Table-spoonful powdered charcoal.

To be given in thoroughwort tea, to which may be added a very small portion of vinegar.

Another, adapted to city use :

No. 58. 1 Tea-spoonful sub-carbonate of soda,

1 Ounce tincture of gentian,

1 l'int infusion of spearmint.

Mix. Give a cow the whole at a dose, and repeat daily, for a short time, if necessary. One-half the quantity will suffice for a smaller animal.

Drink for coughs :

No. 6 ?.
3. Ounce balm of Gilead buds,
2 Table-spoonfuls honey,
1 Winc-glassful vinegar,
1 Pint water.

Set the mixture on the fire, in an earthen vessel; let it simmer a few minutes. When cool, struin, and it is fit for use. Dose, a wine-glassful twice a day.

Another:

$$
\begin{aligned}
& \text { No. 60. } \\
& 1 \text { Ounce baissm copalba, } \\
& 1 \text { Ounce powderti ilcorlce, } \\
& 2 \text { Tuble-spoonfuls honey, } \\
& 1 \text { Quart bolling water. }
\end{aligned}
$$

Rub the copaiba, licorice and honey together in a mortar; after they are well mixed, add the water. Dose, half a pint, night and morning.

Another :

$$
\text { No. } 61 .
$$

$$
\begin{aligned}
& \text { y Ounce balsam of Tolu, } \\
& 1 \text { Ounce powdered marshmallow roote, } \\
& \text { 3/6 Gi!l honey, } \\
& 2 \text { guarts bolling water. }
\end{aligned}
$$

Mix. Dose, half a pint, night and morning. 
Drink for a cow after calving :

No. 62. 1 Ounce bethwort,

1 Ounce murshmallows.

First make an infusion of bethwort by simmering it in a quart of, water. When cool, strajn, and stir in the mallows. Dose, half a pint, every two hours.

Diuretic:

Bearberry ( $u v a$ ursi), is a popular diuretic, and is useful when combined with marshmallows. When the urine is thick and deficient in quantity, or voided with difficulty, it may be given in the following form :

No. 63.

1 Ounce powdered bearberry,

2 Ounces powdered marshmallows,

2 Pounds Indian meal.

Mix. Dose, half a pound daily, in the cow's fced.

Eruption wash :

Borax is a valuable remedy for eruptive diseases of the tongue and mouth. Powdered and dissolved in water, it forms an astringent, antiseptic wash. The usual form is :

No. 64. \& Ounce powdered borax,

2 Ounces houey.

Mix.

\section{Fumigations.}

For foul barns and stables, take,

No, 65.

4 Ounces common salt,

1\% Dunce manganese.

Let these be well mixed, and placed in shallow earthern vessel; then pour on the mixture, gradunlly, sulphurie acid, four ounces. 'The inhulation of the gas which arises from this mixture is highly injurious; therefore, as soon as the acid is poured on, all persons should leave the huilding, which should immedintely be shut, and not opened again for ${ }^{4}$ several hours. Dr. White, V.S., says, "When glanderous or infectious matter is exposed to it n short time, it is rendered perfectly harmless."

Uleeration of the mouth :

A strong infusion of goldthread (coptis trifolia), makes a valuable application for eruptions and ulcerations of the mouth. We use it in the following form : 
No. 66.

1 Ounce goldthrend,

1 l'int boiling water.

Set the mixture aside to cool; then strain, and add a table-spononful of honey, and buthe the parts twice a day.

Astringent :

Kino is a powerful astringent, and may be used in diarrhen, dysentery, and red water, after the inflammatory symptoms have subsided. We aceasionally use it in the following form for red water and chrouic dysentery:

No. 67.

20 Grains powiered kinn,

1 Quart ibin nour gruel.

To be given at a dose, and repeated night and morning, as ocrasion requires.

Simple cough remedy :

The following makes an excellent cough remedy:

No. 68.

1 Dunce powdered llenrice,

1 'Tea-spoonful balsan of 'T'olu,

1 Quart boiling water.

To be given at a dose.

Antacid for hoven :

Lime water is used in diarrhoea, and when the discharge of urine is excessive. Being mu antacid, it is very usefully employed when cattlo are hoven or blown. It is unsafe to administer alone, as it often deranges the digestive organs; it is therefore very properly combined with tonies. The following will serve as an example :

No. 69.

2 Onnces line water,

2 Quarts fufuslon of snakebead (balmony),

Dose, a quart, night and morning.

\section{Tincture for Wounds.}

Myrrh makes an excellent tincture for wounds, prepared as follows:

No. 70.

2 Ounces powdered myrrh,

1 Plut proof spirits.

Set in a close covered vessel for two weeks, then strain through a fine seive, and bottle for use. It should be always kept on hand.

Opodeldoe :

Used for strains and bruises, after the inflammatory action has somewhat subsided. 
Liquid opodeldoc:

No. 71 .

\author{
6 Ounces soft sosp, \\ $1 \%$ Pints Now Englund rum, \\ * Pint vinegar, \\ 2 Ounces oll of lavender.
}

The oil of lavender should first be dissolved in an equal quantity of alcohol, und then added to the mixture.

Nuciliges for eatarrh, etc. :

We lave given pleurisy root, (asclepias tuberosa), a fair trial in cattlo practice, and find it to be invaluable in the treatment of catarrh, bronchitis pleurisy, pneumonia and cousumption. Take:

No. 72.

\% Tabie-spoonful powdercd pleurisy root, 1 Ounce powdered marshmuliow roots.

Boiling water sufficient to make a thin mucilage. The addition of a sulll quantity of honey increases its diuphoretic propertics.

For eruptive diseases :

The birl'k of sassafrus root is stimuluut, and possesses alterative properties. Used in connection with sulphur, for eruptive diseases, and for meastes in swine, in the following proportions, it will be found valuable:

No. 73.

1 Ounce powdered sassafras,

1-8 Table-spoonfui powdered sulphur.

Mix, and divide into four parts, one of which may be given night and morning, in a hot mash.

\title{
IICE ON CATTLE.
}

All cattle, and especially those in poor condition, are liable to attacks of lice of varions speeies, which will propiagate very rapidly, soon infesting other stinck and even the stables aud barns themselves. Treatment must, therefore, be directed promptly at the animals, and their surroundings also. Stables stunth be cleaned and whitewashed. Their seratelsing places should be coated with petroleum or coal tar.

fior treatment of the cattle, poisunous substanees must be shunned carefully, as their habit of lieking themselves would result in their injury. One of the simplest preparations is a stroug solution of tobaceo leaves saturated with rock salt. This may be applied thoroughly on several occasions at intervals of three or four days. Repetition is necessary to the extirpation of the Young, which may be hatched after the first application. If alcohol be used in the decocticn of tobaceo leaves it will destroy the nits as well as the lice, and prove the quickest relief from the pests. 
A good preparation which will remain well upon the hide is this:

$$
\begin{aligned}
& \text { Linseed oil, } 4 \text { parts. } \\
& \text { Common creosote, } 1 \text { part. }
\end{aligned}
$$

Mix well, and rub thoronghly.

An ointment of eayenne pepper, or Scoteh snuff mixed with bog's larl, well rubbed in, will be found very effective. Espeeially look out fur vermin in young stock, or stock in poor condition.

\section{FOUIS IN CATTLE.}

Foul claw, or foul in the foot, is a disease charucterized hy inflammation and suppuration of the substance in the cleft of the hoof. Sometimes it extends to the entire foot, and even includes the whole leg, consing fever, failure, and death in some cases. Usually it affeets the hind feet. Forcign substances between the claws, excessive weight and strain upon the font, or a serofulous condition of the system nay cause this trouble. Its best treatment consists of cureful eleansing of the sore; poulticing, if much influmel, and astringent npplieations. In elennsing, a syringe may be needed, using a solution of earbolie acid. Cloths saturated with the solution shonld be pressed into the opening and bound there. A clean stable, or a dry pasture ground are essential. In extreme cases amputation of the foot has been tried, and the animal afterwards prepared for the butcher. This, however, is scarcely a paying operation.

For a wash, nse carbolic aeid 1 drachm, water 6 ounees.

For au ointment, use :

$$
\begin{array}{ll}
\text { Oil of turpentine, } & 4 \mathrm{oz} . \\
\text { Lard, } & 4 \mathrm{oz} . \\
\text { Powdered :ulphate of copper, } & 1 \mathrm{uz} .
\end{array}
$$




\title{
PART V.
}

\section{Sheep and SheEp Husbandry.} ORIGIN, BREEDS, CHARACTERISTICS

\author{
AND MANAGEMENT.
}




\section{SHE}

ORIO

COSMOPOLITAN

II. BORDE

- Cotswo.

SIIEF.P. WIITE-FAd

-XI. II Dowss.

FLEECE,

vivisjoxs

Where shee first of the an supply the ty Tiney are foun dretic to the To sluow the to quote the el Black-faced, S mimped, Buch may be added 


\title{
SHEEP AND SHEEP HUSBANDRY.
}

\author{
CHAPTER I. \\ ORIGIN, PRINCIPAL BREEDS AND ChARACTERISTICS.
}

COGHOPOLITAN NATURE OF SHEEP. — LONO-WOOLED SHEEP.——. IEICESTER. II. BURDER l.EICESTER.- - H. COTSWOLD. $\rightarrow$ GOOD QUALITIES OF COTSWOIDS. - COTSWOLDS IN TIE WEST.—IV. IINCOLN SHERP.—V. NEW OXFORDSHIRE SILFP. - VI. MUDLE WOOLED SILEP. — VII. CILVIOT SIIEEP. - VIII. WHITE.FACFD IIIGHLAND SHEEP.—IX DORSET SIIEEP. - $X$. BOUTHDOWNS. —XI. IAMPSHILE DOWNS. — XII. SHROPSHIRE DOWXS. - XIII. OXYORD DOWNS. - FINE WOOLED SHEEP. — XIV. AMYRICAN MERINOS. — THE FLEECE. - THE NEAD.—-THE BODY.——THE MOST PROFITABLE SIIEEP.— vivisions of woor.

\section{Cosmopolitan Nature of Sheep.}

Where sheep originated is a question difficult to answer. They are the tirst of the animals domesticated by man, and reasonubly so, since they inply the two principal wants of the barbarian, food and clothing. They are found in every inhabited country, not entirely savage, from tho Aretic to the Torrid zone.

To show the grent diversity in character of sheep, it is. only necessary to quate the classification of Linnæeus, which is: The Hornless, Horned, Blitek-faced, Spanish, Many-horned, African, Guinen, Broad-tailed, Fatrumped, Bucharian, Long-tailed, Cap-bearded, and Bovant. To these may be added the Silerian sheep of Asia, found also in Corsica and 
Barbary and the Cretan sheep of the Grecian Islunds, Hungury, and some portions of Austria, and we have about ull the principal splecies.

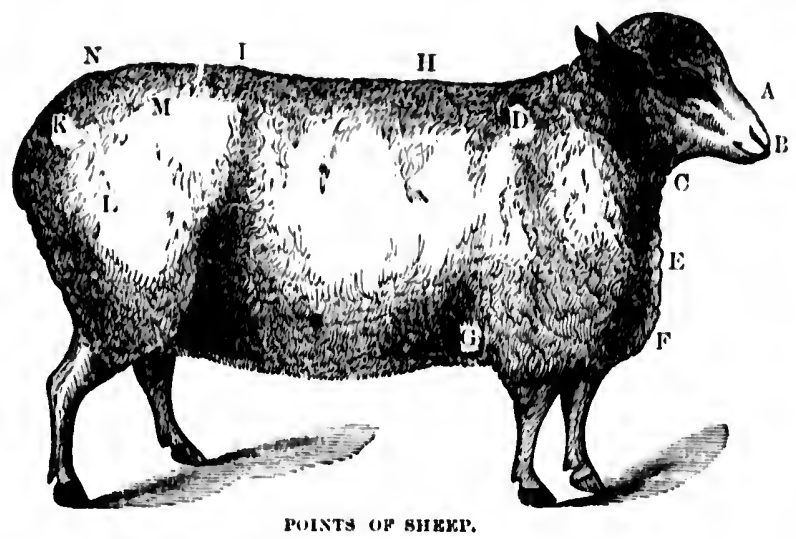

Explanation-A-Face. $B$-Muzzle. $C$-Neck. $D$-Shoulder. $E$-Point of lla Shoulder. F-Breast. $G$-Girth-place. II-Back. I-Loin. $K-$ Rump. $L-$ Thigh. $M-H i p . \quad N-$ Root of tail.

Notwithstanding the fact that sheep aye among the principal souress of wealth of ull peoples, it is only among enlightened nations that they have reached their lighest derelojment; amb among these, Sprin, Finure, (iermany, Great Britain and her colonies, and the United States man he mentioned as those where systematio breediug have produced he nimfaratical results. In no country has this been attrined in the production of tine wowl, to a more excellent dewree than mong what are now known as Amerienn merinoes, the result of seientific hreeding of the sprunis

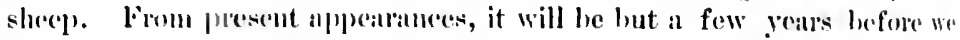
shall exael in the production of longrwooled, and metton sheep. Ihe Vuited States has of course, no native shecp, if we exiept the oris

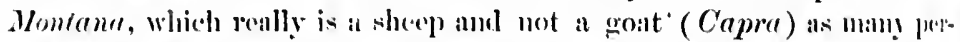
soms suppose. It imhahits the highest ringes of the Rocky Mountrins from well north down to Sew Mexico. The hair, for it is not wool, althengh it is erimperl, resembles the hair of the elk-is conse, but soft to the touch, and slightly erimped thronghout its length ; about two inches lony on its hack, and on the sides one and a half inches. We believe they have never been hred in confinement. In passing it may be interesting to our realers to know that at the Paris Exhibition of 1865 there were exhibited the wild sheep of Barhary, Ovis Tragelapus, more resemblitg 
ary, and

ecies.

$\Delta_{1}^{\Lambda}$

E-Point

-Loin, $h-$

hl somrors of nt ther hase iiil, linmer. mters mall he al \{lic $1110-1$ production now known the spomish is leforo wa sheep. 'the yet the Oris as malils fletountains from ool, althongh soft to the inches lonis believe thes interesting to 5 there were resembliug a goit than our wild nperies. There were alwo shown there the Punjunts

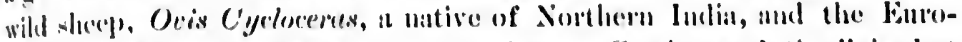

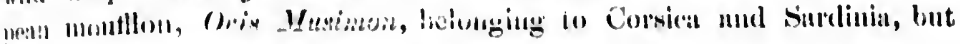

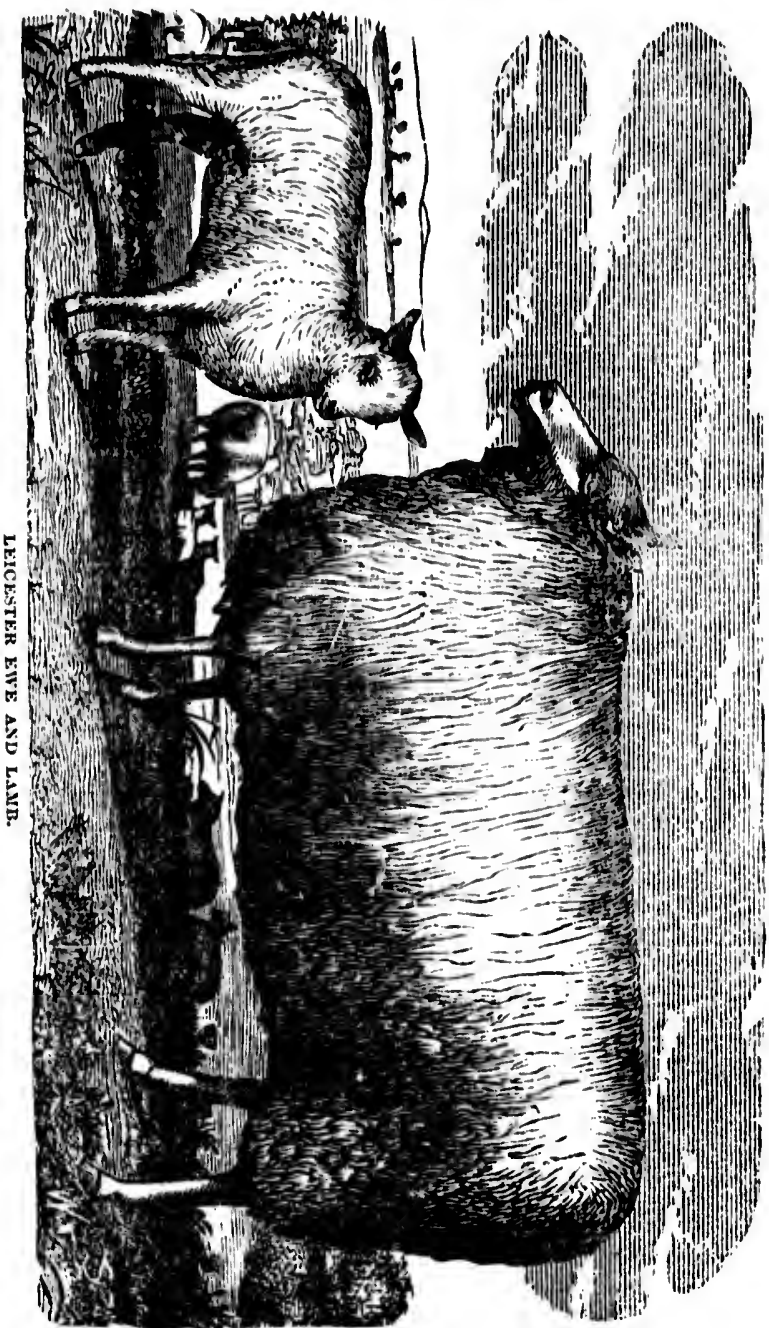

holh bred in confinement. As illustratins somethiug of the chanucteristics of the wild sheep, as well as to ilnstrate points the ent we give on preceding page may serve as an example. 


\section{Long-wooled Sheep.}

There are but a few kinds of long-wooled sheep that have held their own in the improvement of the rice for the last 100 years, sufficiently to be widely disseminated in the United Stntes. These are the Leicester, Cotswold, Lincolı and Romney Marsli. Of these, Leicester, as injproved by 13:kewell anci succeeding breeders, has perhaps exercised a more potent effect in crossing thun any other of the long-wooled varieties. They fitten very kindly, and the best wethers will weigh nt twelve to fifteen months old from 20 to 25 pounds per quarter, and at two years old from 30 to 38 pounds per quarter. The fleeces are valuable as long combing wool, and will weigh from 7 to 8 pounds each.

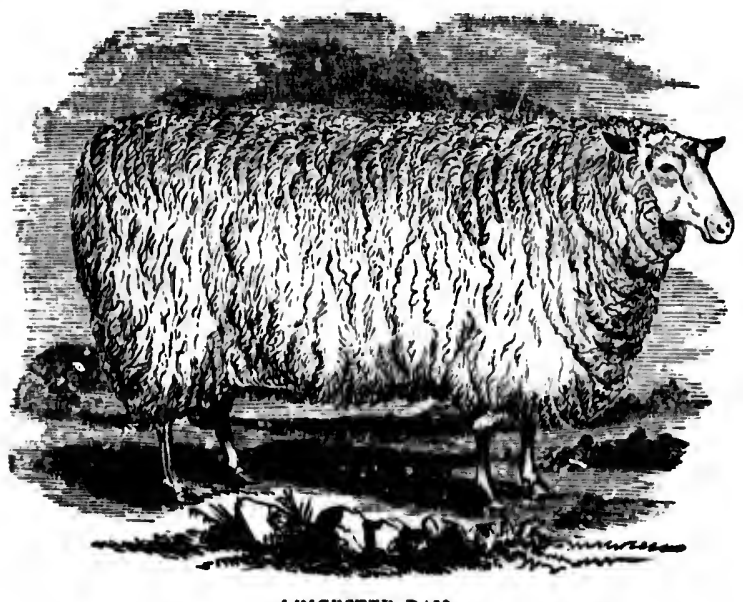

\section{Leicestel's.}

This brend is pure white, tolerably loady, without horms, the liend snill and clean, oyes bright, neck nnd shoulders square and de(p), the back strnight, carcass full, hind-quarters tapering to the tuil, legs cleall, with fine bone, flesh succulent in quality, not the best, being much ton fit fol Americun pulates; nevertheless, the grades muke good meit with the single exception of possessing too much outside fat. Leicesters require the best of eare and shelter, nnd of course good feeding. The ewes are not the best of mothers, and the young lambs require special attention. The wool is nmong the most valuable of my, ireing in especial 
request for combing, and will avernge seven pounds per hend in good flocks.

The Leicesters are well thought of in many parts of the West, nud are increasing in popularity. The true type of the breed is ns follows: The head should be hornless, long, smull, tapering towarl the muzzle, and projecting horizontally forward. The eyes prominent, but with a quiet expression. The ears thin, rather long, and directed backward. The neek full and broad at its base, where it proceeds from the chest, so that there is, with ihe slightest possible elevntion, one contimued liorizontal line from the rump to the poll. Th' breast broad and round, and no uneren or angular formation where the shoulders join either the week or the back; particularly no rising of the withers, or hollow behind the situation of these bones. The arm fleshy through its wholo extent, and even down to the kueo. The bones of the leg sinall, standing wide apart; no looseness of skin about them, and comparatively bare of wool. The chest and barrel at once deep and round, the ribs forming a considerable urch from the spine, so as in some enses, and especially when the animal is in good condition, to make the apparent width of the chest even greater than the depth. The barrel ribbed well home; no irregularity of line on the back or belly, but on the sides; the carcass very gradually diminishing in width toward the rump. Tho quarters long and full, and, as with the fore-legs, the muscles extending down to the hock; the thighs nlso wide and full. The legs of a moderite length ; the skin also moderately thin, but soft and clastic, and covered with a good quantity of white wool.

\section{Border Leicester.}

The infusion of the blond, of the Dishley, or new Iseicester as they were called, but which are now classitied simply as Leicester sheep, upon the border focks of Engla: !, gave rise to a sul)-family, known as Border leicester, and which have won a distinct position in English show yards. Their good and bad characteristics are as follows: Tle most marked fenture in their structure, is the smulness of their hends, nnel of their hones grencrully, as contrasted with the weight of carcuss. They are clenn in the jows, with a full eye, thin ears, and plucid conntenance. Their backs are stmight, broad and flat; the ribs arched, the belly earried very light, so that they present nearly ns struight a line below as above; the chest wide, the skin very mellow, and covered with a beautiful fleece of long, soft wool, which weighis, on the average, from six to seven pounds. On good soils, and under careful trestment, the sheep are usually brought. to weigh from eighteen to twenty pounds a quarter at fourteen months

rus, the head and derey, the il, legrs clem. ing much too ood meat with fecding. The -equire special ing in especial

their own They futto fifteen irs old from ig combing 
old, at which age they nre now generully slaughtered. At this age thei flesh is tender and juicy, but when carried on until they ure older and lowvier, fat accumulates so unduly in proportion to the lean meat as to detract from its palatableness und market vulue. This fat acemmulation on mature animals is pretty constmint in ull the large mol improved breeds.

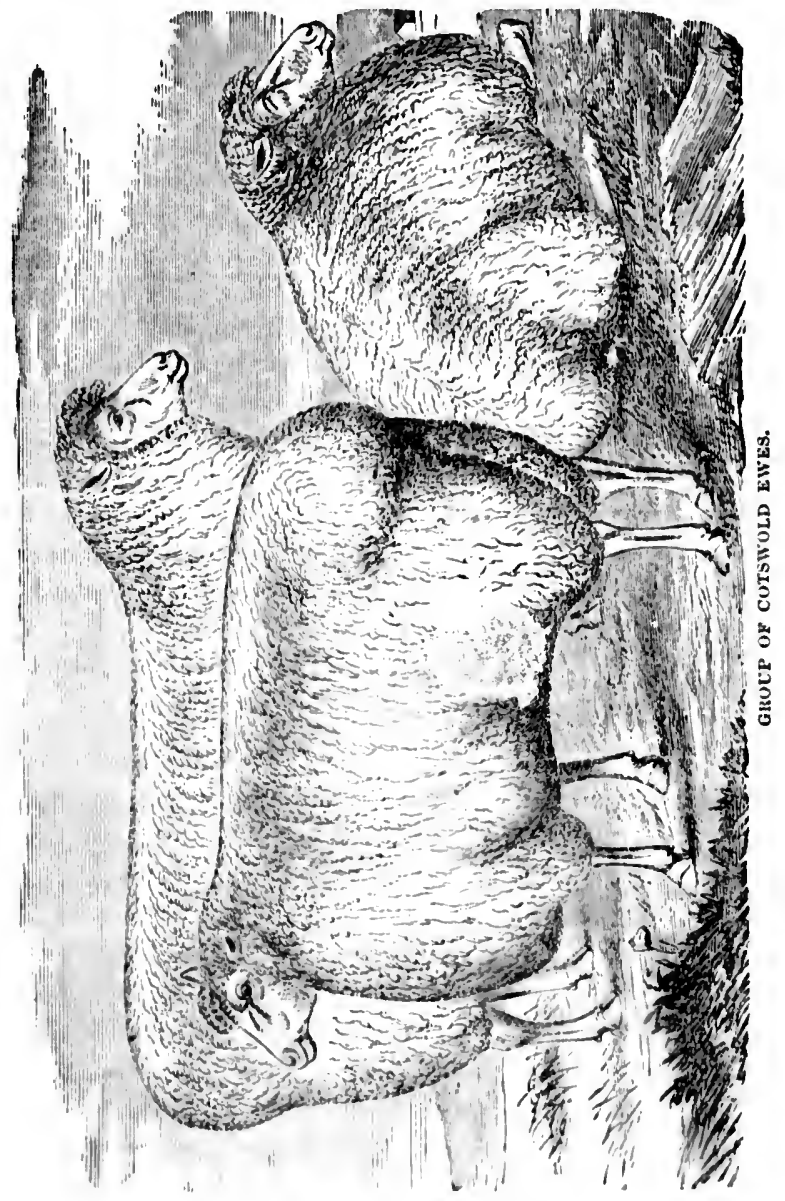

III. Cotswold Sheep.

The Cotswolds were inumorted into the United States abont 18.92, since which time they hase luen reinfored from time to time isy suressive 


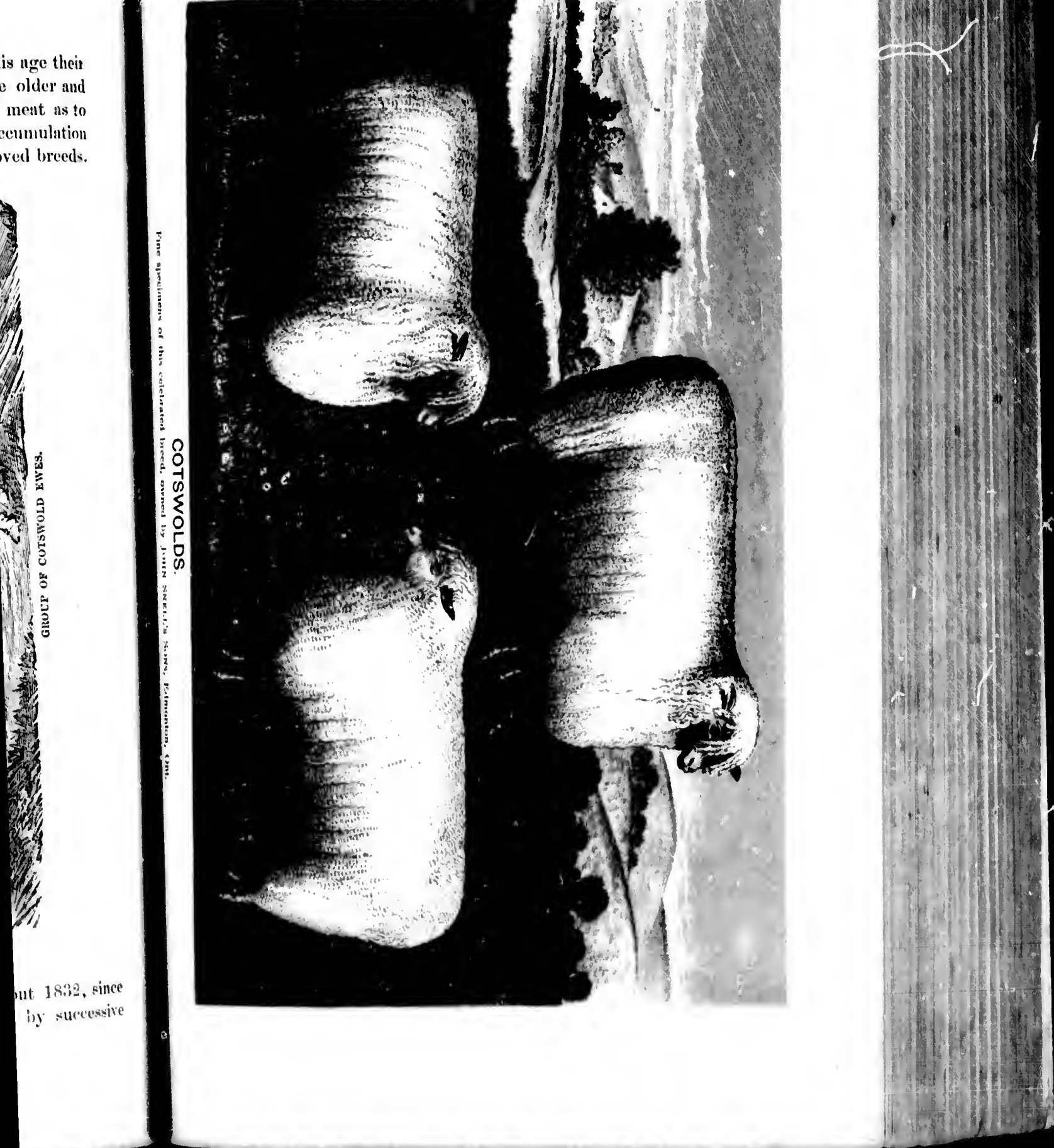


import

wooled

This

smaller

element

gained $i$

than the

tened at

per' pqu:ar

a liarosel

stritiught

for obt:i

They are

rooled 1 ,

hrere. S,

country a

rool shri

The Cots

fingland. I,

mareass not

attainerd.

corrse, 6 to

$\mathrm{Tl}_{\text {a }}$ super 
importntions, and now stand in the West, in the front rank of longwooled sheep.

This is one of the largest English breeds, though the improved race is smaller thm the originals, on account of the influence of the Leicester element in its mmelionation. As a breed, it is of grent antiquity. It h:a's gained in fleece and form, and comes to mniurity enrlier ; is more proliti: thin the Leicester, and has grenter strength of constitution ; is often f:ittened it fourteen montls, yielding tifteen to twenty pounds of mutton jer fuarter, and twenty to thirty, if kept till two years old. They have

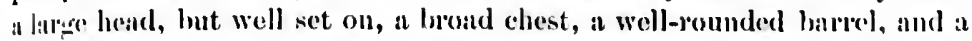
striliplit luek. They aro often used for erossing upon other hreek, and for olt:ining enlier motrket-lambs, hoth in this country and in Finope. They are more widely disseminated in this eountry than any other longwooled hreed, and preserve well the popularity which they have attained here. Soms imported sheep of this breed have borne fleces in this routry of eighteen pomols. A great woight when we remember that the wool shrinks eomparatively little in washing.

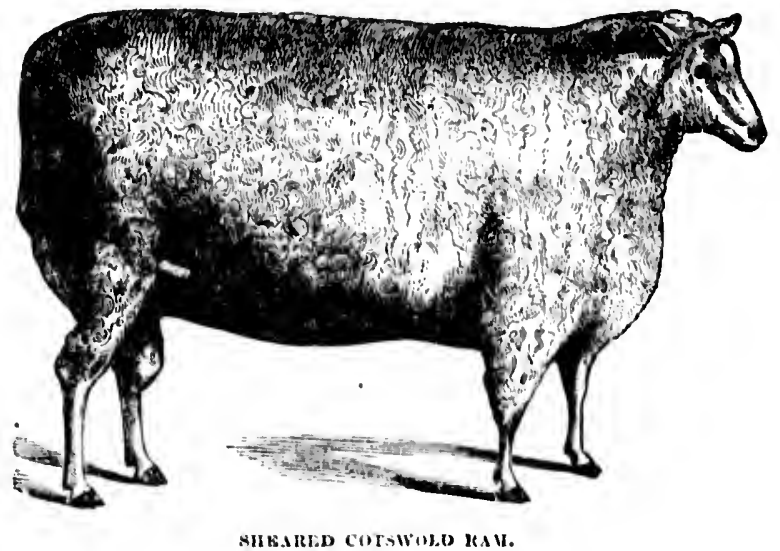

The Cotswolds havo heen extensively erossed with Leieester sheep it England, hy which their size has leen somewhat dininished, but theit careass notably improved, and in addition, earlier maturity has been attinel. The wool is stromer, mellow mexl of coocl color, though rather coirse, 6 to 8 inches in length, and from 7 to 8 pounds per fleece.

\section{Good Quslities of Cotswolds.}

The superion hardihood of the immoved Cotswold over the Leicester, 
and their adaptation to common treatment, together with the prolific nature of the ewes, and their abundance of milk, have rendered them in many pluces rivals of the new Leicester, and has obtained for them of late vears, more attention to their selection and general treatment, urider which management still further improvement appenrs very proballe. The rumlity of the mutton is superior to that of the Leicester, the taliow heing less abundant, with a linger development of muscle or flesh. The eres are prolific, and good mothers und nurses.

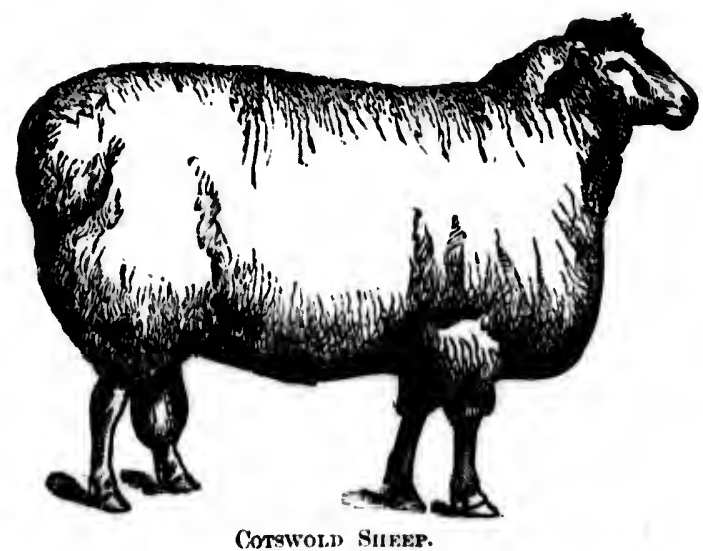

Cotswolds in the West.

Throughout the entire West, the Cotswold has hecome a most farorite hreed, and this not only on account of their long, handsome flecess, specially adapted to the purpose of combing wool, but from the kindliness with which they take to our kecp and elimate. For this reuson we hive given this breed special pronimence in our illustrations. It is not our provine to go into long dissertations or detailed deseription, it wonld take too much spuce, and be moductive of no good end. The illustritions we give will furnish a hetter index of value und charucteristies. The cut on mext page will show the appearance at one year old.

In relatine to the adaptability of this breed South, $x$ prominent Clark eounty, Virçinia, furmer says: It is fur more profitable to keep the different varieties of mutton breeds, thun the fine wools, or Merino breed in this portion of Virginia. I way this from my own experience, and that of many intelligent gentlemen with whom I have conversed. The Cotiwold sheep, and its crosses, with the Southdown are less liable to diseases of ull $k$ their lat

then add $t$ and their :

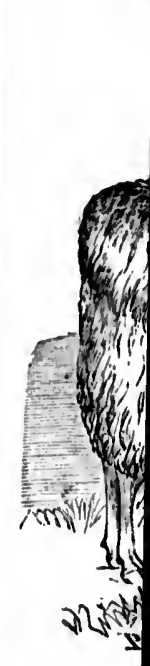

which far o sheep may ed 
of all kinds ; they are more prolific, better nurses, and less liable to lo;o their lambs than the Merino. The lambs are more vigorous and hardy;

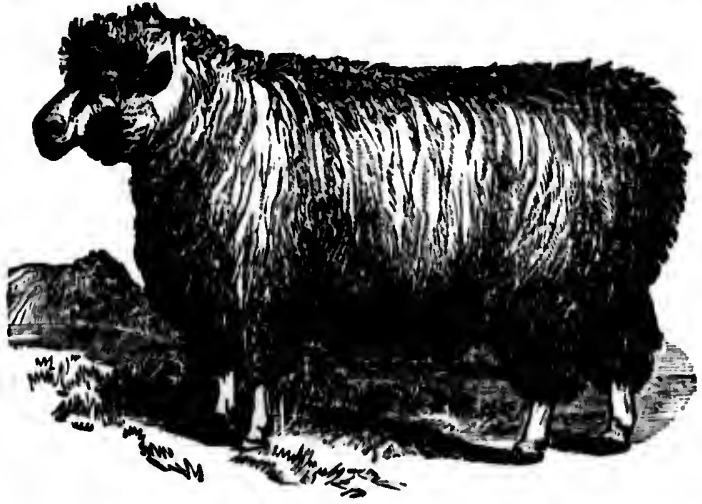

YEARLIXA CUTSWOLD.

then add their early maturity, their fitmess for market ut 18 months wh, and their almost double value when in market, and you hare advantages

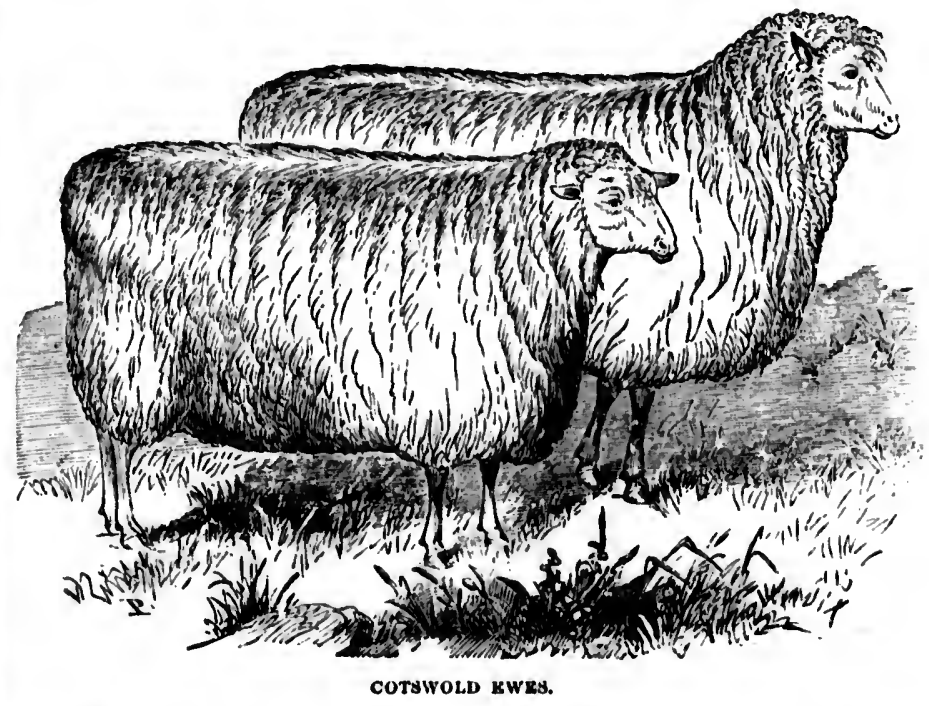

which far outweigh the udditional amount of food which the mutton sheep muy consume in proportion to his size. There is one thing in con- 
neetion with all the long-wooled and lnrge breeds of sheep that may be upproprintely mentioned here: thoy eannot be kept in lurge flocks, like the smullor and fine-wooled breeds. Merinoes are often kept in florks of 1,000 or more in the fur West. The long-wooled, the middle-wouls and the mutton breeds are especially adnpted for farmers, when both mutton and wool are the considerations, and aro seldom herded together in fields exceeding one hundred.

Thus in all the better settled portions of the West and South, where justure and grinin are ubundnnt, and where the nenrness to murket afforis sule for the mutton, the long wools nre iserensing in numbers from year to yenr, and with protit to the breeders and feeders, as well as in the just ippreciation of those who cousume the flesh.

\section{Lincoln Sheep.}

The Lineoln sheop nre both larger and heavier than cither the leicester or Cotswold, and are bred to a limited extent in the United States. The first importation wis made in 1835. They ure hurdy, large feeders, prolific, yield flecees of from 6 to 10 pounds ench, und the curcasses have heen known to dress 125 pounds.

\section{v. New Oxfordshire Sheep.}

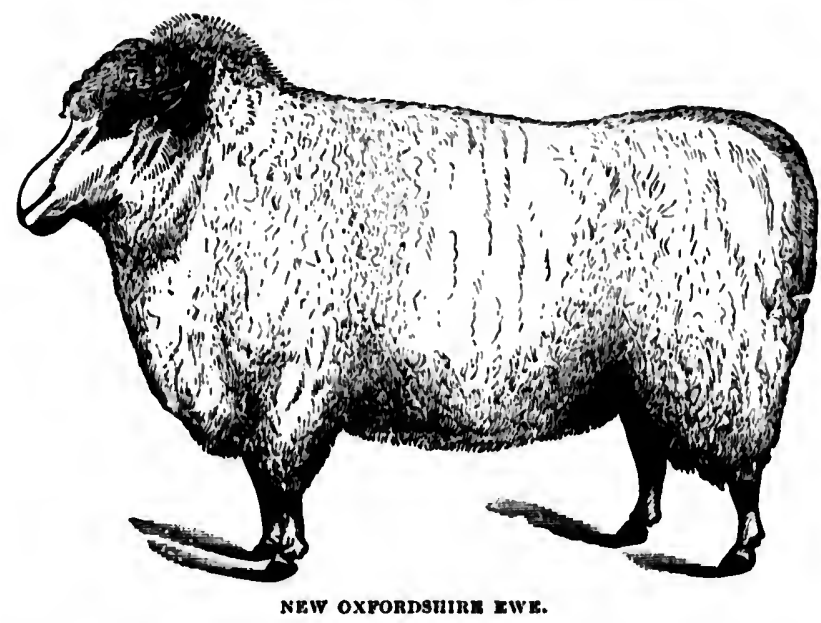

This breed should not be confounded with the Oxford Downs, a cross breed between Cotswold and Hampshire Downs, and which have dark faces. They are less hurdy than the Cotswolds, and have mot made much

This is a extent in $\mathrm{tl}$ etrding wo 
progress in the United Stutes. They ure the result of a eross between the Sew Leicester and Cotswold, the lutter blood being in excess. Howerer they mily be regarded in Eingland, and they are regarded highly, they have not beeome popular in the West, as agninst the Cotswold. On the preceding page, we give nent of n New Oxfordshire ewe, to - Hose the subject of inproved long wools in the Cuited States as embrucing the more prominent breeds.

\section{Middlo-Wooled Sheep.}

Thr Bhock-faved Seoteh Highlund sheep are small, netive and alocilo when we consider that they ure a purely mountuin ruce. They stand grent haudship), and work kindly in large flocks, subsistiug on scanty fare when meressing. Hence they may be vinlunble in cold and momentu regions of the United Stutes, for crossing on other breeds. They have opon lairy floeces, and black fuece, woigh to averuge bis pounds, and will

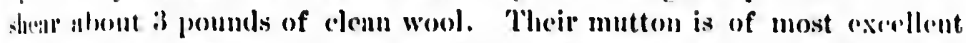
quility, and crossed on lurger breeds their flecees will go to 6 or 8 pounds and their live weight to 128 pounds for wethers.

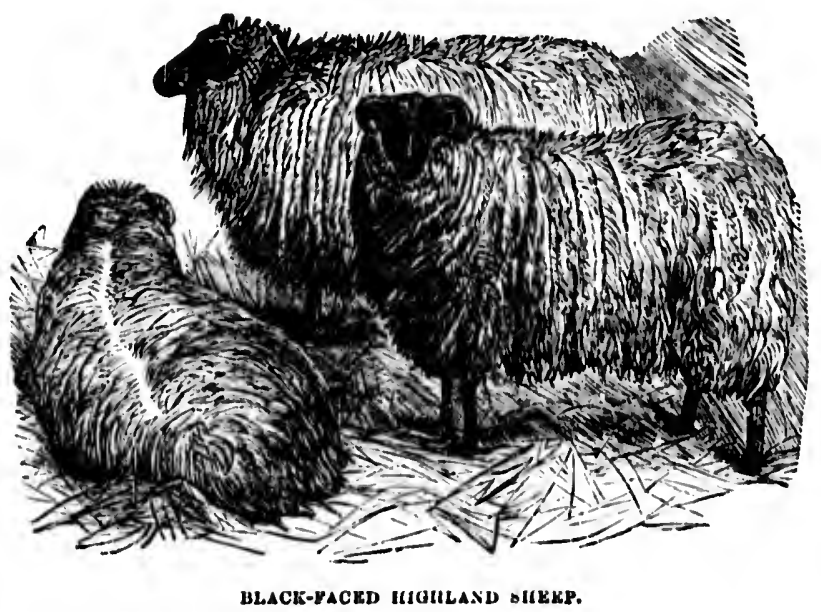

vII. Cheriot Sheep.

This is another mountuin breed that has been introduced, to a small extent in the United Stutes. Their fleceses however, are fon conrse for anding wool. They are less hardy than the black-faced highlands, but 
mro quict mul docile, ensily mumuged, giving floeves avernging ubout is 1.9 [ounuls, furnishing good usuttun, woighing 12 to 18 poumels por quurter, at throe yents old.

\section{Whito-flood Iighland Bheop.}

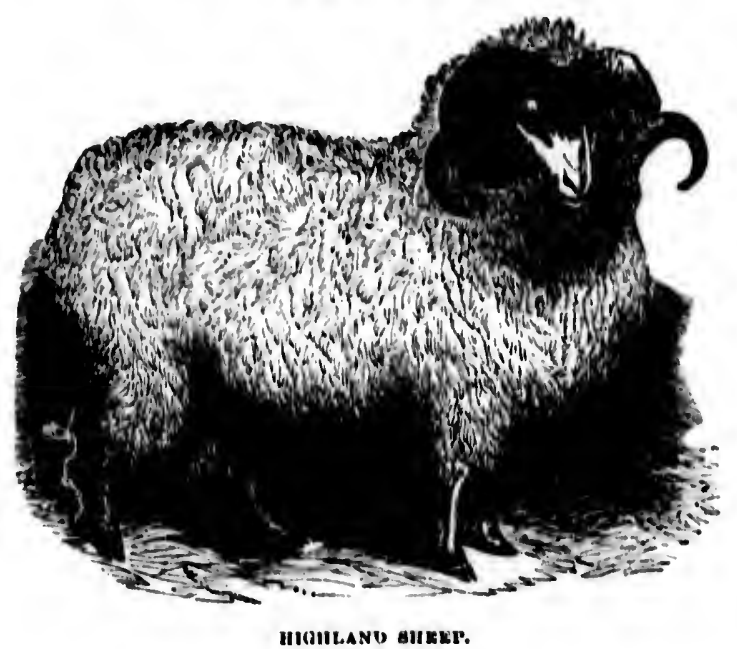

'This is n sheep of gromt hurdiness, furnishing good muttom, lunt net at

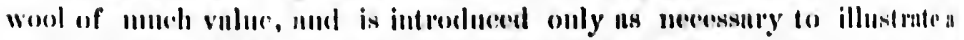
brecel adapted to sterile regions, where better loreeds womld nut survive. M:my such regions are fomnd in our own land, esperinlly in the lioki Monntuin sections, where the trial of this race might well be nunde.

\section{Dorsot shocp.}

Dorsetshire has a Ineod peouliar to itself. Strong, netive, mul well

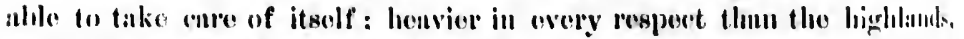

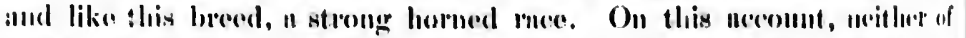

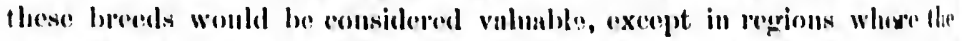
berter fleoend brenels would not live. The cut is griven like that of the

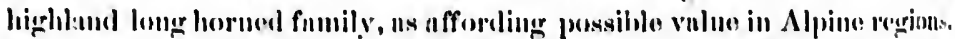
lontmantely there is but little comntry of this muture on this Weatern antiment.

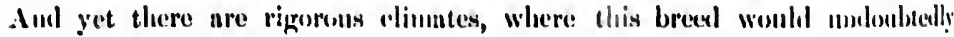
thrive and make a gool return to its cultivator. The expreriment may les male with much hope of enecess. 
Lout 31.9 ore yuuitar,

(iil, lint uot a 1, illustrintria uot survive. In the Rowk! de.

ve, IImel vill to hicrlilinst. 11, Meitlec's of

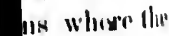
- thiat of the pino regions.

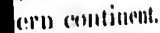
undumberlly inentit may be

\section{Ghort-wooled Engliah Broodn.}

Of the mutton hreeds, tho Downs undoubtedly stimd it the head in

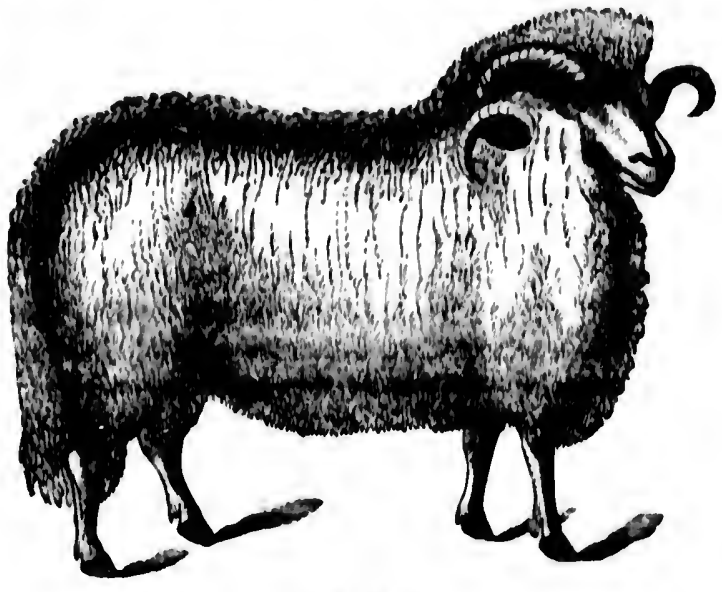

IHIISVE HeaM.

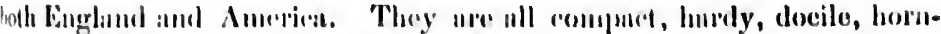

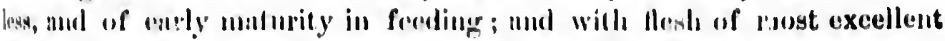

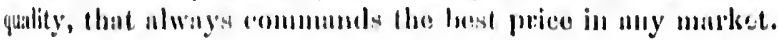
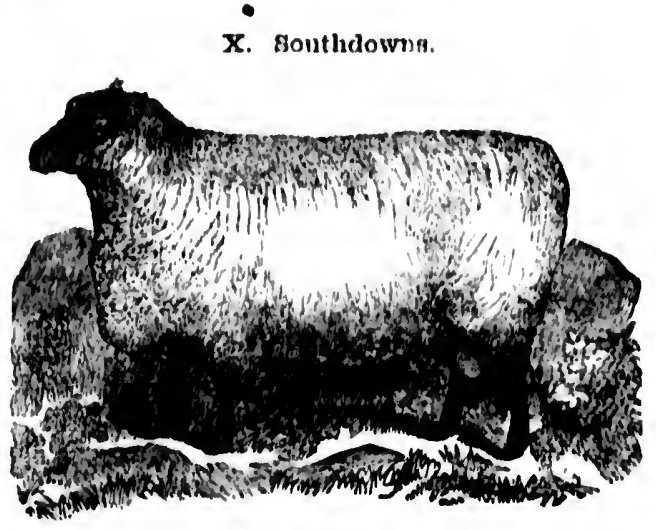

SOUTIIDU:IN IIAM.

These are without douht the most suprerior, tnken ns a whole, of any of the mutton lreeds, und have for many years been bred with the greatest 61 
IMAGE EVALUATION

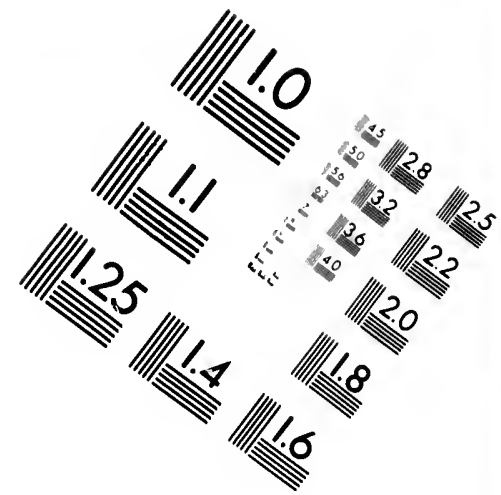

TEST TARGET (MT-3)
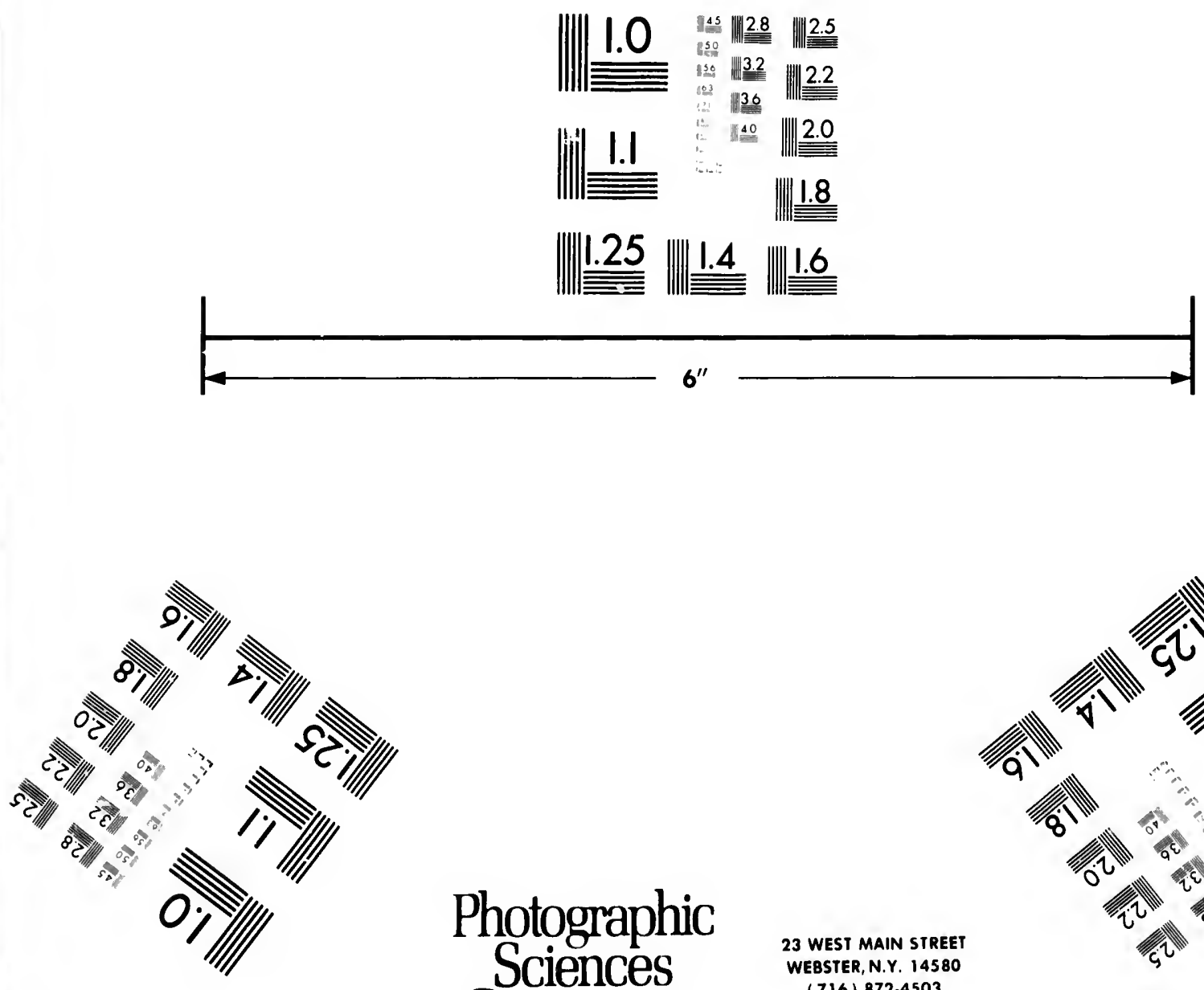

Photographic Sciences Corporation
23 WEST MAIN STREET

WEBSTER, N.Y. 14580

(716) 872.4503

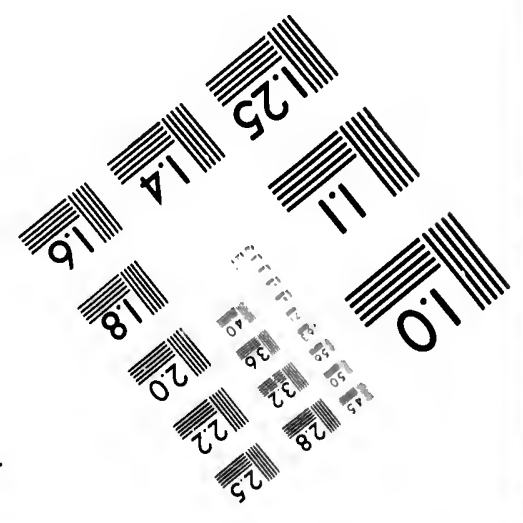


care in both England and Ameriea. Their faces and legs are dark brown, the fore quarters wide and deep, the back and loin broad, with round bodies, and square and full hind quarters.

The ewes are prolific, producing from 120 to 140 lambs, to the flock of 100 ewes. The staple of the wool is fine and curled, with spiral ends well adapted to carding, and will shear on yearling rams and wethers, from 6 to 9 pounds. In the neighborhood of large cities, where there is a demand for mutton, they are most valuable as a distinct breed, or for crossing with the rimmon sheep of the country.

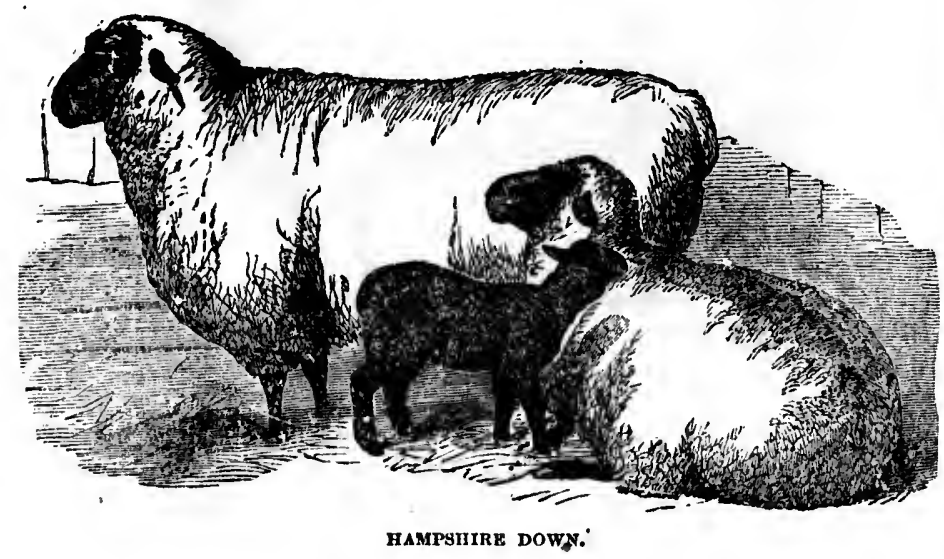

XI. Hampshire Downs.

This breed had its rise in Hampshire, through an infusion of Southdown blood, followed later with Cotswold, and of course, since the Cotswold have an infusion of Leicester, they have this blood also. It has given them increased size, more wool, and at the same time they have preserved their great hardiness of constitution. For many years they have been bred pure, and so far as introduced into the United States, they lave given satisfaction, especially in the South, where, before the war, they were in good repute. Those who have used them, claim that they are more hardy than Southdowns. It is also claimed that they have been crossed upon Cotswold and Leicester grades, with benefit to both, and this we do not doubt, where mutton was to be the object.

\section{Shropshire Downs.}

Of late years this breed has grown into repute in the West, and in Canada. They are heavy sheep, nearly as large as the Cotswold, yield 
lark brown, with round

the flock of ral ends well hers, from 6 is a demand for crossing

n of Southdown ce the Cotswold o. It has given y have preserved they have been States, they have re the war, they aim that they are $t$-they have been hefit to both, and st.

the West, and in he Cotswold, yield nearly as much wool, with thick compact fleeces, are hardy and healthy, bave even, compact, uniformly symmetrical bodies, with dark brown faces and limbs, and are about one third hetvier than Southdowns.

\section{Oxford Downs.}

This comparatively new fumily, which has come into prominence in the United States within the last twenty years, was originally made by crossing the Hampshire or Southdown ewe with a Cotswold ram. They are easyfattening sheep, producing mutton of superior quality, with fleeces of 8 to 10 pounds for ewes and 12 to 13 pounds for rams, and in length from seven to eight inches; a wool of good luster; neither hairy nor harsh.

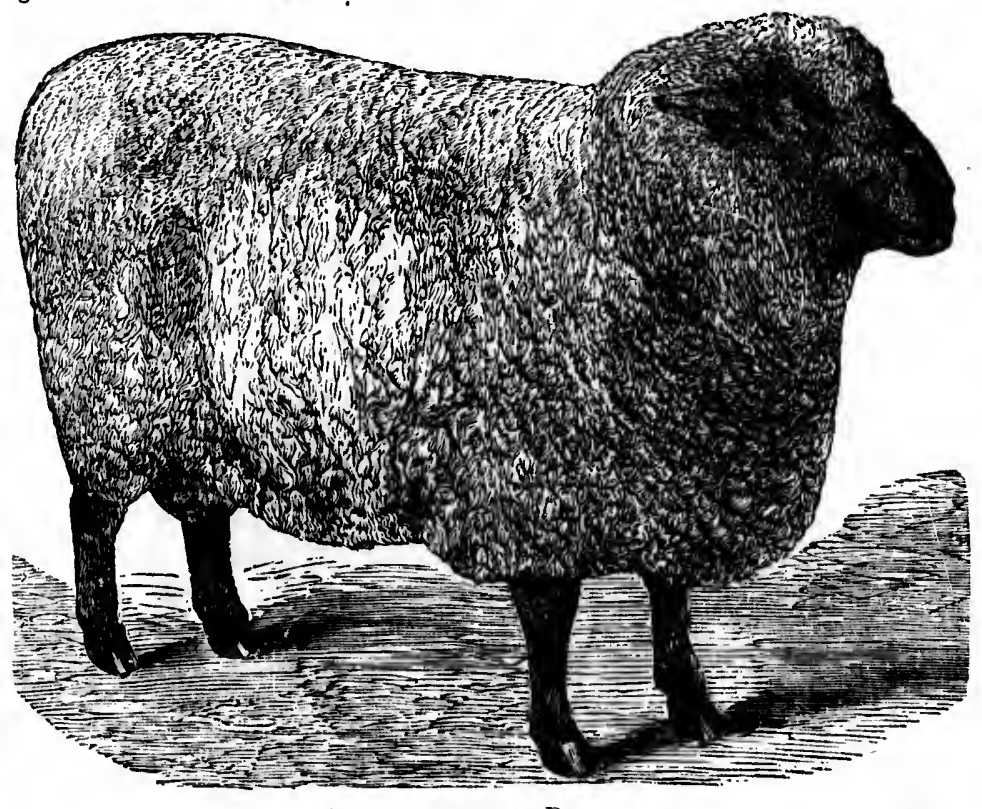

UXFURDDOWNSHIRE RAM.

In reality the only reason why these sheep should be called Downs, is, from their dark legs and faces. They really are not a short-wooled breed, in fact, as we have shown, they are a long-wooled race, and the characteristic has been carefully cultivated by breeders of this viriety of sheep. In color, they are much lighter than the Southdown, their faces and legs being gray, instead of brown. The ewes are prolific, producing with good care, 150 lambs to the 100 ewes. They herd close together, 
are not particular about their feed; they mature early, and upon hill pastures produce mutton of high quility.

\section{Fine-Wooled Sheep.-American Merinos.}

In treating of fine-wooled sheep, it will not be necessury to go into their history. It is enough to say that Spain and France have contributed from time to time their best specimens, which, under such managenent as that given by Mr. Jarvis,-selecting from five families of Spanish sheep, the Paulars predominating,-produced what was knowls as the nixed Leonese or Juryis Merinos. In $1813 \mathrm{Mr}$. Atwood commenced the breeding of pure Merinos, from what was then known as the Humphrey stock. About 1844, Edwin Hummond, of Middlebury, Vermont, conmenced loreeding, taking for his stock selections from the Atwond family. To the judgment and skill of $\mathrm{Ml}$. Atwood, and later followed by Mr. Hammond and other American breeders, we have seen produced what have been known distinctly as American Merinos; perfect in all that

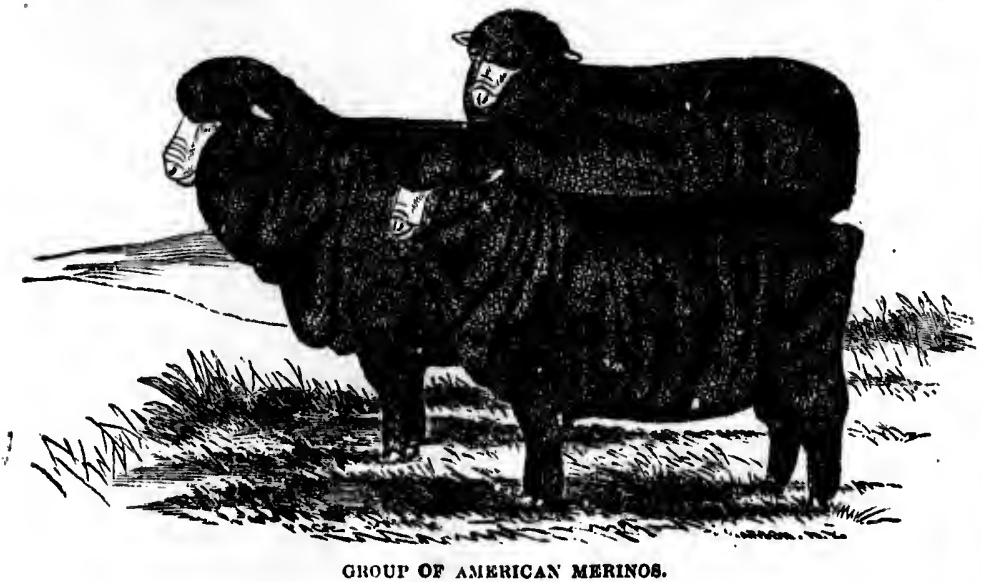

goes to constitute length and thickness of wool, evenness and fineness of staple, that lonseness of skin which, while it lies in low, rounded, soft ridges over the body, offers no olstruction to the shears. These were the points sought, and for the last twenty years well met and sustained by the best breeders, East and West; so that we now have as thoroughly established, the descendants of the Infantade-large and of good length, and the deseendunts of the Paulars, a smaller breed, originally established in the United States by Mr. Silns Rich und his son, of Shoreham, Velmont. Thus making two well marked fumilies, which it is altogether probable would be injured by the infusion of foreign blood. 
upon hill

go into their contributed nanagement of Spanish lown as the nmenced the e Humphrey rmont, comwood family. owed by Mrr. oduced what it in all that

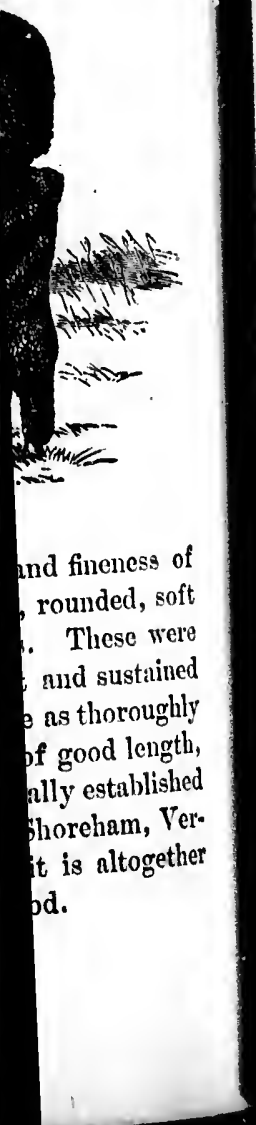

The Fleece.

The fleece is the important point in Merinos; they are not mutton sheep, and their carcass is of secondary importance. Dr. Randall, nearly twenty years ago, in his work entitled “The Practicul Shepherd," in writing of American Merinos, as they then were, says: "The greatest attainable combination of length and thiekness of wool, of given quality, is: the first to be regarded in a market where all lengths are in equal demand. And the more evenly this length and thickness extend over every covered part, unless below the knees and hocks, the higher the excellence of the animals."

It is in this point especially that the moderu breeder has improved on his predecessors ; and it is this, in a very considerable degree, which gives the improved American Merino its vast superiority in weight of fleece, over all other fine sheep, of the same size, in the world.

Wool of full length below the knees and hocks would hardly be desirable, on account of its liability to become filthy ; but a thick shortish coat, particularly on the hind legs-making them appear as large "as a man's arm" -is regarded by unany as a fine, showy point, though it does rot add much to the value of the fleece.

\section{The Head.}

The wool should extend in an unbroken and undiviued mass from the back of the neck over the top of the head and down the face for an inch or two below the eyes, and there abruptly terminate in a squane or rounded shape; it should cover the lower side of the jaws nearly to the mouth, and rise on the cheeks so as to leave only the front face bare, terminating abruptly like tho forehead wool. The cheek and forehead wool should meet unbroken, immedistely over the eye, hetween it and the enr. But it must by no means unite under the eye-though its outside ends may touch thero for a little way. The eye should have just naked space enough about it to leave the sight unimpeded, without any resort to the scissors.

The nose should be covered with short, soft, thick, perfectly white hair. Pale, tan-colored spots or "freckles" about the mouth, and the sume color on the outer half of the ear are not objected to by the breeders of the Paulars - liut Infantando breeders usually prefer pure white. Wool on the lower part of the face, us is often seen on the French Jerinos, whether short or long, is regarded as decidedly objectionable, and any wool which obstructs the sight in any degree, is a fault.

Those who grow sucl fleeces now need not be ashamed to exhibit to-day in the best show rings of the country. 


\section{The Body.}

The frame upon which the wool is to grow is important, for upon form and constitutional vigor depends the value of the animal. Below we give an illustration of a ram that would leave little to be desired. so far as ability to produce the best wool is eoncerned.

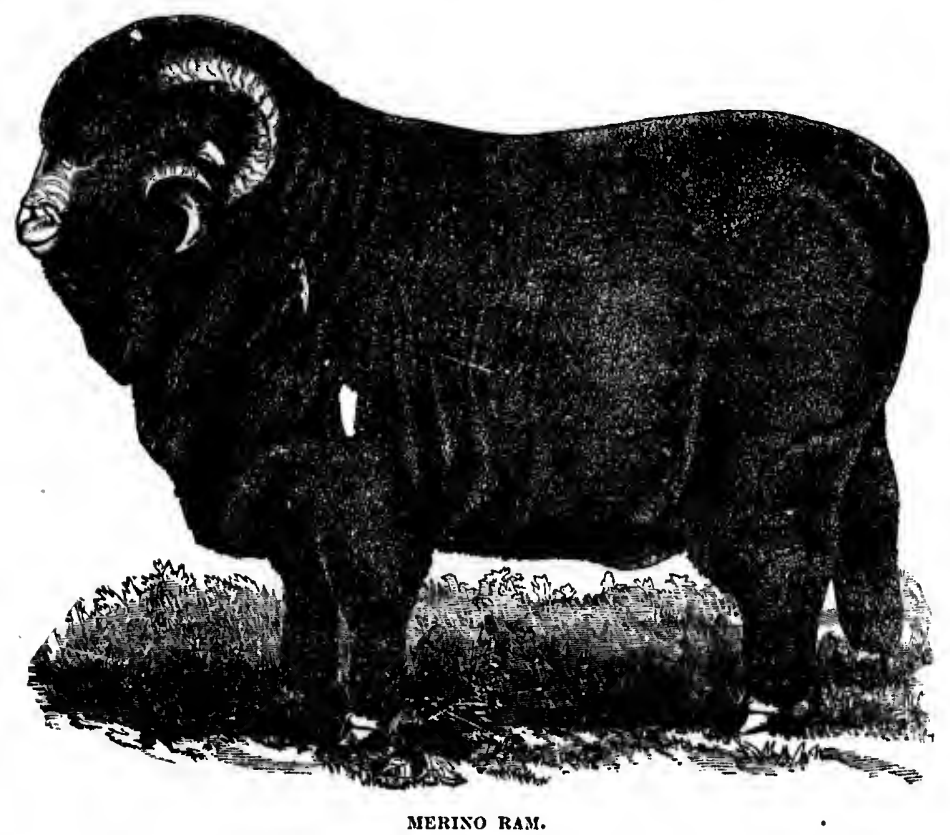

Medium size, for the family, will hold in sheep as well as in other animals. An overgrown animal is not profitable in any breed. The body should he round, deep, of moderate length, the head and neek ghort and thick, back striight and broad, the legs short, straight, but well apart and strong, giving a deep full bosom and buttock. The forearm ample, and the junction of the thighs well down the hocks. The skin should be rather thin; mellow, elastic, ausl loose. If it be thick and rigid, it will evidence a bad feeder, and consequiently inferior wool.

\section{The Most Profltable Sheep.}

Of all the breeds of shecp ever introduced into the United States, the Merino has more than held its own in the estimation of breeders every- 
the wool are found. Some grades of sheep will often exhibit seven or eight qualities in the same fleece, whereas unalloyed breeds show but four qualities. The refina, or pick wool, (1) begins at the withers, and extends along the baek, to the setting on of the tail. It reaches only a little way down on the quarters, but dipping down at the flanks, takes in all the superior part of the chest, and the middle of the side of the neck to the angle of the lower jaw. The fina, (2) a valuable wool, but

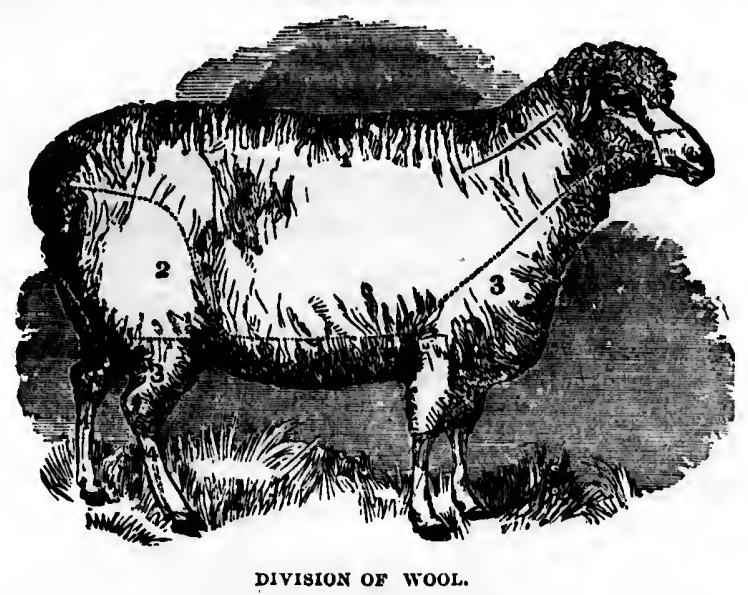

not is deeply secreted, or possessing so many curves as the refina, occupies the beily, and the quarters and thighs, down to the stifle joint; (3) is found on the head, the throat, the lower part of the neck, and the shoulders, terminating at the elbow, fore legs, and reaching from the stifle to a little below the hock; (4) is procured from the tuft that grows on the forehead and cheeks, from the tail, and from the legs below the hock. 
seven or but four hers, and ies only a , takes in the neck wool, but refina, occue stifle joint; the neck, and hing from the the tuft that he legs below

CHAPTER $\Gamma$

\section{BREFDING AND MANAGEMTNT OF SHFEP.}

TATCHFCLNESS NECESSARY. HOW TO BREED. TIME FOR BREEDING. COUPLING. - KEEPING THE RECORD. THE MANAGEMENT OF RAMS. TRAINING RAMS. - PASTURING SIEEP. SHAdE IN PASTURE, - Water.

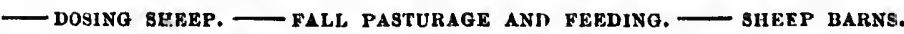
- SPECILL WINTER FOOD. D MANAGEMENY OF LAMBS.—DOCKING LAMBS. CASTRATION. - WEANING. —TIE NURSERY.

\section{Watohfulness Necessary.}

The fecundity of sheep soon enables the breeder to gather a flock. To keep them healthy is one of the most difficult problems of the breeder, since they are generally kept in large flocks, and herding closely together as they do, if un epidemic or contagious disease gets among them, it surely goes, through the whole flock unless the shepherd is ever vigilant. The lack of cure and vigilance causes more than half the losses in sheep, and hence, no person should undertake sheep breeding unless he make up his mind that they are to have not only gentle treatment but daily care and watchfulness, even in the Summer.

\section{How to Breed.}

The ewe may be bred to the buck at the age of eighteen months, and the buck will be fit for service at the same age. If the object be to breed grades, it will be found to be money squandered to buy an inferior buck, 
whitever his blood may be. So, if to save a few dollars, the breeder select a grade buck for breeding purposes, the money is as good as thrown away. One buck if properly kept will serve one hundred ewes, so that the cost per lamb is really ligbt. Thus in breeding grades, pursue the same course as udvised for cuttle. Select a good staunch ram, of well known purity of blood, avoiding the excessively high priced uninuls that are simply the best breeders of pure bloods. Such an one may be bred to the common stock of the country, and to his own progeny, to the third genoration. As a rule the siro will give the leading characteristies of form, size, length and density of flece a:d its yolkiness, he will do this eminently in proportion to the purity of his blood. The tineness and principal characteristics will be prohably controlled by the dam. Hence the importance of none but the best sires.

In crossing, the Merino may be bred upon the common ewes of the cuuntry, alw:lys with benefit to the fleece, und never at the expense of the careass. So the Southdown will improve them in mutton and wool. The Cotswold and Leicester will give increased size, early maturity and length of staple. To breed Merinos on any of the long wooled virieties would be useless. It would detract from the valuable qualities of the wool of either, reluce the value of the mutton, the size, propensity to fatten, and prolitic qualities of the long wool. In the West the sheep for money are either pure Merinos, or pure Merino rams bred unto the common sheep of the country, with the exception hefore stated, where farms we sulll and near markets where prime mutton is in demand.

\section{Time for Breeding.}

The arerage period of gestation in the sheep does not vary much from one hundred and fifty-two days. They usually carry a malo longer than a female, the period of gestation varying a week and sometimes two weeks. Therefore the shepherd can easily calculute when to have his ewes served by knowing when he wants his lambs in the Spring. This as a rule should be at the time of, now grass in the Spring. Allowing that this occurs the first of March the ewes should begin to be served about the middle of September, and the seison will then probably continue to the middle of Oetober. If lambs for slaughter bo the object then the ewes should be served fully a month earlier than usual, and extra shelter, warmed with fire heat provided for lambing time. This always pays. They are the early lambs that command the high prices in the important markets of the country, and he who furnishes these must use proper means to anticipate his neighbors. 
eeder seis thrown s, so that ursue the a, of well imals that y be bred o the third teristies of vill do this neness and in. Henee swes of the pense of the wool. The $y$ and length rieties would the wool of o fatten, and or money are oummon sheep rims are swill

ry much from e longer than ometimes tiro in to lase lis ring. 'This as Allowing that o served about ly continue to object then the I extra shelter, always pays. important marbroper mealls to

\section{Coupling.}

Wo do not adviso the use of tensers-that is, common rums nproned to show the rutting ewes. The better way is to drive the tlock up to the pard twice a day und let the rum out with the flock. Inmediately ho has served a ewe cateh and separate her from the flock. Keep ull served ewes together, and under no consideration allow but one service. If they coule again in hent it will be from the fourteenth to the seventeenth day. Thus thoy may be again returned to the ram after the thirteenth day, and if not in lieat it muy be set down that they have been properly served.

\section{Keeping the Rocord.}

In breeding grades it is only necessiry to keep a correct record of the time of conpling, to correspond to the mark on the ewo. Where pure sheep are bred it will ulso he necessiry to keep a record of the ram used. In the first case it is necessury to lnow when ench ewe will drop her lanb. In the eatse of pure bred sheep it is imperative that a full and accurite record he kept, else confusion will ensue and the breeder will have lost all that was gained before him, and no breeder of pure sheep will buy from his flock. In order to bring the ewes into season at a specific time in seasons of drouth, or scant pasture, the ewes should have extra feed for three weeks before they are required to tike the ram.

\section{The Management of Rams.}

The rams should never be allowed to run with the ewes at any season of the year. They are brutal always in their teasing, and if allowed so to run they not only exhaust themselves, but the ewes drop their lumbs out of seison. His separite enclosure should be dry and comfortable, and kept strictly clean, und be entirely awny from the sight and hearing of the ewes, except when admitted to them. His feed must be the best of hay, or fresh grass, with what oats he will eat elem duily, begimuing six weeks before the senson with half a pound daily, and inereasing the feed gratually to two pounds daily, if he will ent so much. Some flock masters sow oats and pens together, two bushels of the former to three peeks of the latter. This when threshed and ground together and fed, gradually inereasing to a quart a day, makes most excellent feed for a bard-worked ram. On such feed, with pure water within rench at all times, a ram may be expected to properly serve one hundred to one 
hundred and fifty ewes, and but fow of them should come back the second time.

Never keep two rams in the same enclosure. They are essentially pugnacious, and very often a valuable rum is thus sacriticed, through the mistaken eeonomy of the owner. In the beginning of the season, a ram should not be allowed to serve more than two or at most three erres a day. This may be gradually increased to five, and agnin towards the elose of the season, he muy be again only allowed two or' three. 'To do justice and retain full power of fecundation, he must have n good amount of exereise. To insure this, if inclined to be inative, he should be driven about the yard for an hour overy day. As a last word of enution we ndd: Keep the rams away from the ewes in Winter. They often seriously injure them, and hy their teasing are a cause of abortion, to say nothing of other serious injuries they may inflict. The best experience of sheep-raising confirms this rule.

\section{Training Rams.}

It is quite necessary that rams slould be made to understand that any vice will be severely punished. They should be early trained to stand quietly when tied, to lead at the end of the halter. They should never be tied with a rope about the roots of the horns. It is apt to gall, and make lodgment for maggots. Fasten polled sheep by a strap about the neck, and horned breeds in the same manner while they are young. When their horns are large enough, drill a hole through the left horn, near the tip and put in a bolt with eyo and two inch ring, the whole fustened with a nut. Never tense, or allow a ram to bo teased. It is sure - to make them vicious. Handle kindly and gently, yet with a firm hand. If inclined to be vicious, punish them severely and until they are thoroughly cowed. A vicious old ram is dangerous at all times. Sometimes they become incorrigible; when this is the euse geld them at once. It is useless to waste time and patienco on them.

\section{Pasturing Bheep.}

The flock should go in the pasture as early in Summer as possible, but should be housed nights, and during cold storms. They should be regularly salied, at least every otker day, and when salted should he counted and examined for any ailment that may oceur. The best shepherds count every day, and salt every day, graduating the doses so the sheep will eat it entirely clean; and once or twice a week, giving a larger quantity. Care in salting, as in feeding, pays abondantly. 
Sheep are eager for shade in warm weuther. Wo do not believe in shading pastures with trees. It is better and cheaper to have slieds, open on ull sides, and of ample size to shelter the flock. The covering may be of boughs, or anything that is eheap. Wo have used common factory muslin, strotched on n light frume, double pitched roof, with a two foot space at the peak, for the escupe of wind; the shed twelve feet wide and running north and south. This gives freo ventilntion, und is the coolest shinde we know.

\section{Water.}

Witer is not generally considered an absolute necessity to sheep when on pasture. Where they are allowed to graze when the dew is on the grass, or the grass is succulent, they scem to get ulong pretty well. We like them, however, to have a chance at water once a day. In the case of ewes suckling lambs it is necessary that they liave water in plenty. Alsolute purity of water however is always indispensable. Sheep object to drinking foul water, and their instinct ought to satisfy any person that it is not fit for them. Many serious disorders to stock of all kinds are occasioned by drinking impure water.

\section{Dosing Sheep.}

Wiet, low, or mucky pastures are not fit for sheep. It is an entirely true adage that the slieep's foot must be kept dry; nevertheless there are many sheep kept other than among firm, dry, hill pastures. Some shepherds are continually dosing with salt and alum, salt and sulpliur, and various other compounds under the supposition that it tends to health. Give them what salt they need, always, and examine them often for disease. When they are well, however, let well enough alone.

\section{Fall Pasturage and Foeding.}

In the Autumn, as the season advances, sheep should have somo fodder. It is the time of year when, if allowed to fitil in flesh a miselief is done that cannot be remedied. There is a peculinity nbout wool that one shepherd in twenty knows nothing about. To have a uniform grouth, und of equal strength, the wool must grow stendily, as the season advances. If the sheep are allowed to fall suddenly away, the growth of wool ceases. When growth again commences, the wool, instead of continuing even in texture will have what is termed a joint. This is often so wenk that very slight force will break it. The microscope rill reveal every period of starvation and subsequent good feeding that ticep may have experienced in the course of the yeur's growth of wool. 
Thus tho shepherd who would do well for himself must do well for his flock. He must not only feed ind water well, and attend to the general health of the sheep, but he must house well.

\section{Bheep Barns.}

These need not be expensive.structures, but they must protect thoroughly against wind rnd drifting snow, and at the same time be well ventilated. The barn is to be entirely cnclosed with doors and windows, which, if made to slide, will sorve for ventilation. Along the peak

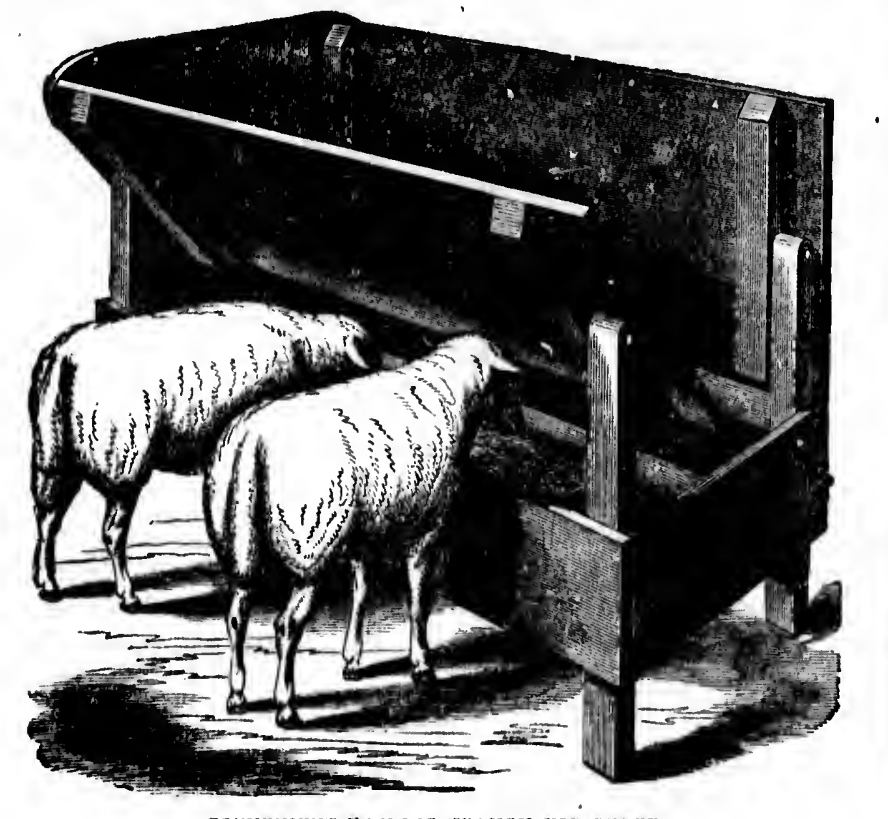

CONVENIExT REEDINa TROUGH FOR BHER.

should be slatted chimneys of wood to assist ventilation. The stable should be divided into suitablo pens to contain from twenty to fifty sheep each, according to the size of the flock, with doors from one to the other, racks for feeding hay, and troughs for grain, and for water also, if the sheep are to be wintered in the barn. There should also be suituble paso sage ways for feeding, etc. The arrangement of these racks, troughs and other conveniences, will readily suggest themselves, by referring to the plan for foeding cattle in barns. There is to be no tying up, of 
look like the young buck, shown at the right hand side of the page. Allowed to shift for themselves as best they may, they will resemble the sheep shown on the left side of the page. Which would you choose?

There is one thing that should be observed in feeding roots. Carrots may be fed at all times. In feeding other roots, feed the Swedish turnips first, and after they arc gone, the beets. Beets fed early in the Winter I have not found profitable. They have an acrid quality, that after the new year seems to be lost. Parsnips may be kept in the ground until Spring, and will be found, in.connection with grain, most excelleut for ewes, after lambing. Until lambing time we prefer to feed carrotb, and corn, with enough bran mixed to keep the bowels fairly open. Thus fed, the fleeces will be heavy and even in texture. The sheep will not shed their wool when put on to grass, and the shepherd, if he has attended to the general health of the flock, will find that sheep really pay twice; once in the fleece, and once in the carcass.

\section{Management of Lambs.}

It is absolutely necessary, when early lambs are expected, that a warm place be provided for the ewe at lambing time. The room need not be large, and may be divided into pens suitable for each ewe when there are a number to lamb at one time. Heat the room by means of a stove, and if the ewes are healthy and hearty they will take care of themselves as a rule. But the sliepherd should be present in casc the young lambs want assistance, and here will be found the advantage in liaving innde the sheep perfectly familiar with and relying on the keeper, for thus there will be no fear displayed. If the lamb appear weak and disinclined to suck, handle it carefully and hold it to the dam. A young lamb is at first the weakest and most foolish animal imaginable. Once it has got on its feet and sucked it is all right.

\section{Dooking Lambs.}

This should be performed as soon us the lamb is fairly strong and growing; say when a week old. Let an attendant pick up thelamb, and holding his rump pretty firm against a post of suitable height, the shepherd seizes the tail, and pressing the skin back toward the body, places a two inch chisel at the point of separation, holding it firmly enough so that it will not slip, when with a light blow of a mallet it is severed. Throw the tails of rams in one pile and those of ewes in another, and enter in the shepherd's book the sexes and numbers. It is well at the same time to place a paint mark on the rump for future recognition. A pinch of

powdere a lamb v to be $\mathrm{re}$ more eff

Many always $b$ discontinu the lamb. success. pressed as pressed str and the scr cuts away off the en connecting part of the pulling awa no bleeding sometimes linen cord as entirely abo slipping of strungulated precisely as i other means success.

Spring lam become fully s corn-ficld he nice feed for found most va which green o lambs, since th be learned to $\mathrm{c}$ under cover, sc is concerned, $t$ 
powdered copperas on the end of the tail will stop bleeding. Occasionally a lamb will bleed severely. If so, tio a ligature tightly around the stump, to be removed in about ten hours, or a touch of red hot iron will be more effective.

\section{Castration.}

Many perform this operation immediately before docking. It has always been practiced by myself and $I$ have never found any reason to discontinue the plan. In any event the sooner it is done the better for 'the lamb. I have docked and gelded at three days old, and with the best suceess. An attendant holds the lamb, rump down, and with the back pressed against his own body; drawing the hind legs up, the body is pressed strong enough to cause the belly to be forced between the thighs, and the scrotum is thus well exposed. Seizing the scrotum the operator cuts away one-third of it ; tako each testicle in turn and sliding back and off the enveloping membrane, with a quick jerk the whole cord and connecting tissues snap and come away. The object in cutting away a part of the scrotum is that it makes a better surface in shearing. This pulling away of the cord may seem cruel. It is not 80 ; there is almost $\mathrm{m}$ bleeding, and the violence of the rupture deadens the pain. It is sometimes necessary to geld an old ram. The best way is to tie a waxed inen cord as tightly as possible about the bag, being careful thut it is tied entirely above the testicles, and that there shall be no possibility of slipping of the knot. Thus circulation is stopped and in a few days the strungulated part will drop away; or the operation may be performed precisely as in the case of the horse. We have however never used any other means either with bulls or rams than that indicated above, and with success.

\section{Weaning.}

Spring lambs should be weaned early enough in the Fall so they may become fully accustomed to grass and to grain before Winter sets in. If a corn-ficld has at the last cultivating been sown with rye, it will afford nice feed for lambs in the Fall, and in the following Spring it will be found most valuable for breeding ewes. If there is stubble ground, in which green onts or wheat have sturted, it makes excellent pasture for lambs, since they will also pick up some grain. In any event, they should be learned to eat grain by having their salt sprinkled on grain in a trough under cover, so they may learn to eat it. So far as Winter munagement is coucerned, the same rule will apply as to other animals. Give them 
the best of the hay and a liberal quantity of grain, to keep them growing right along.

\section{The Nursery.}

In all large flocks there will always be some lambs that do not do well. These should always be separated from the others and have extra care. So in the older sheep-the flock should be graded as to age, size and sex. It is better that the wethers and the ewes be kept apart, and that in the sexes that very strong animals be not'put with weak ones. If they do 11u other mischief, they rob the weak ones of their food, the vely thing they most need. In fact, every farm should have a nursery, however small the flock, where weak ones and wethers may receive special attention and care. Sheep upon farms suited to them are very profitable, but however suitable the farm, the profits will be in direct proportion to the intelligent care and attention the animals receive. 


\section{PART VI.}

\section{Diseases of SheEP.}

CAUSE, PREVENTION AND REMEDIES. 


\section{CHAPTER I.}

\section{ANATOMY AND DISEASES OF SHEEP.}

IUE HBAD. —THE TRUNK.—THE FORE-LEG.—THE MIND-LEG.—-IMPORTANCE OF TIIE IIEAD TO BREEDERS. Diseaseg OF THE HEAD AND BRAIN THE TEETH. - $\mathrm{SWELLED} \mathrm{HEAD.}$ VEGETABLE POISONING.

INFLA MMATION OF TIE EYE.- - SHEEP DISTEMPER.—-HOW TO KNOW IT.- - WHAT TO DO.- - GRUBS IN THE HEAD. - HOW TO SAVE THE SIEEP. - -APOPLEXY. - PREVENTION. - IXFLAMMATION OF THE BRAIN. —TETANUS, OR LOCKJAW.—PALST.—RABIES.— HYDATIOS ON THE BRAIN, — PARASITES OF THE BODY AND SKIN. - THE SCAB.—IOW TO KNOW IT. - WHAT TO DO. - DISEASFS OF THE GENERATIVE ANB URINART ORGANS. - DISEASES OF THE LIMBS AND HOOFS, — FOOT ROT.—-HOW TO CURE IT.- - TOULS, AND TRAVEL-SORE FEET. - - GRAVEL.-THE BIFLEX CANAL. - MAGGOTY SHEEP. -LUNG WORMS._INTESTINAL WORMS. — - ROTTEN LIVER.—-COLIC.

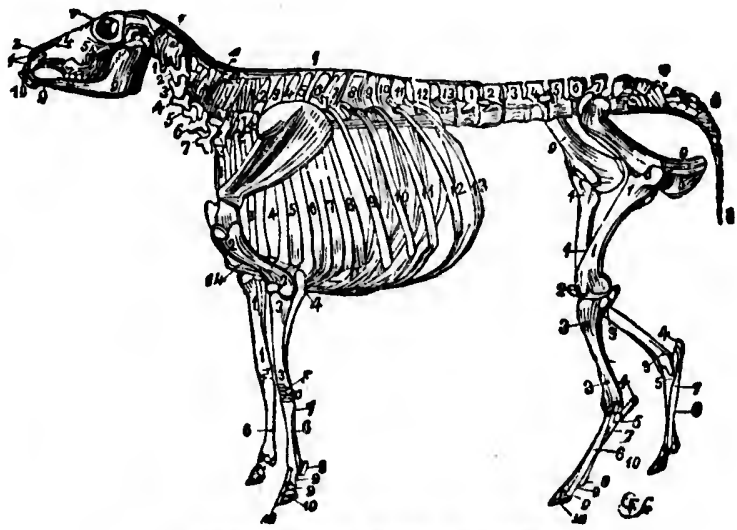

BKELETON OP LEICRSTER SHEBP.

The Head.

Explanation,-1-The intermaxillary bone. 2-The nasal bones. 3-The 823 


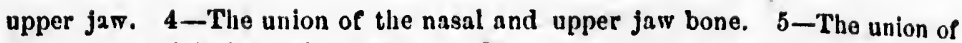
the molar and lachrymai bones. 6-The orbits of the eje. 7-The frontal bone. 9-The lower jaw. 10-The incisor teeth or nlppers. 11-The molars or grinders.

\section{The Trunk.}

1, 1-The llgament of the neck; supporting the head. $1,2,3,4,5,6,7$ The seven vertebræ, or bones of the neck. 1--13-The thirteen vertebrx, or bones of the back. 1-6-The six vertebre of the loins. 7-The sacral hone. 8 -The bones of the tail, varying in different breeds from twelvo to twenty-one. 9-The haunch and pelvls. 1-8-Tlie eight true ribs with their cartilages. 9-13-The five false ribs, or those that are not attached to the breast bone. 14-The breast bone.

\section{The Fore-leg.}

1-The scapula or shoulder-blade. 2-The humorus, bone of the arm, or power part of the shoulder. i-The radius, or bone of the forearm. 4-The ulna, or elbow. 5-The knee, with its different bones. 6--Tho metacarpal, or slank. bones; the larger bones of the leg. 7-A rudiment of the smaller metacarpal. 8-One of the sessamoid bones. 9-The two first bones of the foot; the pasterns. 10-'The proper bones of the foot.

\section{The Hind-leg}

1-The thigh bone. 2-The stifle joint and its bone, the patella. 3 -The tibin, or bone of the upper part of the leg. 4-The point of the hock. 5-The other hones of the bock. 6-The metatarsal bone, or bono of the hind.leg. 7 -Rudiment of the small metatarsal. 8-A sessamoid bone. 9-Tho two first bones of the foot, the pasterns. 10-The proper bone of the foot.

The bones of the loins bear a strong rescmblance to those in the back, but instead of springing from the sides, as do the ribs, they are fixed, bony processes, several inches in length, and their peculiar duty is to nfford protection to the abdomen. They are the timbers that support the roof, or covering of this part of the system. Next in position to the loin comes the sacrum, which is formed in young nuimals of separate bones, but at maturity is consolidated into one. At this point the passage for the spinal cord becomes very much diminished, and, at the end of the bone, terminates in several nerves, which continue their course into the tail. The bones of the latter are numerous, but not perforated. Te pass now to the limbs, and find that the number of joints are the same in the horse, ox, and sheep, but in the latter animals, at the fetlock, these become divided and the four bones beneath it are thus doubled.
The reight shle in radius : bones, the met out of suture 1 danger. tempora the sku bony op bones. ply the matic or the nose which the face. 13 palatine p ginous pa

Explana Upper jar bone sulpl place of The front: of the hor froutal sin movil of a horn. 7--7 cal section The cinerit brain. 10 of the eth -The supe -The sphe

The head mate the qu projects bot 
The bone which forms the elbow-ulna does not support much of tho weight of the animal, but serves to attich the powerful museles, so noticslle in bones, with good fore-arms. The attachment of the ulna to the radius forms a lever. The carpus or knee is composed of seven distiner bones, placed in two rows. The upper row articulates with the radius ; tho metaearjus.

$, 6,7-$

bre, or . al hone. nty-one. urtilages. st bone.

, or rower e ulna, or or shank. retacarpal. ; the yas-

1. 3-The z. 5-Tha ind-leg. 7 ho two first

the back, are fixed, $t y$ is to ufupport the to the loin rate boncs, passage for end of the se into the rated. Tie the same in tlock, these d.

Explanation-1-Occipital bone, depressed out of danger. 2-The parietal bones, the suture having disappeared, and also out of danger. 3-The squamous portiors of the temporal bone-the buttress of the areh of the skull. 4-The meatus auditorius, or bony opening into the ear. 5 - The froutal

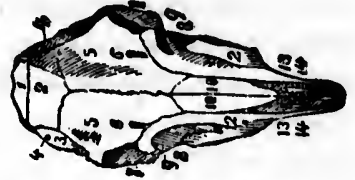

GKULL OF A POLLED SHERP. boues. 6-'The openings through which blood-vessels pass, to supply the forehead. 7 -The bony orbits of the eye. 8-The zygomatic or molar bones, very much developed. 9, 10-The bones of the nose. 11-The upper jaw bone. 12-Tho fortmen, through which the nerve and blood-vessels pass, to supply the lower part of the fare. 13-'The nasal processes of the intermaxillary bones. 14-The palatine processes. 15-'The intermaxillury bone, supporting the cartilaginuus pad, instead of containing teetl.

Explanation-1-Nasull bone. 2Upper jaw bone. 3-Intermaxillary bone supporting the pad, supplies the plice of upper front teeth. 4, 4The frontal sinus. 5--Cavity or sinus of the horn, conmunicuting with the frontal sinus. It is here shown by removil of a section of the base of the horı. 7--The frontal bone. 8-Verti-

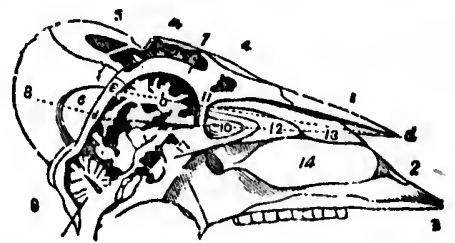

HEAD OF SHERP-VERTICAT, SECTION. al section of the brain. 9-Vertical section of the ecrebellun. $a-$ The cineritious portion of the brain. $b$-The medullary portion of the brain. 10-The ethmoid bone. 11-The eribiform or perforated plate of the ethmoid bone. 12-The lower eell of the ethmoid bone. 13. -The superior turbinated bone. 14-The inferior turbinated bone. 17 -The sphenoid bone.

\section{Importance of the Head to Breeders.}

The head of the sheep is one of the important points by which to estimate the quality and profitableness of the animal. The frontal bone (1) projects both forward and laterally, and gives to the sheep a peculiar 
appearance as regards breadth of forehead and prominence of the cye. This design of nuture is intended for the base of the horns, though in breeds known as hornless, or polled, the same formation is observable. The room from eyo to eye is occasioned by the frontal bones $(5,5$, of polled sheep) reaching as fur below the range of vision as above it, and very materially shortening the nasal $(10,10$, ) bones. These reach upward to the parietal boues (2) which latter constitute an important portion of the posterior, slanting portion of the skull, just below the junction of the frontal and parietal bones; the head falls off in fullness-a backward sloping, so to speak, and the part of the frontal bone most important because covering the brain, is removed from the danger resulting from coneussion of the head in fighting. The form of the brain in the sheep, is similar to that of the horse and ox, but is longer in proportion to size, and broader in the back than in the front. The brain of the shecp so closely resembles, in its conformition and structure, that of aman, though smaller in proportion, that it furnishes the medical student with a good substitute for the human subject. The membrane covering the brain is technically called the pia mater. The dura mater lines the skull, and between the latter and the former is a delicate membrane called ternica arachmides. The nerves, of which ten pairs are connected with the brain, and thirty with the spinal cord, supply the sense of feeling, seeing, hearing, tasting, smelling, \&c., and a portion conveying the volition of the brain to all parts of the body, are termed nerves of motion.

\section{Diseases of the Head and Brain.}

In Europe, and especially in Great Britain, sheep are subject to a long category of diseases. Fortunately, in this country sheep thus far hare been subject to comparatively few diseases, and especially so in the West; owing probably to the fact that, except in the Spring, and sometimes for a short period in the Autumn, the elimate and the soil are dry. Mr. Spooner, the able English veterinary writer, remarks upon the rarity of inflammatory diseases in American sheep. This he attributes to the musculiur and vascular structure of the sheep, comparing the indifferently kept sheep of his day with highly fed British sheep. The real cause, however, of exemption from disease lies more in the cllmate than anything else. Another special reason probably is that our flock masters are, as a rule, men of intelligence, who trust but little to ignorant shepherds, as is not the case in Great Britain and on the continent. We shall therefore touch lightly upon many diseases specially treated of in foreign works, and pay more particular attention to that class of diseases most prevalent with us. 
The Teoth.

The shecp has eight incisors in the lower jaw, and twolve grinderssix on a side in each jaw, -making in all thirty-two teeth. At birth the lamb should have the two central incisors just pushing through. At a month old all the incisors should bo up. At one year, sometimes not until fifteen months old, the two first milk ineisors will be shed, and two new or permanent ones will appear. At two years old past, it will have two more permanent teeth, or four in all. At three years old past it will have six permanent incisors, and at four years old past the eight permanent teeth, of a full mouth, as it is called, will be shown. This will be an accurate test as to the ugo of sheep, up to four years, varied of course by care and keep; highly fed sheep developing faster than illy kept ones. At six the incisors begin to decrease in breadth, and lose their fan shape, as seen at four years old. At seven they become longer and narrower, and ench year this shrinkage continues, until at last they become quite slender, the middle ones long, and at ten years they loosen and begin to drop out. In the West few sheep are kept to the age of ten years, except in the case of valuable ewes and bucks. The principal care necessary with the teeth is, if deeay is suspected, to examine, and extract the decayed ones, or pierce the nerve with a hot iron.

\section{Swelled Head.}

Sheep sometimes are bitten by venomous snakes, but this seldom occurs, and when so the animal is usunlly beyond help before being found. The bites of insects however, sometimes give trouble. When srelling from this cause is discovered, eut the wool from around the wound, wash with warm water dry, rub thoroughly with lard oil, and if the insect may have been a venonous one, give the following dose each bour until relief is obtained:

$$
\begin{aligned}
& \text { No. 1. } \quad * \text { Scruple hartshorn, } \\
& 1 \text { Ounce ralnwater. }
\end{aligned}
$$

\section{Vegetable Poisoning.}

The faces of the sheep sometimes become poisoned from feeding near noxious plants. Bathe the sore place with warm water, and then moisten with the following:

No. 2.10 Grains acetate of lead, 1 Ounce water.

Dissolve. 
This is also excellent for burns, bruises, irrituble and moist ulecrs, influmed tendons, moist skin diseuses, and crucked and itching surfices, and also for sore lips.

\section{Infemmation of the Byes.}

Simple ophthalmy sometimes oceurs in sheep. If there is scrious inflammution, bleed slightly from the fuciul vein-the vein running down obliquely from the eye, and bathe with the following:

No. 3.

3 Grulns sulphate of alne,
1 Ounce water,
16 Dropss luudunum.

Bil $x$, und bathollghily twice a day.

\section{Sheep Distemper.}

Mulignant epizootic eaturrh is an epidemie accompanied by severe congestion und infummution of the lining membrane of the unsal envities and sometimes extending into the stomach and bowels, is as to its cause unknown, but has occasionnlly been very fatul, both East and West.

\section{How to Know It.}

There is depression, a slight wntery diseharge from the nostrils, and the eyes, which are partly closed and paler than mutural. There is more or less loss of appetite. The pulse is normal as to frequency, but is weaker thun usuml. There is no congh, and the breathing is not changed unless the bronehinl tubes are nffected. The symptoms increase, until the end of a week the diseharge from the nose is thick and glutinous, sometimes tinged with blood; eyes half elosed, the lids gummed with n yellow secretion. The respiration is diffieult, emaciation and prostration great; the pulse vely low, the ajpetite is gone, and in from ten to fifteen days the unimal dies.

\section{What to Do.}

At the first symptoms, remnve the shcep to a dry, well ventilated place, where they una be kept comfortubly warm. Give them concentrated and nourishing food and stimulants. If the bowels are costive, give them, say:

No. 4.

8 Gruins corrosive subllmate,

$10 z$ roubarb,

2 Oz. ginger,

2 Oz. gentian. 
Simmer the last three in a quart of water for ten or fifteen minutes; strain, and add the tirst. Give two table-spoonfuls twieo a day. In any easo, avoid all strong purging or bleeding. An equable warmth, good feeding, nourishing drinks, und good nursing, is whit will save, when possible, if taken early. If not well nursed the pntient will be sure to die.

\section{Grubs in the Head.}

In July and August, if sheep are seen standing crowded together with the heads close to the ground, ocensionally stumping violently, or striking with their fore feet, be sure the sheep gad-fly OEstrus Ovis, is attempting to deposit her eggs in the nostrils of the sheep. This fly is somewhat like the ox gad-fly, but smaller. The egg deposited, the muggot soon hatelies, ascends the sinuses of the noso, causing much irritation. Then it grows during Winter, and in the Spring descends and fills on the ground, burrows therein, ussumes the form of a chrysalis, to bo again trunsformed into a porfect lly.

\section{How to Bave the Bheep.}

Prevent the flies from laying their eggs. Plow a portion of the field into furrows of loose soil ; keep the sheep's noses smenred with tur, by tarring onee a day through the season of the fly. I linve cuught them in a light bag net, such as boys uso in eatehing insects. A reward of fivo cents for every fly caught would well repay the sheep owner.

The inaggots affix themselves by their strong hooks, and are not easily dislodged. Violent sueczing will sometimes dislodge them. Thus Scoteh snuff may be blown up the nostrils. The infested sheep may be driven in a close place, and horn shavings or leather burned to irritate the membrane of the nostrils. A better wily, when carcfully done, is to secure the sheep, hold tho head up, and pour into ench nostril a teaspoonful of equal parts of sweet oil and turpentine, well shaken together. Be careful, however, that the sheep is not strangled by the mixture entering the lungs. The grubs are sometimes extracted by tho surgeon. It is a nice operation, and as a rule will not pay its cost

\section{Apoplexy.}

This is a discase seldom scen in the United States, and confined to sheep of a plethoric habit, and is gonorally fatal if not taken early. The sheep leaps suddenly in the air, falls and dies in a few moments. The renedy is early and copious bleeding from the neck (jugular) vein, until 
the sheep shows signs of weakness. A pint of blood is sometimes taken from full-bodied, large sheep and less for smaller ones.

\section{Prevention.}

This is better than cure. If a sheep be dull, and apparently unconscious of what is going on ; if the membranes of the nose are deep red or violet, the nostrils and pupils of the eye dilated, the pulse hard, and the breathing stertorous, bleed immediately, and afterwards give two ounces of salt, to be followed by an ounce every six hours until a copious evacuation is produced.

\section{Inflammation of the Brain.}

This is a secondary effect of the causes which produce apoplexy. The animal is dull and inactive. The eyes are red and protruding, and at length the animal ruslies about in the wildest delirium. The same remedy is prescribed as for apoplexy.

\section{Look-jaw.}

This is produced from a varicty of causes, among the more common, being inflammation of the membranes from inproper gelding, injuring the hoofs, horns, etc. The animal is unable to walk, or only so with difficulty; the jaws are set, and death ensues in a short time. Warmtl, quiet, and bleeding from the jugular vein, is recommended. We should omit the bleeding and give one-lidlf to three-quarters of an ounce of castor oil, according to the age of the sheep, the disease being confined mostly to lambs, and sheep after gelding. Follow the dose of castor oil, in half an hour, with ten grains of opium, and at the end of an hour, give another $t, n$ grains of opium if a decided sedative effect is not produced. Epi psy is a kindred disease, in fact tetanus is considered to be an aggravated state of epilepsy. The remedial means will be the same.

\section{Palsy.}

This is the opposite of epilepsy. The sheep is unable to move its limbs. It is supposed to be pisoduced by cold and improper treatment. It is rare in this country. Take the lamb to a warm place, give it warm gruel, with a little ginger mixed in it. If a purgative is indicatedgive:

\section{No. 8.}

2 Oz. epsom salts,

3. Drachm ginger.

Mix in half pint of ale or water; $t$, be followed by two drachms of laudanum in an hour.
Sheep : strange or as attacke dictate thi

This is fact that 1 once fixed veterinary The bladd an earlier : of the dog, the sheep $t$ the brain, animal. $\mathbf{T}$ and the inse eaten withot herd dogs a One of th ted is to pie and inject in No.

Sheep are produce scab lungs, etc.

This is proc rows under the and which dry great rapidity, insects is $\mathbf{8 0} \mathbf{~ g r}$ tagion after th tive with every 
Rabies.

Sheep are apt to be bitten by rabid dogs. The only preventive is to kill all strange or suspiciously acting dogs. The remerly is to kill the sleep as soon as attacked. The perils attending treatment, and the hopelessness of the case, dictate this course.

\section{Hydatids on the Brain.}

This is a disease of rare occurrence in America, probably from the fuct that range is greater and dogs fewer to the square mile. The disease once fixed, nothing, practically, can be done, at least except a thorough veterinary surgeon be called, since it involves a delicate surgical operution. The bladder worm or hydatid is a form of the tape worm of the dog, in an earlier stage of existancc. The mature tape worm lives in the bowels of the dog, its eggs are voided with the excrement, and in close pasturage the sheep take the eggs while gruzing; hatching, they make their way to the brain, where they grow, and must remain until eaten by some other animal. Thus the dog eats the sheep's head, acquires the tape worm, and the insect again goies its round of life. Allow no sheep's heads to be eaten without thorough cooking, kill all strange dogs, and give your shepherd dogs a good vermifuge occusionally.

One of the plans adopted to get rid of the hydatid when it can be located is to pierce the cyst with the needle of a strong hypodermic syringe, and inject into it half a tea-spoonful of the following :

No. 6.

1 Grain iodine,

5 Grains iodide of potash,

1 Ounce water.

Mix.

\section{Parasites of the Body and Skin.}

Sheep are infested with lice, three different forms of parasites which produce scab, also with ticks, intestinal worms, parasites of the liver, lungs, etc.

\section{The Scab.}

This is produced by a minute, almost microscopic insect, which burrows under the cuticle, producing intense irritation, the escupe of serum, and which drying, brings off with it wool and all, and, spreading with great rapidity, soon infests the whole flock. The teriacity of life of these insects is so great that a scabby pasture has been said to spread the contagion after three years. The prevention of infection should be imperative with every flock master. 
Mix th

The sheep is restless and constantly rubbing itself against posts and other objects it can get near. It bites itself with its teeth, and scratches itself with its hoofs. Soon the fleece becomes ragged and begins to fall out, und the animal appears wretched and unsightly, and at length dies.

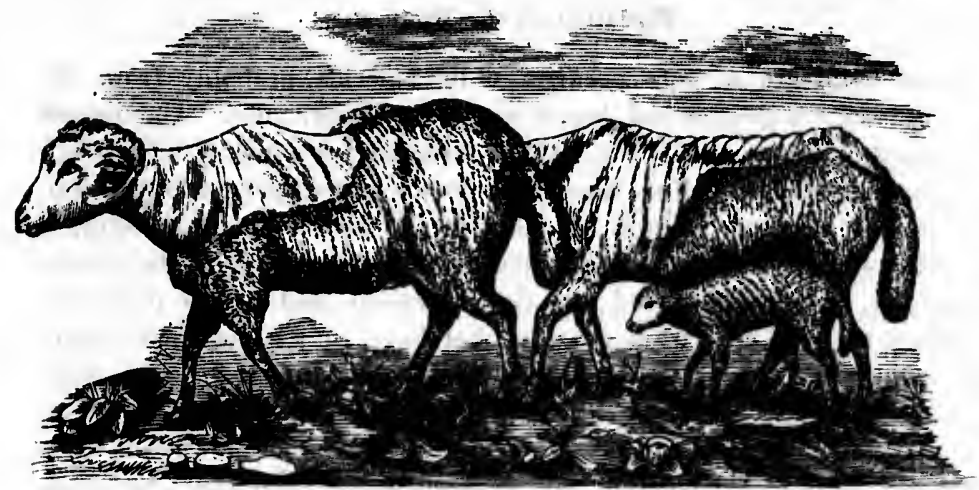

a Bad Case of scaB.

\section{What to Do.}

The remedies are both liquid and oily. A good dip, and one regarded in England as most effective, is the following:

$$
\text { No. } 7 .
$$

$$
\begin{aligned}
& 3 \text { Pounds arsenis, } \\
& 3 \text { Pounds peurl ash, } \\
& 3 \text { Pounds sulphur, } \\
& 3 \text { Pounds son soap. }
\end{aligned}
$$

Mix in ten gallons of boiling water, stir, but avoid the fumes, and add ninety gallons of cold water. Prepare a tank that will easily allow a sheep to be dipped, having a slanted, slatted drain at the side, tight bottom underneath to allow the drip to run back. Dip the sheep, back down, being careful not to allow the head to enter the poisonous mixture, letting the animul remain one minute. Lift on to the slats and rub and squeeze the wool, until pretty well drained, and place in a yard until dry. When dry, go over the flock again, as to the heads, with the following:

No. 8.

\author{
1 Pound mercurlal olntment. \\ 6 Pounds l: . \\ 1 Pound rosin, \\ * PInt oll of turpenting.
}

ring. $\mathrm{Di}$ lard is col head, alon: 'used, subst formula as

A formi lowing :

No.

The sheep four or five as not to ex dried as befo

Use the ren sheep in the $l i$

This is an in ing the inflam. The first sym pale condition becomes somew lext, the moist extends down to walls are then a between the fles ened at the heel it and the fleshy all parts of the sole is disorgani. of corruption, $\mathrm{s}$ fore-feet are us
In the I by Dr. Randai 
Mix the mercurial ointment witn the lard by heating gently and stirring. Dissolve the resin in the turpentine and rub all together when the lard is cold. Part the wool on the head between the ears, on the forehead, along tho neck and under the jaws, and rub in the ointment.

In the United States, tobacco is often used in the place of arsenic; if ' used, substitute ten pounds of strong tobacco leaves for the arsenic in the formulit as given above.

A formula in great repute among Australian shepherds, is the following:

No. 8.

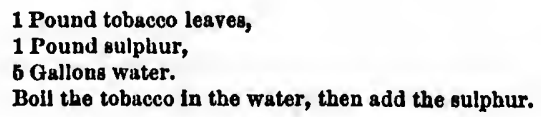

The sheep is dipped in this solution while quite hot, and retained in it four or five minutes, its head being from time to time thrust under so as not to enter the eyes, nose, or mouth, and the wool pressed and dried as before stated.

\section{Diseases of the Generative and Urinary Organs.}

Use the remedies prescribed for cattle, noting tho doses as given for sheep in the list of medicines for animals.

\section{Diseases of the Limbs and Foofs-Foot Rot.}

This is an infectious disease often aggravated by grit and dirt increasing the inflammation. The indications of rot are described minutely by Dr. Randall :

The first symptom is the disappearance of the naturally, smooth, dry, add

pale condition of the skin at the top of the cleft, over the heels. It becomes somewhat red, warm and moist, and slightly rough.or chafed. Sext, the moisture increases to a discharge, and an ulcer is formed which extends down to the upper portion of the inner wall of the hoof. These walls are then attacked, become disorganized, and the disease penetrates between the fleshy sole and the lottom of the hoof. The hoof is thickened at the heel by an unnatural deposition of horn. The crack between it and the fleshy sole pours out an offensive and purulent matter. Soon all parts of the foot are penetrated by the burrowing ulceration, the horny sole is disorganized, and the fleshy sole becomes a black and swollen mass of corruption, shapeless, spongy, and often filled with maggots. The fore-feet are usually first attacked; lameness is early noticed and soon 
becomes complete : the appetite is lost, and the animal dies from exhaustion. The offensive odor of the true foot rot is characteristic, and once made familiar will serve as a certain guide in recognizing the disease. The disease may present itself in a malignant and rupid form, or in a mild one. The first attack on a flock is generally of the severe character. When it is kept under the first year, its appearance the next Sum- . mer will be mild; and the third season still milder.

\section{How to Cure Rot.}

Every part of the diseased structure must be cut away, cleaning the knife from time to time. This thoroughly accomplished, prepare a tunk, which is to be filled to a depth of four inches, with a strong, saturated solution of sulphate of copper, blue vitriol; let each sheep stand in this, heated as hot as they can bear, for ten or more minutes, keeping the whole hot by occasionally plashing a piece of heated iron in it, or adding a quantity of the solution boiling hot. It is also wel! to cover the hoof with chloride of lime, and fill the eleft of the hoof with a piece of tow long enough so the ends can be twisted into a cord to be fastened around the fetlock. This makes a good bandage. The hoofs should be exumined daily for sometime sid the chloride renewed if necessary. Keep the sheep in a dry, well-littered yard, ornn a dry, short pasture, and feed well. If the case is bad, the following tonio given internally will be necessary :

No. 10.

$$
\begin{aligned}
& 2 \text { Drachms common salt, } \\
& \text { y Drachm sulphate of iron, } \\
& \text { K Drachm nitrate of potash. } \\
& \text { Mix as a powder and glve dally. }
\end{aligned}
$$

\section{Touls and Trarel-ore.}

These may be cured, the first by washing the eleft of the hoof with warm water and applying a strong solution of blue vitriol, and the latter by touching the thin places in the hoofs with a feather dipped in oil of vitriol, and smearing over with tar. Or letter, prepare the following lotion and use occasionally:

No. 11.

1 Part solution of chloride of antimony, 1 Part compound tincture of myrrh.

\section{Gravel.}

Sheep often become graveled. If lame in the least examine them, and cut the horn of the hoof to expose the gravel; extract it and cover the wound with tar.
The i

the hoo: advice embedd perhaps compou

Often eggs, eitl about the tagged, 1 diagonall must be $t$

And aft

This dis which som the windp dysentery, the mouth cough and if it lose it:

Pour on warm add:

No.

Mix well

When the into twelved

No.

This is end 
The Biflex Canal.

The issue as it is called (biflex crnal) in the front and upper part of the hoof, sometimes becomes irritated and swollen. Do not follow the advice of ignorant persons and "cut out the worm." If any thing is embedded therein, extract it. If simply swollen and inflamed, and perlups ulcerated, lance it in two or three places slightly and dress with compound tincture of myrrh.

\section{- Maggoíy sheep.}

Often in hot weather, from one cause or another, flies will lay thein eggs, either in a wound, or, if the sheep is dirty, in the accumulated dung about the thighs. The prevention is eleanliness. Keep the sheep well tagged, that is shear the wool from under the sides of the tail, and diagonally thence some ways down the thighs. If maggots exist they must be taken out, and the wounds touched with

$$
\begin{aligned}
& 1 \text { Part creosote, } \\
& \text { No. } 12 .
\end{aligned}
$$

And afterwards bathed daily, until relieved, with tincture of myrrh.

\section{Other Diseases.-Lung-Worms.}

This disease is caused by the presence of worms, the strongulus filmric, which sometimes make their way into the lungs, but are usually found in the windpipe and bronchial tubes and bowels of sheep. If there is dysentery, with fetid stools, examine the evacuations and the mucus of the mouth and throat for indications of the worms. If there is a husky cough and quiekened breathing; if the sheep rubs its nose on the ground; if it lose its appetite and flesh prepare the following:

No. 13. $6 \mathrm{Oz}$. sulphate of magnesia, $4 \mathrm{Oz}$. nitrate of potash.

Pour on these three pints boiling water, and when the solution is milk warm add:

oof with he litter in oil of ng lotion

hem, and cover the

Mix well and give two or three tablespoonfuls every other day.

When the worms are supposed to prevail, the following may be made into twelve doses, one to be given once in two weeks, as a preventive:

No. 15.

$2 \mathrm{Oz}$. oil of turpentine,

$20 z$. powdered gentian,

2 Oz. Isudanum.

Dissolve in a quart of lime water.

This is enough for twelve sheep. 


\section{Intestinal Worms.}

The presence of intestinal worms and other parasite affections may be often found if shepherds would take the trouble to dissect a dead sheep. When found in one, the presumption is good that many are uffeeted, for these parasites seldom appear in individual cases only. As a preventive, when feared, plenty of salt should be allowed, and the following prepared to be given once in two weeks.

No. 16.

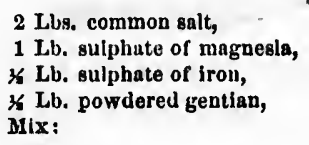

This is sufficient for 80 to 100 sheep to be given in ground feed.

Dr. Tellor says: Ordinary wood soot, as it can be collected from the chimney is a very efficient vermifuge, often used, both in children and the lower animals. It may be mixed with salt, or sprinkled on the fodder. Another cheap and useful vermifuge, in the form of a drink, is-

No. 17.

1 Lb. quick lime,

b Oz. sulphate of Iron.

Mix with five gallons of water, and give a pint twice a week.

As a vermifuge in round and thread-worms, the shepherd may use-.

No. 18.

2 Oz. Hnseed oll,

* $\mathrm{Oz}$. oll of turpentine.

For a drench.

For tape worm, the following :-

No. 19.

\% to 1 Drachm, powdered areca nut, 10 to 20 Drops, oil of small fern.

Give in molasses and water, and follow next day with a purge.

\section{The Rot, or Liver-Fluke.}

This is a disease caused by flat worms, (Fasciola hepatica,) in the liver. If by rubbing the skin of a sheep backward and forwarl at the smiall of the back as taken between the thumb and fingers, it is soft and flubby and there is a crackling feeling in the fingers, as if there were water underueath : if there is weakness and tenderness about the loins; if the belly swells, and the eye becomes jaundiced; if there is a diarrhea, a weak heart and general stupor, and no veterinarian is near, isolate the animals in a high dry pasture, give abundant and nutritious food and prepare the following :
Mix $f$ at a dos

The fi

For thi

The bes since the insects, wl tho germs

Lush pa grain, will gas is solne stomach. give the fol

If the inft a pledget of introduce ge the swelling and plunge a common sha a goose quill 
No. 20.

K Lb. sulphate of magnesia,

3 Drachms ofl of turpentine.

in the $d$ at the soft and re water ; if the a weak animals pare the

Mix for a drench, and give every two days, one-third of the quantity at a dose.

The following is an English remedy and said to be very effective:

No. 21.

1\%. Drachıns yellow resin,

1 Oz. oil of turpentine,

10 Grains calomel,

30 Drops tincture of lodine.

For three doses, one to be given every morning for three days, in grucl.

Colio.

The best preventive is to keep sheep off of pastures liablo to inundation, since the worm passes one stage of its existance in shell fish and water insects, which are carried into such pastures by floods, and the sheep get tho germs with the grass.

Lush pasture to hungry sheep, ergot in fodder, musty or blighted grain, will produce colie or hoven in sheep as in cattle. The presence of gas is sometimes so strong as to rupture the walls of the rumen or third stomach. If the case is not serious, press and knead the stomach, and give the following :

No. 22.

2 Drachms sulphate of potash,

1 Oz. conmon sult,

1 Oz. sweet oll.

Mix in a wine glass full of water.

If the inflation is great, get a rubber tube, of half inch calibre, fasten a pledget of wool over the end to prevent clogging, oil thoroughly and introduce gently down the throat to the stomach. If this means fail and the swelling continues, remove the wool from the most prominent part and plunge a trocar into the stomach. If a trocar is not to be had use a common sharp pointed pen knife, and keep the orifice open by inserting a goose quill. 
HISTOR 


\section{PART VII. \\ SW I N E.}

HISTORY, BREEDS, CHARACTERISTICS AND MANAGEMENT. 

YoRKsIIIR MIDDLE-BREI CHINA.-XI. TERISTICS, -

The great an the fact that $r$ tertiury and dilu wild hogs, from native of Europ is mild enough $\mathbf{t}$ wherever civiliza domestic hog is continue entirely remotest generat 


\section{SW INE.}

\section{History, Breeds and Characteristics.}

\section{CHAPTER I.}

\section{HISTORY LND BREEDS.}

OAJGIN OF THE HOG.—-TEETH OF THE HOG.—-IMPORTANCE OF SWINE TO MAX.

-I. IMPROVLD BREEDS OF SWINE.-ENGLISH BREKDS.-II. TIIE BEIKSIIRE! . - ESTABLISHING THE IMPROVED BERKSHIRE. — STANDARD CHARACTERISTICS OF BERKSHIRES. - II. NEAPOLITAN HOGS.—-1V. ESSEX BREED.—V. YORKSHHE HOG.-VI. SUFFOLKS.-VII. IANCASHIRE HOGS, -VIII. LANCASHIRE MIDDLE-BREED. - IX. LARGE LANCASHIRE. - AMERICAN BREEDS.—X. POLAND CIINA.-X1. CHESTKR WHITES. -XII. JERSEY REDS.-CHESHIRES.-XIII. CHARACTERISTICS. - RECAPITULATION OF BRFEDS.

\section{Origin of the Hog.}

The great antiquity of the hog, sus scrofa of Linnæus, is fixed from the fact that remains of several fossil species have been found in the tertiary and diluvial deposits of Europe, and allied species in India. The, wild hogs, from which the domestic breeds have taken their rise, are native of Europe, Asin and Africa, and are found wherever the climate is mild enough to afford sustenance in Winter, and in a domestic state wherever civilization has been extended. The fact of the origin of the domestic hog is well established from the fact that it will interbreed and continue entirely fertile, the succeeding fertility of the offspring, to the remotest generations, proting the homogeneity of the species. 
In Anerica, in Australia mnd in the Polynesim group, hogs were unknown until introduced. In England tho wild epecies has long been extinct. In Frunce they ure neurly so, but in some purts of Germun, Dennark, Ituly, Greece, und in Asia Minor they mre still met with. In Americu swine ure said to have been introduced into Hispuniola by Columbus in 1493 ; into Florida by Do Soto in 1538; into Nova Scotia and Newfoundland in 1553, into Canuda in 1608, and into Virginiu in 1609. So great was the fecundity of swine in Virgininn forests, that in eighteen years after their introduction the inhabitunts of Jamestown h:d to palisade the town to keep them out.

\section{Teoth of the Hog.}

The domestic hog has, when full grown, forty-four permanent tecth, twenty-eight of which are preceded by temporary, or milk teeth. The teeth are elnssitied as follows: Twelve ineisors or front teeth, six in the upper and six in the lower jaw. The incisors in ench jaw are divided equally, three on each side of the median line, of which the foremost are called the nippers; the next outside of these, intermediury incisors, and the remainder, outside of these are called corner incisors. Next in order aro the four tusks, one on each upper and one in ench under jaw on each side. The true grinders or molars are six in numler, not including the so-called "wolf tecth," four in number, but which are now elissed with the molurs, making really seven on a side in each jaw. Each of the three hindmost molars in the four rows are permenent tecth, or not preceded by milk teeth. The three next in front of these appear soon after birth,one after another, and are called milk teeth(or premolars) and in the course of time are shed one after another, in the order in which they appeared, to give place for the permanent molars. These six molar's are counted from the hindmost one forward. The seventh molar tooth, or the fourth premolar, appears later, in the space between the third premolar and the tusk. This small, apparently supernumerary tooth is sometimes ealled a wolf's tooth, and was once considered as an independent tooth, not belonging to the molars. It is now classed with the molars, to which it undoubtedly belongs. It is a permanent tooth, and is sometimes very small and imperfect, which is aceounted for by the near proximity of the large and strong tusk.

The teeth of the hog may therefore be represented by the following formula : Ineisors, six upper six lower; canines, one upper one lower on each side; wolf teeth, so-called, now determined to be molars, one upper one lower on each side; molars, six upper six lower on each side; in all 44 teeth. 
To Tell the Age of Swine.

Furstenburg, n well known German authority, has given the following sumunry for determining the age of swine:

The animul is born with eight teeth-four corner incisors and four turks.

On the eighth or tenth day appears the second or third temporury molar.

At four weeks old the four nippers nppenr-two in the upper and two in the lower juw.

At the fifth or sixth week the foremost temporary molurs appenr in the upper and lower juw.

At the age of three months the intermediury incisors bave appenred above the gums.

At the sixth month the so-called wolf's teeth will have appeared; and at the sume age appear the third permanent molurs.

At the ninth month the following teeth will have nppeared: namely the permanent corner incisors, the permanent tusks, and also the second permanent molars.

At the twelfth month the permanent nippers will be in view.

With the twelfth and thirteenth months the three temporury molars will hatve been shed, and their permanent substitutes, which, at fifteen montlss of age, will have fully appeared, are now just cutting through the gums.

With the eighteenth month the permanent intermediary incisors and the hindmost permanent molar will have made their appearance; and, with the twenty-first month, they will be fully developed.

\section{Importance of Swine to Man.}

Next to eattle, swine are the most important to man as an article of food. In the adaptability of pork for successfully standing long voyages, either barreled or smoked, in the value of lard for various culinnry, lubricuting and burning purposes, its place could not ensily be supplied now.

As showing the importance of swine breeding in the United States, the following table is given, extending from 1871 to 1878 inclusive :

$$
\begin{array}{ll}
1871-29,457,500, & 1875-28,062,200, \\
1872-31,796,300, & 1876-25,726,800, \\
1873-32,682,050, & 1877-28,077,100, \\
1874-39,860,900, & 1878-32,362,500 .
\end{array}
$$

In the year 1878 the three greatest hog producing States were Iowa, 
Ohio and Illinois; of these Iowa contuined 2,244,800; Ohio, 2,341,411; and Illinois, $3,355,500$ hogs. In 1878 thece were packed in Chicngo alone over 5,000,000 swine, or one-sixth the whole number raised in the United States.

\section{Improved Breeds of Swine.}

To the India hog, the Clinese and the Neapolitan is due more than to any other, the improvement in Engli $h$ breeds, and from those introduced into the United States are due our own Ameriean breeds, that have now become unexcelled in any qunrter of the globe for the purpose for which they are intencled; early maturity, intitude to fatten at any age, and ultimate weight of the mature animal. Of these the Chinese hog has given great fattening propensities.

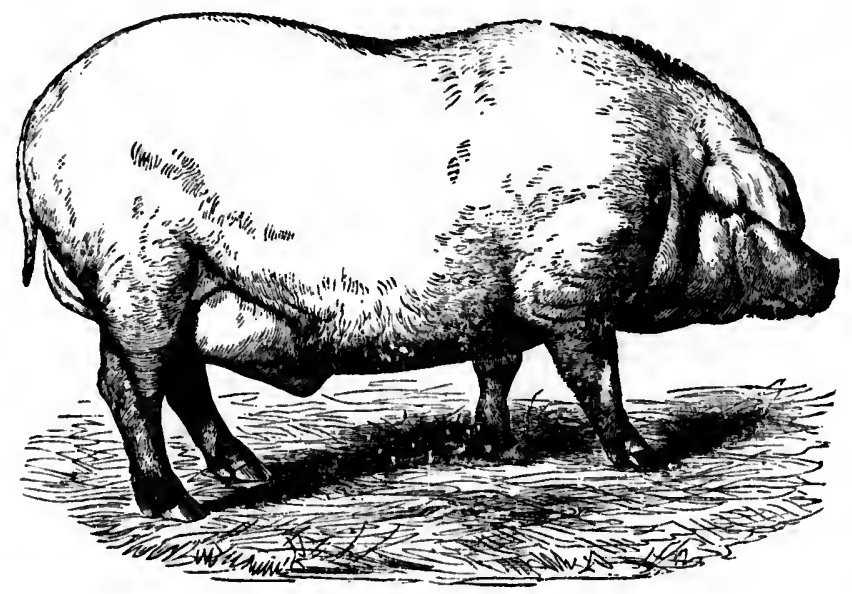

OLD CIIINA BOAR.

The illustration we give will show first, the appearance of the hoar as known yeurs ago, and on the next page the sow. This breed has liad a very marked influence as one of the bases of the Poland-China breed of the present day, and is said to have been introduced in the West, in Ohio, in 1816 .

Civilization in China antedates that of all other nations. Hence it is quite probahle that the systematic breeding of swine amoug that people antedates that of other arcient nations. This again is proved by the prepotency of the blood of this hog. It has formed the basis of im- 
341,411

in Chicago sed in the

ore than to introduced it have now se for which my age, and iese hog has

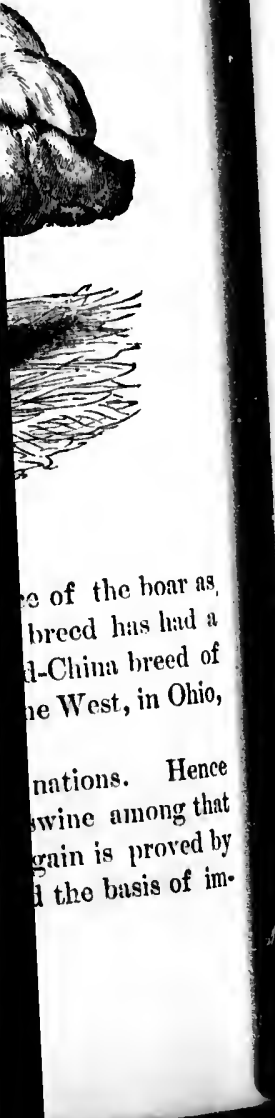

provement in all our modern breeds, both in England and Ameriea. In England its prepoteney has been strongly felt in all the breeds and has transferred the long-legged, coarse-boned, elephant-eared, and big-headed swine of Old England into the deep-b- tied, broad-neeked, short-nosed, compact, and early-maturing Berkshirc Essex, Suffolk, Small Yorkshire and other representative breeds, which bave been further improved by the

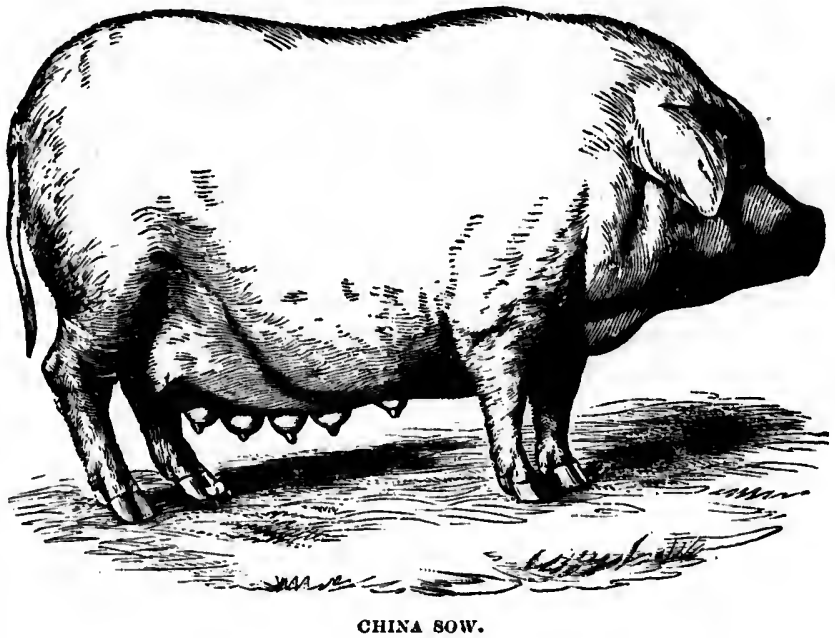

infusion of Neapolitan blood, reducing the hair, hide and bone until now but little more is to be desired. And in our own country it has given us the Poland-China, Chester whites, improved Cheshires and New Jersey reds, - breeds which may compete most favorably with any others in the United States.

\section{English Breeds-The Berkshires.}

This now magnificent breed has been bred in Berkshire, England and in adjacent eountries from a very early day. Their origin is thus reported: The family of hogs in Berkslire. Fngland, which was the foundation of the present improved breed, was of a snndy or buff color, about equally spotted with black; was of a large size, a slow feeder, and did not fully mature till two and a half or three years old. But as such it was very highly esteemed for the proportion of lean to fat in its meat, and for the superior weight of its hams and shoulders, thus rendering the whole carcass peculiarly fitted for smoking, for which purpose it was said to 
excel all other English breeds. The improvement is reported to have commenced sometime during the last century, through the importation and erossing on the females of a Siamese boar. This breed was, in color from a jet black to a dirk slate, or rich plum color; of medium size, quick to mature; very fine in all points, with short, small legs and head; thin jowls ; a dished face ; slender, erect eurs ; broad, deep, compact body, well ribbed up ; extra heavy hans and shoulders ; a slender tail ; thin skin, and firm, elastic flesh.

\section{Establishing the Improved Berkshire.}

After using the Siamese boar in Berkshire to the old style of females as long as it was considered best, he was discarded, and the cross pigs then bred together. In 1838 as we and others bred this swine in Illinois, they were in color a deep, rich plum, with a slight flecking on the body, of white, or buff, or a mixture of the two ; having a small blaze in the face; two to four white feet, and more or less white hair on the tiil. The plum color was preferred to the black or slate, because it calried rather higher style and higher points with it, and a superior quality of flesh, softer hair, and finer skin. Since that time the Berkshires hare been inuch improved in style and compactness, but probably not in excellent meat points. In lean meat in the bacon pieces, and in superior hams and shoulders, they excel all other breeds. It must be acknowledged, however, they were always somewhat harder feeders than the best of the very fat bieeds.

\section{Standard Characteristics of Berkshires.}

The following may be accepted as a standard of characteristics and marks: Color black, white on feet, face, tip of tail, and occusional splash of white on the arm. While a small spot of white on some other part of the body does not argue an impurity of blood, yet it is to be discouraged, to the end that uniformity of color may be attained by breeders. White upon the ear, or a bronze or copper spot on some part of the body argues no impurity, but rather a reappearing of original colors, by reversion. Markings of white other than those named above, are suspicious, and a pig so marked should be rejected. Face short, fine and well dislıed; broad between the eyes; ears generally nlmost erect, sometimes inclined forward with advancing age, always small, thin, soft and showing veins; jowl full; neck short and thick; shoulder short from neck but moderately deep from back down; back broad and straight, or very little arched; ribs long and well sprung, giving rotundity 
orted to have ce importation d was, in color' medium size, legs and head; compact body, tail ; thin skin,

style of females the cross pigs swine in Illinois, ing on the body, mall blaze in the hair on the tuil. cenuse it carried uperior quality of - Berkshires hare ably not in excel1 in superior lams be acknowledged, an the best of the

.

characteristics and il, and ocensional hite on some other $d$, yet it is to be ay be attained by spot on some part caring of original hose named above, cted. Face short, $s$ generally almost ge, always small, di thick; slioulder n; back broad and $\mathrm{g}$, giving rotundity

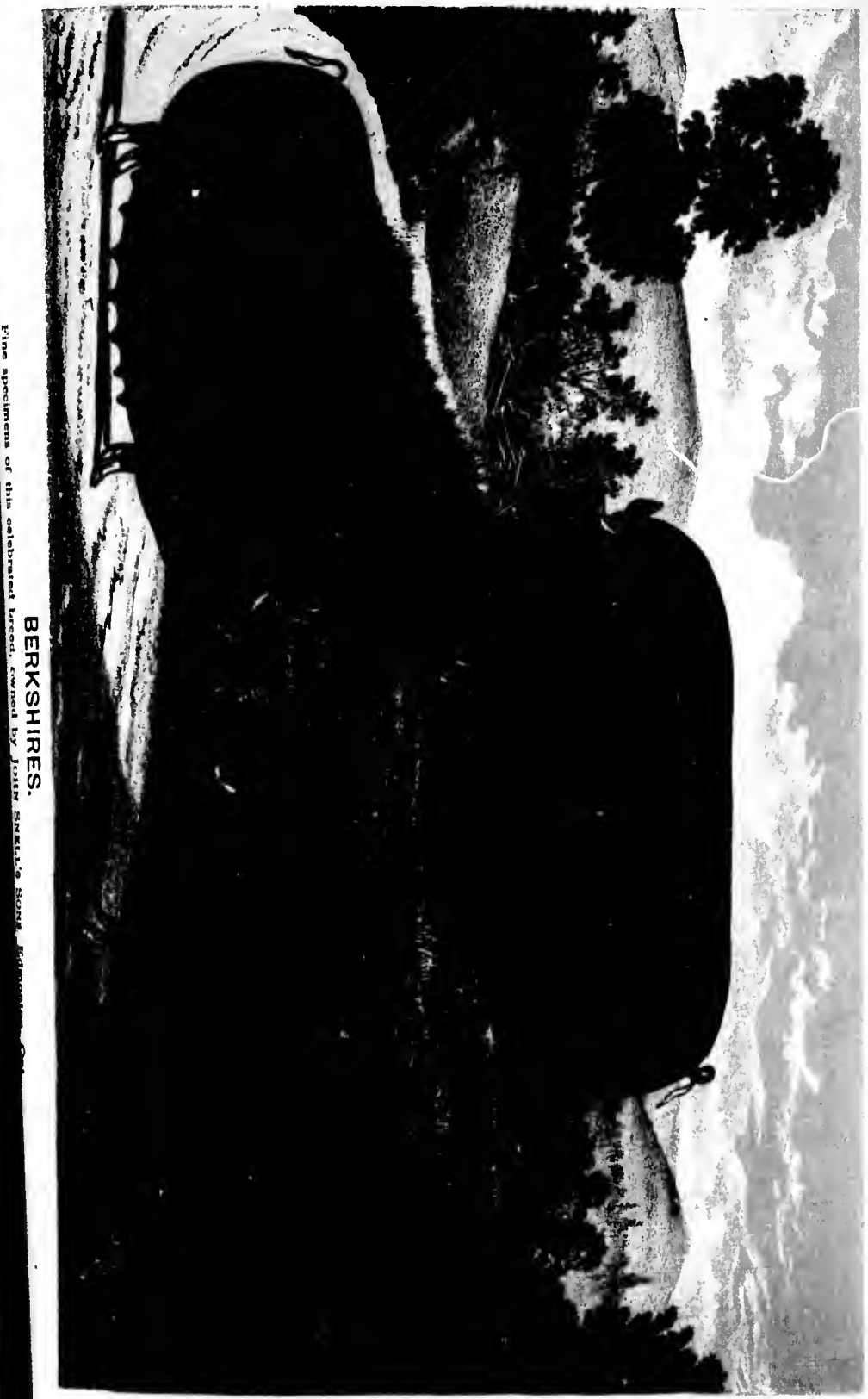


of 1

hips

deep

and

strong, wit

medium, si

rery light ; 
of body ; short ribs of good length, giving breadth and levelness of lom ; hips good length from joint of hips to rump; hams thick, round and deep, holding their thickness well back und down to the hocks; tuil fine and small, set on ligh up; legs short and fine, but struight and very

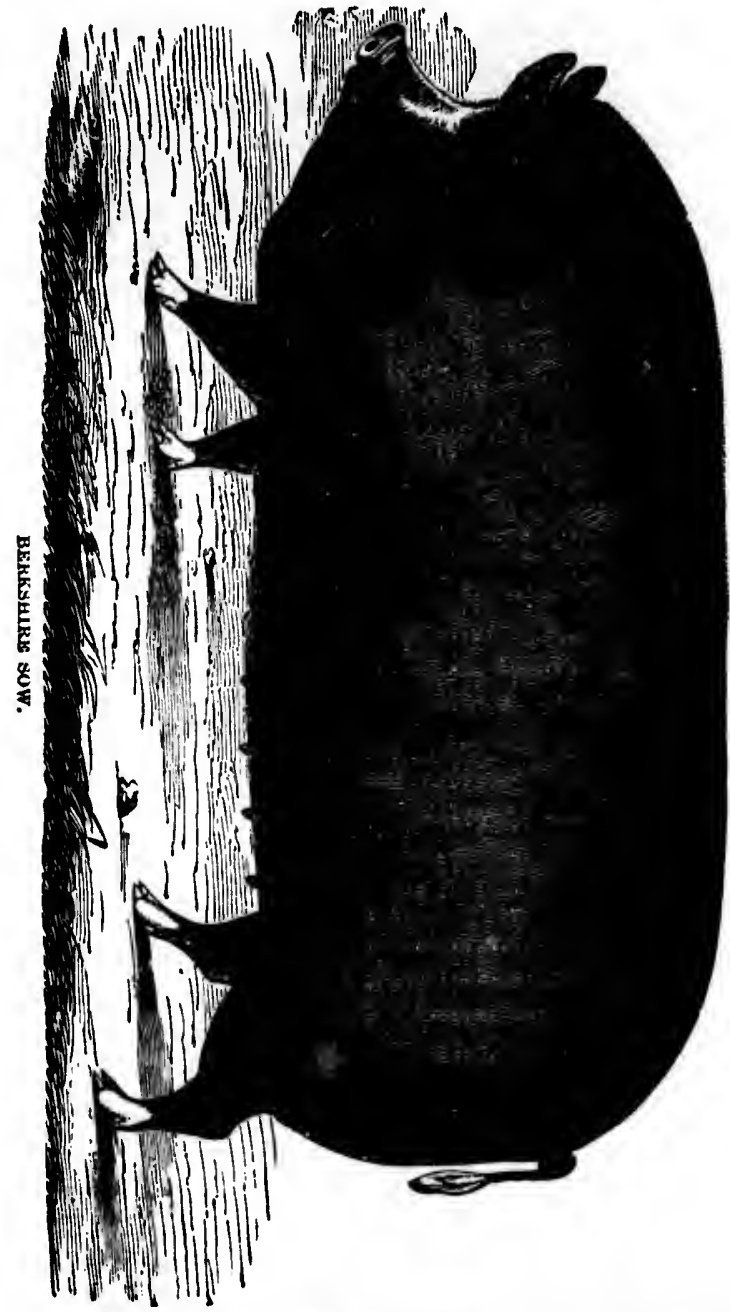

strong, with hoofs ereet and legs set wide apart; size medium; length medium, since extremes are to be avoided; bone fine and compact; offal very light; hair fine and soft; no bristles; skin pliable. 


\section{Neapolitan Hogs.}

Sidney, in writing of the Neupolitun pig, says: "The Neapolitan pig is black, or rather brown, without bristles, consequently delicate when first introduced into our northern climate. The flesh is of fine grain, and the fat is said to be free from the rankness of the courser tribes." Referring to the supposed descent of the breed from the wild boar of Europe, he adds: "It is more probable that the Neapolitans are the descendants of the dark Eastern swine imported by early Italian voyager's and cultivated to perfection by the favorable climate and welcome food." Nexpolitan pigs have been for many "years frequently taken to England. Martin credits the great improvement in English swine, which has taken place within thirty years, ehiefly to the agency of the Netupolitan and Chinese breeds, conjointly, or to either alone. He names especially the Essex, Hampshire, Berkshire and Yorkshire, and to these Youatt adds the Wiltshire, and enforces Martin's statement as to the Berkshire and Essex. Their earliest introduction into the United States was in 1840-41. They seem, however, not to have been well bred specimens. About 1850 a Mr. Chamberlain of Red Hook, New York, made an inportation direct frem sorrento. They were all of a dark slate color, and their pigs were itiet themselves and none with whit', ash or diab color on them. The $\cdots$ ing may be accepted as a perfect description of this breed and their points :

Head small ; forehead bony and flat ; tace slightly dishing; snout rather long and very slender ; ears small, thin, standing forward nearly horizontally, and quite lively; jowls very full; neck short, broad and heavy above; trunk long, cylindrical and well ribbed baek; back flut, and rihs arching, even in low flesh ; belly horizontal on the lower line; hind-quarters higher than the fore, but not very much so; legs very fine, the bones and joints being smaller than those of any other breed; hans and shoulders well developed and menty; tail fine, curled, flat at the extremity, and fringed with hair on each side; generul color slaty, or bluisl plum color, with a cast of coppery red; skin soft and fine, nearly free from hair, which, when found upon the sides of the head and behind the forelegs, is black and soft, and rather long ; flesh firm and elastic to the touch

\section{The Essex Breed.}

It is well known that the Neapolitan was a prime integer in the improve. ment of the Essex breed of swine. In comparing specimens of the tro breeds one can see plainly the eross of a broad, deep, gross feeder with an animul of great delicacy and refinement-the cross proving, when 
tablished, to combine those qualities which ure of greatest value in the parent breeds, and being capable of imparting them to crosses with hreeds less finely organized.

itan pig is when first II, and the Referring Europe, he endints of cultivated Neapolitan d. Martin tilken place and Chinese the Essex, itt adds the e and Essex. 0-41. They bout 1850 a tation direct eir pigs were them. The is breed and ; snout rather early horizouid and heavy flat, and ribs $e$; hind-quarine, the bones ms and shoulthe extremity, 1. bluisl: plum rly free from hind the forec to the touch

in the improve. ens of the trio ss feeder with bing, when es

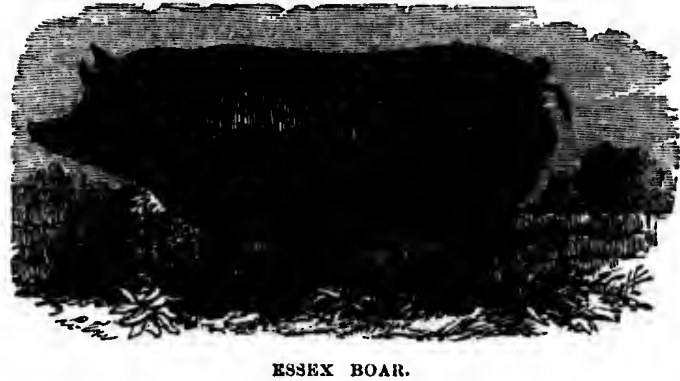

The Essex originated in the south of Englind and are entirely black. They are small to medium in size, and are extensively used in England as crosses on the large cuarse swine, with a view to improving their fattening qualities. The best specimens may be kuown by being black in color; face short and dishing; ears smill and soft, standing erect while young, coming down somowhat with age ; carcass long, broad, straight and deep ; hams heavy, and woll let down; bone fine, and careass when fattened, muinly composed of lard; hair generally rather thin ; fattening qualities superior. The black color of the Essex, as is the case with all the improved black swine, is only confined to the epidermis or scarf skin; when dressed the skin is beautifully white and clean. The out we have given of the Essex boar, will very well represent the Neapolitan witl the exception that the Essex is a comparatively well haired breed.

\section{The Yorkshire Hog.}

The Yorkshires are among the best of the pure bred swine of England, and have stamped their impress upon nearly all the modern white breeds. Their good qualities are: They are of a size, shape and flesh that are desirable for the family or the packer's use. They are hardy and vigorous in constitution, have a good coat of hair, protecting the skin so well either in extreme cold or heat that it rarely chills or blisters. They are very prolific and good mothers; the young do not vary in color, and so little in shape that their form when matured may be determined in advance by an inspection of the sire and dam.

The Yorkshire, medium or middle breed, says Mr. Sydney, is a modern 
invention of Yorkshire pig breeders, and perhaps the most uscful and popular of the shite breeds, as it unites, in a striking degree, the good qualities of the large and small. It has been produced by a cross of the large and the small York and Cumberland, which is larger than the small York. Like the large whites, they often have a few pale blue spots on the skin, the hair on these spots being white. All white breeds have these spots more or less, and they often increase in number as the animul grows older.

It was not until 1851 that the merits of this breed were fully reengnized, when at a meeting of the Keighley Agricultural Society, the judges having called the attention of the stewards to the fact that several superior sows, which were evidently closely allied to the small breed, had been exhibited in the large breed class, the aspiring intruders were, by official authority, withdrawn.

The uniddle Yorkshire breed are about the same size as the Berkshire breed, but have smaller heads, and are much lighter in the bone. They are better feeders than the small whites, but not so good as the large whites; in fact, they occury a position in every respect between these two breeds.

The Cumberland, a middle breed Yorkshire, are not distributed throughout the West, but when thoroughbred specimens have been introduced they are held in great esteem, as well for an animal for exhilition purposes as for family use. They are especial favorites with packers who buy their stock on foot for the reason that they yield liurger proportionate net weights than any other hogs which grow lange enough for their use. They are sinall in bone but large in flesh, of the very best quality, evenly and proportionately distributed over the whole frame.

\section{The Suffolks.}

The Suffolks owe nearly all their good qualities probably to the infusion of Yorkshire blood.

Mr. Sidney says that Yorkshire stands in the first rank as a pig feeding county, possessing the largest white breeds in England, as well as excellent medium and small breeds, all white, the latter of which, trausplanted into the south has figured and won prizes under the name of divers noblemen ald gentlemen, and under the name of more than one county. The Yorkshires are closely allied to the Cumberland breeds, and have been so much intermixed, that, with the exception of the very largest breeds it is difficult to determine precisely where the Cumberland begins and the Yorkshire ends. The Manchester boar, the inıproved Suffolk, the improved Middlesex, the Caleshill and the Prince Alberts or Windsors were

all

pur

kep

foul

are

bree

publ

whic

wort

the I

Suffo

name

Wc

small,

and $v$

rery :

should

out; b

ruther

full.

betwee

ham.

down at

full all

stimdins

bolle fil

tapering

color';

white,

medium.

There

rity, nam white.

This b

The short

enrs; sma

back and

white, alt

spots in th 
all formed on Yorkshire-Cumberland stock, and some of them are nearly pure Yorkshires, transplanted and re-cliristened Spenking of the pigs kept in the dairy district of Cheshire, he says that white pigs have not found favor with the dairymen of Cheshlre, and the white ones most used are the Mauchester boars, another name for the Yorkshire-Cumberland breed. All the writers who have followed him down to the latest work published on the subject, occupy space in describing various county pigs which huve long ceased to possess, if they ever did possess any merit worthy of the attention of the breeder. Thus the Norfolk, the Suffolk, the Bedford and the Cheshire have each separate notice, of which the Suffolk alone is worthy of cultivation, and the Suffolk is only another nume for a sniall Yorkshire pig.

We subuit also a brief description of the Suffolk's " points :" Head small, very short; cheeks prominent and full; face dished; snout small and very short; jowl fine; ears small, thin, upright, soft and silky ; neck rery short and thick, the liead appearing almost us if set on front of shoulder's; no arching of crest; erest wide and decp; ellows standing out; brisket wide, but not deep; shoulders und crop-shoulders thick, rather upright, rounding outward from top to elbows; crops wide and full. Sides and flanks - ribs well urehed out from back, good length between shoulder and ham ; flink well filled out and coming well down at han. Back broad, level and straiglit fiour erest to tail, not falling off or down at tail ; hams wide and fill, well rounded out ; twist very wide and full all the way down. Legs and feet-legs small and very short, standing wide apart, in sows just keeping the belly from the ground; bone fine; feet small, hoofs rather spreading; tail small, long and tapering. Skin, hair and color-skin thin, of a pinkish shade, free from molur; hair fine und silky, not too thick; color of hair pale yellowish white, perfectly free from any spots or other color. Size small to medium.

\section{Lancashire Hogs.}

There are three breeds in Lancashire, England, that have attained celebvity, namely, the short-face, the middle breed, and the large Lancushire white. On next page we give an illustration of the short-faced breed.

This breed of swine may be known by the following characteristics: The shortness of the face from the eyes to the end of the snout; prick ars; small bones; a good coat of whito hair; cubic in form, with broad back and broad hams, well let down. The skin, as well' as the liair, is white, although an occisional one may be found with a fèv dark blue wots in the skin, but never dark or black hairs. The smulk:bjeedihogs 
must have small bones; a short face; silky hair ; fine, small, upright ears; a comparatively square form; must have good square hams, the most valuable part of the hog; must carry the meat near the ground; flat on the back ; straight and cubic in form.

VIII. Iancashire Middle Breod.

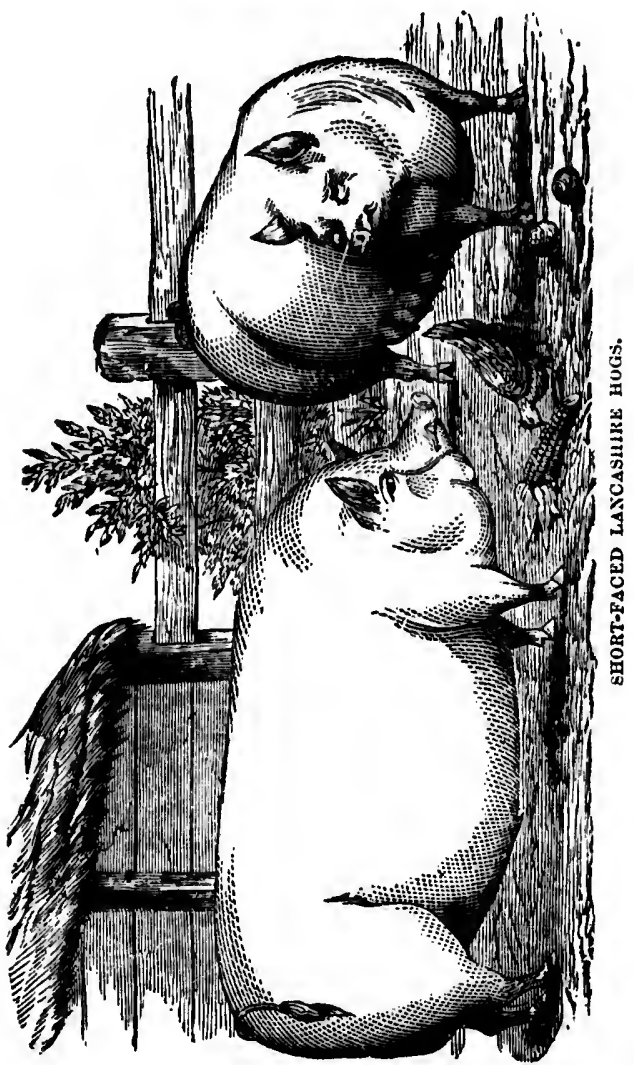

This breed is one which partakes of the quality of the small breed and the size of the large breed. Middle bred hogs are got by crossing large bred sows with small bred boars, but all attempts to attain the same results by reversing the operation, and putting large bred boars to small bred sows, have proved failures. The largest of the middle bred sows are used 
to improve the large breed. A niddle bred hog must have a short face, and all other good qualities of the small breed, except that they may be longer in proportion to their width; must have thicker legs and longer bones to earry the grenter size; should be well haired (fattening to full form often causes the hair to fall off, which must be allowed for.) $\Lambda \mathrm{s}$ gocd a short rule as can be adopted to judge them by is as follows: The best iniddle bred hog should have the greutest possible share of all the qualities of the small breed, with the length, and, in a measure, the lurger bones of the lurge breed.

\section{Large Laneashire.}

This variety of swine have large bones, of great height and length, and are the largest breed of swine known. They ure a true breed, their qualities have descended from generation to generation - tho quality being improved by judicious selection. They must be of large size; grent length ; flat back, with large square hams, and when fattened, must carry their width of back along over the hams; must have deep and tolerably straight sides ; large feet and leg bones ; hair short ; may lave a long face, but it had better be short, as they fatten better ; may have a large, drooping ear, but other quality and size being equal, an upright, smaller ear is preferred. They usually have a long, thick, strong tail. They must be of great weight when fattened.

\section{American Breeds.}

Sagacious breeders in the United States nearly fifty years ago, saw the necessity of establishing breeds of swine that should be eminently adapted to the especial requirements where Indian corn and grass must necessarily form the principal food of the swine from weaning time until slaughtered. Then and until the last twenty years, mere fat was the important product in swine, as it was in a degree in cattle. Since that time the universal introduction of petroleum has reduced the value of lard and tallow to a minimum. Improvemenits in the art of preserving food fresh has made barreled pork, a less necessary product evell for long voyages, and the attention of the breeders was again turned to the production of as much lean meat in their hogs as possible. This naturally led to a reduction in the weight of the hog, or at least, if the animal should be capable of reaching a heavy weight at maturity, it must also possess the important quality of fattening at any age. This has now been fairly met in the best English and Amerienn breeds. If we were asked to choose the breeds from each which would produce the most lean meat for the carcass, we should say the Berkshire of English breeds, and the Poland of American breeds, 
X. Poland Chinn.

Over the history and characteristies of this breed there has been much

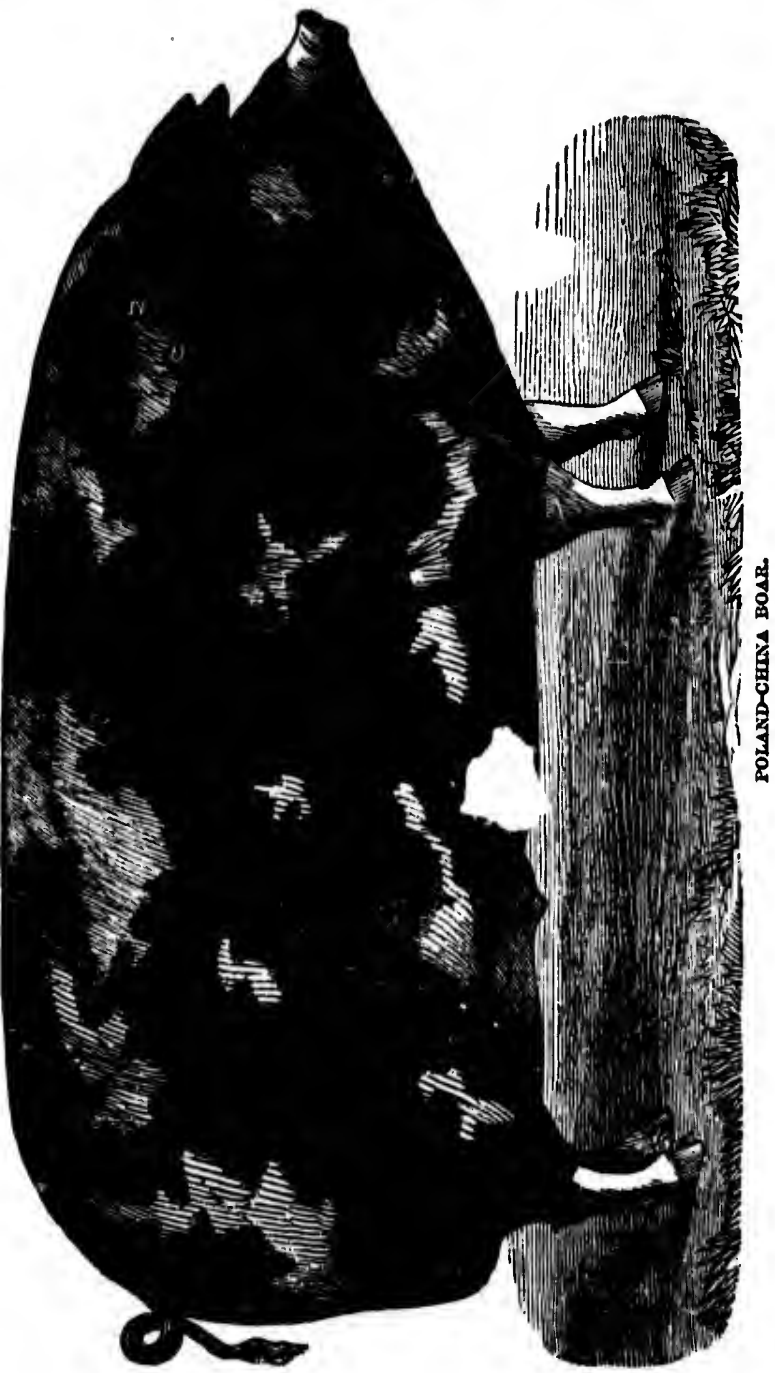

controversy. Individual breeders have sought to take undue credit to themselves in the estnblishment of the breed, and have sought undue 
prominenec by attaching their own names to the swine of their breeding. The facts ure, the numo Polund-Chimn is a mismomer so fur ns Polnud is concerned, for there is not $n$ particlo of evidence that a distinctly I'olish breed of hogs over guve minfusion of blood. 'Tho nearest evidenceand this truditionury - to this effect, is, that long agio a sow was hought of a Polander, which, proving an excellent breeler, it went by tho nismo of the Polumder sow. The breel is now largely indebted to the Chimus and Berkshires for their good qualities. Althongh they certniuly have an infusion of so-ealled Irish grizier in them. Why this breed should have been called gruzier, one can only surmise. They certainly were anything but grass eaters, but the name made them popular for a tine in the then far West where grain at that time was soarce. The fucts nre, the Chinese hogs, imported into Obio in 1816, and bred upon tho best native stock of the country are the bisis of the breed. In 1835 the Berkshire was introdueed, and in 1839 or 1840 the Irisl grazier. These were extensively used by the best breeders, on the best descendants of the Chinit crosses. Since 1842, there is good evidence to show that new hood has not been introduced, but by enreful selection, und judicious breeding, in Ohio and the West, or, by oceasional judicious infusion of Berkshire blood, they now leave little to be desired, as a heavy, well meated breed, that will fatten kindly at any age.

\section{Charaoteristics of Poland-China.}

The best specimens have good length, short legs, broad, straight baclss, deep sides, flanking well down on the leg, very loroad, full, square ham and shoulders, drooping ears, short heark, wide between the eyos, of spotted or durk color, are hardy, vigorous and prolific, and when fit are models, combining the excellences of both large and swall breels.

\section{Choster Whites.}

The Chester Whites originated in Chester county, Pennsylvania, about 1818 , through the importation of a pair of fine pigs from Bedfordshire, England, by Captain James Jeffries. These were inter-bred with the best stock then existing in that comity, and by careful selections a pelmanent strain of large, easily fattened, quiet hogs were prodnced, which continued to loreed with great uniformity. Something like thirty years ago some attempts were made to cross the Suffolk and Berkshire upon them, but it was discontinued as not heing considered an improvement, and the best specimens to-dily should be pure white, with no black about them whatever.

undue credit to sought undue 
In the West this breod became very popular some years ago, and still is an many parts of the Northwest. Farther south, however, in the true corn zone, pure white hogs of any breed are not favored. They are thought not to stand out-door usage so well as black or nearly black swine. Where great weights are required tho Chesters will always be liked.

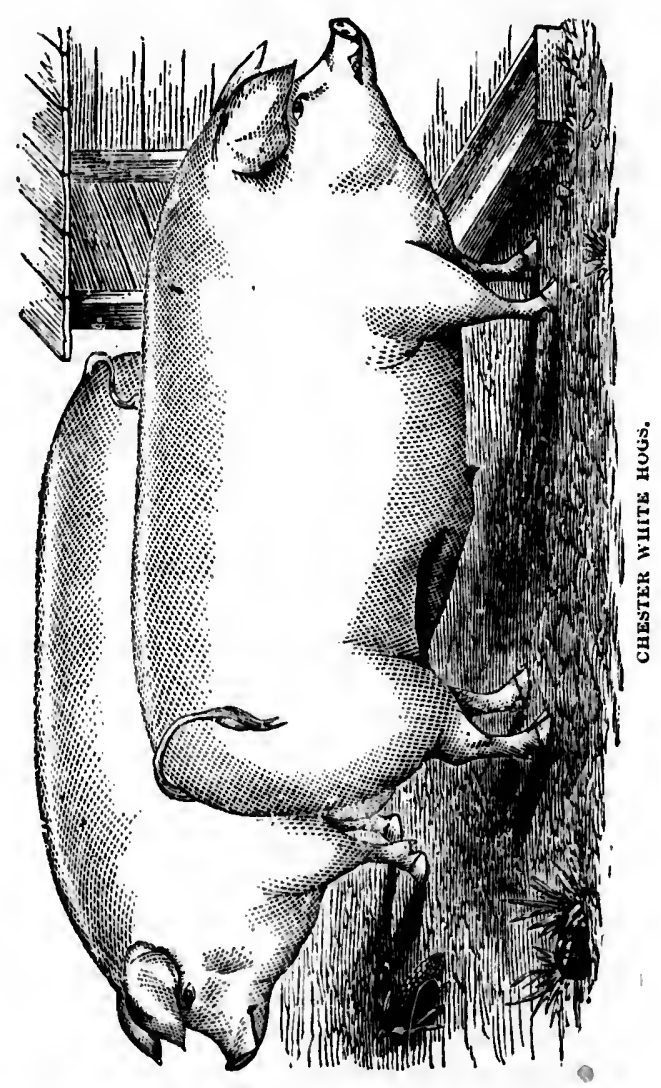

The following may be given as the charncteristics of these hogs : Head short and broad between the eyes; ears thin, projecting forward and lopping at the point; neck short and thick; jowl large; body lengthy and deep; back broad; hams full and deep; legs short and well set under the hody ; coat thin, white and struight; (if a little wavy it is no objection). The tail should be small aud with no hristles. 


\section{Jersey Reds.}

This large and rather coarse breed of hogs have been somewhat disseminated in the West. They are certainly a hardy breed, and well adapted to new countries where there is good range und mast. Their history seems to be as follows:

The positive origin of this fanily of swine is unknown. They have heen bred in portions of the State of New Jersey for upwards of fifty years, and with many furners are considered to be a most valuable family. They are of large size and capable of making heavy growth, 500 and 600 pounds' weight being common. They are now extensively bred in the middle and southern portions of New Jersey. In some neighborhoods they are bred quite uniform, being of dark red color; while in other sections they are more sandy and often patehed with white. They are probably descended from the old importations of Berkshires, as there is no record of the Tamworth, the red hog of England, ever having been brought into this country, nor is this likely, as the 'Tamworth was not considered a valuable breed, and was confined to a limited area. The Reds resemble the old Berkshires in muny respects, but are now much coarser than the improved swine of this breed.

A good specimen of Jersey Red should be red in color, with a snout of moderate length, large top ears, small head in proportion to the sizo and length of the hody, standing high and rungy on their legs; bone coarso, having tail and brush and hair coarse, inclining to bristles on the back.

\section{Cheshires.}

This is a comparatively modern breed, if indeed it is yet fully enough established to he ealled a breed. It has been somewhat disseminated in various parts of the United States, and for villagers and small farmers, possesses about all the good qualities of the Suffolk, without some of their disabilities. They are said to have originated in Jefferson county, New York, from a pair of pigs sent from Albany under the name of Cheshire. It was probably a pet name for an exceptionally good pair of pigs. Sisco then they have been erossed with Yorkshires and other pure white hreeds, until of late years by selection thry have becomo uniform in their make up.

The so-ealled Cheshires are pure white in color, with little hair. They are not uniform in this respect, as pigs in the same litter differ widely in the amount of hair. The snout is often long, but very slender and fine. The jowls are plump, and the ear ereet, fine and thin. The shoulders are wille and the hams full. The flesh of these hogs is fine-grained, and 
they are commended on account of the extra amount of mess pork in proportion to the amount of offal. The tails of the pigs frequently drop off when young.

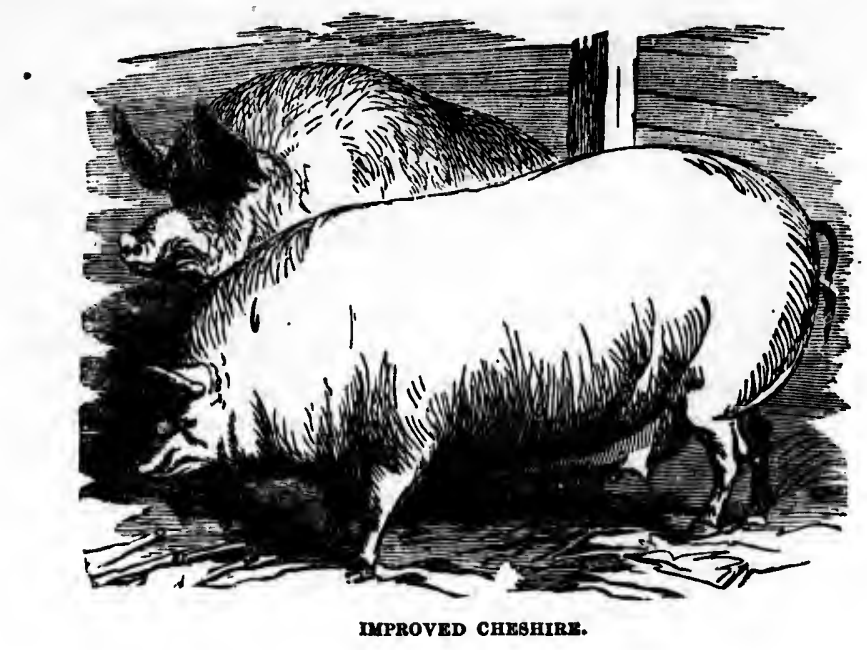

Rocapitulation of Breode.

The principal English breeds are as they were known twenty years ago, the Berkshire, the Essex and the Yorkshire. The Berkshire is a medium breed weighing at full maturity up to 500 pounds. There are large and small Berkshire, but the medium family is the most valuable. They are now bred entirely black except a dush of white in the face and white feet.

The Essex is all black, or rather a blue black, and will weigh up to 450 pounds at maturity. They are one of the most stylish of the sinall English breeds, as they are the largest of the small breeds, and to our mind the best of the small breeds for the West-quite good feeders, handsome and making good pork.

The Yorkshircs are divided into three classes, small Yorkshires, medium Yorkshires, and large Yorkshires. The so called Prince Albert Suffolks are small Yorkshires, and the best of the small white breeds. All the Yorkshires have occasional dark spots on the skin. The hair, however, is white, and these dark spots are not indications of impurity of blood but rather the reverse.

The American breeds, in the best repute, are first, the Poland-China, 
sometimes called, in Ohio, Magie. Twenty years ago they were coarse black and white hogs, with occasional sandy markings. Of late years they have been, through eareful breeding and selection, refined, and are now bred in the West, nearly black, the white, in the most approved strains, being distributed pretty equally over the head and body in flecks and irregular patches. They are tho most widely distributed of any American breed in the West, and fully deserve all that is claimed for them, as large, quiet, early matureri, and kindly feeding hogs.

The Jefferson county, New York, so called Cheshires, are, as before stated, but modified Yorkshires, but in every respect stylish hogs, feeding well and making good pork, and are well adapted for small farms and for feeding in pens. The so called Hospital breed, or Morgan county hog of Illinois, which some years ago gained considerable repute, are undoubtedly, modified Yorkshires, and in no respeet superior to that well knewn breed. They were produced by crossing the Suffolk on the best white hogs of that county. Within the lust five years they have ceased to attract attention. 


\title{
CHAPTER II.
}

\author{
BREEDING AND MANAGEMENT.
}

\begin{abstract}
IMPORTANCE OF SWINE. — A BACK WOODS HOG. — FIXING AND gOLDING THE CHARACTERISTICS, - SELECTION ALWATS IMPORTANT. - BREEDING AGE OF SWINE. C CARE OF BRGEUING SOWS. - WEANING: - MANAGEMENT OF SWINE.- ABSOLUTE CLEANLINESS NECESSARY.—-SUMMARY.
\end{abstract}

\section{Importance of 8wine.}

The breeding and management of swine constitutes one of the most important agricultural interests in the West, and should do so in the South. To be successful none but the best breeds should be allowed on the firm. The fecundity of swine leaves no excuse for holding on to land pikes and the descendants of semi-wild breeds that must be run down by $\operatorname{dog}$ and rifle, in order, when they are killed to get a small quantity of inferior meat. A boar of any of the improved breeds will be sufficient for six or eight sows, and tho increase is so astonishing when there is no epidemic disease, that it would from a single pair take but three years to stock the largest farm. "It should be unnecessary to pursee this matter further. There is no class of farm stock that pays better, a between indifferent and good breeds, than hogs, and the wonder is that it some sections of the country farmers still cling to a breed of grunter that will always greet you with a snort and a boh-o-o, and which $\mathrm{n}$ feeding can fill-in fact animals like those shown on the following pagefully a match for the average dog, always hungry, ready to eat anythin that falls in their way, even to half grown children occasionally, bit which when wanted for meat are nowhere within shooting distance.

The hog lard, bac dacreasing nothing $n$ stid upon by starvin raising, it and labor

In breed degenerat ronder wl not soon s reason is, will be pla been sairl in this point. 
The very first requisite, however, in keeping any improved breeds, or in fact any $\mathrm{l}$ ed from which money is to be made, is the best of fceding; and that daily, from the time they are born until they are slaughtered.

IOLDING THE EDING AGE OF NAGEMENT of

of the most do so in the be allowed on bolding on to must be run bet a small ed breeds rill onishing when pair take but sary to pursue pays better, at nder is that it d of grunter and which $\mathrm{n}$ lowing pageo eat anythin casionally, bo distance.

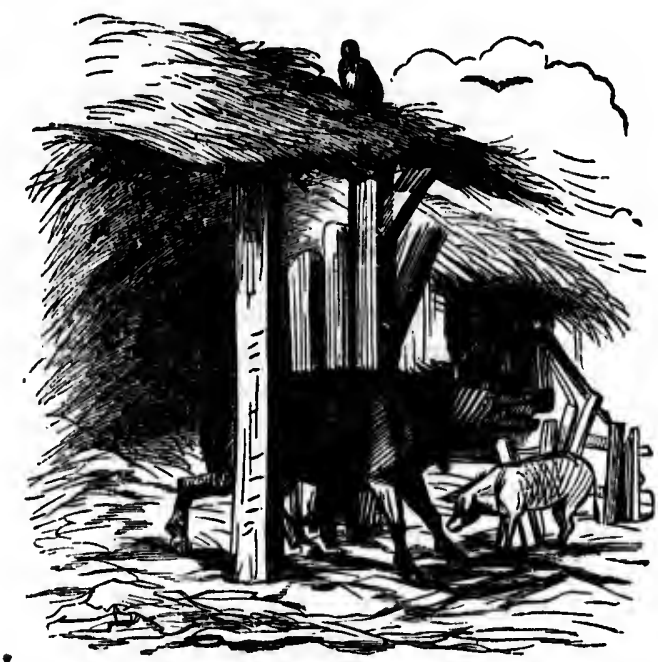

A BACK WOODS HOG.

The hog is simply a machine for making what is to be converted into lard, bacon, salt pork and hams. The average daily gain is a gradually dacreasing quintity from month to month, until after a certain time nothing more can be gained in weight. This ought to be sufficient to be said upon this point. You can neither breed, nor keep a breed profitably by starving or allowing them to shift for themselves. As elsewhere, so in stoekraising, it holds true that what costs little to acquire, brings little at sale. Care and labor to secure the best will always pay the most.

\section{Fixing and Holding the Characteristics.}

Iil breeding swine, however good or perfect the breed, they will surely degenerate unless the greatest care in sclection is pursued. Many persons ronder why it is that from the prolific nature of swine, the country is not soon stocked with none but the most superior animals. The simple reason is, the want of accurate judgment and cure in selection; the error rill be plainly seen by noting what we say farther on. Indeed, what has been said in previous pages on this general topic will apply equally well at this point. Care in selection and breeding is fundamental to success. 
In animals usually having but one young at a time, the progeny pretty uniformly partake of the nature of both parents, and are bred with tolcrably uniform results. In animals producing a number of young at a time, the progeny will be found to vary very considerably in the sane litter. Thus the selection of those specimens that partake of uniform and churacteristic excellence becomes of the first importance, since unwise selections will result in carrying the breeder farther and further from the excellent points to be perpetuated. Agnin, heredity, that is throwing back to an original type, or rather in the sense in which we use it, inleriting certain fixables, as constitutional vigor, inclination to fat, ete., is shown far more clearly in animals having many young ut a time, than those having only one young. The progeny will not only vary more in particular animals, but certain characteristics will reappear by reversion after a greater number of generations, in aninals having many young at a time, and to a greater do thee than in those usually having but one. At least such is our experience. Hence, as we have stated, absolute necessity of the strictest eare, is not only necessary in breeding, but in the selection of animals for future breeding.

In domestic animals it is a matter of common observation that the temper and other peculiarities of individuals are determined by inheritance. Thus, virtually, quietness of disposition, or mildness, tractability or viciousness, courage or timidity, are constantly shown. Now from the general luw that like produces like, and the well determined law that variation is a constant integer in all cross bred animals, and from our own observation that it is often intensified in animals having many young at a litter, the full force, as regards judgment in selection will be apparent; and the fact that the country is not soon filled up with superior breeds of hogs is due mainly to the want of proper care in the sclection of the breeding animals, and also from a lack of accurate knowledge and ability to nicely discriminate by the breeder, in regard to form, constitutional vigor, and excellent points in the young animals selected as breeders. -Absolute accuracy in this respect is in fact possessed by but few individuals in a generation. There must first be a natural tact inherently possessed and digested and matured by years of study and observation.

\section{Breeding Age of swine.}

The sow is capable of breeding at about seven months of age, and the boar is fit for service at the age of one year. As a rule, however, the sow should not be allowed to furrow under the age of fifteen months, and the boar is not fit for continued service until he is eighteen months old.
The sow times iil our best is simply is not ine

The you get chilled good cour first litter ing they w the Summe not catch $\mathbf{t}$ reaned.

good facilit bad better 1 the latitude

Gestation and three da may. A va animals, and time than $m$. for five or si more constan

The sows unine mont? fed only suffic the solrs shou plenty they $\mathrm{c}$ most excellen lood-clover wome kind in fill and Win touse themse 
The sow may, under exceptional circumstances, bo made to breed three times in a year, but two litters are all that should be allowed. Many of oul best breeders do not allow but one litter a year, where the produce is simply required for making pork, and under certain circumstances this is not incompatible with economical management.

\section{A Warm Farrowing Place Necessary.}

The young pig is even more tender than the new-born lamb. If they get chilled before they suck it is difficult to save them. Where there are good conveniences for warming the farrowing pen, sows may have their first litter in March, and if put with the boar the fourth day after farrowing they will generully receive him. This will loring the next litter in the Summer, a very good time for pigs to be wintered. If the sow do not catch the first time she will not eome in heat until the pigs are reaned. Yet this will not throw the next litter later than September. If good facilities are not had for keeping the early litters warm, the farrowing bad better be deferred until May, or at the time of grnss, aecording to the latitude.

\section{Gestation.}

Gestation continues about four months. Three months, three weeks and three days is considered the average time, nud it is not far out of the ray. A variation will sometimes be found of thirty days. Young unimals, and those of feeble constitutions carry their young for a shorter time than mature and strong animals, and sows usually remain prolific tor five or six years, and unless they get overloaded with fat, old sows nre more constant and careful mothers than young ones.

\section{Care of Breeding sows.}

The sows that naturally have a strong tendency to fatten may be bred unine months old, and should be kept breeding pretty steudily, and be fed only sufficient to keep them strong and in fair flesh. During gestation the sows should be kept in good heart but not fat. When potatoes are plenty they cun be substituted boiled, and in comnection witl milk will be most excellent feed. In any event they must have plenty of succulent lood-clover, pig-weed, or other green food in Summer, and roots of me kind in Winter. We have always kept a patch of artichokes for Pall and Winter, when the ground was not frozen for them to root and runse themselves in. The practice of ringing breeding sows to keep 
them from rooting is vicious in the extreme. We have never practiced it at all with any hogs. To remain healthy they must root some. It is their natural instinct. If the pasture be clover, and in the rotation to be followed with other crops, the dumago by rooting will be light in comparison with the health of the swine. Loss at one point will be filly (m)mpensated at the other.

When the sow is near her time her food should be of such a nuture as to keep up her strength and give due sustenance to the young but not stimulating. When the pigs are three or five days old, and danger of inflammation is past, feed liberally, and with rich sloppy food to induce a good flow of milk. But under no circumstances feed so as to make the young pigs unduly fat. Skimmed milk and the mill refuse of wheat, what is known as inill feed, is best, but in the absence of this potatoes, pumpkins and other roots in the Fall, or boiled beets in the Spring, with corn meal enough to keep the sow in good heart, makes admirable food. When there is grass to be had, the sow should be allowed all she will eat. Thus you may get the very best results both in the health and continued usefulness of the sow, and the constitutional growth and vigor of the young pigs.

\section{Weaning.}

The young pig as we have shown is born ready for work. That is, it has teeth that in a short time are competent to grind and prepare food for the stomach. We should weal at six weeks old, allow all the skimmed milk and butter-milk possible to the growing pigs, and with it after the pig is two months old, a fair proportion of ground wheat skimmings, or light rye, barley, ete., ground and made into mush, to be mixed with the milk as a tolerably thin slop. Teach the pig early to eat grass, and at three months old he will take care of himself on good pasture with all the corn he will eat at night. 'By this means the older stock are early freed from cure of the young and become ready for other uses.

At the age of two or three weeks the pigs should be gelded, so they may be well over the difficulty before weaning time. Kieep rings out of the noses of young pigs. They have been the means of spreading colltagious diseases. We prefer slitting the cartilage of the nose, or cutting i notch in it at the time of gelding, if it is absolutely necessary that they do not root. At all events it is time enough to do the ringing the secoad year, if to he kept over. But by proper eare if the litters of pigs come early, any of the better breeds may be turned off the next Christmas, and from this time until the first of February, become fat, and of as heary weight as is profitable in the markets.

rarm beds $i$ them the in bogether, wi is to over lis To have kn heold winte 
cticed it

3. It is

on to be

in com-

(')mpen-

inture as

; but not

d danger

food to

so as to

refuse of

e of this

ets in the art, makes should be lts both in nstitutional

That is, it repare food lll the skimwith it after skimmings, mixed with t grass, and ture with all re early freed ded, so they rings out of reading collor cuttiug " ry that they $\mathrm{g}$ the second of pigs come hristmas, and of as heary
Management of swine.

Hogs are not succeptible to cold when fat. Nature in denying them much hair, has provided them with a thick layer of fat under the skin that acts in the same manner to the skin outside as a covering of hair in other animals. It has also given them the instinct of providing themselves

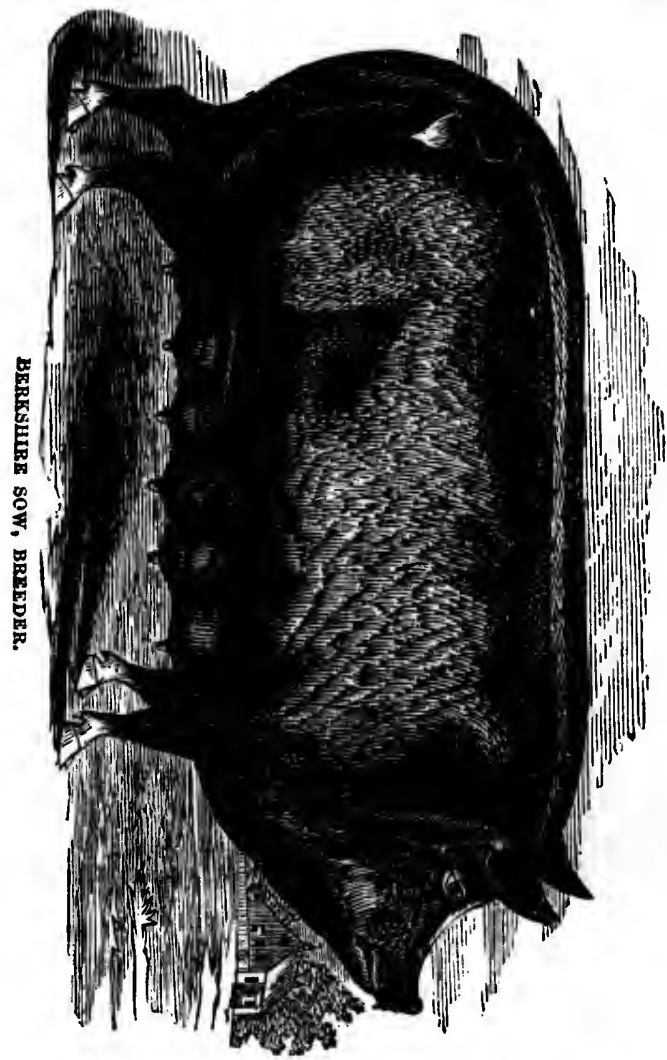

7arm beds in sheltered situations in which to lie, and, in addition, given them the inclination to lie together in considerable numbers; and kept hogether, with insufficient shelter, they will pile together in such numbers w to over lie each other, by which the weaker ones are often smothered. We have known those who considered themselves sensible men, to get up hold winter nights and go to the hog yard and separate the drove, 
when so piled. It is about on a par with the whipping and dogging of cattle about a yurd at night to get up warmth. A nore sensible and eheaper pluh would be to provide comfortablo quurters, where they might lie warm, und separute them into gangs, according to age and strength. Thus with plenty of fat next the skin, and good liberal feeding, very little difficulty will be experienced, in keeping them growing steadily, until of a sufficient age for the slaughter pen.

\section{Absolute Cleanliness Necestary.}

Of all farm animals hogs especially must have plenty of water. It should also be pure. Sivine breeders ean not too soon disiluuse themselves of the idea that swine are dirty, or filthy feeders, or that they naturally incline to wullow in the mud. There are no farm animals uicer in the food they eut than swine if allowed to be. It is true, they are

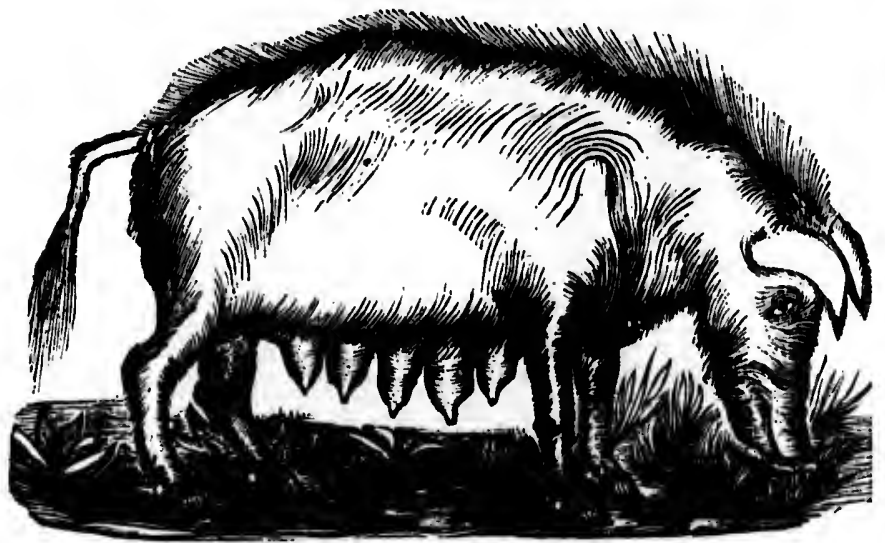

HAZEL-SPLITTER.

omnivorous fecders. So is man. Like man, although they ent fish, flesh, fowl, vegetubles, roots, und grain, they like it fresh. If forced hy hunger they will eat disgusting substances, so again will man. The elephant, the rhinoceros, hippopotamus, und tapir, seek the wuter to clem and coo! themselves in Summer, like all pachydermatous animuls. The wild men like swine will cover themselves with mud to ward off the attacks of biting und stinging insects. In their wild state the nearest tree furnishes to swine the means of rubbing it off when dry, and the rubbing post furnishes them the means of cleaning their sking in a state of domesticity.

If $\mathrm{kep}$ the eles at all, 1

The

underst: forced t mealus it disealse $n$ thit then whose stc kllow hor by the cu sow of $\mathrm{tl}$ $d y$, fir'm and upparar

Hogs, a miter. $\mathrm{No}$ mater withi add tauch t finement, sl shles withir the remedy Oil cake n sseists the berin to ent which the so Bran is no given it is wo an take it w If ordituris: milk and flo dissolved in a in eight hour: sid stomach. Provide a s rals to aecon them project Cistrute pi before weanin 
If kept from the attucks of flies, they will not wallow in the mud but in the cleanest water they can find, and stugnint water they will not drink at all, unless forced to do so, hy dire necessity.

The sagacious breeder and feeder will understands this; they also understund the dingrer of mulignunt disenses attucking their swine when forced to wallow and drink impure water. Henee they strive by every neems in their power that swine ar's kept away from these eatuses of disense and death, and thus such wr uld be alnost entirely exempt, except thit there are always men enough of the shiftless type in a neighborhood whose stock take and spread contagion to their neighbors. We do not know how we ean illustrute more foreibly the two types of breeders thun by the cut given of a sow of an improved breed properly kept, and of a sow of the "hnzel splitting" variety, inproperly kept. The one in a dry, firm pasture, with plenty of pure water, the other on at half marsh, and upparently made to succumb from miasmatic influences.

\section{Summary.}

Hogs, and especially pigs in eonfinement often suffer for want of witer. No mitter how sloppy the food they should always have pure water within reach. If they can have a bathing place in Summer it will add auch to their health, and assist much in fattening. Swine, in confaement, should always have chareoal, bituminous coal, salt and wood shes within reach. They often suffer from ncidity of the stomach and the renedy being near the swine will always use it.

Oil eake mixed with the feed of swine when suekling pigs, $n$ gill a day, asists the milk secretion. It should not be given to pigs. As they begin to eat they should have a trough where they ean go and feed but which the sow cannot get at.

Bran is not valuable for swine. Where highly concentrated food is pirea it is well to have a little dry bran in a separate trough, so the hogss an take it when they want it.

If ordiniry diturhoen attacks pigs give a porridge of sweet skimmed nill and flour. For constipation give two or three drachms of soilp disolved in an ordinary sized tumbler of water, and repeat if necessary in ciglt hours, or give as an injection. It is also " good diuretic and for wid stomich.

Provide a strong scratching post. Bore inch and a half holes at intervals to accommodate hogs of different sizes, and drive in pins letting them project an inch and a half.

Castrite pigs before they aro weaned, say not later than two weeks before weaning time. 


\section{CHAPTER III.}

FEEDING AND BHELTER.

GOOD vs. BAD FOOD. - SUMNER FEEDING. - OTIER sUMAER FOOD, - ROOTs. - THE GHAINS. - FEEDING SUUTII. - XAST. - FELIING IN CONFINE. MLNT. 一IOO BARNS. - A CROSS BAKN. - A SIMPLE PEN.—- SUMMARY, LLGHT VS. IEAVY HOGg.

\section{Good vs. Bad Food.}

Vegetables and grain are the hasis of success in the making of pork whatever the breed mny be. Hogs kept about large stables or distillery yards, where they get only offal, or fed in buteher's yards, on the refuse offal of the slaughter house, nre unfit for human food. They are liable to beeome infested with trichina, and, therefore, no breeder and especiully no feeder should buy unimnls from such loeslities. In fuct there is only ono redeeming feature among the disgusting filth and unstiness in which they are fed-they are generally provided with pure water, and warm shelter.

\section{Bummor Feeding.}

Pasturage is of the first importance. This should be ample. In pasturing swine, but few varieties of $\mathrm{gr}^{n}$ and red, will be the main roline white clover are not natur other members of the pul numily 4I) ed. Clover, botls white it resyion where red and ale alfalfa (lucerne) and Ivell wese may be substituted. Swine take kindly to blue grass, when it is young, and to orchard grass. They do not refuse timothy, but ti nothy has a bulbous root just at the surface of the earth. This swine eat, and thus destroy the grass. Ryc 868 and on grilss a with grt ties als c laca oles ind the the inost as green and ntong pigweed, list of pli the whole

Besides cotte in d: be sown to acre, as ear The swine , fined to giv ent cle:n. either souks in, to bo fol of these fod are the chent is enncerned protit. Heni

Rutabngas rith ('or'n ; 11 Parsijus are Igood Winte isterl. Cabbr chepply kept of Jilluary.

These, after thang swine. 
and oats make good pusturage for bogs. Rye grass and foul mentow grass are ulso well relished. In this respect the feeder should experiment with grasses, to be cut and given in the pen, and then feed to such varirties as do best, and are most engerly enten. Of weeds, pursluin, (povil.laca oleracea), lambs quarter, also culled pigweed, (chenapodium album) and the green amaranth, ulso called pigweed, (amarantus hybridus) ure the most eommon of our native and introdueed weeds, thut ure valunble as green food for swine. There is also a native weed growing in Illinois and along the alluvial banks of the Mississippi and northward; the winged pigweed, (cycloma platyphyllium) that is much liked by swiue. Yet the list of plants enten by them is not large, about eighty species comprising the wholo.

\section{Other Summer Foods.}

Besides clover, the grasses, and weeds, there ure other plants that may come in durug the Sumner, and be used with profit. Onts and pens muy be sown together, two bushels of oats and one of pens, together, per acre, us enrly in the Spring as the ground is in fair condition for working. The swine may be turned into the field when the crop is ripe, being confind to given space, by a hurdle fence, which is to be removed as they eat eleill. A better way, however, is to harvest and thresh, and feed either soaked or dry. Later, Summer squushes and punpkins will come in, to be followed by artichokes in the Autumu. We do not advise any of these foods execpt grass on the sejre of economy. Corn and gruss are the cheapest food in all the West, so fur as mere cost of production iscoucerned. But unless the health of swine is retuined, there is 10 protit. Hence the necessity of these additional foods.

\section{Roots.}

Rutabagas make nn exeellent Winter food for swine in connection rith corn; they are ensily and chenply rajed, as we have already stated. Parsujps are also genemally liked, either raw or cooked. Beets are also gyod Winter feed boiled with meal. The tops are ulso oceasionally rel. bhed. Calhange is a cheap and wholesome food; they are not, howerer, cheaply kept over Winter. They mily be used with profit up to the first. of January.

\section{The Grains.}

These, after all, must be the main dependence, both in raising and fattening swine. The kind of gruin fed will, of course, depend upon the 
climate and region where raised. Where corn is a sure crop, it must be relied on almost entirely. The assertions of theorists, that it is unfit for feeding, except during the short fattening season, although the merest twaddle, in the sense they intended it, will, from another point of view; be correct. The fattening season of swine should be from the time they ure weaned until they are slaughtered. Swine for pork should never Inse in condition from the time they were bora until turned off for the butcher. The feeding of all the corn they will eat in connection with grass and other food, to keep thern healthy, anc which will apply with equal force, whatever the grain fed, will be found not only the most economical throughout the West and Southwest, but in all tiat region of country where corn is natural to the soil and elimate, of where it may be cheaply bought.

\section{Feeding South.}

In nearly all the country South, corn may be cheaply raised as a part of the rotation. Here corn must be the main stay, suppiemented by such grasses and plants as are natural to the region. The artichoke will do well much further south than is generally supposed, and some of the tuberous varieties may undoubtedly be found well down to the tropics. When it an be profitably cultivated, the Jerusalem artichoke should be used. The ne Jeiusalem is a corruption of the Italiun name Girasule, meaning sunflower, the botanical name being Helianthus tuberosus, or the tuberous rooted sunflower.

Chafus, a tuberous rooted grass, (Cyperus), has become widely maturalized in the South, and is highly spoken of for feeding swine, since like artichokes, the hogs are left to gnther them for themselves, :und unlike the artichokes, they are most nutritious and fattening. They nre exceedingly easy to eu'tivate, but are sometimes said to bo difficult to extirpate South. This, however, is probably incorrect, since from their very nature, a thorough Summer fullow will kill. North of thirty-nise degrees they do not survive the Winter. In fact, if frozen anywhere, they are killed.

\section{Mast.}

In all the great timbered region South, tree seeds, acorns, beechnts, chestnuts, the softer shelled hickorynuts, and hazelnuts, formu in most villuable food for swine. They should be utilized to their fullest extent. So papaws, persimmons, a: 1 the other wild fruits of the forests South may be made available in the makiug of pork. Where hogs can haref

plenty of , entirely he fices, if on South, we I native sows of American the South.

In all the hundred hogi life of the an the breeding : coneerned this of view. The fron what the year, who find in Summer and on the skim mil for feeding; se miterial about $\mathbf{t}$ or raw. It is b so is to combi animuls.

The hog house may be in the fo fre feet wide, wi should be provide passing out and $i$ learin to do. The tept clean, will a pens on each side mequire a building rill feed twenty-f building may be $t$ ay, allowing for pens on a side, and iventy-five by forty 
plenty of range, they will do very well with a little faeding, are generslly entirely heulthy, and upon being put up to fatten, a very little grain suffices, if ouly attention has been paid to get the proper breed. For the South, we believe the Berkshire, or erosses of the Berkshire on the best native sows to be one of the most profitable breeds. The Poland-China of $A$ merican breeds will be found most valuable for breeders and raisers at the South.

\section{Feeding in Confinemont.}

In all the great swine growing regions, where from twenty-five to ive hundred hogs are annually fattened and sold from single farms, the life of the animals must necessarily be passed out-of-doors. So far as the breeding stock, and the first few months of the life of the pigs are concerned this is always best, both from an economical and sanitary point of view. Thero are, however, many small farmers, who annually fatten, from what they require for fumily use, up to fifteen or twenty bead a rear, who tind it most convenient and econonical to feed and fatten both in Summer and Winter in pens. All this large elass must depend, first, on the skim milk, buttermilk and whey, and upon the slop of the kitchen for feeding; sceond, upon clover, cut and fed, weeds and other refuse nuterial ubout the farm, and lastly and principally on corn either ground or raw. It is better for all this class that the pens when built be planned so us to combine ease of handling with security and comfort of the animuls.

\section{Hog Barns.}

The hog house need not be an expenslve building. For a few uogs it may he in the form of a parallelogram, with a passage way in the middle fre feet wide, with pens opening into roomy yards outside. Euch pen should be provided with a swing door, hinged at the top, so the hogs in pissing out and in may raise and lower it themselves. This they soon learn to do. The pens may be alout eighi feet by ten feet, which, if kept clean, will accommodate three or four hogs each. Thus, a tange of pens on ench side ten feet deep and a five feet passuge way between will mquire a building twenty-five feet wide. A square building of this size rill feed twenty-four hogs. If a less number is required to be fed the building may be twenty-five feet one way, and, say sixteen feet the other ray, ullowing for pens. If fifty hogs are to be kept it will require six pens on a side, and the building, to secure proper accommodation, must be inenty-five by forty-eight feet. 


\section{A Cross Barn.}

If a large number of hogs are to be kept it is better that there be a central building twenty-five fect square, sixteen feet of which is to be used as a room for the boiler and for storing and preparing the food. Extensions from this on every side are to be built twenty-five feet wide, and is long as necessary to accommodate any required number of hogs. A tight box on four small iron wheels arranged so it will turn short corner's will curry the food to every pell, which should of course be provided with a good trough, into which the feed may be easily poured. This with extensions, each forty feet long and twenty-five fect wide, will give you a cross barn, good for from 150 to 160 full grown logs; and these extensions naty be curried out to accommodate 500, if necessiry, but if more than 100 hogs are to be kept the central building should be forty feet square, three stories high, the upper stories used as a granary with corn cribs next tho outside. Twenty feet square should be given up for the storage and stove room below, and the breeding pens placed next on account of the greater wumth. In a building of this description near Chicago, wo for yeurs kept and fed, in connection with a large market garden, from 400 to 500 annually, the principal food used being the daily waste from large hotel kitchens, which we daily supplied with regetables, the garden furnishing economically the necessary green vegetable food. We had no sickness or difficulty worth mentioning. The water supply was unple and pure; the pens wero duily eleaned and washed in warm weather; the drainuge was earefully attended to; salt and bituminous conl was supplied, so the hogs could take either at will, and we always had fut hogs to supply eity lutehers, and the pigs were turned off at about eight or nine months old, weighing from 250 to 300 pounds each. This was about fifteen year's ago, und the breeds then kept were Chester county sows, crossed with Yorkshire or Suffolk boars.

\section{A Simple Pen.}

When swine are only to be kept in pens during the period of final fattening, und ure allowed to run at large in the fields in the Summer, a pen fourteen feet wide, und of sufficient length to accommodate the number of hogs kept, will suffice. It should be floored tight, and one-lunf of the width allowed for sleeping. These must be closed in and roofed, the feeding pen being open to the weather, the whole being divided into compnrtments or spnces, eight feet one way, or wide enough for four hogs to feed abrenst. This also is a good form whon not more than a dozen hogs are to be kept. 
Still another plan is to select a yard, in a dry, well dinined place, allowing twenty feet square for each ten hogs; thus a lot forty feet square would accomodate twenty hogs. Along the middle of the pen, a

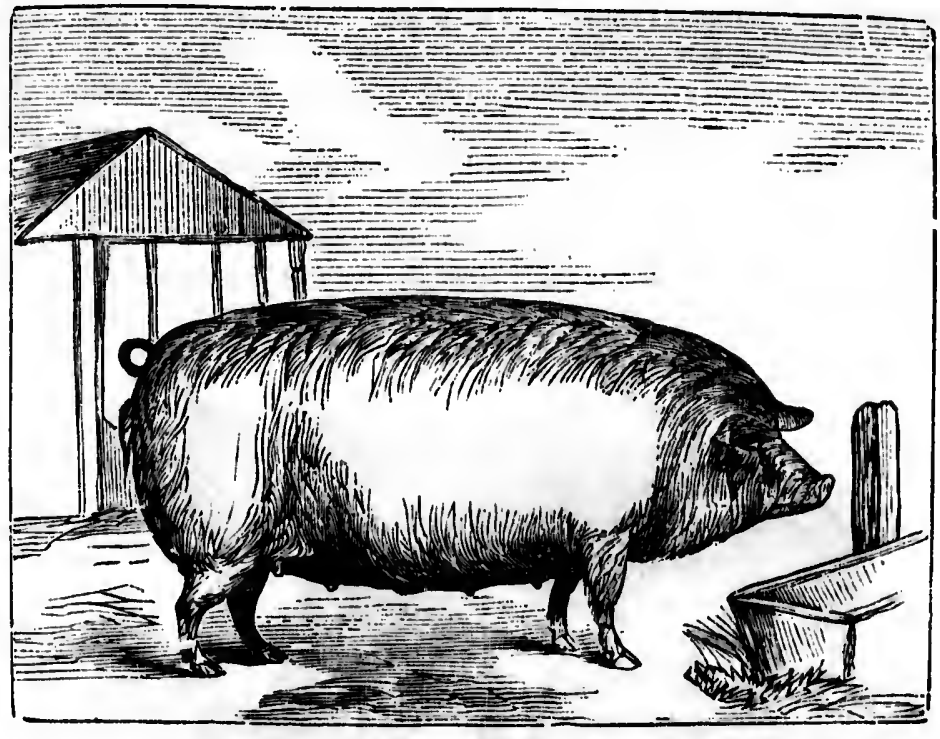

BREKDER IN GOOD FLESH.

bedding place is built, sixteen feet wide, with a partition in the middle, and divided the other way every twenty feet by partitions. The feeding phace should be floored, eight feet wide, and have a low trough two feet wide, along the side for holding ear eorn. Unless the season is very ret and muddy, hogs do very well thus kept. If wet, they must be kept out of the mud by means of hay and litter thrown into the yards from time to time, and the sleeping places must be kept well bedded. Kept in either of the ways we have designated, your hogs will go to the buteher fat, and showing a profit on the right side of the ledger, and your breeding sows will look like the illustration of a well-bred animal, which we give in ordinarily good breeding flesh, on this page. If on the other hand, you let your hogs shift for themselves, running wild over the prisice, or ruming about in the woods, they will, as the illustrution on next page shows, come out pretty much like "Arkansas tooth-picks." Stoek of this kind may be able to care for itself, but it will yield only a paltry return in the narket. 


\section{Bummary.}

In what we have said in relation to feeding in close pens, we are not to be understood as advising the prictice on the farm. There should be plenty of pasture in Summer, and plenty of pure water always. Without this no one can suceed. There must be protection from insects and heat in Summer. The first may be perfectly secured by providing : dark place to which the logs can retire at will. In Winter there must be warm, dry and otherwise comfortable shelter provided, and there must also be plenty of good food, at all times. Of all unimals the hog, at leust, must not be ullowed to lose flesh from the time it is born until it is killed. When fat, kill at once, unless the market hippens so that it will pay to bold for a short time for a turn. As a hog becomes fut, it eats

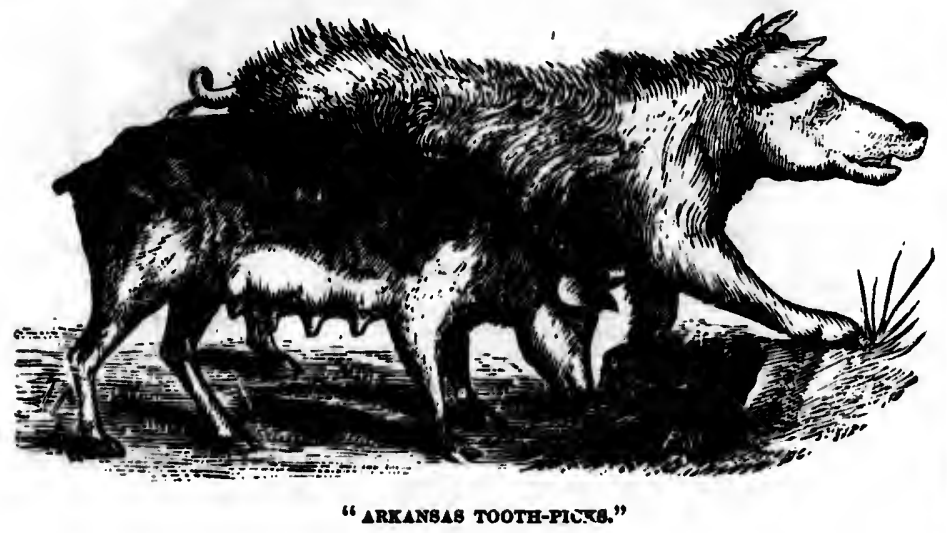

less and less, and it also fattens more and more slowly. Nevertheless, the same daily animal waste goes on. Many good feeders are so particul:ır that they weigh their hogs every two weeks, and note the gain. Then they are able to determine just how much their stock is improving, und ulso as to the proper time for turuing them off. If not ready, or the season and prices are not right, they increase the condition of the food given, so that the sinall quantity taken shall make up in richness what it If .ks in quantity. This cliss seldom sell stock over twelve months old, III. many of our best feeders sell their hogs at ten noonths old, which will turn the scules nt from three hundred to four hundred pounds each. Such feeders never keep hogs two Summers and one Winter, in order to get all average of two huudred pounds each. 
Iight v8. Heavy Hogs.

Years ago, when lard and side pork were the principal hog products looked for, the hetivier the hog, the better the price. We once sold a hog weighing 650 pounds for tifteen cents a pound. Thnt was in wartimes, and it brought one cent per pound over the priee paid for light and well fattened hogs. The same animal to-day, would not bring within a cent a pound, of what nice young nine and ten months, well fattened pigs would, in any of our principal markets. To get the weight named, the hog was fed two years and a lmil. Take three pigs ugainst this one. The difference in the first cost of the three sucklings as against the one, would not exceed three dollars. The three pigs will be fed nine months, and weigh 600 poands, - (we have made pigs farrowed in Murch and killed the next January, weigh dressed, up to 380 pounds, and have more than once turned off such pigs at ten months old weighing alive over 300 pounds average) the other must be fed almost three years, and you must be a good feeder if you make him weigh 600 pounds. In the first case, you huve fed nine months each, or twenty-seven months on the three pigs for 600 pounds, and in the other ease, you have fed thirty-six months for the same weight. The one big hog has eaten more corn than the three pigs, and yet the three pigs weighing the same as the one will bring about six dollars more, giving you three dollars on the original purchase, as between the three and one, and a very considerable amount of corn on the eredit side of your account book. You don't believe it? Examine the tables we have given on feeding and turning off cattle young, as against feeding until they were mature. We could show many instances fully as enviucing as this, in the case of hogs ; but why pile up testimony after the argument is conclusively established beyond coutroversy.

heless, burticgain. oving, or the food hat it is old, which each. cler to 


\section{PART VIII. \\ Diseases of SWine.}

CAUSES, SYMPTOMS AND CURE. 
EXPLANATION OF NURBING TH LIGNANT EP INTESTINAL MENT.

THE GR What ro De $\longrightarrow$ CONTAO SEY, OR STR IN TIIE HEA -THE LAI CURE. LII
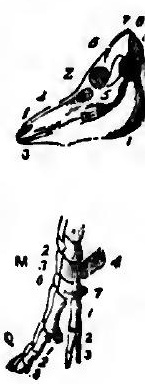

Explanationrertebre. $D-\mathbf{S a}$ cartllages. $\boldsymbol{H}-\mathrm{S}$ pus, or knee. 1. Trapezoid. 6. Os 


\section{DISEASES OF SWINE.}

EXPLANATION OF CUT. - DIFFICULTT IN ADMINISTERING MEDICNNE. - GOOD NURSING THE ESSENTIAL. - MALIGNANT AND CONTAGIOUS DISEASES. - MA. LONANT EPIZOOTIO CATARRH - HOW TO KNOW IT. — WHAT TO DO. INTESTINAL " HOG CHOLERA." — HOW TO KNOW IT. CAUSES. —- TREATMENT. - PREVENTION. - CONTAGIOUS PNEUMO-RNTERITIS. - ITS ORIGIN. -TIE ERYSIPELATOUS FORM. - THE FURY MALIONANT SORE THROAT, WHAT TO DO.- MALIGNANT ANTHRAX, BPLENTO FEVER. - TRUE CHARBON. - CONTAGIOTS PNEUMi)-ENTERITIS. - INFLAMMATORY DISEASES. - QUINSEY, OR STRANGLES - RISTNG OF THE LIOHTS. - PNEUMONIA. C CATARRH IN THE HEAD. - DISEASE OF THE SKIN — MEASLRS. - HOW TO KNOW IT. -THE LARD WORM.—WHAT TO DO. - TRICHINA SPIRALIS. - HOW TO CURE. - LICE - DIARRHEA. - - SUMMARY.

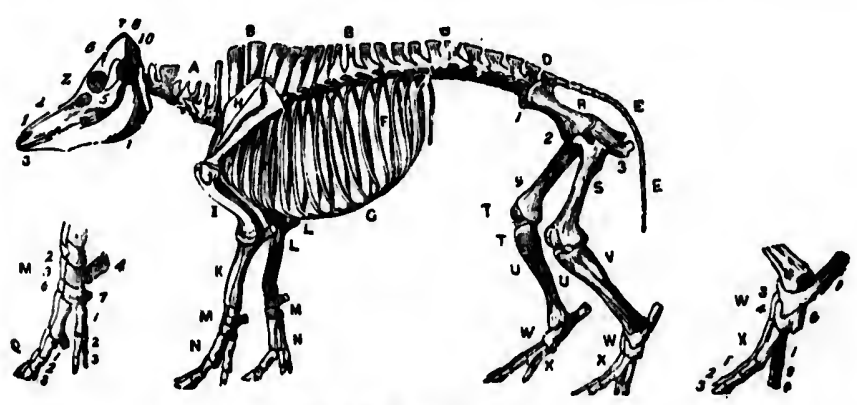

BEELETON OP THE HOO.

Explanation-A-Cervical vertebræ. $B, B$-Dorsal vertebre. $C$-Lumbar reftebre. $D$-Sacrum. $E, E$-Coccygeal bones. $F, F-$ Ribs. $a$-Costal cartllages. $\boldsymbol{H}$-Scapula. I-Humerus. $\boldsymbol{K}, \boldsymbol{K}$-Radius. $\boldsymbol{I}$-Ulna. $\boldsymbol{M}$-Car. pus, or knee. 1. Scaphold. 2. Semilunar. 3. Cuneiform. 4. Trapezium. 5. Trapezoid. 6. Os magnum. 7. Unciform. 8. Pislform. N, N-Large meta. 
carpal, or cannon. $O-$ Small metacarpal. $P, P$-Sesamolil bones. $Q . Q-$ Plialanges. 1. Os suffraginis, or pastern bone. 2. Os coronal. 3. Os pellis, $R$-Pelvis. (Fore-leg of pig. Phalanges 1, 2,3). 1. Ileum. 2. Pulis. 3. Ischium. S-Femur. $T$-Patella. $U$-Tibla. V-Fibula. W-Huck. 1. Os calcls. 2. Astragalus. 3. Cuneiform magnum. 4. Cunclform inediun. 5. Cuneiform parvum. 6. Cuboid. 3, 6. Cubo cuneiform. $X$-Large metatarsal (Hincl-leg of pig. Phalanges 1, 2, 3). $Y$-Small metatarsal. Z-Henl. 1. Inferjor maxilla. 2. Superior maxilla. 3. Anterior maxilla. 4, N sal bone. 5. Molar. 6. Frontal. 7. Parietal. 8. Oecipltal. 9. Laclirymal. 10. Squa. mous-tempoid. 11. Petrous-tempoid.

\section{Diffoulty in Administering Medicine.}

No clnss of farm animals are so difficult to treat in siekness us swine. The horse, the cow, and the sheep, may have medicine administered to them by an intelligent operator with compuritively little difficulty. Not so swine. They resist overy effort with their utmost strength, and medieine can only be foreed down by muin strength, the resistunce itself, being, in nine eases ont of ten more injurious, than the good the medicine may do. When it must be administered by the mouth, the best meins we have ever found, is to place the hog in a narrow pen in which he (anl not tuis round, put a slip noose around the upper jaw, turn the medicine -in the cuse of a drench-down from a horn, or when it may be admissible give it in the form of an injection. In the ease of boluses they min bo laid on the back of the tongue, next tho palute, and the animal thus made to swallow.

\section{Good Nursing the Fssential.}

For the reason that medieine is so difficult to ndminister, it is alwnys best, when the hog will eat or dink to disguise the dose in some food or drink it likes. In fact our practice has always been, if medicine could not be so administered, to let good nursing and enre be the chief dependence in bringing the mimal safely through.

In the case of those malignant forms of epidemic and contagious diseases which, under the eommon name of hog cholera, have so frequently scourged the West within the lnst few yeurs, unless the affected animits nre treated during the fir'st or symptomitic stnge, the only conrse to pursue is to isolate every diseased unimal from the herd ns soon as found, und remove the well animals to a separate place where they me not in dunger, and above all where they camot eome in contnet with other hogs: then with such nedieine as they will eat in food or drink trust to nature and good care to loring them sufely through. 
So far there lins been but little success attending the treatment of these disenses, probalily from the fuct that the incubative stage of the disease was passed and the mnimuls beyond the reach of remedial means before the owners were uware that the animals were attacked. In the trentment of the disenses of swine, we shall first describe fully the three principul. forms of those malignunt diseases termed hog cholern, und for which there ure so many specities ndvertised-some of them by men so ignorant as to call all distempers hog cholera, and prescribe identical treatment for diseases that require entirely different renedies.

\section{Malignant and Contagious Diseases.}

There are threo principal forms of malignant disense3, ealled hog cholerit. The first is malignant epizootic catarrh, which in 1875 and 1876 swept over Illinois, Missouri, and neighboring States, destroying rast numbers of swine; next the disense noticed hy Professor Kline, of England, und described as contagions pnemono-enteritis ; the third, anthrux and splenic fover and a form of intestinal fever closely allied to the last if uot identieal, and which Dr. Luw designates as intestinal fever or hog cholertit.

\section{Malignant Epizootio Catarrh.}

This disense, if it does not originate in filthy yards and putrid pens, is anuzingly developed there. The poison germs find a congenial home in the mucous membrane of such hogs, and in those whose skins are so dirty that the matural perspiratory acts ennot take place, so if perspirittion he cheeked during the previlence of this epidemic, or the swine be exposed to sudden chnnges or the chilly night air, it will surely predisposo them to attacks.

\section{How to Know It.}

There is a short, hoarse cough, difficulty of breathing, with pauting of the flunks. The hend is held in a stretehed and drooping position; there is ferer, a stiff, tottering gait, sometimes running at the nose, often. efforts to vomit, generilly constipation, but at times cliarrhoil. In this form the disease is shown in the dead animal by inflimmation of the lining membrane of the nose and upper part of the throat, thence to the rimdpipe and lungrs, which are more or less solidified.

A seconl form of this disense has a short cough, not so pronouneed as in the tirst form, and there is less oppression in brenthing; but there is more decided parnlysis in the hind quarters mnd the gait is more tottering. There is at first constipation, followed by a profuse and fetid diurrhea. 
The disense is spending itself in the stomach and bowels. The animal arehing its back and especiully the loins from the intensity of the pain. The brin is often affected so there is purtial or total blindness and aimless movements. So nlso the glunds will be enlurged and sometimes scrofulous ulcers will show in different parts of the body. The dead animal shows the lining membrume of the intestines influned und degreucrnted. The spleen enlarged, dark, and soft; the liver diseased, und often water exudations in the chest and belly. The duration in either form is from five to fifteen dnys.

\section{What to Do.}

If the disease has progressed so as to show the latter symptoms we have described, kill, and bury the animal at once, and deeply. In any event separate the animals showing the slightest symptoms from the rest of the herd, and remove the well ones to comfortuble and dry and well ventiluted quarters, and give pure water and good, easily digested food. As soon as the first symptoms are discovered give an emetic as follows:

No. 1.

15 to 20 Aruins powdered white hellebore, * Pint milk.

Mix for a full-grown hog, and let it drink ; if it will not, turn it dorn with a horn as previously described. This having vomited the hog, in a eouple of hours after give two or three gruins of tartar enetic, if the trouble is in the lungs; if in the bowels, two or three grains of calonel; either medicine to be given in the half of $\boldsymbol{n}$ roasted potato or apple if the animul will eat, or to be enveloped in tallow or lard and laid on the root of the tongue and the animul made to swallow. Repent the dose twiee a day until relief is obtained. According ns the lungs or bowels are affected apply to the sore place the following blistering ointment, heating over a moderute fire, for half an hour and stirring to mix :

$$
\begin{aligned}
& \text { No. 2. } 1 \mathrm{Oz} \text {. powdered cantharides, } \\
& 4 \mathrm{Oz} \text {, ollve oll. }
\end{aligned}
$$

Rub in well and repeat the appliention if no blister is drawn. If the animul improves, give every day for a few days the following:

$$
\text { No. } 3 .
$$

20 Grains sulphate of iron,

30 Gralny carbonate of potash.

This, when the lungs have been the seat of disease ; if in the borels, omit the carbonate of potash. Prcfessor Townsend thinks that in many cases the liver is torpid, and thus blood poisoning takes place. When

It is mainly $p$ gement serve the attack he recomm

$$
\text { Or, if co }
$$

In relation scribed, $\mathrm{Dr}$. attended by the membran eral heat and brane spots ar from one to $s$

Incubation $r$ days in warm. under the litte steady gait be temperature (1) currence of he and black spot The tongue is t ing accelerated may be present botrels may be relaxed about $t$ Lymph and blc lases control of miscular trembli
bowels. 
the attack commences with copious and dark discharges from the bowels, he recommends to give at once:

No. 4.

20 Gralna podophyliln.

2 Dracbma bicarbonate of soda.

Or, if constipation be present :

Ne. 3.

\author{
1 Ounce cantor oll, \\ 1 Drachm oll of turpentine. \\ Both to be given ta a pint of millk or gruel. \\ Intentinal "Fos Cholera."
}

In relation to this disease, undoubtedly unalogous to the one last described, Dr. James Law thinks it is a specific contagious fever of swine, attended by congestion, exudation, blood extravasation, and ulceration of the inembrane of the stomich and bowels. That is, fetid diarrhcea, general heat and redness of the surface, and on the skin and mucous membrane spots and patches of a scarlet, purple or black color. It is fatal in from one to six days, or ends in a tedious, uncertain recovery.

\title{
How to Know It.
}

Incubation ranges from a week to a fortnight in cold wenther, to three days in warm. It is followed by shivering, dullness, prostration, hiding under the litter, unwillingness to rise, hot, dry snout, sunken eyes, unsteady gait behind, impaired or lost appetite, ardent thirst, increased temperature ( 103 degrees to 105 degrees F.), and pulse. With the occurrence of heat and soreness of the skin, it is suffused with red patches and black spots, the former disappearing on pressure, the latter not. The tongue is thickly furred, the pulse small, weak and rnpid, the brenthing accelerated and a hard, dry cough is frequent. Sickness and vomiting may be present, the animul grunts or screams if the belly is handled, the bowels may be costive throughout, but more commonly they become relaxed about the third day and an exhausting fotid diarrhon ensues. lymph and blood may pass with the dung. Before death the patient hises control of the hind limbs, and is often sunk in complete stupor, with anseular trembling, jerking, and copious and involuntary motions of the bowels.

\section{Causes.}

orrels, umany When

It is inainly propagated by contagion, though faults in diet and management serve to develop it. The infection is virulent, and may, it 56 
is supposed, be communicated by the wind, and is with difficulty destroyed in hog-pens, fodder, bedding and other articles of contact.

What to Do.

Treatment should not be permissible, unless in a constantly disinfected atmosphere. Fued barley or rye, or in case these raise the fever, corn starch made with boiling water; give to drink fresh cool water, slightly acidulated with sulphuric acid. For the early constipation give a mild laxative (castor oil, rhubarb), and injections of warm water, to be followed up with nitrate of potassa and bisulphate of soda, of each 20 grains at a dose. If the patient survives the first few days and shows signs of ulceration of the bowels, by bloody dung, or tenderness of the belly, give oil of turpentine fifteen to twenty drops night and morning. Follow up with tonics and.careful, soft feeding.

\section{Prevention.}

Kill and bury the disensed; thoroughly disinfect all they have come in contact with ; watch the survivors for the first sign of illness, test all suspicious subjects by means of a slinical thermometer introduced in the rectum, and separate from the herd if it shows 103 or mor degrees Faranhcit. And ss soon as distinct signs of the disense are siown kill and bury deep. Feed vegetable or animal charcoal, bisulphate of soda, carbolic acid or sulphate of iron to the healthy swine, and avoid nil suspected food or places, or even water which has run near a diseased herd. All newly purchased pigs should be placed at a safe distance in quarantine, under sevarate attendants, until their health has been surely established as sound.

\section{Contagious Pneumo-enteritis.}

This discase krown commonly also as "hog cholera," "purple," "ilue diserse,"etc., is a contagious inflammation of the lungs and bowels, accompanied with red and purple blotches of the skin, the last deseribed being one of relative forms of this disease.

\section{Its Origin.}

It is supposed to be caused by extremes of temperature and wet seasons, feeding on low or swampy soils, impure water, filthy feeding pens. Whether these causes originate the disense or not they incline the system to infections from the subtle poison which Dr. Kloin, an eminent English

veterina

(bacillus

M. Rochi appear if rain, well pure wate ing, to int

There ar noticed, as

The anim unwillingly. The bowels bard and dal The next c the disease $\mathrm{sl}$ purple blotel cannot be $\mathbf{m}$ neck, breast a tions are very nose of a dar labored; he $\mathrm{i}$ reeling with $\mathrm{h}$ stage $a$ fetid d in one or thre

Tho general appearance of hue, which we obstructions to duce a train o There are atten ing from the fi animal will sit ito mouth wide the swelling ab 
veterinarian, has proved to be due to a minute vegetable organism, (bacillus) found in the serous fluids, and tissues of animals infected. M. Roche Lubin, a French veterinary authority says the diseuse will disappear if proper sanitary means are used, protection from the sun and rain, well ventilated quarters, and clean bedding, often renewed, with pure water and wholesome food. We have been thus particular in quoting, to intensify what we have repeatedly said, cleanliness and care.

\section{How to Inow It.}

There are two principal symptomatic forms which are important to be noticed, as follows:

\section{The Frysipelatous Form.}

The animal at first is dull, loses his uppetite, lies down and moves unwillingly. He hangs his head, and sometimes makes efforts to vomit. The bowels at this time are generally constipated, the excrement being bard and dark colored; cough and difficult urination.

The next day or in a few hours, even, the characteristic symptom of the disense shows itself. This consists in the appearance of dark red or purple blotches, passing into a bluish-black color. Once seen, they cannot be mistaken. Their most frequent seuts are the ears, throat, neck, breast and inside the fore legs. If he is a white hog the discolorations are very visible. With these there is often a discharge from the nose of a dark purple fluid. Soon his breathing becomes panting and labored; he is palsied in his hind quarters, and if be is driven up runs reeling with his hind legs and his head dropped to the ground. At this stage a fetid diarrhoea sometimes sets i $i 2$. The fatal termination is seached in one or three days.

\section{The Form with Malignant Bore Throat.}

The general symptoms at the commencement are the same; and the appearunce of the throut has that stume deep red, passing into dark purple hue, which we have just noticed in the erysipelatous variety. But the obstructions to the functions of brenthing and swullowing naturally produce a train of charncteristic symptoms not seen in the former ease. There are attempts to vomit, difficulty in swallowing, and labored breathing from the first, the sensation of choking being so distrossing that the animal will sit on its haunches, like a dog, gnsping for breath, opening its mouth wide, and protruding a livid and swollen tongue. Sometimes the swelling about the larynx is so sudden and considerable that the ani- 
mal is choked to death in less than un hour, and before hardly any other symptom has had time to manifest itself (œdema of the larynx).

\section{What to Do.}

The cheapest remedy with animals distinctly. attacked, is to kill at once, and bury deeply out of sight, to prevent contagion. If the animals are valuable, isolate them from all danger of spreading the contagion; give two to three ounces of castor oil, and as soon as it operates, give twenty grains of nitrate of potash, and twenty grains nitrute of soda,mixed for a dose-two or three times a day. Give also powdered charcoal in the drink, and if the bowels are swollen and tender give twenty drops of turpentiue in a little gruel, as may be needed. The prescription of M. Lubin, and one of the most valuable known is :

\section{No. 6. 10 Grains powdered camphor, \\ 1 Druchm nitrate of potash,} 6 Grainw calomel.

Mix and give in a little gruel three times a day, omitting the calomel after the third dose.

The local treatment should be attended to. Frm the swollen part with hot water saturated with copperas (sulphar gangrene, saturate the surrounding tissues with 1. and attend strictly to the general sanitary conditions of the hospital or place where the animuls, both sick and well are kept. Professor Williums advises the use of chlorate of potash as superior to all other medicines. His prescription is :

No. 7.

2 Drachms chlorate of potash, $x$ Pint wator.

Proiessor Turner, the well known Illinois scientist and extensive farmer, ndvises the following as having been successful with him in a preventive, und if taken in ihe carly stages of the diarrhoa, as a cure:

No. 8 2 Lbs. flowerw of sulphur,
2 Lbs. aulphate of iron,
2 Lb. madder,
K Lb. black antimony,
KL Lb. nitrate of potash,
2 Oz. arsenio.

Mix with twelve gallous of slop, and give a pint to each hog; this quantity being for 100 hogs.

Our best worl of advice is, if the affected hogs ennnot he made to take the remedies in thei: food or drink, since it is a question of profit and 
loss simply, then kill, bury at once, and disinfect promptly. For the means of disinfecting, see chapters on contagious diseases in cuttle. If we had simply said kill and bury, our readers would not have beeu satisfied. Thus we have given much point to remedies; yet it will again bear repeating: In all contagious diseases of animals, of a malignamt type, it is cheapest and most humane to KILL AND BURY QUICKLY AND DEEILY. We have never found any remedy effective once it assumes a mulignant form. Unfortunately, there are too many careless or pennywise persons who will not kill, and who constantly spread contagious diseases.

\section{Charbon, Malignant Anthrax. In 8wine, Bplenio Fever.}

It has been denied that this disease attacks swine. Since it is a blood poison known to attack various animals, and which may be coinmunicated to man, there seems to be no good foundation for the assertion. In this country there has not been sufficient systematic investigution to separate the names of the true Anthrax from what is popularly known is hog cholerit. The distinction between Anthrax (Charbon) and contagious pneumo-enteritis is stated explicitly by Dr. Klein as follows:

TRUE CHARBON.

Period of incubation, or latency, from a few hours to three days.

Easily transmissible to other species of animals.

Spleen always enlarged, and uften broken down.

Blood after death dark and fluid.

Bacillus anthracis in the blood.

Lungs and bowels frequently not impliented. Cough muv be present. The discoloration local, and of a true carbuneular appearance.
CONTAGIOUS PNEUMO-RNTERITIS.

Period of incubation from two to five duys and more.

Rarely and with difficulty transmitted to other species.

Spleen irurely enlarged or otherwise changed.

Blood after death of ordinary appearance.

No bacillus anthracis in the blood, but numberless baeilly in the serun of the thronx and abdomen.

Lungs and bowels always both inflamed. Cough always present. The red or purple color diffused over the surface, and of an erysijelutous appeurance.

The most common form of antlurax in pigs is popularly culled " white bristle." There is a carbuncular swelling, usually on the thront, presenting the features of color ulready described. The bristles on the syot turn white and brittle, whence the nawe just given. The swelling extends 
inward, involving the windpipe and gullet, causing difficulty of breathing and swa. owing, and at length death in convulsions through suffocation. Occasionally the true apoplectic or splenic form of charbon appears, and also the variety which attacks the tongue and mouth, both acute and quickly fatal, the apoplectic form ofien killing almost instantly. The flesh of all animals dying of uny form of this disease, as previously stated, is poisonous, and the blood and discharges capable not only of spreading the disease amorg others of the same species, but also, if inoculated into the human system, of bringing on that inortal malady, "malignant pustule." The treatment, if treatment for so fearful and fatal a disesse may be allowed, should be essentially the same as that prescribed in contagious pneumo-enteritis. As \& preventive the recipe of Prof. Turner may be used. We advise to give medicine if only early symptoms be observed, but if animals be distiuctly attacked to kill immediately, bury out of sight, and DIsINFECT THOROUanLY.

\section{Inflammatory Disesses.}

Swine are from their nature, and the psual manner in which they are kept, quite subject to coughs, colds, quinsy, and inflammatory diseases, espeoially of the lungs.

\section{Quinsy, or Btrangles.}

This is a disease quite common and futal. It is an imflummation of the giands of the throat, (tonsils) and often kills quickly through suffocation. If in fecling them there be found difficulty in swallowing, or protrusion of the tongus, and slavering from the mouth, and if there be a swelling under the necis and lower jaw, Irse no time, cast the pig so he may he held firmly, and with a lancei or sharp knife, scarifying the skin of the throat deep enough to druw blood freely. Foment the parts with cloths wet with hot water and partially wrung out, ropentedly applied to induce bleeding, and reduce the inflummation, while un assistant prepares the following injection :

No. 9.

\author{
4 บz. sulplinte of magneaia, \\ 2 Drachmo ofl of turpentine, \\ y l'int kroap suds. \\ Mix.
}

With a fonther fastened to a smu!ll rod, the hog's mouth being lieid ofell, swab the tonsils and inside of the thront as fur as car be renched, with equal parts of lard oil and turpentine, or if the hog will eat, give doses of two tea-sponfuls ench in a pint oi gruel.
This is animal $w$ the throa putting a tar well b

The syn breathing, severe coug animal thor vinegar on

No.

Mix in a horn.

Commonly ct feed and wat

Swine aro finement, un] themselves, e

Measles in name in the $h$ ensioned by tl where they h. feeding on pas and work thei of such auim: liey transfer ing does destr appesintunce of of grains of 1 


\section{Rising of the Iights.}

This is the name applied to an ordinary cold. To cure this, keep the animal warm, feed well, and rub mustard, moistened with vinegar, on the throat and ehest. If it does not yield, give an ounce of tar daily, by putting a slip noose over the snout, opening the mouth, and placing the tar well back on the tongue with a narrow wooden paddle.

\section{Pnoumonia.}

The symptoms of inflammation of the lungs are, quick and laborious breathing, loss of appetite, shivering of body and limbs, more or less severe cough ; and the animal will not eat. The remedy is to keep the animal thoroughly warm and quiet. Rub the prepuration of mustard and vinegar on the ehest, and give internally,

\section{No. 10. 2 Drachms nitrate of potash,}

2 Drachms bisulphate of soda.

Mix in a pint of gruel if the animal will eat. If not turn down from a horn.

\section{Catarrh in the Head,}

Commonly called snuftles. Give the animal a clean, dry, warm pen, and feed and water well; soft food being preferable.

\section{Disease of the 8kin.}

Swine are essentially liable to disenses of the skin, when kept in confinement, unless pains be taken to do for them what they caunot do for themselves, exeept whore they have their liberty.

\section{Measles.}

Mensles in swine have nothing in common with the disease of the same name in the human subject. The name is given to a parnsitie affection, occasioned by the hog taking the eggs of the tupeworm, either in gruzing, where they have been dropped with the excrement of the dog, or from feeding on pastures manured with human exerement. These eggs hatch and work their way into the tissues and become encysted, and if the pork of such animuls is enten, insufticiently cooked to destroy them, hy man, they transfer the tapeworin. In fuct, it is not certain that ordinary cooking does destroy all, therefore it is never sufe to eat measly pork. The appenrunce of the pork is owing to the presence of minute cysts, the size of grains of barley, distributed through the muscular and other tissues. 
There may or may not be, but generally is, a discharge fiom the nose, ruming of the eyes, weakness of the hind parts, and genernl ill health. By examining the skin, small watery pimples will be found of $n$ pink or red color. The remedy is undoubtedly beyond the reach of medicine, though a so-called specitic is smull doses of sulphur and saltpetre, given daily for weeks. The prevention is, to put no human excrement on grizing fields, to keep dogs clear of tapeworm by un occasionul vermifuge, to bury all excrement of dogs found in the pastures, and to kill all stray and worthless curs.

\section{The Lard Worm.}

There is another parasite of the hog, the lard worm (Stephanames Dentatus), from one to one and three-quarters of an inch long, which is occasionally found in all parts of the body ;of swine is frequent in the liver, kidneys and fat around the ribs, and in various organs of the body, including the heart. When present in large numbers, especinlly in the kidneys, its eggs may sometimes be discovered in the urine, by menns of the microscope. Another worm, Eustrongyhs Gigas, also inhabits the kidneys; both may produce wenkness of the back, but it would not be snfo to trent for these parasites, unless this was surely determined by the microseope.

\section{What to Do.}

Do nothing. Various remedies have been prescribed, such ns small dowes of sulphur und salt, given daily for several weeks, or small doses oi sait and turpentine. Noither have certainly been known to do any good. Minute doses of arsenic, one-eighth of a grain, given duily for two or three weeks, so it may be tnken up by the system, would he lise proper eourse indicated. The better why is to prevent their getting measly, by keeping the diseased ones entirely from the well ones, and the young away from the old.

\section{Triohine Spirs.lis.}

This minute parasite is eapable of infesting all domestir animnls, including man. The mature and fertile worm lives in the intestines of the animuls, and the immuture worm in cysts in the muscle. The enting of rats, and other vermin, and slaughter house offal is the prolific source from whence they come. The prevention is obvious. They aro maly found in western farm-raised, corn-fed hogs. There is no dunger from eating pork infected with trichina, if it be thoronghly cooked. There is no means none but form wha and distill

This is c missible to

As soon soap, let it brush, let $\mathrm{t}$.

No

Mix with should be we oughly with s burn all bedd and water. should always lime with it, "

If lice aro have never see any cause, spo and give a littl the feed. Let and safe remec applied whero

Diarrheal aff soll, generully death. Usiunll? from had food, the remedial in where sow and 
no means of discovering them in flesh, except by the microscope. Eat none but corn-fed pork, and that cooked done. Rare cooked pork in any form whatever, is an abomination, and pork fed in slaughter house yards and distilleries should warrant their owners being sent to the penitentiary.

\section{Mange, or Boab.}

This is caused by the presence of a minute insect, sarcoptes suis, transmissible to man, and should not be allowed in any herd of swine.

\section{What to Do.}

As soon as discovered, rub the infested animals thoroughly with soft soap, let it remain an hour, and wash of: with warm water using a good brush, let the animals dry, and apply the following ointment :

No 11.
2 Plnt train oil,
1 Drachms oil of tar,

Mix with sufficient flower of sulphur to make $n$ thick puste. This should be well rubbed in, and remain on three days. Then wash thoroughly with strong soap suds, dry, and change to quarters perfcetly elean, burn all bedding, and cleanse the quarters thoroughly with carbolic acid and water. The carbolic liquor of gas works is good, of which there should nlways be a barrel on the farm. It is cheap. Thin down slaked lime with it, and thoroughly paint all infected places.

Lice.

If lice are found on swine, it is a sign that something is wrong. We have never scen them on well eonditioned swine. When they occur from any cuuse, sponge the animal freely with crude petroleum, or kerosene, and give a little sulphate of iron, (copperns) one quarter drachm a day, in the feed. Let the food also bo ample and nourishing. Another efficient and safe remedy for killing lice is Scotch snuft, rubbed up with lard, and applied where the lice nre found.

\section{Diarrhea.}

Diarrheal affections often attack young pigs during their sucking seasoll, genernlly in the first week of their lifo - and often canses their death. Usinally the cause is due to disensid milk of the sow, either from had food, or other causes. If so, change tice food. In auy case, the remedial means must he used with the sow. Plnce charcoal and salt where sow and pigs may get it, and prepare the following powder : 
No. 12.

2 Pounda fenugreek, powdered,

2 Pounda anise reed, powdered,

1 Pound gentlan, powdered,

2 Ounces carbonate of moda,

2 Pounds chalk, powdered.

Give a table-spoonful of this in the food, cvery time the sow is fed.

\section{Summary.}

From what we have said the reader will easily pereeive that we have not much faith in remedial means in eontugious diseases of swine. The same holds good with any animal when onee the disense is pronouneed, and of a malignant type-unless tho animal be so valuable that it will pay to call a veterinary surgeon. Even then in the malignant forms of the diseases described, and which are known under the popular misnomer of "Hog Cholern," killing und burying is the chenpest nnd altogether the most humane. The danger of spreading; the difficulty of isolation; and the next to impossibility of treating a hog too sick to eat, but never too sick to be contrury, or resist to the full extent of their power, and the ordinarily small cost of swine per head should be woll considered in the treatment of swine. Use proper discretion in treating them, but do not hesitate a moment in killing, when the disease is malignant, and in ordinary cases remember that if the hog will not take his physic kindly in his gruel, better let nuture and good nursing perfect the eure than to violently foree medicino down. Plenso remember the value of good nursing in human patients. To reinforce this we may state the fact that in France, long continued experiments in hospitals, with many putients, treated under the various systems of medicine, n greater proportion recovered with no medicine and good care and nursing, than did under MEdication witu OminakY hoBpital CARE AND NURBing. This may not have been complimentury to tho hospital mnugement, yet in no country in the world are they better or more conscientiously managed.

The necessity of good nursing in the cnse of swine is no less imperative than in that of human beings, and its good results are as nanifest. 

the nany PART IX.

POU L T R Y.

HISTORY, BREEDS, CHARACTERISTICS AND MANAGEMENT. did This in no ed. rative 


\section{POULTRY.}

\section{CHAP'TER I.}

HISTORY AND WILD TYPIRS.

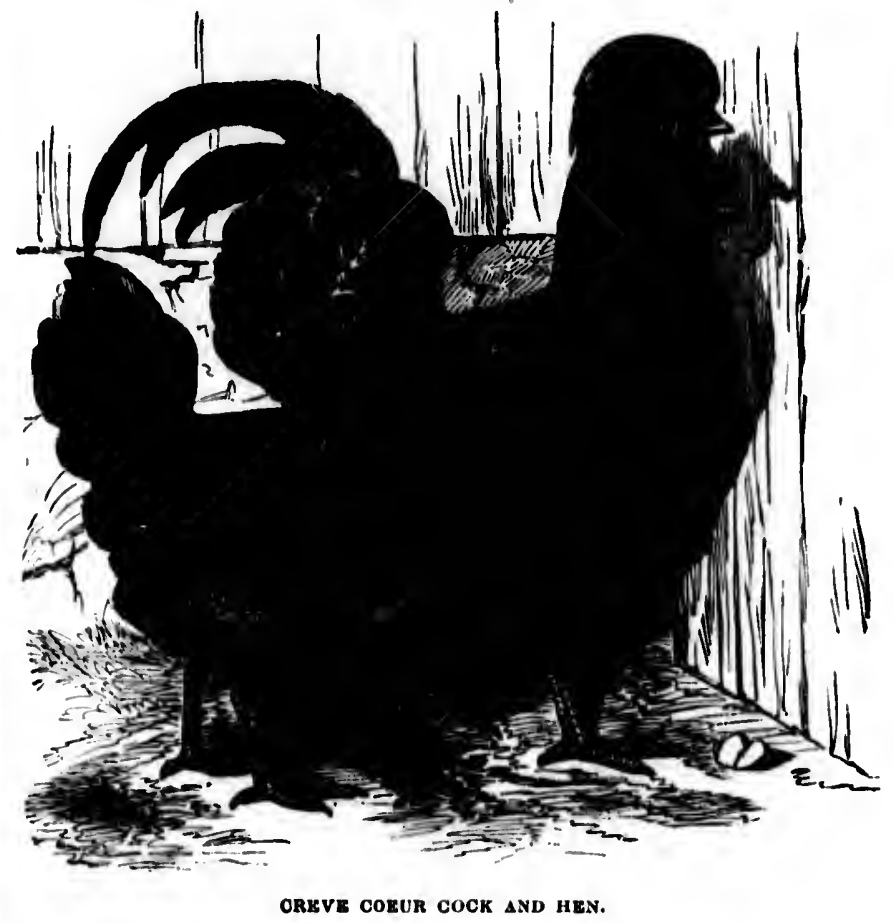

Origin of Domestic Fowls.

The first domestication of the farm yurd fowl is lost in the obscurity of the past. We hive not even tradition to guide us. There is a legend 895 


\section{IMAGE EVALUATION TEST TARGET (MT-3)}
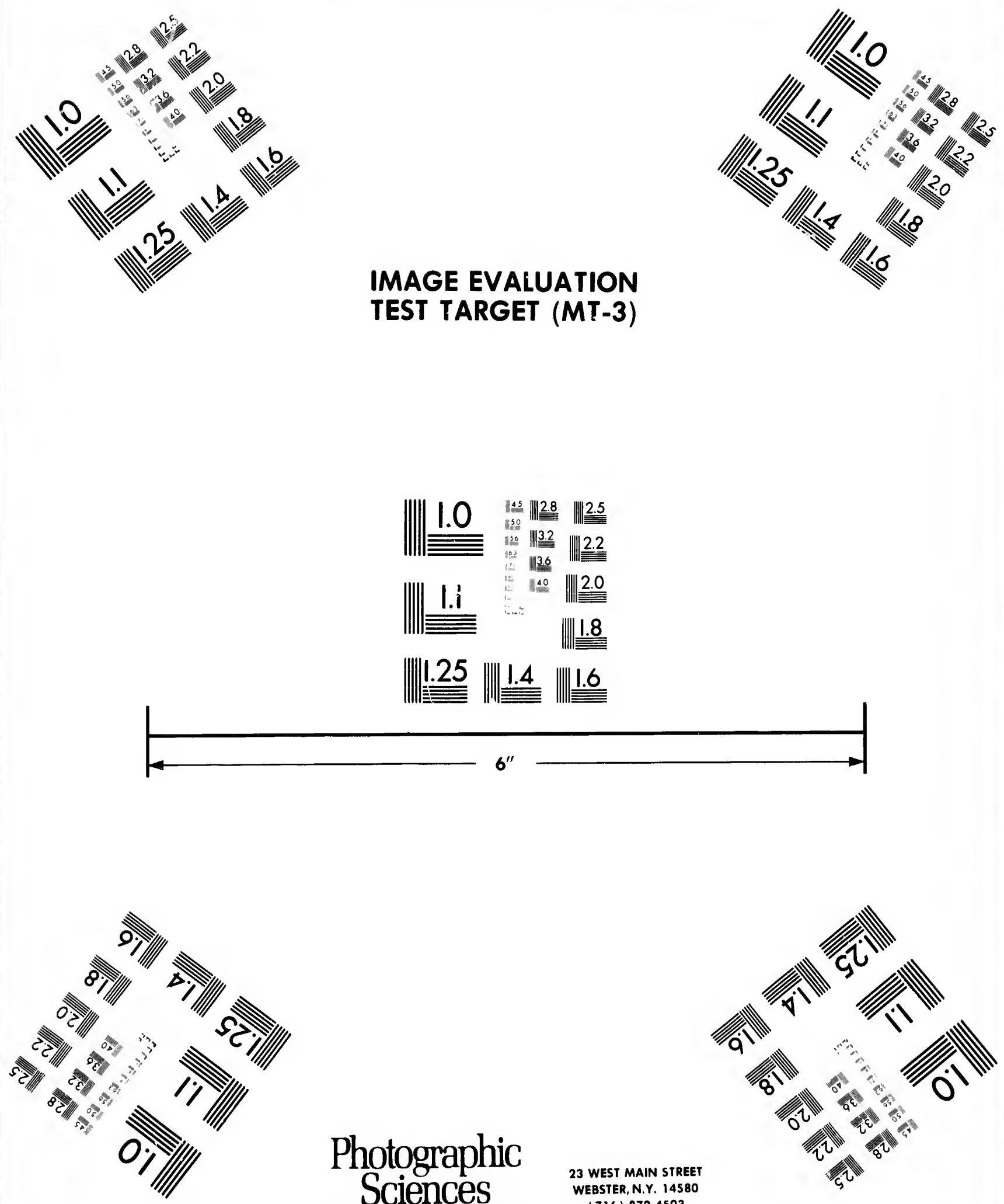

Photographic

Sciences Corporation

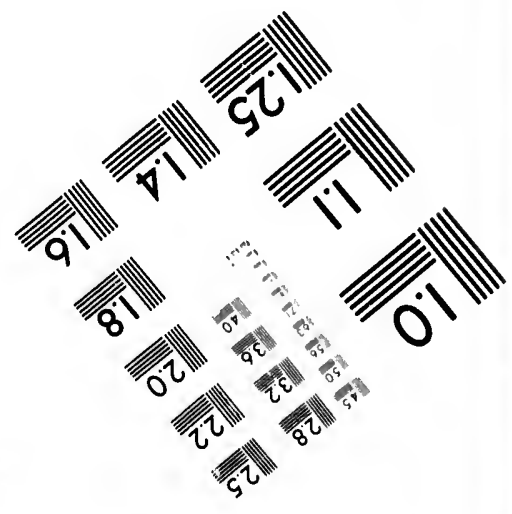





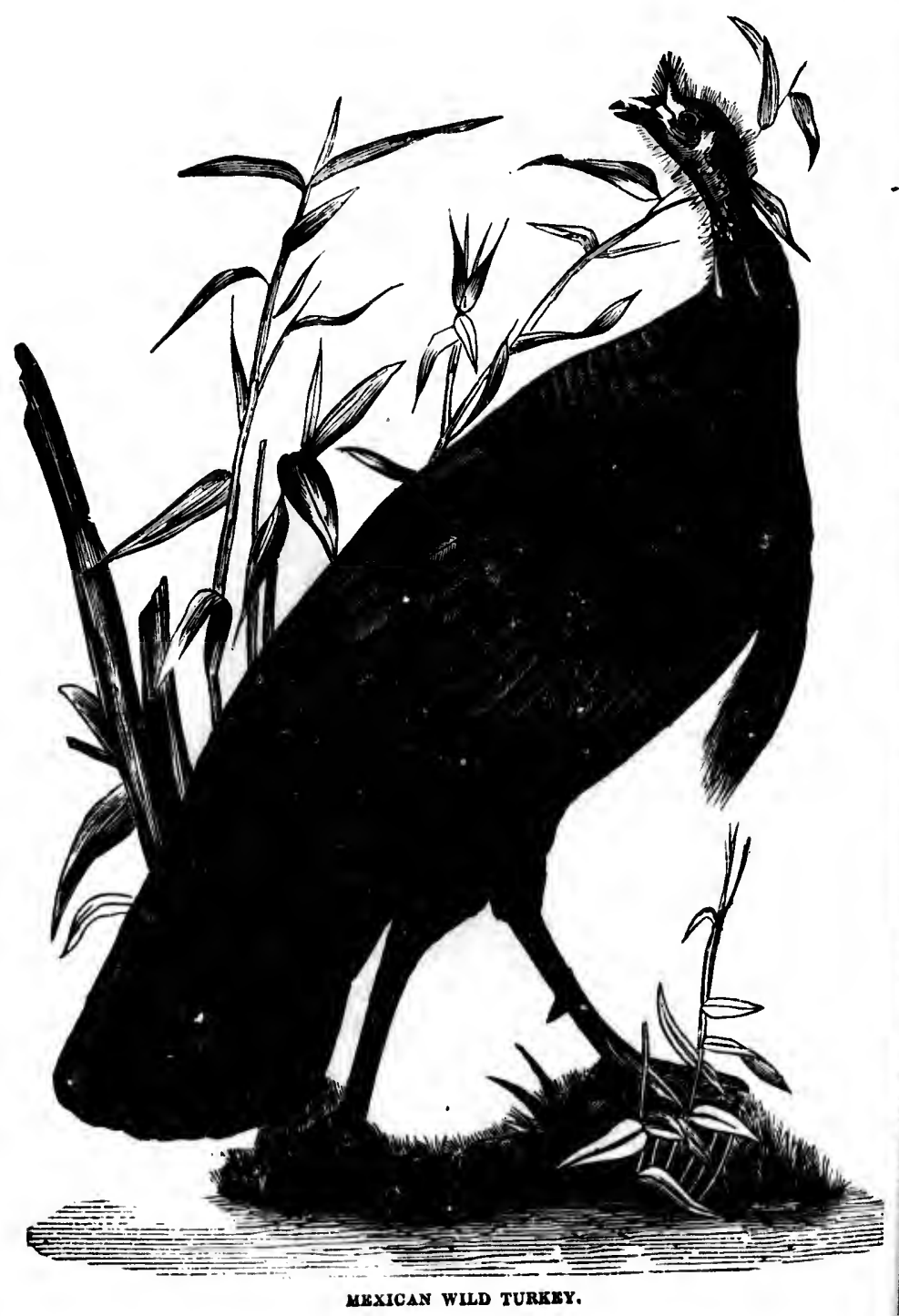


thut Gomer, the son of Japhet, took his name from the cock, and hence it has been inferred that he was the first to domesticate the species. As well might some future historian attribute the domestication of various

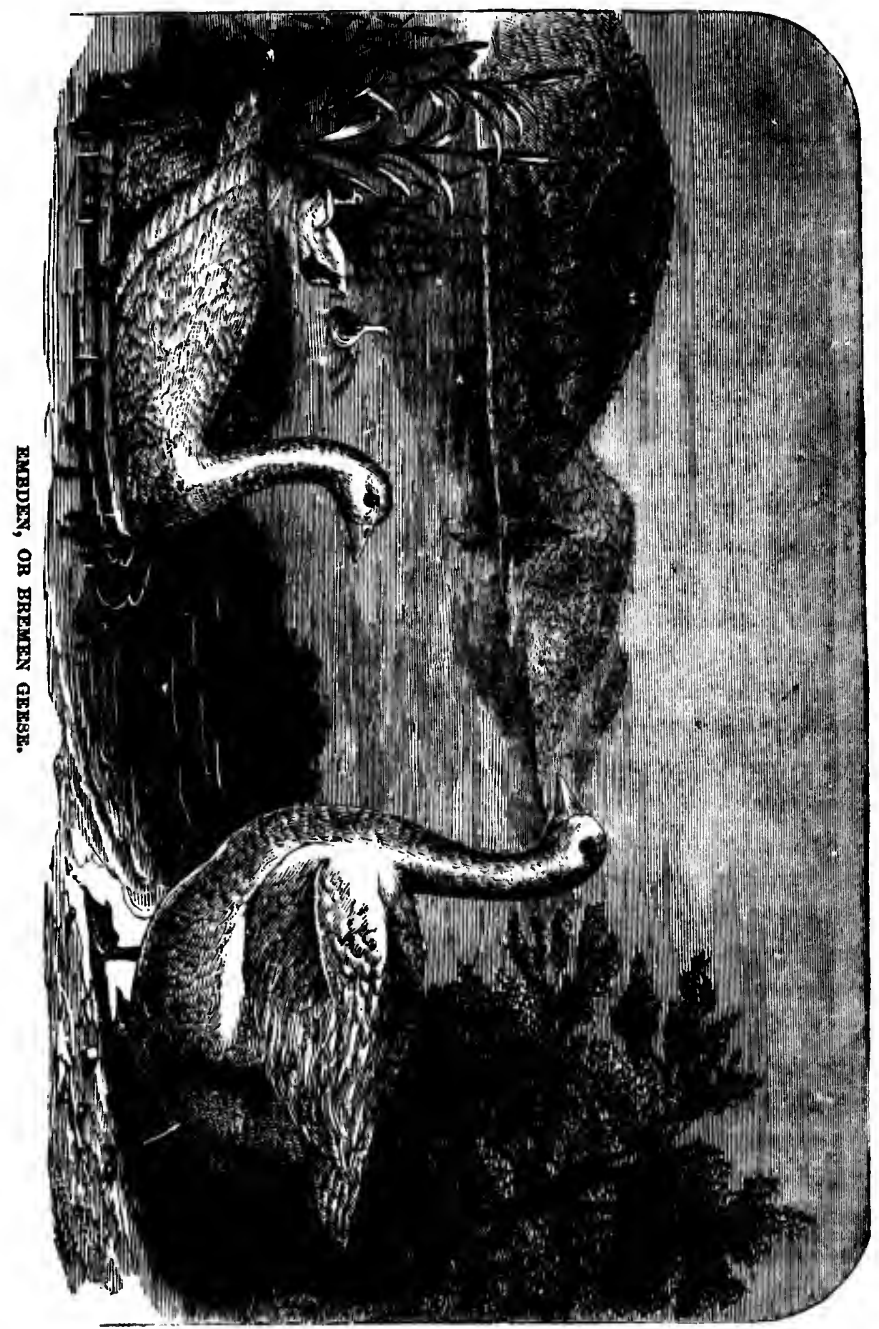

wild and domestic animals of our time to the savage Indian, whose fancy leads him to accept the name of various wild beasts and birds as his own. 
The fact is, the domestication of wild fowls is exceedingly easy, as has been proved within the last three hundred years by the domestication of the wild turkey of America, (meleagris) of which there are but two species known, M. Occellata, a native of Mexico and Honduras, and $M$. Gallopavo, from which oul common domestic varieties have descended. Later the American wild goose, (anser canadensis), a distinct species from the gray legged gọose of the North of Europe, and the supposed ancestor of the common white or gray goose, and the Embden or Bremen goose.

Besides Europe and America, Asia and Africa have furnished us with four sub-varieties of geese, three of which are called China geese, the fourth being the African or Hong Kong variety.

Africa has also furnished us with the Guinea fowl,(Numidia melexgris) called Pintado by the Spanish. It is a native of Northern Africa, where it is still found wild in large numbers, in some parts. The Pea fowl, (Pavo cristatus) has also been known from the remotest antiquity and is often used by ancient writers as an emblem of pride and arrogance, and it may be added, what is also true of the arrogant and strutting turkey, it is as cowardly as it is arrogant and cruel.

The pheasant may here be noticed as a breed long half domesticated, and yet never brought perfectly under the domestication of man. The probable reason for this is that like the Peacock, they have always been considered more ornamental than useful. There are four or five distinct and beautiful species, that as ornamental breeds in parks should be more extensively bred than they are.

The Swan is another breed long known in history and yet which cannot be considered of spccial value, except as ornaments in artificial lakes in the parks and grounds of the wealthy. Their dying song is often quioted from classic literature; so far no one has yet been charmed with its song in modern times, which may prove one of two conclusions, either the ancients were satisfied with a yery low order of vocality, or else the modern taste for musical sounds has become too refined to appreciate the notes of the swan either in health or sickness.

The duck seems to have been one of the most easily domesticated of fowls, and if the varieties are not excessively multiplied, it is because they are not considered a delicacy, and comparatively little uscd as food. Nevertheless, we think them underestimated. Some varieties are very beautiful in plumage; they are handsome in the water, and their flesh is by no means to be despised. Among the most valuable varieties are the Aylesbury ducks, a prominent English breed, an illustration of which we give. 
easy, as has estication of out two speas, and M. o descended. species from osed ancestor remen goose. ished us with na geese, the

dia meleagris) Africa, where The Pea fowl, intiquity and is arrogance, and rutting turkey, f domesticated, of man. The ave always been $r$ or five distinct should be more yet which cannot artificial lakes in $g$ is often quioted ned with its song usions, either the or else the modto appreciate the domesticated of it is because they e used as food. varieties are very and their flesh is varieties are the stration of which
Of the progenitore of barn-yard fowls (Gallus), there are several wild species. Among these may be mentioned the Sonnerat fowl, discovered by the naturalist of that nume in the Ghautes, which separates Mulabar from Coramandel, a thoroughly wild species never yet tamed. Sonnerat was probably mistaken in supposiug they were the primitive type of our

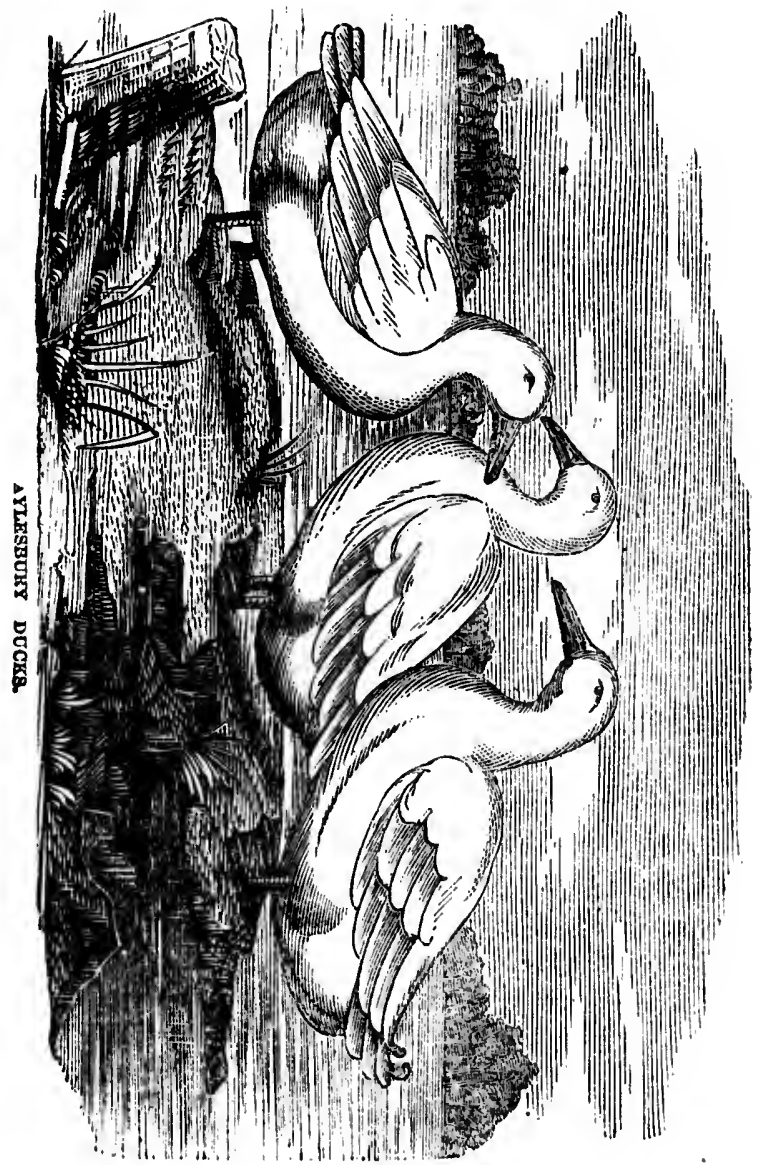

domestic tribe. Damphier had previously found wild cocks in the islands of the Indian Archipelago, that are now known to nearly approximate ours. The Bankiva species in Java, and the Kulm or gigantic cock of 57 
Sumatra and Southern Asia-the jungle fowl of the continent of India, may also lay claim to being the progenitors of our domestic fowls, as well as the species named after the egotistic Sommerit. In India our farm fowls are believed to have sprung from the jungle cock and wild species of Malay and Chittagoney.

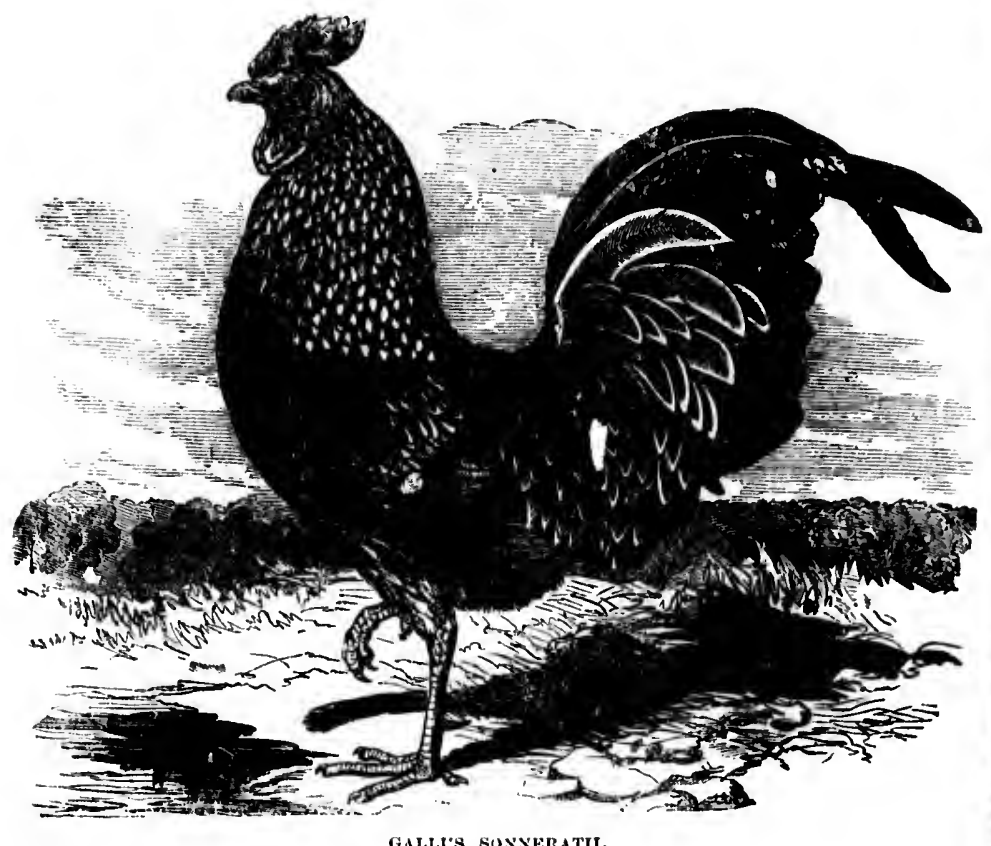

Gallets SWNERatit.

Our Bantams are undonbtedly splung from the Bankiva jungle fowl. Our large Asiatic from the gront Malay and Chittagong races through long generations of breeding and selection in China. Whatever the races from whence they sprung, the wild types are now very scarce and difficult to find, while domestic fowls, in their almost infinite varieties, are found not only in every farm-yard and village lot, but are bred extelsively and successfully in our largest cities.

But wild fowls, of the genus Gallus, are also natives of the Brazillian forests of America. Oliver de Serres writes of them as follows :

"In traveling over the gloomy and inextricable forests of Guiana, when the dawn of day began to appear, amidst the immense forests of lofty trees which fall under the stroke of time only, I often heard a crowing 
of India, fowls, as India our and wild

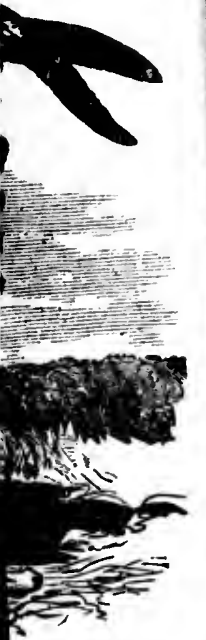

iva jungle fowl. if races through hatever the races scarce and difiite varieties, are are lored exten-

of the Brazillian follows : of Guiana, when forests of lofty heard a crowing similar to that of our cocks, but only weaker. The considerable distance which separated me from every inhabited place, could not allow one to think this crowing produced by domesticated birds; and the natives of those parts, who were in company with me, assured me it was the noise of wild cocks. Every one of the colony of Cayenne, who has gone very far up the country, gives the sime account of these wild fowl. I have ceen one myself. They have the same forms, the fleshy comb on the head, the gait of our fowls, only that they are smaller, being hardly harger than the common pigeon : their plumnge is brown or rufous.

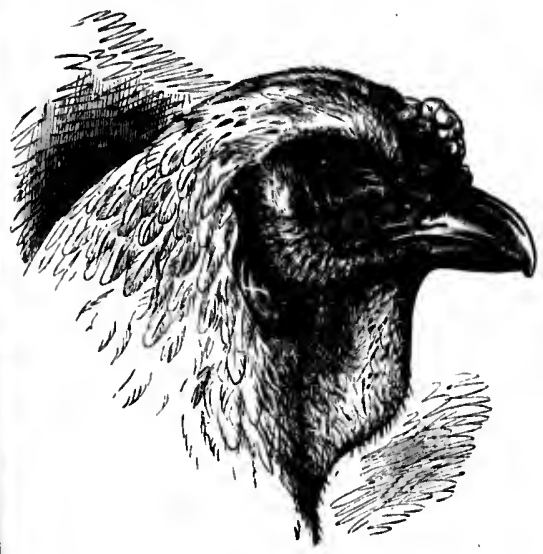

HEAD OF SINGLE-WATTLED HRAHMA FOWL,

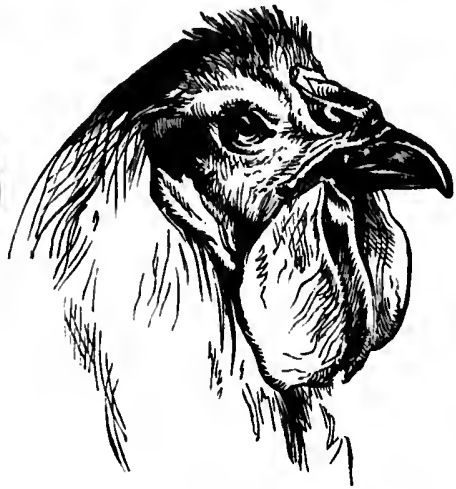

IIEAW OF BREDA, OR GUELDRE.
Before this the wild fowls of America had been mentioned. The Spaniard, Acosta, provincial of the Jesuits of Peru, has positively said that fowls existed there before the arrival of his countrymen, and that they were called in the language of the country, talpa, and their eggs ponto. We are not aware that this species has ever been brought into a state of domesticity, or that the wild species has ever been taken and reared. The wilds of the great South American forests are yet as a raled book, in many respects, to the naturalist. Under the regime of the present practical and scholarly Emperor, this, in Brazil, is being changed, and gradually this immense territory will be made to yield not only inercased stores to our ornithological knowledge, but also in other departments of practical art and science.

Our domestic poultry nay be divided into four groups, each of which Fill be separately considered. 
1. Our Common Barn-yard fowls.

2. Asiatic fowls.

3. Games, including Game Bantams.

4. Pet Bantams.

In the flrst group we shall notice English, American and continental families. In the second group all Asiatic breeds. In the third group all the more important Games, and in the fourth group all the better known small varieties of Bantams, except Games, both smooth and feathered legged.

On the preceding page we give illustrations of two curious varieties in domestic fowls, one in a sub-family of Brahmas, the other in a family of fowls of Dutch origin. 
ontinental 1 group all ter known feathered

us varicties ChaPTER II.

\section{VARHETUES OF BARN-YARD FOWLS.}

2. DORKING FOWLS, - L. SILVEH GRKY DORKINGS. - III. BLACK DORKINGS, - IV, TAWF COLORED DORKINGS. - V. BOLTON GRKYY. VI. DOMINIQUE gowLs. VIX. ILYMOUTI ROCKS. - VII. THE OSTRICI FowLs. — IX. IIAMBURa FowLs. - $X$. BLACE HAMBURGS. - XI. LEGIORNS, - XI, WIITh LEGHORNS. - XIII. BPANISH FOWLY. XIV. FRENCII FOWLS. -XV. THE IOUDANS.-XVI. LA YLECHE YOWLS.-XVII. THB CREVE COEURS. - XVII. LARGF ASTATIO BREEDS. - XIX. TRK CHITTAGONG. - XX.

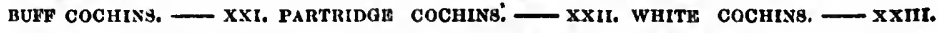
BRAHMA FOWLS._-XXIV. LIGUT BRAKMAS. XXV. FRIZZLED FOWLS. - XXVI. SILKIES. - XXVIT. DREDA, OR GUELDRE FOWLS. - XXVIIT. GAMR FOWLS.- 1 - BROWXBRKASTHD REDS. - 2. KARL DERBY GAME. - 3. DUCK-WINGHD GAMF. - 4. WHTT GHORGIAN GAME. - - 0. GAME BANTAMS. - 6. OTIER BANTAMS.- -7. SEABRIGHT BAMTAMS. - 8. JAPANESH BANTAMS.

\section{Dorking Fowls.}

Of distinet English breeds the Dorkings have become the most celebrated. Of these the White Dorking of Surrey is the typical fowl. It is, as compared with the so-called dung-hill fowls, large, often weighing, the mature cocks fully ten pounds, the hens eight to rine pounds, and at a year old from six to eight pounds. They are of good size, plump, compact, with strong heads, full wattled, and with single serrated comb, short neeks, short white legs, with five toes, and full plump breast, the plumage pure white and without spot. They are tolerably hardy, good laycrs and most exeellent mothers. The illustration on following page is a representative of this breed. 


\section{Silver Gray Dorking.}

This variety is considered to be a sport of the White Dorking perpetuated by careful breeding and selection. With stock from families that have been carefully bred by careful selection they miny be kept to the standard. But they vary much in color, the dark varietios of ten producing silver gray chicks.

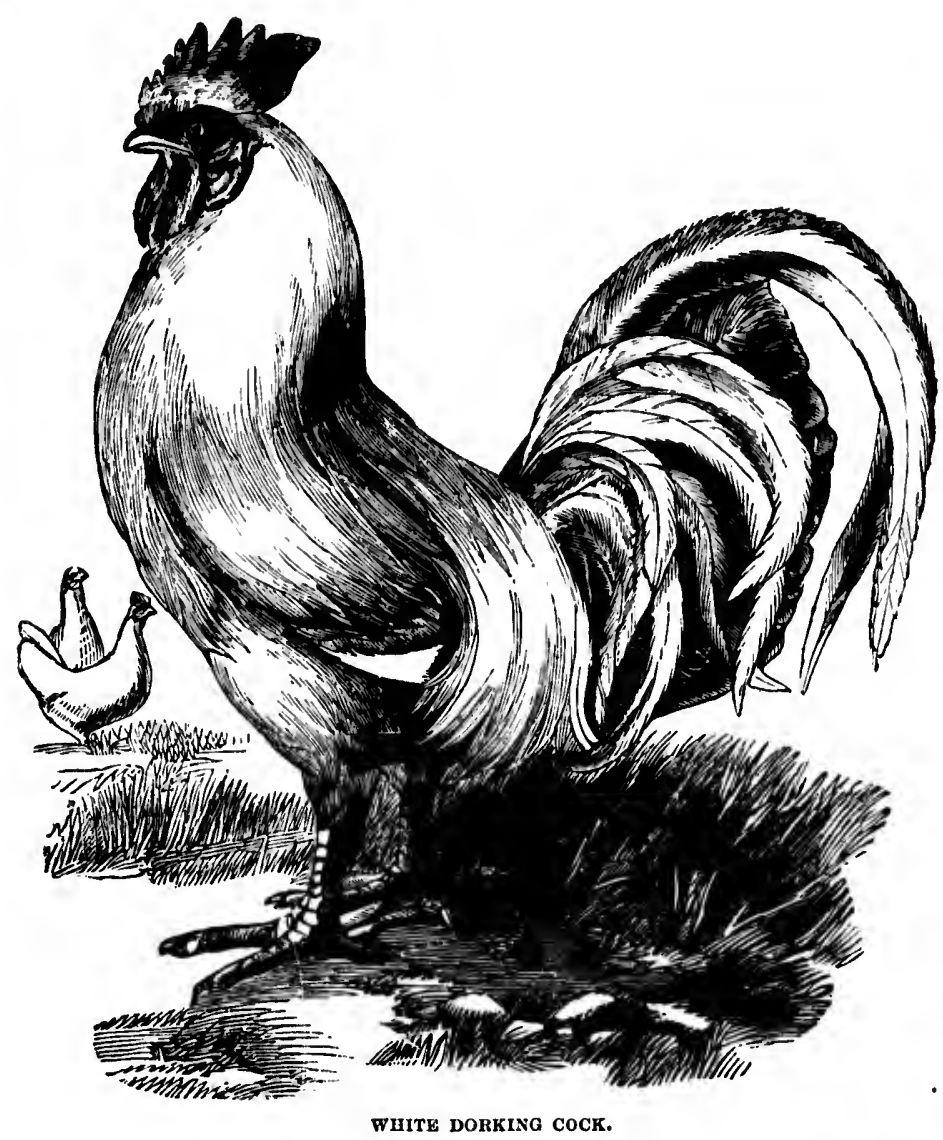

The Gray Dorkings are rapid growers, and if well supplied with food are in condition for the table at any age, often before they fairly get their feathers. The distinguishing colors are : breast, tail and larger tail feathers perfectly black; the head, neck, hackle, back, saddle, and wing 
bow a clenr, pure, silvery white, und neross tho wings a well defined black bar, in striking contrust with the white ontside web of the quill feathers and the white hnckle of the neck mud saddle. The neck of the hen is

ig perpetumilies that rept to the il producing

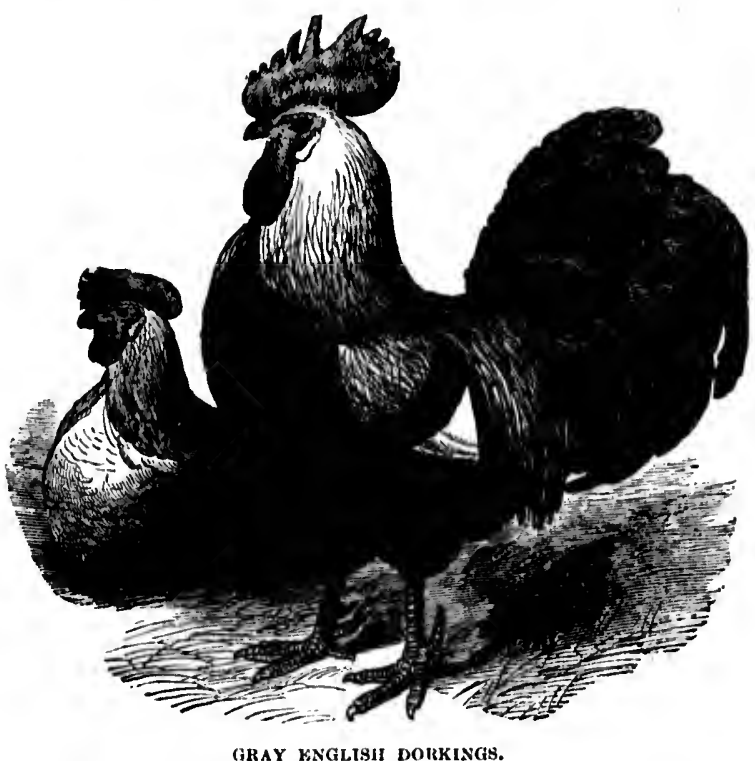

silvery white, the brenst salmon-red, changing to gray near the thighs; the wings silvery or slate gray, and without any tinge of red whatever. The tail should be dnrk gray, the inside nearly black.

\section{Black Dorkings.}

This sub-family are jet black in color, the neck feathers of some of the cocks tinged with gold, and of the hens tinged silvery: The comb may be either rose or single but usually double, short and sometimes cupped; wattles quite sinall and very red near the head. The tail feathers shorter and broader than those of the white variety; the legs black, short, and with the two under toes quite distinct and separate, sometimes showing a rudimentary toe. They are hardy, the hens are grod layers, good setters and eareful nurses, and the eggs are of a large size.

\section{Fawn-colored Dorkings.}

These are handsome birds of high carriage, said to have been produced by a eross between the Whito Dorking and fawn-colored Turkish fowl. 
Their tails ure shorter than any other viriety of Dorkings and the legs black. 'The cocks will weigh from eight to nine pounds nud the hens from six to seven. 'They luve remarkably fino flesh and lay large eggs. In relation to the Dorkings as a class, wo have found them not well adapted to stand wet, colll weather. Yet with proper cure they aro the best of the distinct English breeds.

\section{Bolton Gray.}

This breed, sometimes callod Creole, used to be in good repute in England, and wore bred with such nicety thut individunls could senreely bo distinguished upurt. Thoy aro great layers, but poor setters, and when eurefully bred nro ono of the best breeds for the farm yard. They are a medium sized, plunp, short-legged fowl; neck and body purm white thickly spotted with black, black burs at tho extremity of tho tril.

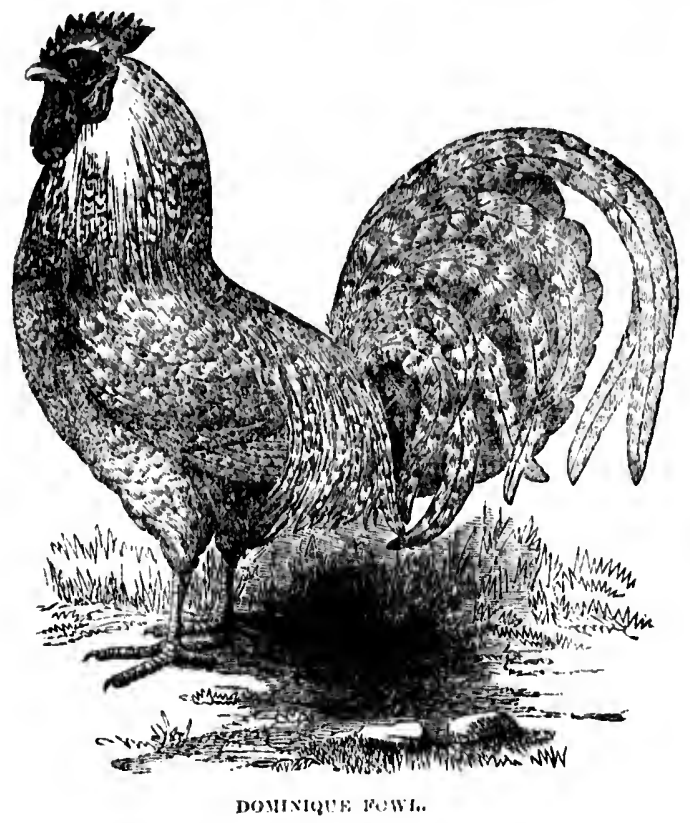

The hens are constant latyers, but the egges, although of grood quality, are rather sinall, weighing about ono and a half ounces each. They are comparatively rare in the United States.

\section{Dominique Fowls.}

The Dominique, a distinctly American breod, and for the ordinary farmer, where hardines:, fecundity, good laying propensity, and excel- 
in the legys d) the hens lingo eggs. in not well hey are the

il repute in ould semreely sotters, und yard. They al borly pure $y$ of tho tuil.

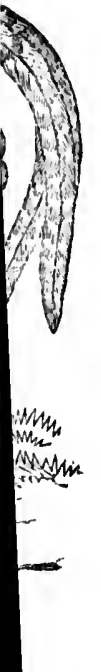

good quality, ure each. They are

for the ordinary pensity, and excel- lence of thesh is concern $h$, in one of the very hent in existence. They breel constant in color, mndiugs, comstitution mul vigor, and aro always well able to take care of themselves.

The true color of the Dominique is a light grommel undulated and penciled in thesoftest manner with slaty blue-almost black-forming bands all over tho body. 'The hens and coeks nre shaded alike except that the plumuge of the erak is more distinct, often with golden inckles, and bronzed wings. The comb of the cock may be either single or double, but, we prefer the single comb, as most indicative it the true type. The iris of the eye is a bright ormge, and the bill and legs a bright yellow or buff color. 'They ure square built, brond breasted, rather short lerged fowls, with little oflinl, and with bigh llavored and profitable flesh; elegant in plumnge, mil a hardy, healthy, profitable and prolific ruce of birds.

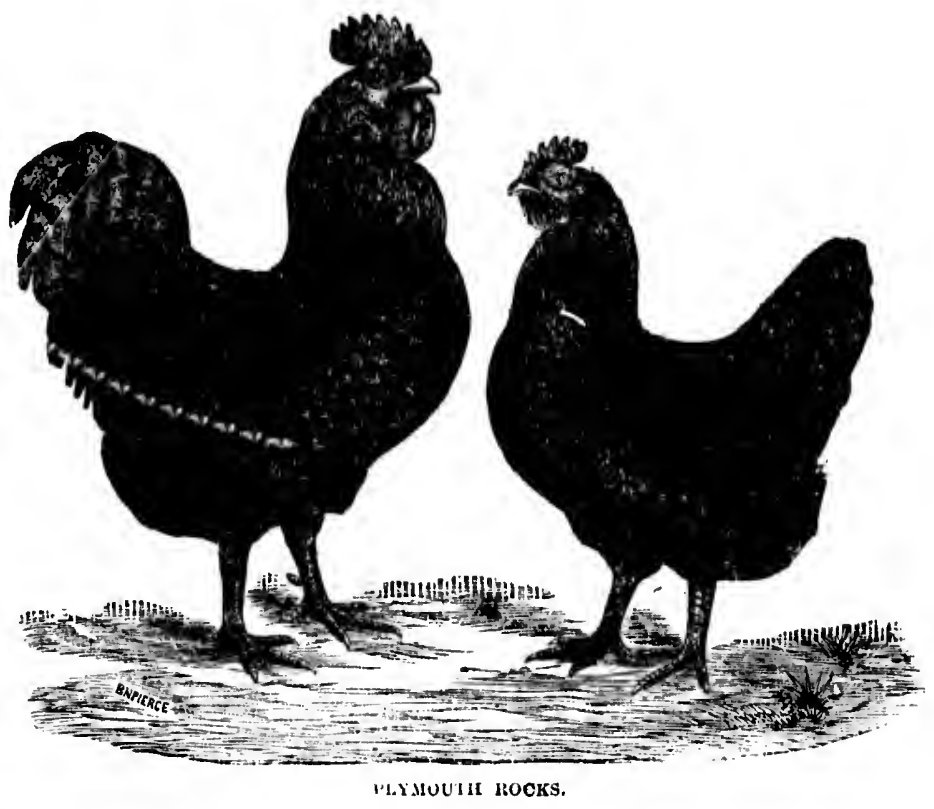

VII. Plymouth Rocka.

This is a modern American breed originated by Dr. Y. C. Bennett, and fist shown at Boston in 1840 Sail to have been produced by in cross of a Cochin-China cock, with a hen, herself a cross between the fawn-colored 
Dorking, the large Malay, and the Wild Indian fowl. Fanciers becoming interested in this breed, it was very considerably disseminated, but fniled to give satisfarion on account of the want of uniformity in the chickens either in marking or form. Much bitter controversy has ensued, which shows that there were several different origins, in which the Java, Cochin, Gray Chattagongs, Dominique, Gray Dorking, and even the eommon dunghill fowl tigured. Of late years fowls have been produced under the name of Improved Plymouth Rocks, the modern style showing excellent and uniform breeding. A fowl that grows rapidly, fledges early, making flesh fist, and which in the hands of expert fanciers, conbines many of the most excellent qualities to be desired, either as layers or as table birds.

\section{The Ostrich Fowls.}

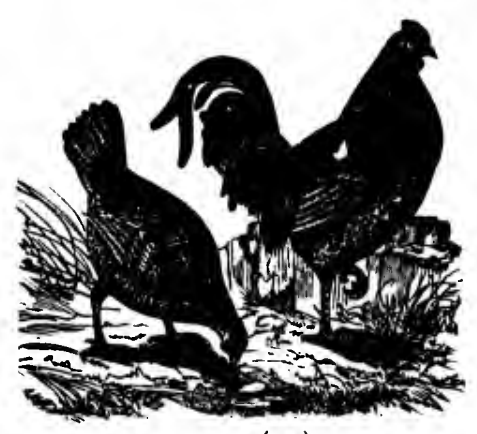

BUCKS COUNTY, (PA.) Howls.

This excellent breed originated in Bucks county, Pa., and were called Bucks county fowls. The cocks of this variety will average nine pounds. 'They are good layers, sometimes producing forty or fifty eggs before becoming broody. The eggs are large and of good flavor; the flesh white, tirm, and of excellent quality. The color of the eock is a dark blueblack; the ends of the feathers tipped with white; wings a yellow or golden tinge; hackle dark, glossy blue. A double rose comb surmounts the head with large wattles beneath. The carriage is bold and alert. The hen is similarly colored, but more sober in shade, with a plump, thick hody, a high serrate single comb, wattles large, and legs short and of a dark color.

\section{Hamburg Fowls.}

The Hamburg fowls all have these characteristies: They have bright double combs, firmly fixed, and ending in a long point turned up behind. They are of medium size, of sprightly carriage; tails large and held upright with long plume feathers; of robust constitutions, great layers, seldom broody; in faet, nlmost never, when kept in confinement. The eggs are small but of excellent flavor.

\section{Black Hamburgs.}

This is probably the best variety of the family for farmers, und in fact one of the very best of the black fowls. Possessing the two-fold value 
ers becoming ed, but failed the chickens Thas ensued, hich the Jatia, even the conneen produced in style showapidly, fledges fanciers, colnaither as layers

d originated in id were called The cocks of re nine pounds. sometimes proeggs befor's beeggs are large the flesh white, it quality. The a dark bluee feathers tipped yellow or goldcomb surmounts bold and alert. , with a plump, hd legs short and

'They have bright turned up behind. ls large and held ions, great layers, confinement. The armers, and in fact the two-fold value of beillg alert, noble looking, handsome fowls, color deep black with a metalic luster; hardy, robust, and the hens constant layers.

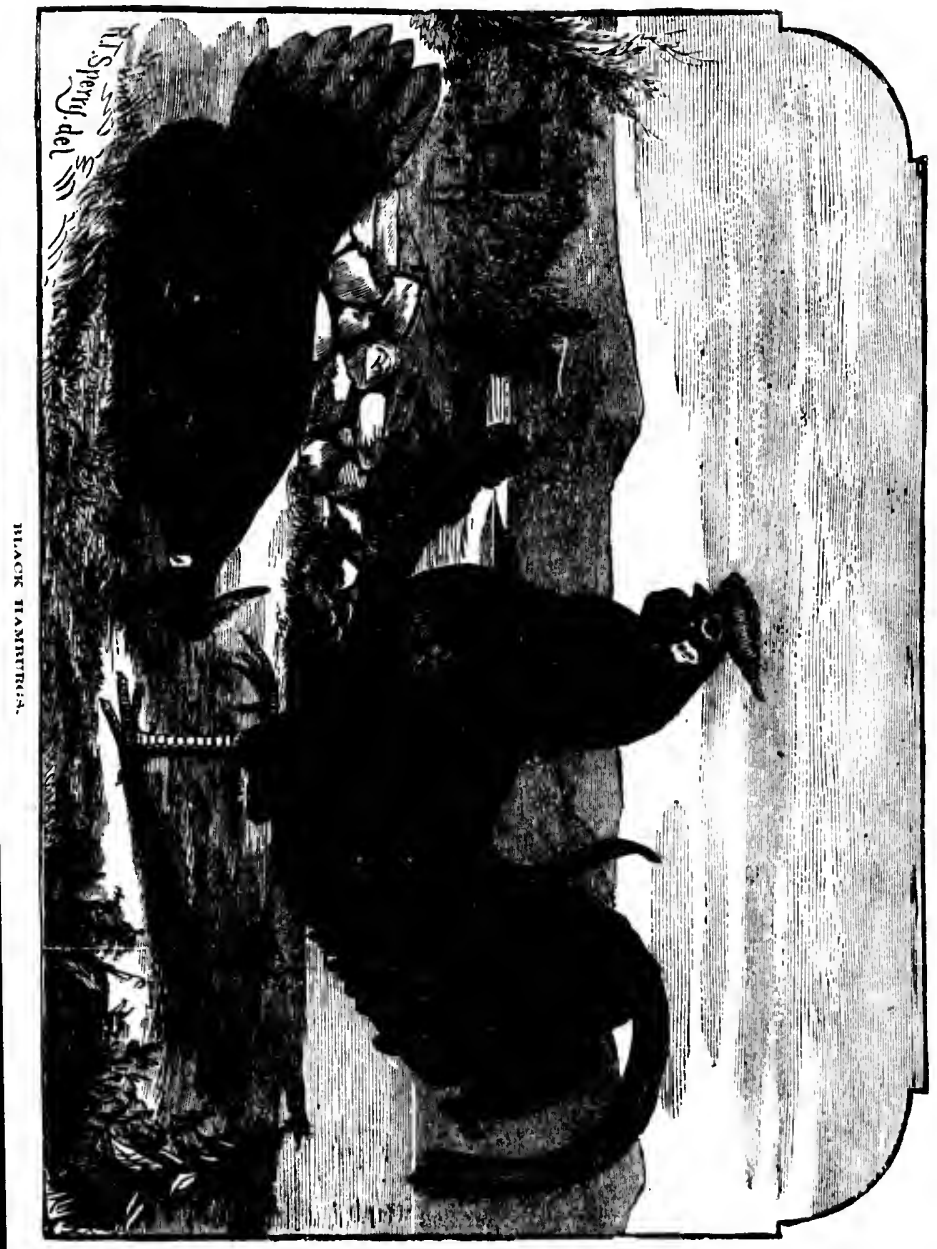

Peneiled Hamburge.

These are of two varieties, the Silver and Golden. In the Silvered sub-f:tmily, the ground color is silver-white, sometimes rith $n$ slight yellow tinge, but every feather margined with the most glossy black. The 
cocks of either variety exhibit the pencilings, as do the hers, but are white or brown in the Silvered or Golden breeds respectively.

There are few, if any, more striking fowls than these in the hands of expert and careful breeders, with their symmetrical, gay and upright carriage, their well-defined deaf eurs, elegant combs and wattles, their ample, well-feathered tails, and fine-boned, taper, blue legs.

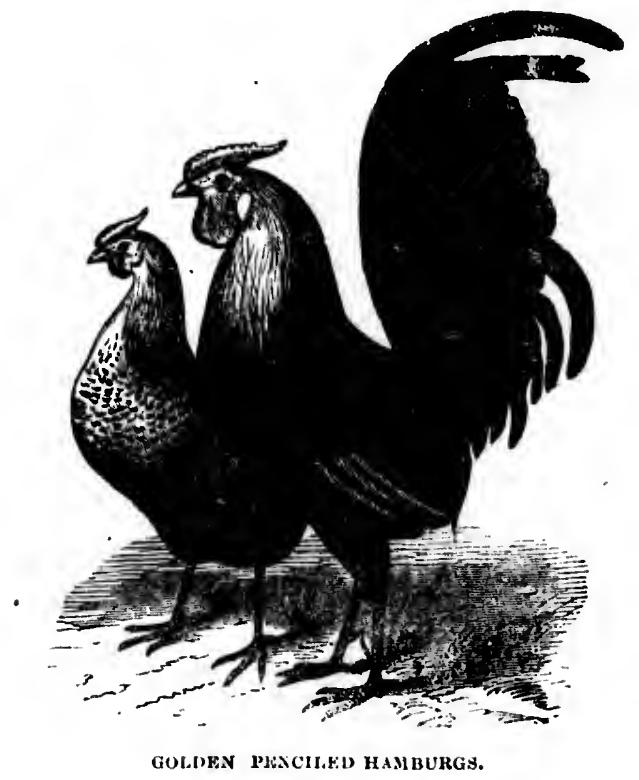

The hens of both varieties must luve the body clearly and definitely penciled, and the hackles of both cocks and hens must be entirely free from dark marks. The engraving which we give fully illustrates the characteristics of the several varieties. As funcier fowls they are superh; as farm fowls delicate.

\section{Leghorns.}

This admirable breed of Luropenn fowls has become widely disseninated in the United States, being valned for their many good qualities, among which are beuty and constant laying propensities. They are bred by fanciers of all colors from whito to black.

\section{Whito Leghorns.}

White Leghorns are, wo think, the most valuable to the farmer as they 
ners, but are y. the hands of and upright wattles, their

Hy and detinitely t be entirely free lly illustrites the s they are sujerh;

ne widely dissemny good qualities, isities. They are

the farmer us they are the handsomest. 'The deseription of this variety will suffice for all, excepting color.

The Whites ure in size nbout that of the Spanish, and like the Spanish the combs of the best hens lop over on one side. 'The plumage is white with hackle feathers slightly golden tinged, the rest of the feathers pure white. They ure compraratively a hardy breed, standing extremes of

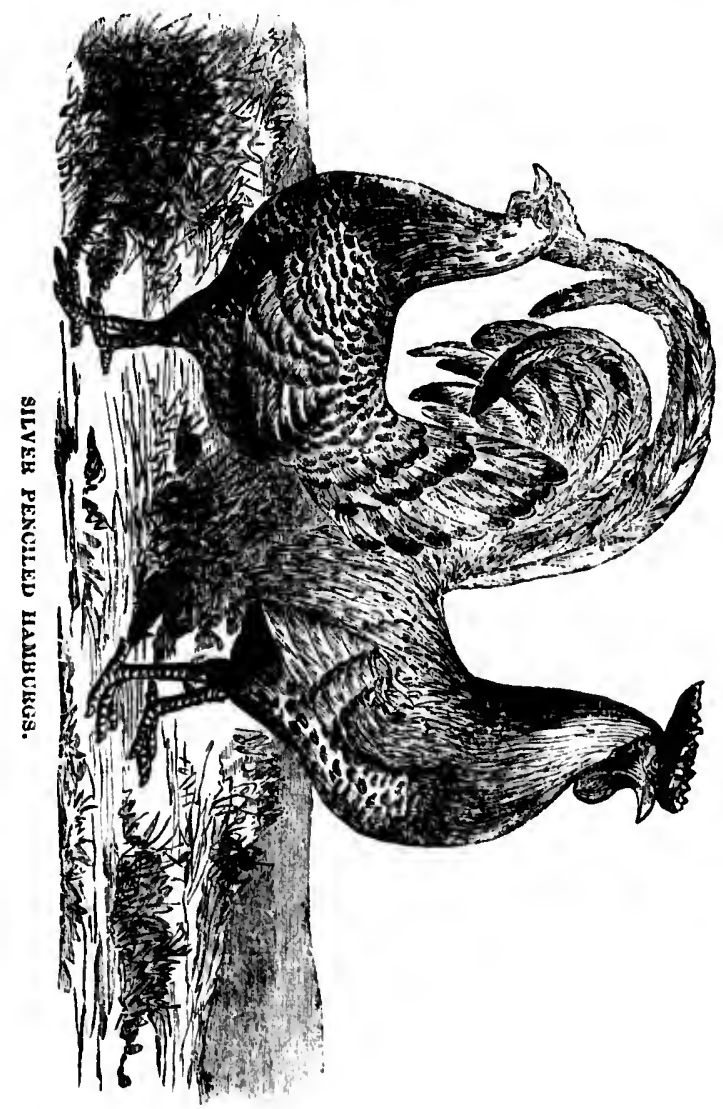

cold and sudden changer finirly, except that their immense single combe are liable to freeze in Winter. The hens are persistent layers, and especially good Winter layers, when they ure kept comfortably housed, and seldom incline to set. The legs and skin are yellow. The cocks bave large single perfectly ereet serrate combs; the divisions being in $x^{\prime-\infty}$ 
fact spiked. The wattles are full and large, with white or eream colored ear lobes, extending sometimes up on the face. The chicks are hardy, good foragers, feather early, and at the age of six to eight weeks are miniature fowls, showing much of the stature and grace of the mature fowl.

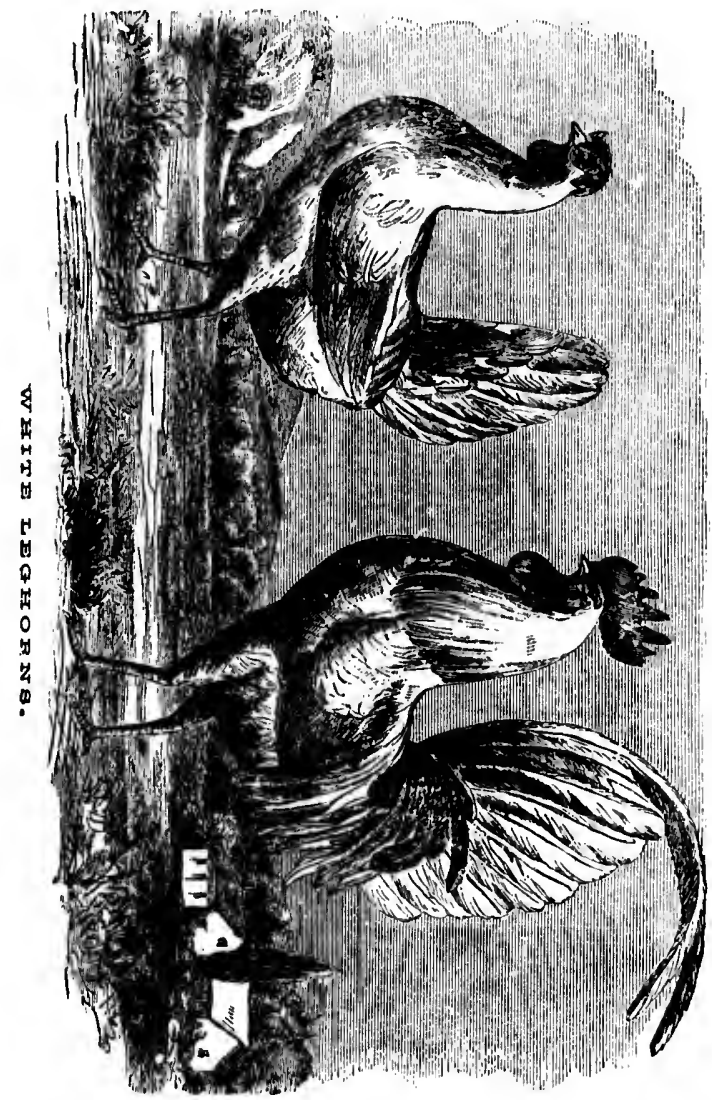

The cut will show what wouid be considered prize fowls in any show ring.

\section{Spanish Fowls.}

The Spanish fowls in their several varieties have long been known and justly esteemed in the United States for their great laying and non-setting propensities. The whole race, however, are rather tender as far as cold 
Fleche, in France, where they are most commonly raised. Besides these there are several other varjeties of useful and ornamental breeds known in France as, first, the de Breda, de Breese, Court Paltas, and du Mans, and among the ornamental varieties the Chamois, Hollindais, Hermines and Padoue. The Bredas have already been described.

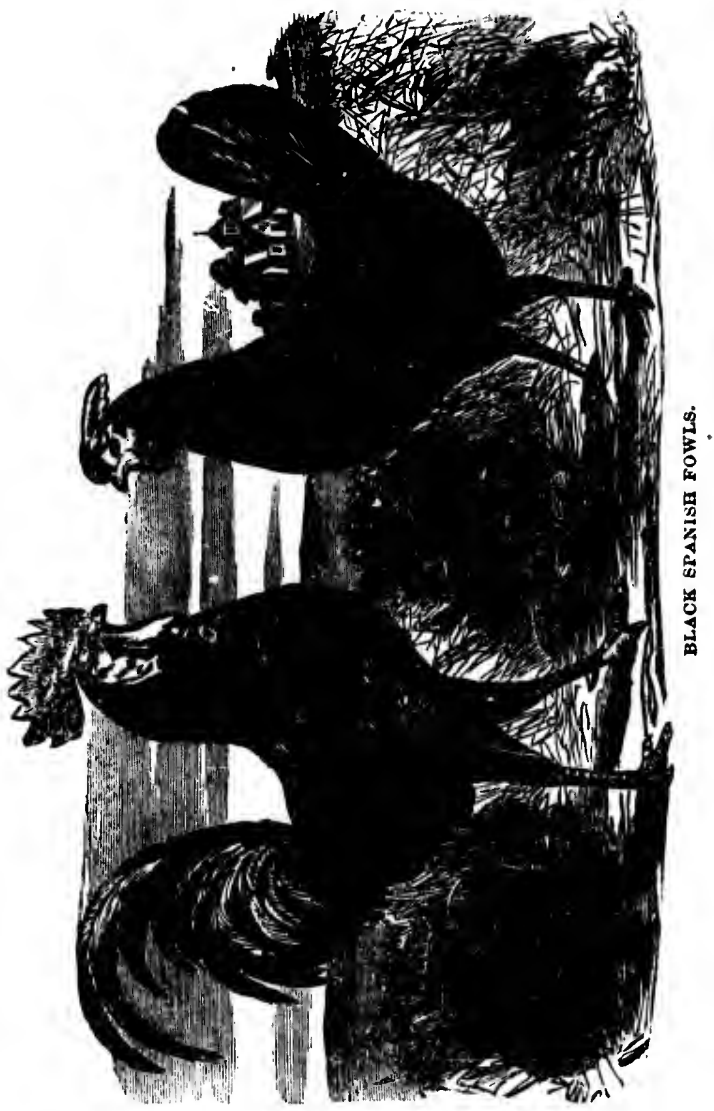

XV. The Houdans.

Thase fowls are held in Franee in fully as high estumation as are the Jorizings in England. They are hardy, easily raised, fatten kindly, lay good sized eggs, and are of a most excellent quality of flesh. They are a five-toed race, and are reported to have originated between a cross of 
the Dorking and the Silver Padoue. They should be of a white and black color, evenly distributed, making them distinctly speckled. Red feathers are not admissible, but an occasional stained feather is sometimes seen in the best fowls. They are very French-like, sprightly, vivacious, loving to wander, but bearing confinement well. The comb is double leafed, and they have whiskers and beard growing well up on their face, which, with the crest or top-knot, gives them a curious and yet striking appearance. The crest of the hen especially being thick and full. In shape they resemble the Dorking, but are less in size. In every respect they are brilliant and striking in appearance.

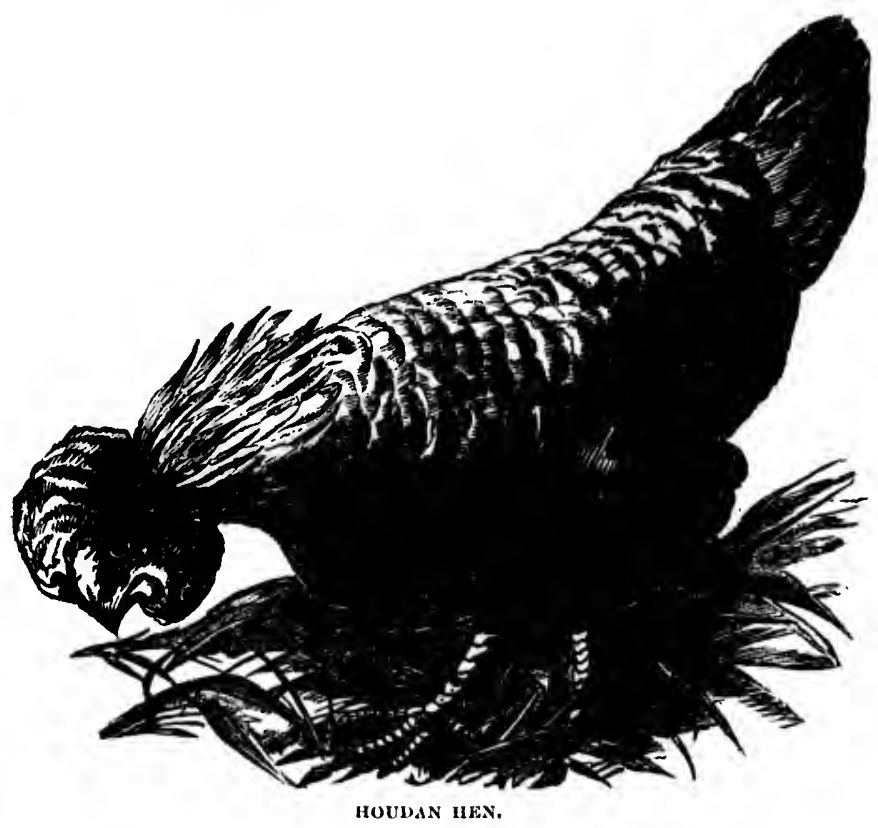

XVI. La Fleche Fowls.

These handsome fowls are very tall but compact; in size equaling the Dorking; yet black, firmly knit, with strong, long limbs; the body rather angular, the plumage firm and dense. The head is handsome, with spikes of feathers behind the comb, looking like a double horn. They have small protuberances between the nostrils, which latter are full and expanded. They have large, opaque ear lobes, cravat like, very long 58 atten kindly, lay flesh. They are etween a cross of 
pendant wattles, II inoderately curved beak, neck hackles long and fine, reflecting violet and green-blick colors, as do the breast, wings and upper tail feathers. The legs are long, slate-blue in young fowls, and a leadgray when old. The hen is colored like the cock. The cocks arrive at their fill growth at eighteen months old ; the hen at twelve. 'The flesh is considered the finest and the most valuable for table uses of any French breed. Those familiar with them are pleased with no other.

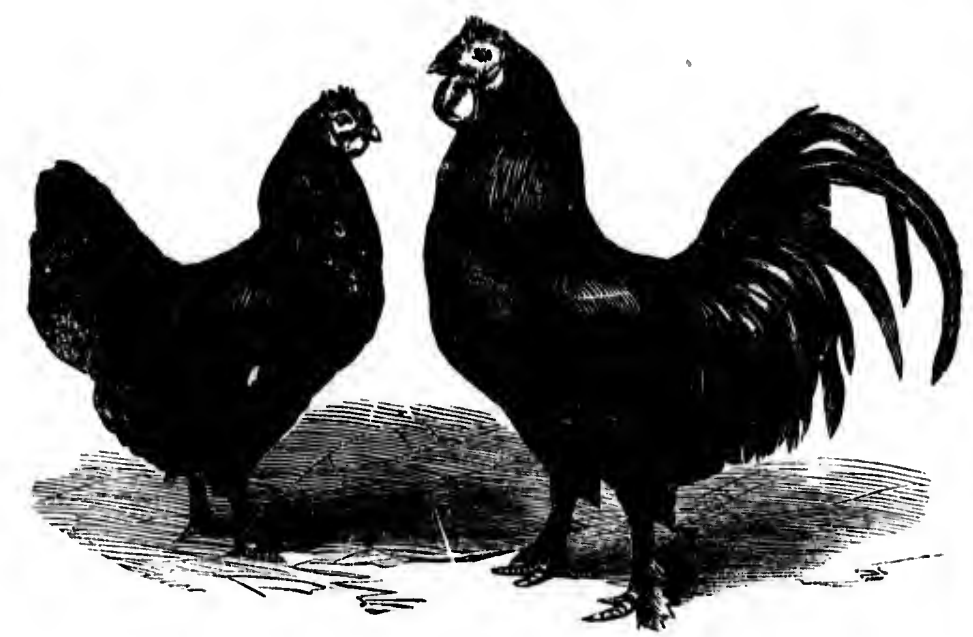

LA H.WCHE FOWI.t.

XVII. The Creve Coenrs.

Iiis is the most striking of the French breeds, their black crested heads being curiously relieved with decp crimson, forked or antlered-like comb. Their aspect is bold and stately, the plumage black, shaded with green, thick and shining. The comb must be conspicuous and fult, wattles long and deep, breast large, full and deep, the back straight not drooping. The legs should be strong, firm, leaden blue, in color, and short, with strong claws. The hen should have a soft, thick, round crest, and very little comb and wattles. The color must be entirely black, no other color being admissible in pure bred fowls. Old birds, however, will sometimes show an occasional white feather in the crest; a sort of turning gray. 
XVIII. Large Asiatio Breeds.

Of the numerous breeds and sub-(livisions of these gigantic fowls, the Cochin-China and the Brabnus stand confessedly ut the head. The Shanghæs, and the Chittagongs have, of latc, fallen into disrepute, and

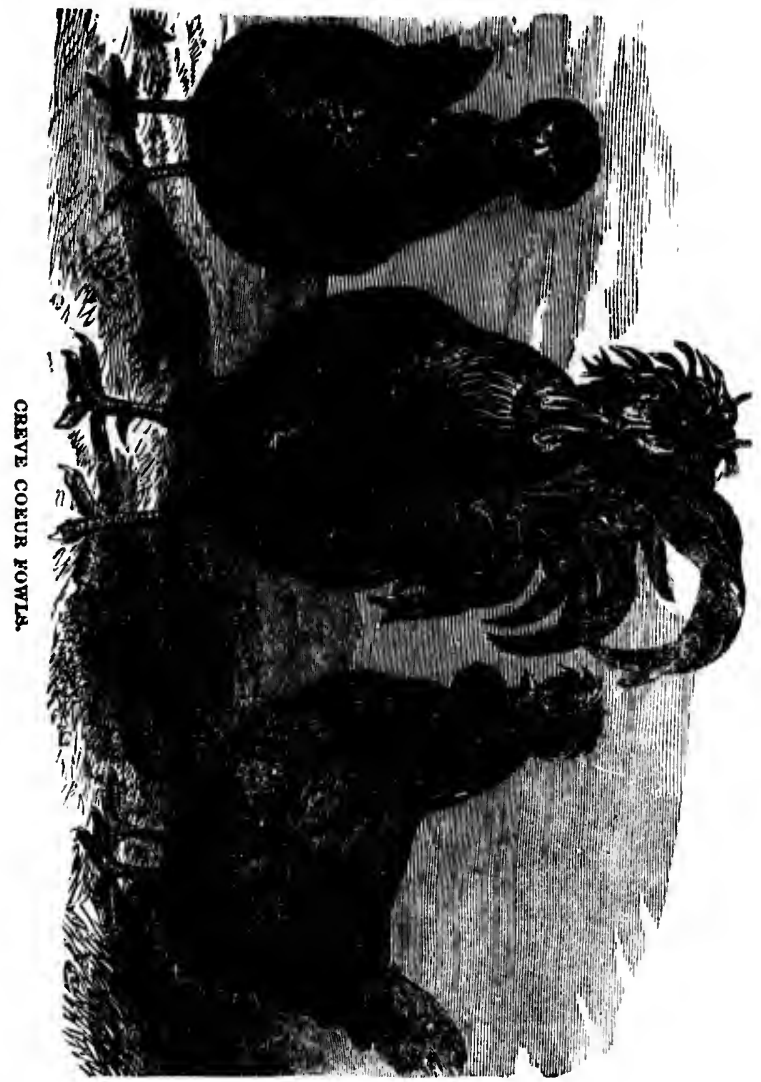

confessedly so, from the superiority of the Cochins and the Brahmas. In the Shanghe family there are vilious colors. Gray, buff, cinnamon, partridge-colored and black. 'Iwenty-tive years ago they were regarded with especial favor, from the fuct that they were of the then largest sizo known. It must be confessed that when bred pure they are quiet, good

black crested or antlered-like ck, shaded with cuous and full, pack straight not re, in color, and ft, thick, round be entirely black, birds, however, a sort of turning 
sitters and nurses, little inclined to rumble, and among the best foster mothers to other chickens thut can be found.

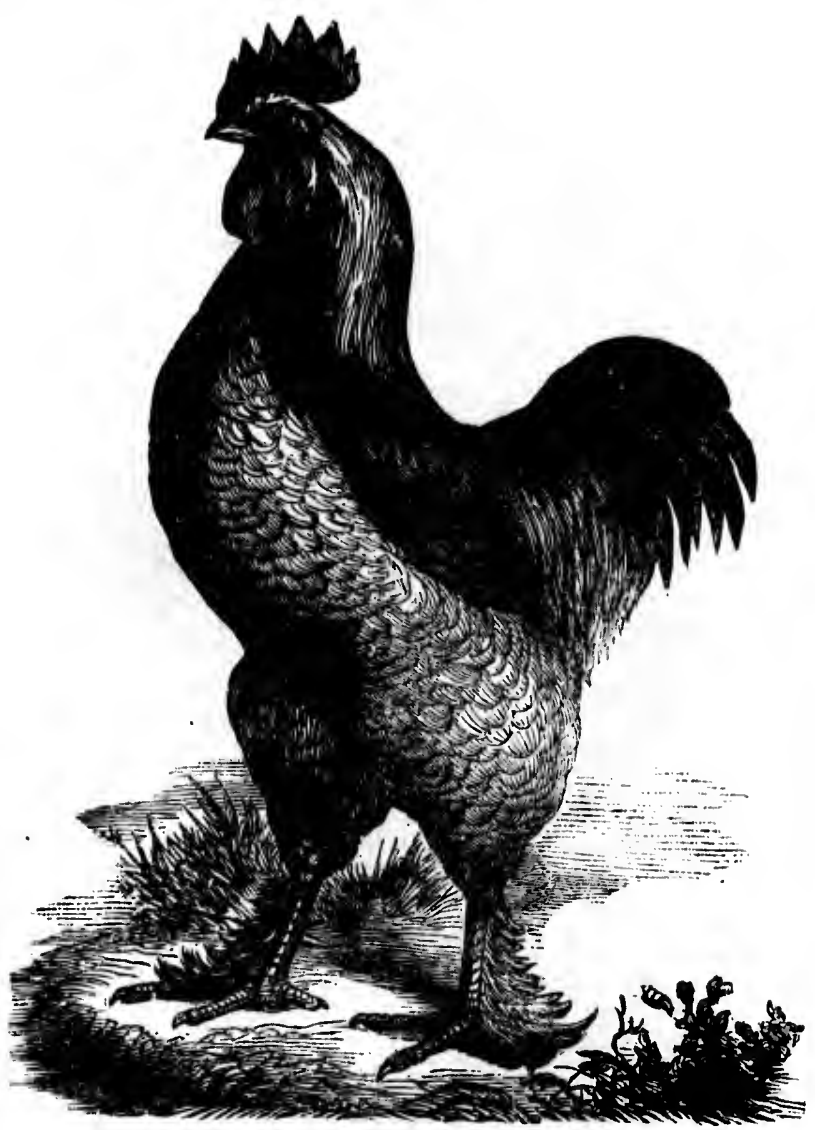

HLFF COCHLN COCK.

XIX. The Chittagong.

This is a giant among fowls, tho cock often standing twenty-six inches in height, and notwithstanding their long lors and necks, they are majestic looking. There aro two principal breeds, the gray being tho larger breed. In the dark red varicty the breast and thighs are black. The hens yellow or brown; legs in both sexes being yollow, heavily covered with black 
feathers, and the enrringe in all the varieties graceful, mujestio, prompt and easy.

\section{Buff Cochins.}

There are several varieties, in color buff, lemon, and cinnamon, the rosult of peenliar crosses and breeding. The buff is the true type of the colored sorts, and for utility we think the best. The coek should bo upright and strong in his carriage; brenst broad, not full, but forming a nearly straight line between the crop and thighs; back short and wide; iail only slightly raised; legs strong and with great thighs and saddles.

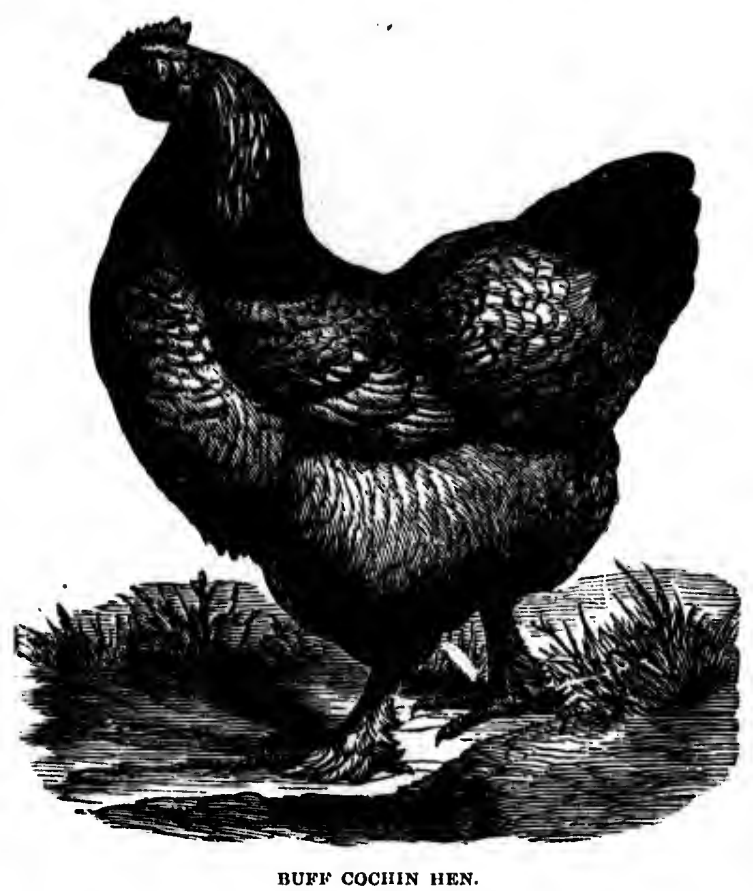

twenty-six inches they are majestic the larger bred. The hens yellow vered with black

The head is sinall, for so long in bird; the beak yellow, stout, short, ourved, and strong at the base; comb single, not large, and with rather sinall wattles, florid, thin and fine; the car lobes well developed, long, thin, fine, and entirely without white. The eye of the cock should be of an ochre-yellow color, and in the hen a darker hue. The hackle of the wek should be full, spreading over the thighs, and of a light bay color, 
and free from markings of my kincl. Tho hackle of the hen is a clean, distinct buff. A slight penciling is mlmimble, a durk colored one not. The saddlo of both eock mind hen slould be free from markings. A black tail in the eock is admirnblo, nnd if the principul feuthers ure bronzed, 80 much the botter. The brenst of both cock and hen should be clenr buff,

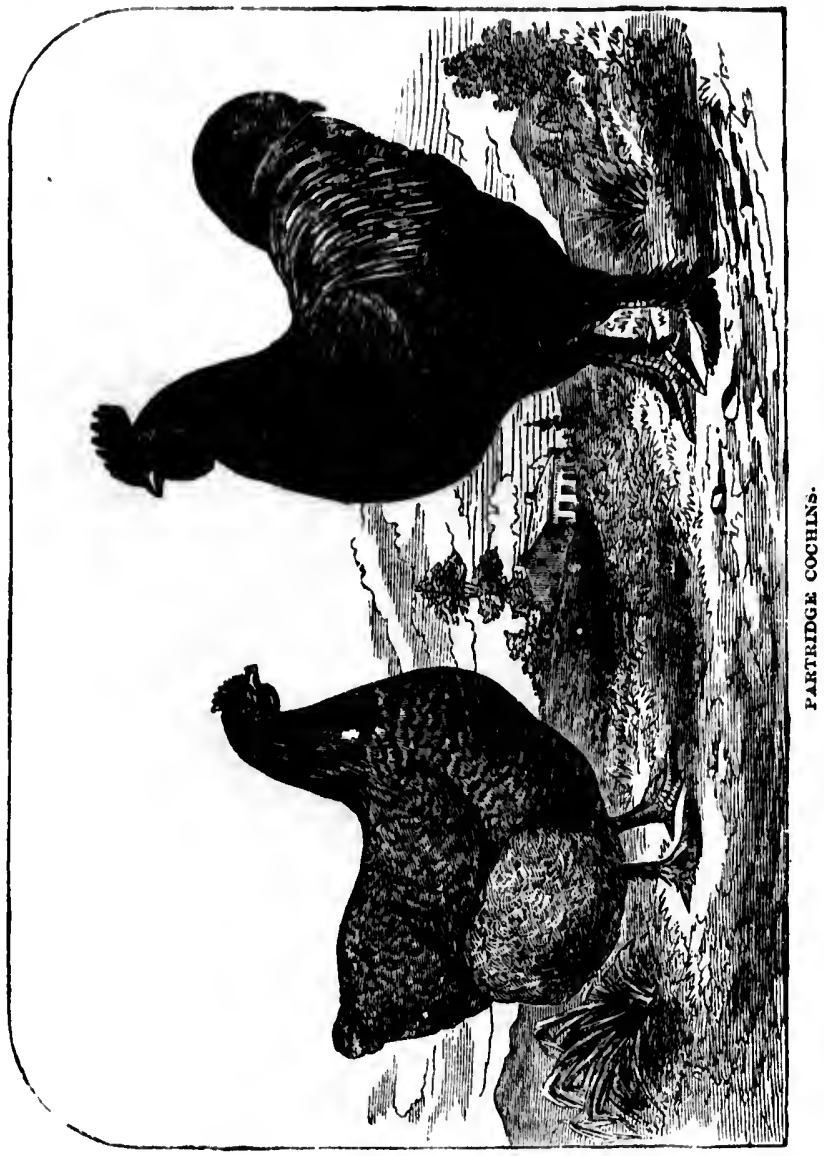

becoming ighter toward the tip, with is wivy ippearance in the sun, and both primary and secondary quill feathors shonld be buff, without other color. The legs should be heavily feathered, covering the outside toe, and partly the one behind. Vulture hocks, us shown in the Black Broda 
variety is not udmissible, as they not only show mixed blood, but are unsightly.

\section{Partridgo Cochins.}

'T'lose are udmirable fowls. Among the heaviest of the Asiatio breeds, attrict attention wherever shown, from their round, full, plump forms, elegant fenthering and majestio carringe. Merely as specimen birds they are objects of bentity.

'The head of the Partridge Cochin is a rich orange red. The hackle and suddle feathers the sume, but ench distinctly marked down the middle with a black stripe. The back, shoulder-coverts and wing are self colored, red and darker than the hackle; the lower wing-coverts black, with greenish or blue reflections forming " "bu" "ncross the wing; the primary wing feathers black, edged brown or buy on the lower edges; secondaries bay on the outer edges and black on the inner, encli feather black on the ond, forming a black edge on upper-side of the butts of the wings; the breast, thighs, tail and leg feathers black and without other color; the leg dusky yellow. The hen should have her hackle golden yellow, each feather striped black along the center, the rest of the plumage light brown, penciled with dark brown, the pencilings over the body should be dense, and the purer the brown the better. On the brenst the pencilings should be crescent shuped. Lcgs dusky yellow, penciled brown as in the body.

\section{White Cochins.}

White Cochins should be white, nure wisite all over. This purity in color is essential, since a yellow or other tinge detracts from the beauty of the bird. The cock should have a medium sized, straight, snooth, freely serrate comb, large, red, deaf enrs, large wattles, red eye, strong, yellow beak and legs, and with plenty of feathers on the feet. This feathering should be characteristie of all Cochins, nvoiding as far as possible any tendency to vulture hocks. Breed also to large stock, of good carringe, and you will have in the progeny as pretty a sight for fowts as conld well appear, either in the farm-yard or on the grass. Yon will also have real value, for such fowls as these will always command a market. Their eggs are large and of good quality, and their flesh is sweet.

The hen should be large; the head, heak, eve, deaf ears and wattles colored as in the cock. Avoid especially a grayish eye. It is supposed to show a tendency to blindness and a generally weak constitution. The body must be broad, the tail small, almost covered with the soft feathers about it, and with well feathered rumps and plenty of fluff.

o in the sun, and ff, without other the outside toe, the Black Breds 


\section{Brahma Fowls.}

These majestic fowls, said to have been originally brought from the banks of the Brahma-pootra river, which waters the fertile territory of

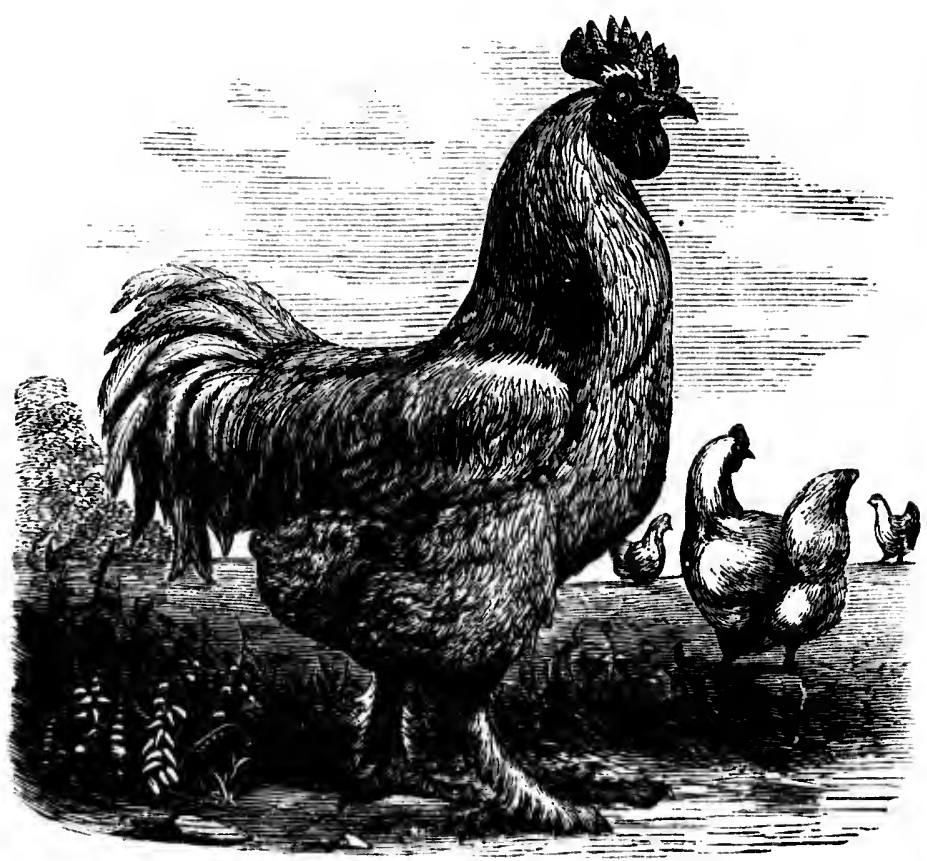

WHITE cochis fowts.

Assam, are divided into two classes, the light and dark, each having their special adnirers, and either good enough for any farm yard. As a mle however, the dark are more highly esteemed, and the fowls sell for higher prices than the light.

The head of the dark Brahma cock should havo a pea comb, that is, three combs runing parallel to each other, and with the length of the head, the middle ono the highest; the beak strong and curved, ear lobes red, and falling below the wattles, which should be full, and like the enr lobes, deep red; the neck short, well eurved, with the hackle ful: silver white, striped with black, and flowing over the back, and sides of the breast; the back strong, very short, wide, flat, the feathers almost white, the saddie feathers long and white, striped witl black; the tail small, sofr, upright, the feathers on the rise from the saddle to the tail, and the 
side feathers of the tail a pure lustrous black; the breast full, broad, rather prominent, the feathers pure black tipped with white, and the feathers at the head white; the saddle feathers and thigh fluffs ample; the wings cmall, with a good black bar across them; the wings well tucked under the sisddle fenthers and thigh fluffs: the fluff on the hinder

rht from the territory of

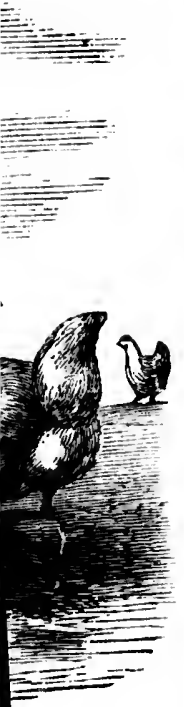

ach having their 11'd. As a rule fowls sell for comb, that is, e length of the urved, ear lobes ind like the ear rekle ful: silver d sides of the rs almost white, the tuil small, the tail, and the

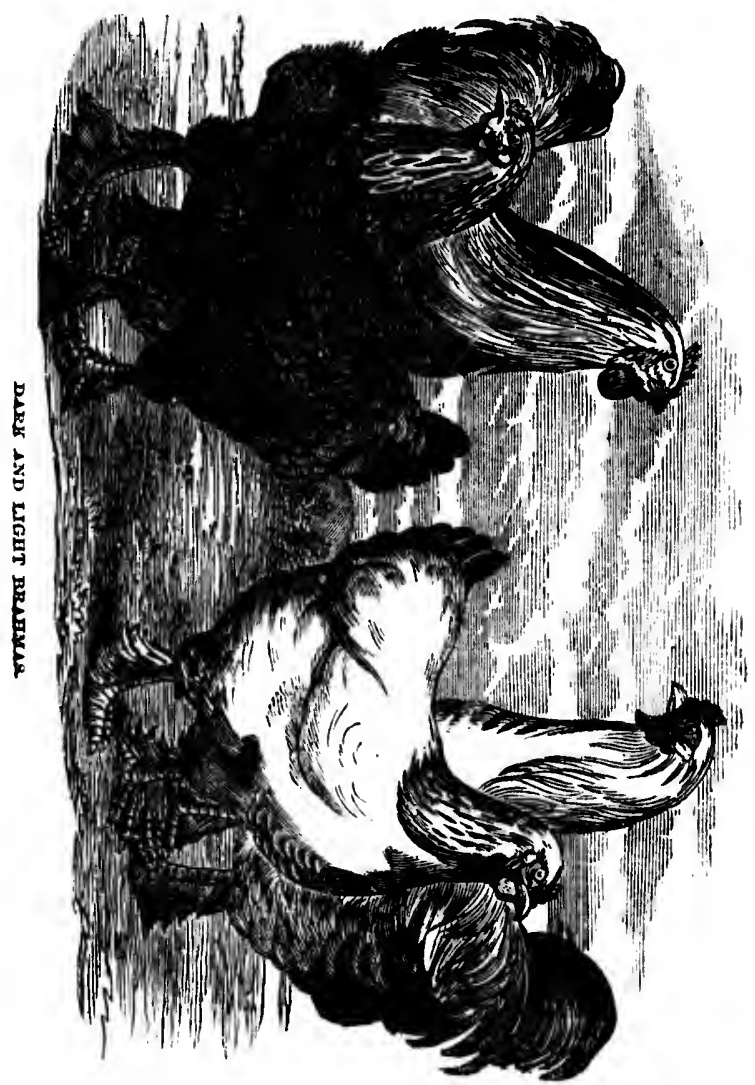

part of the thighs black or dar'k aray, the fenthers on the lower part of the thighs soft and nearly black; legs short, yellow and profusely covored with feathers on the outside.

The marking of the hen is almost identieal with that of the cock, except that it is more uniform all over except the head and tail, each 
feather closely penciled, with dark steel gray on a dingy white ground, and extending nearly up to tho throat, on the breast. In carriage, the hen is not so upright in carriage as the cock, and the legs are very considerably shorter.

\section{Light Brahmas.}

Pure bred fowls are mostly white in color, on the outside, but if the feathers are parted, the under plumage is bluish-gray. This distinetion is strongly marked as between the Light Brahınıs and White Cochins, which latter are white to the roots. The head is of the same general shape as in the dark variety, and with pea combs; the ear lobes and wattles are pure red; the neck hackles are distinctly marked with a black stripe down to the center of each feather, on a white ground; the quill feathers of the wings are black, but when folded the wings should show only white; the tail should be black, tolerably upright, but opening out like a fan, and the within tail coverts reflecting a peculinr green hue in the sunlight: the legs are yellow and well covered with white feathers, sometimes slightly mottled with black. The hen is colored like the cock, except that the plume may be somewhat darker, and the general appearance more sober in color. The tail should be black and smaller than that of the cock.

\section{Frizzled Fowls.}

One of the most curious of the Oriental breeds, and occasionally seen in the yards of amateurs and fanciers, are the frizzled fowls originally brought from Java. Linnæus named them Gallus pennis revolutis, or fowls with feathers rolled back. The color should be white, though they are also bred black and brown. They are certainly curious and interesting as showing freaks in breeding. So far as value, in comparison with other breeds is concerned, it is nil.

\section{Silkies.}

Far more ornamental in appearance, and really of some value, are what are known as Silkies. The best specimens are pure white, and have this peculiarity, the webs of the feathers lack cohesion and are filamentous, henee giving the silky appearance to the plumage.

They are sometimes called negro fowls, from the fuct that the skin is of a dark violet color, almost black, and the comb and wattles often dark purple, low and flat and corered with small warts. The bones are also covered with a dark membrane, which altogether makes this breed the most singular and interesting of the gallinaceous ' ribe. 


\section{Breda or Guelder Fowls.}

The Breda or Guelder fowl is peeuliar in some repects, and shows that there is an infusion of Asintic blood, although they are Polish in shape and elosely related to this breed. They are of various colors, but

, but if the distinction ite Cochins, ame general bes and watwith a black a ; the quill should show ; opening out green hue in bite feathers, like the cock, neral appearaller than that

asionally seen wls originally is revolutis, or e, though they $s$ and interestmparison with

one value, are ure white, and on and are fila hat the skin is tles often dark bones ire also this breed the

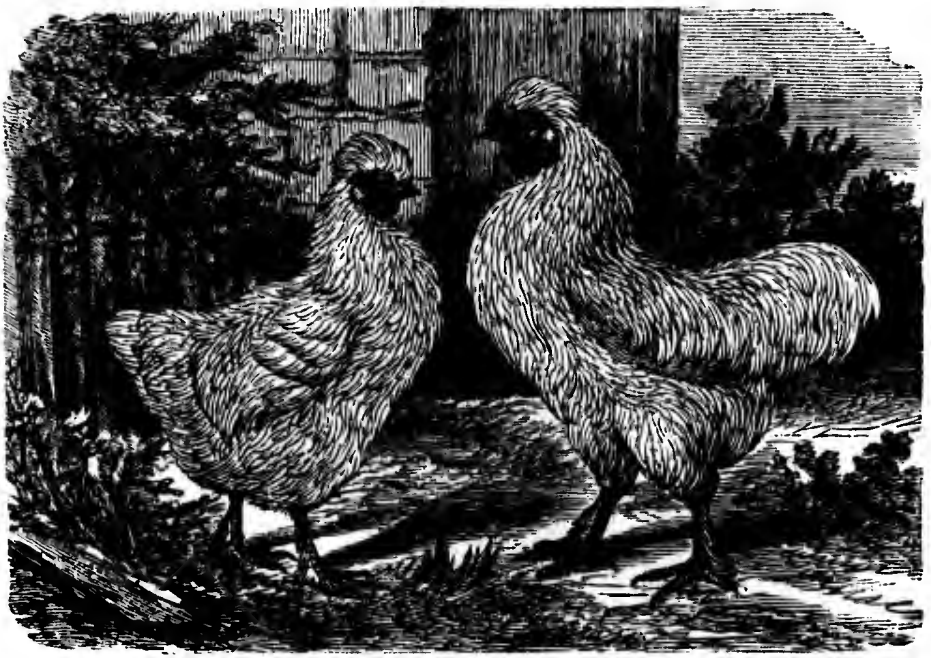

PAIR OE SALK FOWI.'.

the only true families that are bred in the United States are the Cuckoo or Dominique marked, ealled Guelders, and those pure black, denominated Breda, though we believe the true Breda is applied to all the Guchlers, not Cuckoo marked. They have a erest, only just perceptible, and of the same color as the body.

Whatever the eolor, they are lightly feathered on the legs, which are slaty-blue, and the thighs are vulture hocked. They have no comb, but a depression where the comb should be ; the nostrils are cavernous, and particularly conspicuous. The cut given will show their general appearance, and the likeness of a Breda head given on a previous page will show the chief peeuliarity of the head. In size they are medium chicks. ear lobes and wattles red and peculiar in shape, being extremely pendu. lotis in the cock. The plumage is elose and eompact like that of game fowls, with large and flowing tails. The eggs are large, smooth and of good flavor, and the chickens are hardy and feather quickly. 


\section{Gamo Fowls.}

The several varieties of game fowls are the most elegant and noble of the gallinaceous tribe. The cocks are watchful, courugeous, always ready to attack an enemy whatever it muy be, and fighting to the death. And of most elegant earriage and coloring. The hens are good mothers, lay

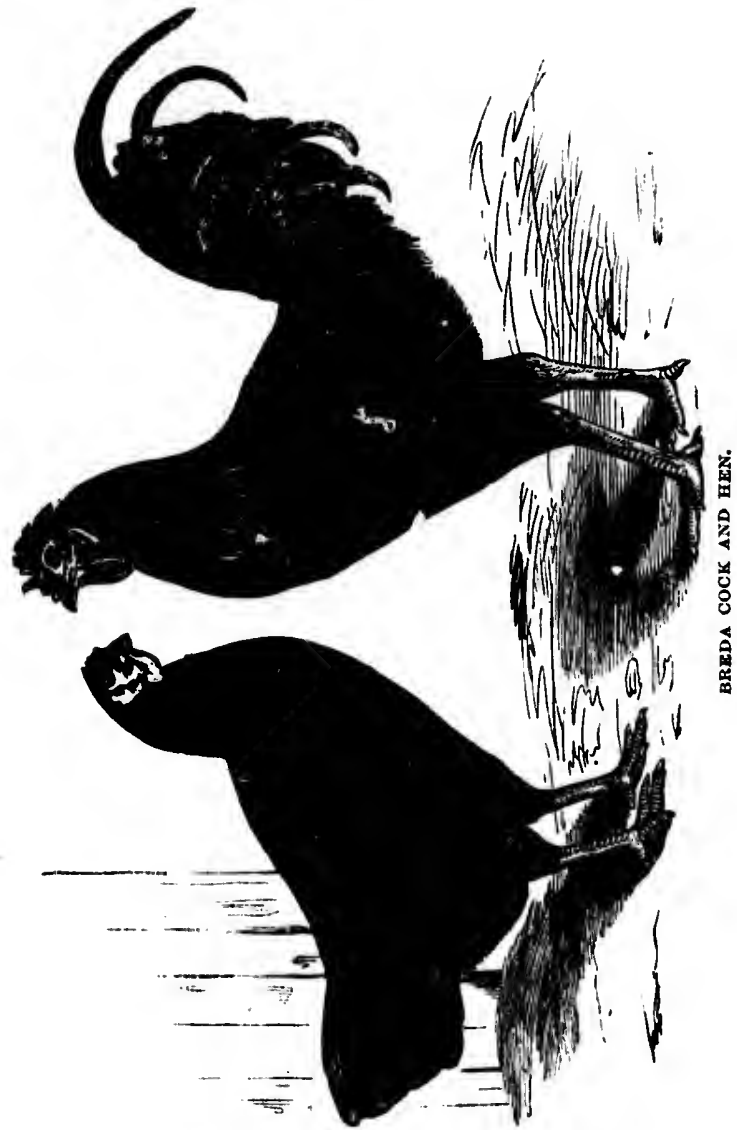

the finest meated eggs of any hreed, are hardy, and excellent foragers. There is hardly a breed of "dung-hill" fowls, but what owe their good qualities to the infusion of this prepotent blood. This general description will suffice for all the varieties, which are innumerable, and belong 
to every country, England, Ireland, Spain, Cuba, Mexico, Malay and China being the most celebrated for their struins of blood. In all these varieties of games the cocks ure noted for the brilliancy of their markings and the hens for their solerness of color.

I noble of ways ready ath. And others, lay

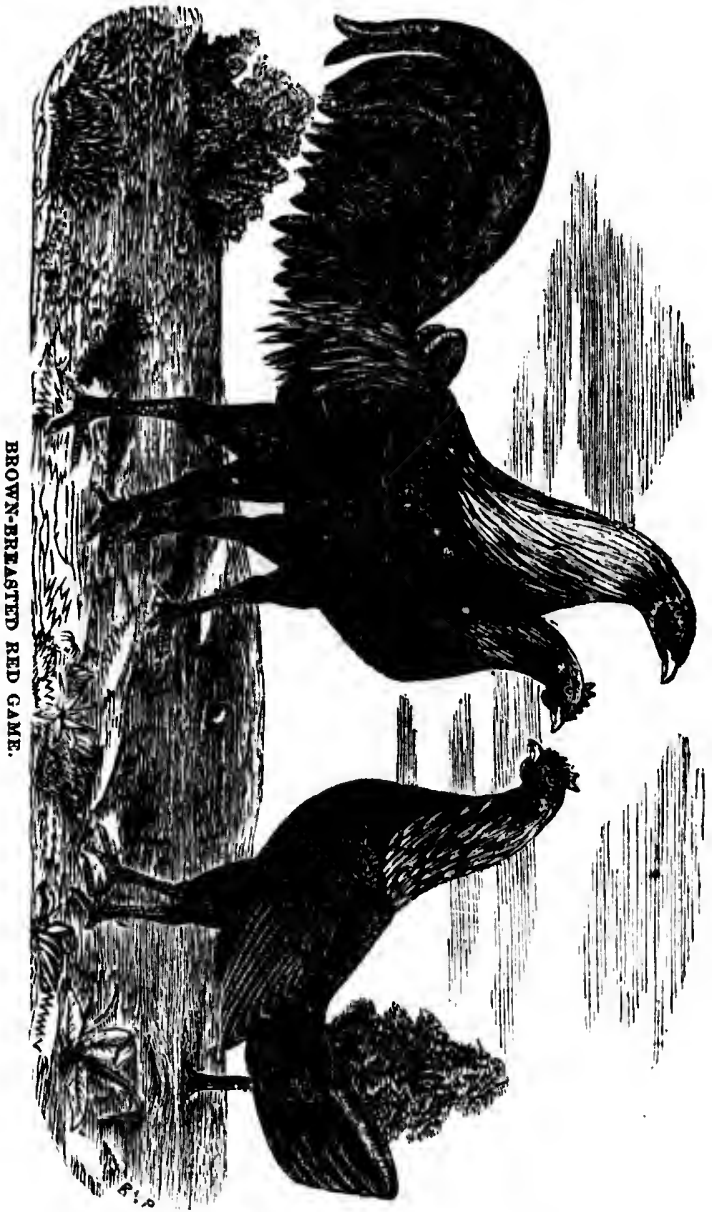

The Brown-breasted Reds. lent foragers. we their good neral descrip$o$, and belong
This variety is considered ns one of the best of the games, an illustrotion of a group of which we givc. In this breed the breast of the cock 
should be red-brown, shoulder sometimes oringe-red. The comb and face must be dark purple, the beak dark; wing butts dark red or brown, with dark talons; hackle with durk stripes; thighs like the breast; tail a dark greenish black; the wing crossed with a glossy, green-hued bar. The plumage of the hen should be very dark brown penciled with light brown; neck hackle dark, golden, copper-red, thickly striped with dark feathers; comb and face much darker than that of the cock. When the tail feathers are spurred and show a slight curve, it is considered indicy tive of strong blood.

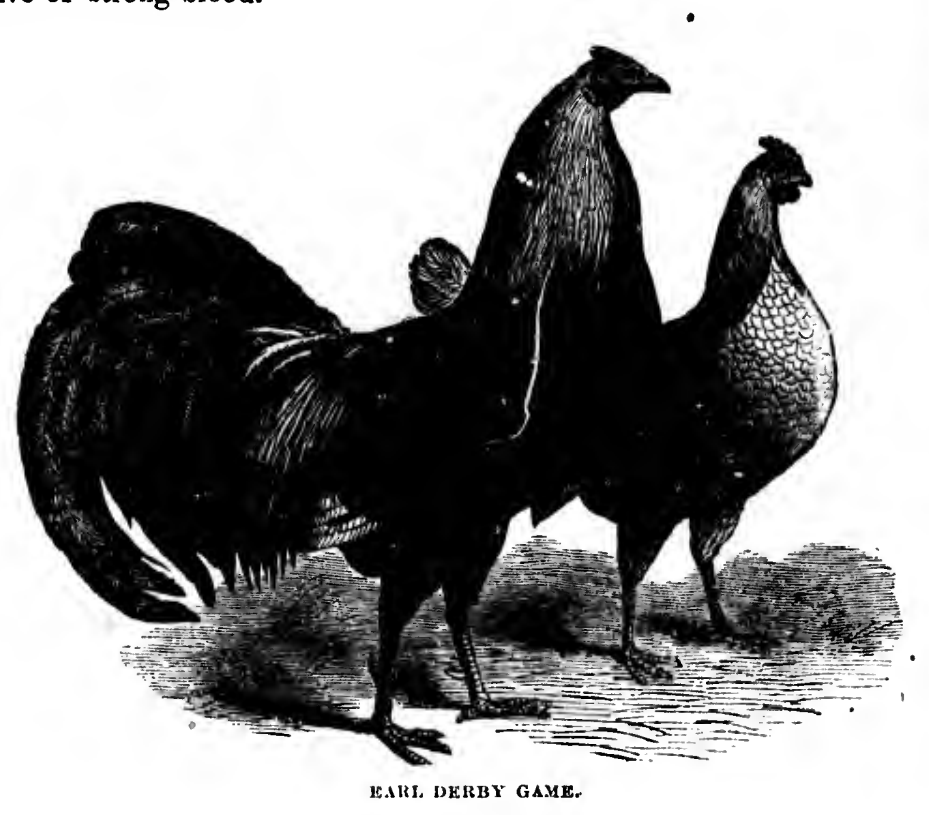

Earl Derby Game.

This magnificent strain which has been bred in great purity in England for over a century, are Daw-eyed, that is the eye is gray like that of the Jackdaw. They have a round, well knit body, on long, stroug legs, with white feet and claws; the head is long, the bill lance-shaped and elegant; the face bright red, with small comb and wattles red; back intense brown-red; lesser wing eoverts maroon colored; greater wing coverts marked at the extremity with steel-blue forming a bar across the wings; primary wing feathers bay ; tail irridescent black; hackle well feathered, touching the shoulders; wings large and well quilled; back short : brenst round and black; tail long and sickled, being well tufted at the root- 
e comb and ed or brown, breast; tail on-hued bar. ed with light ed with dark When the dered indicer

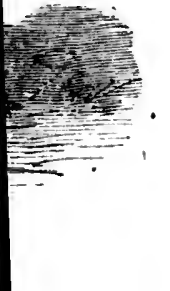

ity in Engla!nd ike that of the rong legs, with ed and elegant; ; back intense $r$ wing coverts oss the wings; well feathered, k short: breast at the root- thiek, short and stiff. The hen is thus succinctly and perfectly deseribed by Beeton in his Engrlish work on poultry: "Hend tine and tapering; face, wattles and comb bright red; extremities of upper mandible and the greater portion of the lower one white, but dusky at its base and around its nostrils; clestnut-brown around the oyes, eontinued beneath the throat; shaft of neek hackles light buff ; web pale brown edged with black; breast shaded with roan and fawn color; belly and vent of an ash tint; primary wing fenthers and tnil black, the latter eurried vertically and widely expanded; legs, feet and nails perfectly white." The carriage of both cock and hen of this breed is upright and dignified.

The pugnacious disposition of the cock equals that of any other game bird; and its endurnnce cannot be surpassed. Years ago they were numbered among the best breed of birds for the cock-pit; and for the table they are not surpassed by the sweet and nutritious tlesh of tho Dorking fowl.

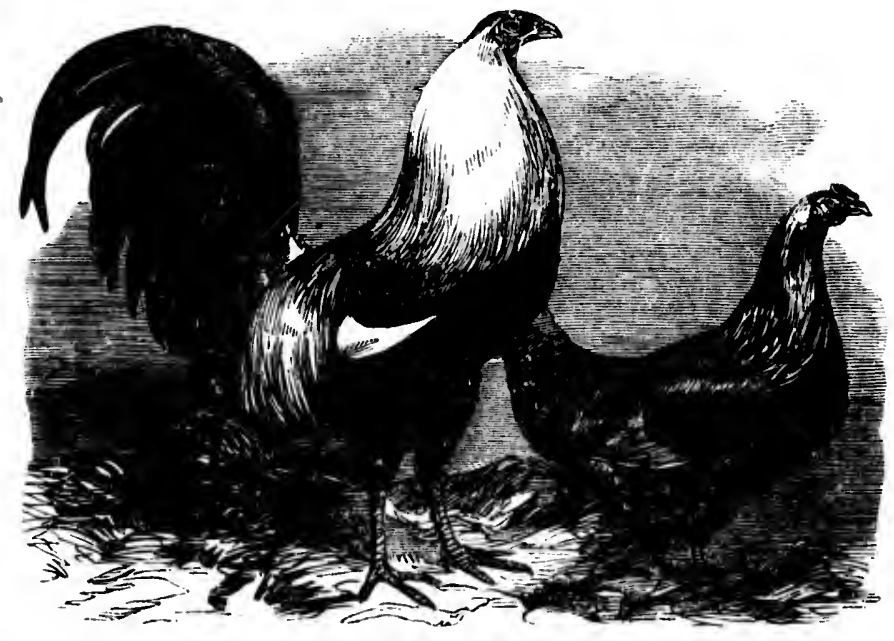

DUCK-WIXG GAME RUWLS.

\section{Duek-winged Game Fowls.}

There are several varieties, including llo Durk-winged game bantams. To our mind the best are the silrer-aray, a pure-blooded, bardy and high couraged bird. The cock must be silver-grily in color; the head, comb, face, wattles and bill of the true game type; the first four of them bright red, the bill light colored; eyes red, skin white, and the legs white: the hackle is striped black underneath, but clean above; the breast a clean, nearly silver-gray; the baek a bright silver-gray; the 
lower part of the wings creamy white, crossed above with a bar steel-blue in color.

In the hen, the plumage should be a silvery bluish-gray, frosted with white; neck hackle silvery-white, striped with blıck, and the breast a

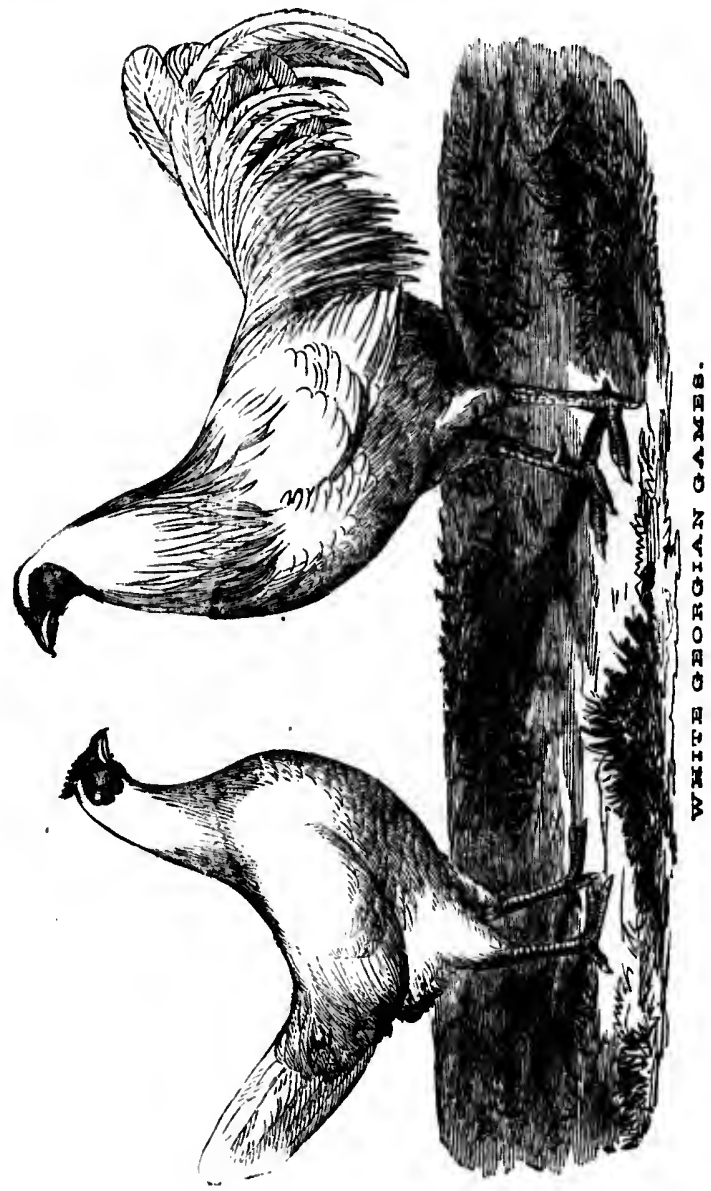

pale fawn color, more subdued than in the cock. 'The other characteristics, as to face eyes and feet, eto.. should bo identicul with that of the male bird. 
White Georgia Game.

This variety, originally bred in Europe, but brought into Georgia many years ngo, and since carefully bred in various parts of the South, are game in the pit, and most excellent farm fowls, being hardy, conrageous, and the flesh most excellent in quality. For beauty of plumage, elegant slitpe und lofty carriage, they have few if any superiors.

In the color they should be pure white all over, with no shade whutever on neck, breast, hock or tail. The legs may be white or yellow. We prefer the yellow, since it is an indication of a stronger constitution. The beak should harmonize with the legs, and the comb, ear lobes and wattles must be of the deepest vermilion color. Such a breed on the lawn makes one of the prettiest sights we have ever seen, and in quality of the flesh they have no superiors.

\section{Game Bantams.}

These are small varieties of the more common large breeds. Alert, courageous little fellows, some of them not larger than good sized pigeons, but fully capable of driving any ordinary barn-yard fowl, however large it may be. The more prominent of these are the Black Breasted red game bantams. As pets they are most attractive and may be kept with any of the large breeds without danger of intermixing as to the hen bantams.

\section{Other Bantams.}

The most highly prized of the fancy bantams are the golden and silver spangled Sebright bantams. There are also bantams of the white and black races of smooth-legged fowls, as there also are of the Asiatics.

\section{Sebright Bantams.}

characterthat of the
There are two varieties of these, the golden pencled and the silver penciled, identical in shape and markings except the color. Both varieties arc remarkably beautiful : pert, lively, - igorous, and when small and well bred, among the nicest pets of the farm-yard. The plumage of the Silver buntam is of a silver-white color with a jet black margin. The Golden varicty is identical except that the ground color of the plumage is golden. The legs are smooth, the heads arc clean, the eomb double and pointed at the back, and the tail straight and without the long sickle feathers. Whether

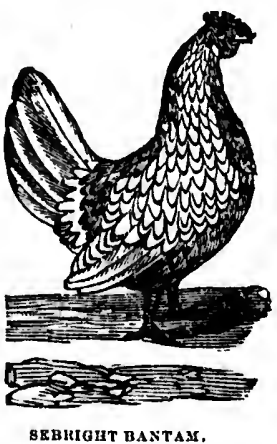
they be golden or silver spangled, the value of the birds consists in the delicacy and pencilings of the markings. The cocks 
should not weigh over twenty ounces at most; the hen not more than sixteen. Hens have been shown weighing not more than twelva ounces, A peculiarity of this variety is, that occusionally an old or a barren

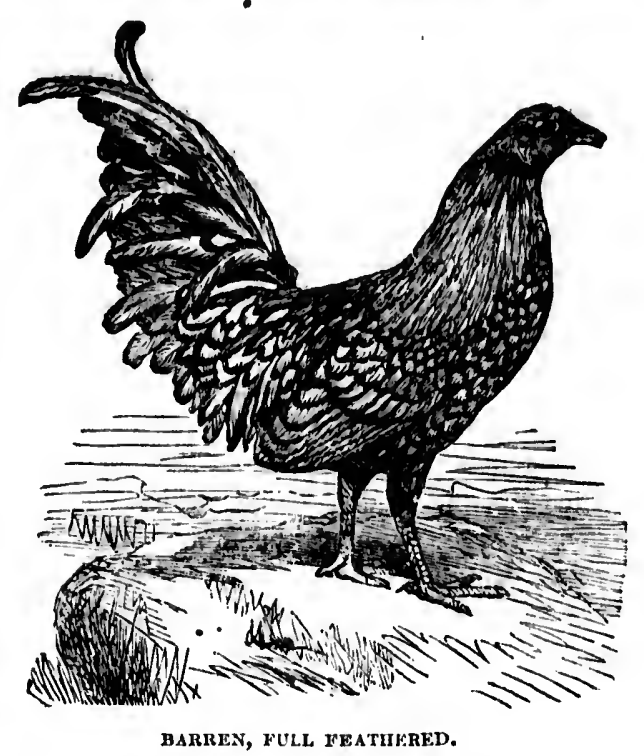

female will assume the plumage of the cock. When we remember that the males of this breed are what are called hen-tailed, the remurkable reversion, as shown in the cut, of a hen, will be interesting to the scientist and curious to all.

\section{Japanese Bantams.}

Among the most curious of the bantam tribe are the Japanese bantams. In this rare breed, the body must be as pure white as possible, the tail black, the sickles very long, upright, little curved, but carried over the hack as shown in the cut. The shafts of the sickle feathers white; the comb large, upright, not too strongly serrated; wattles long and red; legs very short and yellow. The body of the wings should be white, with black flight feathers. The hen should be fan tailed, and the comb crinkled. They are quiet, easily domesticnted. The hens are gond layers and good nurses. The chickens are tender, and for this reason should not be hatched before the weather is warm. In fact as small size in ban- 
tans is an essential point, the best chickens ars fall-hatched and kept through the Winter with only feed sufficient to continue them growing fairly and to keep them in good health.

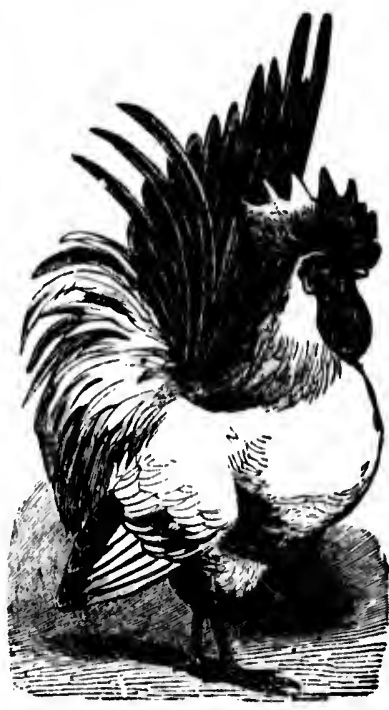

JAPANXGA HANTAX COOK.

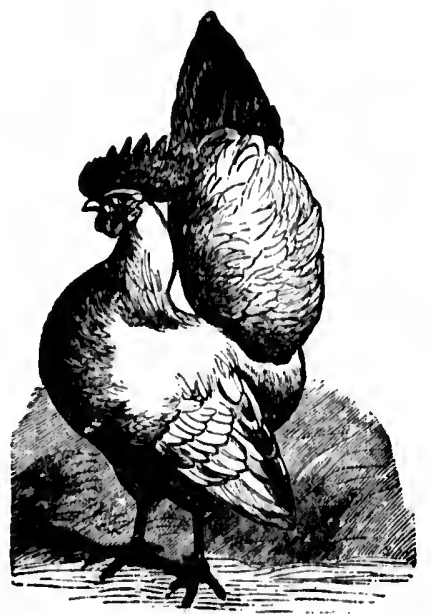

JAPANESE BANTAM ROLLET.

o bantams. le, the tail ed over the white; the g and red; d be white, d the comb e good laytason should size in ban- 


\title{
Chapter III.
}

\section{BREEDING.}

\begin{abstract}
THE PLOMAGE. - IDEAI, SHAPE. - BREEDING TO TYPE.—DISPARITY IN SEXES. MALING. BIEEDING GRADES.
\end{abstract}

Exps

$E-U_{1}$ Thighs

In the breeding of poultry it is absolutely necessary that the breeder have a good and clear idea of the prints of fowls. For this reason we give a series of illustrations showing the entire fowl, and also others accurately figured and explained, so no reader can err. It is absolutely necessary to a correct understanding of any business or profession that a correct knowledge of the techniculities connected therewith be had. The poultry breeder must not only understand how to feed and rear chickens but he must have a nice discrimination as to plumage, the chief eharacteristics of the several breeds of fowls, and their peculiarities of constitutional vigor, style, carriage, etc., but he must also understand something of the anatomy of the fowl, their points, and also those relating to outward parts, and the technical terms used in describing the several parts. In uddition to what follows we have prepared a pretty complete glossary which will be found at the end of the chapters, so that any person may easily inform himself as to the several terms used by the fanciers and breeders. The technical ternis used by poultry fanciers, in describ. ing the points of a fowl, are not always understood by the uninitiated. 934 
For the benefit of such we give an illustrution, with lettered references, which will supply the necessury information on the subject

IN SEXES.

ho breeder reason we also others absolutely cession that ith be had. d and rear e, the chief uliarities of understand hose relating the several tty complete t any persoll the fanciers , in describuninitiated.

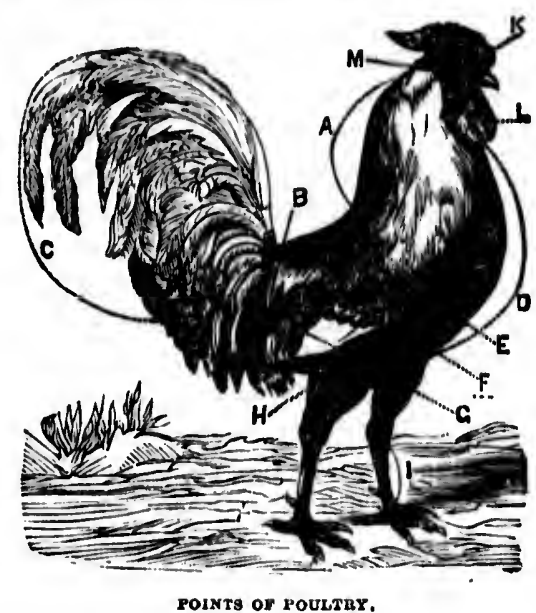

Explanation-A-Neck backle. $B$-Saddle hackle. $C$-Taii. $D$-Breast. E-Upper Wing coverts. $F$-Lower Wing coverts. G-Primary quills. $B$ Thighs. $I$-Legs. $K$-Comb. $L$-Wattles. $M$-Ear lobe.

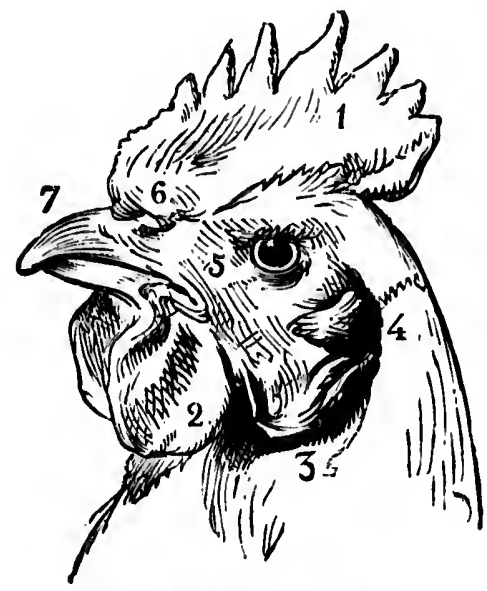

POINTS OF TIIE ERAD OF COCK.

Explanation.-1-The comb, whlch surmounts the skull. 2-The wattles, which hang underneath and on each side of the beak. 3-rhe ear wattles, 
which hang under the cheek. 4-The tufts of little featbers, which cover and protect the auditory organ. 5-The cheeks, which commence at the beginning wear the nostrils, cover all the face and re-unite behind the head by a continua. tion of the flesh of the same nature, but covered with feathers. 6-The nostrils. which are at the beginning of the beak. 7-The beak, of which the two parts, the upper and lower mandible, are horny.

The head of the cock, as of the hen, is composed of two principal parts : 1st, the skull is a firm union of bones, which include the upper part, or mandible, of the beak; 2nd, the lower part or mandible of the beak, being the lower jaw-bone, formed by a single piece. In the skull are the sockets or cavities which contain the eye; the nostrils are in front of the eye ; the auditory organ, or ear, is behind the eye. The head, excepting the beak, is entirely covered by'a fleshy covering, round which may be seen several appendages or caruncles, which are the crest, the two ear-lobes, and the two ear-wattles. This covering forms the cheeks, the color, the size ; the form of each of these parts is varied according to the variety, and ofien serves to characterize each. A tuft of short feathers called "the tuft" covers the auditory organ.
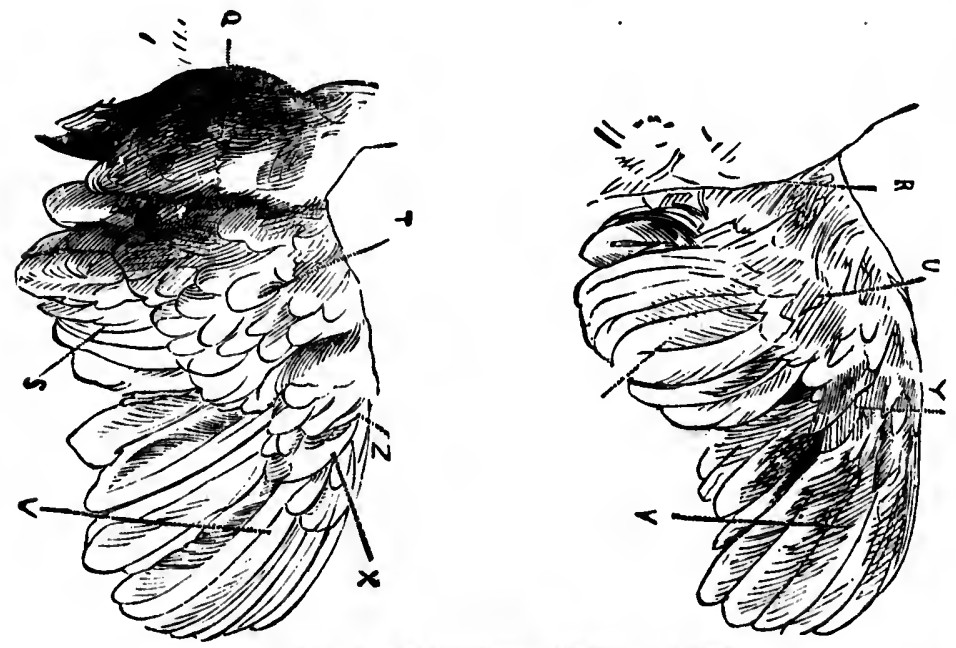

axalybis of wine ploxagr. (See following Page).

The comb is straight or drooping; it is single when it is composed of only one piece, double when there are two alike united or near together, it is triple when it is formed of two alike and one in the middle; it is frizzled when full of granulations more or less deep,and erect excrescences, it is a crown when it is circular, hollow, and indented; it is goblet shupel 
when hollow, vascular, and not indented. There are other forms but they are composed of parts or unions of those particularized.

\section{The Plumage.}

With the hen there may be three kinds of feathers distinguished: 1 . The large feathers on the wings for flying, and on the rump to form the tail ; 2. the middle-sized feathers which cover the large feathers, and are

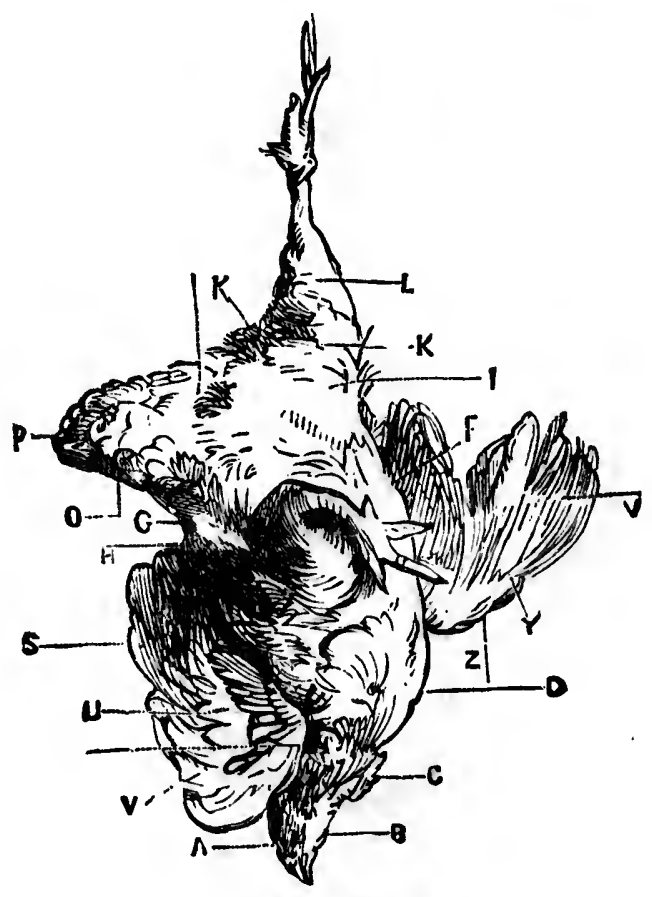

POINTS ON THE FOWL.

also found on the wing and rump; 3 . the neck, the hack, the sides, the throat, the shoulders, and a part of the wings. They are always in liayers compactly covering those beneath them like tiles. We shall designate them by the name of the places they occupy, and refer to the engravings to render them easy to recognize:

Explanation-A-The upper feathers of the head ure very small in those fowls not tufted. 'They surround the skull.

n it is composed lor near together, the middle; it is orect excrescences, it is goblet sbupel

ich cover and

two principal andible of the In the skull ils aro in front round which e crest, the two the cheeks, the short feathers

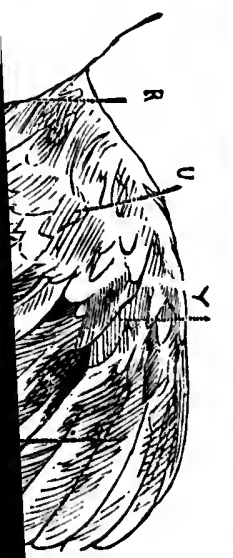


$B-T h e$ undermeath feathers of the heal are almost like bristles. They cover the cheeks in the space whlch separates on the wattles.

$C$-Tie upper feathers of those at the buck of the neck are short, and lengthening lower down, forming what is called the hackle. They becone longer hetween the shoulders when they cuver the beginning of those on the back and the commeneement of the wings. D-The feathers of the back, forming a layer about 10. These teathers are of the same nature as those of the neck, bit a little larger, and form the saddle.

$F-T$ ' ing beyonil the breast-hone at each side and unlting at its end. The whole forms what is termed the breast. These feathers, with the feathers of the loina, overlap those of the sides.

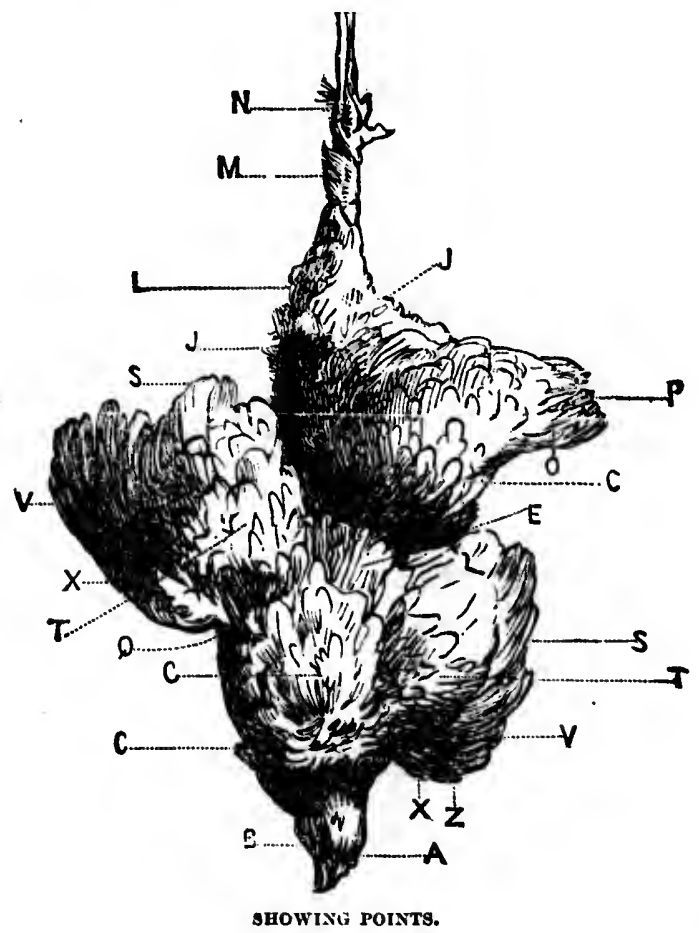

G-The feathers on the sidles cover the loins, taklng In the bnck as far as the rnmp, whleh they go beyoncl asl eover the lower part of the feathers of the tail. 'They also cover the commencement ot the teathers of the flanks, thighs and abdomen.

$H$-The feathers of the flanks are light and llufy. They cover the upper part of the thigh feathers and sllp under those of the bieast.

- I-The feathers of the abdomen cover and envelnpe all this part from the end of the breast to the rump. These fenthers are genernliy flufy, of a silky nature and spread out In a tuft.

$J-T h e$ outside feathers of the thigh cover those of the abdomen and leg. 
ger the cheeks

thening lower the shoulders of the wings. e of the same uscles, extendforms what is erlap those of is far as the rump, 1. They also cover upper part of the om the end of the re and spread out
$L$-The outside and Inside feathers of the leg stop at the heel, $A$ ln some varleties they proceed lower and form what are ealled rutles or vultured bocks.

$M-T h e$ feathers of the feet or sole nre long, short, or entirely absent, in the different varietics. These feathers are along the sliank in either one or several rows. 'Tliey are always on the outsicle part.

$N-1$ lie feathers of the toes appear on the outsides.

0 - I'the middlo tail feathers envelope the rump and eover the bases of the large feathers of the tail.

$P$-The lnger tail feathers are in a regular line of seven on each side of the rump, and form the tail.

Q-The outslde feathers of the shoulders cover a part of the other feathers of the wing. Tiey form the shoulder.

$R$-'The Inside feathers of the shoulclers are smali, thin, and slender.

$S-1$ he lurger feathers of the pinion form, where the wing is opened, a large, arehei surface, and are of different sizes. 'T'hese feathers grow out of the under side of the pinion.

T-The snull outside feathers of the pinlon are of different sizes. They come on nli the outside surfaces from the shoulder to the pinion. They begin quite small on the outsius efge, and flnish a medlum slze on the inside edge.

$U$-The inside feuthers of the plnion are close, midrle-sized, and small, covering the basc's of the large fenthers of the plnion.

$V$-l'he large flight feathers, or feathers of the hand, are large and strong, and are of most nse to the bird in locomotlon. They begin at the under edge of that willeli is called the top of the wing.

$X$-l'lihe outside tlight-fenthers cover the large ones; they are stift and wcll flattened on the ol hers.

$Y$-l'he Inside flight-teathersare, some small and others medlum-sizer ; cover the bases of the flight-leuthers.

Z-An nppendtx called the pommel of the wing, whieh represents the flugered part. It is at the joint of the pinion and has some middie-size't feathers of the same deseriplion as the liarge pinion feathers, and have some small ones to eover them. These feathers assist in the tlight.

When the whole wing is folded, almost all the feathers are hidden by the larger feathers of the pinion and middle external feathers. Classitiation of the feathers of the cock are the same as those of the hen, but the forms of some of them are different.

\section{Ideal Shape.}

The ent on next page will serve to show the contour of the fowl, the Dorking being the oue seleeted on account of its eompact body ; and the nearer the fowl comes to the ideal the more profitable it will be. Nevertheless it must be remembered that each hreed has its peeuliar characteristies and that soine one point must often be sacrificed in favor of another.

\section{Breeding to Type.}

In the breeding of poultry, as well as farm animals, there should be no riolent crosses made. In fact, none but the thoroughly scientifie breeder, who hus given his life study to the task, should undertake 
crossing with a view to forming a new breed. It will not pay. The general breeder should get the best representatives of the breed he pro-

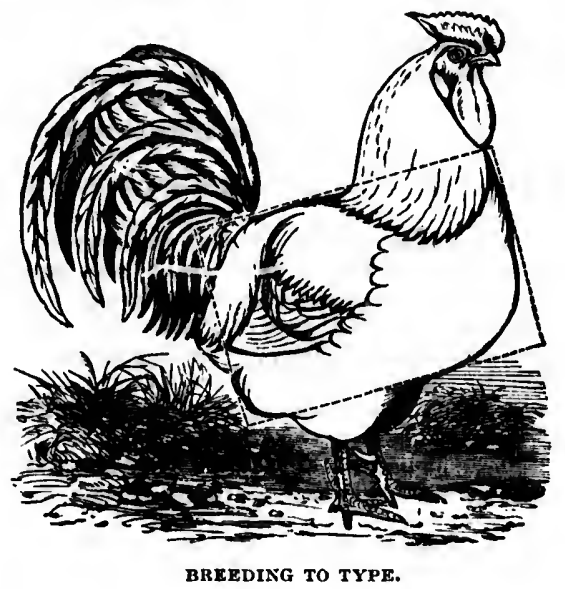

poses to use and confine himself to it. No more than one breed should be allowed on the farm. If so it will end in intermixing and confusion. No more should be attempted than by careful breeding and selection to perpetuate the strain in its purity, and if possible to improve it. $A$ careful study of the foregoing will render this possible, and thus any farmer may breed a given strain equal to the best.

The cock should be large, broad breasted, strong winged, muscular, easy on his legs, and of strong points in his plumage; the hen from good layiur stock or a good mother as the case may be.

\section{Disparity in Sex68.}

As to the number of hens to the cock it will vary with the breeds. With Games, Dorkings, Houdans and Creve Cœurs they may be eight or ten to one; Spanish, Cochins and Brahmas, ten or twelve to one; Hamburgs twelve or fourteen to one. If the flock is large enough so two or more cocks are kept all but one had better be confined, giving them in succession to the flock, and it is better in large flocks to have a reserve to usc when necessary. By this plan much fighting over und unnecessary worry of the hens will be saved. If too many males are allowed to run there will be a loss in eggs, and if too few they will be deficient in fertility, this being one of the greatest drawbacks to this system. So, as between the two, always buy eggs for setting from breeders who give their flocks 
pay. The ed he pro-

breed should ad confusion. I selection to prove it. A and thus any

ed, musculir, een from good

preeds. With eight or ten e; Hamburgs two or more $\mathrm{em}$ in succes-eserve to use ecessary worry to run there at in fertility, So, as betweell se their flocks a good range, and are careful that the hens have neither too few nor too many males.

\section{Mating.}

Always mate a short, compact, deep-bodied male, with long-backed hens, but not the reverse, and as a rule, for the best results the hen should be over one year old when she sets. From that to four years she will do the best. Do net be afraid of breeding in-and-in. Unless carried too far it will result in better suceess than out crosses. So in breeding to color let all self colors be as solid as possible, and in parti-colored breeds study their characteristics, and breed as near to a feather as possible. Avoid vulture hocks in all poultry, and especially so in the Asiatic breeds. In breeding Brahmas and colored Cochins have plenty of color in the males, as the tendency is to get lighter. Yet in this discrimination must be used. If the saddle is very heavily striped, or the neck hackle very dark, the chicks will be apt to run to spots. Yet as a rule heavily-penciled males must he used to get heavily-penciled cock chickens. So very dark hackled cocks and hens with the hackles lightly penciled will produce chickens with delicutely penciled hackles.

\section{Breeding Grades.}

If you cannot get fowls pure get a well bred cock and keep with a few of your select hens. Breed him again to his chicks, so long as he lasts; thus by the exereise of judgment you may have very superior poultry in a short time. A better way, however, is to get a setting of pure eggs and cemmence right at once. They eost comparatively little, are easily sent by express, and will soon repay their cost. 


\section{CHAPTER IV.}

MANAGEMENT OF FOWLS.

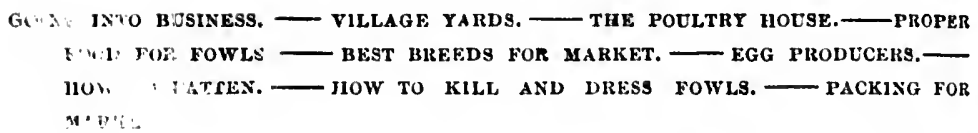

\section{Going Into Business.}

Before going into the business of raising poultry be sure and have comfortable quarters for the fowls. These need not be expensive structures, poles and hay will make a warm, eomfortable roosting and nesting place, until something better can be provided. Be sure that plenty of dry dust for bathing is supplied at all times. It is the great remedy against lice, to whieh fowls are espeeially liable. This with plenty of sun, plenty of pure water, and liberal feeding, will insure suecess both in eggs and chiekens. Do not over erowd the bouse. See that everything is kept serupulously neat and clean. If you build a permanent house, know that there is to be plenty of ventilation; all birds require a large amount of fresh air. Plenty of heat, plenty of food and water, and plenty of fresh air are what give plenty of fresh eggs in Winter, when they are scarce and high. In the Summer let the fowls range over the farm as nuch as they will, they will thus be paying for their keep in destroying insects, and keeping themselves healthy; we are writing for farmers, and not fanciers. In villages the ease will be different; there, fowls must be kept shut up a great part of the time. 
Here, some tact must be used. If the fowls must be kept up during the day, let them out for a run, an hour before sundown, in the street or alley; they will come back all right at feeding time. What you lack in range, you must make up in care and attention to the wants of the fowls, and in the economy of the hen house, and the little range of grass a which they may have: Green food of some kind must be given. Cabbage, lettuce or onion tops, ehopped, are all good. Animal food must also be provided; mny rough meat will do if chopped. One of the mistakes often made is feeding too much at a time. Give them their food so they may take it at will, if it ean be kept clean, or throw down food to then liberally, so long as they eat eagerly, and, make them eat pretty clean.

\section{The Poultry House.}

The poultry house should face the South on one of its broad sides, and the more glass you have in this, the better. One portion should be half dark for the nests, and, for setting hens, this should be large cnough so a dust bath may be supplied also. The roosting place may be in one end, and should not be more than two feet from the floor, especially if the breed be heavy. The perches should be all on a level, and pretty large. A two by four scantling nicely rounded and set on edge, is not too large for the heavy birds. Keep everything about the house serupulously clem. Whitewash at least once a month with lime and if lice make their appearance, fumigate the house, and sprinkle Scoteh snuff among the feathers of the fowls. Follow this up until the lice are exterminated.

\section{Proper Food for Fowls.}

Never give fowls sloppy food. When mixed feed is given, it should be made us stiff as possible. Never feed in a trough, it cammot be kept clean. Have the dough so stiff that, as it falls from the hand it will break, and so, feed on clean ground. Indian meal and snall potatoes cooked together and fed pretty hot in Winter, with a little chopped onion intermixed, makes a good food. Hare broken bones, lime rubbish and gravel always where fowls can get it, and in Winter a sheep's pluck hung where the hens can just reach it, by jumping up to pick it piecemeal, will keep the fowls in good laying trim. Chandler's cake is good, if other meat cannot be had. This may be broken fine and mixed with one of * their ditily feeds. Be cireful, however, that you do not overfeed with meat. If so, it will show in loss of feathers and general ill health.

\section{Best Breeds for Market.}

We do not believe there are any better market fowls, all things considered, than the Brahmas and Cochins. The Dorkings are undoubtedly the most superior table fowls; they are also tender and harder to rear. 
As a cross for carly plump table brecds, a Dorking cock crossed on Brilhma or Cochin hens will give fast growing, plump ehickens of enrly miturity. In this, however, funcy his much to do.

The Asintics are not great layers, but by using judgment, fully as many eggs can be got from either Brahmus or Cochins in Winter as from any other breed, and Winter eggs are whut bring noney. Give them wurm and roomy quurters, with plenty of range for exercise, with liberal feeding, including green vegetnbles, and they will bring you money in eggs.

\section{Egg Producers.}

The Poland, the Leghorn and the Houdan are inveterate layers, and their eggss are good. The Hamburgs nre good layers, but like the blnek Sprmish, tender, and inore tit for the munteur than the practical man. For eggs, there is little doubt that the Polauds should carry the palm. For young chickeus for inarket, Brihmns and Cochins, and for home table use, the Dorkings are best. Why, then, asks the reader, have you described so many fowls? The answer is, so that the table being well filled, you may take your choice of breeds.

\section{How to Fatt $\in$ n.}

When ready to fatten, poultry should be always confined in a small sparce; the smaller the better. Two weeks should make them fit. If lept :Ifter they are fat, or when they eetse to increase, they again immediatcly lose flesh. The best food in the West is corn-meal, boiled into a very thick mush, and then made as thick as possible, while scalding hot, by mixing in all the meal that can be worked. The fowls may be kept in well-rentilated coops, feeding them three times a day with the feed warm, and allowing them plenty of water and gravel all the time, except for the last week, when the gravel maly be onitted. The coops must of course be kept clean, and should be small enough so the fowls cannot turn around; should be littered with clean straw, and never allowed to get foul. If, instead of water, their drink is skimmed milk, they will become extra fat.

\section{How to Kill and Dress Fowls.}

Never kill your fowls until they have fasted twenty-four hours. No matu ever made any money by selling his fowls with their crops stuffed to make them weigh. The petty fraud is too apparent. To kill and dress, tie their legs together, hang the fowl uy, open the beak and pass a sharp pointed, narrow bladed knife into the mouth and up into the roof, dividing the membrane. Death will be instant. Immediately cut the throat hy dividing the arteries of the neck and the bird will bleed thoroughly. 
ssed on of enrly

fully as us from ive them th liberal a money

yers, und the black ical man. the palm. for home have you being well

in a small em fat. If gain immepiled into a alding bot, ay be kept th the feed ime, except ps must of bwls cannot allowed to $k$, they will

hours. No ps stuffed to Il and dress, pass a sharp roof, dividth the throat horoughly.

Wo never seald; the nicest way is to pick the fowl diy and while yct wirm. A little care will prevent tearing the flesh, and the bird will bring enough extr'n in the, market to malke it pay. Most persons, however, will prefer to scald, and for home consumption, or the village market this will do.

Hitve the water just scalding hot-not boiling-190 degrees is just right. Immerse the fowl, holding it by the legs, taking it out und in, until the feathers slip ensily. Persons become very expert it this, the fenthers coming away by brushing them with the hand, apparently. At all events, they must be picked clean. In:mg turkeys and chickens by the feet, and ducks and geese by the head, to cool. It should be unnecessary to say that under no circumstances whatever, should ducks and geese be scalded; they must invariably be picked dry. Take off the heads of ehickens as soon as picked, tie the skin neatly over the stump, draw out the insides carefully, and hang up to cool. Never sell fowls undrawn. They will bring enough more drawn and nicely packed, with the heart, gizzard and liver placed insido ench fowi, to pay for the trouble. Let them get thoroughly cool-as cold as possible-but never, under any circumstances, frozen. There is always money in properly prepared poultry; the moncy is lost in half fitting them for market, the fowls often being forwarded in a most disgusting state. There is moncy in the production of eggs; there is money in raising poultry for the market. Tho money is lost in improper packing and in a foolish attempt occasionally mado to make the buyer pay for a erop full of musty corn, at the price of first-class meat. It is that class of men, however, who are too smatrt cver to make money at anything.

\section{Packing for Market.}

The poultry, having been killed as directed, carcfully picked, the heads cut off, and the skin drawn over the stump and neatly tied-or if preferred, leave the head on, the fowl will not bring less for it-and the hirds chilled down to as near the freezing point as possible, provide clean boxes and plice a layer of clem hay or straw quite free from dust, in the hottom. Pick up a fowl, bend the bead under and to one side of the hreast lone, and lay it down flat on its breast, back up, the legs extending striight out behind. The first fowl to be litid in the left hand corner. So placed, lay a row neross the box to the right, and pack close row by row, until only one row is left, then reverse the heads, laying them next the other end of the box, the fect under the previous row of heads. If there is a space left between the two lust rows, put in what birds will fit sideways. If not, pack in clean long straw, and also pack in straw at the sides and between the birds, so they cannot move. Pack straw enough 
over one laye: of fowls, so that the others ennnot touch, and so proceed until the box is full. Fill the box full. There must never be any shaking, or else the birds will becomo bruised, and loss will ensue. Many puckers of extra poultry plnce puper over and under each layer before filling in the straw. There is no doubt but that it pays. Nail the box tight; mark the initials of the pneker, the number of fowls and variety, and mark pluinly the full nnme of tho person or firm to whom it is consigned, with street und number on the box. Thus the receiver will know at a glunce what the box contains, and does not have to unpack to find out. These directions, if carefully carried out, might save a person many times the cost of this book, every year.

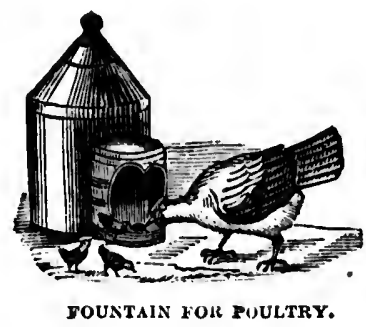


o proceed any shak1e. Many yer before iil the box nd variety, $n$ it is con$r$ will know ack to find e a person

\title{
Turkeys, Other Fowls, Breeds and Management.
}

\author{
CHAPTER v.
}

THE HOME OF THF TURETY.

VAHIETIES OF THE DOMESTIC TULKEY, - 1. THE COMMON TURKET. - 11. EMO. LISH TURKEY. — III. THE HONDURAB TORKEY. - IV. BRONZED-BLACK TORKEY, - V. GUINEA YOWL.—vI. THE PEACOCK.

Although it is only about three hundred years since the turkey-from any well authenticated accounts-was brought under domestication, we already see them broken up into several distinct breeds, although there are but two wild varieties, the brown turkey of North Americi, und the Honduras turkey of Central America; a cut of the latter being shown on following page, and of the former the introduction to poultry in general, illustrate these varieties.

There is, however, one fact peculiar to the turkey as with pheasants. It still retains and persistently holds muny of its wild traits. It is shy, intractable, does not care for home, and like the pea fowl and guinca fowl, is much inclined to wander. When full grown, and indeed after becoming full fledged, they are the hardiest of domestic fowls ; in fact, as hardy us any of our Winter species of wild breeds; yet when young, they are the most delicate, tender and easily chilled. For this reason they should never be hatched until the weather, both nights and days, is warm; and for the reason that the hen turkey is so careless of her 60 
young, und no poor " provider, wo huvo nlwnys raised them under cureful hens, giving " large hen seven eggs and aiming to have two broods come off ut once, giving both broods to one nurse.

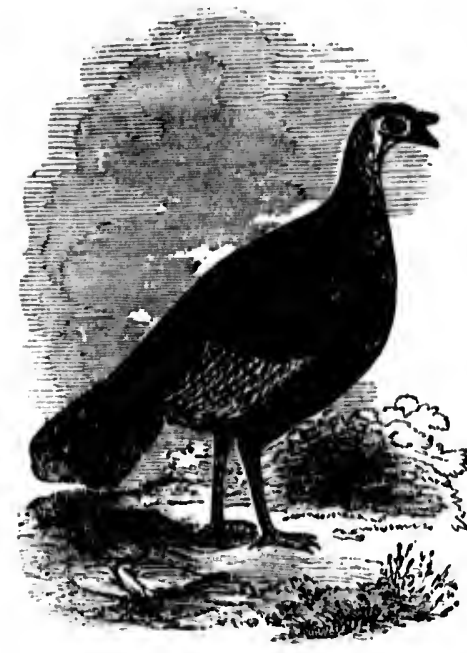

WILD TUKKRY.

The egge require from thirty to thirty-two days to hatch, and for tho first four weoks the young chicks should be carefully watched. They will neithes stund the hot sun, heivy ruius, nor much dow, "N they must be kept warm. Ha siled engrss rubbod up with ontmenl or cornmeal is a good fool for the first two weeks. After whieh, light wheat and cracked cor'n may form the staple. Ahout the time they aequire the real head, which is at about six weeks of inge, which next to the third dity is the most eritical poriod of their life, they should have nutritious food, nnd, if a little bruised hemp) seed is added, so much the better. In fecling give but a littlo at a time and often, and that out of tho reach of ' hen or other fowls. Young onion tops, chopped very fine and wel ed with the food is excellent. Curds of sour milk are eugerly eaten, . . t should not be given as a constunt food. Pure cold water must always bo at hand is in lrink, but occusionally, say once a diy, skim milk may be given. Where cornmeal is the basis of the food, it should always be cooked into a hilld inush before being fed.

\section{Varieties of the Domestio Turkey.}

These are the bronze, the English (so-called) turkey, the white, the buff, and the crested turkey. The latter is extremely rare, having been supposed to have originated in Europe, in the early part of the last century, then entirely lost, and again said to have been recovered, curiously ellougl, from Africa.

Tenminck, in a work relating to pigeons and fowls, printed in Amsterdam in 1813, mentions them as follows: The erested turkey is only a variety or sport of nature in this speeies, differing only in the possession of a feathered erest, which is sometimes white, sometimes black. These crested turkeys are very rare. Mudemoiselle Backer, in her magnificent menagerie near the Hague, had a breed of crested turkeys of $a$ bequtiful Isabelle yellow, inclining to chestnut; all had full crests of pure white. 
under caretwo broods thirty to thirand for the poung chicks tclied. They ot sun, heavy $\rightarrow$ they must siled euriss or cormmeal rst two weeks. at and cracked taple. Alout the red head, wecks of age, rd dny is tho their life, they food, and, if at at is added, so ceding give hut often, and that hen or other ed with the t should not vays bo at land may be given. be cooked into

the white, the re, having been of the last centvered, curiously

nted in Amsterurkey is only a n the possession s black. These her magnificent s of $n$ beautiful of pure white.
Lieutenunt Byum described crested wild turkeys us huving been scen by him in Mexico, but it is supposed ho must have mistaken enraysows for wild turkeys, since no others huve heen nhle to find them, and the rurnssow is thoroughly domesticuted there. 'T'lo white and buff turkeys are simply varieties in color forn tho common forms, which luve in some instances been perpetunted by onoful hreeding mod selection. So also there ure copper-eolored, fuwn-colored, party-colored, and also gray turkeys. 'These can hatrdly ho considered worthy of hreeding excent in mil mateur why for amusement.

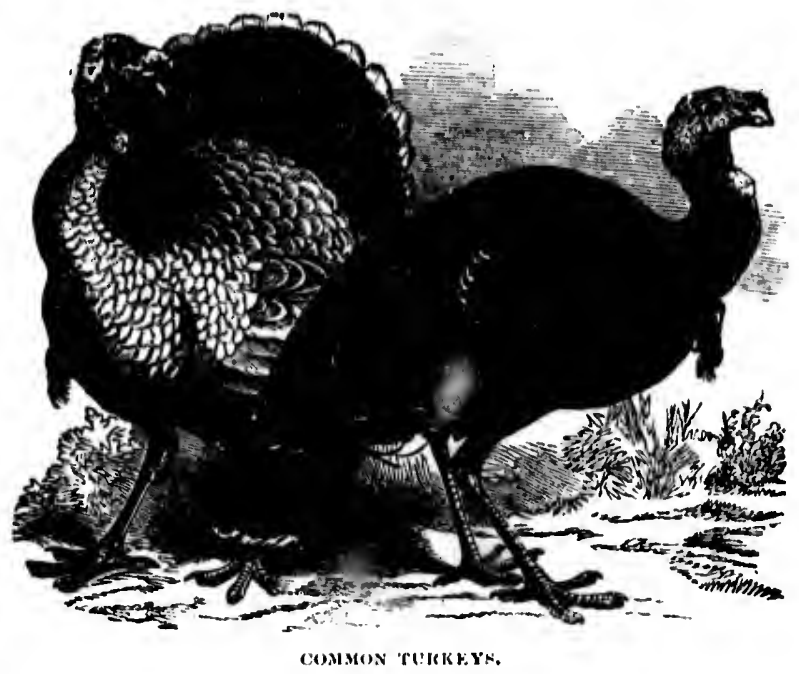

I. The Common Turkey.

These are pure white and black mixed, with the peculiar wattle and head of the wild turkey. 'They are of medium size, less given to wandering than some of the breeds, and will weigh dressed, if fat, at seven or eight months old, from ten to twelve pounds, sad at full maturity sixteen pounds.

\section{English Turkey.}

This is simply a modification of our common turkey, which by careful breeding has been made uniform and of an increased size. Of these the Norfolk turkey is black, with a few white spots on the wings. 'The breed most valued in Cambridgeshire is a bronzo-gray, and longer legged than the Norfolk variety. 


\section{The Honduras Turkey.}

The Hondurus or Ocellated turkey is one of the most elegant of the tribe, and is found all over Central America. It breeds freely with our domestic variety and the progeny is quite fertile. The ground color of the plumage is a beautiful bionzed-green, banded with gold-bronze and shiny black, and lower down the back with deep blue and red. Upon

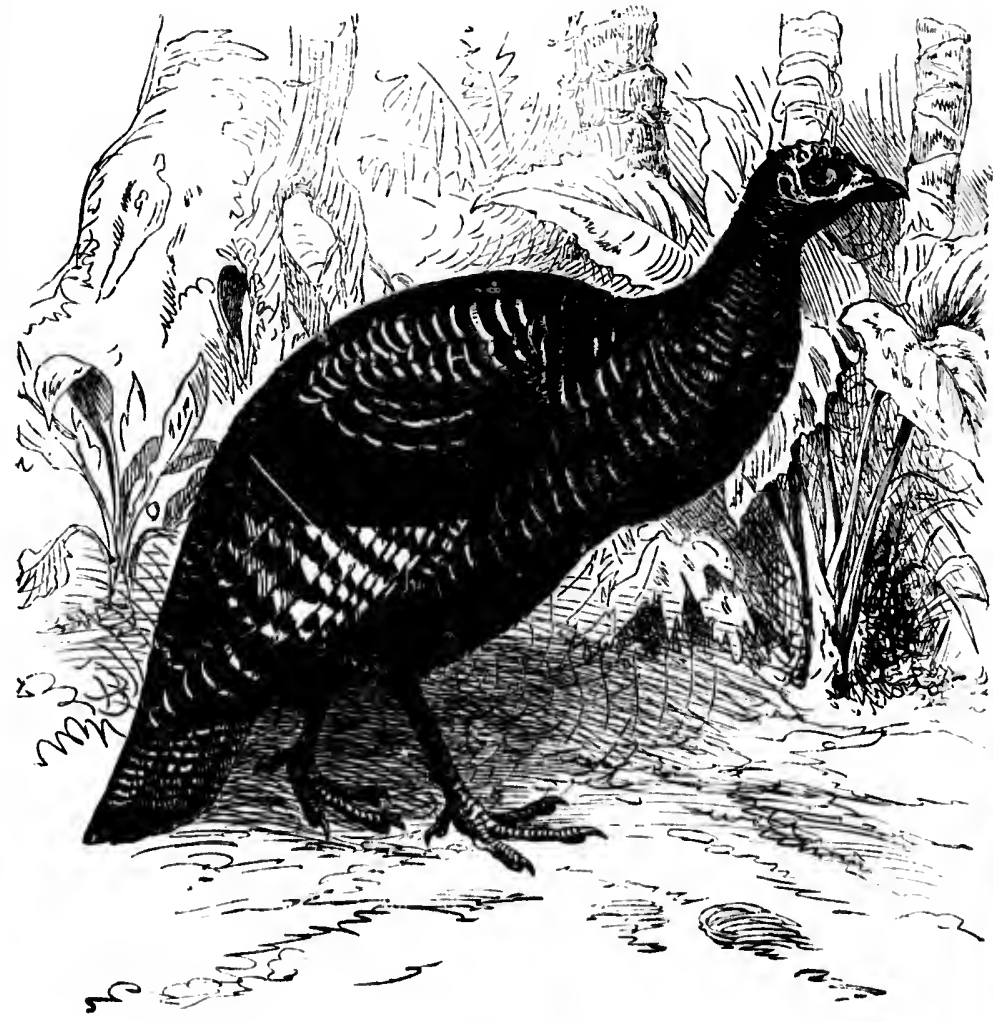

MELATKD TURKEY HKN.

the tail these binds are so well defined and sharp, thit they become ocellated or eyed, and hence the name. Unfortunately their southern origin makes them too tender for the North, but in the South there should be little difficulty in lireeding them. The Mexican turkey differs 
but little from the foregoing. 'There is more white in the tail feathers and tail coverts, and like the Honduras turkey, it breeds freely with our wild or domestic turkey.

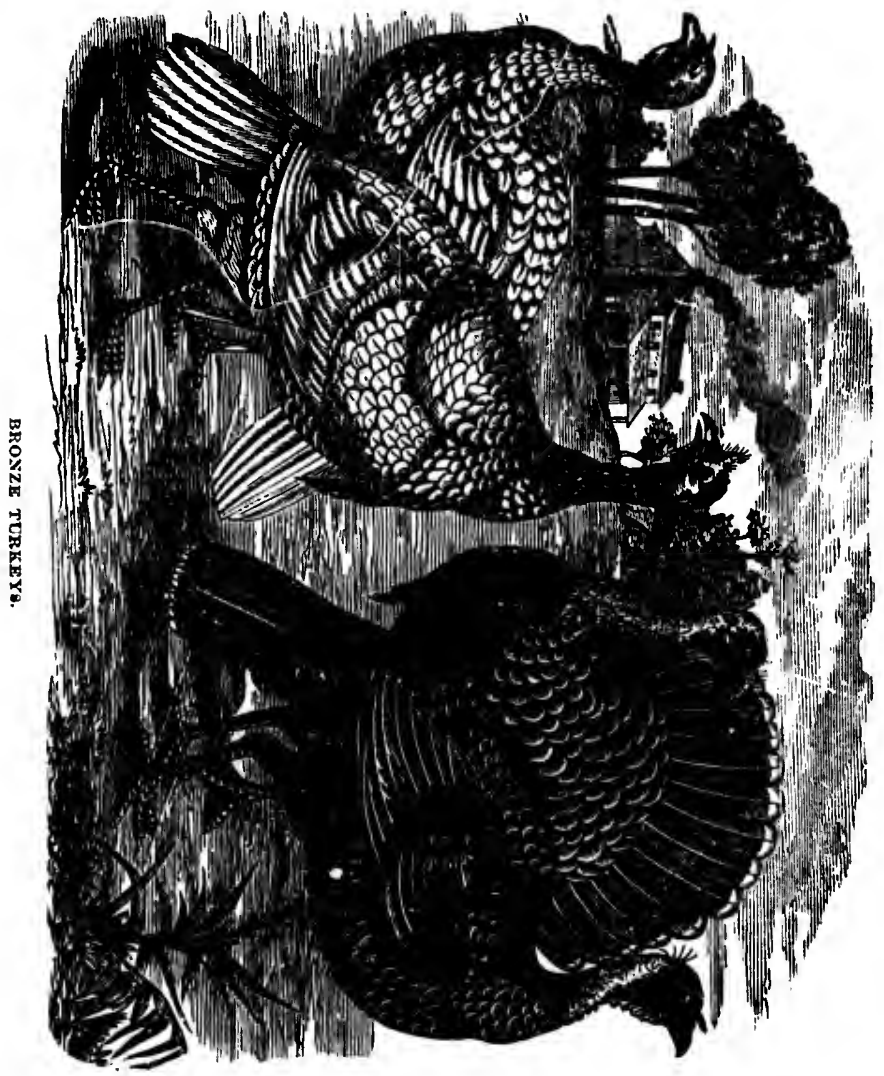

IV. Bronzed-black Turkey.

This is the lurgest as it is the best of the domestic turkeys, and was undoubtedly produced by a cross of the wild nale upon our common turkey, impressed and fixed by careful breeding and selection, until they will weigh with the best specimens of the wild breed, sometimes attaining a weight of o:er forty pounds each. The general average, however, is about thirty pounds for mature, well fattened birds, while hens will go 
from twenty to twenty-five pounds each. It is the largest as it is tho most magnificent in plumage of the domesticated varieties, and as hardy as it is beautiful.

In the cock the face, ear-lobes, wattles and jaws are deep rich red, the wattles warted and sometimes edged white, the bill eurved, strong, of a light horn color at the tip and dark at the base. The neck, breast and back black, shaded with bronze, which in the sunlight glistens golden, each feather ending in a narrow glossy black band extending clear across. The under part of the body is similarly marked, but more subdued. The wing-bow is black, showing a brilliant greenish or brown lustre, the flight-feathers black, barred across with white or gray, even and regular; the wing-coverts rich bronze, the end of each feather terminating in a wide black band, giving the wings when folded a broad bronze band across each; tail black, each feather irregularly penciled with a narrow brown band, and ending in a grayish-bronze band. Fluff abundant and soft; legs long, strong, dark or nearly black. The hen is similarly colored, buî more subdued.

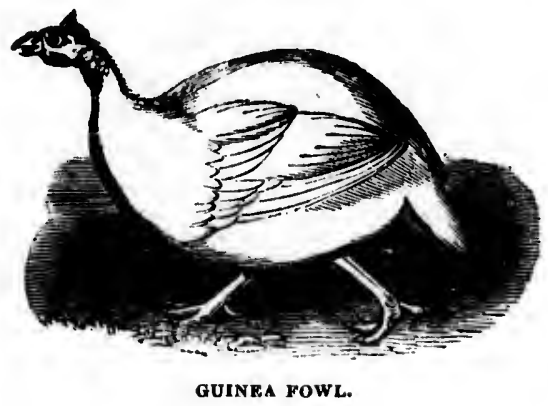

v. Guines Fowl.

The Guinea fowl is quite widely disseminated, bcing found in its domesticated or rather half-domestieated state all over Europe and America; yet can hardly be called common. The reason is they are shy and rather inclined to pair as in the case of other wild birds. II domestication one male may be allowed to about six females. They are grouped by some nnturalists into a eonsiderable number of varieties, but since the so-called species are all quite fortile together, the distinction is probably merely fanciful. They are found wild in the Cape Verd Islands and in Jamaica, having undoubtedly been carried thence.

The hen will lay about sixty or seventy eggs in n year, though they sometimes reach one hundred. The Pearl guinea fowl is the variety 
most usually met with in domestication, the spots being small and white on a purplish-gray ground. Rarely these colors are found reversed. So blue and dun colored birds with but few and even no spots are sometimes seen. There is also a pure white variety, exceedingly rare. The sexes are difficult to distinguish, the colors being so nearly alike. The cock has more wattle, is often more mincing in his gait, as though walking on his toes, and more pugnacious. In fact, their quarrelsome nature and habit of straying has perbaps as much as anything else, prevented their becoming more common.

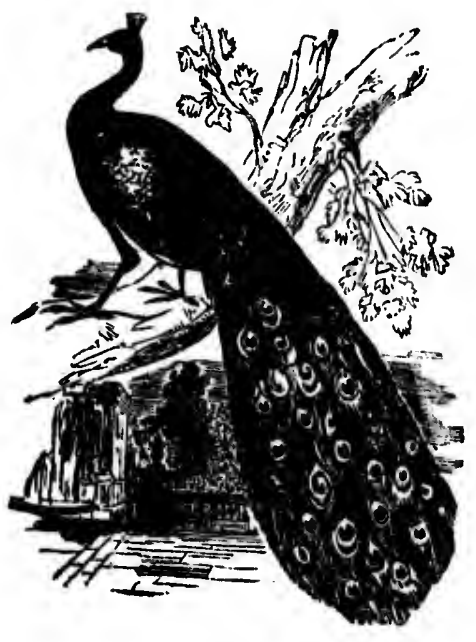

PEACOCK.

d in its ope and they are irds. III They are eties, but e distinctape Verd ugh they he variety

\section{The Peacock.}

This magnificent bird, as useless as it is beautiful for its tail feathers, and a rarity in the barn-yard, is as hardy as a turkey at maturity, and the young are not difficult to rear. The hen is very secret in stealing her nest in some out-of-the-way place where the male bird may not find it, since, if so, he is pretty sure to destroy the eggs. They do not commence laying until pretty late in the season, and keep their brood out of view until cold weather drives them home for food. The male is much given to wandering, often roaming for miles about the country, his strong pinions and immense tail enabling him to fly long distances. 


\title{
Water Fowl.
}

\section{CHAP'TER VI.}

DUCK8.

\begin{abstract}
1. DOUEN DUCKs.- - II. ATLesBuRY DUCKS, - III. CALL DUCKs. - IV. CAYUga BLACK DUCKS.- V. GRAY DUCKS - VI. BLACK EAST INDIA DUCKS. -
\end{abstract} SUMMARY

Ducks and geese are becoming more and more fancied from yeur to Jear on the farm, as they should properly be. The reason why they have not been more extensively raised than they have, is from the erroneous opinion that a pond or lake is essential to them. They should have a pool of water to wash in ; this produced, it is all that is necessary so fur as water is concerned; in fact, without water they are more domesticated and less inclined to ramble. All the principal farm breeds of ducks are probably descended from the Anas boschas, or wild Mallard. Like the wild goose, it is not difficult to domesticate wild ducks. All that is necessary is to get the eggs and rear them under a hen, the eggs hatching in twenty-eight days. There is no farm bird that is a more inveterate insect hunter or more agile than a young duck, one speeimen taking fully double per day what chickens will. Hence their value to the farmer, and especially the gardener, is very considerable in addition to their egg and flesh producing qualities. They should be raised more extensively than they are, and on every farm.

\section{Rouen Ducks.}

Whatever may have been the origin of the name, Rouen, from a town in France, celebrated for its ducks, or roan, from its color, this varicty is simply a wild Mallard, improved and enlarged by selection and care in 
breeding. The marki is as found in the wild variety will very perfectly describe the tame. Good specimens will dress six pounds each, and over; occasionally specimens will weigh nearly eleven pounds, alive. Their

- IV. CAYUga DUCKs.

from yeir to on why they om the erroThey should $t$ is necessary more domes$\mathrm{m}$ breeds of ild Mallard. ducks. All hen, the eggs hat is a more one specimen their valuc to le in addition raised more

from a town , this variety $n$ and care in

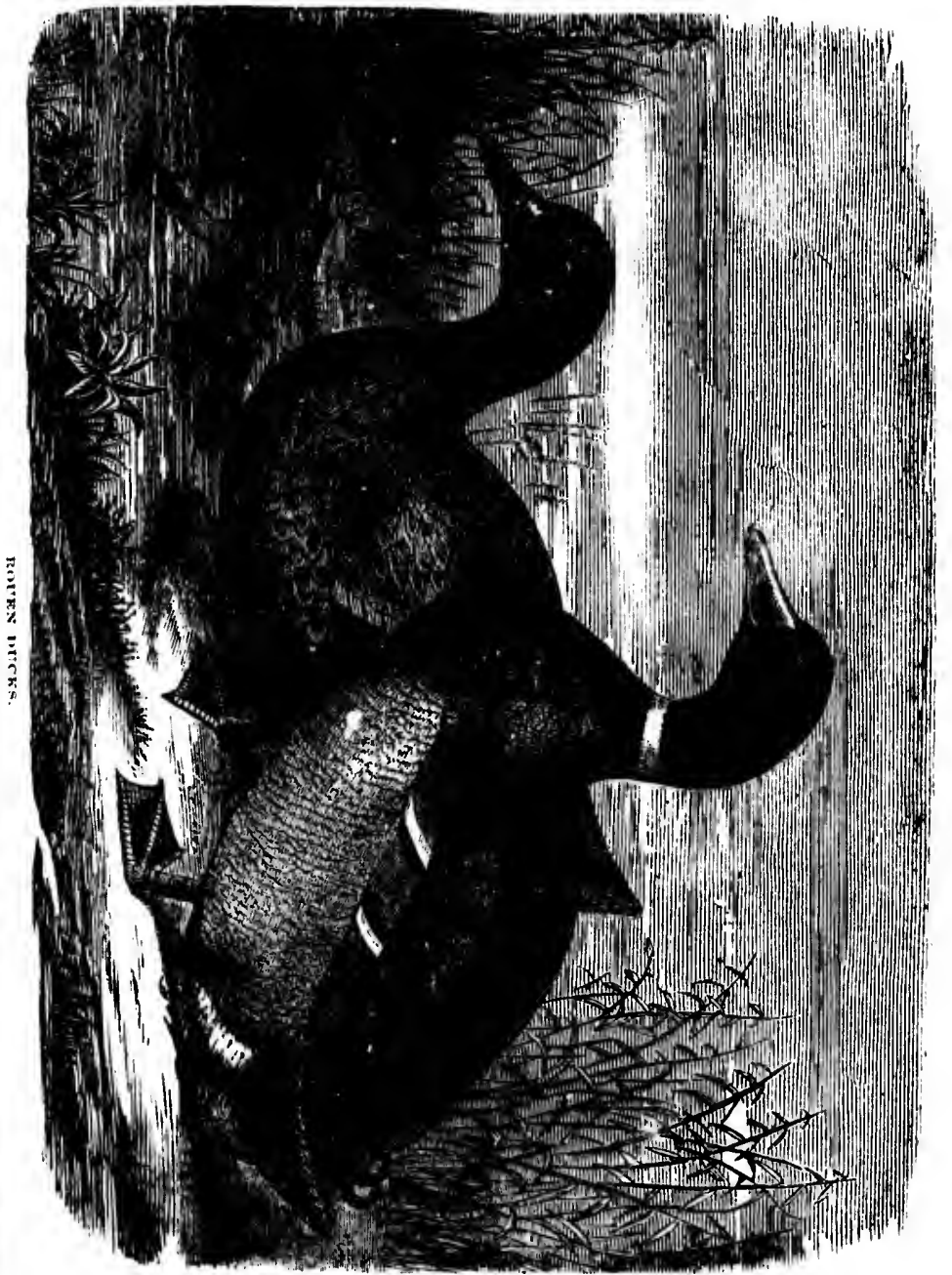

lesh is abundnut and of the very best flavor. They senreely wander at al. In fact, they are so lazy and disinclined to exercise, that if abund 
antly fed they soon become so fat that their abdomens trail on the ground. From their inactivity they mo the mo:st ensily stolen of any variety. The eggs are laid in great numbers, of a hluc-green color, with thick shells, and should average in weight about three and a half ounces.

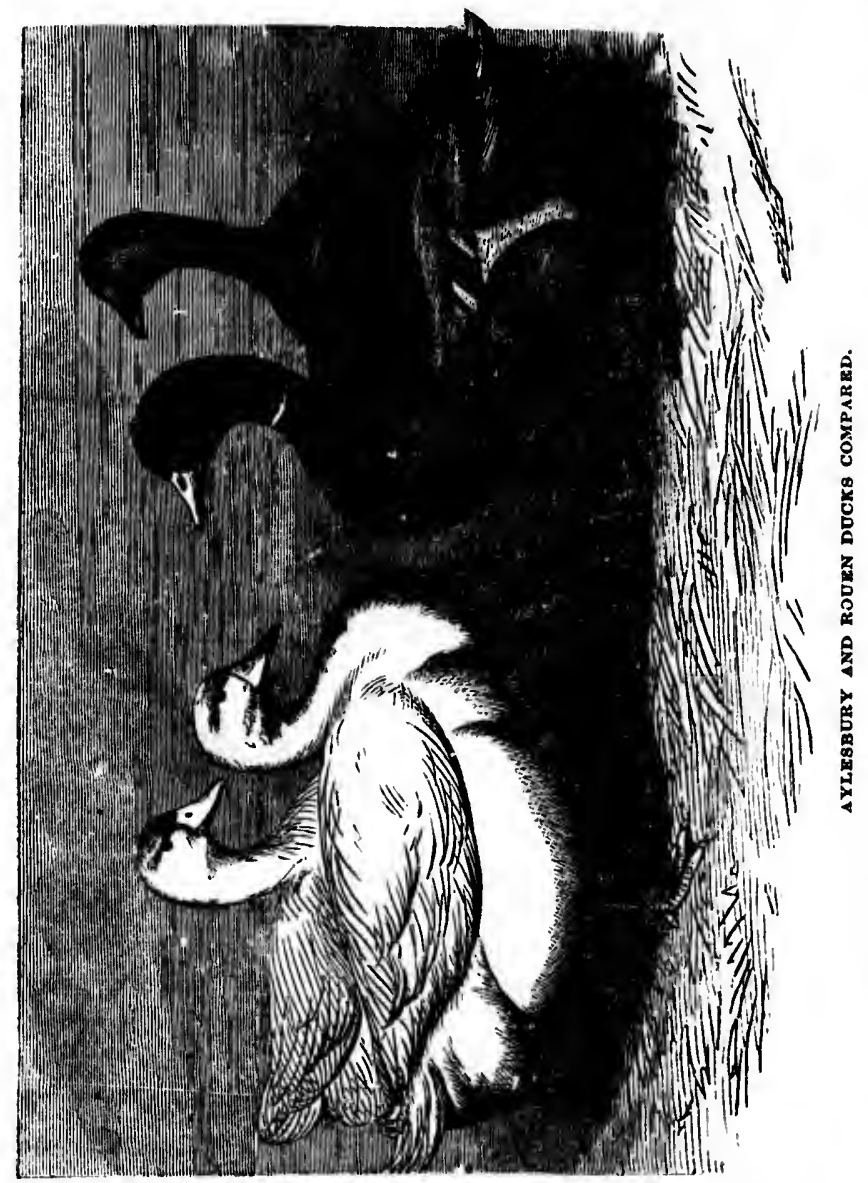

II. Aylesbury Ducks.

The Aylesbury duck is without doult the most valualle of the English breeds, and fully as well appreciated in this country as in England. They bardly reach so great weight as the list inentioned variety, eighteen 
pounds the pair being about the outside figure. They are prolific layers, the eggs of a pure white color, thinner in the shell than those of the Rouen. The ducks are excellent mothers hecause less unwieldy than the Rouens.

In buying dueks for breeding purposes, and especiully the Aylesbury, avoid those that are down behind, from undue stretching of the abdominal muscles; such birds mre always sterile, both as to the ducks and drakes.

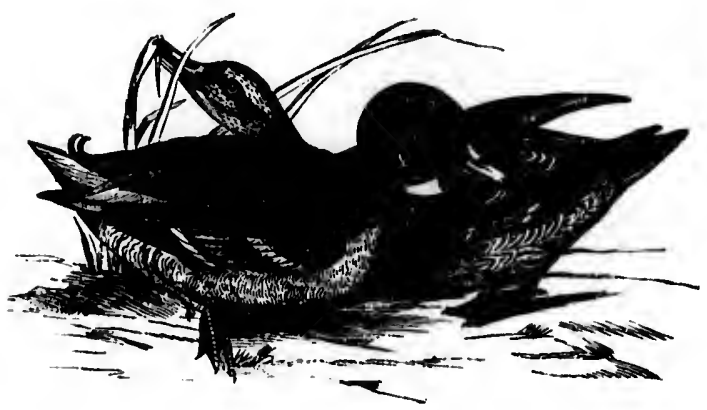

(iRAY CAI.I, DUCKB.

III. Call Ducks.

There are two varieties of small ducks that have the same relation to the large variety, as Bantams have to Barn-yard fowls. One is the Giny Call, the other the White Call duck. The first is an exact counterpart of the Rouen in every respect, even to the legs, feet and bill ; the other being in color like the Aylesbury, but differing in the bill, whieh is n clear fellow, while the Ayleshury is fleshrolored. As fanciful things on a piece of water, they are very pretty, as to either variety. The colored variety

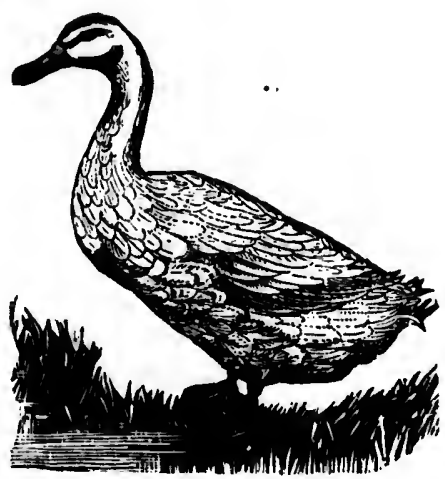

WHTE DUCK. the English gland. They ty, eighteen is much used as decoy ducks for the wild species, being remarkable for their loud, shrill and coutinuous quacking note. Hence their name, as they all the game from great distances and lure then within the range of the sportsmau's rifle. 


\section{Cayuga Black Ducks.}

These are the finest of the American breeds, as they are the largest, most valuable and handsomest of the duck tribe. The plumage is a rich metallic black, with lustrous reflections on the head, neek and wings. The bill is blue-black, with a jet black splush in the iniddle of it.

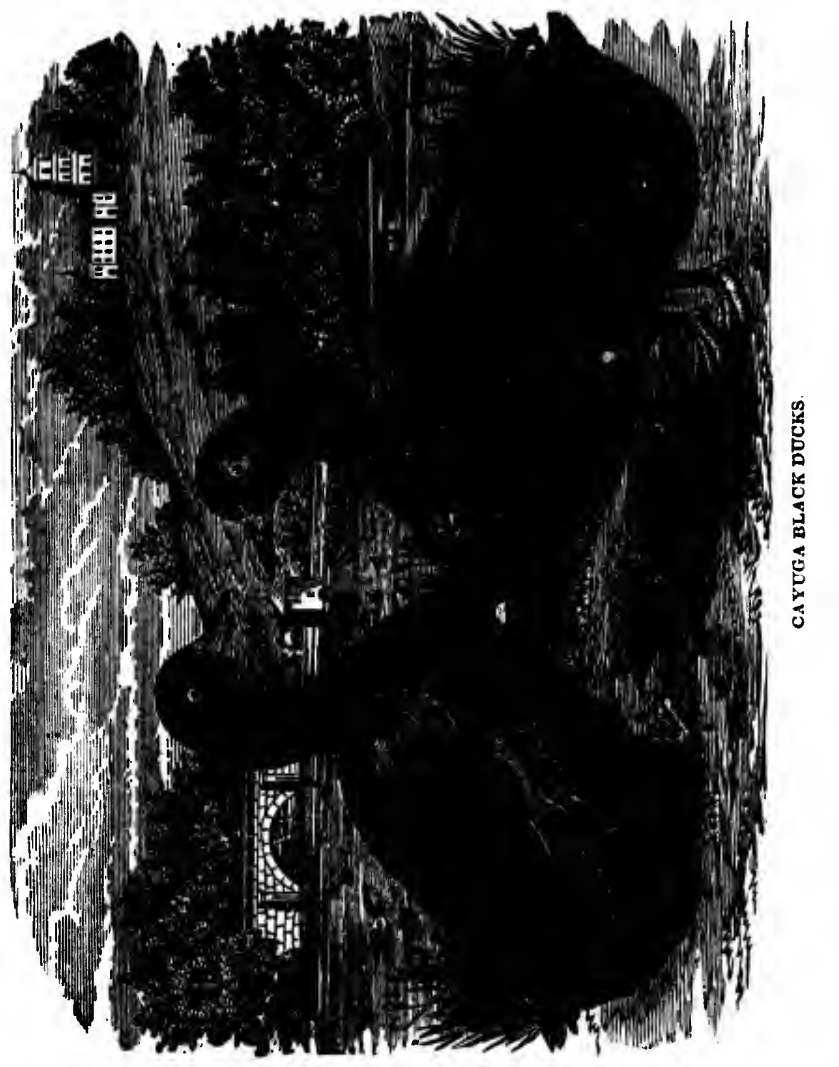

They have long, straight necks, long, straight head and beak, and in size they are fully equal to the Rouen, often weighing ten pounds each: The flesh is gamy in flavor, and to our taste fully equal to any of the wild species, exeept the Canvas-back, Widgeon and Teal. They are prolific in eggs, are quiet, mature nt an early age, and excepting possibly the Bouen, are the most valuable of all domestieated ducks. 


\section{v. Fanoy Ducks.}

largest, is in rich d wings.

benk, and in pounds each: to any of the They are prog possibly the

Among the 'most ormanental of the duck tribes are the Mandarin and the Carolina ducks, both unsurpassed for brilliance of plumage and varicty of eoloring. The Mandarins are a Chinese variety, and the Carolinas the wild wood duck of the United States, domesticated and inproved by careful breeding.

The Muscovy duck is a large breed, and thought to be valuable on this account by some. They are only mentioned here on this aecount, since their strong flavor of musk should keep them from the tables of all who appreciate fine flavor.

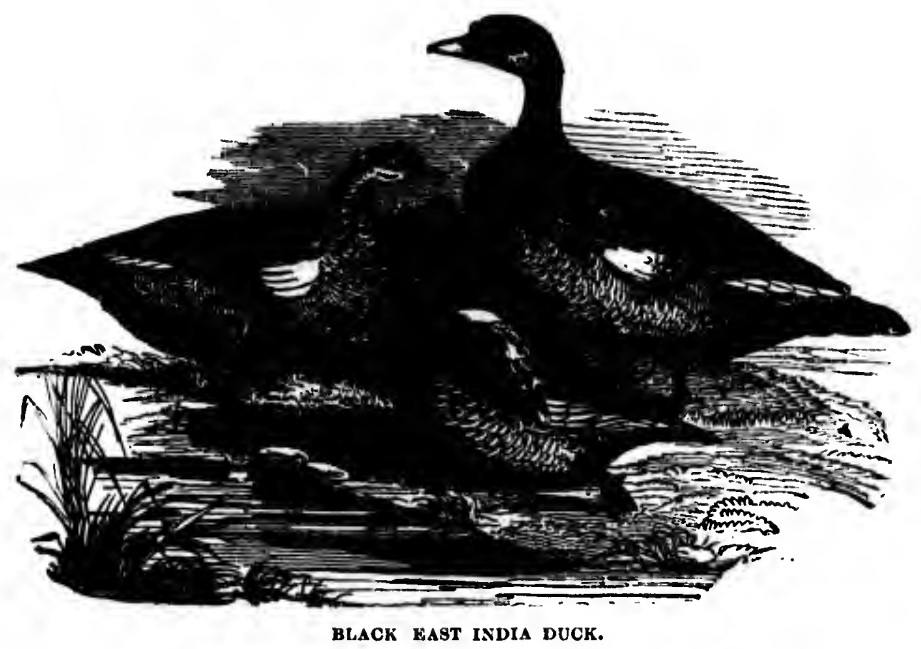

VI. Black Fast India Duck.

The Black East India duck which has appeared from time to time under various foreign names, as Labrador, Buenos Ayrean, and later as Black Brazilians, have little if anything to recommend them in comparison with better and larger breeds. They are undoubtedly a sport of the Mallard, and certainly are among the most beantiful of the small breeds, and are so hardy, and give so little trouble that it accounts probably for their many admirers.

\section{Summary.}

Ducks are valuable both for their feathers and flesh, for their aptitude in foraging for themselves, and especially for the great insect eating propensities of the young, they should be raised on every farm. Wild ducks 
are so numerous in the West that this is probubly a reuson why they are not more extensively bred there. But wild ducks are in the market for only a comparatively short time in the spring and Fall, and at all other

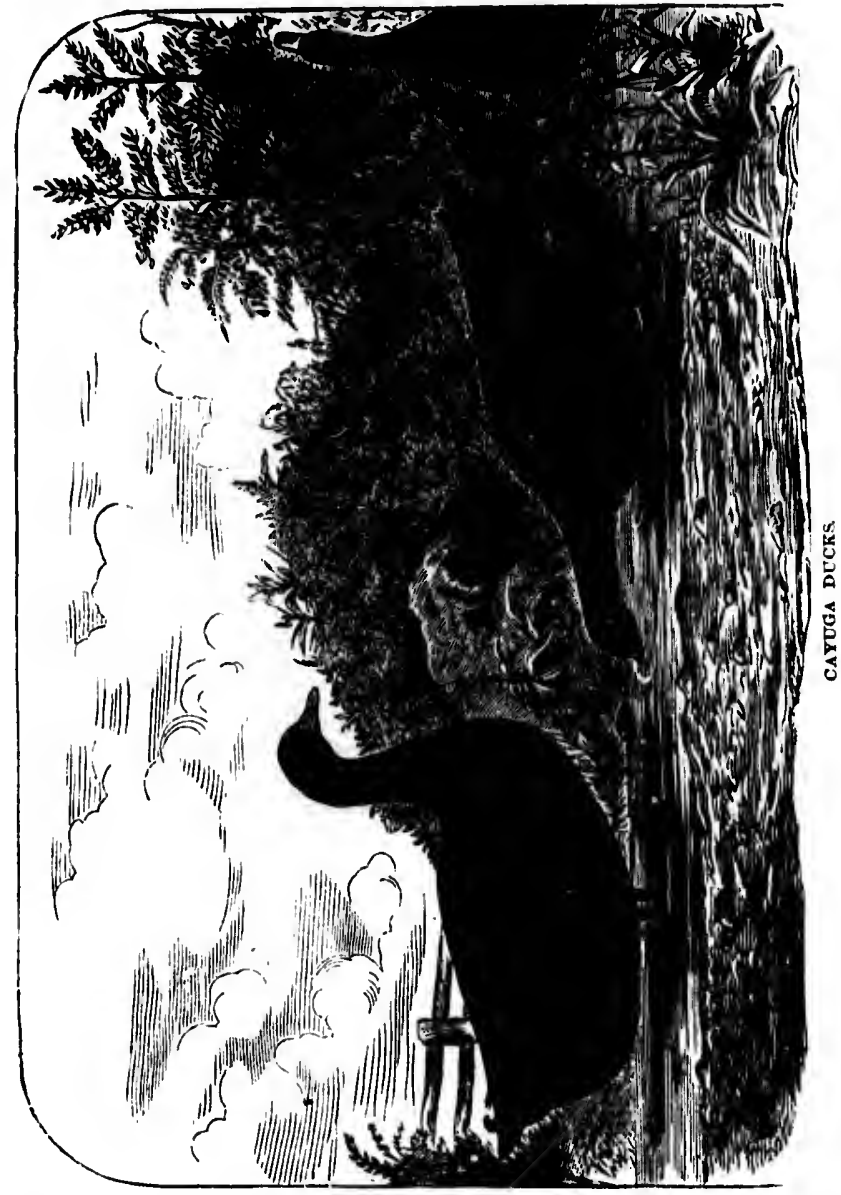

cool seasons ducks may be sold, and are not to be despised on the tables of the farmers.

When flesh is the principal object, and handsome ornamental qualities desired, the Rouen and especially the Black Cayuga will give satisfuction. If white feathers are desired the Aylesbury will be the best variety. As 
they are arket for ; all other

to the rearing it is extremely simple, they are little liable to disease, and woll able to take care of themselves; they must, however, have plenty of water to drink, and a pool to wash and swim in. These being furnished, if hatched under hens, they will give little trouble and fully repay the labor bestowed on them. Their period of incubation is thirty days.

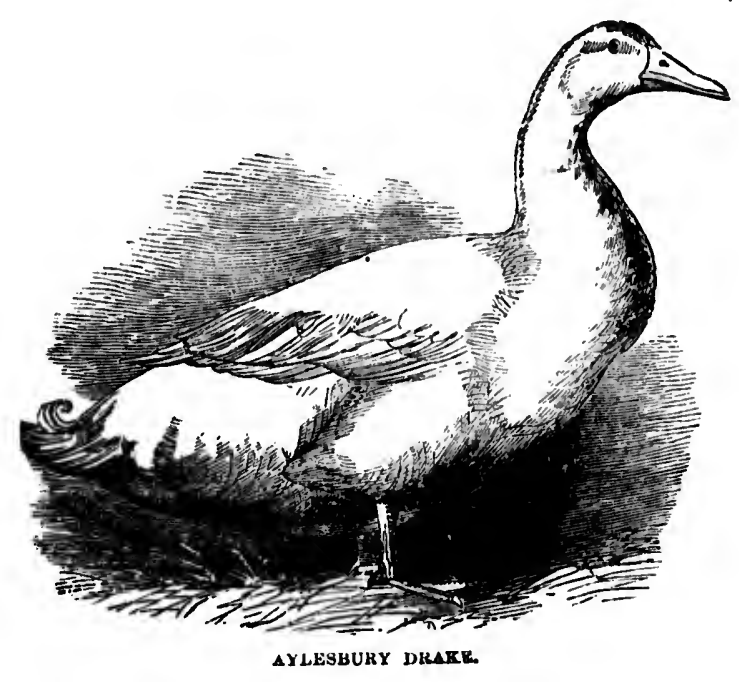

ntal qualities satisfiction. variety. As 


\title{
Water Fowl.
}

\section{CHAPTER VII.}

GEFSE.

\begin{abstract}
h EMBDKN OR BREMRN GKEgE. - I1. TOULOUBK OREBE. - III. HONG KONa GKKGR. IV. WHITE CHINRSE GERBE. - V. THR AFRICAN GEkBE. - VI, CANADA WILD GEESB, -MANAGKMENT OF GRBEK.
\end{abstract}

Geese, like the guinea fowl are noisy creatures, and these two birds are nine times out of ten better "wateh dogs" than the average eur. The former on the ground, and the latter perched high in a tree, see the smallest object and henr the slightest sound, and giving the alarm the noble watch dog wakes up, barks and gets the eredit. There ale only a fow varieties which we shall notice, but these constitute about all that are valuable of those fowls that "saved Rome."

\section{Embden, or Bromen Geese.}

These, the most valuable to our inind of the whole tribe, taken for large size, pure white fenthers, and nptitude to fatten, are worthy a place on any farin. They are spotless white in color throumont hn' male and female, full, and ereet in carringe, the legs crep wh und the bill dark flesh color, the eyes bright blue 'T' , large, and with rough thick shells. This breed att unu wei, , often going over thirty pounds, when mature, a il the use over thirty-five pounds. For breeding purposes twenty pounds will be a full weight for the randers. 


\section{Toulouse Geese.}

Next in order of praction merit, to our mind, is the Toulouse; these are culled ufter the eity of that nume in France. They are most compact in body, not so tall as the Bromon, but will often outweigh them. In

KONO GRTSE. NADA WILI GRBS.

- two birds are rage cur. The a trec, see the the alarm the here ire only a bout all that are

ribe, taken for worthy a place t bot" inale and () $r^{\circ}$ und the large, and i. often goover thirty-five full weight for

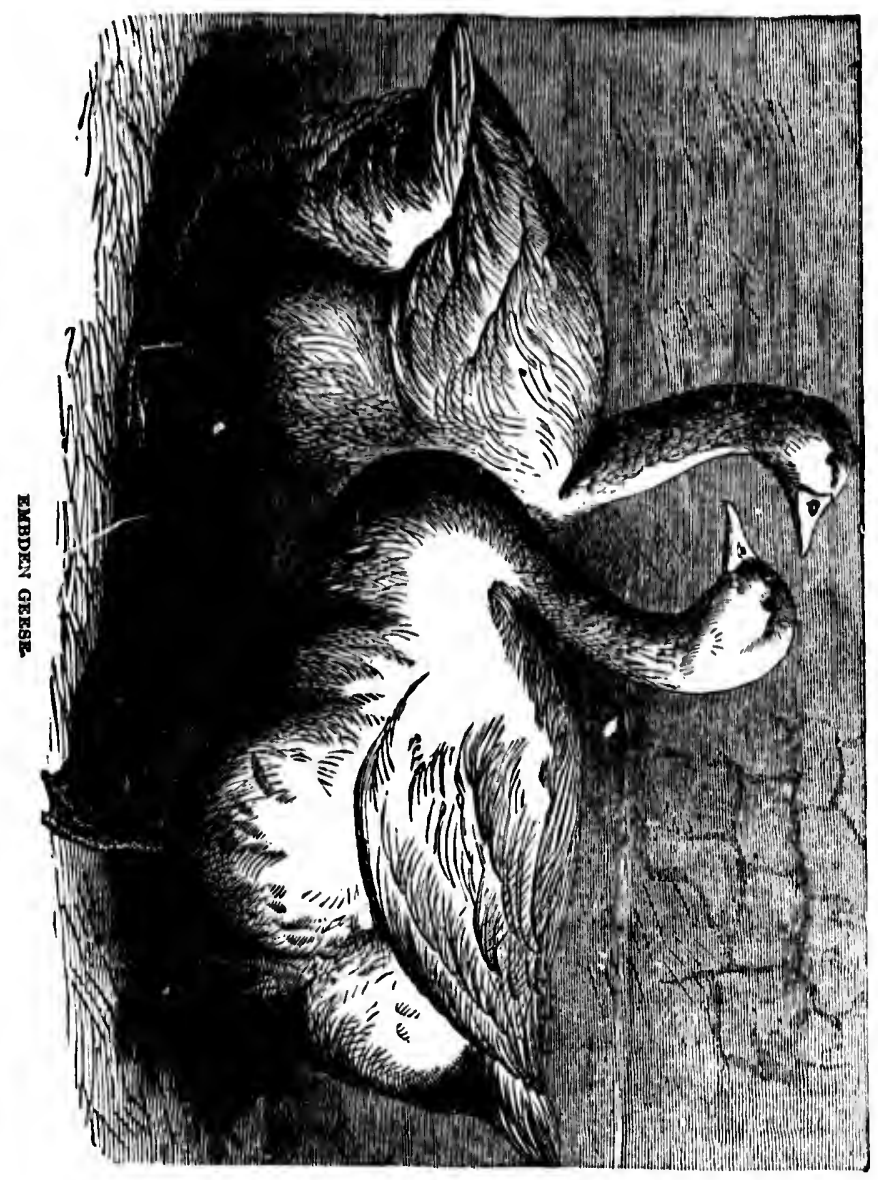

color they are light gray us to their bodies and breasts, the neck dark gray, getting gradually darker until it approaches the buck, the wings are of the color of the nock, shaded off lighter as it approaches the belly and at length becoming white; the legs and feet are a deep reddish orange, 61 
the bill the same, toned somewhat with brown. Both the Embden and Toulouse may be easily raised under hens, by regularly sprinkling the

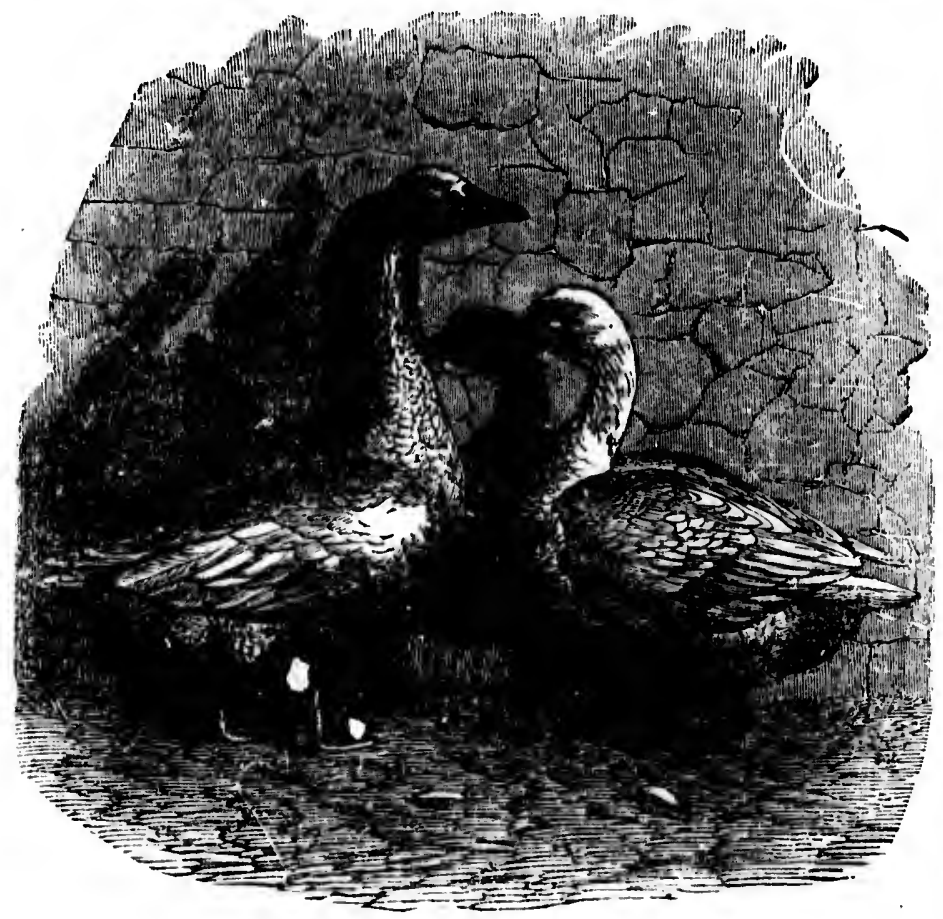

TOULOUSE GKese.

eggs with blood-warn witer, to keep the shells from becoming hard end thus imprisoning the young. This, with even in tub of water set in the ground, and good feeding, will insure success in geese raising.

\section{Hong Kong Geese.}

The China Hong Kong, or Knobbed goose, so named from the protuberances at the base of the bill, really possesses some of the characteristics of the swan as it does of gese. It is also in size, between a medium sized goose and swan, is lighly ornanental in the water, hardy, the most prolifie of any in eggs, und the qunlity of the flesh is superior. It has a harsh, discordant cry, and if nllowed full liberty will steal awity at night, if water for swimming in be near, or it etn find it. This nocturnal habit, bowever, can be prevented by shutting up at night in a place safe from 
foxes or owls, which should be practiced with all geese and ducks. Hong Kong geese vary much in color; they all hatve the same chinacteristic protuberances at the bill, and also a distinct stripe down the back of the neck. They should have a dewlap, or feathered wattle under the throat, the bills and legs should be of an oringe color, and the protuberances at

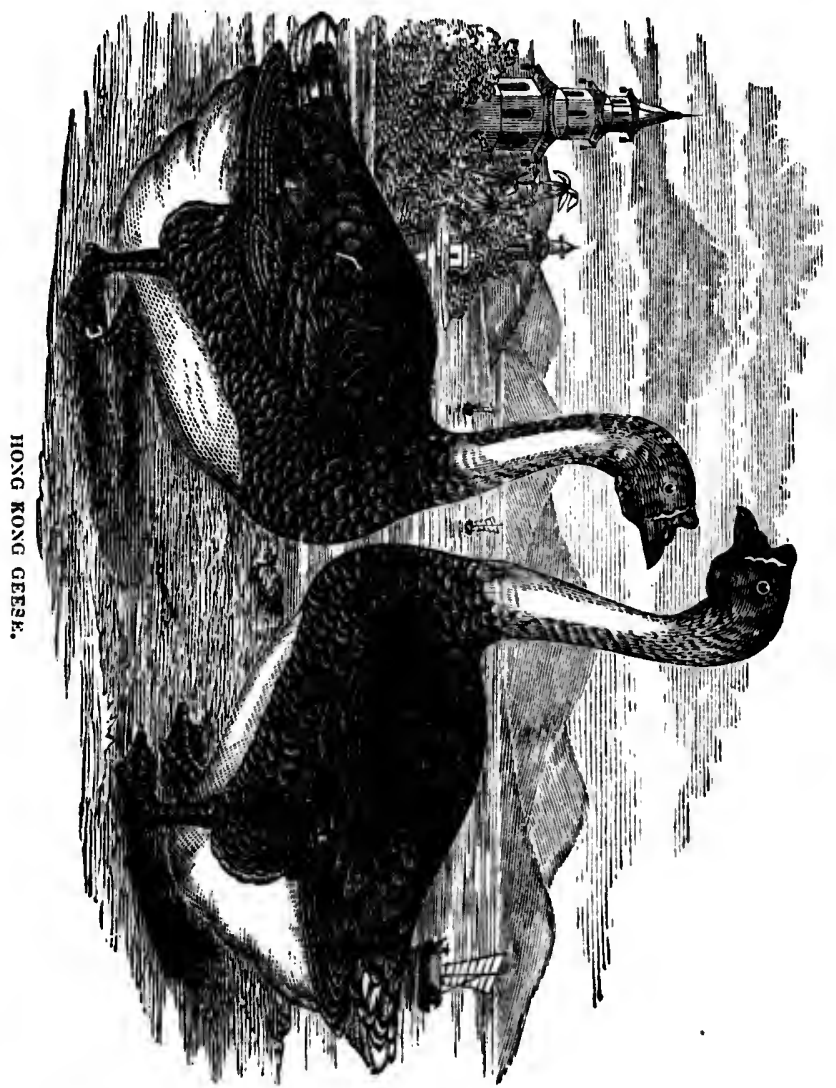

he protuin inedium , the most It has a y at night, runl lubit, sufe from

the base of the upper bill, dark, in fict almost black, the most usual cc!:: is grayish brown on the back and upper parts, changing to white or whitish gray under the alolomen, the neck and breast yellowish gray, with a distinguishing stripe of dirk brown ruming down the entire back of the neck, from the head to the hody. 
IV. White Chinese Geese.

The White Chinese geese are of immense size, pure spotless white throughout; the legs bright orange colored, bill the same color and with a large orange colored knob at its base. It is more swan-like than the

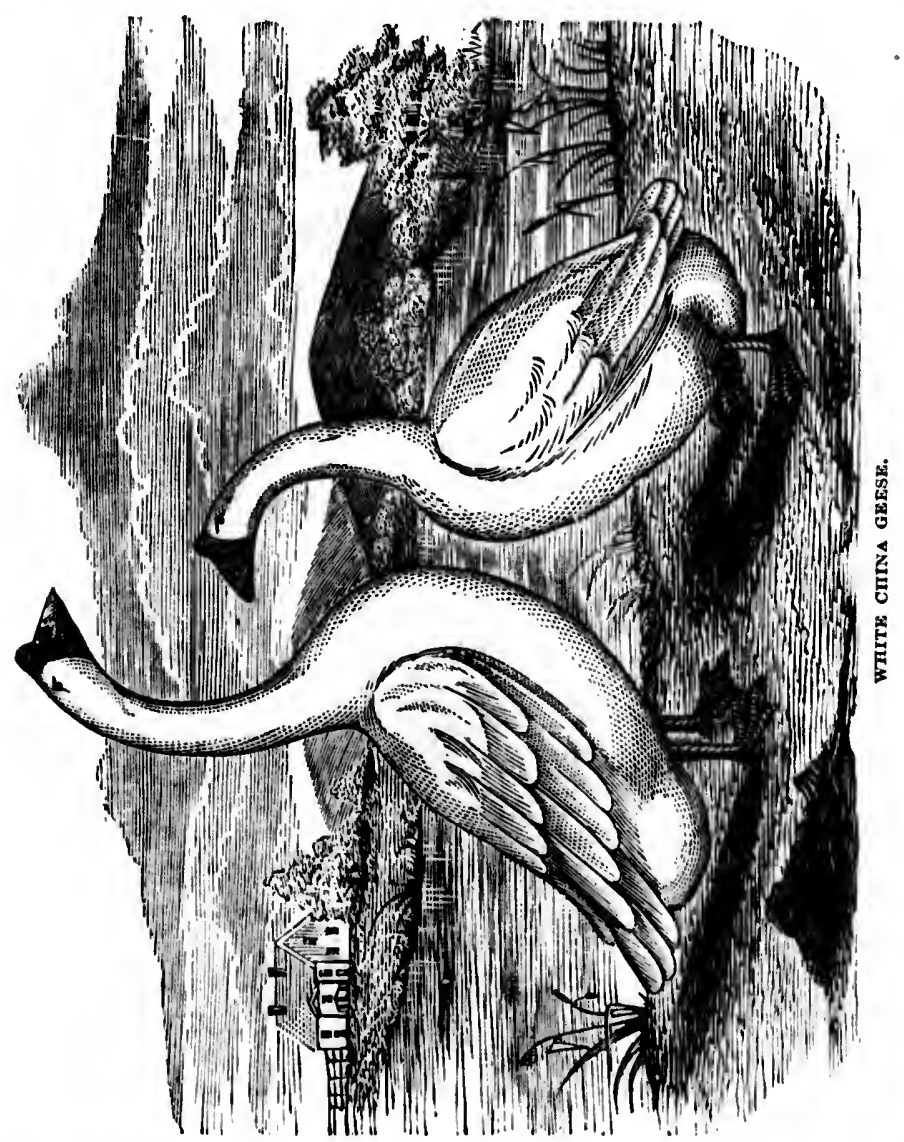

Hong Kong, of which it is perhaps a variety, and either in or out of the water is a most pleasing object. When swimming, its long, slender neck is gracefully arched, and whether for ornament or use, it is certainly a raluable breed. It is certainly as prolific us its colored relation, laying a large nuniber of rather small eggs in a season, breeding three or four times,

the

and

in th

than

$\mathrm{Tt}$

and 1 head what

along th a bright membra name $A$

This e upon bei 
the period of incubation being five weeks. The goslings are easily raised, and are of tiue eating quality. A peculiarity of the breed is the disparity in the relative size of the sexes, the males being often one-third heavier than the females.

\section{The African Goose.}

This immense goose, among the largest of the tribe, is of fine curriage and bulk, carrying its neck upright, and head high, when walking. The head and top of the neck are brown, deep on the upper side and somewhat lighter on the under side; the bill is armed with small indentations

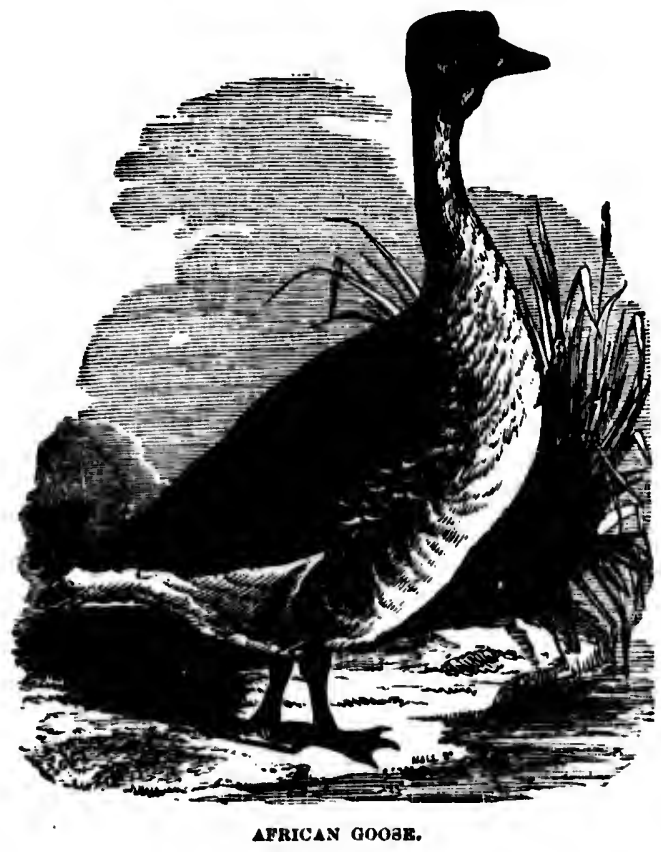

along the sides, and at the base, on top rises a round, fleshy tubercle, of a bright vermilion color, and under the throat is a hard, firm, fleshy membiane. These birds have also been called Siberian geese, but the name Afriean is undoubtedly the proper one.

\section{Canada Wild Grese.}

This excellent goose may be easily hatched from wild eggs, and which upon being domesticated, take kindly to the farm. It is too well known 
to need description; when farn-bred it retains much of the game nature of the flesh of the wild birci. Their sagacity is superior to that of any other goose. It has a wide range of flight in its wild state, being found at proper seasons from the Arctic circle to the Torrid zonc, and in Europe as well as in America; specimens baving been shot in England. It is certainly one of the most beautiful of water fowls. It breeds kindly with any of the common varieties, and is reputed in France to have interbred with swans.

\section{Management.}

There is but little care necessary in breeding gcese. They require a dry place for passing the night; are subject to but few diseases, and these only when young. For diurrhœa, give a drop or two of laudanum in a little water, to be repeated if the first dose does not cure. For giddiness, bleed them in the prominent vein which separates the claw. Insects sometimes annoy them by getting into the nostrils and ears. It may be known by their hanging wings, and the shaking of their heads. Feed them corn at the bottom of a vessel of water. For fattening, there is nothing better than corn-meal, steaned potatoes and skimmed milk, alternated with ground buckwheat, oat-menl or barley-meal. During the fattening process they should be kept closely confined. When futtening, the French pluck the feathers from the belly. They should be fed three times a day, and supplied with plenty of pure water, and when fat, which should be in two or three weeks from the commencement of feeding, they should be sold immediately, since they at once begin to lose flesh again. 


\title{
PART X. \\ Diseases of Poultry,
}

\author{
AND THEIR REMEDIES.
}


ANATONY 0

-INP

To odr

There a as apoplex dies. Otl and thus are difficul of disease fancier are of easy $t r$ visions - d considered weakness, For a bette the skeletc make a gor 
CHAPTER I.

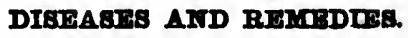

LNATOMY OF THE MEN. - $\triangle$ POPLEXY. - ITS OAOBE. - ROUP.-TO CURE. -

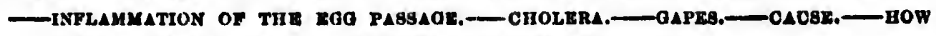

TO CORX.—CROP BOUND. - DIPHTHERU, OR ORONP. - LCE.

\section{Diseases of Fowls.}

There are but few diseases to which fowls are subject. Some of these, as apoplexy, are so sudden and fatal that there is scarcely time for remedies. Others, as so called chicken cholera, are malignant and infectious, and thus require watching. Others again, inflammatory in their nature, are difficult to understand and hence difficult to treat. The general run of diseases, however, to which the fowls of the farmer and suburban fancier are liable to in his flock are, as a rule, siraple in their nature and of easy treatment. We shall, therefore, divide diseases into but two divisions-dangerous and simple ailments. In the first class will be considered those more fatal, and in the second class mere ailments, as leg weakness, bumblo foot, catarrh, diarrhea, pip, lice, and other parasites. For a better understanding of the subjects, we introduce figures showing the skeleton of a fowl, their true positions and proper numes. It will make a good study in connection with those on plumage, etc. 
Explanation.-A-The head, length 23.4 inches. $B$-The neck, length 5 1-2 Inches. $C$-The back or spine. $D$-The hips or hip bones, (the back aud hips

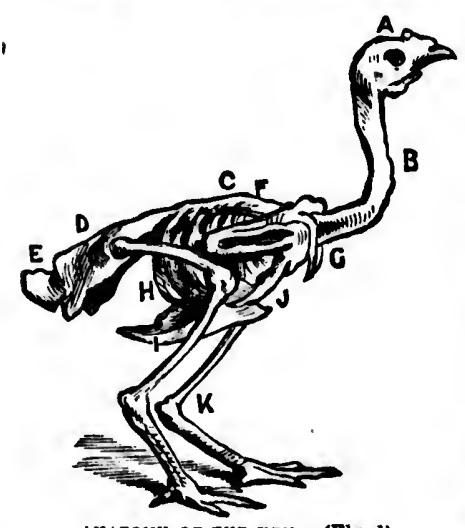

ANATOMY of THE neN, (Flg 1).

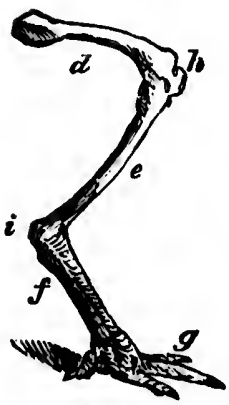

thigh bone, 3 1-7 inches; $e$ - the shin bone, length 4 1.3 inches; $f$-the bone of the foot, the tarsus, length 31.7 inches; $g$-the claws, that of the middle, length 21.3 inches: the two to the right and left, length $16-10$ inches; that of the back, length 8-10 inches; $h$-the patells or knee; $i$-the os calcis or heel.

The engraving (Fig.1.) represents the skeleton of an ordinury hen of an average size, and in the proportions to be generally met with. The only important musoles are those which compose the flesh, from which are formed the breast, the thigh, the leg and (Fig. \&) the wings. All the others are slender and only furnish a little for table use.

People often confound the thigh, the leg, the foot and toes of the hen, and so it is with nearly all animals. One expects to see her walk on the foot, though she walks like them on the toes. It is evident that the tarsus of the hen is the foot she would use on the ground if she walked like man; the end opposite the toes is the heel. Some fowls have five or six toes but they do not all rest on the ground always.

\section{Apoplexy-Ita Causo.}

Over-feeding and over-stımulating of fowls-seldom occurring on the farm-and generally known by finding the subjeot dead, often in the 
nest. Prevention is the proper means to use. Give plenty of exercise and good wholesome food, but not tlut of nu over-stinuluting nature. The cure is by opening a blood vessel and bleeding freely, selecting the largest of the veins on the underside of the wing. Hold the vein between the opening and the body, and relense it when blood enough is tukel. Keep the bird quiet and on light diet until recovered.

Roup.

The symptoms are at first those of severe catarrh. The discharge loses its thin, watery, transparent character, gets opaque, with a peculiar and offensive smell. The inner corner of the eye contains froth, the lids swell, stick together and at last close. The nostrils close from the same accumulation; the sides of the face swell and the bird dies. It is a disease of the lining membrane of the nasal cavities.

To Cure.

Provide warm, dry, well-ventilated quarters, stimulating and nutritious food. Give internally a tea or a table-spoonful of castor oil, according to the size of the fowl, syringe the nostrils with chloride of soda, two parts water to one part of chloride. Inject by inserting the syringe in the slit at the roof of the mouth. Three or four hours after the oil give the following:

No. 1. $\%$ Ounce balsam copaiba, \%. Ounce llquorice powder, * Drachm piperine.

Divide into thirty doses, enclose each in a little gelatine, and give a dose twice a day. Isolate the sick fowls from all others, and kill promptly if they do not yield to treatment.

\section{Fgg Bound.}

In this disability the eggs cannot pass down the passage. Strip a tail feather to within an inch of the end; saturate it thoroughly in lard oil or sweet o:l, and pass it carefully up the passage to the egg, lubricating the whole. If relief is not given, repeat the process.

\section{Inflammation of the Egg Passage.}

Symptoms.-There will be general feverishness, dullness, and the feathers, especially those over the back, will be raised and ruffled. Give the following:

No. 2.

1 Grain calomel,

1-12 Grain tartar emetic.

Mix; envelop in gelatine and place, well back on the root of the tongue until swallowed. If relief do not ensue in two days, give auother dose. 
Symptoms.-There is sudden and great thirst with diarrhœa ; the cvacuations are greenish, but soon change to a whitish character; cramp ensues and the bird totters, falls, and often dies suddenly. Administer every three hours, until relief is obtained, the following:

No. 8.

B Grains rhubarb,

2 Gralns cayenne pepper,

10 drops laudenum.

Give this at a dose for large fowls, and half this quantity to ehickens two months old. Between each dose keep up the strength by giving a ten-spoonful of brandy and water, hulf and half. This is also good for common diarrhoea, omitting the brandy.

\section{Capes.}

Parasitic worms (sclerostoma syngamus) in the windpipe, occurring in chickens up to two or three months of age.

\section{How to Cure.}

Separate the chickens affected; strip a small quill feather to within half an inch of the end. Dip in spirits of turpentine; pass it down the small opening of the windpipe, at the base of the tongue; turn it once or twice around and draw it out. If it does not relieve operate again next day. Give a warm, dry place, plenty of good food, and for drink, milk well sprinkled with black pepper. It is supposed that the gape worm is produced by a small parasite insect resembling a tick found on the heads of young chickens. Examine the heads with a pocket lens and if found use the following, lightly rubbed on.

$$
\begin{aligned}
& \text { No. 4. } 1 \text { Ounce mercurial olntment, } \\
& 1 \text { Ounce lard oll, } \\
& \text { \% Ounce flowers of sulphur, } \\
& \text { \$ Ounce crude petroleum. }
\end{aligned}
$$

Mix, and apply just warm enough to be melted. It is said that a casc of gupes has never been found in which the young chickens were not first infected with the tick paraisite.

\section{Blsok Rot.}

Swelling of the legs and feet, the comb black, resembling mortification. Give a tea-spoonful of castor oil, and then daily, until relieved, half \& 
tea-spoonful of flowors of sulphur. This is also good in sealy leg, and cruptions of various kinds, using also, after washing clean, the following :

No. B.

4 Ounces lard oll,

1 Ounce turmerlo powder.

Anoint the affected parts.

Catarrh-Symptoms like the first in Roup. Cleanliness is the best prevention. To cure, feed black pepper in mashed potatoes. If this fails, take:

No. a

\author{
8 Parto pulverized charcoal, \\ 3 Parts new yeast, \\ 2 Parts flowers of sulphur, \\ 1 Part flour.
}

Mix into pills the size of a hazelnut and give one, three times a day; bathe the nostrils and eyes frequently with tepid milk and water, and keep the fowls otherwise clean.

\title{
Crop Bound.
}

The food sometimes beeomes bound and impacted in the crop. The remedy is to make an incision into the erop sufficiently large so the contents may be earefully extracted with a blunt instrument. Close with a stiteh, and feed with soft food for two or three days, in which a little gentim and cayenne pepper is mixed.

\section{Diphtheria, or Croup.}

It may be known by the cough, raising of the head to breathe, and the offeusive sincll.

What to do-Strip a feather to within half an inch of the end; wet it and dip in powdered borax, and swab the throat well. Nitrate of silver would be more effective. Give to drink, chloride of potassium one-fourth of an ounce dissolved in a half gallon of water.

Preventive-Cleanliness, good ventilation and eare. The rule will apply to roup, catarrh, gupes, pip, and other acute and chronic disenses.

Pip_This is a result of other diseases rather than a disense of itself. Remove the erust at the tip of the tongue and wash with chloride of soda, examine the nostrils for any stoppage, and give a tea-spoonful of eastor oil if the fowl be very sick.

Rheumatism-Cause-Exposure to damp and cold winds, and bad roosting places; remove the fowls to comfortable quarters, and feed warm, rather soft, stimuluting food.

Laying soft eggs-Give plenty of lime rubbish, burned and broken oyster shells, or bone meal. 
Lice.

There should be no excuse for lifestment by these parasites. They will sonetimes make their uppearunee on new fowls, und setting hens will sometimes contruet them. 'They ure of two kinds : the common hen louse, and minute "hen spider," so-called. The latter very minute and infesting every part of the house, and often the horse stables, if the hens are allowed to run there. To rid the house, take out every movable article and wish thoroughly with carbolio acid and water, or with the anmonincul water of gas fuctories, which is chenp. Wash also every portion of the house with the same. Or, fumigate hy elosing every erevice, und burning in an iron pot contsining a burning hot stone, half the size of a man's head, a pound of roll brimstone, keeping the house elosed two or three hours. Then wash every part of the house with lime-wash in which a pound of potnsh has been dissolved to ench quart of water used in thinning the wash. Wash also the furniture, nests, perches and ull else with the potash solution, one pound to a quart of water. Put back the furniture, place fresh hay in the boxes, plenty of dust baths near, and the lice will leave the fowls and die. In case the stuble becomes infested, or other places that may not be fumigated, wash with the potias solution, or the lime-wash, eontaining one part in twenty of carbolic acid.

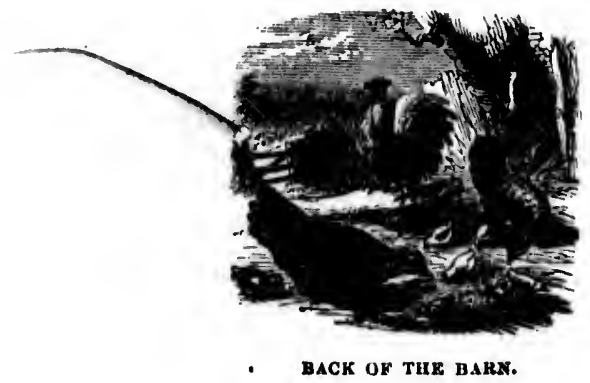




\section{PART XI. Bees;}

THEIR HISTORY, CHARACTERISTICS AND MANAGEMEN'T. 
Bees 1

Insecta.

Greek wo and saw is a large it hears o That whi: honey-bee Bible. S previously Testament whieh sho of rocky c part of $t$ fansiliar $\mathrm{S}$ writing of then in $h$ Pliny the worthy of revival of published ? of Bees." flood of lig Reaumer o and Sprene America, " Quinby, Co so that the 


\section{B E ES.}

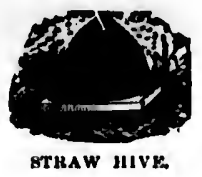

Bees belong to that olass in the animal kingdom known by naturaliats as Insceta. The division in which they range is called Hymenoptera, from two Greek words denoting membrane and wings. Wasps, ants, ichneumon flies, and saw flies, are members of the same family. The uatural history of bees is a large study in itself, and can only be denlt with in these pages, in so far as it hears on the management of an apiary. There are several varieties of bees. That which has been domestiented by man is known as Apis Mellifica, or the honey-bee. The earliest historical referenees to this inseet ure found in the Bible. Samson ate honey that had been stored in the carcass of a lion previously slain by him. Honey is mentioned several times in the Old Testament. It is spoken of as dripping from the flinty rock, an allusion which shows that in aneient times, as now, the bees of Palestine took jossession of rocky cavities as hives and stored honey in them. Wild honey formed part of the diet of John the Baptist. Honey, and the honeycomb, are familiar Scripture emblems. Coming now to pro'; ne history, we find Aristotle writing of bees upwards of three hundred years B. C. Virgil immortalized them in his fourth Georgic, some three hundred years later. Colunella and Pliny the elder wrote about bees during the first century, after which nothing worthy of note is on record conceruing them, until two centuries after the revival of lenrning in Europe. Swammerdam, a Dutel entomoiogist, published alout the middle the seventeenth century, "The Natural Hiștory of Bees." A century later, Linneus, the great Swedish naturalist, threw a flock of light on the whule subjeet of insect halits, those of bees included. Reaumer of France, Bormet of Switzerlaud, Nabricins of Denmark, Kirby and Spence of England, Huber of Gernuny, Packard and others of America, also, later on, Dzierzon, the Baron of Berlepseh, Iangstroth, Quinby, Cook, and a host of others have written trentises on the honey-bee, 80 thnt the literature of this subject forms a large librury in itself. 


\section{Queen, Drones, and Workers.}

There are three kinds of bees in every stock or colony, a queen, a numbei of drones, and a fur greater number of workers. The accompanying euts will give some idea of their differences in size, shape, and general appearance:

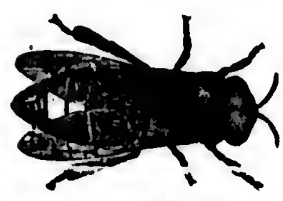

Droxs.

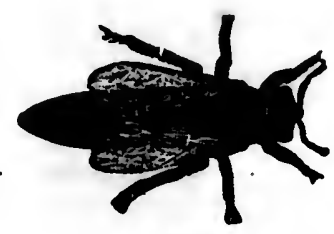

QUEEX.

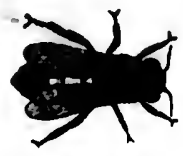

WORKER.

The queen is the most important member of the colony, being the mother bee, and laying all the eggs from which an increase of population is derived. Her wings are short, her boxly long and tapering, and her movenents peculiar. The drones are portly-looking, alctermanic insects, eneh with a jolly corporation of his oww. They are "the lazy fathers of the industrious hive." They perform no work, but live a life of inxurious idleness. The workers are undeveloped females; on them all the labors of the hive depend.

TIF STAGES OF IBEF-I.IFE.

As in the case of other insects, there nre four separate stages in the development of bees, the egg state, the larva, the pupa and the imago. Three of these terms need explaining. Iarva means grub or maggot. The pmpa is sometimes called a chrysalis. At this singe of its life, the insect is like a babe wrupped in swaddling clothes, a thin membrane being bound around its boly. The term imago, or image, refers to the thet that the form of the insect is now complete, real and apparent. Two kinds of eggs are laid by the queen-bee, drones and workers. 'There are two

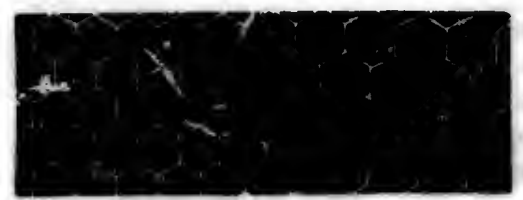

COME FOUNDATON, SHOWINO DRONE AND WOKKER CELLS. sizes of eells in every hive, the larger called drone-eomb, to contnin drone egus; and the smaller called workereomb, to receive worker egres. The instinet of the queen guilles her in muking the eggs enrrespond with the cells in whieh they are laid. When it is necessary to rear a queen, one of the worker cells, containing a newly laid egg, is enlarged until it resembles a pea-nut in shape and size. The following eut will make all this plainer:

$b$, at larve.

The into a rapilly bees; pupa st formed thitn a teenth and res dition.

\section{After} dutirs. from the gocs 'or hive im rloes so to rensle be so $\mathrm{m}$ extinctio unilersta apiary, w abmudant (1) lay wo drone eg preservat into a ce her abdo sticky flu 
The one duty of tho queen is to lny eggs, and the number she will produce, if a good layer, is truly astonishing. Two or three thousand eggs per day will be laid by such a queen, and an extra fertile one will lay three thousand or more in a single day. Hence a hive will increase in population very rapidly during the working season. At such a time many bees arc lost while ont foraing, moreover they are short-lived insects, so that the hive neels constant and quick replenishment. A worker usually lives but a few weeks or at "most months, while the average life-time of a queen is about three years. Drones are usually found in the hive from Mny to November, though it is the eustom of the workers to kill then off early in the summer.

\section{PRODUCTS OF BEES.}

Bees gather honey, an article ton well known to require descijption. They also manufanture wnx out of which the cells are marle, and which forms the bees-wax of commerce. They collect pollen or bee-lurend, which forms the staple fool o: young bers. A substance callel propolis or bee-glue is gathered by the bees. It is the product of varions resinous buds, is soft and plastic when warın, but hard and very allhesive when cold. It is used by the hees to fasten the combs to their supports, to fill up all crevices and rough places inside the hive, or to eover foreign substinces which eannot he removed.

The above is only a mengre slieteh of the natural history, characteristies, and functions of bces, but it must suffice by way of introduction to some brief remarks and directions abont

\section{BEE MANAGEMENT.}

Bec-keejing tol:es rank among tive lesser ceonomies of the farm. In Great Brituin a firm would not he thought properly stockeci unless it had a few hives of bees upon it. This is doubtless the correct view ; but kecping bees is engaged ia by many pe.sons as an independent pursuit. Skillfully manayed, it is found to be a fairly remunemtive business, und, with special talent and application, ma:" properly he rogarlon? as a money-making afficir. There are men on the continent of America who have amassed respectable fortunes out of it. Bees may be kept on a small seale by otliers besides firmers. On a small town or villnge lot, a few hives well-cared for, may be made a source of much plensure and profit. A vast amount of rational wenlth is being lost throngh negleet of bee.. keeping. It is a suitable avocation for women, many of whom are now engaged in is, and some of them rank nmong the best apiarians of the nge.

OLD AND NEW STr̈Lì BFï-KEEPINC.

Until of lute years, bee-kecping vas: a very erude affinir. It was usually carrieci on with straw or bux hives, to the interior of which the bee-keeper 
had no access, consequently the bees were left almost wholly to their own devices during the working senson, at the close of which they were brimstoned, and robbed of their stores. It was a greut step of progress when movable frame hives were invented. By the use of these, artifieial swarming takes the place of natural swarming, and instead of the bee-muster liaving to await the convenience and caprice of the bees, with the risk of losing swarms if whtch of the npiary be intermitted, he cousults his own convenience, divides overpoprulated colonies, and avoids loss of swarms. Moreover, when stocks become queenless and are in clanger of extinction, a new queen, or brood from which to rear one, can readily be supplied; moths can be exterminated; comb, bees and bousy can be given to weak colonies, and surplus honey readily taken. The bees, instead of managing themselves under the guidance of mere instinct, are managed by the superior intelligence of their lumman lords.

\section{THE HONEY EXTRACTOR.}

It was a still further step in improved apiaculture, when the honey extraetor was clevised. This maehine, by the simple application of centrifingal force, enpties the well-filled combs almost to the last drop of loney, and on their
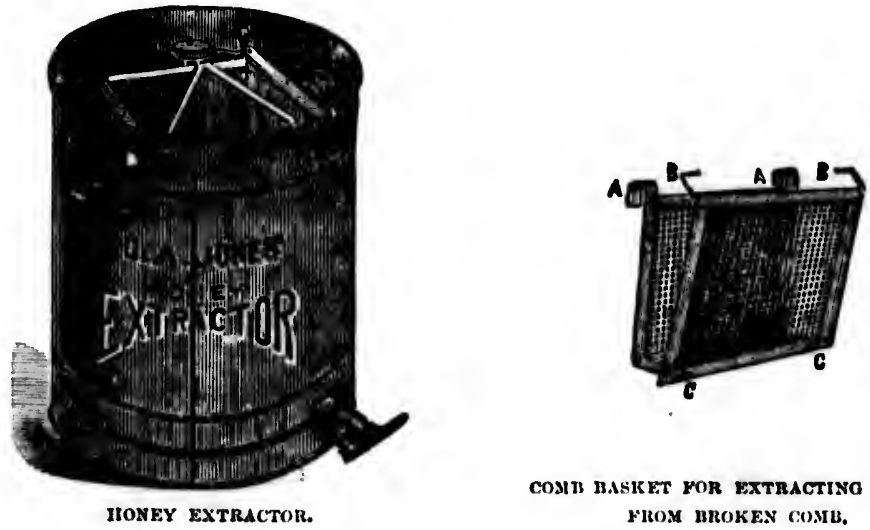

COMI RASIRET MOR EXTRACTINO HONFI HROM HROKEN COMH.

heing replaced in the hive, the bees at once proceed to refill them. By the use of this machine, the yield of loncy is doubled, trebled, and even cluintrupled, in good seusons.

\section{THE WAX FXTRACTOL.}

Wax, to be put in shaje as the bees-wis of commerce, requires to be molterl and strained, so as to secure perfect purity. This is best dowe in a double 
tin vessel, having as the inner receptacle, a strainer. The accompanying

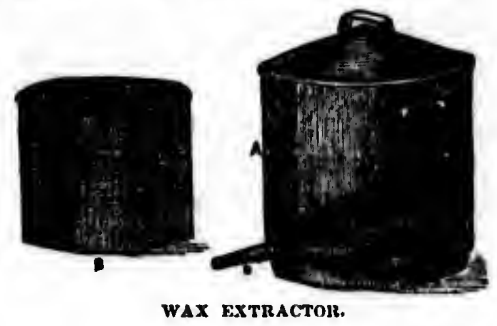

Java, be do greatc deep anou the or as yet and $t$ long. busily years, industr

The importation and breeling of Italinn and other foreign hees is another progressive idea of great valne. Bees, like larger stock, deteriorate by inand-in breeding, and there are common and superior tribes of bees, as there are of cattle, horses, sheep, swine and ponltry. The Italians have proved a great advance on the ordinary black bees. They are hardier, more lmsy than "the little busy bee" with which all are fimiliar, more prolifie, nore

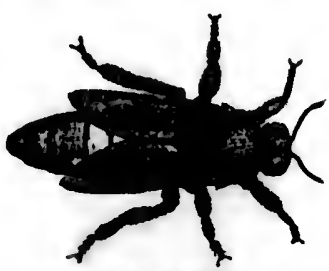

JAVA OT, EEN.

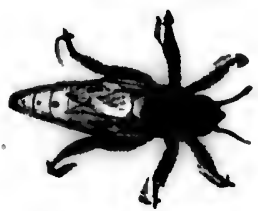

CYPRIAX QTERX.

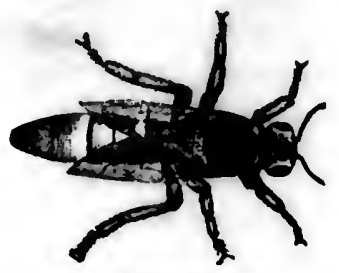

HOLY QUEFN.

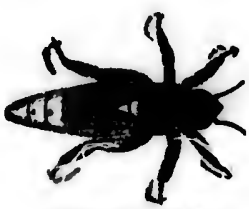

ITALIAN QUEEN.

beautiful in appearance, and, last lont ant least, more pacific-not so insily provoked, and eonsequently less inclines? to sting when medilled with ty man. There are other races of bees from which much is expecterl; uotably those of the island of Cyprns, and the land of Palestine. So far as tried, these are believed to be superior to the Italians. A linge bee found on the island of

Beeattempt on whi obtaince apiarist wise cot Those stulyin More ar might 1 strong, : colonies

It is now-a-d the tim frame $p$ styles of and cost best ; in renownes trial of apiaries , and mos any. It accompan 
Java, apis dorsata, is about to to imported. The bee of the future is yet to be developed by cureful breeding, and it is especially desired to secure a greater length of tongue, so as to penetrate flowers whose honey cells are too deep to be reached by any known race of bees. The red clover vields a vast anount of honey, but it remains ungathered for want of bees able to harvest the crop.

\section{PROSPECTS OF BEEACULTURE.}

Apiarians are sanguine in the belief that bee-keeping is but in its infaney as yet. Great improvements have been made in the urt. of late yeurs, aud there can be little doubt that further advances in it will be witnessed ere long. The mareh of progress bas not reached its limit; seience and skill are busily engaged in experimenting, and it is reasonable to expeet that, in a few years, apiaculture will take a much higher place thau it now does among rural industries.

\section{BTARTING AN APIARY.}

Bec-keeping is an art requiring botls stuly and practice. No one should attempt it who is not resolved, in the first place, to master the prineiples on which it is based. To do this, " goorl manual on the subject shonld be obtainm, and thoroughly studied. Next, it will be well to visit some skilled apiarist, and wateh his methorls. Indeed, a short apprenticeship would be a wise course on the part of any and all who think of going into bees extensively. Those who only meditate keeping bees on a small scale, may venture, after stmlying a manual, and visiting a good bee-keeper, to start with a hive or two. More are not clesirable, at the outset, as in case of failure and mishap, the loss might be serious. In buying stocks, eare should be taken to have them strong, and from the start, the motto will be found to be a wise one, "keep all colonies strong."

\section{IIIVES.}

It is to be presumed that no intelligent person will go into bee-keeping now-a-days witl any intention of using the old-fashioned box-hive, still less the time-lionored and pieturesque-looking straw "skep." The movnble frame principle is essential to any suecess worthy the name. A great many styles of hive have been put on the market, many of them too conpliented and eostly for practical bee-keeping. A simple, cheap hive is us good ns the best; in fiet, is the best. Mr. D. A. Jones, of Beeton, Ontario, the most renowned and successful bee-keeper in the world, at the present time, after a trial of all the hives of any note in Ameriea, and an inspection of the lealing apiaries of Europes, has settled lown on a hive, whieh is the simplest, elusipest, and most ensily managed of any bive now in use; while it is as effective as any. It is male in two styles, single-hourled and donble-boarled. The accompanying engraving will grive an ilea of the double-boarded hive: 
Mr. Jones has furnished the following description of his hives: "My wingle-boarded hive costs one dollar, und contains twelvo frames about $10 \mathrm{~s}$ by (i3 inches. The frames are of the most approved shape, so constructed that the projection at thu bottom prevents the killing or inj:aring of any bees,

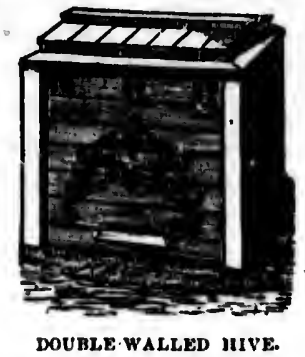

while lifting ont the combs, or manipulating them. It also contains a movable division-board, which is indispensable to success, it being adjusted to suit the size of the colony of bees. No hive is complete without one. The inside dimensions of ny hive ure 1218 by 18 by 15 inches. My donblewalled hive is the same size interiorly, taking the same frume as the singlewalled hive. It is very neat in appenr-

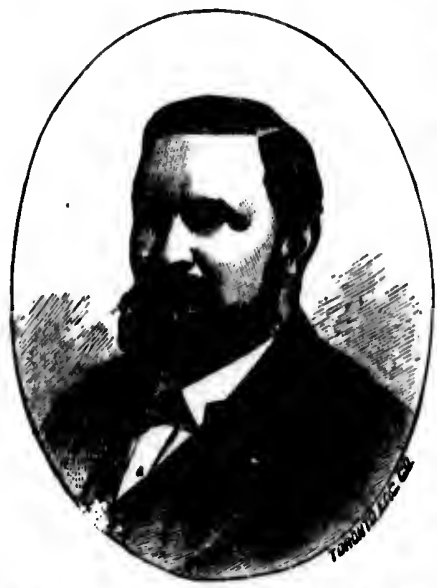

YR. D. A. JONES, TITE CELEBRATED BEEEING OF BELTON, ONTARO. ance, und looks well on a lawn. It is cqually well adupted for hoth extructed and comb honey. From its peculiar emstruction, it ropuires wo extra protection either summer or winter. In it, eolonies may be sufely wintered on their summer stands. The bourds used are thin, yet the hive is strongly constructed. It lase a hollow four-inch wall on all sides of it, and a double bottom, also enclosing a four-inch space. The four-ineh spaces thus mude are closely pucked with straw; cut fine in a cutting./ox, which forms an excellent uon-conductor. A chaft enshion, eight or tew inches thichs, is luill on top of the frames, on the approach of cold weather. Thus the bees are kept at once warm and dry."

TRANSFELRING HEFS.

The beginner in apiaculture will very likely lave to buy bees housed in box-

In the the bee-smu

hive', lives. The b or bro care. little s! give th and tu on the honey, young the box foraging no troul there is barli, pr with ay board of on the 1 flat on the exact partieular comb in. the frum Sct the fi the same cells, is $\mathrm{s}$ picees of frame, twine, or crisul) pra drome-com hive on tl live. If realily fin possession to rights. the strips, the bee-sini 
hives, which will render it necessary to transfer them into movable frane hives. A brief explanation of the trausferring process is therefore desirable. The best time to trunsfer is early in the season, when there is but little honey or brood in the hive. It may, however, be tone at any time, with proper care. The weather must be warm, and the bees busily at work. Blow a little smoke in at the entrance to the hive; pause for two or three minutes to give the snoke time to produce its effect; then carry the hive a few feet away and turn it bottom side up. Place a box over the hive, and with a stick rap on the hive for ahout twenty minutes. The hees will fill themselves with honcy, and go with the queen up into the box, forming a cluster there. A few young bees will, renuin in the old hive, but this is of no consequence. Take the box to the old staul, leaving the front edge raised, so that the bees out foraging can join their companions, and all get tresh air. If other bees give no tronble, the rest of the operation can be performed out-of-doors, but if there is any annoganee of this kind, remove the oll hive into a room, shed, or baru, pry it npart carefully; ent the combs from the sides, and get them loose with as little danage as possible. There should be a barrel set on end, and a bourd of es ivenient size placed on top of it. Iay several thicknesses of eloth on the board, as a soft bed for the comb. Now take a sheet of comb, lay it thit on the eloth, place a frame on the comb, and carefinly cut out the comb, the exaet size of the frame irside. Press the frame over the comb, being particular to have it "right side up" as it was in the old hive, then fasten the comb in the frame by winding around it either twine or fine wire. To mise the frume perpendicular before fistening the conb, tilt the buard beneath it. Set the frame, fixed as deseribed in the new hive, and proceed with the rest in the same way, until all the worker-eomb, $i$. e., that containing the small sized cells, is seeured. It is a good opportunity to get rid of drone-comb. The pieces of worker comb left at the end of the process nuay be fitted into a frame, and secured there by thin flat strips of wood, tied at the end with twine, or tacked with very small tacks. Having fistened all the workereomb practicable into the trames, all the remaining bits looth of worker and droue-comb should be saved as starters for boxes and seetions. Now place the hive on the old stand and shake all the bees out of the box in front of the hive. If the nlighting-board is properly arranged, so thut the bees can readily find their way in at the entranee, they will not be long in taking possession of their new home. They will go to work at onee and put things to rights. In two or three dajs tiney will have all loose combs fastened, so that the strips, wires and strings may be removed.

THE BEF-SMOKER.

In the operation just described, and many others, a little muchine called the bee-smoker will he found very useful. Blowing a little smoke into a hive 
of bees lins a quieting effect upon them, so thut they can be easily handled. The smoker is merely a snull pair of bellows attached to a pipe, into which some combustible material is put; the smoke from this is driven by the

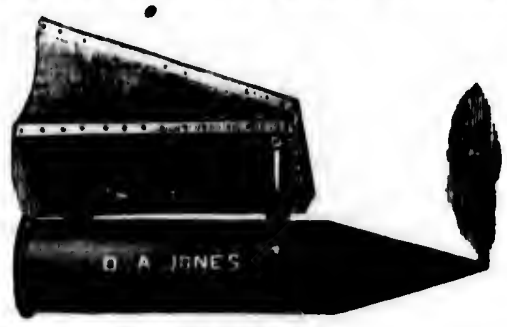

BEE-GMOK ER.

bellows out of the pipe, and can be directed to any place desired. The smoker can be worked with one hand, leuving the other free to do whatever the bee-keeper may wish.

\section{LOCATION OF TIF APIARY.}

The apiary should be near at hand, where it ean be elosely watchel with but little trouble. An easterly nspeet is preferred by mest hec-lieepers, in order that the early moruing sum may strike the hives, and nrouse the inmates to work betimes. Shade during the hottest purt of the clay is desirable. $\Lambda$ grove, if somewhat open, is a nice place for hives of bees. In many cuses they can be set to good advantage in an orchard. A lawn mol slirubbery often afliol eligible places for bee-lives, umler the partial shelter of a slude-tre, an

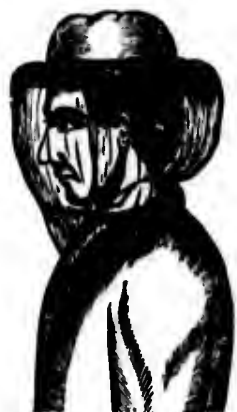

HEE VEIL. evergreen, or a grape-vine. Bee-honses ure generally discarded by the best bee-keepers. It is better to have each hive by itself. In exposed situations, wiul-sereens are necessary. A close board fence is, in many enses, very suitable. The use of a double-walled hive renders several of the precautions just mentioned unuecessary.

BEL VEIIS.

Beginners in bee-keeping and those who are cljeets of dislike to bees, as some people are, find it necessary to wear a veil. A simple piece of black net fastened uround the hat with an elustie string, unel long enough to tuck muler the collar of the coat, will answer the purpose. 'The annexed engraving will show a bec-keeper thus attirel, reuly

for business.

Some also wear gloves, but these are very awkward in handling bees. The best for the purpose are the sheep-slin ganutlets linown as "thistle-mits."

M

anal

boyl

liolel

the

silece

the

hive.

Jarge!

honey

thous:

per lii

he wi

Europu

Land i

who is

sjoriall

dorisetue.

isolitted

excellen

minde in

develonge

contumon

reyuiress

Hittinual

apiacultu

whist lie

following

largest a

"My

it as aply

inerease

"Supp

the first

stinds th

for doing 
moker er the

al with rers, in immates ble. $A$ they cum is aftiorl tree, an ally diswe ened cens are es, very s seseral

bjects of $y$ to wear ound the ck under Tlie ata(all, readly ess. The its."

\section{AN EXAMIS.E OF IIIII,Y SUCCLSSFUt, HEF-KEFINU.}

Mr. D. A. Jones, of Becton, Onturio, lenuls the list of sureessful apiariuns and ranks as the eliampion bee-kecper of the worlt. He has kept bees from boylowel, beginning with the old-fishioned method, but, nt length getting holll of the best moclern looks on lece-keeping, rapidly malle his way to the front, and beene wiser than his teachers. He attuined his highest snecess in 1879, when from three hundred colonics of bees he obtained the marvellous average of two hundred and fifty pounds of honey per hive. The next year being unfuvorable, the honey yield wis less, but he largely increased his colonies in number, so that his protits from stocks and honey were in the neighborhood of six thousand dollars. He has now one thousand colonies, which, at the low average, for him, of ten dollary profit per hive, will yield next season ten thousand dollars. 'The likeliliood is that te will double that amomot of gain. Mr. Jones hoss visited varions parts of Furope, ineluding the island of Cyprus, and has also been to the Holy Land in searels of the best ritees of bees for honey storing. He luss an agent, who is a skillful dpiarian, travelling throngh Asiat on the same errunt, and spectially eluarget to uhtain the best specimens of a large bee called apis dorsettu. 'The races of bees thus solleeted ure being bresl with grent vare om isolated islants in the Georgian Bay, varions crosses unde, and points of excellence noted with seientific neenracy. Grent adsances lave alreuly been mbinle in bee-breeding, and it is believest that a race of bees will yet $b$ s ileveloneed, that will be, like the shorthorn among eattle, firr in alvance of the common and nutive breal. Mr. Jones consiters that bee-keeping only retpines to be better understood to become a vast sonree of individual and nutional wealth. As he has un seerets to hide, and is only anxious to sec apiaculture undertaken more extensively, he is ready at all times to impart whant he knows for the benefit of others, and has furnished for this work the following necount of the way he hambles his bees with a view to seeuring the largest amount of protit attainable from them:

\section{MR. JONES'S WAY OF IBEE-KEFI'ING.}

"My method varies somewhat with sensons and eireumstances. I will state it as applicable to ordinary sensons, and slaped so as to sceure a molerate increase of storks, along with the largest prneticable yield of surplus honey.

\section{BETTING OUT TIIE HIVES IN SIRING.}

"Supposing the bees to luve been winterul in a cellur or frost-proof house, the first care of the ber-kecper in early spring will be to ret them on the stands they are to ocenpe during the summer. No precise date can be given for doing this. I usually set out my bees on the first appearance of black 


\section{IMAGE EVALUATION \\ TEST TARGET (MT-3)}
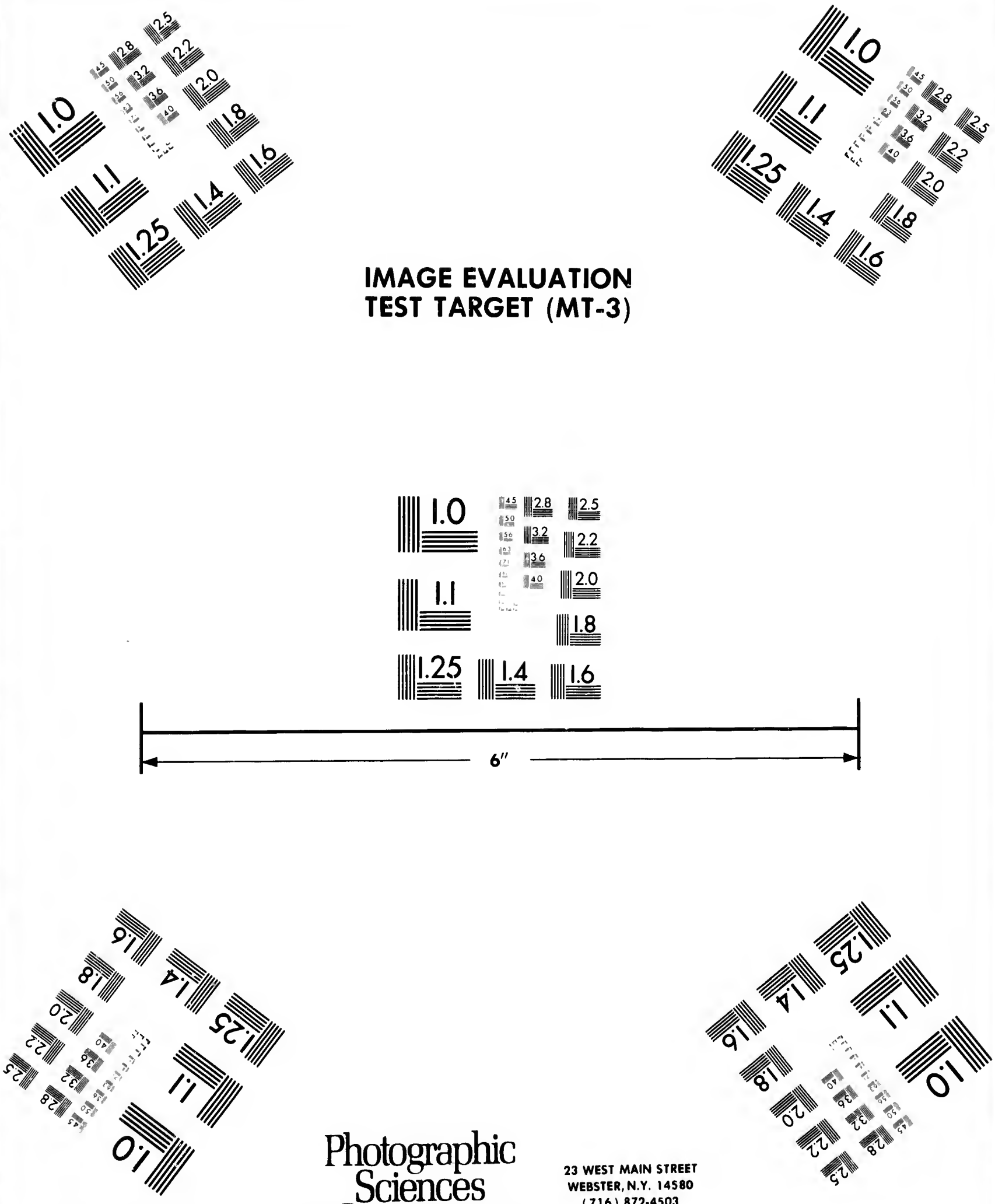

Photographic Sciences

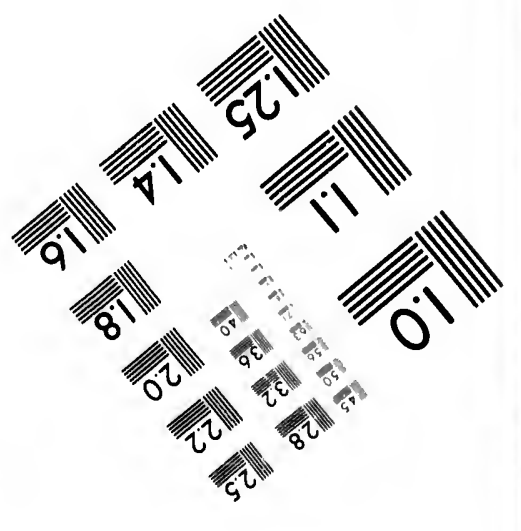
Corporation 

alder bloom, which occurs the first really warm spell of weather. They will take a purifying flight, and then the bee-keeper must seize the earliest opportunity of examining each stock to see that all have queens. Any queenless ones may be doubled up, with weak stocks that have queens. All weak stocks must be doubled up, whether queenless or not, else they will dwindle away to nothing. , Great care must be taken so that they may have plenty of food, as there will be a quick consumption of it when breeding begins. I crowd the bees up into a very limited compass by means of division boards, and fill the spaces between the division-hourds and the walls of the hive with chaff or cut-straw. Feeding the bees daily stinulates the queen to lay, and as the combs become filled with brood, more should be given. By this means a large quantity of young bees will be hatched out really for honey-gathering, and by the time white clover blooms there will be plenty of active workers in the field to gather its yield of honey. Care must be talien not to give extra coinbs too fast, lest the young brool should get chilled. No more combs should be in the hive at any time than the bees can cover. The wholc season's profit depends on the observance of these rules. In addition to these inside regulations; attention must be paid to the outside of the hive. When the weather is cold, and every night through early spring, the entrance must be closed so as only to admit one bee at a time. When the weatler is warm, and every morning as the sun begins to mount up in the heavens, the entrance must be made larger. A little observation and practice will enable the beekeeper to keep the inside temperature of the hive in that state of uniform warmth which is most conducive to the raising of brood.

\section{QUEEN REARING, AND ARTIFICIAL SWARMING.}

"Get the stock from which you wish to raise queens as strong as possible, so that it will proceed to build queen cells. Now, from each one that is strong enough to spare it, take one comb with plenty of brood in it and make a nucleus, by using the division-board as above directed, and after from twenty-four to forty-eight hours, give them a queen or a cell from those which have been started by the extra strong colony already spoken of. In a few days the young queen will begin to lay, and brood should be taken from the parent stock sufficient to keep it just below the swarming-point. The most honey and the best results are obtained by keeping the bees just bclow the sucarmingpoint, which is done by the judicions removal of brood with which to build up the young swarm. In this way, both will be boiling over with bees when the honey season is at its height. . If they cannot otherwise be kept back from swarming, draw a comb from each of six or more hives, putting them with their bees all in one hive, which makes a strong stock by giving them a queen. In every apiary, there shonld be surplus queens on hand thronghout 
They will

be earliest

Iny queen-

All weak

ill dwindle e plenty of begins. I sions boards, ge hive with to lay, and $y$ this means y-gathering, e workers in o give extra more combs The whole lition to these hive. When entrance must ather is warm, $s$, the entrance enable the beeate of uniform

ong as possible, ch one that is in it and make and after from om those which

In a few days from the parent The most honey $w$ the sicarmingwhich to build with bees whell kept baek from ting them with giving thens a hand throughout the working season, ready for such emergeneies. Qneen rearing can be carried on without building up, and one frame of comb answers for the queen to lay in, until it is convenient to add more.

\section{INTRODUCING QUEENS.}

"There are varions methods of introlucing queens. Whatever method is alopted, four things must be carcfully attended to: 1 . The hive must contain no queen or queen-cells. 2. The bees must be made to fill themselves with honey. Smoke will usually do this, but some bee-keepers also sprinkle them with liquid honey or syrup. 3. The queen must he pervaded by the same odor as the bees to which sle is introduced. Some add to the syrup or honey sprinkled on them an essence, such as peppermint or the like. Others de-

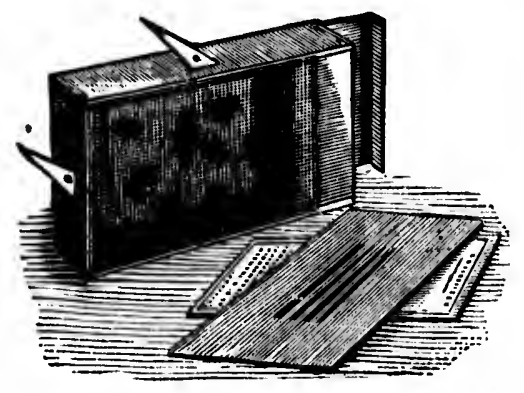

CAGE FOR SHIPPING OR INTRODLCING QUEENS.

pend on smoke, using tobacco which must not be strong enough to stupefy them. 4. The queen must not be introduced hastily, or she will be treated as an intruder, and speedily killed. Coyering the queen with honey or syrup) when she is put among the bees is usually sufficient. By the time they have licked her clean, which they will at once proceed to do, they will be willing to accept her. Many use a cage for introducing queens. She is confined in this for a time, inside the hive, until the bees become used to her. Such a cage is also used for shipping queens to a distance.

\section{EXTRACTING COMB HONEY.}

"Assoon as the brood chamber begins to get crowded with honey, which seldom occurs before white clover blooms, the extractor must be used. Quiet the bees with smoke, draw out the combs, shake and brush off the beer, earry the combs to the extracting-room (which may be a movable-box or tent), with honey-knife shave off the capping of the cells, extract the honey, return the combs to their places, close up the hive, and proceed in the same way with 
the next. In my apiary, I usually have a man or boy taking out frames, and brushing off the bees; one or two boys carrying them to the extracting-room; one

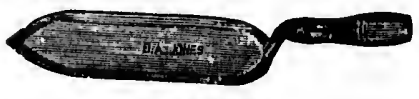

HONEY-KNTHE. uncapping, another extracting, and one putting back the frames as fast as they are emptied. In this way all keeps moving along, and we can take thus from 1,000 to 2,000 pounds of honey per day in the height of the season.

\section{TREATMENT OF EXTRACTED HONEY.}

"The honey is put into large tin tanks and open barrels, left to ripen from six to twelve days. It is then drawn off into tin eans holding $2 \frac{1}{2}, 5$ and 10 pounds. The cans should be made with a bale and screw top, so as to be ready either for shipment or for sale in the original packages. I sometimes ship in barrels. These should only hold 100 pounds, and must be coatel inside with wax.

\section{COMB HONEY.}

"I take all my comb honey in sections. During the past season I have greatly increased the yield of comb honey by the use of a perforated zine plate as a divider. The holes will admit the passage of worker bees, but not the queen, who can thus be confined within a limited space, her laying restricted to that space, and the whole worker force of the hive employed in filling the sections with comb honey. Should this plan eontinue to work well, it will add largely to the yield of comb honey. Section honey can he taken above the frames, and at the back part of the hive. Extracted honey can be fed back to the bees, and stored in sections. By the proper use of the extractor along with sections, more honey can be got, and stocks kept equally strong as on the old system.

\section{PREPARATION FOR WINTERING.}

"When the honey harvest is over, see that all stocks have young or still vigorous queens. Remove all failing queens, and replace with young and vigorous ones. Remove all surplus comb, and store it up for use another year. Crowd the bees into a compact form. If sliort of honey, feed them with pure graunlated sugar syrup (2 pounds of sugar to 18 ounces water). As soon as the honey harvest shows sigus of failure, feed the bees a little to keep up breeding, and, as soon as the first frost kills the flowers, feed liberally, until there is a sufficient store for winter ; then feed lightly to keep up breeding as late in the season as possible. Plenty of young bees are the best security for wintering wel.. If the bees are all old in the fall, they will die off before young ones are hatebed out to take their places in the spring. 
$t$ frames, and or two boys ig-roon ; one and one putas they are seeps moving from 1,000 to

left to ripen ding $2 \frac{1}{2}, 5$ and :op, so as to be

I sometimes must be conted

; season I have perforated zinc ier bees, but not ace, her laying ive employed in ne to work well, ney can be taken ted honey can be oper use of the ecks kept equally

ve young or still with young and use another year. feed them with nces water). As es a little to keep ed liberally, until ep up breeding as e best security for will die off before

\section{WIN'TERING.}

"With good queens, plenty of young bees, and abundance of stores, bees are ready to go into winter quarters whenever cold weather sets in. About thirty pounds of honey or sugar syrup will be required for out-door wintering, and about twenty for in-door wintcring. If wintered out-of-doors, crowd the bees on to four or six frames, pack around them with claff or saw-dust, and lay a good chaff oushion on top of the frames, leaving the entrance open. To winter in-doors, on a sumny diny late in the fall, take off covers and cushions, remove all propolis-coatcd cloths, let the sun dry off the bees thoronglily, lay on clean cloths, cover with cushions, and carry into a beehouse or dry cellar. The bee-house should be built with hollow walls, having not less than twenty-one inclics of space filled in with chaff, tan-bark, or saw-dust. When thus housed in a cellar or bec-house, keep in utter darkness and quiet, maintain a temperature from forty-two to forty-five degrees, and give your bees a good letting-alone until spring returns again. Those who winter out-of-doors in my double-hive, will not require to do any chaffpacking. All that is necessary is to crowd the bees up into small rompass with the division board, and lay a thick chaff cushion on top of the frumes." 


$$
=
$$





\section{THE DOG. \\ HISTORY OF BREEIS ANI) (HARACTERISTICS.}

\section{CHAP'TER I.}

Origin of the dog-Usefulness of the dog to man-The English Setter-The Irish Setter-The Gordon Setter-The Native Setter-The Dropper-The Pointer-The Spaniel-The Newfoundland dog-The Mastiff-The I3ull dog-The Blood hound-The Fox hound-The Beagle -The Slieep dog-The Greyhound-The Dalunatian or Coach dog-The Scoteh Terrier-The English Terier-The Skye Terrier-The Poodle.

\section{HISTORY AND BREEDS.}

IN both the Old and New Testaments the dog is spoken of almost with ahhorrence; everywhere it is designated unclean and an abomination, and yet man has no surer or more tried friend, ever on the guard to protect the property and person of his master. It appears to have been the great object of the Israelites to engender this liatred, in order to prevent the idolizing and worshipping of the dog as was practised by their neighhors and early masters, the Egyptians.

Considerable dispute exists with regard to the origin of the dog. Many naturalists trace him to the wolf, others to the jackal, and some to the Dingo and Pariah; but no satisfaetory' conclusion has been arrived at. There is, however, but little doubt that the wolf and dog are varieties of the same family, as they can be crossed, and their offspring continuing the cross thus made will produee a race entirely different from the original. A circumstance in favor of the common origin of the two quadrupeds is the existence in our own country of the prairie wolf, who whines and barks in a manner so similar to small dogs, that it is almost inpossible to distinguish his voice from that of the terrier.

Judging from the fact that almost every country has its wild dog or wolf, it may not be amiss to conclude that the many varieties of dog now existing have their common origin in either the one or the other, and which by adaptation to surrounding cireumstanees, and care in breeding, have attained their present high standard of excellence.

In Northern India the wild dogs of Nepal hunt in packs; have an exquisite sense of smell ; give tongue after the manner of the hound, and show wonderful intelligence in the chase, and can be domesticated when caught at an early age. 
In Southern India there exists a wild dog readily tamed, and many are to be seen in the possession of the natives of Dakhund. $A$ wild breed termed the Pariah inhabit the lower rauges of the Himalaya Monntains. They likewise hunt in paeks and seldom miss their prey. When trainel by the inhabitants of this country they make useful conpanions of the ehase, bringing the wild boar to bay, or indieating which course he has taken when disturbed.

In Australia the settlers are much troubled by.the Dingo or wild dog of the country. Many sheep are yeurly worried to deatl, and the Dingo proving untamable is the greatest pest wherewith the herder has to deal.

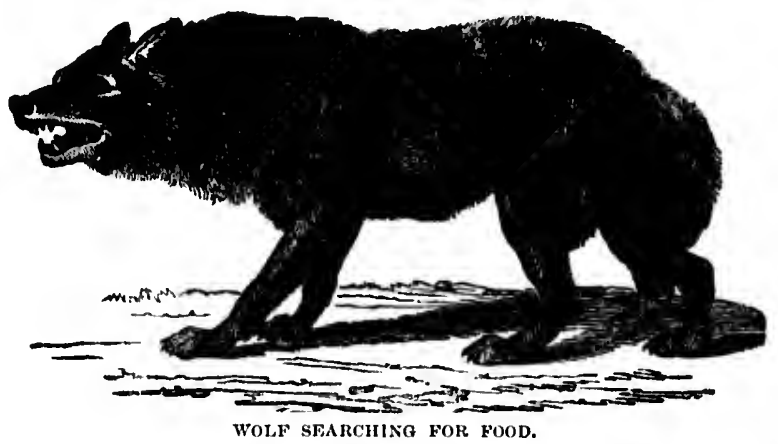

All wild dogs possess the erect pointed ear of the wolf he so much resembles in nature, the eye likewise is oblique or angular as in the fox and the wolf. Prof. Beel gives a very ingenious rason tor the pmpil of the eye of the dog being eireular and not oblique. He attributes the forward direction of the dog's eye to the constant habit for many generations of looking towards his master and obeying his voice.

\section{USEFUI,NFSS OF THI: DGG TO MAN.}

While almost every other quadruped fears man as his formidable enemy, there is one who regards him as a companion, and follows him as a fricud; he does it from choice, seems to be ereated for the very purpose, and is not halpy IInless in his service, askiug but a trifle in return, and a kind word is all that he requires. His swiftness of foot, great strength, courage, intelligence, and highly developed power of smelling, have made him a powerful ally of man against the other animals, and he is the only one that has followed the human being all over the earth a willing slave. To the husbandman he is invaluable as a protector and aid in herding sheep, a useful companion of the chase, an exterminator of vermin, and guard to the house.

It is not our purpose, in these chapters, to divell upon those breeds that are 
many are to d termed the Chey likewise e inhabitants ging the will bed.

ild dog of the )ingo proving

much resenbles $\mathrm{ox}$ and the wolf. e eye of the dog direction of the ling towards his

orinidable enemy, in as a friend; he , and is not haypy d word is all that $e$, intelligence, and verful ally of man ollowed the human an he is invaluable bn of the chase, an hose breeds that are not readily procured and ordinarily possessed by the farmer, or to relate of other than the leading varicties. We begin therefore with

THE LNGLISH SETYTEL.

Authors disagree on the subject of the origin of the setter dog, but it is now very generally conceded he is either descended from the spaniel, or that both sprung from the same stock. Before the invention of gunpowder, at least prior to its use in fowling and shooting on the wing, the spaniel was taught to stop or set with his nose pointing in the direction of the bird, his acute sense of smell indicating the presence of the partridge. His attitude was one lying flat on his belly that he might not impede thr drawing or throwing of a net over the evey or flock before him by the fowler. This act of setting has given the name to the dog supposed to be the improved spaniel. Since the improvement of firearms, and since shooting on the wing is followed by sportsmen, setters almost universally stand erect in their points at game which admits of their close proximity as it lies endeavoring to avoid danger. The most famous strain of English setters is the Lavarack, which talies its name from its celebrated breeder, Mr. E. Lavarack, of Shropshire, England. The pedigree of this farmily of setters dates back to 1825 , when $\mathrm{Mr}$. Lavarack purcliased old Ponto and Moll from the Rev. A. Harrison, of Carlisle, England, who had kept the strain pure for twenty-five years. From the fuct that all Mr. Lavarack's dogs descended from Ponto and Moll, it would strike the reader that unless fresh blood was sought, his animals would be so inbred as to be worthless. But such is not the case. Mr. I avarack declares nll his dogs came directly from Ponto and Moll without an outside cross, and so famous have they become that even at the present day they are eagerly sought for, and fabulous prices are paid for them by breeders who are anxious to improve their own stock. 'Their sense of smell is wonlerfinl, their speed in the field tremendous, and their natural desire for the chase so remarkable, that an introduction of this blood in other fumilies is at once noticeable in the offspring. The Lavarack setter in color may be black, white and tan; white mottled or flecked with black so as to produce a blue-gray appearance (from whence the term blue belton), orange and white, lemon and white, or orange or lemon ticked, termed orange or lemon belton. Mr. Lavarack's system of breeding has decreased the size of his dogs, and when purely bred are most difficult to raise. In the north of England there are very many strains of setters claiming to be fully as fine as the Lavarack; this we doubt, but that of Mr. Purcell Llewellyn we must mention in particular as being yuite as noted, if not superior in some respects to the Shropshire strain. Mr. Llewellyn having conceived the idea that Mr. Lavarack was breeding in and in to an excessive degree, crossed his noted Dan with a pure Lavaraek bitch, and a sister to Dan with a pure Lavaraek dog, and produced sotters which have become famous in England and this 
country, at first termed the field trial breel, but now taking the name of the Llewellyn setter. 'The setters known as the Graham ind Corbet breeds; those of the Earl of 'Tankville, Mnssrs. IVaterpark, Bishop, Bayley, Lort, Jones,

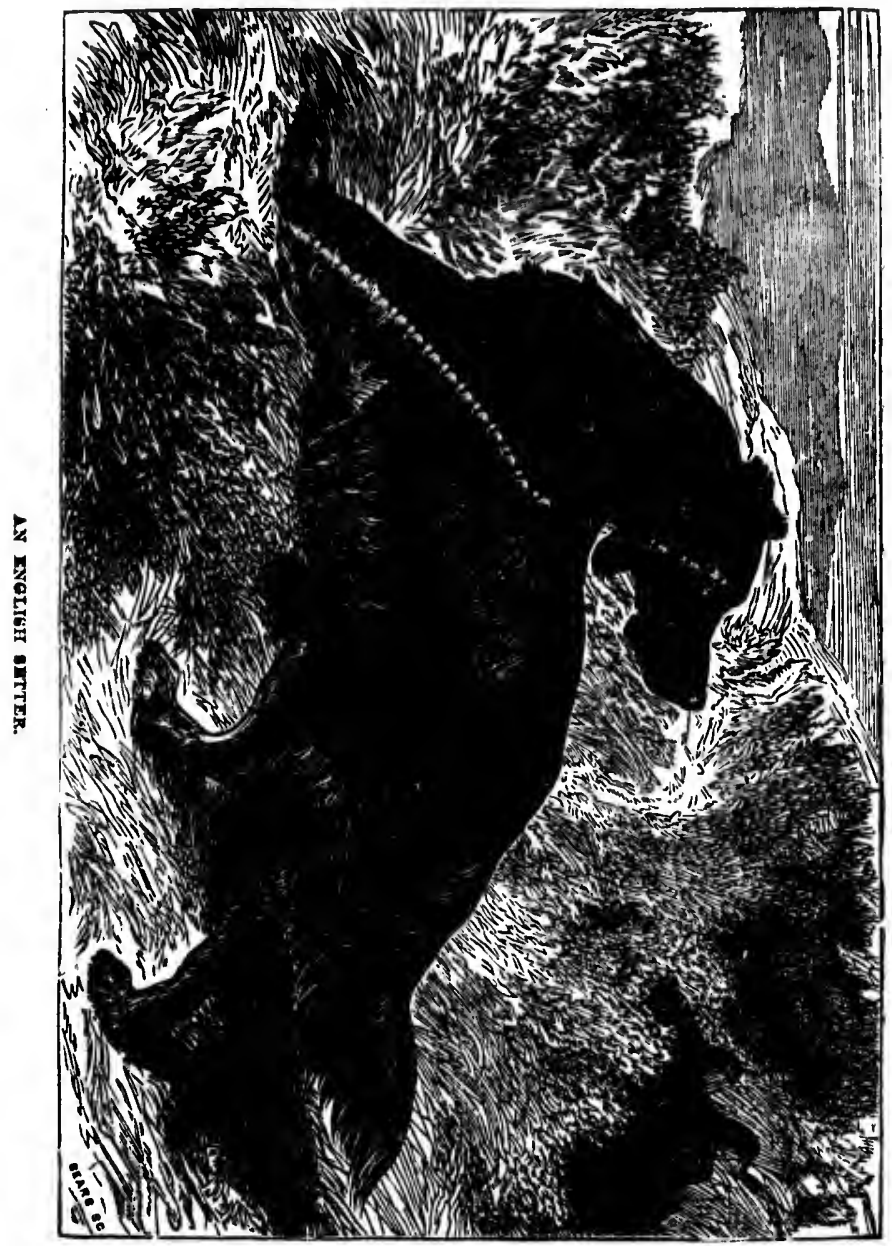

Hackett and Macdona, are noted in England for their superiority, many of these gentlemen using the Lavarack blood in order to obtaiu that which they desired in a good field-dog. The English setter may be thus describel : 
narue of the reeds; those Lort, Jones,

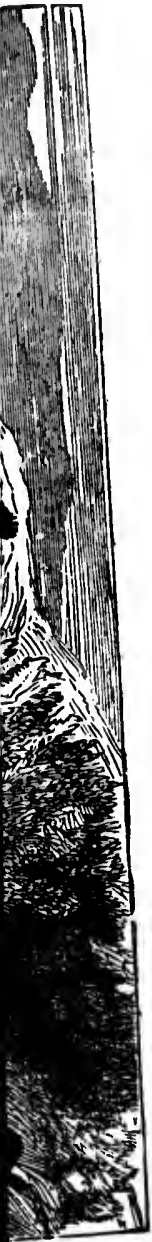

eriority, many of in that which they described:
1. The skull diflers from that of the pointer in not having the squareness of the latter named, does not possess the occipital bone to so large an extent, is narrower between the eyes and lins a smaller brow.

2. The nose is long and brond, and has an avernge measurement of four inches from the inuer eorner of the eye to the end. Midway between the end and the root of nose there should be a dip or depression; a straight one is admissible, but there must be no hump or rise. The nostrils shonld be well open, and in healtlı moist, the color black or liver-colored, but there exists many a pink or flesh-colored nose, carried by a setter of fine scenting powers; using a well-known saying in this connection, "a good horse may be of any color," the most preferable shades, however, are the first mentioned.

3. The ears are shorter than those of the pointer, well set back und drooping towards the neek, and of finer texture, or "leatlier," ns it is called; the eyes full and rounded, and the best color brown or dark laazel.

4. The neck of the setter is more slencler than the pointer's, and set into the loead without any prominenee at the hase of the skull.

5. The shoulders sloping and elbows well down; chest deep and roomy.

6. Back-quarters and stifles. A eurved loin is desirable, but not to snch a degree as to present a sway back appearunee, stifles bent well so that the after legs may be thrown well forward in rumuing.

7. Legs and elbows should be straight, with no inclination to turn in. The al'ms well boned and muselel with strong broal knees and short pasterns.

8. The feet well elothed with hair between the toes, yet not too long so as to accumulate matter in wet and snowy weatlier.

9. The tail should be slightly curved from root to tip, tapering to a fine point at the end and furnished with long silky laair, withont a vestige of curl.

10. The quality or texture of coat in the English setter is soft, silky and shining, without any tendency to curl, fringed ou the lind legs as well as the fore.

11. The English setter may be of any color. The following shades are in order the most fashionable:

White with black mottles so as to appear blue; first with tan marking on the cheeks and over the eyes, and second without it; black, white and tan, black and white, orange and white, lemon and white, orange and lenon mottled, and lastly liver and white, and liver flecked.

\section{TIIE IRISII SE'ITEK.}

'This breed of setter is onc of the oldest in Great Britain, deriving its name from the island where it originated. Yet it is now extensively bred in Kngland, and has many admirers on account of its bold, dashing and untiring disposition in the field. It is rather more difficult to break than the English 
setter, and requires constant use to keep in hunting trim. It differs from the English dog as follows:

1. The head is longer and more narrow, and the occipital bone almost as prominent as that vif the pointer.

2. The nose is longer and square at the end, of a deep mahogany or flesh color.

3. Eyes and enrs. The eyes should be dark brown; ears long enough to almost reach the end of the nose, and more tapering than the English dog's, yet never pointed, and well set back.

5, 6. The Irish setter stands higher than the English; his elbows, notwithstanding, well let down; his shoulders long, brisket deep and narrow, fand his ribs not so long as those of his cousin. Ioin slightly curved, strongly fastened to his hips, but not wide, sloping quarters, and tail set on low but straight, finely tapered and carried with boldness.

7. Legs straight as an arrow; hocks good; bent stifles, and strong but not too heavy liaunches.

8. Feet harelike, not as hairy as the English setter between the toes.

9. The tail ornamented with a long comb of hair, not bushy or heavy; no curl.

The coat of the Irish setter is coarser than that of the English dog, wavy, but not curly, and by no means long; hind legs and fore legs well fringed, but not heavily, the ears covered with feather, with a tendency to wave but not curl.

12. The color is a rich, dark red, without the least trace or tinge of black either on the head or back. A speck of white on the neck, breast or toes is admissible; not too much, however, is seen in good strains.

In the field the Irish setter is most energetic, never tiring. His nose by some is considered not quite so delicate as the Euglish dog's. $\mathrm{He}$ is fast and stylish in his movements, and has many admirers who prefer him for single work. The Ia Touche, Hutchinson's, and the Knight of Kerry's strains are most noted in Eugland.

Plunket, a celebrated Irish setter dog, combining the La Touche, Hutchinsou and Hon. D. Plunket's breeds, is now owned in this country.

\section{THE BLACK-TAN OR GORDON SETTER.}

The black-tan or Gordon setter derives its nume from the fact that the Dukes of Gordon, in Scotland, bred and for a long time owned setters of this color. The breed has never attained great notoriety in the field, being withont doubt deficient in nose when compared with the English and Irish setters, and not having the intelligence of either. The Gordon is apt to be gun-shy, stubborn or mulish. Many writers suspect a dash of the colly or sheep dog blood present in the breed, and charge his color to this cause. Others declare it to 
fers from the

ne alınost as

gany or flesh

ng enough to English dog's, bows, notwitharrow, and his rongly fastened o but straight, strong but not

the tocs.

y or heavy; no

glish dog, wavy, gs well fringed, ney to wave but

$r$ tinge of black breast or toes is g. His nose by $\mathrm{He}$ is fast and - him for single erry's strains are Couche, Hutchintry.

the fact that the ed setters of this ld, being withont Irish setters, and be guu-shy, stub- sheep dog blood thers declare it to have been brought about by a cross of the hound at some remote period. Certain it is, the Gordon setter is fond of hunting the rabbit; in fact, always shows a liking for hair. With all his beauty he is not a fuvorite with the experienced sportsman in England or the United States.

The points of the Gordon setter are very ncarly the same as those of the English dog, excepting the following numbers :

1. The head is heavier.

2. The nose is wider.

9. The "flag" is shorter.

11. The coat is harsher than either the English or Irish setter, and sometimes curled.

12. The color is important; the bluck shonld be deep with a plum shade in some lights and without tan hairs; the tan of a red shade, and not fawn-like in color. Gordon setters were originally very often black, tan and white, but of late years only a little white is allowed, and this must be on the neck, chest, or on the toes, in this class at dog shows. The tan should show on the lips, cheeks, throat, over the eyes, on the forc legs to the elbows, on the lind legs to the stifles, and under the tail, stopping short when coming to the black, the line of color being well defined.

The most noted strains of Gordon setters are those bred by Messrs. Coaths and Barclay Field in England.

\section{THE NATIVE SETTER.}

Very little need be said of the native setter, as lie is a direct descendant of both the Englisli and Irish dog, or in other words a cross or admixture of many families of both. So great has been this admixture and we are sorry to say pointer blood is many times a part, that our own dog, speaking in general terms, has few characteristics to particularize hin. No system has been followed until late years in the breeding of the setter in America, but lovers of this dog are now endeavoring to reach the English standard of excellence iu using the blood of the Lavarack, Llewellyn and Macdona, for this purpose. It is astonishing when we observe the carelessness with which brecders of the United States lave made their choice of sire and dam, that we are able to find so tnany good field-dogs of American breeding. In Delaware, Maryland and Virginia, setters of good quality and finc field performance are often come ucross, but in comparison with the English dog, they are coarse and lumbersume. No description is needed for the native setter; that of the first deseribed will answer every purpcse.

\section{THE DROPLER.}

The dropper is a cross between the setter and the poimer, sometimes pos- 
sessing the long silky hair and feather of the former, and not unfrequently the short satin-like coat of the latter, but often times laving a texture between the two. It is an error to suppose by breeding the setter and pointer together one ean obtain the good qualities of either or both. By unions of this nature it is seldom a good animal is obtained, yet it is true tìe offspring may sometimes turn out fair field-dogs, but their dispositions are never such as are desired, they are cross and sullen, and if good workers on game, headstrong, self-willed and unable to transmit such good traits as they may possibly have to their progeny, whether bred to either a pure setter or pointer. The majority of native setters owe their poor quality to introduction of pointer blood; but of late years we are glad to be able to say our sportsmen and breeders are opposed to the cross, and the dropper is not looked upon with favor. We cannot see why it is when such fine specimens of each race can be so readily obtained in all purity, that the abominable admixture is ever indulged in. A description of the dropper is not needed.

\section{THE POINTER.}

The modern pointer is descended from the Spanish dog of this name, introduced into England nearly three centuries ago, and is so improved by judicious crosses, that the heavy, slow and awkward appearance of the latter is now ontirely lost, and we have instead a quick, active and invaluable dog for field work. The pointer finds and points his game similar to the setter, erect and rigid, his short hair enabling him to hunt on the prairies where water is setrre and to continue without this necessity for a much longer time. In New Jersey, Delaware and Maryland, and in countries where the quail invariably takes to briery thickets when flushed, the pointer is at a disadvantage, and in cold and rainy weather he suffers greatly on account of his short coat. Nevertheless we have seen them so highly strung and ambitions as to work wherever desired at a risk of injury to themselves. The modern pointer has been brought to its present state of perfection by crosses of the fox hound to give him additional speed and nose. He differs greatly from the setter in being furnished with a close, compact, short and fine coat of luir lying close to his skin; the better he is bred the more satin-like it becomes.

The pointer also differs from the setter as follows:

Head noderately large; wide in proportion to its length, with high forehead. Eye of medium size, muzzle broad with square outline not recediug as in the hound ; "flews" not very pendent; ears not set back so far as the setter's, also more rounded and less drooping.

The head should be set well on the neck with that peculiar rise at the base where it is joined, only seen in the pointer. The neck should not be too wrinkled or have too much loose skin visible under it, which gives the dog a * throaty" appearance as it is called. 'The body of good length, strong loins, 
infrequently the ture between the inter together one of this nature it g may sometimes h as are desired, strong, self-willed bly have to their The majority of ter bloud ; but of eeders are opposed r. We cannot see eadily obtained in in. A deseription

of this uame, introproved by judieious. - the latter is now aluable dog for field the setter, erect and where water is scarce ne. In New Jersey, invariably takes to hge, and in cold and hort coat. Neverus as to work wherern pointer has been e fox hound to give a the setter in being ir lying close to his

gth, with high foreoutline not receding $t$ back so far as the buliar rise at the base $k$ should not be too vhich gives the $\operatorname{dog}$ a length, stroug loiws,

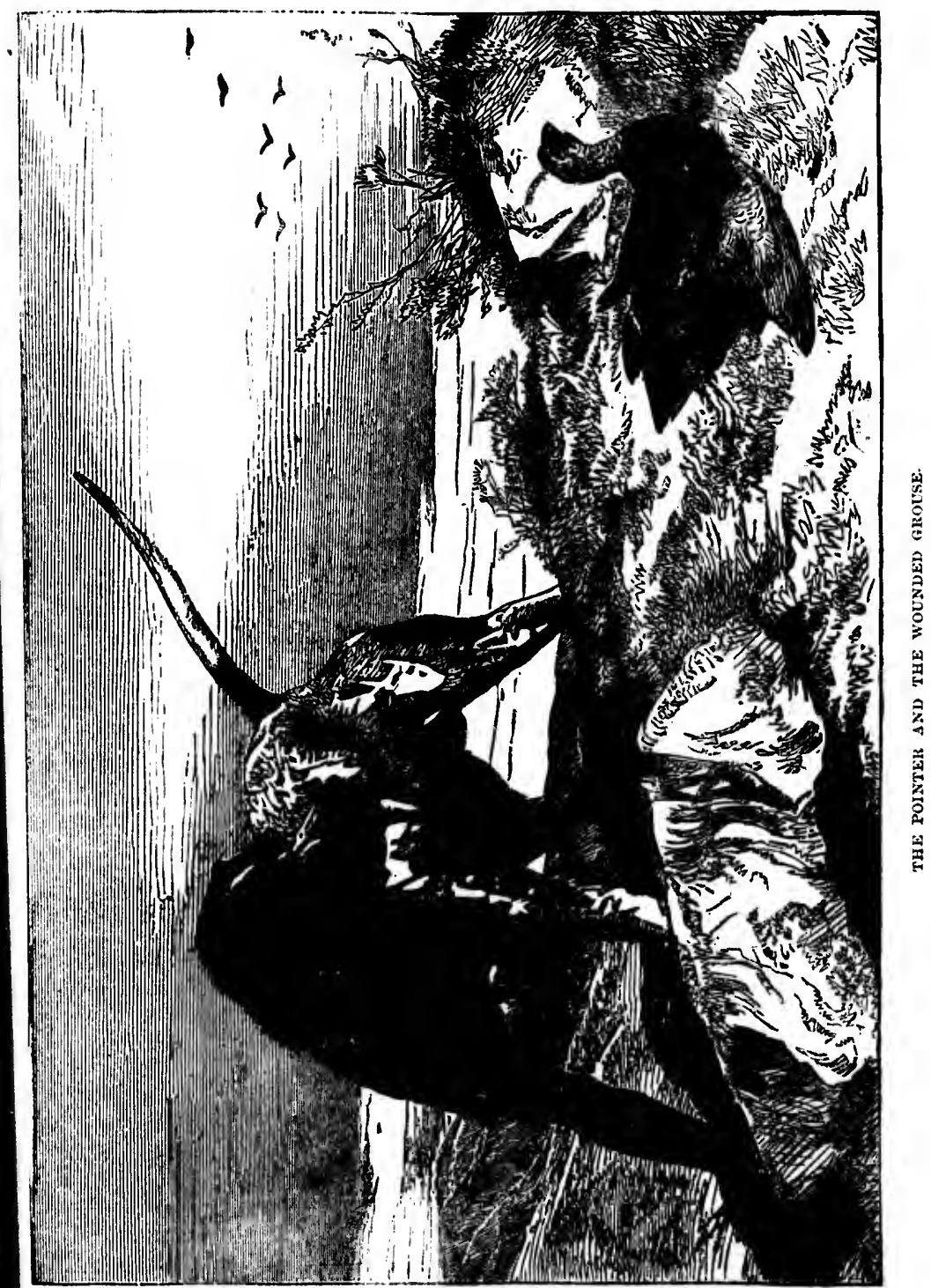


and hips, and arched ribs, chest low and not sharp as in the greylound; the tail is strong at the root and quickly diminishing becomes fine, and then tapers to a sharp point at the end; a thick and chubby tail shows want of breeding. The shoulders are points of importance, and must be muscular and united to a large upper arm. The elbow should be well let down, and the fore arm short. The leg of the pointer must have gool bone musele and tendon, a strong knet, a round foot well protected with a thick sole. Stifles well bent, large hocks, and the hind feet of the same character as the fore feet. The color always mainly white, the more the better if liver or lemon markings are present. White with black, liver, yellow, or lemon-colored heads are most prized, although solid shades are quite common, especially the liver. Some pointers have tan markings on the cheek and over the eye, but this is considered as indicating too much fox hound blool.

The pointers of Gernuny and France are inferior, being coarser than the modern English setter; a few reach this country.

\section{THE SPANIELS.}

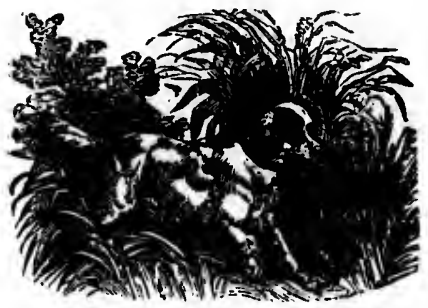

THE HUNTING SPANIEL.

Under this heading we shall only place and describe the Clumber, Sussex, Cocker and water spaniels as counterdistinguished from the toy spaniels. The Clumber and Sussex are seldom met with in this country; the former is even rare in his own. The cocker being of so many varieties, and differing so in appearance, it will be difficult to give a minute description of him. He is the most common of the four, however, in the United States, and the best known.

He is used to find and flush his game to the gun, never pointing at, but indicating its near presence by low whimpering at first and by short quick barks when it is on the wing; for this reason it is trained to work withiu twenty-five yards of the shooter that the bird may not be put up ont of gunshot.

In general he is a light, active dog, of 14 to 20 pounds, of a very lively and spirited nature. He hunts rapidly and earries his tail down, working it vigorously all the time. The eye is medium in size, body fairly long, and his shape much resembling the setter. He is clothed with a soft, wavy coat of hair, not curly, as it would then indicate water spaniel blood; the cocker is well feathered. The colors are solid liver, black, black and tan, white and black, white and liver, white and red, white and lemon. He is higher on the leg than the Clumher or Sussex in proportion to his size, and very mueh more active. It lias been the mustom for a long time to cut off nearly one-half of 
yhound; the $\mathrm{d}$ then tapers of breeding. $r$ and united 1 the fore arm ind tendon, a hes well bent, re feet. The non markings heads are most liver. Some is is considered arser than the

hall only place Sussex, Cocker terdistinguished e Clumber and in this country; his own. The varieties, and will be difficult n of him. He four, however, pointing at, but by short quick to work withiu $t$ up out of gunof a very lively down, working it rly long, and lis oft, wavy coat of od; the cocker is d tan, white and $b$ is higher on the very much more early oue-half of the tail of the cocker spaniel that it might not be worn sore by constant motion in the thickets while hunting.

\section{THF, CIUMBER SPANIEI}

Is a long, low, and heavy dog for his size, weighing 30 to 40 pounds. The head is heavy, much resembling the setter, but more angular. Body very long and strong, clothed with wavy hair not too thick. Tail bushy, but not wnolly. Shoulders wide apart, arms short but strong, elbows not well let down, plenty of bone. Colors always yellow and white, or lemon and white. In motion the Clumber spanicl is slow and deliberate; he has the most exquisite scenting powers, trailing and flushing his game with unerring certainty, working mute, and gives no notice that the hirl is on the wing.

\section{THE SUSSEX SPANIEI.}

Differs from the Clumber in shape and color. In height and weight they are much alike, ancl also in general character of head. In length, however, he is not as reinarkable, yet he may be called a long dog also. He stands higher in the legs than the Clumber, but not so high as the cocker.

The coat is nearly the same in texture, heing soft and silky and free from curl. The head is not quite so heavy. The color liver. Legs and feet strong and well feathered. Tail cropped as with the Clumber and cocker. The Sussex spaniel indicates by voice the rise of the game he has been trailing.

THE WATER SPANIEL.

Head long and narrow, eyes small, cars of nedium length covered with crimpy, curly hair. Body stout, loins strong, and round chest, broad across the shoulders. Feet large and spreading. His body is clothed with very curly hair. Tail curved. The water spaniel, as his name would indicate, is much used as a retricver for duck-shooting, especially that of marsh, upland, or fresh water fowl. He is often crossecl with the larger variety of cocker.

THE NEWFOUNDIAAND DOR.

There are two varieties of the Newfoundland dog met with in this country. 1st, The large long-haired variety, called the large Labrator. 2d, The small compact, comparatively short-haired $\log$ known as the St. John. Both were originally natives of Newfoundland, and are alike good water dogs, and can remain immersed a long time; but the large variety possessing a more woolly coat is hardier. The characteristie points of the large Newfommlland are great size, say from 25 to 30 inches high, form strong and stor t. The head not large in comparison to its size; wide across the eyes. Mnzzle of moderate length, wide, and without "Hews," as in the hound. Eye and ear small, neck 
short, clothed with a ruff' of hair; tail curled. Coat long, shaggy, and shining, without very m!̣ch adınixture of wool. The color should be black, though sometimes it is black and white, or white with a little black or liver color or reddish dun.

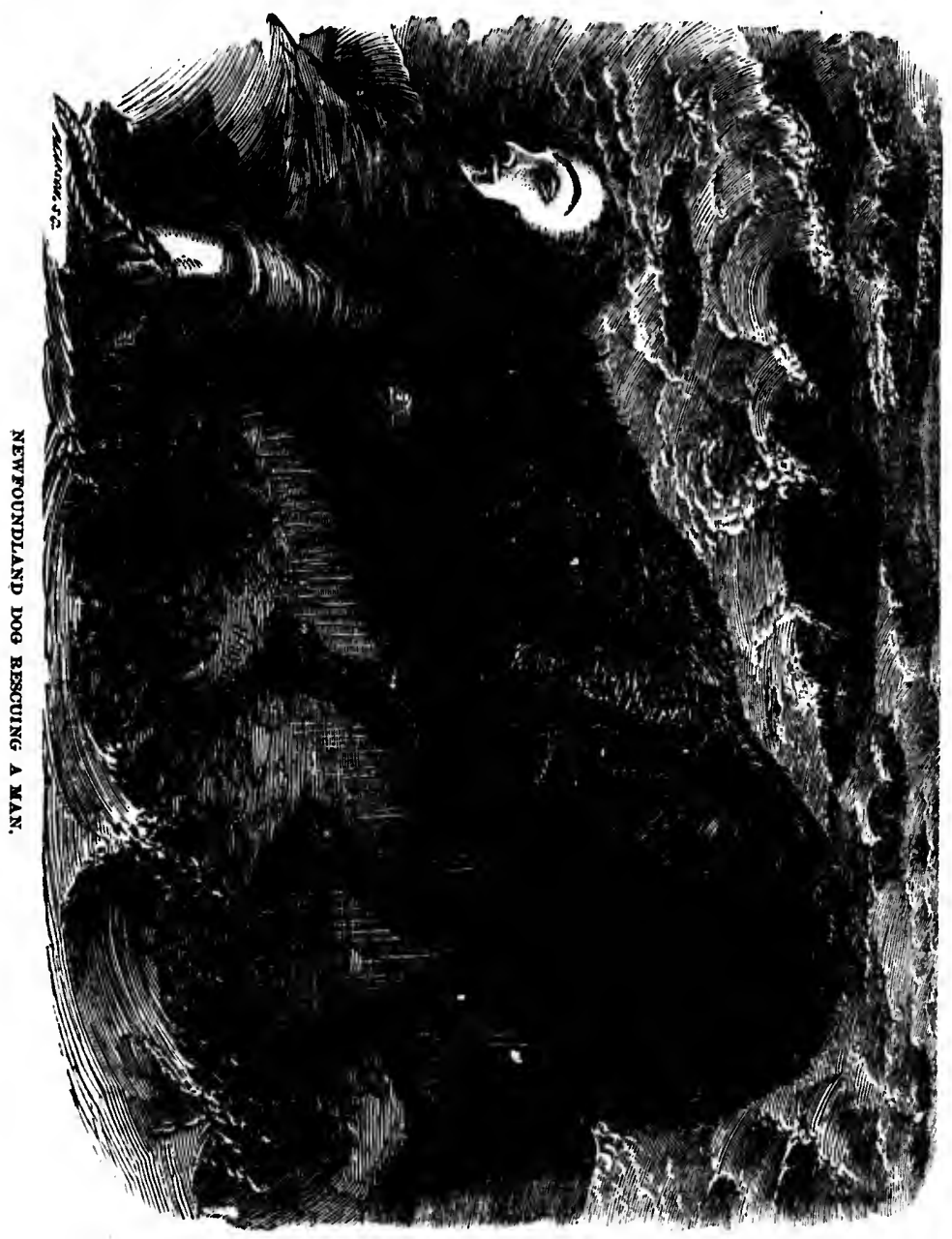

The St. Johns, or smaller Newfoundland, is seldom more than 25 inehes high. The head is larger in proportion to his size, and the ear fuller, neck longer, body far more compact and dothed with slorter hair. In color he is 
shaggy, and ould be black, black or liver

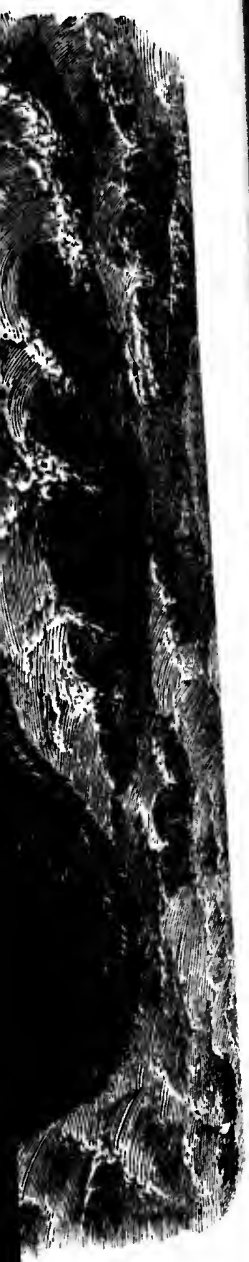

ore than 25 inehes the ear fuller, neck air. In color he is always jet black. As a watch dog the Newfoundland is valuable, becoming much attached to his owner and home, but as frequent bathing is indispensable to his health he is not a desirable animal for the farmer unless a good stream or pond is in close proximity.

\section{THF MASTIFE.}

The mastiff is a command-. ing and powerful animal in every respect, and although possessed of. high courage, his temper can be more relied upon than any of the large dogs. He makes an arlmirable yard dog, and will protect his master's property with zealous vigilance. In England he has been known for many years, and old works give cuts of this breed scarcely changed in characteristics from the modern animal. $\mathrm{He}$ is doubtless indigenous to Great Britain. The Cuban mastiff is much like the English dog, but shows that he has been crossed with the bloodhound. The

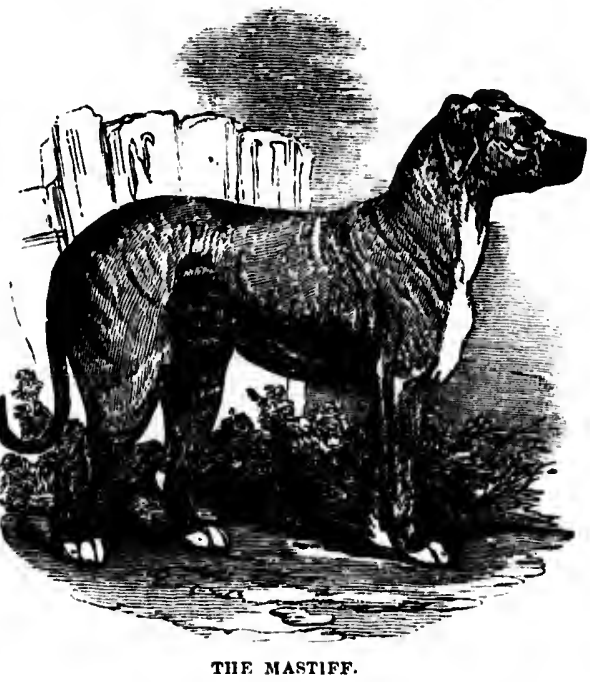
points of the mastiff are: A large head, partaking of the shape of the bloodhound and bull-dog, with great muscle, and having, to a great extent, the hanging upper lips of the hound; ear small, drooping somewhat; eye small. In shape he resembles the hound, but is much more compact and with more bone. Loin well knit and strong, limbs powerful, tail rough and carried over the back. Tone of voice loud and deep, coat smooth, color red or fawn, with dark, or what is preferred black, muzzle, or brindled or black, or black, red, or fawn and white; height, 30 to 34 inches.

The Mount St. Bernard dog is closely allied to the mastiff, but has the appearance of having Newfoundland blood in his veins, with the nature and desire to fetch and carry of the latter. This dog is used by the monks on the Alps to rescue snow-bound travelers.

\section{THE BUII, DOG.}

The bull dog is one of the oldest known breeds native to Great Britain, and has always been described as idiotic in his ferocity. This is a mistaken idea, 


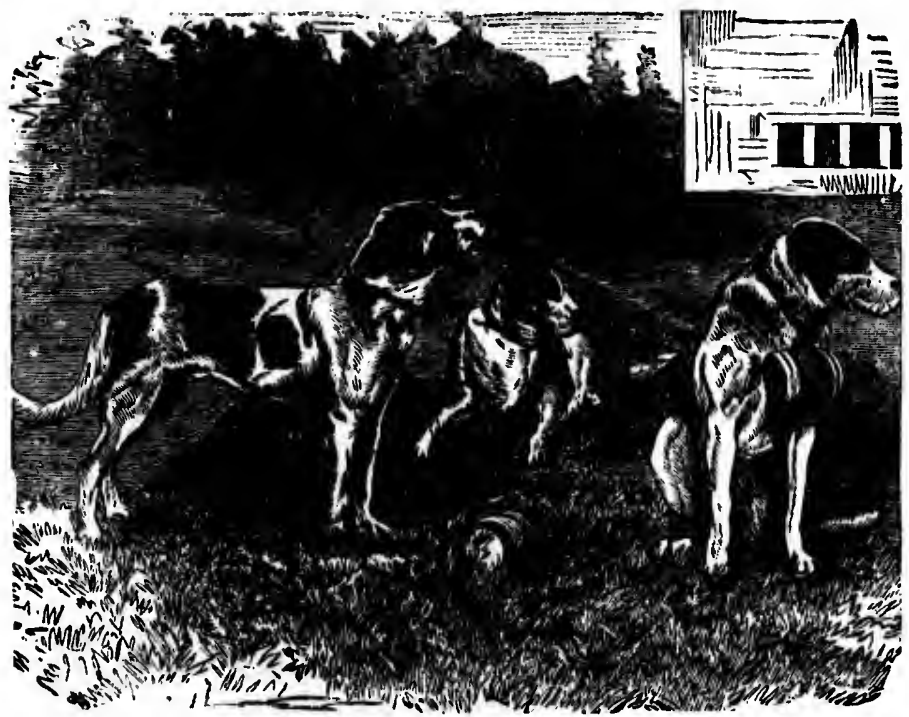

MOUNT ST. BERNARD DOGS.

for he is not at all quarrelsome when purely bred. The bull mastiff, however, a cross of this hog, and also the bull terrier, are pnynacious in the extreme, and excel in this respect owing to their training. 'The bull dog undoubtedly

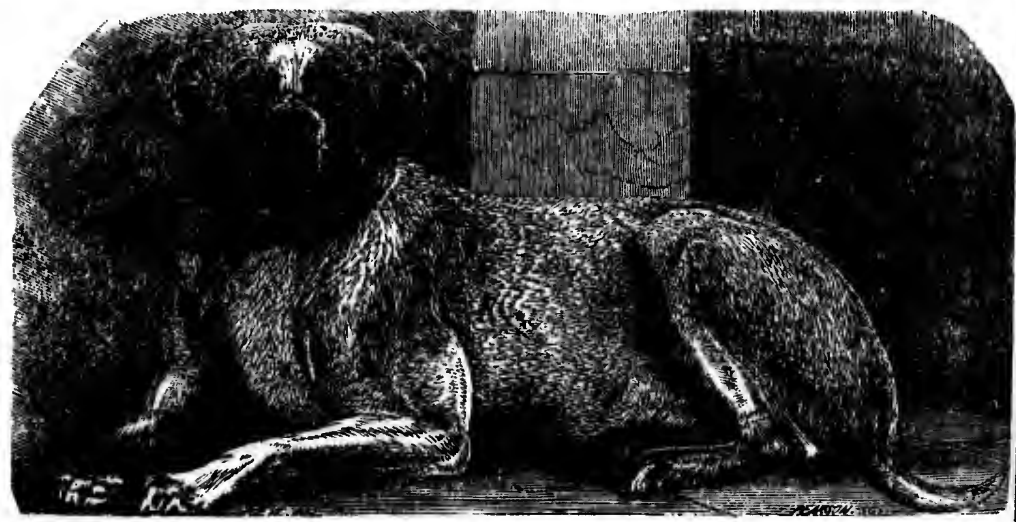

THE BULL, DOG. 
has been used as a cross merely to obtain his very muscular and compact frame, and not for a disposition to combat. The points of a well-bred bull dog are as follows: Head round, skull high, eye of moderate size and forehead decply sunk between them, ears partly erect and diminutive, growing from the top of the head and close together; nose short, and having good chops ; back short, somewhat arched towards the tail, which in well-bred specimens is fine and of medium length. The coat is always fine, the chest deep and broad, legs muscular with good bone, and the foot hare like. The bull terrier, as his name would indicate, is a cross of the English terrier and bull dog, and has the muscular frame of the last combined with the activity of the former. Having been almost exclusively used and trained for fighting purposes, this breed of dog by such cultivation has become irascible to a high degree, and is now most noted for his pugnacity.

\section{THE BLOODHOUND}

Derives his name from the power he possesses of following the scent of wounded animals, and to single out from a number of deer one that has been crippled and hurt, and to stick to his trail until run down. The true bloodhound, as he was bred years ago, does not now exist in Great Britain. The breed is doubtless extinct; but in Cuba and in the Southern States a dog less pure is used for hunting the deer and following runaway negroes, much resembling the old English bloodhomnd, and is still plentiful.

The following are the points of this dog. Height 24 to 26 inches, long and uarrow head, ears 7 to 10 inches, lips low hanging, throat pendulous with plenty of skin. Deep brisket, body round, broad loins, stont legs, straight feet and powerful thighs, tail fine and tapering.

Color black and tan, red or fawn. No white should be seen except on the tip of the tail.

The texture of the bloodhound's coat should be coarser than that of the pointer's, yet smooth and glossy. His voice low and deep, with much melody. Disposition very courageous, yet kind and gentle.

\section{THE FOX HOUND}

Differs from the bloodhound in being not quite so tall. Height should be 20 to 24 inches. Head smaller and fuller in comparison, lips low, hanging, but with not quite so much "flew," less loose skin about the neck, or less "throaty" an appearance. Legs more curved, and shoulders more oblique and better formed for speed. The ears of the fox hound in England are always cropped or rounded off at the ends; if allowed to grow, as they are in this country, they would be low and hanging. The fox hound, otherwise than the above differences, resembles the bloodhound. Those met with in the United States seem to have been crossed with the bloodhound of the Southern States, and show 
many of his characteristica. In fact, so diverse are the different strains in America that the dom night be called another breed than the English. The cout of the fox hound is elose, and likewise not so short as that of the pointer's;

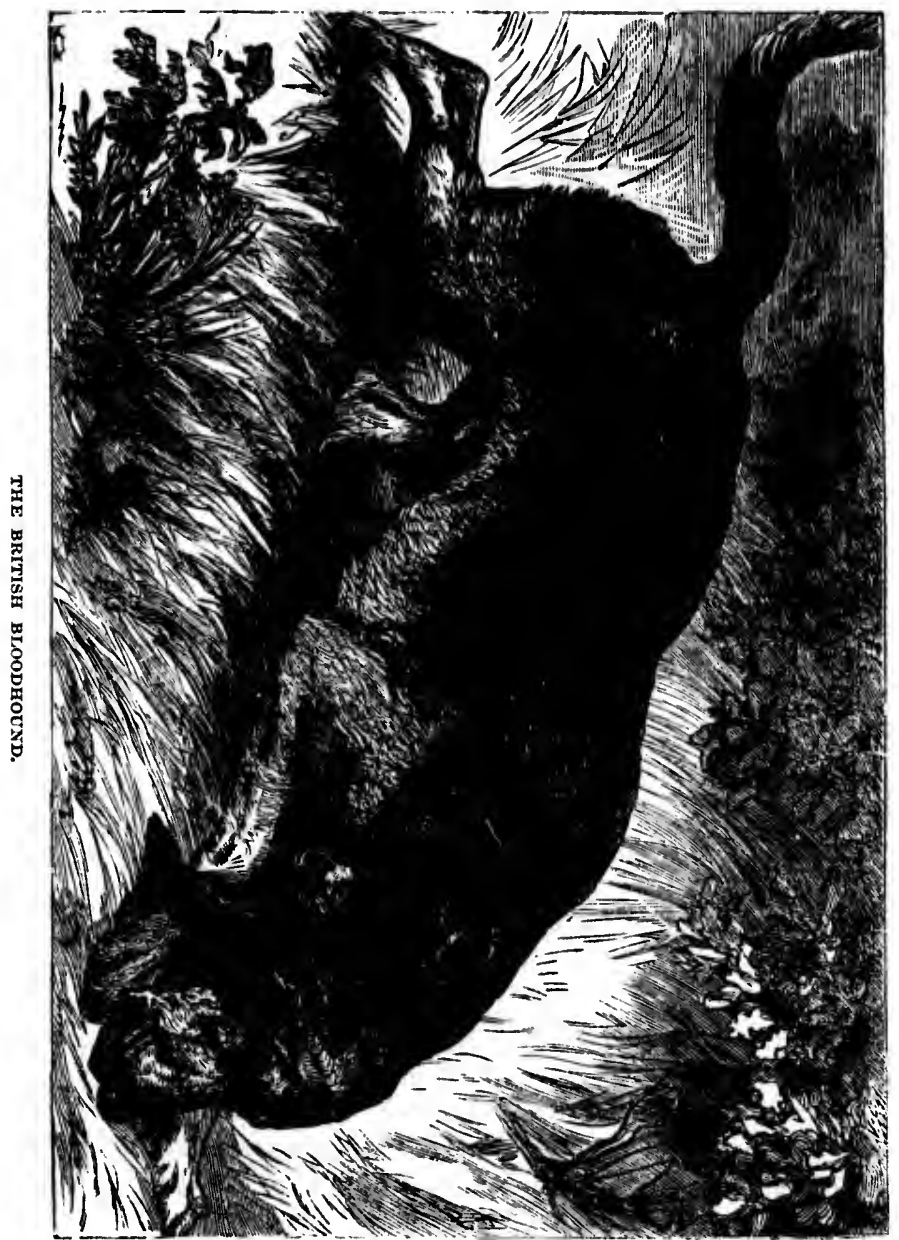

he carries his tail high as he runs, and it is oftener fringed with longer hairs approaching a feather. Colors: 1st. Black, white and tan; 2d. Pied, as red 
$t$ strains in glish. The he pointer's;

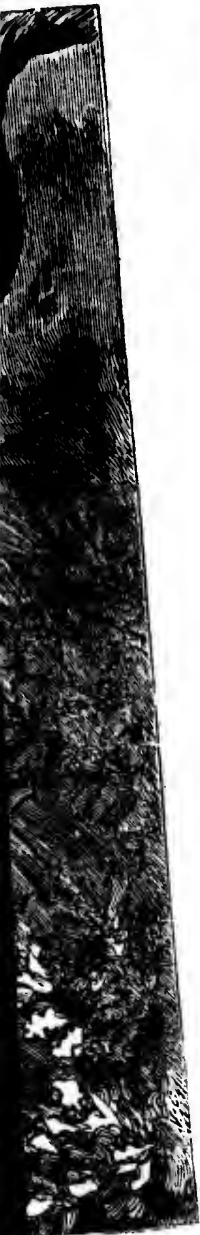

with longer hairs ; 2 d. Pied, as red pie, bluc pie or yellow pie, gray pie, lemon pie; 3d. Black ; 4th. White; 5th. Red; 6th. Blue.

He trails quickly, and is speely and of great bottom, and in this conntry frequently used for rabbit hunting.

\section{THE BEAQLE.}

'The beagle hound of a century back has been almost entirely displaced by the divarf fox hound, or a cross of the small bengle with the fox hound and harrier. In this country they are found of many sizes, and inay be styled the dwarf medium, and the large bengle. He can be appropriately termed a pocket edition of the fox hound, und resembles him very much in appearance.

He is used almost exelusively for rabbit hunting, trailing at a moderate pace with a true nose and musical voice. The dwarf beagle is now scarce even in England, and should measure not higher than 9 to 16 inches. The medium beagle measures 12 to 20 inches high, and the description given can be taken as a type of all. Head wide and round, short nose, drooping and full ears, body that of a diminutive fox hound, and color of the same shades.

\section{THE SHEEP DOG.}

The Euglish sheep dog is found of many varieties, and so differcut are they, that we can only dwell upon the main charatereristics of the leading one. He has a sharp nose, medium size head, small eyes, and well-shaped body covered with thick and almost woolly laair, growing full and strong about the neck and breast. Tail long and bushy; legs strong, and feet protected with hair for work on stony ronds and hills. Sheep dogs are always found with dewclaws. Color grey, or black, or brown, with more or less white. Weight about 50 to 60 pounds.

The colly, or Scotch sheep dog, has a broader head, which gives his nozzle a sharper appearance than the English dog. Hin eye is likewise small, but his ear is slightly more pricked as a rule. His tai is long and bushy, and his form a little stouter than the English shepherd dog's. Color al ways black and tan with little white.

\section{THE GREYHOUND.}

This dog has also been known in Great Britain for many generations, and has always been used for coursing the hare, or in other words to run down his game by sight. His head is very long and narrow, neck slender and ducklike, as it is called, back strong, tail long and ratlike, gradually turning upward as it begins to tajer, hind quarters greatly curved, and shoulders oblique, showing great fleetness. A good measurement for the greyhound wonld be as follows: circumference of head between the eyes 14 to 15 inches, length of neck 10 inches, circumference of chest 28 to 30 inches, length of arm 9 inches, 
length of knee to the ground 41 inches, circumference of loin 18 to 19 inches, length of upper thigh $10 \mathrm{t}$ inches, lower thigh 11 inches, leg from hock to ground $5 \frac{1}{2}$ to 6 inohes. Color black, blue, red, fawu, brindled and white. Coat short, fine and glossy.

The Albanian greyhound resembles the English in form, und like him in every particular excepting that he has long and silky hair.

The Persian greyhound is coated like the setter, and the rough Scotch greyhound, or deer hound, is also in every wuy formed like his English brother, but clothed with rough shaggy hair, and uses his nose to trail his game, while alnost all the other greyhounds hunt entirely by sight.

\section{THE DALMATIAN OR COACH DOG}

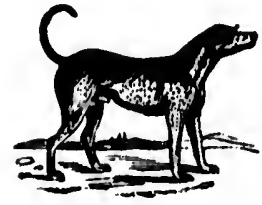

DALMATIAN DOG.

Stands about 24 to 25 inches, and very much resenbles the pointer in form and texture of coat, but is different in color, being beautifully marked with numerous small black spots on a white ground. He is fond of horses, makes his home in the stable, and is never tired of following the carriage.

\section{THE ENGLISH TERRIER}

Is a smoothly-coated animal weighing 6 to 10 pounds. We are now speaking of the useful dog of this breed, and not the diminutive toys that weigh is little as 3 to 4 pounds. His nose is long and tapering, eye bright and liquid, ears well set on, and when not trimmed are slightly raised, turning over at the tips. High forehead, flat skull, and strong jaw; neck strong, body well shaped, loins powerful for his size, chest deep and not too wide; slioulders free and very powerful to enable him to dig well; fore legs strong and straight, bone light; tail fine and tapering; color black and tan.

\section{THE SCOTCH TERRIFR}

Closely resembles the English in all but his coat, which is rough and wirelike. His habits are the same, being a great vermin dog. He is found in color black and tan and sometimes gray. The skye terrier in some respects is like the Scotch, but differs from him in having a long, weasel-like body, short legs, lon 6 wide head, long neck, bandy forelegs, and long straight hair parted down the back and falling over his sides, coarse in texture, but on the legs silky.

There are two varieties of the skye terrier, one smaller than the other, with the coat entirely soft, and the one we have first described. A very favorite cross is made between the large skye terrier und the Dandie Dinmont, which partakes of the nature and form of both. 
019 inches, om hock to and white.

like him in

Scotch greyglish brother, is game, while

cy much rescmof cout, but is marked with ground. He is e stable, and is

To are now speaktoys that weigh as bright and liquid, urning over at the strong, body well ide; shoulders free rong and straight,

is rough and wireg. He is found in - in some respects is asel-like body, short straight hair partel ure, but on the legs than the other, with d. A very favorite die Dinmont, which
The Dandie Dinmont terrier is supposed to be a cross between the Scotch terrier and the otter hound. He hus two shucles of liair, one brown called mustard, the other blue-gray callerl pepper. He has silky hair on the head, legs short, body long, low slioulders, paws long, and muzzle tapered, ears large and hanging, tail eurved up bound-like, and weighs 18 to 24 pounds.

THL: POODL:

Has been known in France, Germany, and England for many yenrs. He is notably intelligent and most easily taught, and is fond of the water. In Fngland he was formerly used for retrieving in duck-slooting. He has a large wide hend, small eyes, square muzzle, pointer-like body, and evered with very curly olose huir, hanging down at some parts in ringlets. His height is 16 to 20 inches. 'The Barbet, a variety of small poodle, is a native of France seldom seen here.

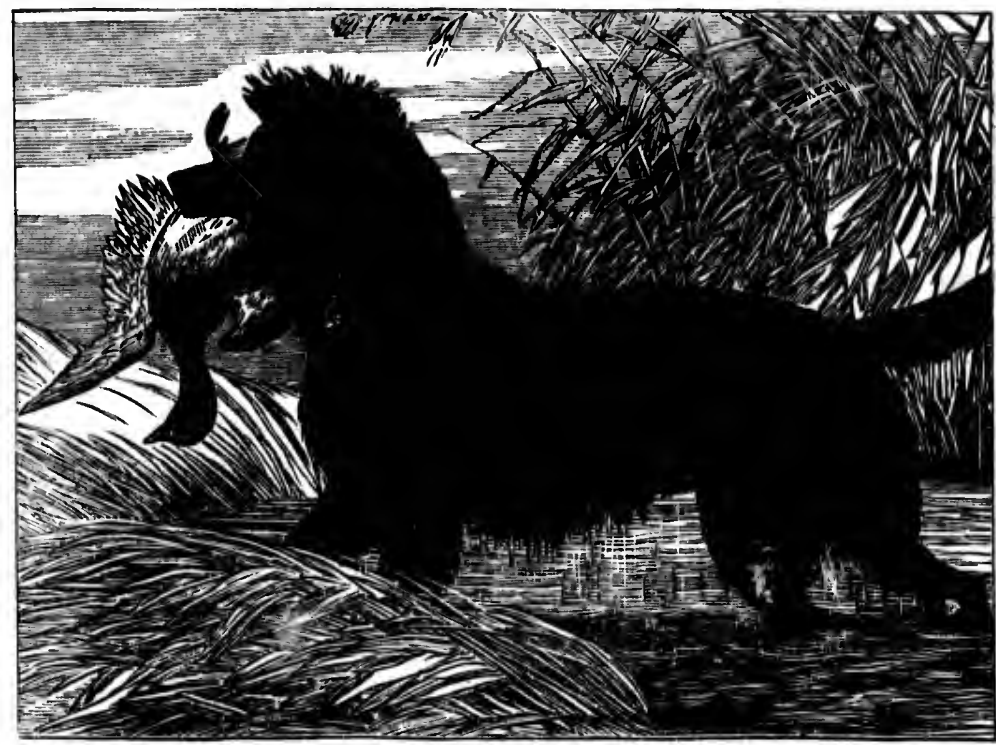

WATER APANIEI. 


\section{CHAPTER II.}

Choice of Sire and Dam in Breeding-Age to Breed-Time of Year to Breed-Management of Bitch in Season-Duration of Heat-Management of Bitch in Whelp-Whelping-Care of Whelps-Weaning-Feeding-Training of Pointers and Setters-Training of Spaniels-Training of Hounds-Training of Vermin Dogs-To Prevent and to Break from Gun ShynesHunting a Bitch while in Whelp.

\section{CHOICE OF SIRE AND DAM.}

IT is of $\varepsilon$ eat importance that the breeder should choose good specimens of both sire and dam of the breed he intends giving his attention to. If setter or pointer, selecting a dog that possesses the qualities or traits that are wanting in the bitch, and which he desires to intensify in the offspring. For instance, if the dam is of a timid nature, but otherwise having no great faults, she should be served by a bold, courageous sire; or, if the dog is not as speedy as is wanted, the dam must be the opposite. Select always such animals whose breeding is assured, and have proven pedigrees if possible. Breeding in and in is generally very beneficial, and tends to stamp any paricular family trait more indelibly in the offspring, but it can be carried to an injurions extent, and a point will be reached when fresh blood must be sought, which being obtained we may go back to original strain again. It is held by some that the first impregnation has an effect upon subsequent litters by different sires. It is necessary, therefore, to be careful in the selection of the cross that it will not neutralize the original impregnation or in like manner be neutralized by it. Like produces like in breeding, so in proportion to the purity of the breed will be the qualities transmitted to the wholps.

\section{AGE TO BREED.}

Most bitches are of an age to breed before they are a year old; but it is advisable to wait until the appearance of the second heat, and allow the first to pass without giving her the dog. At one year old small dogs can be permitted to breed, for at that age they will have reached the period of the second heat. Setters and pointers at 15 to 18 months are perfectly matured and in proper development, but the mastiff and other large dogs, not attaining their full growth until they are two years old, must not be bred until that age.

TIBE OF YEAR TO BREEI).

Spring and fall, if not too early in the firnt mol too late in the last season, 1016 
Ianagement of ping-Care of paniels-TrainGun Shyness-

specimens of to. If setter it are wanting For instance, eat faults, she ot as speedy as animals whose rreeding in and lar family trait njurious extent, ht, which being y some that the ferent sires. It ross that it will neutralized by rity of the breed

ar old ; but it is id allow the first dogs can be perfiod of the second matured and in ot attaining their itil that age.

the last season,

are the best times of the year to allow dogs to breed. If puppies are whelped in the spring they have ample time to grow and be able to stand extreme hot weather, and if in the fall they will have attained a size which will enable them to better endure the winter's cold. The majority of bitches come in season some time in the spring or summer; by allowing a summer "period" to pass without serving, the next will very probably come around during the spring following, when the dog can be allowed. The bitch after this serving will be likely to be regular in the heats.

\section{MANAGEMEN' OF THE BITCH IN SEASON.}

Bitches, when in season, should be confined so that no dog but the one chosen may come to her. This frequently causes ill-health, and will have an effeet upon the whelps unless regular exereise is given (on the chain if necesary), until the period has passed.

\section{DURATION OF HEAT.}

A bitch is in heat about three weeks; the first week she scarcely ever willingly aceepts the dog, and at this time bleeds from the vulva. Not until this bleeding has subsided should she be lined, and then no time should be lost as desire now soon begins to pass away, and continues gradually to do sor the balance of the twenty-one days. It is a mistaken idea that the sex of the whelps can be regulated, by the time of the heat the dog is allowed to go to the bitch. There is no sure rule to follow.

\section{MANAGEMENT OF BITCH IN WHELP.}

A bitch from the time she conceives will run from sixty-tluree to sixty-five days before she gives birth to her litter. As soon as it is diseovered that she is in whelp the exercise begun as directed should be kept up and rather increased daily. Her food now shonld be soft, yet nutritious, and easily digested, such as thiekened soups, oatmeal and boiled milk; oatmeal with lean meat, minced finely, mixed with it. Care being observed that her bowels be kept open. If costiveness slows itself a dose of castor oil or salts may be given.

\section{WHELPING.}

As soon as the day for whelping arrives, a quiet, clean and comfortable place should be provided for the bitch, and she should be left entirely alone, nature being ler best assistant, unless something wrong takes place or malformation slows itself. While in labor and between the throes (it may be she will be the whole day in whelping) no food is required. She must be kept as quiet as possible. Some nervous bitches are apt to cievour their puppies if disturbed at this time. After all is completed a luke-warm gruel of half milk and half 
water may be given the mother. Nothing cold should be placed before her. After the first thirty-six hours the biteh will of herself leave the whelps to empty herself; from this time stronger and more nutritious food can be given,

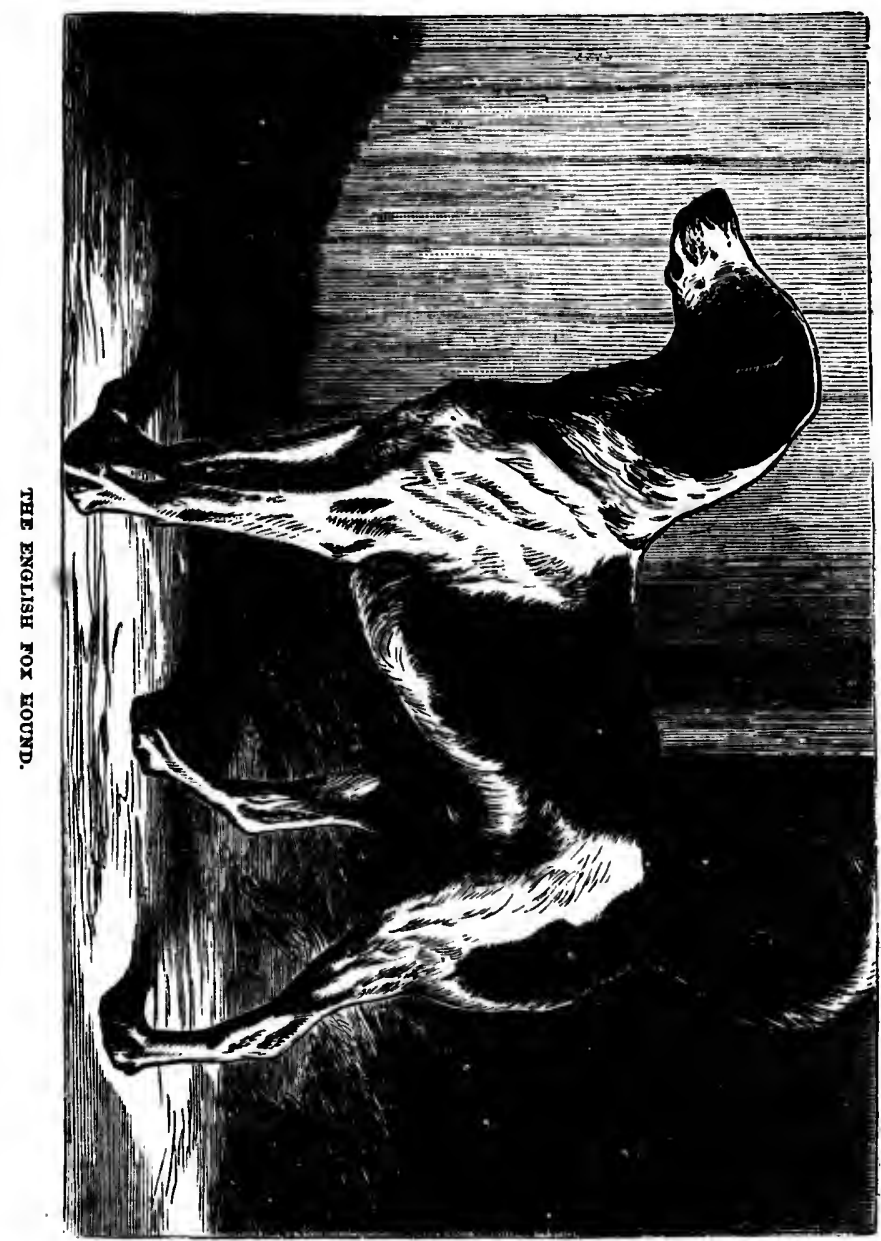

abundant milk allowed, and the most nutritious diet provided to aid her raising her ravenous family.

Exercise must be now eoutinuel, which the mother :.:ll be glad to aceept 
in about two weeks after the birth of her puppies, that she may have an hour or two of rest daily from their growing demands asd sprouting teeth. She may be allowed to go free.

\section{CARE OF WHELPS.}

The puppies should be carefully examined for lice and other parasites as soon as the bitch will allow you to handle them. If any are discovered the whelps should be washed with a lukewarm decoction of Quassia chips or - Persian insect powder carefully rubbed into their coat. The bed or nest must now be changed, new hay or straw being furnished and sprinkled with the insect powder. Nothing troubles and takes away from the growth of puppies nore than lice and fleas. Their quarters must be roomy that they may be able to run about and romp with one another, and thus develop healthy bone and muscle. At about three to four weeks they may be taught to lap onethird water and two-thirds cow's milk preparatory to weaning.

WEANING AND FEEDING.

At five or six weeks the puppies may be safely weaned. They have alrealy learned to lap. Stronger food can now be furnished, the milk given pure, mixed with crumbled bread, or well-boiled oatmeal. Feeding time should be regular and at stated hours three times a day, and the dish, trough or vessel containing the food taken away as soon as the youngsters have filled themselves. After a time food twice a day will be sufficient; say morning and night. As the puppies become larger a bone containing some meat may be given then ; too much flesh is injurious. A sheep's head thoroughly boiled is capital now and then for them to pick at. It is of the greatest importance that the whole litter should be allowed abundance of exercise, and liberty be given them at stated times during the day. Pups deprived of exercise are apt to have the rickets or enlarged joints, or be out at the elbows.

\section{TRAINING OF POINTFRS AND SETTERS.}

In choosing a puppy from a litter of well-bred setters or pointers it becones a difficult task which to determine upon. If possible wait until they have attained the age of four or five months, by which tine they have become somewhat developed. Sit down where you can see them all together, and notice which is the most active and intelligent. The overgrown mother's pet, generally the strongest of all, is frequently lazy, and sleepy, and shows hut half the spryness of his smaller brother or sister. Select a puppy with a good brin development, such a characteristic holds good with the canine as well as the human race. We have never seen a bad dog with a good head and face. 
Having decided upon a young setter take him to yourself, and when he is

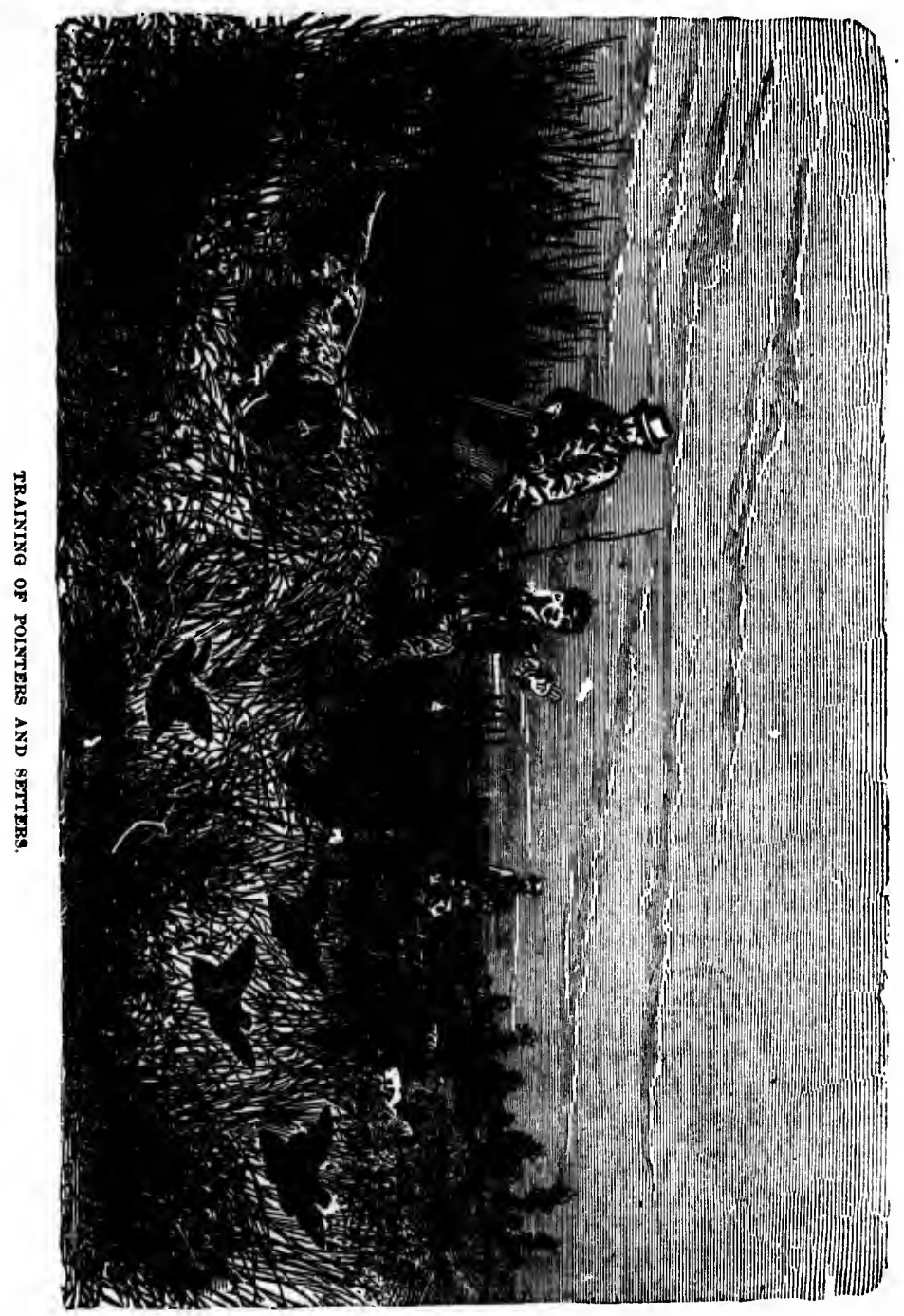

- six or seven months old, eight will do, begin his primary tuition. Allow no 
when he is

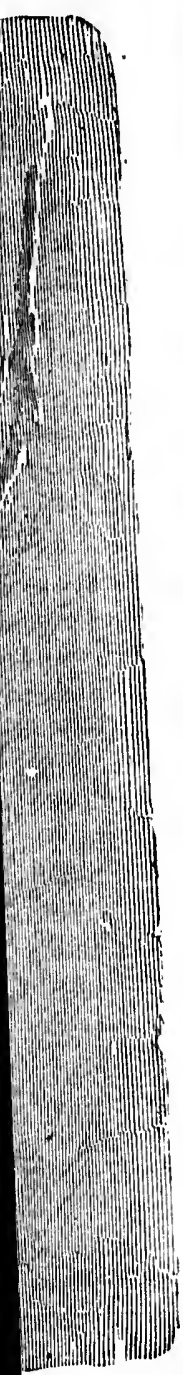

on. Allow no one to feed him, attend to this yourself', accustom him to your voice and manuer, let him follow you on all your walks, and it will soon be noticeable how devoted he will become to your. The dog has a mission to fulfil on earth, that of serving his master, and as soon as he fully understands what is wanted of him it becomes his happiness to serve his owner; therefore study his disposition and assist him in learning his duty. Never flog cruelly and only when you are positive your dog has committeri a wilful fault; then be merciful, for many are ruined in spirit by harsh treatment.

Most well-bred puppies will point from natural instinct and take to hunting withont tuition, but it is absolutely necessary to inpress on your young dog, before taking him into the field, the necessity of prompt and strict obedience, and for this reason begin at home with the check cord at an early age. Provide yourself with some morsels of food, and take your scholar into a room or yard where there will be no one to interfere with the lessons. Fasten a cord four or five yards in length to his collar, and throw a piece of food whers he can see it all ; he will naturally rush for it; allow him to do so, but as he nears it, je $k$ the cord and hold him, saying, "Ho," or "Toho" in a conmanding cone. Practise him in this manner for an hour each day until he will stop over the morsel at the command "Toho," without the jerking of the cord. All this will be found a little difficult, but by patience it can be accomplished. Never let your temper get the better of you, but be cool, determined and persistent. Care should be taken not to alarm your scholar in these lessons, especially if he be of a timid nature; an intelligent dog though will learn very soon, and retain all you impart as he understands what is required of him. He should be tanght that an uplifted hand is equivalent to an order to drop or charge. After thoroughly schooling your young dog indoors or in a yard, and when you are satisfied he is well practised in his lessons, take him into a field with a long cord attached to his collar, say fifteen or eighteen yards, and have one end of it fastened to a stake, which drive firmly into the ground. Begin again as you did indoors, making him hunt out the morsel of food and cheeking him with the cord and "Toho." You can now begin with snapping a cap on your gun at the moment you jerk him, then using a little powder and inereasing the charge until he finally accepts the report as a command to drop. While he is down walk away from him, make him stay there until allowed to rise, then run from hin; he may start :fter you, but the stake will stop him when he comes to the end of the cord, at which time cry "Toho," the monent he is checked. Now walk around him, now from him, again insisting on his being obedient. All this will tend to make your dog steady at the "charge." To teach your dog to return is not an easy task. This idea of fetching should be imparted when the puppy is quite young, giving him a taste for it by throwing an old glove from you and having him run after it, until as we have said before he brings it back for 
another play. From the start in these lessons always repeat the word "fetch," which although not understood at first is eventually associated with the act and its meaning remembered. We will now suppose your dog is perfectly under coinmand, and that by patience, perseverance and kindness you have yard-broken him.

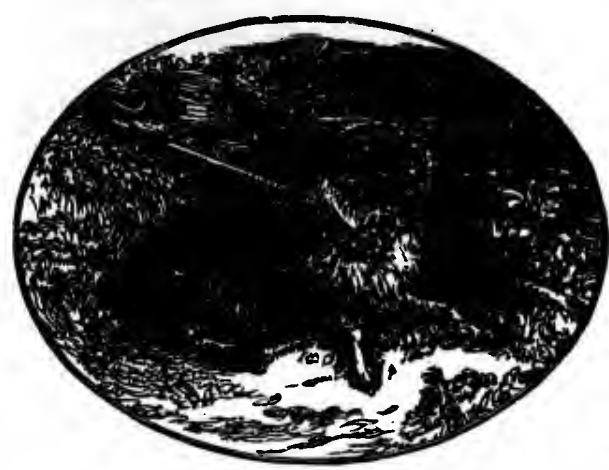

THE SHEPHERD'S DOG.

It may be three or four months before you have broken your young dog perfectly indoors, and practised him likewise in some open field. It is now time to prepare him for real work. If it can be done, select a country where game is plentiful, and have a friend occompany you with an old tried pointer or setter. When you have reached your shooting grnunds, attach a strong cord to your dog's collar, such as is called a loom cord well twisted about the diameter of a pencil, and fifteen or sixteen yards long; allow him to range with it trailing after him; the cord will not tangle or foul as would be supposed. Naturally the old dog will find the first covey of quail, and your pupil will notice the point, and if he is well bred will back; if he does not and is anxious to move forward to the old dog, step on the end of the cord and hold him, saying "Toho" or "Ho," which he should be familiar with by this time. Your companion must now start the covey and kill a bird, and his dog should charge or drop at once, while you must check your own dog to drop also: Allow the old dog to retrieve, and let the young dog see him bring it, which when he has several times observed he may be allowed to do also, having been taught indoors to fetch as described. Continue thus throughout the day for several days. Too much hunting cannot be given your youngster the first season. It would be a good plan to take your puppy out alone during your trip and urge him to find birds on his own account, for fear he may be satisfied to play second fiddle; very frequently young dogs when worked too much with more experienced animals, learn to be satisfied to back the other pointer only.

Do not remove the check cord until le thoroughly knows his business and is entirely under your control. The cord is far better than the whip.

TRAINING OF SPANIELS.

Bpaniels do not point their game; all that is required of them in train- 
" fetch,"

th the act perfectly you have

e or four ave broken erfectly ind him likefield. It is are him for an be done, gere game is ve a friend with an old tter. When your shooting strong cord lar, such as is 1 well twisted long; allow ple or foul as svey of quail, back; if he p on the end he should be covey and kill ast check your the young dog ay be allowed Continue thus be given your our puppy out count, for fear ng dogs when atisfied to back

is business and whip.

them in train- ing is steadiness, obedience, to drop or down charge, to work close to the shooter, and to retrieve. Therefore, in breaking, the same rules may be observed as those in the education of the pointer and setter, excepting that portion which relates to pointing. Spaniels learn retrieving very readily, more so than any dog, save the poodle. Their training may be begun at an earlier age than that of the pointer or setter.

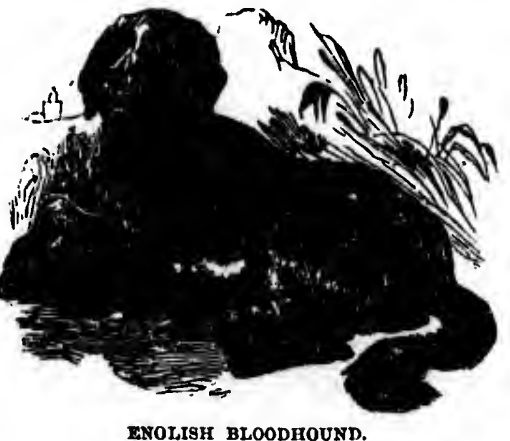

TRAINING OF HOUNDS.

All that is necessary in training hounds is to accustom them to the sound of the horn, to break up any riot in behavior, and to have them obey their master. Young hounds will take to trailing naturally when in company with older dogs. Experience is their best teacher. Beagles are taught that the report of the gun is a call for them to come in.

\section{TRAINING OF VERMIN DOGS,}

Care should be observed not to allow terriers to attack vermin when they are very young, which they will do if allowed, unless they are protected from injury. A good plan to follow is to remove the teeth of a rat and allow the puppy to worry it, or, what is better, give him a mouse for his first victim to kill. A full-grown rat will sometimes so punish a puppy as to render him fearful ever afterwards. Terriers hunt vermin at an early age, and no training is needed. When wanted for rabbit-hunting, and they are useful for this sport, they soon learn from the beagle, with which they may be allowed to run.

\section{TO PREVENT AND TO BREAK FROM GUN-SHYNESS.}

It is discouraging to the sportsman to find his dog, notwithstanding he may be purely bred, to be gun-shy, or afraid of the report of firearms. To avoid all such danger, especially if the animal shows himself to be of a nervous nature, he should never be fed unless a pistol was first fired off, beginning with light charges and increasing the loads when he began to associate the report with the pleasure of satisfying his hunger. Then when we are ready to begin to train, the sight of a gun, and the noise made thereby, can be borne.

A grown dog can be in the same manner corrected of shyness by keeping him with a keen appetite for his meals, and striving to show him that the gun will not injure him, and to associate its report with a pleasure at feeding time. He should be so fed as to be ravenous when the hour for his meals approaches. 


\section{HUNTING A BITCH WHILE IN WHELP.}

There is certainly a sympathy between the mother and the unborn foetus, and puppies that are born shortly after a bitch has been sliot over several times are much easier to break than if she was not worked. They take to hunting and pointing as naturally as a duckling goes to water when hatched. For two weeks prior to pupping make it a duty, therefore, to run your biteh where there is game and have her point as much as possible; it will amply repay the breeder. In like mauner allow hounds to run, and terriers to kill vermin, the more the better, so that your dog does not so injure herself' as to bring on premature labor.

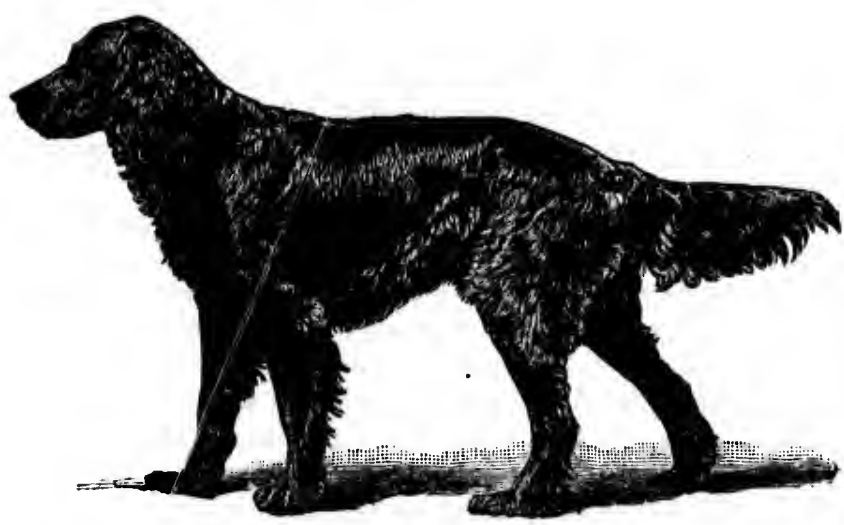

IADY PILOT; A FINE GORDON SETTEIS.

Born July 4th, 1880. Owned by Samuel (i. Dixon, of Philadelphia. 


\title{
DISEASES OF DOGS AND THEIR TREATMEN'T.
}

\begin{abstract}
Treatment of Asthma-Bronchitis-Comnon Cold-Influenza-Pleurisy-Pneunonin-Consumption-Rheumatic Fever-Distemper-Inflammalion of the Stonach-Inflammation of the Liver-Inflammation of the Bowels-Mange-Canker of the Ear-Fleas and Liee-Chorea or Jerks-Fits-Worms-Riekets or Iarge Joints-Tumor und Cuncer-Puerperal Fits-Prowaeted Labor-Sprains-To Harden Tender Feel-Rabies or Hydrophobia.
\end{abstract}

\section{TREATMENT OF ASTHMA.}

Astrima in dogs is ofttimes hereditary, especially in louse and pet dogs, and may be brought about by indigestion or irritation of the stomach. A sudden change of weather will bring it on. Fat dogs are espceially prone to it; the symptoms are: thick, heavy breathing, a hollow, husky bark, much panting, and great constipation. Begin with low diet and alminister

\section{Chareoal, 1 scruple; \\ Iron, 10 grains,}

in a pill three times a week. Exercise and keep bowels moved with castor-oil twice a week until relieved.

\section{BRONCHITIS}

Is caused by neglected colds, cold, damp liennels, want of cure after returning from wet hunting-gromuds, etc., and may be known by a continnous wheezing dry cough, which at times causes an effort to and brings on vomiting, the expectoration being frothy and mixed with bloor, the eye inflamed, and the nose dry ; the tongue parched, with the pulse quick. In the beginning of . the attack give the dog a warm kennel where there are no draughts, and dose with

I to 3 grains tartar emetic, aceording to size of animal.

If this does not cheek give spirits of camphor $\frac{1}{2}$ oz., spirits of æther nit. 1 ounce, ext. liquorice $4 \mathrm{oz}$; a teaspoonful for small dog three times a day, and three times the amount for large dog three times daily. Feed with warm broths and bread and milk.

\section{COMMON COID}

Is known by sudden chillness with heated surface of the body, quick pulse and hurried breatluing. The appetite fails, bowels are costive, and urine high 
colored. Very often there is a slight cough, and a running from the eyes and nose, which is hot and dry. Canse, exposure or sudden checking of the temperature of the body. For treatment give a dose once a day of

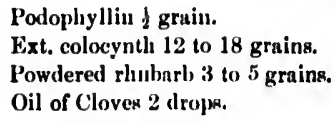

\title{
INFI.UENZA
}

Is diffieult to distinguish from common cold; the running of nose and eyes is more copious and continued, cough severer and fever ligher. Administer dose as for eommon cold, and if not relieved give bolus of

\author{
Ipecactuanha $\frac{1}{2}$ to $1 \frac{1}{2}$ grains. \\ Rhubarb 1 to 2 grains. \\ Powdered opium 1 to $1 \frac{1}{2}$ graine. \\ Compound equill pill 1 to 2 graine.
}

Give night and morning. Keep in dry comfortable kenuel indoors, and feed on light diet.

\section{PLEURISY}

Is an inflammation of the membrane of the lungs caused by debility, eold or inflammation of the neighboring textures, and some times by wounds, or a severe beating of the body. It is ushered in by shivering and quick breathing, inspiration especially short, caused by the pain occasioned by the movement of the ribs. A dry cough is present, fever, nose hot, tongue slimy, eyes watery, pulse hard. 'The dog sits on his hind quarters, with his fore legs stretched apart, as if to elose them caused pressure and pain. Administer

Spts. æether. nit. 2 olusces.

Liq. ammonia acetat. 4 ounces.

A teaspoonful every four hours, nixed with double the amount of linseed tea for a small dog ; twice the quantity of each for large dog.

Apply counter irritants of mustard plaster to ehest.

\section{PNEUMONIA}

Is brought about by exposure likewise, and oftentimes by the animal not being thoroughly dried and protected from the cold after washing in warm water. The dog is seen to shiver greatly; this shivering is followed by high fever, pulse rapid, breathing quiekened, accompanied with a short congh, eyes bloodshot. Treat the same as in pleurisy, especially the counter irritants.

\section{CONSUMPTION}

Is hereditary in the dog as in man. Close eonfinement will bring it on, as 
he eyes and of the tem-

nose and eyes Administer

indoors, and

debility, cold or y wounds, or a fuick breathing, he movement of my, eyes watery, re legs stretched er

tea for a small dog;

animal not being in warm water. d by high fever, ough, eyes bloodritants.

11 bring it on, as will bad food, and excessive in and in breeding; it sometimes follows distemper. All that can be done is to kcep up the strength of the dog, with codliver oil and iron and good diet, avoiding a damp or colel kennol.

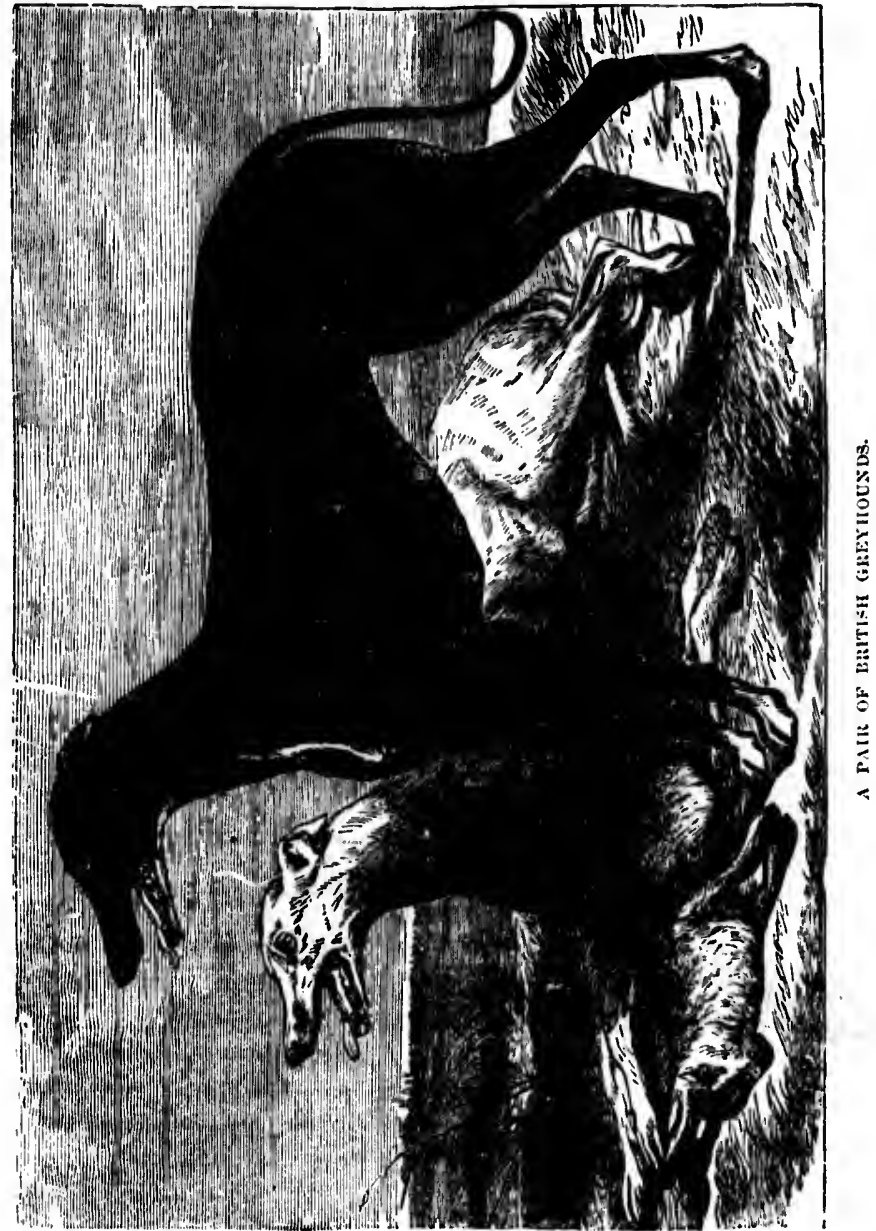

RHEUMATIC FEVER.

Dogs frequently have rheumatism, especially hunting dngs, and it is always accompanied with more or less fever; danp kenncls often cause it. Its signs 65 
are ns follows: there is eonsilleruble fever, but of not very high cliaracter; the pulse is quick with shivering except when tonched, when the slightest appronch will cause a shriek appurently from pain. A good treatment is first a ilose of pliysic of

Calomel 3 to 5 grains.

Julup 10 to 20 grains.

Mixed with ayrup and made into a bolus.

And follow, after it hins operated, with

Calomel 1 gruln.

l'owicered upium 1 grain.

Puwdered colchicum 2 to 3 grainn.

And ayrup enough to make one pill.

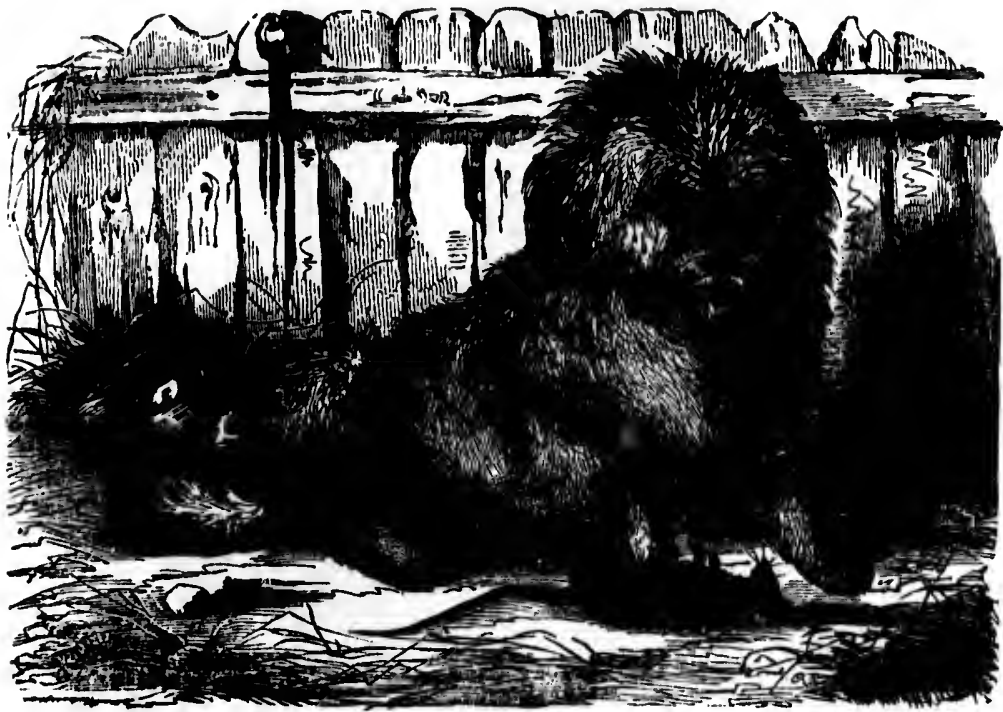

SCOTCH TERRIER.

This is a dose for average dng. The animal may be rubbed with any approved liniment where the pain seems to be present, and his diet be made a low one.

\section{DISTEMPER.}

The great majority of dogs are attacked with distemper about the time they are casting their milk tceth, or a short time after they have gained their second; but few aninals esenpe it. An ordinary course of an attack of distemper is as 
racter ; the

it upronch ti cluse of

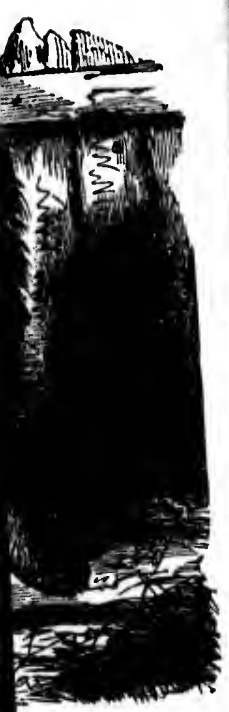

ubbed with any is diet be made

out the time they ned their second; of distemper is as follows: great dullness with loss of appetite, followed in a dny or two by a husky cough, esprecially showing itself ufter exercise; a sneexing is now noticed, strength and flesh mpidly diminish, the stools are inky and offensive, the urine becomes very high colorer, and the membrunes of the eyes and sometimes the whites are greatly inflamed. Some cases of distenper seem to be confined principally to the hend, another to the chest, and the third the bowels. When the bruin is attacked the eyes are more injecterl than when the bowels or the lings are affected. The nose and eyes show increased mucons discharge as the disense progresses. These are the general symptoms which intensify to the third, fourth or fifth week, when the dog dies from disease of the brain, lungs, bowels or exhaustion. When the hend is attacked there may or not be a running from the nose. A fit is most always the surest sign of brain trouble, and when this takes place more than twice, the distemper generally proves fatal, or the animal is ever afterwards affected with elsorea, or the jerks. If the lungs be involved there is rupid breathing, cough, and profuse running fron the eyes and nose. If this rums into inflammation of the lungs the danger is as great as if the head was affected. The bowels are sometimes seized and show by black purgings that these organs are involved, very often in this stage discharges of bleod quickly carry a dog off. The best general treatment for distemper is as follows. At the conmencement of the attack.

\section{Syrup of buckthorn 2 omecr. \\ Syrup of poppy 1 omce.}

A tnblespoonful once or twice at intervals of two days. A seton placed in the back of the neek, covering the tape with blistering ointment, will relieve the head if it appears to be affected. And a fever mixture as follows:

Nitre 1 drachm.

Spts, of nitre 3 drachms.

Midererus spirit 1 ounce.

Camphor mixture $6 \underline{1}$ ounecs.

Two tablespoonfuls every six hours.

If the lungs are severely attacked, a powder must be put upon the dog's tongue every night and morning of

Nitre in powder 3 to 5 grains.

Tartar emetic $\$$ grain.

And a cough bolus of

Ipecacuanha in powder $\frac{1}{2}$ to $\frac{1}{2}$ grains.

Powdered rhubarb 1 to 2 grains.

Purified opium to $1 \frac{1}{2}$ grains.

Compound aquill pill 1 to 2 grains. 


\title{
Administered every night and morning. If diturrhon shows itself eheek it
} will

Prepared chulk 2 to 3 arnchuss.

A romatic confection 1 draclim.

Lamilnumu 8 to 8 druchuts.

lowdered gum urubic 2 draclumis.

Waler 7 ouncen.

Two tiblexpronfuls overy time bowole ure redixed.

For a diet, beef ten thickened with ries enu be given, and fir a time when the dog slowe grent exhanstion, a mixture of tineture of burk 2 ommech, decoction of yellow lark 14 ounces, a lablespoonfiul is timbs a day 10 a large

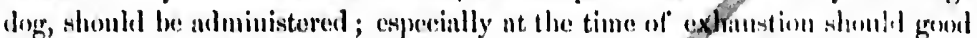
stroug beef ten with the white of an eger broken into it while it is lulscwarm, be given by spoon every two or three hours. Ant if the animul will not swallow it, his heml shomld be held "1p and he should be foreed to. If this tromblem some plun of feeding ia attended to, muny a valuable dogecan be saved to his owner. As strength grndunlly returus the diet em be mole stronger, with anre followed to nllow no exereise mutil n gain is well established, mod strength

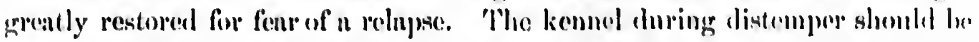

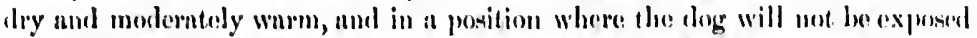

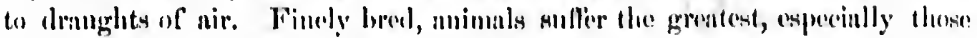

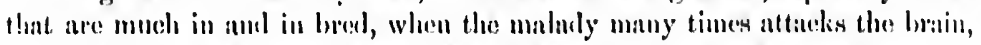
which is the most dhugerous sent of the disense. Fit alter fit taken phace ambl

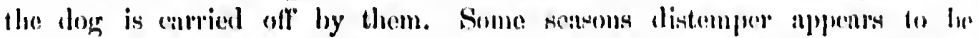
cpidiemic and is more severe and fitul in its efferts, and sempeoly a dong in cortain seetions esenpes. Dogshows are a great means for spremeling the: dise:ase, num it is advisable not to cuter an animal mutil he has had the discase. Distemper enu be lomel twice, but it is selelom a dogr is attacked more th:m once.

\section{TRBATMENT OF INFIAMMATION OF TITS STOMACII.}

luflammation of the stomam or gastritis is brought abont by improper fowed, forcign sulsatance in the stomad or poison. When a dog is sullering form this eomplaint ho imakes frequent and violent eflints to vomit, and lans great thirst, diry und hot nose nnd quick respirntion, and will olttimes lie on the flowr, or pavement, or gronud with his belly in contnct with it ns if to allay the pain. Give

\author{
Culomel 1 grnin. \\ Opium 1 gruin. \\ In pill every three hesirn.
}

Aml feed if he will take it with lyght sonp and gruel. Gustritis nud dyspepsin are much alike and may be treuted the sume. Continue ensily digested forl in dyspepsin; the peculinr posture clescribed is not noticed in the lutter con-pluint. 
Keep on low diet and give exercise. Secondly the foul mange, which is brought about by impure blood, and cannot be cured until it is changed. It is considered hereditary though not contagious. In foul mange the skin becomes thick and discharges an offensive matter, and finally runs into ulcers, with great itching all the time, the hair becomes dead aud falls out, and the animal is nervous and irritable. To cure requires patience and ofttimes long treatment. Change the diet at once, give no meat, starve the dog until lie will accept oatmeal musl with boiled vegetables freely mixed with it, then administer liquor arsenicales with the food, one drop to each four pounds in weight of the dog three times daily, dividing the food into three portions for morning, noon and night. This must be kept up until itching ceases, and very often continued for months. Cosinoline may then be rubbed on the maugy skin thrice daily.

Red mange is a disease of the hair, and may be known by the red appearance always at the roots in spots, at the elbows under the arms and inside of them, also inside the thighs. An ointment for red mange, of the following, well rubbed into the spots, is good:

Grcen iodide of mercury $1 \frac{1}{2}$ drachms.

Spts. of turpentine 2 drachms.

Lard $1 \frac{1}{2}$ ounces.

A wash of carbolic acid 1 part to water 30 parts, and plain cosmoline is efficacious also.

\section{CANKER OF THE EAR.}

Whenever a dog is seen to shake his head continually, and frequently scratch his ear, endeavoring to relieve an apparent inward itching of that organ, it is generally safe to conclude lie has the canker. Sometimes the tips or edges are first affected, and the inflammation will, if not then arrested, gradually extend to the interior, which when attacked discharges offeusive matter. Hunting dogs, especially water dogs, are subject to canker. To cure, place on low diet, and syringe the ear, first having washed it out with lukewarm water, with a weak solution of

Nitrate of silver $\mathbf{2}$ to $\mathbf{6}$ grains.

Water 1 ounce.

According to size of dog,

the first day; and on the second drop into the ear

Green iodide of mercury 1 drachm.

Melted lard 8 drachmr.

Alternate these until relief is had. If there are any sores on the edges of the ear, touch them with blue stone. 
e, which is hanged. It ge the skin into ulcers, out, and the oftimes long dog until he with it, then or pounds in : portions for ases, and very on the mangy

by the red the arms and mange, of the

in cosmoline is

and frequently itching of that metimes the tips $t$ then arrested, harges offensive nker. To cure, tout with luke-

on the edges of
FLEAS AND LICE.

Make a stiff lather that will stand alone of strong rosin soap ; rub it thoroughly into the hair and all over the body, being eareful of the eyes, and let it dry on the dog, and remain an hour. Then wash off, and the water will earry the dead fleas and lice with it. This is safe and most certain.

Persian inseet powder is best for young juppies.

\section{CHOREA OR JERKS.}

This disease, often also called St. Vitus' dance, cannot be mistaken in a dog when he is afflicted. He will have either a continual jerking movement of the paws, hend, shonlders or foreleg, intensified when asleep. It often follows distemper and cannot be cured. The animal's general health does not seen to be affected by it, but it renders him unfit for very hard work. It er idently affects his power of scenting to a degree. Keep fron exposure to wt and cold, and give a tonic when very nervous of

Sulph. of zinc 2 to 5 grains.

Ext. of gentian 2 grains.

3 tines a day.

FITS

are of three kinds. 1st. Those arising from irritation (freqnently worms), and the majority of times in puppies. 2d. Those caused by brain troubles. $3 \mathrm{~d}$. Epilepsy. Fits resulting from irritation come on at the age when puppies begin to eut their teeth. A hot bath will eheck them. Apoplectio fits are generally fatal. The dog does not foam at the mouth in these, but lies quite still on his side and breathes heavily.

Epileptic fits are known by the frothing at the month and a champing of the jaws. These can be cut short by an injection of five drops ather to an ounce of warm water. Give also two grains bromide of potassium twice a day for three or four weeks.

worMs.

There are three kinds of worms that infest the stomaeh of a dog. 1st. The maw worm, of a white color, about an inch long. 2d. The round worm, 4 to 7 inches long, pointed at both ends. 3d. The tipe-worm, often growing a number of feet in length, and composed of many small links or joints. When a dog is tronbled with worms his coat becomes harsh and dead in appearance. $\mathrm{He}$ is eostive and loose at times, and his stonl is generally mixed with a white sliny muens. His appetite is ravenons, yet sometimes poor. He seems to derive no benefit from his food, and may be seen to swallow small pieces of dirt, nshics, rigs or sticks, in order, as it were, to force the worms from the stomach. 
An infallible cure for the maw and round worm is a dose each day of Fahnestock's vermituge on an empty stumach, followed in two hou's with castor oil. This vermifuge is composed of male fern and sautonine. Another good remedy is powdered areca nut-half of an average-sized nut made fine to a dog 30 pounds in weight, given each day, as much as can be held on a 25 -cent piece, wil :m empty stomach, followed in two hours by (astor oil.

A good expellant for tape worm is 3 to 10 drops of turpentine, aecorling to the size of the dog, in a teaspoonful of oil, having well fasted the animal.

Powdered glass, made impaipably fine, combined with lard and ginger, in a bolus, is another expellant much used. Use as much powdered glass as can be heaped on a nickel piece, and follow with dose of oil.

\section{RICKETS OR LARGE JOINTS}

are caused by defective bone substance. Cod liver oil and phospiate of lime (the combination can be readily purchased) will remedy. Dose, dessert

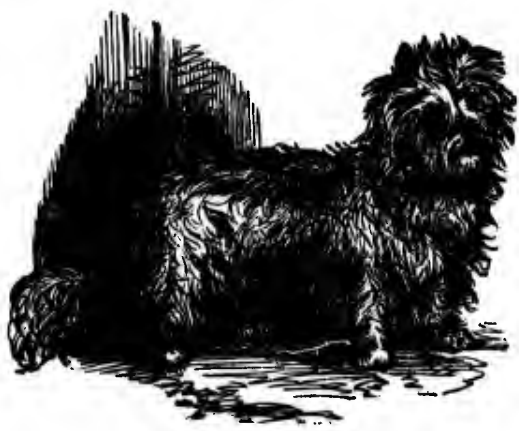

BKYE TERRIER.

sponful tiree times daily for large dog, a teaspoonful three times a day for small dog. A young dog with rickets should have ample exercise. A want of it aids in bringing on the disease.

\section{TUMORS AND CANCERS.}

A dog suffering with tumor or cancer should only be treated by a skiliful veteriuary surgeon, when the knife is alivass resorted to.

\section{PUERPERAI, FITS,}

Sometimes after a mother has given hirth to a litter of puppies, and about the time she begins to suckle them, she is taken with spasms or puerperal fits. When this oceurs, place her at once in a hot bath, and immerse all except the head. 'This is, in the majority of times, unfailing in its effect. 
A healthy biteh very seldom has trouble in giving birth to a litter. The time may be prolonged in some and short in others, but, as a rule, it is best to allow nature to have its course. If, lowvever, assistince is absolutely needed, a gentle manipulation muy be made, and a few drops of ergot a lministered.

\section{Rul the injured part with}

SPRAINS.

Malt vinegar 1 ounce.

Spirits vini et camp 2 ounces.

Aqua 7 ounces.

late of lime

ose, dessert

TO HARDEN TENDER FEET.

Bathe the feet daily in solution white oak bark and alum. Every other day rub into the soles cosnoline.

\section{RABIFS OR HYDIRPHOBFA.}

The term rabies signifies malness, and hydrophobia fear of water. The first is the appropriate name for this dread disease in dogs; the latter conveys the wrong idea, as a rabid animal does not in any manner fear water, nor does the sight of it bring on spasms. The inalility to swallow water and the agony experienced in attempting it, results entirely on acount of the inflamed condition of the throat and the closing of its passanc. The eanse of rabies is not known. Some writers clarge it to the absence or deprivation of natural sexual intereourse on the part of the dog. It is notable that the number of males outumbers that of females in very great proportion, and in rural districts bitel puppies are invariably destroyed owing to the fact of their trouble when in season, and the double tax imposed on their owires in the counties where they are kept, so that the argument is a reasonable one to say the least. Again, wild animals of the canine species, the wolf, fox, etc., are never known to be affeeted with it unless innoeulated. It may oceur in a dog in cold as well as a hot climate, but hot weather seems to generate brain troubles. Symptoms: The dog becomes sullen, has a desire to be alone, hides himself, and when called sneaks off to his retreat again. As the discuse advanees he begins to gnaw and pull at the woolwork of his kennel or slecuingplace. His eyes have a vaeant expression, and will seem at times to be looking into the distance at some imaginary objeet. Small inseets will be attentively nhserved by the sufferer, and will be intently followel in their movements; as they near him he will suddenly jump forwarl and make an angry snap at the supposed offender, and then sneak off as if ashamed of himself. Thick saliva will now come from his lips, and he will champ his jaws. As the

es, and about uerperal fits. ll except the 
disease intensifies the saliva becomes more copions, and he will attempt to paw it from his month. His voice becomes a hoarse howl. The poor animal will at this period start on his tramps to attain as it were relief from agony he is in. His gait is now neither a walk nor a trot, but an indescribable jog, once seen never to be forgotten. Anything crossing his path appears to irritate him, and he will savagely snap at it; very often he will go out of the apparent straight course he has taken, wander into the ficlis and attack cattle, sheep and swine. We can say nothing in reference to the cure of a rabid dog: the best remedy is the shot gun; but as prevention is better than cure, a remely is given for warding off hydrophobia when a subjeet has been bitten by a rabid animal. All dog-hites should be treated as if they were inflicted by a rabid dog, by , mmetiate suction, followed by cauterizing or by application of nitric acid. If rabies is known to be present, suction should be followed by complete excision of the wound. The following communication in regard to what is known as the Goodman cure, was written by a leading and highly respected citiyn of Philadelphia, a prominent wholesale druggist of long standing, and a well prepared to judge whereof he writes. It is proper to state that $i_{1,4} i_{\text {. me! }}$ from a desire to save others from the terrible sufferings of hydrophobi. cons uted without the slightest compensation to our use of this valuable discovery $i$ ' is volum, he has preferred to withhold his name lest he might we:ll 'esiron anging himself rather than the remedy into publicity. He

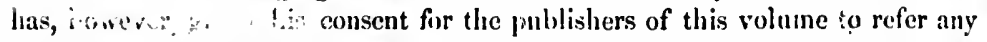
honest inquirer, atce tuil assurance of the inestimable value of this first discovered

PREVENTIVE OF HYDROPHOBIA,

directly to him, but at the same time hopes that as the remedy is simple and the material abundant and cheap (obtainable for a mere trifle of any druggist), no one will neglect to use it should occasion arise. The Goodman cure has been tested numerous times since the instances referred to and found invariably efficacious.

\section{THE GOODMAN CURE.}

"My attention was drawn to Elecampane many years since as a preventive of hydrophobia. The active medical principle of this plant is found in the ront, and is ealled inuline. From my experience, I believe this inuline neutralizes the virus or poison of hydrophobia. Allow me to give a few instances where this simple remedy has been used. My orm nephew, then a small boy, was bitten badly in the face by a dog unmistakably mad. This occurred within a fer miles of this city. The father of the lad came immediately to town to obtain medical advice. We called on an eminent physician (now deceased) who at once prescribed the plant named. The root was obtained and administered as 
mpt to paw animal will agony he is ble jog, once irritate him, the apparent ile, sheep and dog: the best medy is given ratid animal. rabicl dog, by of nitric acid. 1 by complete ard to what is ighly respected g standing, and jer to state that rings of liydroof this valuable ne lest he night publicity. He ume to refer any lue of this first

edy is simple and re trifle of any The Goodman rred to and found

as a preventive of found in the root, ine neutralizes the stances where this ill boy, was bitten arred within a few to town to obtain deccased) who at ad administered as hereinafter directed. No symptom of hydrophobia appeared, and the lad, now a hale, hearty farmer in Montgomery county, lives to show the scar of the wound in the face.

"The physicitn above referred to related to me a number of instances in which the remedy had been used, and always with success. $\mathrm{Hc}_{\mathrm{c}}$ in fuct renarked, 'I never knew it to fail when properly adninistered.' I will give but two cases.

\section{A STRIKING PROOF.}

"First: Two men living near this city were bitten in the haud by the same dog, and within fifteen minutes of each other. The dog, a stranger to them, was sceured and imprisoned to await an owner. The next day he showed unmistakable signs of madness, and finally died with hydrophobia. Alarmed for their safety, both men came to the city and waited on the physician quoted above. He preseribed Elecampane Root. One of the men remarked, "that is an old woman's remely,' and refused to take it. This man, returning to his home, placed himself under the care of his own doctor, who cauterized the wound, and administered medicine to salivate him. On the ninth day he was seized with spasms and died in agony. The other and more fortunate man took the Elcoampane as prescribed, and never suffered in the least degree from the dreaded disease.

"Second: A number of cows feeding in a pasture were all bitten by a mad dog. The circumstances coming to the knowledge of those who had heard of this Elcampane remedy, thought it a good opportunity to give it a trial. The cows were accordingly separated-to one-half the number, the root was administered (in form of decoction), and not one of the cows suffered from hydrophobia; whilst all of those not so treated took the malady and died from its effects or were shot. In quite a number of cases coming under my own observation of persons bitten by dogs supposed to be mad, I have recommended the use of the Elecampanc, and have yet to learn of the first case of hydrophobia resulting from such bite where the root was used. I think, therefore, I have good reason to have confidence in the remedy as a preventive.

"Whether, after a manifestation of the disease, it would have a good effect or any effect at all, I am unable to say. I donbt whether it would. But the antidote is so simple, and so readily oltained, that it would be almost criminal not to employ it. Having said this much, allow me to give the

\section{MODE OF USING THE REMEDY.}

"To one and a half ounces of good, sound Elecampanc Root, bruised in a mortar, add one pint of new milk, boil to half pint, strain off, and when cold, take at a dose in the morning, fasting. No food should be taken for from threc to five hours afterwards. Repeat the dose on the third morning, allowing one 
morning to intervene, and agaiu on the fifth morning. The above quantity is for an adult; for elildren given in proportionate doses, say to one of twelve years, half the quantity."

\section{FACTS MORE POTENT THAN THEORIYS.}

"A correspondent, impelled by the narration of the death from hydrophobia of John Knippel, writes that for thirty years past n farmer named Fry, residing near Allentown, Pennsylvania, has treated hydroplobia with unvarying suecess hy the following simple nethod:

"The patient is to be kept free from excitement of every sort, especially from that cansed by the visits of sympathizing friends. The medicine is to be prepared by taking one ounce of Elecampane Root, powdered; one tablespoonful of madder and one quart of new milk, and boiling them all together slowly (in a water bath if possible), until reduced to a pint. The dose is one wineglassful once a day for three days, then intormit three days, then repeat and intermit again, and again repeat. That is, nine wineglassfuls are taken in all, and there are three intermissions.

"In support of the efficacy of this treatment it is stated that thirty years ago Mr. Reed amd Daniel Mersloon were bitten at Germantown by a rabid dog, that Mr. Reed was treated by an eminent physician, and died of hydrophobia, while Mershon, under Fry's treatment, never suffred at all. A young man named Jaeoby and a daughter-in-law of John Boyer, at the colner of Mill street and Chelten avenue, under similar treatment, recovered fron the drealful disease about twenty years since, and in 1858 a policeman so far gone with hydrophobia as to have to be held in the carriage in which he was driven through Germantown to Mr. Fry's residenee, was also treated with entire success. A number of additional eases are quoted, in all of which the remerly deseribed is elaimed to have effected complete enres."

The writer of this article believes that the Elecampane will cure the disease after violent symptoms have been micnifested. I would say that I have never known a case where it was used after a full manifestation of the disease, but should most eertainly strongly urge its use, particularly so, as no physieian - has any knowledge of a cure for the awful malady. When the person is bitten by a log, mad or otherwise, great care should be taken to avoid talking about it, or doing anything calenlated to exeite the imagination.

The MIadder added in the seeond recipe is of no use whatever, and was, I imagine, put in simply to disguise the medieine, at a time when "Fry" charged an exorbitant price for his secret remedy. 


\section{GLOSSARY}

\section{OF SCIENTIFIC AND OTHER TERMS USED IN THIS BOOK.}

Abdomen-The portion of the body contrining the stomach and intestines; the belly.

Abnormal-That which is not natural or regulnr.

Abortion-The casting of the young in an unnatural manner, and before the proper time.

Abrade, Abrasion-To rub off, to wear away by contnct, as rubhing off the surface of the skin, producing galls.

$A b r u p t-Q u i c k$, sudden ; an ubrupt turn or twist in the intestine may produce strangulation of the parts.

Abscess-A swelling and its cavity containing pus or matter. A cavity containing pus.

Abscission-The cutting away or removal of a part.

Absorb-Swallowing up, drinking in.

Absorbent-In anatomy, those ressels which imbihe or suck up, at the lacteals or lymphatics. In medicine, any substance, as chalk, magnesin, etc., used to absorb acidity in the stomach.

Absorption-The taking up hy the vessels of the body of any substance either natural or unnatural, as the serum of dropsical swellings. Accelerate-Growing quicker or faster, as an accelerated pulse.

the disease have never disease, but o physician e person is void talking

, and was, I hen "Fry" Acid-Sour. The last fermentation before the putrid.

Acidulate-To make slightly sour, as with lemon, vinegar, or the mineril acids.

Accretion-Increase, or growing as an exostosis or unnatural growth of bone.

Aceni-Stony growths of the liver, resembling herries. Acrid-Sharp, pungent, biting, irritating, as the strong acids. Acute-Severe, sharp. In diseases, those which soon come to an end in contradistinction to chronic.

Adhesion-A joining together, as the union of parts in healing. Adhesive-That which adheres, as certain plusters. 
Adipose-Fatty matter ; belonging to fnt.

Aerate-1:ixing with air, as the blood in the lungs, by which it absorbs oxygen.

Affection-Discase, or disease of some particular part.

Affinity-The attraction which causes particles of bodies to adhere.

and form compounds. That which causes substances to cohere.

Albumen-Substances, animal and vegetable, resembling the white of

an egg.

Aliment-Solid or liquid substance taken as food.

Alimentary Canal-The bowels.

Alkali-Any substance which will neutralize an acid, as magnesia, soda, potash, etc.

Alterative-A medicine changing the functions and condition of the organs of the body.

Analysis-To separate into parts, resolving into the original elements. Anatomy-The art of dissecting, or separating the different parts of the body. The science of the structure of the body, as learned by dissection.

Anchylosis_The stiffening or rendering rigid a joint.

Ancesthetic-Agents which deprive of sensation and suffering, as chloriform, ether, etc.

Anodyne-A medicine to allay or diminish pain.

Anomalous-Deviating from the general character or rule.

Antacid-Opposed to or an antidote to acids.

Antagonism-Opposed in action; one contradicting another.

Anterior-Before; in front of another part.

Anthelmintic-Medicine to kill or expel worms.

Antidote-That which counteracts hurtful or noxious substances. A remedy to counteract the effects of poison.

Antiperiodic-Medicine to arrest or retard the return of a paroxysm in periodic disease.

Antiseptic-Agents for preventing, arresting or retarding putrefaction. Anus-The fundument, or lower portion of the bowel at the tail.

Aperient-Laxative Medicine; that which gently operates on the bowels. Approximate-Coming near to. An approximate cure is by inoculating for another disease.

Aqueous-Watery; having the property of water, as watery mattei, aqueous pus.

Aromatic-Strong smelling stimulants, given to dispel wind and relieve pain.

Artery-Blood vessels which carry the red blood from the beart.

Articulate-Joining, working together or upon one another, as the bones. 
vhich it ab-

s to ndhero cohere. tho white of as magnesia, dition of the nal elements. erent parts of as learned by ering, as chloHe.

ther.

ubstances. A a paroxysm in g putrefaction. t the tail. $s$ on the bowels. is by inoculawatery mattei, el wind and rethe heart. another, as the
Asphyxia-Denth from strangulation of tho lungs, from want of air. Asthenopia-Wenkness of the sight or vision.

Assimilate-To muke like another' assimilation of food in the nutrition of the body.

Astralgalus-The largest bone of the hock-joint, lying below the os calcis.

Astringent-That which causes contruction of the bowels or vital structures. Astringents are medicines which suppress discharges, is from the bowels, blood, mucus.

Attenuate-To draw out, to make thin, reduce in size.

Atrophy-Wasting of a part, as the muscles.

Augment-To increuse.

Auricle-The external purt of the car; also parts of the heart, one on ench side resembling ears.

Balk-To refuse to pull, or to refuse to go forward at command.

Base-The lower purt, us the base of the brain; the foundation.

Beneath-Under a certain part.

Biliary-Belonging to or pertaining to bile. Bilinry duct, a canal containing bile.

Boot-Buffer, a leather band, wom to prevent one foot cutting the other in traveling.

Bougie-An instrument for opening the urethra, or urinary, or other passages.

Bounded-Parts lying about another: surrounded by.

Breeding-in-and-in-Breeding to close relations, in the same subfamily, as the produce of the same sire but of different dams, or of the sume sire and dam.

Calcareous-Containing lime, lime like.

Calculus-Any hard, solid concretion found in any.part of the body, us stone in the bladder, gall stones, etc.

Calefacient-Anything producing warmth.

Callous-Induration; a hurd deposit; excess of bony matter.

Cancer-A hard, unequal, ulcerating tumor, which usually proves fatal.

Canker-Eroding ulcers of the mouth; virulent, corroding ulcers. Any sore which eats or corrodes.

Cannon-bone-The shank, or bone below the knee or hock. The metacarpal or metatissal bone of the horse.

Capillary-Hair-like; applied to the minute ramificutions of the blood vessels.

Capsicum-Cayenne pepper. The small, long red pepper.

Capsular Ligaments-Ligaments surrounding the joints.

Capsule-A membranous bag or sac. 
Carbon-Wooly matter. Chareonl is impuro earbon ; the dinmond is pure carbon. Carbonic neid is expelled from the lungs in the net of breathing. Cnrbonic oxydo in tho blood or lungs is fital to life.

Caries-Uleeration of the substance of the bones.

Carminitives-Wurming, stimulınt, aromutie medicines, used in colic and wind.

Cartilage-Gristle; the substnnee covering the ends of bones, moving and working upon each other.

Castrate-To geld, emnsculate, deprive of the iestieles.

Catarrh-A cold nttended with rumning of the nose.

Cathartic-Purgntive medieine, used for freely opening the howels.

Catheter-An instrument used for drawing the witer from the bludder and for other purposes.

Caustic-Any burning ngent, us potash, nitrate of silver. To enuterize is to burn, genemlly applied to the use of the hot iron in disenses.

Cerity-A depression, is the eavity of a wound.

Cellular tissue-The membrane or tissue which invests every tiber of the body, composed of minute cells communieating with each other, and which serve us reservoirs of fut.

Cephalic-Pertaining to the hend.

Cerebral-Pertaining to the brin.

Cervical-The neek; belonging to the neek.

Characteristic-A symptom of character. Charncterize, to r. guish.

Chemical-Relating to ehemistry.

Chirurgical-Belonging to surgical art.

Cholagogue-Medicines to increase the secretion of the bile.

Chronic-A lingering, long-standing disense, sueceeding the ncute stage. A seated, permanent disease.

Chyle-The milky liquid, as taken from the food during digestion, and prepared from the ehyme, and realy to be absorloed by the lacteal vessels before being poured forth into the blood.

Chyme-The food modified and prepared by the action of the stomach.

Cicatrice-The sear left after the healing of a wound or uleer.

Circumscribed-Limited.

Cleft-A nırk; division; furrow.

Clyster-Liquid modicine injected into the lower intestine.

Coagulate-To elot, as the blood when drawn.

Colesion-Comnected; adbering together; sticking together.

Coition-The nct of copulation; union of the sexes.

Conception-Fecundition by action of the male.

Condition-A healthy, serviceable state of the system. A firm state of the muscular tissue. 
diumond is ithe net of to lifo.

sed in colic nes, moving

io howels. the hludder To cantera disenses.

very tiber of wh other, ind

tor. guish.

iile.

ing the acute

digestion, :met by the lactent

f the stomach. ulecr.

ne.

ether.

A firm state
Colic-A griping disease of the intestines.

Collapse-A fuliing together. A closing of the vessels.

Colon-The largest of the intestines, or more properly, tho largest division of the intestinul cunnl.

Congenitnl-Born with another; of the sume birth. Belonging to the individual from birth.

Oongrstion-An ucenumlation of clogged bloot in tho vessels, or in the purts, as the limgs, brinin, ete.

Onstrict-Drawing or binding together, as constriction of the unscles of a part.

Contaginus- $-\Lambda$ disease that may be communicated by contact, or the matter communicated, or proceeding from the breath or emanations of the body.

Contorted-Twisted, twisting, writhing, as the body in pain, or from the result of disense.

Contusion-A bruise; a wound made by a blow or bruise.

Concex-lIaving a rounded surfice. The opposite of concave.

Copious-Plentifinl, abundant, as a copious discharge.

Corouet-The upper part of the hoof, just where it joins the skiu.

Oranium-The skull. Cranial: pertaining to the skull.

Orest-The back or upper part of the neck of the horse.

Crupper-The buttocks of a horse.

Orural-Pertaining to the legs, as the crural arterics and the crural veins.

Crust-The hoof, so-called. The outside lamina of the hoof.

Cul-De-Sac-A passage closecl at one end.

Cutaneous - Of the skin, as a cutureous affection.

Cyst-A small bladder or sac, applied to those containing parasites, which become encysted, or inclosed in an envelope.

Delility-The condition of weakness or feebleness.

Decoction-A fluid formed by boiling in water.

Decompose-The act of decaring. To separate into component parts.

Defenerate-To become worse or inferior.

I)eleterious-That which is injurious, poisonous or destructive.

Dclirium-Insanity; loss of the senses, or a wnndering of them in disease.

Demuleent-That which sheathes and protects irritated surfaces.

Dermal-Belonging to the skin.

Dessicate-To dry. * To make dry. Drying by heat.

Detergent-Medicines having the power of cleansing the ressels or the skin.

Develop-To increase. A disease develops its intensity. To show increasing museular form. Bringing to perfection. 66 
Diabetes-An excessive flow of urine containing sacharine matter.

Diagnosis-Tho distinguisining of ono disease from another.

Diaphoretic-Medicines which cause perspiration or sweating.

Diaphram-The midriff. The membrane, or brain muscle, which divides the thorax or chest from the abdomen or belly.

Diarrha- $\Lambda$ contimued and profuse discharge from the bowels.

Diffuse-To extend or drive out. That which may flow or spread, as a diffusible stimulant.

Digestion-The separation and dissolving of the food in the stomach.

Digestive ointment has the power of resolving tnmors.

Dilate-To open wide, as dilation of the eye.

Dislocation-Putting out of joint.

Dilatation-The expanding of a body, as of the heart, arteries, the blad. der, etc., from over-fullu'ss.

Dilute-To make thin, as a medicine with water, with oil, etc.

Diminution--To make less, to decrease, as of pain.

Distort-Deformed, erocked, out of the natural shape.

Distend-To stretch out, or sivell.

Diurctic-Medicines to increase the flow of urine.

Dorsal-Pertaining to the back. The dorsal column; the back-bone.

Drastic-Powerfully acting medicines or poisons.

Duct-A tube for sonveying a fluid or the secretions of the glands.

Duodenum--The first portion of the small intestine, and through which the bile is poured.

Dysphazia-Difficulty of swallowing.

Dyspnaa-Difficulty of breathing.

Ecliolic-Purturicnts. - Agents causing the contraction of the womb.

Effusion-A flowing out, as of the blood, water or lymph, into the tissues.

Ejecti, $n$-Casting ont, as ejecting improper matters from the stomach.

Elnslic-The property of springing or stretching.

Emliryo-The impregnated orum in the womb after growth has commenced.

Emetic-Medicines given to produco vomiting.

Emollients-Agents which have the power of softening or relaxing.

Enamel-The hard outer covering of the teetl.

Enema-Merlicines given by injection into the bowels.

Eutcric-Belonging to the bowels.

Enteritis-Inflammation of the bowels.

Epidemic-Disease tlat affects a large number, as though carried in the air.

Epiglottis-The covering of the glottis. A tongue-shaped projection, to prevent food or liguirls from entering the wind-pipe.

Ertption-Pimples, blisters, rash, etc., breaking out on the skin. 
atter.

ich divides

els.

pread, as a

he stomach.

ies, the blad-

back-bone.

he glands.

through which

the womb. into the tissnes. the stomach. owth has com. r relaxing.

In carried in the a projection, to the skin.
Esophagus-The gullet, or tube of the throat which eonveys food to the stomach.

Evacuate-To empty or pass out, as, to eracuate the bowels.

Ewe-necked-In the horse, having a neck like a shorn sheep.

Exanthema-Eruption of the skin with fever.

Excorivte-To tear or strip off the skin; to wear away or abrade; to break the skin in any manner, as in galling or with acrid sulustances.

Excrement-Refuse matter. The dung.

Excrescence-Unnatural or superfluous growth.

Excreting-Throwing out írom the body.

Excrition-Separating the fluids of the body by means of the glands.

Exhale-Breathing out, evaporating.

Exostosis-Unnatural growth or projection of the bone.

Extensor-tendon-The tendons which stretch out the limbs.

Extravasate-To let flow from the proper ressels, as in bleeding.

Extremities-Tïe limbs, so-called.

Exude-To discharge through the pores.

Facial-Pertaining to the face.

Faces-The excrement.

Furcy-A disease of the lymphatics of the skin of the horse. Also a disease allied to glanders.

Febrifuge-Medicines to lower the temperature of the body and counteract fever.

Fcculent-Foul or impure matter, formed by the breaking down of the tissues, excrementitious matter.

F'mur-The thigh bone proper.

Fermentation-Incipient decomposition of regetalle sulstances from souring.

Fibrin-An organic substance found in the blood and composing a large part of the tissues of the body. Fibrons membrane-a nem. brane composed of fibers.

Fibula-The small or splinter bone of the hind leg. The outer and lesser bone of the leg; much smaller than the tibia.

Fissure-An opening, a crack.

Fistula - A deep, narrow ulcer, haring a pipe leading to it. Fistulous. Like a pipe.

Flatulent-The generation of gas or wind in the stomach and intestines, as in flatulent colic.

Flex-To bend, as the head, neck or limb; as a muscle flexing the arm.

Flexor-A muscle whose office it is to bend a part; in opposition to exteısor.

Florid-Red or searlet like, from excess of blood in a part. 
Fomentation-The application of warmth and moisture, as with a liquid or poultice.

Forceps-Long pointed pincers or nippers.

Fracture-The breaking of a bone.

Friction-Exciting circulation by rubbing.

Fumigate-The application of smoke or vapor.

Function-The offlce or duty of any part of the body.

Fundament-The anus or extremity of the bowel. The end of the gut. Fungus-An unnatural growth resembling mushrooms.

Gangrene-The mortification or death of any part of the body, or of any of its tissnes.

Gas-An emanation, or invisible fluid, generated in the body.

Gastric-Pertaining to the stomach.

Gelatine-Animal jelly.

Gemelliparous-Producing two at a birth.

Generate-To beget offspring. Generative; employed in begetting or producing young; breeding.

Genital-Relating to reproduction of young, or to generation.

Gland-A structure for secreting certain fluids of the body, and containing a tube.

Glottis-The narrow opening at the top of the windpipe.

Granulate-Matter resembling grains, in the healing of wounds, and new flesh.

Gravid-The state of being with young.

Gullet-The cesophagus or food pipe leading to the stomach.

Haggard-Worn down; thin; ghastly; deathlike.

Homal-Relating to the blood.

Homatin-The coloring matter of the blood.

Haunch-That part of the body which lies between the last ribs and the thigh. In the horse, the bony region of the hips.

Man-The process of the eye-sockct, which is thrown over the eye to clear it of foreign substances.

Hectic-A constitutional and remitting fever exhibited in consumption; produced also by ulcers, sores, etc.

Memorrhage-A discharge of blood from the vessels containing it

IItpatic-Belonging to the liver.

Hepatized-Converted into a liver-like substance.

Hcreditary-Inbred from the parents, as discase, color, vices and other peculiarities.

Hue-Color.

Humerus-The upper arm-bone; upper bone of the fore-leg.

Hysterics-A nervous disability, confined to females, sometimes attack. ing males. 
Illeum-The lower part of the small intestine.

Incision-Cutting into, a cleau cut, cutting as in any operation performed.

Induration-A hardening, as a hard tumor.

Incisors-The frout teeth of the jaws.

Injection-Communicating disease by miasma or emauations from a diseased body.

Ingested-Food taken in.

Inject-To throw in artificially, as from a syringe.

Inoculation-Producing the same disease by virus or matter from a sore, communicated from one animal to auother.

Instinct-Sense, as applied to animals.

Interfering-The cutting of one foot or leg with the other.

Interstice-The minute spaces between the particles of a body.

Intestines-The bowels. The alimeutary canal leading from the stomach to the anus.

Invert-To turn about or upside down.

Invigorators-Streugthening medicines, or agents.

Jejunun-A part of the small intestines.

Jet-The peculiar flow of blood from the arteries, or spurting motion.

Jugular-The large vein of the neck.

Lacerate-To tear. A lacerated wound, is a torn wound.

Lachrymal-Pertaining to the tears. The lachrymal duct is the duct leading from the eye to the membrane of the nose.

Lamclla-A small plate of anything; pertaining to the anatomy of the hoof.

Languor-Weakness, faintness, debility.

Larymgitis-Inflammatiou of the larynx.

Larynx-The swell at the upper part of the wind-pipe, and extending into the throat.

Lateral-At, or to the one side.

Laxative-A mild, loosening purgative.

Lens-A portion of the eye.

Lesion-Disease of a structure; any hurt or injury.

Ligament-The bands of the joints. That which binds together. The fibrous structure of the bones.

Lobe-A division of an organ, as of the brain, lungs or liver.

Local-Confined to a certain part.

Lubricate-To moisten, as the lubrication of the joints and moving parts by their appropriate fluids.

Lymph-A transparent and nearly colorless fluid. The fluid contained in and poured out by the lymphatics.

Lymphatic-The vessels of animal bodies which contain the lymph. 
Macerate-Steeped almost to solution. Thorongh soaking of a part in water previous to dissection.

Malady-Disease or ailment.

Malar-Pertaining to the cheek bone.

Malander-An ulcerous condition on the inside of the legs.

Malformation-Badly or unnaturally shaped or former.

Malignant-Severe; long; dangerous disease.

Mediastiuum-The partition formed by the meeting of the pleura, divid-

ing the chest into two lateral parts.

Medullary-The marrow; pith; a soft substance.

Membrane-A thin animal tissue. Thin covering of the brain, bones and other organs.

Mental-Relating to the mind. The reasoning faculty.

Mesentary-The membrane which attaches the intestines to the spine.

Metastasis-The transference or removal of disease from one part to another, or such change as is succeeded by a solution.

Morbid-A state of disease; an unnatural state, as morbid humors; a failing, sinking state.

Mortification-The death of a part from gangrene.

Mucilage-A jelly-like fluid; one of the proximate elements of vegetables, abundant in slippery elm; the agent which lubricates the joints.

Mucus-The substance secreted by the mucous membranes, and effused upon the surfaces of the membranes, as the running of the nose in a cold.

Muscles-The lean or flesh; the organs producing the active movements of the body.

Narcotic-Drugs which allay pain and produce sleep.

Nauscant8-Medicines that sicken the stomach.

Nephrites - Inflammation of the kidneys.

Nerves-The fibrous system, which convey sensations to and through the body.

Nervous-Having weak nerves.

Neutralize-Destroying the force or effect of anything.

Nitrate of Silver-Lmuar caustic.

Nutritive-That which builds up; strong, healthy food.

Nutrition-The process by which the food taken is assimilated ; to repair waste and promote growth.

Obcsity-Exceeding fatness.

Oblique-Slanting.

Ocular-Relating to the eyes.

Omentum-The caul. A fold of the peritoneal membrane, covering the intestines in front, and attached to the stomach. 
Optic-Relating to e sight, as the optic nerve; relating to the laws of vision.

Organ-The natural instrument by which a process or function is car ried on.

Organic-Composed of organs. Organism. The living body.

Origin-The beginning or first existence of a thing.

$o_{i}$-The technical naine for bone.

Os Calcis-Tho tip of the back.

Osseous-Bone like.

$O_{s}$ Cheocele-Scrotal hernia. Any tumor of the hernia.

Ossification-Changing to bone. Bony formation.

Oxydation-The change formed by the action of air on any substanoe. The changing of the black or venous blood into red or arterial bloor: in tho lungs.

Pabulum-That which is proper for food.

Pachydermata-A thick-skinned animal, as a horse, ox, man, etc.

Palate-The roof of the mouth.

Panacea-A supposed universal cure. A medieine applicable to mang cases.

Pancreas-The narrow, flat gland extending across the abdomen, some times called callet or sweet-bread.

Paroxysm-In disease, a recurrence coming on after an intermission Chills and ferer are paroxysmal.

Parturition-The act of bringing forth young.

Patella-The knee pan.

Patholvgy-Pertaining to the nature and constitution of disease.

Pectoral--Pertaining to the breast, as the pectoral muscles. In medi. cinc, that which is adapted to relieve affections of the breast and lungs.

Pectin-The gelatinizing principle of certain fruits and vegetables.

Pepsin-A substance secreted in the stomach of animals. The active prineiple in rennet.

Peptic-Promoting digestion; relating to digestion.

Pericardium-The serous membrane of the heart.

Perichrondrium-The membrane covering the cartilages.

Pericranium-The membrame lining the bones of the skull.

Periosteum --The fibrous membrane investing a bone.

Peritoneum-The serous membrane lining the cavity of the abdomen.

Permcate-That which may freely invest or pass through without rup. ture or sensible displacement. Water permeates sand; light permeates glass.

Pharynx-The opening or tube at the back part of the mouth which leads to the stomach. 
Phlebotomy-The operation or act of bleeding.

Placenta-The membrane covering the young in the womb.

Plethora-A full habit of body; full of blood.

Pleura-The serous membrane lining the interior of the chest, covering the lungs, reflecting and Inbricating them into its secretions.

Plexus-Any union of vessels, nerves or fibers in the form of net work.

Prcdispose-As likely to occur; inclining to, as being predisposed to disease.

Process-Prominence; à projecting part; any protuberance, eminence or projecting bone.

Profuse-Abundant, plentiful; as a profuse discharge.

Prognosis-The art of judging by the symptoms the probable course of a disease.

Prolapsus Uteri-Falling of the womb.

Prolapsus Rccti-Falling of the rectum.

Pulmonary-Having reference to the lungs.

Pulsate-A beating or throbbing.

Pulse-The action or bcat of the arteries.

Pumices-The letting down or falling of the coffin bone on the sole.

Puncture-Any orifice made with a pointed instrument.

Pupil-The ball or apple of the eye through which the rays of light pass to the chrystaline humors.

Purgative-Any medicine having the power of operating strongly on the bowels.

Pus-The matter flowing from a tumor when lanced, or from sores.

Healthy pus is yellowish white in color and secreted in the process of healing.

Putrefaction-The act of decomposition; corruption; rotten.

I'ylorus-The lower and right orifice of the stomach through which the food passes to the intestines.

Quiescent-At rest. Showing no pain. Making no sound.

Quack-A pretender in medicine. A charlatan.

Qualmish-Sickness at the stomach; nauses.

Quittor-An ulcerous formation inside the foot of the nature of a flstula.

Rabies-Madness; affected with hydrophobia.

Rachitis-Inflammation of the spine; rickets. This is a corruption of rachitis.

Ramify-Branched; running in various directions.

Rancid-A rank, strong smell. Incipient putrefaction.

Raphe-A seam or suture.

Reccptacle-That which roceives or contains another.

Rectum-The last intestine. The anal gut.

Refrigerant-Medicines or lotions to diminish heat. 
Regurgitate-The act of throwing or pouring back, as wind.

Relax-To abate; become more mild, or less rigorous.

Remittent-Ceasing for a time, as a fever or a pain.

Reproduction-Producing again ; breeding.

Respiration-The act of breathing.

Retention-Stopping, holding, as retention of the urine.

Retina-The part of the eye in which the image is produced in the act of seeing, or vision.

Rickets-A diseased state of the bones.

Repulsion-In physics, that power by which particles or bodies are made to recede from each other.

Reunion-The union of parts separated by a wound or accident.

Sacral-Belonging to the os sacrum.

Saline-That which is salt, or containing salt in solution.

Saliva-The secretion of the salivary glands, which moistens the food in chewing ; also keeps the mouth and tongue moist. Salivation. The act of producing an increased flow of saliva.

Sanguinification-The process of producing blood from chyle.

Sanitary-Relating to the preservation of health.

Saphena-Major and minor-veins of the hind leg.

Scaphoid-Shaped liked a boat, as the navicular bone.

Sclerotic-The thick, hard, white outer coat of the eye.

Seiatica-A rhenmatic affection of the hip.

Sear-To burn with a hot iron; actual cautery.

Seeretion-The separation of various substances from the blood.

Sedative-Agents to depress nervous power, or lower circulation.

Sensorium-The seat of sensation. An organ which receives an impression. Sensitive, having feeling. Seusitive lamella, the lamella of the coffin bone.

Septic--Promoting putrefaction. The poison of dead bodies, in contradistinction to that of living ones called virus.

Serum-The yellowish watery portion of the blood remaining after coagulation.

Shank-The bone of the leg from the knee to the ankle.

Sialogogue-Medicine to promote the flow of saliva.

Sinus-An orifice or canal containing poison matter.

Slink-The act of aborting; producing young before the natural time.

Slough-(pronounced sluff.) To fall away, separate from in disease, as in or in mortified parts.

Socket-The depression or process in which an organ works on another. Soporific-Medicine to induce sleep.

Spasmodic-Spasnus, as cramping, fits, etc. Colic pains recurring at intervals. 
Spinal-Relating to the back-bone or spine.

Splint-An excrescence in the shank-bone. Splint-bone, one of the bones of the leg.

Spontaneous-A growth occurring without apparent causo.

Sporalie-Separated, scattered; occurring here and there, as sporadie causes of disease.

Sternum. -The breast-bone.

Stimulants-Agents to temporarily excite the nervous or circulatory system.

Stomachics-Agents to promoto digestion.

Strangulated-Chocked; stoppage of the circulation in any part.

Strangury-Stopping of a passage.

Stricture-Stoppage or obstruction of a passage of the body, by morbid or spasmodic action.

Stupor-A dull, sleepy, stupid sonsation. Loss of sensation.

Styptic-An astringent having the property of restraining or stopping bleeding.

Sudorifie-That which will cause perspiration or sweating.

Suppuration-The process of forming pus or matter; the result of inflam. mation.

Suture-A stiteh or fastening on joining together.

Symmetry-Well proportioned, handsomely and stoutly formed.

Synovia-A fluid resembling the white of an egg, secreted at the joirts and articulations, for the purpose of lnbricating them. Joint-oil, so called.

Tegument-A covering. The skin. Integument, a membrane or skin, which invests a particular part.

Tendon-The dense, fibrous structure in which a muscle ends, and by which it is joined to a bone.

Tent-A pledget or plug introduced into a wound.

Tenuity-The property of being thin, as rarified air.

Tergal-Belonging to the back. Tergum, the back.

Testicle-The seed. The gland containing the seminal fluid.

Therapentie-That part of medicine which relates to the discovery and application of remedies for diseases. The nse of diet and medicines.

Thorax-The chest, or that part of the body between the neck aud abdomen.

Tibia-The large bone of the hind leg.

Tonic-Agents which gradually and permanently improve the system.

Tonsil-An oblong gland situated on each side of the fauces, terminated by the larynx and pharynx, at the rear of the mouth and having excretory ducts opening into the mouth. 
Torsion-Twisting. The aet of turning or twisting, as in drawing a tooth with the turnkey.

Trachea-The windpipe.

Tractile-That which may be drawn out.

Tread-Tramping upon, as the tread of one loof upon the other. The part of the hoof resting on the gromud.

Tuber-A rounded projection of a bone.

Tubercle-A small tumor, as tubercles in the lungs.

Tumor-A swelling or enlargement, generally applied to those which are permanent.

Vlcer-A running sore.

Ulna-The larger of the two bones of the arm.

Ulterior-Beyond a time or division. A last result.

Uniciform-Curved or crooked, as a clam or the finger nail.

Ureter-The tube or canal conveying the urine from the kidneys to the bladder.

Urinary-Pertaining to the urine.

Uterus-The womb.

Vascular-Pertaining to the vessels of animal and vegetable bodics, as the vascular functions. The arteries, veins, lacteals, and the like, compose the vaseular system. Animal flesh is vascular. Highly organized.

Venescetion-Letting blood by opening a vein.

Venous-Pertaining to the veins, or contained in the vein.

Ventral-Pertaining to the abdomen or belly.

Vermifuge-Medicines or agents to kill or expel worms.

Vertebra-A division or separate bone of the spinal column.

Vertex-The top of the head.

Vesicle -A small blister. Any membranons eavity.

Villi-Fine, small fibres. Villous, abounding with minnte fibres, as the inner mucous membrane of the stomach and intestines, called the villous coat, from its abounding with villi or minute hairs.

Virulent-A dangerous disease; poisonous.

Virus-Contagious or infections matter.

Viscera-The organs contained in any cavity of the body, particularly of the head, thorax and abdomen.

Viscid-Any glney, sticky or tenacions substance not easily separable.

Vision-The act of secing.

Vital-Having or containing life. Neccssary to life.

Vivify-To bring to a vital state.

Fulnerary-Plants, lotions, ointments, drugs or other substances useful in the healing of wounds.

Wale-To move slowly on the feet, as in walking. 
Wane-To decrease, as in a fever.

Warbles-Small, hard tumors on the back of a horse, from irritation of the saddle. The tumor occasloned by the depositing of the eggs of the gad tly in the backs of horses and cattle.

Warts-Spongy excrescences on various parts of the body.

Whining-To utter the call of the horse. To neigh.

Withers-The high process of the vertebra between the back and neck.

$X$ erodes-Any tumor attended with dryness.

Xeromyrum-A dry ointment.

Xerotes-A dry habit of body, a dry disposition.

Xiphoid-Sword-like. A small cartilage at the bottom of the breast. bone.

Xyster-A surgeon's instrument for scraping bones.

Yeasty-Frothy, foamy, spumy ; as yeasty pus or matter.

Young-The offspring of animals.

Zarnich-A name applied to the native sulphurett of arsenic, sandarach, or realgar, aud orpiment.

Zein-The gluten of maize.

Zig-zag-Having very short turns.

Zoology-That part of natural history which treats of the structure, habits, classification and habitations of animals.

Zoonomy-The science which treats of the phenomena of animal life, their causes and relations.

Zygomatic-Pertaining to the bone of the head, called also os yagale or cheek-bone, or to the bony arch under which the temporal muscle passes. 


\section{Glossary of Terms Used by Poultry Fanciers.}

tation of eggs of

und neck.

co breast.

sandarach,

structure, animal life, os yagale or bral muscle

Bearl.-A bunch of feathers under the throat of some breeds, as Houd:uls or Polish.

Breed.-Any variety of fowl presenting distinct characteristics.

Brood.-Fumily of young chickens.

Broody.-Desiring to set.

Carriage.-The attitude or bearing of a bird.

Carunculated.-Covered with fleshy protuberances, as on the neck of a turkey-cock.

Chick.-A newly-hutched fowl, until a few weeks old.

Chicken.-Applied to indefinite ages until twelve months old.

Clutch.-Given to the batch of eggs under a setting hen, also to brood of chickens hatched therefrom.

Cockerel.-A young cock.

Comb.-The red protuberance on top of the fowl's head.

Condition.-The state of the fowl as regards health, benuty of plumage -the lutter especiully.

Crest.-A tuft of fenthers on the head; the top-knot.

Crop.-The receptacle for food before digestion.

Cushion.-The mass of feathers over the tail and end of the hen's back, eovering the tail ; chiefly developed in Cochins.

Deaf-ears. - Folds of skin hanging from the true ears, varying in color, being blue, white, cream-colored, or red.

Dubbing.-Cutting off the comb, wattles, \&c., leaving tise head smooth. Ear-lobes.-Stme as deaf-ears.

Face.-The bare skin around the eye.

Flights.-The primary wing feathers, used in flying, but unsecn wheu it rest.

Fluffs.-Coft, downy feathers about the thighs.

Furnished.-Assumed full character. When a cockerel obtains his t:ili, comb, \&e.

Gills. - A term applied to the wattles, sometimes more indefinitely to the whole region of the throat.

Hackles. - The peculiar narrow feathers on the fowl's neck.

Ilen-feathered, or Henny. - Resembling a hen, in the absence of sickles.

Hock.-The elbow-joint of the leg.

Feel.-A word sometimes used to denote the breast-bone.

Leg. - The scaly part, or shank.

Leg-feathers._-The feathers on the outside of the shank.

Mossy.-Confused in marking. 
Pea-comb.-A triple comb.

P'enciling.-Snull stripes over a feather.

Poult.-A young turkey.

Primaries.-The flight-feathers of the wings, hidden when the wing is closed.

Pullet.-A young hen.

Rvoster.- The common term for the male bird.

Saddle.-The posterior of the buck, reaching to the tail in a cock, answering to the cushion in $n$ hen.

Secondaries.-The wing quill-feathers, which show when the bird is at rest.

Self-color.-A uniform tint over the feathers.

Shaft. - The stem of a feather.

Shank.-The scaly part of the leg.

Sickles. - The top curved feathers of a coek's tail.

Spangling.-The marking produeed by eneh fenther having one large spot of some eolor different to the ground.

Spur.-The sharp weapon on the heel of a coek.

Stag.-Another term for a young cock.

Strain.-A race of fowls, having acquired an individunl eharacter of its own, by being bred for years by one breeder or his successors.

Symmetry.-Perfection of proportion.

Tuil-coverts.-The soft, glossv, curved feathers nt the sides of the bottom of the tail.

Tail-feathers.-Applied to the straight, stiff feathers of the tail only.

Thighs.-The joint above the shanks.

Top-knot.-Dame as crest.

Trio.-A cock and two hens.

Under-color.-The color of the plumage as seen when the surfince is lifted.

Vulture-hock.-Stiff projecting feathers at the look-joint.

Wattles. - The red depending structures at each side of the base of the beak.

Web.-Expressing a flat and thin strueture. The web of a feather is the flat or plume portion; the web of the foot, the flat skin between the toes; of the wing, the triangular skin, seen when $11, n$ is extended.

Wing-bar.-Any line of dark color across 1

Wing-bow. - The upper or shoulder part of

wing.

Wing-butts.-The corners or ends of the wing. Game faneiers denote the uppor ends as shoulder-butts ; the lower as lower-l itts.

Wing voyguts. The broad feathers covering the ruots of the secundary quills. 


\section{INDEX.}

\section{THE HORSE AND HIS DISEASES.}

INAOS. Abxlallad, Ballfounder blond, recobd. . 2: Abusing it fuitlıful servant........ 145 Aluse of the hoofs............... 14s Alortion in inaros............... 16.1 Ablominal ('nvity, wounds penctratiug 476 Abortlou, callses of ............. 10.5 " preventives of.......... 19.5

" to provent.............. 105 Alsorbents, Inllammation of . . ...... 390 " " of and recipu.4. 397 Alseess within the brain...... 413, 41 is Acpulred qua! !ities transmitted...... 21s Acute infirmmation of fect......... 4. s A cute lritation of the skin ........49! " " " " " recipe....441 Action, styles of ............. 79 Age of horse................. 4 i $\Delta$ ge of the mule.............., 51 $\Lambda$ ge for breeding horses........... 96 $\Lambda$ ge to train a colt..............113 Albany Pony. ................ 2:7 Alteratives. ................. 5m $\Lambda$ le for tiled liorses............. 139 America, introduction of the horse.. 35 Americul semi-wild horse.......... 5i American vs. Euglislı foals... ...... 111 American wilal loorse.............. 74 " thorolighliped horse....... 85 Anerican trotting liorse, (levelopment. 24i Ambling..................... 124 Antiquity of the horse. .......... 33 Mntiouity of cattle............... 34 Anzsthoties .................. 501 Antisepties .................. 50.2 Anus, soreness of . . . . . . . . . . 35.) Aneient Greek horse .............. 1s8 Anejent Britislı horse............... 199 $\Lambda \mathrm{n}$ infallible rule.............. 30.2 Anodynes ..................5 506 Apparatus, to keep........... 515, 516 Apoplexy ................ 410, 413
PAGE.

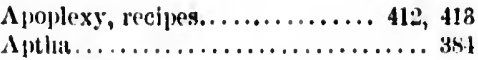

“ reelpes................. 381

Ariel, pedigree................. ving

Artilicial care in trotting . . . . . . . . . 499

A nerverl loorse.................. 17s

Alub horse, first imported into Eug-

limel ..................... 200

Alibibian lorse.................. 63

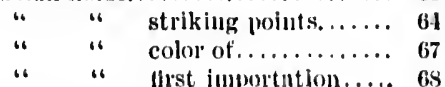

Arteries, enlargement of . . . . . . . 39.2

Astringents................. 40:

13:udlaging the limbs............. 241

Barbaritles fractisad............ 146

13akl usige vs. good usiage...... 147, 145

Bitking and bueking. ............ 169

Balking..................... 179

Bald heals, explunation of.......... 184

Bick teeth of horse ............ 48

Batek furlowing............... 1:13

bitrhary horse $\ldots \ldots \ldots \ldots \ldots \ldots \ldots \ldots$, 1

Borlfom, pedigree............... 207

Bualforil's get $\ldots \ldots \ldots \ldots \ldots \ldots \ldots \ldots . \ldots 17$

[3:.]ltoumler und trotting stock...... 2ts

Bellows ...................... 36

" recipes................. 389)

Butsy Jiaker.................. 247

Bit, the medium of communisation. . 24:

Bits and leins, what tlıey are for..... 242

lbig Ilead and Bigjaw. . . . . . . 455,437

Bites ........................ t!)

Black Maria, pedigree............ 2019

Blanketing . ................. 14,

6 when nees ssary........ 140

blindness................... 170

Blind horse, movement of ......... 171

13loml loorses.................. 151

13leteding from the nose.......... 342

1057 
Blind teeth... $\ldots \ldots \ldots \ldots \ldots \ldots \ldots, \quad 379$

Jlind staggers . ............406, 410

Bladuler, sauml-like deposits in...... 372 .. inflummation of.......... 374 " " " recipes.... 374 " rupture of.............. 375

Blood spavin...................416

Jleeding . . ..............487, 488

l3lack pigment, tumors...........490

Bog spatvin ................416, 417

" recipes............... 437

Bone spavin $\ldots \ldots \ldots \ldots \ldots \ldots \ldots \ldots 439,411$

" recipes...........440,441

Bones of the feet............... 44

Boston, pedigree............... 209

Boston Blue................. 247

IBox stalls. . . ................ 131

Hots, recijes................. $3 \overline{51}$

Bishoped teeth................. i70

Biting .................... 179

Bitting, hatness............ 113, 114

" bridle............. 113, 114

Bots .................. 349, 350

Bot flies................. 350, 351

Bolting ................... 179

Botly and limbs of horse, explanation of $\ldots \ldots \ldots \ldots \ldots \ldots \ldots \ldots \ldots 184,157$

Body of the horse in front.......... 270

Bone spavin................. 169

Breedine up, low to........... 156

lbrenking down.............. 778

Broken wind............ 178, 337, 496

" " thick wind........... 178

Bronchitis.................. 321

" causes .... ......... 321

" how to know it.......... 32:2

" what to (lo......... 322, 324

“ recipes............ 322,323

Breeding, Importance of........... 94

" draft horses........... 101

، ill-ind-in .......... 98, 102

Breeding of mules............... 108

13 lain, nbscess within . . . . . . 413, 415

13rook water.................. 137

13ıusl, the................... 141

Brnshes...................... 143

" Brusl!ing" for speed............. 24t

Brushing or speedy cut........4469,470

Broken knees........... 178, 70, 471

Broken lock.................. 478

Buying cheay horses............. 173

Buying for blood............... 198

Burns .......................487
PAGE.

Cittle, antiquity of $\ldots \ldots \ldots \ldots \ldots \ldots$ 34

Comadiatn lıorse ............... 88

Crunium, inportance of.......... 4

Calmuck horse................. 53

Care necessary in training.........

Carringe of the body in ritling ....... 19.

C'unter...................... 1:5

Currying the reins in plowing ...... 1:7

Carriage floor.................. 131

Cayuga Chief, early racesi.......... 248

Care in preparing the ford......... 240

Care of the feet............... 14:

Cirre of the frog................ 143

Careful man's theory, the......... 1.jl

Ciuses of abortion............... lis

Cataract. . ................. 179, 4:9 recipes $\ldots . \ldots \ldots \ldots \ldots \ldots \ldots . . \ldots 4: 9$

Caries of the lower jaw .......448,450

" " " " recipes.....449

Canker...................4 459, 460

" recipes..................4 460

Cartilages ossified..............466

Cupped elbow.................4 471

Cancer, epithelial...............490

Catharties.................... 50.2

Carminative ................... 508

Catustics ..................... 504

Cistration, time for............. 466 " low performed ........4 457

Chinese horses............... 53

Characteristics of Camadian horse.... is

Clanging the leading food.......... 1:5

Choice of blood. . ................ 295

Clıoice of stitllion . ............. 225

Chopled feed................. 139

Cheap structures available......... 1:33

Chest founder. . . . . . . . . . . . 320, 3:1

recipes............... 3."

Chronic cough ................ 334

"6 recipes............ 335

Clironic gastritis ........... 35:, 350

" 4 recipes........ 355, 3i6

Choking .................474, tio

Cistus culculi................ vis

Cleveland bay horse............. 61

Clyclesdale horse............. 79 :

Clyclesdale stud book............. \$3

Clydesdale horse............... 6:

Cleaning the stable............ 139

Cleaning the horse............... 1t!

Cleaning horses..................142

Cleveland Bay.............. 162, 163 " "s improvement in..... 163 
PAGE.

Colts' teeth.................48, 49 milk toeth.............. 49

Colors of Alubinn horge........... 68

Colts, how to ruise............... 105

Colts' staurveling . . . . . . . . . . . 106

" stabling................. 106

" feeding................... 106

" handling ................. 106

Colt, educuting the.............112

" at weaning time............ 112

" first lesson................. 112

" haltering a wild ............ 112

"6 training a................ 113

"6 age to tritin............... 113

" training to :rork............ 113

"6 how to handle............... 114

" learning to back............. 114

"b handling a vicious............ 116

Colts, saddling and barnessing....... 118

" winter feed of ............. 135

Color in horses ................. 174

Colds, what to do ........... 330, 331

" recipes.................. 331

Colic, spasmodic........... 345, 346 " " reclpes ...... 348,349

" flutulent.................. 348

" " recipes ...... 348,349

Colon, inflammation and rupture of 351-353

Comfortable shelter economical...... 130

Comparison of speed, English and

Amuricun horses.......... 213, 214

Confornation of brood mure....... 221

Conuestoga horse.............. 90

Control of stillion necesstury....... 129

Construction of stables........... 130

Corns......................... 178

Congh ..................... 179

Combs ..................... 143

Conformation in perfect und imperfect

horses................. 184, 185

Cow locked inorse................ 193

Cunsumption................ 320

“ how to know it....... 327

"what to do....... 327, 328

" how to prevent........ 32s

" reclpe............... $3 \approx 7$

Constitutionnl lymphangitis......... 390

Corns..................454, 456

reclies $\ldots \ldots \ldots \ldots \ldots \ldots \ldots \ldots .455$

Contraction of the hoof... ........456 rectpes............... 475

Contused wounds..............470

Counter irritunts.............. 603 67
Cruel care................... 152

Crib-biter's, wear of teeth in........ 51

Crib biting ................... 169

Crib biting $\ldots \ldots \ldots \ldots \ldots \ldots \ldots \ldots \ldots 179$

Crrucked heels.................. 202

" "6 how to know........... 263

" "6 whint to do........... 263

Crib biting................... 380

Cripple, pedigree............... 205

Crimp.......................422

" recipes.................4 422

Cracked hoofs.............445, 45t

" " recipes $\ldots \ldots \ldots \ldots \ldots \ldots 454$

Cut feet....................... 138

Curry comb............... 141, 143

Cunning servants............... 154

Curb...................... 173

Curbs ....................... 182

Curb ..................... 417 recipes for............417, 418

Decay of the teeth, causes of....... 279 " " " how to know it... 279

Defects to be avoided......... 223, 224

Demulcents.................. $\mathbf{7 0 4}$

Deodorizers................... 505 recipes.............. 505

Dentition or teething ........... 378 what to do ........... 378

Deceptions practised in teeth of lorse. 51 Descendants of the Darley A rabian. . 70 Descent of Norman Percheron horse. 76 Dervish.................... 98

Dexter............... 67, 238, 252

Definition of unsoundness or vice.... 183

Degelfe horse.................. 63

Dicky Pier'son, pedigree........... 203

Difticulty of breeding........... 337

Dinphragm, spasm of.......... 857

recipes.............. 357 " reclpes............... 363,364

Diabetes or profuse staling ......... 369 $\begin{array}{llll}\text { " } & \text { " } & \text { "auses...... } 869 \\ \text { " } & \text { " } & \text { " how toknow } 360 \\ \text { " whit to do.. } 369 \\ & \text { " } & \text { " } & \text { recipes...... } 369\end{array}$

Dimness of vision. ............. 430

Diaphrugmatle rupture..........474

Diomed, pedigree.............. 200

Diomed's get................ 200

Dlslocutions.................. 470

Distortions .................470 
PAGE.

Diseases of the ear. 480,481

Division of the tendons. ........... 489

Diaphoretics.................. 504

Diuretics. . . . . . . . . . . . . . . . . . . 504

Disinfectants. . . . . . . . . . . . . 505

Dissections. . ................. 500

Dish hoofs.................... 76

Diseases of the skin and sub-cutaneous tissues............. 259, 294

Distemper...................... 308

" low to know it.......... 309

" what to do ............ 309

"recipes............. 309, 310

Dorimant, pedigree............. 206

Doses, graduating........... 513, 514

Dongola lorse.................. 73

Druft liorse of Vermont .......... 8s

Driving on the road............ 242

Driving. .....................241

evils of hard pulling......... 241

Driving horses................ 79

" "colors of........... 70

Description of the ancient Greek horse.................. 188, 190

Dropsy of the lings.............4400

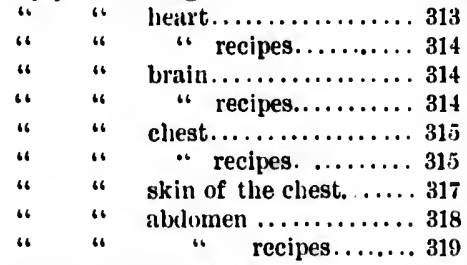

Dutchman, early races............ 047

Durac and trotting blood.......... 248

Early importation of thoroughbreds. . 85 Eally maturity of horses of to-day... 214 Eurly rucing hurses in Tennessee..... 207 Eally lacing stock in Kentucky ..... 207 Farly trainiug useful........... 2:9 Eur, diseases of. . ............480, 481 Eclipse, pedigree................. 208 Eclipse ....................... 60 Economy of shelter.............. 130 Ellueatiug the colt.............. 112 Egyptiun Iorse................ 73

Ellwil Fortest, carly races......... 247 Elhow, cilpped............ 471, 472 Emeties....................... 604 Enlarged glands ........... 331, 392 Enlargement of tise spleen..... 860, 367
Enlargement of the heart.......... 391 " " " $"$ urteries....... 392 " " " hock......441, 442 English roadster............... 60 .6 thoroughbred loorse......... 68 " native stullions in 1730. . 202, 203 English vs. American views on speed. 210 " " " race-courses... 214 Epiglottis, spasmodic actions of..... 340 Epithelial cancer. .............490 Establishing intelligent action....... 243 Ethan Allen ................. 158 Ethan Allen, 1852, record in 1856.... 248 Eıropean lorse.................. 54 Exostosis of the lower jaw.........492 " " " "6 " recipes... 492 Expectorants................. 506 Explanation of good heads..... 181, 184 " " bad " $\ldots \ldots$ 181, 184 horse. ........... 184, 185, 186, 187 Exterual inanifestations of diseaseexplumntion of ............. 250 Extraordiuary performances of horses. 211 Eye, worms of . ............... 430 " fungoid tumors of .......431, 432

Fanny Jenks, early races........... 248

Fanny Murray, 100 mile trot........ 248

Furm training track.............. 128

Farm stable. ................ 133

Farmer Uuthrift's barn.......... 150

" " lione......... 150

Family lıorses.................. 158

Fatty degeneratioil of the henrt. 301,392 Faise quarter.................461 Falling off of hair.............4491

Furn liorses, proper stuture........ 57

Fishion, pedigree................ 210

Fist walking horses.............. 175

Fircy ausl glauders............. 178

Farcy ..................... 302

" catuses $\ldots \ldots \ldots \ldots \ldots \ldots \ldots \ldots \ldots . \ldots 30 \ldots$

" how to know it. ........... 304 ,

"6 whit to do ............... 305

" recipes $\ldots \ldots \ldots \ldots \ldots \ldots \ldots \ldots \ldots, 306$

Fearnaught, pedigree............ 208

Feeding in truluing. ............ 289

Feeding colts................. 106

Feed bius . .................... 131

Feeding.................... 135, 239

roots $\ldots \ldots \ldots \ldots \ldots \ldots \ldots \ldots, 136$

Feed of slow work horses....... 130 
Feed of fast work horses .......... 130

Feeding grain..................... 141

Feet, care of..................... 142

Fever....................... 389, 390

Finely bred roadster.............. 160

First public trot in America......... 247

Fistula of the pa.otid duet...... 385, 387

Fistula......................... 291

" causes.................... 291

" how to know it........ 292, 293

" what to do................ 293

"6 recipes...................... 293

Flexibility ...................... 180

Flexing the horse................. 115

" " jaw................... 115

Flatulent colic.................. 348

"6 "6 recipes................ 349

Fly, Canadian mare............... 248

Flora Temple, in 1853............. 248

Florizel, pedigree................ 206

Foals, American vs. English........ 111

Foul sheath.................... 375

Food, kinds and quantities of ....... 138

Foreign stullions in England in 1730. 202

Founder........................ 45j

6 recipes.................. 458

Foot lameness................... 172

Founder....................... 178

Form and symmetry............. 180

Fore-quarters, showing bad conform-

ations...................... 190

Fresh food, important............. 139

Frog, care of .................... 143

Fungoid tumors of eye......... 431, 432

Frog, injuries to $\ldots \ldots \ldots \ldots \ldots \ldots 456,457$

Frost bite................. 472, 473

"6 "recipes................ 473

Fractures....................... 479

French horses. ..................... 54

Fridi horses....................... 64

Fungus collar tumor.............. 280

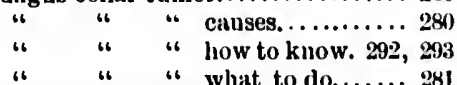

Functional disenses of the liver...... 360

Gabriel, pedigree................. 200

Gabriel's get..................... 207

Galloping ........................ 125

Gastritis, chronic............ 355, 356

"، " recipes...... 355, 356

General Butler.................. 238

Gencrous horses vs. laggards........ 230
Getting correct information.

General utility h

Gestation, treatment of during...... 103

Giving the horse a mouth.......... 242 Glancer....................... 70, 80

Gliss eje ..................... 170

Glanders, cnuses............ 295, 298

" how to know......... 298-298

" what to do............ 300-302

Gold dust.................. 100, 101

Goldsmith Maid, memoir of........ 249

" " in $1863 . \ldots \ldots \ldots . . .249$

" " in $1870 \ldots . . . . . . . . .851$

Good roads favor driving ............ 242

Good slselter, value of............. 148

Good farmer's surroundings......... 149

Good care described .............. 151

Good head, explanation of ....... 181, 184

Gorged stomach.................. 358

recipes............. 358

Graduating doses............. 513, 514

Gravel.......................... 372

Granary ...................... 124

Grent Britain, borses introduced into, 199

Grooming ...................... 135

Gruel, how to make............. 139

Grain should be elean.............. 141

Grease and mange................. 178

Grease, causes..................... 202

" how to know it......... 263, 264

" what to do................ 262

" recipes for................. 204

Guttacarina.................... 433 recipes $\ldots \ldots \ldots \ldots \ldots \ldots 432$

Haw or hooks............. 429, 430 " recipes ............... 430

Hair, falling off of the............ 491 " " " " " recipes...... 491

Hard pullers caused by defect in train.

ing $\ldots \ldots \ldots \ldots \ldots \ldots \ldots \ldots . . .241$

Hardening of the skin............ 492

" "6 " recipes........ 492

IIambletonian, pedigree............ 249

" description of....... 249

Hamstring, rupture of . . . . . . . . 496

Ifandling colts $\ldots \ldots \ldots \ldots \ldots \ldots \ldots, 106$

Ilaltering a wild coit . . . . . . . . . 112

Inuruess, bitting ............. 104, 114

IImrness, training to $\ldots \ldots \ldots \ldots \ldots \ldots .115$

Handling a vicious colt........... 118

Trarnessing and saddling colts....... 118

Innrness, horse .................. 123 
PAGE.

Hand gallop..................... 125

Hitutboy mare ................... 2018

Hay, quantity to feed............. 139

“ and stratw, value of........... 140

Heaves...................... 337, 338

" reclpes.................... 338

IIeart, enlargement of............. 391

" fatty degeneration of..... 391, 392

Herod, pedigree................... 206

Hernia...................... 473, 474

" of the mesentery......... 473, 474

" ventral.................... 474

" omentum .................... 472

Hemotrluage, internal............. 497

Head, bad form... .............. 181

" side view of, good........... 191

" front view of, good............ 181

" sille vlew of, bad.............. 181

" front view of, bad............ 181

Helmsley Turk................... 201

Hide bound $. . \ldots \ldots \ldots \ldots \ldots \ldots \ldots, 276$

" " causes ................. 2ז6

" " how to know it......... 277

" " what to do............. 278

" " recipes.................... 278

High bred roadsters............... 156

" " hunting horse............ 167

High blowing............... 421, 423

" "recipes...............423

Hip sweeny $. . . \ldots \ldots \ldots \ldots \ldots \ldots, 366$

Hitting with the blood............. 225

Hirum Woodruff on driving..... 240, 243

Holding the reins................. 24t

Horse clothing. ................ 239

Horses int.roduced into Great Britain. 199

Horses first kept for racing ........ 200

Horse in King Alfred's time........ 199

" "Atheistan's time..... 200

Horse in William the Conqueror's

time........................ 200

Horse, cleaning the............. 141

" clotlis...................... 141

Horses, cleaning of ............... 142

Horse pails...................... 143

Horse, ftst walking .............. 175

" what he should be........... 177

" slıoulder.................... 177

" upper arm..... .......... 177

" the knee................... 177

" the shank ................... 177

" the camnon bone............. 177

" the pastern joints .......... 177
PAGE.

IIorse, hoofs................... 177

" the hackney................. $5 \theta$

“ Turkomin.............. 63, 72

“ Culmuck .................. 72

“ Turtury .............. 53, 73

" Turkestan.............. 50, 54

" Europe.................... 5t

" Iceland .................... 54

" Italy..................... 5t

" France.................... 5t

" Normandy................ 54

" Normun Percheron........... 54

" Spanish Barb............... 55

" semi-wild, of America........ 55

" the good farm horse......... 55

" the English roadster......... 60

" the heavy draft............., 61

" the Clevelind Bay........... 61

" the Suffolk Punch........... 62

" the Vermont draft........... 62

" the Arabian................. 63

" the Dgelfe................. 63

" the Secaloni................ 63

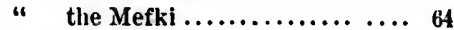

" the Sibi................... of

" the Fridi ................... 64

" the Nejdl.................. 64

IIorses of slow work, feed......... 130

" " fast " " "........... 136

Hours of feeding $. . \ldots \ldots \ldots \ldots \ldots \ldots, 137$

Hoofs, abuse of .................. 148

How to breed up................. 158

Iorses for great speed .............. 168

Horse, view from behind........... 195

" hind quarters bad........... 196

" what not to buy............. 197

“ perfect, not plenty........... 197

Hock, enlargement of......... 441, 442

Horse, antiquity of .............. 33

" brouglit to America......... 35

" where found................ 35

" preserved in his purity....... 35

" framework of............... 37

" suminary of parts............ 41

" general expianatory terms.... 43

"“ head, explanatlon of......... 43

“ foot and lower leg, expiana-

tory terms................ 45

“ external parts, explanation of. 46

" age of..................... 47

" incisors furnish indleation.... 47

" bick teetli of................ 48

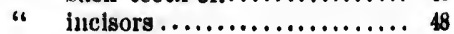


Horse, incisors, how composed....... 48 teeth, wear of............ 48

“. " the mark............. 49

"6 number of teeti........... 49

" wolf teeth................ 49

"when teeth are perfect or ma-

ture................. 50 deceptions practised in teeth.. 51 teeth, vocabulary of........ 52 Chinese ................. 53

Indian.................. 53

Japan................. 53

Siam................. 53

Persian..............53, 72

age for breeding horses...... 90

principles of transmission.... 97

relative size of sexes........ 97

selection, value of......... 97

in-and-in breeding.......... 98

cross lureeding.............. 98

Dervish .................. 98

Marshluand Shales.......... 98

Gold dust............. 100, 101

body and limbs, explanition

of ................ 184, 187

front view of $\ldots \ldots \ldots \ldots \ldots \ldots 188$

front of $\ldots \ldots \ldots \ldots \ldots \ldots \ldots .188$

- of Ancicnt Greeks........... 188

fore-quarters, showing bad

conformations ........... 100

hind-quarters, showing bad

conformations........... 190

illus rutions of fore-quarters. . 191

good inind-quarters......... 192

to examine ............... 103

cow hocked................ 193

IIorses, draft, breeding........... 101

How to raise colts. ............... 105

IIow to handle a colt .............. I14

IIorse, flexing ................. 115

"6 to handle................ 116

"vlcions, to subdne....... 119, 1:0

"w working................. 121

" brenking to work .......... 112

" training to trot............ 122

" the quarters.............. 177

" "

" " hocks................. 177

" "b biek ................ 177

" " withers $\ldots \ldots \ldots \ldots \ldots \ldots \ldots .177$

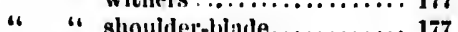

" " croul................ 177

"6 " barrel ............... 177
IIorse, the chest. . .............. 177

"6 " neck.................. 177

" " physical structure of..... 177

Iloofs, cracked ............ 453, 454

" " recipes..............454

" $\operatorname{rot} \ldots \ldots \ldots \ldots \ldots \ldots \ldots \ldots \ldots . \ldots 45$

" contraction of ..............458

Iunting Park Assuciation of Phila-

delphis................... 247

Ifunting horses................ 57

Hunting horse, high bred.......... 167

IIydrophobia. ..............399, 408

Iceland horses................ 54

Importation of Edward III. . . . . . 200

" "Henry VII......... 200

" "Henry VIII......... 200

" "Arabian horse, Eng.

latid ............, 68

Importance of breeding ........ 98, 102

" " large Jacks........... 109

" " fresh food.......... 139

In-bred vs. out-crossed stallions...... 220

Information, correct. ............ 155

Improvement in Cleveland Bay....... 163

Interfering $\ldots \ldots \ldots \ldots \ldots \ldots \ldots, 172$

Inflammation of the lungs, causes. . . . 324

" how to know it ...... 3:5

what to do........... 328

Influence of male on embryo........ 218

In-and-in breeding. . . . . . . . . 219

Influence of first contact. ..........218

Influenza, how to know it.......... 339

" wilat to do ............ 310

" recipes................ 340

Inflammation of the colon....... 351-353

$$
\text { " " " " } \text { " }
$$

Intestation of intestines. ......... 359

Intestlnes, parasites Infesting ....... 361

" " " reclpes. 362

Incisors of the horse............. 39

Indian horse................. 53

Indian pony.................... 02

Italian horses................. 54

Jacks, importance of large. . . . ..... 109

Jaund lce .................... 365, 366

" recipes................ 366

Jaw, flexing the................. 115

Jay Gould..................... 252

Jolın Stewart. . . . . . . . . . . . . . 248

Judge Fullerton................. 238 
PAGE.

Jugulur vein b.................... 198

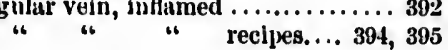

Kndischi horse.

Kuillan horse.

64

Ketping one's temper............. 24:

Kemble Jacksoll................. 258

Kicking................... 169, 179

Kidueys, inflummation of.......367, 308 "recipes....... 368

Klnds and quantities of food........ 138

King Joln's inportation........... 200

Knee joint, intlammation of......... 448

" biokell.....................470

Know what yon breed for.......... 155

Kochlani horso................. 64

Lady Suffolk, early races........... 248

Laying out liands................. 126

Lake water .................... 137

Latrva in the skin. ................ 284

Laryugitis, causes............... 332

recipes ............... 333

Lampas...................... 381

Lachrymal glaud, impediment of .\$32, 433

Lacerated wounds ................ 477

Large Jacks, importance of . . . . . . . 109

Leading foot, changing the........ 125

Leucorrlen, catarrh of the womb.... 376

Lexington, pedigree............... 210

I.ecompte...................... 210

Light hurness, training to.......... 125

" " trotting ............ 125

Linseed meal ................... 140

Light harness horses.............. 163

little Mack..................... 238

Liver, functional diseases of.........360

" congestion of ................ 360

" inflammation of .............. 361

Lime or white urine . ................ $3 \mathbf{3 i 2}^{2}$

Lock juw .................... 419, 422

Longfellow.................... 238

Iong Islind course............. 247

Lower jaw, caries of .........448,450

" " " recipes......... 449

" " exostosis............... 492

Loose boxes in stubles............. 131

Longfeilow................... 167

Lulı.......................... 166

Lungs, dropsy of .................. 490

Lymphangitis.................... 390
PAGE.

Mfake:2ss, pedigree of............. 204

Mare, number of teeth............. 49

" trentment during gestatlon.... 103

" when in season ... ........ 103

Mares, cure of ufter belng served.... 103

Mare, to know when in foul ........ 104

" " " time of forlling....... 104

Marshland shales................ 98

Mrurske, pedigree................. 206

Mares, treatment................ 103

Mungers ....................... 131

Mnshes, how to make............. 139

Manure fork....................... 14t

Mumge....................... 272

" how to know it............ 273

" what to do $\ldots \ldots \ldots \ldots \ldots \ldots \ldots$. 273

" recipes...................... 274

Meallenders....................... 287

" recipes................. 287

Malignant epidemic. .............. 326

Mad staggers................ 403, 406

Maud S...................... 252

Mensurements of fumous horses..... 160

Megrims...................... 179

Metucarpal bones, inflanmation . 446, 447

" recipes...........447

Measures and wejghts............ 508

Mellicines and doses .......... 511, 513

Mefke horse.................. 63

Messenger and trottling stock...... 249

Medley, pedigree of............... 205

Mexicun mustang................ 92

Mismatched colors................ 175

Movement in trotting.............. 123

Miss Colville................... 203

Molstening grain fed .............. 141

Mouth, fliflammation............. 382

Moon eyes .................. 170, 4:8

" recipes................. 428

Morgan horse.................. 86

" " points of.............. 87

Morton's Traveler, pedigree of....... 204

Moroceo Barb................... g)

Model racing horse............... 167

Modern race horse................ 212

Moon eyes ....................... 170

Moses, pedigree................. 207

Monkey, " $\ldots \ldots \ldots \ldots \ldots \ldots \ldots . . . .203$

Movement in walking.............. 176

Mule, to determine the uge......... 51

Mules, vulue..................... 1117

" treatment .................... 107

" breeding $. . . \ldots \ldots \ldots \ldots \ldots, \ldots, \ldots$
$\mathbf{M}$

$\mathbf{M}$

$\mathrm{Ni}$

Nin

Na

Nat

Nat

Nas

Nar

Nai

Nav

Niur

Neu

Nejil

Nece

Norr

“"

Note

s

Obliq

Old ti

Opht!

"“

Orien

Orient

Ossific

Ossiffe

Otho,

Out s?

Out-cr

Over-r

Ovum

Pacing

I'ucing

Parnsit

"6

cip 
PAQE.

Mules, Spanish................ 64

Myositis.....................458

Narragansett pacer .............. 87

Nutive country of the horse........ 34

" Pereheron horse............ 54

Nasul gleet................... 311

" canses................ 311

" how to know............ 311

" what to do.........311, 312

" recipes........... 311, 312

Nasal polypus................ 312

Naturally weak eyes............. 320

Navicuntur disense..........451, 453

"6 " reelpes for......4 4ji3

Narrow heel.................. 456

Nail picking................. 350

Nivel rupture ................... tit

Naleoties .................... 5146

Neurotomy .................. 459

Nejdi horse....................64

Necessity of elean grain........... 131

" "blunketing ............ 143

Norman horse................ 54

" Pereheron...... 75, 76, 77, 78

" " deseent of....... 76

" 6 points of........ 78

Noted horses of the last century, South

Oblique tail.................. 69

Old time trotters................ 247

Ophthalmia ................. 179

" purulent.............431

" recipes for.............431

Organs of generation, inflammation of 375

Oriental blood lin England, time of

Cromwell ...................., 201

Oriental blood and Euglish horses.... 201

" horses no longer profitable .. 20.2

Ussification................. 178

Ossified curtilages. . .............466

Utho, pedigree .................. 206

Out shed.................... 133

Out-crossing ............... 210, 220

Over-reachiug................. 172

Ovum of mammalia............. 217

Preing gait................... 124

Preing ....................... 124

Parusites infesting the intestines.... 361 eipes for.................. 862
Purotid gland, inflammation of. . 284, 285 " duet, fistula of....... 285, 287 Paralysis, partlal........... 498, 499 " " reclpes...........499 Persian horse ............... 53, 72

Periodic lieat .................. 217

Peritoneum, inflammation of....... 350

Periosteotomy ..............486, 488

Picker, the................... 142

Plow, training for............... 126

Plowing right hand furrows......... 126 “ square lands............ 125 “ carrying the reins......... 1\%7

Pleurisy, low to know............. 328

" what to do............. 329

" reeipes $\ldots \ldots \ldots \ldots \ldots \ldots, \mathbf{3 2 9}, 330$

Poluts of Arabian horse.......64, 67

" Norman Percheron....... 78

" the Morgan horse.........87

" the Clydesdale....... 83, 84

Ponies ............... 90,91, 9:, 93

" Shetland................ 02

" Mexiciu ................. 03

" Indian................., 03

Poisoning $\ldots \ldots \ldots \ldots \ldots \ldots \ldots \ldots$ 482, 48t

" internal............. 482, 4\$3

" from stings.............484

" " recipes........4 484

Poisoned skin. ............... 48j

Poll evil, cuuses................. 288

" how to know........ 288,280

"what to do.......... 289, $\$ 90$

" reeipes................ 2sn

Pond water. ................... 137

Preparing food $\ldots \ldots \ldots \ldots \ldots \ldots \ldots \ldots, 139$

Preparation preeeding first trial. 239, 240

Prineiples of breerling......... 216,219

" " trunsmission in horse... 90

Projecting teth................. 38:3

Proper stature of farm horse....... it

Pulling slowly and steadily.......

" at haiter or bridle........... 169)

Pumieed foot ................ 178

Purity, value of in horse.......... 95

Pneumoula, eauses.............. 32 t

" how to know......... 3:5;

wint to do . . . . . . . . . 326

Pryor, pedigree................. 210

Purulent ophthalmia............ 431

recipes.......481

Pumice foot.................. 465

Punctured wounds of the sole inslde. 467 wounds ............. 4it 
PAGE.

Quantity of food to be given........ 248 " Jiay to feed............ 139

Quarter crucks................. 172 ‘f false..................481

Queen Mab. ................... 203

Quittor.................... 178, 461

6 reclpes..................463

Rabies.................. 399, 403

Rucking..................... 124

Racer, to train. ............... 128

kuce riding .................... 128

Racing horses.................. 199

Racing, orlgin of the word......... 199

Race horses lirst imported to America. 203 Race course first established in England....................... 200

Race horses at the North...... 208, 210 Huce course established at Albany, Poughkeepsie, Harlem, New York 208 Rucks.

Rucing horses................. 167

Racer what he should be .......... 167

Rarey's plan.................. 121

Rat tail......................286 ، recipe.................. 286

Relaxants....................507

Rearing.................... 179

Relative size of sexes............ 97

Riheumatism..............422, 424 "6 recipes..........4 423,4:4

Riding, carringe of the body...... 129

lHiding racers. . . . . . . . . . . . . 128

" in the saddle.............245

Rigid pulling a mistake. . . . . . . . 242

Rlver water................... 137

lRingbone................ 169, 178

Ring worm ................. 275

* " causes.............. 275

" " low to know It......... 275

" " whut to do.............276

" $\quad$ recipes $\ldots \ldots \ldots \ldots \ldots \ldots \ldots 276$

Ringbone................442, 443

" recipes...............443

Ripton, early races............. 247

Rotten bone..............447, 448

" recijes............... 448

Rond driving a fine art........... 242

Roadster driving vs. Trotting on the course $\ldots \ldots \ldots \ldots \ldots \ldots \ldots \ldots 243,244$

Roaring................ 493, 495

"6 recipes................ 495

Roots, feeding.
PAGE.

Roaásters, highly bred........... 156

finely bred............ 156

Rogue, the................... 170

Roaring.................... 72

Roundliead, pedlgree of........... 203

Routh's Crub, " "...........203

Rupture of the colon......... 851, 853

" " " stomacl............ 857

Rupture................478, 474

". of hamstring.............496

" " bladder............... 375

Running .................... 125

Rubbing cloths............... 143

Saddle galls.................... 270

" " recipes...........279, 280

Saddle riding In England .......... 245

" horse, good form for......... 165

“ horses of ull gaits....... 165, 166

4 horse, color for ............ 174

" horses, styles of actlon...... 175

" horse. .................. 159

" and larness horses, training

to ......................... 115

Saddling and harnessing colts....... 118

Saldle, training to the........... 121

" trotting under............. 122

Sallenders..................... 287

" recipes $\ldots \ldots \ldots \ldots \ldots \ldots \ldots \ldots . . \ldots 287$

Salt in feed .................... 1:9

Sand crucks................... 172

" crnck................460,461

" " recipes for ............ 461

Scraper..................... 143

Scrutches, cuuses ............. 250, 260

" how to know............. 200

1: what to do...... 260, 261, 262

" recipes............ 261, 262

Scoop shovels.................. 144

Scurvy of the teetl.............. 380

Scald mouth................... 383

" " recipes .............. 384

Scrofula .................... 389

Sclerostomum equinum. . . . . . . . 392

Scarlatina. .................... 397

Scalds ......................443

Sent of the driver.............. 243

Seedy toe.................465, 460

Sedatives................... 496

Semi-wild horses of A merica........ 55

Selection of brood mare............ 221

" " horse, value.......... 97

Selina....................... 203 
Shifting the reach............ 244, 245 " " bit................. 244

Shark, pedigree................ 205

Shying ................... 172, 179

Slioeing..................... 142

Shedding the teeth............... 379

Sharp and projecting teeth......... 383

Shot 0 'gresse.................. 396

Shoulder, sweeny........... 337, 338

" " recipes............ 338

Shetland ponies................. 91

Sitfast.................... 279, 280

Side boikes................ 466, 467

Sham horse.................. 53

Slngle foot. ................. 132

Skin, acute irritation........... 491

" " " recipes........4 491

" hardening................4 491

" " recipes...........492

Skeleton of horse, explauation.... 39, 40

Slings.......................4 491

Slavering. ................... 382

Sleepy staggers, or apoplexy.... 410, 413 recipes $412,+13$

Slinking foals, to know when........ 104

Sinall size of old time racers......... 212

Smart tricks of drivers........... 241

Solndness and vigor in liorses....... 96

Sore liose....................493

Soundness, warranty of........... 179

Sour stomacl................ 344, 34j

" " reeipes............... 346

Soreness of the anus.............. 355

Sore shins................ 446, 447

" " recipes for............ 447

" eyelids..................427

" " recipes for.............427

Spark....................... 203

sponges....................... 143

Splint brooms................. 144

Splints.................... 169

Spasmodic netion of glottis........ 340

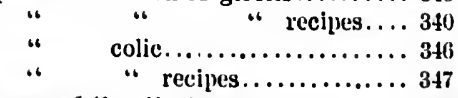

Spasm of the diaphrigm.......... 357

" " " recipes....... 357

Spavin, bog..............416, 417

" blood................... 416

Spleen, eulaigement of ........ 366, 367

Splint..................444, 445

"6 recipes for...............4 445

Spanish barb horse.

PAGR
$\cdots \quad 64$

mulo................... 108

Spavin, bone.............. 439, 441

". " reclpes...........440, 441

Squirt, pedigree................. 206

Staggers, mad.............. 403, 406

" blind.............4 406, 410

"6 recipes................. 419

Steatying the borse............ 242

Stifle .......................444

" recipes for..$\ldots \ldots \ldots \ldots \ldots \ldots \ldots .444$

Strungles. . ................. 343

Stomach, Inflummation of...... 354, 355

"6 rupture of $\ldots \ldots \ldots \ldots \ldots \ldots .357$

$6 \quad$ gorged................. 358

، recipes $\ldots \ldots \ldots \ldots \ldots \ldots \ldots . \ldots 358$

Stoutness the forte of early rucers.... 212

Strungulation of the intestines. . 359, 360

Stımp sucking................. 380

Stringhalt .................... 178

Stable tools................. 143

Straw wisps................... 143

Story of thrift and untlurift..... 148, 153

Stumbling ................... 109

Stable care ................... 141

Stuble, water in............... 134

Staling, profuse, or diabetes, ctuses. . 260

" " liow to know....... 209

" 6 whit to do........ $\mathbf{2 6 9}$

" " recipes............ 269

Strains and sprains . . . . . . . . 468, 409

Stimulants. ................. 507

Stone in the bladder............. 372

Stricture of the urethra........... 375

Starveling colts................ 106

Stabling colts................. 106

Steady und slow pulling .......... 127

Struble, construction............. 128

" loft............... 131, 133

" walls................. 131

Stalls, width................ 131

" temperatme .............. 132

Stilble, cleaning the............ 132

" surroundings............. 133

" yard .................... 134

Surgical and otleer instruments. . 510, 511

Silpuression of urine............ 373

Suffolk Punch, horse............. 62

Surfeit, cuuses................ 270

. how to know............ 270

4 whliat to do.............. 271

، recipes............. 271, 272

Summer blaukets.............. 143 


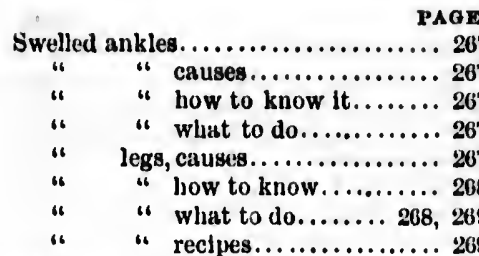

Sweating ..................... 249

Sweet mash................... 130

Swelled throat................. 832

"6 recipes.............. 833

Sweeny, hip.................. 438

Swelliıgs from pressure......... 493

Symptoins, importance of......... 500

Taking hold of the reins........... 244

Tally Roger, pedigree............ 203

Tartar horse................. 53, 73

Teetl of horse................. 48

" " the mark........... 40

$"$ decay.....................879

" scurvy................... 880

" projecting................ 383

Teaching a colt to back........... 114

Tetanus .................4 418, 422

" recipes................420

Temperature of stables........... 132

Tendons, division..............489

Tetter .................... 285

" recipe for................. 285

Teething .................... 378

6 what to do............. 378

Teetl, shedding................ 379

The embryo.................. 217

The Giles horse............... 247

Thickesing of the back sinews...... 178

Thrush, causes................. $\mathbf{2 6 4}$

". how to know............. 265

" what to do.............. 265

" recipes for............. 266

Thrush................. 178, 384

"r rucipes .................. 384

Thumps................. 388, 389

" recjpes................. 389

Thorough pin................ 418

" recipes.............418

“ blood valuable in trotters. . 248

Thoroughbred horses, South..... 204, 208

" horse in America..... 85

" " early importation 85

Time of celebrated horses....... 213, 215

". to clean ................. 142
PAOE.

Toe crack................445, 464

"6 recipes................. 484

Tonics....................... 507

Tongue inflummation ............ 883

To subdue a viclous horse....... 119, 120

Tool room ................... 181

To mnke gruel.................. 140

huy tea................ 140

Tu detect vlces and delects......... 160

Tools of stable................ 143

Topgallant................... 247

Traclieotomy.............. 480, 488

Tumors, blinck plgment...........543

Treadwell mare................. 212

Treatment of mares.............. 103

" mules............... 107

Training to trottling ........... 242

" Intelligent cire necessary . . 239

" condition, importince of... 239

" the 3-year-old........... 248

"6 colts to work ........... 113

" to saddle and hirness..... 115

" to hmrness. ............. 115

" proper care in.......... 117

"6 to the sadile............ 121

" a liorse to trot .......... 122

Trials of speed................ 248

Trotting under the sadule. . ........ 122

"6 movement in............ 123

$"$ in haruess............. 123

Training to trot in harmess........ 1:3

" to light harness......... 125

" for the plow............ 126

" to the wagon........... 1:7

.6 $\quad$ a racer $\ldots \ldots \ldots \ldots \ldots \ldots \ldots \ldots 128$

"6 truck on the finrm........ 128

" a stallion.............. 128

Trotting horses............. 239, 247

". horse of America......... 249

" stallionsin Englumd, time of Henry VIII., by whom kept............... 201

" in light harness.......... 125

" at various speeds ........ 1:9

، horse, to buy ........... 163

Trustee.................... 483

Trotter in light harness . .......... 10.

Tryall ...................... 203

Turf horses... . ................. 199

Turning the toe out............. 17?

Turkestan horse............ 54, 72

Turkoman horse........... 63, 72 
PAOE.

Turkislı horse................. 72

Ulceration of the foot........451,453 " " " recipes... 451, 453

Uitimate trotting speed........ 243, 2.4

Unsoundness, to be noted........... 242.2

" wlut constitutes...... 179

Urine, lime or white . ............ 372

" suppression of............ 373

" $"$ recipes for. 373,374

Urethra, stricture of............ 370

Using the means we have ......... 163

Value of $\operatorname{good}$ bits............. 242

" " purity in horse........... 95

" " selection............... 97

" " mules................... 107

" " hay and straw........... 130

" " good shelter............. 149

Vagina, inflammation of ........... 376

Veterinury surgery...........488, 490

Vermifuges ................... 507

Ventilation of stables........ 131, 132

Vestlbule to stable............... 132

Vermin ................... 283, 284

Vermont draft horse............. 62

Vision, jimness of. ............ 4:0

Vices and defects................. 169

Vicious horse, to subdue........ 119, 120

Vocabulary of horses' teoth........ 5 2

Walking horse................ 122

Wingon, training to.............. 165

Water in stable................ 134

" "tanks .................. 134

Watering............... 185, 137, 240

Water before feeding .......... 137, 138

Wıtering when driving........... 138

Washing the teum............... 142
Washing horses. ................ 173

Warruty for unsoundness and vice. . 179

Wurts ..................... 281

" cnuses .................... 282

"6 whist to do ............... 982

Weak lungs. .................... 173

Weaving in the stuble. ........... 170

Weed........................ 306

Weak eyes. .................... 426

Weights und mensureg............. 508

Well witer ..................... 137

Weur of teeth in crib-biters. ........ 51

Whalebone, euriy races ........... 247

What to feed ................... 136

What constitutes unsoundness. . 178, 179

What a horse should be........... 177

When to feed................... 137

Wheelbarrow .................. 144

White Turk.................. 201

White or llme urine. . . . . . . . . . . 372

White spot.................... 171

Wiid horses of America............ 73

Width of stails................., 131

Windmill. .................... 134

Winter feed for colts. . ............ 130

WVind-galls. . . . . . . . . . . . . . . . . 495

IV ondcock, pedigree............... 203

Wolf teeth in horse's mouth......... 49

Womb, inflammation of.......... 376

" catarrh of ................ 376

IVolf's teeth . .................. 172

Worms in the eye.............. 430

Wounds of the sole.............467

$\begin{array}{ccccc}\text { " } & \text { " } & \text { contused........ } & 476 \\ \text { " } & \text { " } & \text { " } & \text { lacerated } \ldots \ldots \ldots .4 & 477 \\ \text { " } & \text { " } & \text { " } & \text { punctured... } & 477,478\end{array}$

Wry tail..................... 171 


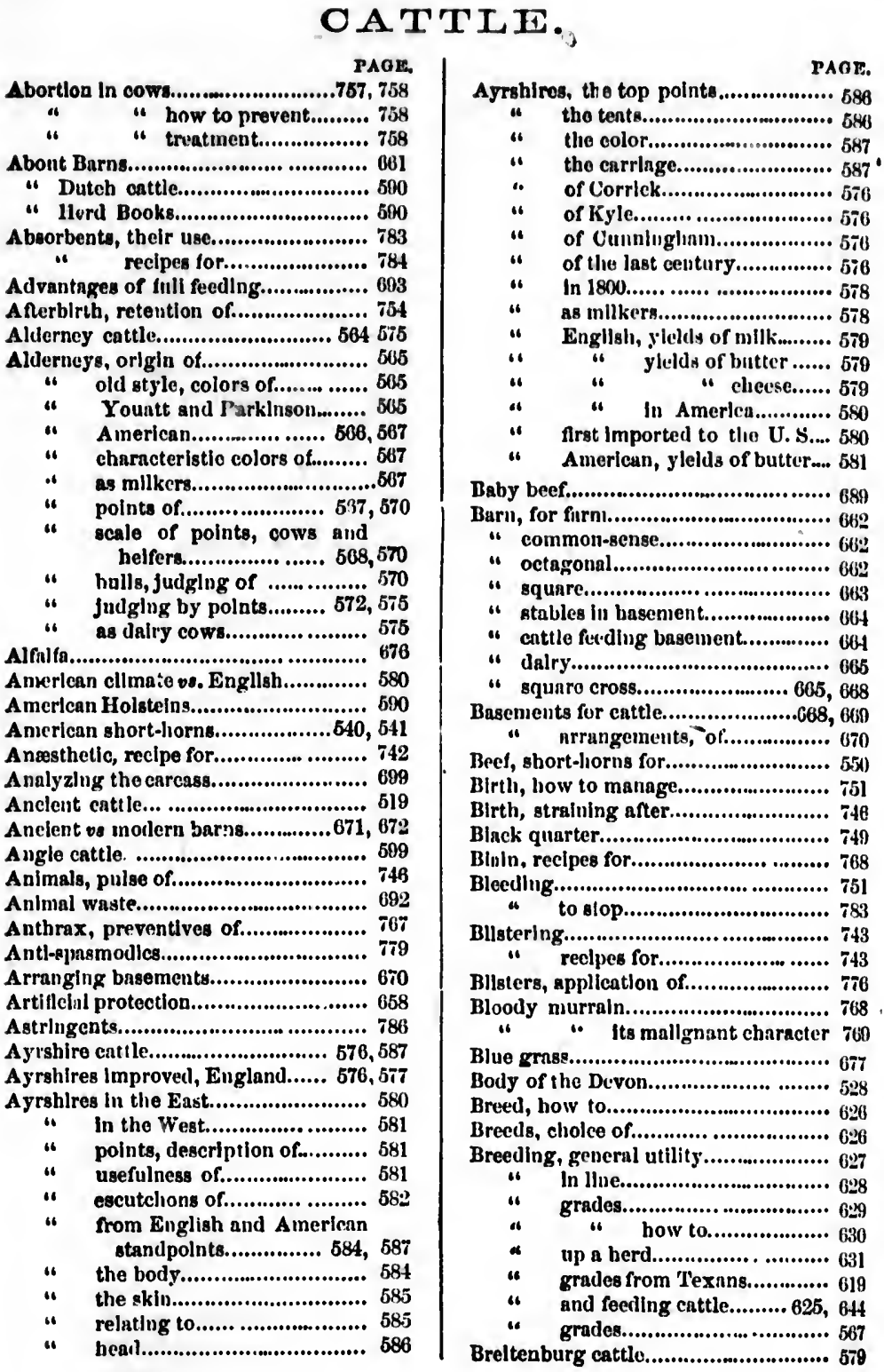


PAGE.

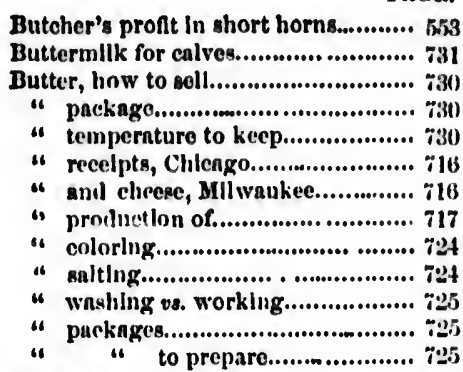

Bulls, scale of polnts...................... 572

Buylug to ferd............................... 697

"4 bremilng cattle..................... 0117

" mlleh cows............................ 702

46 for mllk .............................. 702

Calf, tralning the........................... 64b

at hulterlug................................ 646

" unnatural positlons of.............. 751

a 4 " " how to obvlate................................ 751

Calves, custratlon of........................ 843

"6 enrly feeding of....................... 642

"1 profita oll............................... 643

Calvlng, drinks for cows after........... TS.5

" parulysils after.................... 756

“ " $\quad$ reclpes for, 750,757

Carcass of ox, explanntlon of...........

Caro of milk................................. 720

Castration of enlve's......................... (343

Catarrli, reclpes for........................ 78

Cat's tull grisg.................................. 677

Cattle, naturul history of.................. 519

" domestlentlon of................... 519

"6 anclent................................. 519

4t teeth of.................................. 5 50)

* breeds of............................... $5: 1$

"6 rnces of................................. $5: 1$

4 diseases of....................... 781, 772

"6 henvy welehts...................... 684

" sliort-horis, welght......... 085, 68;

" Interests In Texas................... (i:0)

4 prlume parts li....................... T(10)

"6 how to bly.......................... 701

“ for ferdlug............................ 897

" speclul sigus of clisease 11........ 749

“ ten years' produce In............... (331

" traluing aut! worklng....... 645, 656

4 " ve. brenklug................... 645

Characterlstics of Divon cow........... 524

" " Devons................. 5.88

" " Spaulsh enttle......... 815

Cheap stables................................ 660
PACR.

Chrego maklng.......................... 728.730

“ produetlon of......................... 717

Chesh|re clieese, to make.................. i:n

Childelar " ............................... $7: 7$ " 4 to make................ 7:.8

. 4 slzis of................. i.t.

Cholec of breeds............................... 6:30

Clysters........................................ 741

. forms of................................. 776

4 reulpes for....................... 776, 777

6 silmulitling.......................... 777

4 Inxutive............................. 776

6 emolllent............................. 777

1. dluretle............................... 777

4 nnodyne.............................. 777

" for worms............................ 778

14 satringent........................... 778

“ nourlshlng........................... 778

Clovers of valie............................ (570

" undesirable.......................... (676

Clover rntlons for cuttle................... 639

Coloring butter............................... 784

Color of sliort-horns...................... 560

" "tho Sugsex........................ 537

Colors of Alderisess....................... 567

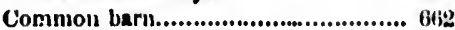

Common squse breculing.................. 633

" " In dlse'ase, value of..... 730

Compnring values............................ 6330

Compurison ot milk prouluets........... 606

Coutuglous aliseases...................7(31, 7iz

Contour of bolly of short horns....555, 550

Corn rutions for cattle........................ 639

Cougli drluks, ruclpes for.................. 779

Coughs, remetly tor......................... 786

Cows, Devon................................. 5:4t

Cow, Hereford.............................. 531

Cows, gestatlon of........................... 634

Cow, to prevent kleklng.................... 650

b. slieking.................. 6.5.2

" 6 hooking................. 6.52

"t to manage a klcking......... ....... (15.55

Cows, vlelonsuess In....................... 650

"6 suckling................................ 6.50

Creamery, ex. of........................... 719

Dalrylng, Importance of................... 715

“ condluons neressary for..... 719

Dalry, the...............................715, 73:

" dralulug for.......................... 719

. sub-eurilı ventlintion............... 720

"6 Importunce of cleanliness........ 701

4 anlmal ollor............................ 721

" temperature of....................... 722

" sliort liorng for..................549, 550

"4 cow. 'Ihe Alderncy............... 575 


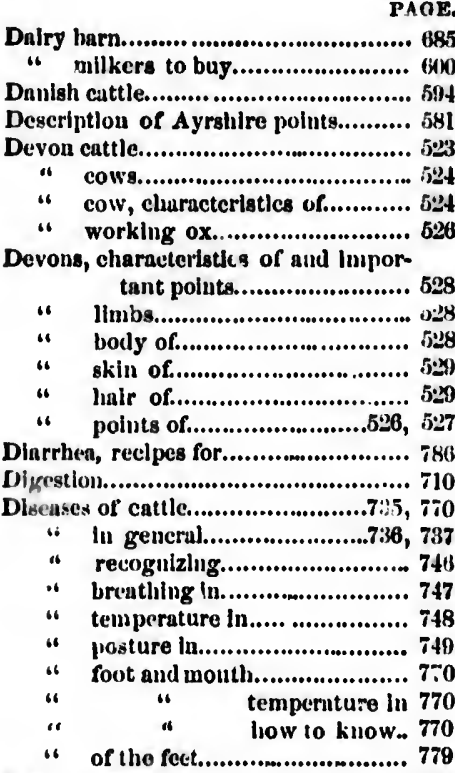

Disscetions.................................. 773

Dlstlngulshing marks of Bu-sex cows 537

Dluretlc driık............................... 785

Doses, formis of.............................. 740

Dr. Geo. Muy, on Dutch enttle........... 588

Drink for cows aner enlving......... ..... 785

Durham bull uni cow, oll style........ 538

Dutch cattle, (seu Ilolstelus).............. 559 " "6 true history of............. 591

14 "what hlstory 8ays.......... 591

" " facts ns to...................... 596

"4 " races of......................... 608

Diteh Fresinn cow........................... 598

Dysentery, reclpes tor....................... 786

Farl Spencer's prize ox..................... 698

Early feculing of culves...................... 642

“ iunturity, profts lu................. 788

Economy of lurge burns................... 867

English feeding, cost of.................... (i21

Epldenic diseases.......................661, 1172

Eruptive " ............................. 787

Escutcheon................................... 702

Becutcheons of best rowr.................. it);

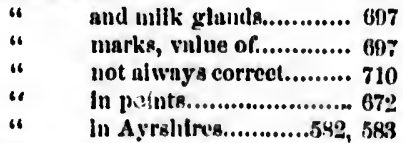

Excrcising common senso in brerding 633
Experiments in feer.

Export butter and clieese................... 717

Eye, cooling wash for...................... 780

" In disease................................. itt

Fucts nbout Dutch cattlo................... 596

Furm burn..................................... 66.

Farvier 'Thrifty's Cattlc..................... 6.58

* Slack's slielter....................... 6 6 69

Fu,tenings.................................. $(6)$

F.t bullocks, ontllite of................... (ing

Feeding quilitice, Iloliand cows......... 60i

. stock euttle......................... (68)

6) nilleh cows.......................... 881

"6 for protit........................... 580

4 cost In Eugland................... 690

" In strmmer........................ 691

14 experlments in.................... 6 6 30

6 stumdard.......................... 637

"6 rations for stecrs.................. 4388

" atock, to buy........................ b98

" chetp corm......................... 641

" "t millklugt time............... ..... 649

Firing......................................... 743

Flooding nfter calving.................... $75 t$

" " " reetpes for........ 7ijt

Fomentations. their operations.......... 779

" rectpes for.................. 759

Food vs. product................................ (i3it

Foods, relutive value of................... 640

Form as an liclex to quality............. 6.49

Foul meadow grass........................ 1 th

Fouls in Cinttle............... 788

Framed sheds................................ (jij8

Frumkish cow................................... 598

Frlusiun cattle................................ 5093

“ " cliaricteristles............. 5906

Full firding, advuntages of............. (6:13

Fiumigants..................................... i 855

"t to minke.......................... is5

Fumigation.................................. itl

Galloway eattle........................... 613

(ielding calves, enre li)..................... (6H

Oenernl utility in breedlug............... 6:27

Gestution of cows............................ (i3t

. tablo relntive to.................. (ii3)

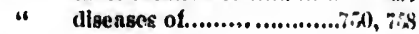

. necluents of..................750), 7.88

.1 plural............................ $7+9$

. multlple........................... 7i0

" what to do during.............. 75l

Gond cure, vulue uf........................ 695

"6 rilurus, how to get................... 695

“ tecdiug profitable..................... 701

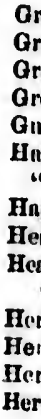

Her

Hert

Hist

Hols

IIols

$$
\text { . }
$$

. 
PAGE.

Orndes, breeding of.......................... 567

Grucluation of dosew......................... 739

Qrusses for stock.............................. 6:5

Grease hutter................................... 715

Quenon's theory..................... 702, 709

Hnir nud condition........................ 748

" of the Devons.......................... 5:9

Hnppy family................................. t50

Hent of iron................................... $7 \mathrm{k} 3$

Heavy weights of enttle................... 68 .

" $\quad$ of short-horn cuttle 685, 680

IIrdlug, cattle, expense of................. 621

Hereiltty....................................... 710

Bureforils..................................... 529

Hereford bull................................. 530

11 tltly years ago................... 531

" cow................................... 531

Hereforils in America....................... 532

6 as mllkers.......................... 532

Bereford ox.................................... 53.t

" cow nud calf....................... 533

1" of to-(lay........................... 534

Aistory of II

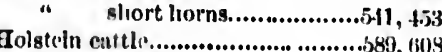

. Iilstory of........................ 539

" cow, escutcheon oll............ 706

IIolstelus, lıuprovement lu............... 650

“ for the prusent century....... 589

. In Amerlea...................... $5 \mathrm{6}$ \%

1. Hist Imported................... 589

" colners of............................. 589

" heril hook......................... 501

" reguinr markets established.. 594

“ Dr. Gun. M.tyor.................. 598

“ Mr. Killppart's testlınony..... 598

" Inportution of W. C. Chen-

ery................................. 503

" ns milkers.......................... 604

" welghts of......................... 80.5

" millk procluets of................. $60(0,5$

.. herl records............... 606, 607

، cow................................ 595

، herel recorils ...................... 60.5

Home dairies................................ i:

Herns nut cortalu fudlentions or age... 713

IIovell...................................... $78(1)$

. remerly for......................... TE0

Llow to lircedl...................................

Ilow to buy nud liow to sall........605, 71.j

How til sluelter..........................657, 67 .

Improvements in Ilolstelus.............. 589

Iılleallü of pall1.......................... 585

Infectious diseases................... 759, 770

Infu-lous................................... 778

Injectlons rule for mukinge................ i78

PAOE. 755

Jersey bull, perfectlon....................... 571 “ sciale of of points.............. 572

Jersey or Alilerney cnttle........... 564, 675 catllo (ece Alderney)

Jerseys, milk mlrrors of.................. 704

Judglng age by teeth....................... 711

Judging Alderney bulls.................... 570

Judging Alderneys by polnts...... 672, 575

Kerry cow....................................609

Kerry',, a rure breid........................ 608

"descriptlou of..................... 609

" hardlncess of....................... 608

Kleking cow, to mauage..................... 655

Khul nud careful treatment..........681, 682

Klippart, on Holsteln cattle.............. 899

Last century, Agrshires of............... 570

Labor, lauguld.............................. 756

I.tughila lnbor............................. 756

Large presentation.......................... 752

I.ice on cuttle................ 786

Limbs if the Devons........................... 528

Llve weight, estlmnting................... 698

loung horus............................................. 522

Miko beef young........................... 689

Muklug cliliry bitter....................... T.2.

Mallguant uutlurax....................... 762

" cutarrh........................... 769

Matmmitis.................. 760

Mensurencuts, estimutlng by........... (i07

Medlelnes nnd instruments........ 770,785

“ aetion of......................... 774

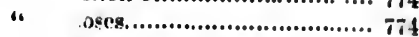

. whin to mluluister............ 730

" how to give...................... 740

Miclleal reclies for enttle.......... 775, 7 87

Mlldille horms................................

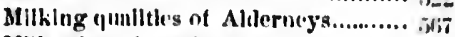

Milk nirror lı polnts....................

Mlilkligr quilillieg of Ilolsteins.......... (i) 3

Nilk produets of IIolstelus................ (604

" " comparcd.................. (3)

" " of lieriy cows............ 010

Mllking, timluling to........................ ti.t8

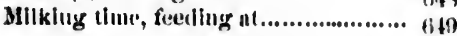

" $\quad$.......................................... 670

Millel cows................................. 671

Mllik und bef eow, description of 701,70$)$

" mirrors................................ 70.2

Milkers in all breeds........................ 70?

Alilk velng..................................... $7 \mathrm{~T}$ 
PAQE.

Mllk, care of.................................... 720

"6 4 ..................................... 723

Milk Fever.................... 758

Model cow, perfection...................... 470

4 dalry, leseripiton of........ 704, 70.5

" creninery, ground pian of....... 719

Murruln, preventlves of.................... 769

„ reclpes for...................... 709,770

Mudlageg, 1186 of.............................. 780

Natural history of Cattle.... ............. 519

“ tempernture of stock............ 657

" water In fool........................ 689

Neck of short horns.......................... 555

Nutritlve qualities of IIolstelıs............ 60t

Necessity of sheiter....................657, 674

New industries, rushing Into............. 684

North Devon cow............................... 5:55

North IIolluud cattle.......................... 600

Octagoumi barms............................. 663

Oid style furm yird........................... 6.58

Opodeldoc, to inake........................ 787

Orchard grnss................................. 678

Oleomargiriuc................................ 715

Outline of short liorn cow............... 537

Oxcu trainluge................................ 650

Packing butter..................................... 731

Parnlysis, ufter calving....................... 756

P:sture, feed and water................675, 682

Pasturage............................................ 675

Pasturing, thmo for............................... 679

P:ttton1.............................................. 541

Pedigree of Comet............................... 63:2

cow Florissa..................... 632

Perection fa cow........................565, 564

Pleuro pucumoula, virus oî.............. .. 763 6 "6 perlind of husuln-

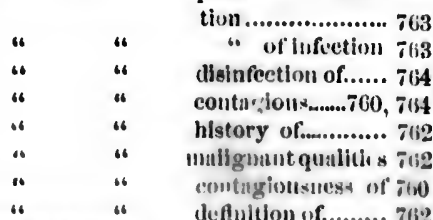

Poirsts of enwe..........................5:50, 507

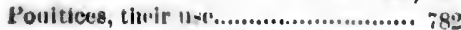

-4 stimulating...................... 7

↔ to promote suppura:lou...... $78: 3$

Polled entlle,..................................... 6 611

Poluts of short-hurns........................ 5.53

64 4 o described............. 550

Prolmgel iabor........ ................. 70 ?

Presentation large.................................. 75 ?

Prlme parts in cuttle............................. 500

Protits from breeding Texan graileg... 619

" on 'Texun tattle.................... 623

. of early maturity................... 747

. of good feeding.................... 701

Pulse in diseusc............................. 746

6. of unimnls............................. 746

Purity, value of............................. 567

Quality, form as an index to............ 629

Qusterale...................................... 759

Races of Dutch cattle...................... 598

Ritlous for mlich eows................... 637

Rulsing crenm, various methouls........ 722

" " Dutch method........... 7.22

" " Ilolstein method........ 72.2

" " Devoushlro ". .......... 724

" " Gussmuler " ......... 72.2

Raising culves, experimcists tn.......... 731

. young enttle........................ 642

Relative value of different fonds........ 610

Rked top........................................ 638

Respirition.................................... 711

Retentlon ot aiterbirth.................... 75t

" 4 recipes for........ 755

Renient for cheese.......................... 7\%9

Rlpe cittle for profit...................... T01

Rough shed................................. 658

Rowis..................................... . 74t

IRule for meusuring catule.......... ... . , , ;

Salting Butter.

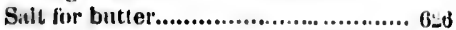

" impurities hil........................., 6:06

Scaie of points, shori-lietu bulls...501, 502

" " " " cows.... 6192,504

" " $"$ cows and inelfers....568, 5i9)

• “ “ Jersiry limil............... 57.

Selectlon in breet!ilet...................... 632

" of buils for 'T'"X:18.............. (i:3]

" " chives for ' T'exas............... 6 6..."

Setons........................................ itt

“ recipes for.......................... itt

Sheiter, how to..................... B57, $67 t$

.6 where to plaut...................... 673

Shallow pang............................. i 701

Short-iorns, cows, wiole of poluts, 562, 564

s!ior-horns, the latk..................... $5: 7$

"4 1 ill...................... 5.57

16 $\quad$ " IImb..................... 5i57

" 4 skin..................... 5.57

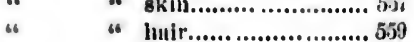

4 "4 handling................. 5.58

6. $\quad$ "6 color........ ............... $5 t(10)$

4 perfection In............. 560, 564

"6 bulls...................... 561, 0 :

.6 scale of points........... 501,562 
Bhort horn proper............................ 539

it history of..................530, 553

“ in America............... 541, 450

4 Importation 1815.............. 541

" "6 $1817 \ldots \ldots . . . .541,542$

" 6520 แnกl 1821... 542

“ $4 \quad 1822$ to 1830 ....... 549

“ Ohio importation 1834...... 544

.4 "1 1824 to 1828 ,

1833 to 1840544

16 41840 to $1850,: 45$

" 4 " 1850 to 1851,546

6 6 4 1858...,........ 549

16 In the West................... 549

" for berf.................... 550,553

". " dairy................... 549,550

". polnts ol:........................ 553

66 butcher's profit lit........... 553

" the hetd................... 553,5.54

" the neck........................ 555

“ boly, contour of........ 555, 55,56

c proper shnpe for futtenlng, 550

" the crops......................... 5;7

short horn breels.................... 537, 5it

Slgus of discase in cattle.................. 740

Skim unilk, value of........................ 732

Skim checse.................................. 715

Skeleton of ox, explanatlon of............ 7it

"6 " nul liorse compared.... 753

Skin dlseases, wash for..................... 780

. and condition.......................... 748

. of the Devons........................... 829

Slnck shciter................................... 609

South IIolinnd callie..................5 590, , 991

Spat !sh cattle................................ 815

Spra! ling ....................................... $\mathbf{7 4 1}$

Splen'c fever................................ 759

Squars baru................................. 663

Silimulating tincture..................... 781782

Starting the herd.......................... 031

Stabies in bascineut........................ 364

Siock enttle, feeding......................... 670

6 fecding...................................6 670

“ well and lll kept...................... 681

Stenming...................................... 641

4 application........................ $6 H 1$

16 nose bag for........................ 641

Strainling after birth......................... T.50

Sumner feeding............................... (39)

. shelter................................. 6 6 62

Busgex cntlle, distinguishing murks of .j37

" cow..................................... int

"6 the color ol........................... int

Swiss cow......................................... 5its

Styptics, vuluable........................... T82

68
Table on gestrtion.......................... 635

'Talnts from impurities in milk........... 72;

Treth of cittle................................ 5120

'Teeth, Judging age by................713, 714

Temperature of dairy...................... 7.2

“ cheese vat................. 7.?

Texas cattle ..............................615, 024

" “ Intercsts lil..................... $6 \mathrm{D}^{0}$

" " accilmating improved bulls

In............................. 821

1. "s selectlon of calves for........ 622

4 fever.................................. 767

" " how to know it.............. 765

" ". reclpes for...................... 706

- .1 16 whint to do....................... 760

Texnns, feeding î stable.................. 616

“ improved blood.................... 619

Ten years produce in cattle............ .631

The young calf.............................. 639

The toueh, value of........................ 700

Thermometricil tests for hent........... its

Timothy....................................... 677

Time for pnsturing.......................... 680

Tongue in disease........................... T46

'Trulning and woikitug caltle........64), 6\%;0

" vs. breaking..................... fi4;

4 tho calf............................. (648

" to milk................................. 348

" $\quad$ oxen.................................. 672

6 stock young...................... 654

. cuttle, Anmuming $11 . . . . . . . . . . .6674$

True grasses................................. 677

True history of IIollallil eatl|(4.......... ;91

Twist, veins of ............................. 711

Twisted suture.............................. 745

Uiller, vius of......................... 711,712

Ulecrntion of tile: montil................. Tst

. recipes for....................... 780

Unnatural presentation.................... 7.i.

4 positiong of eall.............. 75.2

Urus.......................................... 0119

Uecfulicss of Ay' rolitres................... 582

Vulue of purity............................. 567

Valies, compantison of...... ............... 6.399

Valuable elovers............................ 67

Value of gool care....................... $69 \mathrm{i}$

. " milk niirrors....................... 703

Vinpors......................................... T41

Velns of twist and uilter, Infallible nurks.................................. 712

Veterinary surgery, Importance of..... 736

6" pretenclers...................... 73!3

Virus, how earried........................ 761

Wash for eruption.......................... 785 


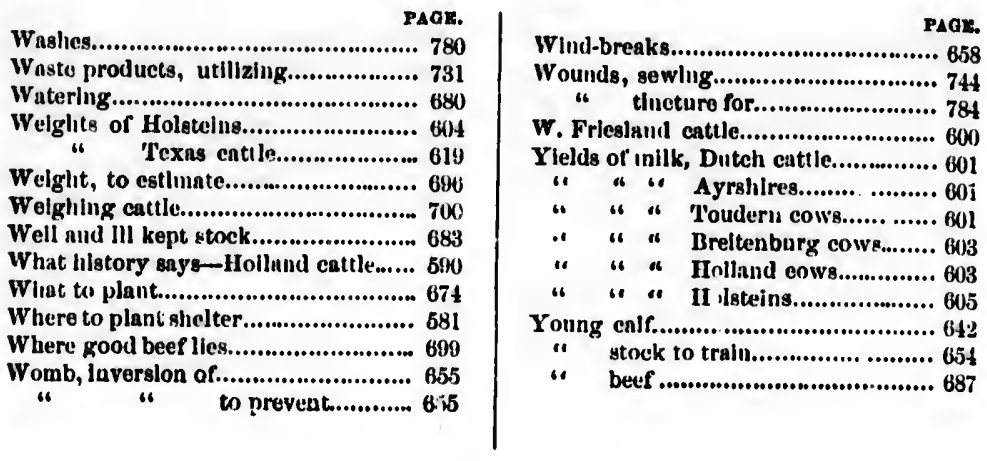

\section{SEEEP.}

PAGE.

Age foi breeding sheep.................... 812

Amerlenn merinos........................... 806

" orlgln of............... 807

A poplexy ........................................ 823

Burbary sheep................................. 793

Bidlex canal, infiammation of............835

Bluck-faced Highland sheep........... 703

Burdel Lelcester................................ 790

Cistrutlig Jambs............................ 818

rams............................... 818

Chevlot shetp................................ 801

Collc............................................. 837

Cotswold sheep.............................. 796

" " value ć́....................7 796

"6 "South...................... 798

"6 Jambs.............................. 798

Coupling aheep.............................. 812

Disense's of sheep........................8:1, 837

" " beal and bruin............... 826

b. " urinary organs................. $\$ 333$

"6 " generatjve organs............ 833

Dlvision of wool.......................... 810

.4 " "6 Illnstrutlon............ 810

Docking Jimbs...............................813

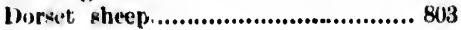

Disslng elieep.................................. 81 j

Epllepsy ...................................... 830

Fill pasturing of sheep.................... 815

" feeding of sheep....................... 815)

Fine wooled sheep........................... 806

Foot rot......................................... 898

“ " treatıne.nt ............................ 834

Fouls in the fet............................... 834

Gencratlve organs, dlinrasek............. 8333

Gravel......................................... 844
Grubs In tho head............................ 83

6. " " " to prevent.............. 839

" extrractlon................................ 839

Hampshire Downs............................. 804

Hydrophobia................................. 831

Hyilatids on the brain...................... 8:31

Intlammation of the $e_{j}$, $28 . . . . . . . . . . . . . . .828$ " " " brain................. 830

"6 symptoms :.................... $\$ 30$

Intestinal worms......................... . 831

Jatinbing room.............................. 818

Iambs, castration............................. 81!

Lelcester sheep............................... 800

Lincoln sheep................................ 800

I.jver Altuke.................................... 830

I.ockjaw, trentment............................ 830

Lolig wooled sheep......................... 7.4t

. 4 " Ascklng.............. 800

Lung worms................................ 83;

16 6t treatment................... 83 j)

Maggut; sheep.............................. \$3.j

" " recipes........................ \$3.5

Management of lambs..................... \$ \$ 23

Merinos, Americnn........................... th

" fleeces ............................... bitt

. the head........................... 847

. the bodr............................. 8118

.6 charpcteristles.............. . 807, 803

6. for profit.......................808, 849

Mlildle woolied shepp........................ 801

New Ieleeskles sheep........................ 7y.j

" Oxfordshile sherp.................... 800

Nursary for lambs........................... 8.8.3

Oxford Downs................................. $x_{0 . j}$ 


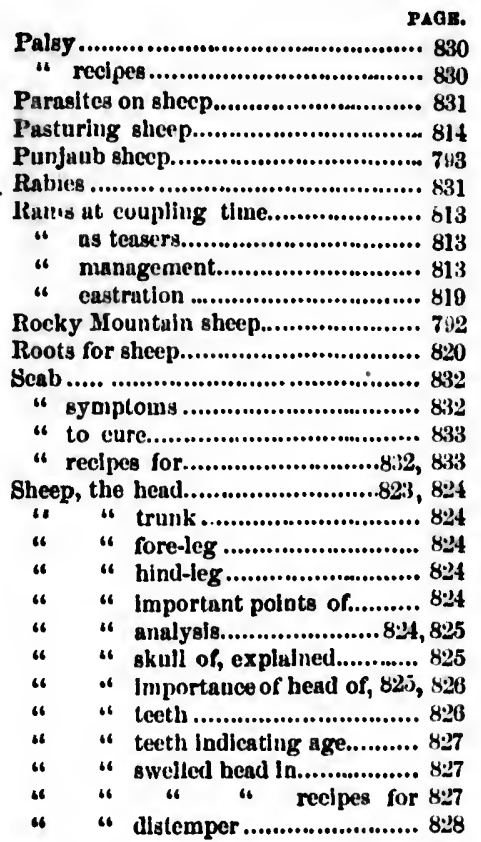

PAGR.

Sheep distemper recipes for ............... 828

Sheep husbandry ............................791, 8:0

“ varietles .................................. 791

“ Importance of.......................... 701

“ points of, explained............... 7!:2

Shropshire Downs............................... 804

Slicep breeding................................ 811, 8:1

. management of....................811, 8:1

“ barus ................... ................... 816

16 trough...................................... 816

Sheep, dlseases of..........................8.1, 837

Skeleton of sheep, description of.......... 824

Special Winter feeding of sheep......... 817

Training rams....................................... 814

Travel sore........................................ 834

The rot In sheep ............................836, 837

Urinary organs, diseases of............... 838

Varietles of sheep................................ 791

Vegetable polsoning............................. 8.8

Watering sheep reclpes for......... 828

Weaning sherp................................. 819

White-faced Highland sheep................ 802

Winter managemert. of sheep.............. 819

Worms, Intestinal.................................. \$36

" lung ........................................ 835

" liver-tluke .............................. 838

" the rot.................................. 837

\section{SWINE.}

Age of swine, to tell.

$8+3$

American breet............................ 853, 869

. bred swinc.................... 853, 869

Antiquity of the hog.......................... 841

Anthrax, unalignнut ........................... 887

Arkunsns tooth-pick.......................... 8it

Berkshires.......................................... 84ts

“ churueteristies of........... 848, 847

Breels of Ameriem Swine........... 853, 85;

. recupitulation of.................... $\times 558$

Brecoilng und managewent of swinc,

18 age of sivine....................... 869

Care of sows....................................... 863

Catarrh in hearl..................................... 88:

Charbon....................................... 887

Contagious purumo-enteritls with mallguant sore throat............. 885, 886
Contaglous disenses, summary of........ 892

Contuglons puenmo-euteritis with

malignant sore throat, rectpes for,

Caleshill swine............................... 849

Cutarrh, mallgnant, eplzootle............ 881

" " " reclpes for 88:, 883

Chinese hog....................................... 84

China bour........................................... 844

* EOW........................................... 845

Chinese swine and crosses...................

Characteristles of Berksilires.............. 846

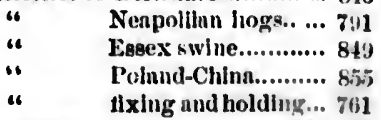

Chester whites..............................5\%, 8.58

.4 West........................ 8 46 
PAGE.

Cheshires.......................................... 887

$$
\text { ." inproved......................... } 858
$$

Clean caro necessary......................... 867

Contagious and unilgnnut disenuse..... \$S1

. pueumonia enturtis...884, 887

$$
\text { " " origlı of....884, } 4855
$$

" 4 erjsipelintous form 855

Cross-barn for swlne....................... T2

Cumberland swiuc............................ 850

Dlurritea........................................ 891

. recipe for........................... 89.2

Difheulty In ıdılulstering................ 880

Diseuses of swiluc........................879, 89)2

.6 the skill.......................... 889)

English breeds.............................. 855

Essex swlue.................................... 848

“" ort giul of............................... 848

Farrowing of swinc......................... 8063

Feeding and shelter....................868, 878

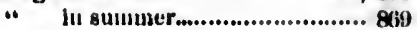

" gruill................................. 870

4. soutli.............................. 870

. III confluement.................. 871

Gestatlou of swlne........................ 8833

Good vw. food................................... 868

Good uurshy linportmut................... 880

Gruill feedellırk................................ 870

Hog, origilı of....................... 841,84 ?

" instiquity of............................ 841

"6 Introduction luto Atmeric:1......... 842

" "6 " Floridia.......... 84:

" $"$ "Nova scotia... 84:

" " " N. Foundlaud, 84:

" 4 46 Cumuda.......... 842

6 " 4 Virginla........ 842

“ explanation of skeletus of........ 877)

. light vs hieuvy........................ 875

liospltal breed............. .......... 8\%0, 8783

IIog clsolera, intesthul.............. 883, 844

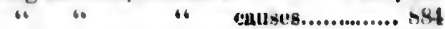

6. "6 preventioll..... str

Ilog barus........................... 8i 87,873

1ilustrution of shetetom.................... . .

lu1portunce of swine......................... \$43

lmpruveri breeds of swille................. \&

. Herkshire ........................ . Wh

. Sulfolks...................... 850, wil

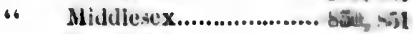

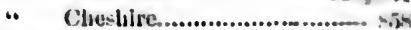

Importance of swiue........................ stin)

1. " stelettloll..................... Ati:

.6 " goud sursing.............. S4)

Intestinal $\log$-eholera.................883, . .44

.6 "6 .6 cruser............. as as:

" 4 " preventh.ille..... the

Endiu liog. 844

Inflammntory dlseases................ 888, 802

Jersey reds..................................... 857

Jefferson County lsogs..................... 85i)

Lilrgo Lancishlre, white................... 85i]

Lancustbiru hogs....................... 851, 85j

"6 midale-breed...................... 8533

Lard worm.................................... 890 ,

Llght vs lieavy logge.......................875

“ hogrs profltible...................... 875

Lighte, rising of............................. 889

Liet............................................. 891

Mnyie hog8.................................. 850

Mulignuit and contaglons disentses..881, 888

" epizootic cutarriı............... 851

" 4 gyuptous............ 88:

6 " ' reclpes for.......882, 883

6. nutlırax............................ 857

Mange......................................... 89.

Maungement of swine..................... 865

Marklings of Berkshires................... 847

Mist as foot.................................. 870

Medietue, dialenlty lı uduluistering... 878

Mensles......................................... 8 8

Middle-bred Yorkshires................... 8.50)

.6 Lanchshire.................. 85,2

Morgun county logs....................... 850

Neapolitan hogs...........................8 847

$$
\text { "6 " Imported to U. Stutes sil }
$$$$
\text { } 6 \quad \text { hog.............................. } 84 t
$$

Origin of Essex awine..................... 849

" P'olund-Chinu.................. 8 . in

“ Cluester Whilie................... 855

Poluts of Suftivik swine................ .851

Poland-Clsina................................ 85t

Pueumo-enteritis.....................854, 887

" "6 origin of.............884, 855

" $"$ erysipelitous fornu... obi

-6 ve, nutlirax, distinc-

tion b.tweets......... $89 \pi$

Pueumonia.................................. 859

Quln.sy......................................... 858

Ree.ıpituintion of lireeds..............858, $\mathrm{si9}$

Ruxts for swine.............................. 866

Rising of thr Ilghti........................ 8 s8

Seab................................................ Sill

- recipes for............................... 8.1

Selection, luportance of..................... 84:

Stort-faced Lancushire.................8.51, Ri:?

Sheltur und feeding.......................kis, bit

Siamese hog, and Berkshlire............. 84t

Sheleton of bug........................... 879

Stutili Yorkshlres............................ ki

Spleule fever in swinc...................... S46

Strangleb........................................ 84t

4. recipe for............................. 857 
PAGE.

Buffolks......................................... 850

$4 \quad$ origlin of.............................. 850

(4 Princo A.berts..................... 851

4 polıts.................................. 851

Summer feeding.............................. 8528

Summury of necessary enre............... 8 b7

$$
\text { "6 care of sivine................. 8it }
$$$$
\text { " contaglous disenses......... } 892
$$

Swine, history, breels and characterterlstles.............................741, 892

" ago of, to telL........................ 743

.. breding In $A$ mericn............... 743

16 In I INWh........................................ 74

4. ill Olile................................................ 74

6 In Illinois.......................................... 744

" improved breels of................ 744

"4 breeding ugo of..................... 862

" minngemeut of....................... 885

“ eleauliness neuessnry.............. 866

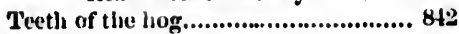

Y'richlun Splrulls................................ 890

Weaulng....................................... 863

Yurkshire swlne........................849, 850

\section{POULTRY.}

Afrlenr geesc................................ 967

Americau wild turkey........................ 898

Anulysis of wing plunnge..........936, 938

Anatomy of the hen........................ 97 tt

A poplexy.............................974, 975

Aslutic breeds..........................017, 9:4t

A jesbbury ducks............................ 956

Buntans, orjgin of.......................... 910

6. ................................ 831, 933

. Senbright....................... 931

Barn-yard fowls, varieties of.............. 033

Best breeds tor murket...................... 041

Bluck Dorking................................ 905

“ II 1 miburgs............................ 908

“ Enst Indja duek...................... 059

" rot........................................ 970

4"6 reeipe for........................ 977

Bolton Grny................................... 900

Binhusa fowls......................... 8:1, 0:2t

Brilla $\quad$. ................................... 0.2.3

Browu-brensted red gane................. 9:27

Breedling of poultry................... 9:34, 941

Breeders, Glossary of terms used 910,970

" to type............................... 940

Bronze gray 'Turkey........................ 9.5)

"6 bluck ". ......................... 9.j1

Buf Coching................................... 019

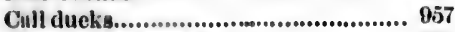

Canada wild goose.......................... Ut57
TAกF.

Care in packing fowis....................... 946

Cuyıgn bluck ducks......................... 9.58

Chiltagoug.................................... 9]8

Cholera............................................ 07 (t)

Common turkey............................. 949

Crevo Cours..................................... 918

Crested turkey................................. 048

Crop bound..................................... 977

Croup............................................. 977

Dark Bruhıa.................................. 0.8

Derby gane................................... 928

Divisious of domestio poultry........... 902

Dlspurity ill sexes.......................... 940

Dlsenses of fowls.......................073, 178

Diphtheria.................................... 977

Dounestlo fowls, origlı of............ 80.5, 912 “ poultry, how divided.......... 912

Dorking fowls.......................... 004,900

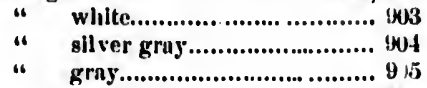

. fiw wi-eolored...................... 40.5

Domiulque fowls....................... 906, 907

Douestie turkey . varietles of..... 948, 949

Dressing fowls................................ 94t

Duck-wing gane...................... 0.0, 0.0

Ducks, Routll........................ 874, 9i5j

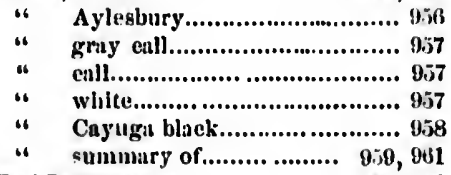

Eard Derby game.................... 9:8, 9:0

Egg-produching fowls.................... 914

Egy bound.................................. 975

Eaiblen, or Bremen geese................ 9152

Euglisli turkey............................. 940

Fawn-colored Dorklig....................... 90.5

Faneler's glossary of terms........ 969, 970

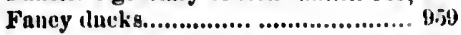

Fowls, matugement of............. 94:, 946

"t the house.......................... 943

.. proper foud for....................... 943

" exg proilucers........................ 144

" for market............................ 144

" to fatten.............................. 14

"6 to kill................................. 94

.. to clress ................................ bitt

" pueking lor marhet................ 945

French fowls........................... 913, 916

Frizzled " ................................. 8:t

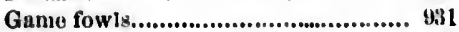

") batitinims............................... 931

Gapes, remedy for........................ 976

Geese, sub-varletles of....................... 998 
PAOE.

Goorgla game.................................... 031

(Heege........................................... 082, 068

" Embdon.................................. 962

16 Bremen................................... 902

1" Toulouse.................................... 863

a Hong Kong............................... 064

"1 whits Chinese......................... 9ut

1 Afrlean ..................................... 967

11 Canada wllt........................... 967

11 management of....................... 088

Golden-penelled Humburg................... 910

Golng linto buslness........................... 942

Glossary of terms used by linclers,

000,970

Gray Dorking...................................... 004

Gray eall dueks................................. 057

Guinet fowl, where natlve.................. 868

Gueldar fowls.................................... 025

Guluen fowl............................. 950, 051

$$
\text { " } 4 \text { number of eggs lield........ } 950
$$

Hamburg fowls................................... 908

Hen, anstomy of................................. 074

Hondurus turkey................................ 050

Hong-Kong geese................................994 964

Houdans........................................... 014

fileal shupe........................................ 939

Inflammation of egrg possage.............. 975 " " " reelpo for 975

Japanese Bautams................................ 032

KIIllug fowls..................................... 044

Lafleche fowls..................................... 915

Largo Aslatlo breeds......................017, 024

Laylug soft eggs................................ 977

Leghorns.............................................. 910

Leg bone of hell.................................. 974

Llce.................................................... 978

Light Brahma.......................................... 924

Management of fowls...................800, 048

"1 guese........................... 948

Marketing fowls............................... 945

Mating......... ............................... 941

Moxlean wihd turkey.......................... 896

" turkey................................. 951

Ocelated turkey..................................... 950

Criglil of ilumestio fowls..................895, 902

Ostrich fowls................................... 908

Packir.g for market............................... 045

Purtridge Coeliln.................................. 021

Peacock............................................... 053
PAOE.

Penclled Llamburgs............................ 919

Plp.................................................... 1777

Plymouth Roek fowls........................ . (H)7

Polnts of poultry, expnluntlon of........ 9:27 " tho head " $\quad . .9855,938$ " fowls " ...936, 139

Poultry, history aud management 865,078
“

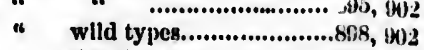
$455,(40) 2$
" the pluuage...................537, 038
11 diseases of..................... 973, 978

Rlueumatlsm......................................... 977

louen ducks.................................05t, 055

Roups................................................ 975

" reclpe for................................... 975

Senbright Bantams............................. 931

Sexes, dlsparity In............................. $\theta 10$

Sllky fowls........................................... 919

Bllver-gray Dorklng............................ 904

" penelled llamburgs.................... 909

Sonnerat fowls...................................... $\$ 100$

South American fowls........................ 901

Spanish fowls..............................94:, 843

Spotted Guinen fow............................... 9:53

Btaudard whitto leghorns..................... 943

Summary of ducks.........................9;9, 861

Sub-varleties of geese.... ................. 898

Toulouse geese................................... 963

Turkeys...................................... 951,052

"C domestlo varletles of.. ...... 948, 949

“ time of lintchling eggs............ 948

1" common................................... 949

11 crestell......................................... 948

" English................................... 949

" bronzo gray............................. 919

" Honduras.................................... 950

" Ocelates...................................... 950

4. Mexiran..................................... 951

" brouze...................................... 851

" 1 blaek............................ 951

Varjeties of domestic turkeys........948, 9.59

" burn-yard fowls............9013, 933

Water fowl-dueks........................051, 0.54

" " -geese.......................962, 068

White Dorking..................................... 8013

"1 Leghorn..................................... 010

" Coeli 1 18....................................... 0.21

“ Georgia games........................... 930

4 guinen fowl................................ 0.53

1. duokt.......................................... 957

4t Chlna geese................................ 968

Wild spectes of domestlo fowl............. 900

“ goose ........................................... 067

Wing plumage, analysis of...........9:6, 838
$\mathbf{B}$

Ast:

Brot

Bar

Hire!

Jull

Blos

Bars:

Bres

Cand

Conte

CanI

Cimu

Chor

Cons:

Dise

Dill!

Dron

Dins

Dist

Fits

Flea 


\section{BEES.}

\begin{tabular}{|c|c|}
\hline $\begin{array}{l}\text { PAGE. } \\
\text { See Valls. . ......................... } 0888\end{array}$ & Products of Bees................... PAite. \\
\hline omb........................... 080 & Queen Bees........080, 081, 081, 890, 091 \\
\hline 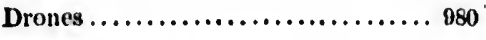 & Rnces of Bees. . .... \\
\hline $\begin{array}{l}\ldots \ldots \ldots \ldots \ldots \ldots \ldots \\
\text { ix and of Honey..... } 083\end{array}$ & \\
\hline y of Bes...... & $\begin{array}{l}\text { Sturting Bee-culture.................. } 885 \\
\text { Swurming........................ } 890\end{array}$ \\
\hline ILoney lixtructor........ & 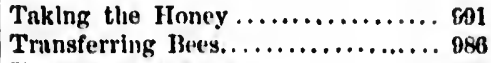 \\
\hline I.ocation of Ilives........... & .... 602 \\
\hline Mimagement....... & $\begin{array}{l}\text { Wax Ext } \\
\text { Winteriı } \\
\text { Working }\end{array}$ \\
\hline
\end{tabular}

\section{DOGS.}

Astluma in Dogs..................1025

Brenchitis in Dogs................1025)

Barbet, the .....................1015

Brenels of Dogg.... ............... 607

binlt Iogg ......................... 1000

Blocsllomend, the...................1011

Bengle, the ......................1013

Breceling..........................1010

" choice of sire and dam..... 1016

" age....................... 1016

" time of year...............1010

، mam.1gement............... 1017

Cancer in Dogs.....................1034

Conch ])og, the....................101t

Cimker of the cir..................1032

Commonat eolle in Dogs.............. 10.25

Clecrean ur jerkis......................1033

Consumption in Dogs............ 10:0

Diseases of Dogs ..................1025

Dilmbatian, tlie.................. 1014

Dropper, the.................. 1003

1)ingo of Australin... ........... 998

Distemper in Dogrs..................1028

Fits............................ 1033

Fle:as on Dogg...................1033
Foxhound, tho....................1011

Greyhound, the..................1013

Hydrophohia................. 1035

" the Goolmin cure for 11303

" instmes's of cure..... 10137

Influenza in logs ............... 10@0

Inflanmation of tha slomach . ....... 11180

" " liver...........1131

" " bowels........ 1081

Jerks, or cliorea....................1033

Lice on Dogs .................... 1033

Mounit St. Bernard Dogs.............1010

Mustiff...........................,

Newfoundland bog...............107

Pointer, the................... 1004

Poowlle, the ................... 1015

Plentrisy in Dogs ................... 1028

Puetumonia in Dos's................. 10:6

P'nerperml fits .....................1034

Protructed labor ..................1035

Rabies or hyilmoluhia...............1035

Rheumutic fever in Dogs............ 1027 


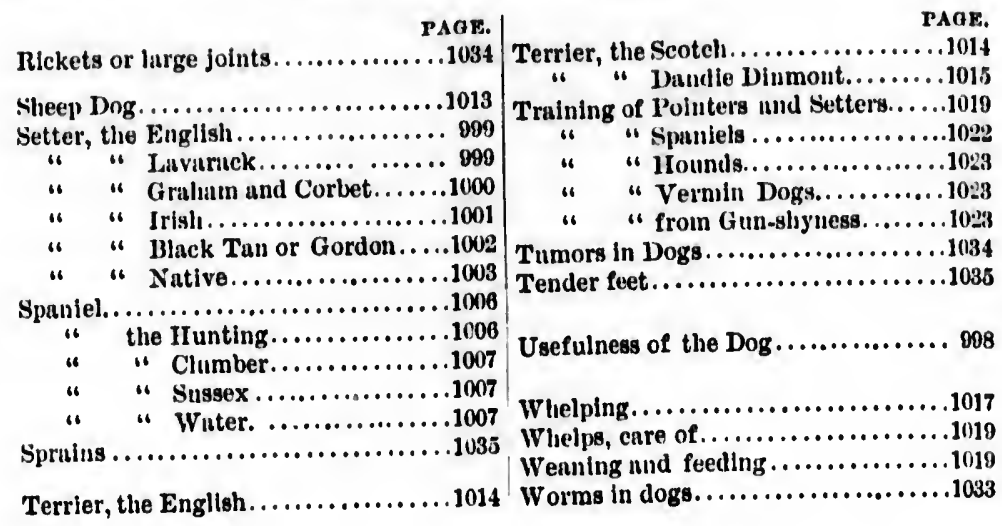




\section{AGENTS WANTED.}
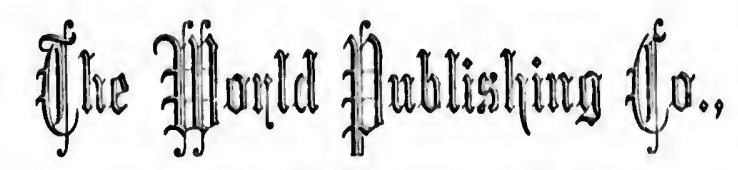

GUEIPI, OITARIO.

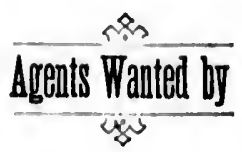

\section{TEACHERS, BUSINESS MEN, SMART YOUNG MEN FROM THE COUNTRY.}

publish and sell only the best books, ns we nre the most extensive publisher's in Canada, selling twice as many books as all other subscription bouses in Camada put together. The public and our agents en see that we can sell a better article for less money than any other house.

As we have agencies in Australia, New Zealand, Chinn, Hindoostan, Ceylon, South Africn, West Indies, South America, and many parts of the United States, we make books in very large qunntities to supply all these countries, and cun give our patrons in Cannda the benefit of the reduced cost of publishing large editions, which no other house in Canada is in n position to do.

We want agents in countries named. Young men going to these countries, if suitable to the business, we will give you letters to our branches, when you can immedintely make large returns and see the country extensively.

Agrats For Canada.-We constantly require first-class men to work in Camadia. Agrents make fur more working for us than for any other firms.

Write to us, or come and seo us.

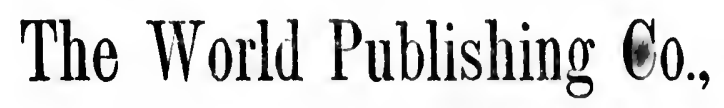

GUELIH, ONTARIO. 


\section{IMAGE EVALUATION TEST TARGET (MT-3)}
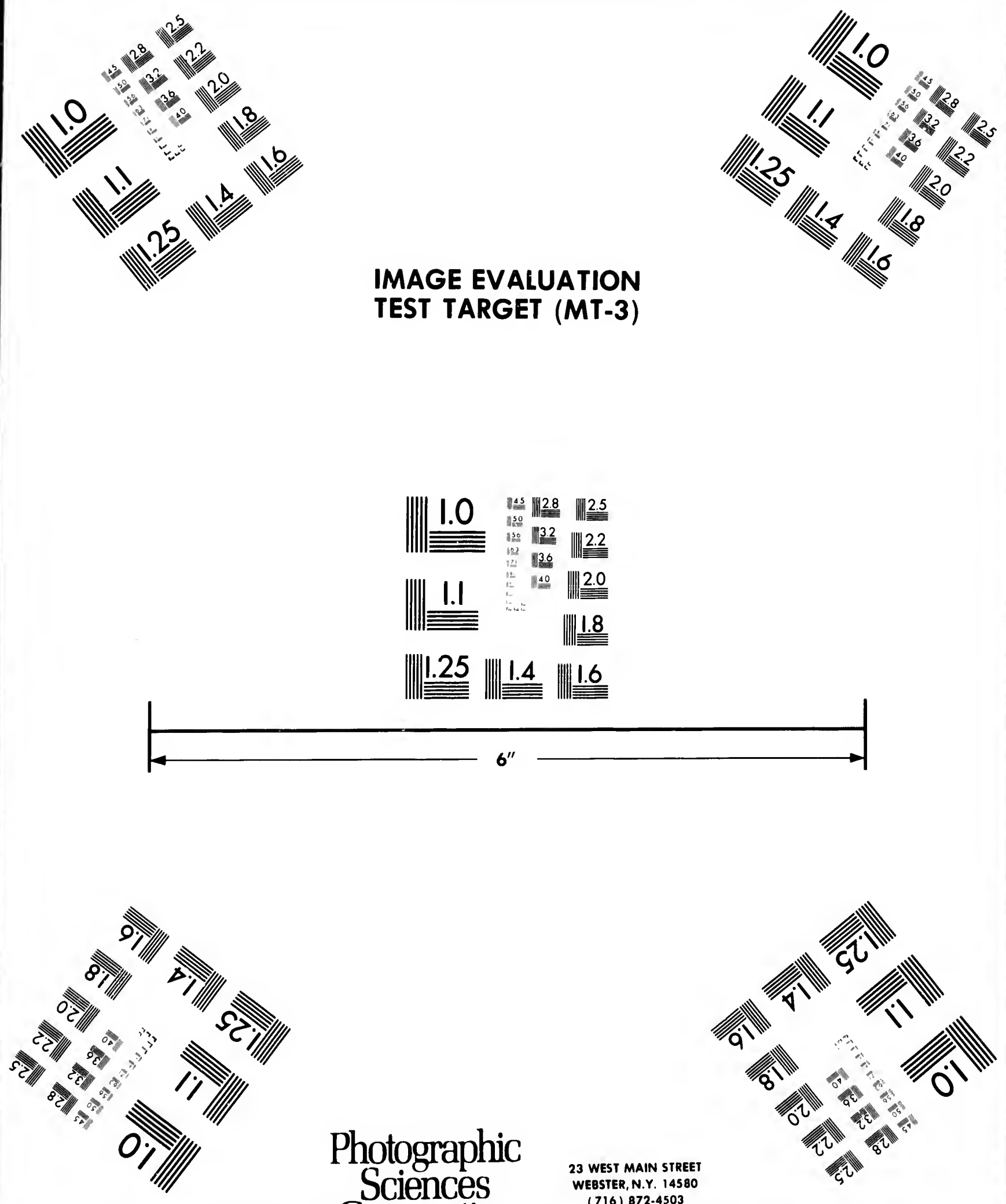

Photographic Sciences Corporation
23 WEST MAIN STREET WEBSTER, N.Y. 14580 (716) 872.4503

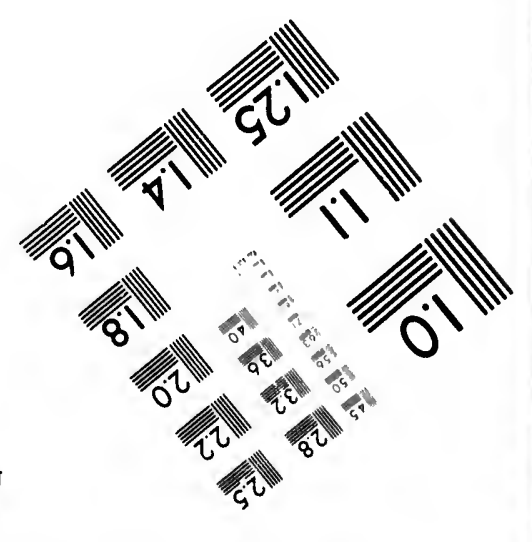





\title{
FARMIERS,
}

It WILL PAY you to use

\section{TII ERTIITER}

MANUFACTURED BY US.

GIVE IT A TRIAL AND YOU WLLL NEVER USE ANY OTHER.

\section{GDOD IEAVY CROPS}

\author{
dANNOT FAIL TO FOLLOW ITS DSE.
}




\section{FERTILIZING COMPANY of CANADA. GUELPH, ONTARIO.}

\section{TO THE FARMERS AND GENERAL PUBLIC.}

WE take great pleasure in calling your attention to this Circular. We are now firmly and permanently established in business and have our arrangements complete for the purchase of bones, blood, meat, potash, pure sulphuric ncid and all animal matter from which to inanufacture our Fertilizer. Our Fertilizer is honest and good, and has never yet been used by any person who will not certify to its excellence; many of our patrons and the persons whose nanes we give, have used all the different brands imported from the United States, as wcll as Guano, and the various so-called Fertilizers manufactured in Canada. We only ask a trial of ours by the side of any mule, and we are open to publish its results. A large amount of capital has already been put into the Company, und it is our determination to manufacture a first-class article nud make it universally known. Samples have been placed in Prof. Pike's hands, of the Toronto University, nud so soon as the analysis is complete, the same will be published. We would call attention to the fact that all Fertilizers imported are obligel to pay twenty per cent. duty, and additional cost of freight. Heretofore, some of the United Stites Companies have come to Canada to purchase materials. We purpose to purchase all available materials to be bad anywhere in Ontario, and to manuficture the same and keep the wealth in the country. We rely upon the material we make for success as well as upon the public spirit and patriotism of our Canadian people.

Faitlifully yours, FERTILIZING COMPANY OF CANADA.

\section{DIRECTIONS FOR USING OUR FERTILIZER.}

It is best to apply when the weather is damp, and especially beforc rain is expected. It will be best to mix well with soil for transplnuting all plants, as our Fertilizer will be found too strong without this precaution, although it may not injure the tender fibres, a thorough mixing with soil is advised. For wheat, barley, oats, buekwheat, rye, and all other gruin crops when sown broadcast, use from 250 to 300 pounds per acre at time of sowing, and harrow in sare. If the gran is drilled in, it is best to drill in Fertilizer nt same time.

You will find this Fertilizer will give every and all Satisfuction. 
Cons.-Put a dessert spoonful in each hill, and cover with soil before dropping in Corn, also a handful just before first hoeing, but the Fertilizer should not come iu direct contact with the Corn, as it might retard germination.

Stawberries, Asparagus, Etc.-If beds are made, we advise top dressing in September, and again in March or April. In case of vew beds being made, the scil should be stirred deep and the phosphates should be liberally incorporated with the top soil and then a slight dressing after seeds are just cove:ed, just before first hoeiug or before a warm shower.

Flowers, Shrubs, and Fruit 'Trees.-We call special attention to its use. Apply as liquid manure, or top dress before watering.

Tomatols, Melons, Cabbage, Cucumbers, Vegrtable Marrows, Squash, Eтc., Erc.-Put in two tablespoensful about one inch under the seeds-then just before hoeing first and secoud time apply abont one tablespoonful. This Fertilizer does no harm to seeds, and iu using as above, the worms and bugs will not attack the root or plant.

Hops.-Use p!entifully around roots early in spring, and top dressed on the top and covered with soil slightly. It vay also be applied in the fall with exeellent results after picking.

Potators.-Put a small handful in the hill, mixing the soil very carefully at same time, then plant the seed. Exceedingly large crops have been raised by the use of the Fertilizer; a haudful in each hill at first hoeing covered with soil.

Grass.-Sow brondeast early in spring, and after mowing, or in the fall, from 250 to 500 pounds per nere. It is better to apply the Fertilizer when the ground is moist from recent rains or before rain.

Pras and Beans.-If sown broalcust, sow the Fertilizer same as with wheat; if in drills or hills, use as directed (see Corn) at the rate of about 400 poutsds to the acre.

Radisines, Beets, Turnips, Onions and Carrots.-Sow with the seed moderately at time of drilling or sowing and top dress at time of thiuning out und weediag. These crops will be unusually early and large.

Tobacco and Corron.-Use from 300 to 400 pounds per acre nt plauting, and balance at hoeing. Very excellent results follow the use of the Fertilizer on these crops, the most favorable reports being received from our eustomer's, stating they have raised treble the amount of crops and they have proved of far greater value by the use of it.

As these are very valuable crops, we would advise a very liberal application, say up to half a tou to the acre, especially on poor soils.

Upon Grape Vines, Frut Trees and Shrubs it may be used liberally, the results being truly marvellous.

For Plach, Plum, Ornamental and Valuable Trees a liberal top dressing sprinkled with the soil should be applied.

I'e would call our patrons' attention to the very excellent properties of our Fertilizer for Flowers of all kinds, as it, increases the richuess of blossom and foliare, nlso having the advantage of much earlier production of same, as the Fertilizer maty be applied in the winter with good effect.

Remember it is an essence; a teaspoonful is sufficient.

It has taken First Prizes und Diplomas wherever Introduced. 
efore dropling ould not conic

se top dressing eing made, the ly iucorporated :ed, just before

ntion to its use.

ROWS, SQUASH, eeds-then just This Eertilizer will not attack

dressed on the full with excel-

very carefully at en raised by the 1 with soil.

in the fall, from when the ground

ne as with wheat; ut 400 potsuds to

v with the seed thinning out aud

acre nt planting, the Fertilizer on ustomet's, stating ed of far grieater

eral application,

e used liberally,

liberal top dress-

properties of our blossom and foliame, as the Fer-

\section{roduced.}

\section{TSIIMIOIVIAIS. \\ THE FERTILIRING COKIPANY OE CANADA. \\ lioth the Guelph Weekly Hercury of 21th March, 1581.}

IJaving in a business wny eome into contact with the Fertilizing Company of Carnda, whose

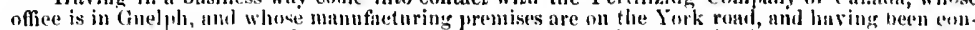
vineed that there nas never been in Gelph, or even in Canala, an estublishment that was ever s: important to a large class of our renders, viz. : the farmers, we have concluded to gor to a eousiderable trouble in the interests of our subseribers to investigate their establishment and their garls.

1st. The eompany are eomposed of men of enpital and baeked by eapital to an unliuited ex tent, and are fimmeially one of the strongest firms in Guelplis.

2al. Ther are men of homor, whose wirt eannor he questioned.

3i. Their manufieturer is a thoroughly pratieal man of life-long experienee, and is probals] the best qualified of any man in Conacla to fill the position.

4th. The company's fertilizer has been used for three years and has proved superior to any artiele of the kind ever made in (anada or imported into the comntry, and the universal testimong of humlreds of their patrons who have tested it by tha sile of ather bramts is to be retiet numii and we think they ean as we have seen the original testimonials in their own himdwriting signet by their names, voluntarily forwarded and given by them.

5 th. Work hats ben on a limiter seale until the artiele shonld beeme known and appreriated.

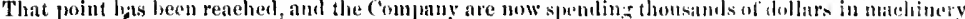
anel mnterials and are prepared to make a mued better artiele than cver hethre and are detcomineil to make it known as such inywhere within the next six months. They desire every farnur in Wollington county to purehase at leist a small quantity this spring an!l experiment with it, anul they ofler in any ease to publisli the resalts six montlss niterwards.

6th. Superphoshates of lime, ete., previonsly munfactured, have been ehiefly from glue tiactories, and niter the glue and other important projerties have howen extracted the firtilizing unatter

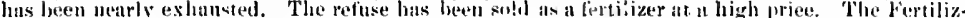
ing (company of ('atada make nothing bat their fertilizer, and it ean be relied upon to eontain the full stringtli of' properties used.

7th. The eompany are purchasing bones, blood, ment and other material an Toronto, llamilton,

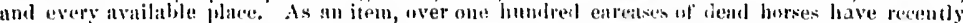

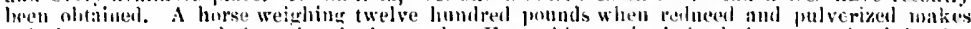

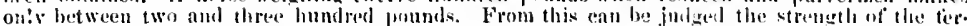

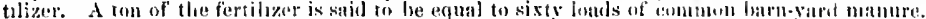

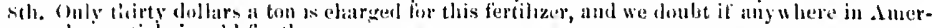
iea as aroul ain article is solld fin the same money.

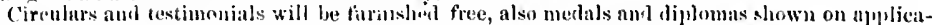
tion at the Company's Oftice, Douglas street, isext the I'ost Oflice, Ciuclph, Ontario.

The Superphosphate whieh you are selling eonlains some of the most important ingredients necessary to plint growtli.

lour, respectitilly,

$$
\text { J. HOY'LA PANTOM, }
$$

Prof. of Chemistry, Ontario Agrieultural College.

\section{Fertilizing Compayy of Casada.}

$$
\text { OAKVille, ONT., February, } 1881 .
$$

Gexilkus:-I take pleasure in stating that I have used your Superplosphate of lime for two years. In 1878 I bought it tom, which I used as follows:- Ohe-half fun on un aere and a halit of strawherries, I selected the two best and most promising rows, nod on them I put no manure whatever, the ground being then in reh and gond emblition; all throngh the seamon there was a very makked improvement on the plants where tised, and at tine of pieking the berries on pows

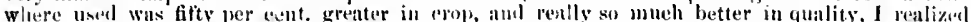
thonhle from each row, than I di,l from rows where not used, and I have sinec leaned from Montral that my berries for that yeall were the best berries that wire brought to the eity. I trien a purtion on my plum trees in the bil, and the following vear my drees metrly broke down with an extril-

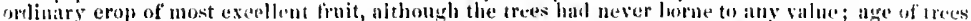

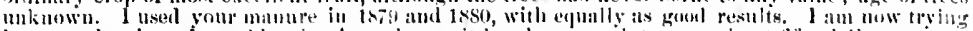

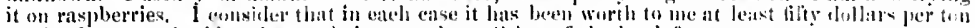

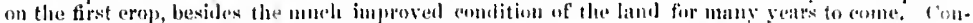

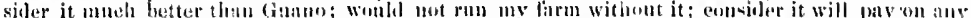
erop. It is partienlarly valtable njwn tall whent at the of sowing, it will also insure grass sced

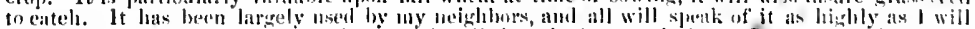
myselt. As prepared hy you it is easily handled and almost onlorless. Fut on strawherries in Siptember.
Notics the Increase of Lour Crops. 
Ferthlizing Compani of Caxada.

Gisticyex:-I used your Superphosphates of Lime, 50 pounds on one-furth ure of eorn In hill nfter planting. Adjoining I had three fourths acre of coru ou equally us gowl laul, where I did not use it. All through the senson there was a matket dillerenee in fivior of the qunrter nere where used. Where not used, erop was alout 50 busliels to the nere in the enr; where uked, linlly so bushels, whichl wnilil give an inerense of 30 bushels to the tere. Hy tising 200 pumbls of the Superphosphutes, besides un inprovement in the lund for yeurs to come, as will be seen the extra eorn would be worth sill at 33t per bushel, enst of superphosphates ut 530 per ton, \$1.50, Also used it cin tresh plunted asparagus beds, looo plnuts, two years old, roots jut out in A pril, wns lonking poorly in July, used 150 pounls Superphosphntes on them, and nguin smo nmount in Outolur; shwwed womlerful improvement in greut thiekness of stalk. I now expeet a first-eluss usparagus leel, all of which I now consider is the result of the Superphosphutes, and without it I an eontilent I woulil lanve lost iny time and the use of the grounl. I lave now applied it to my fruit and garien crops and do not intend to be wilhont it so long as it enn be hatl.

CIIRISTIAN J. ROBINSON, Burlington, Fruit Famer and Gardener.

OAKنILI, February 23d, 1881.

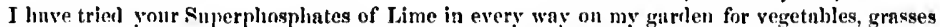
and trees, can speak of its high quality. I ensider this (he lyest fertilizer in use, und I have nsed mnny ditherent brunds imported fron the United States and foreign eountries, ns well ns Gumo and its diberent brands atvertised as made in Canula. I wish no other so long as yours is to be had. 1 was toe lirst to introlnce Superphosphates in this seetion of the l'rovinee.

Wishing you sllectss, Yours fitithtully,

W. WASS, Banker und Experimental Farmer.

Your Superphosphates of Lime gave very satisfactory results.

Duxdas, February 19th, 1881.

$$
\text { Yours, ete., AATON MORRIS, }
$$

Manager Hanilton Cotton Company, ITaniilton.

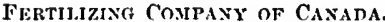

Burlingtos, Fehruary 22d, 1881.

tikxtcamex:-The sample of Smperphosphates of Lime supplied hy you, 1 mplied to my root crop gatve me great satisfitetion, so mueh so that I very mueh regret I had not pureliased a larger quilitity.

Respectinlly yours,

$$
\text { JOIIN FO'TIERGIIL, }
$$

Prize taker for farm entered for competition before the Agrieultural Commission of Ontario.

Dundas, 21st Februnry, 1881.

In reply to your inquiry I beg to testify that the Superphosphates of Iime I purelinsed of you when here, to apply to no lawn and flowers, gave me entire satisfinetion, and that l prefer it in every way to any other preparation that I know of.

Yours truly,

JOHN A. FISIJER, Paper Mills.

Dundas, February 18th, 1881 .

It nffords me great pleasure to inform you of the results of my experiment with the Superphos. phates of Lime mul the other urtifieial manires you supplies. In every instance where used a very marked improvement was the result in a profission of thower and foliuge, the seels eame along quicker nul with more vigor and in greater quntity. A poor soil is a siek soil nul why not use the snme means to it as is used to a siek man or animal. It is my intention to enntinue my experimeats this year.

D. McMIl.LAN, Librarian.

Hamiton, February 19 th, 1881.

I luve great pleasure in suving that I have used your Superphosphntes of Lime ou our garden and found a great dillerenee between where I nseal it, and to prove its qualities, I did not put it on nll parts of the gurlen, and would advise all parties to use it on roots, shrubs, vines and pluats und it will recomuend itself. Yours truly,

A. M. FORSTER, Foundryman.

Jerseyvilue, February 7th, 1881.

I have mueh pleasure in stating that your fertilizer has proved all you represented it to be on turnips, trees and grass. Have seen its effeets on grass and have every fuith in it. It is just what the fitrmers need.

Yours truly, J. D. IJOWELL, Farmer.

There is no Mincrut Matter in our Fertilizer. 
th arie of eorn oul lami, whese he quartor nete here used, finlly poumis of the seen the extra II, \$1, iol. Also it in April, was ane muonut in eet a tirst-elass ant without it I ipplied it to my

Gardener.

23爪l, 188 . getulules, grasses ind I have used ill as Giumin and urs is to be had.

tal Farmer.

y 19 th, 1881.

y, IInmilton.

ry $22 \mathrm{~d}, 1881$.

pplied to my root urchnsed a larger

II of Ontario.

bruary, $188 \AA$. pureliased of you irefer it in every

Paper Mills.

fy 18 th, 1881 .

h the superphosvhere used a very feerls eame along antl why not use time my experi. \$, Librarian.

y 19 th, 1881 . we on our garten fijd not put it 11 es andi plunts und

Foundrynan.

ry 7 th, 188 .

ented it to be on . It is just what

I.L, Farmer.
DUxD.1s, February 17 th, 1881 .

We have muel plensure in eertifying to the exeellent qualitios of yut superphosphntes of Llne, it having cmmpletely restored an Olender plant which we thought past restorntion und which has since been the atmiration of all who have been fiortunte enrogh to see lt, and we may also ald that its benefieinl etleets on shrubs, vines, lawn gruss und llowers, was all that conld be desired. We wish you every sueess in this very importnnt industry.

Jours truly,

ii. F. \& GBO. SU'TER,

Clerk of Distriet Division Court, County Wentworth.

Governon's Rond, West Flanbono, June 18 th, 1880.

I take great pleasure in recommendiug your Superplosphates of Lime. I to] d ressed whent and sowed it with barley, and ean say without hesitucion thut 1 hat the lest crop of burley in the township. The effeet was really wouderful to wy whent; in spots I could not get any growth previously iu any respect.

Yours very trinly,

GEORGE ATKINS, Furmer.

Dunbas, Februmry, 1881.

I have found your Superphosphates of Lime to prove most benefieiul to my flowers unl trees and can strongly recommend it.

M. WhlGilT, Commission Agent, formerly Brewer.

Duspas, February 15 th, $18 s 1$.

Having used your Superphosphates of Lime on my flowers, st mabherries ant veyetubles in uny garden, I enn say with pleasure that it is without exception the most perteet I have ever ined ir seen nsed. I cheerfully recommeut and advise every farmer ankl gardener to use it in preference to any other. Yours respectfully,

\section{ALFRLD BENNETT,}

Aldensiot, near Mamiton.

I beg to eertify that I have used the Superphosphates of Lime prepared hy you: and it is all that it elaims to be, having used it on my vegrtable erops to their very marked idvantige. I wisl you ull the suecess that this most important business deserves.

$$
\text { Truly yours, }
$$

GEO. ANDERSON, Gardener.

Rock Cirapei, Dusdas.

In reference to the Superphosphate of Lime I bought from you, I tried it on wheat, poitatnes and turnips, Un whert the yield wis very great, nlso turnips and potaters. I nsed piof pounds to the acre, on ten acres, and eonsider ' tut it paid me four-fold, ratising an extra goot erop on glound which was previonsly in very por sondition. In all $I$ have used seven tons, and shall try no ocher fertilizer while yours can be hai. JUIIN BORLE, Farmer aud IIller.

\section{Axcaster, February 21st, $18 \times 1$.}

I have much pleasure in reeommending gour Superphospliates of Lime. I have used it on my wheat num I found a great benefit buth in regard to.yield of gratin and growth of straw. It paid nie well. I am, yours trilly

Wh. FEIRIE, Farmer.

Fertilizivo Compaxy of Canada.

A ccaster, Februnry $23 \mathrm{~d}, 188^{\circ}$.

Gextlemes:--It gives me great pleasure in having used your Superphosphate of Iiwe for hops, that its results have been very satisfactory. I ean reeomment it for that parpose.

ALEXANDER GERRIE, Furmer and IIop Grower.

13ARTON STREET, HIAMUTON.

I applied your Superphosphate of Lime on nats, barley and corn, and the return was sto grent that 1 would recommend it to every furmer und gardener.

FRANK RUIILIS.

IIAMLTon, February, 1ss1.

Having used your Superphosphntes of I.ime on my wheat in the yenrs $18 ; 8-i$, Ifoumd on harvesting that it gave me in return of 37 s bushels to the acre, the woiglit exceeding the measurement, the grass having seedet at the same time. I ean eertainly sperk highly of its general benefieial results. The land upon " hieh this whest was grown was in poor condition, ant eoutd not have been relied upon for a erop, hat your fertilizer atot heen userl.

WALTEI JUURHEAD, Farmer, eto. 
Bevenix, Felurtary 16 th, 1881.

Havleg tried your Superphosphates of Llme on ny whent in the fall of 1879 , I have mueh plensure in statiug that it proved all you claimed for it, having suwed it on part of my field, 280 pounds to the nere, und on the other part, I manured it with barn-yard munture, 30 loats to the atere, und I beg leave to stute that where I sowed the phosphates it enme out fully thece cluys sonner in heod, and was in yield eousidernbly better, and in mother part of the fiekd where no maunre wns put, it way onde week later in eoming ont in hend nul was gery thin in the ground. I huve used other Superphospluates, but I preter yonts ta uny I have evor hal. Wishing you every sueeess in your business, I remuin, Yours filith fully,

JOIIN MALCOLI, Farmer and Stock Breeler.

OAKv'llat, February 221, 1881 .

I have been very plensed with your Superphosphates of Lime whieh I used on my struwberrics and lispluerries. W'ishing you well in your undertaking.

\title{
B. G. MOORE, Furmer and Gardener. \\ HAmitos, February 17th, 1881 .
}

I used your Superphosphates of time last year upon my three-vear-olu grape vines. I have great pleasire in stating that its atfiets not only in giving vigor to the plant, but also in hringing forwathl the fruit so phum und full in buneh that l eonsiler it the finest mnnure that I luve ever known.

lours respeetinlly,

ROBERT IOPKIN, Wholesale Boot aud Shoe Dealer and IIortieulturist.

February 19th, 1881.

The Superphosphates of Lime which I purchased from you gave me entire satisfuetion. I so:ren it on fall wheat. I an satisfied that the inerease yield was from five to six bushels per acre, and if it hat not heen winter-killed it would have heen mere. I wish you every sneess in your umlertaking, us $I$ thiuk it is just the thing that Canadian firmers want.

$$
\text { JOIN LAWSON, 4th Con. Flamboro. }
$$

Dexdas, February $16 \mathrm{th}, 1 \mathrm{~s} 81$.

The fertilizer, Superphosphates of Lime, whieh I olstained from you was used on house-plants and gave every sutisfiction, the flowers being improved thereloy, both in eolor and boliagt: of flower atd growth of plant. Ifoping you will meet with every sucess in handling your fertilizer,

$$
1 \text { remitin, yours, ete., }
$$

W. DICKIL, Groeer.

IIAmitox, February 17th, 1se1.

I am pleased to have to inform you that the benefieial results of your Superphosphat s's ol Lime was most satisfietory, bith on my graje vines, Howers and shrubs.
$1 \mathrm{am}$, yours, ete.,
c. S. (iIIIGGS, Constable, Ilanilton Police Foree.

Dexdas, Feloruary 17th, 1 ss

I have great pleasure to say that your Superphosphates of Lime proved a great suecess on aspurngus, eelery, corn und garden stuff, also on flowers. All who have nsed it in this section are satisficd als to its value.

F. B. RILEY, llotel l'repritor.

Grexsville, Februtry 19th, $1 \varsigma \$ 1$.

The Phosphates of Iime I hought of yon, I applied on trees ausl genernl garden purposes. It gave me every satistuction for the country's good. I wish you suceess.

\section{JOHN STEELE, Maltster.}

BULLOCK'S CORNERS, BEVERLY.

I ean sny that your Superphosphates of Lime gave me great delight on everything I applied it to, onts unil barley espeeially. JOHN likEERCK, Farmer and Hoiel Proprictor.

OAKville, Fel)ruary 23u, $1 \leqslant 81$.

Have used your Superphnsphntes of time on strawberries und garden stuff gutierally. Would reeommend all gardeners and farmers to try it.

\author{
JOIIN MASON, Fruit Grower anl Buteher.
}

OAKVILle, February 23k, 1SSI.

I have nsed your Superphosphate of Lime on all my vegetables, corn aut strawherries, and hase foud it superior to any f'ertilizer I have had, and I have tried uany. I was formerly ngent for Croeker's Ilonest liullilo Fertilizer and several other brands. W. II. JUNES.

\section{The Effect is Almost Immediate.}


Iary 16 th, 1881.

1879, I liave much art of my field, 280 are, 30 lounds to the y three days sonner I where no manure ge groutud. I have tg you every suecess

Stoek Breeder.

'uary 22d, 1881.

on my struwberries

and Gardener.

\section{and $\mathrm{G}$}

ary 17 th, $188 \mathrm{l}$.

rupe vines. I have

ott also in loriuging re that I luve ever

IIortienlt nrist.

tary 19 th, 1881.

tire satisfaction. I

$i x$ bushels per aere, ery suceess in your

Con. Flamboro.

lary $16 \mathrm{th}, 1 \& 81$.

sed on house.plants

nel foliage of tlower ur fertilizer,

CKIL, Groeer.

tary 17 th, $18 s 1$.

phosphates of Lime

Police Force.

tary 17th, 1 sst.

a great suecess on $t$ in this section are tel I'ropurietor.

tary 19 th, 18.81 .

arden purjonses. It

ELE, Maltster.

ERs, Beventy.

rything I applied it otel P'roprietor.

ruary $231,1881$.

generally. Would

or and buteher.

ruary 23l, $18 \mathrm{sl}$.

ul strawherries, and

is formerly ugent for

W. H1. JUNES. 


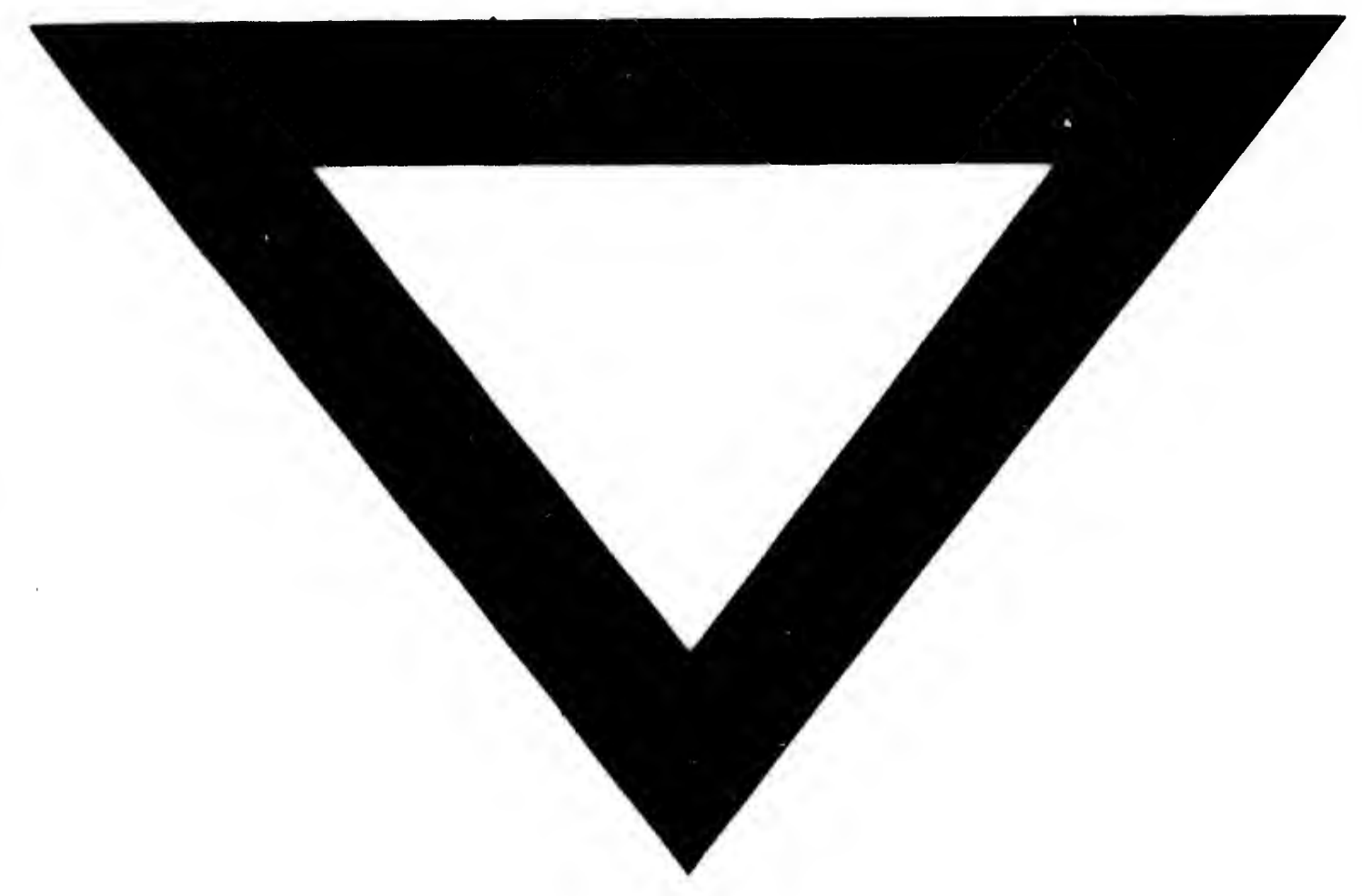

